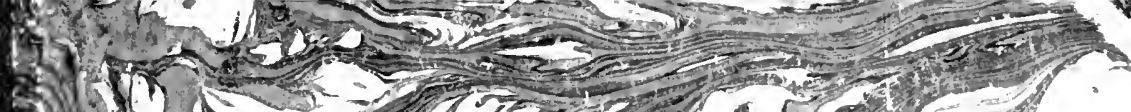

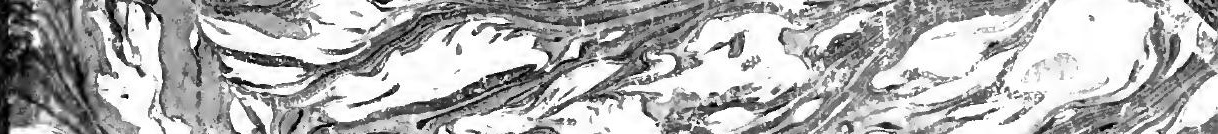

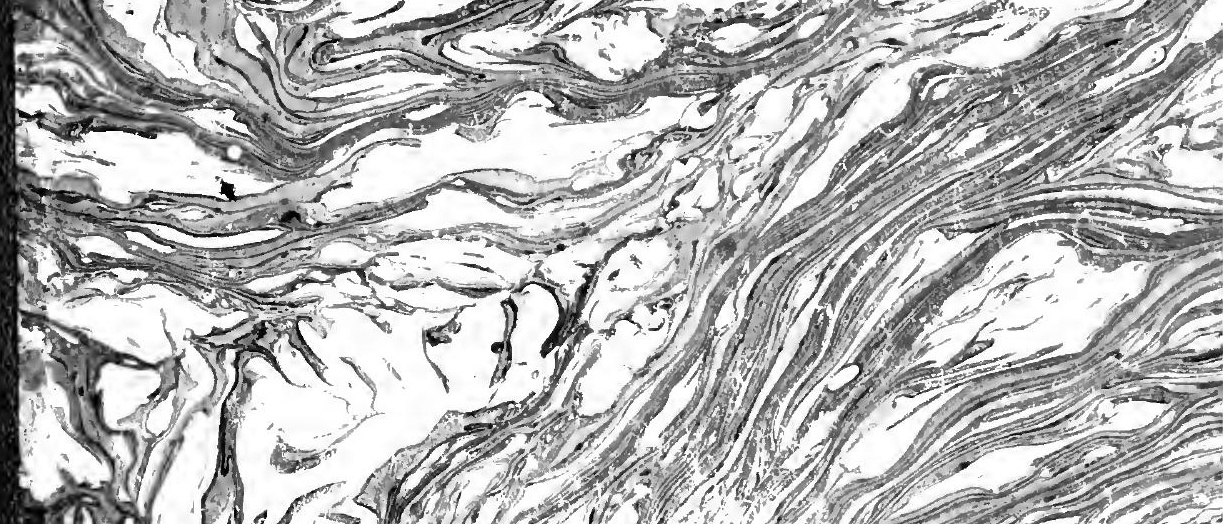

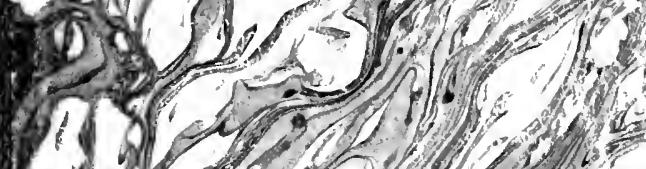

1) 120

1).

1) 2

I.

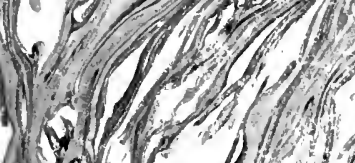

3010 , d f

- s)

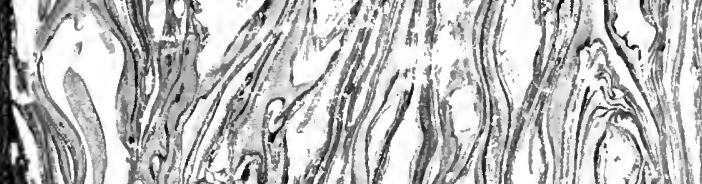

A)

visent

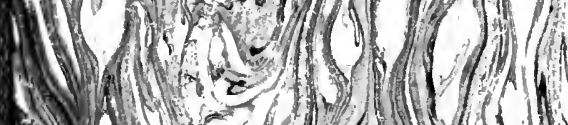

6) A

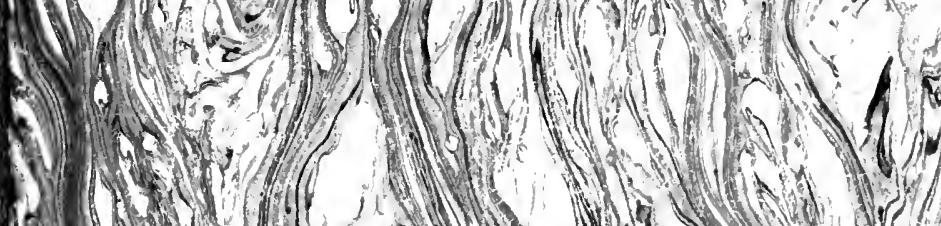
16.

(1)

8)

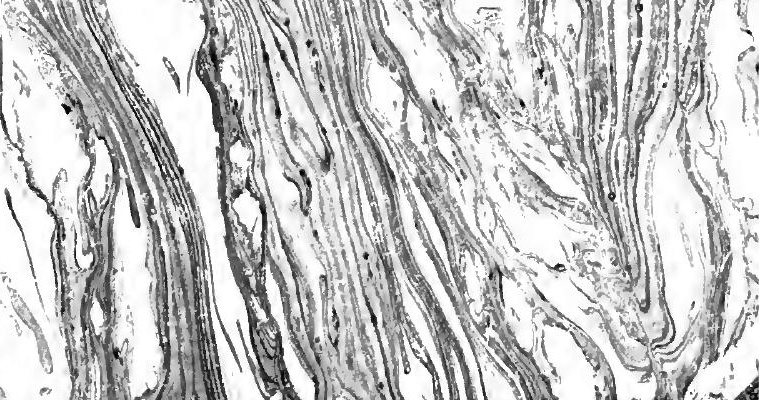







\title{
Lehrbuch der
}

\section{Geschichtsphilosophie}

Von

\author{
Dr. Georg Mehlis
}

Professor an der Universität Freiburg i. Br.

Berlin

Verlag von Julius Springer

1915 
Alle Rechte, insbesondere das der

Ubersetzung in fremde Sprachen, vorbehalten.

Schutzformel für die

Vereinigten Staaten von Amerika:

Copyright 1915 by Julius Springer in Berlin. 
Sinem rerehrten Lehrer

Herrn Geheimrat Professor Dr. Heinrich Rickert in Dankbarkeit gewidmet

$$
\text { volil Verfasser }
$$





\section{Vorwort.}

Wir haben unser Buch Lelurbuch genannt, weil w die Resultate der modernen idealistischen Gerehichtephilo:ophie für Lehrzwecke geordnet und nach Problemen gegliedert hat. Meine geschichtsphilosophische Anffassung bant sich in der Hauptsache anf der Geschicht-philosophis Heinrich Rickerti auf. Sie hat den Vermch gemacht, von einer Wisenschaftstheoric der Geschichte ansgehend, bis zu ciner inhaltlich miversalhistorischen Konstruktion rorzudringen. Von idealisticchem Geist erfüllt, ist sie der Tree der Kultur restlos zugewendet. Den Sinn der Kultur in ihrer Vidgentaltigkeit sucht sie zu renten, und den Simn des Weltgeschehens möchte sie verstehen aum der Erfüllung und C̈borwindung dieser irdischen Kulturwirklichkeit.

April 1915.

Georms Mehlis. 


\section{Inhaltsverzeichnis.}

Torbemerkungen

Erster Teil.

Probleme der Geschichtsphilosophie oder 'Theoric der Geschichte und Iniversalgeschichte.

Erstes Buch.

Geschichtsphilosophische Grundiragen.

1. Kapitel. Allgemeiner Charakter der Geschichtsphilosophie und ihrer Probleme . . . . . . . . . . . . . . . . . . . .

a) Philosophie, Geschichte und Leben . . . . . . . . . . . . . . . 7

b) Die rerschiedonen Ziele der Philusophiegesehichte und Geschichtsphilosophie 10

c) Der philosophische Faktor in der Philosophiegeschichte. . . . . . . . 11

d) Doppelsinn der Geschichte . . . . . . . . . . . . . . . . . . 14

e) Unirersalgeschichte und Phänomenalität. . . . . . . . . . . . 18

f) Die Grenze der Logik . . . . . . . . . . . . . . . . . . . . 22

உ. Kapitel. Der Begriff der Philosophie . . . . . . . . . . . . ㄴ.4

a) Philosophie als Lehre rom Ganzen . . . . . . . . . . . . . . . . . . 94

b) Weltphilosophie und Lebensphilosophie . . . . . . . . . . . . . . 25

c) Grenzen wissenschaftlicher Theorien . . . . . . . . . . . . . . . . . 20

d) Metaphysik und Wissenschaftslehre . . . . . . . . . . . . . . . . . . 34

e) Philosophie als Formwissenschaft . . . . . . . . . . . . . . . . . . 35

f) Philosophie als Wertlehre . . . . . . . . . . . . . . . . . . . . . 4 .

g) Die religiöse Wertsphäre . . . . . . . . . . . . . . . . . . . tt

h) Die sittliche Tiertsphäre . . . . . . . . . . . . . . . . 44

i) Die theoretische Wertsphäre . . . . . . . . . . . . . . . . 4 .5

k) Die ästhetische Wertsphäre. . . . . . . . . . . . . . . . . 万

1) Idee einer rergleichenden Wertlehre. . . . . . . . . . . . . . . 5l

m) Vorwurf der Ethisierung . . . . . . . . . . . . . . . . . . . . 56

n) Das Problem der Metaphysik . . . . . . . . . . . . . . . . . . is

o) Philosophie als Weltanschanmgslehre und als strenge Wissenschaft . . . . 62

p) Problem der Antinomien . . . . . . . . . . . . . . . . 63

3. Kapitel. Der Begrift der Geschichte . . . . . . . . . . . 68

\$ 1 . Gesehichte und Leben ... . . . . . . . . . . . . . . . (is

§. Geschichte als Teil der ästhet ischen Kultur . . . . . . . . . . . . . 73

a) Das Gemeinsame ron Kunst und Geschichte. . . . . . . . . . i.

b) Das Gegensätzliche ron Kunst und Geschichte. . . . . . . . . . :

c) Die Kunst bringt das Allgemeine im Besonderen zur Darstellung is

(1) Die Geschichte sucht das Individuelle zu begreifen . . . . . . sil

c) Die Allgemeinheiten der Geschichte. Wer historische Begriff . . . \$1

f) Die historische Persöulichkeit. . . . . . . . . . . . . 82

g) Die historischen Gruppenbegriffe . . . . . . . . . . . . . 83

h) Der historische Typus. . . . . . . . . . . . . . . . 84

i) Dic Intuition . . . . . . . . . . . . . . . . . . 
§3. Die Historie als Wissenschaft . . . . . . . . . . . . . . . . . . . . 90

a) Sehwierigkeiten einer historisch-wissenschaftlichen Auffassung . . . 92

b) Die historische Objektivität . . . . . . . . . . . . . . . . . . 93

c) Die Idee der Kultur als das Objektive der Gesehichte . . . . . . . 93

d) Das historische Verstehen . . . . . . . . . . . . . . . . . . . 95

e) Das Unsystematische hat keine Wahrheit . . . . . . . . . . . 96

f) Antinomie des historischen und naturwissensehaftlichen Denkens . . 96

g) Das Prinzip des Widerspruehs und die Gesehichte . . . . . . . 98

h) Terhältnis der Pliilosophie zu Geschichte und Naturwissenschaft . 101

i) Das gesehichtsphilosophische Problem bei Kant . . . . . . . 101

k) Gesehichte und Kulturphilosophie . . . . . . . . . . . . . . . 104

1) Der Begriff der Gesehiehtpshilosophic . . . . . . . . . . . 106

m) Geschichte und Gesetz. . . . . . . . . . . . . . . . . 109

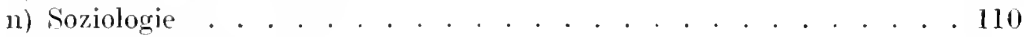

o) Völkerbiologie. . . . . . . . . . . . . . . . . . . 110

1) Völkerpsychologie . . . . . . . . . . . . . . . . 111

q) Rassentheorie . . . . . . . . . . . . . . . . 112

r) Autonomie der Gesehichte. . . . . . . . . . . . . . . . 113

s) Kulturwert und Typus . . . . . . . . . . . . . . 1It

Zweites Bueh.

\section{Geschichtsphilusophische Einzelprobleme.}

1. Kapitel. probleme der reschiehtslogik. . . . . . . . . . . . . 119

§ 1. Do erste Problemkreis. Die Probleme des Zieles . . . . . . . . . . 121

a) Das Interesse der Gesehichte am allgemein Mensehlichen . . . 122

b) Die Besonderheit menschlicher Gestaltung . . . . . . . . . . . 12:3

c) Die Indirilualitit . . . . . . . . . . . . . . . . . 124

\$.2. 1) zweite Problemkreis. 1) Po Probleme des historisehen Objektes . . 128

a) Das Geschehen als Objekt der deschichte . . . . . . . . . . . 129

b) Totalität oler Auswahl! . . . . . . . . . . . . . . . . . . . 130

(e) Rationalismus uncl Irrationalismms . . . . . . . . . . . . . . 1333

(1) Die Willenshandlungen de großen Persönliehkeiten . . . . . . . 136

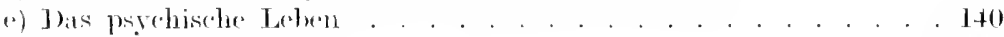

1) 1)as geistign J debell . . . . . . . . . . . I41

g) Gesehichte als Jicich der Freiheit. . . . . . . . . . . . I43

h) Kultur als Ghjekt der desehichte. . . . . . . . . . . 144

i) Kulturtitigkritern. . . . . . . . . . . . . 147

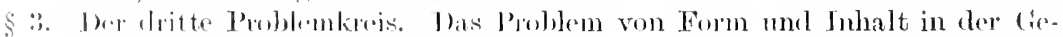
sthichte. . . . . . . . . . . . 148

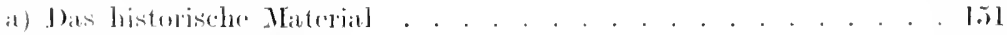

(.) Vorhistorisches Miaterial. . . . . . . . . . . . . . . 1.52

(.) Quellemnaterial . . . . . . . . . . . . . 1.52

(1) 'latsahemmaterial . . . . . . . . . . . . . 153

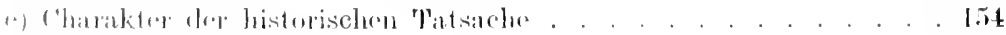

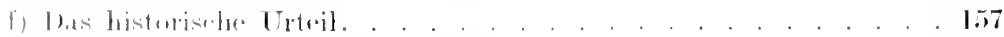

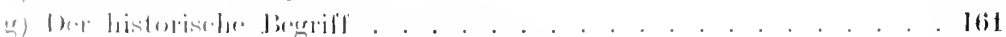

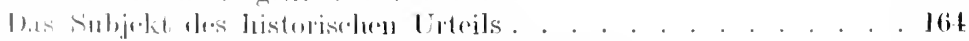

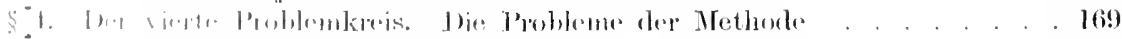

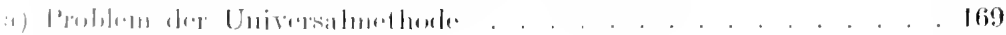

1.) Horristik . . . . . . . . . . . . . . . . . . . .

1.) Ilistolisthe Kritik . . . . . . . . . . . 176

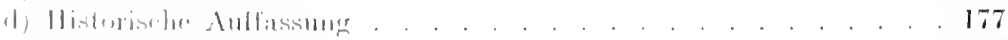

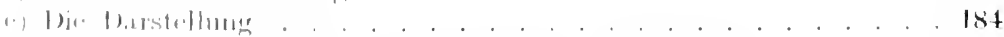

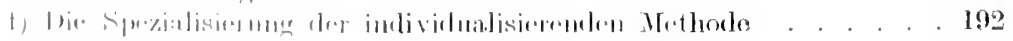

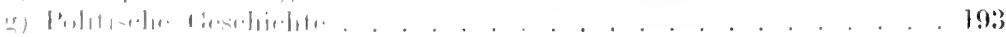


h) Kunstgesehichte . . . . . . . . . . . . . . . . . . . 194

i) Philosophiegeschichte . . . . . . . . . . . . . . . . . . . . . . . . . . . . . . . .

§ 5. Der fünfte Problemkreis. Das Problem der historischen Benrteilung . . . 201

a) Es gibt cine historische Beurteilung . . . . . . . . . . . . 201

b) Historische Beurteilung und geschichtsphilosophische Beurteilung 20:3

c) Ablehnung eines einseitigen Kulturmaßstabes . . . . . . . . . . . . 204

d) Kriterien der historischen Beurteilung . . . . . . . . . . . . . 204

e) Gegensatz der historischen und geschichtsphilosophisehen Beurteilung 20\%

2. Kapitel. Probleme der historischen Wertlehre. . . . . . . . . . . . 212

§ 1. Der erste Problemkreis. Das Problem der Geltung. . . . . . . . . . 219

a) Notwendigkeit absohuter Geltung zum Verstelien dir Fieschichte. 219

b) Anfang der Geschichte . . . . . . . . . . . . . . . . . . . . 221

c) Ende der Geschichte . . . . . . . . . . . . . . . . . . . . . . 2..5

d) Kann ein Kulturwert den anderen ablösen ? . . . . . . . . . . . .26

e) Verhältnis der absoluten Werte zu den Kulturwerten . . . . . . 2:30

1. Wissenschaft und Wahrheit. . . . . . . . . . . . . 2:31!

2. Kunst und Schönheit . . . . . . . . . . . . . . . . . 2:3r

3. Freiheit und sittliches Leben . . . . . . . . . . . . . . 241

Das Heilige nud die Religion . . . . . . . . . . . . . 2.2.2

§ 2. Der zweite Problemkreis. Das Leistungsproblem der Kultumerte . . . 2.;

a) Prinzip der Auswahl . . . . . . . . . . . . . . . . . . . . . . is

b) Die morahische Auswahl. . . . . . . . . . . . . . . . . . . . 25s

c) Die logisehe Auswahl . . . . . . . . . . . . . . . . . . . . . 271

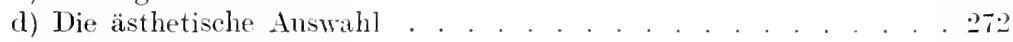

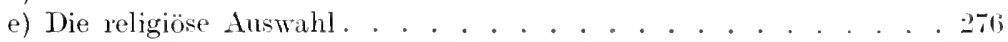

f) Die theoretische Beziehming als Prinzip cler Gliederung . . . . . . 27?

g) Die theorctisehe Beziehung als philosophisehe Vertiefung des Kulturbegriffs . . . . . . . . . . . . . . . . . 282

h) Theoretische Wertbezichung als Erkenntnisprinzip. . . . . . . . $28 t$

i) Der Typus. . . . . . . . . . . . . . . . . . . . . . . . . . 2911

\$. Der dritte Problemkreis. Das Strukturproblem . . . . . . . . . . . 294

a) Allgemeine logische struktur der Kulturwerte . . . . . . . . . 294

b) Sonderstruktur der Kulturwerte . . . . . . . . . . . . . . . . . . . .

c) Versehiedene Möglichkciten in rer Behandlung rles Strukturproblems $29 s$

d) Die statischen Werte . . . . . . . . . . . . . . . . . 301

e) Quantitative Wertordnung . . . . . . . . . . . . . . . . 3010

f) Qualitative Wertordnung . . . . . . . . . . . . . . . . 302

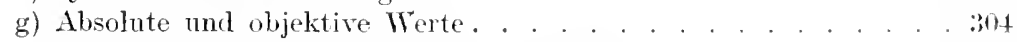

3. Kapitel. Die Probleme der Unirersalgeschiehto. . . . . . . . . . . :306

a) Antinomien . . . . . . . . . . . . . . . . . . . . . . . 307

b) Geschichte als Organon der Philosophie . . . . . . . . . . . . . 308

c) Universalgeschichte im Terhältnis zu Philosophie und Wissensehaft . . . . 311

d) Idee des Fortsehrits. . . . . . . . . . . . . . . . . . . . 312

e) Die lebendige Inhaltlichkeit . . . . . . . . . . . . . . . . . . . . . :31:2

f) Der Begriff der Entwieklung . . . . . . . . . . . . . . . . . . . . . : :31;

g) Wertauwachs und Wrertsteigerung. . . . . . . . . . . . . . . . . . . :31t

Spezialprobleme der Unirersalgeschichte . . . . . . . . . . . . . 3Is

$\$$ 1. Das erste Problem der Universalgeschiehte: Das Verhälnis von Wertund Zeit 320

$\$ 2$ Das zweite Problem der Universalgeschichte: Die möglichen Sinngebungen des historisehen Gesehehens

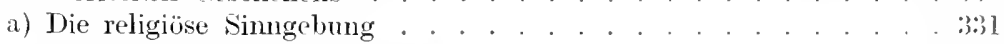

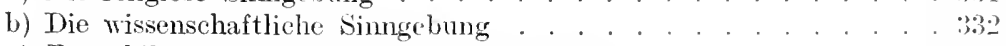

c) Die philosophisch-theoretische simngebung . . . . . . . . . . . :338

d) Die moralische Sinngebung . . . . . . . . . . . . . . . . . :34t

(.) Die ästhetische Sinngebung . . . . . . . . . . . . . . . . . . . . . . . . . . . . . . . .

f) Probleme einer umfassenden und eimheitlichen Sinngebung . . . . : :36 


\section{Zweiter Teil.}

Die Geschichte der Geschichtsphilosophie.

Einleitung

1. Kapitel. Das Werden des geschichtsphilosophisehen Gedankens in dem griechischen Kulturkreise . . . . . . . . . . . . . . 345

a) Die Idee des Griechentums. . . . . . . . . . . . . . . . . . . . 345

b) Das Charakteristisehe des griechischen Kulturbewußtseins . . . . . . . . 346

c) Die Bewertung des Allgemeiner. . . . . . . . . . . . . . . . . . . . . 349

(d) Die Nation als höchster sozialer Wert . . . . . . . . . . . . . . 350

e) Fehlen des Fortsehrittgedankens . . . . . . . . . . . . . . . . . . . 353

f) Rationalismus tes Griechentums . . . . . . . . . . . . . . 354

g) Kontemplatives Leben . . . . . . . . . . . . . . . . . . . . . . . . 353

h) Keine Philosophie der Kultur. . . . . . . . . . . . . . . . . . . . . 355

i) Anfänge der geschichtsphilosophisehen Spekulation bei den Gricehen . . . 357

k) Problem der beielen Wege . . . . . . . . . . . . . . . . . . . . 3.57

h) Der Begriff der Entwicklung bei Empedokles . . . . . . . . . . . . . 360

iii) Der Weltprozeß des Anaxagoras . . . . . . . . . . . . . . . . . . . 363

11) Der Platonische Idealismus . . . . . . . . . . . . . . . . . . . 365

(1) Der Begriff der Entwicklung bei Aristenteles. . . . . . . . . . . . . . 37.)

2. Kapitel. Jie Entfaltung des gesehichtsphilosophisehen Gedankens in der "hristlichen Philosophic. . . . . . . . . . . . . . . . 380

1. ])ie christliche Geschichtsphilosophie. . . . . . . . . . . . . . . 380

а) Die Messiasidee . . . . . . . . . . . . . . . . . . 381

Ђ) Prinzipien des Wertgeschehens . . . . . . . . . . . . . . . . 383

c) Apollonins von Tyana . . . . . . . . . . . . . . . 384

(1) Die beiden Wege bei Philon. . . . . . . . . . . . . . . . . 386

(.) Die drei stufen der Rïekkehr. . . . . . . . . . . . . . . . . 388

f) Christentum nnd Universalgeschichte . . . . . . . . . . 388

g) Die Stufen der Offenbarming. . . . . . . . . . . . . . . 389

h) Bie testalt ('hristi . . . . . . . . . . . . . . . . . 390

i) Die Weltgeschichte als Drama von siindenfall nund Erlösung . . 391

k) Die (ieschichtsphilosophie der Gnesis. . . . . . . . . . . . . . 39:3

1) J)ic Geschichtsplitosophio des Originess. . . . . . . . . . 3960

111) Roegressiss bei Plotin . . . . . . . . . . . . . . . . . . . 3977

n) Augustins Lahe von den beiden Staaten. . . . . . . . . . . . 3:s

1) Jie Konstruktion des welthistorischen Prozesses bei Augustin . . 401

p) Hie Weltgeschichte ()ters ven Freising . . . . . . . . . . H(1:3

(1) Dantes deschichtephilosophie und Thomas ron Aquino . . . . 408

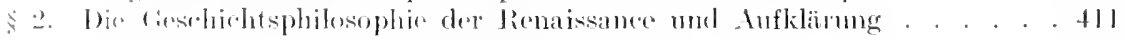

a) Macehiavelli und die Jdere der Nation . . . . . . . . +11

b) Methodologiselore Prolleme . . . . . . . . . . . . . 4:3

(1) Balcon. . . . . . . . . . . . . . . . . 41:3

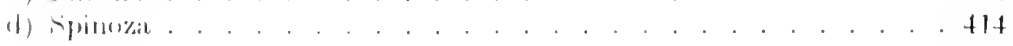

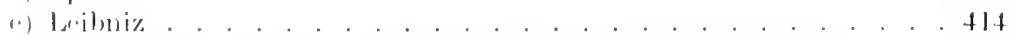

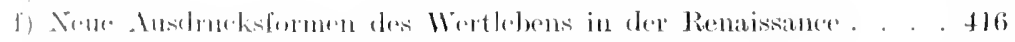

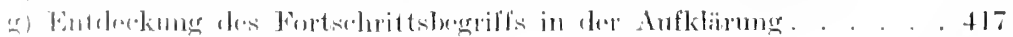

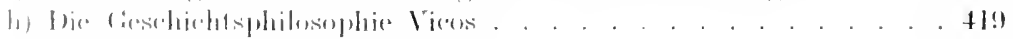

1) cindented . . . . . . . . . . . . . . . . . . .

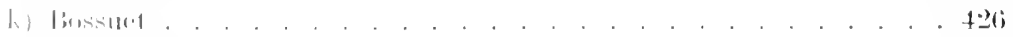

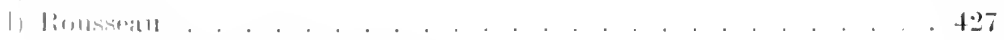

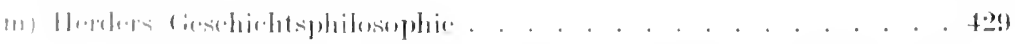

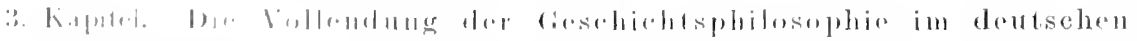

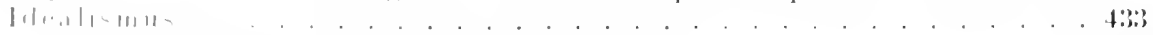

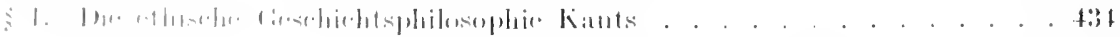

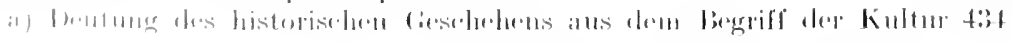


b) Vollendung der moralischen Probleme in der Creschiehtsphilosophic 4:35

c) Natur und Kultur . . . . . . . . . . . . . . . . . . . . . . 436

(l) Die Bedentung der Leidenschaften . . . . . . . . . . . . . . 4:37

e) Bedeutung des Gegensatzes . . . . . . . . . . . . . . . . . . 4:35

f) Der historische Sündenfall . . . . . . . . . . . . . . . 4:36

g) Das Ziel des historischen Geschehens. . . . . . . . . . . . . . 4;8

\$ 2. Die ethisch orientierte Geschichtsphilosophie Fichtes . . . . . . . . . 44l

a) Geschichte und Geschichtsphilosophic . . . . . . . . . . . . . 411

b) Vernunftfreiheit als Endzweck . . . . . . . . . . . . . . . . 41

c) Ursprung der Menschheit . . . . . . . . . . . . . . . . . . $44:$

(l) Die fünf Stadien . . . . . . . . . . . . . . . . . . 44

e) Der rationale und der irrationale Geschehensfaktor . . . . . . . 443

f) Der Sündenfall der Geschichte . . . . . . . . . . . . . . . . 44.

g) Der Aufbau einer neuen Geistesknltur . . . . . . . . . . . . . 446

h) Die Vermunfticleen . . . . . . . . . . . . . . . . . . . . . . 447

i) Die Helden der Feschichte . . . . . . . . . . . . . . . . . . 4t7

k) Konkrete Anffassung der historischen Indiridualitäten. . . . . . 4tS

1) Der Staat und die Kulturwerte . . . . . . . . . . . . . . . . 44 !

§ 3. Die romantisehe Geschichtsphilosophic . . . . . . . . . . . . . . . 4.jt

a) Schiller's Philosophie der Kunst . . . . . . . . . . . . . . . . 4.i:;

b) Noralis . . . . . . . . . . . . . . . . . . . . . 4. . . . . . . . . . . . . . . . . . . . . . . . . . . . . . .

c) Friedrich Schlegel . . . . . . . . . . . . . . . . . . . . . 4. 4

d) Schellings Geschichtsphilosophie ats Tollendung dor romantischen Idee . . . . . . . . . . . . . . . . . . . tis

e) Der tragische Charakter der lieschichto . . . . . . . . . . 458

f) Der ideale und der reale Faktor. . . . . . . . . . . . . . . . 459

g) Die chrei Mrelten . . . . . . . . . . . . . . . . . . . . . 4. 49

h) Geschichtsphilosophic und empirisehe Botrachtung des Geschehens 459

i) Die historische Kunst. . . . . . . . . . . . . . . . . . . . 460

k) Der künstlerische Wert als leitend. . . . . . . . . . . . . . . 461

1) Stadien der Menschheitsentwicklung. . . . . . . . . . . . . . . 46:"

m) Politische Entwicklung . . . . . . . . . . . . . . . . . . . 464

n) Religiöse Entwicklung . . . . . . . . . . . . . . . . . . . 46i

o) Künstlerische Entwicklung . . . . . . . . . . . . . . . . . . 46.

p) Eude der Geschichte . . . . . . . . . . . . . . . . . . . . . 467

q) Die religiöse Geschiehtsphilosophie des späteren schelling . . . . 46s

\$ 4. Die theoretische Geschichtsphilosophie . . . . . . . . . . . . . . . . 471

a) Stellung der Geschichtsphilosophie im System . . . . . . . . . 47l

b) Die Sphäre des objektiren Geistes . . . . . . . . . . . . . . 47:

c) Hegels absolute Werte . . . . . . . . . . . . . . . . . . . . 47:3

d) Die Uhjektivität der Geschichte. . . . . . . . . . . . . . 47t

e) Die Ternunft des historischen (ieschehens . . . . . . . . . . . 47.

f) Die Freiheit als Ziel der Terumn't . . . . . . . . . . . . . . . 47

g) Das Ende der Geschichte . . . . . . . . . . . . . . . . . . . 47

h) Die rernünftige Wirklichkeit . . . . . . . . . . . . . . . 479

i) Die Berlentung des Helden . . . . . . . . . . . . . . . . . . 47!

h) Die Volksgeister . . . . . . . . . . . . . . . . . . . . . 4\$1

1) Stadien des Weltgescheherns. . . . . . . . . . . . . . . . . . 4si

Die Geschichtsphilosophie in 19. Jahuhundert. . . . . . . tht

a) Die Philosophic des Positivismus . . . . . . . . . . . . . . 450

b) Die materialistische Geschichtsphilosophic. . . . . . . . . . . . 497

c) Naturwissenschaftliche Auflassung der Geschichte . . . . . . . . 4!s

d) Sehellings Philosophie der Mythologie und offenbarung . . . . . in

e) Schopenhauer . . . . . . . . . . . . . . . . . . . . . 51

f) Die Cieschichtsphilosophie Carlyles . . . . . . . . . . . . . . . . inl

g) Nietzsches Bewertung der Jurividualität . . . . . . . . . . . . . il:? 
1) Der Darwinismus . . . . . . . . . . . . . . . . 503

i) Das Cresetz der Differenzierung . . . . . . . . . . . . . . 505

k) Die Geschichtsphilosophie der Gegenwartskultur . . . . . . . . 505

1) Der Nenkantianismus . . . . . . . . . . . . . . . . . 506

m) Lotze und Windelband . . . . . . . . . . . . . . . . 507

n) Heinrich Rickert . . . . . . . . . . . . . . . . . . . . 507

(1) Die Gesehiehtsphilosophie Diltheys. . . . . . . . . . . . . . . 509

p) Georg Simmel . . . . . . . . . . . . . . . . . . . . . . 511

4) Die Marburger Schule . . . . . . . . . . . . . . . . . . 511

r) Croce und Bergson . . . . . . . . . . . . . . . . . . .512

Dritter Teil.

\section{Jas System der Geschichtsphilosophie oder inhaltliche Fonstruktion der} Universalgeschichte.

1. Kapitel, Der Sinn des historisehen Gesehehens . . . . . . . . . 1:3

a) Dic Probleme der Geschichtsphilosophie und ihre Lösung . . . . . . . . .53

b) Wahrheitsgehalt einer miversalhistorischen Konstruktion . . . . . . . 514

(.) Das historische und naturwissenschaftliche Bewrotsein . . . . . . . . . 5l4

(l) Das Irrationale der Universalgeschichte . . . . . . . . . . . . . . . . 515

c) Das universal-historisehe fieschehen . . . . . . . . . . . . . . . 5l5

f) Die Idee rler Kuntur . . . . . . . . . . . . . . . . . . . . . . .16

«) Kultur, Leben und Tod . . . . . . . . . . . . . . . . . . . . . . .ls

h) Kultur und persënhedes Ichen . . . . . . . . . . . . . . . . . . 521

i) Die Idee rer Zeitlichkeit . . . . . . . . . . . . . . 521

k) Der Staudpunkt der schöpferischen Tat . . . . . . . . . . . . . . .222

1) Tollcndungswerte und Beitragswerte . . . . . . . . . . . . . 523

m) Persönlichkeit unl Wertidee . . . . . . . . . . . . . . . . . . . . . .527

11) Sim der Kulturbewegung . . . . . . . . . . . . . . . . . 525

(1) Die doppelte Bestimmung des historisehen Geschehens . . . . . . . . . 53l

p) Die Typen des Kulturlebens . . . . . . . . . . . . . . . . . . . . . 534

4) Eliederung des miversalhistorisehen Geschelens . . . . . . . . . . . 534

r) Die Werteindlichkeit . . . . . . . . . . . . . . . . . . . 536

s) J)ie J) 1ppetheit des Vermunftgegensatzes . . . . . . . . . . . . . . . 539

2. Kapitel. Allemeine Komstruktion des universalhistorisehen Pro\%essece. . . . . . . . . . . . . . . . . . . . . .

a) Der Infing des M[onschengeschlechts . . . . . . . . . . . . 545

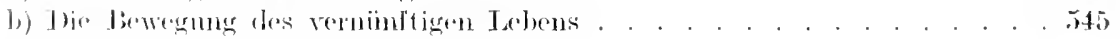

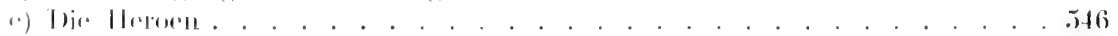

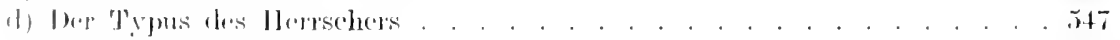

(.) lir rymble des tonles . . . . . . . . . . . . . . . . .48

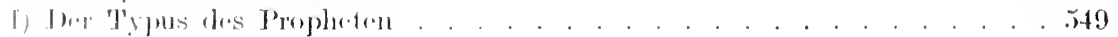

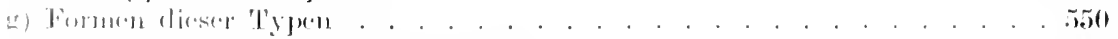

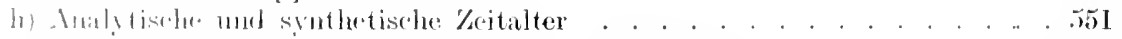

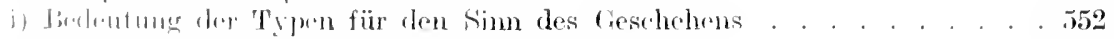

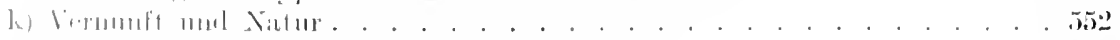

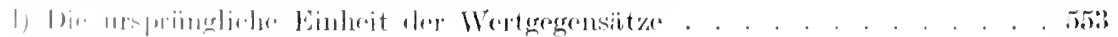

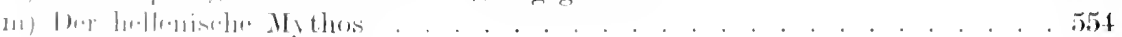

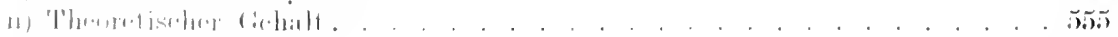

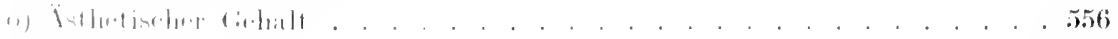

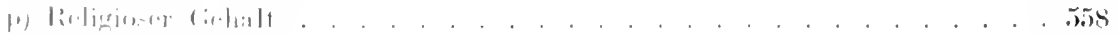

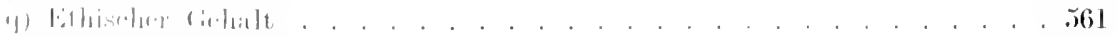

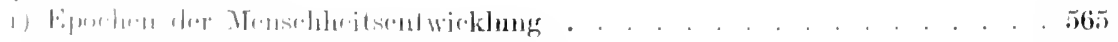

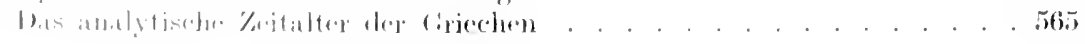


3. Kapitel. Die religiöse Entwicklung . . . . . . . . . . . . . . . . . . . .

a) Die Dimensionen des religiösen Bewrußseins . . . . . . . . . . . . . . . 566

b) Typus der griechischen Religion . . . . . . . . . . . . . . . . . . .668

c) Pythagoras . . . . . . . . . . . . . . . . . . . . . . . . . . . . . . . . . . . .

d) Heraklit . . . . . . . . . . . . . . . . . . . . . . . 570

e) Empedokles . . . . . . . . . . . . . . . . . . . . . . . . . . .

f) Aristipp . . . . . . . . . . . . . . . . . . . . . . . . . . . . . .

g) Die Stoa . . . . . . . . . . . . . . . . . . . . . 5;

h) Anfänge der Mystik . . . . . . . . . . . . . . . . . . . . 574

i) Christus . . . . . . . . . . . . . . . . . . . . . . . . . . . . . . . . . .

k) Vertiefung des religiösen Bewußtseins . . . . . . . . . . . . . . 576

l) Plato . . . . . . . . . . . . . . . . . . . . . . . . . . . . . . . . . . . . . . . . .

m) Aristoteles . . . . . . . . . . . . . . . . . . . . . . . . . . . 577

n) Der synthetische Uharakter der christlichen Welt. . . . . . . . . . 5\%7

o) Die Lehre Christi . . . . . . . . . . . . . . . . . . . . . . 578

p) Das Johanniserangelium . . . . . . . . . . . . . . . . . . . . . 581

q) Die Idee des tausendjährigen Reiehes . . . . . . . . . . . . . . . . . .s I

r) Die Idee des dritten Reiches . . . . . . . . . . . . . . . . . . 582

s) Das historische Christentum . . . . . . . . . . . . . . . . . 58:3

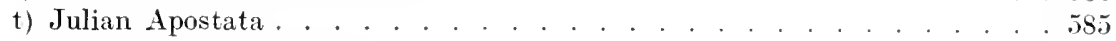

ı) Organisation des synthetischen Zeitalters . . . . . . . . . . . 586

v) Die Idee der Kirche. . . . . . . . . . . . . . . . . . . . 586

w) Die endliche und unendliche Gottheit . . . . . . . . . . . . 587

x) Die Gnosis . . . . . . . . . . . . . . . . . . . . . . . . . . . . . . . .

y) Plotin . . . . . . . . . . . . . . . . . . . . . . . . . . . . . . . .

z) Augustin . . . . . . . . . . . . . . . . . . . . . . . 590

aа) Die Idee des Papsttums . . . . . . . . . . . . . . . . . . . . . . . .91

bb) Hugo von St. Victor . . . . . . . . . . . . . . . . . . . . . . . . 59:3

ce) Franz ron Assisi . . . . . . . . . . . . . . . . . . . . . . . . . . 594

dd) Das päpstliche Herrsehertum . . . . . . . . . . . . . . . . . . . . . 59;

еe) Bonifaz VIII. . . . . . . . . . . . . . . . . . . . . . . . . . . . 596

ff) Meister Eckhart . . . . . . . . . . . . . . . . . . . . 596

gg) Das neue analytische Zeitalter . . . . . . . . . . . . . . . . 98

hh) Julius II. . . . . . . . . . . . . . . . . . . . . . . . . . . . . . 599

ii) Savonarola . . . . . . . . . . . . . . . . . . . . . . . . . . . . 600

kk) Die Reformation . . . . . . . . . . . . . . . . . . . . 601

li) Protestantismus und Katholizismus . . . . . . . . . . . . . . $60^{\circ}$

mm) Jakob Böhme . . . . . . . . . . . . . . . . . . . . . . . 601

nn) Nicolaus ron Cues. . . . . . . . . . . . . . . . . . . . . . . 606

юо) Pascal . . . . . . . . . . . . . . . . . . . . . . . . . . . . . . . . . . . . . . . .

pp) Spinoza. . . . . . . . . . . . . . . . . . . . . . . . . . . . . . . . . . . .

qq) Die Naturreligion . . . . . . . . . . . . . . . . . . . . . . . . 60!

rr) Das Freidenkertum . . . . . . . . . . . . . . . . . 610

ss) Sozianismus . . . . . . . . . . . . . . . . . . . . . . 610

tt) Deismus . . . . . . . . . . . . . . . . . . . . . 611

uu) Die Romantik . . . . . . . . . . . . . . . . . . . 611

4. Kapitel: Die ästhetisehe Entwieklung. . . . . . . . . . . . 614

a) Das ästhetische Grundverhältnis . . . . . . . . . . . . . . . 614

b) Die ästhetische Idee . . . . . . . . . . . . . . . . . 61.

c) Die ästhetische Individualität . . . . . . . . . . . . . . . 616

d) Typische und eharakteristisehe Kunstform . . . . . . . . 616

e) Naive und sentimentalisehe Kunst . . . . . . . . . . . . . . 617

f) Wertgegensatz und Wertharmonie. . . . . . . . . . . . . . . . . . 617

g) Die verschiedenen Formen des künstlerischen Lebens . . . . . . . . . . 619

li) Der Geist der Plastik und der (ieist der Musik . . . . . . . . . . . . 62011

i) Gliederung ästhetischer Entwieklung . . . . . . . . . 6:0 
k) Die Dichtung Homers . . . . . . . . . . . . . . . . . . . . . . . . 622

1) Die griechische lyrik . . . . . . . . . . . . . . . . . . . . . . . . 624

m) Das griechische Drania . . . . . . . . . . . . . . . . . . . . . . . 625

1) Die griechische Plastik . . . . . . . . . . . . . . . . . . . . . . 628

o) Die Kunst des Mittelalters . . . . . . . . . . . . . . . . . . . . . . 632

p) Die mittelalterliche Hichtkunst . . . . . . . . . . . . . . . . . . . . 634

q) Dic Renaissance . . . . . . . . . . . . . . . . . . . . . . . . . . 635

r) Die Frührenaissanee . . . . . . . . . . . . . . . . . . . . . . . 636

s) Michelangelo . . . . . . . . . . . . . . . . . . . . . . 636

t) Corregio . . . . . . . . . . . . . . . . . . . . . 640

u) Shakespeare . . . . . . . . . . . . . . . . . . . . . . . 641

ץ) Das neue Kunstideal und die Tlee der Musik . . . . . . . . . . . . . 64:3

w) Die romantische Kunstform . . . . . . . . . . . . . . . . . . . . . 644

x) Wolfgang Goethe . . . . . . . . . . . . . . . . . . . . . . . . . . . 645

y) Die Musik des bel canto . . . . . . . . . . . . . . . . . . . . . . . . 647

․ Kapitel. Jie philosophisehe Entwicklung. . . . . . . . . . . . . . 650

a) Iie Philosophie im Verhältnis zu ren anderen Werten . . . . . . . . . 650

b) Der philosophische Grundgegensatz . . . . . . . . . . . . . . . . . . 652

c) Wertfeindlichkeit und Versöhnung. . . . . . . . . . . . . . . . . . . . 653

(1) Verhüllung der Wertgegensätze hei den Griechen. Die Vorsokratiker . 655

(2) Die Sophisten und folirates . . . . . . . . . . . . . . . . . . . 65̃

f) Demokrit unel Plato. . . . . . . . . . . . . . . . . . . . . . . . 658

g) Thas System des Aristoteles . . . . . . . . . . . . . . . . . . . . . 660

1) Begrenztheit der griechisehen Philosophie . . . . . . . . . . . . . . . 662

i) Jas alexandrinische Zeitalter . . . . . . . . . . . . . . . . . . . . . 66:3

k) Das Siystem Plotins . . . . . . . . . . . . . . . . . . . . . . . . 664

1) Die Philosophio des Mittelalters . . . . . . . . . . . . . . . . 667

17) Augustin . . . . . . . . . . . . . . . . . . . . . . . . . . . . . 668

11) Thomas von Aquino . . . . . . . . . . . . . . . . . . . . . . . . . 670

o) Remaissance und Aufklärung . . . . . . . . . . . . . . . . . . . . 672

p) Das Fystem Deseartes'. . . . . . . . . . . . . . . . . . . . . . . . 673

1) Jas System Spinozas . . . . . . . . . . . . . . . . . . . . . . . 674

1) Jas Kystem Leiloniz' . . . . . . . . . . . . . . . . . . . . . . . . 676

s) 1 ha analytische Geist der Aufklärung . . . . . . . . . . . . . . . . . 677

t) Dic Sirstemc des dentschen Idealismus . . . . . . . . . . . . . . . .679

i1) Kant . . . . . . . . . . . . . . . . . . . . . . . 680

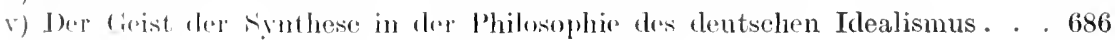

w) livhts. . . . . . . . . . . . . . . . . . . 686

х) Sichelling . . . . . . . . . . . . . . . . . . . . . . . 688

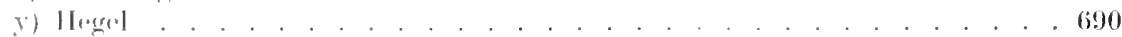

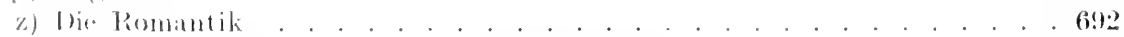

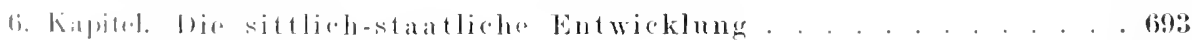

a) Jole ethisehe (imuldgegensatz . . . . . . . . . . . . . . . . . 093

1) bio Ethik llomors . . . . . . . . . . . . . . . . . . . . 694

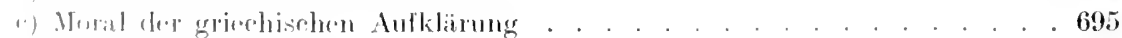

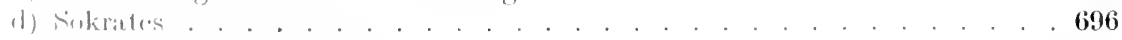

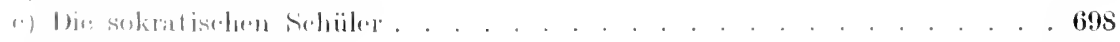

1) Platess sithlicho lathe . . . . . . . . . . . . . . . . . . . . . . 699

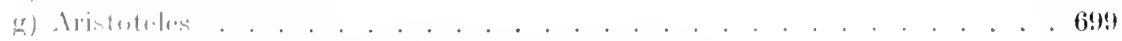

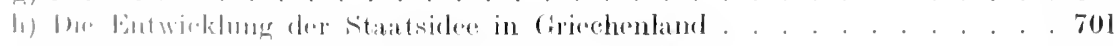

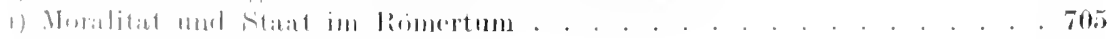

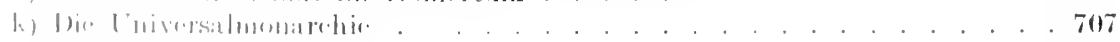

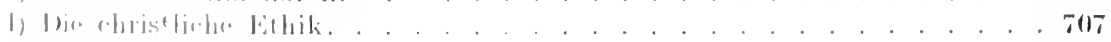

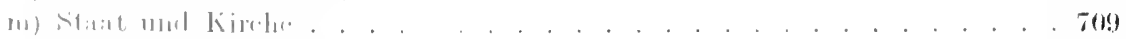

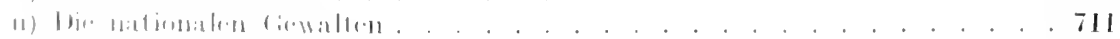

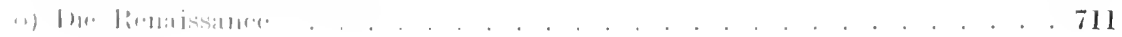


P) Der Individualismus der thuflining Seite

p) Der Individualsmus der Aufklärung. . . . . . . . . . . . . . II3

q) Die französische Revolution . . . . . . . . . . . . . . . 714

r) Kants Reorganisation des sittlichen Bewußtseins. . . . . . . . . . T14

s) Die schöne seele . . . . . . . . . . . . . . . . . . . 716

t) Fichte . . . . . . . . . . . . . . . . . . . . . . . . . . . . . .

11) Die Sittlichkeitsidee der Pomantik . . . . . . . . . . . . . . . . . 719

v) Die Entwicklung des Staatsgedankens durch den deutschen Idealismus . 720 
.

. 


\section{Vorbemerkungen.}

In den letzten Jahrzehnten sind die philosophischen spekulationen über die Geschichte wieder neu und mächtig hervorgetreten und haben eine Fülle wertvoller Gesichtspunkte und Auffassungen ergeben. Unverkennbar maeht sich in den historischen Wissenschaften ïberall das Bestreben geltend, ihre methodischen Grundlagen zu verstehn, und man ïberlegt und besinnt sich, welche Aufgabe wohl der historisehen Wissenschaft im Reiche des Wissens beschieden sein möge. Und die moderne Philosophie, die die große Erbsehaft des Idlealismus von $\mathrm{K}$ ant bis $\mathrm{Hegel}$ angetreten hat, ist mehr als je von historischem Geist erfüllt. Unter diesen Unständen muß es reizvoll erscheinen, eimmal den Ertrag aller dieser auf die Geschichte gerichteten Spekulationen zu ziehen und sie in der Form eines Lehrbuches zu rereinigen. Soll num ein solches Lehrbuch ein philosophisches Werk sein, so muß es eine Einheit haben, d. h. es muß eine ganz bestimmte und notwendige Auffassung rom Wesen der Gesehichte vertreten. Unsere philosophische Uberzeugung ist die des Neu-Idealismus wie er ron Windelband und und Dilthey, Simmel und Münsterberg, Eucken und Sigwart, besonders aber von Heinrich Rickert in seiner Philosophie der Werte vertreten wird. Auf Grund dieser Wertphilosophie stellen wir das geschichtsphilosophische Problem, und ron ihr aus ergibt sich uns eine notwendige Auffassung des historischen Lebens. Wem wir aber ron einem bestimmten philosophischen Standpunkt, ron der Philosophie der Werte her, an die Geschichte herantreten, so werden wir im Vorbeigehen anch rliese Philosophie erläutern müssen, da unser Lehrbuch die Geschichtsphilosophie des Neu-Idealismus darśellt. Die Geschichtsphilosophie ist ja nur der verhältnismäßig kleine Teil eines großen Systems, und wir können ummöglich den Teil hegreifen, ohne die Grundidee des Ganzen zu besitzen. Wir müssen die allgemeine Natur des Ganzen kemnen und wissen, wie dieser Teil mit dem Ganzen zusammenhängt, wo seine Stelle im System ist, und welche Bedentung er für das Ganze besitzt. Wie überhaupt im Reiche des Wissens, so hängt hesonders in der Philosophie alles auf das engste zusammen, und das erschwert die reinliehe. Darstellung eines Einzelgebietes, denn wir lanfen Gefahr, immer wieder auf benachbartem Gebiet zu verweilen, um den Charakter des Spezialproblems durch Vergleich deutlich zu machen. Vor solchen Abwegen musich ein Lehrbuch der Geschichtsphilosophie ganz besonders hüten, denn es soll ein Leitfaden sein zum Verstehen des Wichtigen und Notwendigen. Auch muB die kritischpolemische Haltung hinter der dogmatischen Darstellung positiver Ergelmisse zurücktreten. Natürlich werden wir uns gelegentlich mit jenen auseinander- 
zusetzen haben, welche die Geschichte und ihre Philosophie anders verstehen als wir. Aber wir müssen uns hier auf das Notwendigste beschränken und dürfen die eigene Auffassung durch ein Übermaß der Erörterung fremder Lehrmeinungen nicht rerdunkeln.

Wodurch sich ein solehes Lehrbuch der Gesehichtsphilosophie, wie wir es verstehen, von einem Lehrbuch der historischen Methode im Sinne Bernh eim s ${ }^{1}$ ) unterscheidet, soll num im folgenden auseinandergesetzt werden. Augenscheinlich treibt anch Bernheim Geschichtsphilosophie, und seine Auffassungen werden manchmal den unserigen begegnen. Bernheim ist der philosophisch interessierte Tertreter der Geschichtswissenschaften. Ihm kommt es vor allen Dingen auf die Methode der Geschichte an, und in der Entwickhng der Methode beriihrt cr alle Einzelheiten der historischen Methodologie: das Finden, die Kritik, das Deuten und Auffassen und schlieBlich die Darstellung. So wichtig dieses Buch auch für das Verständnis der Einzelheiten der historischen Forschung sein mag, so ist darin für die Geschichtsphilosophie doch nur wenig getan. Wir lernen ans ihm weder die Grundbegriffe der historischen Wissenschaften kemnen, noch verstehen wir. was das historische Wissen leistet und im Ganzen der Erkenntnis bedeutet. Wir schen anch nicht, was das Wichtige und Entscheidende in der historischen Methode ist. Gewiß ist die Methodenlehre als Logik der Geschichte ein wichtiger Teil der Geschichtsphilosophie, aber weniger als Methodologie, sondern vor allen als philoso phische Methodenlohre. Unter Methodologie rerstehen wir die Besimmung, welche der Historiker rollzieht, indem er alles das hervorholt und begrifflich fixiert, was er wirklich und tatsächlich tut, wemn er seiner Forschertätigkeit nachgeht. Fis handclt sich hier um eine Art Selbstrerstehen der cigenen Handlungen, das sogleich zu eincr scharfen Selbstkontrolle führt. Wir erfahren, was der Historiker alles beachten. was er rerstehen und im Auge haben muB, soll or die Wahrheit finden und zu historischer Erkenntnis gelangen. Es handelt sich $u m$ eine Anweisung, Geschichtsforschung $z u$ treiben. um wertrolle Ratschläge, wie sie nur der Kenner der Sache, ler Fachmann geben kamn, der selber dic historische Wolt durchforscht hat. Wir lernen das Finden rerstehen, die mamnigfaltigen Denkmäler schätzen, wolehe dic Vergangenheit nus überliefort hat, aus denen wir mun lesen und rerstchen sollen den Geistes- und und Simgrehalt einer längst entrïckten Zeit. Wir werden in das Wesen der

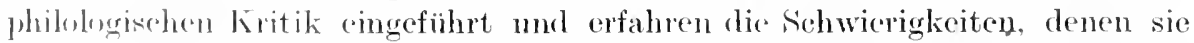
muterworfen ist. Wir lesen in ler Deutumg und Auffasinng, die der Historiker am Vaterial vollzicht, wnd erfahren, was dic Darstellung für das historische

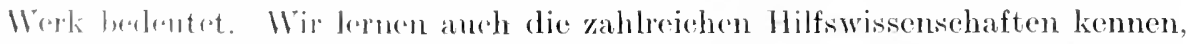
dir in den l)iont der Geschichte treten, wir schen das ganze grofo Feld der Histerid vor uns ansgehreitret, aher wir sehen in der Hauptsache auch nur

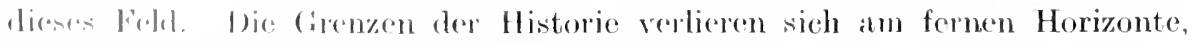

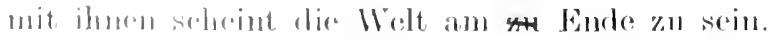

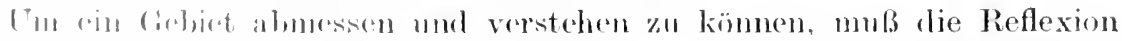

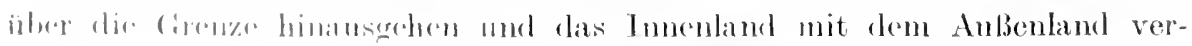

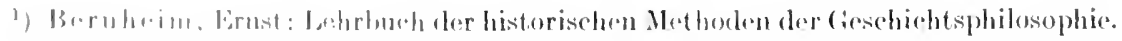
1. Aufl. Iripgig I!Mr. 
gleichen. Erst dann wird es zu einem Verstehen kommen in dem Simne, dạß wir erfahren, was die historische Erkenntnis im Ganzen des Wissens bedeutet. • Erst wenn wir die historische Erkenntnis als eine Art, als eine bestimmte Form der Erkenntnis rerstehen, machen wir sie rergleichbar und können uns über ihren Leistungswert schlüssig werden. Erst bei diesem Hinausgehen wird dann auch das Ziel der Erkenntnis deutlich, die besondere und eigentümliche Aufgabe, die die Historie sich stellt. Bleibt man in den Grenzen stehen. so erweckt man die Auffassung, als ob alles Historie sei, als ob in der Historie das Reich des Wissens beschlossen wäre und alle Gegenstände notwendig historisch anfgefaßt werden müßten. Wir möchten meinen, da $ß$ eine Methodologie. wie sie von Bernheim verfaßt ist, doch in der Hauptsache dabei stehen bleibt. anzuzeigen und geltend zu machen, was der Historiker tut, wen er der historischen Forschung sich befleißigt. Dagegen ist die geschichtsphilosophische Besinnung doch ror allem daranf gerichtet. diese Handlungen der historischen Forschung ihrem ganzen Bedeutungsgehalt nach zu verstehen. Bei der Geschichtsphilosophie handelt es sich nicht nur um eine Besinmmg anf die Prinzipien der historischen Forschung und um die einfache Herausstellung dieser Prinzipien, sondern gleichzeitig um eine Reflexion über ihre Tragweite. ihren Sinn und ihren Wert.

Werke der philosophischen Methodenlehre in dem ron uns gemeinten sinne sind etwa Windelbands geschichtsphilosophische Aufsätzel), Simmels Probleme der Geschichtsphilosophie ${ }^{2}$ ), Dilt theys psychologische und geschichtsphilosophische Arbeiten ${ }^{3}$ ) nnd ror allen Rickerts Grenzen (ler naturwissenschaftlichen Begriffsbildung ${ }^{4}$ ). So Verschiedenartiges anch an diesen Werken der modemen Geschichtsphilosophie unser Interesse und unsere Bewunderung erregt, gemeinsam ist ihnen allen der echt philosophische Geist, mit dem sie den schweren Rätselfragen der Erkenntnis und des historischen Verstehen: nachspüren. Windelband sieht in der Geschichte die gestaltenreiche Fülle des Wirklichen in ihrer Mannigfaltigkeit und Einmaligkeit, die eimmalige schöne Wirklichkeit des Lebens, das zn immer höheren Formen schreitet. Dagegen in der Naturwissenschaft die strenge Gesetzmäßigkeit, das Reich des Müssens, dem wir als Natmresen unbedingt angehören. Dilthey meint, daß die beschreibende Psychologie, der nach ihm die Grundlegung der Geisteswissenschaften und die Erforschung der geistigen Phänomene als das Reich desobjektiven Geistes zufällt, das Leben in seiner unberührten Wirklichkeit erfassen kömute. Da soll nichts umgebildet und umgemodelt werden, sondern alles wird anfgenommen und rerstanden, so wie es ist. Das Verstehen ist die eigentümliche Form der historischen Erkenntnis. Als rerstehender Jensch durchleuchte ich den Gegenstand gleichsam ron innen heraus. ich lasse ihn anfblïhen und

1) Windelband, Prälndien, 1883, 4. Auflage. Tübingen 1911. Naturwissenschaft und Creschichte 1894 .

$\left.{ }^{2}\right)$ Simme1. Probleme der Ceschicutsphilosophie, 1892. 3. Auflage Leipzig 191\%.

3) Dilthey, Einleitung in die Geisteswissenschaften. 1853. Ideen über eine beschreibende und zergliedernde Psychologie, 1894. Aufbau der geschichtlichen Welt in den Geisteswiesenschaften, 1910.

4) Rickert, Grenzen der naturwissenschaftlichen Begriffsbildung. 1896-1902. 2. Auflage, 1913. Kulturwissenschaft und Naturwissenschaft 1899. 2. Auflage Tübingen 1910. 
aufleben. whne ihn zu verändern. Simmel ist besonder's mächtig angezogen ron fler Frage: wie die Erkenntnis ron der eigentiumlichen Geistesbesehaffenheit grober historischer Persönlichkeiten möglieh sei, mol rührt damit in der Tat an cine der sehwierigsten Fragen der geschichtsphilosophischen Spekulation. Welche Allgemeingültigkeit und Notwendigkeit ist den Gestalten der Persönlichkeiten eigen. die der große Historiker schafft? Mit welchen Kategorien sind sie greformt? Wie fügt er das Material der Geschichtsüberlieferung zu einer notwendigen Einheit zusammen? Rickerts Verdienst um die Geschichtsphilosophie ist endlieh ror allem darin zu suchen, daß er die philosophische Inthodenlehre im wesentlichen vollendet und die historische Erkenntnis mit ihren Zielen und Aufgaben sowie der ihr eigentïmlichen Begriffsbildung von aller naturwissenschaftlichen Erkenntnis auf das sorgfältigste gesehieden hat. Wir glanben, daß diese Untersuchungen in gewisser Hinsicht etwas Vollendetes und Abschließendes bieten und stimmen mit ihren Grundergebnissen vollkommen ïberein. Immerhin ist dieses Werk keine ahgesehlossene Gesehichtsphilosophie. Was dort im wesentlichen gelöst ist, das sind die Probleme der Geschichtslogik oder der philosophisehen Methodenlehre. Dagegen sind zwei andere große Gebiete der Geschichtsphilosophie ron Rickert nur in den allgemeinsten Grundzügen entwiekelt, nämlieh die Prinzipien des historischen Lebens, die Geschichtsphilosophie, sofern sie Lehre vonden Kulturwerten ist, und endlich die Geschichtsphilosophie als Univers a lgeschich te. ${ }^{1}$ ) Diese beiden Teile der Geschichtsphilosophie werden daher ron uns eine besonders sorgfältige und eingehende Darstellung erhalten. In der Behandlung dieser Gehicte kann wicder der Untersehied festgestcllt werden, daß die Grundfrage der Prinzipien gelöst ist, während die Lehre von der Universalgeschichte durchaus in der Problematik verharrt. Was aber die Gesehiehtslogik anlangt, (6) muB sie in cinem Lehrbuch für Geschichtsphilosophie notwendig eine von Rickerts methodologischem Hauptwerk sehr verschicdene Darstellung erhalten. Rickart will in scincm Werke dieGrenzen der naturwissenschaftlichen Begriffsloildung klarlegen. Er will die Einseitigkeit und Begrenztheit der matmwisconschaftlichen Begriffshildung zeigen, die ihre souverïne Beherrschung Wre Wirklichkeit, ihe strenge Notwendigkeit, Abstraktheit und Allgemeinheit mit dem Vorhut der Wirklichkeit bogahlen mul. Dor Naturwissensehaft gegenïbro ist die Geschichte in dem simne Wirklichkeitswissensehaft, daß sie mit ihren bregriffen der Wirkliehkeit weit näher kommt, ohne jedoeh die Wirklich-

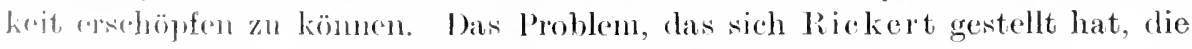

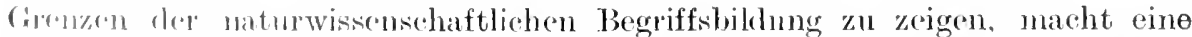

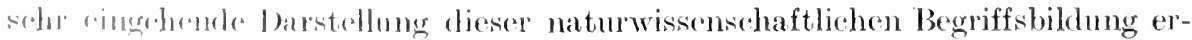

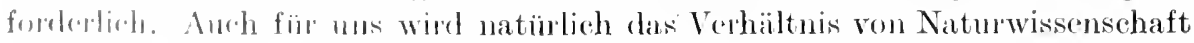

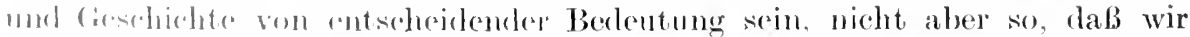

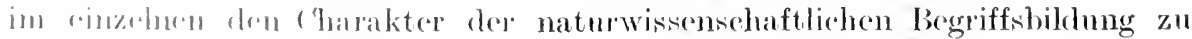

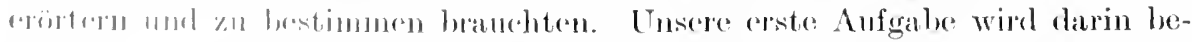

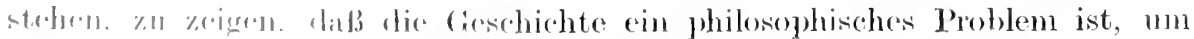

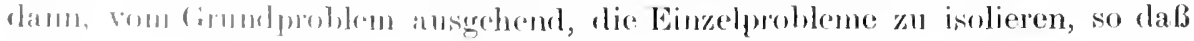

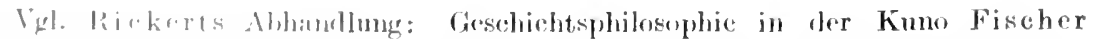

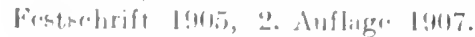


es möglich wird, sie in ihrer Eigenheit zu würdigen und zu verstehen. In diesem ersten Hauptteile, den wir als , Probleme der Geschichtsphilosophie" bezeichnen, wird naturgemüß mehr gefragt als geantwortet. Tor allem bleibt die Universalgeschichte noeh in ihrer Problematik erhalten. Immerhin wirk dabei sehon auf die Pichtung rerwiesen, in welcher die Lösung zu erfolgen hat. In dem zweiten Teile, den wir als den , historisch-kritischen" bezeichnen, wird die Entwicklung der geschichtsphilosophischen Probleme. der Fortgang in der geschichtsphilosophisehen Spekulation rom Griechentum bis zur Gegenwart erörtert. Hier wird sich zeigen, daß die Fragen, die unser erster Teil erörtert hat, in der ganzen Entwicklnng des wissenschaftlichen Lebens immer lebendig gewesen sind. Der letzte Teil, den wir als den systematisehen bezeichnen, versucht damn, die Lösmng der geschichtsphilosophisehen Probleme durch eine universal-geschichtliche Konstruktion zu geben. 
Eister Teil.

\title{
Probleme der Geschichtsphilosophie oder 'Theorie der Geschichte und Universal- geschichte.
}

\author{
Erstes Buch. \\ Geschichtsphilosophische Grundfragen.
}

\author{
Erstes Kapitel. \\ Allgemeiner Charakter der Geschichtsphilosophie \\ und ihrer Probleme.
}

Wenn wir von den Problemen der Gesehichtsphilosophie handeln wollen, (1) müss'n wir uns den Begriff, der die Aufgaben stellt, erst einmal selber (twas genuer anvehen. Wir haben also zu fragen, was Geschiehtsphilosophie sci. Wir müssen eine vorläufige Verständignng über diesen Begriff vorausschicken. Bei dieser vorläıfigen Erklärung der Wortbedeutung ist es ziemlich gleichgii]tig, mit welchem Gegenbegriff wir ihn vergleichen, um seine Problematik hoportreten zu lassen. Wir wählen rein aus pädagogisehen Gründen den Begriff dor Philosophiogeschichte. Unter Geschichtsphilosophic verstehen wil

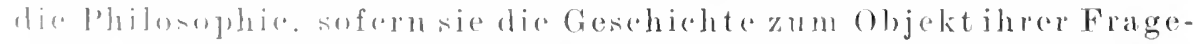

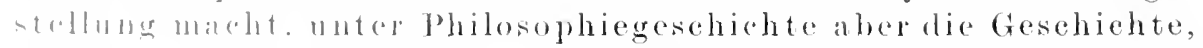
sofoll sie a mit ler Entwieklung des philosophischen Denkens \% 1111 hat. Nach dieser allgemeinen Erklälung ist also nur die Gesehichts-

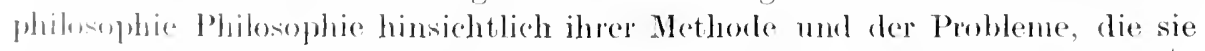

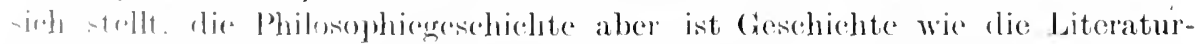

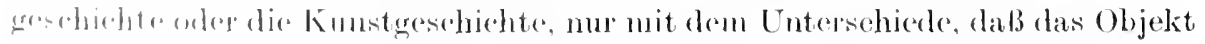

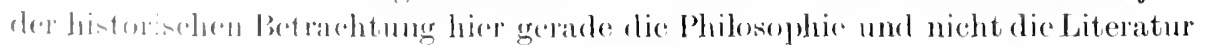

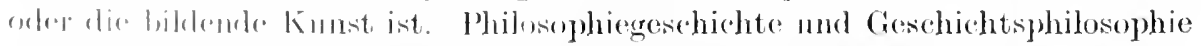

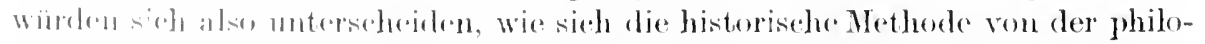

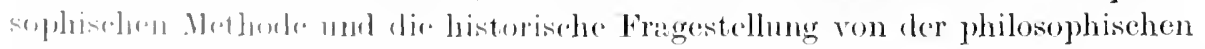

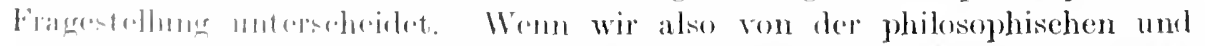

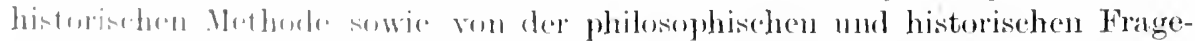

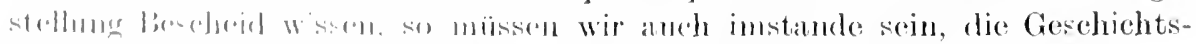

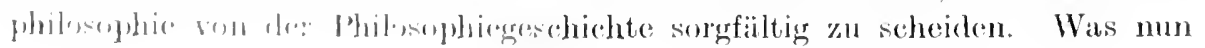


aber der Untersehied der philosophischen und historisehen Fragestellung sei, das müssen wir uns in großen Zügen deutlich zu machen suchen. Sehen wir doch zu, welche Einstellung erforderlich ist. um den Gegenständen der Philosophie und Geschichte zu nahen, oder, in der sphäre des Lebens verweilend, ron der wissenschaftliehen Erkenntnis geschieden zu sein.

\section{a) Philosophie, Geschichte und Leben.}

Nehmen wir ein Beispiel. Wir rerweilen inder Betrachtung eines Menschen, den wir lieben; der geliebte Menseh wird ja immer der Gegenstand umseres gesteigertenInteresses, unserer sorgfältigstenBeobach tung sein. Da kann damn unsere Auffassung und Betrachtung zwei sehr verschiedene Wege gehen, wenn wir uns das Herz nehmen, ihn aus der engen Verbindung und Beziehung zu unserem allerpersönlichsten Selbst abzulösen, und die Frage erheben. was denn an ihm und ron ihm für alle gilt. Gewiß wird der geliebte Mensch immer sehr viel reicher und schöner sein in dem Verhältnis zu uns als in dem Verhältnis zu allen. Gesetzt auch, wir können das Dunkel tilgen, das für die Augen der anderen über der Gestalt des Freundes ruht, wir könnten ihnen deutlich machen, was er ist, und was sein Wesen bedeutet, wir können seine geheime, uns vertraute Gestalt in die liehte Sonne des Kulturbewußtseins rüeken: niemals kann er für alle das sein, was er für uns ist. War er uns ein Helfer und eine Freude und eine Sehönheit des Lebens, so ist er uns vielleicht unendlich viel oder sogar alles gewesen. Aber für die anderen ist er damn nur der Helfer und Tröster oder auch die Freude und Schönheit eines Menschen mit bestimmten Eigenschaften, der eine bestimmte Stellung einnimmt, diese Stellung bis zu einem gewissen Grade ausfüllt, und der zu mir ein ganz bestimmtes Verhältnis der Liebe und Freundsehaft besitzt. In den Verhältnissen des Lebens fühlen wir uns als ganze Menschen, hier sind wir noeh ungeteilt und nicht beschränkt und nicht zerstückelt. Was uns hier gesehieht, geschieht uns in unserer Totalität, in dem ganzen Reichtum unserer Empfindungsinhalte. Und insofern dieser Reichtum wohl immerhin eine Welt genannt werden kamn, ist das, was der Geliebte mir tut, notwendig ein Weltgesehehen. Aber für die anderen wird diese Welt zu einem Etwas ron mehr oder weniger Inhalt, das seine bescheidene Stätte hat auf dem großen Schauplatz des wahrhaftigen Weltgesehehens.

Wenn wir den Mut haben, das rein persönliche Verhältnis aufzugeben, indem wir die Fülle der Gefühlsbeziehungen und die damit rerbundenen Wertqualitäten lösen und löschen und den Menschen zum Gegenstand der philosophischen oder wissensehaftlichen Betrachtung machen, dann ist der Mensch unserer Betrachtung der geliebte Mensch nicht mehr. Dann hat auch er den Totalitätscharakter verloren, er, der früher der Mensch meiner Liebe war, ist nur ein Mensch geworden, dessen Verhältnis zu mir sich vielleicht nur noch in die dürre Formel kleidet, caß er mir nahesteht. Jetzt will ich ihn nicht so betrachten, wie er mir persönlich in den Wirklichkeiten des Lebens gegenübersteht, sondern vielmehr so, wie er dem Auge der Welt erscheint oder vielmehr dem Auge der Welt erscheinen soll. Denn so viel ist mir gewiß, daß das Auge der Welt ihn nicht richtig sieht. Jede wissenschaftliche oder 
philosophische Behauptung wendet sich an das Urteil der Allgemeinheit, und deswegen mul.s sie den Gegenstand der Liebe mud des persönlichen Interesses der individuellen Beziehmgen entkleiden. Sie muß ihn, wie wir zu sagen pflegen, objektiv betraehten, a. h. so, wie er für das urteilende Bewnßtsein der Allgemeinheit ist. Aber jede wissenschaftliche Behauptung ist eine Korrektur an der bestehenden Meimung und dem bestehenden Urteil, jede wahrhaft wissenschaftliche Behamptung schließt eine Kritik in sich ein. Und so will ich den Gegenstand meiner Liebe und meines Interesses, wemn ich ihn objektiviere, so darstellen. Wie er für die Allgemeinheit in Wahrheit ist. Aber anch damit ist das Ziel des wissenschaftlichen und philosophisehen Strebens nur unollkommen angedentet. Was bedentet jene Allgemeinheit, von der hier die Rede ist? Was ist jenes urteilende Bew Btsein. an das sich das Erkemntnisstreben wendet, wenn es den Gegenstand so darstellen will, wie er in Wahrheit ist? Was int jenes Bewnßsein der Welt, ror dem meine simnlichen und persönlichen Beziehungen mwichtig und berlentungslos sind? Was ist jene Hamblung der Erkemntnis anders als ein Herrortretenlassen eines höheren Bewußscoins in seiner Reinheit? Ganz gewiß ist dies Bewußtsein nicht das Durchschnit tshewatsein der Zeit und ebensowenig das Allgemeine der Gattung. Wahrlich, mir kann es gleichgültig sein, wie der Gegenstand meiner Liebe dem Durchichnittsmenschen erscheint. Nicht deswegen entkleide ich ihn der persönlichen Gefühlsbeziehmngen, um ihn den Durchschnittsmensehen adäquat. zu maehen. Wer wiurde wohI seinc Liebe dem Urteil der Welt als dem Urteil des Durchsehnittsmensehen opfern? Ist jenes Allgemeine der Durchschnittsmenseh, damn lohnt es sich doch nicht, etwas anders zu schauen und zu ergreifen, als wie es ganz individuell und persönlich gelebt und gefühlt wird. Es muß wohl cin höheres ideales Bewubtscin sein. an das wir denken, wenn wir den Gegenstand unserer Liche so betrachten wollen, wie er in Wahrheit ist. Wir opfern, religiös gesprochen, das Persönliche und Individuelle der Gottheit. Indem ich aber den Gegenstand meiner Liebe dem erkennenden Bewubtsein zuwende, wie wir das ideale Bewnbtsein einmal nennen mögen, hlcibt er dorh für mich in der Sphäre des Lebens das, was er frïher war. Meine Lixbe mol meine Neigung, die den schönen Gegenstand des Lebens zum Eniversmm macht, don Menschen, der, wie ich zu sagen pflege. mir Alles ist, wirl vor dem strongen Angesicht der Wahrheit getilgt. Aber wem ich auch in der theoretirchen Erkenntnis vom Leben mich entfernen muB, so kehre ich

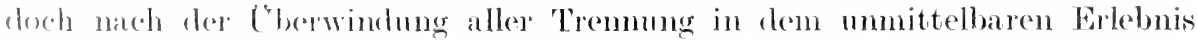

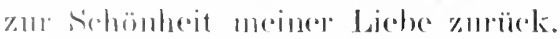

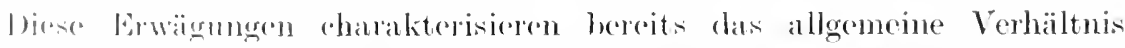

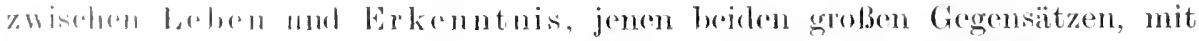

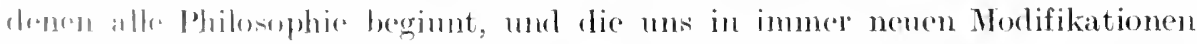

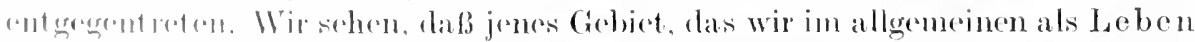

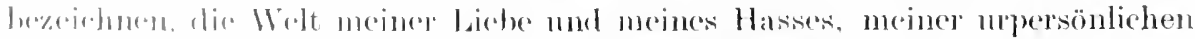

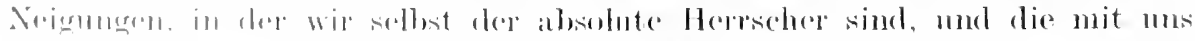

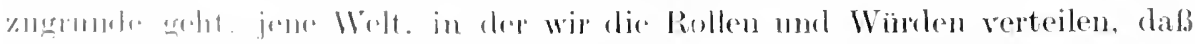

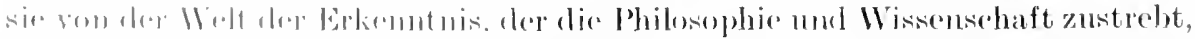

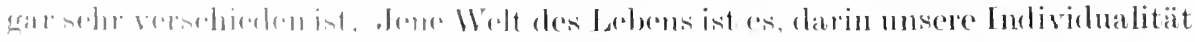

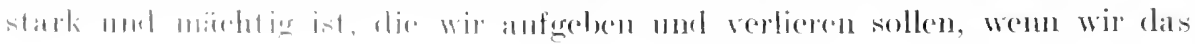


Reich des Wissens betreten. Demn der theoretische Mensch, der zum reinen Subjekt des Erkennens geworden ist, er ist ganz gewiß auch gleichzeitig der unpersönliche Mensch, vor dem die schönen Ilhusionen des Lebens in niehts zerstoben sind.

Die theoretische Besehäftigung mit dem geliebten Gegenstand, die ihn der rein persönlichen Illusionswerte entkleidet, sie geht aber angenscheinlich in rerschiedener Richtung. Die erste Frage ist die Frage des Werdens orler des Ursprnngs. Wie ist er ein soleher Mensch geworden. welche Faktoren haben im einzelnen hierzu beigetragen, welche Umstände haben ihn so gemacht? Das ist die historische Frage. die Frage der Genesis. Dem Lebenden ist die Art des Werdens gleichgültig, wertvoll ist ihm allein rlas ..daß” des geliebten Mensch, die Tatsache, die gottgegebene, die sehön gefügte. daß er so ist, wie er ist. Aber der historische Menseh nimmt dem Individuum seine allmächtige Position und stellt und ordnet es ein in einen Zusammenhang. Nun sind die Eigenschaften des Individums nieht nehr sein selbstverständliches Verdienst, sondern das Erbteil der Generationen. Cnd wenn der historisch denkende Mensch das Individum in dieser Weise in einen Zusammenhang eingestellt hat, daß er nun weiß. wodureh es in den Besitz seiner Eigenschaften und Fähigkeiten gelangt ist. sei es als Gabe der Natur oder durch den Einfluß der sozialen Lmwelt und der Erziehung. damn ist es ihm aneh kein Rätsel mehr. Es ist das ganz gewiß ein Gedanke, welcher dem Menschen, der sein Leben lebt, vollkommen fernliegt. Solange wir die nmmittelbaren Beziehungen des Lebens besitzen und festzuhalten suchen, kann das Wrodure h uns wenig kümmern. Weshalb sollten wir von dem Menschen unserer Liebe und unseres Hasses mehr wissen, wenn wir erfahren, durch welehe Cmstände er zu diesen Eigensehaften gekommen ist. die unsere Liebe und unseren Haß erregen? Wir kennen ihn loch so genan und gut, ohne alles Wissen ron dem Wodurch und dem Woher. Wemn mir jemand entgegentreten und behaupten würde, dieser Mensch ist deiner Liebe und deines Hasses nicht wert. so würde ich seine Unwissenheit mit Entrüstung zurüekweisen. Denn im ummittelbaren Leben der Gegenwart habe ich das Recht, ihn so zu sehen, wie ich will. Ich will ja nur, daß er mein sei. End wenn ich rernehmen sollte, daß dieses Fürmichsein des geliebten Gegenstandes Täuschmng und lüge ist, so werle ich unter Umständen mit Gewalt die alte Inlusion anfrecht zn halten suchen. Diesem Wissen und Erleben der allmächtigen Gegenwart gegenüber kann die historische Fragestellnng nicht viel bedeuten. Sie wird erst mächtig. wemn die Forderung anftritt, das etwas an dem Individuum für alle Bedeutung haben soll. Gewisse Eigenschaften werden dam herausgehoben und als wesentlich betrachtet, die für das Leben nicht im entferntesten diese überragende Bedeutung besitzen, und das Werden dieser Eigenschaften wird erklärt. Eine Eigentümlichkeit der Historie ist aber die rersöhnliche und irenische Tendenz. Die Tat des Hasses und der brutalen Leidenschaft, die unter dem Gegenwartsstandpunkt als mverzeihliehes Verbrechen auftritt, sie wird durch die Gesehichte des Verbrechens gemildert. Demn durch die Gesehichte gelangen wir häufig zu jenem großen Verstehen, das alles verzeiht. Wenn ich die böse Tat werden und wachsen sehe, so rerliert sie für mich et was ron. ihrer Furehtbarkeit, weil sie mich nicht mehr mit der Gewalt einer schreck- 
lichen Tatsache üherfällt, sondern mir die Zeit läßt, mich hineinzufinden. Und in der historischen Betrachtung behält das Individumm auch nicht die Selbständigkeit und Lniversalität, mit der es im Leben des Einzelnen erscheint, sondern, eingefügt in einen Zusammenhang, scheint es unterworfen zu sein der Macht fremder Einflüsse und der ganzen Ungunst der Umwelt.

Es gibt aber noch eine andere Betrachtungsweise, durch welche ich das Individum ron meiner Individualität ablösen kamn, um es in Beziehung zu setzen zu einem überpersönlichen erkennenden Bewußtsein. Das geschieht, wemn ich die philosophische Sinnfrage an den Gegenstand meiner Liebe richte. Dann frage ich nicht. wie das Individum so geworden ist, condern was das Individum wert ist, und zwar nicht, was es mir wert ist als Gegenstand meiner Liebe und Freude, sondern was es allen gilt und bedentet. Auch frage ich nicht, was das Individuum für eine Zeit gilt, etwa für die Zeit, in der es lebt, nach seiner Bramchbarkeit frage ich nicht, noch nach seiner Kulturbedeutung und seiner Leistung für einen sozialen Kreis. Ich frage vielmehr nach seinem Wert schlechthin und entrücke es allen persönlichen und zeitlichen Beziehungen. Diese Frage nach dem Wert des Individuums schlechthin ist die Frage nach seiner Persönlichkeit. Die Forderungen, die wir an die Persönlichkeit stellen, gelten unabhängig von aller Zeit. So soll die Persönlichkeit etwa zu allen Zeiten Universalität besitzen oder ihrer ethischen Gesimnung nach edel, hilfreich und gut sein. Der philosophische Begriff der Persönlichkeit fällt so wenig mit dem Begriff des großen historischen Individumus zusammen, daß wir uns sehr wohl eine große Persönlichkeit denken können, die nur geringe oder auch gar keine historische Bedentung besitzt. Der Menseh meiner Liebe, die historische Individnalität, die Persönlichkeit im philosophisehen Sinne verdanken ihre Bildung ganz verschiedenen Interessen des geistigen Lebens.

\section{b) Die verschiedenen Ziele der Philosophiegeschichte und Gesehichtsphilosophic.}

In der Philosophiegeschichte ist die Philosophie das Objekt der historischen Fragutrellung. Das Gebilde des philosophischen Denkens, das philosophische Wrek orler die philosophische lehre soll also in Zusammenhang mit anderen bhitnsophischen Lehren erk lärt werden. Wir sollen sehen, wie das philosophische Wrek geworlen ist. In der Gesehichtsphilosophie dagegen ist die Geschichte das ()hjekt der philosophischen Fragestellung. Sie erhebt also die Frage nach lam Wert der Gesehichte orler, wie wir anch sagen können, nach dem Sinn dre historischen Lebens. Daf das historische Jeben einen sim hat, daß

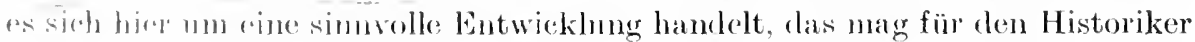

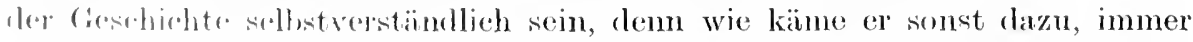

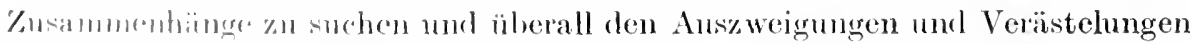

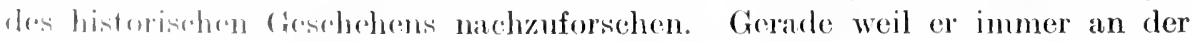
Arheit ist, zu chlwiren mud dentlieh zu machen, mub man annehmen, daß

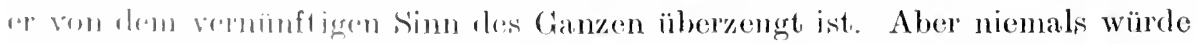

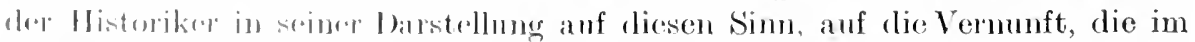

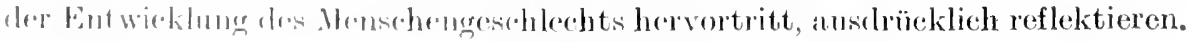

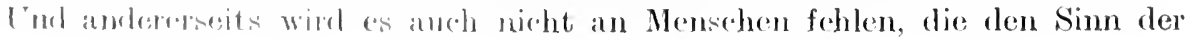


Geschichte verneinen, die in ihr nichts anderes erblicken können als die Anhäufung eines zwecklosen Geschehens. Es ist ganz gewiß keine ron vornherein feststehende Tatsache, daß die Geschichte ein vernünftiger Sinn durchwaltet, der von der Sinngebung der Epochen und Generationen unabhängig ist, ein ewiger objektiver Sinn.

Soweit scheint also die Anseinanderlegung ron Philosophiegeschichte und Geschichtsphilosophie höchst einfach und selbstrerständlich zu sein. Die Philosophiegeschichte ist eine historische Darstellung derEntwicklung und Aufeinanderfolge philosophischer Lehren und systeme. Die Geschichtsphilosophie ist eine philosophische Disziplin, welche die Fragenach dem Sinn oder auch nach dem Begriff der Geschichte erhebt. Die Philosophiegeschichte will die Philosophie historisch und die Geschichtsphilosophie die Geschichte philosophisch begreifen. Die Philosophiegeschichte fällt also nach dieser Auffassung vollkommen anf die Seite der historischen Wissenschaften. Sofern mun auch die Philosophie als solche dem historischen Geschehen angehört, selber einen Teil der Geschichte bildet, wird die Geschichtsphilosophie ihre Frage nach dem Simn des Geschehens auch an das Werden der philosophischen Lehren zu richten haben.

Ohne Zweifel hat die Geschichtsphilosophie ein sehr viel größeres Gebiet als die Philosophiegeschichte, denn die Geschichtsphilosophie hat es mit dem gesamten historischen Leben als solchem zu tmo, und zwar in philosophischer Hinsicht, die Philosophiegeschichte aber lediglich mit der Philosophie in historischer Absicht. Anderseits kam die Philosophiegeschichte auch die Geschichtsphilosophie zum Gegenstand ihrer Darstellung machen, indem sie die Frage nach dem Werden der geschichtsphilosophischen Spekulation erhebt.

\section{c) Der philosophische Faktor in der Philosophiegeschichte.}

Aber in dem Begriff der Philosophiegeschichte und der Geschichtsphilosophie liegen doch noch weiter erhebliche Schwierigkeiten, auf die wir von vornherein hinweisen müssen, weil sie für unsere ganze Auffassung ron entscheidender Wichtigkeit sind. Das Problem der Philosophiegeschichte liegt nämlich vor allem in der Frage, ob der eigentümliche Charakter des Gegenstandes, mit dem es die Historie als Philosophiegeschichte zu tum hat, den rein historischen Charakter umbildet und verändert, ob die Philosophie, sofern es die Historie mit ihr zu tun hat, nicht anf die Geschichte abfärbt und ihr ein philosophisches Gepräge gibt. Das ist num aber augenscheinlich die Auffassung ron Wilhelm Windelband, wie er sie 11. a. in der Einleitung zu seinem Lehrbuch der Geschichte der Philosophie vertreten hat. Dann wiurde also die Philosophiegeschichte, wenn auch nicht selber Philosophie sein, so doch einen philosophischen Faktorin sich tragen, und dieses philosophische Moment der Philosophiegeschichte ist nach Windelland das Noment der Beurteilung oder Kritik ${ }^{1}$.

Die Vorstellung, daß in der Philosophiegeschichte, durch den eigentümlichen Gegenstand bedingt, sich ein Moment geltend macht, das in keiner

$\left.{ }^{1}\right)$ Lehrbuch der Geschichte der Philosophie, 6. Auflage, S. 13, Tübingen 1912. 
anderen historischen Wissensehaft zu finden ist und ihrer Methode einen philosophischen Charakterzug gibt, kann nicht so ohne weiteres abgelehnt werden. Augenseheinlich bedingen sich Methode und Gegenstand wechselseitig. Je nach ihrem Gegenstand wird die Methole der Geschichte rerschiedene Gestalt annehmen. Die staatengesehichte, die man anch wohl als politische Geschichte bezeichnen kann. wird in ihrem methodischen Verfahren ron der Kunstgeschichte erheblich abweichen. Staat mol Kunst bedingen diese Verschiedenheit. Und so tritt auch in der Philosophiegeschichte etwas ganz Besonderes herror, was gerade durch diesen Kulturwert erzengt wirl und methodischen Einfluß gewinnt. Wir kömnen dieses Eigentümliche hier ganz kurz andenten, wenn wir daran erinnern. daß es die Philosophiegeschichte notwendig mit dem Zusammenhang philosophischer Ideen zu tum hat, wie etwa: das absolute Wesen, die Unsterblichkeit, die Freiheit. die Notwendigkeit, die Schönheit, die Freude oder Glückseligkeit. Sie alle stellen dem erkennenden Geist Aufgaben, deren Lösmng er nachsinnt. Die lösmng, die notwendig den Charakter des Vorläufigen an sich trägt, sind die philosophischen Lehren oder die philosophischen s.rsteme. Eine Notwentigkeit liegt in der Aufgabe, die immer wieder ron neuem die sehicksalsschwere Frage erhebt und immer wieder nene Kulturepochen zu nenen Lösmngen führt. Die philosophische Idee aber ist gewissermaBen Aufgabe und Lösung zugleich. Lösung im Verhältnis zur Vergangenheit und Aufgabe im V'erhältnis zur Zukunft. Zu den furchtbarsten Rätselfragen, welche die Menschheit gequält hat, gehört notwendig das Problem des Todes. Was bedentet der 'Lod? Er zerreibt den schönen und hochgewerteten Zusammenhang dos Lebens. Er scheint uns zu lehren ein absolutes Ende und eine absolnte Tremmug. Ende ohne neren Anfang, 'Tremmung für immer. Aber Platos philosophischer Genins fand eine Lösmg und lehrte die Ensterblichkeit. End der Gedanke der Unsterblichkeit der mensehlichen seele ist wicherum eine neue Aufgabe fïr den erkennenden Geist. So wird die Tdee immer wieder zmm Problen, und der Problemzusammenhang, den die eine Idee heraufbeschwört, verhinclet sich mit dem der anderen. Wir haben es in der Philosophiegeschichte vielfach mit rinem rein gedankliehen Zusammenhang zu tmo, der kein willkïrliches Konglonerat ron Einfällen und Meimmgen bildet, sondern eine irloelle Notwendiglicit offenbart in der ganzen Art und Wcise, wie die Probleme ronwirts geschoben und weiter getrieben werlen. Indem die Philosophicgrenchichte in dem philosophisehen Gedanken, dem Begriff, der Itee den thenkbar alstaktasten. der Wirklichkeit formsten Gegenstand einer historisehen Betrachtumg besitzt, tritt sie in Gengensitz zu jeder ameren Form der Historie,

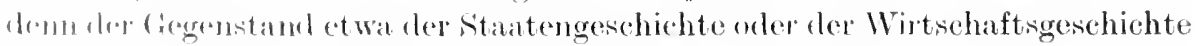

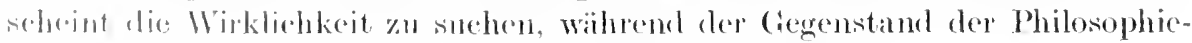
gesehishte die Wirkliehlecit zu

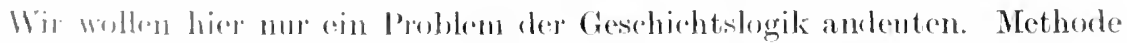

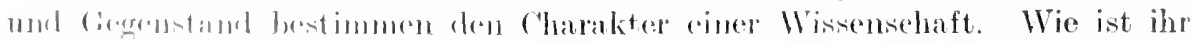

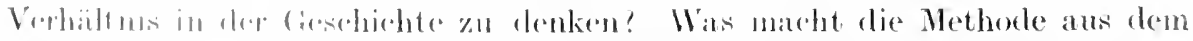

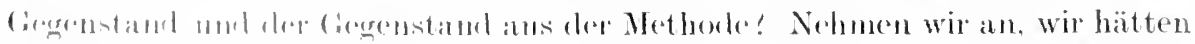

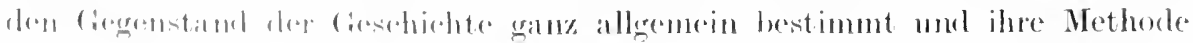

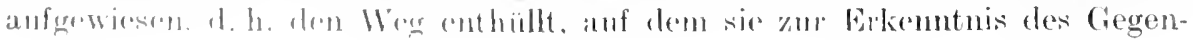


standes gelangt: kann ein bestimmter Gegenstand, der isoliert wird und auf dessen historisches Verstehen es ankommt, kamn er den Weg der Erkenntnis, die Methode veränlern, wohl gar, um bei unserem Beispiel zu bleiben, in die Form der historischen Erkenntnis ein Moment des philosophisch-systematischen Begreifens eintreten lassen? Mnß eine historische Darstellung der Philosophie notwendig philosophischen Charakter tragen?

Suchen wir nach der philosophischen Erkenntnisform in der Philosophiegeschichte, so liegt sie nach unserer Auffassung ror allem in der Idee des Problemzusammenhanges, ron dem die Sinnfrage, wie es scheint, unablösbar ist. Windelband betont jedoch besonders den kritischen Faktor der Beurteilung als den eigentlich philosophischen. Damit stehen wir damn sofort vor dem wichtigsten Problem der Geschichtslogik, ob es eine eigentümliche Form der historischen Benrteilung gibt oder nicht. Trägt jede Wertung, die wir in Beurteilungen vollziehen, notwendig cinen philosophischen Charakter, oder gibt es anch Wertungen. die der Geschichte eigentümlich sind, die ihrer Methode angehören und doch mit Philosophie nichts zu tun haben?

So treibt jede Frage eine nene Frage herror, aber diese Fragen treiben doch zu einem bestimmten Ziele hin. Es schien uns anfangs sehr leicht, die Geschichtsphilosophie in ihrem Verhältnis zur Philosophiegeschichte zu bestimmen. Die Geschichtsphilosophie ist eine philosophische Wissenschaft, die Philosophiegeschichte ist Historie, aber auch in der Philosophiegeschichte scheint sich ein philosophischer Faktor anzukündigen. oder ihre Methode ist nicht rein historisch. Es fragt sich nun, ob die Philosophiegeschichte notwendig einen philosophischen Faktor enthält, mag er mun in der Idee des Problemzusammenhanges oder in der kritischen Beurteilung gesucht werden. Ist die Philosophiegeschichte aber teilweise Philosophie, so genügt der Unterschied von historischer und philosophischer Wissenschaft noch nicht, $\mathrm{mm}$ Philosophiegeschichte und Geschichtsphilosophie zu tremen.

Die Betonung res philosophischen Charakters der Philosophiegeschichte kann dahin führen, die Philosophie mit dem Begriff ihrel Geschichte gleichzmsetzen. Ist die Geschichte der Philosophie eine rein historische Disziplin, dann steht ihr die systematische Philosophie als die absolut andere Betrachtung der Dinge gegenüber. Dagegen kann eine extreme Betomung der philosophischen Momente in der Philosophiegeschichte schließlich dahin gelangen, in ihr die Vollendung aller systematischen Philosophie zu erblicken, wem auch eine solche Anffassung, die alles philosophische Lebcn tötet, durchans nicht als Konsequenz einer philosophischen Wertung der Geschichte angesehen werden kanm. Die Philosophiegeschichte braucht ja auch damm nur eine philosophisehe Disziphin unter anderen zu sein, wie etwa die Ethik oder die Religionsphilosophie. Auch könnte sie, ohne den anderen philosophischen Disziplinen ebenbürtig zu sein, einen philosophisch-historischen Charakter tragen. Jene, die da meinen, daß die Philosophie als Wissenschaft nur Philosophiegeschichte sein könne. behaupten, daß die Philosophie im Grunde genommen schon tot ist, daß sic eine veraltete und längst abgetane Form der Betrachtung menschlicher Dinge sei. Wäre dies der Fall, damn würde die Liebe und das Interesse des Historikers wohl schwerlich den philosophischen Phänomenen gehören. Jene, die solches behaupten, rergessen nur zu sehr, daß die Historie es immer zu tum hat mit dem 
Vergangenen, das weiter lebt, und daß Kulturwerte wie die Philosophie oder die Wissensehaft und Kunst wohl niemals überlebt sein kömnen, weil in ihnen eine eigentümliche und notwendige Form menschlieher Kulturbetätigung vorliegt, so daß ein Aufhören dieser Betätigung eine Verstummelung des Lebens bedenten würde.

Wenn es einen Punkt gibt, wo die Geschiehte in Philosophie umschlägt, so ist es augenscheinlich die Philosophiegesehichte als die Gesehiehte der philosophischen Begriffe und Ideen, die ja die abstraktesten und allgemeinsten Gegenstände der historischen Betraehtung sint. Ist das aber der Fall, so bedeutet sie einen höchst willkommenen Ansatzpunkt für die gesehiehtsphilosophische Spekulation, weil gerade in ihr das historisehe Gesehehen schon eine gewisse philosophische Form angenommen hat, so daß in den geschichtsphilosophischen spekulationen über Philosophiegesehiehte sieh Philosophie mit Philosophie berührt. So wird die Philosophie der Philosophiegeschiehte eine ähnliehe Bedentung für die Geschichtsphilosophie hahen wie die Logik für die anderen Teile der systematischen Philosophie.

Der Begriff der Geschichtsphilosophie setzt voraus, daß wir im allgemeinen orientiert sind über das, was wir unter Philosophie und Geschichte rerstehen. Wollen wir erfahren, was Geschiehtsphilosophie ist, so müssen wir zunächst anf die Frage antworten: Was beleutet Philosophie, und was bedentet Gesehichte?

Was Philosophie sei und bedente, daß ist natürlieh eine Frage, die nicht mit wenigen Worten abgetan werden kann. Darïber werden wir in unserem nächsten Kapitel das Notwendige ausführen. Und ebenso kanı der Begriff der Geschichte erst im weiteren Verlanf unserer Darstellung geklärt und verstanden werden. Wenn wir aber von Philosophie der Geschichte sprechen, so rwächst sogleieh eine Doppeldeutigkeit, die beseitigt werden muß, um unser Problem wenigstens in seiner größten Allgemeinheit etwas deutlicher zu niachen.

\section{d) Doppelsinn der Geschichte.}

Wrom von Geschichtsphilosophie die Rede ist, so wissen wir, daß in dieser Disziplin die Geschichte zum Gegenstand philosophiseher Cherlegungen gemarht wirl. Das Wort Geschich te bleibt aber zweideutig, dem wir verstehen unter Geschichte einerseits die historische Wissensehaft, welche die Kulturbetiitigung der Menschheit genetisch zu crklären sucht, und andererseits be\%orknen wir mitdrmsetben Name nauch das rea le Wel geschehen. Geschichte ist also cinelseits dine Wissensehaft, ein ideelles Gebilde, das repräsentiert wird luseh dire groben historisehen Werke, eine ungeheure summation von Urteilen nud l’egriffen, das liesultat eines langen Kulturapheit, ciner gewaltigen Denk-

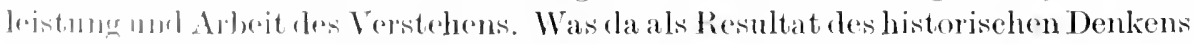

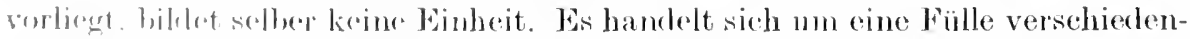

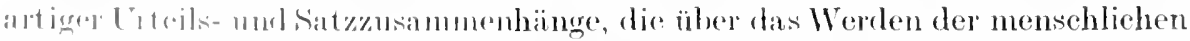

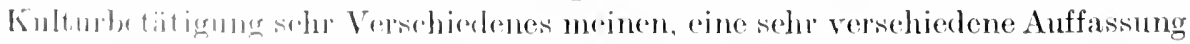

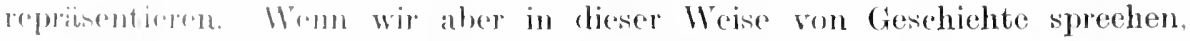

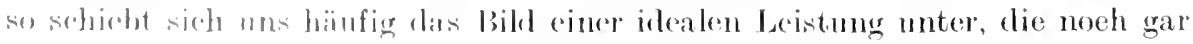

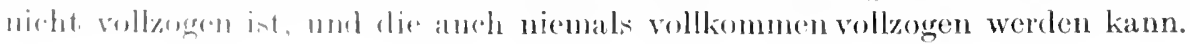


Wir denken an die rollendete Geschichte, an die exemplarische Form der historischen Auffassung und Darstellung. Wenn wir also unter Geschichte das Resultat einer bestimmten menschlichen Kulturbetätigung verstehen, so bleibt es doch wieder zweifelhaft, ob die gegenwärtig rorliegenden Resultate der historischen Darstellung oder das irleale historische Wissen gemeint sei, in dem sich die Geschichtsforschung vollendet.

Es ist gewiß nicht gleichgïltig, ob als Objekt der Philosophie die rorhandenen Formen und Gegenstände der historischen Darstellung oder die ideale Wissenschaft der Geschichte gedacht wird. Gegen die zweite Auffassung ließe sich der Einwand erheben, daß die ideale Geschiehte nicht geschrieben ist und niemals geschrieben wird und deswegen anch unmöglich zum Gegenstand der philosophischen Fragestellung gemacht werden könne. Demgegenüber kamm man mit Recht die Frage erheben, warmm sich die Philosophie nicht ebensowohl mit der idealen historischen Wissenschaft wie mit dem idealen Staat befassen solle. Hat sie es doch ror allem mit dem Nichtwirklichen und Uberwirklichen zu tun.

In dieser von uns gemachten Unterscheidung liegt für die Geschichtslogik eine wichtige Direktive. Es fragt sich nämlich, ob die Philosophie als Methodenlehre ihre Aufgaben erfüllt, wenn sie einfach nur feststellt, auf welchen Wegen die Historiker ihr Ziel zu erreichen suchen. Wenn sich die Philosophie ihre Aufgabe in dieser Weise stellt, so enthïllt sie eine große ZahI verschiedener Wege und Methoden, sowie eine Mannigfaltigkeit von Auffassungen ïber das Ziel der historischen Erkenntnis. Damm will die Philosophie nichts anderes tun, als die Arbeit der Geschichte verstehen und in dieser Maniigfaltigkeit von Wegen und Zielsetzungen eine einheitliche Grundlage und eine gemeinsame Zielbildung finden. Die Philosophie, so pflegt man wohl zu sagen, darf die Wissenschaft nicht schulmeistern und korrigieren wollen. Um den Weg zur rechten Erkenntnis muß die Geschichte selber bemüht sein. Die Philosophie darf nicht fragen, welcher Weg wohl am besten zum Ziele führt. Sie hat die vorschiedenen möglichen Wege einfach zu registrieren. Fehlt es ihr aber durchans an kritischer Stellungnahme, so muß die Gesehichtslogik dahin gelangen, alle Wege für gut zu halten. welche die Geschichte jemals gewandelt ist. Als das Wesen der historischen Erkenntnis hat sie dann dasjenige herauszuheben, was aller auf historisches Geschehen gerichteten Forschungmethode gemeinsam ist, und sie läuft Gefahr, dies Gemeinsame in Regeln und Prinzipien zu fixieren. deren abstrakte Allgemeinheit von der spezifisch-historischen Inhaltlichkeit gar zu weit getrennt ist.

Diese Auffassung, nach der die Philosophie die Geschichte möglichst zufrieden lassen soll. indem ihr lediglich die Erlanbnis zuteil wird, die vorhandenen Formen des historischen Forschens und Darstellens zu deuten. ergibt sich aus dem Spannungsrerhältnis zwischen Philosophie und Wissenschaft, wie es das 19. Jahrhundert gezeitigt hat. In diesem Jahrhundert ist der Gedanke ron der Einheit des wissenschaftlichen Lebens, der im 16.Jahrhundert so mächtig aufleuchtete, fast rölligverloren gegangen. Die große Irlee der Wissenseinheit wurde problematisch. Die Wissenschaften wandern nunmehr gesonderte und getrennte Wege. Gefährlich ist der Einfluß der Philosophie auf die Wissenschaft und der Einfuß der Wissenschaft anf die Philosophie. 
IVir bemühen uns. zu zeigen. daß Philosophie und Wissenschaft, wie wir sie verstehen wollen. einander nicht schaden können. Ein unerquicklicher Kompetenzenstreit beschäftigt sich mit ihrem Verhältnis und den Ansprüchen, die sie zu stellen berechtigt sind. Die Geschichte, durch welche die Philosophie Kraft und Lehen erhält, sie soll den systematischen Geist der Philosophie lurch die Macht des historischen Denkens überwuchern und ersticken, und die Philosophie soll die Frische des historischen Lebens durch den ödenZwang ler Konstruktion vernichten und zerstören.

IVir glauben nicht an diesen Antagonismus von Philosophie und Geschichte, mnl deswegen ist es für uns so gut wie selbstverständlich, daß es die Philosophie nicht nur mit der geschriebenen und dargestellten Geschichte, sondern anch mit der Geschichte der Zukunft, der idealen Wissenschaft der Geschichte zu tun hat. Das Verhältnis der Philosophie zur Geschichte ist nicht nur ein ruhig hinnehmendes, sondern auch ein kritisch stellungnehmendes. Natürlich ist es für uns ron größter Wichtigkeit, die Werke der großen Historiker kennen zu lernen und die Aufgahen zu verstehen. die sie sich selber gesetzt haben. Ja, die Geschichtslogik wird sogar immer wieder darauf hinzuweisen haben, daß das, was hicr rorliegt, in der Tat in cminentem Sinne Geschichte ist. Aber wie, wenn sich dic Behauptung erhebt, daß das, was ein Ranke und ein Jacob Burckhardt mer Geschichte verstanden haben, ïberhaupt keine Greschichte sei, und die Soziologie als Erfüllung des historischen Denkens behauptet wirl? Wird die Geschichtslogik da nicht von selbst ror die Aufgabe gestellt, Richtlinien für die idcale historische Wissenschaft zn ziehen, falls sie nicht stillschweigend mit der Behauptung übereinstimmt, daß die Soziologie, wie sie etwa ron Auguste Comte gedacht ist, die ideale historische Wissenschaft sei?

Wir schen sogleich, dab wir mit einem bloßen Deuten und Verstchen der historischen Methode nicht auskommen. Tatsächlich liegen sehr verschiedene formen der Methode ror, und rerschieden ist auch die Auffassung von dem Ziele der historischen Wissenschaft. Da hat mun die Philosophie von einer allgemeinen Idee des Wissens auszugehen und die möglichen Erkenutniswege und Eikenntuiszicle deutlich zu machen. Die Philosophie hat dentlich zu machen, worin das Wesen des historischen Denkens und der historischen Erkenntnis bromt. Nicht als oh in irgendeiner historischen Wissenschaft die reine Form (les historischen Denkens sich darstellte. Niemals wird diese Form rein zum Auslruck kommen, immer wird sie mit fremden Elementen und Bestandteilen unmisht sein. Fs giht im Grmule keine ideale oder ahsolute historische Wissen-

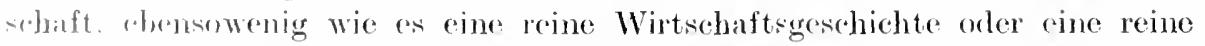

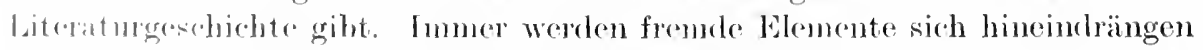
nurl dureh an fromles axoterisches Interesse wirl der reine Gang der

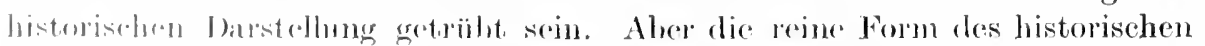

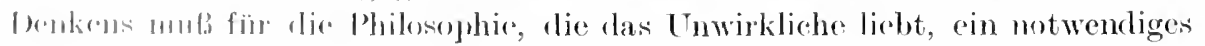
Prolinloll sill

Sir wirt alse die Geschichtslogik, wie wir sie verstehen, es immer zu tun

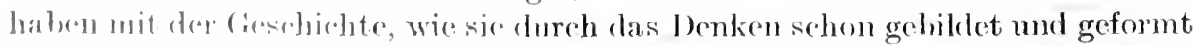
int, nurl mit der irloalen Geschiehter, cin Work des historischen Denkens, das

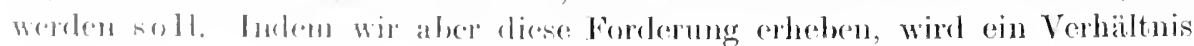


der Gegenseitigkeit von Philosophie und Gesehichte verlangt. Dic schroffe und teilnahmslose Schranke, die ein t’bermaß ron kritischer Besorgnis zwischen Philosophie und Geschichte errichtet hat, muß eingerissen werden. Es darf dem philosophischen Gedanken nicht rerboten sein, ïber die ideale Form der der historisehen Wissenschaft nachzusimmen. Die Philosophie soll nieht nur das Vorliegende und Gegenwärtige verstehen und deuten, sie soll auch die Aufgabe der historischen Wissensehaft über alles Gegenwärtige hinaus zu ergrinden suchell.

Wir branchen deswegen nicht hesorgt zu sein. dal3 wir in der Philosophie Geschichte und in der Geschichte Philosophie treihen. Wir wissen die erklärende Tätigkeit des Historikers ron dem Denten des Philosophen viel zu gut zu unterseheiden, als daß wir Gefahr liefen, sie jemals in ungebiihrlieher Weise zu verwirren und zu verwischen. Wir müssen jerloch ein für allemal mit der Torstellung breehen, daß das Verhältnis der Wissenschaften zueinander. ein ruhiges Nebeneinanderhergehen bedeute. Jede Wissenschaft ist eine Art des Begreifens, eine Form des Denkens, verschieden ron jeder anderen Form, und aus dieser eigentümlichen Form des Verstehens heraus ergeben sich nur zu häufig Ausblicke und Fernblicke, die für das Fortschreiten einer anderen Wissensehaft wertroll sind. Und so hat das philosophische Verstehen die Geschichte und das historische Verstehen die Philosophie gefördert.

Doch es fragt sich ror allen Dingen, ob wir bei dem Begriff der Geschichtsphilosophie lediglich an die Geschichte als Resultat der historischen Forschung und als ideale historisehe Wissencchaft zu denken haben. Ist wirklich nur der Urteilszusammenhang des historischen Wissens Gegenstand der philosophischen Fragestelhung, oder hat es die Geschieht philosophie nicht auch mit dem realen Weltgesehehen zu tun? Die Entscheidung dieser Frage ist ron ganz prinzipieller Bedeutung. Nehmen wir zunäehst einmal an, die Geschicht-philosophie habe es wie die Geschichte mit dem realen Weltgeschchen zu tun. Damn scheint doch die Geschichtsphilosophie zur Konkurentin der Geschichte zu werden. Die Geschichtsphilosophie richtet sich rann, wie die Geschichte. unmittelbar auf die wirklichen Tatsachen und wird, so werden ängstiche Gemüter behaupten, durch ihre ronzeitigen Konstruktionen den ruhigen gewissenhaften Gang der historischen Forsehung hemmen und verwiren. Dic Konstruktion wird den Tatsachen Gewalt antun und einen willkürliehen simn aus ihmen herauszupressen suchen. Und so läuft die Geschichte Gefahr, durch die Geschichtsphilosophie in Dilettantismus auszuarten.

Wie oft ist dies behauptet worden und damit der Versuch gemacht. den Problemen der Geschichtsphilosophie ein für allemal den Boden zu entziehen. Geschichtsphilosophie als Universalgeschichte sollte ihrer ganzen Fragestellung nach so mmöglich sein wie die Metaphysik. Wie Kant nachgewiesen hatte. daß sieh in theoretischer Hinsicht über Gott, Unsterblichkeit und Lniversum nichts ausmachen läßt, so sollte auch die Frage nach dem Simne des historischen Geschehens ein für allemal der Erimerung angehören. Das Resultat einer. solchen Uberlegung war dam natürlich, daß man die Geschichtsphilosophic verurteilte, in der Hauptsache Geschichtslogik oder Methodologie zu sein. Man ließ die geschichtsphilosophische Spekulation ïberhaupt gar nicht zu Worte kommen und hemmte so gewaltsam die Weiterbildung der gesehichtsphilosophi- 
schen Probleme. Dabei gab man sich anch wenig Mühe, zu zeigen, warum denn eigentlich die geschichtsphilosophische Problemstellung ummöglich sei, und worin der Irrtum aller Geschichtsphilosophie zu suchen ist. Den Agnostizismus in Beziehung anf Gott, Unsterblichkeit und Welt hatte Ka nt im Zusammenhang eines großartigen Systems begründet ${ }^{I}$ ). Seine Nachfolger brachen vielfach mit den Grundroraussetzungen dieses Systems und wollten doch die Negation der Metaphysik anfrecht erhalten. Die wichtigsten Probleme der Geschichtsphilosophie wrden aber immer den metaphysischen Problemen analog behandelt. Und so begnügte man sich denn in der Hanptsache, zu fragen. wie historische Erkenntnis möglich sei, und auf welchen logischen Toraussetzungen die historische Begriffsbildung mht. So wichtig und unentbehrlich diese Fragen mun auch sein mögen, so kömnen sie doch das metaphysische Problem nicht im geringsten erschöpfen. Eine Geschichtsphilosophie, die in Methodologie stccken bleibt, verdient diesen Namen nicht, und wir betrachten es als eine der wichtigsten Aufgaben, die wir uns in diesem Buche stellen. der Geschichtsphilosophie den alten Unkreis ihrer Probleme zurïckzugewinnen.

\section{e) Universalgeschichte und Plänomenalität.}

Wenn wir aber fragen, was denn eigentlich an diesem Verkennen der Crundprobleme der Geschichtsphilosophie Sichuld trage, so scheint uns vor allen Dingen Kants Lehre von der Phänomenalität der Zeit znMißrerstänłnissen über das geschichtsphilosophische Problem Anlaß gegeben zu haben. Kant hat die moderne Geschichtsphilosophie inauguriert, und an Kant erwochs die methodologische Fragestellung hinsichtlich der Geschichte. Suchen wir ms die Schwierigkcit, dic Kants Lehre hinsichtlich ler Geschichtsphilosophie mit sich bringt, eimmal dentlich zu machen. Zwei Wrelten kennt die Philophic Kants: eine Welt des Unsinmlichen und eine sinnliche Wirklichkeit. Ton diesen beiden ist nur die Simmenwelt der logisehen Erkrnntnis zugängig. Alle Formen des Denkens gelten num für diese unsere sinnliche Welt. Auf die simnliche Materic sind sic hingewiesen. in der Sinnenwelt lie.nt fïr den Mensehen das Arbeitsfeld der Erkenntnis. Die Formen des wissenshaftlichen Denkens hahen es nur mit der raumzeitlichen Wirklichkeit zu tun. Realität und Kausalität gelten nur fürsinnliche Inhalte, und die Philosophie mußs dagegen Einspruch erheben, daß diese Begriffe anch auf das Unsinnliche, Intrelligibele angewendet werden. Wir haben kein Recht zu behaupten, daß jene. Welt "xistiert in dem sinne, wie wir orfahrungsgemïb die Existenz erlebt haber, mol vollonds ist der Gedanke der NatmgesetzmäBiglseit von jener Sphäre dre [usimblichen forn zu halten. Die Reflexion anf das wissensehaftliche Laben kann die Philosophie nienals zur Gewibheit der ïbersinnlichen

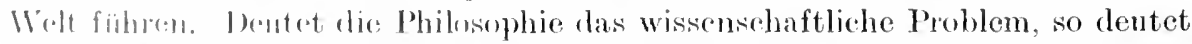
sie as in limginhung \%ur Diessejtigkeit. Die Philosophie erkennt, daß die natur-

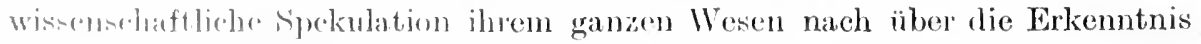

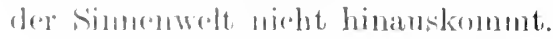

Wohl Hindantungen mul Himweise anf as Intelligibele, aber keine Gewiß-

1) Kants Wrerk, lid. III. Kritik der reinen V'rnunft. (Akadomieausgabe.) 
heit der ïbersinnlichen Welt vermag die Philosophie als Sinngehalt in dem Tun und Verlangen der wissenschaftlichen Erkenntnis zu entdecken. Die Wissenschaft begnügt sich mit der Diesseitigkeit, ihr ist der Gedanke des Jenseits ferm und fremd. Wir bedürfen der Gewißheit der intelligibelen Welt als Männer der Wissenschaft keineswegs, und dem Interesse der theoretischen Philosophie ist Genüge geschehen, wenn gezeigt wird. daf die Formen der wissenschaftlichen Erfahrung über die Erfahrung hinausragen oder, wie Kant sich ausdrückt, ihr zugrunde liegen. Gewißsind die Formen der Erkenntnis im Unsinnlichen begründet. denn die Form der Wahrheit ist nicht ron dieser Welt; aber diese hohe Herkunft der Kategorien ist mit Erkenntnisfremdheit gegenüber der eigenen Heimat verbunden. Die Kategorien, die uns die Erkenntnis der sinnlichen Welt rermitteln, wissen ron ihrer eigenen höheren Heimat nichts. Sie sind in ihrer Erkenntnisleistung auf die Raum-Zeitwelt zugeschnitten und reichen nicht aus, um die Weit des Jenseits zu erfassen. Zu diesen Formen aber, die ein für allemal an das sinnliche Naterial gebunden sind und nur im Verhältnis zu diesem Sinnlichen eine Erkenntnisleistung rollziehen, gehört auch die Zeit. Augenscheinlich hat es keinen Sinn. das Ewige in der Form der Zeit anzuschauen; denn das Ewige ist ja gerade das, was der Beziehung zur Zeit vollkommen enthoben ist.

Die Gewißheit dieses Ewigen gewährt die praktische Philosophie. Wohl gemerkt: die praktische Philosophie, nicht etwa die sittliche Úberzengung ${ }^{1}$ ). Die sittliche Úberzengung ist nur Objekt und Phänonen der philosophischen Untersuchung, ganz in derselben Weise wie die Urteile der Wissenschaften die theoretische Philosophie interessieren. Kant ist es gar nicht eingefallen, wie mancher wohl behauptet hat, den Glauben oder die sittliche Uberzeugung über die Erkenntnis der theoretischen Philosophie triumphieren zu lassen. Der sittliche Glaube kann uns niemals die logische Gewißheit der übersinnlichen Welt geben, sondern erst die Reflexion über diesen Glauben. Und wie es Ǩant durchaus fern lag, die Unschuld des sittlichen Bewußtseins über die Philosophie triumphieren zu lassen. ebensowenig hat er behauptet, daß es eine praktische Erkenntnis als eine höhere Form der philosophischen Erkenntnis gibt. Es gibt kein praktisches Philosophieren, das dem theoretischen Philosophieren überlegen wäre. Es gibt ganz gewiß nur ein theoretisches Philosophieren. Daß dieses theoretische Philosophieren in der praktischen Termunft weiter vorwärts dringt als in der reinen Vernunft, das liegt an der Fruchtbarkeit des Objektes. Die sittliche Úberzengung, das sittliche Werterlebnis des Sollens ist ein größeres und tiefsinnigeres Problem für die Philosophie als die Mittelbarkeit wissenschaftlicher Erkenntnis. Daß es nun allerdings eine sittliche Úberzeugung, eine sittliche Gewißheit gibt über das, was gut und recht ist, die mit theoretischem Wissen nichts zu tun hat, das ist eine fundamentale Tatsache. Der klügste und einsichtsvollste Mensch entbehrt nur zu häufig des feinen sittlichen Taktes und der ethischen Genialität, die in allen Fällen weiß, wie gehandelt werden soll und deren Pat und Urteil daher mnstergiltig ist. Das Werterlebnis des Sollens deutet die philosophische Erkenntnis, wie sie

1) Die der unserigen entgegengesetzte Auffassung wird besonders von Lask vertreten. Die Logik der Philosophie und die Kategorienlehre. S. 261. Tübingen 1911. 
das wistenschaftliche Urteil dentet, und die Interpretation des sittlichen Erlebnisses in der Form ethiseher Imperative führt zur Erkenntnis einer Form, die ihrerseits die Welt des Unsinnlichen ms dentlich macht: diese Kategorie, die für das ṫbersimmliche gilt und den Namen einer praktischen Idee erhält, ist der Begriff der Freiheit. Und so versteht Kant die unsimmliche Welt als die Welt der höchsten Menschheitsanfgaben wie Wahrheit und Sittlichkeit. Pecht und Schönheit, deren letzter Sim in der Kategorie des Zweckes ein (thischer ist ${ }^{1}$ ). Dies Reich der Z wecke ist aber auch zugleich das Reich der freien Persönlichkeiten. Und ron dieser höheren Welt ans gesehen, ist die rammzeitliche Wirklichkeit die bloße Erscheinung, und die Formen dieser Welt, so anch die Form der Zeit, sind Formen eines Erseheinenden und selber anch erscheinend, nichts als Symbol und Gleiehnis für die Formen der intelligibelen (Velt $\left.{ }^{2}\right)$.

Nux in der Zeit ist Bewegung und Gesehehen möglich. Die Zeit ist die Form eines Erseheinenden als ron etwas, das nieht in sich ruht und durch sich begrïndet ist. Kant hat den unglücklichen und mißverständlichen Ausdruck geprägt, daß die Zeit eine Form des imneren Simnes sei. Mit dieser Vorstellung der Zeit als eine Form desinneren Sinnes und der Erscheinmngen hat Riekerts Erkenntnislehre gebrochen und dadurch der Universalgeschichte rlie Wege geebnet. Wem Kant die Zeit als Form des inneren simnes bezeichnet, so meint er damit, daß in ihr vor allem mser psrehisehes Leben, msere psychischen Phänomene gegeben seien, daß die Erkenntnis, sofern sie anf das Verstehen unserer Individnalität gerichtet ist, in ihr eine notwendige Grenze habe. Daß sie es ist, die uns hindert, in das Geheimnis unserer Intividnalität einzudringen, en numittelbares Wissen ron unserem Sein und unserem Wert ansschlieBt. Nur als ein Individum ron zeitlicher Berlingtheit können wir uns wissen und verstehen, und flamit machte er verstïndlieh, jenen eigentümlichen Zustand des mensehliehen Wesens, von dem Nächsten und Unmittclbarsten des eigenen Seins nichts Adiignates zu wissen. Er legte damit jene eigentimliche Fremdheit frst, rlie wir unseren cigenen Selhst gegenüber besitzen, das uns immer das großo Rüitsel blcibt, zu dem ein einsichtswoller Zugang uns ein fïr allemal versehlosicu ist. Er zoigte tamit auch ein für allemal die Grenzen der psychologischen Drkanntuis, deren Prinzip die innere Beobaehtung ist. Wie sollte sie jemals llir Serele, ihr Shehicksal, ihr eigenstes Wesen verstehen? Sie hleibt an der Ober-

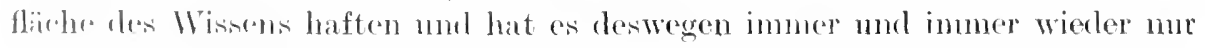
mit. Erecheinmugen zu tum.

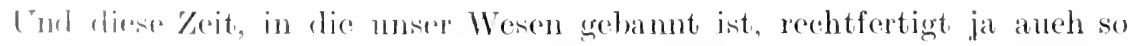

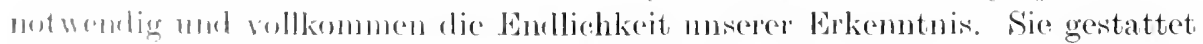

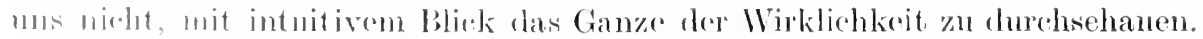

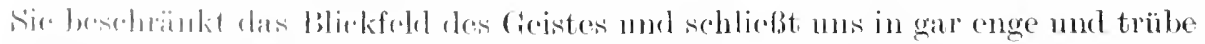

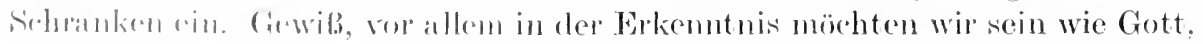

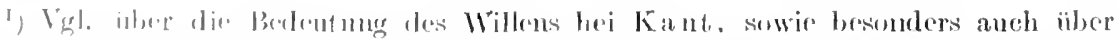

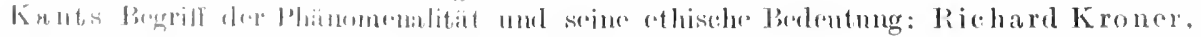

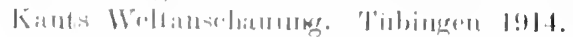

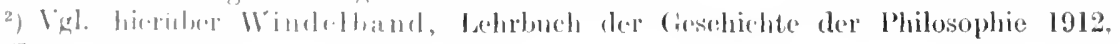
S. 4.tili. 
aber die simnliche Natur unseres Wesens unterliegt dem Gebot rler Endlichkeit, und die Zeit ist die Form aller endlichen Erkenntmis.

Aber die Zeit ist nicht mur die Form der imneren Erfahrugen, sie ist die Form aller Erfahrung und simmlichen Wirklichkeit. Auch die Welt der äußeren Natur können wir nur sub specie temporis erkennen. Jene Blätter und Blüten und der flüchtige Strom, jenes fremde, bald kalte und gleichgïltige, bald persönlich mich tief berührende Leben, das mich hier in dieser Stadt umflutet, alle diese Stätten und mancherlei Gestalten, die mich hier umgeben: ich sehe, schane und erkenne sie so, wie sie in der Form der Endlichkeit, der Zeit sich darstellen. Ich kann sie nur begreifen, sofern sie in der Zeit sind. All mein Tun und Leiden und all das große Geschehen des einsamen und öffentlichen Lebens: es unterliegt dem Gebot der Endlichkeit und der Zeit als dre Form aller Anschauming.

Ist dies num aber der Fall, ist die Zeit die Form unserer Anschaumng, reicht sie uns alle Dinge dar, die Gegenstand einer wissensehaftlichen Erkenntnis sein können, kommen wir nie und nimmer über die Zeit hinaus, können wir uiese unsere Endlichkeit nie überwinden, sind alle Dinge, die wir erleben, nur Phänomene, Hindeutungen auf ein tieferes Leben, das dahinter flutet, so könnten wir zu der Vermutung gelangen, daß in dieser unserer simblichen Wirklichkeit überhaupt nichts gesehieht. Ist doch alles Geschehen und alle Bewegung an die Zeit gebunden, die Zeit aber ist die Form des Erscheinenden, der endlichen Erkenntnis und damit selber an die simnliche Wirklichkeit gefesselt. Das Erscheinende ist Hindeutung auf ein höheres Sein oder vielleicht auch etwas, was in einem höheren Sein besehlossen ist. Die Zeit ist Form des Phänomenalen und damit selber phänomenal. Das Geschehen aber, das in ihr sich darstellt, muß diesen Flueh der Phänomenalität mit ihr teilen. Ist das Geschehen unwirklich, verliert das historisehe Leben seinen Realitätscharakter, so scheint es nur so, als ob alles sich entwickelt und vorwärts drängt. In Wahrheit aber gibt es kein Kulturgeschehen und Weltgeschehen. Damit wäre das Problem der Universalgeschichte ron rornherein als ein numögliches dokumentiert.

Selten aber ist eine tiefsinnige Lehre ron großem metaphysischen Klang so falseh gedentet worden wie in dieser nur zu häufigen Intrrpretation. Weil die Zeit die Form des endlichen Geistes und aller simlichen Wirkliehkeit ist, in der das Geschehen sieh vollzieht, deswegen soll das Geschehen keinerlei Realität besitzen und die Welt stille stehn? Selbst wenn wir Kants subjektivistische Wendung beibehalten, daß die Zeit eine Form unserer Anschaumg sei, so bleibt mit dem endlich erkennenden Bewußtsein doch auch die Zeit als Form dieses Bewnßtseins zu Recht bestehen und damit auch dem Geschehen sein Reich gesiehert. Besser bezeichnen wir aber die Zeit als eine Anschaungsform, die für das endliche Erkennen gilt und gesetzt ist, nach der das endliche Bewußtsein sieh richten muß. Dentlieher kommt dam zum Ausdruck, daß das endliehe Bewtitsein einerseits der Zeit unterliegt und andererseits die Zeit nötig hat, um der Wahrheit der anf die Simenwelt gerichteten Erkemntuis willen. Müßig ist jede Spekulation, welehe die Frage erhebt, was demn nun sei, was demn aus dem Geschehen werle, wemn wir das endlich erkennende BewuBtsein fortclenken. Eine solche Frage stellt an uns 
das Ansinnen, darïber Klarheit zu rerschaffen, was denn eigentlich sei, wenn wir die letzte Bedingung zerstören, unter ter allein für uns ron einem einsehbaren Erkenntnisbegriff die Rede sein kann. Ohne die Idee des endlichen Erkennens hat es gewiß keinen Sinn, ron Zeit als Form der Anschauung und von Geschehen zu sprechen. Aber warum sollten wir auch an der endlichen Erkenntnis zweifeln, da doch nichts so evident und eine so schmerzliche Wahrheit für uns ist wie gerade diese unsere Endlichkeit und Begrenzung?

Wir glauben damit gezeigt zu haben, daß Ka n ts Lehre von der Phänomenalität der Zeit, wenn sie richtig interpretiert und aufgefaßt wird, sich sehr wohl mit dem Gedanken eines historischen Geschehens verträgt, das für die Geschichtsphilosophie unentbehrlich ist. Keine Ủberlegung kann uns dazu zwingen, an dem Begriff der Endlichkeit und des endlichen Erkennens zu rütteln. Solange aber diese zu Recht bestehen, so lange bleibt auch der Begriff des Geschehens unangefochten. Nur dann, wenn eine monistische Tendenz die Dualität von Endlichkeit und Unendlichkeit vollkommen aufheben will und das endliche Erkennen zum absoluten erweitert, dann verlier't auch der Gedanke des Geschehens alle Bedeutung. Wemn alles in die Sphäre des Ewigen hinaufgehoben ist, dann fällt auch das reale Geschehen in nichts zusammen und muß seine Wirksamkeit vollkommen einbüßen. Für ein unendliches und schrankenloses Bewußtsein besteht die Zeit nicht mehr als Norm, und das Geschehen ist nicht mehr ein Unbeherrschtes, das uns zu umschließen scheint, sondern ein Umschlossenes und Beherrschtes.

Der Gegensatz rom Unendlichen und Endlichen und rom unendlichen und endlichen Erkennen verbürgt somit die Realität des Geschehens und ist Bedingung jerler geschichtsphilosophischen Problemstellung. Im Grunde genommen ist das Problem der Geschichtsphilosophie auf Grund der Hegelschen Philosophie, welche die Grenze zwischen dem Endlichen aufhebt und in einer großen Synthesis allen Dualismus vernichtet, ebensowenig zu lösen wie auf dem Boden des Spinozismus. Darüber dürfen wir uns nicht täuschen, mag auch die Hegelsche Philosophie in einzehnen Teilen mit noch so viel Liebe und Verständnis der Geschichte zugewendet sein, und die Geschichtsphilosophie hei Kant nur gleichsam peripherisch in Schriften auftreten, denen er selber keine streng wissenschaftliche Berleutung beigemessen hat. Aber anch der Dualismus Kants gefährdete mit den Zweidentigkeiten seiner Zeitlehre das nniversal-historische Problem. Erst die Renaissance des Idealismus, wie sie sich in den letzten Jahrzehnten der philosophisehen Entwicklung vollzogen hat, die Erweiterung der logischen Grumdlagen, jene Uberwindung des Kintischen Subjektivismus, die doch gleichzeitig, den absoluten Idealismus vermeidrum, an dem Prinzip des Gegensatzes festhielt, so wie sie vor allem in Puickerts Wortphilosophie vertreten wird, hat neue Möglichkeiten für eine miversalesachichtliche Konstruktion gesehaffen.

\section{f) Dio Grenze der Logik.}

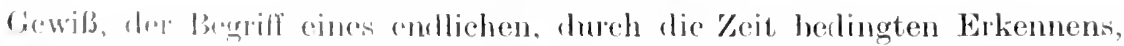

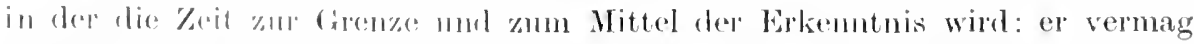

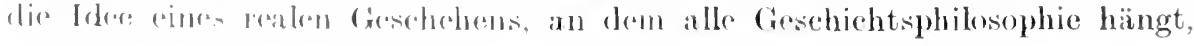


nicht zu zerstören; aber alle erkenntnistheoretisch-methodologische Fragestellung begeht schon in ihren Grundbegriffen eine ungeheure Abstraktion, die sie unfähig macht, an die eigent lichen Hauptfragen der Geschichtsphilosophie auch nur heranzutreten. Das muß eimmal rollkommen eingesehen und klargelegt werden. Die moderne Erkenntnistheorie löst die Wirklichkeit in ein dünnes Netz ron Begriffen auf, in Form und Inhalt zerlegt sie die ganze Seinswirklichkeit der Welt. Damit ertötet sie aber gewissermaßen (lie Lebendigkeit der Welt. Auch das Geschehen wird gleichsam versteinert. Wenn wir in der Logik ron dem Weltinhalt reden und dem Verhältnis ron Form und Inhalt. so sind beide gleichsam erstarrt. Sie sind die ewig gleichen regungslosen Bedingungen der Wirklichkeit. In der logischen Welt stockt das Geschehen, das Geschehen selber ist hier starre Form. Das soll selbstrerständlich keinen Vorwurf gegen Logik und Erkenntnistheorie bedeuten. Ohne sie wäre eine Bemeisterung der philosophischen Grundprobleme ummöglich. und die Logik ist es auch allein, dje auf unser Fragen und Forschen nach dem Weltensimn die erste große Antwort zu geben vermag. Niemals aber ist das Reich des Wissens in ihr beschlossen, noch rermag sie allein das Bild einer simmollen Wirklichkeit zu entwickeln. Die Logik ist die grundlegende philosophische Disziplin, nicht aber die abschließende. Nur die Geschichtsphilosophie vermag unsere Deutung der Wirklichkeit zum Abschluß zu führen. So widersinnig es ist, den Gedanken des Geschehens oder der Entwicklung in das Reich der unsinnlichen, zeitlos geltenden Formen einzuführen, um diese Formen wie in der Hegelschen Logik aus einander hervorgehen zu lassen, so notwendig ist doch auch wieder der Gedanke der Entwicklung und des Geschehens zu einem abschließenden Weltbegreifen. So kömnen wir verstehen. wie jenes statische Weltbild. das die Grundbegriffe der Kantischen Logik errichtet hatte, schon bei Fichte zu einer Geschichte des Selbstbewußtseins führte. Damit wurde aber der ursprüngliche sinn dieser Prinzipien rollkommen geändert. Was nun als höchste logische Bedingung gemeint war, die reine Form, der reine Begriff wird zu einer metaphysischen Wirklichkeit, die simnlich qualifiziert gedacht erscheint, sofern sie sich rerändert. Die wiederholten Versuche des deutschen Idealismus, den Entwicklungsgedanken in das Reich der logischen Formen hineinzutragen. sind als vollkommen gescheitert anzusehen, aber die Forderung besteht zu Recht, daß das Geschehen nicht ausgelöscht werden darf und wederdurch den Begriff einer kategorialen Form noch durch den Begriff eines bloßen Inhaltes aufgehoben werden kann. Das Geschehen mußnicht nur in den Wissenschaften, sondern auch in der Philosophie einen adäquaten Ausdruck finden, und der Ort hierfür ist die Cniversalgeschichte. Ohne sie würde das Bild der Welt, das die Philosophic anfzuweisen bemüht ist, starr und kalt sein und der lebendigen, schöpferischen Bewegung sowie des letzten sinnes entbehren.

Diese Überlegungen führen mit Notwendigkeit zu der Behauptung, daß die Geschichtsphilosophie nicht nur eine philosophisehe Spekulation über rlas Wesen und den Begriff der Geschichtswiscenschaft bedeutet, oder, mit anderen Worten. daß sich die Aufgabe der Geschichtsphilosophie in den methodologischen Problemen niemals erschöpfen kann. Vielmehr verweisen uns die Formen der historischen Erkenntnis schließlich auf einen Standpunkt, wo es sich, über die Theorie der Wissenschaft hinans, nummehr um die Frage handelt, 
wie die absoluten Werte zum historisehen Leben und zum Weltgesehehen stehen. An der Hand der methodologisehen Probleme müssen wir uns auf diese letzten Probleme der Geschiehtsphilosophie besimnen, die ein für allemal in der Idee der Lniversalgesehiehte besehlossen sind. Ob und in welehem sime eine solche Universalgesehiehte als Metaphysik aufzufassen ist, sofern sie ja üher die Ziele der Erkenntnistheorie hinaus die Wirkliehkeit nieht mehr in Begriffe auflöst. sondern synthetiseh das Getrennte wieder zusammen-chließt und sich der sinnliehen Wirkliehkeit wiederum zu bemäehtigen sueht, das müssen wir vorläufig problematiseh lassen.

Die Aufgabe dieses Kapitels muß darin gesucht werden, über den Charakter der Gesehiehtsphilosophie ganz allgemein zu orientieren und dabei ihre allsemeinsten Probleme bloßzulegen. Wir gingen von dem Gegensatz zwisehen Gesehichtsphilosophie und Philosophiegesehichte ans, der uns sogleieh auf len allgemeinen Gegensatz von philosophiseher und historiseher Fragestellung führte, die beide in so verschiedener Weise den standpunkt der persönliehen Anteilnahme, wie ihn das Leben haben will und soll, das den Gegenstand seines Interesses zum Universum macht, zerstören und vernichten, die es in so verschiedener Weise einem Allgemeinen zum Opfer bringen. Wie aber der Begriff ler Philosophie vorläufig noeh problematisch bleiben mußte, so auch der Begriff der Geschiehte, die wir in doppelter Bedeutming verstehen, sofern darunter eimmal die Kulturerseheimung der historisehen Wissensehaft rerstanden wird und andererseits das reale Weltgesehehen selber. Wir fragten uns, ob die berïhmte Deutung, die Kant dem Phänonen der Zeit hat zuteil werden lassen, (1) sie wirklich die Realität des historischen Geschehens bedroht, und mubten diese Frage verneinen. Ja, wir sahen uns sogar zu der Behauptung gerlrängt, daß nur unter dem Aspekt des wahrhaft endliehen Wesens und des ungetilgten Gegensatzes ron Endlichkeit und Unendliehkeit das Problem der Geschichtsphilosophie zu Reeht besteht. Wir mußten fermer aueh sogleieh darlauf hinweisen, da B die erkenntnistheoretische Ủberlegung das Geschehen stejcham erstarren läBt und damit das Leben verliert, und claß eben dies Geschehen, das die Jogik niemals vollkommen mudenten und aufclenten kann, in der Lniversalgeschichte wiederkehrt. So muls zwar alle geschiehtsphilosophiwhe (therlegung von einer Theorie der historischen Wissensehaft ausgehen; aber die besinumeg auf ihre Formen treibt anch mit Notwendigkeit weiter zor der Fragr nach dem allgeneinen Simn des realen Weltgesehehens.

\section{Kweites Kapitel. \\ Derl Begreiff der Philosophie.}

a) Philosophie als Lehre vom Gianzen.

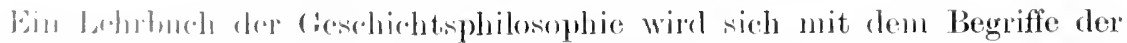

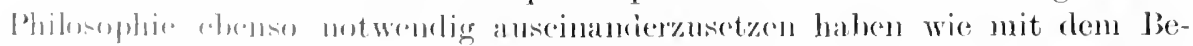

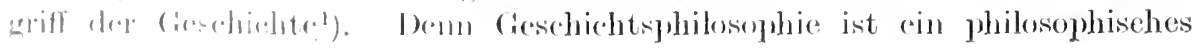

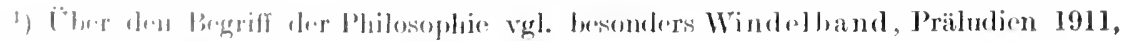
und Heiturich Rickort, Logos, Bed. 1, Il. 1. 
Deuten der Geschichte. Was nun aber Philosophie sei, daribber gehen die Meinungen und Auffassungen weit anseinander. Was ist nicht alles unter Philosophie rerstanden worden. War nicht ursprünglich jede Form der Erkenntnis Philosophie? Ist nicht die Physik im Sinne des Aristoteles genan so gut ein Teil der Philosophie wie etwa für den modernen Philosophen die Logik oder die Asthetik? Aber sogleich ergibt sich doch ein Cntersehied, sofern eine Erkenntnis, die nur auf das Verstehen des Einzelnen gerichtet ist, den Namen der Philosophie nicht zu verdienen scheint. Es liegt im Wesen der Philosophie, sich nicht mit der Erkenntnis des Einzehnen zu begnïgen, sondern alles Einzelne aus einem allgemeinen Prinzij verstehen zu wollen. Die Erkenntnis des Ganzen der Wirklichkeit ist die Aufgabe der Philosophie, die Erkenntnis des Einzelnen bedentet im Sinne der Philosophie ein Unrollendetes. Dagegen können wir uns eine Form der Erkenntnis denken, welche die bewußte Selbstbeschränkung sich anferlegt, daßs sie es nur mit einem Teile des Wirklichen zn tun haben will. Eine solehe Selbstbeschränknng, eine Festlegnng der Erkenntnis auf ein bestimmtes Gebict würde dam etwa der Natur des spezifisch wissenschaftlichen Denkens entsprechen. Die Philosophie wäre somit nach unserel ersten Bestimmung die Wissenschaft rom Ganzen der Wirklichkeit. In diesem Sime ist etwa die Aufgabe der Metaphrsik ron Aristoteles festgelegt. Während die rerschiedenen Wissenschaften segmente oder Ausschnitte der Wirkliehkeit bearbeiten nnd erkennen, hat es die Philosophie mit dem Ganzen der Wirklichkeit zu tun. Diesen Gegensatz der Aufgaben und Ziele. wie er zwischen der Philosophie mol den anderen Wissenschaften besteht, hat der große grieehische Denker ganz ohne Zweifel richtig erkannt, dies partikulare Interesse der Einzelwissenschaften. die ron ihren besonderen Prinzipien geleitet an die Erkenntnis der Wirklichkeit herantreten, und das miversale Interesse der Philosophie.

\section{b) Weltphilosophie und Leheusphilosophie.}

Allerdings fragt es sich, ob diese Cnterscheidung und Bentimmmng im vollen Umfange aufreeht zu halten ist. Gewiß gibt es eine Form der Philosophie, die vollkommen bewnßt eine Erkenntnis des Weltganzen anstrebt, diese Philosophie ist die Metaphysik. Sie erhebt die Frage nach dem sinn der Welt und sucht eine Antwort zu finden auf die schicksalsschweren Fragen des Woher und Wohin der menschlichen Seele. Gottes und der Seele Wesen sucht diese hohe göttliche Wissenschaft zu begreifen. Aber gibt es nicht anch andere Formen der Philosophie, die ebenso berechtigt sind, ja die vielleicht gerade wegen der Begrenztheit der Aufgaben, die sie sich gestellt haben, ein hohes Maß ron Vertranen rerdienen? Hat es nicht Philosophen gegeben, die anf jede Welterkemntnis bewußt Terzicht geleistet haben, und denen es lediglich daranf ankam, über die Bedentung unseres Lebens sich Rechenschaft zu geben? Sie stellten ein Prinzip der Lebensführung auf: das Gute, das Schöne, das Indifferente, das Schmerzlose, die Lust. In diesem Prinzip sahen sie das Ideal der Lebensführung. Schönheit oder Lust sollte der Simn des Lebens sein. Entbehrten nmm solehe Denker wic śokrates und Aristipp der miversalistischen Tendenz, da sie es doeh nur mit dem Le ben zu tun hatten mnd nicht mit der Welt? 
Wie verhalten sich zueinander Welt und Leben?. Wie sich das Ferne zum Nahen und das Ganze zu den Teilen verhält. Denn das Leben, was hier gemeint wird. ist das menschliche Leben, mein, dein und unser Leben, das sich als besonders wichtig und bedeutsam heraushebt aus dem ganzen Zusammenhange der Welt. Den Sim des menschlichen Lebens will ich verstehen, die Forderungen kemnen lernen, denen der einzelne zu genügen hat, um seine Bestimmung zu erfüllen. Meine ich etwa, dies Ziel sei die Schönheit, und ich bejahe diesen Simn, so lebe ich das Leben der Schönheit. Wenn ich nach dem Lebenssinn frage, so frage ich nach etwas, was mich ummittelbar angeht, und die Erkenntuis, die ich hier zu gewinnen suche, hat etwas Terpflichtendes und Bindendes fïr mich. Bin ich zur Erkenntnis des Sinnes gelangt, so werde ich ihn anerkemnen oder verwerfen. Terwerfe ich ihn, so muß ich das Leben remeinen, bejahe ich ihn. so muß ich bestrebt sein, den Simn des Lebens zu erfüllen. Deutlich ist hei dieser ganzen Fragestelhng die Beziehung zur einzelnen Individualität. Wie soll ich und du und jeder für sich sein Leben einrichten, um es wertroll zu gestalten, um es in der Richtung auf einen letzten Simn zu formen? Nicht auf große allgemeine Zusammenhänge geht hier die Fragestellung. nicht wird Erfüllung gesucht in dem gemeinsamen Schicksal der Menschheit, weder mit dem Sinn der Welt noch mit dem Simn der Geschichte wird das Leben des einzchen verbunden, sondern es handelt sich um eine Frage, die den einzehnen als einzehnen angeht. Wir fragen nicht, was das Absolute sei für die Welt oder für die Menschheit, sondern was das Absolute und das Letzte sei für dich mol für mich. Gibt es einen Sinn des Lebens, den jeder einzelne für sich erfüllen kam? Wemn nun die Frage bejaht wird und die Forderung sich erhebt: ..Lebe das Leben der Schönheit", und der Mensch in der Bezichung zum Schönen als einem umbedingten Wert, der das Leben erst bedeutungsvoll und wertroll macht, seine Bestimmung ergriffen hat, dann ist im Grunde genommon auch die Antwort gegeben auf die metaphysische Frage nach dem sinn der Welt und die geschichtsphilosophische nach dem Sinn des Geschehens. Hat das Jeben des Menschen einen vernünftigen sinn, so ruht dieser Sinn anch in Welt mol Geschichte. Nur wird der Philosoph des Lebens sehr häufig verzichten, ihn dort aufzusuchen, wo er am Horizont seines Blickfeldes noch matt erglänzt, da er ihn nmmittelhar ergriffen hat in seinem eigensten und innerit (en lerbent.

Aneh die 'Tenclenz der Jebensphilosophen ist unirersalistisch anf das Gamze gerichtrot. Sic verstehen das mensehliche Lehen als die höchste form des Mreltoulascins und damit die Welt, wähend der grobe Metaphysiker die

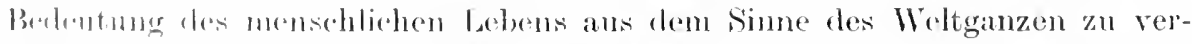
stchensucht Immer sucht die Philosophio das Eine, das Letzte das zugleich

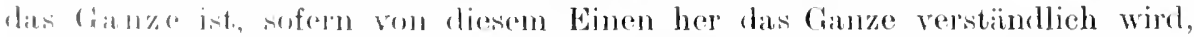

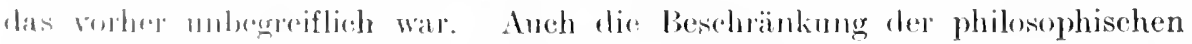

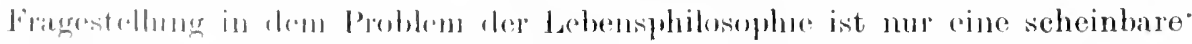

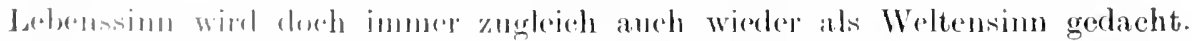

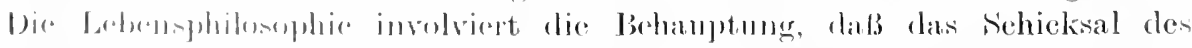

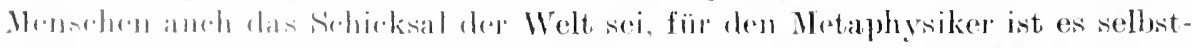

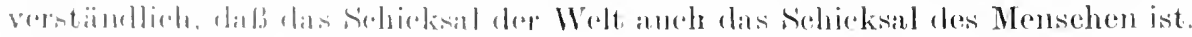

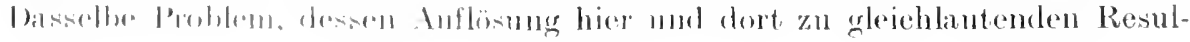


taten führt, wird in dem einen Falle mehr nach der Seite der Fonkretheit und Individualität, im anderen Falle mehr nach der Abstraktheit und Allgemeinheit gewendet.

So läßt es sich wohl aufrecht erhalten. daß die Philosophie es immer zu tun hat mit dem Ganzen, sofern sie es mit dem Einen zu tun hat. welches das Ganze deutlich und rerständlich macht, nur daß dieses Eine in der Yorstellung der Metaphysik die Welt erhellt und mit einem Abglanz auf dem Leben leuchtet, während es in der Vorstellung der Lebensphilosophie des Leben erhellt und mit einem Abglanze auf der Welt leuchtet.

\section{c) Grenzen wissenschaftlicher Theorien.}

Wenn somit die universalistische Tendenz der Philosophie auch keinem Zweifel unterliegt, so ließe sich doch ein Einwand erheben gegen die Behauptung daß das wissenschaftliche Denken, wie wir es im Gegensatz zur Philosophie verstehen wollen, auf die Erkenntnis des einzelnen abzielt. Ist das Ziel der wissenschaftlichen z. B. naturwissenschaftlichen Erkenntnisnicht auch das Ganze der Wirklichkeit? Bedeutet die Trennung der Naturwissenschaft in Mechanik. Physik, Chemie, Biologie ein Endgüiltiges oder nu ein Vorlänfiges? Welcher Gesichtspunkt bestimmte diese Aufteilung der naturwissenschaftlichen Objekte? Handelt es sich hier um ein der Arbeitsteilung verwandtes Prinzip, sofern der Physiker geschickter ist, das Phänomen des Lichtes und des Schalles zu erklären, während etwa der Biologe den organischen Erscheinungen ein reiferes Verständnis entgegenbringt? Sind etwa psychische Qualitäten der Aufmerksamkeit und Beobachtungskunst die Mittel, deren Kultivierung den menschlichen Geist befähigt, den rerschiedenen Graden von Kompliziertheit, wie sie in den einzelnen naturwissenschaftlichen Erscheinungen vorliegen, gerecht zu werden? Ist etwa der Biologe dem Chemiker gegenüber nur der zartere und feinere Beobachter zarterer und feinerer Erscheinungen, oder gehen sie verschiedene Wege zur Erklärung und Erforschung verschiedenartiger Gegenstände? So sehr nun auch das Bestreben rorzuliegen scheint, die Trennung zwischen den einzelnen Naturwissenschaften und ihren Objekten zu überwinden. so sehr leistet doch die Natur der Objekte diesem Bestreben Widerstand. So liegt etwa in dem Phänomen des Lebens ein Objekt der Erkenntnis ror, dessen eigentümlicher Charakter und logischer Sinn eine Zurückführung auf physikalische und chemische Erscheinungen rollkommen ausschließtr). Und so eng auch die Beziehungen zwischen dem Physikalischen und Chemischen sein mögen, so verschieden ist doch auch wieder das logische Interesse. das sich in diesen Wissenschaften kundgibt, sofern die Physik die Natur verstehen will als ein Geschehen des Gleichartigen, die Chemie aber als ein Sein des Verschiedenartigen. Wir müssen annehmen, daß es sich in den einzelnen naturwissenschaftlichen Disziplinen um eigentümliche, nicmals vollkommen auflösbare Gegenstände der Erkenntnis handelt, die durch ein besonderes Vernunftinteresie gefordert sind, und zu deren Erforschung und Erklärung eine eigentümliche Methode erforderlich ist.

1) Vgl. Riohard Kroner, Zweck und Gesetz in der Biologie. Tübingen 1913. 
Nun hat sich ja immer wieder die Forderung erhoben, die verschiedenen Saturwissenschaften als cine Einheit zu begreifen, und indem man den Gedanken der idealen Taturwissenschaft ergriff, glaubte man alle Erkenntnis als Form der Naturwissenschaft rerstehen zu sollen. Die Idee dieser miversalen Naturwissenschaft als umfassende Form des Weltrerstehens gehört ler Renaissance. Abgewendet der Erkenntnis der äbersinnlichen Welt, erschien rlieser Zeit die Natur als der Inbegriff des Wertrollen. Es gibt mur einen Gegenstand der Erkemntnis: die Natur, und nur eine Form der Erkenntnis: die mathematisch-naturwissenschaftliche. War der Anfang der Renaissanceepoche ron der Idee des Organismus beherrseht, so herrscht im 16. und 17. Jahrhundert rie Idec des Mechanismus. Die psychischen Phänomene, die sozialen Institutionen wie Gesellschaft und Staat, die Bläte des geistigen Lebens, Moralität und Sittlichkeit. ja sogar die Leidenschaften der menschlichen seele sollte der Mechanismus begreiflich machen, der Mcehanismus, der darauf gerichtet ist, die Individualität und Verschiedenheit nach Kräften auszulöschen. Er lehrt die ewig gleichen Gesetze, die für alle Dinge dieselben sind. und diese Dinge und Substanzen sind dic gleichen Atome, die in dem kontinuierlich gleichartigen Medium res Raumes sich bewegen, denen jedoch noch eine quantitative Individualität zulommt, sofern sie einen bestimmten Ort im Paum einnchmen, in einer bestimmten Richtung sich bewegen und eine bestimmte Geschwindigkeit besitzen; aber auch die Individnalität der Lage wird bedroht durch den Gedanken, daß immer nach Ablanf einer bestimmten Zeit eine gleiche Gruppierung der Atome im Raume sich vollzieht, also durch die Idee der Wiederkehr des Gleichartigen in der Atome Rublage und Bewegnng. Von der Idee des Mechan ismus beherrscht, crhob also die Naturwissenschaft den Anspruch anf universale Welterkenntnis.

Lm romantischen Zeitalter siegte dann unbedingt die Idee des Organismus um der Gedanke einer naturwissenschaftlich teleologischen Erklärnng Irer Nitur, vor allem in der Naturphilosophie s'chellings.

Schelling kennt aber einen Naturbegriff, der nicht mehr das Ganze der Wirklichkcit unfaßst, sondern eine Teilwirklichkeit als Unterbau einer höheren ureistigen Welt und nur als Mittel im Dienst dieser wertrollen Welt selber beIroutsan. So sicute in der Naturphilosophie Seh ellings die Idee des Organismus wllkommen ïbor len Mechanismms ${ }^{1}$ ). Der Mechanismus gilt der Romantik Als cine dürre Alstraktion, die kein Leben in sieh birgt und deshall vollkommen unwirklich, cin blolies Nichts ist. Wir begegnen also in der Entwieklung des naturwissonschaftlichen Denkens den beiden 'Tondenzen, die einander entgegenlinf(1), nämlich entweder alle Erscheimmgen durch den Mechanismus oder aber

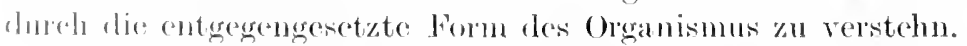

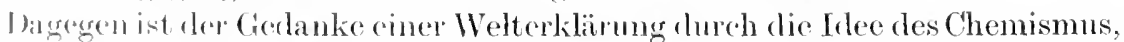
als derjenigen Form, die \%wischen dem Mechanismes und Organismus steht, nir. in ser dentlicher Form hervorgetreten²).

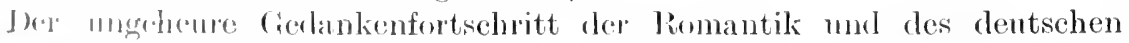

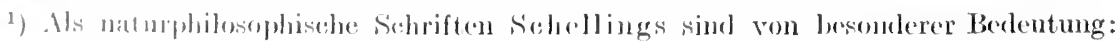

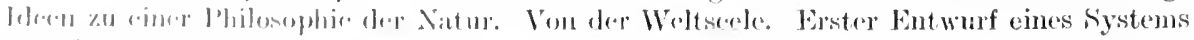
Arer Nitturphilemephire.

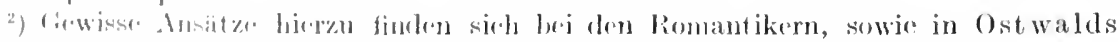

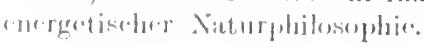


Idealismus gegenüber der Renaissance zeigt sich ror allem in der Einsicht, daß in den verschiedenartigen Formen der Naturerklärung mol ihren verschiedenartigen Gegenständen versehiedene Formen der Erkenntnis zum Ausdruck gelangen, in denen ein besonderes Vermunftinteresse sich kundgibt. Dals Mechanismus, Chemismus und Organismus Kategorien les naturwissenschaftlichen Denkens sind, dashat vor allem Hegel eingesehen, und währent die Renaissance in der Idee des Mechanismus oder Organismus sehafft und lebt. hat Hegel als Nachfolger ron Kant und Schelling ihren logischen sim aufżuhellen unternommen. Die Naturphilosophie der Renaissance, sofern sie sich von der Idee des Organismus leiten ließ, war der mechanisehen Welterklärung noch unkundig. Sie muß der Welterklärung eines Galilei gegenüber unbedingt als die primitivere und nachgeordnete Form der wissenschaftlichen Theorie erscheinen. Die Philosophie des deutschen Idealismus sucht diese beiden Denkgebilde zu verstehen und sie in ihrem verschiedenartigen Erkenntniswert gegeneinander abzugrenzen. Und so kommen dem Kant, Schelling und Hegel zu drei rerschiedenartigen Deutungen von Meehanismus und Organismus, ihrem gegenseitigen Verhältnis und ihrer Erkenntnisbedeutung.

Die Auffassung Kantsin läßt sieh in Kürze dahin zusammenfassen, daf der Mechanismus für ihn die Form der Simnenwelt ist, während die Idee des Orga nismus die Sinnenwelt überwindet. Der Mechanismus, die Erklärung durch äußere Ursachen und allgemeine Naturgesetze, sie leistet weit mehr, als der Organismus und die teleologische Erklärung zu geben vermag, ja der Meehanismus ist die für die Simnenwelt einzig branchbare Erklärungsweise. Und insofern die Anfgabe der Wissenschaft darin gesucht werden muß, das Reich der Erfahrung, die Sinnwelt uns kund zu tun, muß der Mechanismus als die einzig wissenschaftliche Erklärungsart der Phänomene und die mathematische Naturwissenschaft als die Naturwissenschaft schlechthin betrachtet werden. Auch vor dem Leben darf der Mechanismus nicht Halt machen, auch die organischen Phänomene muß er mechanisch zu erklären suehen. Die Aufgabe der Naturwissenschaft muß darin gesncht werden, diese ganze Simnenwelt als unterworfen den Gesetzen der mechanischen Bewegung deutlich zu machen. Allerdings ist diese Aufgabe mnłöslich und unerfüllbar, und zwar in doppelter Hinsicht, eimmal, weil die Aufgabe der Wissenschaft gegenüber der Fülle des immer wieder nen zu bestimmenden Inhalts überhaupt mnendlieh ist, weil immer wieder neneMaterial der logischen Formung sieh darbietet; weiter aber in diesem Falle darüber hinaus noch unlöslich, weil zwischen Mechanismms und Leben eine Inkongruenz besteht, die ein für allemal unüberwindlieh ist. Was wïre auch wohl so prinzipiell entgegengesetzt wie Mechanismus und Leben? Tnüberwindlich ist das Leben für den Mechanismus, und im Mechanismus ist das Leben zerstört. Das Leben ist durch den Mechanismus. der alles dureh äußere Ursachen erklären will, nie und nimmer zu verstehen. J)ie Bewegung der Himmelskörper, aber keinen Grashahm vermag der Meehanismus verständlich zu machen. Demn der logische Sinn, welcher in der Idee des Organismus rerborgen liegt. ist die Wechselbestimmung des Ganzen dureh die Teile und der Teile dureh das Ganze. Die Kategorie des Zweckes, die der übersimnliehen Welt gehürt,

1) Besonders in der Kritik der Urteilskraft. Kants Werke Bd. Y, (Akademiesausgabe). 
und unter den Formen der Erscheinungswelt als den Formen des Mechanismus keine Stelle findet, sie tritt im Leben dentlich hervor. Mit dem Leben verbindet sich Sinn und Zweck und Wert. MitSinn und Zweck kann aber der Mechanismus nichts anfangen. Er muß den Sinn auslöschen und vertilgen, denn nur das Sinnlose kann er verstehn. Der Mechanismus ist somit die einzig mögliche wissenschaftliche Erklärungsart. Die Idee der idealen Naturwissenschaft und der wissenschaftlichen Einheit erfordert eine Erklärungsart und einen Gegenstand der Erkenntnis. Die Erfüllung dieser Aufgabe scheitert am Leben, am Organismus. Die Wissenschaft mit ihren Erkenntnisformen kann also die sinnenwelt nicht bemeisterm. In der Sinnenwelt liegt etwas, was über die Sinnenwelt hinausgeht. Dieses über dic Sinneswelt Hinausragende ist Gegenstand der philosophischen Spekulation. Daß die wissenschaftliche Spekulation mit dem Organismus nichts anfangen kann, daß die teleologische Erklärung ein rom wissensehaftlichen Standpunkt unmöglicher Aspekt ist, besagt nichts gregen die Bedentung des Organismusbegriffes und der teleologischen Betrachtungsweise. Die wertfreie Betrachtungsweise der Wissenschaft kann mit ihnen nichts anfangen, wohl aber handelt es sich hier $n$ m Begriffe von eminent philosophischer Bedeutung. Ein Gegenstand, der niemals wissenschaftlich restlos rerstanden werden kann, der notwendig auch der Philosophie gehört, an dem sich wissenschaftliche und philosophische Spekulationen treffen und trennen, ragt in die Sinnenwelt hinein, das Leben, der Organismus. Sein logincher Sinn bedentet einen Hinweis anf die übersinnliche Welt, auf den Endzweck der Natur und das Reich der übernatürlichen Zwecke.

Fassen wir das Resultat von Kants Untersuchung zusammen, so vermag nur der Mechanismus als die wertfreic wissenschaftliche Betrachtungsweise einc inhaltliche Erkenntnis der Simneswelt zu gewähren, aber diese Erkenntnis ist niemals vollendet und bezicht sich auf eine Welt der Erscheinung, nicht aber auf ein Reich wahrer und ewiger Dinge. Den Organismus und die teleologische Erklärung darf die Wissenschaft nicht dulden und kann sie doch nicht aus der Welt schaffen. Was also für die wissenschaftlich Spekulation ein Unbegreifliches bleibt, las bereichert die philosophische spekulation, demn der Organismus ist durch die Form des Utbersinnlichen, dureh den Begriff des Zweckes konstituiert. Und so wird das wissenschaftlich Unmögliche und Unhegreifliche zu dem philosophisch Wertvollen. Mechanismus mol Organismus verhalten sich wic Wissenschaft und Philosophic, wie simnliche und ïhersinnliche Welt.

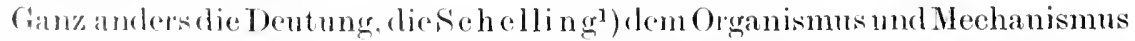
zutcil werden läßt. Bei Kant waren die Formen des mechanischen Weltver-

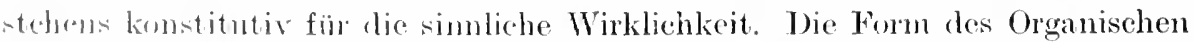
hatte für die Erseheimungswelt cine nur regulative Belentung. Für Schelling

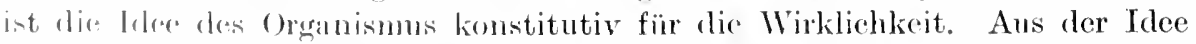
des Organismus nuiisson alle Formen der Natur abgeleitet werden. Die mechanischon forman der Repulsion und Attraktion werden als niedere Formen des

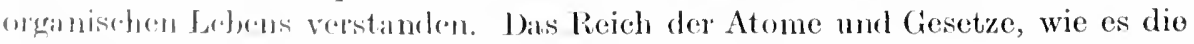
mathematische Natmwissenschaft aufbaut, ist cine dïrre Abstraktion von der

1) Bescombery in den Schriften zur Naturphilosophie. 
Fülle der Lebensformen, welche die göttliche Natur in unbezweifelbarer Realität aufweist. Hier bei den Philosophen der Pomantik erringt also die Idee des Organismus einen rollkommenen Sieg über den Mechanismus.

Eine rorläufige Lösung des Problems in einen großen metaphysischen Zusammenhang hat dann Hegel gegeben ${ }^{1}$ ), der den Mechanismus mit dem Urganismus zu rersöhnen suchte. In dem system Hegels soll ja alles seine Stelle finden, sollen alle Gegensätze miteinander rersöhnt, in der Idee eines höchsten konkreten Allgemeinen aufgehoben sein. Die Iclee des Mechanismus und des Organsimus wird eingeordnet in das große Stufenreich der Gottesund Welterkenntnis. In ihnen weiß das Absolute die Welt, und in ihnen wissen wir das Absolute, sofern es sich in der Welt darstellt. Der Mechanismus ist im Vergleich zum Organismus das weniger adäquate Weltwissen. Es gribt drei Stufen des Naturwissens, Mechanismus. C'hemismus und Organismus. Alle drei sind konstitutive Formen der Wirklichkeit, d. h. die Natur ist sowohl Mechanismus wie Chemismus und Organismus. Das Reich der mechanischen Gesetze und der Atombewegungen ist die unvollendete Natur, die Natur in ihrer Abstraktheit, sofern eine solche Auffassung nur etwas aus der Wirklichkeit herauspräpariert und als Natur bezeichnet. Wenn die Pomantik den Mechanismus als Abstraktion bezeichnet, so meint sie. daß die Naturgesetze nichts sind als allgemeine Begriffe ron den Dingen, die nur für mnsere Reflexion bestehen, aber das Wesen der Dinge nicht berïhren. Nicht in diesem Sime ist der Nechanismus bei Hegel abstrakt. Er ist es im Sinne des Undifferenzierten und Unentfalteten. Der Nechanismus ist Form der Wirklichkeit, aber in ihm ist die Idee der Natur noch nicht zur Erfüllung gelangt, sondern auf der ersten Stufe des Werdens.

Wir sehen somit, daß die Philosophie immer wieder den Versuch macht. den Gegensatz ron Mechanismus und Organismus zu ïberwinden. In allen diesen Versuchen wird die Naturwissenschaft zur Naturphilosophie. Die Idee der Natur als eines geordneten Ganzen und die Idee eines einheitlichen Wissens von der Natur, das sind Vorstellungen. die den synthetischen Bestrebungen der Philosophie entspringen mag num in einem Sistem der Logik die Versöhnung des Organismus mit dem Nechanismus vollzogen werden oder als Erfülhung der naturwissenschaftlichen Erkenntnis die Idee einer letzten Naturwissenschaft sich erheben ${ }^{2}$ ). Für die Naturwissenschaften bestehen die verschiedenartigsten Gegenstände und Phänomene, die eine resschiedenartige Behandlung und Forschungsmethode rerlangen. Die Philosophie erhebt die Forderung der Einheit des Verschiedenen und Getrenuten. Es bleibt aber zunächst zweifelhaft, in welcher Richtung sich diese Utberwindung des Gegensätzlichen zu vollziehen hat, ob etwa die Aufgabe der Naturwissenschaft darin gesucht werden muß, daß sie alle Phänomene auf letzte Dinge, wie etwa die Atome, und auf Beziehungen zwischen diesen letzten Dingen zurückführt oder alle als verschiedene Stufen eines einheitlichen Weltlebens begreift. Was aber realiter und tatsächlich in den einzelnen Naturwissenschaften gegeben ist, hat bisher allen Versuchen einer einheitlichen Erklärungsart Widerstand

1) Hegel: Enzyklopädie. Zweiter Teil: Naturphilusophie. S. $66 \mathrm{ff}$.

2) Rickert: Die Cirenzen der naturwisschaftlichen Begriffsbildung. Tübingen 1913. 
geboten $\left.{ }^{1}\right)$. Die chemisehen Erscheinungen lassen sich nicht auf die mechanischen zurïckführen, und das Leben läßt sieh aus dem chemischen Prozeß nicht restlos erklären. In dem ehemischen Gegenstand tritt zum meehanischen etwas Xenes hinzu, und dasselbe gilt für die Phänomene des organischen Lebens im Verhältnis zu den ehemischen. Dieser Gedanke der Unableitbarkeit der höheren Phänomene aus den niederen ist im Altertmm zuerst von Aristoteles, in nenerer Zeit besonders von Auguste Comte vertreten worden. Nach Aristoteles bedeutet dieses Neue, das zu den chemischen Phänomenen etwa hinzutritt, um sie zu organischen zu machen, eine neue und höhere Formung des Stoffes. Auguste Comte konstatiert mun einfach ein Stufenreich vou Phänomenen nach dem Maße ihrer Einfachheit und Alsstraktheit oder nach dem Grade ihrer Kompliziertheit ron der Astronomie bis zur Soziologie. Dem Grade der Kompliziertheit gemäß ist damn anch der Charaliter des Gesetzes, das diese Phänomene beherrscht. So sind die Wissenschaften tatsächlich anf verschiedenartige Phänomene hingewiesen, deren Eigentümlichkeit keine Reduzicrung und Auflösung duldet, was noch dentlicher ist, seitdem die Bedeutung und der Charakter der historischen Wissenschaft erkannt wurde. Es ist sinnlos und ummöglich, das ästhetische Gefühl mechanisch zu erklären oler in rein historischer Form über Regenwürmer und Grashałme zu handeln. Jede Wissenschaft hat ihr Gebiet, sie hat Grenzland, bei dem die Zugehörigkeit zweifehhaft soin kann, denn noch sind die Marken des Wissens nicht fest und deutlich hestimmt, aber niemals vermag eine Wissensehaft das Ganze der Wirklichkeit zum Gegenstande ihrer Entersuchung zu machen.

Wir gehen noch einen Schritt weiter. Es gibt eine philosophische und cine wissenschaftliche Auffassung der Natur. In der philosophisehen liegt aller Nachdruek auf Form und Einheit, in der wissenschaftlichen auf Inhalt und Mannigfaltigkeit. Philosophiseh kamn ich das Ganze der Wirklichkeit sowohl meehanisch wie auch chemisch und organisch rerstehen. Wissenschaftlich muls ich cinen Teil der Naturphänomene meehanisch, einen anderen ehemisch, einen dritten organisch begrcifen. Für die Philosophie erweist sich schließlich dep Mechanismms als ein Komplex ron Denkregehn umd der Organismus als ein Sinngebilde, das durch ganz bestimmte logische Forderungen konstituiert ist. Dio: Philosophie bricht also mit der Vorstellung selbständig dasciender merbanischer und organiseher Phänomene. Der Stoff des Wissens ist ein an sich Inelifferentes, das, in die versehierlensten Formen gegossen, immer wieder urore Erkenntnis zutage förlert. Die Intelligenz formt und bilket den Tnhalt

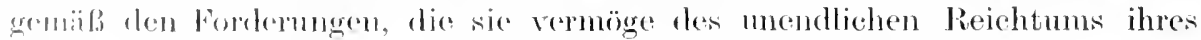

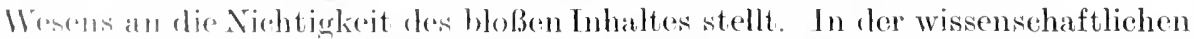
Auffassumg werden dagegen eigentiimbehe Phänomene unt Objekte der Er-

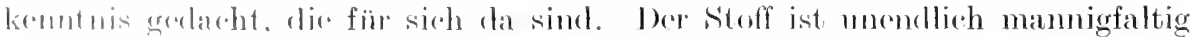

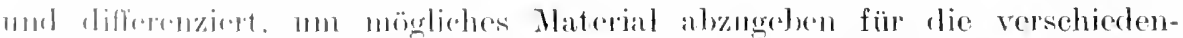

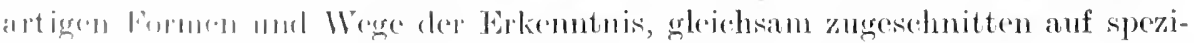

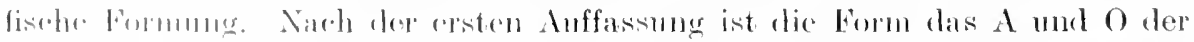

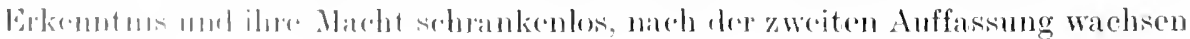

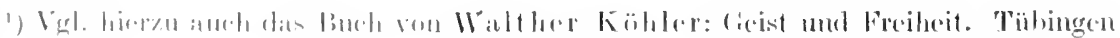
$1 ! 11$. 
der wissenschaftlichen Forderung aus der Natur des Stoffes eigentiumliche Probleme der Erkenntnis zu.

Von hier aus verstehen wir die Unmöglichkeit einer wissenschaftlichen Universalmethode. Sie erwächst aus dem Gedanken der Gleichgültigkeit des Stoffes im Verhältnis zur Form und ist deswegen rollkommen unwissenschaftlich. Denn zım Wesen der Wissenschaft gehört nun eimmal die zärtliche Rücksichtnahme auf besondere Inhaltlichkeit. Für die wissenschaftliche Universalmethode schrumpft aber die Verschiedenheit mechanischer, chemischer und organischer Phänomene auf die Gleichgïltigkeit desselben Weltstoffes zusammen. Die universale Methode der Naturwissenschaft, die sich seiner bemächtigt, kann dann sowohl die mechanische wie die biologische Erklärung sein, Arbeitsmethoden, von denen die mechanische vermöge ihrer mathematischen Exaktheit den Vorzng zu rerdienen scheint. Der philosophische Geist der Synthese offenbart sich in der Idee eines gemeinsamen Erkenntnisweges, der überall zum Ziele führen muß, weil der Weltinhalt im Grunde genommen durchaus gleichgültig ist. In der Idee der Universalmethode kommt die Forderung zum Ausdruck, daß das ganze weite Gebiet des Wissens doch schließlich einer einheitlichen Erkenntnisgestaltung unterliegt. Die verschiedenen Formen der Erkenntnis müssen sich ergänzen und unterstützen, und schließlich muß ron einem gleichartigen Gesichtspunkt aus die ganze Wirklichkeit deutlich und verständlich sein. Daß das historische Verstehen der naturwissenschaftlichen Erklärung ergänzend zur Seite treten soll, das ist gewiß eine notwendige und sinngemäße Forderung des Bewnßtseins, die aber niemals aus dem Interesse der wissenschaftlichen Erkenntnis ableitbar ist, das immer gegensätzlich und konfliktreich bleiben mu, sondern dem ernsthaften Nachdenken als eine philosophische Forderung sich erweist, sofern die Einheit des Wissens in regulativem Sinne als unendliche Aufgabe gestellt ist.

Der Geist endgültiger Synthese entstammt immer dem philosophischen Bewußtsein, und es sind zwei rerschiedene Forderungen, die ron ihm aus an die Wissenschaften ergehen, nämlich eimmal der Gedanke eines einheitlichen Zusammenschlusses sämtlicher Inhaltserkenntnis in der idealen Wissenschaft und dann die Idee eines systematischen Zusammenhanges aller der Denkformen, die den Inhalt so verschiedenartig gebildet und geprägt haben.

Die Idee der Natureinheit, welche die Philosophie denkt und der wissenschaftlichen Erklärung als Prinzip der letzten Naturwissenschaft entgegenhält, ist darüber hinans auch eine innere Angelegenheit der Philosophie, die sich mit der Wirklichkeit auseinanderzusetzen sucht. Das kamn aber in doppelter Weise geschehen, nämlich entweder so, daß die Philosophie der Naturwirklichkeit einen metaphysischen Inhalt unterlegt und sie zu verstehen sucht als das Reich des Unbewußten, des träumenden Weltgeistes wie in der Naturphilosophie Schellings, oder indem die philosophische Reflexion sich richtet auf das Gemeinsame der Form in aller naturwissenschaftlichen Erkenntnis, wie es die Erkenntnistheorie als Logik der Naturissenschaften sich zur Aufgabe macht. 


\section{d) Metaphysik und Wissenschaftslehre.}

Hier scheiden sich die Wege der Philosophie, sofern die Metaphysik mehr auf die Erkenntnis des Weltinhaltes gerichtet ist, während die Erkenntnistheorie nach der Erforschung der Formen und Prinzipien trachtet, auf denen das Wissen ruht, und nach denen unsere Erkenntnis sich richtet. Im ersten Falle handelt es sich in der Regel $11 \mathrm{~m}$ eine Uniformierung des Wirklichkeitsstoffes. Das Wirkliche ist Geist, Leben, Materie, Wille usw. Im zweiten Falle handelt es sich $11 \mathrm{~m}$ die Auffindung eine Gewißheitsprinzipes, einer Form der Wahrheit, einer letzten logischen Voraussetzung, auf der das ganze System der Erkenntnis ruht; die cogitatio Descartes, die Apperzeption Kants. Dieser eigentïmliche Charakter der beiden philosophischen Disziplinen hat dahin geführt, von der Abstraktheit und dem Formalismus der Wissenschaftslehre gegenüber der Fülle und dem Reichtum des metaphysischen Denkens zu sprechen. Sieht es bei dieser Gegeniiberstellung nicht so aus, als ob die Erkenntnistheorie niemals zur Erkenntnis des Wirklichen gelangen könnte, als ob sie uns lediglich aufzuklären vermöchte über den Weg, den wir gehen sollen, das Ziel aber ein für allemal in Schweigen und Dunkelheit ruhen läßt, oder ist jene Form der Wahrheit, anf der unser Wissen und alle Grundbegriffe der Methode ruhen, nicht vielleicht auch gleichzeitig das Ziel, das wir suchen? Was wir $11 \mathrm{~m}$ eines anderen willen erstrebten, was uns den innersten Gehalt des Wirklichen enthïllen sollte, das enthüllt sich mun selber als dieser innerste Gehalt.

Die Úberlegungen aber, die ron der Metaphysik fort zur Wissenschaftslehre hingedrängt haben, sind vor allem folgende: Es gibt keine Erkenntnis der ïbersinnlichen Welt. Mag uns auch in der Form des Denkens die Möglichkcit gegeben sein, jene Welt des Übersinnlichen zu verstehen, so ist doch dem Begriff, der aus der Sphäre des Simnlichen in die Sphäre des Ưbersinnlichen hiniiherleitet, keine Anschanung gegeben, kein intelligibeles Material, um Gott und der Seele Schicksal sowie das Große, Ganze der Welt zu wissen und \%u verstehen. Wir wissen, daß es eine übersinnliche Welt gibt, und wir wissen anch cinc Reihe von Forderungen und Irlealen, dic für jene übersinnliche Welt grelten und dort ihre Erfüllung finden; aber diese äbersinnliche Welt in ihren ganzen Quale wissen wir nicht. Daß die übersinnliche Welt ein Reich der Wahrheit und Sehönheit und Freiheit sei, wissen wir wohl, und dennoch bleiben uns die Wahrheit und die Freiheit und die Schönheit verhüllt und verborgren. Sie sind Fordernugen, die wir an oin Etwas richten, das alles Maß der likenubarkeit iibernchreitet, Begrifte für das Unhegreifliche, aber doch notwendige und absolute Begriffe, dic Bedentung haben müssen, so wahe der greflen Mensehhoitsentwicklung und dem Gesintlehen der Kultur irgendeine Bodentumg \%ukmmmt. Die höehsten Formen des Wisiens und des Kulturverstrhers bleiben für die Wissensehaftsklehre gewiswermatien gegenstandslos, sofern sir sich anf ein Etwas beziehen, das dunked und nächtig bleibt und dureh jone höchsten Prödikationon, die dem Sim einer Gexamtkultur erwachsen, nicht whellt mul ollenchtet wird. Jene höchsten Ifleen des menschlichen Geistes, zu donem wir mit Notwendigkeit grotrichen werden, dïrfen wir weder zu Substanzen rorlichten noch zu Eigensehaften ler Gottheit machen. Sie

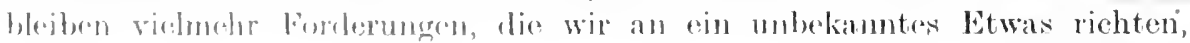


eine Forderung, die auf uns zurïckfällt in der Gestalt des Sollens. Der Begriff der Wahrheit ist so leer und mbestimmt wie der Begriff der śchönheit, wem wir ihn abgelöst ron der Wirklichkeit des Kulturlebens betrachten. Nur im Verhältnis zu Wissenschaft und Kunst wächst ihnen Leben und Bestimmtheit zu.

Wenn nun somit der Philosophie nach der Anffassung der Erkenntnistheorie ein inhaltiches Wissen ron der übersinnlichen Welt rersagt bleibt, so wird sie damit, wie es seheint, um so entsehiedener auf die sinnenwelt hingewiesen. Sucht sie aber eine solche Erkenntnis der Sinnenwelt sieh zu erwerhen, so tritt sie in Konkurrenz mit den Einzelwissenschaften. Sie strebt dann wie diese nach einer Erkemntnis simnlicher Inhalte. Sie sucht die Erseheinungen der Natur und Geschichte zn verstehen und zn deuten. Diese Versuche der Philosophie, mit der exakten Forschmngsweise der Wissensehaft in der Erkenntnis der Simmenwelt zu konkurrieren, müssen notwendig zum Dilettantismus führen. Somit ist, wie es scheint, die Philosophie von aller inhaltlichen Erkemntnis abgeschnitten. Die inhaltliche Erkenntnis der Sinneswelt wird durch die Einzelwissenschaften geleistet, ron denen jede mit ihren Begriffen und ihrer Forschungsmethode ein besonderes Gebiet des Wissens erforscht und bearbeitet; die inhaltliche Erkenntnis der übersinnlichen Welt ist der Philosophie versperrt, weil ihr eine übersinnliche Ansehaumng niemals gegeben ist. So scheint die Philosophie zum reinen Formalismus verurteilt zu sein. Sie maeht zu ihrem Gegenstand die letzten Toraussetzungen der Wissenschaft. Sie hat es mit dem Fundament von Axiomen und Prinzipien zu tum, anf denen alle wissenschaftliche Erkenntnis ruht, und sie fragt nach dem, was anerkannt werden muB, damit von Kunst, Sittlichkeit und Religion überhaupt die Rede sein kann.

Diese formalen Voraussetzungen der Erkenntnis, die letzten Bedingungen des Kulturlebens sind ron Kant als Ideen, als Normen, als Postulate, Regeh oder Kategorien bezeichnet. Die morlerne Bezeiehnung für diese höchsten und absoluten Begriffe, welche die Philosophie $\mathrm{n}$ ihrem Gegenstande macht, ist der Begriff des Wertes. So problematiseh dieser Begriff auch klingen mag, so sehr er versehiedenartigen Mißdeutungen ansgesetzt ist, so glïeklich bezeichnet er doch auch wieder den einzigen und wahhaften Gegenstand aller Philosophie. Der Gegenstand der Philosophie ist also die Form der Erkemntnis, des sittlichen Lebens, der Kunst usw. und riese Form ist in ihrer höchsten Gestalt Wert, und zwar absoluter, allgemeingültiger Wert. Nicht mit dem Inhalt und dem Wertlosen, sondern mit der Form und dem Wert hat es die Philosophie zu tum.

\section{e) Philosophie als Formwissenschaft.}

Gegen die Bestimmmng, daß es die Philosophie mit der Form und nicht mit dem Inhalt zn tun habe, richtet sieh der Einwand des Formalismus, gegen die Bestimmung, daß der Gegenstand der Philosophie der Wert sei, richtet sich der Einwand der Ethisierung der Philosophie oder auch wohl der Torwurf des Relativismus. Rechtfertigen wir zuerst den Begriff der Form. Daß der Gegenstand der Philosophie die Form sei als das Ewige und Unrergängliehe, das ist schon ron den großen griechisehen Denkern, ron Pla to und Aris to teles 
eingesehen. Nieht mit den flüchtigen, vergänglichen Erscheinungen der Sinnenwelt hat es die Philosophie zu tun, sondern mit dem Unsimnlichen und Bleibenden. Es gibt kcine Philosophie der Sehmetterlinge und des Laubwaldes, es gibt auch nieht eimmal eine Philosophie vom Mensehen. Aueh der schöne, geliebte Menseh, der unsere künstlerische Anbetung und Verehrung herausfordert, der mir vielleieht das Gefühl gegeben hat, an dem der Ewigkeitsgedanke so groß und mächtig wurde, er ist kein Gegenstand der Philosophie, die dem Ewigen zugewendet ist. Tom Blımendasein eilt die Philosophie zu der Idee des Lebens, rom Menschenschicksal zum Menschheitsschieksal. Mit dem Leben und der Gesehichte der Menschheit hat es die Philosophie notwendig immer zu tun.

Kann nun diese Tendenz der Philosophie, immer auf das Allgemeine zu gehen, auf die Bedingung sich zu richten, die den wechsehnden Erseheinungen zugrunde liegt, anf die Form zu reflektieren, welche die Fülle der sinnliehen Erseheimungen beherseht und bestimnt, als Formalismus bezeichnet werden? Die Formen, mit denen es die Philosophie zu tun hat, sind doeh nieht die leeren Hülsen, die ihres bedentungsvollen Inhaltes beraubt sind. Vielmehr sieht die Philosophie gerade in ihnen den Sinn und die Vermunft der Welt. Die Philosophie erkennt in ihnen das Entscheidende und Bestimmende für die Lösung des Weltproblems. Jede dieser Formen birgt in sich ein Problem des Wissens, deren Gesamtlösung zu dem Verstehen des Veltganzen führt. Die Erkenntnis des Inhaltes in seiner Mannigfaltigkeit, die Erkenntnis etwa der Natur in der Fülle der anorganisehen und organischen Bildungen und Gestaltungen, sie ist Aufgabe (ler Wissenschaft, bedeutet aber keine Mannigfaltigkeit philosophiseher Probleme. Für die Philosophie besteht nur das Problem des Inhaltes überhaupt, aber nieht das Problon eines bestimmten Inhaltes. Alle philosophisehen Probleme sind Formprobleme, nicht aber Probleme einer bestimmten Inhaltichkeit.

Suchen wir uns den Begriff der Form deutlich zu maehen. Die Form in philusophischer Bedentung ist ein Begriff, aber nicht jeder Begriff ist Form. Sufern die Form Begriff ist, tritt sie in Gegensatz zu dem simnlich Wirklichen. Das simnlich Wirkliche oder die Natur hat Dasein und Existenz. Der Begriff ist das Unwirkliche im Gegensatz zur Sinnenwelt als dem Wirklichen. Der Bugriff ist das Allgemeine im Gegensatz zu den Einzeldingen, die ein Besonderes sind, die cine cigentïnliehe Gestalt, Charakter und Indiviclualität besitzen. Fud withrend das Besmolere anf sich angewiesen ist und die Tendenz zur Isolienng in sich schließt in dem Gedanken des Andersseins, liegt in dom lBegriff fer Limwis und die Hindentung auf viele, deren Qualität dureh ihn bestimmt wirl. I) Thegriff hat seine Sphäre, die er beherrseht, ein gewisses Marhthrareh, ainch Krois von Erscheinumgen, der zu ihm gehört. Für diese Erachnomugan gilt der Begriff, das ist oine weitere neuc, von Kant erst her-

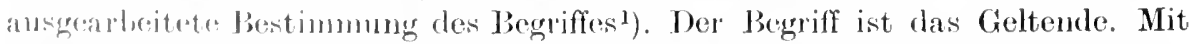
direser logischon bestimmung tritt er der Natur oder Sinnenwelt als dem Wirkliehen eneneniiber. Es war der Irrtum dor alten Philosophie, daß der

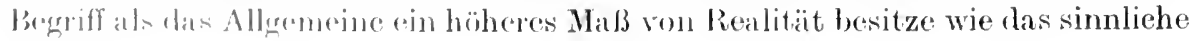

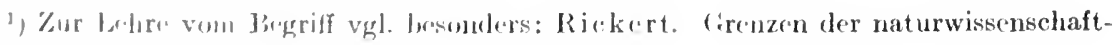

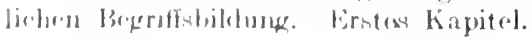


Einzelding, daß es, wie man wohl gelehrt hat, ein Stufenreich von Realitäten geben solle, daß etwas um so wirklicher sei, je höher der Allgemeinheitscharakter ist, der ihm zukommt. Das simnliche Einzelding, etwa diese mit ihren dunklen Kronen so schön aufgebaute junge Tanne hier, hat am wenigsten Realität, ist am flüchtigsten und rergänglichsten in ihrem Dasein. Was aber in allen Nadelbäumen immer wieder hervorbricht in Gestalt und Laubschmuck, in eigentümlicher Natur: dies Gemeinsame, was wir wohl als allgemeine Organisation und als Artcharakter bezeichnen, hat ein dauerhafteres Dasein und reicht über Jahrhunderte und Jahrtausende hinaus. Und die Torstellung des Allgemeinen, das in den individuellen und einzigartigen Erscheinungen sinnlicher Dinge immer wieder hervortritt, verdichtet sich zu einem substantiellen Wesen, das gleichsam fester, danerhafter und weniger leicht zerstörbar ist wie das Einzelding, das mehr Kraft und Gewalt besitzt, sich durchzusetzen und zu erhalten. Und wenn das Gemeinsame der zahlreichen vielgestaltigen Bäume schon eine solche Lebensfähigkeit besitzt, wieviel mehr dann noch jenes Etwas, daß allen Pflanzenformen imnewohnt. Weit mächtiger und substantieller aber muß sein das Gemeinsame aller Organismen und am gewaltigsten und mächtigsten das Gemeinsame aller Dinge, das, was in allen ist, die Gottheit. So erscheint die Wirklichkeit als das große Reich des Seienden, das, stufenmäßig aufsteigend ron dem Individuellen als dem Vereinzelten. auf sich Angewiesenen und mit dem Mindestgrad an Realität Behaftetem, zn demjenigen sich erhebt, das als Prinzip des Zusammenhanges sich über allem ausbreitet, das für alle ist, und dessen Realitätswert so groß ist, daß er niemals aufgeboben und vernichtet werden kann.

Diese Auffassung des Begriffes oder der Idee als des Allerrealsten und Allerwirklichsten verwischt die Klnft zwischen dem Simnlichen und dem Unsinnlichen. Kontinuierlich geht das Reich des Simnlichen in die Sphäre des Unsinnlichen ïber. Je unsinnlicher und allgemeiner, je inhaltsärmer und abstrakter, um so wirklicher. Vielleicht ist Plato der einzige gewesen, der vor Kant zu der deutlichen Vorstellung gelangt ist, daß die Kluft zwischen dem Sinnlichen und dem Unsinulichen durch Realitätsstufen niemals überbrückt werden kann, und daß das Problem des Seins nicht das höchste Problem der Philosophie ist. Sein Begriff des ajuyó ist vor allen Ideen dadurch gekennzeichnet, daß er noch über den Begriff des Seins hinausgeht und anderseits auch nicht die Verkörperung eines bestimmten Ideals, etwa des sittlichen oder des logischen bedentet ${ }^{1}$ ). Während alle anderen Ideen ganz augenscheinlich die Sinnenwelt durch ihr höheres Maß ron Realität übertreffen. ist das Gute die einzige Idee, die des Seincharakters entbehrt und damit im Verhältnis zur Sinnenwelt als ein Unwirkliches gedacht werren muB. Ohne das Gute würden die Ideen ihre Bedeutung einbüßen. Das Gute macht das Schöne erst zum Schönen und dás Wahre zum Wahren. Es macht sie zu Aufgaben der Erkenntnis und des künstlerischen Strebens. Ohne das Gute würde der menschliche Geist nichts von den Ideen wissen. Wie uns die Somne die Dinge dieser Welt erkennbar nnd deutlich macht, so das Gute die Dinge jener Welt.

1) Platos Staat, 6. und 7. Buch. Das hivoitó, ließe sich auch als eine Kategorie der übersimnlichen Welt bezeichnen. Tgl. Lask: Die Logik der Philosophie und die Kategorienlehre. Tübingen 1911. 
Der Begriff ist dann weiter das Bestimmte und Bestimmende im Gegensatz zum L'nbestimmten als dem Etwas, das bestimmt wird. Je größer die begrifflich Durcharbeitung des Gegenstandes, je weiter die Rationalisierung vorgeschritten int. $u m$ so höher das Maß der Erkenntnis. Der Begriff klärt anf, erhellt, macht deutlich. läßt den Gegensatz hervortreten und beherrscht das Etwas, das Aufgabe der Erkenntnis war, in der Definition. Er ist die höchste Form des Wissens, die rollendete Erkenntnis im Vergleich mit den niederen Formen des Terstehens und der Einsicht, dem Torstellen, Ahnen, Meinen, Glauben u. a. Ex ist die Tollendung des theoretischen Weltverstehens, das spekulative Nachdenken über die Welt kann nur im Begriff zur Ruhe kommen. Anch Religion und Kunst können zu einer Welt- und Lebensanffassung führen, aber diese Auffassung ist unbegrifflich. Die Kunst bedient sich der Anschaung, um das Übersinnliche deutlich zn machen, und anch die Religion arbeitet mit Srmbol und Gleichnis. Wollen wir auch die nicht begriffliehe Art des Verstehens als Wissen bezeichnen, so kann man natürlich im Vergleich mit der theoretischen Erkenntuis Kunst und Religion als niedere Wissensstufen denken. Tut man das, so legt man den logischen Maßstab an Gebilde, die nicht in die theoretische Sphäre gehören ${ }^{1}$ ). Da ist es denn selbstrerständlich, daß die sittliche Utberzengung von dem, was gut und recht ist, daß das religiöse Vertrauen und der Geschmack und das Mittel der kïnstlerischen Anschaumng an begrifflichen Wissen gemessen etwas Minderwertiges sind, denn ihnen fehlt der Charakter der Bestimmtheit. Sie dulden auch keine Umbildung und Bean heitumg, durch welche sie von diesem Charakter der Unbestimmtheit erlöst würlen; (2ine solche Umbildung, wie sie etwa auf dem Wege der Rationalisierung versucht worden ist, hat immer zur Zerstörung ihres eigentümlichen Wesens geführt. Die sittliche Uberzeugung hat mit Klugheitsmaximen nichts gemein. Die kimstlerische Anschaumg verbirgt die Idee und macht sie unbegreiflich, nnd dic Position aller wahren Religionen ist das Rätselhafte, Geheimmisvolle und Tubestimmte.

Toch anf manche andere Eigenschaften des Begriffes kömnte an dieser S.t.llo bingewiesen werden. So ist er aneh das Prinzip) der Diskretion im Gegensatz zur Anschaumg als dem Kontimuierlichen²). Der Begriff sucht die Anschaung zu übrewältigen, zerlegt sie und löst sie auf. Der Begriff macht die Anschaunng anm. Man kamn also auch sagen, daB der Begriff mur wenig ron clem Reichtum der Anschamung fassen kann, daß er in Vergleich mit ihrer unbegrenzten Fiille diurftig, inhaltsarm und abstrakt ist. Wenn so die Betomung der Abstrakthrit des l)egriffes dahin führen mul, seine Machtosigkeit gevenüber der Anschanumg zu hehaupten, fïhrt eine andere Überlegnng dahin, den Begriff als den jualon Tryms oder als die ideale Forderung zu denkem, die von der Natur

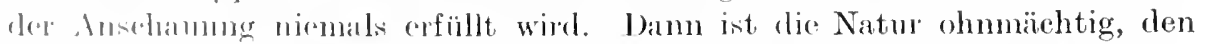

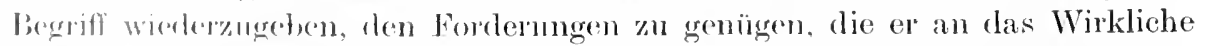
stellt. In dar liswertung der Ansehaumg kïnligt sich stets ein gewisser Em-

1) Sho Hegel in der Enzyklopädie. Vgl. besonders die Einleitung und die Lehre vom absubutan (ir.iale.

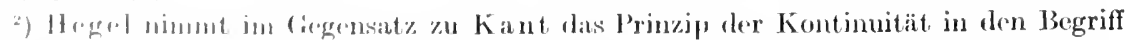

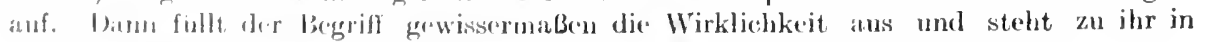
kroincrlei ringrinsatte. 
pirismus und Irrationalismus an, in der Bewertung des Begriffes gegenüber der Anschauung kommt der Rationalismus zum Ausdruck.

Alle Form ist Begriff. aber nicht jeder Begriff ist Form. Es gibt im Sinne der Kantischen Philosophie reine Begriffe im Gegensatz zu den empirischen Begriffen. Nun hat es ja die Philosophie als Logik mit dem Begriff als solchem zu tun, aber doch in sehr verschiedener Weise. Nit dem empirischen Begriff, so etwa mit dem Begriff des Baumes oder des Hauses, nur ganz allgemein. in generalisierender Weise, mit den reinen Begriffen aber wie Schönheit, Wissenschaft, Widerspruch, Allgemeinheit in individualisierender Weise. Hans und Baum sind für die Logik in gleicher W'eise Begriffe ron Objekten der sinnlichen Wirklichkeit. Die reinen Begriffe dagegen oder die Formen sollen in ihrer eigentünlichen Natur erkannt und in ein System eingestellt werden.

Wodurch unterscheiden sich nun die reinen Begriffe ron den empirischen Begriffen? Zunächst einmal dadurch, daß die empirischen Begriffe Begriffe ron sinnlichen Wirklichkeiten sind. Das, was sie meinen. das, woranf ihre Intention sich richtet, sind simnliche Wirklichkeiten, oder sie drücken das Gemeinsame von simnlichen Wirklichkeiten aus. Allen empirischen Begriffen ist gemeinsam, daß in ihnen eine gewisse sinnliche Inhaltlichkeit gemeint ist, was Kant dahin formulierte, daß sie ihrem Charakter nach a posteriori sind. So meint der Begriff Alexander der Große die unvergleiehliche Gestalt und die bedeutsamen Züge einer historischen Persönlichkeit in der Mannigfaltigkeit ihres Lebens und Wirkens, und der Begriff des Menschen drückt das Eigentümliche und Wesentliche unserer Gattung im Vergleich zu den anderen Lebensformen und Daseinsformen aus. Die reinen Begriffe sind dagegen von jener sinnlichen Inhaltlichkeit frei, die immer ein Bedingtsein durch Raum und Zeit einschließt. Sie meinen nicht Objekte oder Gegenstände der Simnenwelt. sie sind auch keine Abstraktionen ron solchen simnlichen Dingen, sondern was sie meinen und zum Ausdruck bringen, das ist immer der logische Simn und Zusammenhang der Welt.

Man kann diese reinen Begriffe im Gegensatz zu jenen, die eine simnliche Wirklichkeit meinen, die an konkrete und best immte Verhälnisse in irgendeiner Weise gebundensind, anch als rein form a l bezeichnen. Diese Formalität bedeutet natürlich keine Leere, keine bloße Form. Der Begriff der Kansalität, der bestimmend ist für alle Versuche der Naturwissenschaft. die Bewegung in der Welt zu hegreifen, hat ganz gewiß seinen logischen Inhalt, seinen vernünftigen Simn. durch den er sich von anderen Formen unterscheidet, so etwa von dem Begriff der substanz, der bestimmend ist für alle Versuche, ein Substrat des sinnlichen Gesehehens zu denken. Aber diese logisehe Inhaltlichkeit, dieser Vermunftsinn der reinen Formen des Denkens ist niemals Ausdruek für simnliches Material, so daß man mit Recht behaupten kann, diesen höchsten Begriffen hafte keine empirische Inhaltlichkeit an. Die Sinnenwelt kennt. wie schon Pla to richtig erkannt hat, weder das Schöne noch das Gleiche, und auch die Kansalität ist, richtig rerstanden, eine unvollziehbare Forderung, die wir an die Sinnenwelt richten, und insofern etwas, das über die Sinnenwelt hinausgeht. Denn was kann der Begriff der Kausalität anderes bedenten als die Vernunftforderung, alle Erscheinungen in ihrer notwendigen Aufeinanderfolge zu begreifen? Kausalität ist nichts Wirkendes und Wirkliches, nieht was realiter geschieht, sondern rielmehr 
eine Vernunftnotwendigkeit und Gesetzmäßigkeit, die sieh in unserem Denken kundgibt, eine Regel, nach der wir die sinnliche Wirklichkeit rerstehen und ordnen sollen. Was sie über diese Simnenwelt hinaus noeh bedeuten mag, bleibt unserer endlichen Erkemntnis ein für allemal verborgen.

Diese reinen Begriffe, die, wie wir gesehen haben, einerseits unwirklich im Terhältnis zur Sinnenwelt und andererseits rein formal, d. h. losgelöst von aller empirischer Inhaltlichkeit sind, haben eine doppelte Mission zu erfüllen, sofern sie einerseits den Begründungszusammenhang für die wichtigsten Kulturgebiete: Wissensehaft. Kunst, Religion und sittliches Leben abgeben, andererseits aueh selber den Gegenstand (ler philosophischen Spekulation bilden. So ist etwa der Begriff der Kausalität die letzte Voraussetzmng für alles naturwissensehaftliche Verstehen. Kausalität macht, so können wir sagen, Natur und Naturwissenschaft erst möglich. Ohne Kansalität würde es clas nieht geben. was wir Natur nemmen, nämlieh eine gesetzmäßige Ordnung der simnlichen Erseheinungswelt, und ohne Freiheit würde es das nicht geben, was wir unter sittliehem Lehen verstehen, kein wertvolles Handeln, keine edle Gesinnung. keine Verantwortung und kein Verantwortlichmachen. Die Welt der Natur steht und fällt mit der Kausalität und die moralisehe Welt steht und fällt mit der Idee der Freiheit. Natur ohne Kausalität wäre eine Natur ohne Gesetze, eine Welt des Zufalls und der Willkür, wie sie der große Individualist, der lächeInde Verneiner der Theorie, Epikur, gedacht hat, eine Welt der Wunder, wie sie lebt in den Träumen des religiösen Genies und in der Phantasie des sagenkundigen Diehters. Niemals kamn daher ein scheinhal willkürliches empirisches Geschehen zur Instanz erhoben werden gegen den reinen Begriff der Kausalität. Wir korrigieren die Naturerseheinungen nach der Kansalität, nicht aber den Begriff der Kansalität naeh der Natur.

Doch ist die Bedeutng der reinen Begriffe in ihrer Hinwendung zu den einzelnen Kulturgebieten nicht erschöpft. Das philosophische Interesse kamn nicht stchen bleiben bei der Frage, wie Wissenschaft oder sittlich-religiöses Lebrn möglich ist. Nach Kant kömnte es so aussehen, als ob die Aufgabe der theoretischen, Philosophie sich erfülle in ler Begründung der wissenschaftlirhen Erkenntnis, in dem Anfweis derjenigen Prinzipien, von denen die Geltung allar wissmsehaftlichen Lrteile abhängt. Die Frage der theoretisehen Philosophie derekt wich nicht mit dem Problem wissenschaftlieher Erkenntnis oder mit dor Frage nach den Prinzipien, anf denen ihre Sieherheit und Exaktheit beruht. Dir rersehierlenen Kulturgebiete sind mu der Ansgangspunkt für hio. Philnophie; ihe Sehnsucht und ihr Ziel ist immer die äbersinnliche Welt

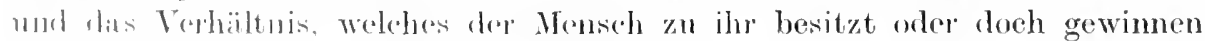
killu

Sholange dir Philosophie sich daranf beschrinkt, lie Frage zu erheben

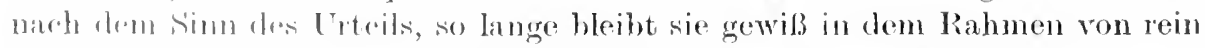

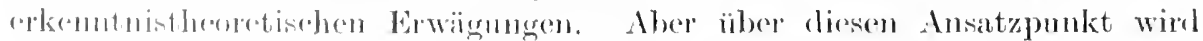

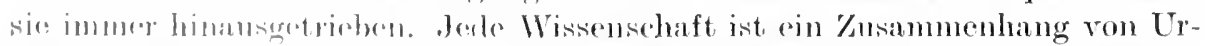

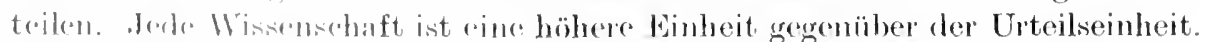

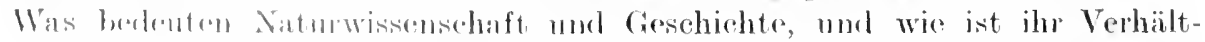

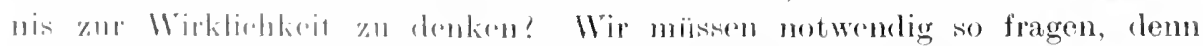

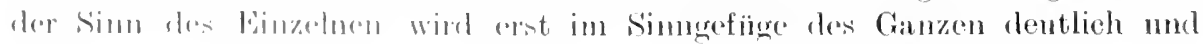


bestimmt. Und ron den einzelnen Wissenschaften wird die philosophische Spekulation fortgetrieben zu der Idee der Wissenschaft oder der idealen Wissenschaft und ihrem Verhältnis zum Wirklichen. Weiter aber wird sich die Frage èrheben nach dem Sinn des Sittlichen und Religiösen sowie der Kunst und des künstlerischen Schaffens, und die Philosophie wird sich der Forderung nicht entziehen können. ihr Terhältnis zum Wirklichen und zur Welt zu bestimmen. Und so läuft doch alle erkenntnistheoretische C'berlegung darauf hinaus, den Weltensinn zu verstehen und das Wirkliche zu deuten und zu begreifen.

Man kamn ron philosophischen Deutungen im Gegensatz zu wissenschaftlichen Erklärungen sprechen. Worin ist der Unterschied zwischen diesen beiden geistigen Fähigkeiten zu erblicken? Für alle Erklärungen ist das Prinzip der Kausalität rou entscheidender Bedeutung. Es handelt sich bei aller wissenschaftlichen Forschung darum, festzustellen. wie das eine aus dem anderen wird, oder wie das eine aus dem anderen geworden ist. Diese kausale Erklärung vermag bereits im hohen Maße Licht zu bringen und aufzuhellen. So verstehe ich etwa die Tat des Verbrechers, wenn ich seinem Lebens- und Erziehungsgang nachspüre, wenn ich weiß, daß seine Eltern degenerierte Menschen waren, wenn ich erfahre, welche bösen und schädigenden Einflüsse auf ihn gewirkt. wie groß die Versuchung war, die an ihn herangetreten ist. Aber diese durch die Wissenschaft erklärte Tat des Verbrechens bleibt unter dem philosophischen Gesichtspunkt noch rollkommen unverstanden. Die Wissenschaft bemüht sich, eine Reihe von Bedingungen und Motiven aufzuweisen, deren Zusammenwirken die schuldrolle Tat verursacht hat. Für die Philosophie ist das wissenschaftlich Erklärte noch ein absolutes Problen.

Denn, wenn ich auch den Weg kenne. auf dem das Furchtbare geschah, wenn ich auch alle Stadien der Entwicklung kemne, die den Unschuldigen zum Schuldigen machten, wenn auch das , da $\beta^{6:}$ vollkommen erklärt wäre bis in alle Einzelheiten hinein, und die Entstellung und Veränderung des Charakter auf der vorigen Entwicklungsstufe das noch mehr entstellte moralische Antlitz auf der folgenden plausibel macht, so sagt uns diese Erklärung doch nichts ïber das , warum" und, wozu". Das eben ist die philosophische Frage: Warum mußte das Unschuldige und Schöne häßlich und sehuldroll werden? Es gibt eine Verfassung der Seele, die wir wollen und bejahen, und eine andere. die wir verneinen und verwerfen. Für die Naturwissenschaft gibt es diesen Unterschied des Wertvollen und Wertwidrigen nicht, und die Geschichteresigniert in dem Gedanken des schmerzlichen und tragischen Unterganges des Sichönen und Liebeswerten, densie als notwendig zu begreifen sucht. Aber die Philosophie mit ihrem großen Vernunftoptimismus, mit ihrer Überzeugnug von einem einheitlichen Sinn der Welt und des Weltgeschehens kann sich mit dieser Lösung nicht zufrieden geben. Das wissenschaftlich Erklärte bleibt das metaphysische Rätsel. Denn das ist die Úberzeugung der Philosophen, daß es ein Wertrolles und Vernünftiges gibt, daß dem Termünftigen und Wertrollen ewige Daner beschieden sei, und daß das Wertrolle niemals zum Bösen und Wertfeindliehen werden kamn. Und so versucht die Philosophie eine Deutung des wissenschaftich erklärten metaphysischen Rätsels. 
Das Leben lehrt. wie es seheint, daß das Schöne und Schuldlose zum Häßlichen und Schnldhaften wird. Diese Behauptung gilt der Philosophie als die Lüge und Täuschung des Lebens. Jene Schönheit und Schuldlosigkeit ist noch kein wahrhaft Wertrolles. Es ist die Schönheit der bloßen Körperlichkeit, es ist die Unschuld des Unberïhrten und Unerprobten. Was das Leben hier als wertroll empfindet, ist in Wahrheit das Indifferente und Gleichgültige, was jensejts liegt von Gut und Böse. Das Paradies des Anfangs ist ein Zustand, der äberwunden werden muß. Das Indifferente kann sich zum Wertrollen und Wertfeindliehen, zum Guten und Bösen gestalten, das Wertvolle wird Wert bewahren. Dem Indifferenten als dem Hort der Mystik steht das logische Denken feindlich gegenuiber, denn die logische Sehnsucht ist darauf gerichtet, daß alles differenter werde, daß aus der ungeschiedenen Einheit des Anfangs eine Einheit in der Mannigfaltigkeit wird. Und deshalb wird die Zerstörung des Anfangs freudig bejaht, die Vertreibung aus dem Paradiese der Kindesunschuld, der Weg, die Arbeit des Negativen ist die Befreiung und Erlösung ron dem Dunklen und Unbestimmten. Mag dieses Negative, das den Anfang rernichtet, auch zunächst eimmal das Böse sein: durch Schuld und Irrtum gelangt die Menschheit aus dem Zustand des Indifferenten zum wahrhaft wertrollen Zustand.

So dentet die Philosophie an allen Erscheinungen des Lebens, $u$ m ans den widlerspruehsvollen Tatsachen, die uns begegnen, einen einheitlichen Weltensinn herausulesen. Und diese Dentung ist immer eine Werteinschätzung, eine $\overline{\mathrm{Be}}$ urteilung. Auch dasjenige Prinzip, von dem aus die Wissenschaft alles versteht und rrklärt,das Prinzip der Kansalität, wird von der Philosophie noeh gedeutet und auf seine Bedeutung eingeschätzt. Was ist denn eigentlich Kausalität? fragt die Philosophie. Ein reiner Begriff. Wie ist seine Dignität einzuschätzen? Kausalität ist eine Form des Denkens, die für die Sinnenwelt gilt. Es gibt aber auch andere Formen, die sich unmittelbar anf die ïbersinnliche Welt beziehen, so etwa die Irlee der Freiheit.

\section{i) Philosophic als Wertlehre.}

Immer hat es die Philosophie mit Beurteilungen und Werten zu tum. T)er Bogriff des Wertes soll über den Begriff der reinen Form und des reinen Beyriffes hinaus don Gegenstand der Philosophie noch deutlicher machen. l) mererno Philosophie hat sich als Philosophie der Werte bestimmt. Darin liegt den Grumel zu einer lieihe von Mißrerständnision, die dazn geführt haben, von rincr Ethisierung und Relativierung der Philosophic zu sprechen. Deswegen ist as rur allem wichtig, dentlich zu machen, in wolcher Hinsicht es die Philosophie init Werterl zu tun hat, da der Begriff des Wertes zu einem modernen Sohlagwort gerosten ist, ron lem man auf den verschiedonartigsten Gebieten Anwendung malht.

l"m gloich rom rornhorein moseren standpunkt festzulegen: wir halten es nirbt fir sinngenuab, alle philosophisehen begriffe als Worte zu bezeichnen.

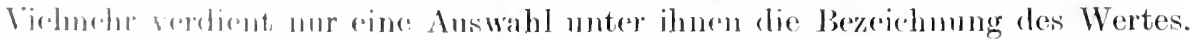

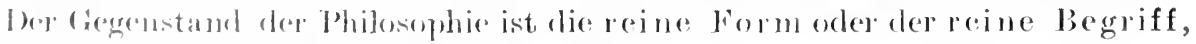

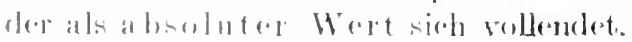


Henn wir den Gegenstand der Philosophie anch als Wert bezeichnen, so sei gegen den Vrormurf der Relativierung gesagt, daß der Wert, ron dem in der Philosophie die Rede ist, niemals ein Individıalwert sein kamn, d. h. ein Gut, das die persönliche S'rmpathie des einzelnen wertet, und das lediglich durch diese persönliche Wertung rla ist und Geltung hat. Der Wert, mit dem es die Philosophie zu tun hat. mußron der persönlichen Mertung und Beurteilung des einzelnen unabhängig sein. Ein solches Gut. das nur für mich gilt, ist etwa der von mir geliebte Mensch. Der Individnalwert ist das Eine und Einzigartige, das mur für den Einen gilt. Dieser eine Mensch, der geliehte, auf den meine persönliche Neigung sich richtet, und den ich in gewisser Hinsicht als wertroller empfinde wie alle anderen Menschen, ist eine Erscheinung. die meinem eigentümlichen Wesen, meiner besonderen Art angemessne ist. und die auch deswegen ron keinem anderen Mensehen so genossen und rerstanden werden liann wie ron mir. Es gibt Güter, die nur für mich da sind. deren Wert erlischt. wenn sie abgelöst werden von der Beziehung zn meinem wertenden Ich. Diese Individualwerte der Lust. Neigung und Liebe, die ich persönlich schaffe und bilde, sie sind in gewisser Hinsicht Schein und Illusion. Sie sind Schein. sofern sie mur für mich gelten, sofern ihr Dasein nur ron meiner persönliehen Wertung abhängig ist. Für mich ist dieser geliebte Mensch vielleicht tatsächlich wertvoll, sofern cr meine Kraft und mein stolzes Selbstgefühl erregt - für einen anderen mag er nichts bedenten. Er kann ihm vielleicht sogar schädlich und hinderlich sein. Ich glaube, daß der Gegenstand meiner Liebe die Huldigung aller verdient und bin doch der einzige, der sie ihm wahrhaft und aufrichtig zuteil werden läßt. Es liegt in dem Charakter dieser Güter, daß sie auf Exklusivität gerichtet sind, daß ihre Größe beruht in dem allseitigen und alleinigen Bedeuten für mich als den einen. So ist es mit lebenswerten wie Liehe. Freundschaft und Glück. Sie tragen einèn durchans relativen Charakter. Was für mich Gegenstand der Liebe und Freude ist, bedentet für den anderen Haß und Traurigkeit. Iögen auch Glück, Liebe und Freundschaft Güter sein, die uns das Leben anfgibt: indem wir sie erleben und erschaffen, hören sie anf, für alle das Gleiche zu bedeuten. Die erste Tänschung und Illusion, die wir in dicsen Beziehungen erfahren, liegt also darin, daß wir nur zu hänfig dem Wahne leben. da ß dasjenige, dessen Bedeutung sich in der persönlichen Beziehung zum Einzelnen erschöpft, den Anspruch erheben darf, für viele zu gelten. Zwiefach aber ist die Ilusion, wemn es sich $u m$ ein vermeintliches Gut handelt, wemm der geliebte Mensch meiner rein persönlichen Wünsche und Hoffnungen mich nicht bereichert und erhöht, sondern vernichtet und zerstört.

Von dieser Gruppe von Werten, die einen durchaus relativen und illusionären Charakter tragen, und die wir als Lebenswerte bezeichnen wollen, müssen diejenigen Werte mnterschieden werden, die ihrem Simme nach absolut gelten. Diese absoluten Werte haben ein notwendiges Verhältnis zur Kultur, und gerade in dieser Beziehung zur Kultur sind sie für die Geschichtsphilosophie von Bedentung. Die Lebenswerte dagegen stehen nicht in diesem notwendigen Verhältnis zur Geschichte. Ja, man kam sogar sagen, daß die Kulturwerte den Lebenswerten bis zu einem gewissen Grade feindlieh gegenüberstehen. So hat man immer mehr eingesehen. daß die Kultur in der Entwicklung ron Wissenschaft, Kunst und wirtsehaftlichem Leben das Individumm nicht 
glïeklicher macht. Die Forderungen, die Stat und Gesellsehaft an den Wensehen stellen, bedeuten in sehr vielen Fällen Verzicht und Überwindung. Die Lebenswerte können natürlich auch zum Gegenstand einer philoso. phischen Spekulation gemaeht werden, aber für unsere geschichtsphilosophischen Probleme sind sie ohne erhebliche Bedentung.

\section{g) Die religiöse Wertsphäre.}

Das Leben gibt sich hin an die Kultur. Auch Lebenswerte oder Lebensgüter wie Freundschaft, Liebe und Gliick erhalten ihren höchsten Reiz und ihre sehönste Vollendung erst durch Kultur. Die ganze Summe der Kulturgüter aber läßt sich nicht so ohne weiteres angeben und aufzählen. In der Regel pflegt man vier Gebiete anzuführen, nämlich das Gebiet des moraliseh-rechtlichstaatlichen Lebens. das Gebiet der Kunst und des Kunsttechnisehen, das Gebiet der Wissensehaft und der Religion. Diese Einteilung geht von der Voraussetzung aus, daß es vier "Werte gibt von absoluter Geltung, von denen der mensehliche Geist weiß, solange es Gesehichte und Kultur gibt.

Da ist vor allem die Idee des Heiligen und Reinen, die er munittelbar mit dem göttlichen Wesen sowie auch mit dem gottdienenden und gottgeweihten Menschen verbunden hat. Mit der Idee dieses Wertes geht zusanmen die Vorstellung des Quietivs, des Sehicksals, der Erlösung, der Ewigkeit. Schuld, Sünde und Verzweiflung sind Begriffe, die den Verstoß gegen die Idee des Heiligen zu deuten suehen. Sofern sich nun diese Gottesidee des Heiligen, Ewigen und Unendlichen in dem Leben cler Völker offenbart, spreehen wir von Religion, und die Religion ist das älteste Kulturgut, der gemeinsame Boden, ans dem alle anderen Kulturgiiter herrorgegangen sind. Der religiöse Menseh wird ron Gott erfüllt in der frommen Sehusucht der Mystik. Die Idee der Unsterblichkeit hat hier ihre Stelle ebenso gut wie die Irlee der Aufhebung aller Individualität und aller Grenzen. Und wenn der Mystiker lebt mit dem frommen Gefühl der Abhängigkeit von Gott, so führt die Bejahung der Individualität in dem Streben der Magie zur gewaltsamen Bestimmung der Gottheit. In dem religiösen Leben kann sich eine Bewegung geltend machen, die den historischen Prozeß und damit anch das Kulturgeschehen, sofern es dureh die anderen Werte bedingt ist, untorbinden und alles getrennte Leben wieder zu Gott zurüekführen möchte. Suforn abor die Religrion einen Kompromißzu schließen sueht, mit dem Werden mul Wachsen ler Kultur, sueht sie nach groben und sichtbaren Symbolen für dir. Irlor dros Heiligen und wird Wirkliehkeit in der Gestalt der Kirehe.

\section{h) Jie sittliche Wertsphäire.}

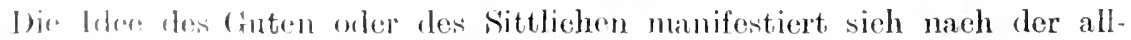
gemeincon Luffassung in Recht. Moralitä, Gesellsehaft, Familie und Stant.

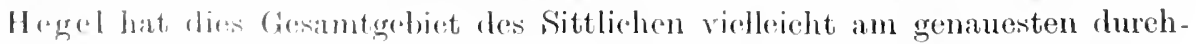

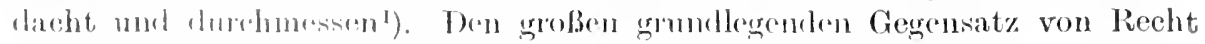

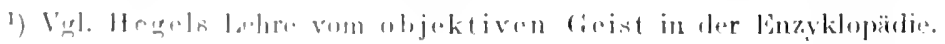


und Moralität hat vor allem $\mathrm{K}$ a $\mathrm{n}$ t herausgearbeitet, indem er auf die Innerlichkeit des Sittlichen im Gegensatz zum Recht als der Sphäre der Legalität und Außerlichkeit hinwies ${ }^{1}$ ). Der Wert des Sittlichen liegt in der Gesinnung und hängt nicht am Tun als solchem. Man kann sagen, daß Begriffe wie: Sollen, Zweck und Norm, die auch für die anderen Wertgebiete fruchtbar gemacht sind, einen spezifisch ethischen Charakter tragen, wie etwa die Begriffe der Unendlichkeit, Erlösung, Ewigkeit und Schuld ron ursprünglich religiöser Bedeutung sind. Diese Begriffe können ron ihrem heimatlichen Wertgebiet fortgenommen und auf andere übertragen werden. So hat die religiöse Idee des Unendlichen ebensowohl wie die moralische des Sollens eine fruchtbare Anwendung auf alle Kulturgebiete erfahren. Ihr wahrhaftiger Ort ist eine bestimmte Sphäre. Unendlichkeit und Erlösung sind schließlich religiöse Probleme, aber durch Analogie leisten sie einen wichtigen Beitrag zum Verständnis der anderen Gebiete. Der Begriff des Sollens, der so eng verbunden ist mit dem Begriff der Pflicht und der Freiheit, ist ganz gewiß eine ethische Kategorie. Aber mit Recht kann man sagen, daß der Sollenscharakter allen Kategorien, auch den theoretischen und ästhetischen beiwohnt, sofern der Begriff des Sollens am besten jene Notwendigkeit charakterisiert, die den Normen des Denkens, den reinen Begriffen und Ideen. wenn sie auf menschliches Tun bezogen werden, in der philosophischen Reflexion zukommt ${ }^{2}$ ). Diese Úberlegungen führen dahin festzustellen, daß die Gebiete des geistigen Lebens, deutlich geschieden und doch eng verbunden sind. Kant hat mehr die Gegensätze und Grenzen, Hegel mehr die Beziehungen und Übergänge zwischen den einzelnen Wertgebieten betont. Wie notwendig hängt doch die Idee der Ruhe, die Meeresstille der Seele, von der Demokrit spricht, mit dem religiösen und auch mit dem theoretischen Bewußtsein zusammen. die hier ein hohes $\mathrm{MaB}$ von Gemeinsamkeit offenbaren. während etwa die Idee des Tuns vor allem der sittlichen Vernunft angehört. Und wenn wir das religiöse und ethische Bewußtsein an den logischen Grundkategorien der Einheit und des Gegensatzes messen, so gehört zum religiösen Bewußtsein die rollkommene Einheit, die Austilgung jedes Gegensatzes, während das Spannungsverhältnis von Pflicht und Neigung, ron Sein und Sollen für das sittliche Bewußtsein durchaus wesentlich ist $\left.{ }^{3}\right)$.

\section{i) Die theoretische Wertsphäre.}

Der theoretische WVert ist der Begriff der Wahrheit, der in Philosophie und Wissenschaft Kulturgestalt gewinnt. Wenn die Philosophie nach einem Namen für das Absolute sucht, so wählt sie den Begriff der Wahrheit. Gott ist die Wahrheit. Alle Erkenntnis, die wir zu erreichen bemüht sind, ist ja doch schließlich von dem Begriff der Wahrheit überschattet. In der Philosophie ist das letzte Wort der Begriff der Wahrheit. Auch wenn das sittliche Leben

1) Kants Werke, Bd. 4. Grundlegung zur Metaphysik der Sitten. Akademieausgabe.

2) Vgl. Rickerts Gegenstand der Erkenntnis. 4. Kapitel.

$\left.{ }^{3}\right)$ Über die verschiedene Struktur der Werte und ihre systematische Gliederung vgl. besonders Heinrich Rickert, Logos IV. 3, System der Werte, und Münsterberg, Philosophie der Werte, Leipzig 1908. 
in den Kreis des Nachdenkens gezogen, anch wemn das Gerchmaeksurteil im Reieh des sehönen ron der philosophisehen Speknlation gedentet wird, hat der Wrahrheitswert die höchste Macht und Bedeutung, denn er lehrt uns anch jene in ihrem eigentümlichen Charakter verstehen. Weil wir dureh den theoretischen Wert eine Erkenntnis, d. h. ein begriffliches Wissen ron den anderen Werten und Gütern haben, so muB er wohl naeh der Auffassung vicler Denker die Darstellung des Höchsten bedenten, wenn auch die theoretisehe Idee als Abschlusswert nicht immer ausdrücklieh mit den Namen der Wahrheit bezeichnet wird, und etwa Plato das Erkenntnisgebende als das Gute bezeichnet hat. Wäre mun alles Zuteilwerden und Habhaftwerden des Göttliehen und Wertvollen ein Akt der Erkemntnis, so hätte allerdings der theoretische Wert den mbedingten Vorzug, und die Philosophie und Wissenschaft rermöchten allein den Weg zum Übersimnliehen zu weisen. Diese Anffassung, die zu dem Resultat gelangen muß, daß sittliehe Ubyerzengung, religiöser Glaube und künstlerischer Gesehmack nur unklare nnd versehwommene Stufen begrifflicher Einsicht sind, muß unbedingt zurüekgewiesen werden, demn sie führt zu einem ungerechtfertigten Pationalismus, zu einer Auffassung von Kultur und Leben, die den theoretischen Wert als herrschenden und leitenden, die anderen aber als dienende betrachtet. Wie etwa im Mittelalter alle Werte dem Heiligen und seiner Kulturerscheimung der Religion dienen sollten, indem die Auffassmg bestand, daß dogmatiseher Glaube mehr sei wie begriffliche Einsicht, wie etwa die Romantik daranf ausgeht, das Sehöne als Einheit aller Werte zu denken und den gesehmackrollen Menschen mehr schätzt wie den großen wissenschaftlichen Kopf, so ist unsere Zeit, vor allem sofern sie im Bamkreis eines Comte und Hegel steht, sehr geneigt, die alleinselignaehende theoretische Erkemntnis zu preisen. Anch das bedentet cine Uherspanmung, die einseitige Hervorhebung und Knltivierung des Einen zum Schaden des Anderen. Die Philosophie wiirde gut tun, zu zeigen, wir riel Religion mol Kunst und Sittlichkeit bedenten. Sie muß deutlich machen, daßs es ein Wertwissen giht, das mit begrifflicher Einsicht nichts zu tun hat. Geschmack und sittliche Uberzeugung sind anch ein Wissen, aber ein Wissen ganz anderer Art wie das begriffliche Wissen des Wertes. Kungheitsgrïnde kïnnen keine sittliche (Therzengung anfheben, und der dem sehönen. \%ugewandtr Menseh wiclestrelst der Strenge des sittlichen Sollens. Wissen ist natimlich iiberall, wo es sieh $10 \mathrm{~m}$ ein Wertrorhältnis handelt; denn in der Anerkemmung mol in dem Wissen des Wertwollen offenbart sich die Vermunft. Abre die Ankïndignng mol offenbarung des sitwlichen and schönen bedarf

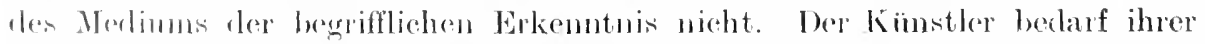
so wenig wie der grofore molatische Menseh. Sie ist lediglich das Instrument fiir den Isthetiker und Ethiker $\left.{ }^{1}\right)$.

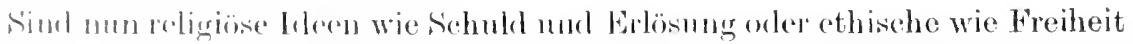

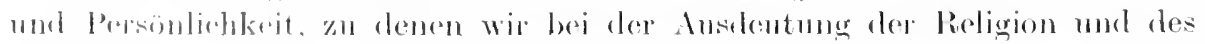

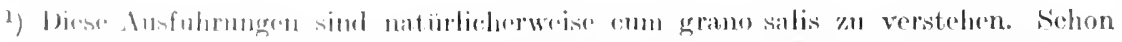

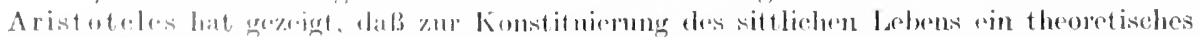

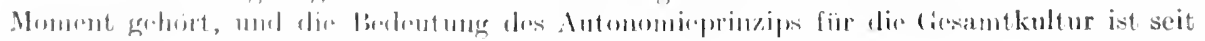

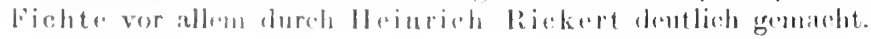


Gemeinschaftslebens gelangen, sind sie als Produkt der theorctischen Erkennt. nis nicht schließlich auch wissenschaftliche Begriffe?

Gewiß ist Erlösung ein Begriff, aber kein wissenschaftlicher, sondern einer von jenen reinen Begriffen, die wir als Werte bezeichneten, und zwar speziell ein religiöser Wert, eine philosophische Dentung des religiösen Lebens. Er ist es wenigstens, solange wir mit Erlösung den Gedanken verbinden, daß wir dereinst die sinnenwelt überwinden und befreit von dem tiefen Leid des Lebens in einer höheren Form des Daseins dem Göttlichen für immer nahe sind. Diese Erlösungsidee wird zum theoretischen Begriff erst in der wissenschaftlichen Reflexion, die etwa feststellt, der Erlösungsbegriff sei eine utopistische Idee, groß und mächtig geworden in einem Milieu, das scharfe soziale Kontraste aufweist, als Vorstellung der Bedrückten und Elenclen von einer endlichen Milderung und endgültigen Besserung ihrer sozialen Lage, als Trostmittel und Beschwichtigungsmittel der Führer und Priester, das Elend dieser Welt zu ertragen in Hoffnung auf eine bessere Welt. In diesem wissenschaftlichen Erklärungsbegriff ist natïrlich der religiöse Wert untergegangen.

In der Sphäre des Theoretischen liegt der ungeheure Reichtum derjenigen Begriffe, durch die wir Welt und Leben zu verstehen suchen. in denen die Wissenschaft verankert ist, und die in den anderen Gebieten der philosophischen Reflexion uns wieder begegnen, nachdem sie das theoretische Bewußtsein vorgebildet hat. Ich meine die Begriffe, die Kant als Anschaumgsformen und Kategorien bezeichnet hat, sowie die auf ihnen ruhenden logischen Axiome. Dahin gehören Einheit und Mamnigfaltigkeit, Identität und Verschiedenheit, Kausalität und Inhärenz, Raum und Zeit usw. Für diese theoretischen Formen ist der Begriff des Wertes irreführend. Man kamn hier wohl von Geltung sprechen, nicht aber ron Wert. Kausalität und Inhärenz sind ebensowenig das Ziel des theoretischen Denkens wie Raum und Zeit. Das Ziel des Theoretischen ist die Wahrheit, die absolute Erkenntnis, die Utberwindung des Zweifels in der erhabenen Ruhe vollkommener Gewißheit, das philosophisch wissenschaftliche Verstehen der Einheit in all der Mannigfaltigkeit. Wahrheit, Erkenntnis, synthetische Einheit des Mannigfaltigen, das sind theoretische Wertbegriffe. Die Kategorien und Anschaumgsformen sind keine in sich ruhenden Werte. Sie dienen vielmehr lediglich der Erfüllung höchster Werte und werden infolgedessen besser als Normen und Pegeln des Denkens und Anschauens oder auch ganz allgemein als Kategorien bezeichnet.

Die theoretischen Formen, die Kategorien fungieren nicht nur in der Logik und Erkenntnistheorie, im Gebiet des wissenschaftlichen Denkens, sondern in verwandter analoger Bedeutung auch in der Sphäre des sittlichen, Religiösen und Ästhetischen. So kann man etwa die theoretische Form der Kausalität auch für das Verständnis des Kunstwerkes nutzbar machen. so entspricht etwa dem theoretischen Begriff der Einheit die ästhetische Kategorie der Harmonie und der theoretischen des Gegensatzes die Disharmonie und der Kontrast, während die theoretische Form der Mannigfaltigkeit sich in der ästhetischen Idee des Reichtıms und der Fïlle wiederfindet.

Betrachten wir dann die Kategorie Jediglich in theoretischer Hinsicht, so kann man unterscheiden zwischen konstitutiven und reflexiren Fategorien, 
wie es Windelband getan hat ${ }^{1}$ ), indem man ron der Überlegung ansgeht, daß es Formen des Denkens gibt, welche die Natur als solche bestimmen, die Wirklichkeitsbedeutung besitzen wie ctwa der Begriff der Kausalität, der den Zusammenhang des Wirklichen herstellt, und andere, die nicht über das Wrirkliche regieren, sondern über den begrifflichen Niederschlag, den wir dem Wirklichen abgerungen haben, wie der Begriff der Gleichheit oder das Verhältıis des Allgemeinen zum Besonderen. Durch den Begriff der Kausalität ist unser Denken mit Notwendigkeit an gewisse Vorstellungsinhalte gebunden, ganz bestimmte Vorstellungsinhalte fordern mit Notwendigkeit den Begriff der Kausalität, und unsere Reflexion ist gezwnngen, unter bestimmten Gegebenheiten diesen Begriff anzuwenden. Dagegen stehen die reflexiven Kategorien wie die Formen des Unterseheidens und Gleichsetzens in einem weit loseren Terhältnis zum Vorstellnngsinhalt. So können alle Vorstellnngsinhalte in das Terhältnis des Untersehiedes gesetzt werden.

In dem Verhältmis der konstitutiven und reflexiren Kategorien drückt sich der Gegensatz ans zwischen den Prinzipien der formalen Logik und den Prinzipien der Erkenntuistheorie und Metaphysik. Die Kategorie hat nicht nur ihre Stelle in der Erkenntnistheorie, wie es Kants vermeinte, sondern auch in der formalen Logik. Es gibt Kategorien, die abstrakte Begriffsinhalte ordnen, wie es Kategorien gibt, die Wirklichkeiten ordnen. Die Urteile, die sich anf Wirklichkeit und Erfahrung beziehen, werden durch konstitutive Kategorien bestimmt. Begriffe wie Einheit und Mamnigfaltigkeit, Identität und Verschiedenheit, Kansalität und Dinghaftigkeit, konstituieren die Natur, sie sind, $n m$ mit Kant zu sprechen, die Gesetze, welche der Verstand der Natur vorschreibt. Anderseits unterliegen die Begriffsurteile als Niederschlag des eigentliehen Erkenntnisprozesses, sofern es sich hier um Ordnung und Gruplpierung des erworbenen Erkenntnisstoffes handelt, den reflexiven Kategoricn. Hier ist das Verhältnis des Allgemeinen zum Besonderen maljgebend. indem anf Unfang und Inhaltsfülle der Begriffe reflektiert wird. In den Iosischen Prozesisen der Abstraktion und Determination sowie auch in der Ichre rom Schlieben tritt uns immer wieder das Verhälnis des Allgemeinen \%um Besonderen, des Gattungsbegriffes zum Arthegriff entgegen, nnd es ist. (tem phiksophisehen Denken als mögliche Aufgahe erschienen, alle Bogriffe nach ihrem Alggemeinheitscharakter zu orduen, rom leeren Etwas his zur Fiille der Daseinshegriffe. Für diese Ordnung der Begriffe nach dem (imole ihrer Allgemeinhoit sind die Kategorien des Gleichsetzens und Unterschodelens rom Wiehtigkeit, da es ja zum Wesen des Artbegriffes gehört, in gewism Hinsicht dem Gattungshogriff gleich zu sein, in anderen aber sich rom ihm mal seincn Nobrubegriffen, den koordiniopten Artbegriffen zu unter-

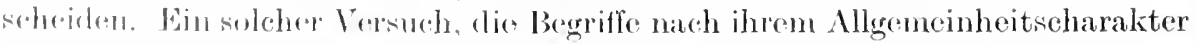

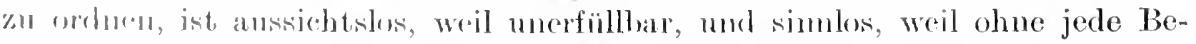

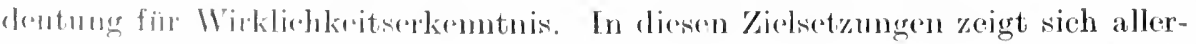

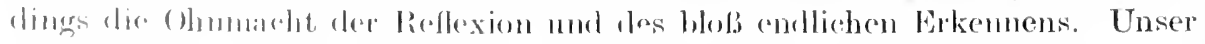

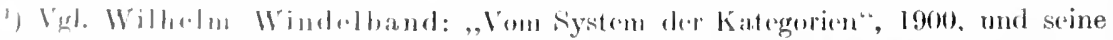

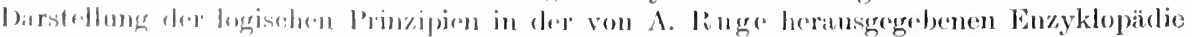

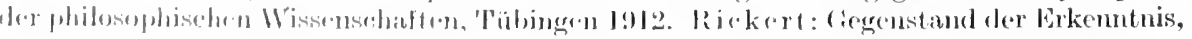

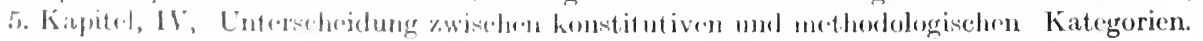


diskursives Denken, das in dem Grundverhältnis des Allgemeinen zum Besonderen verweilen muß, ist genötigt, die Wirklichkeit numzubilden. Das soll geschehen in einem System von Begriffen, das den Zusammenhang des Wirklichen ausdrïckt. Das bloß reflexive Denken sucht einen Zusammenhang zwischen Abstraktionen herzustellen, der jeder sachlichen Bedentung entbehrt.

Nichts wäre nun aber verfehlter, als wollte man $11 \mathrm{~m}$ dieser möglichen Irrtümer der Reflexion willen die reflexiven Kategorien verurteilen und geringschätzen ${ }^{1}$ ). Denn nur durch sie können wir zur Erkenntnis der konstitutiven Formen der Wirklichkeit gelangen. Weiterhin ist es aber anch ein Problem. ob es uns überhaupt möglich ist, den rein konstitutiven Gehalt der Kategorien zu entdecken. Denn was uns im Denken gegeben ist, sind nicht sowohl die Formen der Wirklichkeit als vielmehr die Formen wissenschaftlicher Erkenntnis. Der Begriff der Kausalität normiert unser Denken als Gesetz der Natur oder als historische Kausalität. Es sind zwei getrennte Forderungen. wenn einerseits die Aufgabe an uns herantritt, die Kansalitätsallgemeinheit des Gesetzesbegriffes zu verstehen und zu begrïnden, welche die wechselnden und wiederkehrenden Naturerscheimungen bestimmt, und anderseits das Problem darin gesucht werden muß, zu zeigen, wie der eimmalige Ablanf der historischen Entwicklung durch Kausalitätseinmaligkeit in der Zeit bestimmt ist. Die Kansalitätsform der wissenschaftlichen Erkenntnis kann entweder als das Allgemeine gedacht werden, das immer wieder in Erscheinung tritt, wenn eine bestimmte Konstellation vorliegt, als die Regel, die den Ablanf zweier Erscheinungen a und b bestimmt. In dieser Form wird die Kamsalität in der Naturwissenschaft gedacht. Oder aber die Kansalität, als das Bestimmende. das die Verbindung herstellt zwischen den getrennten Ericheinungen, gilt als die einzigartige, nie wiederkehrende Beziehung zwischen historischer Inhaltlichkeit. Im ersteren Falle drückt die Kausalität als Gesetz das Gemeinsame in den Beziehungen sukzedierender Naturbewegungen aus, im zweiten Fall rerbindet sich der Kausalitätsgedanke mit der Aufeinanderfolge individueller historischer Begebenheiten. Die eine Ursache ist immer alt, ist immer dieselbe, die andere ist immer neu und verschieden.

Die philosophische Besinnung kamn sich nun darauf richten, festzustellen. was denn eigentlich das Gemeinsame der naturwissenschaftlichen und historischen Kansalität sei, denn die Form der Wirklichkeit mu alle Erscheinungen in gleicher Weise bestimmen²). Den Charakter der konstitutiven Wirklichkeitsform zu ernieren, mag eine mögliche Aufgabe der Erkenntnistheorie sein. Auf jeden Fall ist sie dasjenige, was die Abfolge der Erscheinungen bestimmt. Die Geschichtslogik hat es nicht mit dieser reinen Wirklichkeitsform, mit der Kausalität an sich, sondern mit der historischen Kansalität zu tun. Diese Formen wissenschaftlicher Erkenntnis wie die naturwissenschaftliche Kansalität des Gesetzesbegriffes und die historische Kansalität bezeichnen wir am besten als methodologische Formen ${ }^{3}$ ). Wenn wir ihren logischen Charakter zu verstehen suchen, so müssen wir sie als Gebilde bestimmen, die ein konstitu-

1) Vgl. hierzu Lask. Die Logik der Philosophie und die Kategorienlehre, S. $138 \mathrm{ff}$.

2) Vgl. als Versueh einer solehen Ableitung Sergius Hessen. Individuelle Kausalität. Kantstudien, 1909.

$\left.{ }^{3}\right)$ Vgl. hierzu Riekert, Gegenstand der Erkenntnis, 5. Kapitel. IT.

Mehlis, Geschichtsphilosoghie. 
tires und ein reflexives Moment in sieh vereinigen. Die methodologischen Formen sind eine Synthesis von reflexiver und konstitutiver Form. Der reflexive Charakter der methodologischen Form ist aber bestimmt dureh den Zweck und das Ziel einer bestimmten Wissensehaft.

Die Logik wird etwa zu zeigen haben, daß in der methodologisehen Form des Gesetzesbegriffes die konstitutive Form der Kausalität mit der reflexiven Form der Gleichheit verbunden ist. Die naturwissensehaftliehe Erkenntnis ist ja immer auf das Wiederkehrende, Gleiehe und Allgemeine gerichtet. Die Reflexion der naturwissensehaftliehen Erkenntnis stellt die Kausalität in die Form der Gleiehheit und Allgemeinheit, während die Reflexion der historisehen Erkenntnis die Kausalität in die Form des Untersehiedes und der Individualität stellt. In dem Kausalitätsverhältnis, wie es die Naturwissensehaft denkt, ist das Bestimmende gedacht als das allgemeine Gesetz, welehes das Geschehen immer wieder in gleieher Weise determiniert. Das Gesehehen wird so zu einem wiederkehrenden, sieh immer in gleieher Weise wiederholenden Gesehehen. In dem Kausalitätsverhältnis, wie es die Geschiehte denkt, ist das Bestimmende eine individuelle. einzigartige Ursache, die immer wieder ein Neues und Einzigartiges hervorbringt.

Sehen wir anf das Verhältnis von Ursache und Virkung, so werden in der naturwissenschaftlichen Reflexion beide egalisiert. Die Wirkung ist gleich ler Ursache. Hier handelt es sich um Kausalitätsgleiehungen. Ursaehe und Wirkung werden quantifiziert. Ursache und Wirknng werden betraehtet wie die mathematisehen Größen einer Gleiehung ${ }^{1}$ ). Dagegen haben wir es in der Geschichte mit Kausalitätsungleiehheiten zu tun. Hier steht die Kausalität im Zeichen des Untersehiedes. Kleine Ursachen können eine große Wirkung auslösen und große Ursachen von geringer Wirkung sein.

Zur Aufgabe der Gesehichtsphilosophie gehört nun augenseheinlieh die Entwieklung der historiseh-methodologisehen Formen aus dem Ziel und der Aufgabe der historisehen Erkenntnis. Eine solche Deduktion setzt jedoch sehon die allgemeine erkenntnistheoretisehe Grundlegung roraus. Sie untersucht auch nicht weiter die logische Struktur der methodologisehen Formen, noeh sucht wie diese auf höhcre Kategorien zurückzuführen, sondern weist sie nur auf in der historisehen Wissensehaft als Grundvoraussetzungen dieser eigentümlichen Erkenntnisform. Damit berühren wir die spezielle Aufgabe der Geschichtshogik, die den Ausgangspunkt für alle gesehichtsphilosophische Uherlegung hildet.

\section{k) Die ästhetische Wertsphäre.}

Dor historischen Folge naeh am spätesten ist die Autonomie und absolnte Bedentung des Schönheitswertes anerkannt, der sich in den Gebieten der Natur und Kunst darstellt, und zu dessen Erforschmng Kants Kritik der Urteilskraft in ihrep Jinstimmung des Schönen und Erhabenen, sowie auch vor allem in der Jahre ven den ïsthetischen Ideen anßerordentlich viel geleistet hat. Die Gegenïl)erstellumg les Naturschönen und des Kunstsehönen ist von größter Brobutung zun Verständns der Entwieklung der ästhetischen Ideen. In

1) Vgl. Rickert, Prychophysische Kausalitid mol psyehophysischer Parallelismus. 
dem ästhetischen BewuBtsein liegt eine doppelte Wertungstendenz, nämlich entweder so, daß es die Natur höher wertet als dic Kunst oder die Kunst höher als die Natur. Dem Geist der Antike angemessen ist die Höherbewertung der Natur. Wie sollte das Bildwerk des Künstlers jemals erreichen die nackte Schönheit des menschlichen Körpers! Das Kunstwerk ist ein Abbild der Natur. Die schöne Natur gibt der schönen Kunst die Pegel. Im modernen ästhetischen Bewußtsein, das rom Geist der Pomantik getragen ist, macht sich die entgegengesetzte Wertungstendenz bemerkbar. Die Kunst ist kein Abbild der sehönen Wirklichkeit. Was die Natur bloß andeutet. wird durch die Kunst zur Vollendung geführt. Nicht die Natur schreibt der Kunst die Regel vor, sondern die Kunst der Natur.

\section{1) Idee einer vergleichenden Wertlehre.}

Eine der wichtigsten Aufgaben der reinen Wertphilosophie wïrde es sein, den verschiedenen Wertcharakter zu zeigen und dentlich zu machen, wodurch sich nun etwa der ästhetische Wert ron den anderen Werten unterscheidet. Dazu ist es natürlich notwendig, die Werte in Beziehung zu Fultur und Leben zu denken, denn in ihrem reinen Ansich können wir keine begrifflichen Unterschiede feststellen.

Um die Werte zn rergleichen, ist es notwendig, sie an gewissen logischen Grundkategorien zu messen, von denen hier Einheit, Subjektivität, Irrationalität und Wirklichkeit genannt sein mögen. Ein Vergleich mit diesen Formen ergibt die eigentümliche Mittelstellung des ästhetischen Wertes. Messen wir die Werte an der Kategorie der Einheit, so sind am meisten entfernt der religiöse Wert und der ethische Wert. Das Spannungsverhältnis, das zwischen ihnen besteht, beruht anf dem rerschiedenen Verhalten zur Kategorie der Einheit. Das religiöse Bewußtsein rerurteilt den Gegensatz als ungöttlich. Gegensatz bedentet Trennung und Ablösung ron dem Alleinen. Das ethische Bewußtsein lebt geradezu ron dem Gegensatz zwischen Sein und Sollen. Es bedarf des Gegensatzes, der Antinomie zu ihrer Bekämpfung und Ủberwindung. Mit der Austilgung dieses Gegensatzes wïrde es crlöschen. Der ästhetische und logische Wert nehmen hinsichtlich der Kategorie der Einheit eine Zwischenstellung ein. Für das ästhetische Bewußtsein ist neben der Harmonie als der ästhetischen Einheit auch die Disharmonie erforderlich. Ein Wechsel ron Spannung und Lösung gehört zum Charakter des Kunstwerkes. Der Gegensatz soll nicht restlos beseitigt werden, wie das im Streben des religiösen Bemußtseins liegt, er wird nur aufgelöst, $u m$ neu zu erwachen, und dieser Wechsel trägt den Charakter des Spiels. Die ästhetische Schöpfung ist in der Überwindung des Gegensatzes jedesmal rollendet. Darin zeigt sich ihre Strukturverschiedenheit gegenüber der sittlichen Leistung; denn für das moralische Gebiet ist der Gegensatz nicht nur Mittel, sondern Lebensbedingung. Das ästhetische Phänomen rollendet sich in der Úberwindung des Gegensatzes, das moralische geht an der absoluten Überwindung zugrunde.

Messen wir die Werte an der Idee der Subjektivität, so müssen wir wohl sagen, daß der religiöse Wert der subjektivste ist. Wir rerstehen aber das höchst zweideutige Wort, ,Subjektirität" hier nicht in dem Sinne des Re- 
lativen. Das Subjektive ist hier nieht das persönliche Bedeuten. WVir meinen nicht etwa, daß dem religiösen Wert das geringste Maß von Objektivität und Allgemeingiiltigkeit zukommt. Die Werte, ron denen wir hier handeln, haben insgesamt allgemeingültige Bedeutung. Wir rerstehen hier viehmehr unter Subjektivität die Innerlichkeit, den Mangel an sichtbarer Gestalt in der Darstellung und Erscheimung des Wertrollen. Hier hat nun das höchste Maß ron Objektivität und Sichtbarkeit das Theoretische als die Form des Wirklichen. Die Objekte der Wahrnehmung und Erfahrung sind die festen Gestalten der Sinnenwelt. Dagegen kommt den Gestalten oder viehmehr Ungestalten des religiösen Wertes das höchste Maß von Innerlichkeit zu. Es gibt wohl nichts in der Sinnenwelt, was den Namen he ilig verdient, was wir als heilig beurteilen und anerkennen, ausgenommen vielleicht jenes Erlebnis der unmittelbaren Gottesnähe, ron dem die Mystiker reden. Der ästhetische und ethische Wert sind in ihren Ausdrucksformen weder so subjcktir wie der religiöse, noch so objektir wie der logisch-theoretisehe Wert. Für das Ästhetisehe ist es allerdings anch ron entseheidender Bedeutung, daß die küustlerische Intention Gestalt gewinnt. Erst in der Schöpfung, erst im Kunstwerk liegt das Wertrolle, die Erlösung ron dem unseligen Widerstreit, erst hicr tritt das Göttliche in die Erscheinung. Doch hat das Ästhetische weniger Objektivität wie das Theoretische, denn das ästhetisch Relerante ist nur die Gestalt des Objektes, nicht etwa sein Dasein. Das ästhetisehe Wertrolle bedarf des Daseins nicht. Dagegen ist das sittliche Phänomen dureh ein höheres Maß von Innerlichkeit dem Peligiösen mchr zugewendet wie dem Theoretischen. Ist rloch nach Kant der reine Wille in seiner Unsichtbarkeit das Einzige, was in der Welt schlechthin als gut bezeichnet werden kamn. Der Wille, der mit dem Sollen eins geworden ist. Das ist die Wirklichkeit der moralischen Geisteswelt. Hier hat der Inhalt allen Widerstand aufgegeben und ist restlos von Form durchdrungen ${ }^{1}$ ). In dieser Sphäre der Innerlichkeit, in diesem unsichtbaren Reich der Gesinnmng, kann dem sittlichen Bewabtsein eine Einheit gegeben werlen, die ihm dem siehtharen Jaben gegenüher unbedingt versagt bleibt. Der sittliche Wert haftet an der Gesimmung. Die Gesimmung ist der Wesenskern des Sittlichen. Die Handlnngen des Menschen, die politischen und sozialen Gestaltungen der Verhältnisse, sie haben sittlichen Wert nur als Ausdruckform einer wertrollen Gesimmung.

Von Wichtigkeit für das Verstïndnis des cigentümlichen Wertcharakters ist rlann writer auch das Messen der Werte an dem Begriff des Irrationalen alsdem Begrifs]osen. Selbst verstïnllieh steht da der theoretisehe Wert im größten Gegronsatz zon dem Begriff des Irrationalen; dem zum Wesen des Logischen

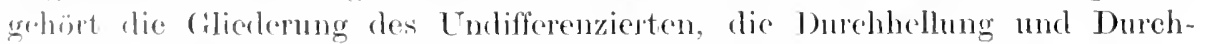
Inuchtmmg des Donklen nm Unhestimmten. Hier ist der Logos das Lieht, das in dex Finsternis scheint. Anders im Geldict des religiösen Wertes. Die Mrstik. in lex das Wreltereheimnis der Religion am schönsten anfluewaht wird,

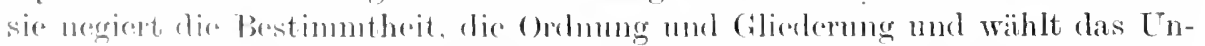

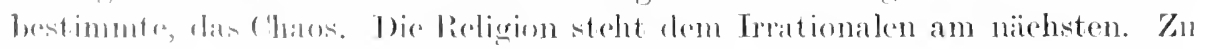

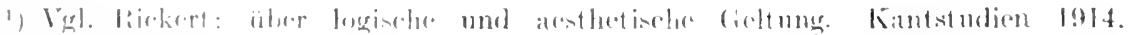
1i1. N1X 11. I 11. : 
ihrem Wesen gehört es, das U'ubegreifliche und Unerforschliche still zu rerehren. Wollen wir den religiösen Wert bestimmen, so ist der Charakter des Unbestimmten und Unendlichen bei weitem des zutreffendste Ausdruck für die eigentümliche Form seiner Erscheinung.

Der ästhetische mud ethische Wert stehen im Verhältnis zum Irrationalen zwischen dem theoretischen und religiösen Wert. Der Sinn eines Kunstwerkes oder, wie wir mit Kant auch sagen kömmen. seine ästhetische Idee ist begrifflich niemals zn erschöpfen. Diese Cnfaßbarkeit und Tuangreifbarkeit, die das Kunstwerk gegenüber der wissenschaftlichen Begriffsbestimmung besitzt, zeigt seine enge Beziehung zum Irrationalen. In dem Unendlichkeitscharakter des Kunstwerkes offenbart sich die Terwandtschaft zwischen dem religiösen und ästhetischen Wert.

Der ethische Wert endlich steht im Gegensatz zum ästhetischen Wert im Vergleich mit dem Irrationalen dem theoretischen Werte näher. Fiur das Sittliche besteht wie für das Theoretische die Forderung der Deutlichkeit und Bestimmtheit. Diese beiden streben zum hellen Tageslicht, das Ľnbewnte, Magische und Rätselhafte haben hier keine Stelle. Nit Kunst und Religion würde das Mrsterium aus der Welt entweichen.

Mit dieser Beziehung zum Irrationalen, mit diesem Näher-oder Fernersein dem Unbegreiflichen hängt dann der verschiedene Formreichtum in den einzelnen Gebieten zusammen. Die größte Zahl dentlich geschiedener Formen begegnet uns in der theoretischen Sphäre. Hier gibt es eine Fülle allgemein anerkannter Prinzipien. Geringer ist dieser Reichtum an Normen in der Ethik, relativ klein die Zahl der sittlichen Maximen, die als bindend und rerpflichtend für unseren Willen anzusehen sind. Für das Ästhetische soll es nach Kant überhaupt gar keine für alle Zeiten gültigen Regeln geben, sondern der Künstler schafft die Regeln, die für das Kunstwerk gelten. Hier. müssen wir jedoch einen Unterschied machen. Für den Künstler gißt es kein verpflichtendes Sollen, dessen Befolgung die ästhetische Wirkung garanticrt. Vielmehr schafft der Künstler mit rollkommener Freiheit, aber das Kunstwerk trägt eine Notwendigkeit in sich, die sich dem verstehenden Geist als Inbegriff erfülltex Forderungen darstellt. So gibt es Regehn und Begriffe, die in jeder Kunstbeurteilung roransgesetzt sind, trotz der Behauptung Kants, der das Meisterwerk der Schönheit der pedantischen Schulanfsicht der Gelehrten ein für allemal entziehen wollte. Doch mag es dabei bleiben, daß die Zahl der ästhetischen Normen beschränkter ist als die der ethischen, oder daß ihre Herausarbeitung größeren Schwierigkeiten unterliegt. Das hängt natürlich auch mit der Individualität und dem Einmaligkeitswert des Kunstwerkes zusammen. Je mehr der Wertcharakter sich unmittelbar mit dem Indivichellen rerbindet, um so mehr tritt die Idee einer normativen Gesetzmäßigkeit zurück. Das Normative des religiösen Lebens verhüllt sich am meisten.

Ein letzter wichtiger Gesichtspunkt, den verschiedenen Wertcharakter zu entdecken, wäre etwa, das Verhältnis zur Wirklichkeit festzulegen. Da kann man nur sagen, daß derjenige Wert, der sich am unmittelbarsten mit der Wirklichkeit verbindet, die Idee der Wahrheit ist. Denn die Wahrheit ist nicht nur die Voraussetzung aller wissenschaftlichen Erkenntnis, sondern auch die Toraussetzung der Wirklichkeit überhaupt. So geht ja auch das Streben aller 
Wissenschaft auf die Erkenntnis des simmlichen Daseins und bejaht die Realität dieser Welt. Es kommt ihr darauf an, die Wirkliehkeit so festzuhalten, wie sie ist, mag sich auch die naturwissensehaftliehe Reflexion in ihrem Prozeß der Abstraktion noch so weit von der Sinnenwelt entfernten. Und die Sehnsucht der Philosophie ist auf das ewig Gleichbleibende einer übersinnliehen Wirklichkeit geriehtet. Dabei liegt im theoretisehen Verhalten aneh wieder anderseits eine starke Abwendung von der Fülle der Anschaumng und des Lebens zur granen, lebensfremden Theorie. Und was das Verhältnis zur Kultur angeht, so ist der Wert der Wahrheit, sofern er sich in Philosophie und Wissensehaft darstellt, vielleicht das stärkste Agens aller Kulturbewegung, und doch ersehöpft sich der Wahrheitswert keineswegs in der wissensehaftliehen Entwicklung. Denn die Wirklichkeit, welche die Wissensehaft bearbeiten und verstehen will, hat bereits ihre Wahrheit. Die Wahrheit wird nieht durch die wissenschaftliche Entwieklung, sondern sie hat ihr Herrsehaftsbereieh schon vor aller mensehlichen Kulturtätigkeit. Das Werdende ist die Wahrheit der wissensehaftliehen Erkenntnis, nieht aber die Wahrheit der Wirklichkeit.

Der ästhetische Wert hat ein feindliehes Verhältnis zur Wirkhichkeit, sofern das Strcben des Künstlers darauf gerichtet ist, die Welt in ihrem Dasein zu zerstören und eine neue Welt zu sehaffen in den Phantasiegestalten der Schönheit. Er besitzt diese notwendige Schonungslosigkeit und Unduldsamkeit gegenüber den Material, daß er es formt und gestaltet nach einem wirkliehkeitsfernen Schönheitsbilde. Dieser Raub und diese Gewaltsamkeit, die der Künstler am Leben begeht, daß er es zu dem macht, was er will, daß er es in die absolute Materialstellung drängt, mu 3 ihn als Feind der Wirklichkeit erseheinen lassen. Und doch ist der Künstler auch wieder der ganze, der ungeteilte Menseh in der schönen Harmonie seiner Kräfte, der Mensch, der mit der Konkretheit vertraut ist im Gegensatz zu der Abstraktheit und Einseitigkeit des theoretisehen Menschen. Wie der Wahrheitswert gehört anch der Schönheitswert mit dem Gebilde der Kunst zu denjenigen geistigen Mäehten, die an stärksten mit der Kulturbewegung rerwachsen sind. Nur dureh die Kultur kann die Kunst blühen und wachsen, und so sind denn auch die Vertreter von Wissensehaft, Kunst und Technik ein für allemal die Freunde und Liebhaber der Kultur. Dabei erschöpft sich der S'chönheitswert nieht vollkommen im Verhältnis zur Kunst. Auch die ungestaltete Natur, in welcher der menschliehe Geist noch ruhte und die groben Herdichkeiten des Kunstschaffens noch nicht begonnen hatte, sondern gleiehsam als natüliches Kunstwerk weilte und träumte, trug bereits den S'tempel der Sahönheit, stand schon unter diesem Wertaspekt, wem auch vielleicht erst durch Ausïbung des künstlerisehen Triebes diese Welt der Naturschönheit für den Menschen Sichtbarkeit gewann.

Auch der ethisehe Wert und das ethische Bewußtsein stehen in einem "ppositionellen Verhältnis zux Wirklichkeit, sofern das ethische BewuBtsein die Simonwelt nicht so haben will, wie sie ist. Niemals kann dem ethisehen benulistein ein Zustand rlieser Sinncuwelt genügen, immer wird es dureh rastlose Forderungen zu nenem 'Tun getrieben. Das ethische Bewubtsein will keine Ihantasiewelt an Stelle der Sinncnwelt, es will auch keine Aufhebung dieser sinnonwelt, soudernseinstreben ist daranf gerichtet, die Simnlichkeit mithöherem 
Leben zu erfüllen und die menschlichen Verhältnisse besser und edler zu gestalten. Wem somit auch das ethische Bewußtsein dem großen Zuge der Kultur vertraut, so bejaht es diese doch nicht so umbedingt und ist ihr nicht so rücksichtslos und vertrauensvoll hingegeben. Wohl erkennt es den Wert des Handelns an, aber es bedeutet auch gleichzeitig das ewig wache Gewissen, das nach Recht und Gerechtigkeit verlangt. Es weiß von verfälschter und verfehlter Kultur, die weit entfernt ist von seinem Ideal reiner Menschlichkeit. So möchte es manchmal die Entwicklung der Kultur ungeschehen machen und von einem neuen Anfang aus neue und schönere Formen der Sittlichkeit sich entfalten lassen. Dabei ist der sittliche Wert, wie es scheint, am meisten dem Mensehlichen hingegeben, der sittliche Wert ist der spezifisch menschliche Wert, der uns den entscheidenden Maßstab hergibt für die Anerkennung einer Persönlichkeit ${ }^{1}$ ). Das sittliche Verhältnis, wie es sich entfaltet in der Beziehung der Persönlichkeiten zueinander und in ihrem gemeinsamen Verhältnis zu Familie, Gesellschaft, Staat und Recht, ist das einzig zuständige Gebiet des ethischen Wertes. Das Sollen, das im Ethischen zum Ausdruck kommt, setzt den Gegensatz von sinnlicher und übersimnlicher Natur als ein Gebot, das an die Vermunft sich richtet und dem unsere sinnliche Natur mehr und mehr unterworfen werden soll.

Der größte Feind der Wirklichkeit ist das religiöse Bewußtsein. Die Idee des Reinen und Heiligen ist, so könnte man sagen, noch in einem anderen Sinne unerfüllbar wie etwa die Idee des Schönen orler des Wahren. Wir wissen, daß das Schöne wirklich ist und lebt und Gestalt gewinnt, und dies Gestaltwerden des Schönen empfinden wir nicht als wunderbar. Es gibt etwas in dieser Welt, was wir als schön oder wahr beurteilen, das Kunstwerk, den theoretischen Satz. Aber die Welt, die uns umgibt, kennt das Heilige nicht ${ }^{2}$ ). Es gibt kein Objekt der religiösen Beurteilung wie es einen Gegenstand der theoretischen und ästhetischen Beurteilung gibt. Das Heilige ist nicht nur nicht von dieser Welt, sondern auch der Feind dieser Welt. Es will dieser Welt Ende und Untergang. Das gerade liegt in dem Charakter des religiösen Wertes, daß er die Sinneswelt aufheben und rollkommen vernichten will. In der Vorstellung der transzendenten Welt führt aber die Betonung des Unbestimmten und Unendlichen im Wesen des Absoluten bis zur Behauptung des Nichts, des Nichtesnicht als Eigenschaft des göttlichen Wesens. Mit diesem feindseligen Verhältnis zur Wirklichkeit hängt es zusammen, daß das religiöse Bewußtsein ganz überwiegend die Kultur bekämpft oder sie doch zum mindesten gering achtet. Die Idee einer Kulturreligion ist in vieler Hinsicht eine contradictio in adjecto. Im allgemeinen ist die Religion der Kultur feindlich gesimnt. Das behaupten wir aber nicht, um der Würde und der Bedeutung der Religion Abbruch zu tun, sondern um die Grenze der Kulturwertigkeit zu betonen. Wir dürfen nicht glauben, daß alles wertvolle Leben in der Idee der Kultur, wie wir sie verstehen wollen, beschlossen sei. Als das Christentum zur Kulturreligion wurde oder doch anfing, der Kultur Konzessionen zu machen, da hat es wohl manches eingebül

1) Das bleibt als Wahrheit der Aristotelischen Lehre bestchen. Vgl. die Ausführungen der nikomachischen Ethik.

") Vgl. hierzu auch den Vortrag vou Jonas Cohn , Religion und Kulturwerte" 1914. Philosophische Vorträge, veröffentlicht von der Kantgesellschaft. 
und aufgegeben. was in seinem ursprünglichen Geiste als religiös wertvoll angesehen werden muß, und der Mystiker, das religiöse Genie, rormag noch immer nicht, der zeitlichen Entwickhnng des religiösen Lebens unter der Leitung von Staat und Kirche wahrhaft religiösen Wert beizumessen. Denn er, der ein unmittelbares und immer gleiches Verhältnis zum Ewigen zu besitzen wähnt, wird dem Ablauf der Zeit, in der sich die Kulturentwicklung vollzieht, keine Realität beimessen können. Die Simnenwelt in Zeit und Raum verdient nicht den Namen ler Wirklichkeit, und das, worauf der menschliche Geist so stolz ist: diese große Entfaltung der Kultur, sie ist im letzten Grunde nur Simnenwahn und 'Trug. Im mystischen Erlebnis ist alle Zeit überwunden, und in diesen großen Feierstunden des Geistes wird es offenbar, daß alles in der Zeit Erscheinende nur Symbol und Gleichnis ist für ein Verhältnis von Gott und Seele, das über alle Dinge hinausgeht und in zeitloser Ewigkeit beschlossen ruht.

Ein näheres Eingehen auf die verschiedene Struktur der Kulturwerte war bereits an dieser Stelle nötig, da ron ihr aus sich jener Unkreis ron Problemen ergibt, den wir am besten zusammenfassen unter dem Begriff der Prinzipien des historischen Lebens oder Geschehens. Wie sich aus der allgemeinen erkenntnistheoretischen Fragestellung nach den Bedingungen der Wirklichkeit und den Toraussetzmngen des Wissens die Spezialfrage der Logik als Geschichtsphilosophie nach den Bedingungen der historischen Erkenntnis ergibt, so folgt aus dem Sichselhstverstehen der Philosophie als Lehre von den allgemeingültigen Werten die Aufgabe der Geschichtsphilosophie, diese Werte, sofern sie als Güter im historischen Geschehen verwirklicht werden, als Prinzipien des historischen Lebens zu begreifen. Denn um dieser Kulturgüter willen machen wir das Geschehen zum Objekt der historischen Erkenntnis. Es ist eine notwendige Aufgabe cler Geschichtsphilosophie, den versehiedenartigen logischen Sinn der Kulturwerte zn bestimmen und die Wertfeindlichkeit dentlich zu machen, die sich in ihrem gegenseitigen Verhältnis kundgibt. In den anderen philosophischen Disziplinen stehen die Werte gleichsam allein. Dic Logik hat es mit den Formen der Wahrheit oder der Erkenntnis, die Asthetik mit ren Formen der Sehönheit zu tum. Die Geschiehtsphilosophie, sofern sie es mit den Kulturwerten zu tun hat, ist gleichsan vergleichende-Wertwissenschaft. Wie muersöhnlich sich mun aber auch der Wertgegensatz in der Cieschichtsphilosophie als der Lehre von den Prinzipien des historisehen Lebens cffonbart, die höchste Aufgabe muß schließlich doch darin gesucht werden, fine Versölnung dieser notwendigen Gegensätze zu denken. Das aber ist dir Anfgabe der Lniversalgeschichte, die das Wertproblem mit der Realität des historischen Gesehehens verbindet und die Inlee der Wertverwirklichung in ion Mitterpunkt ihror ťborlegungen stellt.

\section{iii) Vorwurf der Ethisirung.}

1)ies. Frörterungen drïngen nus endlich noch zur Frwägung von ein

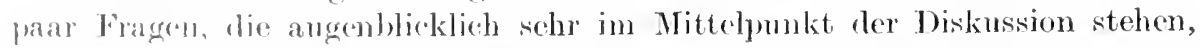
mul zul dench stollung genommen worten mus, wenn wir den Begriff der Philosophie wonierstons in soinen Mauptzägen fassen wollen. Wir halden gesehen,

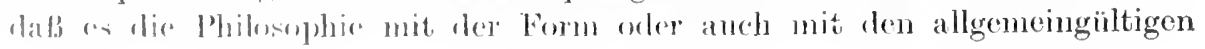


Werten zu tmn hat. Die Begrïndung der Antonomie des logischen, cthisehen, asthetischen, religiösen Wertes weist den Vorwurf des Relatirismus zurüek. Gegen die Wertphilosophie wird aber anch der Vorwurf erhoben, daß es sieh hier um eine Ethisierung der Logik handele. Die Werte sind doeh augenscheinlich das Ziel unserer Sehnsucht, unseres Verlangens und Begehrens. Folglich haben wir es hier, psyehologisch betrachtet, mit dem Willen zu tun. Der Wille ist aber das psychologische Substrat für die Ethik. Das war in der Tat die Auffassung der Kantischen Erkenntnistheorie. Die moderne Psyehologie hat jedoeh gezeigt, daß es die Erkenntnis nicht nur mit Vorstelhmgen zu tun hat, wie es Kant unter dem Einfluß der alten Vermögenstheorie in seiner Kritik behauptet hatte. Jedes Urteil schließt, psyehologisch betrachtet, ein willensmäßiges Moment in sich. Das Urteil, in dem sich der eigentliche Erkenntnisprozeß vollzieht, da Begriff und Vorstellung als solehe weder wahr noch falsch sind. ist eine Verknüpfung ron Wille und Torstellung. In Trteilen handelt es sich um ein Bejahen und Verneinen, ein Anerkemnen und Verwerfen. Die moderne Logik, sofern sie ron dem psychologischen Befund und dem urteilenden Subjekt ansgeht, hat den Sim dieses Willensmäßigen zu denten unternommen nnd erkannte in ihm ein eigentümliehes Moment theoretischer Stellungsnahme, das in Bejahung und Verneinung sich entfaltet ${ }^{1}$ ). Ethik und Logik haben es als psychologisches Substrat mit dem Willen zn tun, aber der Charakter der theoretischen Anerkennung und Billigung ist ron dem der ethischen sehr verschieden, und es wäre die Anfgabe einer Transzendentalpsyehologie, dicse Unterschiede im einzelnen festzustellen. Mag sein, daß die logische Billigung, ,kälter" ist als die ron Leidensehaft und Liebe getragene Bejahung der sittlichen Tat. Aber vielleicht kommt es auch hier darauf an, was für ein Mensch man ist. Man kömnte meinen, daß das sittliche uns persönlicher angeht wie das Theoretische, daß in sittlichen Handeln unsere Individualität wächst und wird, während die Entrleckung neuer Wahrheiten als solche meinen Charakter nicht formt und bildet. Aber gibt es nieht anch Enthusiasten des Theoretischen, wie es Enthusiasten des Ethischen und Ästhetischen gibt? War nicht für Spinoza die Erkenntnis die höchste und heftigste Leidenschaft, und hat nicht die Liebe zum Wahrheitswert die eigentïmliche Form des theoretischen Menschen gebildet? Das allerdings ist ein Wertgegensatz zwischen dem Ethischen und Theoretischen, daß das Gute die Liebe, die es empfängt, anf andere Menschen wiederscheinen läßt, daß sie teilhaben an der Liebe zum Licht, die in dem einzelnen so groß und stark geworden ist, während die Wahrheit alle Liebe, die sie erhält, dem Liebenden wiedergibt, so daß sie gleichsam isoliert ron aller Welt in demselben ruhigen Lichte zn wohnen scheinen.

Der Vormurf der Ethisierung der Logik durch die Philosophie der Werte hängt auch daran, daß man gemeint hat, der Wert sei gleichbedentend mit dem sittlichen Begriff des Zweckes, nnd es handle sich bei ihm um Ziele und Aufgaben, die das sittliche Bewußtsein sich setzt, und an deren Lösmng gerade

$\left.{ }^{1}\right)$ Vgl. zu dieser Frage: Rickert, regenstand der Erkenntnis S. $84 \mathrm{ff}$. mit der dort angegebenen Literatur. Vgl, auch Rickert: .'Zwei Wege der Erkenntnistheorie. Transzendentalpsychologie und Transzendentallogik.". Kintstudien, Band 14, Heft 2 . 1909, und „Urteil und Crteilen“ Logos Bd. 3. H. 2. 
diese Form unseres geistigen Lebens Anteil nimmt. Wenn man jene Notwendigkeit, mit der es die Philosophie zu tun hat, als ein Sollen charakterisierte, so wurde dieses Sollen ethisch gedentet im Sinne des Pflichtbegriffes. Es gibt jedoch nicht nur ein Sollen der ethischen Pflicht, sondern auch ein Sollen der Wahrheit und Schönheit. Es soll pflichtmäßig gehandelt werden um der Gerechtigkeit und um des Guten willen, und es soll widerspruchslos gedacht werden um der Wahrheit willen. Das Sollen ist der allgemeine und einzig zutreffende Ausdruck für alle idealen Forderungen, die an den menschlichen Geist sich richten, sofern er sich dafür entscheidet, das Reich der Wahrheit und Schönheit in der Sinnenwelt zu errichten. Wer aber der Wahrheit im Sinne der theoretischen Erkenntnis oder der Terwirklichung des Schönen nachgeht, der braucht deswegen noch kein sittlicher Mensch zu sein. Wer im einsamen Verkehr mit der Wahrheit alle Beziehıng zum Leben und alle Rücksicht auf soziale Bindungen vergißt, der ist gewiß kein Mensch ron großen sittlichen Qualitäten. Und wer um des göttlichen Kunstwerkes willen, um die große Passion zu schauen und zı erleben, den jugendschönen Geliebten an das Kreuz schlägt, der unterliegt gewiß der absoluten Verurteilung durch das sittliche Bewutßsein. Und doch folgt auch er einem Sollen von unbedingtem Wert, der idealen Forderung, daß aus schlichter Sinnengestalt die Form der Schönheit werde.

Wenn num aber der Wert anch um seiner selbst willen erstrebt und anerkannt wird, und die Verschiedenartigkeit der idealen Forderungen, die doch immer wieder in dem Gedanken eines Sollens schlechthin zusammenstimmen, nachgewiesen ist, so liegt doch eine nicht merhebliche Schwierigkeit in der Frage, welches Maß3 von Absolutheit denn eigentlich jenen Werten zukomme, welche die Philosophie zum Gegenstand der Frkenntnis gemacht hat. Gewiß ist des Wert, den die Philosophie meint, nicht relativ in dem Sinne, daß seine Geltungsmacht sich mur auf bestimmte Individuen in ihrer besonderen Gefühlsqualität bezieht. Die Schönheit in ihrer Gesetzmäßigekeit darf nicht für den einen diese, für den anderen jene Gestalt amnehmen. Das Kunstwerk gilt für alle, soll ron allen als schön anerkannt werden. Dagegen ist der Gegenstand ler Liebe immer relatir, je nach der Form, welche die Leidenschaft in dem Einzelncn gewinnt. Mag auch die Bedentung der Liebe über das Momentane und Simuliche weit hinausgehen, so wird doch die schöne Gestalt zur geliebten erst dureh das Verhältnis zur Persönlichkeit dos Einzelnen. Liebe und Freundschaft stiften ein persönliches Verhältnis. Schönheit und Wahrheit ein überpersönliches. Wtwas soll sehön sein für alle immer in gleicher Weise, die geliebte mul befremulcte Gestalt gilt für mich zu einer bestimmten Zeit in versehiedener Weise. Niemals kann die Bedentung des Kunstwerkes sieh erschöpfen in dor bezinhung zu riner Anzahl auserlesener Geister. Wenn nicht an die Stelle jener anserlescnen Menschen ein ïberindividuelles Bewnbtsein tritt, kann von Antononic im Isthetischen keine liede sein. Der Wert, den die Philosophie neint, batucht nur von wenigen zu gelten, notwendig aber gilt er für alle.

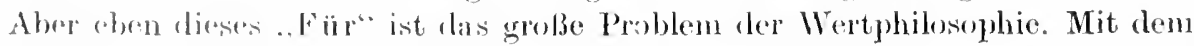
(irlfon von otwas kommen wir ummöglith aus. Das Gelten , von" ist nur die "ine Seite der Rellexion. Gowiß, die Kansalität gilt von etwas: sie gilt von der der Natur, aber sire gilt anch für etwas, für lats Bewnßtsein von äberindividu-

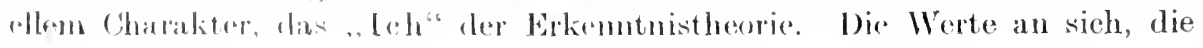


in sich ruhenden Werte, sind doch schließlich nur ein Produkt der Abstraktion. Sie haben mit Notwendigkeit auch das GeltungsverhäItnis zum Bewußtsein. Sie sind, um im Sinne der Hegelschen Philosophie zu sprechen, nicht nur , , an sich", sondern auch, ,für sich". Die Werte an sich sind abstrakt und unbestimmt, erst durch die Beziehung zum Bewußtsein gewinnen sie Fülle und Mannigfaltigkeit. Es war eine große Einsicht der Hegelschen Philosophie, daß der Weg der Abstraktion in der Logik nur betreten wird, um überwunden zu werden.

Wenn nun die Werte, von denen die Philosophie handelt, unbedingt für alle gelten, kann man dann von absoluten Werten sprechen, oder schließt nicht vielmehr die Idee des Absoluten die Vielheit aus? Ist nicht das Absolute dasjenige, was nichts neben sich duldet, was im vollkommenen Sichselbstgenügen, in unendlicher Daseinsfülle alles umfaßt und umschließt? Ist das Absolute nicht notwendig das Ganze, die Totalität der sinnlichen und übersinnlichen Welt?

Würde das Absolute von der Philosophie der Werte als ein Seiendes gedacht, so müßte diese Frage unbedingt bejabt werden, denn das Absolute al Seiendes ist unbedingt das こ̌v. Aber das Absolute der Wertphilosophie int ja kein Seiendes, sondern ein Geltendes. Die Absolutheit bezieht sich nicht auf das autonome Existieren, auf ein Dasein. das sich selbst genügt und keinen fremden Einfluß erleidet, sondern vielmehr nur darauf, daß der Wert ein Unbedingtes, ein Letztes ist, über das wir nicht mehr hinauskommen können. Der Wert gilt unbedingt für alle, ist aber auf ein bestimmtes Gebiet beschränkt. Schreiten wir von den absoluten Werten zur Idee des Absoluten, so gelangen wir zu den eigentlich metaphysischen Problemen, deren Lösung besonders schwierig sein muß, weil die Idee des Absoluten den schon häufiger berührten Gegensatz, den wir in den einzelnen Kulturgebieten rorfinden, zu überwinden bestimmt ist.

\section{n) Das Problem der Metaphysik.}

An dieser Stelle ist es notwendig, das Problem einer metaphysischen Philosophie einmal kurz zu berühren. Der Neu-Kantianismus hat geraume Zeit die Auffassung vertreten, daß die Metaphysik durch Kant ein für allemal widerlegt sei. Diese Widerlegung Kants trifft aber selbstrerständlich nur die vorkantische Metaphysik, vor allem Leibniz-Wolff und Spinoza. Es ist ein Irrtum, anzunehmen. daB Kant, indem er die Kritik der reinen Vernunft schrieb, auch gleichzeitig die Unmöglichkeit aller künftigen Metaphysik gezeigt habe. Die Waffen, die der Neukantianismus aus der Rüstkammer der Kritik hervorholte. $1 \mathrm{~m}$ die Unmöglichkeit der Metaphysik des deutschen Idealismus zu zeigen, erwiesen sich als vollkommen unzureichend. Der Streit über die Möglichkeit einer Metaphysik ist in der Hauptsache leeres Gerede, weil jeder unter Metaphysik etwas anderes versteht. Legen wir aber die Vorstellung Kants zugrunde, daß die Metaphysik Begriffe zu Wirklichkeiten macht und eine theoretische Einsicht in die whre Natur der Dinge anstrebt, so muß man sagen, daß die notwendige Konsequenz aller Erkenntuistheorie die Metaphysik ist. Alle Erkenntnistheorie versucht doch schLießlich auch eine Deutung der Wirklichkeit, sie müBte dem, nachdem sie das a priori der Kultur- 
gebiete aufgewiesen hat, gewaltsam Halt machen und die angeschnittenen Probleme nicht weiter verfolgen. Die rein erkemntnistheoretische Frage nach den Bedingungen der Erkenntnis ist ebenso notwendig wie unzureichend. Sie ist vielleicht die glänzendste Frage, die in der Philosophie jemals gestellt ist. Sie hat ein für allemal Weg und Gebiet gwiesen. Will ich etwas von der Wirklichkeit behaupten, so muß ich die Mögliehkeit der Erkenntnis voraussetzen. Sonst hat es überhaupt gar keinen Simn, zu forschen und zu denken. Folglich lautet die Grundfrage aller Philosophie: ,wie ist Erkenntnis möglich?" Aber diese Frage erwirbt uns mur den Standpunkt, von dem aus wir weiter forschen und fragen sollen nach dem Znsammenhang ron Welt und Leben.

Unmerklich geht das Problem der Erkemntnistheorie in das Problem der Metaphrsik ïber. Die Frage nach dem Sinn des theoretischen Satzes ist gewiß eine erkemntnistheoretische. Wemn ich aber den Sinn des Satzes geclentet habe, so werde ich dahin getrieben, weiter zu forschen nach dem Sinn der Missenschaft, denn was ist die. Wissenschaft anders als eine ungeheure Summation ron Urteilen. Weiter werden wir die Bedeutung von Philosophie, Religion und Kunst im Verhältnis zur Wissenschaft zu bestimmen haben, und schließlich wollen wir wissen, welehe Beziehungen zwischen diesen Kulturerscheinungen und der Wirklichkeit bestehen. Damit tritt aber die Philosophie sogleich an das alte metaphysische Problem heran, das Universum, die Wirklichkeit theoretisch $\mathrm{zu}$ verstehn.

Es wäre vielleicht möglich, die Philosophie in den Grenzen der rein erkenntnistheoretischen Fragestellung zu halten, solange man ihre Aufgabe auf das Verstehen von Wissenschaft und sittlichem Leben beschränkt. Religion und Kunst aber sind gleichsam entwurzelt, wenn das religiöse und ästhetische Problem abgelöst wird rom metaphysischen Bedenten. Es ist num einmal die Grenze der Erkenntnistheorie, daß sie mit ihren Deutungsversuchen boschrinkt ist anf die Analyse des theoretischen Urteils, der sittlichen beurteilung und Forderung, der ästhetisehen Bewertung, wie sie im Genchmacksurteil ${ }^{1}$ ) crscheint, und der Anerkenmung des religiösen Wertes. Ẅ̈hrend aber das Verstehen des theoretischen Satzes und der ethischen Forderung uns das Reich des Theoretischen und Nittlichen weit öfnet, kann die erkenntuistheoretische Frage in der Kunst prinzipiell nicht zum Ziele greführt werrlen, und der religiösen Jenrteilung fehlt rollkommen die simnliche ( Aogenwäitigkeit des Objektos. Kant hat in der Kritik der Urteilskraft die rigentlich erkemntnistheorctikche Position, die Analyse der ästhetischen Beurtcihng, verlassen mul den Versuch gemacht, das Schaffen des Künstlers scllyor zu deuten. Im Douten des Kunstschaffens handelt es sich aber augenscheinlich um ein metaphysisches Verstehenwollen. Es handelt sieh um dio Frage nath dem $1 W^{\prime}$ sen des Genies, der Eigentïmlichkeit seiner Schaffenstat

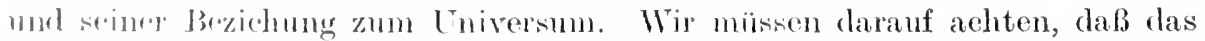

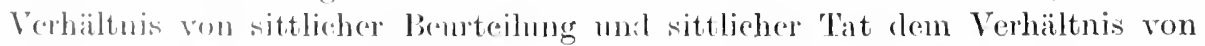
ästhetischep Jeneteihng mol kïnstlerisehem Schaffen durchaus nicht konform ist. Von der sittlichen benrtcihng her lïBt sieh das sittliche Handeln seinem idealen ('haldater mach woit hesser verstehn als vom Geschmaeksurteil aus

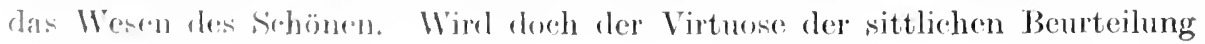


in der Regel auch gleichzeitig der Virtuose des sittlichen Handelns sein. Wer sittlichen Takt und sittliches Gefühl besitzt, wird auch nach der Erfüllung des Sittlichen streben. Der Alt der sittlichen Anerkennung, das Wollen des Guten, die Gesinnung ist hier das Entscheidende. Dagegen ist der Tirtuose des Geschmackes sehr häufig weit daron entfernt, ein Virtuose des kïnstlerischen Schaffens zu sein. Alles sittliche 'Tun ist ein Korrigieren an dem Bestehenden aus höherer sittlicher Einsicht, aus einem vertieften ethischen Gewissen heraus. Das sittliche Handeln wird geleitet durch die sittliche Beurteilung. Das künstlerische Tun ist ein Schaffen aus dem Nichts, absolute Nengestaltung, und an diesen Schöpfungen, die aus dem Ransche der Leidenschaften und dem Unbewußten herrorgehen, die ihrem wertrollsten Gehalte nach der Leitung und Aufsicht entbehren, bildet sich das Geschmacksurteil. Man kann dies verschiedene Verhältnis dahin formulieren, daß man das künstlerische Tun als das a priori der ästhetischen Beurteilung, die sittliche Beurteilung aber aldas a priori des sittlichen Tums bezeichnet.

Die religiöse Beurteilung unterscheidet sich jedoch ron allen anderen Beurteilungen dadurch, daß sie sich auf ein Objekt bezieht, das muirklich ist. Gibt es doch nichts in der Simnenwelt, was heilig genannt werden könnte. so wie ich etwas als gut oder schön berurteilen kamm. Das Sittliche hat auf Erden eine Heimat. Es gibt Handlungen der Menschen, die wir als wertroll im sittlichen Sinne, die wir als gut bezeichnen können, aus denen allmählich soziale Ordnungen erwachsen, die eine höhere Gemeinschaftsform an die Stelle der alten setzen. Das Heilige aber ist nicht ron dieser Welt. Kein Mensch und keine Institution der Sinnenwelt verdient, das Ideal des religiösen Bewußtseins genannt zu werden. An einer Rede kann etwas wahr, an einem Menschen etwas gut sein, niemals aber kamn ron einem Werk, einer Handlung, einem Menschen gesagt werden, daß etwas daran heilig sei. Während die anderen Werte relativ an den Dingen rorhanden sein können. und etwas Schönes ein Werk zum Kunstwerk macht, gehört es zum Wesen des Heiligen, in allem alles zu sein. Will die Philosophie den religiösen Wert rerstehn. so musie die übersinnliche Welt und die Gottheit denken. Eine gottlose Religion ist eine contradictio in adjecto ${ }^{1}$ ).

Will die Philosophie ihre Probleme zu Ende denken, so muß sie durch die Wissenschaftslehre zur Metaphysik rorschreiten. Die erkenntnistheoretischen Úberlegungen sind Ausgang und Durchgang für alle philosophische Speknlation, niemals aber kann sich die Philosophie in der Erkenntnistheorie rollenden. Die Erkenntnistheorie ist die große Selbstbesinnung der Philosophie. ihr „Erkenne Dich selbst". Aber diese Selbstbesinnming kann niemals Selbstzweck sein, sie treibt mit Notwendigkeit dem Weltverstehen und damit jenen Problemen zu, die wir am zutreffendsten als metaphrsische Probleme bezeichnen. Niemals kann sich die Philosophie zufrieden geben mit jenem hloß analytischen Gang des Denkens, der die Wirklichkeit in Form mul Inhalt zerlegt. immer wieder wird sie zu der Frage Stellums nehmen müssen, was die Form für den

1) Unter diesem Gesichtspunkt können wir dem schönen Artikel ,. Das Prohlem rev religiösen Lage" ron Georg Simmel nicht zustimmen: vgl. das Buch .. Weltanschaume." Berlin 1911. 
Inhalt und der Inhalt für die Form bedeutet. Indem sie aber den Zusammenhang zwischen Form und Inhalt zu verstehen sucht, wird sic immer wieder das große Rätsel der Wirklichkeit einer Lösung entgegenzuführen suchen.

\section{o) Philosophie als Weltanschaungslehre und als strenge Wissenschaft.}

Man hat wohl im philosophischen špos ein doppeltes Interesse zu unterscheiden gesucht, nämlich ein weltanschaumgsmäßiges und ein wissenschaftliches. Die Sehnsucht des Philosophen ist darauf gerichtet, eine Antwort auf die Welträtsel zu finden. Diese Antwort will er selber geben aus einem starken metaphysischen Bedürfnis heraus. Während der wissenschaftliche Menseh ein Beitragender ist, ist der Philosoph, in diesem Sinne verstanden, immer allein in der großen Arbeit des Erkennens. Er will die volle, ganze Antwort geben. nicht nur einen Beitrag zur Lösung der Weltprobleme. Darum fängt die Philosophie immer wieder von neuem an, und das Nene baut sich nicht auf der Leistung der früheren Denker auf. Dann besteht die Auffassung, daß der philosophische épos mächtiger ist als die Geschichte und die Kraft besitzt, jederzeit anf die Probleme der Wirklichkeit zu antworten, daß er nicht zu warten braucht, bis einem späten Geschlecht am Ziele der menschlichen Entwicklung die Stunde der Erfüllung schlägt, indem die Wahrheit anfgehoben wird für das Ende der Geschichte.

Dieser Auffassmng der Philosophie als Weltanschammgslehre wird der Vorwurf der Unwissenschaftlichkeit gemacht, den sie richtig verstanden wohl rertragen kann. Man meint aber, daß diese Art zu philosophieren auf unöglichst nahem Wege eine Befriedigung persönlicher Herzenswünsche herbeiführen wolle. Ihr gilt der Vorwurf des Dilettantismus. Sie hat keine Zeit zu warten und vermag sich auch nicht einzuordnen dem allgemeinen Kulturbewußtsein der Menschheit. Immer will diese Art Philosophie das Letzte. Sie duldet keinen Aufschub und ist mit dem Vorletzten nie zufrieden.

Und dieser Weltanschaumngslehre gegenüber, die sich anmaßt, jederzeit an den geheimnisvollen Grund aller Dinge rühren zu können. wird die Forderung erhoben, daß die Philosophie, die bisher so reich an Phantastereien und maßlosen Ansprïchen auf absolute Erkenntnis war, nun endlich beginnen möge, Wissenschaft zu werden. Koin Philosoph darf künftig mehr die Anmaßung hegen, das Werk der Erkenntnis aus eigener Kraft zu Ende fïhren zu wollen. Die Philosophie wird anvertraut der Arbeit der Generationen. In sorgfältiger gewissenhafter Einzelarbeit soll das Werk der Philosophie sich rollenden. Es gilt, Richtlinien für rino Gesamtarbcit zu ziehen und gemeinsam nach vorExotztrm Plan das lieich des Denkens in seiner ganzen Mannigfaltigkeit des Wissens zu durchforsehen. Die Jeistung der Philosophie wird sich in der Logik vollenden, die das mugeheure Repertoire der Denkformen in ihrer ganzen Mamnigfaltigkeit entwickeln soll $\left.{ }^{\mathrm{T}}\right)$.

lis ist unschwer cinzuschen, dab es sich hier um rlie Betommg eines Gegensatzos handelt, der in dieser Sehmofheit für die Philosophie nicht besteht.

1) In boug inf diese Frage besteht ein besonders scharfer Gegensatz zwisehen. Diltheys Auffassung der Philosophie als Weltanschaungslehre und Husserls Deutung der Philesophie als strenge W"issenschuft ; vgl. Logos, Bd. I, H. 3. 
Sollen wir uns für einen der beiden Standpunkte entscheiden. so würden wir nicht zögern zu behaupten, daß die Philosophie Weltanschanungslehre und keine Wissenschaft sei, wenn wir mun eimmal die beiden großen Formen des Begreifens in der Sphäre des Theoretischen einander entgegensetzen wollen. Bringen wir aber die Philosophie in Gegensatz zur Wissenschaft, so soll das natürlich weder eine Herabsetzung der Philosophie noch der Wissenschaft bedeuten. Es soll nur bedeuten, daß das Wissen überhampt verschiedene Aufgaben zu erfüllen hat und deshalb auch verschiedene Wege wandern muB. Das Ziel der Philosophie ist aber notwendig immer die Erkenntnis des Ganzen der Wirklichkeit, und ron dieser Erkenntnis aus gelangen wir zu einer Weltanschąuung, d. h. zu einer Einsicht in den Sinn und Zusammenhang des Unirersums.- In dieser Leistung aber bleibt die Philosophie wie die Kunst in wesentlichen immer die Tat des Einzelnen und nicht der Gesamtheit.

Das schließt nun gar nicht aus, daß die Philosophie sich zur Herbeiführung ihres Zieles, die Welt in Begriffen zu denken, einer streng exakten Methode bedient. Auch ist der Gegensatz zwischen den verschiedenen philosophischen Systemen nicht so radikal und unüberwindlich im Einzelnen, wie man vermuten sollte. Die Fülle der Systeme schließt sich zu wenigen Grundformen oder Typen der Weltanschanung zusammen, und wir müssen annehmen, daß die Denker, die einen bestimmten Weltanschamungstypus, etwa den Idealismus, vertreten, im wesentlichen dieselbe Intuition von Welt und Leben gehabt haben und nur in der begrifflichen Auslegung des zuror Geschauten roneinander abwichen. Und so hat Plato Kant gegenüber im Wesentlichen nicht geirrt. Beide haben mit furchtlosem Blick das murerhüllte Antlitz der Wahrheit geschaut.

\section{p) Problem der Antinomien.}

Wir hatten als Gegenstand der Philosophie die allgemeingültigen Werte als die Formen der verschiedenen Kulturerseheinungen und der Wirklichkeit kennen gelernt, und auf die IVertfeind lich keit, auf den Gegensatz, der zwischen den verschiedenen Forderungen besteht, die aus ihrer Natur entspringen, waren wir näher eingegangen. Je besser wir diesen Gegensatz zwischen den einzelnen Wertgebieten verstehen, $\mathbf{m m}$ so dringender erhebt sich die Forderung, ihn auszugleichen und zu versöhnen. Wie lassen sich, so müssen wir fragen, die Forderungen des ethischen Bewußtseins mit denen des künstlerischen Bewußtseins versöhnen? Gibt es vielleicht einen Einheitswert, eine höchste Form, in der alle Gegensätze versöhnt und aufgehoben sind? Oder sind die Gegensätze, die Antinomien der Wertgebiete unversöhnlich? Wie verschieden doch die Werte zur Idee des Zieles oder Endzwecks stehen, das muß ja jedem deutlich werden, der einmal ernsthaft über solche Fragen nachgedacht hat. Niemand hat die Bedentung dieses Unterschiedes so tief gefaßt und so tiefsinnig gedentet wie Schelling ${ }^{1}$ ). Er konstatiert mit Rücksicht auf das Ziel einen Gegensatz zwischen dem ethischen und wissenschaftlichen Bewußtsein auf der einen und dem ästhetischen Bewußtsein auf der anderen Seite. Wie groß der Gegensatz zwischen dem Charakter des Sittlichen und theoretisch

$\left.{ }^{1}\right)$ Schelling besonders im System des transzendentalen Idealismus. 
Wissenschaftlichen auch sein mag, so haben sie nach der Einsicht der Philosophie doch das gemeinsam, daß ihr Ziel im Unendlichen liegt. Niemals ist das sittliche Leben am Ziele, stets muß dem Sein des Gegenwärtigen ein nenes sollen entgegenstehen als Fordernng eines nenen Zieles, als Aufforderung, ein nenes Tun zu entfalten. Und anch die Wissenschaft ist unendlich, dem mit ihrer Aufgabe, allen Weltinhalt in Erkenntnis umzusetzen, alles Unrerstandene rerständlich, alles Begrifflose begreiflich zu machen, kommt die Wissenschaft nie zur Vollendung. Die Erfüllung der wissensehaftlichen und sittlichen Idee liegt am Ende einer mendlichen Reihe. Dagegen ist die Schönheit jederzeit an Ziele. Das, was den Sinn der Kinnst ausmacht, in jedem großen Kinnstwerk ist es zu finden. Sittliches Leben und Wissenschaft ist und bleibt unrollendet, aber das Kunstwerk ist jederzeit rollkommen. Im Kunstwerk kann man den großen Ausgleich, die schöne Iösung des Widerstreites erblicken, der innerhalb der anderen Kulturgebiete und in ihrem Verhältnis zueinander zu finden ist. Und dieser Allgegenwärtigkeit des Schönen im Kumstwerk gibt S'ehelling die Dentung, daß in ihm das Göttliche sich ummittelbar offenbart.

Wenn somit zwischen den einzehnen Kulturgebieten, wie dem Sittliche und Asthetischen. ein Gegensatz besteht, der nach Versöhnung und Ausgleich in einer höchsten Werteinheit drängt, so finden wir auch weiter, daß jedes große Gebiet des geistigen Lebens selber wieder dureh einen Gegensatz getragen wird. Die Grundprinzipien aller theoretischen Auffassung der Welt sind Form und Inhalt. Der theoretische Wahrheitswert offen bart sich in diesem Spannungsverhältnis. Der Inhalt ist das Erkenntnislose. das Unbestimmte, das bestimmt weriten soll, die Form ist das Prinzip der Frkemtnis und das Bestimmende. Durch die Form wird der Inhalt gedacht, ohne sie wäre der Inhalt ein Dunkles und Näichtiges. Die logische Sehmsneht ist darauf gerichtet, rlaß alles differenter werde. Diesem Streben setzt der Inhalt sehwerfälligen Widerstand entgegen. Dor bloße Inhalt ist, das Indifferente gegenüber dem theoretisehen Werte. Er ist Nicht-Wert, nieht etwa Negation cles Wertes, sondern nur in dem Sinne des vom Werte Unberïhrten. DaB der theoretisehe Inhalt Nicht-Wert ist und keine Wahrheit hat, darf nicht dahin gerleutet werken, daß der Inhalt das Wertose im sime des theoretiseh Bedentungslosen oder gar das Wertwidrige sej. Er ist für die Form durchaus notwendig, ihr zugeordnet, nach ihr hingewendet. In ihm findet die Form ihre Erfüllung.

Die Wirklichkeit in theoretisehen Sinne verstehten wir als das Produkt ron Form mul Inhalt. Sie ist, theoretisch betrachtet, weder ein helles Reich der Veromnt, das dio Erkenntnis mïhelos dureheilen kam, noch der Sitz der blofon Curomunft. Sie ist eine Verbinhung des Rationa len mit dem Frationalen. Dieno: Wirklichkeit als solehe ist ethisch betrachtet, das blok Zuständliche.

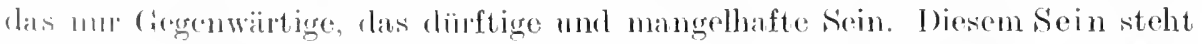

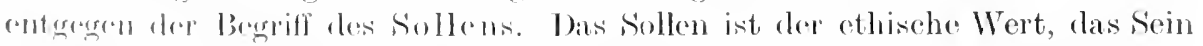

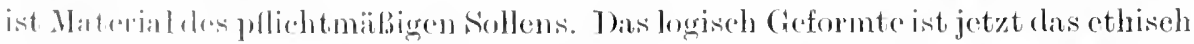

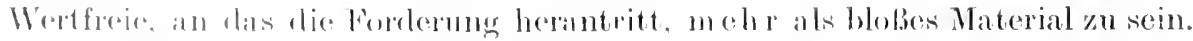

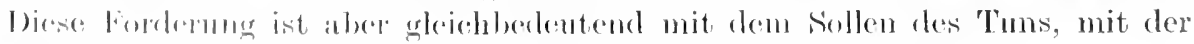

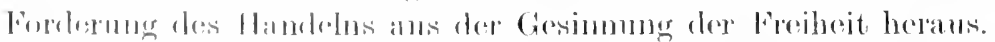

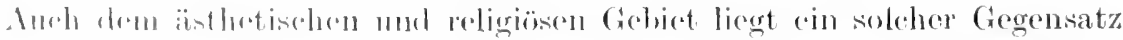

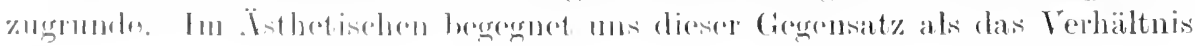


ron ästhetischem Material, Stoff, Form und Idee. Unter ästhetischem Material verstehen wir das Gebilde, das die Idee des Künstlers versinnlicht und sie in die Sphäre der Anschamung überführt, also den Marmor, die Farbe, das Wort, den Ton. Unter ästhetischem Stoff rerstehen wir den Gegenstand, das Motiv, welches sich der Künstler gewählt hat, und aus dem wir entnehmen, was das Kunstwerk darstellt. Dieser Stoff kann unter Umständen vollkommen unwirklich, eine freie Schöpfung der künstlerischen Phantasie sein. Die ästhetische Form gibt dem Marmor die Gestalt, der Farbe Ton und Kontrast, Licht und Leben, dem Worte Klang und Bildhaftigkeit und der Folge der Wortverbindung Rhythmus und Stil. Der Ton aber erwächst zur Melodie und zum musikalischen Motiv, in denen seine Flïchtigkeit feste Form gewinnt. Die ästhetische Idee endlich gibt dem Kunstwerk seinen eigentümlichen Simn und letzten kïnstlerischen Wert. Sie ist die Seele des Kunstwerkes, die begrifflich niemals vollkommen zu erschöpfen ist. So haben wir in der Kunst ganz deutlich einen doppelten Begriff ron Form und Inhalt. Die Form als Mittel der künstlerischen Gestaltung, die wir am besten als Stil bezeichnen. und die Form als Idee dieser Gestaltung, für welche wir den von Kant geprägten Begriff der ästhetischen Idee beibehalten wollen. Der Stoff als Material der Versinnlichung und der Stoff als Materia! der gedanklichen Prägung. In allem künstlerischen Schaffen vollzieht sich in engster Terbindung eine Materialgestaltung und eine Bedeutungsgestaltung. Tan kam auch von einer doppelten Materialgestaltung in der Kunst sprechen, einer mehr äußeren und einer mehr innerlichen Gestaltung des Stoffes. Dabei handelt es sich in beiden Fällen um einen Kampf der Form mit dem Stoff. Die äußere Gestalt bringt zum Ausdruck, was die Form dem spröden Material abgerungen hat, die innerliche Gestaltung ist die Erhebung der bloßen Bedeutung zu tiefem poetischen Sinn. Dem theoretischen Objekt als dem Produkt ron Form und Stoff entspricht die sittliche Leistung und die ästhetischeGestalt. Dem theoretischen Streben das sittlicheTun und der künstlerisehe Trieb und Drang. Die künstlerische Schöpferliebe und die Gestalt als Gegenstand dieser Sehnsucht, das sind dann. wie wir später sehen werden, die beiden Grundelemente, auf denen sich die gegensätzliche Welt der Kunst in Musik und Plastik aufbaut.

Endlich findet sich auch auf dem religiösen Gebiet ein Gegensatzpar, das aller religiösen Vorstellung zugrunde liegt, und in dem alle Probleme der Religion begrïndet sind. Das ist der Gegensatz des Endli ch en und Un end lich en. Die Idee des Heiligen oder des Göttlichen entfaltet sich in der Torstellung einer ursprünglichen Einheit des Endlichen und Unendlichen, einer Einheit, die zur Trennung führte und damit zur Süinde und Schuld.

Die religiöse Sehnsucht aber ist darauf gerichtet, daß diese Tremnung wieder überwunden werde und einer vollkommenen und endgültigen Einheit von Gott und Seele weiche.

So liegt der Gegensatz einerseits zwischen den Wertgebieten, anderseits baut sich jerles Wertgebiet auf einem Gegensatz auf. Es gibt nun aber auch Begriffspare, die nicht auf ein einzelnes Gebiet beschränkt sind, sondern auf allen Gebieten sich wiederfinden, so daß man sagen kann, d a B ger ade die

Me hlis, Geschichtsphilosophie. 
Antinomie es ist. Weleh die Einheit zwisehen den verschiedenen Geistesgebieten herstellt. $\mathrm{Zu}$ diesen Antinomien gehört, um nur wenige Beispiele zu nemnen, der Gegensatz zwischen dem Enendlichen und Endliehen, der Einheit und der Mannigfaltigkeit, dem Relativen und dem Absohuten, der Freiheit und Notwendigkeit, der Form und dem Inhalt. Wir nennen diese Begriffspaare Antinomien in Erinnernng an die großartige Erfassung des philosophischen Gegenstandes durch Kant und Hegel, wir sehen in ihnen das Hauptproblem der Philosophie und speziell auch der Geschichtsphilosophie. Wir sehen aber den Nangel der Philosophie ron Kant und Hegel vor allem darin, daß der Begriff der Antinomie hier noch keine ausreichende Klärung gefunden hat. Kant hebt vor allem die Antinomie zwischen dem Unendlichen und Endlichen und der Freiheit und Notwendigkeit hervor. Er weist ihren logischen Ursprung nach und zeigt, daß die Schwierigkeit, die in diesen Begriffen steckt, durch den transzendentalen Standpunkt gelöst wird ${ }^{1}$ ). Hegel kennt eine Fülle ron Antinomien. Er faßt aber das Verhältnis dieser logischen Grundbegriffe einseitig als Widerspruch. Dieser Widerspruch soll dureh einen höheren Begriff versöhnt werden. Die Dialektik aber, die Hegel in der Logik treibt, vermag nirgends überzengend zu wirken. Wohl sind wir ron der weittragenden Bedeutung der Antinomie, der Antithesis überzengt, aber clas Kunstwerk der Synthesis entzieht sieh jeder Einsicht mud Beurteihng. Es mutet als Willkür an und rermag nieht $\mathrm{zn}$ ïberzengen.

Frst rom Standpunkt der Wertphilosophie ans kam das Problem der Antinomien dentlich werden. Die Antinomien sind der Gegenstand der Philosophie, die Antithesis ist das Grundprinzip des Denkens, und somit ist die Position aller wahrhaften Philosophie der Dualismus. Die Antithesis, der Gegensatz, int gegeben, die Synthesis aber, die Versöhmung der Gegensätze, ist anfgegehen. Dieser Gegensatz, der zwischen den logisehen Grundbegriffen besteht, ist jerloch nieht der Widersprueh. Nach dem Prinzip des Widersprushes wiude die Bejahung des einen Begriffes die Verneinung des anderen Pegriffer arforlorn, und zwischen Begriffen, die sieh widersprechen, gibt es niemals eine Tersöhnung. Der Begriff des Absohuten and des Relativen oder das Verhältnis von Endlichkoit mnd Unendlichkeit mub dahin verstanden werden,

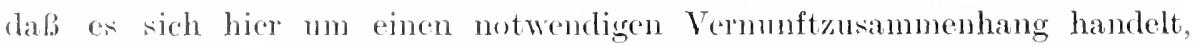

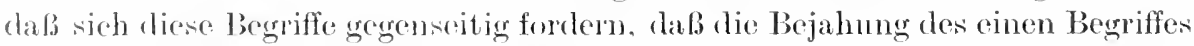
anch die Beojahumg des anderen Begrifles vorlangt. Denke ich den Begriff les lialativen, so muls job notwoudig anch den Begriff des Absoluten

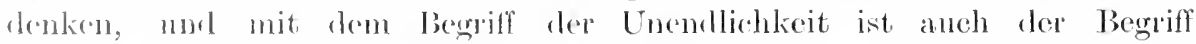

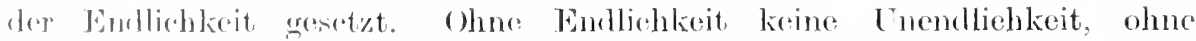

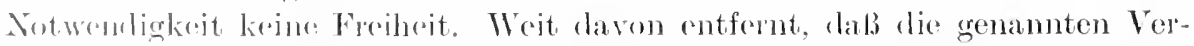

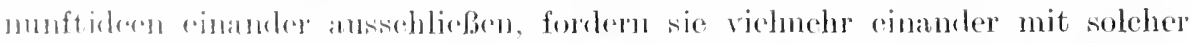

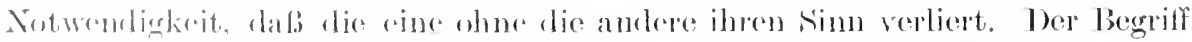

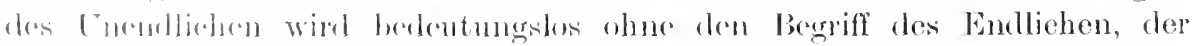

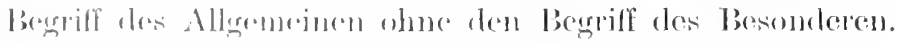

1) Kritik der reinen limunft. Antinomicnlehere. Schriften, Bd. 3. Akademiealusgialw. 
Das Verhältnis der Korrelativität, des gegenseitig Bezogenseins, dieses eigentümliehe Abhängigkeitsverhältnis, das die alte Logik nieht kennt, kann nun seinerseits wiederum sehr verschiedene Gestalt annehmen. Es kann sich nämlich entweder um ein Verhältnis des Gleichwertigen handeln, wie etwa der Begriff des Allgemeinen vor dem Begriff des Besonderen an sich nicht ausgezeichnet ist, mag auch etwa die antike Philosophie die Vorstellung des Allgemeinen unmittelbar mit der Idee des Wertvollen rerbunlen haben. Die gereifte logische Einsicht muß dahin gelangen, daß ein verschiedenes Wertinteresse das Allgemeine vor dem Besonderen und clas Besondere vor dem Allgemeinen auszeichnet. Die Bedeutung des Allgemeinen liegt darin, daß e: von vielem oder gar von allem gilt, daß es bestimmend ist für ein ganzes Gebiet. daß es in grandioser Einseitigkeit das Nebensächliche und Zufällige von sich abgestreift hat und somit der Ausdruck des Wesentliehen zu sein scheint. daß es der vernünftigen Einsicht in hohem Naße zugängig ist. Dagegen hat das Besondere den Vorzug der Individualität und Eigentümlichkeit. der Einmaligkeit, der Unwiederholbarkeit. der Fülle und Vielseitigkeit. Für große Denker und große Kunlturepochen ist es ron entscheidender Bedeutung gewesen, ob ihre Wertungstendenz dem Allgemeinen oder dem Besonderen zustrebte. Etwas Ähnliches wie für das Verhältnis des Algemeinen zum Besonderen gilt für das Unendliche in Beziehung zmr Idee der Endlichkeit. Das moderne Kulturbewußtsein erhebt das Unendliche über das Endliche. Die Antike verehrte im Endlichen die Irlce der Begrenztheit. Dagegen ist im Verhältnis des Absolnten zum Relativen der Wertakzent dahin gerichtet. daß er rollkommen auf dem Begriff des Absoluten liegt. Wenn es eine Philosophie gibt. die das Relative als Wahrheit verkïndet, so zerstört diese Philosophie die Grundroraussetzung aller Erkenntnis und hebt damit sich selber auf.

Bei dieser Bestimmmng der Philosophie als der Lehre von den Antinomien wollen wir schließlich noch unsere Anfmerksamkeit darauf richten. in weleh verschiedener Gestalt und Wertbedentung dieselbe Antinomie in den verschiedenen Geistesgebieten erscheint. Als Beispiel nehmen wir das Verhältnis des Unnendlichen zum Endlichen.

Auf theoretischem Gebiet tritt der Gegensatz ron Endlichkeit und Unendlichkeit in der Antinomie von Begriff und Anschamung hervor, die wie Kant in der Kritik der reinen Vermmft gezeigt hat, in ihrer Gemeinsamkeit die Erkenntnisleistung bedingen. Der Begriff erscheint hier als das Prinzip der Begrenzung, das AbschluB und Bestimmtheit verlangt. Die Anschaumng ist das Prinzip des Grenzenlosen und Cnendlichen. Cnd in der Unausgegliehenheit, in der Inadäquatheit ron Begriff und Anschaunng liegen alle Schwierigkeiten der Erkenntnis. Der Begriff kamm die Anschaumng nicht erschöpfen, ihre Mannigfaltigkeit nicht überwinden, und die Anschaumng kann den Begriff nicht erreichen. Und anderseits entspricht dem Begriff, der für das Übersinnliche gilt, keine intelligibele Anschauung.

Im ethischen Gebiet kehrt dieser Gegensatz wieder in dem Verhältnis zwischen der Endlichkeit und Begrenztheit des Individumms als des Trägers sittlieher Werte und der Unendlichkeit der Aufgabe, die in der Idee des Sollens dem Individum entgegentritt. Auf ästhetischem Gebiet ist der Sinn des Kunstwerkes, seine Idoe, begrifflich niemals zu erschöpfen, unendlich ist 
der Sinn und Bedeutungsgehalt, der in ihm ruht, begrenzt aber die Form als das Werk des Geschmaekes und der Reflexion. Im Religiösen endlich ist dieser Gegensatz heimiseh in einer sehroffen Antinomie zwischen dem Wertvollen und dem Wertlosen. sei es nun daß das Endliche oder das Unendliche als das Göttliche verehrt und der Gegensatz entsprechenderweise als das Schuldhafte verurteilt wird.

Soviel über den Begriff der Philosophie. der hier mur so weit erörtert wird, als notwendig ist für eine Einsieht in das geschichtsphilosophische Problem. Wit der Form, dem allgemeingültigen Wert und der Antinomie hat es die Philosophie zu tum. "Was ist Philosophie" lautete unsere erste Hamptfrage, insere zweiterichtet sich auf die Berleutung und den Begriff der Geschichte.

\section{Drittes Kapitel.}

\section{Der Begriff' der Geschichte.}

Das 19. Jahrhundert war kein philosophisches Zeitalter, denn mit der Philosophie des deutschen Idealismus wurde die große metaphysische Philosophie in Dentschland im Wesentliehen zu Grabe getragen. Es war in der Hauptsache (ein Zeitalter. das cine großartige Entfaltung der Wissenschaften, und zwar in gleicher Weise der Naturwissenschaft und Geschiehte, erlebt hat. Die neue Kulturerseheinung war die Geschichte, die mit dem romantischen Zeitalter einen ungehenren Aufschwung erlebte. und so ist es demn sehr begreiflich, daß die Geschichte hänfig zum Gegenstand einer philosophischen Fragestellung semacht wirl. Es erhebt sich nämlich das Problem: was die Geschichte denn eigentlich s.i. Es erhebt sich die Frage naeh dem Begriff und Zweek der Cieschichte. Wir wollen wissen, was es heißt und bedeutet, Geschichte zu treiben. Wir fragen naeh ihrem Begriff. Auf diese Frage hat aber das 19. Jahrlumalert im allgemeinen drei Antworten gegeben, nämlieh:

1. die Geschichte soll dem Leben dienen,

2. die Geschichte int Kunst.

3. die Ceschichte ist Wissencthaft.

\section{\$ 1. Geschichte und Leben.}

I)al' dic Geschichte nur benrteilt werden köme nach jhrer Berleutung fur das Iehen. diese Aufassung ist in 19. Jahrhundert an wirksamsten von Frialrich Nietsicho rerteten worden, vor allem in seiner Sehrift rom

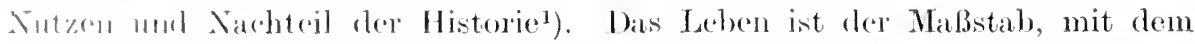
Niotzorhe an lie Gescludehte herantritt, und zwal neint er mit dem Begriff

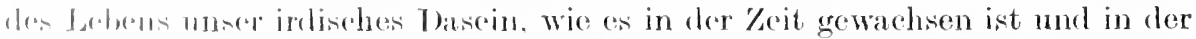
Zeit sich mefaltet. Das Juben gilt Nietzsche als Gut, ja das Leben ist der

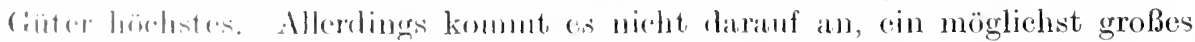

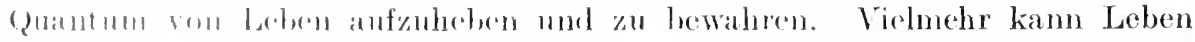

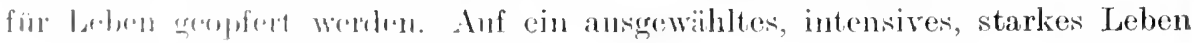

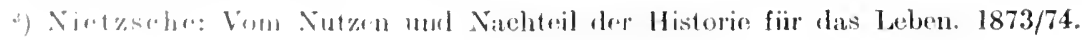


kommt es an. Auf das Leben und Tachstum der Völker, auf ihre Gesundheit, Kraft und Macht. Und vor allem auf das Leben der großen Persönliehkeiten kommt es ihm an. sowie darauf, daß große und starke Menschen ihr Leben leben; denn ohne sie ist kein großes Leisten und Geschehen möglich. Die plumpen Massen als solche lösen kein Gesehehen aus. End indem nun Nietzsehe auf die Geschichte reflektiert und sich auf ihre Beziehung zum Leben besinnt, geht er mit ihr streng ins Gericht, indem er ihren Nutzen und ihren Schaden darzulegen sucht.

Das gewichtigste Argmment. das Nietzsche geltend macht, ist dieses: durch ein Ủbermaß von Historie leidet die Unmittelbarkeit des Fühlens und Empfindens. Um Großes leisten zu lïnnen, muß man imstande sein, zu vergessen. Die Geschichte aber als die Tochter der Mnemosyne pflegt die Erinnerung des Menschengeschleehtes. Indem dann Nietzsehe den Beziehungen nachgeht, welche die Gesehichte zum Leben gewinnen kann. glaubt er eine dreifache Form des Bedentens unterscheiden zu kömmen. Die Geschichte gehört nach seiner Auffassung dem Mensehen 1. als einem Tätigen und Strebenden, 2. als dem Bewahrenden und Terehrenden und 3. als dem Leidenden und der Befreiung Bedürftigen. So bedeutet die Geschichte Torbild und Aufberahrung für den Strebenden und Terehrenden, für den Leidenden aber etwas. das überwunden werden soll.

Die Geschichte wird dem strebenden Menschen als Vorbild dienen. in diesem Sinne ist sie monumental. Ter eimen großen Kampf zu kämpfen hat, richtet seine Blicke gern auf die Tergangenheit. Er will kämpfen. wie Cäsar gekämpft, sterben, wie Brutus gestorben. Und so gewinnt der Held des gegenwärtigen Lebens Trost und Halt an dem Helden der Vergangenheit. Die Taten der Tergangenheit steigern den Enthusiasmus der Lebenden. Groß ist hier die Macht der Toten. die in ihren Taten fortleben.

Der sehwerstwiegende Einwand, der sich gegen die monmmentalische Gesehichte erheben läßt, liegt wohl in der Besimnung darauf, daß die Geschichte einen eimmaligen Prozeß bedeutet, daß das Vergangene sich niemals in derselben Weise wieder ereignen kann und wird. Wir können nieht handeln wie Brutus, weil die Bedingungen seiner Tat nie wiederkehren. Der schaden aber, der aus der monmmentalen Historie erwaehsen kann, liegt ror allem darin, daß sie die Blicke des Sehwärmers und Abenteurers auf die großen Lichterscheinmugen der Vergangenheit riehtet und zu simnlosen Taten der Zerstörung, zu Fürstenmord und Revolution, zu wilden Eroberungskriegen anstachelt.

Insofern damn weiter die Geschichte dem verehrenden Menschen gehört. wird er zum anbetenden Bewunderer entsehwundener und erstorbener Größe, und dieser Kultus der Vergangenheit kamn zu einem großen Nachteil für das Leben werden, denn nur die Tergangenheit erseheint diesem Trpus als groß und bedentend. die Gegenwart aber als klein und umbedentend. Und so erwächst das sehwächliche Gefühl des Epigonentums, das keine große Tat der Gegenwart duldet und ein für allemal das Vergangene als unerreiehbar betrachtet. In dieser Beziehung der Historie zum Leben ist auch jener Reliquienkultus begrïndet, für den alles bedeutungsvoll wird, was überhaupt jemals geschah und nicht mehr ist. So wertroll bei richtigem Maß und ïberlegener 
Einsieht das Wurzeh in der Tradition, die fromme Verehrung des Vergangenen anch sein mag. im L'bermaB wird sie zu einer schweren Last, die sich anf das blühende Leben der Völker legt und sie zu Boden drückt. Und so sollten wir richten und Anslese halten in dem, was uns die Vergangenheit überliefert, und uns ron dem Übermaß der Tradition befreien, solange es Zeit ist. Denn mit den Jahren wächst sie immer gewaltiger an und läßt uns immer weniger Zeit. der Gegenwart zn leben. Im Interesse des Lebens müssen wir uns mit aller Schärfe verwahren gegen die antiquarische Geschichte, sofern sie nicht qualitativ anf das Große und Bedentsame, sondern quantitativ auf die Fülle ler Ereignisse gerichtet ist.

Die antiquarische Gesehichte ist aber nicht nur für den Bewahrenden, sontern anch für den Verstehenden. und es läßt sich unschwer zeigen, daß auch ein Übermaß ron Verstehen dem Leben feindlich ist. Der alles Verstehende ist mit universalem Mitgefühl hingegeben an das Ganze des historischen Geschehens. Er vermag allen Motiven des Handelns gerecht zu werden, und indem er alles rersteht, ist es sein Schicksal, niemals und nirgends Partei sein zu können. Dadmeh entsteht jenes UbbermaB rom Objektivität, das uns unbrauchbar macht für die Fordernngen des Lebens.

Endlich gehört die Geschichte dem Leidenden, dem der Befreinng Bediirftigen. Das ist ler Standpunkt der kritisehen Geschiehte. Hier gilt das Vorgangene als dasjenige, was überwunden werden soll. Das Vergangene hat umrecht. und der Lebende hat recht. Hier wirft sich der Mensch zum Richter auf über die Vergangenheit. Der Mensch hat sich abgelöst von jedem tragischen Mitgefühl. Er verurteilt das Vergangene. Weil es geworden ist und entstanclen war, ist es anch des Unterganges wert. Das ist der Bruch mit der Vergangenheit, die Befreinng von der Tradition, die Úberwindung des Historischen. Anch dieses Verhältnis des Lebens zur Gesehichte ist nicht ohne Gefahr, dem wir sitzen zu Gericht über dasjenige, dem wir mnseren eigenen Ursprung verdanken. Wir richten uns gleichsam selber in der Vergangenheit und lösen uns ah von den tausendfältigen Fäden, die uns mit unserem Ursprung verbinrlen.

Wir mubten jene 'Theorie, welehe die Auffassung vertritt, daß das Leben den Maßstal, für die Historie hergibt, etwas genaner darstellen, denn sie ist shr andmoksvoll und mïchtig ror allem durch die große Persönlichkeit ihres Autors, dex sie mit himeiBender Berelsamkeit vertritt. In der 'lat, was klingt so einlenchtend für den Proselyten des Wissens, a ls da B die Gesehiehte benteilt werlen mul3 mach dem Nutzen und schaden für mser Leben, nach I'm Vorteil oled Nathteil, den sic nnserem irdischen Dasein gewährt, und Inch lst das lebend als irdisches Dascin ein ebenso mmöglieher Begriff zur

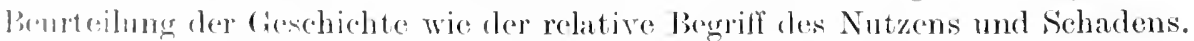

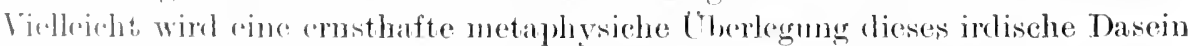

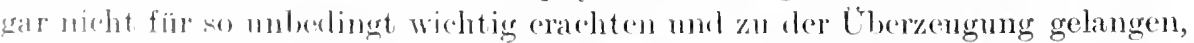
lat.s der simn der Geschiehte darin besteht, dieses unser simmlich irdisehes

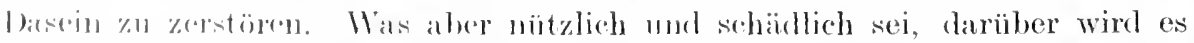

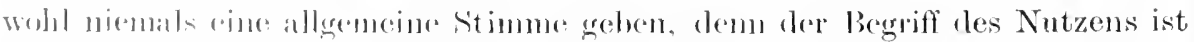

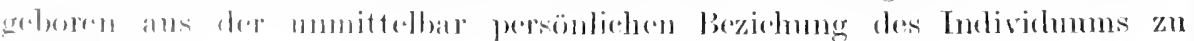
den l)ingens. 
Damit soll num aber nieht gesagt sein, daß der Standpunkt Xietzsches nur Unberechtigtes enthielte. Er ist nur haltlos in der letzten Orientierung des historischen Problems. Tm einzelnen enthält er manche wertrolle Einsichten. Ja, Nietzsehe rührt sogar an eins der tieftsen und emsthaftesten geschichtsphilosophischen Problęne, an die Antinomie zwischen dem Historischen und Srstematischen.

Wir müssen Nietzsche zugeben, daß die Geschichte ein besonders enges Verhältnis zum Leben besitzt. In gewissem simne ein näheres Verhäitnis als die Naturwissensehaft. GewiB dient auch die Naturwissenschaft dem Leben. sofern sie aufhört, reine Theorie zu sein, und in den mamnigfaltigen Formen der Technik unser soziales, wirtsehaftliches und industrielles Leben umformt und gestaltet, die Erde uns wohnlich macht und ihre verborgenen Kräfte in unseren Dienst zwingt. Und nicht nur den praktisehen Nutzen rermag die Wissenschaft von der Natur zu gewähren. Sie vermag auch ähnlieh wie die monumentale Geschichte unseren Enthusiasmus zu erweeken. So ist es vor allem die Wissenschaft ron den Himmelskörpern, die uns mit staunen und Bewunderung erfüllt, der wir eine unbedingt tiefe und nachhaltige Becleutung für unser Leben beimessen müssen. Schon der antike Mensch mßte, daß die Kemntnis der großen vernünftigen Ordmung der himmlischen Körper unser sittliches Empfinden heben und veredeln muß. Ist es doch die astronomische Welt, die das Gefühl des Erhabenen erregt. Anderseits ist aber cine Wissenschaft wie die Astronomie nicht so gefahrroll für das Leben wie die Historie. Niemals wird eine Naturwissensehaft wie die Astronomie in uns das sehwächliche Gefühl des Epigonentums erwecken, denn die Betrachtung des gestirnten Himmels macht uns in dem Gefühl des Erhabenen klein und zugleich groß. Die Astronomie wird niemals unsere Selbständigkeit ertöten noch uns zum Sprachrohr für andere machen und mit der schweren Fülle der Tradition uns belasten. Denn zum Wesen jeder Naturwissensehaft gehört das Ĺberwinden, zum Wesen der Geschichte aber immer in erster Linie das Aufbewahren. weswegen Bacon meinte, daß das Gedächtnis für die Gesehichte wesentlich sei, wie etwa für die Kunst die Phantasie oder für die Naturwisenschaft der Verstand.

Wir werden später genaner festzustellen haben, worin dieser Gegensatz zwischen Naturwissensehaft und Geschichte, wie er uns in seinen rersehiedenen Wirkungen auf das Leben entgegentritt, eigentlich seinell Grund hat. Wir werden sehen, daß es der Gegensatz des Systematischen und Unsystematischen ist, welcher sich hier ankündigt. ein Gegensatz, der ron ungeheurer Bedeutung für die ganze Theorie des Wissens ist, und dessen Bedeutsamkeit man bisher noeh zu wenig hervorgehoben hat.

Auf jeden Fall müssen wir zugeben, daß die Historie auf das Leben eine schädliche Wirkung auszü̈ben vermag, welche die Naturwissenschaft als solche nieht auslösen wird. Man muß den konservativen Charakter der Geschichte gegenüber dem fortschrittlichen Geist der Naturwissenschaft betonen. Dieser konservative Geist der Gesehiehte mit seinem Kultus der Tradition ist gegenwartsfremd und ohne Interesse für die brennenden Fragen des Tages. Die systematische Wissenschaft von der Natur hat es mit dem ewig Gegenwärtigen, die Geschichte aber mit dem Vergangenen zu tun. Das Gegenwärtige, die 
starke Fülle des Lebens, widersetzt sich ihr und kann in seiner Dascinsmacht nicht so ohne weiteres dem Vergangenen assimiliert werden. Die Vergangenheit lastet auf der Gegenwart und zwingt sie dazu, im Vergehen, dureh den Zanber des Todes berührt, zu etwas anderem zu werden als sie war.

So geht ron der Gesehichte wohl Not und Sehaden für das Leben aus, aher Nietzseh hat mit einem einseitigen Maßstab gemessen, wenn er so überwiegend die Naehteile der Historie hervorhebt. Dieser Maßstab aber ist die Wertschätzung des Individuellen.

Es liegt in der Geschichte eine starke 'Tendenz nach dem Allgemeinen und Ganzen hin. die derartige Schärfen ammehmen kann, daß das Individum darin untergeht. Wir erinnern an die Geschiehtsphilosophie Hegels, die das Individum zum blinden Werkzeng degradiert, wir erimsern an all jene Abhängigkeiten, die sich mit dem Wesen der Geschichte verbinden. Und so vermochte der französische Positivist Auguste Comte ${ }^{1}$ ) die Bedeutung der Historie für das Leben vor allem darin zu sehen, daß sie wie keine andere Wissenschaft die sozialen Gefühle steigert und den egozentrischen Standpunkt mutergehen läßt in der Idee des Ganzen.

Da ja in Nietzsche das Prinzip der Individualität gewaltsam zum Ausdruck kommt, Auguste Comte aber in seiner Lehre das Ganze, die Idee der Mensehheit im Auge hat, so mußte Nietzsche vielfach verurteilen, wo Auguste Comte ancrknute. Wir sehen hieraus, daß es ror allem wichtig ist, lie Bedentung des Individuellen gegenüber dem Allgemeinen abzugrenzen und festzustellen, demn mit der Festlegung dieses Gegensatzes hängt die Einsehätzung der Historie für das Leben auf das engste zusammen. Weiter erhebt sich dann die Frage: wie verhält sieh das Problem des Individuellen und Allgemeinen zum Problem des Systematischen und Unsystematischen.

Wem Nietzsche die Geschichte in den Dienst des Lebens als des Gegenwärtigen stellen will, so tritt er damit in einen extremen Gegensatz zu der Lehre des französischen Philosophen, dem nach Auguste Comte soll das Lebendige dem Toten dienen. Das Tote ist weitaus mächtiger und wirksamer als das Lebendige. Die Iree der Mensehheit, in weleher Auguste Comte don hödhsten Bogriff des historischen Geschehens erkennt, ist der Inbegriff aller wertvollen Leistnug, und an dieser wertrollen Leistung haben die Toten weitaus mehr Anteil wio die Lebendigen. So verteidigt Auguste Comte in seiner Anffasisunger les historischen Prozesses der Toten grobes Reeht, Nietzsehe aber das liecht der Lehenden. Nach der Auffassmug des framzösischen Denkers wirl in der Idee her Vensehheit als Inbegriff aller großon Kulturleistung die

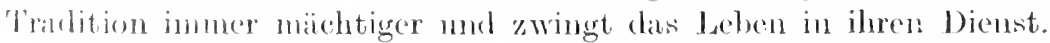

Augraste Comte sucht das daehendige in Simne des 'loten, das heibt im Grois drer Tratition, Nietzsehe mugekeht das Tote im Simne des Lebendigen,

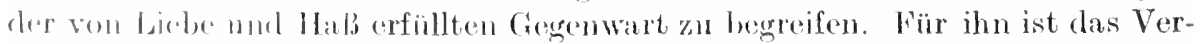
gangen. modh nicht in den grobon und ruhigen behatten des Allgemeinen getroten. Es hat seint individuelle Besonderheit nieht al)gestreift. Es ist nach

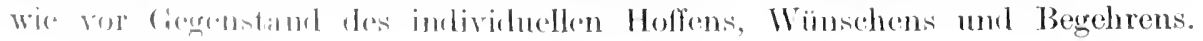

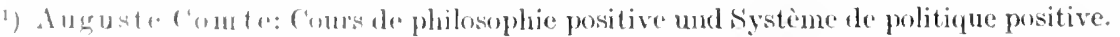

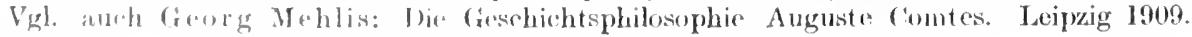


Die Leidensehaften sind in rer Gesehichte nicht untergegangen; sie glühen und leben fort. Cnd so bleibt ihm das Vergangene Gegenstand des Abscheus und der Liebe. Nichts widersteht ihm mehr, als das Vergangene wie ein Ruhende; und Vollendetes zu denken. Nichts ist erreicht, anch kein vorläufiger AbsehluB ist hier gebildet. Alles kamn in seiner Bedeutung wieder in Frage gestellt und in den großen Strom des Geschehens wieder hineingerissen werden. Das Tergangene hat nach dieser Deutung nur Sinn, sofern es für das gegenwärtige pulsierende Jeben brauchbar ist.

Dieser Begriff des Lebens aber, wie ihn Nietzsche geprägt hat, bleibt vollkommen undeutlieh und unbestimmt. Dieses Leben ist doeh mehr als das sinnliche Dasein ter Einzelexistenz in ihrer individuellen Triebbestimntheit, mehr auch als die Summe dieser Einzelexistenzen. Ein Leben des Allgemeinen. ein Leben der Kultur wird darin gedacht, die Größe der Persönlichkeit, das Schicksal der Völker. Sie alle sind gemeint, wemn Nietzsehe von dem Begriff des Lebens sprieht. Das Leben, das er meint, ist das Leben der großen Persönliehkeiten, der Völker, die berufen sind, Kulturträger zu sein. Wenn er rom Leben sprieht, so denkt er an den leuchtenden Fackellauf, dureh den das Große weiterlebt. An die Lichtspender denkt er, nicht an das schwächliche und gleichgültige Dasein der , Vielzuvielen". Das Leben, das er meint, ist kein gleichgültiges Dasein, sondern ein großes, bedeutungsvolles Leben ${ }^{1}$ ).

Nietzsches Begriff des Lebens bleibt ein Problem. Wir wissen nicht, was dieses bedeutungsvolle Leben ist. Und in der starken Hervorhebung des utilaristischen Standpunktes läuft er Gefahr, die Geschichte durch platte Nützlichkeitsbeziehungen herabzusetzen oder auch den Begriff des Lebens, dem die Historie dienen soll, rein biologisch-naturwissenschaftlich zu orientieren. Viel Wahres, Naehdenkliches und Schönes steckt in Nietzsehes berühmter Sehrift über Nutzen und Nachteil der Historie. Aber der Begriff des Lebens bleibt unbestimmt, und jene Beziehungen zum strebenden. bewahrenden und überwindenden Menschen, die er uns enthüllt. sie sind Beziehungen zu gewissen gesteigerten Jebensformen des kulturellen Daseins, die selber erst der Rechtfertigung bedürfen. Und so müssen wir die erste Frage naeh der Bedentung der Historie, die ihre Beantwortung finden sollte in der Erklärung, daß sie dem Leben zu dienen habe, als ungelöst zurückweisen. Historic ist mehr als ein bloßes Werkzeug im Dienste des Lebens.

Ist aber der Sim der Historie nicht Förderung und Hemmnung unseres Daseins, so soll sie vielleicht durch die Torstellung des Erhabenen uns rïhren oder zum Genuß reiner Schönheit uns hinleiten. Die Geschichte ist allein ästhetiseh zu werten, und der Historiker ist der Kïnstler des gesehichtlichen Lebens.

\section{\$ 2. Geschichte als T'eil der ästhetischen Küultur.}

Damit gelangen wir zu einer ganz anderen Dentung und Auffassung der Geschiehte, zu einem ganz andersartigen Verstehen ihres eigentümlichen Wesenskerns. Die Gesehichte ist ein Kunstwerk, ein Werk der kïnstlerischen

$\left.{ }^{1}\right)$ Vgì. über den Begriff des Lebens besonders Rickert: Lebenswerte und Kulturwerte. Logos, Bd. II, H. 2. 
Intuition, das Große und Bedentsame an ihr ist ein Produlit phantasieroller Gestaltming. Dem Künstler ist es gegeben, in letzte Tiefen zu schauen. Er hat ein Terhältnis zum geheimnisvollen Grund aller Dinge. Er hat es mit dem Ewigen mnd Gleiehbleibenden zu tum. Das eben war der Torwurf, den man gegen die Geschichte erhob, daß sie es mit dem Flüchtigen und Vergängliehen. mit dem Zufälligen und Individuellen zu tun habe. Auch mit dem Äußerlichen, sofem die Macht großer Verhältnisse ihren bestrickenden Zauber auf den Historiker ausübt und ihn reranlaßt, dem Geschick der großen politischen Persönlichkeiten und der Entstehung und dem Verfall von Völkern und Reichen nachzudenlien. Er vergißt, daß der Weltgeist sich nicht nur in den großen Begebenheiten, sondern aneh in den kleinen Verhältnissen spiegelt. Das aber weiß der Künstler. (lem die Geschichte eines Dörfleins so wichtig wird wie die Geschichte cines Königreiches. So hat man wohl behauptet, daß die Kunst weitaus philosophischer sei als die Geschichte; d.h. verwandter der Philosophie, weil sie ein mmittelbares Terhältnis zum Ewigen hat und uns lehren will, das Universum anzuschanen, das Große und Ganze im Kleinsten zu sehen und zu lieben.

Wenn wir mu die Behauptung aufstellen, daß die Historie Kunst sei, so treffen wir damit wohl besser die Meimmg und Überzeugung des Historikers, der wohl geneigt sein mag, sich für den Künstler des gesehichtlichen Lebens zu halten. Geschieht doch dureh diese Behauptung der Würde der Historie vollkommen Genïge, denn was könnte wertvoller erscheinen als die Durchdringung der großen historischen Begebenheiten mit kïnstlerischer Intuition und ihre Formmug und Gestaltung zum unvergänglichen Kunstwerk? Und diese Behamptung entbchrt auch nicht einer Begründung, sie scheint etwas scelbstverständliches und Einlenehtendes zu haben, denn zwischen Geschichte nucl Kunst hesteht in der Tat eine enge Beziehung. Daß die Historie dem Leben zu dienen habe, wird der Forscher der Geschichte wohl schwerlich als las Wesentliche bei der Betrachtung seines Gebietes, seines eigentümlichen Gegrenstandes einschen und behaupten. Dagegen mag ar häufig zustimmen, wenn wir sagen, daß3 ex der Künstler des historischen Lebens sei. Denn ist es ja doch soine Funktion, zu bilden und zu gestalten, dem Material fermer Vergangenheit aine Scele zu geben und die große Auferstehmng der Toten durch die Macht seiner Gestaltung herbeizuführen.

Wrm wir den Historiker als Künstler hezeichnen, so spreehen wir damit dror Geschichte emen absoluten Wert zu. Die Gebilde der Historie ordnen sich dann cin der Siphïre des Schönen und können mur vom Schönen her bewertot mut beurteilt werelen. Damn soll die Historie nicht mehr dienen und nïtzen, dann ist sie von ihrem Sklavenverhältnis zum Leben befreit und hat rincesöno Freiheit erworben. Sie gehört zu den großen Formen der ästhetischen Kultur, sie rückt cin in die Sphäre äbergreifender Vernunftzusammenhänge. IVir lassen die Frage dahingestellt, wie weit die Geschichte bedentsan sein nlag fiir dic: Biklum der Individualitiit, wie weit cine Philosophie des Lebens aus ihe loctans Matarial zichen wirl, wir sehen die fiesehichte jetzt mur noch

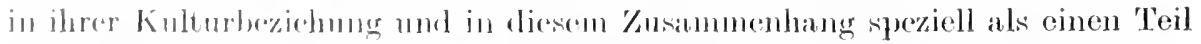

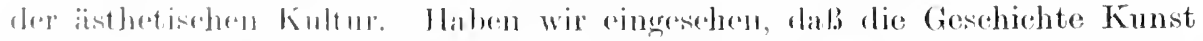
int so ist sic damit ein für allemal der sphäre des Lebens enthoben, und eino 
philosophische Ästhetik würde die eigentümliche Natur ihrer ästhetischen Bedeutsamkeit zu erläutern haben.

Daß die Historie Kunst sei, dafür spricht in erster Linie ihr Werden. Sie war ursprünglich doch ganz augenscheinlich der Gegenstand einer ästhetischliterarischen Betrachtung und Darstellung. Das Interessante und Bedeutsame historischer Fernen wurde durch die reiche Phantasie des epischen Erzählers zum Kunnstwerk der Sage, in dem das Wirkliche nicht mehr m seiner selbst willen da ist, sondern nur den Anhaltspunkt und Ansatzpunkt hildet, um das ïppige Gewebe und Geranke mythenbildender Phantasie zu stiutzen und zu halten.

Wenn die Geschichte eimmal Kumst gewesen ist, wird sie ja doch wohl auch Kunst bleiben müssen. Wie ist es möglich, daß sie aus einer ganz bestimmten Kultursphäre in eine andere übertritt? Wie konnte sie ihrer ursprünglichen Natur entfremdet werden? Achten wir zunächst einmal anf das, was die Historie mit der Kunst gemeinsam hat. sehen wir zu. wo die Beziehungen zwischen der ästhetischen und historischen Formgestaltung liegen.

Bei einer jeden Kulturleistung läßt sich ein Dreifaches unterscheiden. nämlich 1. das Material, das gebildet und geformt wird. 2. die Mittel dieser Bildung und Formung, 3. das Ziel oder der Zweck der Bildung. Zerlegen wir ein Kulturprodukt in diese drei Komponenten, so können wir am besten in sein Verständnis eindringen. Da sehen wir nun in der Tat. daß Historie und Kunst starke Ähnlichkeiten aufweisen, die ihre Ineinssetzung begreiflich machen.

\section{a) Das Gemeinsame ron Kunst und Geschichte.}

Wenn wir auf das Material sehen, so liegt die größte Gemeinsamkeit ror zwischen der Geschichte und der historischen Kinst. Hier haben es Kunst und Historie in gleicher Weise mit dem tatsächlich Gewesenen, mit den Gestalten der Vergangenheit zu tm. Diese Gestalten will dic historische Kunst genan so gut heraufbeschwören wie die Geschichte. Um aber eine solche Wiederbelebung der Vergangenheit vollziehen zu kömnen, bedarf der Historiker wie der Künstler jener Gabe des Verst eh ens, die dem Gegenstande hingegeben ist, sich zeitweilig an ihn verliert, ihn nacherlebt und non erzeugt aus der Fülle des Eigenlebens herans. Für den Künstler wird es in diesem Falle in ähnlicher Weise wie für den Historiker bedentsam, ein Verhältnis zu dem Gewesenen zu gewinnen. Und beiden steht nicht so ohne weiteres der Zugang zu all und jedem offen. Erst wem das Frende und Ferne zum Befreundeten und Vertranten geworlen ist, kann der Prozeß der historischen und künstlerischen Gestaltung beginnen. Aber jene psychologischen Prozesse des Auffassens, Deutens, Nachlebens, Verstehens, Mitfühlens entscheiden doch angenscheinlich schon bereits über den Charakter und Wert der Leistung. Wie könnte ein Historiker über Griechenland schreiben ohne Verständnis für die eigentümliche Individualität des griechischen Volkes; nur dam kamn er richtig deuten und auffassen, wenn er mitfühlt, mitlebt und mitleidet, was jene gefühlt, gelebt und gelitten haben. Denn nicht als Richter steht der Historiker dem Vergangenen gegenüber, sondern in erster Linie als Freund. 
In diescm Gebiet des Cnausgesprochenen und Ungeklärten, in jenen psychischen Torgängen, da Künstler und Historiker noch nicht zum eigentlichen Prozeß des Schaffens übergegangen sind, lassen sieh nun aber schon verschiedene Tendenzen unterscheiden, die den Gegensatz zwischen dem historisch mnd künstlerisch eingestellten Menschen verraten. Das Gegensätzliche in dem Verfahren des Kïnstlers und des historisehen Mensehen liegt ılarin, daß dieser, indem er bemüht ist, die Wirklichkeit zu verstehen, vor jeder gewaltsamen Umbildung zuräckschreckt. während der Künstler auf das Wirkliche keine Rücksieht zu nehmen braucht. Der Künstler hat das Recht, das Wirkliche zu rergewaltigen, es schwer zu schädigen bis zur vollkommenen Zerstörung. Der historische Menseh darf die Rücksicht auf das Wirkliche nie aus den Augen verlieren. Wenn in irgendeiner geistigen Tätigkeit, die der Mensch ausübt, der Gedanke des Abbildens noch einen Simn hätte, dann wohl am ersten in der Gesehiehte. Der Historiker will die Vergangenheit aufleuchten lassen. Er will zeigen, wie alles so geworden ist. Der Historiker hat den Sim für das Wirkliche, für die großen Realitäten des Lebens, welche die stürmische Cngeduld des Künstlers beiseite schiebt und nicht zu Worte kommen läßt. Der Historiker will zur Wirklichkeit hinleiten, und der Künstler will sie verniehten. Der Historiker verlangt naeh wirklicher Größe. Wirklicher Größe gibt er die große Form. An feste Konturen ist sein Schaffen gebunden. Der Künstler vermag auch in das Unbedentende das Große hineinzulegen. Er ist Herr und nieht Diener des Wirklichen.

Wenn somit auch das Beispiel der historischen Kunst uns zeigt, daß die Psychologie des Künstlers gemeinsam hat mit dem Historiker den rerständnisreichen sinn für vergangene Größe, so reißt sie der verschiedene Charakter ihrer Zicle doch bald nach entgegengesetzten Riehtungen fort. Dem der Historiker verlangt nach dem Wirklichen und wïnscht, daß es in voller Klarheit no erschein'm möge, wie es ist. Er ist der treue Sohn der simnlichen, farbenfrohen Wirklichkeit, und mag auch sein Geist, der still sich mit ihr beschäftigt, die ferncen Gijfel der Vorzeit vergolden, so wirl er doch immer ernsthaft bemüht sein, das Diggwesene zu sehauen, und dicses Dagewesene in sich aufzunehmen

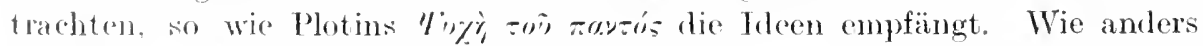
dagegen dor Künstler, anch wem er dem historischen Stoff zugewendet ist. Er hat keine Achtung und Dennt vor seinem Gegenstande, sondern eine freudige Jiebe, alie mit ihm macht, was sie will.

Fir die Creschichte wie fiur die Kunst ist das Moment der Ansehauung ron yrößter Bedentung. Geschiehte und Krunst haben es mit Anschaumug zu tun. Lixilen aignet rin hohes Mab von Konkretheit. Gestalten führen uns I)ichtlumst und bildende Krumst (notgegen, Gestalten, die in der Anschammg weilen und lureh Anschaumg gesätigt sind. In der Anschammg findet eler

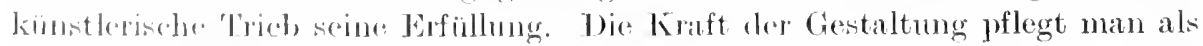

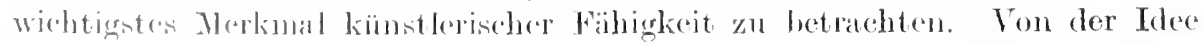

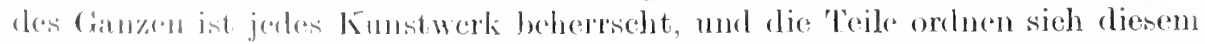

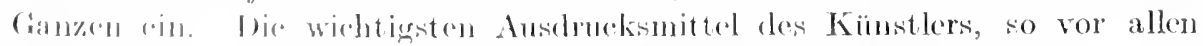
das symbol, tragen cincu anschaulichen (haraliter. Dasselbe gilt für den

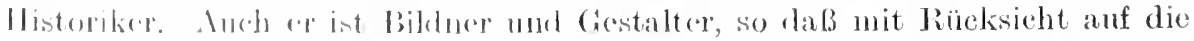

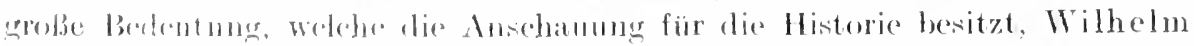


Windelband ihr Verfahren und ihre Methode als idiographisch bezeichnet hat $\left.^{1}\right)$. Alle Ereignisse ordnet die Geschichte einem Ganzen ein, und in der Darstellung macht sie in reichem Maße von anschaulichen Bildern Gebrauch.

\section{b) Das Gegensätzliche ron Kunst und Geschichte.}

Dennoch offenbart sich in dieser Gemeinsamkeit ein großer Gegensatz. Ist doch das eigentliche Werkzeug der Geschichte der Begriff und nicht das Bild. während für die Kunst ungekehrt der Begriff das Sekundäre ist. Die Geschichte erkennt durch den Begriff und belebt das Erkannte durch Anschaumng, die Kunst stellt durch Anschaumng dar, und wenn sie den Begriff nicht entwaffnet, so verurteilt sie ihn doch zu einem wirklichkeit,fremden Sein im Peiche des Imaginativen.

Man kann dann weiter Geschichte und Kunst gegeneinanderkehren. wenn man sich darauf besinnt, daß es die Geschichte mit dem Individuellen, die Kunst aber mit dem Allgemeinen zu tun hat. Diese Behauptung erscheint allerdings anfänglich recht willkürlich. Man könnte, wie es scheint, ja auch das Gegenteil behaupten und den Begriff der Kunst ror allem mit dem Eigentümlichen und Individuellen rerbinden. während man die Geschichte hinweist anf das Gesetzmäßige der Erscheinungen. Wir können doch nicht leugnen, daß Begriffe wie Eigentümlichkeit, Originalität und Einmaligkeit durchaus der Sphäre der Kunst angehören. Mag die gleiche wissenschaftliche Entdeckung, die sich unabhängig voneinander vollzieht, unsere Bewunderung erregen, ablehnen müssen wir es durchaus, wenn die Schöpfung eines Künstlers dem Kunstwerk eines anderen gleicht. Was ist es num aber, was notwendig originell sein muß? Der Stoff, das Material?

Als künstlerisches Ausdrucksmittel bleibt es im allgemeinen konstant, sofern dem Marmor immer wieder die schöne menschliche Gestalt entspringt. Dennoch ist es in der besonderen Wahl wichtig und bezeichnend für Küunstler und Kunstwerk. Tizians leuchtende Farben rermögen uns etwas anderes zu sagen als das süße Helldunkel Correggios. Das gilt auch abgesehen von der Komposition der Farben, die ja schon als Prozeß der Formgebung betrachtet werden muß. Auch das Material ist ästhetisch relevant und hängt schon mit der Frage der Einzigkeit zusammen. Und wie steht es mit dem Stoff als dem Bedeutungsmäßigen im Kunstwerk? Immer wieder wird der Dichter sagen und singen ron der vergangenen Stanfenherrlichkeit in Sizilien und Apulien. Immer wieder wird der Bildhauer schönes jugendfrisches Menschenleben gestalten und der Maler die Felsenküste von Capri mit des Meeres ewig rechselndem Farbenspiel auf der Leinwand festzuhalten suchen. Doch ist des Bildners Sehnsucht immer wieder auf ein neues und selt enes Modell gerichtet, und die vollendete Behandlung eines Stoffes entzieht ihn gewiscermaßen einer neuen Formung. Wie gewagt und rerwegen, nach Goethe ein Faustdrama zu schreiben oder nach Shakespeare einen Hamlet! Hier ist der Stoff geweiht durch rollendete Behandlung und damit auch gleichzeitig der künstlerischen Betätigung entrückt.

$\left.{ }^{1}\right)$ Wilhelm Windelband: Naturwissenschaft und Geschichte. 1894. 
An demselben Stoff Kann sich die Erfindung des Künstlers in sehr verschiedener Weine wirksam erweisen. An der ganzen Art der Stoffbegrenzung tritt schon die formgebente Tätigkeit hervor; vollends in der Gruppierung und in dem Bezogensein der einzelnen Gestalten. Die Form wird es in erster Linie sein, die das Kumstwerk zu einem neuen macht. Aber an welche Form hat man hier zu denken. an die innere Form, die den einheitlichen Sinn des Ganzen herstellt, oder an jene äuBere Form, die den Stil des Kunstwerkes bestimmt? Beide hängen natürlich auf das engste zusammen. In dem Stil spiegelt sich des Diehters Gestalt oder auch der Charakter einer Schule und eines Zeitalters. Die derben und üppigen Franengestalten Rubens' sind ebenso charakteristisch für die Stileigentümlichkeit eines Dichters und eines Milieus wie die blumenhaft schlanken Gestalten der Frührenaissance. Ist Zuschnitt, Ordnung und Einteilung des Stoffes zunächst einmal nur eine Sache der äıBeren Formgebmng im lioman, so laßst diese äußere Behandlung und Terschiehmng gleiehsam als Kulisse und Dekoration schon das hervortreten, was den eigentümlichen Sinn, die Tiefe und den Charakter des Kumstwerkes anmacht. Die äußere Form muß der inneren Form entsprechen. So wird etwa dem Charakter einer Diehtung und der Idee, die sie zum Ausdruck bringt, arch die Form dor Rede, die Gestaltung dor Verse, die Sprache der Bilder mol Metaphern angemessen sein, falls es sich m ein wahrhaftes Kunstwerk handelt. Und doch können wir uns vorstellen, daB dieselbe ästhetische Idee in versehiedener Form auftritt, und wir möchten behaupten, daß es die Aufgabe der Kunst sei. die ästhetischen Ideen, die Vorbilder aller wahren Kunst, die so alt sind wio das Mensehengeschlecht und erfüllt ron einem mendlichen Sinn, in immer wiorler neuer Gestalt zur Darstellung zu bringen. Wobei gewiß vorausgesetzt wird, daß das ewig Mensehliche mol Göttliche, das in ihnen whoht, in jedem newen Kunstwerk sieh einen anderen Körper baut und in versehiedener Werthetomung und Wertverbindung nemen Widersehein lenehten läßt.

\section{c) Iie Kunst bringt das Illgemeine im Besonderen zur Darstellung.}

IVas alko nen und origindl sein muld, das ist in erster Linie der Stil des Kunstwerkes. Das Kunstwerk selber mub den (hamkter des Originellen und Einzigartigen an sich tragen mot in diesem simne eine Individualitait soill. Damit ist aber moch niehts über den Gegenstand der Kunst gesagt, der niomals das blol. Individnetle sein kamm, sofern die Aufgabe der Kunst darin

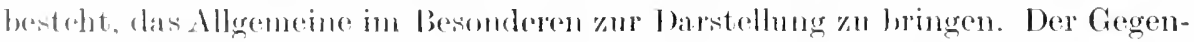

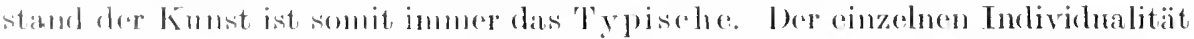

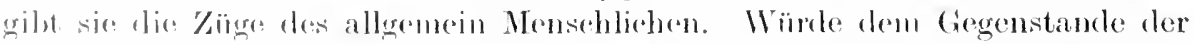
Kumst diese bogiehung anf das allgemein Mensehliehe fehlen, wärle das Indivi-

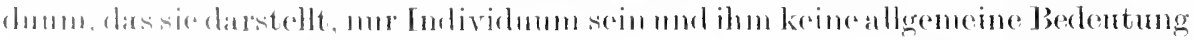

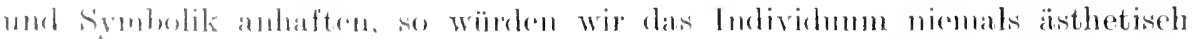

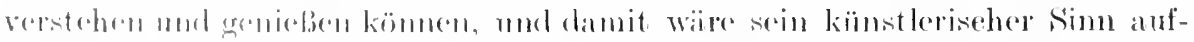

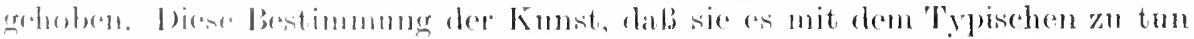

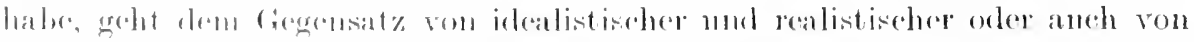

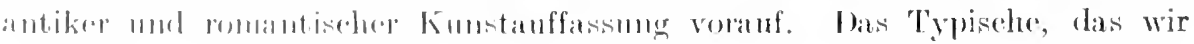


hier meinen, ist nieht gleichberlentend mit dem Idealen und Vorbildlichen. Wenn eine frühere Pichtung der Kunst nur Ideale der Sichönheit zur Darstellung brachte und ihr gegenüber die Forderung sich erhob, das ('harakteristisehe und Interessante zur Darstellung zu bringen, weil nur so dem Streben der Kunst nach Lebenswahrheit und nach Erfassen des Individuellen Genüge gesehehen kann, so ist unser Begriff des Typus nicht Partei in diesem Streit: Einerlei, ob es sieh um idealistisehe oder um realistische Kumst handelt, niemals bleibt sie bei der Darstellung des mur Individuellen in der Anschaunng stehen. Das Individuelle gewinnt stets ein allgemeines Bedeuten, als Repräsentant der Mensehheit steht der einzelne da. Die Kunst berichtet uns nicht mur ron Emannel Quints Schicksal, sondern zeigt uns. wie in Emannel Quint die mystische Seele leidet. Dieser Allgemeinheitseharakter der künstlerisehen Naturen gibt uns die Möglichkeit, mit ihnen zu leben und mit ihrem Schicksal zu leiden.

Daß die Kunst das Wirkliche nieht abbilden kann, wie es ist, selhst wemn Kunst aus einem gefährliehen Mißrerständuis heraus sich diese Aufgabe stellen würde, das ist wohl allmählieh die herrsehende Üherzengung geworden. Niemals bildet die K̈unst das Wirkliehe ab, niemals stellt sie ein Individumm dar, wie es gewesen oder noch ist. Tielmehr ist das Individuum der Kunst von der Bedürftigkeit des historischen Individums befreit, nu unter ganz bestimmten rämmlichen und zeitlichen Berlingungen sein zu kömen und zu gelten. Es ist ron allen einengenden Bedingungen erlöst und isoliert, dem Banne der Notwendigkeit entrüekt, in eine Sphäre der Freiheit hinaufgehoben. Das ideale Sein jener Gestalten, die wahre Kunst geschaffen, ist ein allgegenwärtiges, ewiges Sein. Das Allgegenwärtige und Ewige an ihnen ist die ästhetisehe Idee. Das Eigentümliche des ästhetischen Phänomens muB darin gesehen werden, da B das Allgemeine, das als solches doch raun- mol zeitlos gilt, sich in die Form der Anschaung gegehen hat ${ }^{1}$ ). Wohl weist dadurch die Ansehaumg notwendig über sich heraus, demn sie bedentet weit mehr als das bloße Diessein, aber das Allgemeine, welches die Schranken der Endliehkeit überwunden hat, geht nieht mehr daranf aus, das Simnlich-Anschauliehe von sich abzustoßen. Das Allgemeine soll hier das Besondere und das Besondere das Allgemeine sein ${ }^{2}$ ). In jedem wahren Kunstwerk ist die Flee, dasjenige. was zeitlos gilt, endlieh geworden. sofem sie an gewissen simulichen Berlingtheiten verwirklicht ist.

Die Antigone eines Sophokles bedentet mehr. mendlich viel mehr bedeutet sie als die fromme Tochter des Ödipus, und wenn wir des groben Realisten Dostojewski gedenken. so ist Aljoscha nicht nur der jüngste Sohn des alten Karamasow oder der .gute und fromme". Junge des heiligen Sossima. Jenes allgemein Menschliehe und Úbermensehliehe, das die Zufälligkeiten der besonderen Individualität und Nationalität ïberwunden hat. ist erst das Große des Kunstwerkes.

$\left.{ }^{1}\right)$ Tgl. Pickerts Bestimmung der künstlerischen Aufgabe, daß sie das Allgemeine in der Anschaumng zur Darstellung bringt. Kulturwissenschaft und Naturwissenschaft. Tübingen 1910.

2) Vgl. hierzu auch Schellings Philosophie der Kunst. 


\section{d) Die Geschichte sucht das Individuelle zu begreifen.}

Während somit die Kimnst das Individuelle und Persönliche inmmer in die Sphäre des Allgemeinen hinaufhebt, ohne dadurch die Anschauung zu verlieren, oder auch das Allgemeine in die Sphäre des Anschanlichen hineinbezieht, ohne das Allgemeine anfzugeben, ist das Wesen des Historischen tarin beschlossen, daß es das Individuelle zn begreifen sucht ${ }^{1}$ ). In diesem Tersuch der Historie, das Individuelle und Persönliche in seiner Einmaligkeit festzuhalten. liegt, wie wir noch sehen werden, das eigentliche Problem der Geschichte. Will die Kunst in dem Individumm das Allgemeine und in dem Allgemeinen das Individuelle sehen, dasjenige, was immer ist und immer gilt, in seiner Beziehung zum Endlichen und Vergänglichen verstehen, so lehrt uns die Geschichte die Tergänglichkeit, so gibt sie uns die eigentümliche Daseinsform, die als solche niemals wieder sein und werden wird. Und weil die Geschichte zu uns spricht von der Schönheit und Herrlichkeit des Einzigartigen, das als solches unwiederbringlich dahin ist, das keine Zukunftsweiten wiedergeben können, so gehört zu ihrem Wesen notwendig der Gedanke des unwiederbringlich Verlorenen, so ist alle Geschichte ihrem immersten Wesen nach tragisch. Das haben alle großen Meister und Verstehende des historischen Lebens tief empfunden. Schelling hat gelehrt. daß ohne die Idee der Tragödie die Geschichte ïberhaupt nicht zu rerstehen sei ${ }^{2}$ ), und Nietzsche spricht ron dem groben Werden der griechischen Philosophie als von der Philosophie im tragischen Zeitalter der Griechen. Die Kunst ist das ewig Junge, das nicht altern und sterhen kann, das ewig Gegenwärtige. Die Geschichte ist das Reich rles cimmal Gewesenen und für immer Verlorenen.

Und um noch einmal zu Nietzsehe Stelhng zu nehmen: so wahr es ist, daß die Geschichte dem Bewahrenden und Verehrenden gehört, so unglücklich int doch dor Begriff einer antiquarischen Geschichte als wesentliche Bestimmung für eine historische Anffassungsweise. Nicht um die Aufbewahrung des Alten handelt es sich. Anch ist es nicht das Alter, Ras den Wert des Verlorenen bestimmt. Unsere liebe und Verehrmng gehört nicht vor allem dem längrst Entrïckten, das aus graner Vorzeit zu uns herüberdämmert, sonst würde alle historische Kunde Altertmmskmnde sein. Unscre Jiebe gehört dem Einzigartigun, das dereinst scine gehommisvollen Lebenskreise gezogen, dem vollen schoncen Laben, das einst greblïht.

Wenn man num aber auch zugeben mag, dab der Gegenstand der Kunst das ewig Gegenwärtige und der Gegenstand der Goschichte das ewig Versangem. mol Verlonene ist, wem man anch weiter zugestcht, dab dem Kunstwerk eine von den individnellen bediurftigkeiten und Zufälligkeiten freie Alegrmeinheit immenoht, während der historische Begriff die Individualität

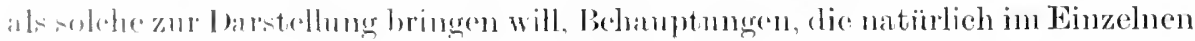
meh zu rechtfertigen sind, so arhehen sich doch von vornherein Zweifel, was

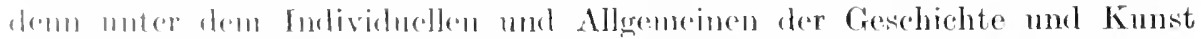

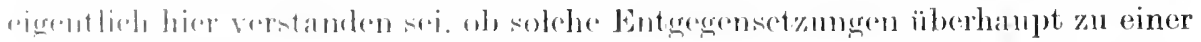

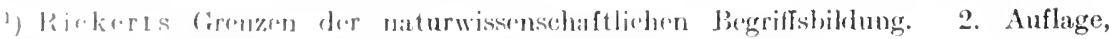

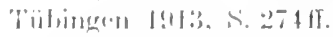

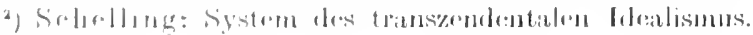


fruchtbaren Unterseheidung führen können, ob die Begriffe, wie wirsie bisher gebrauchten, nicht außerordentlich zweideutig sind, und ob man nicht von einem anderen Gesichtspunkt her den allgemeinen Charakter der Geschichte und die Individualität der Kumst betonen kamn. Bildet nicht die Historie zur Erfassung des Wirklichen Begriffe, und ist nicht der Begriff ein Allgemeines? Und anderseits: ist nicht die Kunst dasjenige Gebiet, wo der Begriff seine Grenze findet und das Kunstwerk jenes Urindividuelle, das keinem Allgemeinen untergeordnet werden kann, für das es keine Theorie und Regel gilst? Sprechen wir nicht von der Individualität des Kunstwerks und von dem Kunstwerk der Persönlichkeit? Und ror welche paradoxe Aufgabe stellen wir die Kunstgeschichte, wenn sie mnter dem Aspekt des awig Vergangenen das ewig Gegenwärtige begreifen soll? Unsere Unterscheidungen erklären also nichts, sie ziehen uns vielmehr nur in eine Fülle von Fragen hinein, die schon hier eine Erörterung finden müssen, um die Eigentümlichkeit und Verschiedenheit der Geschichte gegenüber der Kunst sicherzustellen.

\section{e) Die Allgemeinheiten der Geschichte. Der historische Begriff.}

Wenn wir sagten, daß es die Kunst mit dem Allgemeinen im Besonderen, mit dem Unendlichen im Endlichen zu tun hat, die Historie dagegen mit dem Individuellen, so ist hier die Rede ron dem Gegenstand oder der Aufgabe der Kunst und Geschichte. Die Kunst will das Allgemeine in dem Besonderen der Anschaumg darstellen, die Historie aber das Besondere der Wirklichkeit in der Form des Allgemeinen, des Begriffes ${ }^{1}$ ). Das ist die erste und selbstrerständliche Art des Allgemeinen in der Gesehichte. Wie jede Form der Erkemntnis hat es auch die Geschichte mit dem Allgemeinen des Begriffes zu tun. Indem nun die Historie den Versuch macht, das Individuelle und Einzigartige in die Form des Begriffes zu erheben, kamn sie diesem Bestreben durch den Begriff doch niemals vollkommen genügen. Niemals begreift die Historie die Wirklichkeit, wie sie ist, sondern immer werden ihr die Individuen zu Abstraktionen. Nur etwas von der Fülle ihres wirklichen Daseins geht in das Reich der Geschichte ein. Die Gebilde der historischen Wirklichkeit sind also allgemein, nur wenige große Wirklichkeitszüge sind in ihnen aufbewahrt, die allerdings für ihren Charaliter wesentlich und entscheidend sind orler doch wenigstens nach der Anffassung des Historikers wesentlich und entscheidend sein sollen. So ist es etwa für Diogenes Laertius in historischer Beziehung wesentlich und entscheidend, daß er über die Torsokratiker geschrieben hat. Abgesehen ron dieser Tatsache besitzt sein Leben und Dasein nicht das geringste historische Interesse. So gehören manche Individnen der Geschichte nur an durch ein schlechtes Buch, das sie geschrieben, oder durch ein wildes Wort, das sie gesprochen haben. Was aber an ihnen im höchsten simne gut und groß war, und worin ihre Seele lebte und wirkte, das ist nicht eingegangen in den großen Strom des historischen Geschehens, es ist lantlos rerklungen, es ist unwirksam und stumm und tot geblieben.

$\left.{ }^{1}\right)$ In der Cieschichte handelt es sich um die Darstellung eines Individuellen im Begriff. Vgl. Rickert: Kulturwissenschaft und Naturwissenschaft.

If hlis, Geschichtsphilosophie. 


\section{1) Die historische Persönlichkeit.}

Anch die großen historisehen Persönlichkeiten, wie sie in der Gesehichte weiterleben. ind notwendigerweise Abstraktionen ron der konkreten Fülle des Wirklichen. Die historisehen Persönlichkeiten sind ein Allgemeines. Das ist die zweite. spezielle und entseheidende Form, in der das Allgemeine in ler Geschichte sich kundgibt. Auch das Resultat der historischen Begriffsbildung ist ein Allgemeines. So reich die historische Forschmng das Bild Goe thes auszugestalten sueht, so groß das Material ist, das ihr bei dieser Tätigkeit zur Verfügung steht, der historisehe Goethe ist niemals der ganze Goethe. Eine Fïlle seines Tuns und Lebens ist in die historisehe Erkenntniswelt nicht eingegangen. Bei dieser Art der Abstraktion und Erfassmng der historischen Per-önlichkeiten ereignet sich ein für die Gesehichte höchst charakteristischer Vorgang. Die Geschichte meint es gut mit ihren Helden. Wie anch der Standpunkt des Historikers im einzehen sein mag, notwendig neigt er dazu. die historischen Individuen und die großen geschichtlichen Begebenheiten zu veridealisieren. Je größer das Maß des sehon vorliegenden Bedentens sein wird, um so mehr fühlt er sieh gedrängt, die Bedentung zu steigern. Das führt dann hänfig zum Kinltus der historischen Persönlichkeiten, zu dem Phänomen der Heldenverehrung. Mit höchstem Maß wird die historische Gestalt gewertet. Goet he wirl zum Dichter der Welt mol Kant zum Philosophen der Mensehheit.

Unter dem Anpekt des Kultus der großen Persönlichkeiten könnte die Wahrheit der Historie in Frage gestellt werden. Haben jene idealisierten Gertalten der Geschichte, denen man alle Derbheit und Gewöhnlichkeit genommen hat. $u m$ sie in einem eigentïmliehen Lichte seheinen zu lassen, haben so ̈̈berhanpt noch irgend einen Wahrheitsgehalt? Diese Frage kömnen wir ruhig bejahen. Das, was eine Persönlichkeit in Wahrheit ist, das kam nicht durch lie Fïlle ihres konkreten Soseins beantwortet werden. Vieles mag wohl dom Mensehen eignen, das nieht zu seiner wahren Natur gehört. Der grobe Aspekt del Geschichte trifft ganz gewiB mit vicl mehr Sicherheit und Bentimntheit das whlnhaftige Antlitz der Persönlichkeit wie der beschränkte und ärmliche Gesichtspunkt des Kammerdieners. Es kam natürlieh eine sitrigernng des Heroenkultus geben. wo die feste Form der Erkemntnis sich zu phantastischem Nehel rerflürhtigt. Dam schwindet die Wahrheit aus der (ierchichte.

Die groben und stakken Ziige der historischen Pröonlichleeit, das weiBe Licht und den tiefon Sichatten. dureh die Kraft der Inastellung sueht sie der Historiker noch deutlieher zu machen. 1)en Wirklichkeitscharakter der histori-

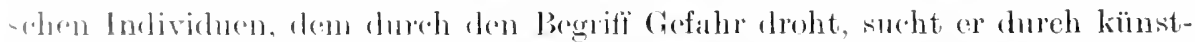

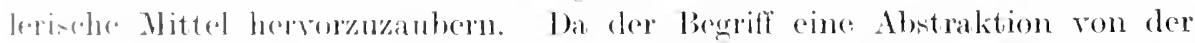

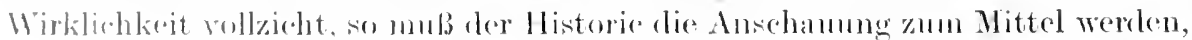

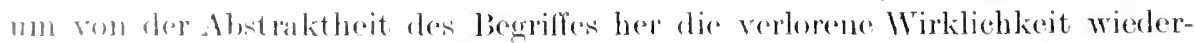

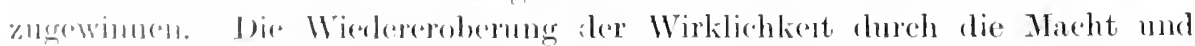

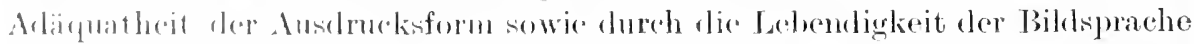
int Aufgabre Hor historischen Darstellung, mul in dieser seiner darstellenden

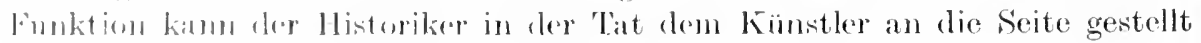

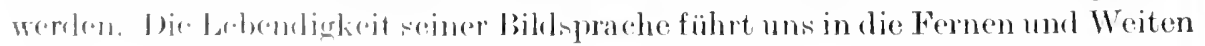


der Vergangenheit und läßt uns sehen. was wir nie geschaut. Sie gibt unserer Phantasie die Wirklichkeit wieder. Und die Angemesrenheit rles Ausdrucks läßt das den Intentionen des Darsteller's Gemäße ror unsere Seele treten, in dem alles Fremde und störende untergeht. Wir können somit die Aufæabe der Historie vorläufig dahin bestimmen, daß sie rlie Individualität der Vergangenheit darzustellen bemüht ist. Dieses Ziel sucht sie zu creiehen. indem sie das rorgefundene und ïberlieferte Naterial der hegrifflichen Formung unterwirft und das durch die Abstraktion Verlorene sowie rlie Lücken der Überlieferung durch anschauliche Bildhaftigkeit zu ergänzen sucht. So sind etwa von der Persönlichkeit des Sokrates eine Reihe mehr oder weniger zuverlässiger Daten überliefert. die gewiß nicht annähernd geniigen, die in ihrer absoluten Konkretheit unfaßliche Individualität des griechischen Weisen zur Darstellung zu bringen. Aus diesen wenigen Bausteinen mus nun der Historiker die Gestalt des griechisehen Denkers zu gewinnen suchen. Hat ex nun etwa den Grundbegriff eines großen und weisen Nenschen ron tiefimnerlichem ethischen Pathos, von bodenloser Originalität, ron faszinierender Häßlichkeit gewomnen, so wird er von hier aus die Gestalt und das Wesen des Sokrates dureh ansehauliche Mittel der Darstellung zu füllen und zu ergänzen suchen. Wenn num die historische Individualität eine Abstraktion ron der ganzen und rollen Individualität des lebendigen Nensehen bedeutet, so ist diese Tatsache der Abstraktion zunächst eine ungewollte, sofern sie sich aus der Dürftigkeit des überlieferten oder rorgefunclenen Materials ergibt. Weiter ist diese Abstraktion eine notwendige. inden der Begriff als solcher niemals die ganze Fülle der konkret-simnlichen Anschanung zu überwältigen rermag. Endlich aber ist diese Abstraktion, wie wir noch sehen werden, anch eine gesollte, denn wir können dem Begriff nur die Anfgabe stellen. das Wesentliche zu erfassen und aufublewahren. Die Aufgabe. der Gegenstand ist das Individuelle, das Mittel der Darstellung das Allgemeine, der Begriff.

\section{g) Die historischen Gruppenbegriffe.}

Wir haben bisher zwei Formen erwähnt, in denen das Allgemeine in der Geschichte erseheint. Eimmal als historischer Begrift zur Ltherwindung der Mamnigfaltigkeit, als Mittel der Erkenntnis. Damn aber aneh als historisches Individumm, als Resultat der Erkenntnis, das etwas Einmaliges und Unwiederholbares bedentet und doch den Charakter der Allgemeinheit an sich tragen muß, weil die ganze Lebensfülle der konkreten Individualität in keine Begriffsbildung einzngehen vermag. Was der historische Begrift Alexander der Große meint, das ist doch nur relativ wenig ron jenem Alexander, der einst sein blühendes Leben gelebt. Cnd dennoch ist in den Begriffen ron historischen Individualitäten das Streben der Historie nach dem Individuellen und Eimmaligen nur zu deutlieh zu spiiren. Aber bildet die Historie nieht auch Begriffe, die, wie es seheint, doch ganz augenscheinlich ihren Grund haben in dem sehnsïchtigen Streben nach dem Allgemeinen? Geht lem die Geschichte immer daranf aus, historische Persönliehkeiten in ihrer Individualität. zu begreifen? Angenscheinlieh faßt ner Historiker nicht alle historischen Individuen als Persönlichkeiten auf, sondern die bei weitem größte Zahl von 
historisehen Erscheimmgen faßt er unter allgemeinen Begriffen zusammen wie: Bewegung der Massen. Volk, Staat und Kirchen, Orden, Rittertum, Patriziergeschlechter, das Heer, die Flotte, der vierte Stand. Dabei ist allerdings zu bemerken, daß diese Begriffe auch wieder ein hohes Maß von Konkretheit an sich tragen. Eimmal deswegen, weil sie in der historischen Darstellung in der Regel doch ein ganz bestimmtes daseiendes oder dagewesenes Objekt meinen. Die Geschichte hat nicht mit dem Volk oder dem Staat äberhaupt, dem Ordens- oder Mönchswesen. dem Charakter des vierten Standes als solchem zu tum, sondern mit dem deutschen Tolk, dem französischen Staat, dem Templex- oder Johamiterorden, dem Mönchswesen des 4. und 5. Jahrhunderts, der Bewegung des vierten Standes zur Zeit der französisehen Revolution. Familie, Staat, Geschlecht, Gesellsehaft überhaupt sind etwa Gegenstand der Rechts- und Staatswissensehaft, der Soziologie und Nationalökonomie. Ferner liegt aber in allen Gesellsehaftsbegriffen bereits ein hohes Maß ron Konkretheit. Die naturwissenschaftlichen Begriffe Bam und Mensch sind im Terhältnis zu den einzelnen Bäumen und Mensehen weitaus abstrakter als der Begriff Staat im Verhältnis zu den einzelnen Bürgern. Jene naturwissenschaftlichen Allgemeinbegriffe enthalten weiter niehts, als was den Artbegriffen gemeinsam ist, ohme daß dies Gemeinsame noch den Charakter einer lebensvollen Beziehung beibehält. Bei Begriffen wie Tolk und Staat sind die Fndividuen in ihrer wechselseitigen Beziehung, die als soziales Moment die statliche Organisation oder

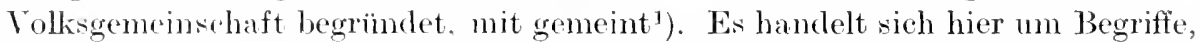
die man am besten als Totalitätsbegriffe hezeiehnet, insofem das Ganze hier die Teile in der Fülle ihrer wertrollen Beziehungen in sich trägt. So ist etwa in dem Begriff clar Ordensgemeinsehaft das Ordensgelöbnis notwendig mit gemeint, das hier die cigentïmliche Bezichmng, anf der das Wesen des Ordens bermht, gestiftet hat, und gemeint sind aneh die psychischen Relationen, die anf Grund dirses Gelöbnisses die Omlensglieder miteinander mol die Gemeinschaft selber mit ibrem höchsten Herm verbinden. Wem aber aneh diese Begriffe cine Gemeinschaft ums ammen, ohne die einzelnen Gestalten individualisierend hervorteten zu lasisen, so ändert das niehts an der Bohauptung, daß das Ziel dor Gesehiehte das Tndividuclle sej. Demn die Bildung dieser Totalitäsbegrifle ist doch zwoifollos ron dem Interesse geleitet, las einzigartige und einmalige Leben wertvoller sozialen Verbände zur Darstellung zu bringen. Aueh kann man mit vollem liecht cin Tolk als Individualitä im Großen anffassen, und selbst in den Formen des stathehen mol kirchlichen Jebens. wie es die Geschichte zur Larstellung hringt. verrät sich ganz dentlich der Wille za individu(Her Gestaltumg.

\section{h) Der historische 'Typus.}

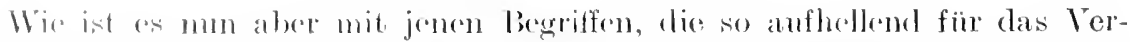
stehen do historischen Wirkliehkeit sind, weil sio das ('hankteristisehe vieler

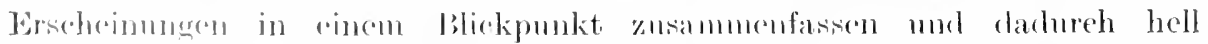

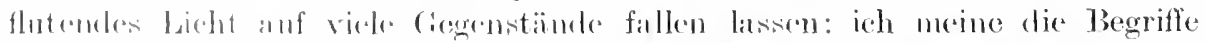

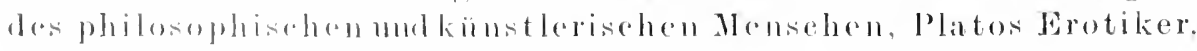

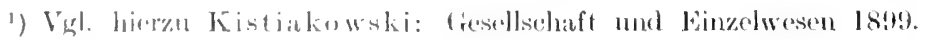


den Magier und Mystiker. Antike, Romantik und Aufklärung. In ihnen seheint doch der Weg des historisehen Denkens ron dem Besonderen zum Allgemeinen sich hingewendet zu haben. Romantik und Aufklärung sind keine bloßen Epoehenbezeichnmmgen. Diese Begriffe bedeuten nicht nur das Ganze, in dem eine Folge historischer Erscheinungen besehlossen ruht, sondern die Heraushebung des Wesentlichen und Charakteristischen der Geschichte. In ihnen kündigt sich an die Erleuehtung der historisehen Innerlichkeit, gleiehsam die Erfassung des metaphysisehen Wesens, die Offenbarung des Grundes. Der Begriff der Romantik ist nicht mur der Begriff für eine bestimmte Zeit, er ist vielmehr das immer Wiederkehrende des historischen Geschehens. Immer wieder wird es Zeiten und Menschen geben, für die der Begriff des Romantischen einzig bezeichnend ist. Alle diese Begriffe bringen das Eigentümliche und Bedeutsame gewisser Kulturerscheinungen zum Ausdruck, und man kömnte zweifelhaft sein, ob ihre Bildung ein Werk des philosophisehen oder des historischen Denkens ist. Ich möchte schon hier darauf hinweisen, da 3 diese Begriffe eine ähnliche Zwischenstellung zwischen Philosophie und Geschichte einnehmen wie der Begriff des Organismus zwisehen Philosophie und Naturwissensehaft. Und wie die Idee des Organismus gleiehsam das Einfallstor gewesen ist und immer sein wird, durch das die Naturphilosophie ihre Spekulationen in die Naturwissenschaft hineinträgt, so sind jene Begriffe der historisehen Kultur, die wir mit Dilthe $y^{1}$ ) als Typen bezeichnen wollen, der Ansatzpunkt für jede konkrete, inhaltlich gerichtete gesehichtsphilosophische Auffassung des historischen Universmms.

Wie sich diese Kulturtypen, die angenscheinlich für die Geschichte ron größter Wichtigkeit sind, mit Individualität als Ziel und Aufgabe der Gesehiehte vertragen, das muß hier rorläufig problematisch bleiben. Auf jerlen Fall sind Romantik und Antike teleologische Einheiten, die zu einem philosophisehen Terstehen einladen. Dentlich ist es ferner, daß diese historischen Typenbegriffe nicht unabhängig ron Zeit überhaupt, wohl aber ron einer bestimmten Zeit sind.

Wir werden später sehen, daß auch der Begriff des Typus dem vorgezeichneten Ziel der Geschiehte dient. Dagegen ist das Anfgegebene der Kunst ein für allemal das Allgemeine am Individuellen, das Übersimnliche am Simnlichen. Wenn wir sagen, daß die Kunst auf das Allgemeine als solches gerichtet sei, so ist diese Bestimmung ebenso unvollstänlig, wie wenn wir sagen, sie wolle das Individum in seinem natürlieh-sinnlichen Dasein zur Darstellung bringen. Die Kunst will das Allgemeine, die ästhetische Idee, nicht ohne die historischsimnliche Erscheinung und umgekehrt, und ihre Vollkommenheit liegt gerade darin, daß sie das Entgegengesetzte zu einer absoluten Einhoit führen und das Unendliche mit dem Endlichen versöhnen will. Was ist etwa das Allgemeine, die Idee der Antigone oder des Aljoscha? Beide sind nicht begrifflich wiederzugeben, sondern nur zu erleben. Die ästhetische Idee eines Kunstwerkes ist unendlich, unerschöpflich, durch den Begriff niemals zu bewältigen. Wenn der historische Begriff die anschauliche Wirklichkeit nicht dureholringt

1) Vgl. über Diltheys Begriff des Typus das Buclu von Arthur Stein: Der Begriff des Geistes bei Dilthey. Bern 1913. 
und nicht zu rationalisieren vermag, so kann man hier nicht eigentlich von der Ohmmacht des Begriffes sprechen, sofern der Begriff an der Anschaumg seine logische Aufgabe erfüllt. Wenn aber der Begriff die ästhetische Idee eines Kunstwerkes nicht wiederzugeben vermag, so ist ihm hier in der Tat eine absolute Grenze gesetzt. In die Seele des Kunstwerkes ist dem Begriff der Eintritt rerwehrt. Die Logik scheitert am Künstler. Gewiß wird wird man den Versuch machen zu erzählen, was die ästhetische Idee des Aljoscha Karamasow oder der Antigone sei. Man wird etwa von der Antigone sagen können, daß sie zum Ausdruck bringe die Idee der beiden Gebote, des geschriebenen und ungeschriebenen, des menschlichen und göttlichen, die im Widerstreit sind und nieht in Einheit, wie Heraklit gelehrt. Daß sie den Sieg des göttlichen Gebotes über das menschliche, daß sie den furchtbaren Konflikt des Menschliehen und Göttlichen, daß sie dem inneren Wesen nach den Sieg des Göttlichen ïber das Menschliche, wiewohl dem äußeren Dasein nach den Untergang des Göttlichen ror dem Menschlichen in ihrer hohen und reinen Gestalt zur Darstellung bringt. Aber das Gesagte kann nichts bedeuten gegenüber der Idee der Antigone, welche die große Tragödie des Sophokles bis in alle Einzcheiten hinein ron einem undurchsichtigen sichmerz durehzittern läßt.

Und von Aljoscha Karamasow kömnte der Begriff behaupten, daf er die reine Darstellung des religiösen Menschen sei, der seine Simnlichkeit nicht getötet hat und deswegen so schön geblieben ist, dessen Unsehuld sein Wissen, und dessen Wissen seine Unschuld ist. Das durch keine Torurteile, durch heinen Verdacht und Argwohn verdunkelte Gemït. Der Mensch mit den großen Kinderaugen, der Heilige, der doch ein trener Sohn der Erde ist. Die grobe Liebe, die alles versteht, die Reinheit, die vor Schmerz und Schande nicht zurückbebt. So steckt rein Nenschliches und Übermenschliches gar vieles in der ldee des jungen Karamasow, aber der Begriff kamn mur ein paar Bruchstücke geben und nieht die volle Einheit der Idee. Denn diese hat sieh mit hoher Gewaltsamkeit aller Einzelheiten des groben Kunstwerkes bemächtigt und trägt ainc Fülle und rinen Reichtum in sich, den der Begriff nicht ausschöpfen kamn.

Democh ist, wenn wir die Trle als die Form des Kunstwerkes bezeichnen, dic Individualität des Inhaltes nicht gleichgültig. Die fromme Tochter des Oedipus und der junge Ka ramasow sind notwendig und hoch bedeutsam fur die asthetisehe Form. In ihnen hat die ästhetische Form den adiquaten stofflichen lubalt gefunden. Wer ldee des Kunstwerkes korrespondiert ein individnelles berdenten, das dem Allgemeinen orst die asthetische Wirklichkeit

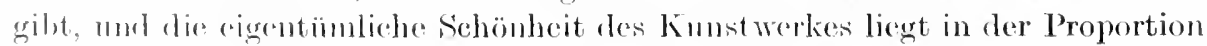
von Idee mol sinnliehem sinlstrat. Wenn wir von der Individualiät eines Kinntwerkes sprehen. so meinen wir die Einzigartigkeit, mit dereine aisthetisehe leloe in romer besmeleren simnliehen Gestalt sieh verwirklicht hat. In der simulichron Eswheimung schalft sich die ästhetische Jdee ihren Organismus.

form mul Thhalt, wis wir sie untersehieden haben in der Beziehung

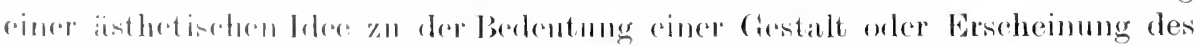

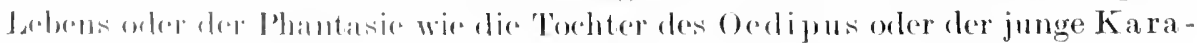
masow, bilden das boterisehe, das Geheimnis der Kunst. Denn darin muß 
die Aufgabe des Künstlers gesehen werden, daß er mit dem flüchtigen Bedeuten der Erscheinmng, mit der vorübergleitenden historischen Gestalt einen ewigen und unvergänglichen Simn verbindet. Dieser Sinn, der uns zu fragen und zu raten gibt. macht die Seele des Kunstwerkes aus. Künstlertum heftet ewigen Sinn an flüchtige Gestalt. Wohl kann der Mensch, der von den Behauptungen der Philosophie und der Religion nicht ïberzeugt ist, an dem Simn der Lebens verzweifeln, niemals aber an dem Sinn des großen Kunstwerks. Deswegen ist das Absolute, wie bereits Plato erkannt hat, auch nirgends so gewiß. wenn auch verhüllt und heimlich zugegen wie in der Kunst. Deswegen verdient auch alle ideenlose Kunst nieht mehr den Namen des Kunstwerkes. Nichts ist so sehr an der Veräußerlichung der Kunst sehuld wie die Verkennung dieser fundamentalen Tatsache des kïmstlerischen Lebens. Solange man die Anffassung vertritt, daß eine gut formierte Erzählung oder ein gut rhythmisiertes Gedieht seiner technisehen Vorzüge wegen schon ein Kunstwerk sei, steht man seinem inneren Wesen rollkommen rerständnislos gegenüber.

In jedem Kunstwerk handelt es sich vor allem um die Bindung des Allgemeinen an das Besondere. um die Ċberwindung des Gegensatzes von endlieh und unendich, darin das eigentliche Wunder der Kunst und ihre Vollendung liegt. Dieses Innerliche der Kunst ist aber auch gleiehzeitig dasjenige, was sich der begrifflichen Einsieht entzieht. Nur so weit kann von einer philosophischen Analyse des Kunstwerkes die Rede sein, als die Grundformen alles Wissens: das Allgemeine und Besondere, das Notwendige und Freie, Form und Inhalt, Einheit und Mannigfaltigkeit, endlich und mendlieh 1 . a. m., auch in der ästhetischen Sphäre erscheinen. Allerdings mit einem Sinn, der von dem logischtheoretisehen erheblich verschieden ist.

Ton dieser esoterischen Sphäre der Kunst ist die exoterische wohl zu unterseheiden. Hier handelt es sich um das Problem der ästhetischen Formgebung im Sinne des Stilproblems, un die Frage. wie soll die Seele des Kunstwerkes mit ihrem besonderen Bedeutungsgehalt sich stofflich konkretisieren und offenbaren? Hier haben wir es mit den verschiedenen Arten der Kunst, mit den Gegensätzen von Dichtkunst und bildender Kunst sowie mit ihren eigenartigen Möglichkeiten und Ansdrucksmitteln zu tun, wodureh derselbe Stil dam wieder eine ganz verschiedenartige Ausprägung erfährt. Dabei muß er immer dem ästhetischen Gegenstande angemessen sein und in enger Beziehung stehen zu dem Geist eines bestimmten Volkes und einer bestimmten Zeit. Hier ist das Gebiet der ästhetischen Theorie, die sphäre, die dem Begriff größtenteils offensteht.

Ist somit dasjenige, was man die Individualität des Kunstwerkes zu nemnen pflegt, in erster Linie die Einzigartigkeit der Bindung des Allgemeinen an das Besondere, die ihren Ausdruck findet in der Eigentümlichkeit des Stils. in dem sich das Leben des Künstlers mit dem Leben des Kunstwerlies und mit dem Geist der Zeit vermählt, so wird die Vorstellung von der Cnwiederholbarkeit und Einzigkeit des Kunstwerkes noch gesteigert, wenn wir erwägen, daß es keine Regeln des Schönen gibt, wie Regeln der Wahrheit, die für alle Zeiten festgesetzt sind. Ist es doeh der große Kïnstler, der die Regeln des Schönen schaffend erzengt. Tor allem aber ist es die kïnstlerische Isolation, die den 
Eindruck der Freiheit macht und damit zugleieh die Vorstellung ron der Individualität des Kimstwerkes hervorbringt. Losgelöst aus der Kette notwendiger Kausalbeziehmingen, ist das Kunstwerk eine geschlossene, autonome, in sich ruhende Welt. Im Gegensatz dazu wird die historische Individualität dem Kausalzusammenhange eingegliedert. Die historische Individualität kamn und wird niemals die Freiheit haben, die dem Kunstwerk eigentümlich ist. Sie ist Glied eines Zusammenhanges und nicht eine Welt für sieh.

So eng sich daher das Gebiet der Kunst anch mit dem Gebiet der Geschiehte berïhren mag: die Behauptıng, daß die Geschichte Kunst sei, ist doch niemals zu reehtfertigen. Thre Wege, Ziele und Aufgaben sind verschieden. Ftwas anderes ist die Behauptung, daß das Ästhetisehe und der ästhetische Wert für die Historie bedentsam sei, etwas anderes die Behauptung, die Geschichte sei Kunst und der Historiker der künstlerische Mensch. Das Ziel der Geschiehte ist Wahrheit und nicht Schönheit, so viel auch die Schönheit für die Historie bedenten mag. Nur von der Idee des letzten Zieles aus kömnen wir den Charakter einer Kulturerscheinung rerstehen. Daß der Historiker Kïnstler sei, wird unter Verkemmng der grundlegenden Bedingungen immer wieder behauptet, und wir glauben dieser irrigen Behauptung um so entschiedener (nt gegentreten zu mïssen, weil sie mit Notwendigkeit zu einer ungehenerlichen Fälschung unseres Weltbildes führt.

Allerdings gesehieht diese Fälschung des Weltbildes in einer Richtung, die alle Beachtung verdient, und die zu den großartigsten Interpretationen gehört, die der Menseh jemals an der starren Wirkliehkeit versucht hat. Sie führt zur romantisehen Weltansicht. Diese romantische Weltansieht meint, (aB die kïnstlerische und ästhetische Funktion die höchste Form des ueistigen Lehens sei, und sie will dem ästhetischen Wert, dem Wert der Schönheit die leitende Stelle in Kultur und Leben anweisen. Sie meint, dal b rie höchsten Prohleme in letzter Hinsicht ästhetische Probleme sind, dals die Kunst es ist, welehe die Antwort auf die letzten Pätselfragen des Lebens zu geben vermag. Diese romantische Weltanschammg will anch die Geschichte für die ästhetische Problemstellung mutzbar machen und sie dem kiinstlerischen Wert unterwerfen. Die ästhetisch-romantisehe Wreltanschammog prägt den Begriff einer intuitiven Erkenntuis dureh Schanen, "incr intuitiven Wahrheit, und diese Form der Erkenntnis gilt mehr als die beErifflirhre Erkenntnis. Das Shanen, die intellektuelle Anschammg, die Funktion des religiosen und kïnsterischen Mensehen, sie soll anch auf dem Gebiete der Likrnntuis die entscheidende Rollespielen. Wassoll das aber heißen? Der Begriff Jor lntuition ist angenseheinlich rin sehr vieldentiger Begriff. Was kann diese Amalogir von Kunst mul Wiscensehaft für einen Wort zmm Verständnis inres

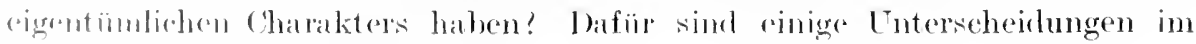
lexeriff lar Intuition arforderlich.

\section{i) Dir Intuition.}

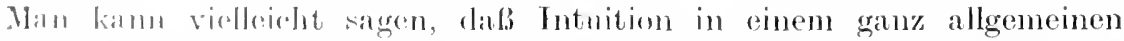

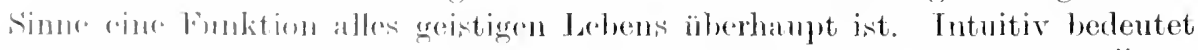

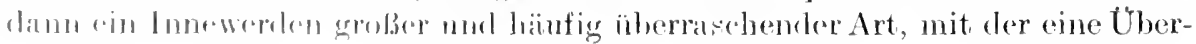


zengung und ein Glanbe unmittelbar zusammengeht. Es ist eine wundervolle, seltene und höchste Verfassung des Gemiites, die mühsames Forschen belohnt und heiße Erkenntnisliebe stillt. In diesen Augenblicken weiß der menschliche Geist, wozu all das Frühere notwendig war, und er hat einen Höhepunkt des Lebens gefunden. von dem aus alle Niederungen. die bisher in Schatten gehüllt waren. klar und hell werden. Intuition ist hier ein Finden des Gesnehten, ein Verknüpfen und Terbinden zerstrenter Fäden, ein leichtes Übersehanen mühsam durchforschter Wege. Flüchtig und rorübergehend sind solche Feiertage des Geistes für die Menge der Mensehen, den Großen und Einsamen werden sie häufiger zuteil. Dieses Finden aber kann ein Finden der Wahrheit, der Schönheit oder des Glanbens sein.

Ganz anders, wemn der Begriff der Intuition, speziell auf dem Gebiete der Erkenntnis, entgegengestellt wird dem diskursiven, begrifflichen, rerstandesmäßigen Denken. Damn wird die Intnition manchmal zu einem besonderen Organ des Philosophierens, das die enge begriffliche Schranke zu überwinden und das Irrationale zu erleuchten und zu rationalisieren vermag. Sie wird zu einer Gabe und Fähigkeit besonderer Art. zu dem 气̈nos der metaphysischen Sehnsucht, der keine Grenzen der Erkenntnis kennt.

Man kann aber noch in einem anderen Sinne ron Intuition sprechen, sofern die Anschammg als die wesentliche Erfüllnng der Erkenntnis gilt. Das Denken kann mehr oder weniger anschanlich sein, mehr oder weniger anf den Gestalten ruhen. Das Denken Goethes ist anschanlicher als das Denkens Kants'). Goethe rerbleibt bei seiner Erkenntnis der Natur in lebendigen, ansehauliehen, phantasiebelebten Bildern, aus der Idee des Ganzen heraus die Teile der Welt in nachsimnendem Geiste verstehend. Er opfert nicht die Fülle der Gestalten dem dïrren Begriff und seheint somit eine Art ron Erkenntnis zu repräsentieren, die der Diehtkunst nahe steht. Man kann dann rielleicht ron einer Erkenntnisdichtung oder ron einer Phantasieerkenntnis sprechen, indem man die Auffassung vertritt, daß die kühne Phantasie des Dichters und die Weisheit des Denkers hier zusammengewirkt haben, um ein Wissen ron den Dingen zu erzengen. Man kamn aber auch zu der Behauptung gelangen, daß es sich in all diesen Fällen um ein kïnstlerisches Verstehen der Dinge handelt, das mit theoretischer Einsicht und Erkenntnis so gut wie nichts zu tun hat.

Wemn die Geschichte Kunst genannt wird, und die Intuition als die eigentümliche Methode des Historikers in Anspruch genommen wird, so ist in dieser Bestimmung die romantisehe Sehnsucht deutlich zu erkenmen. Auf die Natur wird sehmerzlicher Verzicht geleistet. Sie wird der strengen Wissenschaft des Begriffes überlassen. Aber Kunst, Geschichte und Leben in ihrer wundervollen Konkretheit lassen sich nur durch Intnition verstehen. Die begriffliche Erkenntnis hat es lediglich mit den Phänomenen der Natur zu tun, die schanende Erkenntnis dagegen mit der Kultur.

Das Gebiet des Theoretischen ist nach dieser Anffassung durch den Begriff rer Naturwissenschaft muschrieben. Alle Wissenschaft ist Naturwissenschaft. In der Geschichte sind vielleicht gewisse theoretische Iomente enthalten

1) Vgl. Eugen Kühnemann: Herder, Kant, Goethe, Logos, Bd. III, Heft 2. 
aber in der Hauptsache ist sie ein Gebikle, das der ästhetischen Problemstellung gehört.

Lst aber die Naturwissenschaft die einzig mögliche Wissenschaft, so hat sie allein das Recht. die Frage der wissenschaftliehen Wahrheitserkenntnis zu beantworten. die der theoretische Mensch niemals dem Erkemntnisdichter überlassen kann und darf. Die letzte prinzipielle Antwort der Naturwissensehaft wird notwendig der Mechanismus sein. Diese Lösung widerstreitet dann wohl auf das äuBerste den Forderungen unseres ästhetischen, religiösen und sittlichen Bewußseins, aber wir müssen uns bescheiden. Die Natmrwissenschaft als die einzig wahre wissensehaftliche Erkenntnis hat entschieden. Es gibt keine theoretisch wissenschaftliche Erkenntnis neben der mechanischen. Eine philosophische Dentung des wissenschaftlichen Lebens mu 3 dahin gelangen, daß es in all seinen Begriffsbildungen auf die Verneinung des Werthaften, auf die kalte und kahle Herrsehaft ruhiger Gesetze abzielt.

Ganz anders. wenn die Geschichte selber Erkenntnis zn geben vermag, oder wemn sie gar eine eigentïmliche und selbständige Form der Erkenntnis bedentet. Demn damn ist für die Lösung der wissenschaftlichen Probleme nicht mehr die Naturwissensehaft als solche die entscheidende Instanz. Die Frage der wissenschaftliehen Erkenntnis der Welt vollendet sieh dann nicht mehr in den Naturwissenschaften. Dann ist aber anch vielleicht die Möglichkeit gegeben, die wissenschaftliche Erkenntnis in Einklang zu bringen mit den Gesamtforderungen des Kulturbewbtseins. Wir sehen also, daB die Frage nach dem Begriff der Geschichte weit daron entfemt ist. ein bloß methodologisches Problem zu sein. Jas heißt ein Problem, das die Selbstbesimmmg dieser Kulturdisziplin angeht. Jedes methodologische Problem hat anch seine Bedentung für unsere Wcltansicht und Weltanschammg. Wir können jedes methodologische Problem cinerseits so betrachten, wie es die Technik und das Verständnis der cinzelnen Wissenschaften angeht. Aber das ist immer nur die eine Seite der Sache. Jole Entscheidung über Methode ist zugleich eine Entscheidung für allgemeinste philosophische Probleme, für Weltansehamung und Leben. Das können nur dicjenigen verneinen, die der Meinmng sind, daß in der Methode keinerlei Wert nud Notwendigkeit enthalten sei. Wrumerbar nur, daß sie meinen, dureh ein paar technische Kunstgriffe zu dem zu gelangen, was wir als wissenschaftliche Erkenntnis rerehren. Vergessen wir nieht, da B die Methode der Wey zur Wahrheit ist und deswegen im höehsten Mabe das philosophische Interesice crwecken muls.

\section{\$3. Die Historie als Wissenschaft.}

bal3 nun aber die Historie Wissensehaft sei, das int die große neue Erkenntuis des 19. Jahrhunderts, die aus den bestromugen des dentsehen Idealismus herporgewathon ist. Mit dieser Einsieht hat das Gebict des Wissens eine

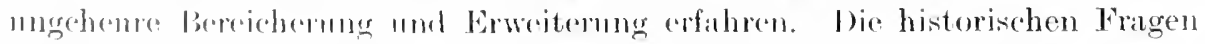

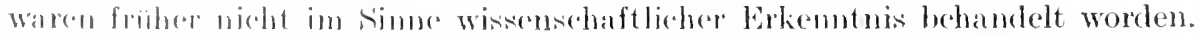

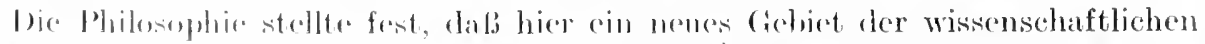

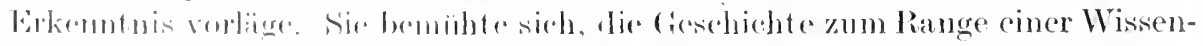

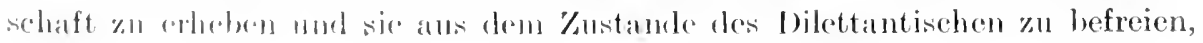


und die Historie hat am Anfang des 19. Jahrhunderts diese große Emanzipation an sich rollzogen und durch die Herausarbeitung einer exakten wissensehaftlichen Methode mehr und mehr dem theoretischen Ideal sich angenähert. Wenn vorher, je naeh Belieben. Teile und Fragmente des Vergangenen durch die Pietät des Chronisten aufbewahrt. zu Ehren der Großen und Mächtigen sowie zu Ehren Gottes gestaltet waren, so handelt es sieh nummehr darum, alles Wissenswerte aus der ungeheuren Masse einer vieltausendjährigen Mensehheit zu erklären und darzustellen. Ja. es mußte zunäehst so erscheinen. als ob alles Vergangene zurückerobert und in das helle Licht der Gegenwart versetzt werden sollte. Und zu welchem Zweeke? Nicht mehr, um den Mächtigen zu huldigen und Gott zu dienen. sondern 1 m der Wahrheit des Tatsäehliehen und der Wahrheit des Geschehens willen.

Kant, der Begründer des dentsehen Idealismus, hat die Wissensehaftlichkeit der Geschiehte nicht anerkennen wollen. Schelling, Fiehte unr Hegel haben ihrer Erhebung zur Wissenschaft rorgearbeitet, indem sie den muvergänglichen Wert der Historie betonten und das pragmatisehe Interesse ron ihr abzulösen suehten. Was jene großen Denker erstrebt hatten. fand dann seine Erfüllung. als die Historie mit dem 19. Jahrhundert so mächtig wurde. als die großen klassischen Werke der historischen Wissensehaft entstanden. Seitdem hat die Historie zahIreiche Beweise dafür gegeben. wie fein ihr methodisches Werkzeng ausgebildet ist. Und man kann sogar von einer historischen Voraussicht reden, sofern manehe kühne Hypothese ïber das Vergangene, die an der Hand eines relatir dürftigen Materials anfgestellt wurde. durch spätere Funde rollkommene Bestätigung fand. Nach all diesen Erfolgen ist der wissenschaftliche Charakter (ler Geschichte im logischen Bewußtsein der Gegenwart rollkommen anerkannt.

Wir haben die Aufgabe, welche sich diese neue Wissenschaft stellt, im allgemeinen dahin präzisiert, daß sie das Individuelle der Vergangenheit, das. was geschehen und nnwiederbringlich verloren ist, durch den Begriff gestalten und aufbewahren will. Sie soll das Vergangene schildern. wie es wirklich gewesen, sie soll uns dentlich machen, wie alles so geworden ist. wie es im Verhältnis zueinander steht, unabhängig ron dem unruhigen und lanten Standpunkt der Gegenwart, die ihrem eigenen Charakter entspreehend bald zu einer Überschätzung, bald zu einer Untersehätzung der Vergangenheit hinneigt. Wird sich doeh das gegenwärtige Zeitalter bald als Tollendung der Vergangenheit, bald als ein schwächliehes Epigonenzeitalter fühlen und rerstehen. Daß die Vergangenheit auf die Gegenwart bezogen wird, ist ja mbedingt notwendig. denn die historische Fragestellung lautet: .. Wie ist das Gegenwärtige aus dem Vergangenen geworden?". Wir müssen der Gesehichtswissensehaft ror allem die Vergangenheit zuweisen, können sie aber ron der Gegenwart nieht ausschließen und müssen ihr den Hinweis anf die Zukmnft gestatten. Die Gesehichte kann ron der Gegenwart nicht erlöst werden. ohne ihr Verhältnis zu uns, d.h. zu dem Kulturbewnßsein unserer Zeit, zu verlieren, und sie kann in der Beziehung zur Gegenwart nicht verweilen. ohne immer wieder aufs neue umgedeutet und umgewertet zu werden. 


\section{a) Schwierigkeiten einer historisch wissenschaftlichen Iuffassung.}

In dieser Beziehung der Geschichte zur Gegenwart liegen große Schwierigkeiten für den Historiker, denn das Leben der Gegenwart ist umhüllt von dem Ghuthanch der Leidensehaften. Ton unserem Wïnschen, Lieben und Hassen ist sie durchdrungen und widerstrebt der Objektivierung. Die Welt, inder wir leben, hassen und lieben. ist die Welt, in der wir notwendig Partei sein müssen und sollen. Wir können sie nicht in dem ruhigen Lichte des kontemplativen Denkens schanen. denn diese Welt des historisehen Lebens, sie geht uns ummittelbar so sehr viel mehr an als die ruhige und große Welt der Natur, die uns umgibt. Wemn wir demnach der Geschiehte die Aufgabe zuweisen, darzustellen, wie das Vergangene zum Gegenwärtigen geworden ist, so wird dadurch, wie es scheint, die Geschichte des Tergangenen immer wieder durch den Wechsel des Gegenwärtigen ron neuem ergriffen. Die Gegenwart unserer Zeit ist immer wieder eine andere, und an dieses immer wieder Andere soll der Historiker das Geschehene ankniipfen. Der Historiker. welcher der romantischen Epoche angehört. schlägt seme Brüeken rom romantischen Zeitalter aus. Wir schlagen unsere Brïcken von dem noch namenlosen gegenwärtigen Zeitalter her. Das Ufer und der Standpunkt des historischen Betrachters wird immer weiter geschoben. Immer wieder sinken die Brücken in den Strom des Werdens, um immer wieder von nenem aufgeriehtet zu werden. So muß das Schlagen immer nener Brücken als die eigentliche Sisyphosart)eit des historischen Mensehen erseheinen. Lnd diese Tatsache, da 3 die historische Leistung sich überlebt und die Geschichte immer wieder neu geschrieben werlen mo, sie hängt nicht, we in der Naturwisencehaft, mu damit zusammen, daß nene Entdeckungen «cmacht sint, welche die alten Theorien über den Haufen werfen, sontern sie hängt zusammen mit dem Wandel der Zeit und mit der notwendigen Anknüpfung an diesen Wandel. Die Vergangenheit ändert ihr Gesieht mit jedem Schritt, den die Menschheit vorwirts tnt. Etwas anderes bedentet das Griechentum für das romantische Zeitalter, etwas anderes für uns. So hat etwa die Philosophie Hegels zum Dentschland der 70er Jahre ein ganz anderes Verhältnis als zur Gexenwart mol dent entsprechend eine ganz andere Einsehätzung erfahren. dus nencen Verhältnissen mol Gegobenheiten heraus schauen wir das Vergangene immer wieder mit newen Augen, treten mit immer anderen, rastlos weehsoluten Fordemugen an dio Vergangenheit heran, denten von einem neuen Stamlpumkt ans das Alte immor wieder nen mol versehieden, legen immer wieder andere Vabstabe an und lasien es niemak zur Rohe kommen. Das Vergangene

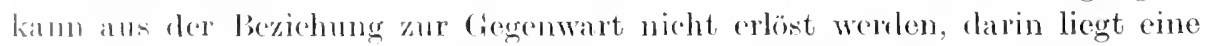
grolice (infahr foir die Wissenschaftlichlecit dor (ieschichte. Denm was des

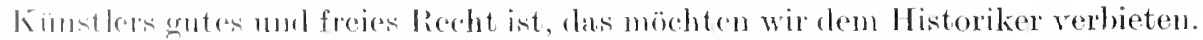

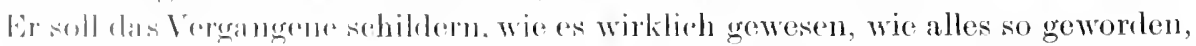

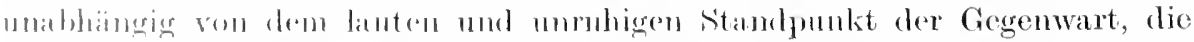

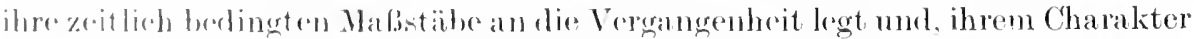

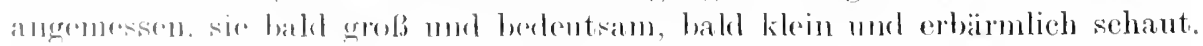

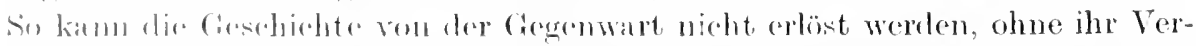

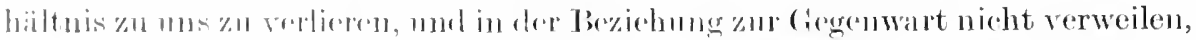

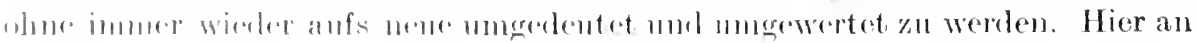


dieser Stelle erhebt sich die schwierige Frage, in welchem sime ler Historiker objektiv sein kann und soll. Müssen wir die kühle Ohjektivität rerneinen oder für ummöglich erklären, so seheint damit auch der wissenschaftliche charakter der Geschichte aufs äußerste bedroht zu sein.

Gerade in dem. was die wissenschaftliehe Begrïndung der Geschichte so sehr erschwert, liegt mun auch wieder etwas Wertrolles und Reizrolles. Ist die Geschichte als die Wissenschaft ron dem für immer Verlorenen ihrem inmeren Wesen nach tragiseh, so hat dies Verlorene doeh anch eine eigentiimliche Gewalt und Zauberkraft. Das ist die Magie der Gesehiehte, daßsie jedem nenen gegenwärtigen Zeitalter in einem anderen Lichte leuchtet, daß sie so vielen etwas sein und jedem Zeitalter ein Anderes und Nenes sein kamn. Deswegen ist die Geschichte dem Historiker der wundertätige Proteus, der immer none Gestalten zeigt, der Spiegel, in dem ein Zeitalter sein Bikl hald schwach, bald mächtig sieht, und darin offenbart sich ihr Reichtum und ihre Größe. daß sie so riel zu rersehenken hat und immer Neues gibt.

Was aber das Gemüt beglückt und bezaubert, kann für deul theoretisehen Simn qualvoll werden. Welche L̇berlegungen können uns ron dem Bilde dieser großen Vergängliehkeit, dieses ewig Wechselnden erlösen - rom ästhetischen Genuß zur Ủberzeugung und zum Wissen führen? Wie erweist der Historiker seine Objektivität und Parteilosigkeit, wie gewinnt das Bild der Geschichte klare und ruhige Formen, die ron allen verstehenden Menschen in gleicher Weise anerkannt werden mïssen?

\section{h) Die historisehe Ohjektivität.}

Man hat den Historiker wohl den Riehter des historischen Gesehehen: genannt. Man wollte damit andeuten, daß er über den Begebenheiten und Parteien stehen soll. Hegel sagt sehr sehön, daß ein Pichter sein Amt sehr sehlecht und töricht verwalt en würde, wenn er nicht im höchsten Ma Be interessiert wäre für das Recht und auf Grund der Reehtsidee alles beurteilte ${ }^{1}$ ). Er ist also Partei, sofern er interessiert ist für die Verwirklichmug der Rechtsidee und damit Feind des anarehischen und gesetzlosen Zustandes, mparteisch aber, sofern das persönliche Interesse des Vorteiles und Gewinnes rollkommen sehweigt. Ganz angenscheinlich gibt es mun auch für den Historiker einen solchen Gegenstand allgemeinen Interesses und allgemeiner Anerkemmung, nur daß dieser Gegenstand riel umfassender ist als der Begriff des Reehtes, der das Interesse des Richters bestimmt, und ganz augenscheinlich wird anch an dieses Etwas die historische Beurteilung. falls eine solche überhaupt möghich ist. anknüpfen. Dieses Etwas bezeichnen wir ganz allgemein als Kultur. Wie also der Richter für das Recht als einen bestimmten Kulturwert interessiert ist, so der Historiker für Kultur ïberhaupt.

\section{c) Die Idee der Küultur als das objektive der Geschichte.}

Ist das Interesse des Richters die Terwirklichung des Reehter. so ist das Interesse des Historikers die Verwirklichung der Kultur. Int das der

1) Hegel: Enzyklopädie. Lehre rom objektiven Geist. Die Weltgeschichte. 
Fall. so wäre er keineswegs interesselos und urteilslos, sondern er hat den Willen z u K Kultur. Die ...shlechte Subjektivität" des Historikers würde dann immer in einer gewissen Partikularität zn suchen sein, die in der Hauptsache in zwei Dimensionen sich äußern wird, nämlich eimmal in der einseitigen Betonung und Hervorhebung eines bestimmten Kulturwertes, etwa der Religion oder des Staates. anderseits in der einseitigen Auszeichnung gewisser sozialen Gruppen und Einheiten. Eine historische Darstellung, die clas wirtschaftliche Leben als ausschlaggebenden Faktor des historischen Geschehens betrachtet, rerleugnet ebensowohl den Standpunkt der Objektivität wie jede einseitige Dynastengeschichte.

Das Problem, mit dem wir es hier zu tun haben. läßt sich etwa folgendermaßen formulieren: ..Gibt es gegenüber dem wechselnclen Bedenten etwa des Griechentums oder der Renaissance für versehiedene Epochen der Menschheitsgeschichte nicht auch ein allgemeingültiges historisehes Bedeuten?" Wir müsen doch die Fordermug erheben, daß wir in der Auffassung des Vergangenen zu einer gewissen Konstanz vorzudringen hahen. Das Antlitz des Griechentums hat je nach dem Charaktcr des reflektierenden KulturbewnBtseins sich gewandelt. Man hat in seinen schönen Zügen kalten Śpott und herbe Frivolität leuchten sehen. Die griechischen Götter ersehienen als die schönen Genien der Sünde. End damn war auf eimmal jerler böse und aufklärerische Zug getilgt, und einem anderen Kulturhewußtsein erschien dieses Tolk seinen Göttern gleich als das Volk der ewigen Jugend und Schünheit. Der gricchische Geist erschien als das Jünglingralter des Menschengesehlechtes, das gricchische Volk als das Volk (lex schönen Individualität $\left.{ }^{1}\right)$. Das Unbewnte, Naive und Heitere des Griechentumes wirl eingesehen, das mit der Natur im Bunde und mit dem Geschick in hohen Einklang steht. Und wieder veränkert sich das Antlitz des Griechentumes: wilile Leilenschaften, der Ransch der Mystericn bricht hinter der nur scheinharen großen klasischen Ruhe hervor. Ein Friedrich Sehlegel erhebt die Forlerung, da Bas Orgien und Mysterien die gricchische Philosophie abzulciten sei. mal Frielrich Nietzsche suehte den Geist der griechischen Trasionlie zu rerstehen und zeigte wie sie geboren ist ans dem Rausch und aus lem Traum. Wirl moser Terstehen immor ein weohselndes sein? Werden wir immer nenen und ankeren Simn mit den Gebilden der Vergangenheit verhinklun! Mit dar chronologischen Einstellung der Begebenheiten ist der histori-chen Erkemntnis doch ganz gowiß nicht Genïge getan. Gesehichte als Wissen-chaft ist nur bam möglich, wom die historisehe Auffassung zu einer Allgemeinsiiltigkeit des bodentens hinführt. Wemm Kant anf dem Gebiet der KunstMhilosphire die Frage nach dem ästhetischen Gemeinsimm erhebt, nach der

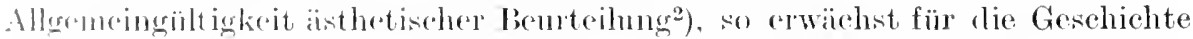
das Problem des historischen Gomoinsinns, das Problem des all-

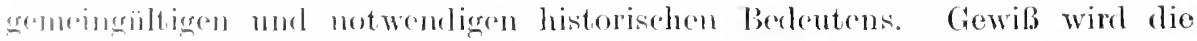

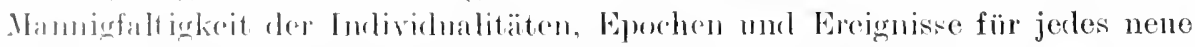

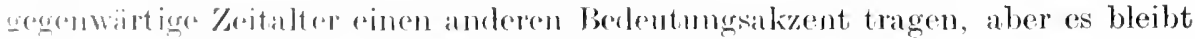

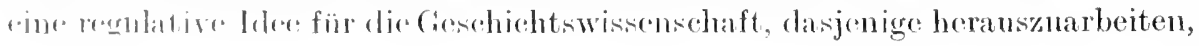

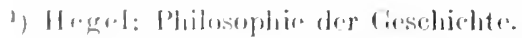

2) Kants Kritik Jor ITteilskaft. Sohriften Bid.5. 
was bedeutend war und ist. Wohl mag die Bedentung der Renaissance und Aufklärung bald mehr in diesem, bald mehr in jenem gesucht werden und gesucht worden sein, aber was ihre Unvergängliehkeit im historischen Bewußtsein sein sollte, das ist der Begriff einer großen Zeit. Ein Zeitalter. das aufhören wïrcle, in Sokrates oder Alexander historische Größe zu rehen, ein solehes Zeitalter würde des historischen Nimnes verlustig gegangen sein. Einem solchen Zeitalter würde das historisehe Gewisen fehlen. Es würde das Verhältnis zur Vergangenheit verloren haben, mu Historie als Kulturleistung wïrde unmöglich sein. Ohne Anerkenmung der Wahrheit keine Wiscenchaft, das gilt ohne Zweifel auch für die Historie. Aber die Historie verlangt noch mehr als die Anerkenmung des logischen Wertes.

\section{d) Das historische Verstehen.}

Das, was die Historie noch mehr verlangt, was eine notwendige Voranssetzung aller ihrer Urteile bildet, das bezeichnen wir ganz allgemein, wenn wir sagen. daß ohne Anerkennung des historisch Bedeutsamen und ohne Sim für historische Größe keine Geschichte möglich sei. Was dem Historiker ganz in erster Linie zur Pflicht genacht wird, ist Sinn für Größe. Wo dieser Sinn und Geist herrschend int, fühlt er sich tief gekränkt und beleidigt durch jede kleinliche und herabsetzende Kritik, welche die großen Individualitäten des historischen Geschehens nach einseitigen Maßstäben meistern will. Gegen solche kleine und kleinliche Kritik empört sich das historisehe Gewissen, weil es weiß, daß ein Geltendes hier rerletzt, ein Wertrolles entweiht und entwertet wird ans Mangel an historischem Verstehen.

Wem wir aber ron Größe und historiseher Bedentsamkeit sprechen, ein Begriff, der noeh näher zu rechtfertigen und zu begründen ist, so muß diese Bedeutung unabhängig sein ron den Gefühlen der Sympathie und Antipathie, die ich gewissen historischen Erscheinmgen entgegenbringe. So müssen wir dem Zaren Peter ron RuBland historische Größe znerkennen. mag anch seiner Taten Art das menschliche Empfinden noeh so oft anf das schwerste verletzen. So etwa dam, wenn er nach Nierlerwerfung des sehweren Aufstandes der Strelitzen im Jahre 1698 anf furchtbare Rache simnt und den Massenhinrichtungen zuschaut, umgeben ron seinen Bojaren. Hofnarren und Günstlingen bei wildem Gelage, munfrieden mit der Arbeit der Henker, on Verurteilte an den Zeehtisch bringen läßt und sie eigenhändig unter Hoeh rufen und rauschender Musik hinrichtet. so daß Wein um Bht sich rermengt. Wem er seinem Volke, dem seine Gransamkeit ein Schrecken und seine Bemühungen um europäische Kultur unverständlich waren. wenn er seinem geängstigten, für seine Bestrebungen unempfänglichen Tolke als furchtbarer Verkünder des Weltunterganges, als Antiehrist erschienen, so kam uns diese zeitlich bedingte Auffassung an der Größe dieses russischen Zaren nicht irre machen. Denn daß der moralische Maßstah zur Beurteilung historiseher Größe vollkommen unzureichend ist, darüber sollte seit Hegel kein Zweifel mehr herrschen, und vielleicht hat dieser große Kenner des historischen Lebens auch darin reeht, wenn er behauptet, daf die wesentliche Charakteristik des Geistes und seiner 
Zeit immer in den großen Begebenheiten vorhanden ist, und ansdrüeklieh davor warnt, die Schilderung des Partikulären in der historischen Darstellung zu sehr zu betonen. weil es gegen den Begriff der objektiven Wahrheit verstößt, die Kleinigkeiten der Zeit und Personen in die Torstellung der allgemeinen Interessen zu sehr einzuweben $\mathbf{1}$ ).

Wenn wir num aber anch den historischen Simn als den Sinn für Größe voraussetzen, so erhebt sich doch ron einer anderen Seite her ein Einwand gegen die Gesehichte, der ihre Wissenschaftlichkeit vor allem in Frage stellt, das ist der Einwand, daß die Geschiehte keine Wahrheit habe und keine Wahrheit geben könne, weil sie ihrem ganzen Wesen naeh unsystematiseh sei, und alle Wahrheit mur im systematisehen liegen kam.

\section{e) Das Unsystematische hat keine Wahrheit.}

Die Naturwissenschaft, so wird man sagen, hat es mit lem immer Wiederkehrenden und Vollendeten zu tum. Die Geschichte dagegen nit dem immer Neten und Unrollendeten. Ein für alle Mal ist das Interesse der Naturwissenschaft auf dasjenige gerichtet, was immer war und immersein wird. Wohlhat sie dieses Bleibende und Wiederkehrende stets rersehieden bestimmt, und für jede Naturwissenschaft ist es ein anderes: Atom. Molekül, Element, Kíeimplasma usw, aber das Interesise dieser Wissensehaften geht immer auf das Gleiche, während das Interesse der Gesehichte auf das immer Neue geriehtet ist. Wenn wir behaupten: es gibt nichts Nenes unter der Somne, so ist das echt naturwissenschaftlich gedaeht. Die naturwissenschaftliehe Systematik fordert die Konstanz der Naturelemente. Ein elementar Nenes darf nicht hinzukommen. Dagegen behauptet die Historie, daß sie es mit dem Nenen, noch nie Dagewesenen zn tum habe ${ }^{2}$ ). Gerade las Nene. noeh nie Dagewesene ist das Interessante nul Bedentsame für die Geschichte. Würde es nichts Nenes unter der Sonne golen, so hätte os keinen Simn, Historie zu treiben. Wie läßt sich nun die Idee des Nourn mit der Ideo des Konstanten und Gleichen rersöhnen? Wie kamn Nences geschehen, wenn doch alles dasselbe bleiht? Ist etwa die Konstellation ewig gleicher Elemente der Grmm der Wirklichkeit, der tiefe Schoß der Dinge, iiber den die Gestalten des historischen Geschehens als Erscheimugen dahingleiten? Fine solche Anffassung wïrle der Naturwissenschaft metaphysisehe Borlentung beimesen, dio Geschichte dagegen als ein bloß erseheinendes Irissen betrachten. Hüten wir mis ror solchen Hypostasen, mol suchen wir mhig zo verstehen, was dio natmrwissenschaftliche Erkenntnis einerseits und dic historische Erkemntuis anderseits roranswetst, so stehen wir vor einer Antinomir des historisches mol natmwissensehaftlichen Denkens. Die Naturwissonsehaft behampted: ,Alles ist immer alt, alles kehrt immor wieder".

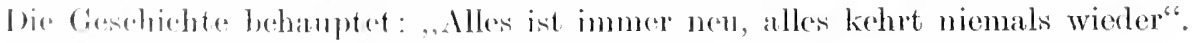

\section{1) Antinmmie des historischen und naturwissensehaftliehen Denkens.}

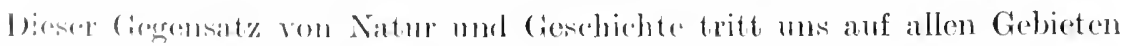

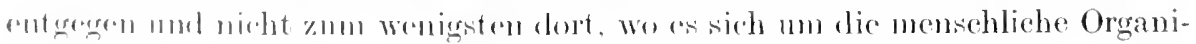

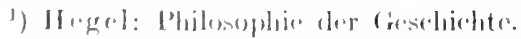

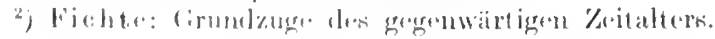


sation handelt. So liegt es ganz augenscheinlich in einem gewissen Denkinteresse, die Gleichförmigkeit der menschlichen Organisation und ihre immer gleiche Bedürftigkeit zu behaupten. Wir wollen nicht zugeben, daß das Bild der Menschheit, wie es Geschichte und Leben lehrt, sich jemals absolut verändern könnte. Daß der Mensch etwa aufhören sollte, nach Erkenntnis zu streben, aufhören sollte, zu lieben und zu hassen, aufhören sollte, Kriege zu führen und staatliche Gemeinschaft zu pflegen. Diese Lehre behauptet, daß der Mensch nicht über sich hinaus kamn. Und auf der anderen Seite stehen Forderungen, die den Nenschen überwinden wollen, welche die unendliche Vervollkommnungsfähigkeit der menschlichen Natux behaupten. Auch hier haben wir es augenscheinlich mit einem Widerstreit des naturwissenschaftlichen und historischen Denkens zu tun. Eine begrenzte Entwicklung aber rom Naturmenschen zum Kulturmenschen ist logisch ebenso sinnvoll wie eine unbegrenzte Entwicklung bis zum Ubermenschen. An der Entscheirlung dieses Widerstreites hat augenscheinlich unsere Ternunft das lebhafteste Interesse. Seit dem 18. Jahrhundert ist immer wieder die Forderung erhoben worden, der Mensch solle einmaI aufhören, Mensch zu sein. Das vollkommene Wesen sollte er werden oder der absolut friedliche Weltbürger, der Krieg und Kampf verschmäht, oder der absolut Keusche, der den Simnengenuß verweigert, oder der absolut Große und Starke, wie ihn Nietzsche geträumt hat.

So dieser Widerstreit, und wir gelangen immer mehr zu der Überzengung, daß das Neue und Fragmentarische der Naturwissenschaft Feind ist. Denn es hindert die Vollendung und Systematisierung. Gewiß ist anch für die Naturwissenschaft die Entdeckung bedentsam, die den bereits bekamnten Elementen ein neues hinzufügt. Aber das Newe der Entdeckung, etwa eines chemischen Elementes, ist nur historisch bedentsam. Es ist wertvoll für die Geschichte der Chemie. Für die Naturwissenschaft wird das Neue sofort zu einem Alten, zu einem Bleibenden, ewig Dagewesenen. Gewiß denken wir hier in erster Linie an die exakte, mathematische Naturwissenschaft.

Und so hat die Naturwissenschaft ihren Rahmen ausgespannt, ihr festes Gefüge von Begriffen ewig gleicher Dinge und ron Relationen, die zwischen diesen Dingen bestehen. Alles, was neu geschaffen und geboren wird, gehört diesem Alten an und muß auf dieses Alte zurückgeführt werden können. Damit ist der Naturwissenschaft die Möglichkeit gegeben, ein System von Begriffen zu entwerfen, die sich gegenseitig stïtzen und begründen. Auf einem wohlgefügten Fundament ron Grundsätzen und Leitsätzen erhebt sich ihr Begriffsgebäude. Dem Historiker fehlen Grundsätze im Sinne der Naturwissenschaft; wenn es auch eine Reihe wichtiger Postulate des historischen Denkens geben mag, so können diese doch niemals die Funktion naturwissenschaftlicher Grundsätze ausüben. Gewiß gibt es Grundsätze, unter denen allein historisches Leben möglich ist, so wie es Grundsätze gilut, unter denen allein naturwissenschaftliche Erkenntnis nöglich ist. Wir können uns etwa einen Grundsatz der Geschichte denken, der für die Historie ähnliche Bedeutung besitzt wie der Satz von der Erhaltung der Energie für die Naturwissenschaft. Vielleicht ist es der Satz von dem ewig Neuen des historischen Lebens. Aber Grundsätze der Geschichte können niemals in derselben Weise historische Wahrheiten begründen, wie die naturwissenschaftlichen Prinzipien und Grund- 
sätze naturwissenschaftliche Wahrheiten zu begrïnden imstande sind. Das Ideal der Naturwissenschaft würde darin bestehen, aus den Obersätzen und Grundsätzen der Erkenntnis die naturwissenschaftlichen Urteile abzuleiten und zu begründen. Wie weit diese Ableitung durch irrationale Faktoren getrennt ist oder getrennt zu sein scheint, ist eine andere Frage. Dagegen ist eine systematische Ableitung und Entwicklnng historiseher Wahrheiten prinzipiell ausgeschlossen. Die Naturwissenschaft ist eine systematische Wissenschaft, deren Urteilszusammenhang dem logischen Prinzip des Widerspruchs unterworfen ist. Dieses Prinzip verliert für den Urteilszusammenhang der Historie seine grundlegende Bedeutung.

\section{g) Das Prinzip des Widerspruchs und die Geschichte.}

Natürlich belarf der Historiker dieses Prinzips, wemn er das historische Faktum aus den Quellen heransholt, auch darf er in der Darstellung nichts Widlerspruchsvolles behaupten, etwa daß sokrates hier und dort geboren und Alexander zu flieser und jener Zeit gestorben sei. Aber dio historischen Urteile über die geschichtlichen Begebenheiten unterliegen in ihrem Verhältuis zueinander nicht dem Prinzip des Widterspruchs. Den mathematischen Satzzusammenhang kann ich mit dem Prinzip des Widerspruchs anf seine Wahrheit und Zuverlässigkeit nachprüfen. Zwischen ten Urteilen äber individuelle historische Tatsachen besteht kein logischer Zusammenhang, ler eine solche Nachprüfung erlaubte. Es hat keinen Simn, die Urteile über Cäsars Leben mit den Urteilen über Brutus' Tod nach dem Satz des Widerspruchs zu vergleichen. DaB Brutus bei Philippi den Tod erwählte, steht weder im Widerspruch noch im widerspruchslosen Zusammenhang mit dem Urteil, daß Cäsar an den Iden des März ernordet ist. Hier handelt es sich um die Wahrheit des Faktums. um die Wahrheit der Tatsache sowie um das Verhältnis von inclividuellen Vorgängen zueinamler.

Das gröbte System des dentschen Idealismus, das System Hegels, will das Verhot des Widerspruchs nicht anerkennen. Dies alte rationalistische Wahrheitskriterim hat in seiner Philosophie alle Bedeutung eingebüBt. Die Cribule gegen den Satz des Miderspruchs hat man als das spezifiseh Unwissemsehaftliche und Phantastische in der Hegelschen Philosophie angesehen.

1)ic morleme Philosophie sicht sich grenötigt, zu dem Problem des Wirler-

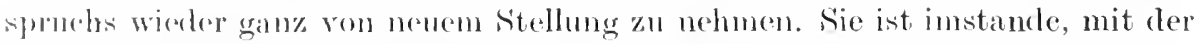

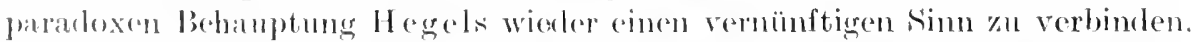
Es gribt in ler 'Tat ein Gehiet wissemsehaftleher Urteilshildung, wo dem Prinzip

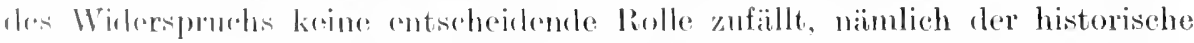

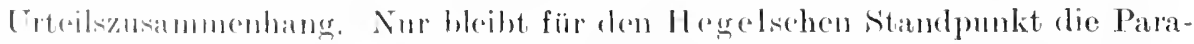

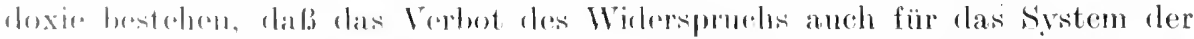

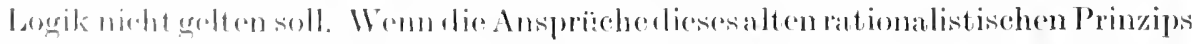

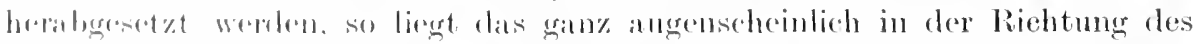

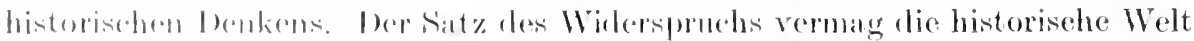

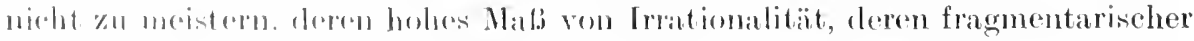

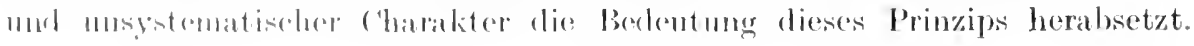


Ein Urteilszusammenhang gilt als wahr, wenn er in sich widerspruchslos ist, oder auch: die innere Widerspruchslosigkeit eines Urteilszusammenhangeist für uns ein Kriterium der Wahrheit. Das gilt für die Wissenschaft, soferm sie einen systematischen Charakter trägt wie Mathematik und Naturwissenschaft. Damit das Prinzip des Widerspruchs wirksam sei, ist immer ein gewisses Maß von Bestimmtheit und Allgemeinheit des Crteikzusammenhanges erforderlich. Aber in der historischen Welt kamn man nur mit Einschränkung von der Logik der Tatsachen sprechen. Wie das Leben selber irrational und widerspruchsroll mit dem brutalen Faktum uns entgegentritt, wie die einzelne Individualität als solche eine Fülle ron Wirlerspritichen und Gegensätzen in sich vereinigt, so vermag anch die historische Wirklichkeit nicht in jene ruhige Sphäre der Allgemeinheit einzugehen, wo der Satz des Widersprueh. sein unbedingtes Herrscherrecht geltend macht. Nur ron der Mathematik und Naturwissenschaft her kann die Behauptung erhoben werlen, daß die Wirklichkeit in sich vollkommen widerspruchslos sei.

Daß es eine Sphäre gibt, in welcher der Satz des Widerspruchs herrscht. und eine andere, in der dies rationale Prinzip seine Berleutung verliert, das hat schon Leibniz in seiner Gegenüberstellung von ewigen und tatsächlichen Wahrheiten eingesehen $\left.{ }^{1}\right)$. Der Begriff der ewigen Wahrheit verbindet sich mit dem systematischen Begriffsgefüge, mit dem Widerspruch und dem Allgemeinen. Der Begriff der tatsächlichen Wahrheit mit dem Unsystematischen und Individuellen.

Gewiß hat Leibniz bei dieser berïhmten Unterscheidung, die ror allen Dingen die Beziehung der Mathematik zu den empirischen Wissenschaften angeht, nicht ausdrücklich das Verhältnis ron Naturwissenschaft und Geschichte oder allgemein das Verhältnis der systematischen Wissensehaften zu den unsystematischen im Ange gehabt. Dennoch können wir mit rollem Recht die Geschichte als Erfahrungswissenschaft im eminenten Sinne bezeichnen. Die Begriffe der Naturwissenschaft sind Konstruktionen, die wir nieht erleben können, aber die Begriffe der Geschichte kömnen wir leben und verstehen. Die Begriffe der Geschichte meinen ja doch die konkrete Fülle des simnlichen Daseins, die Wirklichkeit der Begebenheiten. Und dieses Einzelne und Tatsächliche, mit dem es die Geschiehte zu tun hat, soll in seiner Wahrheit begriffen werden. Gibt es eine Wahrheit des Individuellen und Tatsächlichen, oder hat das Individuelle und Tatsächliche keine Wahrheit und keinen Wert? Hat das Individuelle in der Eigentümlichkeit seiner Daseinsform, in seiner ganz besonderen Bestimmtheit Wirklichkeit, Wahrheit und Wert? Oder fehlt dem Individuellen jede Eigenbedeutung und Geltung? Hat es nur Sinn und Wahrheit in der Unterordnung unter allgemeine Begriffe?

Leibniz hat behauptet, daß es eine Wahrheit les Tatsächlichen giht. aber die historischen oder tatsächlichen Wahrheiten sind keine ahsoluten ewigen Wahrheiten wie rlie Sätze der Wathematik und die Sätze der formalen Logik. Gewiß ist es eine Wahrheit, daß Napoleon auf St. Helena gentorben ist, aber diese Wahrheit hat nicht die Evidenz des mathematischen satzes. daß zwei mal zwei vier ist. Die mathematischen Wahrheiten können nicht

1) Leibniz: Meditationes de cognitione, veritate et ideis. 
anders gedacht werden, daß aber Napoleon auf St. Helena gestorben, das ist nicht in derselben Weise notwendig wahr, das hätte aueh anders sein können. Indem aber Leibniz nach dem Prinzip sich umsieht, das die Wahrheit der historischen Begebenheiten verbürgt, nemnt er den Satz vom Grunde und damit zugleich das Prinzip der Kausalität. Der historische Zusammenhang von Ursache und Wirkung, von Grund und Folge ist es, darin die Wahrheit des Tatsächlichen ruht. Was für die systematisehen Wissenschaften der Satz vom Widerspruch als Prinzip der Wahrheit leistet, das leistet für die unsystematischen, empirischen Wissenschaften das Prinzip der Kausalität. Widerspruch und Kausalität gelten absolut, aber nur das auf dem Satze des Widerspruchs Begründete ist wandellos. Das andere ist dem Wandel unterworfen.

Das Problem der Geschichte führt also auf die Frage: wie kann die Wahrheit des Individuellen gerechfertigt werden, die zugleich die Wahrheit des Unsystematischen ist? Das historische Ereignis hat seine Wahrheit und gilt um seiner Wahrheit willen. Nicht $u$ m seiner Schönheit willen wird es aufbewahrt, noch als Gegenstand der Freude, des Nutzens, der persönlichen Anteilnahme. Ol) die Geschichte wie ein Kunstwerk auf uns wirkt, das ist für die Geschichte nicht wesentlich. und ebensowenig kann sittliche Veredelung oder Belehrung als Zweck der Geschichte gelten, wenn wir aneh gern zugeben, daß historische Größe zum sittlichen Vorbild werden und die Vergangenheit uns belehren kann. Diese pragmatisehen Gesichtspunkte, die so weit entfernt sind von dem Geiste wahrer Wissenschaftlichkeit, treten ms nur zu oft in Abhandlung, Wort und Rede über das Wesen der Geschichte entgegen. Hier liegen alle Ansätze zu einer spiclerischen und dilettantenhaften Behandlung der Geschichte. Hier ist die große Auffassung des Griechentums von dem selbständigen Wert jeder wahren Wissenschaft vollkommen preisgegeben. Der historische Pragmatismus, vor dem Schelling in seiner schönen Vorlesung über das Studium der Historie ${ }^{1}$ ) so dringend warnt, gegen den er seine eindringliche und beschwörende Stimme erhebt, ist noch nicht ïberwunden. Jener Pragmatismus, der darin besteht, daß er kleinliche oder gar außerhalb des Wesens der Historie liegende Gesichtspunkte an die Geschichte heranträgt. Nur zu treffend sagt Schelling über den Pragmatismus: , Woleh ein willerlicher Anblick, das Bild groß3er Begebenheiten im Organ eines kurssichtigen und einfültigen Mensehen entworfen, besonders wonn er sich noch Gewalt antut, Verstand zu haben und diesen etwa darin setzt, die Größe der Zeiten und Völker nach beschränkten Ansichten, z. B. Wichtigkeit des Handels, diesen oder jonen nützlichen oder verderblichen Erfindungen zus schitzen mut ïherhaupt einen so viel als möglich geneinen Mal3stab an alles

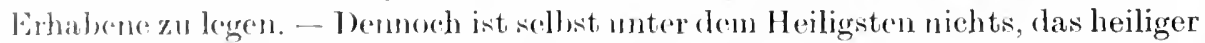
wäre wis dis: Geschichte, dieser große spiegrel des Weltgeistes, dieses ewige Gerlicht des götthichen V'rstandes, nichts, das weniger die Berührung unreiner Hänlle ertrü̈ge."

Indenu wir mun daranf reflektieren, wie weit die Kantische Philosophie

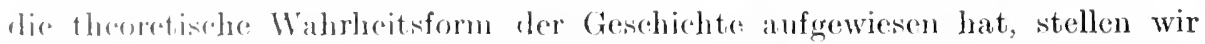

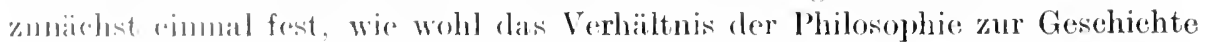
und Naturwissenschaft zu denken sei, und was vor allen Dingen die Philosophie mit rore Naturwissenschaft und Geschichte genesusam hat.

1) Sirhelling: Mrethode des akademischen studiums. 


\section{h) Verhältnis der Philosophie zu Geschichte und Naturwissenschaft.}

Wir sahen, daß der Naturwissenschaft, weil sie es mit dem Bleibenden, Abgeschlossenen und ewig Wiederkehrenden zu tun hat, das sie in allgemeinen Begriffen zu erfassen glaubt, die Möglichkeit gegeben ist, die Wirklichkeit systematisch zu durchdringen und zu verstehen. Den systematischen Charakter hat sie mit der Philosophie gemeinsan. Auch die Philosophie will im System zur Ruhe kommen. Die Wahrheit der Naturwissenschaft und Philosophie liegt im System. Vielleicht in verschiedener und in gewisser Hinsicht entgegengesetzter Weise, aber der systematische Charakter ist doch die große Gemeinsamkeit von Philosophie und Naturwissenschaft. Auch das Interesse der Philosophie fordert eine begrenzte Zahl von Prinzipien oder Begriffen, deren Zusammenhang das System bildet. Philosophie und Naturwissenschaft glauben in gewissen Grundbegriffen ein Wissen rom Ganzen zu besitzen: die Naturwissenschaft ron dem, was ist, die Philosophie ron dem, was gilt. Die Geschichte, die ihrem Wesen nach unsystematisch ist, mußsich immer wieder begnügen und zufrieden geben mit dem, was war und gewesen ist. Das kann aber niemals das Ganze sein.

Aus der Gemeinsamkeit des systematischen Charakters erklärt sich der enge Zusammenhang von Philosophie und Naturwissenschaft, die aneinander und auseinander sich gebildet haben. während die Entwicklung der Geschicht:wissenschaft besondere Wege ging. Die Forlemungen des naturwissenschaftlichen und historischen Denkens können sich aber àuch in der Philosophie geltend machen. So steht etwa die Philosophie Kants unter dem ïberwiegenden Einfluß des naturwissenschaftlichen Denkens, während die Philosophie Schellings oder Hegels in weit höherem Maße historisch orientiert ist.

\section{i) Das geschichtsphiloso phische Problem bei Kant.}

Sehen wir nun zu, wie die Philosophie Kants imstande war, die Historie als Wissenschaft zu begründen und damit das moderne geschichtsphilosophische Problem zn stellen. Wir möchten jedoch an dieser Stelle nicht mißrerstanden werden. Kant hat ausdrïcklich behauptet, da B von Wissenschaft in strengen Sinne des Wortes nur so weit die Rede sein könne, als Mathematik darin enthalten ist ${ }^{1}$ ). Die Geschichte ist für ihn ebensowenng eine Wissenschaft wie die Psychologie. Die Grundlegung der Philosophie Kants geht unr auf die mathematischen Naturwissenschaften. Nichts lag ihm ferner als eine Erkenntnistheorie der Geschichte. Wir müssen jedoch das Beabsichtigte und Gewollte ausdrücklich von der philosophischen Leistung trennen. Kant hat mehr getan, als er gewollt hat. Sein neuer Wahrheitsbegriff gab die Möglichkeit, auch den Wahrheitsgehalt der Geschichte deutlich zu machen. Dieser Wahrheitsbegriff ist das berühmte a priori. Ein vollkommen neuer Begriff. ein rollkommen neues Problem, ein ganz anderes Verstehen der Wahrheit.

Wir können diesen neuen Wahrheitsbegriff $\mathrm{K}$ ants hier nur ganz kurz andeuten, da er seine eigentliche Stelle in der Logik hat. Fr interessiert uns in

1) Vg! Kant: Metaphysische Anfangsgrïnde der Naturwissenschaft. Akademieausgabe IV, S. $468 \mathrm{ff}$. 
diesem Zusammenhange nur, soweit er für die Geschiohte bedeutungsvoll geworden ist. Nach der alten Auffassung ist das Wesen aller Erkenntnis in der Abbildung des Wirklichen beschlossen. Die fertige Wirklichkeit wird dureh das Denken abgebildet, und es entsprieht num dem widerspruchslosen Zusammenhang der Begriffe der widerspruchslose Zusammenhang der Wirklichkeit. Ganz a ugenscheinlich geht dabei der Gedanke des Abbildens mit dem Gedanken der Rationalisierbarkeit des Wirkliehen zusammen. In einem hellen Spiegel sehen wir das wahre Bild der Wirklichkeit. Die Welt da draußen erseheint noch einmal in Auge des Geistes, oder auch das Dasein der Dinge, welehes fest und unabhängig dasteht und vor uns liegt, ist in der Vorstellung erfaßt und führt in ihr ein zweites Dasein. So primitiv diese Erklärungen sind, so sehr sie der schlichten Erfahrung widerstreiten, so unglücklich und unhaltbar die Vergleiche sind, deren sie sich bedient, so sehr entsprach diese Auffassung doch im allgemeinen aller vorkantischen Philosophie.

Das im Geiste der alten Philosophie Wißbare und Wissenswerte war sehr viel weniger als das, was der modernen Erkenntnis zum Problem wird. Das Konstante und Bleibende der Natur war ein Begrenztes und als solches rationalisierbar. Daneben besteht eine unendliche Fülle des Individuellen und Zufälligen, das kein Prinzip der Wahrheit hat, und ron dem es keine Erkenntnis gibt, was nicht zur Ordnung der Natur und Vernunft gehörte, sondern danebenlag und dureh das Verumftgesetz der Natur nieht bestimmt wurde. Nur die erhabenen Formen des Daseins prägten sich nach dieser Vorstellung der Seele auf und führten zu einer begrenzten Zahl von Urteilen und Begriffen über die Wirkliehkeit, für deren Zusammenhang der Satz rom Widerspruch das entseheidende Kriterium abgab.

Weil der Gegenstand der Erkemntnis ein begrenzter war, so hatte auch lie Abbildtheorie ihren guten Simn. Sie mußte aber notwendig versagen, als die Mannigfaltigkeit der individuellen Erscheinungen, als der unendliehe Gegenstand der wissenschaftlichen Erkenntnis gedacht wurde. Als es sieh nicht mohr darum handelte, die festen und ruhigen Naturformen, die begrenzte Zahl der Arten in der Definition zu erfassen, sondern nummehr aneh das Individuelte als ein Etwas angesehen wurle, das der Ordmung und Gesetznäßigkeit der Natur muterlag, nach rlieser Gesetzmäßigkeit sich richtete, nicht aber als ein Etwas, das diese (Orlnung fälsehte mul trübte.

Wir können diese verschiedenartige Auffassung des Erkemntnisprozesses dahin formulieren, dal. es sich in der alten Erkenntnistheorie um eine Erkenntnis des Auserwihlten handelte, in der molernen krkenntnisdentung aber un eine Auswahl der Erkenntuis, um eine Auswhl, die der erkemnende

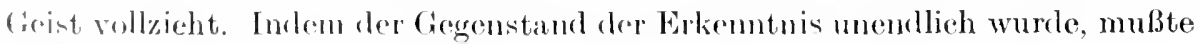
die 'Tat der Auswahl, der Vereonfachung, Gliederung und Bildung des Stroffes

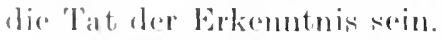

J)ese Auswahl und likilung des Stoffes ist nun aber, wie Kant gezeigt hat, krine: willkürliche, hureh dir Natur des Einzelindividumms hexlingte, sonderu untrelingt vielunhr motwendigen und unveränderlichen Prinzipien, dio im peyehischen Mrehanismus sich geltemel machen mol der Struktur des Bewußtsoins gemälis ain rinheitliches mul notwendiges Wrelthild erzengen. Diese Formen

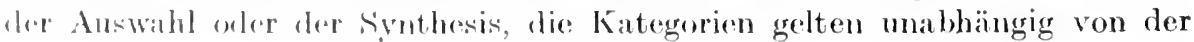


Individualität des Einzelindividuums. Sie stiften zwischen den Inhalten der Erkenntnis einen Zusammenhang, der für alle in gleicher Weise gilt im Gegensatz zu dem unsachlichen und unlogischen Zusammenhang. zu dem sich die Elemente in Gedächtnis nach den Gesetzen der Assoziation zusammenfinden $\left.{ }^{1}\right)$.

Diese Formen oder Kategorien wie Einheit und Vielheit, Notwendigkeit, Kausalität und Dinghaftigkeit sind also Formen der Wahrheit. Indem sie im Urteile die Inhalte zusammenschließen, wird erst durch sie logischer Sinn erzeugt. An ihnen hängt die Wahrheit und Gültigkeit des theoretischen Satzes, und da sie den wechselnden Erkenntnisinhalten gegenüber die ewig gleichen Formen der Auswahl und Verknüpfung sind, die alle inhaltiche Erkenntnis bedingen, so sind diese Formen der Wahrheit auch der eigent liche Gegenstand der Philosophie. Die unveräußerliche Wahrheit eines jeden Naturinhaltes besteht etwa in einem notwendigen Bedingtsein durch die Form der Kausalität, und die Wahrheit eines jeden Naturgesetzes als eines generellen Urteils gründet in diesem logischen Prinzip. Und diese Formen, die alle Wirklichkeit und alle wissenschaftliche Erkenntnis begründen, sind doch selber nichts Existierendes, besitzen weder psychische noch phrsische Realität.

Nun macht sich aber bei Kant neben diesem allgemeinen Wahrheitsprinzip des a priori, das die Sphäre des Wissens der Möglichkeit nach ins Unendliche erweitert, noch ein zweites Prinzip geltend, das die philosophische Fragestellung in ungebührlicher Weise verengt und die Wissenschaft der Geschichte aus dem Reich der Erkenntnis ausschließt. Es ist das nämlich die Ủberzeugung $\mathrm{Kants}$, daß alles Besondere auch zugleich in einem gattungsmäßig Allgemeinen begründet sei, und daß das Individuelle als solches keine Wahrheit habe. Anssagen über individuelle Vorgänge, die bloßen Wahrnehmungsurteile wie: „,dies ist grün" oder ,,ich sehe den Baum" haben noch keine Wahrheit. Sie haben erst dann Erkenntniswert, wenn sie als allgemeine Erfahrungsurteile sich den höchsten Grundsätzen der Erkenntnis unterordnen lassen. Von Kant wird also neben dem a priori auch die Subsumierbarkeit zur Erfüllung des Erkenntniswertes gefordert ${ }^{2}$ ). Das Einzelne wird immer als Exemplar im Verhältnis zu einem Gattungsbegriff gedacht. Da num aber die historischen Tatsachen unwiederholbare Eimmaligkeiten sind, die niemals wiederkehren, so dulden sie auch keine Unterordnung unter ein gattumgsmäßiges Allgemeines. Wir können das kurz dahin formulieren: Kant hat in dem Begriff des a priori als dem Begriff des Geltens einen neuen Wahrheitsbegriff entdeckt. Er hat aber aus naturwissenschaftlichem Interesse dem Begriff des Geltens sofort eine nähere Spezifikation gegeben, die das Problem der historischen Urteile ausschließt, indem er den Begriff der Allgemeingültigkeit mit dem Begriff der Allgemeinheit verband und das Allgemeingültige als das Gelten für alle gleichzeitig: a uch zu einem Gelten von allem im Sinn des Gattungsmäßigen und der empirischen Gesetze machte. So hat nach Kants einseitiger Festlegung auf das Problem der Naturwissenschaft nu das Allgemeine, ler allgemeine Begriff

1) Vgl. hierzu den Aufsatz von Windelband: Normen und Naturgesetze. Präludien. Tübingen 1911.

2) Vgl. hierüber Richard Kroner: Über logische und ästhetische Allgemeingültigkeit, Leipzig 1908. 
einen Wahrheitswert, oder mit anderen Worten: es gibt nur Formen des Allgemeinen, aber keine Formen des Individuellen und Einmaligen.

Wenn nun aber auch diese Begrenzung des Problems innerhalb des neugeschaffenen Wahrheitsbegriffes in der $\mathrm{Kantischen} \mathrm{Philosophie} \mathrm{gewissermaßen}$ ein geschichtsfeindliches Moment bedeutet, so wird diese Einseitigkeit doch teilweise wieder dadurch kompensiert, daß sich in der Kantischen Philosophie eine starke und entschlossene Hinwendung zur $\mathrm{K} u \mathrm{lt}$ u r vollzieht. Die Philosophie Kants muß als Kulturphilosophie verstanden werden ${ }^{1}$ ). Wann hätte sich die philosophische Spekulation vor $K$ ant jemals so eingehend und tiefbohrend mit unseren höchsten Kulturgütern: Wissenschaft, Kunst, Moralität, Recht, Staat und Peligion abgegeben. Durch das Verstehen der Kulturgüter will die Philosophie nummehr zum Verstehen der Wirklichkeit gelangen. Das ist der neue und eigenartige $\mathrm{Weg}$, den zuerst $\mathbf{K}$ ant eingeschlagen hat. Und von hier aus hat sich auch $\mathbf{K a n t}$ dem Problem der Geschichtsphilosophie genähert und eine Reihe geschichtsphilosophischer Abhandlungen verfaßt, deren allgemeiner Sinn dahin bestimmt werden muß, daß der Simn der Geschichte nur in der Entfermung von der Natur sowie in ihrer Uberwindung liegen kann, ind daß der Endzweck der Geschichte ein Reich wahrhafter Kultur sein muß $\mathbf{B}^{2}$ ). Was also Kant in seinem ganzen System zum Ausdruck gebracht hatte, daß der Sinn der Wirklichkeit nur von den Kulturwerten her zu bestimmen sei, das ist auch für seine geschichtsphilosophische Überzeugung entscheidend geworden. Und wenn nun $\mathrm{K}$ a $\mathrm{n} t$ auch den Kult urbegriff ebenso einseitig mo ra lis $\mathrm{h}$ wie die Wissenschaft einseitig naturwissonschaftlich bestimmt hat, so ist doch damit ein für allemal eine notwendige Beziehung eingesehen.

\section{k) Geschichte und Kulturphilosophie.}

Die Kulturphilosophie ist als Philosophie notwendig systematiseh und stellt dadureh ihr Verhältnis zur Naturwissensehaft her. Sofern jedoch der Gegenstand der Philosophie die Kulturwerte sind, tritt sie in ein besonders nahes Verhältnis zur Geschichte. Die Begründung der historischen Objektivität führt uns hinein in die ganze Fülle wertwissenschaftlicher Ưberlegungen. Denn nicht nur mit der Sphäre des Logischen haben wir es zu tun, wenn wir das Problem der historischen Allgemeingültigkeit anfrollen, nicht nur mit den logischen Begriffen der Wahrheit, der Kausalität, des Allgemeinen und des Besonderen: auch der religiöse und künstlerische Wert, die Normen des rechtlichen und statlichen bebens und ror allem auch die Formen des Sittlichen werden für die Geschichte in einer ganz besonderen Richtung zum Problem. Um es noch dentlicher zu machen: die Geschichte ist ebensowenig Kunst oder Sittlichkeit wie die Philosofnhe Kunst oder Nittlichkeit ist. Beide aber haben es mit den Kulturwerten in der Form dex Wissens, d. h. in theoretischer Hinsicht zu tun. Womm die llistorie Wissenschaft ist, so ist damit noch nieht gesagt, daß die Forum dor lougik als solche allein für die Fundamentierung der Geschichte

1) Vgl. himern andh den Aufsat\% wn Windelband: Kulturphilosophie und transzendentaler ldealismas. Langes, Bid. I, Heft 2.

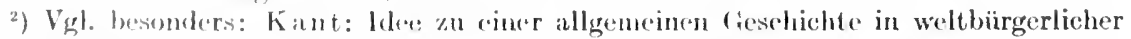

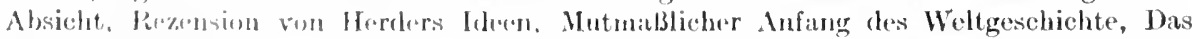
Eude aller l)inge. 
wesentlich und bedeutsam sind. Daß die Naturphilosophie sich in absoluter Abhängigkeit von der theoretischen Philosophie befindet, ist zuzugeben. Die Geschichtsphilosophie ist dagegen nicht nur der theoretischen Philosophie, der Logik, sondern der Philosophie als Ganzem zuzuordnen. Philosophie und Geschichte haben es beide mit dem Inbegriff der Werte zu tun.

Daß die Geschichtsphilosophie in ihrem prinzipiellen und entscheidenden Teile, nämlich als Universalgeschichte, es ausdrücklich mit allen Kulturwerten zu tun hat, schließt es aus, daß wir die Geschichtsphilosophie etwa als Vollendung der Rechtsphilosophie und Moralphilosophie oder anch der Gesellschaftsphilosophie betrachten können, wie das so häufig geschehen ist ${ }^{1}$ ). Um das deutlich zu machen, muß vor allem gezeigt werden, daß die geschichtsphilosophischen Probleme keineswegs ausschließlich in der Ethik vorgebildet sind, und daß es eine eigentümliche Form der historischen Beurteilung gibt. Wenn es nun aber auch als verfehlt erscheinen $m u ß$, die Historie durch ethische Kategorien zu begründen, so ist damit doch die Möglichkeit nicht ausgeschlossen, daß die Geschichte in einem besonders nahen Verhältnis zur Ethik steht. Denn es ist ja augenscheinlich, daß der Gegensatz von Sein und Sollen, der für die Ethik grundlegend ist, in unserer Auffassung des historischen Lebens seine entscheidende Rolle spieit, und Begriffe wie Persönlichkeit, Freiheit, Menschheit, die fundamentale ethische Kategorien sind, treten uns auch in der geschichtsphilosophischen Spekulation entgegen. Wir müssen uns jedoch von vornherein hüten, den Begriff der ethischen Freiheit und der ethischen Persönlichkeit ohne weiteres auf das historische Leben zu übertragen. Es könnte wohl sein, daß Begriffe wie Persönlichkeit und Freiheit in ethischen und geschichtsphilosophischen Sinne etwas Verschiedenes berlenten. Um das festzustellen, bedarf es augenscheinlich erst einer sorgfältigen Analyse der Kulturwerte.

Um die Leistung Kants noch eimmal in Kürze zu präzisieren: er schuf einen neuen Wahrheitsbegriff, das a priori, der die Möglichkeit gewährte, auch den Wahrheitsgehalt der Geschichte zu begreifen, aber er beschränkte die Wirksamkeit dieses Gedankens, indem er als zweites Kriterium die Subsumierbarkeit einführte und die Úberzeugung vertrat, daß die Wahrheit des Besonderen das Allgemeine sei. Er begründete dann weiter eine starke Gemeinsamkeit des historischen und philosophischen Interesses. sofern durch ihn die Philosophie zur Kulturphilosophie geworden ist. Wenn aber somit der Kulturwert es ist, der für die Philosophie und Geschichte eine Gemeinsamkeit begründete, so zeigte die $\mathrm{K}$ antische Philosophie doch ron romberein eine starke Parteinahme für den sittlichen Wert.

Die Vorliebe für die mathematische Naturwissenschaft ist für die $\mathrm{K}$ ant ische Philosophie charakteristisch. Da es nach seiner Lehre keinc Wahrheit des Individuellen gibt. kann es auch keine Logik der Geschichte geben. Gleichwohl treibt er Geschichtsphilosophie und sucht von dem Begriff der Kultur her das historische Geschehen zu denten, aber dieser Begriff der Kultur wird ihm unter der Hand zu dem Begriff einer moralischen Küultur. T'm Philosophie und Geschichte in ein Verhältnis zu setzen und Geschichtsphilosophie möglich zu

1) Die Verbindung ron Geschichtsphilosophie und Ethik findet sich bei hant. Fichte, Schelling. In neuerer Zeit auch bei Windelband und Cohen. 
machen. war daher ein Doppeltes notwendig. Einerseits mußte der Begriff einer bloß moralischen Kultur und einer bloß moralischen Einschätzung und Beurteilung der historischen Begebenheiten überwunden werden. Das ist im wesentlichen die Leistung der Hegelschen Gesehichtsphilosophie. Wenig-tens prinzipiell ist diese İberwindung hier vollzogen. Dieser Hegelschen Geschichtsphilosophie lag aber jede erkemntnistheoretische Begründung der historischen Wahrheit fern. Sie lehrte als metaphysische Begründung des historischen Geschehens die Offenbarung des absolnten Geistes und drohte dureh ihre ganze Wirklichkeitsauffassung die historischen Probleme zu vernichten.

Die zweite Fordermng, die erkenntnistheoretische Grundlegung der Geschiehte, ist eins der wiehtigsten Probleme, das in den letzten Jahrzehnten die dentiche Philosophie beschäftigt hat. Dazu war es notwendig, dem Ka n tisehen Wahrheitshegriff jene Verengung zu nehmen, die durch den Begriff der Subsmmierharkeit und der allgemeinen Gesetze hineingekommen war. Diese Untersuchungen über den Cha rakter der historischen Methode sowie über eine Wissensgrundlegung der Geschichte sind in einer Reihe ansgezeichneter Schriften vollzogen worlen. Zu nemen wären hier Jotze, Sigwart, Wilhelm Dilthey, Georg Simmel, vor allem aber Wilhelm Windelband und Heinrich Rickert. Rickert hat diese Entwicklung zmm Abschluß gebracht, indem er durch seine Kategorie der Gegebenheit den Wahrheitsgehalt des Tatsächlichen erkenntnistheoretiseh hegrïndete und durch die Ablösnng der historischen Kausalität vou dem Begriff des Gesetzes den Eigenwert der historischen Methode (lentlich machte'). Diese Korrektur an dem Kantischen Wahrheitsbegriff und Kulturhegriff, wie sie einerseits durch die Hegelsehe Philosophie und anderseits durch die erkenntmistheoretischen mol methodologisehen Untersuchungen der letzten Jahrzehnte vollzogen ist, hat erst die Geschichtsphilosophie als eine selbstänlige philosophische Disziplin formiert, und damit int anch zugleich der eigentïmliche wissenschaftliche ('harakter der Geschichte dentlich geworden, den man zum Ausilruek bringen wollte, wenn man von ihr -prach als der Geisteswissenschaft schlechthin, der Anschaumgswissenschaft, der Gestaltruwissenschaft, der Kulturwiscensehaft.

\section{1) Dar Begriff der Geschichtsphilosophie.}

Ws liegt eine notwendige Beriehung in dem Verhältnis ron Philosophie mul Wistensehaft trotz der groben Verschiedenheit, ihrer Fragestellung. Sie trennen sich mur, mu wieler vereinigt zu werden. D) Philosophie ist eminent historisch, wail sie ihr ganzes leben don groben historisehen Zeitmomenten rodenkt, mol die Geschichte ist eminent philosophisch, weil nur dureh die

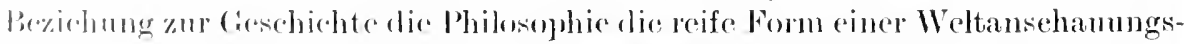

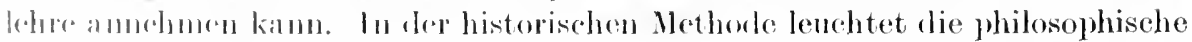

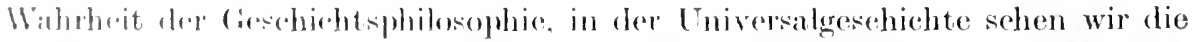

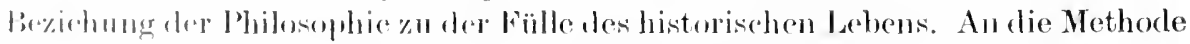

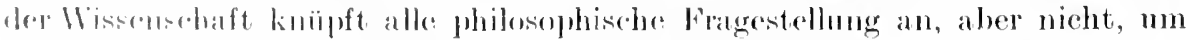

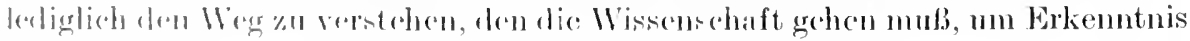

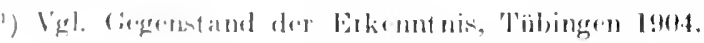


zu erzielen, sondern um ron dem Verstehen der wissenschaftlichen Leistung her zum Verstehen der Wirklichkeit zu gelangen.

Es ist das große Verdienst Rickerts, die Probleme der Geschichtsphilosophie übersichtlich geordnet zu haben, indem er den streng wissenschaftlichen Weg ron dem Problem der historischen Methode zum Problem der Universalgeschichte gebahnt hat ${ }^{1}$ ). Die alte Art der Methaphysik war es ja immer gewesen, mit dem Letzten, mit der Universalgeschichte anzufangen. Und anstatt den Sinn der Geschichte so zu verstehen, wie er aus dem Charakter der historischen Methode mit Notwendigkeit folgt, liebte man es, in willkürlicher Weise ron gewissen einseitigen Yoranssetzungen her einen Sinn in die Geschichte hineinzubringen. Es gibt in der Tat drei Formen oder auch drei Stufen geschichtsphilosophischer Untersuchungen, nämlich 1. die philosophische Methodenehre der Geschichte, die Theorie der historischen Wissenschaft. Eine solche Untersuchung führt damn notwendig zu dem Prinzip, das aller historischen Wissenschaft und allem historischen Geschehen zugrunde liegt. Dieses Prinzip ist die Idee der Kultur, die in einer Wertlehre zu entwickeln ist, um die Mannigfaltigkeit der Kultur und die Bedeutung ihrer verschiedenartigen Formen deutlich zu machen. Auf die philosophische Methodenlehre der Geschichte folgt also 2. die philosophische Wertlehre der Geschichte, ein Gebiet, das bisher nur im geringen Umfange der logischen Untersuchung zugängig gemacht ist. Nach der Analyse der Kulturwerte, die das notwendige Prinzip alles historischen Verstehens und jenes Allgemeine sind, das den wissenschaftlichen Charakter der Geschichte in ähnlicher Weise begründet wie das naturwissenschaftliche Gesetz den Wahrheitsgehalt der Naturwissenschaft, treibt die geschichtsphilosophische Untersuchung mit Notwendigkeit dem Problem der Unirersalgeschichte zu. In dem Fortgang zur Universalgeschichte wird der Boden der bloßen Wissenschaftslehre endgültig rerlassen, denn es kommt nummehr darauf an. zu zeigen, wie sich das Prinzip mit der Lebendigkeit des historischen Lebens verbindet und dievem Leben sim und Bedeutung verleiht. Auf die philosophische Wertlehre folgt somit 3. die philosophische Universalgeschichte, die es nicht nur mit der Wissenschaft der Geschichte, sondern mit dem realen historischen Geschehen selbst zu tum hat. Nummehr hört das Geschehen anf, eine abstrakte Form zu sein, zu der es die logische Betrachtung sub specie aeternitatis gemacht hatte, jetzt handelt es sich darum, festzustellen, wie und mit welcher Absicht das Zeitlose und Ewige einen Bund eingeht mit dem Zeitlichen und Endlichen.

Indem wir nummehr darauf ausgehen, die Probleme der Geschichtsphilosophie zu isolieren, wollen wir noch einmal hinweisen auf den notwendigen Zusammenhang. der zwischen den drei Problemgruppen der Geschichtsphilosophie, den Problemen ler philosophischen Methodenlehre, den Prinzipien des historischen Geschehens und der Universalgeschichte besteht. Von einer Theorie der historischen Wissenschaft muß alle Geschichtsphilosophie ansgehen. Wir müssen wiscen, was Geschichte bedentet, was der Begriff der Geschichte ist. Unmöglich kömnen wir mit der Cniversalgeschichte 1907.

1) Vgl. Richert: Geschichtsphilosophie. Festschrift für Kuno Fischer. 1905. 2. Aufl- 
beginnen und sogleich mit einer Wertformel, mit der Idee eines Endzwecks und daraus ableitbaren Begriffen für die einzelnen Epochen der Entwicklung an die Geschichte herantreten. Dieser Weg der alten metaphysischen Gesehichtsphilosophie ist für uns nicht mehr gangbar, wenn wir aueh ruhig zugeben wollen, daß wir eine Fülle wertvoller Einsichten über das Wesen des universalhistorisehen Prozesses jenen tiefsinnigen Konstruktionen der alten Metaphysiker von der Gnosis bis Hegel verdanken. Wir beginnen mit der Theorie der historisehen Wissensehaft, indem wir die eigentümliche Erkenntnisform zu verstehen suehen, in der unser Wissen ron dem historisehen Leben niedergelegt ist. Unsere Analyse der historischen Wissensehaft und der Elemente, aus denen sie sich aufbaut, des historisehen Begriffes und des historischen Urteils, hat festzustellen, was in dieser Form der Erkenntnis gemeint ist, und welchen Ansprueh auf Erforsehung und Beherrsehung der Wirklichkeit sie erheben kann. Die Wahrheit der historischen Urteilsbildung und Begriffsbilchung sowie die Grenze ihrer Leistung ist aber bedingt durch die Formen dieser Urteilsbildung und Begriffsbildung, die methodologischen Kategorien der Gesehiehte, denen wir unsere besondere Aufmerksamkeit zuzuwenden haben. Dahin gehören Begriffe wie Individuum, Entwicklung, Kausalität sowie auch die Kategorie des Neuen und das Verhältnis des Ganzen zu seinen Teilen. Diese methodologischen Kategorien sind rein formal, sofern in ihnen keine historisehe Inhaltlichkeit gemeint ist und anderseits alles historische Denken ihnen gemäß sich vollziehen muB. Man hat diese historisehen Kategorien ihrer bloßen Formalität wegen gering geschätzt. Gewiß, so pflegt man zu argumentieren, alles historisehe Leben steht in der Form der Entwieklung, und die Einheiten, um die es sich hier handelt, die dem historischen Leben zugrunde liegen und ihm sein hoehflutendes Dasein verleihen, es sind, das geben wir zu, Individuen von eigenartiger Form und Bildung und wesensversehieden durehaus von dem Charakter der naturwissenschaftlichen Substanzen. Aber ist es schließlich nieht eine Trivialität, zu wissen, daß alles historische Leben in der Form der Entwiekhing verläuft, daß auch die Kausalität hier eine maßgebende Rolle spielt und die Individuen die Träger des historischen Geschehens sind? Dem gegenüber ist festzustellen, daß hinter der bloßen Formalität der historischen Kategorien eine Fülle des logischen Bedcutens steht, die ihrem lässigen Aburteiler in der Regel völlig unbekannt ist. Allerdings müssen wir zugeben, daß die Gesehiehte in den historisch methodologischen Formen noch keineswegs vollendet dasteht. Unser Erkenntnisstreben ist etwa in der Physik befriedigt, wenn wir die Gesetze ler Körperbewegungen erforscht haben. Dagegen genügt es für die Geschichte nicht, wenn wir die historischen Begebenheiten an dem Faden der Sukzession orlor Ier Kausalitat aufgerciht haben, d. h. wenn wir anf Grund methodischor Einzeluntersuehung feststellen konnten, wolcher historisehe Vorgang einem anderen gegenüber ler frïhere war, unl in weleher Weise ein historisehes Geschehen anf ein anderes einzuwirken vermoshte. Das Gesetz bedeutet für die Nintur unt ihre Erkenntnis weit mehr wie die Kansalitat der Gesehiehte für das historischo Leben und seine Erforschung. Die Geschichte in den methodologischon Kategorien ist gleichsam noch et was Indifferentes, Ungegliedertes und Unbetontes. Hior berlarf es noch besonderer Prinzipien, welehe die Gesehiehte erst als Missenschaft vollenden, indem sie ihre eigentümliche Bedeutung 
kund tun und das Bleibende und Danernde in diesem Strom des Werdens offenbaren. Wohl haben die historisehen Kategorien die historischen Tatsachen verbunden, aus dem bloßen Aggregat eine organisehe Einheit gemaeht, aber ron ihnen aus können wir nicht wissen, was die Tatsachen bedeuten, was ihre Stellung, ihr Charakter, ihr Wert im Ganzen der Historie ist. Denn das ist das Eigentümliche der historischen Tatsachen, daß sie niemals in die bloße Materialstellung gerückt werden können, daß sie die absolute Egalisierung nicht vertragen, daß sie ron dem Gleiehheitssehema sinnloser Atome ewig entfernt sind. Wenn somit in dem Gedanken der Gesetzmäßigkeit der Körperbewegungen die phrsische Welt vollendet ist, so bleibt unter dem bloßen Aspekt der kausalen Ordnung die historische Welt noch rollkommen fragmentariseh.

Was ist es mun aber, das der historischen Welt die Würde der Gesetzmäßigkeit verleiht und die bloße Singularität dureh den Charakter eines allgemeinen Bedeutens adelt? Was ist das Allgemeine der Gesehichte? Jene Regelmäßigkeiten, die wir in der historicchen Bewegung beobachten können, legen den Gedanken nahe, daß es Gesetze des sozialen Lebens gibt, die für die Geschichte eine ganz ähnliche Bedeutung besitzen können wie etwa das Gesetz der Gravitation für das Reieh der Natur.

\section{ii) Geschichte und Gesetz.}

Diese Gesetze könnte man etwa die Entwieklungsgesetze des historischen Lebens nennen. Ihre Geltung würde sich darin offenbaren, dab jedes Volk bzw. jeder Völkerkreis ganz bestimmte Phasen oder Stadien seines geistigen Wachstums durehlaufen muß, um sich als soziales Wesen zu vollenden und auszuleben. Jedes Volk würde ganz bestimmte Phasen des wirtschaftlich ökonomischen Lebeus in vorgezeiehneter Reihenfolge zu durchlaufen haben. Die Tendenz, welehe diese Entwicklung beherseht, würde etwa in dem Gedanken der Differenzierung und Spezialisierung sowie anderseits auch in der Idee der Erweiterung, der Weiterbildung des Partikularen zum Universellen sich ausdrücken. Die erste Gesetzmäßigkeit hat schon Plato als bildenden Faktor für die Entstehung des St a a tes gedacht. Die alle Grenzen des Völkerlebens überwindende universalistiche Tendenz der wirt-ehaftliehen Entwieklung konnte ein Grieche unmöglich denken, da sie seinem Gemeinschaftsideal im Grunde widerstrebte, und die Möglichkeit einer solehen Weiterbildung ist erst glaubhaft und wahrseheinlieh geworden durch die unabweisbare und mächtige Wirklichkeit der wirtsehaftliehen Phänomene im 19. Jahrhundert. Man könnte das Gesetz aufstellen, daß das ökonomische Leben eines Volkes sich anfangs in einer doppelten Art ron Gebundenheit hält, nämlieh so, daß die Fülle möglieher wirtsehaftliehen Betätigung jedem einzelnen zur Last fällt und dadureh eine Entfaltung und Ausbildung der versehiedenen wirtschaftlichen Formen unmöglieh gemaeht wird, und daß zweitens dieses ganze ökonomisehe Leben an den denkbar engsten sozialen Kreis gefesselt bleibt. Das Gesetz der wirtschaftliehen Entwieklung würde dann weiter bestimmen. daß das wirtschaftliehe Leben ron seiner ursprünglichen Gebundenheit befreit wird, daß der Menseh, der als Ausübender auf allen Gebieten beruflos war, nach dem 
Prinzip der Arbeitsteilung sich für einen Beruf entscheidet, und daß das ökonomische Leben, das ursprünglich mur ganz enge partikulare Kreise zog, zum Weltrerkehr und Welthandel sich erweitert.

\section{n) Soziologie.}

Eine solche Betrachtungsweise, die in der Gesehichte das Wiederkehrende sucht und für das Gleiehe und Gemeinsame an den historischen Vorgängen interessiert int, $m u B$ selbstrerständlich als durehaus berecht igt anerkannt werden, aber allerdings diese Betraehtung sueht etwas in der Gesehichte und ist infolgedessen selber keine historisehe Betrachtungsweise mehr. Die Feststellung derartiger Regelmäßigkeiten interessiert die Volkswirtsehaftslehre und die Soziologie, die auf allen Gebieten des gesellschaftlichen Lebens derartige Regelmäßigkeiten in der Al,folge kultmreller Ersoheimmgen konstatieren möchte. Sofern aber die Soziologie bemüht ist, eine Gesetzeswissensehaft des Kulturlebens zu sein, mußsie wertfrei verfahren und an den Kulturphänomenen jeden Wertakzent auslöschen. Sie muß sie so betrachten, als ob sie bloß naturhaft wären, denn das Gesetz, der große Gleichmaeher auf Erden, verlangt nach absoluter Parität. Betrachten wir unser Beispiel, das der wirtschaftlichen Kultur entnommen ist, also einer Sphäre, von der wir den Wertgesiehtspunkt gewiß viel leichter ablösen könncn wie etwa von der Sphäre des wissenschaftlichen und kïnstlerischen Lebens, so sehen wir doch aweh hier, wie sehwierig, ja fast unmöglich es ist, Kulturphänomene des auszeichnenden Bedeutungsmomentes zu entkleiden. Der Weg vom beruflosen, mndifferenzierten Universalmenschen zum differenzierten spezialisten und Berufmensehen! Müssen wir nicht Stclhung nehmen, müs: en wir nieht diesen Gang bejahen oder ablehnen? Leht nieht hier eine Fülle ron Bestimmungen, die wir anzurenden gewöhnt sind, wenn as sich um das Ideal der Persönlichkeit handelt? Verstehen wir nieht Rousseaus Ablehmmg del Arbeitsteilung ans seiner Liebe für den ganzen und ungeteilten Menschen? Ist es nieht cine ewige Aufgahe der Persönlichkeit, lie grobe einseitig gewentote Leistmng mit der Fïlle ciner allseitig gerichteten Natur harmoniseh zu verbinden?

[uel was sollen wir sagen ron jener Entwicklung, die ans dem engen wirtschaftlichen mol somialen Kreis zmm Welthandel mol Weltrerkehr geführt hat? Immer wirl man ge\%wmgen sein, aneh hier Stellung zu nehmen. Man wirl den Untergang des dylls bedauern oder die gesteigerte lebensmacht fremelig ancerlinnem.

\section{o) Vïlkerbiologie.}

Em das Allgemenene der Gerchichte zu finden, hat man sich häufig sehr weit

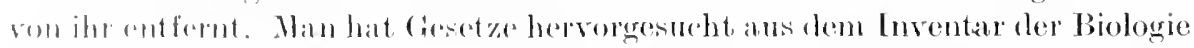

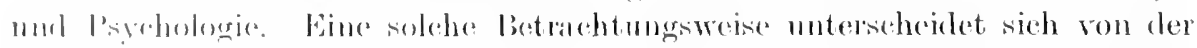

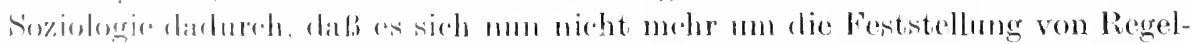

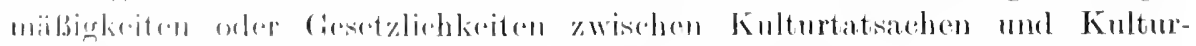

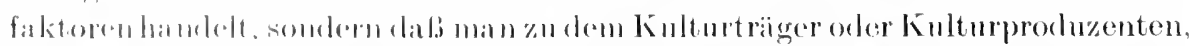

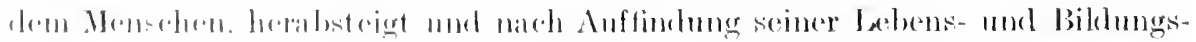

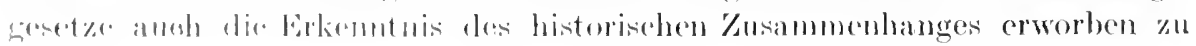


haben glaubt, indem man von dem seheinbar unumstöBliehen Gedanken ausgeht, daß, da alle Kultur menschliche Kultur ist, das absolute Menschenverständnis auch zum absohuten Kulturverständnis hinleiten muB. Man liebte es vor allem, ein Volk oder gar die ganze Mensehheit mit einem Organismus zu vergleichen, der allmählieh sich entwickelt ınd allmählich zerfällt, nachdem er seinen Höhepunkt erreicht hat. Was kann einfaeher sein als eine historische Erklärung, die da spricht von dem Wachstum und der Blïte der Nationen sowie von den Anzeichen des Verfalles. Wie passend und einleuchtend läßt sich auch die historische Entwickhng mit den Jahresaltern des menschlichen Lebens vergleichen. Wie gut läßt sich vom Knabenalter, Jünglingsalter und Mamnesalter der Menschheit plaudern und erzällen! Was ron den großen Geschichtsphilosophen des deutschen Idealismus als schönes Bilı gelegentlich gesucht war, das wollte man später ganz ernsthaft zum leitenden Gesichtspunkt der historischen Betrachtung machen. Ein Volk ist dem Verfall anheingegeben. wenn das, was man sittliche Kraft zu nennen pflegt, gebrochen ist. wenn Entsittlichung und Verweichlichung zum Leben der Lust geführt hat. Das Griechenland des vierten vorchristlichen Jahrhunderts, das Rom des zweiten und dritten Jahrhunderts n. Chr. war wert, daß es zugrunde ging! Seltsame Moral, seltsamehistorisches Verstehen und Ċhersehen! Diesen Fanatikern der Gesundheit gegenüber wollen wir den berauschend sehönen Duft der Gräberbhunen preisen, die eine sterbende Kultur so wundervoll erblühen ließ. Es wäre wahrlich Zeit, allmählich einzusehen, daß wertvolle leistung mit Kraft und Gesundheit durchaus nicht immer zusammenzugehen braucht.

\section{p) Völkerpsychologie.}

Man hat das Allgemeine der Gesehichte zu finden gesucht, indem man auf die psychologische Einheit der Tolksseele oder auf die mehr physiologische Einheit der Passe rekmrrierte. Die Theorie der Völkerpsychologie und die Theorie der Rasse sollten das Fnndament und die leitenden Gesicht-punkte für die Historie hergeben. Dazu ist erforderlich die Kenntnis der versehieflenen Völkerseelen bzw. die Kenntnis der verschiedenen Rassen sowie das Verstehen der Gesetzmäßigkeit, nach der sie die verschiedenen Phasen ihres Daseins durchlaufen. Welches Schicksal, welchen Erfolg, welches Encle schließt in sich die Gestaltung einer Volkssecle oder einer Passe mit den mol den Eisrenschaften? Schon bei Plato können wir die Anfänge der Völkerpsychologie vortinden. Er unterscheidet zwisehen vernünftigen, muthaften und begehrlichen Völkern. Nur die ersteren, deren Repräsentanten vor allen die Griechen sind, gelangen zum Staat als der Vollendung ihres sittlichen Daseins. Den Barbaren des Nordens und den semitischen Völkern bleibt dieses Ziel rersagt. ihre reelenverfassung kann niemals zur Entfaltung eines wertrollen Gemeinschaftslehens führen. Augenscheinlieh verbindet Plato dabei mit den verschiedenen Völkerseelen gewisse Wertbestimmungen. Die Seelen der Völker sind nicht nur versehieden in dem Sinne, wie etwa im Gebiet des Psychischen sich das VorstellungsmäBige von dem Willensmäßigen unterscheidet, sondern darüber hinaus besteht von vornherein ein Wertuntersehied zwischen den einzelnen Volksseelen. Die auf den Wert der ooçí bezogene Seele des griechisehen Volkes, sie ist die denkbar 
höchste Seelenform und rermag als solche allein ein wahrhaftes Kultursystem zin erzeugen.

Die Probleme der Völkerpsychologie sind gewiß von ungeheurem Interesse. Es handelt sich darum, die eigentümliche Kultur eines Tolkes, wie sie sich in Sprache und Recht, in Religion. Kunst und Wissenschaft, in Sitte und Gewohnheit offenbart, als Produkt seiner eigentümlichen Naturanlage und des besonderen Milieus, in dem sich diese Naturanlage entfaltete, zu erkennen und zu verstehen. Vielleicht hat es niemand gegeben, der das Verhältnis der Nationalkultur zu der eigentümlichen Natur der Volksseele so schön und verständnisvoll dargestellt hat wie Herder. Gibt es wohl eine Sprache, die in sich selber sehon ein so großes Kunstwerk ist wie die griechische? Welches Tolk war also wohl in seiner Sprachschöpfung in gleicher Weise wie das griechische ron künstlerischem Gestaltungstrieb bewegt? Welches Volk hat Größeres anf dem Gebiet der Musik geleistet wie das Volk der Mrstik? Wie groß ist die politische Befähigung und Organisationskraft des englischen Tolkes. Warum rerbinden wir so gern das Wort ..treu" mit dem Namen Deutschland, der Franzose aber spricht von , la belle France" und der Russe von dem, heiligen Rußland". Wie interessant ist es doch, nachzuweisen, auf welcher eigentümlichen Naturanlage jede eigentümliche Kultur beruht. Und wie wertroll ist anch ein soleher Nachweis, sofern er uns die unersetzliche Bedeutung der großen Kulturindividuen deutlich macht. Nun will es mir immer scheinen, als ob das Bestimmte und Gewisse, die offenbarte Kultur, die bestimmten Leistungen, die sich abgelöst und ein selbständiges Dasein gewonnen haben, bei der Zurückleitung ihres Ursprungs auf die Individualität der Volksseele aus einem weit Unbestimmteren und höchst Problematischen begriffen werden sollen. Wir können die Kulturleistung durch die Volksscele niemals erklären, sondern wir können aus der Kulturleistung die Volksscele mur ahnend erschließen. Die eigentümliche Natur einer Volksseele offenbart sich am deutlichsten in gewissen Wertsetzungen. So ist es gewiß

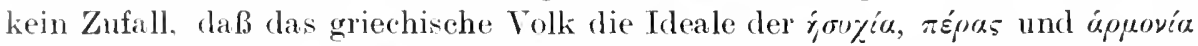
gebildet hat. Wie nun aber aus der Natur der versehiedenen Volksseelen die Gesetzmäljigkeit ihrer Entwicklnng verstanden und somit das Allgemeine der Geschichte gefunden worden soll, bleibt unerfindlich.

\section{4) Rassentheorie.}

Eine Theorie der Rasse zur Begründung der historischen Entwicklung herbejzuzichen, mul, aber erst recht verfehlt erscheinen. Hegel hat in seiner Euzykfopürlic sehr schön gezejgt, wie weit der Begriff der Rasse, der in die Sphäre des subjaktiven Geistes gehört, von dor Sphäre des objektiven Geistes als der aigentlichen Sphäre der Kulturleistung noeh entfernt ist. In Begriffen

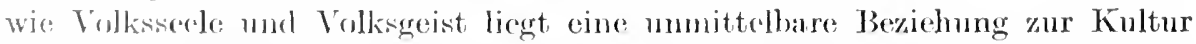
vor, dom der lienriff des Volkes orler der Nation ist ein lustoriseher Begriff und moint rine Einheit, die in der Gesehichte geworden und selber Träger des

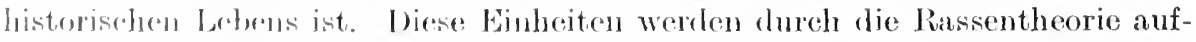
gedïst. Es handelt sich nun nieht mohr darmm, fostzustellen, welehen Gesetzen Jio Volksicold mutersteht, wenn sie anf den eigentümlichen Wege ihrer Entfaltung Sittr. Sijarache, Sehönheit, Recht mol die mannigfaltigen Formen des 
Lebens schafft, sondern die Untersuchung verläßt das Reich der Kultur und sucht den bloßen Naturmenschen, den Rassemenschen auf. Ist es doch augenscheinlich, daß die Tolksgemeinschaft sich zusammensetzt aus rerschiedenartigen Rassen. Was ist das griechische Tolk, die griechische Nation? Ein Konglomerat verschiedener Rassen. Die Einheit, welche die verschiedenen griechischen Staaten zu einem Volke zusammenschloß, zu dem Volke rler Hellenen, eine Einheit, deren sich der Grieche den Barbaren gegenüber mit frendigem Stolz bewußt war, dieses Einheitsbewußtsein, diese Gleichartigkeit, diese Gemeinsamkeit des historischen Schieksals - sie müssen nummehr der Passeneinheit weichen, und es stellt sich heraus, daß die Kulturleistung des griechischen Volkes ein Produkt sehr verschiedenartiger Passenleistungen ist. Es fragt sich eben nur, ob die Rassenelemente, aus denen sich das griechische Tolk zusammensetzen soll, das geleistet hätten, was sie historisch geleistet haben. wenn sie nicht getragen gewesen wären ron der Kraft des griechischen Nationalbewubtseins. Es fragt sich nur, was mehr bedentet: die historische Einheit des Tolkes oder die Natureinheit der Rasse.

Un das Allgemeine der Geschichte zu finden, geht die Rassentheorie auf das Vorgeschichtliche zurück, auf das bloß Naturhafte, denn was kann einlenchtender sein, als daß der Weg der Menschheit rom Stande der Natur zum Stande der Kultur geführt hat. Niemand kann es leugnen. Folglich hat die Natur die Kultur erzeugt, und die naturhaften Eigenschaften und Instinkte der Rasse sind das treibende Agens in der historischen Entwicklung. Kennen wir die Instinkte und Eigenschaften der Rasse und die Gesetze ihrer Entfaltung, so kemnen wir anch die Entwicklung der Kultur und die Gesetzmäßigkeit des historischen Lebens. Schade nur, daß man, wie es doch im Simne der Sache lagr, bei dem bloß Naturhaften nicht stehen l,lieb, sondern mit den Qualitäten der Passe sofort gewisse Wertmomente in dem Gedanken der Kulturleistungsmöglichkeit verbunden hat. Hier eröffnet sich mun das ganze Feld der Diskussionen, die darauf ausgehen, zu zeigen, daß die reine, unverfälschte Rasse am leistungsfähigsten ist, oder die umgekehrt den Beweis dafuir antreten, daß die Mischung der Rassen und überhaupt eine passende Blutmischung kulturfördernd sei. Dazu kommt dann noch die Idee einer auserwählten Rasse, die überall dabei war, wo etwas Vernünftiges gemacht ist, und hinzu tritt damn schließlich noch was Darwinismus in dem Gedanken der natürlichen Auslese.

\section{r) Autonomie der Geschichtr.}

Denen gegenüber, die das Allgemeine der Gerehichte in irgendeinem Gesetz suchen, steht geschlossen die Gruppe derjenigen Denker, welche rlie Antonomie und Selbständigkeit der Geschichte gegenüber der Natmmissenschaft behaupten, und zu denen so rerschieden gerichtete Philosophen wie Dilthey, Windelband. Rickert, Simmel, Sigwart. Wundt in gleicher Weise gehören. Der Beweis dafür, daß die Geschiehte niemals eine Form der Naturwissenschaft sein kann, ist in den letzten.Jahren noeh benonders eindringlich ron Rickert in der Festschrift für Kuno Fischer geführt worden. Wen diese Darstellung nicht belehrt hat, der wird überhanpt schwerlich zu belehren sein. Erst wem die Tatsache begründet ist, daf rlie Geschichte eine 
ron der Naturwissensehaft rollkommen verschiedene Auffassung und Deutung der Welt bedeutet, erst dam kann natülich in eminenten Simne von einem Problem der Gesehiehtsphilosophie die Rede sein.

\section{s) Kulturwert und Typus.}

Es ist num aber dieses Allgemeine, das die Geschichte als Wissenschaft begriunden soll und das dem naturwissenschaftlichen Gesetz entspricht, ror allem in zwei verschiedenen Formen ansgesprochen worden, nämlich einmal als Kulturwert ron Riekert und zweitens als Typus oder historischer Prinzipalbegriff bei Dilther. Beide sollen dasselhe leisten, beide sollen die Eigentümlichkeit und Unahhängigkeit der historisehen Erkemntnis gegenüber den Naturwissensehaften begründen. Das ist die große Gemeinsamkeit dieser beiden Begriffe, deren Charakter sonst so versehiedenartig ist, und an deren Bilknng ein so durehaus verschiedener Geist gearbeitet hat. Aber diese Gemeinsamkeit müssen wir doeh bei aller Versehiedenheit energisch unterstreichen. Kulturwert und Typus sind in gleicher Weise Prinzipien des historisehen Lebens, ohne sie wäre keine Geschiehte als Wissenschaft möglieh. Beide formen und rollenden erst die historische Welt.

Was jenen beiden Begriffen, wie sie von Rickert nnd Dilthey geprägt sind, ihren eigentümliehen Glanz gibt, das läßt sieh am besten durch zwei andere Begriffe deutlich machen, die mit ihnen ummittelbar rerwaehsen sind. Das A mul O der Geschichte ist nach Riekert die einmalige, einzigartige, unersetzliche Individualität. Der unersetzliehen Indiridualität ist der Kulturwert zugewendet. Das a priori der Geschiehte, welehes nach Dilthey das Versteben ist, gelangt zum Erfassen des Wesenhaften im Typus.

Es ist hiel noch nicht der Ort, zu dieser gegensätzlichen Auffassung des Allgemeinen in der Geschichte Stellung zu nehmen. Wir möehten jedoch sehon hier auf einige charakteristische Gegensätze anfmerksam maehen, die das Verständnis so verschiedenener Formen als Resultat einer philosophisehen Speknlation ïber die Geschichto deutlich maehen. Notwendig gehen Riekert und 1)ilthey ron verschiedenen Voranssetzungen ans, notwendig ist ihr philosophisehes lnteresse an der Geschichte trotz des gemeinsamen Zieles ihrer wissenschaftlichen begründung ain sehr verschiedenes. In jeder Philosophie ist etwas Unbewiesenes nul Unleweishates, das gleichsan dogmatisch behauptet wird und gar hänfig die ticfste mul heiligste Clyerzengung eines Denkers offenbart. So otwas Gewisses, Selhstrerstindliches und loch Unbeweishares war etwa, un ein grolbes beispled der antiken Philosophie anzufühen, für Plat to der Begriff der Lidese, der die Tremmung des Endlichen vom Enendlichen äberwindet. Ein ahnlich Heiliges ist für laickert die Individualiä, die niemals begriffen,

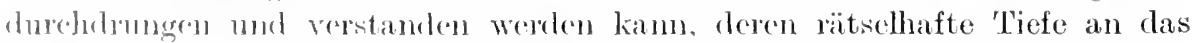

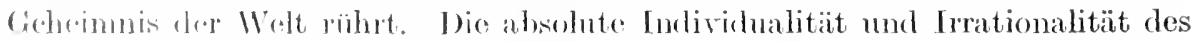

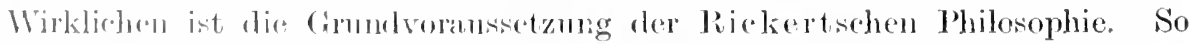
stoht sic vor uns da diese Wirkliehkeit, lockend und sehön in der simnlichen Pracht jhrer Anschanumgäulle, eine extensive mul intensive Unendliehkeit

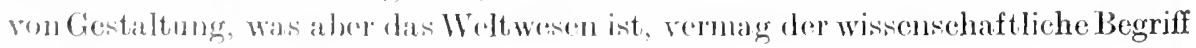
nienals auszulrü̈tom. 
Ganz anders das Glaubenshekenntnis der Diltheyschen Philosophie. Der Geist hat eine Macht, eine Gabe, die ihn befähigt, einzudringen in unermeßliche Tiefen. Diese Gabe ist die für den Künstler und den Historiker nnentbehrliche Funktion des Verstehens. Dies Verstehen ist unsere Stärke und Allmacht der Welt des geistigen Lebens gegenüber, im Verhältnis zu all den Dingen, die wir in letzter Hinsicht anf die Idee der Menschheit beziehen. Während das Verstehen an der fremden Welt der Natur notwendig scheitern muB, wenn nicht die geniale Begriffsphantasie des großen Metaphyikers auch diesem Fremden Geist und Leben gibt, steht die Welt des psychischen Erlebens dem alluächtigen Verstehen offen. Wo erlebt wird, da kamn ich anch verstehen.

Also schon in diesen ersten Voraussetzungen bestcht zwischen Rickert und Dilthey ein einschneidender Gegensatz. Nach Rickert gibt es nur eine Form der Erkenntnis, die wissenschaftliche durch den Begriff, Dilthey dagegen unterscheidet zwei Arten des Wissens, die naturwissenschaftliche Erkenntnis und das historische Verstehen. Die erstere sucht sich mit Hilfskonstruktionen eines Gegenstandes zu bemächtigen, der dem Wesen der Seele fremd ist, in den Geisteswissenschaften aber hat es der Geist mit Werken des Geistes zu tun. Das Terstehen ist also eine Art intuitives Innewerden des eigenen und des rerwandten geistigen Wesens. Das Verstehen ist ein unmittelbares, das Erkennen ein mittelbares Wissen. Wenn die Natur ein Werk der Zerstörung verrichtet, wem die simnlose Gewalt der Elemente das Schöne und Fromme zugleich mit dem Häßlichen und Erbärmlichen begräbt, dann können wir wohl erkemmen, aber nicht verstehen, wemn aber im Auge des geliebten Menschen die Frende auflenchtet, damn wissen wir, damn verstehen wir. Das rerwandte Objekt des Geistes ist es also, das in der Historie und überhaupt in den Geisteswissenschaften eine andere Form des Wissens lebendig werden läßt, ron der wir in der naturwissenschaftlichen Erkenntnis keinen Gebranch machen können, nämlich jene wunderrolle Gabe des Terstehens, die Dilthey selber gegenüber den historischen Erscheinungen, den großen Persönlichkeiten nnd Knlturbewegungen der Geschichte im höchsten Maße besessen hat. Diesem Verstehen bengt sich die geistige Welt. Es vermag ïberall einzulringen, es findet keine Schranken.

Ein solcher Begriff wie das ., Versteh en“ kann matürlich den Anforderungen der Logik nicht genügen. Dafür ist ex viel zu unbestimmt und irrational. Wir können das Verstehen schwerlich als die andere mögliche Form des Wissens der naturwissenschaftlichen Erkenntnis zur Seite stellen. Wohl aber hat Dil they in überzengender Weise gezeigt, da B es ein Wissen gibt, das keine Begriffserkenntnis ist. So vermag ich ein Gedicht nachzuerleben und zu verstehen, ohme daß ich das Gelesene oder Gebörte auf einen begrifflichen Ausdruck zu bringen vermöchte, und ein gewisses Terhalten. gewisse Ausdrucksbewegungen des geliebten Menschen reranlassen mich, ihn anders zu behandeln und zu nehmen als an alltäglichen Tagen, ohne daß es mir begrifflich irgendwie deutlich wäre, ob jenes Andere, das ich an ihm bemerke, seinen Ursprung habe in Freude oder Schmerz. Ich verstehe es, daß er anders ist wie sonst. und richte danach mein Verhalten ein, und indem ich die große Bewegung des Freundes als Freude verstehe, war ich schon auf dem Wege, ihn als einen Freudigen zu behandeln. 
So kommt bei Riekert und Dilthey von vornherein ein durehaus verschiedener Wille, ein ganz anders gerichtetes Interesse zum Ausclruck. Pickerts Position ist klar und dentlieh die des Erkenntnistheoretikers und Systematikers. Er will zeigen, daß die allgemeinsten Formen der Erkenntnis, zu denen die Philosophie Kants noch nieht rorgedrungen war, und die er als die konstitutiven Formen der Wirklichkeit bezeichnet, daß eben diese, durch das besondere Ziel wissenschaftlicher Erkenntnis bestimmt, in Naturwissenschaft und Geschiehte eine Umbildung erfahren haben, wodureh sie zu den methodologisehen Kategorien als den Erkemntnisprinzipien einer besonderen Wissensehaft geworden sind ${ }^{1}$ ). Dilth eys Position ist dagegen in erster Linie die des nachfühlenden und nachsinnenden Küunstlers, der große Persönlichkeiten erlebt und großes historisehes Leben wahrhaft geliebt hat. Er wïnscht, daß man die Prinzipien der Geisteswissensehaften in dieser Zeit ihrer ersten Grundlegung noeh nieht mit den allgemeinsten Prinzipien des Wissens und der Wirklichkeit verbindet, sondern sie mabhängig von allgemeinen systematischen Erwägungen untersucht. Dabei ist es ihm aber von vornherein denthich, daß die Geschichte als Geisteswissencehaft eine so abstrakte Grundlegung, wie sie $\mathbf{K a n t}$ für die Naturwissenschaften versucht hat, nicht verträgt. Er will nicht etwa wie Riekert in Analogie zu den Kategorien der Naturwissenschaft, wie sie ron Kant anfgewiesen waren, die Formen der Historie entwiekeln. Vielmehr bedentet eine Grundlegung der Geisteswissenschaften etwas ganz anderes als eine erkenntnistheoretische Begriundung der Naturwissensehaften. Der unerlebłaren Phänomene der Natur muß ieh mich mit Hilfskonstruktionen und erkemntnistheoretischen Prinzipien, mit Begriffen a priori im Simne Kants bemäehtigen. Die Welt des Geistes ist mir im Erleben gegeben und wird im Verstehen ron mir gewußt. Es gewährt den Ansehein, als ob Dilthey die von ihm geliebte Sehönheit und Lebendigkeit der Gesehichte den abstrakten Begriffen (ler Erkenntnistheorie nicht aufopfern möchte ${ }^{2}$ ).

Dabei ist Dilthey gegenüber dem Allgemeinen der Geschiehtsphilosophie Riekerts, den Kulturwerten als den Prinzipien des historisehen Lebens, sehr schnell mit dem Torwurf bei der Hand, daß diese Begriffe rein formal seien. Was hier als Torwurf gemeint ist, kamn im erkenntnistheoretisehen Interesse nur als Vorzug gelten. Gewiß sind alle erkenntnistheoretischen Prinzipien und alle höehst'n Bogriffe der Philosophie formal, sofern sie niemals einen Inhalt der simnlichen Wirklichkeit meinen, aber deswegen sind sie doeh keineswerss leere Hïlsen, sondem sie haben cinen ganz bestimmten fim und eine ('minente Bedentung. Was Religion, Kunst, Stat, Nation, historisehe Perönlirhkeit ist und bedentet, das auseinandorzulegen mul als eine der wiehtigsten Anfughben dexjenigen Teiles der Geschichtephiksophie betrachtet werden, den wir als dis Jahre von den historiselon Prinzipien oder sehlechthin

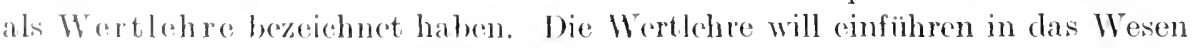
und dis Jasistmug des Kulturwertes, mul wir glanben versichern zu kömnen,

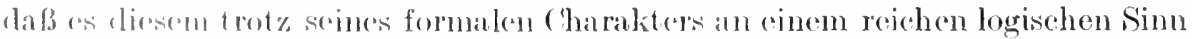

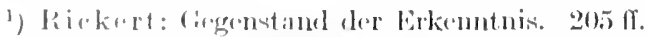

$\left.{ }^{2}\right) \mathrm{Vgl}$. Wilholm Dilthey: Dor Ausbau der gersehichtlichen Wolt in den Geistes-

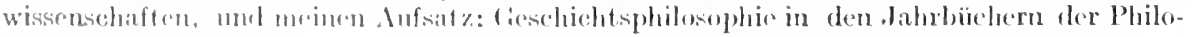
sopphis. Jurlin 191:3. 
nicht fehlt, den auszuschöpfen eine ewige Anfgabe unserer Erkenntuis sein wird. Daß es die Philosophie nur mit Religion überhaupt und mit Kunst überhaupt, nicht aber mit einer bestimmten Kunst oder mit einer bestimmten Peligion zu tum haben kamn, ist selbstrerständlich, demn die bestimmte Kulturgestalt ist angenscheinlich Gegenstand der Geschichte. So meint auch Dilthe ys Typus nicht die bestimmte simnliche Einzelerscheinung. sondern ein Etwas, das als immerleitende Fonstante immer wieder von neuem im Leben der Geschichte zutage tritt. Dahin gehören Religion und Wissenschaft als teleologisch bestimmte Kultur- oder Wirkungszusammenhänge. Desgleichen ist ein Typus nach Dilthey der religiöse oder kïnstlerische Mensch in der besonderen Art seiner Wesensentfaltung. Was den Typusbegriff Diltheys ron Rickerts Kulturbegriff entfernt, das ist vor allem der Umstand, daß der Typusbegriff von Dilthey nicht systematisch eingestellt wird, während Rickerts Kulturwert auf ein System absoluter Werte hinweist. Gerade auf der Beziehung der Geschichte zu den absoluten Werten der Philosophie, die durch die Kulturwerte gegeben ist, beruht ihre Erkenntuisbedeutung und, wie wir später noeh sehen werden, ihr gewissermaßen philosophischer und weltanschauungsmäBiger Charakter. Die Begründung der Allgemeingültigkeit der Geschichte scheint Dilthey weniger zu interessieren. Indem seine Fragestellung häufig den philosophischen Charakter eimbiißt, verweilt er mit Torliebe bei der Frage des Werdens. Und so läßt er denn die Welt der gegenständlichen Erkenntnis, die Welt der Natur und der Geschichte in ihrem Stufenaufbau hervorwachsen aus der Natur der Einzelseele, aus dem Strukturzusammenhang ihres Erlebens, in dem die Tendenz zu einer gegenständlichen Auffassung der Welt ron romherein angelegt ist. Die gegenständliche Auffassung der Welt blüht aus der Einzelseele hervor, und der teleologische Zweckzusammenhang ihres Seins soll es begreiflich machen, daß es Werte und Zwecke gibt, um welche die Menschheit kämpft und nach denen die Menschheit sich richtet. Hier soll also der Wert erklärt werden aus dem simnvollen Erlebnis, nicht aber das Erlebnis verstanden werden ron der Natur des Wertes her, der doeh das unbezweifelbare noú-spuv cícs: des Erlebniszusammenhanges ist, der nur damn simnvolle Bedeutung gewimnt, wenn die Werte, nach denen das Wachstum der Seele hinarbeitet und hingeleitet wird, den Charakter einer notwendigen Allgemeingültigkeit tragen.

Ein Bedenken allerdings erhebt sich gegen die Lehre ron den Kulturwerten, das mit voller Entschiedenheit zuerst von Frischeisen-Köhler geltend gemacht ist, das ist nämlich die Frage, ob sich die Charakteristik einer Persönlichkeit, wie sie der Historiker darstellt, erschöpft oder erschöpfen kam in einer bloßen Aufzählung derjenigen Eigensehaften, die mit Rüeksicht auf einen Trert unersetzliche Bestandteile des Ganzen bilden. Wird nicht vielmehr die Geschichte immer die Grundzïge eines Charakters und den imneren Znsammenhang aller seiner ÄuBerungen und Handlungen zu ermitteln streben? Es könnte sein, daß die Lehre von den Kulturwerten nieht ausreicht, um die Tätigkeit des Historikers begreiflich zu nachen, sofern sie darauf gerichtet ist, die großen historischen Persönlichkeiten zu erklären und zu verdentlichen').

1) Vyl. Frischeisen-Köhler: Über die Grenzen der naturwissenschaftlichen Begriffsbildung. Archiv für systematische Philosophie 1906. 
Die Lehre ron den historischen Prinzipien wird den Begriff des Kulturwertes zunächst einmal im Verhältnis zu den absohuten Werten der Philosophie zu bestimmen suchen und etwa feststellen, daß sich der Kulturwert als das Allgemeine der Geschichte zum absoluten Wert ähnlich verhält wie die methodologischen Kategorien zu den konstitutiven Wirklichkeitsformen. Sie wird damn weiter die allgemeine logisehe Struktur des Kulturwertes feststellen und seine Leistung für die historische Erkenntnis deutlich machen. Des weiteren aber beruht ein wichtiger Teil der Wertlehre in der Verdentlichung der besonderen Struktur der einzelnen Kulturwerte sowie in der Aufweisung der zwischen ihnen bestehenden Relationen.

Auch die Reflexionen der Wertlehre sind so in der Hauptsache methodologisch erkenntnistheoretischer Natur. Die Form, um die es sich hier handelt, wirk und kann allerdings nur verdentlicht werden in Beziehmng zu der ganzen Lebendigkeit des wissenschaftlichen, künstlerischen und religiösen Lebens, aber die Funktion, die der Kulturwert ausübt, wird mu betrachtet im Verhältnis zur Erkenntnis der historisehen Wissenschaft. Es wird gezeigt, wie er das ans der Wirklichkeit herausholt. Was wir historisch bedeutsam nemmen. Er fungiert also hier als das höchste Prinzip der historischen Erkenntnis.

Wir hatten die Lehre ron den Kulturwerten aber anch als die Lehre von den Prinzipien des historischen Geschehens bezeichnet. Dies Verhälnis der Kulturwerte zum realen Geschehen, erfährt seine endgültige Bestimmung erst im letzten und wichtigsten Teile der Geschichtsphilosophie, der es mit der Universalgeschichte zu tum hat. Während es sich bisher darmm handelte, was der Kulturwert für die wissensehaftliche Arbeit des Historikers leistet, handelt es sich nummehr darum, festzustellen, was der Kulturwert für die Wirklichkeit leistet. Die Philosophie beginnt in der Logik mit dem Verhältnis von Wert und Wirklichkeit und sucht diesen Gegensatz aufzulösen und zu verstehen. In der Unirersalgesehichte kehrt dieser Gegensatz noch eimmal wieder und wird hier einer endgültigen Lösung entgegengeführt. Nur der erste 'Teil der Lehre von dex Universalgesehichte trägt noch einen wissenschaftstheoretischen C'harakter, sofern sich die Frage erhebt, was demn eigentlich die Universalgeschichte im ganzen Zusammenhang des Wissens bedentet. Die weitere wichtige Frage aber, die zum Verhältnis ron Wert und realem historischen Geschehen ïberleitet, kamn man formulieren als die Frage nach dem Verhälnis der Universalhistorie znr Wirklichkeit. Endlich hat die Universalgeschichte, und das ist ihre bei weitem wichtigste Aufgabe, die Simmfrage an das historisehe Geschehen zu richten. Ihr steht die Ent scheidung zu über das Problem. ob wohl überhanpt inn historisehen Geschehen irgendein vernünftiger wim walten möge. und wenn das der Fall ist, wrin wohl diescre simn des historischen Geschehens zu suchen sei. Ins ist die Frage, anf die es recht eigentlich ankommt, das ist die Frage, mon derentwillen immor weder die Philosophie mit der Gesehichte sieh beschätigt hat. Wenn die Nitur dem Mensehen in der ganzen Art ihres Waltens und (ieschellens fremel und simnlos erschien, so wandte sich sein Blick der Ge-

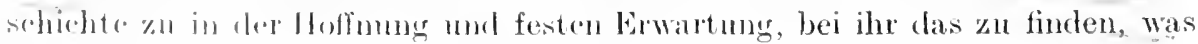
ihn dir Nitnr fïr immer versagte. Geschichtsphilosophie kamn nur damn als

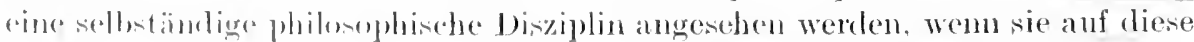

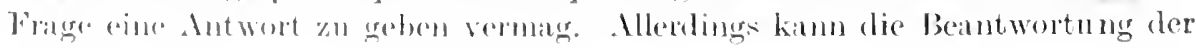


Frage erst damn gegeben werden, wenn alle methodologischen Vorfragen entschieden sind. Während die alte Metaphysik, sofem sie einen universalhistorischen Charakter trug, sogleich Antwort zu geben versuchte auf die Frage nach dem Endzweck und Sinn der Geschichte, hat die moderne Philosophie dies Problem an das Ende ihrer geschiehtsphilosophischen Untersuehungen gestellt. Wenn sie aber auch erst den schwierigen und miihsamen Weg erkenntnistheoretischer und methodologiseher Untersuchungen durehmessen muß, un Material für die Universalgesehichte zu gewinnen, so hat sie das Ziel der Geschichtsphilosophie, die Frage nach dem Sinn des historischen Lebens, darum nicht aus dem Auge verloren, wie es in der Idee der Wertverwirklichung zum Ausdruck kommt. Es ist deutlich, daß diese Frage in einem gewissen Zusammenhang steht mit dem Problem der Religionsphilosophie, ob und wie sich der Wert, das Sollen, in der irrationalen Wirklichkeit durchzusetzen vermag. Wird aber eine Antwort der letzten geschichtsphilosophisehen Frage gefunden, so vollendet sieh die Philosophie in der Geschichtsphilosophie und führt zu einer historischen Weltanschaumg. Eine solche remag niemals die historische Wissenschaft selber zu geben, wohl aber die Philosophie, sofern sie auf das Wesen der Geschichte und den Sinn des historischen Lebens in ihrer Reflexion gerichtet ist und zu der Einsicht gelangt, daß die letzten Probleme der Gesamtphilosophie ihre Auflösung in dem Problem der Universalgesehichte suchen.

Wir wollen nummehr versuehen, die Einzelprobleme der Geschicht;philosophie zu fixieren und zu isolieren, damit uns dann im zweiten Hauptteile die Möglichkeit gegeben ist, die Genesis dieser Probleme an dem bisherigen Verlanfe der philosophiegeschichtlichen Bewegung zu erläntern. Eine solche Aufteilung der Probleme führt uns aber zuerst auf eine Analyse der verschiedenartigen Probleme der Geschichtslogik.

\title{
Zweites Buch. \\ Geschichtsphilosophische Einzelprobleme.
}

\author{
Erstes Kapitel. \\ Probleme der Geschichtslogik.
}

Es ergibt sich für uns die Aufgabe, mit derjenigen Problengruppe zu beginnen, die problemgeschichtlich erst sehr spät zum Bewußtsein gekommen, auf welche der menschliche Geist erst dam verfallen ist, nachdem er anf die Frage nach der Bedeutung des Ganzen sehon eine Antwort gefunden hatte. Daß der mensehliche Geist in der Aufstellung und Beantwortung philosophiseher Fragen den Weg vom Großen zum Kieinen, vom Sichweren zum Leichten, von dem Ganzen zu den Teilen geht, das hängt wohl in erster Linie damit zusammen, daß die jugendliche Menschheit, vom Mut des Entaleekertums erfüllt, noch kein Maß besitzt zur ruhigen und sachlichen Einsehätzung ihrer Kräfte, und daß sich das große Wunder des Ganzen, der Welt, der Natur und Geschichte, der 
stamenden seele des Menschen so gewaltsam aufdrängt, daß er vermeint, nicht leben zu können, ohne eine Antwort auf diese Frage zu finden. Daß auch in dem Kleinen ein Problem liegt, das wird er erst dann bemerken, wenn er dieschmerzliche Erfahrung der Enttäusehung seines leidenschaftliehen Strebens nach Weltverstehen gemacht hat. Wenn er immer wieder vergeblich anpoehte an den verschwiegenen und ruhigen Bau der Naturnotwendigkeit, und wenn seine freudige Erwartung, daß der Sieg im historischen Wettlauf der Völker dem bestien und edelsten zuteil werde, rerniehtet und zerbrochen wird im Anschauen des tragisehen Unterganges ron alle dem, was er als groß und sehön geliebt hat.

Die Probleme, welehe in die Sphäre der Gesehichtslogik fallen, lassen sieh ihrerseits wieder in fünf Problemgruppen zerlegen. Alle philosophisehe Fragestellung beginnt mit dem Begriff des Zieles oder Zweekes. Daß wir Geschichte treiben, ist für den Historiker einfach eine Tatsache, genan so gut wie die Tatsaehe unseres Lebens und Erlebens, aber der philosophische Menseh wird die Frage erheben, wozu lebe ich, was ist der Gehalt und Zweck meines Lebens? Und so wird er auch der Historie mit der Frage entgegentreten: wozu treiben wir Geschichte? Was ist der Zweck und das Ziel der historisehen Betrachtung? Gewiß wird die Mensehheit schon lange Geschichte getrieben haben, bevor sie darïber reflektierte, wozu sie demn eigentlich den Gang der Vergangenheit erforschte, wie die Nenschheit schon lange gelebt hat, bevor sie dazu kam, über den Simn des Lebens nachzudenken. Immer ist das Faktum und das bloße

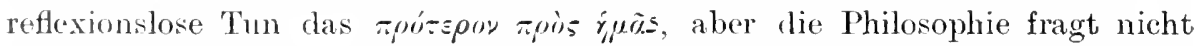
nach dem Ersten in der Zeit, dem Ersten für uns, dem bloßen Faktum, sondern vielmehr nach dem logiseh Ersten, wach dem Ziel, nach der Aufgabe, die allein mein Handeln und mein 'Jun rechtfertigen und verständlich maehen kann.

Indem wir aber dem Ziele der Geschichte nachdenken, reflektieren wir gloichzeitig anf die Objakte oder die Gegenstände, mit denen es die historisehe Forschung zu tmo hat. Und damit stoßen wir anf den zweiten Problemkreis der Geshichtslogik. Ich muB mir das Ziel, die Aufgabe der Gesehichte dentlieh machen, ich mul aber auch die Natur des Objektes kennen, das den Forderungen fes Zicles unterworfen wird. Alle geschichtslogische Besimmung begimnt mit rex (iogenüberstellung ron ()h,jekt mul Ziel. J)as Ziel bestimmt die Art der Formung und Comgestaltung, die das ()bjekt erfahren soll.

Fïr eine anfache alkenntnistheoretischo Besinnung ergibt es sich clamn sogleich, daß das, (Ol,jekt" der Historie ebensowenig wio das Ziel oder die Anfgabe der Geschichte etwas sein kann, was frei und mabhängig ron unserer

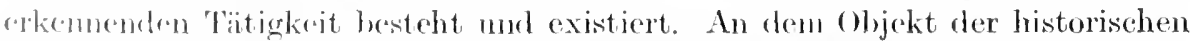

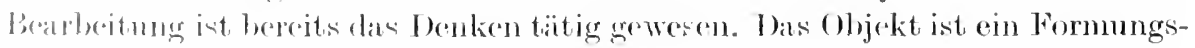
jormlitit.

In cincom dritten P'oblemkreis steht dann die Geschichte vor der Aufgabe, las ()hjekt, anf das sich die historisehe Erlenutnis richtet, in seine beiden Kompmenten, Form und Inhalt, zu zorlexen und daturch den lonkanteil

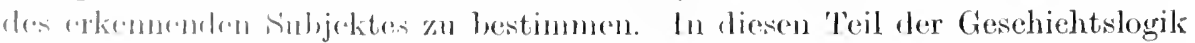

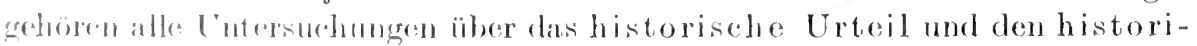

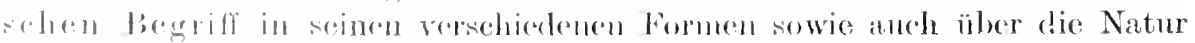
des Materials. das der legeriffiehen formunger moterworfen wird. 
Mit diesen Untersuehungen ist die Basis für eine genaue Bestimmung der historischen Methode gewonnen, die sich ergibt aus dem Verhältnis von Objekt und Ziel, ron Form und Inhalt der Erkenntnis. Die Nethode muB abhängig gedacht werden einerseits von dem Ziel der historisehen Forschung, anderseits ron dem Material, das bearbeitet werden soll. Es besteht so die Möglichkeit, entweder den Materialcharakter oder die Natur des Zieles zur maßgebenden Bestimmung der historisehen Methode zu maehen.

Der letzte Kreis der Probleme der Geschichtslogik, der zugleich zum zweiten Teile der Geschichtsphilosophie, der Kulturwertlehre, überleitet, hat es mit der Frage der historischen Beurteilung zu tun.

\section{$\$$ 1. Der erste Problemkreis. Die Probleme des Zieles.}

Die Frage des Zieles hängt zusammen mit der Frage nach dem Begriff der Geschichte. Demn ich muß wissen, was Geschichte bedeutet, um klare und feste Zielsetzungen der historischen Forschung gewinnen zu können. Daher war es notwendig, in einer Untersuchung über den Begriff der Geschichte die Natur dieser Kulturerscheinung deutlich zu machen. Es galt ror allem, ihren wissenschaftlichen Charakter zu verteidigen und zu betonen gegenüber jener Anffassung der Historie, die in ihr nur ein Produkt kiunstlerischer Leistung erkemmen will, und es galt, ihre theoretische Würde, die unabhängig ist von Nachteil und Torteil des Lebens, auf das schärfste hervorzuheben. Speziell in der Kontrastierung von Kunst und Geschichte haben wir die Frage des Zieles bereits in Erwägung ziehen müssen. Anf jeden Fall ergab sich für uns als Resultat, daß die Historie Wissenschaft sei, und daß ihr Ziel deswegen nur in der Erkenntnis gesehen werden kann. Die Erörterungen über den wissenschaftlichen oder nicht wissenschaftlichen Charakter der Historie liegen an der Grenze der Geschichtslogik. Indem wir die Geschiehtsphilosophie als Logik der Geschichte bejahen, sctzen wir den wissen chaftlichen Charakter der Gesehichte bereits voraus.

Wir gehen also in der Geschichtslogik ron der Toranssetzung aus, daß die Historie Wissenschaft sei, wobei es allerdings durch den Gang der Untersnchung im einzelnen erst nachgewiesen werden muß, worin dieser wissenschaftliche Charakter der Geschichte besteht, und wie er logisch zu rechtfertigen ist. Ist uns die Geschichte Wissenschaft, so hat sie es auf jeden Fall mit den Objekten der Wirklichkeit zu tun. Sie wird sich die Aufgabe stellen, die Objekte der Wirklichkeit zu verstehen und zu begreifen. Diese Objekte der Wirklichkeit sind aber in einer anschaulichen Mamnigfaltigkeit gegeben, die in dem nnendlichen Reichtum ihrer Bildungen und Gestaltungen sowie in der mübersehbaren Fülle ihrer Beziehmngen niemals zum Eigentum der Erkenntnis werden kann. Darin liegt in der Tat das Eigentïmliche der Geschichte, da.B es ihr auf das Besondere der Wirklichkeitsmannigfaltigkeit ankommt, sofern sie jemals gewesen, sofern sie ist, und sofern sie noch werden kamn. Das historische Problem in der Ausdehnmng, wie es sich die moderne Geschichtswissensehaft gestellt hat, konnte für die Antike noch nicht bestehen. Daf der Mensch schon frühzeitig um die große Ordmung der Natur belïmmert ist, das ist verständlieh und wohl begreiflich, denn die Gesetze der ewigen Natur gelten für alle Menschen. 
Wie aber soll mich das Leben und Schicksal ron Menschen interessieren, die tausend Jahre ror mir gelebt haben. und die schon längst verdorben und gestorben sind. End vor allem: das Interesse, welches ich an diesen Menschen nehme, soll nieht nur ein ästhetisches sein, die Freule etwa an ihrer Schönheit und Größe, oder ein gleichsam lehrhaft pädagogisehes, indem ich darauf reflektiere, was ich ans der Geschichte lernen kann, sondern viehmehr ein rein wissenschaftliches, indem ich die historischen Erscheinungen 1 m ihrer selbst willen zu erkenmen und zu erforsehen suche.

Es gab gewiß Zeiten, die gelacht haben würden über jenen Sonderling, der mit ängstlieher Sorgfalt alles das aufbewahrt, was nur erimern mag an Dinge, die einstmals geschehen sind. Wie seltsam und töricht wäre wohl jenem stolzen und einsamen Bewnßsein der Vergangenheit, das nur mit sich beschäftigt war, jene Bemiuhung um Fremdes und Entferntes, jene Sorge $11 \mathrm{~m}$ das Zukünftige ersehienen, die das historisehe Bewußtsein zu bewegen scheint.

Das Interesse für die Geschichte war bekanntlich im allgemeinen der Antike rollkommen fremd. Wohl hat es belentende Historiker im Altertum gegeben, aber es fehlte doch im Grunde genommen das eigentlich historische Bewußsein. Es fehlte die Anerkennmng aller derjenigen Phänomene, die erst so viel später zum Begriff des Fortschritts geführt haben. Es fehlte die Zentrierung aller Erseheinung anf eine große soziale Einheit, ohne die keine Weltgeschichte möglich ist, nämlich die Idee der Mensehheit. Die Bildung und Formierung des historisehen BewnBtseins war erst die Leistung des Christentums.

\section{a) Das Interesse der Geschichte an allgemein Menschlichen.}

Das Interesse, clas sich in der Geschiehte kundgibt, und das zur Gewinnung und Eroberung ganz neuer Erkenntnisgebiete führte, kann zunächst einmal als ein Interesise an dem allgemein Menschlichen bezeiehnet werden. Während clas Interesse, das in den Naturwissenschaften sich äuBert, darauf gerichtet ist, dic Formen kemmen zu lernen, die alles individuelle Dasein bestimmen, die große Notwendigkeit zu verstehen, die den Gang des Geschehens in vorgesehriebene Bihnen leitet, und der Nenseh es in der Erforschung der Natur somit ron Anfang an mit demjenigen zu tum hat, was ihm an Macht und Gewalt weit ïberlegen ist. ist ex in der Geschichte rorwiegend nur mit den verwandten Gestalten der eigenen Art besehäftigt. In aller Natmrerkenntnis ist ron vomlercin das Intrense wirksam, jenes Eine kemnen zu lernen, das alle Welt bewegt. Ale Naturwissenschaft wid geleitet ron ler Sehmsneht meh Goteserkenntnis, wïhrent in der Geschichte die Riehtung anf das Eine anfinglieh vollkommen zuriicktritt hinter dem Lnteresse und der Frende an der bunten Mamigfaltigkeit des menschlielem ledens. Dieses Lehen aber wird nicht wie in der Naturwissenschaft anf seinc let \%ton Formen und Elemente hin seprïf und zerlegt, sondern ('s wirl in seiner Ganzheit und Totalitit in voller Lebendigheit belassen.

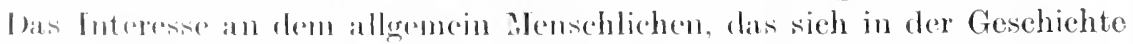

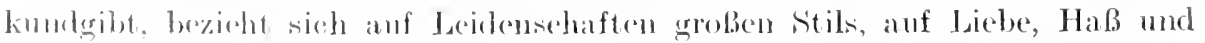

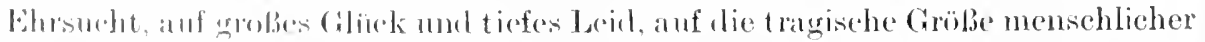

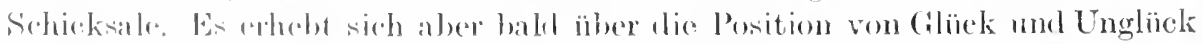

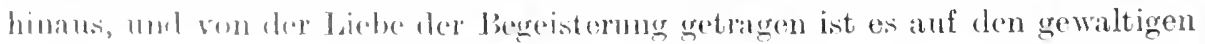


Zug der großen Begebenheiten, auf Heldentod und Heldenleben gerichtet. Es erhebt sieh damn immer mehr im Terstehenwollen der mamnigfaltigen Sehöpfungen, die der Menschengeist in den Jahrtausenden vollbracht, seien es nun die Institutionen mannigfaltiger Städtegründungen, die Gesetzgebungen der versehiedenartigsten Völker, das Werden ihrer Macht mul ihres Wohlstandes, oder mag es sieh $1 \mathrm{~m}$ die sehöneren und reineren Formen handeln, die der mensehliehe Geist in Kunst und Wissenschaft hinterlasien hat.

Indem nun aber dieses Interesse am allgemein Mensehlichen immer mächtiger wird, das sehließlich neben den großen und starken Zügen auch die leisen und geheimen Spuren des verborgenen Lebens zu entdecken bemiiht ist, schwindet immer mehr der rohe und primitive Standpunkt einer bloß egozentrischen Einstellung, und das soziale Gefühl einer Solidarität alles menschlichen Tuns und aller menschlichen Schicksale wird stark mon mächtig.

\section{b) Die Besonderheit menschlicher Gestaltung.}

Was aber ist es nun, was wir an der Wirklichkeit, wie sie in der anschauliehen Fülle der Vergangenheit vorliegt, zu entdeeken und festzuhalten bemüht sind? Es ist angenseheinlich die Besonderheit und Versehiedenartigkeit mensehlicher Gestaltungen, dieser Reiehtum ron Formen, der immer wieder ron neuem unser Interesse herrorlockt und es bald nach dieser, bald naeh jener Seite wendet. Würde uns die Geschichte nieht diesen Reichtum gewähren, so würden wir sie auch nieht lieben. Das historische Interesse ist ein Interesse an der Fülle der Gestalt. Deswegen hat man wohl die Gesehichte als Gestaltenwissensehaft bezeichnet. So glücklich es mu auch diese Bezeichnung zum Ausdruck bringt, daß das Streben der Gesehiehte darauf geriehtet ist, die Gestalten der Wirklichkeit zn erfassen, so legt doeh auch diese Bestimmung wieder die irrtümliehe Auffassung nahe, daß es sich in der Geschichte in erster Linie um die künstlerisehe Gestaltung der Begebenheiten handle. daß also das Interesse der Gesehichte in erster Linie ein Gestaltungsinteresse, nieht aber ein Begriffsinteresse sei.

Wir vermeiden es daher, die Gestaltung als Zielbestimmung der Geschichte aufzufassen, und wählen dafür lieber die Begriffe des Besonderen und dè. Singularen. Das historische Interesse rerbindet sich mit dem Besonderen und Singularen. Damit soll natürlich nicht gesagt sein, laß das historische Interesse selber ein partikulares sei, vielmehr ist der historische Erkenntnistrieb so umfassend und universal wie möglich. Das historische Interesse ist anf Vollständigkeit und Totalität gerichtet, aber es sucht in allem immer das Besondere als das Verschiedenartige und das Singulare als das Einzelne. Das Einzelne, das ron jedem Anderen rersehieden ist. oder, wie wir auch sagen können, das Individuelle ist das Ziel der Geschichte. Ob die Wirklichkeit selber vollkommen individuell ist, daß können wir niemals mit Sicherheit hehaupten, nur so, wie sie in der simmliehen Anschammg uns entgegentritt. gewinnen wir den Eindruck der Individualität. Aber so viel ist doch gewiß, daß sich die Geschichte die Individualität des Wirklichen als Erkenntnisziel gesetzt hat. 


\section{c) Die Individualität.}

Diesen Nachweis hat vor allen Rickert in überzengender Weise geführt, inden er zeigte, wie die Terschiedenartigkeit des wissenschaftlichen Interesses, das in den rerschiedenen Formen der Geschichte und Naturwissenschaft zum Ausdruek kommt, die Gesetzessehnsueht und das Streben nach Individualität und Konkretheit sich bereits in den Formen des vorwissensehaftliehen Denkens offenbart. So wird man sehließlieh dahin getrieben, anzunehmen, daß das Interesse der Termunft ein doppeltes ist, indem es in Gesehiehte und Naturwissenschaft anf rersehiedenen Wegen das Ganze der Wirklichkeit zu erfassen strebt'1).

Allerdings stellt der Begriff des Individuellen, wie wir ihn mit Riekert als Zielbestimmung der Geschichte gebranchten, sogleich ein Problem. Es fragt sich nämlich, was hier unter Individualität zn verstehen sei ${ }^{2}$. Bei einer Analyse des Wirklichen stoßen wir notwendig auf zwei Faktoren, auf den Begriff der Form und den Begriff les Inhaltes. Wir kömmen uns den Begriff ron etwas denken, das joder Form entbehrt, das ist der Begriff des Irrationalen, des Cnerkemnbaren. Mit diesem Begriff des Irrationalen kann der Gedanke des Individuellen verbunden werden. Was hier unter dem Individuellen verstanden wirl, ist gewiß etwas Unerkemmbares und Unwirkliehes, etwas Unbestimmtes und Formloses, der Bestimmung und der Form Bedürftiges. Denken wir etwa an den Begriff der "̋ir, bei Aristoteles. Anderseits kömen wir unter dem Individucllen auch das Individum verstehen, die Lebenseinheit des Wirklichen, wo es sich gewiß um geformten Inhalt, nicht aber $u$ die reine Inhalthichkeit, den bloßen Stoff handelt. Der reine Inhalt ist mwirklich, die Lebenseinheit der Persönlichkeit ist wirklich. Der reine Inhalt ist vollkommen irrational, dic Lebenseinheit hat an dieser Irrationalität Anteil, aber sie ist dem Verstehen und Erkemen nicht rollkommen entzogen. Es ist ein Problem, wie diese beiden Begrifle der Inrlividualität zusammenhängen, und bis zu welehem Grade die Lebenseinheit als irrational bezeichnet werlen kann. Wenn wir der historischen Betrachtung das Inclividuelle als Ziel dor Erkenntnis setzen, so ist dieser Begriff natürlich virl weiter als der Begriff der T'ersönlichkeit, und doeh möehten wir behaupten, dak allem historischen Erkemmen- und Verstehenwollen ein hohes Mals ron Sehnsmeht nach persönlichem Leben zugrunde liegt.

Dide Interessen der Erkenntnis sind also rerschieden gerichtet, es gibt oine Form ler wissensehaftliehen Erkenntnis, die nach dem Überpersönlichen, nach dom Algemeinens treht, clas ist rlie Naturwissenschaft. Solange die Naturwisenechaft als Naturphilosophie noch nach einem alsohten Weltengrunde forshte, war ihr dies Algeneine die Gotheit. In der Gesehichte wird dagegen in dem Stroben, das Bila orler die Struktur der individnellen Wirklichkeit

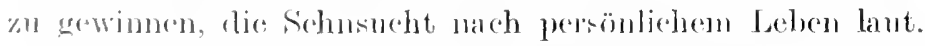

Aurh in vorwissonsehaftlehen Denlien, also in rer Sphäre des Lebens,

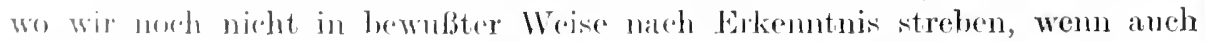

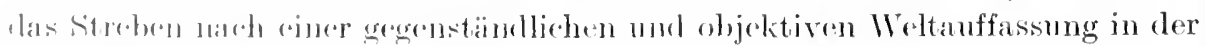

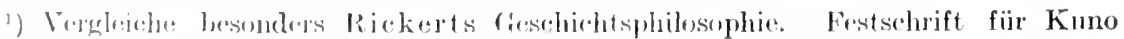
Fischer 1!63\%. 2. Anfligg 1!n67.

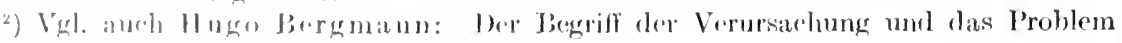

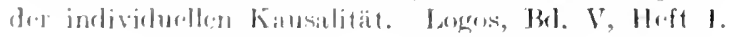


ganzen Natur unseres psychischen Erlebens angelegt sein mag, in dieser ungeteilten Sphäre der urpersönlichen Stellungnahme, wo ich Freund und Geliebter bin und immer Partei, schon dort macht sich jenes Doppelinteresse bemerkbar, das auf das Allgemeine und anf das Individuelle gerichtet ist. Denn angenscheinlich gibt es viele Dinge, und diese Dinge kömnen auch Menschen sein. an denen uns nur ein Etwas, die eine Seite ihres Wesens interessiert, also das. was sie mit anderen gemeinsam haben. Dagegen gibt es andere. und das sind im Leben ror allem die Menschen meiner Liebe, bei denen uns alles interessiert. Dies All des Menschen oder irgend eines Dinges ist aber seine Indiridualität. $\mathrm{Es}_{\mathrm{s}}$ ist eine ganz besondere Lebensform oder Lebenseinheit, die nach muserer Auffassung einzig ist in der Bildung des Körpers nnd in der ganzen Art, wie sich ihre Erlebnisse gefunden und verbunden haben. Wemn wir ron Sehnsucht und Liebe ergriffen sind nach der Individnalität. so trachten wir nach demjenigen. wodurch sich der Gegenstand oder das Objekt unseres Interesses ron allen anderen unterscheidet. Diese seine Besonderheit macht ihn uns so wert. und wir sind daron überzeugt, daß diese schöne Besonderheit in dem großen Reiche des Wirklichen nur eimmal da ist.

Aber nicht nur an Menschen, sondern auch an Dingen kam uns ihre Ganzheit oder ihre Individualität interessieren, und wem unser Interesse anf dit Totalität eines Dinges gerichtet ist. so nemnen wir es mit eigenem Namen. Der Eigenname kennzeichnet den Eigenwert. Das Kind nennt sein Spiclzeng. der Reiter sein Pferd, die Mntter ihr Kind mit eigenem Namen. Wie wichtig und bedeutsam sind sie für einander in der Sphäre des Lebens! Aber im Reiche der Geschichte sind diese namenlos und in das Allgemeine anfgenommen.

Verschieden ist in der Sphäre des Lebens das Interesse an der Individualität. Den einen Menschen interessiert diese, den anderen jene Gestalt. End wenn uns ein Gegenstand in seiner Eigenart wichtig ist, oder wemn wir ihn lieben, nennen wir ihn beim Namen. Lnd wem msere Liebe gar groß und mächtig ist, können wir nicht genng Namen finden. um den geliebten Gegenstand zu rufen und zu bezeichnen.

Wir berühren mur flüchtig jene Stufe des Erkenntnisinteresses. wo gewissermaßen eine Nentralisierung der beiden Richtmngen des Denkens zn konstatieren ist, wo weder die Hinwendung zum Allgemeinen noch die Hinwendung zum Besonderen mit roller Energie betont ist. Wo die Hinwendung zum Allgemeinen vorliegt und doch anch wieder durch eine gewisse Tendenz, das Individuelle zu wissen, gehemmt wird. Der Peiter nennt sein Pferd mit Namen, aber der Hirt kennt vielleicht nur das weiße, das schwarze, das starkwollige. das bekreuzte Lamm. Anf jeden Fall aber gibt es ein weites Gebiet des Lebens. wo das Interesse am Allgemeinen rollkommen überwiegt und die Individualität weder durch Eigennamen noch durch charakteristische Merkmale anfrecht erhalten wird. Die Blätter des Banmes, die Sandkörner am Strande des Meeres. die Bausteine des Hauses, die weißen Schneeflocken, die Grashalme des Rasenplatzes - sie gelten mir in der Regel nicht als Individualitäten. wem sie anch für mich individuelles Interesse erlangen können. Würde mich überall dic Individnalität interessieren, würde ich alles mit Eigennamen nennen wollen. so stände ich vor ciner unlöslichen Aufgabe und käme mit meinem Erkennenund Terstehenwollen nicht rom Fleck. Das Tnteresse am Algemeinen erlöst 
uns von der Qual, ewig die Individualität zu suchen. Es gibt uns die Mögliehkeit und Freiheit, eine Auswahl ron Wenigem in seiner Individnalität zu lieben und zu begehren.

Seltsam, daß der Richtung des menschlichen Denkens und der Art unseres Empfindens gemäß das Geringste und das Höchste namenlos ist. Das Sandkorn und die Gottheit. Das cine ist des Namens nicht wert, und Ihn nennen keine Namen. Für das eine ist die Namengebung zu bedentungsreich, für das andere zu beleutungsarm.

Wenn auch die ethische Forderming bestehen mag, in jedem Menschen die Persönlichkeit zu suchen und zu ehren, so besitzen doch in der Sphäre des Lebens und des täglichen Umganges bei weitem nicht allo Menschen ein individnelles Interesse für mich. Wohl aber pflegt sich das Interesse, das wir an Menschen nehmen, vielfach in der Weise zu wandeln, daß sie, die nns früher nur das Exemplar eines Allgemeinen bedenteten, inden wir uns damit begnïgten, in ihnen lediglich den Angehörigen eines bestimmten Standes oder Bernfes oler den Typus einer gewissen Menschenklasse zu sehen, daß diese Mensehen nun anf einmal in ihrer Totalität gewertet werden, indem das Interesse am Allgemeinen in das persönliche Interesse umschlägt, und das Unbekannte zum Bekannten wird; so z. B. wenn der Reisegefährte, mit dem der Zufall mich zusammenführte, sich als Bernfsgenosse, der Berufsgenosse als gleichstrebender Mencch sich enthällt, und dieser mir in seiner Eigenart zum Erwählten, zum Freund und Tertrauten wird.

Dies Interesse am Individuellen nnd Allgemeinen, wie wir es in der Unmittelbarkeit des Erlebens zu nehmen gewöhnt sind, führt in der wissenschaftlichen Welt zur Aufstellung verschiedener Ziele und dementsprechend zu einer ver chiedenen Form der Lrteilsbildung mnd Begriffsbildung. Im Leben bezeichnen wir und geben Namendem Einzelnen oder der S'mmme des Einzelnen zum Zweek der Terstänligung. Aler diese Wortbedentungen, die wir den rorgestellten Gegenständen beilegen, geben uns noeh nicht den logischen Sinn, den Begriff des Gegenstandes. Nur zu leicht glauben wir, den Gegenstand zu wissen, wenn wir ein Wort für ihn geprägt, wenn wir ihn bezeichnet haben. Aber die Wortbezeichmung ist nur ein Hinweis auf den Gegenstand, mit der sich zugleich rine gowisse Horaushelung des Gemeinsamen ans der Fülle des Wirklichen vollzicht. Die Leistmog der Erkemntnis beginnt erst mit der wissenschaftlichen Reflexion anf den Sinn des Gegenstandes. Die Reflexion auf das Gleiche und auf das Verschierlene ist es aber, welehe die Bildung der versehiedenen Begriffsfromen bestimmt mol in Natmwissensehaft und Geschichte ein so entgegengeret \%tes Ziral der Erkenntnis errichtet. Von dem Prinzip der Versehiedenheit galeitet, gelangt die Geschichte \%ur Mannigfaltigkeit der individuellen Formen in ihrer Einzollecit und Bimmatigkeit; durch die Idee des Gleichen bestimmt, «relangt die Natmrwissonschaft zur Einheit der Natur als der Gesetzmäßigkeit des Mllgameinen in Wechsel und Wiederkeder der Erseheinungen.

IVir stoben hier anf jene beiden Formen des Denkens, die fïr die Bildung

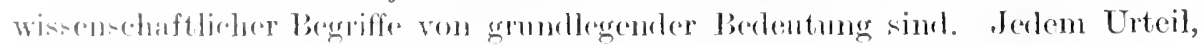

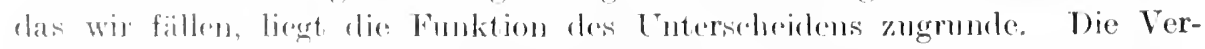
hindmeg zwischen zwoi Vorstellumgsinhalten, die sich im Irteil vollzieht,

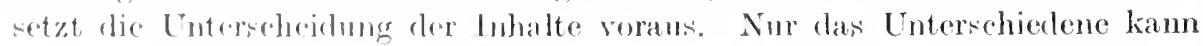


verbunden werden. Damit aber etwas verbunden werden kann, muß es auch in gewisser Weise gleich oder ähnlich sein. Die Verbindung des vollkommen Heterogenen ist unsinnig. (Die Gerechtigkeit ist grïn.) Solehe Lautreihen können weder als Urteile noch als Sätze in logischer Hinsieht bezeichnet werden, weil sie der Sinneinheit rollkommen entbehren. Dagegen führt die Verbindung des absolut Gleichen zur leeren Tautologie, dem sogenannten identischen Urteil. (Mensch ist Mensch.) Zwischen diesen beiden Polen liegt alle Urteilserkenntnis.

Zwei entgegengesetzte Tendenzen des Denkens treten hier herror: der Geist der Einheit, der zum System führt, der die Mannigfaltigkeit üljerwindet, jener stolze, herrische Geist, der das Besondere zum Opfer bringt. Der siegreiche, überwindende Geist. Und jene andere Riehtung des Denkens. die anf Reichtum, Fülle und Mannigfaltigkeit gerichtet ist, die das einzelne aufbewahren und festhalten will. Der Sinn für Indivichalität und besondere Gestaltung. Der liebevoll verstehende Geist. Wer hätte nicht die eine oder die andere Denkrichtung in sich beobachtet, wie sie einem ganz bestimmten Ziele zueilt. Haben wir nicht eine Tendenz in uns erlebt, die darauf ausging, in absoluter Einheitssehnsucht der Struktur eines einzigen Begriffes das Luiversum zu unterwerfen? Oder jene andere, die ein leidenschaftlieher Gegner ist aller gewaltsamen Konstruktionen, die nicht genug Begriffe bilden kann, um der Mannigfaltigkeit und Buntheit des historischen Lebens gerecht zu werden? Beide Grundformen des Denkens sind für die Erkenntnis notwendig. Jedes Urteil und jeder Begriff ist Einheit einer Mamnigfaltigkeit. Da gibt es Gebäude des Denkens, in denen bis aufs änßerste die starre Einheit betont ist, und andere, die dem Prinzip der Mannigfaltgikeit die größte Konzession machen. Die Richtung auf das Mannigfaltige läßt den Reichtum der Individualität hervorgehen, die Richtung auf Einheit ordnet das einzelne dem Allgemeinen unter.

Reflektieren wir auf das Gleiehe und Ähnliche der Dinge, so nähern wir uns den Gebilden der Mathematik und Naturwissenkchaft. Was wir als gleich anerkannt haben, bewahren wir auf in der Form des Allgemeinen. Das Allgemeine ist in diesem Falle das Gemeinsame, das, was bei allem in gleicher Weise vorhanden ist. Reflektieren wir aber auf das Terschiedene. Eigenartige, so formen wir das Individuelle.

Wenn nun die Gesehiehte das Individuelle sueht. formt und gestaltet. und so, wie es scheint, die Lebenseinheiten des Wirklichen zu erreichen bemüht ist, so darf sie doeh durch dieses ihr Bestreben nieht dahin geführt werden, die Mannigfaltigkeit als solehe einfach zu bejahen und hinzunehmen, ohne den Versuch zu machen, sie zu vereinigen und zu rerbinden. Wenn somit anch die Geschichte im Gegensatz zur Naturwissen-chaft in allem das Prinzip der Mannigfaltigkeit betont, so ist sie ron der absohuten Mannigfaltigkeit doch weit entfernt; ebensoweit wie die Naturwissenschaft weit davon entfernt ist, das eine in allem zu sehen. Es wird die Aufgabe der Gesehichte sein, die Tergangenheit mit der Gegenwart zu verbinden und nach verwandten Zügen im Bilde der Vorzeit zu spähen. Sie wird aber auch der Mannigfaltigkeit im weiten Umfange Rechnung tragen und in die Eigenartigkeit eines fremden Kulturkreises einzudringen suchen. 
Damit ist die allgemeine Pichtung des historischen Denkens eindeutig bestimmt. Noch aber stehen wir bei der individuellen Gestalt der historischen Wirklichkeit. In ihr kann unmöglich das Ziel der Geschiehte ruhen. Sie wird das künstlich für die gesonderte Betrachtung und Erforschung Isolierte auch wieder einstellen in den großen Zusammenhang des Gesehehens. Mit den isolierten Tatsaehen. Vorgängen. Handlungen, Gestaltungen. Bewegungen der Vergangenheit, die wir der Versunkenheit und Vergessenheit entrissen, deren stumme Sprache wir verstanden, deren Stimme wir wieder laut werden ließen. und deren Starrheit und Abgesehiedenheit wir durch die Glut unserer Anteilnahme und unseres Mitgefühls belebt haben, durch sie allein besitzen wir noch keine Erkenntnis des historisehen Gesehehens. Wir müssen wissen, wie sich das eine zum anderen verhält, wie das eine aus dem anderen hervorgegangen ist, wie es so sein mußte, um so zu werden, wie es so ist, weil es so gewesen war. Wir wollen das einzelne verstehen, wir wollen aber auch das einzelne aus dem einzelnen begreifen, das eine aus dem anderen erklären, schauen, wie das eine aus dem anderen folgt, und verstehen lernen, daß dieses nur da sein kann, wenn jenes ist. Und so können wir die Aufgabe und das Ziel der Geschichte vorläufig dahin formulieren: da $B$ sie, von dem Prinzip der Versehiedenheit geleitet, die Mannigfaltigkeit der individuellen Formen in ihrer Einzelheit und Einmaligkeit in einem erklärenden Wirkungszusammenhang darzustellen sueht.

\section{§ 2. Der zweite Problemkreis. Die Probleme des historischen Objektes.}

Mit der Frage des Zieles geht auf das engste zusammen die Frage des Gegenstandes oller, wie wir lieber sagen wollen, die Frage dles historischen Objektes. Wenn wir ron dem Ziele der Geschiehte reden, von den Aufgaben, die sie als wissensehaftliche Leistung zal erfüllen hat, so müssen wir auch jenes Etwas kennen, das diesen Ziele entgegengeführt wird. Dieses Etwas sind augenscheinlich die mannigfaltigen Gestalten des Wirkliehen, die, wie wir gesehen haben, in der Geschichte ihre Individualität bewahren sollen. Wie werden diese Gestalten des Wirklichen gedaeht, wie erseheinen sie vor dem Blick des Historikers? Sie sind nieht fest und bleibend und beharrend, wie die Elemente der Naturwissenschaft, sie kommen und gehen, sie treten auf und rersehwinden, sie lösen einander ab. Aus der versunkenen Herrliehkeit des Alten wiehst las Neue hervor und trïgt Blïten und Früchte und ist groß und stark und mächtig. Lat es aher seine Vollendung und die Sehönheit seiner Gestalt entfalteot, int es zum mächtigen Schicksal, zum Segen oder lineh geworlen, dann verschwindet es wieder und mub zugrunde gehen. Die Gestalten dos Wirklichen, mit denen es die Geschichte zu tum hat, lösen einander ab, erehen anseinander herror und vergehen wieder, indem die nachfolgenden

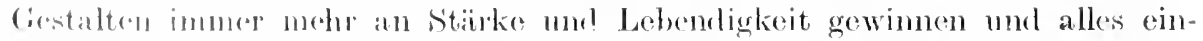
bezogen int in den ainen Sitrom des Geschehens. Das Bikl von dem FluB, von dem Strom des Geschehens, wie es so hïufig auf den historischen Verlauf

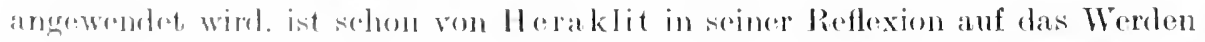

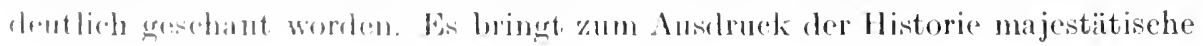


Pracht, den ewigen Wechsel, das immer Neue, demn wie Woge von Woge abgelöst wird, ähnlich und doch stets verschieden, so folgt aufeinander der große Schicksalslauf der historischen Gestalten, und aus geheimnisvollen Tiefen tauchen Wunder und Rätsel auf. Und die Bestimmung des historischen Geschehens durch das Bild des Flusses gibt auch wieder jenes Steigen der Lebenswogen, jenen immer größeren Reichtum der Gestalten, der um so mächtiger wird, je mehr wir uns dem Ende nahen, dem freien Einströmen in das Neer der Unendlichkeit.

\section{a) Das Geschehen als Objekt der Geschichte.}

Man hat wohl gesagt, daß es die Naturwissensehaft zu tun habe mit dem Bleibenden im Wechsel, die Geschichte aber mit dem Wechsolnden im Bleibenden. In dieser Definition wird nairdogmatisch rorausgesetzt, daß es ein Bleibendes und ein Wechselndes gibt. Der Naturwissenschaft kommt es vor allen Dingen auf die konstanten Elemente des Wirklichen an, die unveränderlich sind, ebenso wie die Gesetze, nach denen die Bewegung dieser Elemente sich richtet. Die Geschichte interessiert die Veränderung, das Geschehen, der Wechsel der Gestaltungen und sie reflektiert nicht auf den bleibenden Wesenskem im Wechsel der Bewegung. Das Bleibende ist hier gewissermaßen das Ganze. die historische Welt, in der das Geschehen stattfindet, jene Welt, die im Ganzen sich gleich bleibt, wemn auch das einzelne immer verschieden ist. Die historische Welt ist eine Welt, die uns in ihrer Totalität niemals gegeben ist, die für mns keinen Anfang besitzt und kein Ende und so für unsere Erkenntnis immer den Charakter des Fragmentarischen trägt, weil der Wissensstandpunkt für die historische Betrachtung immer ein neuer wird, indem zugleich immer wieder neue Gestaltungen die Kette des Werdens vergrößern und so unsere Einsicht erweitern. Die Naturwissenschaft hat gewissermaßen die vollendete Welt vor sich, und wir kömnten uns ein Stadium ihrer Entwicklung denken, wo die Elemente der Natur ein für allemal gefunden und erschöpfend bestimmt wären, wo wir auch absolute Kenntnis gewonnen hätten ron den Gesetzen, die diese Welt regieren. Dann würden wir wohl noch neue Erscheinmgen finden, aber diese ließen sich restlos zurückführen auf die erkannten und erwiesenen Grundphänomene der Natur. Ganz anders in der Historie, wo dem Vertrauten und Bekannten des Gewesenen immer wieder ein neues großes Unbekanntes ron selbständigem Charakter zugeführt wird.

In dieser Vorstellung, daß es die Geschichte mit dem Geschehen oder auch mit dem Bleibenden im Geschehen zu tun hat, ist noch nichts darüber entschieden, ob die Totalität des Wirklichen Objekt der Geschichte ist, oder ob der Historiker nur einen Teil, einen Ausschnitt des Wirklichen zur Darstellung bringt. Es könnte ja sehr wohl sein, daß alles Wirkliche in die Form des Geschehens einginge und so ron der Geschichte zur Darstellung gebracht wird. Diese Auffassung scheint auch von Ranke vertreten zu sein, wenn er die Behauptung aufstellt, daß es Aufgabe der Geschichte sei, darzustellen, wie alles so geworden ist. Danach soll sie doch augenscheinlich die ganze Lebensfülle der Zeitalter und Epoehen aus der Fülle des vergangenen Lebens erklären. 


\section{b) Totalität oder Auswahl?}

Auf jeden Fall gibt es zwei Möglichkeiten, das Objekt der Geschichte zu denken, nämlich entweder so, daß man die Totalität des Wirklichen der historischen Forschung zuweist, oder daß man nur einen Ausschnitt des Wirklichen als das eigentliche Feld ihrer Tätigkeit ansieht.

Nehmen wir den ersten Fall, so gibt es anch hier wieder zwei Möglichkeiten, nämlich entweder so, daß die Geschichte imstande ist. die Totalität des Wirklichen zu erfassen. Dann ist sie im eminenten Sinne Wirklichkeitswissenschaft, und jede andere Form dor Erkenntnis bedeutet eine Abstraktion voon dem Leben, mit dem es die Geschichte zu tun hat. Oder die Geschichte ist nicht imstande, dic ganze Fülle des Wirklichen zu erfassen. Trotzclem könnte ihr aber die Aufgahe zufallen, der absohuten Erforschung des Wirklichen sich so weit wie möglich anzunähern.

Im anderen Falle wird behauptet, daß das Objekt der Geschichte niemals die ganze Wirklichkeit oder das ganze Leben sei, und zwar nicht nur, weil das Wirkliche der historischen Erforschung Schranken setzt, sondern weil es dem Charakter und Sinn der Geschichte so entspricht, die ganz bewuBt, von ihrem bestimmten Interesse geleitet, eine Auswahl am Wirklichen vollzieht.

Wenn die Geschichte imstande ist, die Totalität des Wirklichen zu erkennen, so wird sie zur Königin unter den Wissenschaften, indem sie uns das wahrhafte Weltleben offenbart. Bei einer solchen Auffassung der Geschichte wird im Gegensatz dazu die Leistung der Naturwissenschaft sehr gering eingeschätzt werder. Sie ist dann eime Wissenschaft, die an das Wirkliche niemals herankommt, die seinen Gehalt nicht auszuschöpfen, ja nicht einmal einen Teil, einen Ausschnitt des Wirklichen zu gewinnen vermag, sondern in blassen Abstraktionen sich von der Wirklichkeit entfernt, Diesem Vorwurf der Abstraktion kann dann die Natwwissenschaft durch den Einwand begegnen, daß es die Geschichte doch nur mit den groben Konturen der Wirklichkeit zu tun habe und an der Oberfläche bleibe, weil sie aus Pietät vor der Gestalt des Lebens sich nicht entschließen kann, eine kraftvolle Analysis durchzuführen. Die Naturwissenschaft aber vermag gerade vermöge der Analysis in die Wirklichkeit einzudringen und sie in allen ihren Teilen zu konstrnicren.

Dem Gedanken, daß es die Geschichte mit der 'Lotalität des Wirklichen zu tun habe, stehen unäberwindliche Sich wierigkeiten entgegen, weilder Geschichte diese Totalität niemals gegeben ist. Die Aufgabe der Wissensehaft ist ja überhaupt eine unendliche, und auch die Naturwissensehaft wird ohne Zweifel auf ihrem Wege der Analysis und Abstraktion nie zum Ziele gelangen. Aber der Naturwissenschaft ist doeh die Natur gewissermaben gegeben, da zu dem, was cinmal $z u$ ihr gehört, nie etwas hinzukommen wird. Bei der Naturwissenschaft hängt ja nun eimmal alles Interesse an den Elementen und nicht an len Gestalten und Produkten des Wirklichen. Ganz anders in der Geschichte, da ist das wirhtigste Erkemntnisohjokt oin Gewesenes, nicht mehr Daseiendes und (ixgrebenes. Dieses Vergangene ist uns in Denkmïlern anfluewahrt, die selber eine richöpfung und Leistung des Menschengoistes sind. Aus dienen Leistungen d.r Vergangenheit entspringt dic Gegenwartsleistung der Erkenntnis. Jieso Donkmäler der Vorgangenheit aber sind nur zum geringen Teil erhalten und anflewalde. Sohr vich ist endguiltigem Vergessem anheimgefallen, und 
nur an den aufbewahrten Denkmälern kamn sich der crkennencle Geist des Historikers betätigen. Damn hat er noch die Gegenwart als das aus der Vergangenheit zu Erklärende zum Objekt der Erkenntnis, diese Gegenwart, die dem historischen Verstehen so große Schwierigkeiten bereitet. Wenn wir den Begriff der historischen Gegenwart richtig fassen, so dürfen wir darunter nicht nur das absolut Gegenwärtige verstehen, den Zeitpunkt, an dem sich das Individum augenblicklich befindet. In der Geschichte erhält die Zeit eine gewisse Dauer und Stabilität durch den Gedanken des Zeitalters. Das Gegenwärtige in der Geschichte ist das Zeitalter, das durch verwandte Gefühle. Gedanken und Ideen geeinigt ist, die ihren Niederschlag in allen Leistungen und Produkten eines bestimmten Kulturkreises gefunden haben. Das ist die Epoche, in der wir leben, die Zeit, der wir angehören. Wir verstehen sie wohl am besten von allen Zeiten, und doch bereitet sie einer unbefangenen Würdigung die größten Sichwierigkeiten, weil es unser Zeitalter ist, in dem wir notwendig Partei sein müssen. Endlich hat es die Geschichte aber auch mit dem Zukïnftigen zu tum, und dieses Zukünftige ist das Unüberwindliche, das immer neue Gestalten hinzubringt und dem erkennenden Geist keine Ruhe läßt bis ans Ende der Geschichte.

Dem Wirklichkeitscharakter der Geschichte steht also die Tatsache entgegen, daß der Zugang zu diesem Ganzen der Wirklichkeit der Historie ein für allemal verschlossen ist, und zwar besonders wegen der fragmentarischen Denkmäler der Vergangenheit, wegen der Leidenschaften der Gegenwart und schließlich auch wegen der immer neuen Gestalten der Zukunft. deren Aufhören das Ende der Geschichte bedeuten würde. Wie aber dies Zukïnftige beschaffen sein möge. das kömen wir aus clem Charakter der Vergangenheit und Gegenwart nur zum geringsten Teil erschließen.

Da nun die Denkmäler der Tergangenheit verhältnismäßjg nur gering an Zahl sind und um so unvollkommener. je weiter wir in die Vergangenheit zurückgehen, so muß eine absolute und restlose Ausbentung der Tradition als selbstrerständlich erscheinen, wenn die Tendenz der Geschichte tatsächlich auf das Ganze der Wirklichkeit gerichtet ist. Und doch finden wir, daß der Historiker nicht alles das in die Geschichte aufnimmt. was er in Denkmälern entdeckt und gefunden hat. Uns ist manches überliefert, was der Historiker der Gegenwart nicht mehr für wert der Darstellung erachtet. Der Chronist eines früheren Zeitalters wollte es festhalten, ihm schien es merkwürdig und interessant zı sein, für den Historiker der Gegenwart aber besitzt es keine Bedeutung. Jener hat die Aufgabe der Geschichte anders rerstanden wie wir sie verstehen. Jedes Kuriosum erschien ihm der Aufbewahrung wert.

Es läßt sich nicht lengnen, daß der Historiker manches beiseite läßt ron dem, was die Tergangenheit aufbewahrt, und daß er ebensowenig bestrebt ist, alles, was in der Vergangenheit geschieht, zur Historie zu machen oder als historisch wesentlich zu betrachten. Der Begriff eines hist orischen Torganges. der uns ja allen gelänfig ist, impliziert bereits, daß es Torgänge gibt, die nicht historisch sind. Der historische Torgang, die historische'Tat, die historische Situation, so werden wohl Ereignisse ron uns bezeichnet, über denen eine gewisse Weihe liegt, Geschehnisse, mit denen wir hänfig ein Gefühl lebhafter Rührung und Ergriffenheit verbinden. Der Grund dieses Gefühles läßt sich vielleicht ganz schlicht und einfach dahin präzisieren. daß es der I'berzengung 
entspringt, wir sind weitergekommen, dem es ist etwas Nenes geschehen, was noch niemals da war, und weiter: es gibt mensehliche Größe, denn das, was geschehen ist, dazu gehörte mehr als der Verstand des Durchschnittsindiridumms.

Es läßt sieh jedoch einwenden, daß das, was hier ein historischer Vorgang genannt wird, was man als historisehe Situation mit dem Hochgefühl dankbarer Frende erlebt, historische Ereignisse im eminenten Sime des Wortes sind, die im Laufe der historischen Entwicklung die großen Wendepunkte des Geschehens bilden und mit sehieksalsschwerer Bedeutung verknüpft sind. Man muß demmaeh unterscheiden zwischen den großen Ereignissen, die ihr eigenes und selbständiges Leben leben, und jener Flut ron historisehen Kleinigkeiten, die niemals ausdrüeklich genannt, aber immer implicite mit gemeint sind. Gehört nicht in die Geschichte auch die Entwicklung der Mode und die Knltur der Früchte? Wir werden es nicht leugnen. Folglieh gehört in die Geschiehte auch die Gesehiehte les Fächers, der Hutnadel und des Limonenbaumes. Wir müssen es zugeben. Aber gehört in die Gesehiehte auch das schicksal jedes einzelnen Fächers in seiner Besonderheit, die Gewimnung des Materials, aus dem gerade er geworden, seine Herstellung, die Eigenart der Gestalt, durch die er sich ron anderen mnterseheidet, die Bewegungen, in die ihn seine schöne Besitzerin versetzt, die zarten Berührungen, die von ibm ausgegangen, die Epoche seines Glanzes und sein tragisches Ende? Gehört in die Gesehichte auch das Schieksal jeder einzelnen Limone? Ihr Werden und Wachsen in der besonderen Umgehung eines Blätterkranzes von leuehtendem Grün, ihre eigentümliehe Farbe, das Werden der kleinen Rumzeln und Vertiefungen anf ihrer Schale, die besondere Art und Wcise, dureh die gerade sie rom Baum gepflïekt, verkauft, verladen, zubereitet und verzehrt werden? Wer wollte es lichaupten! Und ebensowenig können wir sagen, daß die Gesehichte des Fïhers und die Geschichte der Limone anch alle die individuellen Erlelmiss: und Schicksale meint, dio dem einzelnen Fächer und der einzelnen Jinone auf ihrer Erlobnisreise zustoßen.

Die Geschichte des einzelnen individuellen Fächers kann wohl die Phantasie des D)ichters in märchenhafter Ausgestaltung zum Symbol des Menschlichen machen oder ihn in beckentungsvoller Weise mit menschlichem Sehicksal verliniijfen. Anch kann viclleicht der bestimmte Fïcher im höfisehen spiel der Intrige eine historische Bedentmug gewinnen, aber weder für das Spiel der Thantasie noch im Sipel der Tutrige wirl jeder Fïcher kïnstlerisch oder historisch bedentsam. Historisch herlentsam wurde etwa jener bestimmte Fächer Jer Marquise von Pompadour, kimstleriseh bedentsam kamn jeder beliebige "xistionende oder nicht existicrende Fïcher als Symbol des allgemein Menseh-

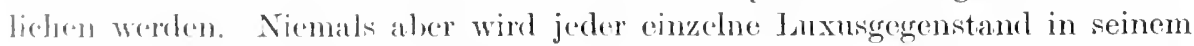
indivinellen Merden mul Vergehen zum Geurenstand der Historie. Was ist mun alse dasjenige, was ein (Jbjekt zu eincm historischen macht, wenn nieht

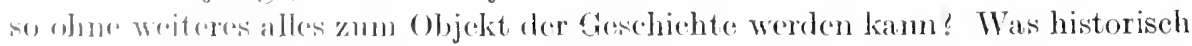

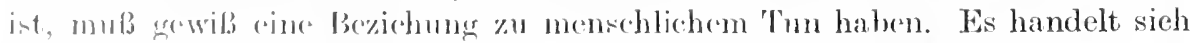

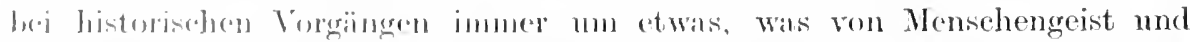

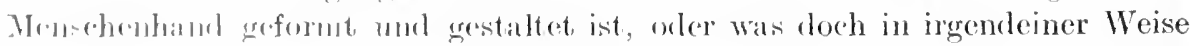

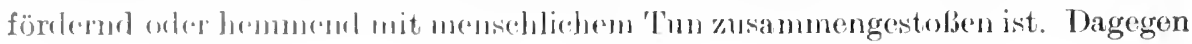


können wir uns Naturvorgänge des organischen und anorganisehen Lebens denken, die sich abspielen fern von uns und ungesehant von uns. Sie haben für uns keinen Wert und keine Bedeutung, sie haben keinerlei Beziehung zu uns und sind infolgedessen rollkommen unhistorisch. Aber wie ist es mit unserem Beispiel bestellt? Die Gesehichte jedes Fächers und jeder Frucht hat doch eine Beziehung zu menschlicher Tätigkeit, und trotzdem müssen wir ihren historischen Charakter remeinen.

Das sehwierige Problem, welches wir soeben berührten, können wir an dieser Stelle noch nicht auflösen. Auf jeden Fall hat es die Gesehichte nicht mit dem Ganzen der Wirklichkeit zu tun, sondern mit besonderen Phänomenen, deren Charakter etwa Auguste Comte als ,sozial" bezeichnet hat, indem er damit ausdrüeken wollte, daß diese Phänomene, woran wir nieht zweifeln können, eine Beziehung zu mensehlichem Tun, zu mensehlieher Gesellsehaft und schließlich zur Idee der Menschheit besitzen ${ }^{1}$ ).

Wenn wir der Geschiehte die Aufgabe stellen, wiederzugeben alles, was war, und zu schildern. wie alles geworden ist, so verlangen wir von der Historie nicht nur etwas, was sie niemals erfüllen kann, sondern auch etwas, was sie niemals erfüllen soll und darf, was gar nicht in ihrer Absicht und ihrem Interesse liegt. Die historisehe Wirklichkeit ist niemals die Wirklichkeit des Lebens und will aueh diese unsere Welt des Lebens nicht sein. Der historisehe Vorgang ist nicht der lebendige Vorgang des wirklichen Geschehens. An den Vorgängen des Lebens gewinnt irgend etwas historische Bedeutung: irgend ein Willensentsehluß, irgend ein Gedanke, irgend eine leidensehaftliche Erregung des Gefühls. Sie alle gingen über die Erlebniswelt des einzelnen hinaus. Sie drängten nach Objektivierung, nach Gegenständliehkeit. sie führten die wertvolle Leistung herbei. Die Historie hat solehe Vorgänge zu isolieren und als Gegenstände ihres Studiums und ihrer gesonderten Betrachtung aus dem Lebenszusammenhang herauszuheben.

Wenn wir aber behaupten, daß die Geschiehte die Fülle des wirklichen Lebens niemals darstellt, so soll das keine Herabsetzung der Historie gegenüber dem Leben bedeuten. Es könnte ja sein, daß dasjenige, was die Historie nicht in begriffliche Erkenntnis umsetzen will und kann, ohne jede Bedeutung ist und deswegen ruhig dem Vergessen anheimfallen kamn.

\section{c) Rationalismus und Irrationalismus.}

In der Bestimmung des Verhältnisses von wissensehaftlichel Erkenntnis des Wirklichen und dem Wirklichen selber oder, wie wir aueh kurz sagen könuen, von Begriff und Leben sind in der Philosophiezwei entgegengesetzte Auffassungen vertreten worden. Nach der einen ist der Begriff so viel mehr wert wie das Leben; nach der anderen ist das Leben so viel mehr wert wie der Begriff. In den Begriffen der Gesehichte ist niedergelegt und aufbewahrt alles das, was historisch wertroll ist in dem großen Bereiche des Lebens. Das Leben selber aber ist noch jene unberührte, durch keine Reflexion beschränkte und getrübte Einheit des Wirkliehen.

1) Anguste Comte: Cours de philosophie positive. 
Der Anwalt des Lebens behauptet, dab das Leben mersehöpflich und reich sei. Sein Reichtum und seine Fülle gehe nicht ein in clie dürren Formen der begrifflichen Abstraktion. Das Leben sei so mendlich viel mehr, als der Begriff zu fassen vermag. Dureh den Begriff entweicht die köstliche Fülle und Schönheit. Der Anwalt des Lebens sträubt sieh gegen jede Begrenzung seiner Tnendlichkeit. Das Leben soll so bleiben, wie es ist. Es soll nicht umgredeutet und rerunstaltet werden. Was vermag demn die kalte und nüchterne Theorie gegen das blühende und mächtige Leben! Der Anwalt des Lebens liebt das Rätselhafte und Unbegreifliche, und er verkündet uns, daB das Wissen weiter reicht als der Begriff. Es gibt ein Irrationales, das ich wohl wissen, aber nicht begreifen kamn.

Gegen den Anwalt des Lebens wendet sich nuit schroffer Entschiedenheit der Sehirmherr des Begriffes, der Rationalist. Er bet ont die Ohnmacht, Halbheit und Unvollkommenheit dieses wirkliehen Lebens. Der Begriff ist die ideale Forderung, die wir an das Leben stellen, und der das Leben niemals zu genügen vermag. Das Ideal der Art und Gattmng wird von keinem einzelnen erreicht. Anderseits ist es die Art und Gattung, die alles Wertrolle und Wesentliche am Einzelindividnm in sich schließt. Weit gefehlt, daß der Begriff ohnmäehtig ist, das Leben und die Wirklichkeit zu beherschen, erfaßt er vielmehr alles, was der Erkenntnis wert ist. Ja, der Begriff ist selber die wahre Wirkliehkeit, und das Besondere existiert nur, sofern es am Algemeinen teil hat. Das Algemeine aber ist dasjenige, was von der Vielheit des Besonderen gilt.

Wem wir diese entgegengesetzten Forlerungen erwägen, in denen der Gegensatz zwisehen Rationalismus und Irrationalismus zum Ausdruck gelangt, damn könnte es einen Augenblick so seheinen, als ob im Rationalismus der Idealismus zn Morte kommt, während rer Irrationalismus sich mit dem Positivismus verbündet. Es könnte so seheinen, als ob der Rationalismus sich im Begriff eine höhere Wirklichkeit aufbant, während der Irrationalismus nicht imstande ist, diese muscre plumpe simnliche Wirkliehkeit zu überwinden. l) (xwegen weheint aller wahrhaft wissensehaftliche Geist dem Rationalismus zuzustreben. während der Positivismms, der die Ninnlichkeit und das Leben $\therefore$ lieb hat, dem Dilottantismms und Skeptizismus notwendig anheimfällt.

Diese Auffassmng des Rationalismus als alleinigen Vorkimpfers des Idealismus erwichst ans der irrigen Ansicht, dab diestarke Betomung des Irrationalen

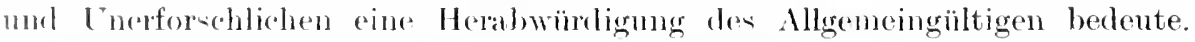
Jemgegenüber läßt sich zeigen, daß3 jenes Allgemeine, das der Rationalismus so häutig als das philosophiseh Allgemeingültige lchrt, gar nicht das wahrhaft Allgomone ist. Der Rationalismus begeht eine fundamentale Verweehsehung,

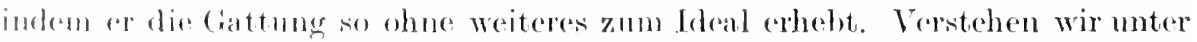
(atatung ain Allgemeines, das ron eincr Vietheit von Exemplaren gilt, clic sänstlich diesem lingriff untergeordnet werken können, so wird dasjenige, was das Judivilumm nit allen anderen gemeinsam hat, für den Rationalismus zom Irlesal. Wir kömnell uns diese Verwechselung recht dentlich machen an llom lingriff der Monschheit. Tnter Menschhoit verstehen wir einerseits rincon matumisnomshaftlichen Algemenhegriff. Dam ist Menschheit dasjonige. Was luei jerlem Mensehen anzutreffen ist. Also im (trunde genommen

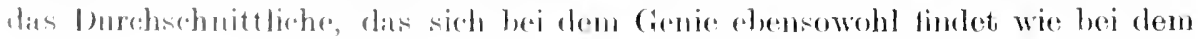


Idioten. Oder aber wir verstehen unter Menschheit eine Idee, die niemals erreicht und niemals wirklich ist, einen Inbegriff des Guten und Wertvollen, der für alle gilt. Er gilt nicht ron allen, aber $f$ ü $r$ alle. Liegt in jenem ersten Menschheitsbegriff die Yorstellung, daß es ihr allgemeines Los sei, schwach zu sein, so liegt in dem zweiten Menschheitsbegriff die Forderung der Uberwindung dieser Schwäche. Das, was in ilın gedacht ist, findet sich nicht an jedem und findet sich auch an keinem ganz. Die großen Persönlichkeiten stehen ihr so viel näher als die Schwachen und Niedrigen. Menschheit ist dann dasjenige, was für alle gilt, aber nur von wenigen erreicht wird. Menschheit ist dann etwas, was nicht da ist, sondern erst erreicht werden soll. Mag unter Menschheit mehr die ideale Persönlichkeit oder die ideale soziale Gemeinschaft verstanden werden, Menschheit ist immer dasjenige, was $\mathrm{für}$ alle gilt, nicht aber von allen gilt, dasjenige, was da sein soll, nicht aber, was da ist. Verstehen wir unter Menschheit den naturwissenschaftlichen Begriff der Gattung, so können wir behaupten, daß das allgemein Menschliche jederzeit in allen Individuen wirklich sei. Dies Allgemeine ist also immer da und wird immer da sein. Verstehen wir dagegen unter Menschheit das Ideal, einen sittlichen Wertbegriff, so ist die Menschheit dasjenige, was erst wird und sich im Prozeß der Geschichte vollendet ${ }^{1}$ ).

Diese Auseinandersetzungen waren notwendig, um zu zeigen, daß die Philosophie einen Begriff des Allgemeinen kennt, der sich sehr wohl mit einem durchgreifenden Irrationalismus verträgt, und der der Geschichte und dem Leben sehr viel näher steht als der naturwissenschaftliche Begriff des Allgemeinen. Wenn nun aber auch das nahe Verhältnis zu einem Allgemeinen, das der naturwissenschaftlichen Allgemeinheit fremd ist, der Geschichte und dem Leben eignet, wie auch in beiden ein starkes Herrortreten des Irrationalen bemerkbar ist, so darf diese Gemeinsamkeit doch niemals dahin führen, das Leben mit der historischen Wirklichkeit als der Welt der Geschichte zu identifizieren und somit der Historie die Aufgabe zu stellen, das Problem des Lebens zu lösen.

Die Geschichte ist keine Wirklichkeitswissenschaft in dem Sinne, daß sie die Totalität des Lebens verstehen will. Yom Leben kann es niemals eine Wissenschaft geben. Wohl gibt es Lebensweisheit und Lebenswissen, aber niemals Lebenswissenschaft. Wemn ich in der Wirklichkeit des Lebens den Freund oder Geliebten verstehen will, so geht mein Wunsch und meine Sehnsucht viel weiter, als den Forderungen des historischen Bewußtseins angemessen ist. An dem Freund und Geliebten ist mir alles wichtig und wertvoll, auch das, was anderen gleichgültig und uninteressant ist. Die Liebe geht auf das Verstehen des Ganzen. Sie will in der Tat die unendliche Mannigfaltigkeit der Individualität überwinden. Und mag die Liebe auch den höchsten Lebenswert bedeuten, so ist die Wertung der Liebe doch augenscheinlich individuell. Gehört doch zum

1) Nietzsches Begriff des Übermenschen nimmt eine eigentümliche Zwischenstellung ein zwischen dem naturwissenschaftlichen Tattungsbegriff und der sittlichen Idee der Menschheit. Sofern der Übermensch nicht da ist, sondern erst werden soll, ist er dem naturwissenschaftlichen Begriff der Menschheit nicht gleich zusetzen. Der Übermensch ist der Mensch der Zukunft und nicht der Mensch der Gegenwart. Anderseits unterscheidet sich der Begriff des Übermensehen von der sittlichen Idee der Mensehheit, sofern der Übermensch ein Erreichbares, die Idee der Menschheit aber ein Unerreichbares bedeutet. 
Wesen der Liebe notwendig die Illusion. Die Liebe hat ein Wissen von unendliehem Reichtum, aber dieser unendliche Reiehtum von Bedeutungen besteht nur für den Liebenden allein. Der historische Begriff kann diesen Reichtum nicht erwerben, er muß sich bescheiden und will sich auch bescheiden. Die historische Persönlichkeit, die der Forscher der Gesehichte herausarbeitet, der Held, der Staatsmann, der Feldherr, ist niemals die ganze Individualität, sondern dieIndividualität in ihrem allgemein gültigen Bedeuten, dieIndividualität, sofern sie der Gesamtheit, nicht aber dem einzelnen etwas ist. Wenn ich den Helden zu meinem Helden mache, so ziehe ich ihn von dem grofen Schauplatz der Geschichte in die enge Sphäre meines Eigenlebens und meiner Eigenwerte hinein.

Und so müssen wir auf das entsehiedenste betonen, daß die Gesehiehte die Fülle der Wirklichkeit weder darstellen kann noch will. Weder hat die Gesehichte, die bisher geschrieben wurde, diesen Zweck verfolgt, noch wird sich die Geschichte der Zukunft jemals diesen Zweek setzen. Würde die Geschichte jemals darauf ausgehen, die Fülle alles individuellen Werdens darzustellen, so wiurden die großen Höhenzüge der historischen Linienführung immer mehr an Dentlichkeit und Siehtbarkeit verlieren, un sehließlich zu versehwimmen und unterzutauchen in dem bunten und mannigfaltigen Gewühl des Gesehehens. Das Werden und Vergehen der Unbedentenheit des einzelnen wiurde in den Tordergrund treten, nicht aber das Schicksal des Großen, das dem Kleinen und Unbedentenden wiederum zum Sehicksal wird.

\section{d) Die Willenshandlungen der groBen Persönlichkeiten.}

Daß nicht jedes Geschehen historisch relevant ist, daß das Objekt der Geschichte einen Aussehnitt des Weltgeschehens bedentet, muß als feststehend angenommen werden, so schwierig es sein mag, die Grenzen dieser Auswahl anch nur in groben Umrissen festzulegen. Vielleicht mag in der Tendenz unserer jetzigen empirischen Geschichtsforschung etwas liegen von dem Bestreben, das Ganze des Geschehens zum Objekt der Geschichte zu machen und so den Gegenstand ihrer Betrachtung ïber Gebühr auszudehnen und zu erweitern, während etwa die Gesehichtsanffassung des deutschen Idealismus von einer entgegengesetzten Tendenz erfüllt war. Naeh Sehellings Definition des historisehen Objektes hat es die Geschichte mit den Willenshandhungen der großen Persönlichkeiten zu tun ${ }^{1}$ ). So gewiß Schelling in dieser Definition einen Faktor des historisehen Geschchens von entscheidender Bedeutung genant hat, so angenscheinlieh begrenzt diese Definition das Objekt der Geschichte viel zu eng und bereitet die gröbten Schwierigkeiten für eine logische Abgronzung der Geschichte von den anderen Geistesgebieten.

Die Dofinition Schellings will mur einen Teil des psyehisehen Lebens, nimlich das Willenslchen, soweit es sich in Hamllungen umsetzt, als Objekt dor Geschichte berïcksichtigen. Warum mur diese, mübte mosere erste Frago sein, warmu nicht anch das Willensleben, dessen Impulse nieht so kräftig waren,

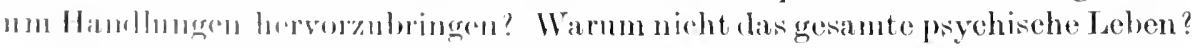

1) Sichelling: Sirstem des transzendentalen Idealismus. 
Was macht ferner die Größe der historischen Persönlichkeit aus? Und ist denn wirklich alles dasjenige, was die große Persönlichkeit tut, auch historisch? Wird sie nicht eine Fülle ron Handlungen begehen, in denen sie sich von dem beliebigen Durchschnittsindividumm nicht wesentlich unterscheidet? Gewiß gehört nicht nur das öffentliche Leben der großen Persönlichkeitender Geschichte, sondern auch das Privatleben des Helden ist zum großen Teil historisch relevant. So kann etwa das Liebesleben des Helden, sein Verhältnis zu Freund und Eltern historische Bedeutung gewinnen. Aber die großen Verhältnisse des Lebens haben nicht immer eine notwendige Beziehung zu den großen Verhältnissen der Geschichte. Das Heldentum des Lebens bleibt nur zu oft unhistorisch und soll unhistorisch bleiben. Was den Heroen am wichtigsten und wertvollsten gewesen, kann den Historiker unter Umständen am flüchtigsten interessieren. Er wird darin ṿielleicht eine Ka price sehen, eine Verirrung und Sch wäche, die er mit historischem Takt zu retuschieren unternimmt. Heldenglück und Heldengröße sind in den meisten Fällen disparat. Als Genießender tritt der Held in den Schatten des Lebens. An den Wendepunkten der Geschichte, den historischen Situationen, in denen sich seine Größe offenbart, leidet der Held. Die heroischen Menschen sind nicht glücklich ${ }^{\mathbf{l}}$ ). Heldentum ist ein großer Leidensgang. Denn das Heldentum verbindet sich mit dem Kämpfenden, nicht mit dem kampffrohen und kampfmüden Sieger. Der Held ist der Überwindende, nicht aber der Uberwinder. Seine Pose ist ror allem Bewegung und nicht Ruhe.

Wir haben in der Geschichte stets zn unterscheiden zwischen solchen Ereignissen, die an sich etwas bedeuten, und auf deren Darstellung es dem Historiker eigentlich ankommt, und solchen, die mur um anderer willen da sind, die sich als notwendige $Z$ wischenglieder in die Kette der historischen Geschehnisse einschieben, die illustrieren, beleuchten, Ǔbergänge vermitteln. Ganz augenscheinlich charakterisiert die geniale Schlachtenleitung unmittelbar die große historische Persönlichkeit und ist von primärer historischer Bedeutung. Dagegen ist etwa das ruhige Eheglück des Helden als solches historisch irrelevant, kann aber dazu dienen, in sekundärer Weise gewisse Eigenschaften seines Wesens zu verdeutlichen.

Schon Kant hat darauf hingewiesen, daß Kultur und Leben in einem gewissen Antagonismus stehen. In dem natürlichen Sinnendasein liegt das Glück des Tieres, aber in den Verhältnissen des intimen, persönlichen, alltäglichen Lebens liegt auch das Glück des Helden, denn der Rausch des Erfolges, der in den seltenen Weihestunden des Glïcks auch sein öffentliches Leben zur Quelle der Freude zu machen scheint und sein Herz mit dem stolzen BewuBtsein seiner Größe erfïllt, diese Stunden werden ihm vergällt durch Neid und Haß und Undankbarkeit. Auch lassen ihn die Lorbeeren nicht schlafen, sondern treiben seine Kräfte von neuem an, machen ihn rastlos, halten ihn in ewiger Spannung und entfernen ihn vom schönen und friedlichen Genießen. Weil sich der Held so viel mit Kultur befassen muß, leidet er so viel. Gesundheit und Genesung findet er nur, wenn er untertaucht in der Flut des Lebens.

Viele Handlungen, die der Held rollzieht, gehen nicht unter seinem Namen

1) Hegel: Philosophie der Geschichte. 
in die Geschichte ein. aber sie summieren sich mit den Handlungen anderer Individuen und bilden so mit diesen zusammen die Partikelchen einer politischen oder anch etwa einer großen wirtschaftlichen Bewegung. Wenn diese Art Handhungen des Helden, in denen er mit der großen Masse zusammen Produzent oder Konsmment ist, nach der Definition Schellings mit in die Geschichte hineingehören, so ist nicht einzusehen. warum nicht auch die ökonomischen Handlungen des schlichten Staatsbürgers an der Historie Anteil haben sollen.

Darüber hinans wird der Held aber auch ganz gewiß noch eine große Zahl ron Handlungen begehen, die rollkommen unhistoriseh sind. Oder sollen etwa die Trivialitäten des Ankleidens und Auskleidens sowie jene Fülle von Bewegungen, in denen sich der Rhythmus des Alltäglichen bewegt, von historischer Bedentung sein? Wir meinen, daß ebensowenig alle Handlungen des Menschen historisch sind, wie etwa alle Handlungen des Menschen den sittlichen Maßstab vertragen. Letzteres ist ron Fichte behauptet worden. Nach seiner Lehre fällt die Handbewegung, mit der ich den Kopf auf den Arm stütze, ebensowohl unter den Begriff des Sittlichen wie die große Tat heldenhafter Anfopferung. Nach Fichte ist all unser Tum ron dem Geist der Sittlichkeit umgeben. Wir stehen hier vor der außerordentlich wichtigen Frage der Kompetenz der einzelnen Merturteile oder Beurteihngen. Man könnte die Frage erheben, ob wir das ganze Universum bis in alle seine Einzelheiten unter den logischen, ethischen und ästhetischen Gesichtspunkt rïcken kömmen. Kamn für uns alles, was geschicht, zum (bjekt des Rechts oler Unrechts, des wahr oder falsch, des schön oder häBlich, des gut oder böse gemacht werden, oder gibt es Grenzen, über die hinaus gewisse Beurteilungen ihren Sinn verlieren? Hier nimmt das Theoretische eine Ansmahmestelhung ein: alles Wirkliche kamn unter den Gesichtspunkt der Wahrheit geriiekt werden, aller Weltinhalt steht in theoretischer Form. Aber für alle anderen Wertbenteilungen gibt es Grenzen. Und wemn Kant mit Pecht das sittliche Leben in nahe Beziehung zum IVillen und danit anch zmm Handeln gehracht hat, so sind doch deswegen alle Handhungen weder sittlich noch historisch relevant. Es giht hier ein großes Gehiet des Gleichgültigen, das sich diesen Formen der Beurteilung entzicht. Wohl aber kann alles zum fogenstand irgendeiner Beurteilmng gemacht werden. Es gilt eine Reihe ron Handhmgen, die ich ästhetisch, abor nicht ethisch qualifizieren kam. Und rlasscllbe gilt für die Geschichte. Aneh die großen Porsönlichkeiten, die das historische Leben erzengen und seine wechsehnden Gestalten in sich zentricren. sio gohören als Individualitäten nicht restlos der Geschichte an. Vieles von dem, Was sie sagen und tun, ist absoht mbhistorisch. Wüßten wir alle psychischen Vorgänge, die sich in der Secle des Helden abspielen, wiißten wir roin T'm bis in alle linzolheiten hinein, betrachteten wir ihn mit den geschärften Augen allumfassculer, durchdringender Menschenkenntnis, so müßte seine (Erïle verdunkelt worlen. Eine solehe Betrachtmosweise wïe mnhistorisch. I) (enn die Wahrheit der 'lat im historischen Simne ist das, was ans Licht getreten ist, nicht abor dasjenige, was in humpen Tiefen brütet. Die historische Percionlichkeit muls von allem Zufälligen und Allägliehen gereingt sein. In der

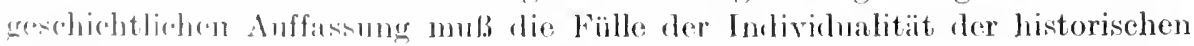

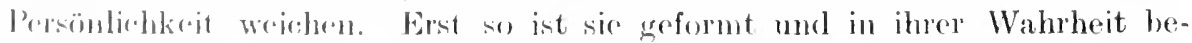
yriffe'11. 
Niemals darf der Historiker in ungebührlicher Weise das hervorheben, was die historische Persönlichkeit mit allen anderen gemeinsam hat: Erdenrest und Erdenschwere. Das Selbstrerständliche sollten wir in der Geschichte verschweigen, das Selbstverständliche, daß auch das Große nicht rein und fleckenlos, sondern menschlich ist. Die historische Art ist nicht absolute Tugend oder absolute Stärke, sondern eine eigentümliche Proportion von Stärke und Schwäche macht ror allem die Natur des politischen Helden aus. Die Leidenschaften sind ihm so notwendig wie Brennstoff dem Feuer. Das Auge des Historikers ist aber ror allem der hellen Flamme und nicht der trüben Naterie zugewendet.

Das darf natürlich nicht so verstanden werden, als ob der Historiker jemals verschweigen dïrfte die Furchtbarkeit der Leidenschaften, die große Reiche aufgebaut und zerstört haben. Aber an der Finsternis dämonischer Leidenschaften soll er aufleuchten lassen das Licht der Größe. Er soll die Leidenschaften nicht um ihrer selbst willen zur Darstellung bringen, sondern nur, sofern sie Kultur geschaffen und vernichtet haben.

Der Historiker sollte sich hüten, gar zu sorgsam den Irrgängen der menschlichen Seele nachzuspüren. Er wird sonst immer wieder den Versuch machen, das, was über den Durchschnitt hinausgeht, das Historische, aus dem Durchschnittlichen, dem Unhistorischen und Naturhaften, zu erklären. Dabei ändert sich aber gar zu leicht der Aspekt der Betrachtungsweise. Was über den Durchschnitt hinausgeht, ist natürlich für den Historiker das Wertrolle, denn er will, daß die Menschheit fortschreitet. Der Durchschnittsmensch aber baut keine neuen Welten auf. Die Dutzendmenschen und Durchschnittsmenschen lassen alles beim alten. Nit ihrer Natur unvereinbar sind die starken Reibungen und Spannungen, durch welche die Geschichte lebt. Was über den Durchschnitt hinausgeht, ist aber für den naturwissenschaftlichen Denker das Schlechte und Minderwertige, das Törichte und Verstiegene, dem das Durchschnittliche ist das Normale, und das Normale ist das Ideal des naturwissenschaftlichen Denkens.

Das naturwissenschaftliche BewuBtsein will das Bleibende und nicht den Wechsel, das Undifferenzierte und nicht die qualitativen Differenzen, das Allgemeine, für alle Gleiche und nicht das Besondere und Individuelle. Das historische Bewußtsein lehnt sich anf gegen das, was ewig in clem Gleise alter Gewohnheiten rerhart: nach nenen Ausdrucksformen ringt es und nach neuer Tat. Und dieses Neue, Seltsame, Rerolutionäre, auf dem alle Größe ruht, ist dem naturwissenschaftlichen Denken ein Produkt des Anormalen. Und so wird unter diesem Aspekt das Genie dem Verbrecher nahegerückt, denn sie teilen beide das Schicksal, rom Durchschnittlichen und Normalen abzuweichen. Glauben wir doch ja nicht, daß wir den Helden besser verstehn, wenn wir das Pathologische zur Erklärung seiner Größe benutzen!

Alle diese Überlegungen führen uns zu der Einsicht, daß wir als Objekt der Geschichte nicht wohl die Handlungen der großen Persönlichkeiten bezeichnen dürfen, wie es die Philosophen des deutschen Idealismus getan haben. Diese Definition ist zu eng, weil die Geschichte nicht ausschließlich ron den großen Persönlichkeiten handelt, und anderseits ist sie zu weit, weil nicht alle ihre Handlungen in die Geschichte eingehen. Dazu stecken in dieser Defi- 
nition, die so einfach aussieht, schwierige Wertprobleme, dem sie setzt den Begriff der historischen Größe voraus. Wichtig ist dagegen die Hervorhebung der Handlung bei dieser Bestimmung des historischen Objektes, denn in dem Begriff der historischen Handlung offenbart sich das Verhältnis der Geschichte zur Sphäre des sittlichen Lebens sowie zur Sphäre des Rechtes und des Staates, mit der sie ganz besonders eng rerbunden ist. Endlich komnt in dieser Definition auch die von Schelling so stark betonte Beziehung der Geschichte zur Tragödie zum Ausdruck, wie er sie in seinen geschichtsphilosophischen Jugendschriften dargelegt hat.

\section{e) Das psychische Leben.}

Suchen wir nach einer anderen Definition der Geschichte, so werden wir durch die für sie lange Zeit übliche und anch jetzt noch mit Nachdruck verteidigte Bezeichnumg als Geisteswissenschaft dahin geführt, das gesamte psychische Leben als Material der Geschichte zu denken. Abcr auch diese Definition ist recht unbefriedigend und sehr vieldeutig. Vor allem erhebt sich die Frage, was wir dem eigentlich unter Geist verstehen. In dem gewöhnlichen Sprachgebrauch und auch nach der Lehre vieler Philosophen und Psychologen fällt der Begriff des Geistes mit dem Begriff der Seele zusammen. Wenn wir ron geistigen Phänomenen sprechen, so meinen wir damit die psychischen Phänomene. Interpretieren wir also den Begriff der Geisteswissenschaft zunächst einmal mit der Wissenschaft rom psychischen Leben. Ganz augenseheinlich ist diese Defunition einerseits zu eng und anderseits viel zu weit.

Ganz gewiß gehört doch auch das Physische teilweise in die Geschichte. Das Prychische als solches ist niemals historisch wirksam, sondern mur, soweit es sich durch das Medium körperlicher Vorgänge in Leistungen unsetzt. Das geschichtliche Leben vollzicht sich nicht mu in den Köpfen der Indivichen. Die Gestalten, die in der Geschichte leben, sind Individuen, und ihre Leidenschaften, Gedanken, Wollungen, Bestrebungen und Gefühle haben die Form der Körperlichkeit nicht abgestreift. Nicht nur die Gedanken der großen Prrsönlichkeiten erfüllen diese reiche und schöne Welt, sondern anch der Austruck ihres Leibes, die Haltung und Bewegung ihres Körpers. Und neben diesen Großen geht auch die ungeheure Wirkung ler Massen in ihrer psychophysischen Leistung in die Geschichte ein. Gerade diese Tatsache, daß die Geschichte nicht isoliert in dem Simme, daß sie das Prychische rom Physischen tremnt oder etwa den Versuch macht, das eine auf das andere zu reduzieren, gibt den Gestalten, zu wolchen sie durch ihre eigentimuliche Begriffshildung gelangt, diesen Zanber ummittelharer Wirklichkeitsnähe und dem Verstehenden die Möglichkeit des Nacherlebens längrst entachwundener Zeiten. Daß Psychisches dureh Physisches und anf Physisches wirken kann, ist eine der Grundvoraussetzungen, welche dio Historie zu machen sich genötigt sicht. Dio Lehre vom prochophysischen Parallelismus, dab Psychisches und Physisches einander entspechen, aber nicht anfeinander wirken, kann als loanchbare naturwissenschaftlide 'l'henric angeschen werlen, sofern sie die Möglichkeit gibt, einen

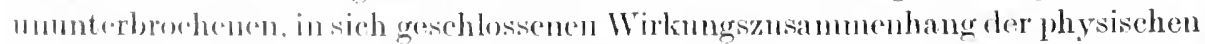

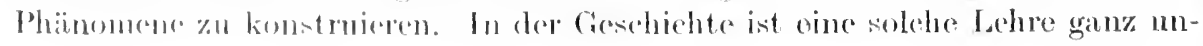


möglich und widersinnig. Das Leben der Geschichte ist keme körperlose Geisterschlacht ${ }^{1}$ ).

Úber den menschlichen Körper hinaus können aber auch andere Organismen und anorganische Dinge historiseh bedeutsam werden. Denken wir an das Roß des Reiters, an das weiße Pferd, das der Große Kurfürst in der Schlacht bei Fehrbellin geritten, mit dem sich die Gefahr seines Todes verband, ans der er befreit wurde durch eine Tat frommer Gefolgstrene. Und die weite Welt der toten, leblosen Dinge, Berg und Tal und FluB, als Sehauplatz der Tat, als Schauplatz des Handelns gewimnen sie historische Bedentung.

So rauschen die Wellen des Skamanders dem griechisehen Heldenjüngling Gefahr, und das Felsentor der Thermopylen in seiner starren Größe ist durchlenchtet und verklärt dureh die Tat opfermutiger Vaterlandstreue. Und jene mbändigen Wogen des Bosporus, die das Joch tyrannischer Brüeken nicht tragen wollten, sie empfingen ihren historischen Rittersehlagg durch die Geißehn des persischen Großfürsten. Und anderseits gibt es nun doch auch eine Fülle von psychischem Leben und eine Fülle von seelischen Vorgängen in allerlei Lebewesen, die absolut ohne historisches Interesse sind. Was sollten wohl für die Geschichte die Liebesgefühle des Paradiesvogels auf den fernen anstralischen Inseln oder die Träume des Falters bedeuten, was jene Welt des unsichtbar Kleinen, das den Wassertropfen mit Leben erfüllt.

\section{f) Das geistige Leben.}

Aber vielleicht treffen wir das Wesen des Historischen bester, wenn wir sagen, das Objekt der Geschichte sei das geistige und nicht das psychische Leben. Wir benutzen damit den alten Gegensatz von in den frühchristlichen geschichtsphilosophischen Spekulationen Bedeutung gewinnt und als Wirklichkeitsunterscheidung ron der jüngeren Stoa formulicrt ist. Unter Geist verstehen wir damm das höhere seelische Leben, das sich in Glauben und Denken, in frommer Zuversicht und heiliger Ehrfurcht entfaltet, die Vision des Künstlers und Propheten. die große sittliche Ủberzengung, das reine Pflichtgefühl. Wir bezeichnen dieses höhere Leben des Geistes anch gern als Vernunftleben und stellen es dem tierischen Leben als der bloß psyehischen Existenz gegenüber. Nit dem geistigen Leben verbinden wir dann weiter gern den Glauben an Unsterblichkeit und Ewigkeit.

So hat es die Geschichte also mit dem geistigen Leben zu tun, oder das geistige Leben als das vernünftige Leben ist das Wichtigste in der Geschichte. Und diese geistige Sphäre des Lebens überragt sehon nach der Vorstellung des Origines die psychische Sphäre ebensoweit, als die Welt des Psychischen die Welt des Physischen übertrifft. Wem etwa das Evangelimm des Geistes als die höchste Form der göttlichen Offenbarung gilt, so wird das Geistige hier zu einem reinen Wertbegriff. Ganz dentlich wird es, daß die Definition der Geschichte als Wissen chaft des Geistes mit dem Begriff des Psychischen nur sehr wenig gemein hat. Es handelt sich vielmehr darum, festzustellen,

1) Tgl. Heinrich Rickert: Psychophysische Kinusalität und psychophysischer Parallelismus. 
daß sie es mit der höchsten Form des Lebens, dem vernünftigen und sinnvollen Leben, zu tum hat.

Nach der Lehre des letzten großen Philosophen des deutsehen Idealismus gehört die Weltgesehichte zur Philosophie des Geistes. Dureh ihn hat der Begriff des Geistes eine ungeheure Erweiterung erfahren. Hegel unterscheidet nicht zwischen einer körperlichen, psychischen und geistigen Wirklichkeit, sondern für ihn ist alle Wirkliehkeit Leben, und alles Leben ist Leben des Geistes. Das Weltleben des Geistes erscheint in semer konkretesten Gestalt als Weltgeschichte. Auch die Naturphilosophie Hegels handelt vom Geist. Aneh die natïrliehen körperlichen Vorgänge sind im Grunde geistige Prozesse. Das Geistige erseheint hier noch in der Form der Natur. Auch das Leben der Natur spiegelt das eine große Weltleben, die Wirkliehkeit des absoluten Geistes. Aber in der Natur ist der Geist noch verborgen, er steht hier auf einer niederen Stufe seiner Offenbarung. Erst in Staat, Recht und Gesehichte, in Religion, Kunst und Philosophie tritt er unverhüllt in Erscheinung. Hegels Philosophie des Geistes oder das Objekt dieser Philosophie verhält sieh zu der Natuphilosophie und ihrem Gegenstande nicht so, wie sich Psyehisches zu Physischem verhält, sofern wir unter diesen beiden Begriffen entgegengesetzte Wirkliehkeiten zu verstehen pflegen, vielmehr ist die Welt der Geschichte nur eine Steigerung und Erhöhung des in der Natur ruhenden geistigen Lebens.

Wenn die christliche Religionsphilosophie und Hegel das Objekt der Gesehichte als Geist bezeichnen, so ist geistiges Geschehen hier gleichbedeutend mit wertrollem Geschehen. Deswegen ist naeh der Lehre des Origines das Erangelium res Geistes, das noeh zu erwarten ist, dic höchste Offenbarung Gottes, und Hegels Philosophie des Geistes leitet zu den höchsten Kulturwerten hin, wie sie in Knnst, Religion und Philosophie uns entgegentreten. Wir verstchen es sehr wohl, daß man die Geschiehte als Geisteswissenschaft bezejchnet, sofern sie es mit renjenigen psychisehen Phänomenen zu tun hat, dis wir als die bedentsamsten Erscheinmngen des sechschen Gesehehens zu betrachtan gewöhnt sind. Demmoeh bleibt der Begriff des Geistes in seiner wechschden Bedentung unsicher und zweideutig. Schon die so naheliegende Verwechsehung des Psychisehen und Geistigen sollte davor warnen, als Objekt der Geschichte das geistige Leben zu nemnen $\left.{ }^{1}\right)$. Der Begriff des Geistes setzt eine Reihe von Enterscheirlungen voraus, die nach ursprünglieh metaphysisehen Gesichtspunkten rollzogen sind. Wir sagen das nicht, mm gegen die Metaphysik zu jolemisicren. Die Metaphysik ist gewils cler notwendige Absehluß jeder Philosophic. Aber die Metaphysik darf in der Philosophie immer nur das letiate, nicht aber das erste Wort haben. Wir diufen msere ersten Unterscheidungen, die wir zur Abgrenzung mol zum Vorständnis des wissensehaftlichen Labens zn machen genötigt simbl, nicht mit der sohweren Wueht metaphysischer Goramsetzungen helasten.

lbas gristige leben sollte nach ler Meinumg der alten Metaphysik den

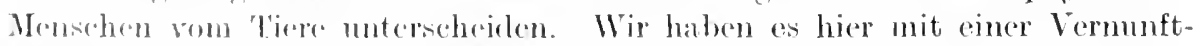

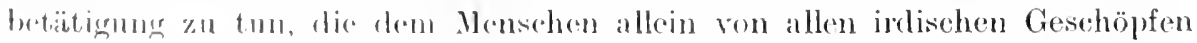

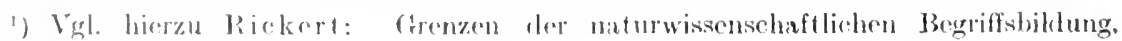
$\therefore$ Kapital; vor allem S. 17itft. 
eignet. Die Vernunftbetätigung, die dem Menschen eigentümlich ist, ragt auch zugleich äber den Menseheu hinaus und gibt ihm ein Verhältnis zur übersinnlichen Welt, denn das Vernünftige als das Geistige ist notwendig unsterblich. So hat der ehrwürdige $u$ ul erhabene Begriff des Geistes riel zu lange in dem Dienste metaphysischer Systembildungen gestanden, als daß er den Gegenstand der Geschichte eincleutig präzisicren könnte.

\section{g) Geschichte als Reich der Freiheit.}

Wenn wir aber den metaphysischen Begriff des Geistes verschmähen, gibt es nicht, so kömnen wir uns fragen, gewisse Grunrbegriffe ler Erkenntnis. von denen aus sich eine Gliederung der Wirklichkeit vollziehen läßt? Und so werden wir denn, der erkenntnistheoretischen Fragestellung zugewendet. zu jener berïhmten Unterscheidung getrieben, von der Kant zuerst Anwendung gemacht hat, $u$ m das Wesen der Geschichte zu bestimmen. Es ist der Gegensatz ron Notwendigkeit und Freiheit. In gewissem Sinne ist diese Unterscheidung die wertvollste und bedentsamste, welche die Logik der Geschichte zur Bestimmung des historischen Objektes bisher gefunden hat. Das Psychische als Gegenstand der Geschichte ergab sich als zu weite und auch wiederum zu enge Begriffsbestimmung, desgleichen die Definition, daß es die Historie mit den Willenshandlungen der großen Persönlichkeiten zu tun habe. Der Begriff des Geistes als Objekt der Geschichte führte dann sogleich in das voraussetzungsreiche Gebiet der Metaphysik. Haben wir nicht mit dem Begriff der Freiheit eine Bestimmung gewonnen, die dem Charakter des historischen Lebens in vollem Maße Genüge tut? Ist nicht in der Tat die Geschichte das Reich der Freiheit und die Natur das Reich der Notwendigkeit? Hängt nicht das Wesen der Geschichte an dem Begriff der Freiheit, und werden nicht die großen welthistorischen Ereignisse zu einer Farce, wenn'ihnen eine blinde Notwendigkeit unterliegt, die alles in strenger Gesetzmäßigkeit determiniert. die alle Selbstbestimmming und Wahlentscheidung aufhebt, die alles Eigenleben vernichtet, deren simnlose und brutale Gewalt alles blïhende Leben zur bloßen Triebkraft der Naschine macht? Ist nicht ohne jene Frciheit, die uns Eigenmacht und Selbständigkeit gibt, sowie die Möglichkcit, ein eigenes Leben zu formen und zu gestalten, der Gott der Geschichte vergleichbar jenem großen Götzen, der immer neue Opfer fordert, um sein blutbeflecktes Dasein zu erhalten, dem Millionen ron Hekatomben reifen und geopfert werden? Führt nicht die sinnlose Notwendigkeit in der Geschichte zur Vorstellung jenes furchtbaren Gleichmachers, vor dem es kein Großes und Kleines gibt, kein Verdienst und menschliche Würde? Ist unter diesem Gesichtspunkt der Herr der Geschichte nicht der starre Tod, und alles blïhcnde Leben nur Schein und Illusion? Und so hängt doch, wie es scheint, alles, was wir unter geschichtlichem Leben verstehen, an diesem einen Begriff der Freiheit. Gewiß ist die Geschichte auch nicht das Reich des Zufalls, des bloß Willkürlichen, des regellosen Spiels, aber der Begriff des Fatums und der blinden Naturgesetzmäßigkeit zerstört doch angenscheinlich den Begriff der Geschichte.

Wenn wir Geschichte denken, so denken wir an ein Reich zwecksetzender Individuen, und wir meinen. daß wir hier Ketten ron Ursachen und Wir- 
kungen aufweisen kömmen, die in ihrer Eigenart auf ein einzigartiges Wesen hinweisen. Wir wollen ja die Freiheit nicht im Simne der Ursachlosigkeit verstehen, aber wir meinen doch, daß in der geschichtlichen Welt eine ganz andere Art ron Bestimmtheit sicht geltend maeht als diejenige, welche in der Welt der Mechanik als Druck und Stoß eingesehen wird.

Tnd sollte auch im letzten Grunde die Welt durch Naturgesetze bestimmt sein. der Schein ron Freiheit bleibt doeh für die historische Wirklichkeit bestehen. Niemals dürfen wir die historischen Persönlichkeiten so betrachten und beurteilen, als ob sie bloße Puppen wären, die hierhin und dorthin geschoben werlen. Ein solcher Aspekt würde die ganze Gesehichtswissenschaft über den Haufen stürzen. Die Freiheit ist in irgendeiner Form absolut notwendig für historisehe Betrachtung. Aber hier ist noch nieht die Stelle, wo der geschiehtsphilosophisehe Begriff ron Freiheit einsetzen kann, der sich ganz gewiß mit dem ethisehen Begriff der Freiheit auf das engste berïhrt. Der Begriff der Freiheit ist viel zu sehwierig und kompliziert, $n$ m zu einer Bestimmung des historischen Objektes benutzt zu werden.

Suchen wir nach einem Begriff, der die Objekte der Gesehichte in relativ roraussetzungsloser und doch charakteristischer Weise bestimmt, so gelangen wir zu der Einsieht, daß es ganz augenscheinlich die Bezichung zu menschlicher Tätigkeit ist, das Empfangenhaben ron uns, das Gestaltet- und Gebildetsein durch uns, was sie besonders und eigenartig macht gegenüber den $\mathrm{Ob}$ jekten der Natur. Die Objekte, mit denen es die Naturwissenschaft zu tun hat, sie sind das, was sie sind, ganz mabhängig ron unserem Tun und Leiden, ron mserem Wirken und Schaffen. Die Bewegungen der Mechanik, die Moleküle der Phrsik, die chemisehen und biologisehen Phänomene: sie sind nieht von uns hervorgebracht, sie haben ein selbständiges Dasein gegenüber unserem Willen. Diesc Naturphänomene sind durch sieh geworden. Sie haben kein Verhältnis zu nnserer Sittliehkeit oder zu unserem Rechtsbewußtsein in dem Simne, daß man ihnen gegenüber mit Begriffen wie gut und böse, recht oder unrecht etwas anfangen könnte. Die Natur ist weder gütig noeh grausam. Sie ist unserer ethischen Zwecksetzung gegenüber vollkommen indifferent. Wenn wir dann allerdings ron Naturzustand und ähnlichen Dingen reden, so haben wir nicht mehr den Begriff der Natur, wie er hier von uns gemeint ist. Man kann ja mit der Irlee ller Natur die ganze Fiille der Wertprädikationen verbinden. Die Natur von göttlieher Liebe durchwaltet, der natürliche Mensch als der nugezwungene, freie und anfrichtige Mensch, der naive, natürliche mul deswegen harmonisehe Kïnstler, das alles sind Beispicle von Introjektionen, die: an sich nit dem liegriff der Natur niehts zu tum haben, sondern nur in einem lorru Analogieverhäiltnis zu seiner wahluaftigen Bedentung stehn.

D) Natur, jene, Wolt von Ohjekten, mit denen os die naturwissenschaftlidhe dirkenntnis zu tun hat, int froj won jeder Setzung mensehlieh wertvoller 'Tait iglieit.

\section{h) liultur als Ohjokt der Geschichte.}

J) he Summo menschlich wertvoller 'Tatigkeit, aber, welche anf die Natur ansgë̈ht wirl, 110 sis nild gewissen bwecken zu bilken und zu gestalten,

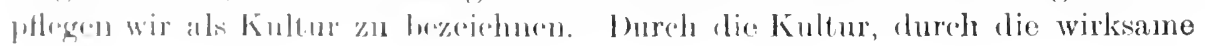


Pflege des Menschen verliert die Natur ihren ursprünglichen Charakter. Das aus der Natur durch den Menschengeist Gebildete und Geformte nennen wir Kulturprodukt. Dureh die Ternunftätigkeit des Menschen wird die Natur gleichsam begeistet, indem Gebilde entstehen, die den Stempel menschlicher Vermunft und menschlicher Bedürftigkeit an sich tragen und als solche auch noch ron den spätesten Generationen begriffen und verstanden werden ${ }^{1}$ ).

Von Sitte, Recht und Sittlichkeit kann mur in Beziehung zu menschlicher Tätigkeit gesprochen werden. Das Sittsame, das Rechte und das Gute berührt der Natur großes und stilles Walten nicht. Anders steht sie jedoch zum Wahrheits- und Schönheitswert. Es hat keinen Simn, die Natur fromm und gerecht zu nemnen. Sie hat mit ethischen und rechtlichen Maximen nichts zu schaffen, wohl aber reden wir ron der Wirklichkeit und Schönheit der Natur. Wem wir von der Wirklichkeit der Natur sprechen, so messen wir sie am logischen Wert, reden wir von ihrer Schönheit, so vergleichen wir sie mit dem ästhetischen Wert. Es ist wohl darauf zu achten, daß nur die ethisch-rechtlichen Prädikationen für die Natur simnlos sind, nicht aber die logischen und ästhetischen. Mit dieser unbezweifelbaren Tatsache hängt es zusammen, daß die Geschichte immer mit Vorliebe unter den moralischen Gesichtspunkt gestellt wurde, weil man ja in der Beziehung zum Sittlichen ihren Gegensatz zur Natur richtig erkannte, und so der Begriff der Freiheit als Idee eines höchsten sittlichen Wertes besonders geeignet erschien, ihr eigentümliches Wesen zu bezeichnen.

Der Gesichtspunkt des Wahren und des Schönen, unter den die Natur gestellt werden kann, ist num allerdings niemals die naturwissenschaftliche Betrachtungsweise, sondern vielmehr lediglich eine philosophische Deutung der Naturphänomene. Die Naturwissenschaft wird zu ihrer Erklärnng der Dinge niemals einen Wertgesichtspunkt heranziehn. Für sie sind die Dinge in ihrer reinen Naturhaftigkeit vollkommen wertlos. Die Natur der Naturwissenschaft, die ron Gesetzen beherrschten Bewegungsrorgänge, das ist der Begriff ron einem Wertfreien und bildet den denkbar größten Kontrast zu der wertbezogenen Welt der Geschichte.

Die Objekte der Geschichte sind also Kulturtätigkeiten, Kulturrorgänge, Kulturprodukte. Bloße Naturvorgänge, wie etwa die Zirkulation des Blutes in einem beliebigen Organismus oder die Regungen des Sexualtriebes orter der Tropfenfall des Gewitterregens, sind für die Geschichte als solche nicht interessant. Naturvorgänge interessieren sie mur, wemn sie zu menschlicher Kulturtätigkeit in eine ausdrückliche Beziehung treten. So hat etwa das Erdbeben von Messina eine historische Bedeutung gewommen, weil es eine blühende Stätte der Kultur vernichtete, die wirtschaftliche Entwicklung Siziliens bedrohte und hemnte, gleichzoitig aber auch sämtliche Nationen Enropas zu einem gemeinsamen Werk internationaler Hilfeleistung rereinigte. So hat im 18. Jahrhundert das Erlbeben von Lissabon eine weit größere historische Bedeutung gewonnen, weil es mächtig dazu beigetragen hat, die Weltanschauung einer ganzen Epoche, den Optimi-mus der Aufliärung,

1) Vgl. Rickert: Kulturwissenschaft und Naturwissenschaft. 1910. Grenzen der naturwissenschaftlichen Begriffsbildung, 1913, n04ti.

M e hlis, Geschichtsphilosophie. 
zu zerstören. Wenn Unkultur durch Natur zerstört wird, so ist das historische Interesse nur gering. Das Erdbeben ron Messina, das so viel blühendes Kulturleben zerstörte. ist historisch sehr viel wichtiger als die Pest, der etwa im Inneren ron Asien dieselbe Menschenzahl zum Opfer fällt.

Aber wir wissen auch, daß nicht alle Kultur Gegenstand der Geschichte ist, wemn wir nnter Kultur alles das verstehen, was von Menschen gepflegt und geleistet wird. Sind doch auch jene Handlungen des Menschen, die auf Befriedigung ron Hunger und Liebe hinauslaufen, und die ursprïnglich als reine Naturvorgänge anzusehen sind, Handlungen, die in ihrem Auftreten bei einem beliebigen Individum in allen Einzelheiten gewiß keine historische Bedeutsamkeit besitzen, doch schon dmrch Kulturformen gebildet. Und wenn wir die Tölker im Innern Zentralafrikas in der ganzen Gleichgültigkeit ihres Tuns und Handelns ans der Geschichte ausschließen und sie als kulturlose und deswegen unhistorische Völker betrachten, so müssen wir bedenken, daß diese sogenannten Naturvölker vielleicht Fragmente und Trümmer einer verlorenen Kultur sind.

Die Geschichte hat es sowohl mit der Kulturtätigkeit als auch mit den Kulturprodukten zu tun, also sowohl mit der Funktion, die formt und gestaltet, als auch mit dem Niederschlag dieser Tätigkeit, dem Formungsprodukt. Die Geschichte bringt zur Darstellung, wie der erfinclerische Menschengeist nene Kultur schafft und enthüllt, sei es im Reiche des Gedankens die Herrorhebung der neuen Idee, sei es im Reiche der künstlerischen Anschauung die Schöpfung und Auffindung des neuen Ideals, die Bildung des neuen Stils, sei es im politischen Leben die Bildung und Organisation des nenen Staates, die Kämpfe um seine Erweiterung und Erhaltung, sei es im Reiche der Technik die Konstruktion der neuen Maschine, die Erfindung des neuen Modells. Erst in zweiter Linie kommt das Schicksal des Geschaffenen, des Kulturproduktes in Frage, der individnelle Lebensgang des Kunstwerkes, wie es verwittert und alt und morsch wirl, obwohl immor noch Züge der Schönheit zeigend, wie es seine Besitzer wechelt und von Ort zu Ort geführt wird. Und im wirtschaftlichen Leben ist os gleichfalls in erster Linie die wirtschaftliche Tätigkeit, die den Histrriker interessiert, nicht das Wirtschaftsprodukt mit seinem wechsehnden Sichicksal. Auf die Erzengung des Neuen, anf die Gewimnung, Erwerbung umel l'berfïhrung der Prorlukte kommt es an, nicht auf das, was aus jedem cinzelnen Produkte wirl. Wie die wirtschaftliche Tätigkeit von dem eng hegrenzten Kreis der Hausindustrie zur Weltindustrie sich entfaltet hat, wie die prinitiven Verhältnisse des Tauschverkehres sich zum Welthandel entwickelten, wic das P'rorluktionsmitted des sklaven zum Produktionsmittel der Maschine, das natürliche bahlumgsmittel in das künstliche der Münze und Panknote sich gewandelt hat, das vor allem interessiert die Wirtschaftsgreschichte.

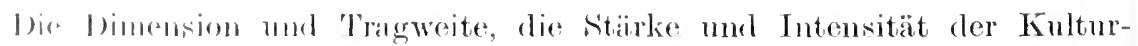
loitung int angenscheinlich ron ansischlaggehender historischer Bedentung. Shohilors fieskn spricht in der lat cine Maxime der Gesehiehte aus, wenn

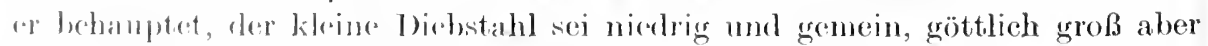
ler butcehlul, cine Krone zu stehlen. Dureh dic Gröle dos Gegenstandes wird sonit, dir Sichwere des Verbrehens gemildert. Hier maeht sich ein Ge- 
sichtspunkt geltend, der zu den Forderungen des sittlichen Bewußtseins in einem gewissen Gegensatze steht; demn es ist wohl sicher, daß rom streng moralischen Standpunkt betrachtet die Größe und Bedeutung des Objektes für die Tat gleichgültig ist. Ob Taler oder Million gilt hier einerlei. Hier sind ganz andere Gesichtspunkte maßgebend. Und wenn wir an die Umsetzung ethischer Normen in Rechtsmaximen denken, so steigt vielmehr mit der Größe des Gegenstandes die Größe der Schuld. Ans den Worten des Fiesko redet der Geist des historischen Bewußtseins und der Wille des geschiehtlichen Menschen. Ton Streben nach Macht und Herrschaft besesen, ron hohem Ehrgeiz erfüllt, nimmt die Tat des historischen Menschen immer jene großen Dimensionen an, die das Gute und Schöne in hoher Vollendung erseheinen lassen, das Böse und Schlechte aber mit dem Reiz des Dämonisehen umgeben.

\section{i) Kunlturtätigkeiten.}

So haben wir also als Objekte der Geschichte Kulturvorgänge und Kulturprodukte zu bezeichnen, wobei allerdings der Begriff der Kultur seinem Bedentungsgehalt nach rorläufig noch unbestimmt bleibt. Wenn wir unter Kultur alles rerstehen, was menschliche Tätigkeit aus der Natur macht und sehafft und biklet. und hinzunehmen die Weiterbildung des Geleisteten und schlieBlich anch alle jene Handlungen, die in der sphäre des neu Geschaffenen sich bewegen, ohne doch seine Struktur wesentlich zu verändern, so ist der Begriff der Kultur als Bestimmm für die historischen Objekte doch wohl zu weit. Es gibt Kulturtätigkeiten, Kulturvorgänge und Kulturprodukte, die niemals historische Bedentung gewinnen. Wem wir aber darauf reflektieren, welche Art von Knlturvorgängen im weitesten Sinne des Wortes wohl unhistorisch sein mögen, so lassen sich in der Hauptsache drei Gruppen ron Handlungen aufweisen, deren ganzer Charakter auf das Ungesehichtliche hinweist.

Die erste Gruppe solcher unhistorischen Kulturvorgänge ist ausgezeichnet durch die Pichtung auf das Kleine, das Idyllische und Isolierte. Der Gegenbegriff hierzu ist der Begriff der Größe und speziell der historischen Größe. der selber ein schwieriges Problem für die Geschichtsphilosophie lilelot. Wir kömnen uns Kulturhandlungen denken, die, auf das Kleine und Unwichtige gerichtet, sich inmer mehr von dem wahrhaft Historisehen entfernen. So war es, um das von Windelband gewählte Beispiel zu gebranchen, gewiß historisch unwichtig, daß Goethe eimmal abends seinen Hansschlüssel vergessen hatte. Dieser Vorfall hätte aber historische Bedeutung gewinnen können, wemn gewisse folgenschwere Ereignisse mit diesem Geschehnis sich verbunden hätten ${ }^{1}$ ).

Auf eine andere Gruppe von Kulturhandlungen, die auch das Bestreben haben, sich aus der Geschichte zu entfernen, ist bisher weniger geachtet worden. Ich möchte sie ganz allgemein dahin charakterisieren, daß es sich hier immer um die Beziehung des Ethischen zum Einzelnen handelt. Der Gegensatz hierzu wäre das Ethische in sozialer Hinsicht. Es ist nicht zu verkennen, daß im Ethischen ein soziales Moment vorliegt, das uns die Richtmng auf die Gesellschaft gibt. Die Gesellschaft gilt dem einzelnen gegenüber als Gut. Ans

$\left.{ }^{1}\right)$ Windelband: Naturwissenschaft und Geschichte. 1894. 
der Leistung fïr die Gesellschaft wächst den Handlungen der Individuen Bedentung zu. Es gibt aber eine doppelte Art der Bewertung sozialer Verhältnisse und Kreise, nämlich einerseits so, daß mit der Größe des Kreises der Wert steigt. Nation gilt mehr als Familie, Menschheit mehr als Staat oder Tation. Gerade diese Tendenz ethischer Bewertung verbindet sich mit dem Interesse der Gesehichte. Im Gegensatz dazu steht jene Wertungsweise, nach der gerade mit der Enge der Verhältnisse Wert und Bedentung steigt. Familie ist mehr als Staat, Fremdschaft mehr als Familie. In dieser Form der Anerkennung liegt ein gewisses Streben nach Einsamkeit und Entfernung ans der Gesellschaft. Menschen, die so mit ihrer großen Liebe dem Einzelnen leben, haben einen unhistorischen Charakter, weil der Simn der Geschichte die Leistung für das Allgemeine einschließt. Hätte Sokrates nur dem Phaedon gelebt und Phaedon nur dem Sokrates, so würden sie wohl beide keine Stelle in der Geschichte gefunden haben, weil sie den Weg zur Öffentlichkeit nicht fanden. Lnd so wird das ganze sittliehe Leben, das nur dem Einzelnen geweiht war, die großen Taten der Aufopferung und Sorge einer Mutter für ihr Kind, trotz ihres hochbedentenden ethischen Gehaltes, in der Regel keine selbständige Bedentung in der Geschichte gewimnen.

Endlich schließt die Beziehung zum Religiösen ein antihistorisches Moment in sich. Man kam überhaupt mit Recht die Frage erheben, ob die Religion denn wirklich ein Kulturwert sei wie Wissenschaft und Kunst. Wenn wir an das Urehristentum denken, so sehen wir ganz deutlich, daß eine gewisse Kulturlosigkeit sich mit der Religion verbinden kann. Was kam Wissensehaft und Kunst und Menschheitsfortschritt für den seinen Gott wissenden Menschen Großes bedeuten? Der werdende Gott und die Kultureligion sind im Grunde genommen eine Paradoxie, dem mit der Anerkennung der Religion greift las Ewige unf Zeitlose gar mächtig in die Sphäre des Endlichen ein. Und der Mystiker, der in seliger Wesensrereinignng Gott schaut, er hat der Geschichte flïchtiges Wrorden und damit zugleich die Welt äberwunden.

\section{\$3. Der dritte Problemkreis. Das Problem von Form und Inhalt in der Gieschichte.}

Wir hatten bisher gan\% allgemein nach dem Ziel und den Objekten der historischen Wissensehaft gefragt und die Probleme entwickelt, die mit dieser Fragestelhug zusammenhängen. Als Ziel umd Aufgabe der Geschichte bezeichneten wir dic Darstellung der individuellen Formen und Gestalten des Wirklichen in ihrer Einzelheit und Einmaligkeit sowie jhre Einstellung und Einordmung in cinen esklärenden Zusammenhang. Wollen wir aber diese Objekte nibser bestimmen, so war es cler Kultureharakter, der ihre Figentümlichkeit ansmachte. D) Frage nach Ziel mul Ohjekt einer Wissenschaft drängt sich

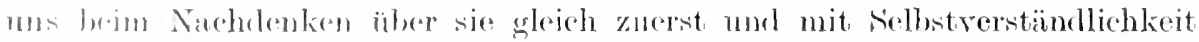

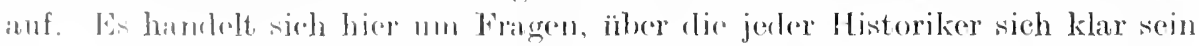
muls. Wrzu trejhen wir Geschichte, zu welchem zweek und im Hinbliek anf

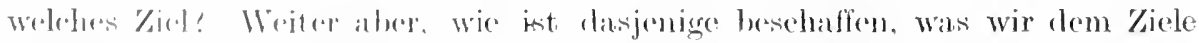

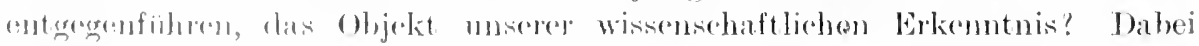

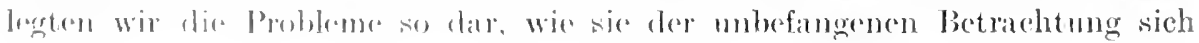


darbieten. Wir faßten Objekt und Ziel ganz realistisch auf. Hier liegt, ganz unabhängig von unserer Erkemntnis, ein Objekt vor uns, der Kulturvorgang, das Kulturprodukt. Wit diesem geschieht etwas, auf daß er zu einem Ziel der Erkenntnis gelangt. Jetzt müssen wir daranf reflektieren, welche Mittel der Erkenntnis notwendig sind, um das Ziel zu erreichen. Diese Mittel der Erkemntnis sind Begriff und Crteil. Durch Begriff und Crteil bemächtigen wir uns des Objektes und führen es dem gewollten und gesollten Ziele entgegen. Augenscheinlich ist damn das Ziel ein Zusammenhang ron Erkenntnissen, ein Urteils- oder Begriffszusammenhang. Die Produkte des Wirklichen ruhen jetzt in der Form der Erkenntnis. Jedes Geschichtswerk bedeutet solch einen Urteilszusammenhang, einen Erfolg, den das Denken errungen hat, einen Raub an der Wirklichkeit. Allerdings ist ein solch erreichtes Ziel immer nur ein rorläufig Erfülltes. Nene Wirklichkeit bietet sich dar, und die Erkenntnis muß sich ihrer bemächtigen und sie mit dem erworbenen Wissensreichtum rerbinden. Und so schreitet die historische Forschung einem idealen Erkenntniszusammenhang entgegen, ohne ihn doch jemals zu erreichen.

Reflektieren wir num aber auf das Objekt. das diesem Erkenntniszusammenhang entgegengeführt wird, so ergibt die erkemntnistheoretische Utberlegung, daß wir dieses Objekt niemals umberührt rom Denken aufweisen können, sondern daß das Denken an ihm bereits eine Tätigkeit ausgeübt hat. Nennen wir nun den Erkenntnisanteil des Objektes Begriff oder Form, so kommen wir zu dem Gedanken des von der Form noch nicht Berührten, des Unbegriffenen, des bloßen Inhaltes. Das Interesse der reinen Logik ist nur a uf die Form schlech thin und auf den Inhalt schlechthin gerichtet. Sie strebt nach der von kiner Inhaltlichkeit getrübten Form und nach dem von keiner Form berührten Inhalt. In der Geschichtslogik ist die reine Logik determiniert. Sie handelt nicht ron der Form schlechthin, ron der reinen Form, sondern von der historischen Form, sie handelt auch nicht von dem reinen und absoluten Inhalt, sondern von dem historischen Inhalt oder dem historischen Materia l. Dies historische Material ist schon etwas durch das Denken Geformtes, und die historischen Formen sind bereits auf eine bestimmte Inhaltlichkeit zugeschnitten. Es ist ja gewiß notwendig, daß Form und Inhalt einander entsprechen. Die Form muß geeignet sein, den Inhalt anfzunehmen, und der Inhalt muß die Möglichkeit haben, von der Form umgriffen zu werden.

Das logische Gebilde, von dem jede erkenntnistheoretische t'berlegung ansgehen mus, wird immer das Urteil sein. Wir haben nicht zu untersuchen, was seine Stellung im Reiche des Theoretischen ist. Man hat ihm nenerdings eine eigentümliche Zwischenstellung zwischen den beiden Gebieten der Erkenntnis, der gegenständlichen und formalen, angewiesen ${ }^{1}$ ). Es soll an der Grenze der formalen Formen stehen, zugewendet dem Reiche des gexenständlichen Simnes, den es nur in verstümmelter und abgeblaßter Form enthält. Doch bleibt anch in dieser Lehre, welche die logische Bedentung des Lrteils, wie sie etwa in Kants Erkenntnistheorie rorliegt, erheblich herabsetzt, die

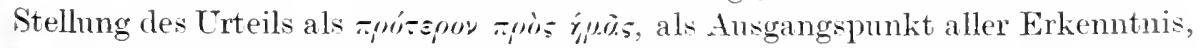
im wesentlichen gewahrt. Den Begriff mit seinen verschiedenen Merkmalen

$\left.{ }^{3}\right)$ Vgl. Lask: Die Lehre rom Urteil. Tübingen 1912. 
der Allgemeinheit. Bestimmtheit und Geltung können wir mit Rickert sehr wohl rerstehen ali ein gleichsam fest gewordenes Urteil, als Niedersehlag der Urteilsproduktion. Das Lrteil ist der geeignetste Ausgangspunkt für eine logische Untersuchung. weil die eigentümliche Zusammengehörigkeit von Inhalten, die in seinem Charakter liegt, uns die Möglichkeit gewährt, in dem Gebiete des Begriffes selber wieder zu unterseheiden. Jene Inhalte, mit denen wir es im Urteil zu tum haben. und die sich anf eine simnliche Wirklichkeit, etwa einen historischen Vorgang, beziehen. wie las Urteil ,Friedrich der Zweite hat den modernen Staat geschaffen" sind keine reinen Inhalte, sondern schon etwas begrifflich Bearbeitetes und Geformtes. Der Begriff Friedrich der Zweite meint eine historische Persönlichkeit, und wieviel Denkarbeit liegt nicht in dem Begriff des modernen Staates. Beide Begriffe aber sind Begriffe von sinnlichen Wirklichkeiten, also in der Sprache Kants empirische Begriffe. In ihnen kommt das simnlich Wirkliche der historisehen Welt zum Ausdruck. AnBer diesen Begriffen ron simntichen Wirklichkeiten, die kein spezielles theoretisches Interesse besitzen, können wie jedoch am Urteil noch eine eigentümliche Form der Zusammengehörigkeit konstatieren. Diese Form der Zusammengehörigkeit besteht zwischen den beiden Begriffen ron simnlichen Wirklichkeiten und weist anf eine kategoriale Beziehming hin. In unserem Beispiel ist diese Beziehung etwa die Kategorie der Inhärenz, denn wir haben es mit einer Urteilsklasse zu tum, die eine gewisse Eigenschaft des Subjektes, in unserem Beinpiel die organisatorische Tätigkeit des Staufenkaisers, zum Ausclruck bringt. Dieses Inhärenzverhältnis erscheint aber hier in dem Zugeschnittensein auf historisehes Material. und nur mit historischer Form und historischem Material haben wir es in der Gesehichtslogik zu tun. Eine solche Kategorie, dic als Prinzip der Begründung einer gewissen Wissenschaft zugrunde liegt, bezeichnen wir ats methodologische Kategorie im Gegensatz zu den allgencin geltenden wirklichkeitsbegründenden konstitutiven Kategorien. Hier hat die Wirklichkeitsform durch ihre Anwendung anf ein bestimmter Material und durch das eigentümliche Reflexionsprinzip der betreffenlen Wissenschaft eine gewisse Verengung und Veränderung erfahren.

Nurmit der Klasse der methodologischen Kategorien und speziell der historisehen haben wir w in der Geschiehtshogik zu tun. Für diese, wie überhaupt für alle Kategorien, wollen wir den Ausdruck des Wertes vermeiden. Unter Wert rerstehen wir lestiglieh die in sieh ruhenden höchsten logischen Prinzipien, die das zślos für ein bestimmtes Kulturgebiet bilden, so etwa die Wahrheit für das leich des theoretisehen Simnes. Um der Wahrheit, um der Erkenntnis,

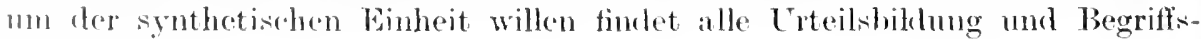
bildung statt

Die Katregrien sind Diener und Gehilfen der Wahrheit. Sie verhelfen ilı zum Austruek, sic bringen die Wahrheit, an den Tag, ohne doch selber das Zical morerer schnsitehtigen Erkemmtnishebe zu sein. Win System der Logik,

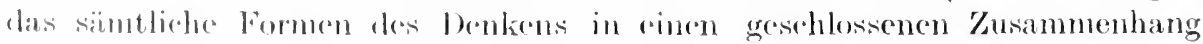
brärhte, wie as wat Fichte nud Hegel ressucht haben, kömnte, seine Riehtig-

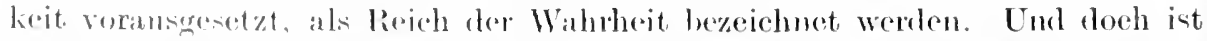
jones Sigstem ron Formen, das wir violleicht logisch konstruieren können,

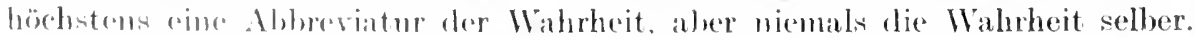


Wir sehen einen Zusammenhang. der zwischen den höchsten Prinzipien dies Denkens besteht, und dieser Zusammenhang überzeugt uns von einer wundervollen Organisation der Vernunft, doch gibt er mir kein Wissen von der übersinnlichen Welt. Die Logik weist einen Formenzusammenhang auf, und wir sehen ein, daß alle Wahrheit des Simnlichen in ihm beschlossen und begründet ist, aber wir kömnen ihn nicht deuten. Er gleicht der rätselhaften Feuerschrift des Belsazar - und uns fehlt der Prophet.

Wenn sich die Geschichtsphilosophie mit den Formen des historischen Geschehens beschäftigt, so sollen diese weder auf ihre letzte Gültigkeitsgrundlage hin geprüft, noch in einem vollständigen Zusammenhang entwickelt werden. Es kommt zunäehst darauf an, die logische Grundlage der Geschichte deutlich hervortreten zu lassen, wie sie zum Ausdruck kommt in der historischen Urteilsbildung und Begriffsbildung. Nach den Formen der historischen Urteilsund Begriffsbildung fragt die Geschichtslogik. Was ist die eigentümliche Form und der besondere Charakter des historischen Urteils und des historischen Begriffs? Was sind die Regeln der historischen Urteilsbeziehung und Begriffsverknüpfung, die Kategorien der Geschichte? Das sind die Fragen, welehe die Geschiehtslogik zu beantworten hat. Dabei ist von vornherein zu bemerken, daß diese Fragen keineswegs in formallogischer Absieht gestellt sind, sondern es kommt der Geschichtslogik vor allem darauf an, die Eigentümliehkeit der historischen Erkemntnis in das rechte Licht zu rücken. Es soll gezeigt werden. daß es ein ganz besonderes und eigentümliches Gebiet des geistigen Lebens gibt, das nur in diesen Formen einen angemessenen Ausdruck finden kann, und das sich nicht aufgeben darf und fortgeben an ein anderes, das fremden und fernen Interessen nachgeht. Es handelt sich $1 \mathrm{~m}$ die Selbstbesinnung der historischen Vermunft. Es gilt festzustellen, daß es zwei ganz rerschiedene Formen der Urteils- und Begriffsbildung gibt, entsprechend den verschiedenen Interessen des Geistes und dem verschiedenen Objekt der Erkenntnis. Es handelt sich um einen Gegensatz, der schon in den Interessen des täglichen Lebens zum Ausdruck kommt, der das wissenschaftliche Leben nach entgegengesetzten Richtungen hin bewegt und so seine Mannigfaltigkeit und seinen Reichtum hervorbringt, der in den höchsten Formen des Denkens Gestalt und Wahrheit gewonnen hat, dessen spuren wir in allen philosophischen Systemen nachgehen kömen.

\section{a) Das historische Material.}

Um nun die historischen Formen, durch die das Objekt der Geschiehte in seiner Eigentümlichkeit gestaltet und gebildet ist. festlegen zu können. ist es notwendig. das Material oder den Inhalt der Geschichte eindeutig festzustellen. Dieses Material oder der Inhalt der Geschichte würde zunächst einmal dasjenige sein, was der historischen Denkleistung als substrat vorliegt, also dasjenige, aus dem durch die historische Begriffsbildung und Urteilsbildung ein historisches Objekt oder ein historisches Formungsprodukt werden soll. Augenscheinlich ist also das historische Material oder der historische Inhalt von dem historischen Objekt dadureh rerschieden. daß an dem historischen Objekt sich die historische Denkleistung schon vollzogen hat und das historisehe 
Objekt selber etwas Historisches ist, während das historische Material erst zu einem Historichen werden soll. Wir müssen aber mit Rücksicht auf den Prozeß der Formung des historischen Objektes mehrere Arten ron historischem Material unterscheiden. Dabei muß von vornherein darauf aufmerksam gemacht werden, da:ß die naturwissenschaftlichen Begriffe zum großen Teil unmittelbarer der Wirklichkeit abgerungen sind als dic historischen. Die komplizierten Gebildedes historischen Lebens setzen die Bekanntschaft mit einer Reihe von naturwissenschaftlichen Begriffen roraus. Das sind zum Teil Begriffe, die auf dem Wege naturwissenschaftlicher Begriffsbildung liegen, zum Teil aber auch wohl solche, an denen eine spezifische naturwissensehaftliche Begriffsarbeit vollzogen ist. Daß die naturwissenschaftlichen Begriffe von der Geschichtswissenschaft genutzt werden, hängt mit der früheren Entwicklung der Naturwissenschaft entsprechend dem einfacheren Charakter ihrer Phänomene zusammen.

\section{b) Vorhistorisches Material.}

Was nun der Historiker in der Regel als historisches Material bezeichnet, das sind die Quellen der historisehen Forschung. Dahin gehören also die Werke frïherer Geschichtsschreiber, deren Leistung überholt ist, und deren Arbeit wiederum als Material für nene historische Arbeit gilt. Ferner die Aufzeichnungen der Chronisten, die rielfach in der Form der poetischen Erzählung gehalten sind und die noch keine eigentlich wissenschaftliche Form erhalten haben. UTkunden, Wappen und Siegel, Münzen und Inschriften aller Art, die in irgendeiner Weise ein Urteil der Vergangenheit oder auch nur einen Hinweis, ein Anzeichen für das Dasein ron Persönlichkeiten und Völkern zu irgendeiner Zeit, in irgendeinem Lande enthalten. Diese historisehen Dokmmente sind also sehr ungleich in bezug auf die historische Leistung, die an ihnen vollzogen ist. Zı ihnen gehören ja in gleicher Weise die Schriften des Herodot und die Inschriften des Höhlenmenschen. Immerhin hat in den meisten dieser Quellen schon eine historische Formung stattgefunden. Diese Urteile tragen zum größten Toil schon einen historischen Charakter. Wollen wir also einen primärsten Begriff des historischen Naterials bilken, so würde dieser noch unter dem Nirean der Quellenformung liegen. Es würde sich hier um Urteile und Begriffe vorwiskenschaftlicher Natur, um Anfänge der naturwissenschaftlichen Begriff,bildung sowie anch um Personen, Vorgänge und situationen handeln, wie se als Wahrnehmungsobjekte in der Anschanung uns entgegentreten. Dieser Begriff eines Materials, das historisch noch nicht geformt ist, besitzt fïr den Geschichtsharsteller relativ mur geringe Bedeutung. Er wird hauptsachlich mur dam alituell, wenn der Historiker bemüht ist die Gegenwart zu leobachten, zu crleben und zu verstehen, wenn er zum Darsteller der eigenen Zcit wird. Diecen Begriff des Materials wollen wir als den vorhistorischen l)(*t)

\section{c) Quellenmaterial.}

Betreten wir dann das Gebiet des historisch Geformten, so können wir

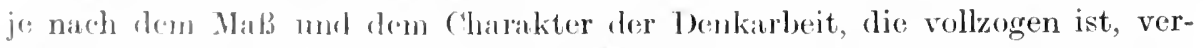
schirdene stufen der immer stärkeren formung des Materials unterseheiden. 
Am niedrigsten muß für den Historiker das Quellemmaterial stehen, an dem sich seine Tätigkeit recht eigentlich erst entfaltet. Das Quellenmaterial liegt an der untersten Grenze des historischen Formungsprozesses. Unter Quellenmaterial rerstehen wir ja die ganze Masse der Tradition in ihrem teilweise noch rollkommen ungesichteten und ungeklärten Zusammenhang, aus welcher der Historiker die nackte und schlichte Tatsache herrorholt. Das Eruieren der Tatsache aus der großen Fülle des Quellenmaterials mit allen Mitteln der historischen Methode ist ein änßerst wichtiger Prozeß der historischen Erkenntnis. Was der Historiker hervorgeholt hat aus den Widersprïchen der t'berlieferung, das ist die schlichte Tatsache des Gevesenen, das ist das Wirkliche, so wie es war. Sie ist gereinigt ron allen falschen Deutungen und Auffassungen. Sie ist ron fremden Zusätzen durch eine gewiscenhafte Kritik befreit.

\section{d) Tatsachenmaterial.}

Aber mit der Auffindung der Tatsache ist der historische Formungsprozeß noch keineswegs rollendet. Die Tatsache ist Formungsprodukt hinsichtlich des Quellenmaterials, aber sie ist noch nicht das vollendete historische Erkenntnisprodukt. Noch ist die Tatsache isoliert. noch wissen wir nicht, welche Beziehung besteht zwischen ihr und allem anderen, was gewesen. Gegenüber dem Prozeß der Einstellung und Einordnung, den der Historiker vollzieht, ist die Tatsache wiederum Material. Sie wird in den historischen Zusammenhang hineingearbeitet. So haben wir es also in der Geschichtslogik mit drei ganz verschiedenen Begriffen ron historischem Material zu tun. nämlich erstens mit dem vorhistorischen Material, das schon eine gewisse Formung durch das vorwissenschaftliche und naturwissenschaftliche Denken erfahren hat. Zweitens das Quellemmaterial ron sehr verschiedenem Wert und sehr verschiedener Formung, aus dem der Historiker die einzelnen Fakta des Gewesenen erschließt. Und endlich das Tatsachenmaterial, das aus den Quellen Gefundene, was seinerseits wieder durch Einstellung in den historischen Zusammenhang geformt wird und als Erkenntnisprodukt in historischen Kategorien wie Kausalität und Entwicklung steht. Das sind die drei Materialbegriffe, mit denen es die Geschichtslogik zu tun hat, aber auch mit ihnen ist der Formungsprozeß noch nicht vollendet. Die Lehre von den historischen Prinzipien oder die historische Wertlehre, der zweite Teil der Geschichtsphilosophie, wird deutlich zu machen haben, daß erst die Beziehung zum Allgemeinen der Geschichte, daß erst die Verbindung der historischen Zusammenhänge mit den Kulturwerten den historischen Erkenntnisprozeß abschließt. So ergibt sich ein vierter und letzter Begriff des historischen Materials, den man als Gliedmaterial bezeichnen könnte, sofern es sich 1 m das kategorial geformte historische Leben handelt, das schliesslich den Kulturwerten gegenïber noch einmal in Materialstellung tritt und durch die Beziehung auf diese erst eine abgeschlossene und vollendete Formung erhält.

In der Geschichtslogik haben wir es nur mit dem Begriff des Quellenmaterials und des Tatsachenmaterials zu tun. Während num aber eine Methodologie der Geschichte, wie sie in mustergültiger Weise ron Bernheim rerfaßt 
ist, vor allem darauf ausgeht, das Quellemmaterial in seinen verschiedenen Gestalten zu beschreiben und seine Bedeutung für die Geschichte einzuschätzen. ist für die Geschichtslogik das Material als Tatsache bei weitem von größter Bedeutung. An ihm sind die wichtigsten Prozesse der historischen Methode rollzogen, es ist bereit, in den historischen Zusammenhang aufgenommen zu werden. So etwa, um ein Beispiel zu erwähnen, die sorgfältig in allen Einzelheiten auf Grund historischer Quellenstudien festgestellte Tatsache ron Sokrates Tode. Wie ist der allgeneine Charakter einer solchen historischen Tatsacho zu bestimmen etwa anch im Vergleich mit dem Charakter einer naturwissenschaftlichen Tatsache?

\section{e) Charakter der historischen Tatsache.}

Was uns da vor allem in die Augen fällt, ist der selbständige Bedentungscharakter der historischen Tatsachen. Die historische Tatsache bedeutet etwas für sich, sie ist nicht nur illustrierend für ein anderes. Habe ich die Bedingungen des freien Falles oder einer elektrischen Entladung oder einer chemischen Verbindung hergestellt, so ist der Vorgang, der so durch mich herbeigeführt wird, gewiß kein historischer. Die Handlungen, zu denen wir die Natur im naturwissenschaftlichen Experiment veranlassen, sind keine historischen Handlungen. Man sollte meinen. sie wären es, da es sich doch um Handlungen bandelt, die der Menseh veranlaßt hat, und da der Zweck dieser Handlungen doch augenscheinlich Kultur, nämlich naturwissenschaftliche Erkenntnis ist. Ein gewisses Kultumoment spielt augenscheinlich in diese durch Probleme naturwissensehaftlicher Erkenntuis geforderte Herbeiführung von Naturphänomen hureh Experiment hinein. Die Natur ist nicht sich selbst überlassen, das Naturphänomen ist kïnstlich herbeigeführt. Der Mensch hat die Frage der Erkenntnis an die Natur gerichtet und sie gezwungen, ihm zu antworten. Die Tätigkeit des Naturforschers ist historisch oder kann doch wenigstens historische BeAcutung gewinnen; wie die Wissenschaft von der Natur gehört auch er der Geschichte an. Aber die durch eine Fülle ron Experimenten herbeigeführten Naturerscheinungen. sie finclen keine Stelle in der Geschichte. Historisch kamn höchstens das Experiment oder der durch das Experinent herbeigeführte Naturvorgang werlen, der zur Entdeekming einer nenen naturwissensehaftlichen Erkenntnis geführt hat. An sich hat der naturwissensehaftiche Einzelrorgang keine selbständige Bedeutung. Er ist nur des Gesetzes wegen da, das er feststellen mul verifizieren soll. 1)as einzelne der Geschichte, etwa der 'Ioul des solrates, ist nicht in dersedhen Woise für ein anderes da, wie das Fallen des Steinos dazu da ist, 11 m das Fallgesetz zu demonstrieren. Das heibt aber: dio historisehen Tatsachen hesitzen Eigenwert, die naturwissensehaftlichen nicht.

bie experinentellen Vorginge der Naturwissensehaft haben gewil3 ver-

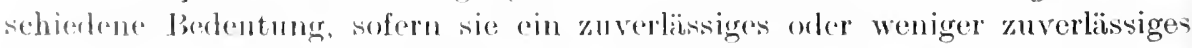

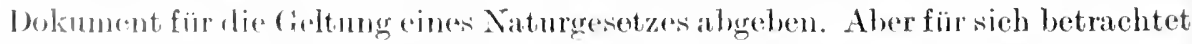

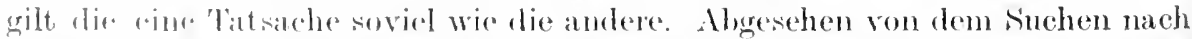
Bestatignug für cine wissenschaftliche Theorie, dio vom Naturforseher aufgestellt int, bestät igt jorler Naturvorghng in dersellen Wrise die Geltung des Gesetzes. frur mich als dent Niturforscher ist der eine Naturvorgang wichtiger zur 
Bestätigung meiner Theorie als irgendein anderer, aber ror dem Gesetz ist alles gleich. Dagegen sind die historischen Tatsachen und Begebenheiten nicht gleichwertig. sondern sehr verschieden in ihrem Eigenwert und ihrer Eigenwichtigkeit. Hier kann man nicht sagen. daß das eine so gut wahr ist wie das andere, sondern die Wahrheit des einen ist mendlich viel wichtiger und bedeutungsvoller als die Wahrheit des anderen. Deswegen ist anch das Interesse der Geschichte darauf gerichtet, die Wahrheit ganz bestimmter Tatsachen zu erweisen. Bei dem einen ist es gleichgültig, ob es war oder nicht, bei dem anderen ist das Gewesensein von unendlicher Wichtigkeit.

Die historische Wahrheit, daß Sokrates gelebt hat und für seine Ctherzengung gestorben ist, bedentet mehr als die ephemere Existenz eines Peripatetikers der alexandrinischen Zeit. Die Kreuzzüge sind als historische Tatsache weit wertvoller als irgendein beliebiges Dokument des mittelalterlichen Fehdewesens, mag auch der Wahrheitsgehalt der beiden Tatsachen gleich gut begründet sein. Der Wertunterschied ruht hier auch nicht auf dem höheren Grade der Wahrscheinlichkeit, sondern auf dem, was wir im allgemeinen die Größe oder die Tragweite eines historischen Ereignisses zu nenmen pflegen, Begriffe, die vorläufig noch ungeklärt bleiben müssen.

In der naturwissenschaftlichen Erkenntnis liegt der Sachverhalt augenscheinlich ganz anders. Die Fakta des Geschehens sind ror dem Gesetz gleichwertig. Gilt das Gesetz der Gravitation, so wird es durch den Fall des Weltkörpers genau in derselben Weise bestätigt wie durch den Fall des welken Blattes. Ist das Gesetz noch nicht gefmnden, handelt es sich vielmehr im naturwissenschaftlichen Experiment um die Entdeckung und Auffindung ron bisher unerforschten Zusammenhängen, so gewimnt das naturwissenschaftliche Experiment, das die Entdeckung reranlaßt hat, eine auszeichnende Bedeutung, aber diese Bedentung ist dann bereits eine historische Bedeutsamkeit. Hier erscheint in der Sphäre der naturwissenschaftlichen Forschmosarbeit der Begriff des Nenen, um mnter dem Aspekt des ewigen Gesetzes sofort wieder zu verschwinden.

So bleibt in der naturwissenschaftlichen Betrachtung die Tatsache das auf bloße Illustration Herabgesetzte, und keine lenchtet ror der anderen hervor. Die Wertunterschiede liegen hier in der Sphäre des Allgemeinen, sofern das eine Gesetz vollkommener ist als das andere. So sind etwa die Gesetze der Mechanik, die Relationen zwischen kleinsten Teilen des Wirklichen behaupten, weitaus vollkommener als die Gesetze der Psychologie. Wenn wir von einem naturwissenschaftlichen Wahrheitsbegriff und Wahrheitskriterium reden dürfen, so liegt es darin beschlossen, daß das eine Gesetz ron allem gilt, das eine ron der ganzen Welt, daß alles unter seine Herrschaft gebeugt ist, daß uns durch seine Kenntnis die Wahrheit des Universums vermittelt wird. Wenn ich nicht weiß, was von allem gilt, so weiß ich anch nicht, was von dem einzelnen gilt. Ohne Wissen des Ganzen kein Wissen des Einzelnen. Daher das Streben der Naturwissenschaft nach einem allgemeinen Gesetz, nach einer Weltformel als ,Sesam öffne Dich" der naturwissenschaftlichen Erkenntnis. Der naturwissenschaftliche Wiahrheitsbegriff richtet sich gegen das beschränkte Gelten. Je enger der Kreis ron Phänomenen ist, der einem Gesetz unterliegt, um so geringer ist auch die Dignität des Gesetzes. Als ob 
die Wabrheit immer von allem gelten mïßte, als ob es nicht Sätze gibt, die unr ron einem einzigen ansgesagt werden können und in dieser Beziehung zum einzelnen gewiß sind!

In der historischen Betrachtung bleibt die Versehiedenheit der Tatsachen. in der Tersehiedenheit ilures Bedentens. Die historisehen Tatsachen sind verschieden und gelten verschieden. Dabei ist die Sicherheit und Zuverlässigkeit einer historischen Erkenntnis für ihren Wert niemals aussehlaggebend. Eine historische Wahrseheinlichkeit kann viel mehr bedeuten als eine historisehe Gewißheit. Das Leben Descartes', um einen Großen zu nemnen, ist eine unbezweifelbare und höchst bedentsame Tatsache, und doch besitzt sie nicht annähernd die historisehe Bedeutung der für die Forsehung problematisehen Existenz Christi. Wir wollen es noch dahingestellt sein lassen, worauf das beruht. Wir wollen nur feststellen, daB die mögliche Existenz Christi eine weit größere historische Perspektive gibt als die Gewißheit von Deseartes' Leben. Dabei betonen wir austrücklich den rein wissensehaftlichen Charakter dieser Wertung. Die größere oder geringere Bedeutsamkeit, die wir meinen, ist nieht ein Produkt unseres Hasses und unserer Liebe, ist nieht dureh unsere persönliche Sympathie und Antipathie an die Gestalten der Geschichte herangetragen. Ton der Liebe des weisen oder frommen Mensehen zu dem einsamen Denker ader dem großen Religiösen wird vollkommen abgesehen. Nur soviel scheint gewiß, daß die Tragweite einer Handlung oder einer Persönlichkeit für das historische Leben etwas Ähnliehes bedentet wie die Geltungssphäre des Gesetzes für die Welt der Natur.

Mit den historischen Tatsachen verbinden wir durchgängig ein größeres coler geringeres Maß von Eigenwert, der mit dem zusammenhängt, was wir historisehe Größe nemnen. Und dieser eigentümliche Charakter des historischen Tatsachenmaterials erhebt die Forderung einer gewissen Selbständigkeit gegenüber dem Allgemeinen und duldet keine despotische Unterordmung. Der Inhalt verlangt eine entsprechende, eine angemessene Form zu seiner Bearbeitung. Wo anch immer historisehes Material von historiseher Form bearbeitet wirl, wo immer ein Objekt zum Gegenstand historiseher Erkemntnis wirl, da trägt es bereits diesen Bedeutungseharakter an sieh. Wir müssen das einfach konstatieren und dïrfen an dieser Stelle noeh nieht nach dem letzten Grumbe dieser Eigenwertigkeit und Selbständigkeit des historischen Materials fragen, das seinem Charakter nach nicht zum bloßen Exemplar eines Allgeneinen heribgeset\%t, werden darf. Genug, daß ein eigentiumlicher BeVeutungscharakter dem historisehen Material niemals mangelt.

Wir haben in fler Gesehichtslogikzwei Arten von historischem Material unterschierlen, nämlich fas Quellemmaterial und das Tatsachenmaterial. Beide sind nur in relativem Simne Matrial, beide haben schon eine gewisse Formung erhalten. Ans dran Qurllemmatrerial wird das Tatsachenmaterial mit allen Mitteln der historischen Forsehmog erschlossen, und das latsachommaterial wird dann weiter in den historischen /usammenhang cingestellt. Dic Form, in der beide mos entegerentreten, sind das historisehe Urteil und der historische

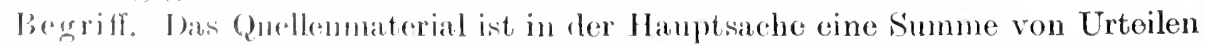

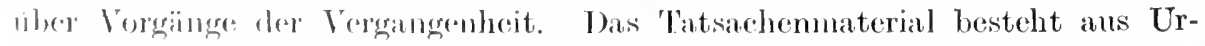
triken, die anf diesen Crteilen geegründet sind und jene teils verdrängt, teils 
erweitert, teils geläutert haben. Sehen wir uns die logisehe Struktur eine: solchen historisehen Urteils einmal etwas näher an.

\section{f) Das historische Urteil.}

Die Position des historischen Urteils, wie wir es in den Werken der großen Historiker rorfinden, ist die Singularität. Sokrates trank ren Giftbeeher, Leonidas fiel bei den Termoprlen. Cäsar übersehritt den Rubicon. Geschehnisse kündet die Geschiehte, die bedeutsam sind, das Zuständliehe soll nur dazu dienen, das Gesehehen noch wirksamer hervortreten zu lasien. Das Sein ist nur Kulisse für das Tun. Das historisehe Trteil haftet in der Regel an einer bestimmten Zeit und an einem bestimmten Paum. Nicht mit dem, was zu allen Zeiten war, sondern mit dem, was mur einmal war, hat es die Gesehichte zu tum. Zu den Ansehaungsformen Raum und Zeit steht das historische Urteil in einem besonders nahen Verhältnis. Deswegen hat man die Gesehiehte auch wohl als. Anschaumngswissensehaft bezeichnet. Die Tatsache, die im Urteil zum Ausdruck gelangt, bezieht sich auf einen Zeitpunkt. Ich weiß, daß das historische Ereignis zu einer ganz bestimmten Zeit gesehehen ist, und seine historische Bedeutsamkeit liegt häufig in dem Zeitmoment. Wäre dieselbe Tat zu einer anderen Zeit geschehen, so wäre sie vielleicht nieht groß und historisch mächtig. So ist es das Los rler historischen Größe, auf das engste mit der Zeit verbunden zu sein, der Zeit ihren Tribut zıl zollen. Das Große ist häufig das, was an der Zeit war. Daß Cäsar den Rubicon übersehritt, war bedentsam zur Zeit ciner bestimmten politisehen Situation. Diese Handlung bedeutete Kampf gegen Rom, und die Größe dieser Handlung liegt zum großen Teil daran, daß sie Kampf gegen Rom zu rechter Zeit bedentete, Kampf gegen Rom, nachdem alles aufs sorgfältigste vorbereitet und die Gunst des Angenblicks gesucht war. Haftet somit die Bedeutung der historischen Tatsache an einem Zeitmoment, so ist doch die Wahrheit der historisehen Tatsache unabhängig ron der Zeit. Immer wieder, zu jeder Zeit leuchtet uns die Somne, aber zu einer ganz bestimmten Zeit lenchtete Cäsars kriegeriseher Erfolg. Lieht und Sonne kehren wieder, aber das Heldenleben ist immer neu. Wemn num aber aueh die Bedeutung ron Cäsars Taten auf das engste mit der Zeit rerbunclen ist, sofern seine Handlungen diesen großen historisehen Sim nur in einer ganz bestimmten Epoche gewimnen komnten, so geht das Historisehe in dem Gedanken der Wahrheit und Größe doeh auch wieder über die Zeit hinaus. Daß Cäsar eine große, für alle Zeiten bedentungsvolle Persönlichkeit war, ist eine Wahrheit, und die Wahrheit gilt zeitlos. Auch steekt in jeder großen historischen Persöhnlichkeit etwas. was die Zeit überwindet, sofern in ihr das zum Ausdruck kommt, was wir zu allen Zeiten als Heldentum rerehren.

Die enge Verbindung des Zeitlosen mit dem Zeitlichen, wie sie uns in der Gesehichte entgegentritt, hat das Denken rler Geschichte gegenüber skeptisch gemacht. Wie kann die Paradoxie hinweggeräumt werden, da $\beta$ ewig gilt, was Cäsar damals war? Die Wahrheit des Toten, des Tergangenen, des niemals Wiederkehrenden ist angenscheinlich ein schwierigeres Problem als die Wahrheit des Allgegenwärtigen, ewig Daseienden. Diese Wahrheit der Tat- 
sache. die im historischen Urteil zum Ausdruck gelangt, und welche die Zeiten ïberdanert. gilt für jedes historische Ereignis und darf nicht verwechselt werden mit jenem Ǔberdanem der Zeit im Sime der UnvergeBlichkeit, wie es den großen historischen Individuen zuteil wird. Dahin gehört etwa Sokrates und die griechische Kmst. Sokrates wird historische Größe besitzen, solange die Menschheit sieh selber ehrt, und die griechische Kunst wird der Mensehheit wertroll sein, solange sie das Wesen der Schönheit verstehen kamn. Sie wird Vorbild bleiben, mag anch das Ziel und die Aufgabe der Kunst eine andere geworden sein.

Das historisehe Urteil haftet an Zeit und Raum, sofern es die Geschichte mit der Tatsäehlichkeit des Geschehens zu tun hat. Das einzelne Geschehen wie die gesamte Epoche hat immer ein notwendiges Verhältnis zur Zeit. Und immer haben wir es in der historisehen Betraehtung auch mit dem Raum als dem notwendigen Schauplatz der historisehen Begebenheiten zu tun. Und zwar hat es die Gesehichte immer mit einer bestimmten Zeit und mit einem bestimmten Ramme zu tun, und dieser bestimmte Raum und die bestimmte Zeit sind für das Geschehnis ron Wiehtigkeit. Es ist nicht gleichgïltig, ob ein Ereignis früher oder später, hier oder dort geschieht. Seine Bedentung liegt im hohen Naße an dem Da und Jetzt. Für den experimentellen, ehemischen oder physikalisehen Torgang ist das individuelle Zeit- mol Rammmoment gleichgïltig. Es bedarf lediglich des Raumes und der Zeit ïberhaupt, nm stattfinden zu können. Raum und Zeit gelten anf diesem Erkenntnisgelict nicht als die allgemeinen Bedingungen des Geschehens, die das betreffencle Ereignis in seiner Konkretheit individuell bestimmen. Wo und wam auch immer das Naturgeschehen stattfindet, in derselben Weise dient es dem Gesetz. Aber das historisehe Gesehehen bedentet in seinem Jetzt ofler Später, in seinem Da oder Dort etwas ganz Versehiedenes für das historisch Allgemeine, welches wir das historische Ganze nemen $\left.{ }^{1}\right)$. Der naturwissenschaftliche Vorgang ist ein kïnstlieh Isoliertes aus der Fïlle des Geschehens, und dieres kimstlich Fsolierte wirl einem Allgemeinen untergeordnet, der historische Vorgang aber hat seine notwendige Stelle in cinem kontinuierlichen Zusammenhang, mond in diesem Zusammenhang ist er mersetzbar. Die naturwistenschaftlichen Torgänge sind so individualitätslos, daßsie gegeneinander umgetanscht worlen kömmen. Anf dieser Individualitätslosigkeit beruht die Möglichkeit, sie der Herrsehaft der Mathematik zu unterwerfen. Das sich Bewegende ist inmer und iiberall Materie oler Energie - nichts mehr, und (ter Raum ist das allgemeine Orthmessprinzip dieser Naterie.

ber naturwisionschaftliche Satz: ,Der Körper x bewegt sich von a naeh b mit einer S'chnelligkeit von y" hat es nicht mit einer bestimmten Zeit und mit vinem hestimmmten Raum, somlern lediglich mit Zeit und Raum als allgemeinen Fmuktimen zu tum. Anch hat der Bewegnngsvorging, den das Urteil aussagt, kesme solbstandige Berlentumg. Tom der Wahrnehmung eilt die naturwissen-

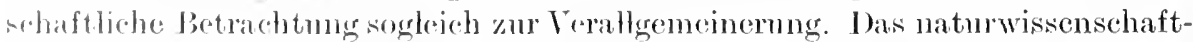
liche Lrteil, lab mein Magnet diese Ferler anzieht, gewinnt erst Bedentung, wenn ich zu dror Eikenutnis gelangt hin, lablor Magnetstein das Eisen anzieht.

1) Vgl. Rigkert: Gronzen der naturwissensehaftlichen Begriffsbildung. S. $353 \mathrm{ff}$ 
Die Subsumierungsmöglichkeit macht den Naturvorgang erst bedentungsvoll. Beror ich in der naturwissenschaftlichen Betrachtungsweise das Einzelne unter ein Allgemeines registrieren kann, bleibt es eine Kuriosität. Dagegen hat es keinen Sinn, das historische Urteil: ,.Sokrates trank den Giftbecher" zu verallgemeinern. Das rerbietet die Eimmaligkeit des Vorganges, die Unvergleichlichkeit der Sokratischen Persönlichkeit. Es liegt hier eine Gemeinsamkeit vor zwischen dem ästhetischen und historischen Gebiet. Kant hat in der Kritik der Urteilskraft gezeigt, daß jedes ästhetische Urteil ein Singularurteil sei, und daß eine Unterordmung mnter einen allgemeinen Begriff oder unter eine allgemeine Regel unmöglich ist. In der Welt der Kunst schließen sich alle Gegenstände als rollkommene Individualitäten gegeneinander a.b. Was das Kunstwerk charakterisiert, und was seine eigentümliche Schönheit ausmacht, gerade das hat es mit keinem anderen Kunstwerk gemeinsam Der Gedanke der Werteinmaligkeit verbindet sich für uns unmittelbar mit dem Kunstwerk. Wenn zwei Gelehrte unabhängig voneinander dieselbe Entdeckung machen, so schadet das ihrer Leistung nicht. Im Gegenteil, ihre große Tat erhält noch eine besondere Weihe und Zuverlässigkeit. weil sie auf verschiedenem Wege gewonnen wurde. Aber das Kunstwerk muß einzig sein und einzig bleiben. Das Allgemeine, das die Kunst darstellt und zur ästhetischen Idee rerklärt, muß immer wieder einen nie erreichten Ausdruck finden. Ewig, einzig und unersetzlich muß es sein. Das zweite absolut gleiche Kunstwerk wiurde unheimlich wirken als Doppclgänger und ernüchternd als Kopie.

Böcklins Wunderwald, durch den das Märchen des Schweigens zieht, ist eine Individnalität. Was ich ron ihm sage. was ich an ihm werte, gilt für ihn allein: es gibt keine allgemeine Regel. nach der ich vorfahren könnte, um Märchenwälder zu malen, und keine Anweisung. jencs große lastende Schweigen, dessen grausame Furchtbarkeit Leonid Andrejew so gut verstanden hat, in eine künstlerische Wirklichkeit zu bilden. - Das wahrhaft künstlerische Interesse freut sich nicht der Gemeinsamkeit. sondern der Einzigkeit. Das Aufsuchen des Gemeinsamen ist Sache einer unkünstlerischen Reflexion.

Es gibt eine Funktion der Seele, die der große Theologe S̈ch leiermach er auf einen glücklichen Auscluck gebracht hat, die dem Historiker ebenso not tut wie dem Künstler, dem schaffenden sowohl wie dem Kïnstler des Lebens, das ist der Sinn für eigentümliche Natur. Schleiermacher hat daron in seinen Monologen gesprochen. Wir sollen bemüht sein, ein eigenes Leben zu leben und eigentiumliches Leben zu rerstehen. Nein Wert liegt an dem, darin ich einzig und unersetzlich bin - und mag dieses Einzige auch nur ein Kleines sein. Und diesem Eigentümỉchen soll der Historiker in der Geschichte nachgehen, und der Künstler soll es bilden, indem er der allgemeinen Idee die nie erlebte und nie wieder erlebbare eigentïmliche Gestalt verleiht.

Der Charakter der Singularität ist den ästhetischen und historischen Urteilen gemeinsam. Bei beiden bezieht sich die Aussage, die prädikative Bestimmung in letzter Hinsicht auf ein Individuelles. Asthetische Beurteilungen wie: ,Dies ist schön, lebendig, plastisch, wirksam, interessant" beziehen sich auf eine individuelle Wirklichkeit wie die Fülle der historischen Urteile. So allgemein die so eben erwähnten ästhetischen Wertprädikate auch sein mögen, 
und so groß dementsprechend ihre Anwendbarkeit anch ist, im Falle der Anwendung werden sie immer notwendig auf eine bestimmte kiinstlerische Individualität bezogen. Sie beziehen sich anf das einzelne in seiner Konkretheit, und dies Terhältnis zum einzelnen ist so wesentlich, daß die Verwandlung des singularen Urteils in ein generelles ohne ästhetische Bedeutung ist. Die Schönheit dieses Kunstwerkes oder dieser Wirklichkeit des Lebens kann nicht dadurch gerechtfertigt werden, daß ich sie einem allgemeinen Begriff unterordne. Denn in der Welt der Kunst ist das eine schon das Vollendete, das Gesuchte und das Erreichte, darin das Streben zur Ruhe kommt. Und das ästhetische Gefühl kann durch das Bewußtsein des Gemeinsamen nicht wachsen, sondern muß vielmehr daran zugrunde gehen. Die Gemeinsamkeit in der Art und Weise, wie ein ästhetisches Problem gelöst ist, mag wissenschaftlich interessieren und ist doeh künstleriseh betrachtet ohne Wert. Wir verlangen, daß das Kunstwerk originell sei, daß es seine eigene Seele habe. Anders in der ästhetischen Theorie, die uns ein philosophisch-wissenschaftliches, nicht ein künstlerisches Verstehen geben soll. Da hanlelt es sich nicht mehr um jenen so besonders schön gebildeten Sklaven der Sixtina, noch um den Propheten Ezechiel oder die Sibylle ron Cumä, wie sie seine Meisterhand dort gemalt, sondern mu den ganzen Michelangelo als Kïnstler, nicht mehr um die Meistersinger, sondern um das Musikdrama Richard Wagners überhaupt.

Woh! kann die Geschichte das generelle Urteil nicht entbehren. Sie bedarf seiner sogar im weiten Umfang. Tnd loch werden die bedeutsamsten historischen Urteile Singularmrteile bleiben müssen. Gibt es doch nur einen Solirates, eine griechische Nation und eine Renaissanceepoche. Wie jedes große Kunstwerk, so hat auch jede große Kulturepoche ihre besondere Seele. Und ron dieser Seele des Zeitalters hat der Historiker zu reden. Die Seele des Zeitalters ist seine Originalität. Bin ich etwa imstande, das Verhalten und den Tod des Sokrates aus dem Typus des griechischen Weisheitslehrers zu entwickeln und zu begreifen? Fälle ich nicht eine Fülle von Urteilen über das griechische Tolk, die mur für dieses Trolk gelten? Ist nicht seine Philosophie und Kunst etwas, das sowohl der Aufteilung wie auch der Verallgemeinerung in der historischen Betrachtung Widerstand leistet und als Indiviluum begriffen sein will? Soll ich griechisehe Philosophie und Kunst mu als Spezialfälle allgemein philosophiseher und künstleriseher Bewegungen betrachten? Soll die Renaissance für mich mur eine von den vielen Wiederfrebungiversuchen vergangener Kultur bedenten? MuB nieht an einer solchen Auffasing die Geschichte zugrumde gehen? (Ohne Sinn für das Eimmalige mml Vingigartige kanm kein wahrhafter Histoniker sein, demn hier ist die Stätte

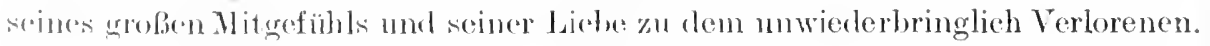
lir weifs, daß das Großse so, wio es gewesen, niemals wiekler sein wirk.

Mit Nachdruck wirl cr davon reslen, daB Griochenland war und Alexander

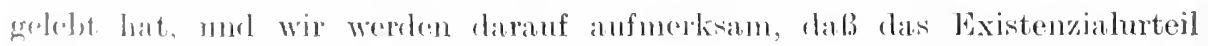

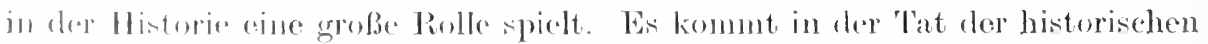

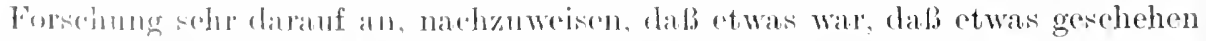

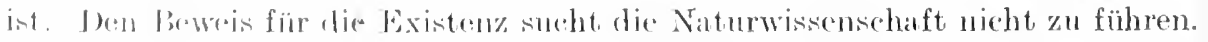

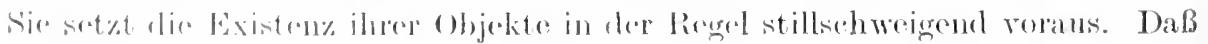

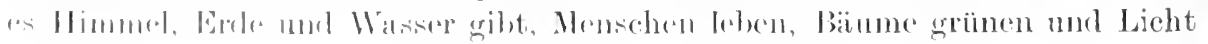


leuchtet, das sind selbstrerständliche Tatsachen. deren wir uns nicht erst mehr zu vergewissern brauchen. Für die Kulturvorgänge ist die Wirklichkeit nichts Selbstverständliches, denn für sie gilt nicht das beständige Dasein, sondern das wechselnde Gewesensein. Die Existenz ist für die Historie ein Problem.

Die größere Stabilität der naturwissenschaftlichen Objekte, welche die Existenz als selbstverständlich roraussetzt, während die Geschichte immer wieder die Daseinsfrage erhebt, hängt mit dem rerschiedenen Verhältnis der beiden Wissenschaften zu Raum und Zeit zusammen. Der Raum ist für die Naturwissenschaft, die Zeit für die Geschichte am wesentlichsten, wenn auch die Naturwissenschaft nicht ohne die Zeit und die Geschichte nicht ohne den Raum auskommen kann.

Die Naturwissenschaft deutet die Zeit in Raum um. Sie sucht die Zeit als Funktion des Raumes zu begreifen. Sie legt die Zeit fest. Sie macht das Flüchtige konstant, sie versucht die Zerlegung des ewig Fließenden und Wechselnden. Die Naturwissenschaft zerlegt und teilt die Zeit, wie man eine Strecke teilt. Und so wird die Zeit rationalisiert, begrifflich und zahlenmäßig beherrscht. Aber in der Geschichte bewahrt (lie Zeit ihre Rätselhaftigkeit $\left.{ }^{1}\right)$. Hier ist sie durch die Zahl nicht beherrscht, sondern nur in ein loses und äußerliches Terhältnis zur Zahl gebracht. Die Zahl ist im Grunde genommen etwas ganz Gleichgïltiges und Nebensächliches für die Geschichte. Die Peihenfolge der Ereignisse ist wesentlich, aber nicht die zahlenmäßige Bindung. Dagegen ist der Raum für die historische Betrachtung ein Sekundäres. Der Raum interessiert hier nur unter dem Gesichtspunkt der Zeit, wie in der Naturwissenschaft die Zeit unter dem Gesichtspunkt des Raumes.

\section{g) Der historische Begriff.}

Die Urteile über historische Vorgänge und historische Individuen verdichten sich im Begriff. Jeder historische Begriff ist als Niederschlag zahlreicher historischen Urteile anzusehen. Der historische Begriff ist das ruhige Depot des Wissens, im historischen Urteil liegt die eigentliche Lebendigkeit der Erkenntnis ${ }^{2}$ ). Im Urteil rollzieht sich die Stellungnahme zum Begriff der Wahrheit. Im Begriff ist die Erkenntnis zur Ruhe gekommen. Der Begriff Centaur ist weder wahr noch falsch. Nur wenn die Torstellung des Centauren auf den Begriff der Existenz bezogen wird. muB Negation gefordert werden.

Im historischen Begriff ${ }^{3}$ ) sammelt sich der Reichtum der historischen Urteilsbildung. Er ist inhaltlich weit reicher als der naturwisseuschaftliche Begriff. Die mathematische Gerade ist die kürzeste Verbinclung zwischen zwei Punkten. Damit ist alles Wichtige über die mathematische Gerade gesagt. Mehr brauchen wir nicht zu wissen. In die erwähnte Definition geht alles ein, was wir von der Geraden zu wissen brauchen. Und wie die Grundbegriffe der Mathematik, so sind auch die der Naturwissenschaft bald erschöpft. Dagegen ist ein historischer Begriff wie Sokrates oder Renaissance sehr reich an

$\left.{ }^{1}\right)$ Vgl. Henrí Bergson, Essai sur les domnées immediates de la conscience.

$\left.{ }^{2}\right)$ Vgl. Rickert: Zur Lehre von der Definition. 1888.

3) Vgl. über die historische Begriffsbildung Rickert: Grenzen S. 274ff.

Mehlis, Geschichtsphilosophie. 
Bestimmungen. Der mathematisehe und naturwissensehaftliche Begriff lassen sich durch Definition so ziemlich erschöpfen, der historische niemals. Wenn ich sage: Demokrits Atome sind unteilbare, qualitätslose Wirklichkeiten, unwahrnehmbar klein, von Gestalt und Größe versehieden und von Ewigkeit her in Bewegung, so habe ich über das Atom des Demokrit wohl so ziemlieh das Wesentliche gesagt. Wenn ich aber sage: die Renaissance ist die erste Epoehe der neweren Gesehichte, sie unfaßt das 14.-16. Jahrhundert und steht unter dem Einfluß des klassischen Altertums. so genügen diese Bestimmungen absolut nicht, $m$ den Begriff der Renaissance zn verstehen. Von den mathematischen und naturwissenschaftlichen Begriffen kömnen wir immer nur verhältnismäßig wenig wissen, von den historischen Begriffen aber sehr viel. Der Simn der mathematischen Figur und der chemischen Verbindung ist leicht einzusehen. Wir können ihn uns bałd merken.

Dagegen umfaßt der historisehe Begriff etwa des griechischen Volkes einen solchen Peichtum, daß er uns immer wieder nenes zu denken und zu denten gibt. Damit hängt es zusammen, daß derselbe historisehe Begriff für den einen so unendlich viel und für den anderen so seltsam wenig bedeuten kann. Wemn ich die Renaissance etwa durch die Zahlen 1400-1600 definiere, so genïgt das allerdings zur Verständignng über den Zeitramm, der gemeint ist, aber der Begriff der Renaissance ist doch nicht nur der Begriff eines Zeitraumes, sondern der Begriff einer großen Kulturbewegung, die diese Epoche erfüllt hat. Unter Begriff verstehen wir immer das, was eine wissenschaftliche Erkenntnis meint, woranf eine wissenschaftliehe Erkenntnis abzielt. Der Begriff der Sache ist nicht etwa die individuelle Vorstellung als Akt oder Tätigkeit des seelisehen Geschehens, sondern vielmehr dasjenige, darin die Erkenntnis vollendet und beschlossen ist. Jeder wissensehaftliehe Begriff ist ein Erkenntnisideal. das als solches nicht existiert, und er ist gleichzeitig ein Surrogat für die Wirklichkcit - allerlings ein uwureiehendes, ungenügendes Surrogat. Wir dürfen den Begriff nieht mit der Wirklichkeit verwechseln, den Begriff nicht zur Wirklichkeit machen. Der Begriff ist die Wirklichkeit, wie sie für die Erkenntnis da ist. Aher die Wirklichkeit ist nieht nur für die Erkemntnis da. Dic Wirklichkeit hat anch für Kunst, Religion, Philosophie und Leben ihren Simn, der wesentlieh rerschieden ist ron dem Erkenntnisdasein der Welt, wie es im wissenschaftlichen Begriff sich darstellt. Durch den historisehen Begriff wirl mehr Wirklichkeit in den Dienst der Erkenntnis gezwongen, durch den naturwisensehaftliehen Begriff das Wenige mehr in Erkemntnis anfgelöst. Wenn wir aber in dieser. Weise zwisehen dem natmrwissensehaftliehen und flem histerischen liegriff unterscheiden, so ist dasjenige, was wir hier muter begriff veptehen, schon ein sehr zusammengesetztes uml kompliziertes Gebilele, das ainen groben Weg der Erkenntnisarbejt hinter sich hat. Augenscheinlich baurn sich diese bedentumgsejehen wissensehaftlichen Begriffe auf cinfachen Cimurlelementen anf. I)er komplizierte wissen haftliche Begriff weist anf einfarbe Elementarbegriffo hin. Man kamm sagen, daß diese Elementar-

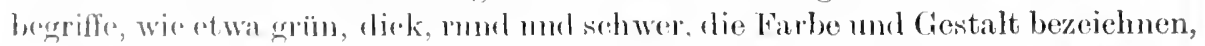

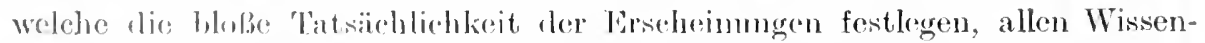
schaften gemeinsam sind, sofern jerte spericlle wissensehaftliche Erkenntnis mir sehon voranksetgt. Sire drïekron rin Minimm von Denkleistung aus, das 
an den Objekten vollzogen ist. Uns scheint eine solche neutrale Auffassung der Elementarbegriffe angemessener zu sein als ihre Registrierung unter die Anfänge der naturwissenschaftlichen Erkenntnis. Wir wollen nicht leugnen, daß die Geschichte als die weit spätere der beiden Wissenschaften sich manche Begriffe der naturwissenschaftlichen Erkenntnis zunutze gemacht hat, aber jene Elementarbegriffe, die der Beschreibung der Objekte und der Fixierung einfacher Grunderlebnisse und Empfindungen dienen, sind in ihrer rein beschreibenden Funktion noch nicht dem besonderen Ziele spezieller wissenschaftlicher Erkenntnis zugewendet.

Die einfachen primitiven Begriffe müssen den komplizierten Begriffen Inhalt und Fülle geben. Sie haben keine selbständige Bedentung, sondern sind für jene da. Wenn wir daher den historischen Begrift als reicher oder, wie wir auch sagen können, konkreter bezeichnet haben als den naturwissenschaftlichen Begriff, so bezieht sich das nicht auf die Begriffselemente, die wir in allen Wissenschaften wiederfinden und gleichmäßig brauchen, sondern auf die zusammengesetzten Begriffe als die wichtigsten Produkte der wissenschaftlichen Erkenntnis.

Zım Begriff irgendeines Objektes gehört nach unserer Auffassung nicht nur das, was zur eindeutigen Fixierung ausreicht und unser Objekt in Verhältnis zu anderen Objekten zum Zwecke der Verständigung und Unterscheidung hinlänglich deutlich macht, der Begriff ist nicht ein Notbehelf ron allgemeinen Merkmalen, die zısammengefügt sind, $1 \mathrm{~m}$ den Menschen auf der großen Landkarte der Welt und des Lebens besser zu orientieren, sondern der Begriff ist der volle und vollendete Erkenntuisinhalt. Nur diese Auffassung vermag ihm die Würde zu geben, die ihm gebührt, und ihn jener utilitaristischen Deutung zu entziehen, durch die sein selbständiges Belleuten im Gedanken der Denkökonomie bedroht wird. Gewiß, der Begriff erfüllt auch diese Funktion, durch die Möglichkeit des Generalisierens und Zusammenfassens wird jene ungeheure Arbeitsersparnis des Denkens geleistet, welche die Erkenntnis überhaupt erst möglich macht. Da der Begriff für vieles gilt, für alles, was in seinen Umkreis fällt, so branche ich die besondere Art des Geltens nicht immer wieder am einzelnen abzulesen. Aber dieser Dienst, den die Natur des Begriffes dem menschlichen Nachdenken zuteil werden läßt, ist doch im Grunde genommen nur etwas Nebensächliches und Gleichgültiges für ihn. Weit besser wird sein Wesen charakterisiert in dem Gedanken der Gegenstandsbemächtigung. Nach dieser Auffassung dient der Begriff der Erkenntnis, nicht aber der menschlichen Bedürftigkeit. Anderseits kommt doch in dieser Bestimmung noch nicht zum Ausdruck, daß der Begriff nicht nur Mittel ist, um diese sinnliche Wirklichkeit zu rerstehen und uns zum Gegenstand der Erkenntnis zu führen, sondern daß im Begriff als Ideal der Erkenntnis die Aufgaben des Wissens gelöst sind. Habe ich etwa den Begriff der Renaissance in der Fülle seiner Bestimmungen mir deutlich gemacht, so ist von ihm aus eine der schönsten Bewegungen menschlicher Kultur in der Fülle ihrei Bedeutung rerstanden.

Unter dem wissenschaftlichen Begriff rerstehen wir den rollendeten Erkenntnisinhalt. Die Elementarbegriffe sind dienender Natur, sie dienen der gegenseitigen Verständigung unter Menschen, sie dienen dem wissenschaftlichen Begriff. Dieser wissenschaftliche Begriff aher ist in seiner ganzen 
Struktur von der Idee und Zielsetzung seiner Wissenschaft abhängig. Was an einem Objekt von einer gewissen Zielsetzung der Wissenschaft aus betrachtet wiscenswert ist, das gehört auch zu dem Begriff des Objektes. Während aber der abstrakte und relativ einfaehe Begriff des Atoms für eine Fülle ron Wirklichkeiten gilt, die alle Atome sind, ist der historische Begriff so mosaikartig bunt, reich und wechselvoll zusammengesetzt, daß er nur für einen ganz bestimmten Teil des Wirklichen gilt und für keinen anderen. So ruhen etwa in dem Begriff der Renaissanee alle die Begriffselemente, welche diese Epoche zu einer vollkommen eigenartigen machen. Wir werden deswegen darauf verzichten müssen, eine Definition der Renaissance zu geben, und zu einer eingehenden Beschreibung greifen, um alle diejenigen Bestimmungen zu entwickeln, die wir mit dem Begriff der Renaissance verbinden. Welche Merkmale da nun im einzelnen bedeutsam sind, das läßt sich nicht mit Sieherheit entscheiden. Aber wir wissen, daß eine große Fülle ron Bestimmungen dahin gehört, die nur in einer sehr großen Zahl von Urteilen flüssig gemacht werden können. Renaissance ist ein idealer Erkenntnisinhalt, der dem Historiker immer wieder neue Aufgaben stellt. Wird num clieser Urteilskomplex, den wir als Begriff der Renaissance bezeichnèn, in Einzelurteile aufgelöst und etwa (las Urteil gefällt: ,Die Renaissance hat einen großen Aufschwung des wissenschaftlichen Denkens zur Folge gehabt", so kann unter Renaissance nur das historische Individium in seiner Ganzheit, nicht aber ein Teilinhalt des Gesamtbegriffes rerstanden werden.

\section{Das Subjekt des historischen Urteils.}

DaB im Subjekt rles historischen Urteils immer clas Ganze gemeint ist, würten wir dem umbefangenen Denken gegenüber nicht ausdrücklich zu betonen haben. wenn nicht ein so großer Logiker wie Lotze seinerzeit eine entgegengesetzte Anffassung vertreten hätte, die dann Bergmann kritisiert und widerlegt hat. Lotze sucht das historische Urteil: ,Cäsar überschritt den Rubikon" durch das Prinzip der Identitäit zu hegründen. Er fragt bei der Amalyse dieses Crteils, was das Subjekt wohl sei, welehes das Prädikat meint. Seine Antwort lautet: „Nicht der schlafende, sondern der wachende, nicht dor zweifelnde, sondern der entschlosiene Cäar. Der Cäsar, den das subjekt meint, ist nur derjenige, den das Prädikat bestimmt, nämlieh der über den lubikon gchende. In allen frïheren Augenblicken war er nicht das Subjekt, an wolches das Prïlikat sich hätte knüpfen lassen. Auch leuch tet schwacher Fassmugseabe cin, dals Cäisar, als er ïber den Fluß gegangen war, nieht fortfahren komnte hiubloczugehen. Cäsar kamn anch in Urteilen äber spätere historische begebenloeiten niemals das Subjekt soin, welches wir meinten, la wir das loveil fällton: "(Gäar überschrit. den Rubikon". Somit ist der isher den Rubikon grehende (aisar das Subjokt mol derselbo auch das Pröilikat').

So surht Lotze das historische Erteil durch die Nom der Identität zu begrimen. Das historische Coteil ist ain identisehes Coteil. Subjekt und Prä-

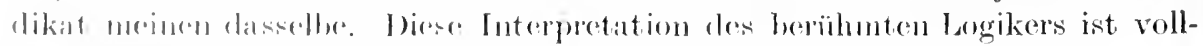

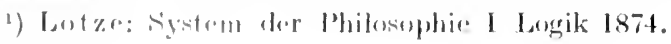


kommen verständlich, wenn wir bedenken, daß Lotze zı einer Zeit gelebt und geschrieben hat, wo das Problem einer Geschicht-logik noch nicht ernsthaft diskutiert wurde. So hat denn auch diese Auffassung erst nach Erweiterung des geschichtsphilosophischen Verständnisses in der Logik Bergmanns einen entschiedenen Gegner gefunden ${ }^{1}$ ). Das Gewaltsame von Lotzes Interpretation springt ja sofort in die Augen. Gewiß bildet, wie Bergmann betont. dieselbe Vorstellung das Subjekt aller Urteile über Cäsar. Nicht liegen ihnen verschiedene Vorstellungen zugrunde, die sich sozusagen in den Cäsar der sein Dasein umfassenden Zeit nach teilen. Tielmehr meint das Prädikat die historische Persönlichkeit Cäsar. Wie das Urteil: ,Sokrates trank den Giftbecher", so hat auch das Urteil: „Cäsar überschritt den Rubikon“ etwas Emphatisches an sich, das ein Erleben und Verstehen des Bedeutungsgehaltes fordert, der in diesem Namen beschlossen liegt. Sokrates, der den Giftbecher trank, ist nicht nur jener heitere gefaßte Greis, der den Anordnungen des Henker. gewissenhaft folgt und bis zum letzten Athemzuge der Pflicht eingedenk ist. Er ist auch der Sokrates, der über die Unsterblichkeit gesprochen und dic schönen Haare des Phädon gestreichelt. Er ist der Sokrates, der verlangt hat, im Prytaneum gespeist zu werden, der alle Vorschläge zur Flucht von sich wies. Er ist der Lehrer des Alkibiades und Platos, der großc Weise. der einer überzeugungslosen Zeit seinen mächtigen Glauben an die Wahrheit. an die Vernunft entgegenhielt. Er ist der Sokrates, der bei Potidäa Kriegsdienste tat und das Leben seines schönen Freundes rettete. Dies und vicl mehr ist Sokrates, der den Giftbecher trank, als ein unvergleichlicher Wert für die Menschheit. Und auch für Cäsa r gilt etwas Analoges. Wenn wir das Urteil aussprechen: „Cäsar überschritt den Rubikon", so liegt ein ganz hesonderer Ton auf dem Namen Cäs ar. Cäs a r überschritt den Rubikon, nicht ein anderer von den consulares oder equites, von den Senatoren un Pittern Poms, sondern Cäsar, Roms größter Sohn, der so ruhmvolle Taten in Gallien ausgeführt und der getragen wurde ron der Kraft und Liebe seiner Legionen. Alles, was er getan und geleistet hat, sein stolzes Geschlecht. sein mutiger Ehrgeiz. alles das meinen wir mit dem Cäsar, der den Rubikon überschritt. Er und kein anderer durfte es wagen, mit den gallischen Legionen feindlich gegen Pom zu marschieren. Eine volle Persönlichkeit steht hinter jenem Urteil, das eine welthistorische Handlung zum Ausdruck bringt.

„Cäsar, welcher den Rubikon überschritt”, das ist eine Bestimmung. die sich nicht auf ein Segment der historischen Individualität, sondern auf die ganze historische Persönlichkeit bezieht, so wie der ,. Sieger ron Austerlitz.* sich mit der Gestalt Napoleons zu einer Einheit verbindet.

Gewiß hat Lotze recht, wenn er in seiner Analyse des historischen Urteils die notwendige Beziehung zum Zeitmoment scharf hervorhebt. Aber diese Beziehung trifft im Grunde nicht das subjekt als Gegenstand des Urteils. sondern vielmehr das, was das Prädikat aussagt. Die Persönlichkeit geht über die Zeit hinaus, während allerdings die Handlung, die ron ihr vollendet wird, nur an einer ganz bestimmten Stelle im Zusammenhang des Geschehen: historische Bedeutung gewinnt.

3) Bergmann: Allgemeine Logik. 
Daß es numöglich ist, die Urteilsverknüpfung auf Identität zurückzuführen - das hatte ja sehon Kant in der Kritik der reinen Vermunft gezeigt und den synthetizehen Charakter cles Urteils enthüllt. Daß der Prädikatsbegriff in der naturwissenschaftlichen Erkenntnis ïber den Subjektsbegriff hinausgeht, das war Kants große Entdeckung. Was aber für die naturwissensehaftliche Erkenntnis gilt, muß erst recht anch für die historisehe Erkenntmis gelten.

Sonst bewegt sieh die Gesehichte in lauter Tautologien wie: der den Rubikon überschreitende Cäsar übersehritt den Rubikon, der von Brutus ermordete Cäsar wird ron Brutus ermorlet. Bei einer solehen Auffassung des historisehen Urteils teilt die Geschichte überhaupt nichts Nenes mit. Die ganze Analyse ist so gewaltsam und simnverwirrend, daß wir ersehroeken fragen, welche Uberlegungen wohl zı so künstliehen Deutungsversuchen geführt haben mögen. Die Antwort finden wir am besten, wenn wir uns den historischen Subjektsbegriff noeh etwas deutlicher machen mo ihn mit dem naturwissenschaftlichen rergleiehen. Da hat nun angenseheinlich der naturwissensehaftliehe Subjektsbegriff, wie er als Ideal gedacht wird, das letzte Ding, die Substanz, Materie oder Energie, die Eigensehaft der Unveränderlichkeit. Die Elemente der Wirklichkeit, welehe die Naturwissensehaft in ihren letzten Dingen zu besitzen slaubt - sie verändern sich nicht - sie sind immer dieselben, die ewig gleiehen. Die historischen Subjekte dagegen sind in Wandhung und Veränderung begriffen. Für sie ist es wesentlich, daß sie sich entwickeln und fortsehreiten. Während clas naturwissenschaftliche Atom unabhängig ron der Zeit immer dasselbe bleibt, und ieh infolgedessen berechtigt bin, jederzeit meine Aussage mit ihm zu verbinden, entspringt für die historisehe Urteilsbildung das Problem, ob die Anssagen, die für den Knaben Alexancler gelten, auch für den Mann ihren Sim behalten, und ob Brutus, der Cäsar liebte, es war, der Cäsar den Tod gab. Wenn wir so ganz anders geworden sind, können wir auch nieht mehr 'Träger unserer früheren Taten sein. Wir sprechen ja davon, daß jemand ein anklerer Mensch goworten sei, und die Religion vieler Völker kennt die Nenwrolung des Mensehen, die Wiedergeburt, geweiht dureh heilige Handlungen, durch die der Mensch rein wirl und unschuldig, wie er als Kind war, bevor er schnldig wrole, oder so, wie ar niemals gewesen. Diese beiden Tendenzen sind rlutich: der Mensch soll werden, wie er anfangs war, oder der Menseh soll werlen, so wir or niemals war. Sis : iubern sich in lem Wunseh, ein neues Leben zu beginnen, der so äuBerst paralox ist und doch etwas Gewohntes für nns(r) Vorhaben, nurl anderseits in der stolzen Besimmung: , Ich bin num c.jomal, was ich bin. Ihr kömnt mich nicht verändern*. Die Dentung des historischen Crteils, wie sic Lotzo gegeben hat, wïrde den Gedanken des absolutan Wandelns vertreten. Der Menseld bleibt nicht das, was er war, und verhatrt nicht bej dom, was ("r ist. Das historische subjekt ist immer ein anderes. IVas für den Konsul Jona parte gilt, das gilt nicht für den Kaiser der Franzosen.

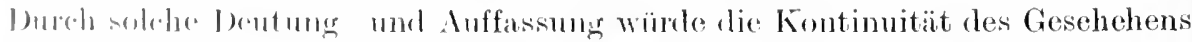

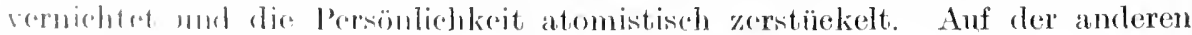

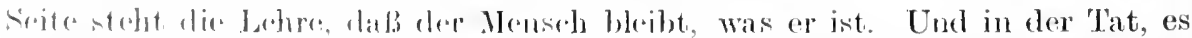
kommt ms manchmal $\rightarrow$ vor, als oh, wir, in nichts verindert, geblieben wären,

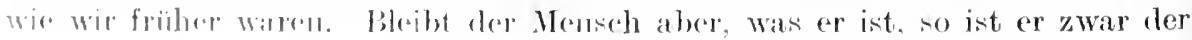


einheitliche Beziehungspunkt aller seiner Handlungen und als solcher einzuschätzen, doch wissen wir dann nicht, wozn er in den historischen Prozeß hineingestellt ist, und das geschichtliche Leben scheint seine Bedentung zu verlieren. Wir werden sehen, daß der Begriff der historischen Entwicklung diese Schwierigkeiten zu lösen unternimmt. Der Simn der Geschichte erfordert es, daß die historischen Handlungen in der Persönlichkeit ihr Zentrum finden, daß sie auf eine konstante Einheit bezogen werden. Während aber dieselbe Individualität als Träger aller der Handlungen gilt, die sie in ihrer wechselvollen Entwicklung vollzogen hat, unterliegt die Individualität doch in sehr vielen Fällen keinem einheitlichen Maßstabe, da es für uns ummöglich ist, ein Gesamturteil zu fällen. Sehr häufig tritt das Gesamturteil zurück oder wird sogar zu einer Unmöglichkeit. So können wir nur schwer den jungen Tiberius mit dem alten gransamen und finsteren Kaiser ins Einvernehmen setzen. Bemerken wollen wir anch schon hier, daß für die Geschichte der Grundsatz gilt, daß ein Geschehenes niemals ungeschehen gemacht werden kamn, was der sittlichen Beurteilung augenscheinlich widerstreitet.

Das Singularurteil der Geschichte wies auf das Einzelne als Gegenstand der Historie hin. Die Kompliziertheit und Konkretheit des historischen Begriffes war ein Hinweis auf die Fülle und Mamnigfaltigkeit des historischen Objektes. In dem Individuellen und Eimmaligen crkannten wir den Gegenstand der historischen Begriffsbildnng. Das Allgemeine ist für die Historie nicht Zweck, sondern Mittel, das wird uns immer deutlicher und selbstrerständlicher werden trotz mancher scheinbaren Gegeninstanzen, die rorgebracht werden können. Die Historie brancht die allgemeine Bedentung des Wortes, um vernehmlich zn werden, und die Elemente, aus denen der historische Begriff sich zusammensetzt, sind gewiß allgemein. Aber dieser Begriffskomplex, den wir als historischen Begriff bezeichnen, meint das Individuelle.

Wir haben damit unsere Untersuchung über Form und Inhalt der Geschichte so weit geführt, als die Erörterung dieses Problemkreises in unserem einleitenden, die Probleme in ihrer allgemeinsten Struktur kennzeichnenden Teile erforderlich war. Das Problem ron Form und Tnhalt in der Historie ergab sich für uns, indem wir das historische Objekt, mit dem es der zweite Teil der Geschichtslogik zu tun hatte, unter den Gesichtspunkt der Erkenntnis stellten. An dem Objekt läßt sich ein Anteil des Denkens unterscheiden; diesen Denkanteil bezeichneten wir ganz allgemein als Form. und im Verhältnis zur Form ließen sich verschiedcne Begriffe ron historischem Material unterscheiden. Die allgemein logischen Figuren, in denen die Form zum Ausdruck gelangt, sind Urteil und Begriff, auf deren eigentümlichen Charakter im Gebiet des historischen Wissens wir hingewiesen haben. An dem UrteilsmäBigen und Begriffsmäßigen läßt sich aber wiederum eine Unterscheidung vornehmen, auf die wir ganz allgemein in einem anderen Znsammenhange schon hingewiesen haben. Von Begriff und Urteil läßt sich etwas ablösen, was im eminenten Sinne den Charakter der Form trägt und deshalb als reine Form bezeichnet werden mag. Diese reinen Formen sind keine Begriffe von sinnlichen Wirklichkeiten wie die empirischen Begriffe Haus und Baum, sondern sie drücken eine notwendige Zusammengehörigkeit zwischen sinnlichen Wirklichkeiten aus. Sofern riese Begriffe der Geschichte zugewenrlet sind unr 
die letzten logisch-theoretischen Grundlagen und Voranssetzungen der historisehen Wissenschaft bilden, bezeichnen wir sie als die historiseh-methodologisehen Kategorien, deren Erörterung in die Gesehichtslogik gehört. Von diesen Kategorien unterscheiden wir die Werte, die als allgemeine Kulturwerte überhaupt in der historischen Wertlehre als der Lehre von den Prinzipien des historischen Gesehehens abzuhandeln sind, und die dann zweitens als die speziellen geschichtsphilosophisehen oder metaphysisehen Werte der Universalgeschichte angehören.

Zn den historiseh-methodologischen Kategorien gehören vor allem der Begriff des historisehen Individuums, der historischen Kausalität, der Begriff des historischen Zusammenhanges und der historischen Entwicklung. Ganz angenscheintieh entspreehen diesen Kategorien ebenso unentbehrliche Begriffe der Naturwissensehaft. So entspricht dem Begriff des historischen Individuuns der naturwissenschaftliche Begriff der Substanz als Atom, Kraft und Energie, so entspricht dem Begriff der historischen Kausalität der naturwissenschaftliehe Begrift des Gesetzes. So entspricht dem Begriff des historisehen Zusammenhanges, der in dem Verhältnis des Ganzen zu den Teilen sich entfaltet, das naturwissenschaftliche Verhältnis von Gattung und Exemplar. So steht der einmaligen historischen Entwicklung der biologische Entwicklungshegriff entgegen. Alle diese historischen Kategorien sind dadureh charakterisiert, daß sie dem Individuellen, Einmaligen und Konkreten angemessen sind, daß in ihnen die Reflexion auf das Verschiedene, nicht auf das Gleiche, auf das Nene, nieht auf das Wiederkehrende gerichtct ist. In all diesen Begriffen ist zunächst eimmal ein rein theoretisches Verhältnis gemeint. Das historisehe Individum bildet die logisehe Einheit, die der historischen Betrachtung als Substrat zugrunde gelegt wird ${ }^{1}$ ). Das historische Individuum ist eine Individualität, deren Aufteilung dem Sinne der Historie widerstreiten würde. Solche historische Individuen sind historische Individualitäten, Handłungen, Leistungen, Vorgänge, die als Einheiten begriffen werden sollen und die als Einheiten wichtige historische Faktoren sind. Aber im Theoretischen ist der Begriff des Indiviłuums nieht vollendet. Dazu bedarf es gleishsam noth einer zweiten Formung, und zu dieser zweiten Form gelangen wir, wemn wir daranf reftektieren, was es demn eigentlich ist, das ms zwingt, bei dem Individuum Halt, zu machen, was uns mit historisehen Individualitäten und historischen Leistungen als letzten Einheiten operieren läBt. Warum trenne ich nicht räsars Seele von Cäsars Körper, warum zerlege ieh nicht seinen Organismus in kleine und kleinste Teile. warum reflektiere ich nicht auf die Summe der Bewegungsmomente, in welche ich Cäsars Uherschreiten des liubikons zerlegen kinn? Augeuscheinlich weil diese Handlung durch einen bostimmten Zweek zu einer Einheit formiert ist. Der Zweekgesiehtspunkt oler Wortgesichtspunkt aher, 1 m den es sich hicr handelt, ist dasjenige, Was wir ihe Kulturbedentung nonnen, und er volhindet sich ummittelbar mit der politischen (ivelie mud Entfaltumg des römischen Waltrejehes.

Ahnliches gilt nun aber anch für die anderen, zunichst rein theoretischen Begrilf. So otwa für den Begriff des historischen Zusammenhanges'2). In

3) Vel. Rickert: Firmzen, S. 300ff.

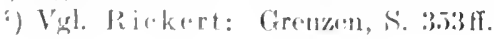


der historischen Begriffsbildung wird das Individum als Teil eines umfassenden Ganzen eingeordnet oder eingegliedert, um Finordnung handelt es sich hier. nicht um Unterordnung. Der Begriff des Ganzen aber bedeutet mehr als seine Teile oder Glieder. Der Begriff der Renaissanceepoche meint und bedeutet mehr als die Summe seiner Glieder, die versehiedenen historischen Individualitäten dieserZeit. Aber mit dem Begriff des Ganzen ist die Idee des historischen Zusammenhanges nicht voliendet. Es handelt sich um ein kulturbedeutsames. ein kulturwichtiges Ganzes. Fassen wir den Begriff der Kultur ganz allgemein als Inbegriff von Gütern oder Werten, so können wir sagen, daß in der hist orischen Begriffsbildung das Individuum zur Wertindividualität, das Ganze zum Wertganzen wird. Und auch der Begriff der historischen Entwicklung und der Begriff der historischen Kausalität entbehrt nicht dieser allgemeinen Beziehung zu Werten. Die Kausalität erscheint als Wertleistung und die Entwieklung als Wertzuwachs.

Damit gehen aber unsere Ausführungen schon über das Gebiet hinaus, das der Geschichtslogik eignet, und wenden sich dem zweiten Teile der Geschichtsphilosophie, der historischen Wertlehre zu. Bevor wir jedoeh auf dieses Gebiet näher eingehen, gilt es noch die bisherigen Untersuchungen für die Probleme der historischen Methode und der historischen Beurteilung nutzbar zu machen. Denn es ist ja deutlich, daß sich der Charakter der historisehen Methode mit Notwendigkeit ergibt aus dem Verhältnis von Objekt und Ziel, von Form und Inhalt der Erkenntnis. Die Methode ist bestimmt durch den Charakter des Zieles und durch den Charakter des Materiales. Wir haben zu fragen, welchen Weg wir gehen müssen, um ein Ziel zu erreichen, und wir haben zu überlegen, welche Erkenntnismittel wohl am geeignetsten sind, um ein Material in erschöpfender Weise zu gestalten und zu bilden. Je nachdem nun mehr das Ziel betont wird, das erreicht werden soll, oder die Eigentümlichkeit des Stoffes, der zur Erkenntnis gebracht wird, ergeben sich verschiedene Möglichkeiten für die Auffassung der historischen Methode.

\section{$\$$ 4. Der vierte Problemkreis: die Probleme der Methode.}

\section{a) Problem der Universalmethode.}

Man darf wohl behaupten, daß sich in unserer Zeit der Gedanke durehgesetzt hat, daß die Geschichte ihre eigentümliche Methode gegenüber der Naturwissenschaft besitzt, und daß diese ihre Nethode nicht umgebildet und umgemodelt werden darf, sondern vielnehr den einzigartigen Weg zur Wahrheit für das historische Bewußtsein bildet. Mag aneh die Stimme derjenigen noch nicht verstummt sein, die alles Denken und alle Nethode lediglich im naturwissensehaftlichen Sime verstehen, so kann man doeh wohl behaupten. dal.3 sich dieser Kampf um die Methode früher oder später zugunsten derjenigen entscheiden wird, die der Historie ihre selbständige Bedeutung bewahron wollen.

Der Gedanke eines Monismus mit Rüeksicht auf die Methode hat immer wieder den menschlichen Geist bezaubert und ergriffen. Wie es nur ein A bsolutes, nur einen letzten Einheitsgrund der Welt gibt, so gibt es auch 
nur e ine n Weg. sieh diesem Ziele zu nähern. Es gibt nur eine Wahrheit und einen Weg zur Wahrheit. Vielleieht ist dieser Gedanke einer einheitlichen Uni= rersalmetode, die auf alle Welt, auf alle Gebiete des Wissens anwendbar ist, nje= mals so groß und mächtig gewesen wie im Zeitalter der Renaissance. Die Idee der Tniversalmethode hat etwas Großes und Mächtiges an sich, wje jene schöne Zeit. die ihn mit solcher Lebendigkeit verfochten und rertreten hat. Damals hat Spinoza die mathematische Methode als die einzig wahrhaftige und zurerlässige verfochten und auch philosophische Einsicht auf mathematischem Wege erstrebt. Seinem erhabenen und seltsamen Versuche, alle methaphysischen Wahrheiten more geometrico zu entwickeln. liegt die verborgene Einsicht zugrunde, daß zwischen Philosophie und Mathematik die große Gemeinsamkeit besteht, daß sie es beide mit dem Unwirklichen zu tun haben, die Einsicht ferner auch, daß der Mathematik und ihren Gegenständen eine Art Zwischenstellung zukommt zwischen der Welt des Sinnlichen und Unsinnlichen. so daß, wemn überhaupt, am natürlichsten und gegebensten von der Mathematik aus der Weg zum Simnlichen und Úbersinnlichen betretbar sei.

Noben der Mathematik ist es die Mechanik gewesen, ron der aus man eine einheitliche und umfassende Naturerklärming erwartete: der Gegenstand aller Erkenntnis ist der mechanische Gegenstand, der Weg aller Methode ist die mechanische Methode. Wie in der Meehanik muß alles verstanden und begriffen werden, so auch das psyehische und moralische Leben. Ohne mechanische Einsicht bleibt alles unverstanden.

Diese Zurückführungaller Erscheinungen auf mechanische Grundphänomene ist ron anderen großen Enthusiasten der Naturwissenschaft bezweifelt worden. Man machte der Mannigfaltigkeit der Erscheinungen die Konzession, daß die eine naturwisicnschaftliche Nethode, die zugleich auch die wahrhaft philosophische sei, in den verschiedenen Zweigen der Naturwissenschaft verschiedene Gestalt gewönne, wenn auch alle Erscheinungen in gleicher Weise der Notwendigkeit des Gesetzes unterliegen. Die Geschiehte ist nach dieser Auffassung die höchste Form der naturwissensehaftlichen Erkenutnis.

Dil 3 nun die Geschichte Naturwissensehaft sein soll, muß dem unbefangenen Denker sehr widersimig erscheinen, denn die Naturwissenschaft, so wird man sieh sagen, hat es doch augenscheinlich mit einem ganz anderen Gegenstande zutun als dic Geschichte. Sofort abex besinnen wir uns, daßes roch prinzipiell kejueswegs ansgesehlossen ist, dab sieh die Naturwissenschaft mit alle dem beschäfigt, womit sieh die Geschichte besehäfigt. Wa]um sollte die Naturwisconchaft nicht alle Erscheinungen, auch die Erseheinungen des religiösen und asthetischen Labons, zum Gegenstand ihrer Betrachtnngsweise machen können? Vielleicht ist das schwierig, aber prinzipiell ausgeschlossen ist es doch sichere nicht. Und ros allen anderen zuverlässig muß uns doch die naturwissen-

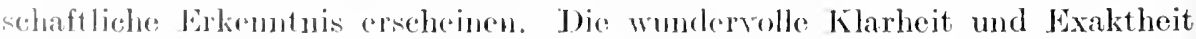
ihrer lourschungsmeshode zerstört alle irrationalen Gefüge des Lebens und gibt ms die Wahrheit, sofern sie mensehlicher Wrforschung zugängig ist, und gibt uns das Wichtige mod Wiblare vom Wesen der Welt.

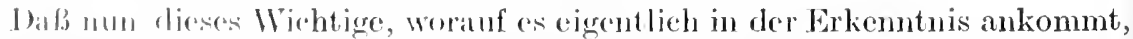
die Diturgentze siul, dal.s allo wohlverstandene Philosophie Naturwissenschaft, allo wahlaft philosmolikehe Mlethorle die nat urwissenschaftliche soi, dab endlich 
in der Geschichte als physique sociale sich alle Naturwissenschaft vollendet, das war die Úberzeugung des großen französisehen Philosophen Auguste Comte. Seine Hauptwerke bedeuten den letzten großen Versuch der Begrïndung einer Universalmethode für alle Gebiete des Wissens ${ }^{1}$ ).

Wir mïssen scharf betonen, daß3 an sich die Forderung einer Universalmethode vollkommen berechtigt ist. Nur unter dieser Voraussetzung kann es. so möchten wir meinen, eine einheitliche und umfassende Deutung und Erklärung aller Erscheinungen geben. Wir müssen es doch als ein Ideal der Erkenntnis betrachten, daß alle Dinge schließlich nur einer endgültigenErklärungsform unterliegen, daß ron einem normativen Gesichtspunkt aus alles in seiner Wirklichkeit und wahrhaftigen Bedeutung klar und verständlich wird. Gibt es rerschiedene Methoden und verschiedene Formen der Erkenntnis, so bedeutet das einen Verzicht auf einheitliche Welterklärung, und mit Notwendigkeit muß sich die Frage erheben, welche von diesen verschiedenen Methoden nun eigentlich den Vorzug verdient, welche denn wohl am meisten Zuverlässigkeit bietet für denjenigen, der zur Erkenntnis der Welt gelangen will.

Auguste Comte stellte sich die Aufgabe, die mangelnde Form aller Erkenntnis zu finden. Sie liegt in der Naturwissenschaft. Ganz augenscheinlich muB doch die Wissenschaft als ein einheitliehes System ron Lrteilen gedacht werden. Es gibt einen in sich geschlossenen Organismus des Wissens. Ein solcher ist aber ohne Eimheitsmethode ganz undenkbar. Diese Einheitsmethode kann nur die Naturwissenschaft geben, weil sie die einzige anerkannte Wissenschaft ist. Das geschieht auf dem Wege der Induktion, die zur Feststellung der allgemeinen Gesetze hinleitet. Unter diesem allgemeinen Gesichtspunkt der Auffassung der Geschichte als Naturwissenschaft gibt es nun aber wieder zwei Möglichkeiten, je nach der Auffassung des Gesetzesbegriffs. Faßt man den Gesetzesbegriff im Sinne der mathematischen Naturwissenschaften, ist der Gesetzesbegriff der mathematisehen Naturwissenschaften vorbildlich für die Geschichte, dam steht die Geschichte unbedingt sehr niedrig in der Rangordnung der Wissenschaften. Damn wird man sagen: die Geschichte ist leider noch keine exakte Naturwissenschaft, sie soll es aber werden. Die Exaktheit der mathematischen Naturwissenschaften wird ihr als ein Ziel gesetzt, das sie niemals erreichen kamn. Dann ist die Gesehichte vermöge der Kompliziertheit ihrer Phänomene dauernd dazu verurteilt, eine dienende Stellung unter den Naturwissenschaften einzunehmen. Oder aber der Gesetzesbegrift der Naturwissenschaft wird sehr allgemein und unbestimmt gefaßt, wie es der französische Positivismus getan: dann war es möglich, der Gesehichte als der Gesetzeswissenschaft rom den kompliziertesten Phänomenen sogar die höchste Stelle in der Rangordnung der Wissenschaften anzuweisen, wie es Anguste Comte tatsächlich getan hat ${ }^{2}$ ).

Als Beweis dafür, daß auch das historisehe Leben bestimmten Naturgesetzen unterliegt, und deswegen die Geschichte in ihrer rollkommenen Ausbildung eine Art Naturwissenschaft sein muls, hat man immer wieder auf die unbezweifelbar vorliegenden RegelmäBigkeiten hingewiesen, die das Kultur-

1) Auguste Comte: Cours de philosophie positive.

$\left.{ }^{2}\right)$ Vgl. mein Buch: Die Geschichtsphilosophie Auguste Comtes. 
gesehehen aufweist. Man glaubte, eine ganz bestimmte Abfolge in der Entfaltung der Kulturphänomene feststellen zu kömen. Eine Nation wird zuerst etwas Künstlericehes leisten und darstellen, um dann erst später den wissenschaftlichen Problemen und der Mamnigfaltigkeit ihrer Lösungen nachzugehen. So kann man etwa beobachten, daßs, je abstrakter und allgemeiner die Phänomene sind, mit denen es eine Wissensehaft zu tum hat, um so früher auch der Zustand der Exaktheit für sie zu erreichen ist. So wurde die Mathematik zuerst als exakte Wissenschaft verstanden. Ihr folgten Astronomie, Physik, Chemie Biologie und endlich die Geschichte als die späteste Naturwissenschaft. So erhebt sich das sittliche Bewußtsein aus dem Zustand des Egoismus zu immer höherer Sozialität. Die egoistische Moral weicht der vaterländisehen Moral und der Tugend des Patriotismus. Die vaterländische Moral weicht der allgemeinen Mensehheitsmoral und der Tugend der allgemeinen Menschheitsliebe. Alle diese Regelmäßigkeiten sind Ausdruek eines rein notwendigen Gesehehens. Es gilt, die Gesetze dieses Geschehens festzustellen. Mögen die Erscheinungen des sozialen und historisehen Lebens auch noch so kompliziert und schwierig zu durehschauen sein - auf jeden Fall gibt es doch Gesetze, denen diese Phänomene unterworfen sind. Denn dem Gesetz muß doeh alles in gleieher Weise unterliegen. Die Historie ist die Naturwissenschaft ron den kompliziertesten Phänomenen.

Diese enge Eingliederung der Gesehichte in den Zusammenhang der naturwissenschaftlichen Erkenntnis, wie sie Auguste Comte erstrebt hat, eine Auffassung, die ihre Autonomie rernichtet und ihrer Eigentümlichkeit nicht gerecht zu werden vermag, muß in unserer Zeit als ïberwunden gelten. Es gibt keine Einheitsmethode, das ist ohne Zweifel das Resultat all der sorgfältigen Unterswehungen, die man im 19. Jahrhundert über den Charakter der philosophisehen und wissenschaftlichen Methode angestellt hat. Dieses Resultat hat den Gedanken der Unerkennbarkeit und Irrationalität des Wirkliehen moch vertieft und erweitert und damit gleichzeitig den übermäßigen Ansprüehen der Naturwissenschaft auf Welterkenntnis eine Grenze gesetzt. Dieser Gedanke liegt in der Konsequenz des Kritizismus. Wir wissen, daß die ethische Utherzeugung odler der kïnstlerische Gesehmack ein Wissen bedeutet, das der theoretischen Wromntnis niemals gleichgesctzt werden kann und darf. Wir schen ein, dals der Weg, den der religiöse Mensch geht, um Gott zu wissen, nicht der Weg der theoretisehen Frkemntnis ist. Treten wir dann in das Gebiet ler brkenutnis (in, so gibt as anch hier wieder versehiedene Wege. So steht of wa in schoffen Gegensaty dic philosophische Form oder Werterkenntnis and die wissemschaftliche Wirklichkeitserkenntnis. Aber auch in der wissensobaftlichen Wirklichkoitserkemutnis gibt as rerschiedene Wege. Nicht nur

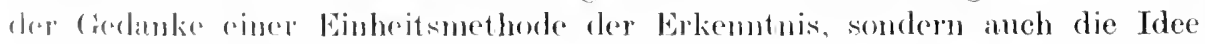

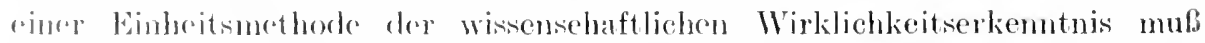
fallon gelassen woglen. As man die cigentiumliche Fragestellung der Philo-

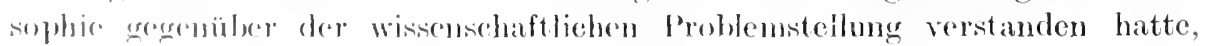
da lorote man ande die Besonderheit der Historie gegenüber der Naturwissenschaft verstehens. Dan arkimste, dets der Gegensatz von naturwissensehaftlicher und historisehor Mathole anf dem Gobiet der wissensebaftlichen Erkenntnis prinzipioll moibberwindlich ist. Weder dic Naturwissensehaft noeh die 
Geschichte vermag zu einer einheitlichen Erkenntnis der ganzen Wirklichkeit vorzudringen. Daraus ergibt sich weiter, daß die Einheit des Wissens überhaupt nicht auf dem Gebiet der seinswissenschaftlichen Erkenntnis gesucht und gefunden werden kann. Das heißt aber mit anderen Worten, daß weder die Naturwissenschaft noch die Geschichte eine Weltansicht zu geben vermag, ja daß das Problem der Weltanschauung für sie überhaupt nicht besteht. Damit ist der philosophischen Spekulation ausdrücklich das Recht eingeräumt, das Ganze der Wirklichkeit und dieses unser Wissen von dem Ganzen zum Gegenstand ihrer Fragestellung zu machen, und daraus ergibt sich ohne Zweifel ein wichtiges Moment für das geschichtsphilosophische Problem.

Mit dieser Einsicht in das Wesen der historischen Methode verband sich die Kritik des naturwissenschaftlichen Gesetzesbegriffes. Die philosophische Methodenlehre entzog diesem Begriff alle jene Attribute, mit denen das vorwissenschaftliche Denken ihn umgeben hatte. Die philosophische Methodenlehre zerstörte den Glauben an das Gesetz als an eine metaphysische IVirklichkeit, als an eine Macht, die alles Geschehen regiert, beherrscht und bestimmt. Das Gesetz ergab sich als ein Begriff der naturwissenschaftlichen Methode, als ein notwendiges Erkenntnismittel zum Begreifen der Wirklichkeit mit Rücksicht auf die naturwissenschaftliche Fragestellung. Daß die Naturwissenschaft mit dem Erkenntnismittel des Gesetzes und der durch ihre Aufgaben bedingten naturwissenschaftlichen Begriffsbildung niemals zu einem restlosen Verstehen der Wirklichkeit gelangen kann, das ist ron Rickert in seinen Grenzen der naturwissenschaftlichen Begriffsbildung, dem wertvollsten Werk der historischen Methodenlehre, in überzengender Weise dargetan.

Aber bei dieser Zurückweisung der metaphysischen Gesetzesbegriffe ist man nicht stehen geblieben. Man hat auch zu zeigen vermocht, daß die Gesetzesbegriffe, wie sie vielfach geclacht werden, überhaupt gar keine Gesetzesbegriffe sind, nämlich Gattungsbegriffe, die das ewig wiederkehrende Geschehen determinieren, sondern vielmehr begriffliche Formulierungen für eine einmalige wertvolle Entwicklung. Es ließ sich zeigen. daß diese sogenannten Naturgesetze ein Wertsystem voraussetzen, da 3 sie also auf einem ganz anderen Boden gewachsen sind als dem Boden naturwissenschaftlicher Erforschung. Man glaubte Naturwissenschaft zu treiben und trieb Geschichtsphilosophie.

Die Geschichtslogik bestimmt die historische Methode nach den Werken der großen Historiker. Sie vermag zu zeigen, daß es ein ganz besonderes Gebiet des geistigen Lebens gibt, das einer ganz bestimmten Form der Begriffsbildung bedarf und nur in ihr einen angemessenen Ausdruck finden kann, das sich nicht aufgeben und fortgeben darf an ein anderes, das fremden und fernen Interessen nachgeht. Diese Methode ist der naturwissenschaftlichen im wesentlichen entgegengesetzt. Es handelt sich $u m$ einen Gegensatz, der schon im täglichen Leben sich geltend macht, sofern mein Interesse bald dem Gemeinsamen vieler Dinge, bald der unvergleichlichen Individualität des einzehen gehört. Es handelt sich um einen Gegensatz, der das wisenschaftliche Leben bewegt und seine Mannigfaltigkeit und seinen Reichtum hervorbringt, der in den höchsten Formen des Denkens Gestalt und Wahrheit gefunden hat, dessen Spuren wir in allen philosophischen Systemen nachgehen können. Ich meine den von Rickert zuerst klar und eindeutigherausgearbeiteten Gegensatz von in di vidu- 
alisierender und generalisierender Begriffsbildung. Nichts wäre ver= kehrter, als in dieser Unterscheidung nu eine interessante und zweckmäßige Formulierung zu sehen, die lediglich aus methodologisehem Interesse eine Gliederung und Klassifikation der Wissenschaft ermöglicht. Gewiß hat die Unterseheidung von individualisierender und generalisierender Begriffsbildung unter anderen auch die Bedeutung, daß durch sie ron rein logisehen Prinzipien aus eine Gruppierung und Ordnung der Wissenschaften ermöglicht wurde. Weit wiehtiger aber ist es, daß diese Unterscheidung den selbständigen Erkemntniswert der Historie sichergestellt hat, dem Materialismus der naturwissenschaftlichen Metaphysik den Boden entzog und die wahrhaft historische Weltansicht rorbereitete. Die Gesehichte will den einmaligen Verlauf der individuellen Wirklichkeit durch indiridualisierende Begriffsbildung erfassen, die Naturwissensehaft betrachtet das Wirkliehe, soweit es unter allgemeine Gesetze subsumierbar ist. Die Geschichte setzt die Einmaligkeit und Individualität des Wirklichen, die Naturwissenschaft die gleichen Dinge und die Wiederholbarkeit des Geschehens voraus. Der Philosophie ïberlassen beide Wissensehaften diese ihre Antinomio zur Auflösung.

Das methodologische Problem, das die Geschichtslogik aufrollt, bezieht sich in erster Linie auf die Form. in welcher die historischen Ereignisse zur Darstellung gebracht werden. Wenn wir mit Bernheim unterseheiden zwischen Heuristik, Kritik, Auffassung und Darstellung, so ist das Dargestellte ror allem der Gegenstand der methodologisch-geschichtsphilosophisehen Uberlegungen ${ }^{1}$ ). Die Heuristik, das Suchen nach dem Material, die Feststellung und Auffindung der Tatsachen hat die Historie mit den anderen induktiven Wissenschaften im wesentlichen gemeinsam, abgesehen ron den Modifikationen, die sich aus der Eigenart des historikehen Objektes ergeben.

\section{b) Iteuristik.}

Wie aus der Fülle des mündlich und schriftlich Uberlieferten, den Denkmälern und Urkunden der Vergangenheit die schlichte Tatsache, der historische Vorgang als solcher herausgearbeitet und in der Wahrheit seines Gewesensoins durch neuc historisehe Funde ersehüttert oder bekrätigt wird, der Wahrscheinliehkeitswert, den die Historie im einzelnen besitzt, die Beseitigung der Fehlerguellen durch die Feinheit und Genaugheit des Forsohens und Suchens: in all dem steckt gewiß eine Fïlle logischer Probleme, und die Methodologie der Genchichte, die das loginche Gesantfundanent der Gesehichte anfweisen will, hat ganz gewil, anch auf diese fragen Rüeksieht zu nehmen. Aber wo gesalgt: das weite Gebiet der Induktion teilt die Historie mit den anderen empirischen Wissensehaften. Das Eigentümliche der historisehen Forschung liegt nur vielfach darin, dabsie ihe Olojekte und Tatsachen nicht so unmittelbar dean lagenwidtigen abgewinnt wie das naturwssemehaftiche Experiment, somblem dab lis Historie ibre Arbeit immer an geleisteter Denkarbeit vollzioht. In das () hejekt der Naturwissensenaft wird der-Jegriff erst hineingetragen,

1) Bernheim: Jehrbuch der historisehen Methoden der Geschichtsphilosophie. Leiprig 190x. 
hier wird unmittelbar Natur in Kultur, das Unverstandene und Begriffslose in wissenschaftliche Leistung verwandelt. Anders in der Geschichte. Hier ist das, worauf die Tätigkeit des Forschens gerichtet ist, immer ein bereits Geformtes, ein Etwas, an dem die Ausdrucksmittel der Kultur sich bereits betätigt haben, ein Simrolles und Bedeutungsvolles, mit einem Worte selber Kulturprodukt. Die Historie verwandelt also nicht das Kulturlose in Kultur, das Sinnlose in ein Simnvolles, sondern sie sucht vielmehr ein schon vorhandenes Sinnvolles zu deuten und zu verstehen oder auch dem Alten und Ċberlebten einen neuen Simn zu geben.

Gewiß lassen sich auch in der ganzen Induktion, in den Methorlen des Forschens interessante und bedeutsame Gegensätze zwischen der Historie und den anderen Wissenschaften feststellen. So rerbietet sich etwa für den Historiker ganz ron selbst das Experiment, und die Art ihres Forschens ist mehr wie die jeder anderen Wissenschaft darauf angewiesen, von der Idee des Ganzen zu den Teilen vorzudringen. Um ron einer historischen Tatsache etwas wissen zu können, muß ich die Möglichkeit haben, sie einzuordnen und einzustellen. Das einzelne bedentet hier für mich nichts, wenn ich nicht die Idee des Zusammenhanges habe. Die Idee des Zusammenhanges leistet für die Geschichte etwas Ähnliches wie die allgemeine Thcorie für die Naturwissenschaften, und es wäre nicht uninteressant, unter diesem Gesichtspunkt beide zu vergleichen.

Die Art und Weise, wie Naturwissenschaft und Geschichte ihr Material suchen, wurde für Auguste Comte maßgebend, um ihr gegenseitiges Verhältnis zu bestimmen. Alle diejenigen Denker, welche die Geschichte als Naturwissenschaft interpretieren, sei es nun, dal sie in ihr eine höchst vollendete oder mangelhafte Form des naturwissenschaftlichen Denkens erblicken, berücksichtigen in einseitiger Weise nur dieses erste Stadium der historischen Erkenntnis, die Erschließung des historischen Faktums dureh die Induktion, in der das Gemeinsame aller Erfahrungswissensehaften zum Ausdruck kommt. Sie achten also, was die logische Grundlegung der Geschichte betrifft, in der Hauptsache nur auf das logisch Formale, nicht aber anf das logisch Gegenständliche.

\section{c) Historische Kritik.}

Wenden wir uns nun der historischen Kritik zu, so verstehen wir vollkommen den Wert, den Bernheim ihr beimißt, denn sie ist in der Tat für die Geschichts. wissenschaft von grundlegender Bedeutung. Handelt es sich doch dabei um die Feststellung, ob ein historisches Dokument echt ist oder nieht, hängt doch die Wahrheit der historischen Resultate zum großen Teil an einer sorg. fältigen und gewissenhaften Kritik. Diese historische Kritik, welche an dem Quellenmaterial rollzogen wird, ist einerseits mehr mechanisch-technisch und anderseits im höchsten Sinne des Wortes philologisch. Mechanich-technisch, sofern es sich darum handelt, den erloschenen oder absichtslos verdorbenen Text einer Handschrift zu rekonstruieren, philologisch, sofern die Echtheit oder Unechtheit eines.historischen Dokumentes sicherzustellen ist. Bei der Häufigkeit historischer Fälschungen ist diese Aufgabe sehr erschwert. Tor allem aber hat der Historiker häufig genug Stellung zu nehmen dem Wider- 
streit der Meimungen gegenüber, der entweder aus persönlicher Teilnahme oder aus mangelhafter Kenntnis der Dinge entstanden ist. Was der Historiker besitzen muB, um diesen Widerstreit und Widerspruch zu beseitigen und die einfache Tatsache zu finden, das ist vor allem ein reiches, gerecht abwägendes Kult urbewn Btsein, das die überlaute Stimme der Leidenschaft ebensogut versteht wie das nicht gesprochene Wort. Und so holt er aus allen Verhüllungen und Terdunkelungen die schlichte Tatsache hervor, indem er seine Kritik an ruhigen, durch die Erfahrung gefestigten Maßstäben orientiert.

Ob ein Dokument wahr oder falsch ist, darüber entscheidet ja in erster Linic der feste Bestand des bereits gesichteten Materials. Stimmt ein neuer Fund mit der gesicherten Ủberlieferung überein, so spricht das für seine Echtheit, während das Gegenteil für seine Unechtheit spricht. Zugleich erhöht der übereinstimmende Vorgang den Sicherheitswert des schon Gefundenen. Das vor der Zeit Gesagte, das heißt die Auführung von Persönlichkeiten und Dingen oder auch die Erwähnung von Ereignisser, die dem Resultat der gesicherten Forschung nach erst einer späteren Epoche angchören, gilt als Beweis der Unwahrheit. Das neu Gefundene, das berufen zu sein scheint, ein neues Licht auf die Vergangenheit zu werfen, das aber mit seimen Behauptungen vereinzelt dasteht und sich in Widerstreit mit erprobten Quellen befindet, muß mit größter Sorgfalt geprüft werden. Wie zahlreich auch die Regeln sein mögen, die auf diesem Gebiet die Erfahrung gebildet, unendlich viel b'eibt doch hier dem Takt und der Feinfühligkeit des Historikers überlassen, da die Individualität der Fälle keine schematische Regulierung duldet. So bilden etwa ein höchst interessantes Objekt der Kritik die rhetorischen Stilübungen und künstlerisch geformten Briefe, die unter dem Namen berühmter Nämmer gehen, und die ron der Antike her eine so große Rolle in der historischen Forschung spielen. Lange hat sich die historische Kritik dureh diese Briefe täuschen lassen, man muBte ihren Zweck und Sim ron einer fremden Kulturlage aus erst zu begreifen suchen. Dann hat man sie mit übermäßig scharfer Kritik beiseite getan. Später aher ist man wieder zu ihnen zurïckgekchrt und sucht sie nutzbar zu machen, da man zu der Ansicht gelangte, dab in diesen Quellen und Dokumenten neben lem Gewebe ron Täuschung und Phantasie doeh einzelne Goldkörner lor Wahrheit aufweishar sein möchten. Dies Ausnutzen von Quellen, die Wahrleit und Lïge in buntem Gemisch enthalten, ist durch die Lückenhaftigkeit dor historichen U̇berlieferung geradezu gefordert und stellt an den Scharfsinn des Historikers die größten Anforderungen. Wie gut muß w doch kemnen den Gaist der fremoten \%oit und die Natur der menschlichen seele, um äbrall das (fewebe von Täuschung und Jüge, die lllusion und i"bertreibung zu durehdringen und dic schlichte 'Tatsache hervortreten zu lassen. Wrnn man alle Schwierigkeiten dieser Kritik in Erwägung zieht, s) mö̈hts man meincon, dals der Historiker niemalis zur Wahrheit vorJringren kitum, und dueh int diene Möglichkeit auch wieder in höherem Maße

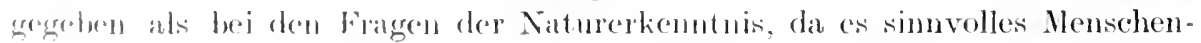
urok int. Wrmit dor Historikor sich beschäftigt. Der Mensehheit eigenstes

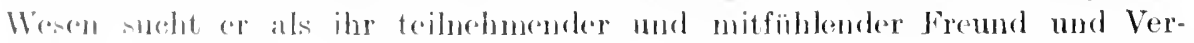
tranter alliblerall zu verstehen und zu wiindigen ohne Chersehätzung menseh-

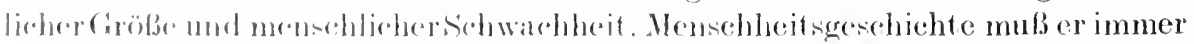


schreiben, auch dann, wenn er das Kleine und Einzelne erzählt. Niemals darf nationale Engherzigkeit oder konfessioneller Fanatismus das Bild jenes großen Geschehens trüben und verunstalten, zu desien Darstellung er berufen ist.

So wichtig num aber auch die historisehe Kritik sein mag, deren Bedingung, Maßstäbe und Tragweite die Methodologie der Geschichte bis ins einzelne zu verfolgen hätte, so ist sie doeh für die philosophische Methodenlehre. die den ersten Teil der Geschichtsphilosophie bildet, ron weniger großer Bedentung. Sie ist. wie wir meinen möehten, dic mehr interne Angelegenheit des historischen Arbeitsgebietes. Wie das Suchen nach dem Naterial und seineerste Durchforschung und Durchdringung a uf allgemeine Regehn der Indukt ion hinweist. die wir in allen Erfahrungswissemschaften wiederfinden, so ist die historische Kritik im Gegenteil eine Angelegenheit, die gleichsam in der Historie verbleibt und der philosophischen spekulation relativ fern und fremd gegenübersteht. Wir wollen damit nicht behaupten, daß diese Regeln der historisehen Kritik ein für allemal für rlie Philosophie bedeutmngslos bleiben, aber wie sie uns bei dem jetzigen Standpunkt der historischen Forschnng entgegentreten. bleibt ihr a priori dem Auge des Philosophen noch verborgen. Und so bezieht sich die geschichtsphilosophische spekulation der philosophischen Methodenlehre ganz in erster Linie auf die Auffassung und Darstellung der historischen Tatsachen. Es handelt sich also nicht darum. festzustellen. durch welche Formen des Denkens die Tatsachen aus dem historischen Material eruiert werden, sondern um die Auffassung und Darstellung der Tatsachen im historischen Zusammenhang. Wir nehmen also an. daß die Tatsachen bereits aus dem dunklen Grunde des historischen Quellemmaterials heraufgeholt sind. daf die Grubenarbeit der historischen Forschmeg bereits geschehen ist. Die aus dem Material herausgehobene Tatsache steht auf dem Niveau der historischen Tatsachen, denen wir beiwohnen. Sie gilt ums als Wirklichkeit. Alles Falsehe und Unechte soll von ihrabgestreift sein. Aber noch ist die Tatsache unverstanden und isoliert. Wir wissen, daß sie etwas bedeutet, da 3 es sich um eine historische Tatsache handelt. aber wir wisen noch nicht. worin der Bedeutungrsgehalt der Tatsache liegt. Und hätten wir sie aufgefabt und verstanden. so bliebe noch die Stellung zu bestimmen, welche ihr im Zusammenhang des historischen Geschehens zukommt.

\section{d) Historische Auffassung.}

Wenn wir von der historischen Auffassung sprechen, so tritt sofort in den Mittelpunkt unserer Utherlegungen der Begriff des historischen Verstehens. Damit rerbindet sich der Gedanke der eigentümlichen Psychologie, welche der Historiker treibt. und die Hoffunng, ron hier aus die Wirkliehkeit zu gewinnen, das Leben zu ergreifen, wie es gewesen, wit es geworden und wie es gewachsen ist. Die Würde der Geisteswissenschaft. wie Dilthey sie auffaßt, tritt vor unser Auge und die Riesenaufgabe. die der Philosophie aus ihrer Grundlegung erwächst. Diese Kunst des Verstehens spielt ihre Rolle ja schon gewissermaben in der historischen Kritik, sofern der Historiker den Geist und Charakter der alten Autoren verstehen muB, denen er sein Material verdankt. Aber von ausschlaggebender Bedeutung wird sie vor allem dann. 
wenn es nun gilt. die erprobte Tatsache, die entdeckte Individualität in ihrer eigentümlichen Bedeutsamkeit hervortreten zu lassen.

Worin besteht nun die Eigentümlichkeit in der Funktion des historischen Verstehens? Wemn wir mit Kant zu der Einsicht gelangt sind, daß alles Erkemmen synthesis bedeutet, daß es sich immer um die Formung, Gestaltung und Terbindung gegebener Inhalte handelt, und wemn wir die Formgebung als das Wesentliche der Erkenntnis betrachten, so werden wir vor die Frage gestellt, ob es nicht ein rexschiedenes Maß der Formgebung gibt. Wir kömen mis rorstellen, daß das Denken zu gewissen Inhalten mehr hinzutut wie zu andern, wir kömen niedere und höhere Grade der Formung unterscheiden. Wir können das auch so ausdrücken. daß die Spontaneität des Denkens gewissen Inhalten gegenüber mehr und anderen gegenüber weniger in Aktion tritt, und so ließe sich eine Skala errichten rom Minimum bis zum Maximum der Spontaneität. Die Funktion des Verstehens würde jenes Minimum ron Spontaneität bedenten, das dem gegebenen Inhalt möglichst wenig hinzıfügt, das denkbar geringste Maß Umgestaltung mit ihm vollzicht. Je höher das Maß ron Spontaneität, um so weniger Scheu und Achtung vor dem dargebotenen Material. um so größer die Entfernung ron der Wirklichkeit, um so größer das Maß ron Abstraktion, der Verlust an Wirklichkeitsgehalt. Es läßt sich zeigen, daß das Prinzip der Synthesis auch auf anderen Kulturgebieten maßgebend ist, so speziell auf dem Gebiet der Kunst, und wir meinen, daß es der Künstler ist, der am schärfsten und gewaltsamsten den ProzeB der Entwirklichung vollzieht. Die historische Funktion des Verstehens will den Gegenstand in lieberoller Sorgfalt und Behutsamkeit so lassen und aufbewahren, wie er ist.

Die Funktion der Verstehens sucht den Gegenstand gleichsam ron innen heraus zu durchlenchten und hütet sich, ihn zu verändern. In der liebevollen Wertung ma Berïcksichtigung von Kleinigkeiten offenbart sich eine Tendenz, die sehr rershicden ist ron jener Gewaltätigkeit, mit der der Künstler das Grobe vor uns hinstellt, nachdem er dem Wirklichen entnommon, was er brauchte, und rernichtet und getötet hatte, was seinem Zweck entgegenstand. So liegt in dem historischen Verstehen die heilige Soheu ror der Wirklichkeit und dem Leben. dessen eigentümliche Sehönheit nicht zerstört werden darf.

Denn mit den eigentïmlichen und großen Formen des Lebens hat es der Historiker zu tun, und dic Funktion des Verstehens offenbart sich in dem Sims für das Eigentümliche und Individuelle. Der Historiker ist überzengt von dem unvergleichlichen Wert der Individualitat, nurl er besitzt ihr gegenäber jene Dankbarkejt, die der Kïnstler nicht kenut. Denn der Künstler heth mur wemiges empor ans der bunten Mammigfaltigkeit des leebens und

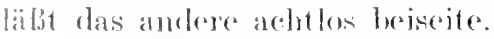

J)e: Minimmm vom Formung, das die Geschichte vollziehen soll, führt zur lowahrung des inhaltlichen Reichtums. Wem wir vom Verstehen sprechen,

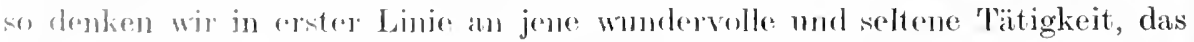

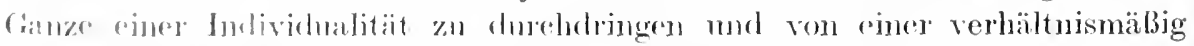

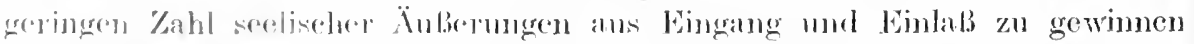
in die Mirklichkeit dos vollon wnd ganzen Lobens eince anzigatigen Individualitiit. Weniges leifort den Vorstehenden anf vieles hin. Aus den dürftigen und 
rhapsodischen Spuren des Gewesenen rekonstruiert er die einzigartige Gestalt. Jede Regung des Geistes belauscht er mit teilnehmendem Verständnis und weiB Schuld und Schicksal zu deuten aus dem Wesen eigentümlicher Art. Niemals ist er Ankläger, sondern immer Anwalt, Freund und Berater. und indem er von der Individualität zum Ganzen fortschreitet und rom Ganzen zurück zur einzigartigen Individualität, belauscht er mit Andacht und Rührung der Menseh. lichkeit großes Herz. Groß wie sein Terstehen muß die Kraft seines Erlebens sein. Denn nur wer vieles erlebt hat, kann vieles verstehen. Aus der Fülle des Erlebens wächst ihm das Verstehen zu. Dies Verstehen kamn zum Großen und zum Kleinen führen. Denn in der Virtuosität des Verstehens liegt einerseits die Gefahr der Charakterlosigkeit, indem die Toleranz unbegrenzte Dimensionen annimmt, anderseits führt sie zu jener wahrhaft großen historischen Auffassung, nach der die Gestalten der Geschichte wie große Notwendigkeiten dahinschreiten und jeder kleinlichen Kritik weit entrückt sind.

Für die Auffassung und Deutung des historischen Lebens wird mun auch die Psychologie wichtig, ja unentbehrlich. Man hat mit Recht die Psychologie als eine Hilfswissenschaft der Geschichte bezeichnet. In der Geschichtswissenschaft begegnet uns nämlich das eigentümliche Phänomen, daß sie eine Reihe anderer Wissenschaften in ihren Dienst stellt, deren Resultate und Ergebnisse ihren Zwecken nutzbar gemacht werden. Dahin gehört vor allen Dingen auch die Sprachwissenschaft, die durch die Emsigkeit ihrex Forschung das historische Material gar sehr bereichert hat und die stummen charaktere fremdartiger Rätselschrift verständlich und deutlich macht. Besonders aber verraten uns die Art der Wortbezeichnung, der Reichtum des Ausdrucks und der Ausdrucksmöglichkeiten, die Bildungsgesetze der einzelnen sprachen, ihre Wandlungen und Abhängigkeiten gar manches über die Kultur eines Volkes. Ist doch in der Bildung der sprache ummittelbar der künstlerische Gemeinsinn eines Tolkes an der Arbeit, und auch das sittlich religiöse Leben eines Volkes sowie seine naturwissenschaftliche Reife finden in der Sprache getrenen Widerhall. Wir verstehen sehr wohl den Enthusiasmus, mit dem der Philologe dem Wundergebilde der griechischen sprache nachdenkt und in der unendlichen Schönheit und Mannigfaltigkeit ihrer Lautformen die Seele ron Hellas nahe fühlt.

Wie die Sprachwissenschaft stellt sich num auch die Psychologie in den Dienst der Historie. Die Psychologie aber, um die es sich hier handelt, ist nicht die Psychologie als Gesetzeswissenschaft. Die Psychologie als Gesetzeswissenschaft sucht wie alle Naturwissenschaften Relationen zwischen letzten Einheiten herzustellen. Sie wird etwa die ganze Mamnigfaltigkeit des psychischen Lebens auf den Generalnemner der Empfindung bringen und nach gleichförmigen wiederholbaren Prozessen zwischen diesen letzten Einheiten forschen ${ }^{1}$ ). Die Psychologie, mit der es der Historiker zu tun hat, ist deskliptiv und genetisch. Es handelt sich nämlich in erster Linie darum, die seelischen Vorgänge einer historischen Persönlichkeit in ihrer Eigenheit zu beschreiben, um ihr Charakterbild zu gewimnen. Um ein liebe- una vorständnisvolles Eindringen in den Erlebniszusammenhang der historischen Individualität handelt es sich hier. Weiter aber gilt es, die Handlungen der historischen Individualität durch

1) Münsterberg: Grundzüge der Psychologie. 
gewisse Hotive zu erklären und deutlich zu machen und endlich die wechsel. vollen Hotive ans einem einheitlichen Erlebnisgrund zu erklären. Was hat den historischen Helden bewegt und getrieben, diese Tat zu vollziehen? so werden wir uns häufig fragen. War es eine Tat der Liebe, der klugen Berechnung oder des finsteren Hasses? War für diese Tat eine weise Staatsräson maßgebend, oder war sie ein Werli der Unüberlegtheit und Unbesomenheit? Hat ein weltfremder. phantastischer Idealismus in ihr seine Form gefunden? Bei allen diesen Fragen rekurrieren wir auf die Wirklichkeit des seelischen Geschehens. Wir suchen nach Gefühlen, nach Willensregungen, aus denen die Tat geboren sein soll. mol mit der Mannigfaltigkeit dieser psychisehen Wirklichkeiten, in denen sich die Stellungnahme der historischen Persönlichkeit zu den Gütern des Lebens, seine Einsehätzung menschlicher Verhältnisse und sein Verhältnis zum Unendlichen ausdrückt, verbinden wir Wertungen positiver und negativer Natur.

Der Wert einer Tat steigt für uns, wemn wir sie betrachten als ein Werk der Liebe, und sinkt herab als das Produkt eines finsteren und traurigen Hasses. Und so rerbinden wir den Wert der Tat mit dem Wert der Persönlichkeit. Wir meincn, daß eine wertvolle Tat nur durch eine wertvolle Persönlichkeit hervorgebracht werden kann. Als ob das alles so selbstrerständlich wäre, als ob nicht auch die gute und wertvolle Tat unter Umständen das Werk des Schlechten und Mlinderwertigen sein könnte. Gilt es für die Historie wirklieh so umbedingt, dak Gutes aus Gutem entsteht, kann nicht hier viehmehr anch Gutes aus Bösem erwatehsen? Mub mit einem Worte die Kausalität in der Geschichte so gedacht werden, daB Ursache und Wirkung in gleichartiger Weise wertbetont sind? Und was ist hier überhaupt das Wichtige und Entscheidende: die Leistung oder das Motiv? Und ist das Motiv so ohne weiteres aus der leistung zu konstruieren? Worauf beruht die ungehenre Wertung des realpolitischen Sinnes in der Geschichte? Wie sollen wir es rerstehen, daß die grobe ethische Persönlichkeit der historisehen Auffassung gemäß den Mangel an staatsmämnisehem Sinn nieht wettmaehen kann: mag die ethische Kultur noeh so groß mud ïberlagend sein, der politische Fehler findet so leicht keine Entsehuldigung. Bestcht in der Tat zwischen Ethik und Politik eine unlösliehe Antinomie? Das sind Fragen, diems besehäftigen werden, wenn wir dem Problemeincr agentiumlichen historischon Benrteilnng nähertreten. Die Frage der Psychologie in der Historie trieb uns anf die Frage der Begründung eines historischen Geschehens dureh Motive historischer Persönliehlieiten. Ist mit dem Feststellen der Motive. Welehe die Veranlassmug zur Auslösmug eines historisehen

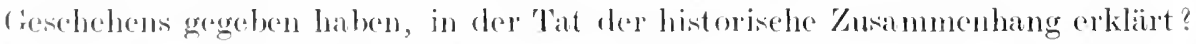
J) Vertreter des dontschen Idealismus haben auf das lebhafteste bestritten, dals die mendliche Manngefaltigkeit der Motive, we sie in den einzelnen Persönlichkraten wirkisum sind, den cinheitlehen und vernïnftigen simn und

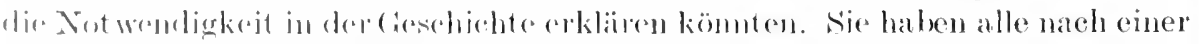

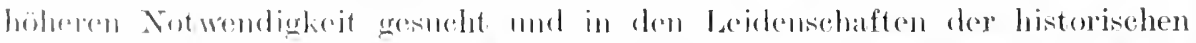

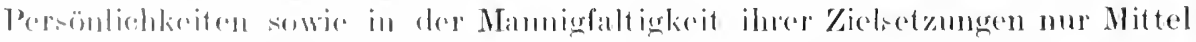

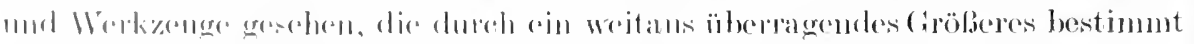

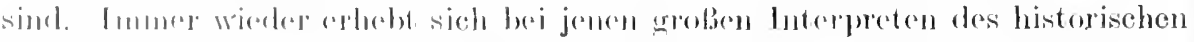

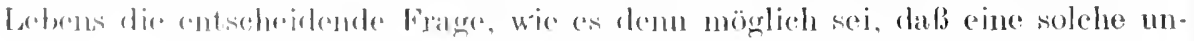


geheure Mannigfaltigkeit entgegengesetzter Wünsche und Bestrebungen in den Dienst eines eimheitlichen mo vernünftigen Weltgeschehens gestellt werden konnte, was es demn eigentlich sei, wodurch dieses Chaos zum Kosmos wird. Und diese Frage ist augenscheinlich eine berechtigte und geschichts. philosophisch vielleicht die allerwichtigste ${ }^{1}$ ).

Wir sind gezwungen, die grole Bedentung anzuerkennen. die der Auffassung in der Methodologie der Geschichte zukommt. Die Auffasinng aber ruht auf der Gabe des Verstehens. und Verstehen ist nicht zu denken ohne die Kraft des Erlebens. Täuschen wir uns jectoch nicht darüber, daß hier in erster Linie an ein genetisches Verhältnis gedacht wird, das für die philosophische Fragestellung nicht in Betracht kommen kamn. Ich muB erlebt haben, um zu rerstehen, dem erleben und verstehen verhalten sich zueinander wie die reflexionslose Hingabe zu dem bewußten und gewollten Erfasen des Ciegenstandes. Icherlebe, ohne zu wissen, und ich will verstehen. aber ich kam nicht erleben wollen. Ohne Verstehen int es damn weiter nicht möglieh. zu einer allgemeingültigen Auffassung des historischen Lebens zu gelangen. Diezen genetischen Zusammenhang geben wir zu. Doch nur nach dem logischen apriorifragt die Geschichtslogik. Lnd so wird das methodologische Element der Auffassung und des Verstehens für sie num soweit von Interesse sein, als es sich um die Frage handelt, wie dem ein allgemeingültiges Anffassen und Deuten des historischen Geschehens möglich sei. Der Historiker mag die Schönheit des Gedankens bejahen. daß die Historie jeder neuen Generation des Menschengeschlechtes immer wieder zu einem anderen wird, die Philosophie wird bemüht sein. diesen Relativismus zu überwinden und jenen Maßstab aufzuweisen, nach dem die Auffassung und Einschätzung der historischen Objekte sich richtet. So weist ein wichtiger Teil der Lehre rom Verstehen auf eine Theorie der historischen Beurteilung hin, in der alle Geschichtslogik ihren AbschluB findet. Ton ihr aus aber wird auch das Organ des historischen Verstehens, der Historiker selber, deutlieh, dessen Eigenart in der Geschichtsphilosophie gewiß ebensoriel Beachtung rerdient wie in der Philosophie der Kumst das Genie als der Schöpfer schöner Gegenstände. Worin beruht die Allgemein gültigkeit des historischen Auffassens. mol was ist das Wesen des historischen Ienschen? Das sind Probleme, auf welche die Geschichtophilosophie zu antworten hat.

Alle jene, die im Ủbermaß dic geschichtsphilosophicche Bedentung des Verstehens betonen, unterliegen einer Reihe ron Irrtümern prinzipieller Natur hinsichtlich der Theorie der Geschichte. Der schwerst wiegende liegt darin. daß sie der Geschichte ein Verhälnis zur simnlichen Wirklichkeit geben. das sie nicht besitzt und ihrem ganzen (harakter nach auch nicht besitzen wollen kann. Es ist der Gedanke, daß die Historie Wirklichkeitswissenschaft sei in dem Sinne, daß sie die Möglichkeit hat, den ganzen Inhalt der simnlichen Wirklichkeit zu erschöpfen. Dies Ausschöpfen der Totalität des Wirklichen ist begrifflich ummöglich, da jeder Begruf̂f cine Umgestaltung an der Wirklich. keit vollzieht; deswegen soll das Erkemen in des Historie prinzipiell verschieden

$\left.{ }^{1}\right)$ Vgl. besonders Hegels Geschichtsphilosophie und Schellings geschichtsphilosophioche Schriften. 
sein ron dem Erkennen in der Naturwissensehaft. Nur dem Verstehen allein ist die Maeht gegeben, in alle Tiefen des Lebens einzudringen, und so steht dem Historiker als dem rerstehenden Mensehen auch der Zugang offen in das verborgene Gewebe von Motiven, Gefühlen und Wollungen, die in dem Heroen wirksam waren, als er den Entsehluß faßte zur welthistorisehen Tat. Die genane Erforschung dieses Motivationslebens, die genaue Durchdringung der Erlebniszusanmenhänge, in denen die Ansätze zu allen möglichen Zielsetzungen, Wertungen und strebungen deutlich vor uns liegen, sie befreit uns von der Aufgabe der Metaphrsik, nach dem Notwendigen in der Geschichte zu fragen, und macht ein Srstem letzter Werte überflüssig.

Erwägen wir dagegen. daß die restlose Ausschöpfung der simlichen Wirklichkeit für die Historie weder möglich ist noch ihrem Ziel und Wesen entsprechen kann, so steht nichts mehr im Wege, einen einheitlichen Erkenntnisbegrift für sämtliche Wissenschaften zu bilden. Damn handelt es sich in der Historie wie in der Naturwissenschaft $u$ Begriffserkenntnis, nur daß die Art der Begriffsbildung in beiden Wissenschaften verschieden ist. Dann ist das Verstehen zwar noch viel in der Geschichte, aber nicht mehr alles. Das Verstehen ist für uns eine Funktion ron höchster Lebensnähe, ein begriffsloses Wissen, mit dem die Logik nichts anfangen kamn. Der künstlerische Geschmack ist logisch so unbegreiflich wie die Nacht des Verstehens. Das Verstehen ist im Grunde der Fïlle des Lebens zugeordnet, nicht aher der Welt der Geschichte, wenn auch seine unfaßbare Wissensart in die Welt der Geschichte, die dem Leben so nahe steht, gar mächtig eindringt. Der Historiker muß zu der begrifflichen Funktion, die er ausübt, die Lebensnähe des rerstehenden Menschen haben. Was an dem Verstehen logisch bewältigt werden kam, das scheint mir allein die Frage eines allgemeingültigen, von einheitlichen Wertmaßstäben orientierten Auffassens und Deutens des historischen Lebens zu sein. Warum soll jenes so aufgefaßt und mit Glanz und Ruhm bekleidet, jenes aber in Nacht und Schweigen begraben werden? In einer Theorie der Geschichte kömnen wir nicht bei dem göttlichen Verstehen als einem Letzten stehen bleiben, sondem wir müssen d('s zu verstehenden Menschen Art zu beschreiben und den Rechtsgrund für ein allgemeinguiltiges Auffassen des historisehen Lebens uns deutlich zu machen suehen. Wis kömnen uns nicht dabei beruhigen, daß alle Allgemeingütigkeit im Vratehen berubt, wir wollen die Notwendigkeiten des historischen Lebens näher zu ergriunden trachten. Der spärliche Hinweis auf eine überindividuelle Notwendigkeit, die in dem Godanken eines allumfassenden Verstehens liegt, kann der Lagik nieht genügen.

Wir geben zu, dals dem Vorstehen als eined logisch mnfaßlichen Wissens. form die höchste Aufgabe zufällt bei der Erkemntnis der ('haraktere großer historischer Persönlichkeiten. Der Historiker kanm sich nicht damit begnïgen, die knlturbodeutsanen Momente an einer historischen Persönlichkeit aufzuweisen. br muls sie anf don einheitlichen lebengrumb der historischen

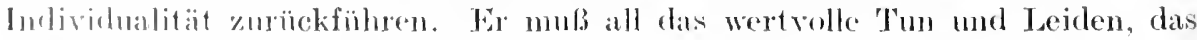
machtvolle Stfolxen, den Kampf nu Gut nud Böse aus einem Einheitsstrahl hervorleuchten lassen. So muls er die Aufgabe sieh stellen, dahin muß sein

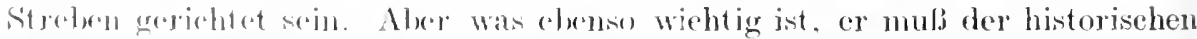

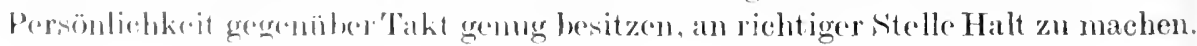


Er darf nicht auf das Kleine und Kleinliche verfallen. Er muß sich entschließen, das Unerforsehliche still zu verehren, und zu der t'berzeugung gelangen, daßs in der Geschichte die große rollendete Leistung das Maßgebende ist.

Auch die Geschichte rermag das Leben nicht wiederzugeben, wie es eigentlich war, und wie es eigentlich ist. Diese Undurchdringlichkeit des Lebens, auf die wir immer wieder hinweisen müssen, soll keine Apotheose des Lebens bedeuten. Wir wollen damit weder sagen, daß das Leben so stark und so reich und so mächtig ist, daß der wissensehaftliehe Begriff hier zusehanden werden muß, noch meinen wir anderseits, daß der Begriff aus der Wirkliehkeit alles hervorholt, was des Aufhebens wert ist. Das Leben gehört nicht nur der Wissenschaft, sondern vor allem auch der Philosophie, Kunst und Religion. In irgendeiner Weise gehört es ihnen als Ansatzpunkt, als Ausgangspunkt, als Aufzuhebendes, als ein zu Überwindendes. Und auch dem sittlichen Streben gehört die Fülle des Lebendigen, und schließlich ist das Leben aneh für sich da, hat es seine eigenen Werte, die wir im Kultus der Liebe und Freundsehaft verehren. Viel rom Leben gibt die Gesehichte, niemals aber das ganze Leben. Was in die Geschichte eingeht, das sind nicht die Menschen mit dem ganzen Reichtum ihrer Eigenschaften und der ganzen Fülle ihres seelischen Erlebens, sondern vielmehr Abstraktionen, die nach gewissen Wertgesiehtspunkten gebildet sind. Ist etwa die künstlerische Leistung eines Menschen bedeutsam so wird in ihm der Künstler gesehen und in der Regel nur der Künstler, niemals aber der ganze Mensch. Die Kulturleistung des Mensehen wird in dem historischen Begriff aufbewahrt, nicht aber das Elementare, Primitive seines Gefühls und Empfindungslebens, das den Weg der Entfaltung verfehlt hat Die Menschen sind in der Geschichte ein für allemal mit Etiketten rersehen. Sie sind verurteilt, nur Philosophen, Dichter oder Statsmänner zu sein. Vielleicht auch eine Kombination des einen mit dem anderen, aber immer werden sie hier unter einem bestimmten Gesichtspmmkt gesehen und niemals als ganze Menschen gewertet. Die einzige Form der historischen Darstellung, die auf die Erfassung eines ganzen Lebens gerichtet scheint, ist die Biographie. Und hier gibt es in der Tat eine Höhe der Meisterschaft, die uns bis an die Schwelle des Lebens führt. Zwischen dem Biographen und seinem Helden muß ein Verhältnis sein, wie zwisehen Ienschen, die sich im Leben nahestehen. So groß ist die Fülle der Gesichtspunkte, so reich die ZahI verständnisvoller und berechtigter Fragen, die er an das Heldenleben richtet. Und so mag dem der Biograph wohl meinen, die Individualität in ihrer Ganzheit zur Darstellung gebracht zu haben - was ihm doch niemals ganz gelingen kann.

Daß nun die historische Individualität sich niemals deckt mit der lebenswirklichen Persönlichkeit — das hat sein Gutes und sein Schlimmes. Sein Gutes, dem nur von dem Beschränkten, von dem in der Fülle seiner Bestimmungen und Beziehungen Reduziertem vermögen wir Erkemntnis zu gewimnen. Der historisehe Begriff läßt nur die großen und bedeutsamen Züge hervortreten - alles andere wird beiseite gelassen. Nicht als ob der große Historiker es versäumte, auch das rein menschlich Wertrolle und Interessante zur Darstellung zu bringen und das Bild seines Helden nicht auch vielfach mit einer Fülle ron Einzelzügen beseelte. Aber der historische Begriff tritt an den Menschen mit der Forderung heran, seinen Wert oder Unwert für ein bestimmtes 
Kulturgebiet zu enthüllen. Die Gesehichte ist num einmal das Reieh der Höhen und der Tiefen. So bleibt die Individualität, wie sie die Gesehiehte versteht, eine Abstraktion. und darin liegt eine gewisse Gefahr der Egalisierung aueh für die histurisehe Erkenntnis. Dureh die Form der Abstraktion ist das historisehe Geschehen vergleichbar geworden. Das, was an sieh individuell und unvergleich. lieh ist, ist durch den Begriff einander genähert. Somit bietet die historisehe Wirklichkeit in weitem Umfange analoge Erseheinumgen dar. Wir durehspähen die Vergangenheit, um AufsehtuB darüber zu erhalten, was wir sind, und welcher Zeit wir angehören: der Blüte, des Verfalls oder des hoffnungsfreudigen Werdens. So ist etwa eine religiös gestimmte Epoehe, wie das alexandrinische Zeitalter es war, geneigt, in der Philosophie der Griechen dieselbe religiöse Erregung zu erblicken. So schuf die Romantik das Mittelalter nach ihrem eigenen Bilde. So vergleichen wir unser gegenwärtiges Zeitalter bald mit dem Epigonenzeitalter der Griechen, bald mit dem frisehen Werden der Renaissanceepoche.

\section{e) Die Darstellung.}

Soviel in diesem Zusammenhange über das Verstehen und seme methodische Bedentung. Das Wichtigste und Bedeutsamste für die philosophische Net horlenlehre blejbt doch schlieBlieh die Form, in der das Resultat der historisehen Erkenntnis zur Darstellung gebracht wird. Wenn wir den Begriff in den Urteilen (ler vollendeten historischen Darstellung untersuchen, so erkennen wir, was gemeint war, so erfahren wir, welcher endgïltigen Absicht der ungeheure Apparat der historischen Erforschmng dient. Wenn wir diese Begriffe betrachten, so schen wir ganz deutlich, wje sehwer sie zu tragen haben an der ganzen Fülle des historirchen Lebens.

Niemals kam die Entwicklung der historischen Wissenschaft dahin gehen, die komkreten Bewriffe der Historie ihres Reiehtums zu berauben, niemals dor Versueh gemacht werden, in einer mageren Definition die Köstlichkeit und Sehönheit des P(rikleisehen Zeitalters zn ersehöpfen. Auf Reiehtum Imd Füllo angelegt, werden sieh die historischen Begriffe diesen ihren Reiehtum bewahron und somit cin für allemal in einer ganz anderen Richtung gehen wie dic schajf murissenon, durch eine präzise Definition crschöpften und ausgelöstrn Begriffe der Naturwissenschaft. Gerade dieses ist für den historisehen Begriff. für dies, eigentümliche Form der wissensehaftliehen Allgemeinheit "harakteristisch. dak sie das Konkrete, das Individuelle, das Finmalige zum Ausdruck bringen will. Das klingt paradox und ist es anch his zu einem gewissen Cirales, denn das Allgemeine ist der Feind der Indlividualitit und kann sie,

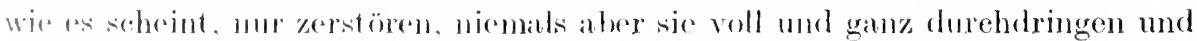
orfascols. Wir verstehen as, dab dic Aufgabe der Wissonschaft leiehter zu arfiillan ist deft. wo der Brogriff das Allgemeine sucht, das vielen Gemeinsame

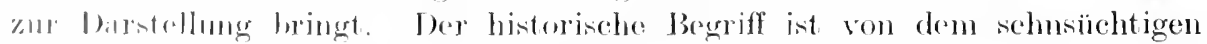

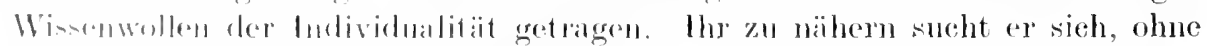

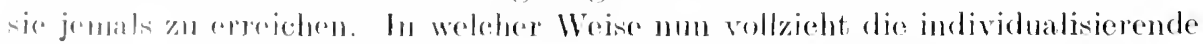

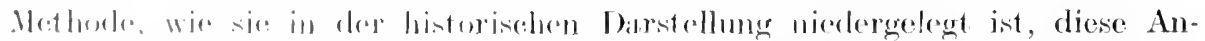

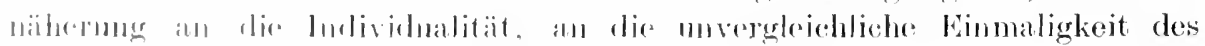

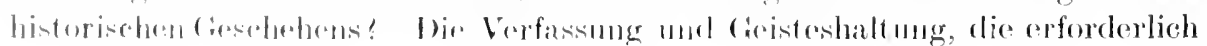


ist. um den Weg der Historie mit Erfolg zu gehen, ist das Achten auf das Eigentümliche. Das Eigentümliche ist dasjenige, wodurch sich ein Objekt ron allen anderen unterscheidet, wodurch es zu einem einmaligen und einzigartigen wird. Wie die Welt der Sinne bis ins Kleinste und Einzelne gebildet ist, kömnen wir mit Bestimmtheit nicht wissen. Wir rermuten, daß die Gestalten der sinnlichen Anschauung alle verschieden gebildet sind, daß es in der Welt niehts absolut Gleiches gibt. Früher hat man wohl den Gedanken absoluter Gleichheit mit der Behauptung zurückgewiesen. daß das absolut Gleiche notwendig zusammenfalien, da $B$ es ein Identisches abgeben müsse. Diese Auffassung beruht auf einer Verwechslung ron Identität und Gleichheit. Wir können uns zwei Dinge oder zwei Individuen denken, die einander rollkommen gleich sind und doch nicht zusammenfallen, weil sie zeitlich und räumlich getrennt sind. Prinzipiell ist es nicht ausgeschlossen, daß es zwei so vollkommen gleich artige Dinge in der Welt gibt, ja unmöglich ist es sogar nicht, daß die sinnlichen Wirklichkeiten in ihrel Grundstruktur vollkommen gleichartig sind, und daß nur ihre wechselnden Lageverhältnisse den Schein der Mannigfaltigkeit und Verschiedenheit ergeben. Die Behauptung der Gleichartigkeit des Wirklichen ist ebensowohl ein Dogma wie die Behauptung seiner Individualität. Die Behauptung, daß die simnlichen Wirklichkeiten individuell gebildet seien, entspricht am besten dem Standpunkt unseres natürlichen und unbefangenen Empfindens und Auffassens. Ein Beweis läßt sich nicht dafür erbringen, aber unsere Simne scheinen dieses große Naturfaktum immer wieder zu bestätigen. Trotzdem könnten wir uns rorstellen, daß einmal die Forschung auf zwei Dinge stoßen würde. die auch der sorgfältigsten Analyse und Beobachtung als vollkommen gleich erscheinen müssen. Daß das Gleiche immer notwendig eine Abstraktion sein soll, ist ein Vorurteil über die Natur des simnlich Wirklichen, das nicht so ohne weiteres die allgemeine Anerkennung finden wird.

Wie wir uns nun aber auch die Natur der sinnlichen Wirklichkeit rorzustellen haben, der Forderung der historischen Forschung gemä13 muB sie individuell gedacht werden. Der Historiker will die Gestalten der simnenwelt in der Wirklichkeit ihrer Individualität ergreifen. Das historische Bewubtsein tritt an die Wirklichkeit mit der Forderung heran, daß alles individuell und eigenartig gebildet sei. Ob diese Forderung des historischen BewnBtseins zu Recht. besteht, das ist natürlich eine Frage, die in der Geschichtslogik nicht entschieden werden kann.

Wemn die Naturwissenschaft immer auf dasjenige abzielt, was vielen oder mehreren Dingen gemeinsam ist, wenn ihr Interesse ein für allemal dem Individuellen abgewendet ist, so liegt diesem Verhalten die Auffassung zugrunde, daß das, was nur einmal, so ganz releinzelt rorkommt, kein zurerlässiger Bürge der Wirklichkeit sei, daß vielmehr nur das an und in vielen Seiende Wirklichkeitscharakter besitzt. Dagegen ist der historischen Auffassung gemäB gerade das an vielen Vorhandene das Gleichgïltige, das Durchschnittliche, was nur geringe Macht und Größe des Lebens besitzt. Der Historiker ist von der Wirklichkeit des Individuellen, der Naturwissenschaftler dagegen von der Wirklichkeit des Gleichen überzengt.

Wenn ich die Forderung der Individualität an die Wirklichkeit richte. so kann das in verschiedener Weise und in verschiedenem Maße gescheher. 
Es kam in dem radikalen Sinne gemeint sein, daß alles grundverschieden ist, daß etwa die Charaktere der einzehnen Menschen weit auseinanderliegen wie Gott und Tenfel. Während der naturwissenschaftliche Forscher, der an dem Begriff der Gattung orientiert ist, immer geneigt sein wird, auf Verwandtschaft und Ähnlichkeit aller menschlichen Naturen hinzuweisen, kommt es dem Historiker darauf an, semes Helden unvergleichliche Art zu zeigen und ihn ron dem Durchschnittlichen und Allbekannten zu trennen und zu befreien. Das wahrhaft historische Denken wird die Kluft sehr groß werden lassen zwischen der Tat des Heroen und der Kleinheit und Spießbürgerlichkeit des gewöhnlichen menschlichen Tuns. Liegt in diesem Falle die Betonung der Individualität ror allem in der Aufweisung des Kontrastes ron Klein und Groß, so kann der Gedanke der Individualität anch die Wendung annehmen. daß wir die Überzengung vertreten. das Wirkliche sei bis in seine kleinsten Teile hinein immer wieder anders gebildet. Denke ich mir das Wirkliche bis in die denkbar kleinsten Teile aufgeteilt, so sind alle diese Teile immer wieder verschieden. Nicht nur. daß die Individnen verschieden sind, sondern auch die Teile, aus denen sich die Individnen zusammensetzen, sind es durchgängig. Es erhebt sich dam sofort das Problem, wie denn bei einer solehen radikalen, bis in die letzten Strukturelemente hineinragenden Verschiedenheit die Mög. lichkeit des Vergleichens. Entgegensetzens und Unterscheidens gerechtfertigt werden kömne. Eine solche Vergleichung erfordert doch augeuscheinlich eine gewisse Gemeinsamkeit, Verwandtschaft und Ähnlichkeit der Eigenschaften. Diese Ähnlichkeit im einzelnen muls doch schließlich darin ihren Grund haben, daß zwei Individuen, mögen sie als ganze Individualitäten anch noch so viele Gegensätze aufwejsen, in einigen Eigenschaften gleich sind. Dann würde es also doch gewisse Teile des Wirklichen geben, die, von ihrer Komposition in cinem individuellen Ganzen abgesehen, als bloBe Stïcke und Teile des Wirklichen einander vollkommen gleich wären.

Rein logiseh betrachtet ist es geviß möglich, daß die Wirklichkeit aus gleichartigen substanzen besteht, oder daß doch zum mindesten gewisse Indivjduen einander gleich sind oder aus Elementen gleicher Natur sich zusammensotzen. Die sinnliche Anschaume als solche allerdings vermag uns nicht von der Wirklichkeit des Gleichen zu überzeugen. Ihr gegenüber erscheint vielmehr das Glejehe als ideale Forderung, der die Dinge nur von weitem entsprechen. Untersuchen wir nur einmal kurz, was dic Behauptung des Gleichen in bezug auf zwei Individnen bedenten mag. Ich stelle zusammen das weit Entfernte, scheinbar dureh Welten Getremnte. Den wundervollen Jïngling wähle ich, den göttlichen Sehönon, den die Neisterhand des P'raxiteles zum A poll gabildet, und jene alte mïle mul gebrochene (iestalt, das entnervte und voruckte, das zerlorohene mul zertretene Geseböpf der Straßse. Was ist ihmen boiden gemeinsam? Sind sie nicht grumdrersehieden? Ist nicht jener in seiner scliggen Siehönheit mserer Anbetung und Verchrmug wert, jenes aber in seinem

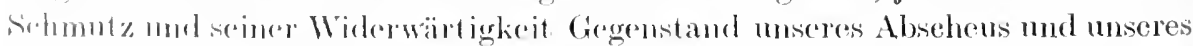

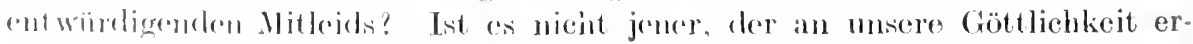

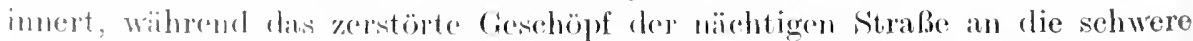

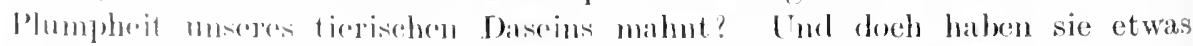

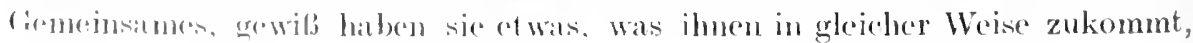


das ist die allgemein menschliche Organisation, die sie von der Tierheit scheidet, das ist, um nur ein Beispiel zu wählen, die aufgerichtete Gestalt.

Die aufgerichtete Gestalt ist das Gleiche, und dabei kann man schwerlich etwas Verschiedeneres sich rorstellen als diese gleiche Art des Aufgerichtet. seins. Jener, in der schönen und sanften Biegung seines Leibes, in der ganzen Pracht seiner jugendlichen Glieder, und jenes müde und gebeugte Geschöpf, dessen Körper ron Laster und Krankheit rerunstaltet wurde. Liegt wirklich ein Gleiches ror in ihrer Art des Aufgerichtetseins? Ist nicht vielmehr gerade die Körperhaltung immer und ewig verschieden zwischen diesem Vorbild des jugendlichen Gottes und der verblühten und verkommenen Hetäre? Was also hier das Gleiche ist in der Haltung des Leibes, das ist nur dieses eine Homent der körperlichen Organisation, das Aufgerichtetstehen mit erhobenem Haupt. Sonst ist alles verschieden, denn des jugendlichen Gottes Haltung zeigt eine wundervolle Beherrschung der Glieder in dem weichen, flüssigen Rhythmus seines Leibes, während die Gestalt des Weibes, gekrümmt und gebeugt. in den zerstörten Formen des Körpers das ganze Elend des Lnterganges unrl des Vergehens offenbart.

Das Gleiche ist also in diesem Falle nicht darin zu suchen, daß irgendein Teil des einen Körpers dem andern gleich wäre. Vielmehr sind der jugendlich blühende und der verwelkte Körper ja denkbar weit entgegengesetzt. Das Gleiche ist vielmehr nur als Moment in der beiderseitigen Körperhaltung rorhanden. Dieses eigentümliche Dasein des Gleichartigen als Moment der Organisation ist es mit in erster Linie gewesen, was Aristoteles zu seiner Lehre von den Formen gefüht hat. Wir wollen hier nur konstatieren, daß Gleiches entweder als Teil des Wirklichen gedacht werden kann oder als Moment, das den Dingen anhaftet, das den Dingen zukommt. aber nicht unabhängig ron ihmen sein kann. Auf diese letztere Art des Gleichseins ist die Naturwissenschaft gerichtet. Überall. wo sie vorliegt, besteht die Möglichkeit, die Objekte oder Gegenstände unter einen allgemeinen Begriff zu subsumieren.

Wir haben festgestellt, daß es der Historie auf das Eigent ümliche ankommt und nicht auf das Gleiche, so daß die Geschichte die Realität des Gleichen nicht einmal anerkennen will, indem sie behauptet, daß mur das Individuelle existiere. Wir sehen ferner. daß die Geschichte, indem sie die Bedeutung ihres Gegenstandes zur Geltung bringen will, Distanz und Gegensatz auf das schärfiste betont.

In dem Kontrastieren und Distanzieren ist das Grundprinzip der individualisierenden Methode zu erblicken. Die Individuen werden nicht einander genähert, um mit ihren $\ddot{h}$ mlichkeiten in die Form des naturwissenschaftlichen Allgemeinbegriffes einzugehen, sonclem vielmehr in unüberwindlicher stärke einander gegenübergestellt und, ihrem Werte angemessen. weit roneinander entfernt. Wenn die Geschichte jenen göttlichen Jüngling schaut, den der Künstler zum jugendlichen A poll gebildet. und das verworfene Geschöpf der Straße, die arme, gealterte Hetä1 ihm zur Seite steht, so wird sie nicht wie die Naturwissenschaft diese unversöhnlichen Gegensätze durch den Begriff des Menschen verbinden. sondern sie wirl dem göttlichen Jïngling in Reiche des Schönen eine wohnliche Stätte bereiten, jene Lnselige aber an den Ort verweisen, wo die Verlorenen hausen. Während die Naturwisenschaft nicht 
grenug die immer gleiehe Art des Mensehen betonen kann, lehrt die Geschichte der Heroen gottähnliche Gebilde, die den armen Simmensklaven so weit übertreffen, wie dieser von tiersscher Bildung verschieden ist.

Wir dirrfen nur nieht die Vorstellung haben, daß die Gesehichte in allen Ienschen ein Eigentümliches sueht, das heißt eine cinzigartige Lebensgestaltung, hrrchdrungen von dem Bewußtsein eines unwiederholbaren Lebenssinnes, entsprechend etwa der Auffassung rom Menschen, wie sie Schleiermacher in seinen Monologen vertreten hat. Nach der schönen Metaphysik, die dort entwickelt ist, soll jeder Mensch seinen eigentümlichen Lebenssinn haben und ihm entsprechend seine Bestimmung ergreifen, glücklich zu preisen aber ist ror allem der Mensch, der nicht nur sich selbst, sondern auch andere in ihrem eigent ümlichen Lebenssinn rersteht, der ein Wissender ist eigentümlicher Natur. Der Historiker sueht naeh dem Eigentümlichen der Individualität, aber nieht in allen Menschen. DerSonderhing, das Original als solches kann sein Interesse nieht erweeken, obwohl gerade in ihnen doch sehrstark der Gedanke der Besonderheit lebt. Der Historiker sucht das Eigentümliche lediglich in der historischen Persönlichleit, die für die Kultur wichtig ist, die für die Kultur etwas Großes geleistet hat. Die ganze Masse der Individuen wird nicht in ihrer Eigentümlichkeit aufgesucht mo aufbewahrt. Diese Individuen sind in ihrer Einzelheit nicht wichtig, wohl aber als Glieder eines Standes, einer Gesellschaftsklasse, einer Partei, cines Volkes, eines Staates. Diese Individuen sucht der Historiker nicht in inrer Einzelheit, sondern als Glieder und Teile einer Kaste, einer Gesellschaft, eincs sozialen Verbandes zu verstehen. In diesem Ganzen aber der Partei orler des Volkes, in dem clas Einzelindividum untergegangen ist. sucht der Forscher der Geschiehte wiederum das Eigentümliche zu erfassen. Die Stoiker der rönischen Kaiscrzeit, das Mönehswesen des 5. Jahrhunderts, die Vasallität der Staufenzeit, die portugiesisehen Juden, zu denen spinoza gehörte, alles das sind historische Begriffe, die darauf abzielen, das Eigentïmliche, nur eimmal Dasciende nnd niemak Wiederkehrende in sciner Lebensfülle zu erfassen. Cud dassell,e l'rinzip waltet vor, wenn wir ms vom den kleinen Verbänden und (romeinschaften zu den Epoehen und Zeitalten, zu den großen Völkerfamilien, zu umfassenden Kulturkreisen erheben, wie etwa das Zeitalter des Perikles, die Gomeinschaft der indogermanisehen Völier und als Heimatstätte der Bildung dic Mittelmeerkultur.

Fnd seblichlich erheben wir uns zu der fore cines Ganzen, in der alle Fülle des historiselom labens anflewahte ist, gewils in versehiedener Gestalt aufhewaht, aber doch in ihm beschloseren. Ws ist der Gedanke des historischen loniversums. In ihm ist all daxjenige noch in deutlicher form zu finden,

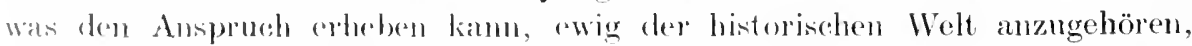

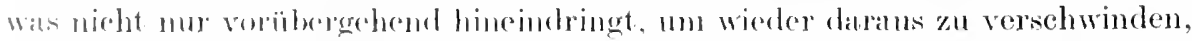

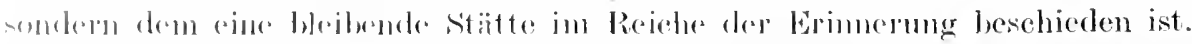

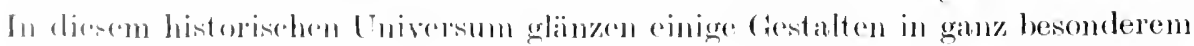

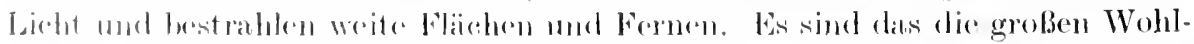

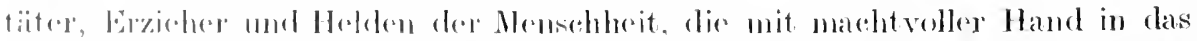

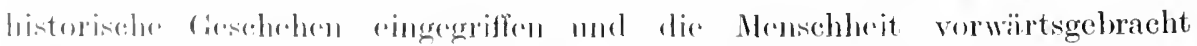

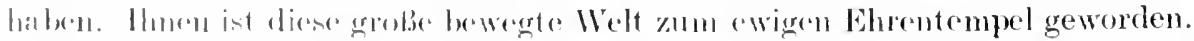
loul zeitallor lenehten daneinen in besonderem Glanze, da cine wundervolle 
Höhe des denkenden Verstehens und des liebenden Schauens der menschliche Geist erreicht. Und Völkerindividualitäten stehen vor unseren Augen. um deren lockige Häupter die begeisterte und dankbare Nlitwelt und Nachwelt Kränze des Ruhmes wand.

Und so ist die Methode des Historikers, der Weg, auf dem er der Wahrheit sich zu mähern sucht, immer auf das Individuelle gerichtet, mag dieses Individuelle nun die einzelne Persönlichkeit oder das Ganze des historischen Geschehens, das Universum der Geschiehte sein, das eingebettet liegt zwisehen zwei dunklen Ufern, einem unerforsehlichen Anfang und einem unerforschlichen Ende.

Das Allgemeine ist nur Mittel der historisehen Forschung, niemals aber das Ziel. Der Begriff in seinen verschiedensten Gestalten dient dieser gemein. samen Aufgabe: Begriffe ron Persönlichkeiten wie Sokrates und Alexander, Begriffe von Völkerindividualitäten wie Grieche und Germane, Begriffe von Nationen und Staaten und auch naturwissenschaftliche Gattungsbegriffe wie Tier und Wald und Meer. In der historischen Methode aber geht der Weg immer von der Individualität des Ganzen zu der Individualität des Einzehen und ron der Individualität des Einzelnen zu der Individualität des Ganzen. Ich muß eine Vorstellung haben von dem Ganzen der historisehen Welt mit ihren Höhen und Tiefen. um die Einzelindividualität in sinngemäßer Weise in den großen Znsammenhang einstellen zu können, und ich muß die Individualität ergriffen und durchleuchtet haben, um von ihr aus die historische Welt zu verstehen. Aus dem historischen Ganzen verstehe ich die Leistung und Aufgabe der Persönlichkeit, und aus der Persönlichkeit verstehe ich die historisehe Weit. WüBte ieh Christus und Sokrates nicht zu verstehen und jene anderen groben Heroen der Menschheitsgeschichte, so wüßte ieh anch nicht, was das historische Ganze bedentet.

Wenn wir num aber in so eindringlicher Weise alles historische Geschehen seinem letzten Grunde nach unter den Gedanken der Individualität stellen. so sei dabei gleichzeitig betont, dab diese Bestimmung keine Entscheidung bedeutet über den Streit der Historiker, ob wohl dic Geschichte aufzufassen sei als eine Geschichte der Persönlichkeiten oder als eine Gesehichte der Massen. bewegungen.

Bekanntlich werden diese beiden entgegengesetzten Auffassungen noch jetzt häufig geltend gemacht. Nach der einen ist es im wesentlichen die grobe Persönlichkeit, welche Geschichte macht, die Geschichte ist dif Geschichte der Heroen. Nach der anderen wird die Leistung der großen vereinzelten Individualitäten erheblich herabgesetzt: sie können nur etwas leisten. insofern sie getragen werden ron einer großen Kulturbewegung. Sic sind gleichsam nur die Organe einer solchen Bewegung wie das Zeitalter der griechischen Aufklärung, aus dem Sokrates hervorging. okter jene ungeheure Bewegung am Ende der griechischen Welt, ans der die Gestalt des Erlösers herrorging. Nach der einen Vorstellung wäre die ganze Bewegung resultatlos verlaufen, wenn nicht der große Mensch, der Heros gekommen wäre, nach der anderen war der Held und seine Loistung das notwendige Resultat dieser Bewegung. Hochgehoben und getragen ron ihr versuchte er etwas zu leisten, aber es war gewissermaßen gleichgültig, ob die Bewegung der Ilasien 
diesen oder jenen so hoch heraushob. Die griechische Aufklärung hatte manchen Sokrates und die griechische Alexandrinerzeit manchen Christus.

Wir wollen nicht zu entscheiden rersuchen, auf welcher Seite das größere Recht liegt. Mit der individualisierenden Methode sind an sich beide Auffassungen vollkommen vereinbar. Wie die historisehe Forschung sich bemüht, die eigentiumliche Erscheinung des Perikles zu rerstehen, so kann sie in gleicher Weise getrieben sein. die unvergleichliche Art jenes Zeitalters zu prüfen, da der Zweifel an den Erkenntniskräften des menschlichen Geistes so mächtig geworden war, daß Verzweiflung die Völker ergriff. Das unglückliche und zerrissene Berußtsein der Zeit glaubte die Entdeekung gemacht zu haben, daß der Himmel leer sei, und konnte diesen Gedanken doch nicht ertragen. Ich meine das alexandrinische Zeitalter, da man in Rom auf immer neue Götter das erschütterte religiöse Bewußtsein der Zeit zu richten rersuchte. Sowohl die Persönlichkeit des einzehnen wie auch eine große Bewegung der Massen kann in ihrer Unvergleichlichkeit und Einmaligkeit zur Darstellung gebracht werden. Erst wenn der Historiker nieht mehr nach dem Eigentümlichen, sondern nur nach clem Cleichartigen fragt, wem er in der griechischen Aufklärung dasselbe sieht wie in der Aufklärung des 18. Jahrhunderts, wenn er die ewige Wiederkehr des Gleichartigen lehrt, die nur durch die neuen Völker als Träger der alten Bewegung eine etwas andere Färbung und Ansgestaltung erhält: erst dam ist die indiridualisierende Betrachtungsweise rerlassen, und es erfolgt der U̇bergang zu ejner naturwissenschaftlich generalisierenden Betrachtung der Geschichte.

Mit dieser naturwissenschaftlich generalisierenden Betrachtungsweise rlarf nun aber nicht rerwechselt werden eine eigentümliche Begriffsbildung, die durchaus im Dienst dex individualisierenden Nethode steht und in der doch scheinbar das Interesse dem Allgemeinen zugewendet ist. Dilthey hat diese Form der Begriffsbildung. die in hohem Mafe geeignet ist, in das Verstehen der historischen Welt einzuführen, als Typenbildung bezeichnet. Suchen wir uns dieses P'roblem an Beispielen deutlich zn machen. Wir lemen einen Menschen kemen, der über seine eigentümliche Individnalität hinaus uns als Repräsentant einer allgemeinen Kultur und Lebensbildung erscheint. Wir sagen etwa: dieser Mensch ist ein echter Grieche oder ein Romantiker oder ein spezifisch religiöser Nensch orler eine künstlejische Natur. Sehen wir in ihm den Grjechen oder den Romantiker, so meinen wir, daB ganz bestimmte und notwendige Züge, dic wir in den Menschen der Periklejschen Zeit oder in den llenschen an Anfang des 19. Jahrhunderts geschant haben, in ihm glejchsin anflewaht und uns anfgeboben sind in frischer lebendiger Ge-

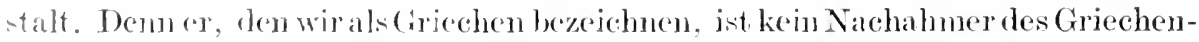

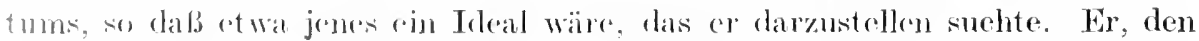
wir als Griechen brocichnes, ahmt das Gricohentum nicht nach, er kopiert

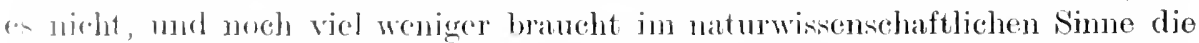

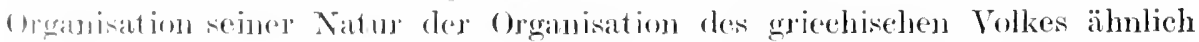

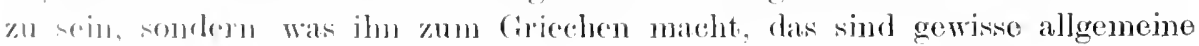
IVertstzungen, growses Leben- und Kulturideale, die er mit dieser Nation gremeinsan hat. Ind deswegen wird anch seine Scele bis in das Tiefste bewegt,

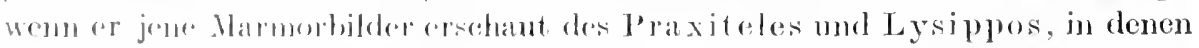
ror berwirklicht und dargestallt sirht. Was seine eigene beele ahmungsreich ge- 
fühlt. Utberlegen wir also luhig, was wir meinen, wemn wir diesen Menschen unserer Zeit jenem Tolke hinzuzählen, so denken wir in Grunde genommen nur, daß er dieselben Werte anerkennt. Wenn wir aber weiter darüber nachdenken, wie es demn möglich ist, daß jene fernen Lebens- und Kulturideale noch Anerkennung finden, so kann es nur darin liegen, daß sie niemals so fern und fremd geworden sind, wie man wohl meinen möchte, sondern daß in ihmen etwas niedergelegt ist, was als ein dauernd Wertrolles immer wieder zur freudigen Anerkemmung bewegt.

Noch viel einfacher liegt das Faktum. wenn wir in irgendeinem Mlenschen etwa das religiöse oder künstlerische Moment stark unterstreichen und ihn einen religiösen oder künstlerischen Menschen nennen. Wir meinen, daß in einem solchen eine einseitig starke Hinwendung nach einem bestimmten Wert sich rollzogen hat, so daß bei ihm dieser eine Wert, sei es nun die Religion oder die Kumst, zur leitenden Dominante geworden ist. Hier ist es also nicht ein rielfach rerschlungenes Gewebe mannigfacher Wertsetzungen. wie etwa dasjenige, in lem das romantische Kulturbewobtsein sieh äuberte. was Anerkemung fundet, sondern einem einzigen Kulturwert sind alle anderen mehr oder weniger zum Opfer gebracht, und dieser eine hat danernd Gestalt gewomnen in der ihm zugewendeten Seele.

Wenn wir von Griechentum und Romantik sprechen. so denken wir in erster Linie an einen bestimmten Zeitabschnitt. Wollen wir nicht mehr darmer rerstehen, so ist allerdings das grieehische und das romantische Zeitalter untergegangen. Anders steht es von vornherein mit Begriffen wie religiöse und künstlerische Natur; hier werden wir wohl kaum zweifeln. daß es solehe zu allen Zeiten geben wird trotz aller derjenigen. die dem religiösen Menschen den Untergang prophezeit haben, und die da meinen. daß in unserem Zeitalter der herben Technik, das dem Gefühl kein Recht eimräumen will, daß in diesem Zeitalter auch die Kunst stirbt. Der religiöse und künstlerirche Menseh sind angenscheinlich an keine Zeit gebunden. Solche kann es zu allen Zeiten geben. Griechentum und Romantik gehören urspringlich einer bestimmten Zeit an. Indem aber das historische orler geschichtsphilosophische Bewnßtsein den Ewigkeitsgehalt erkemnt. der in diesen Begriffen schlummert. gibt es ihnen eine Bedeutung über eine bestimmte Zeit hinaus und erhebt sie damit auf dieselbe Stufe wie jene zuror genannten. Jetzt haben anch sie die Bedentung eines Typus gewomnen. Ein solcher Typus ist. wie wir noch später zu zeigen haben werden, kein naturwissenschaftlicher Allgemeinbegriff oder Gesetzesbegriff. Er bedentet die Verbindung des Kulturwertes mit bestimmtem Leben. mit einer besonderen Organisation. Wenn in dem Begriff der Schönheit noch nicht die Verbindung mit der Simenwelt gedacht ist, wemn in dem Begriff der Kunst als einer mensehlichen Kulturtätigkeit nur die allgemeine Organisation dieses Kulturwertes, seine besondere Art in Gegensatz zu anderen Werten und seine Geltung für ein besonderes Gebiet zur Erörtermng gelangt, wie das in erster Linie die Aufgabe der Philosophie der Kunst ist, so gehen wir mit. dem Typus des künstlerischen Menschen erst eigentlieh in das Leben hinein, indem wir nunmehr zeigen, wie dieser allgemeine Kulturwert an einer bestimmten Gestalt Leben gewimnt. Ein solcher Typusbegriff bedentet also immer die Realisierung eines allgemeinen Kulturwertes in hestimmter Form. Er ist rom 
Leben durchsättigt und durchdrungen, während der Kulturwert als solcher rein formal bleibt. Die Bedeutung dieser Begriffe besteht a!so darin, daß sie weit tiefer in die historische Welt eindringen als die Kulturwerte, wenn sie auch lediglich in diesen begründet und verankert sind. Sucht nun die Ge. sehichte diese allgemeinen Typen auf, so tut sie es nieht, um bei ihnen stehen zu bleiben, wie etwa die Naturwissenschaft bei den Gesetzen stehen bleibt. Der Begriff des Typus treibt ja in seiner logisehen Vollendung nach dem Begriff des Kulturwertes hin. Der Begriff des Typus legt lediglich die enge Beziehung fest zwischen dem Simnlichen und Unsinnlichen und zeigt uns, wie in dem welchsehden Verlauf des Gesehehens immer wieder ein Unveränderliches und Bleibendes zum Durchbrueh kommt.

\section{g) Die Spezialisierung der individualisierenden Methode.}

Naehdem wir so im allgemeinen den ('harakter cler individualisierenden Methode bestimmt haben, müssen wir in diesem Zusammenhange noch andeuten, welche Probleme sich aus ihr für die Darstellung der Entwicklung in den einzelnen Kulturgelieten ergeben; denn soviel sei von rornherein bemerkt, daß eine allgemeine Kulturgeschichte. welche eine zusammenhängende und ineinander übergreifende Darstellung der Entwicklung sämtlicher Kulturgüter, der Philosophie, der Wissenschaft, des sittlichen und staatlichen, des religiösen und rechtliehen Lebens gibt, zwar prinzipiell nicht ausgeschlossen ist, aber doch im einzelnen großen Schwierigkeiten unterliegt. Diese Schwieriglieit steckt vor allem darin, daß3 hier dic Fülle des Materials eine deutliche und übersiehtliche Entwieklung des Ciesamtverlaufs ersehwert. Auch liegt die Gefahr vor. daß bei einer solchen Darstellung, in der das Interesse nach den verschiedensten Seiten gewendet ist, das einzelne nicht zu seinem Rechte kommt. Diese Gefahr ist besonders groß für die Genchiehte der Philosophie. sofern sie in den Zusammenhang einer allgemeinen Kulturgeschichte eingestellt wird. Denn in der Geschichte der Philosophie kommt es ror allem auf aine (ieschiehte der Ideen. auf eine Geschiehte der philosophischen Bogriffe an. Es soll dargestellt werlen die Notwondigkeit, mit der eine Idee dic andere hervorgerufen hat, diese immanente Abhängigkeit der Ideen voneinander soll gezeigt werden $\left.{ }^{1}\right)$. In einer allgemeinen Kulturgeschichte wird lagegen die ncue philosmphisehe Idee und das System, in dem sie sich organisiert hat, als Produlit der versehiedenartigsten Kulturströmungen begriffen, so dals die stobe und strenge Linie der philosophisehen Entwickhung dureh die Hervorkehrung von Nohomsachen flüchtig und flichond gemacht wird.

Ferner besteht die große Schwierigkeit, einen Kulturwert zu erwählen, l(1 als leitender fär die Bostimmmng der Gesamtentwieklung zu gelten hat.

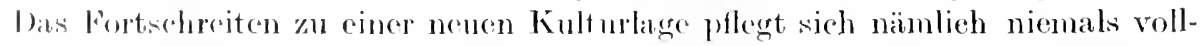
kommen slejohzeitig zo vollzichen. So kann, um ein Beispiel zu erwähnen, dice liomantik lereits ihre schönsten Blïten anf dem Gebiet rler Diehtkunst trejhen, mol worh ist in Philosophio mul Wissonschaft niehts von diesen neuen

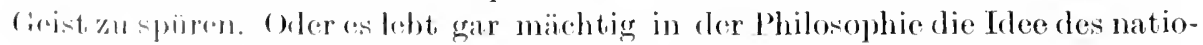

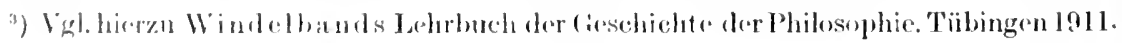


nalen Staates. und die politischen Verhältnisse sind ron der Verwirklichung dieses Gedankens noch weit entfernt. Will man nm einen Kulturwert zum leitenden erheben, so rerfährt man am konsequentesten, wenn man hierfür entweder den bestimmt, der es mit den abstraktesten Phänomenen zu tun hat, also den Kulturwert der Philosophie, indem man die Úberzeugung vertritt, daß die ideelle Macht des Gedankens in ma Bgebender Weise die politischen und sozialen Verhältnisse bestimmt, oder wenn man denjenigen Kulturwert als ent= scheidend betrachtet, der es mit den konkretesten Erscheinungen zu tun hat, nän= lich den Kulturwert des Staates. Je nachdem nun die Begriffsgeschichte oder die Staatengeschichte im Zusammenhang einer Kulturgeschichte schärfer betont wird, muß das Gesamtbild sehr veränderte Züge tragen. Dabei bleibt für eine verständnisvolle und übersichtliche Darstellmmg immer noch die Notwendigkeit bestehen, die Entwicklung der Kultur in rerschiedenen Reihen abzuhandeln. So daß etwa auf die Schilderung der politischen Lage und ihrer Entwicklung die Darstelhung der philosophischen, religiösen und kïnstlerischen Bewegung der Zeit folgt. Mögen wir also den Gedanken einer allgemeinen Kunturgeschichte verteidigen wollen oder ihn ablehnen: auf jeden Fall hat anch sie Rücksicht zu nehmen auf die Besonderheit der so verschiedenartigen Phänomene, dic in ihr zu einer gemeinsamen Darstellung gelangen.

Wir wählen aber drei verschiedene Formen oder Gestalten der Kultur aus, um an ihnen die Modifikationen deutlich zu machen, welche die individualisierende Methode bei ihrer Anwendung auf Einzelgebicte erfährt, nämlich die Philosophie in der abstrakten Form der Begriffsgeshichte. als äußersten Gegensatz hierzu die politische Geschichte und schließlich ron den rerschiedenen Formen der Kunst speziell die Geschichte der Dichtkunst.

\section{g) Politische Geschichte.}

Wie steht es mun mit der Herausarbeitung des Eigentïmlichen auf diesen so verschiedenen Gebieten? Man möchte da zunächst meinen, daß die Bestimmungen, die wir der individualisierenden Methode gegeben haben, in der Hauptsache anf die politische Geschichte hinzielen, wo wir es mit großen aktionsfreudigen, in die Verhältnisse des Lebens eingreifenden Persönlichkeiten, mit Staatenbildungen, ihrer Organisation und Ausgestaltung; mit dem Völkerleben und Tölkerschicksal in seinen mannigfaltigsten Formen zu tım haben. Hier, wo das Leben so stark und mächtig vor uns steht, da können wir gewiß in erster Linie von der Sehnsucht nach Individualität sprechen, welche die historische Methode charakterisiert, weit mehr als dort, wo es sich in erster Linie um Gebilde handelt, die das Denken oder die Phantasie so fern ron der Wirklichkeit erzeugt hat. Haben wir es in der politischen Geschichte doch zu tun mit dem Leben, wie es tatsächlich sich entwickelt und entfaltet hat, in der Geschichte der Dichtkunst und in der Geschichte der Philosophie aber nur mit dem Leben, wie es sich in der Phantasie des Dichters spiegelt oder den Forderungen der Vernunft gemäß sich entfalten sollte. Also nur in der politischen Geschichte wendet sich die Darstellung, wie es scheint, dem wirklichen Leben zu und sucht das wirkliche Leben zu erfassen. in der Geschichte der Philosophie und Dichtkunst aber hat sie es mit einem Leben zu tun. das schon 
unwirklich geworden ist durch die Phantasie des Dichters und durch das Denken des Philosophen.

Allerdings kommt auch in der Geschichte der Philosophie und in der Geschichte der Literatur die Gestalt des Lebens zur Darstellung, wenn wir in die Persönlichkeit des Dichters und des Philosophen einzudringen suchen. Wie verhalten sich mun die drei von uns angeführten Formen der Geschichte in der Wiedergabe der Individualität? Bedeutet sie ihnen allen gleichviel, oder legt die eine oder andere Form mehr Nachdruck anf das Werk als auf den Helden? Wird vielleicht jene aus dem Simn ihrer Aufgabe heraus das Bild des Hełlen abstrakter gestalten müssen als diese? Hüten wir uns hier auf jeden Fall vor einem allgemeinen Schema. Es scheint in der Tat so, dal.s jene drei Formen der Geschichte, welche alle die Individualität suchen, zı einer verschiedenen, mehr oler weniger konkreten Ansgestaltung der Persönlichkeit gelangen müissen.

Es sind drei Welten, denen drei verschiedene 'Typen ron Persönlichkeiten gegenüberstehen. Die Welt, mit der es die politisehe Geschichte in erster Linie zu tun hat, das ist die Welt des offentlichen Lebens, die Welt der politischen und sozialen Kämpfe, jene große Welt, wo es vor allem ankommt anf die unbengsame Gewalt des IVillens, dem in der wunderbaren Kraft seiner Entfaltung keine feste und unüberwindliche Schranke gesetzt werden kam. Hier ist das Reich der Tat. Hier geht Leben mit Leben zusammen. Und so müssen wir denn ein möglichst konkretes und vollständiges Bild zu gewimnen suchen von dem politischen Helden, dessen gewaltige Energie in die Welt ansströmt und alle Verhältnisse umbildet und umgestaltet. Aber wir wollen dieses Leben anch nur kemnen lernen, soweit es der Öffentlichkeit zugewendet ist. Das private und intime Lehen des politischen Hellem. in das die große Welt nicht hineingedrungen ist, vermag uns nur in weit geringerem Maße zu interessieren. weil dieses Lehen keine große Gestalt gofunden hat.

\section{h) Kinnstgeschichte.}

Dieser kleinen Welt, der Volt des inneren Erlehens, der Welt der persönlichen Gefühle von Liebe und Haß und Schmert, diesem Allereigensten, von der großen Welt so Entfernten, giht der Dichter die sehöne Form und Gestalt. Und wenn er, iiber die innerliehe Wolt der lyrisehen Dichtung hinausgehend, im Epos und im Drama die objektive Welt hineinragen läBt in das stille Reieh, wo er als Fürst gebietet, so kann doch das geschulte Ohr des Verstehenden ohne große Mühe crkemen, daß jene epischen und dramatisehen Gestalten widertönen des Dichters Liebe nnd des Dichters Qual. Wenn uns die Erlelniswolt der ancteren Mrensehen, falls sie nieht als Geliobte und Fremole morere eigene. Welt gestalten holfen, gleichgiiltig und bedentumgslos areheint, so gewimnt die Erlebniswelt dre Viahters in ihrer sehönen Ausgestaltung för uns cine mermebliche Bedentung. Und so erwiohst den hier der histerischen Nothode die Anfgabe, in die Erlebmiswrelt, des biehters einzullingen, um ans jhe heraus das große Werk somer Kunst nachfïhlend zu rerstehen. Hier ist also in viel höherem Mabo ein Limblengen in die eigentïmliche Erlebniswelt geboten. Und doch

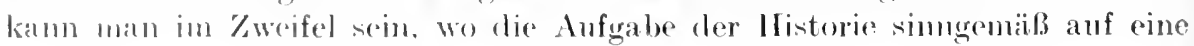


höhere Erfassung der Konkretheit abzielt, dort, wo es, wie in der politischen Geschichte, gilt, ein Heidenleben im Kampfe mit der großen Welt zu rerstehen, wo durch die Tat des Willens das weite Leben selber zu neuen Formen gestaltet wird, oder dort, wo die Aufgabe des Historikers darin gesucht werden muß, zu zeigen, wie aus der begrenzten Welt der einzelnen Persönlichkeit heraus die schöne Welt des Scheines erzeugt wird.

Auf jeden Fall wird der Ausgangspunkt in der politicchen Geschichte und in der Gesebichte der Dichtkunst ein sehr verschiedener sein. Um das Heldenleben zu verstehen, ist die Kenntnis der Weltlage zunächst ganz all gemein und dann in jeder Phase kritischer Entwicklung immer wieder ron neuem erforderlich. Fast zu Boden gedrückt waren die Karthager durch Roms siegreiche Kraft, da trat auf den Schauplatz des Kampfes der Mann, der schon als Knabe Rom ewige Feindschaft geschworen, und dem es, wie es schien, beschieden war, die drohende Weltherrschaft Roms aufzuhalten und des Vaterlandes Freiheit zu erkämpfen: Hannibal, Hamilkars šohn. Um die Leistung Hannibals zu rerstehen, ist die Kenntnis ron Roms Nacht und ron Karthagos Ohnmacht erforderlich. Es gilt, die ungeheure Spannung im Gegensatz zweier Kulturen zu begreifen und die ungeheure Tragweite, die der Sieg der einen oder anderen für das Schicksal des Menschengeschlechts notwendig haben muB. Und dam tritt die Leistung hervor. die große Tat, die das mächtige Rom fast vollkommen vernichtet und zu Boden geworfen hätte.

Dagegen ist der Ausgangspunkt der Geschichte der Dichtkunst des Dichter. Erlebniswelt. Während wir dort aus dem Weltleben zum Heldenleben hingeführt werden, um die Größe seiner Tat würdigen zı können, führt uns die Geschichte der Kunst in die Erlebniswelt des Dichters ein, wo wir jene Spannungen und Gegensätze finden, deren Lösung das Kunstwerk herbeiführt Die Erlebniswelt wird objektiviert, und in der Sphäre des Unwirklichen wird die Lösung des Konfliktes gezeigt, der die eigene Brust durchbebt.

Neben dem angeführten Wege, das Kunstwerk aus der Erlebniswelt des Dichters und die Erlebniswelt des Dichter's aus dem Kunstwerk zu rerstehen. könnten wir uns noch einen anderen Weg für die individualisierende Methode denken, der dieVoraussetzung macht, daß die Kunst bestimmte Aufgaben zu lösen hat. Ich denke dabei nicht nur in erster Linie an gewisse Stilprobleme, wie etwa die Verbindung des Gotischen und Romanischen in den Strebepfeilern und Wölbungen des deutschen Domes, oder die Verdrängung des Reimes in der Dichtkunst durch den triumphierenden Rhythmus, Dinge, die mehr die äußere Form berühren; ich denke auch nicht an die Probleme der Raumbeherrschung, wie sie für die Malerei so wichtig sind, noch wie es in der Skulptur möglich war, das Problem des freien bewegten Körpers zu lösen : - auch sie können gewiß für eine Geschichte der Kunst zu leitenden Gesichtspunkten erhoben werden, und eine solche Darstellung würde zeigen, wie gar tief alle diese Fragen den Charakter einer eigentümlichen Kultur berühren. Welche Gebundenheit des Körpers in der ägyptischen Skulptur, und wie herrlich schreitet in der griechischen Kunst der nackte schöne Nensch in wundervoller lebendiger Bewegung immer freier und göttlicher daher! Aber neben diesen Entwicklungen, die von einem äußeren Formproblem zum andern fortgehen, und in denen wir den großen Zug der Kultur verfolgen können. ließe sich auch eine Geschichte der Dichtkunst 
und der anderen Kïnste denken, wo es mchr anf die innere Form, auf da-jenige ankommt, was man als die Idee des Kunstwerkes bezeichnen muß3. Gewiß kann es sich hier niemals um eine begrifflich ersehöpfende Beschreibung dieser Idee, sondern immer mur m Hindentung und Andentung handeln. Eine solche Darstellung würde eine Gesehichte der künstlerischen Ideale bedenten.

Daß das Problem einer solchen Geschichte der ästhetischen Ideale besteht, unterliegt keinem Zweifel. Als Vorläufer und Verfechter einer solchen haben vor allen Winckelmann ${ }^{1}$ ), Lessing ${ }^{2}$ ), Herder ${ }^{3}$ ) und Schiller ${ }^{4}$, von den Romantikern besonders Fricdrich Schlegel ${ }^{5}$ ) und Schelling $\mathrm{g}^{6}$ ) und schließlich Hegeli) zu gelten. Daß die nenere Kunstgeschichte und speziell anch die Literaturgeschichte dies Problem hat fallen lassen. weil sich ein Teil der Moderne zu einer ideen- und gedankenlosen Kumst bekennt, hebt das Problem nieht auf. Es wird wohl noch die Zeit kommen. wo man dieser gedankenlosen spielereien anf künstlerisehem Gebiet herzlich müde sst mnd wieder nach einer Kunst rerlangt, die ron einem hohen Sinn getragen wird. So viel ist gewiß, daß das Werden und die Entwieklung der einzelnen Künstler und ihrer Werke noch keine Kimstgeschichte gibt, demn zur historisehen Darstellung gehört notwendig der Zusammenhang, das historisehe Ganze und speziell in unserem Falle das historische Ganze der Kunst. Wollen wir num nicht bei einer Stilgeschiehte stehen bleiben noeh bei einer Gesehichte der allmählichen Clberwindung jener Bindungen und Abhängigkeiten, die dem Künstler aus der Natur des Materials erwachsen, so kommen wir notwendig zn einer Ideengeschiehte orler einer Geschichte der künstlerischen Ideale, und in diese ließen sich zum mindesten eine Anzahl der größten Meisterwerke aller Zeiten einstellen. Diese Geschichte der ästhetischen Ideale darf natürlich nicht verwechselt werlen mit einer Gesehichte der ästhetisehen Theorien. Die Geschichte der ästhetischen Theorion gehört der Gechichte der Philosophie an. Hier handelt es sich um Gedanken der Philosophen über die Kimst, um verschiedene Formen der Äthetik, wie sie sich nachemander gebilde haben. Aber in der Geschichte der ästhetischen Ideen soll der Historiker ummittelbar das gemeinte Ideal ans dem Kunstwerk alyulesen suchen. Die Geschichte der ästhetischen Theorien setzt bereits eino rollzogene Denkleistung am Kunstwerk roraus, nicht so dic Geschichte der ästhetischen Ideale, die dem Kimstwerk mit derselben Unmitcolharkeit zugewendet ist wie einer historischen Persönlichkeit.

Tha ist nun ein für allemal ron den großon Begrïndern eincr Tdeengeschichte dror Kunst dor entischeidende Gegensatz anfgestellt zwischen dem Irleal der antiken mud dem foral der modernen christlich romantischen Welt. Auf der cinen Soite das foleal der Sichönheit, anf der anderen das Ideal des Interessanten.

1) Minckelmann: (keshichte der Kunst des Altertumes. ,Trattato prehminare."

2) Lassing: Latukerrm.

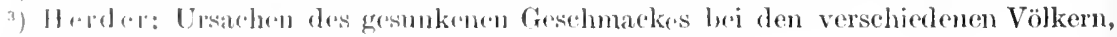
lit w gerbliiht.

") Shehiller: Über naive und sentimentalisehe Dichtong.

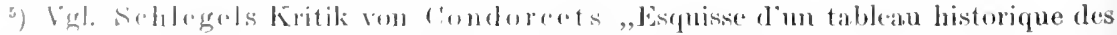

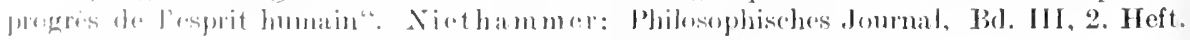

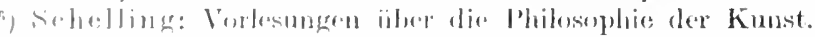

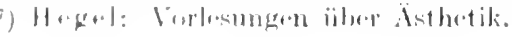


Dort Ruhe und Begrenzung, hier Bewegung und Progrel.j. I)ort Einheit, hier Gespaltenheit. Dort Einfachheit, hier Kompliziertheit, dort Endlichkeit, hier Unendlichkeit - und wie man diesen Gegensatz zweier Welten noch sonst charakterisieren mag. Es wäre eine durchaus mögliche Aufgabe der Geschichte, aus den großen Meisterwerken aller Zeiten zu zeigen, wie in der Kunst das Ideal der Antike durch das neue Ideal der christlich romantischen Kunst verdrängt wird. Es wäre auch nicht unmöglich, am einzelnen Kunstwerk deutlich zu machen, in welcher Modifikation das allgemeine Ideal einer in sich geschlossenen Kunstwelt hier zum Ausdruck gelangt.

Nehmen wir, um ein Beispiel zu gebrauchen, den Apollo Sauroktonos des Praxiteles, von dem uns eine schöne Kopie erhalten ist. Die griechische Skulptur war so groß und die Lebensbedingungen für sie auch in der römischen Welt danernd so günstig, daß sie den Untergang der nationalen Unabhängigkeit überlebte und auch damn noch herrliche Werke schuf, als Philosophie und Dichtkunst ihr letztes Wort gesprochen hatten. Sehen wir nun diesen Apollo des Praxiteles, so gelangen wir in der Tat zu einer Torstellung menschlichsinnlicher Schönheit, die alles Wirkliche weit überragt. Mögen wir noch so sehr erfüllt sein von dem Gedanken. daß die Natur Wunderbares und Köstliches bildet, angesichts dieser Gottheit müssen wir still verehrend anerkennen: hier ist mehr als Natur. End doch ist diese Gestalt wieder ganz Natur, sofern in der schönen Bildung des Leibes die Idee möglicher menschlichen Šchönheit vollkommen gewahrt ist. Nicht versucht hier die Kunst bei ihrer Darstellung des Göttlichen durch Größe zn wirken, durch feierlichen Ernst und Strenge in Haltung und Gewandung, noch ist hier der Tersuch gemacht, den Körper gleichsam zu verklären, durch Bildung einer zarteren und feineren Organisation auf das Ủbersinnliche hinzudeuten.

Es handelt sich hier um eine Erhöhung des menschlich Schönen, die gleichsam kontimuierlich von den Gestalten des Wirklichen fortführt, die das Göttliche nicht als ein anderes dem Menschlichen entgegensetzt, sondern die unsere eigene Natur liebevoll über uns hinausführt. Es ist nicht ganz richtig zu sagen. daß in diesem Bildwerk das Göttliche in das rein Menschliche übersetzt sei. wir müßten uns sonst zunächst eimmal darïber klar werden, was hier das rein Menschliche bedeutet. Die wundervolle Vereinigung ron Ruhe und Bewegung. die Schlankheit, Feinheit und Flüssigkeit der Gestalt, sie sind nicht um ihrer selbst willen da, um ein schönes und beglïckendes Biid ron Jugend und Anmut zu gewähren. Alles das weist anch wieder über sich hinaus. Dieser junge Apoll ist auch wieder ganz Apoll. Wenn seine Glieder sich entfalten und ausreifen, so wird sein Erscheinen jene hohe Göttlichkeit ammehmen, die wir am Apoll rom Belvedere bewundern. Der ganze Bau dieses Leibes in seiner herrlichen Schlankheit, die hohen Beine, die feine Muskulatur, die zarten Knöchel, sie finden sich bei dem vollendeten und bei dem werdenden Gott. Und nun ist wohl die künstlerische Idee ror allem diese. Es gab Götter, zu deren Wesen wohl nach der ursprünglichen Auffassung die Kindlichkeit gehört hat. So sehen wir den Eros und den Dionysos vielfach als Knaben oder in der ersten Blüte des Jünglingsalters dargestellt, und lann immer mit einer gewissen Weichlichkeit in Form und Haltung. Als Srmbol des seligen Raurches und der törichten irrenden Liebe scheint diese Form der Kindlichkeit und 
de: Werdens angemessen. Aber Apoll ist ein Symbol des Vollendeten. Wenn -chon je der Göttertypus nach der tiefsimnigen Auffassung Schellings ein Cnendliches in der Begrenzung darstellt, sofern es sich immer um eine Potenz, Funktion oder Kraft handelt, die im Bilele des Gottes in denkbar höchster Form. gleiehsam mendlich groß erscheint, die Begrenzung aber in der notwendigen Isolation des einzelnen liegt: so tritt bei Apollo das rein Ideelle, das Enendliche besonders mächtig hervor, weil er der Gott des Lichtes ist, der Schönheit und der Kunst, sowie der heilige Schützer des Rechtes. So war es die Idee des Künstlers, dieses höchst Vollendete als ein Werdendes dazzustellen. Dieser Apollo Sauroktonos ist nicht der vollendete Gott, ebensowenig wie das liebliche Jesuskind auf den Armen der Sixtinischen Madonna der vollendete Christus. Dort anf dem großen Gemälde der Transfiguration. (lort ist er vollendet, wie er so groß und siegreich und allmächtig zum Himmel sich erhebt.

Diese eigentümliche Paradoxie, clas Vollendete als ein Werdendes darzustellen, gibt der Gestalt, des jugendlichen Apoll etwas unendlich Reizvolles und Rïhrendes, mol zugleich muß diese Pereinigung des Vollendeten als des wahrhaft Göttlichen mit dem Gedanken des Werdens als des Jugendlichen, noch nicht Ausgereiften, das alle schönen Möglichkeiten des Seins noch in sieh birgt, ein Kunstwerk bedeuten, das im besonderen Maße dem Kultus des Schönen dient. Es war eine offene Frage der Philosophie in Griechenland, was denn wohl eigentlich sehöner sei, das Werlende oder das Vollendete, was dem wohl besser sei und glïcliseliger. Die Philosophie hat diese Frage nicht zu beantworten remoeht. Demokrit hat den Vollendeten und deswegen anch das Greisenalter, das überwunden hat, andere haben das Werdende als schön nnd selig gepriesen. Die Kunst löst diese Antinomie in der Idee des werdenden Gottes. Er ist rollendet, dem diese ganze Erscheinung offenbart des Gottes rollendete ciestalt, aber er ist cin Wordender, demn er ist ein Knabe, der im sipel nud in der Cnschuld des Knabentrammes lebt. Jene Hand, die spätey den furchtbar klirrenden Bogen als nubezwinglicher Ferntreffer zu fïhron weib, sie fïhrt spielerisch leicht mit schlankem Knabenarm dieschlanke lanze nach der hurtigren Eidechse am Bamme ront. Er will gewiß nicht töten, (re mag wohl wiscen, dalib das flinke Geschöpf des Waldes seinem Wurfentgeht. Sorglos kindlich zielt a dorthin. um seine jugendliche Kraft zu iiben. Oder

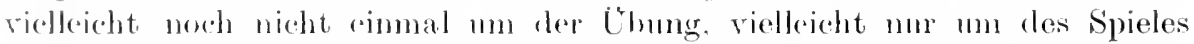
willen; denn cine selige wohlige Rule ist, ïber die ganze feine biegsame Gestalt

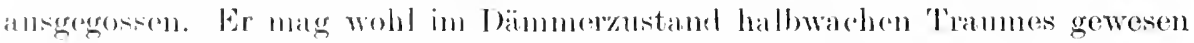

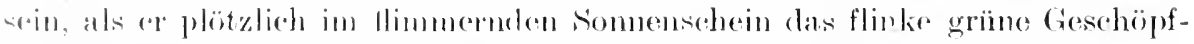

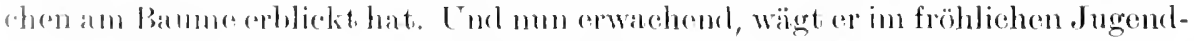

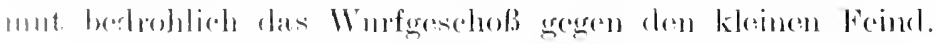

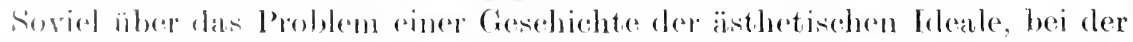

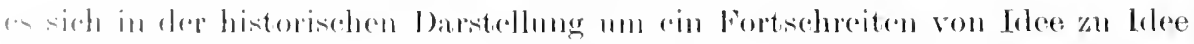
handrolt. Wo dann nicht mohr die Brlehniswelt des Kïmstlers den Ausgangs-

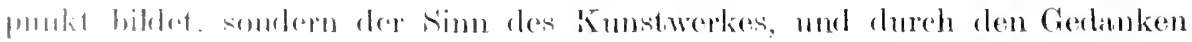

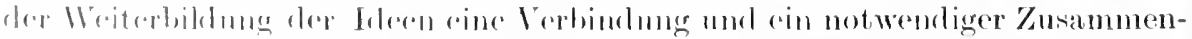

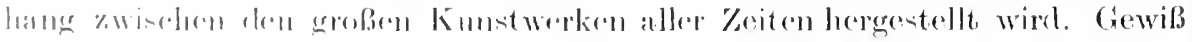
wirl as anch hier die Gerehichte noch in hohem Malor mit der Konkret- 
heit zu tum haben, indem sie die Individualität des Künstlers und die Individualität seiner Schöpfung zur Darstellung bringt, aber sie wird all dieses mehr konkrete Material bei der ganzen Bearbeitung und kïnstlerischen Gestaltung orientieren an einer Geschichte des Sinnes, die sich durch die Welt der Kunst dahinzieht. Bei dieser Ideengeschichte ist nun ein Moment der Konstanz und ein Moment des Neuen und Wechselnden zu unterscheiden. Wemn die Menschheit eine gewisse Höhe der Entwickhng crrejcht hat, dann mag sie wohl alle ästhetischen Ideen zur Darstellung gebracht haben, aber dem Künstler bleibt immer noch die Möglichkeit rorbehalten, der schon von anderen dargestellten Idee in seiner eigenen künstlerischen Gestaltung eine ganz nene Modifikation zu geben.

In diesem Zusammenhıng möchten wir nun gleich darauf hinweisen, daß wohl kein Gebiet des Geistes der naturwissenschaftlichen Begriffsbildnng so sehr widerstrebt wie das Gebiet der Kumst. Wird doch gerado hier in hohem Maße das Neue, das Einzigartige, das Originale gewertet. Niemals stehen wir dem Wesen der Kunst feindlicher gegenüber, als wenn wir das Kunstwerk oder den Künstler zmm Exemplar eines Gattungsbegriffes herabsetzen oder den Gedanken der künstlerischen Freiheit und schöpferischen Tätigkeit durch die mechanische Notwendigkeit des Naturgesetzes bedrohen. Gewiß werden wir bei einer Geschichte der Kunst anch Gemeinsamkeiten zum Ansdruck bringen, indem wir sie allgemeinen Begriffen unterordnen, nämlich vor allem dort, wo es sich nicht $1 \mathrm{~m}$ die Darstellung der großen Meister, sondern viehmehr um die Schulen handelt, die ron den Ideen des Meisters erfüllt sind, aber im allgemeinen wird der konkrete und individnelle Begriff, der Begriff, der mnmittelbar das Einmalige und Einzigartige sucht, nirgends ein so weites Feld der Anwendung haben wie gerade in der Geschichte der Kunst. In einer Geschichte der Kunst und Literatur müssen wir nur immer wieder bedauern, daß die menschliche Sprache nicht reich genng ist. um diese Fülle desTerschiedenartigen zum rollendeten Ansdruck zu bringen.

Wir betonten, daß die Kimst vor allem der naturwissenschaftlichen Begriffsbildung sich entzieht. Es liegt aber bis zu einem gewissen Grade in ihrem Wesen begründet, daß sie überhanpt der wissenschaftlichen Erkenntnis sich entzieht und ein feindliches Verhältnis zum Begriff hat. Der wissenschaftliche Begriff bleibt doch nun eimmal der große Gleichmacher und Zerstörer der göttlichen Freiheit und Selbstherrlichkeit des Kunstwerkes. Was dam speziell das Verhältnis ron Kunst und Geschichte betrifft, so ist es das hohe Maß ron Abgeschlossenheit, das dem Kunstwerk eigentiumlich ist. das eine historisehe Darstellung erschwert, die immer auf Zusammenhang und auf Auflösung der festen Grenzen sich richtet. Während die politischen Geschehnisse unmittelbar miteinander verflochten sind und ineinander übergehen, stehen die Künstler der verschiedenen Völker und Zeiten sich in einer Alggeschlossenheit gegenüber, die zu überwinden und flüssig zu machen, ais eine der schwierigsten Aufgaben der historischen Methode angesehen werden muB. Und dann noch jenes andere, was wir schon in einem anderen Zusammenhang betonten. Es rennt eine gewisse Ideenfeindlichkeit, ein entgegengesetzter Grundcharakter Kunst und Geschichte. Dem diese hat es mit dem für immer Vergangenen and Verlorenen zu tun und ist deswegen ihrem Grumdcharakter nach durchaus 
tragiseh, jene aber ist das Reich des ewig Jungen und Gegenwärtigen. Dieses Auseinandergehen in Grundbedenten ergibt eine Spannung, die sehwer zu lösen ist.

\section{i) Philosophiegeschichte.}

Vergleichen wir den Gegenstand der Philosophiegeschichte mit dem Objekt der politischen Geschichte und der Kunsthistorie, so hat er augenscheinlich den Charakter einer gewissen Abgesehlossenheit mit dem Kunstwerk gemeinsam. Das philosophisehe System ist auch eine Welt für sich und setzt der Idee des historisehen Zusammenhanges einen gewissen Widerstand entgegen. In der Philosophiegeschichte handelt es sieh wie in der Literaturgesehiehte in der Hauptsache um eine ideelle Welt oder viehmehr um ideelle Welten, die nieht in einem lebendigen Wirkungszusammenhang verbunden sind.

Die Philosophiegeschiehte läßt diese ideellen Welten ineinander übergehen, indem sie mit dem Gedanken des Problemzusammenhanges an die so verschiedenartigen Objekte der Philosophie herantritt. Und dieser Gedanke des Problemzusammenhanges bringt Ordnung und Gliederung in die mannigfaltigen Systemwelten hinein. Auch das seheinbar Entgegengesetzte wird einander so sehr genähert, daß ein gemeinsamer Maßstab der Beurteilung möglich ist. Die problemgeschichtliche Fragestellung, wie sie in exakter Weise ron Wilhelm Windelband, dem Meister der Philosophiegesehichte, erhoben ist, läBt zwisehen den so außerordentlich verschieden gebildeten Systemen der Philosophen, zwisehen dem widerstreitenden und seheinbar einander vollkommen aussehlieBenden Sinn ihrer Werke eine hohe Gemeinsamkeit und einen logischen Zusammenhang hervortreten. Diese logische Notwendigkeit zwischen Problemen gibt der Geschichte der Philosophie ihren philosophisehen Charakter und macht sie selber zur Philosophie. Wollen wir aber diese Art der Philosophie systematiseh philosophiseh orientieren, so weist sie nach der Universalgesehiehte hin. Nur fehlt ihr hierzu die Idee eines Zieles, die Fortsehrittsidee und ein einheitlicher Wertmesser der Beurteilung. Auch die Ideengeschichte der kimst leitet naeh der Universalgesehiehte hin, sofern in der Fortführung und Weiterbildung der künstlerisehen Ideale ein allgemeiner Vernunftzusammenhang sich offenbart. Die historisehe Darstellung, die in dieser Form die Dinge zu denken und zu gestalten, ihre höchste Stufe erreicht, läßt bei ihrer Erfassung der historisehen Objekte eine höhere Notwendigleit iiberall hindurehscheinen.

So ergab sich also als Ausgangspunkt fiir dic politische Gesehichte die Weltage, die allgemeine Situation, für die Gesehichte der Literatur und Kunst das Erlebnis oder die Idee des kunstrerkes, für die Philosophiegsehiehte (ndlich das Problem. Die Notwendigkeit, so versehiedene Ausgangspunkte zol wählen, wie es sich aus den ('harakter der historischen Objekte ergibt,

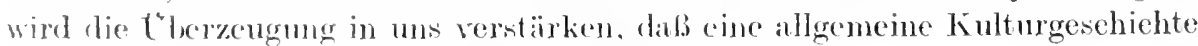
mit den grobisten Sehwierigkeiten zu kiimpfen hat.

Was damn endlich die Darstellung der Pexönlichleiten hetrifft, so wird dio Philosmphirgeschichte nur ein sehr allgemeines Bild des Denkers geben und nur dir groben und berlontsamen Züge hervortreten lassen. Die Individualitiat dos lenkers wirl in der Geschiehte dor Philosephie am abstraktesten 
und allgemeinsten gehalten werden. Nur dasjenige ist von Interesse, was ihn als Denker charakterisiert. Immer wird es sich um einen eigentimlichen Denkertypus handeln und um ein eigentümliches Denkerleben. Dagegen ist die Persönlichkeit für die politische Geschichte unentbehrlich, und gerade weil sie hier vor allem notwendig ist, empfängt sie in der Geschichte des politivchen Lebens die reichsten und simnlich anschaulichsten Züge. Wir können uns eine Darstellung der Geschichte der Literat ur ohne Dichter und Kïnstler zum mindesten denken, eine Darstellung der Philosophiegeschichte ohme näheres Eingehen auf des Leben der Denker ist sehr wohl möglich. Aber die politinche Geschichte kann des Heldenlebens nicht entbehren, das in ihr seine breit ansgeführte Darstellung erhalten muß.

\section{$\S$ 5. Der fünfte Problemkreis. Das Problem der historischen Beurteilung.}

Das Problem der historischen Beurteilung ist vielleicht die wichtigste Frage der Geschichtslogik. Sie steht am Ende dieser Disziplin und weist bereit, auf den zweiten Teil der Geschichtsphilosophie hin, der ron den Prinzipien des historischen Geschehens oder auch ron den Werten des historischen Lebens, den Kulturwerten, handelt. Es handelt sich hier um eine vielfach umstrittene Frage; denn gerade die Logiker. denen wir die größte Einsicht auf dem Gebiete der philosophischen Erkenntnis der Geschichte zu verdanken haben, gelangten zu dem Resultat, daß es eine historische Beurteilung überhaupt nicht gibt, d. h. daß der Historiker nicht berechtigt ist, die historischen Fakten als solche einer wertenden Beurteilung zu unterziehen, sondern daß er sie nur zu den leitenden Kulturwerten in Beziehung zu setzen habe, die das Prinzip der Auswahl für seine Darstellung hergeben, und mit deren Hilfe er das Wesentliche des historischen Werdens zu erfassen und zu durchdringen rermag. Wenn der Historiker democh irgendwelche Beurteilungen vollzieht, so überschreitet er seine Kompetenz und fängt an, Philosoph zu werden, denn die Beurteilungen als die verschiedenen Stellungnahmen zu Werten sind recht eigentlich das Gebiet der Philosophie. Nur in philosophiseher Hinsicht läßt sich die Geschichte beurteilen, und das Prinzip, das diese Beurteilung leitet, ist der geschichtsphilosophische Begriff des Fortschritts.

\section{a) Es gibt eine historische Beurteilung.}

Wir kömnen uns mit dieser Auffassung nicht einverstanden erklären und vertreten die Ansicht, daß es eine eigentümliche historische Beurteilung gibt. Unter Beurteilung aber verstehen wir die Wert bestimmung cines Objektes. Es handelt sich um die Würde. die wir dem Objekt zusprechen, um die Rangstellung, die wir ihm anweisen. Jede Beurteilung erfordert ein Objekt, das eingeschätzt und gewertet wird. jede Beurteilnng erfordert aber auch einen Wert. auf Grund dessen die Beurteilung erfolgt. der den Gesichtspunkt und den Zweek der Beurteilung sowie das Maß des Wertes oder Cnwertes hergibt.

Sofern nun die Philosophie, wie wir sie verstehen, Kulturphilosophie oder Wertwissenschaft ist, sind die Beurteilungen rol'zugsweise der Gegenstanr 
der Philowphic. Es gibt aber anch relatire Beurteilungen. die für kein Kulturgebiet werentlich sind. anf denen sich keine besondere Sphäre, kein besonderes Reich des geistigen Lebens aufbaut. Dahin gehört etwa die hedonische Bemrteihmg. das Trerten nach Lust mod Lnlust. und es gibt auf der anderen site Bensteilungen. die absolut gelten, mit denen as die Philosophie zu tun hat. folehe Benrteilungen sind aber rorzugsweise diejenigen, welche durch die Begriff-parare wahr und falsch. gut und böse. schön und häßlich konstituiert werden. Ein und dasselbe Objekt, ein und derselbe Vorgang kamn den verschiedensten Beurteilungen unterliegen. Wir sind etwa Zenge einer leidenschaftlichen Tat, und ron vier verschiedenen Zuschanem werden ebensoviel repshiedene Beurteilungen ausgesprochen. Dic erste lautet: diese Tat war imposant, die zweite: sie war sündhaft, die dritte: sie war gemein und niedrig, die vierte: diese Tat war ein Tahnsinn und Cnsinn. In der ersten Beurteilung kiundigt sich das ästhetische Verhalten zu den Dingen und Geshehnissen. in der zweiten das religiöse Verhalten. in der dritten das moralisehe Bewnbtsin und in der vierten das logische Bewubtsein an. Dasselbe Objekt kann rerschiedenen Benteilungen unterliegen. Inmer aber handelt es sich um die stellungnahme zu einem bostimmten Wert, mag dieser Wert nun der asthetische oder der religiöse, der moralische oder der logische sein.

Van kann nun behaupten, dab in den erwähnten vier Benteilungsweisen, ron denen dic religiöse wioder noch eine besmdere Ausnahmestellung eimnimmt, dor Kreis der letzten und absoluten Beurteilungen beschlossen ist. Es gibt jal gewiß noch andere Benteilungen, die für dic Kultur ron größter Bedentung -ind, nämlich diejenigen. die wir in der sphär der Rechtsphilosophie und Geschichtsphilosophie vollziehen, inden wir et was a ls rechtsgiltig oder als bedentsam im historischen Simne bezeichnen. Aber man könnte behaupten, dab die legale Benrteilung in letzter lustanz dureh jene vorhergenannten Wertungen begriundet ist. Nan könnte moinen. dab die Entschejdung über' Recht mod Unrecht in letzter lustanz dem sittlichen Bewubtscin zufällt. dab das Recht gleichsam nur der "xoterische Auslluck des sittlichen BewuBtseins soi, daß das Recht sbewnBtsein

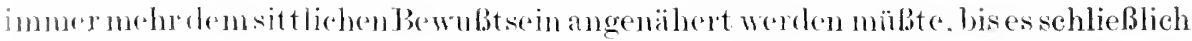
mit ihm zusammenfält, dal.s somit die Rechtsnom keinen spezifischen Wert, -omdern 13 e cinen Annäherungswert auf dem Wege zum Sittlichen dastellt. Cond (r)enso könnte man meinen, dab die Beurteilungen, die uns im historisehen laben entgegentreten. dab sie in letzter Hinsicht wom whisehen Werten ab-

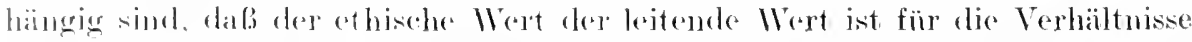

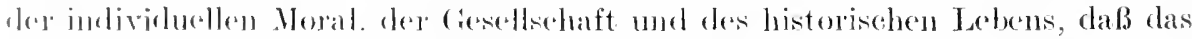

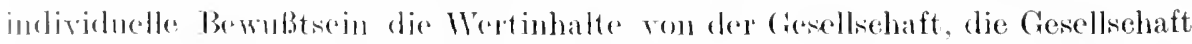

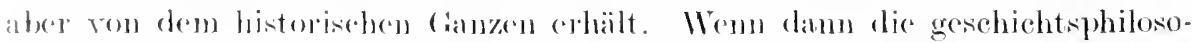

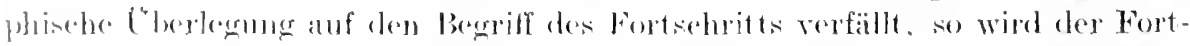

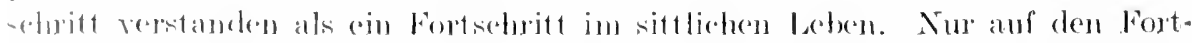

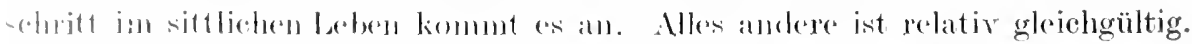

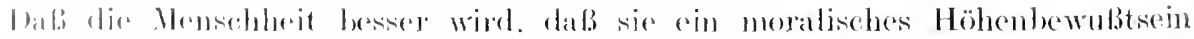

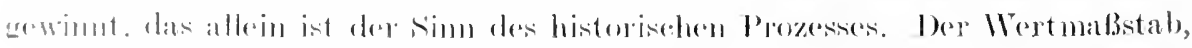

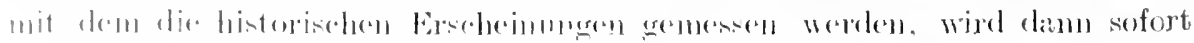

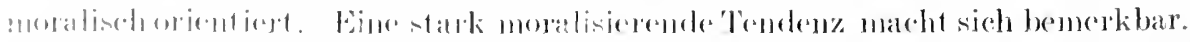

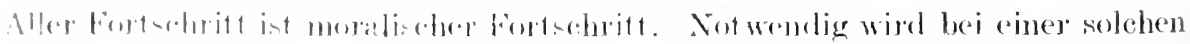


Orientierung auch der ethische Begriff der Aufgabe stark betont. Auf die sittliche Arbeitsleistung kommt es an, a uf die Pflichten. die erfüllt a uf die Leistungen. die rollzogen sind. Wie der einzelne, so hat auch das Volk Aufgaben zu erfüllen. Ind worin kömnte die sittliche Aufgabe eines Tolkes anders bestehen als in der Entfaltung aller semer Kräfte und Anlagen zu einem wahrhaft großen und wertrollen Kulturleben?

Aber bereits hier haben wir einen Ansatzpunkt, die Orientierung des historischen Bewußtseins am moralischen Bewußtsein in unbedingtem sinne zu rerwerfen. Diese Orientierung mag wichtig sein, aber sie ist nicht entscheidend. Es ist ein Irrtum, anzunehmen, daß das sittliche Bewußtsein und das System der moralischen Werte auf eine unbedingte Bejahung der Kultur hinausläuft. Gewisse Tendenzen des sittlichen Bewubtseins führen augenscheinlich aus der Sphäre eines reichen und mächtigen Kulturlebens hinaus und dulden nicht seine volle Entfaltung. So kömen wir in großen ethischen Naturen wie Rousseau und Tolstoi ein starkes Moment der Kulturverneinung erblicken, zum mindesten ein Bestreben, dem vollen Ausreifen der Kultur gewisse Grenzen zu setzen. Der einseitig betonte ethische Wert kam also sehr wohl in einen gewissen Gegensatz treten zu der Bejahung des Kulturganzen.

\section{b) Historische Beurteihung und gesehichtsphilosophische Beurteilung.}

Wemn wir aber von der Beurteilung sprechen, die uns in der sphäre des Historischen entgegentritt und deren Untersuchung in die Geschichtslogik fällt, so müssen wir hier unterscheiden zwischen der Beurteilung. die der Historiker vollzieht, und der im engeren Simne geschichtsphilosophischen Beurteilung. deren Toraussetzung der geschichtsphilosophische Begriff des Fortschritts ist. in dem sich die historische Beurteilung rollendet, mit dem aber der Historiker als solcher nichts zu tun hat. Was der Begriff des Fortschritts leistet und zu leisten rorgibt, der uns in jeder geschichtsphilosophischen Nonstruktion entgegentritt. clas werden wir erst später zu untersuchen haben. Augenscheinlich ist die Unirersalgeschichte als philosophische Disziplin cine systematische Wissenschaft. dem jede Form der Philosophie drängt zum Srstem. Das Eigentümliche und Paradoxe dieser Disziplin liegt aber darin, daB sie es mit dem Unsystematischen, mit der Geschichte zu tum hat. Es handelt sich also um eine systematische Wissenschaft rom Cusystematischen. Auf jeden Fall läuft die Tendenz der philosophischen Geschichte auf cine gewisse Systematisierung und Heraushebung des Tertrollen aus dem ganzen historischen Beurteilungszusammenhang hinaus, und der Begriff des Fortschritts ist für diese Systematisierung entscheidend. Aber wir haben es mit der Frage einer historischen Beurteilung zu tun, die der Historiker selber vollzieht. Wertet der Historiker die Objekte der historischen Wirklichkeit, und gibt es ein Prinzip, der allgemeinen Anerkemung für seine Beurteilung?

Die Ablehnung einer solchen historischen Beurteilung ergibt sich, wie es scheint, aus der Ủberlegung. daß die Geschichte das Recht jeder historischen Wirklichkeit rertritt. Gewiß gibt es Torgänge, die keine historische Bedeutung besitzen. Wemn aber eimmal auf Grund der historischen Ausleseprinzipicu die historische Wirklichkeit geformt ist, dam soll, so pflegt man zu behaupten 
der Historiker das eine historische Gebilde ebenso anerkemnen wie das andere. In das historisch Bedeutsame soll er selber nicht ausdrïcklich Wertunterschiede setzen. Er soll dem historisch Gewordenen, so sagt man, gleiche Liebe und gleiches Interesse entgegenbringen. Indem er der gestaltenreichen Fülle des historischen Lebens allüberall das gleiche Mitgefühl entgegenbringt, hat er cinfach festzustellen, wie alles so geworden ist.

Was num die Art dieser historischen Beurteilung angeht, so darf sie nicht ron außen an die Geschichte herangetragen sein, um sie zum Material für fremde Zwecke herabzusetzen, wie es etwa geschieht, wemn die Geschichte als Medium der Unterhaltung, Erbaumng, der Zukunftsberechnung und des ästhetischen Genießens gilt. Unter diesem Gesichtspunkt wird die Geschichte dem Historiker zur Anekdotensammlung, zum Erbaumgsbuch, zum statistischen Material, zum Kunstwerk.

\section{c) Ablehnung eines einseitigen Kulturmabstabes.}

Ebenso mïssen wir es ablehnen, dab der Historiker in seiner Beurteilung des historischen Lebens sich von dex Meinung leiten läßt, daß nur ein bestimmter Kulturwert für die Geschichte maßgebend sei, mag nun der religiöse oder der wirtschaftlliche Wert als der leitende Wert betrachtet werden und dementsprechend eine religiöse oder eine materialistische Geschichtsauffassung sich ergeben. In allen diesen Fällen ist bereits eine Wertordnung vollzogen, die unbedingt der philosophischen Begründung bedarf. Ich setze dam etwa schon voraus, daß das moralische Leben in seiner Bedentung alles andere iiberragt. Der Historiker hat die Gleichberechtigung der verschiedenen Kultursuiter anzuerkemnen. Er kann nicht darüber entscheiden, ob die Wissenschaft kulturbedeutsamer ist oder etwa die Kunst. Alle historisehe Beurteilung die ein vorgefalites System voraussetzt, muls als mustorisch verworfen werden.

Die historische Beurteihmg hat somit folgenden Anforderungen zu genügen.

I. Fis soll cinc Beurteilung sein, die ron der Voraussetzung frei ist, daf aine lostimnte Wertordnung besteht, dal. etwa der ethische Wert für die Geschichte den leitenden Wertmalsistab hergibt; dem eine solche Betrachtungsweise ist bereits philosophiseh.

2. Sie mulo einen Mabstab anfweisen, der in dem llesen der historischen Wissenschaft fregrindet liegt.

3. Dieser Malsutab hat mit Fortichute im Sime rom liertsteigerung und Wextreminderung nichti zu tun.

\section{d) In riterien der historisehen Benrtailung.}

Fiir dic historische Brurteilung sind alle Kulturwerte gleich bedeutsam, und innerhall, ciner botinmten Entwieklungreihe, et wa der literarischen,

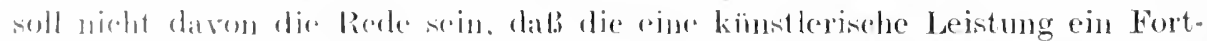

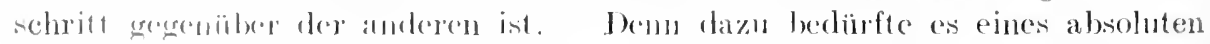

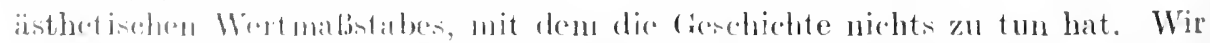

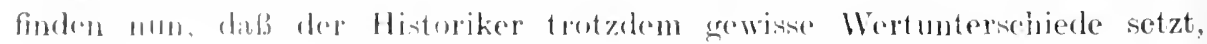


daß er seine Anerkemmung verschieden verteilt, einiges herrorhebt, anderes mehr zurücktreten läßt, daß er wejt daron entfernt ist, alle Erscheinungen als gleichwertig zu setzen. So spricht der Historiker etwa von der Jugend und dem Alter eines Tolkes, von der Zeit seiner Blüte. von der Zeit seines Verfalls, von seimem Wachstum. von der Fruchtbarkeit gewisser Ideen und Einrichtungen, ron ihren Abzweigungen und Auswïchsen usw. Kurz. er orientiert die Geschichte mit Vorliebe an dem organischen Begriff der Entwicklung. Augenscheinlich handelt es sich hier nur um eine lose Analogie, wenn an die bloß äußerliche Entfaltung des organischen Lebens, an Gesundheit und Kraft, Verfall der Kräfte und Lntergang gedacht wird. Und doch hat man geglaubt, mit diesen Bestimmungen des organischen Lebens für eine Geschichtsphilosophie auszukommen. Es schien mgehener plansibel, tiefsimnig und einlenchtend zu sein, daß die Völker wachsen und rergehen, wie das organische Leben vergeht, und man spürte mit besonderem Interesse den Kennzeichen des Verfalls nach. Mangel an Zeugungskraft und überflüssiger Luxus, Ausschweifungen aller Art mochten damn als Zeichen des Cntergangs betrachtet werden. Immerhin dürfen wir nicht rergessen, daß es sich hier doch um eine lose Analogie handelt. Dem Einzelorganismus als solchem ist eine bestimmte Grenze gesetzt. Hier kam man daron sprechen, daß nummehr der Höhepnnkt, das Ziel der Entwickhng überschritten ist. Aber dem Leben eines Volkes, das sich der Möglichkeit nach immer neu entfalten kamn, ist auch ihm eine bestimmte Grenze gesetzt, und woher wissen wir ron einer solchen? Ind das geistige Leben überhaupt, hat es nicht als solches die Möglichkeit immer neuer Gestaltung? Kann ich nicht der Höglichkeit nach immer nene Kenntnisse er. werben? Kann mein Wollen und meine Sehnsucht jemals an einem absoluten Ziele sein? Bedentsam ist die Analogie mit dem organischen Leben erst dann, wenn nicht die organische Entwicklungsstufe als solche, sondem die eigentümlichen Ideale der rerschiedenen Entwicklungsstufen. das Ideal des Kindes, des Jünglings und Mannes, zum Vergleich mit dem Völkerleben gesetzt werden, wie das etwa Hegel getan hat ${ }^{1}$ ).

Sehen wir zu, was wohl hinter der Bildsprache steckt, die in immer neuen Wendungen Völkersprache und organisches Leben vergleicht, so ist es wohl ror allem die Bewertung des Reichtums und der Intensität der Kulturleistung. Das ist mir mieder besonders deutlich geworden, als ich in dem Buche eines Historikers die bezeichnenden Worte las: , Wichtig ist die Erfor:chung der Wahrheit, wichtiger, die Geschichte mit lebendigen Gestalten bevölkern". Ja, das ist seine Liebe und seine Sehnsncht, diese weite Welt der Geschichte mit ihrem starken und mächtigen Leben uns wieder schanen zu lassen in rollendeter Gestalt! Diese Gestalten aber sind nicht Gebilde der Phantasie, sondern bedeutende Alenschen, die gelebt und an der menschlichen Entwicklung gearbeitet haben. Sie in dem Reichtum ihres Lebens zu fassen und zu formen, ihrer Leistung für menschliche Kultur nachzugehen, sie ron dem Schlummer der Vergangenheit zu befreien und so den ganzen Reichtum des Kulturlebens deutlich zu machen, das muß gewiß als eine der wichtigsten Aufgaben des Historikers betrachtet werden.

$\left.{ }^{1}\right)$ Hegel: Philosophie der Geschichte. 
Wollen wir nummehr die Natur der historischen Benrteilung fixieren, so orientieren wir uns am besten an einem großen metaphysischen System, in dem die eigentümliche Beurteilungsweise des Historikers eine geradezu rorbildliche Ausgestaltung erfahren hat. ich meine das System Fichtes. Wir sehen in diesem Sxstem die historisehe Beurteilung in monmmentaler Form heransgearbeitet und groß und ruhig hingestellt als das Gesetz der Welt. Die Metaphysik Fichtes verkündet, daß aller Sinn des Lebens und der Welt im Tun beschlossen sei. Der tätige Mensch ist der wertvolle und sittliche Mensch, der untätige Mensch wertlos und unsittlich. Je höher unsere Aktivität, je stärker mser Widerstand gegenüber dem Leben. Je mächtiger der Einflu, den wir verbreiten, um so höher ist unser Wert. Denn je stärker wir das Moment der Aktivität in uns betonen, um so mehr entziehen wir uns der Sphäre des Gleichgïltigen und Indifferenten, dem Znstand des Toten, der bloßen Materie, die den Nullpunkt der Aktivität bedentet. Jedes Handeln hat seine sittliche Bedeutung, jede Bewegung hat teil an der sittlichen Welt. Nur das Handiungslose und Bewegungslose ist das Bedentungslose.. Aktivität und Wert fällt also bei Fichte im wesentliehen zusammen. Denn alles Tun ist ein Dokument göttlicher Freiheit. Es leuchtet ein. wie sehr diese große Alstivitätsphilosophie den Problemen der Gesehichte gerecht werden komte, wie sehr sie ron dem Begriff des Tuns her in ihr Verständins eindrang. Dem die Geschichte ist ja der Schauplatz der großen Handlungen. Nur verband Fichte wohl etwas zn eng den Begriff des Tuns mit dem Begriff des Wertes. Als ob etwas schon als ein Getanes sittlich relevant sein könnte. Er führte die Kantische Gesimmungsethik anf die Wahlstatt des Handehs. Und wenn Kant immer wieder betont hatte, daß dor pflichttrene reine Wille, daß die Gesimmung entseheidend sei, so betonte er die Offenbarung dieses reinen Willens in der Umformung und Umbildung der Wirklichkeit.

Wir müssen ctwas sehärfer betonen, daß es nicht das Handeln überhaupt, sondern die Leistung für eigentiumliche Kultur ist, mit der wir das Wertmoment verbinden. Die Kulturberleutung tritt uns aber nirgends so unmittelbar ('ntgegen wie als Objekt der Geschichte. Die Kulturleistmug ist es augenseheinlich auch. von der das Soin oder Nichtscin der Geschichte abhängt. Daß Güter geschaffen orler momgebildet werden. darauf kommt es in der Geschichte ganz allein an. Zaiten, in denen keine Kulturbetätigung stattfindet, sind mhistorisehe lecere \%ojten. Dabei ist nun ganz angenseheinlich die Fülle der lasistung ein gewisses Aquivalent für die Grobe der Leistung. Die ans-

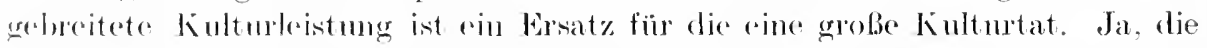
vereinzelte grobe Kulturleistumer vermag noch nicht den Gedanken der großen \%oil zu crwecken. Dir aine grobe Kulturleistung remug noch keine Epoche :11:\%)

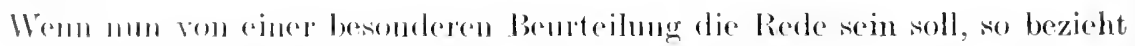

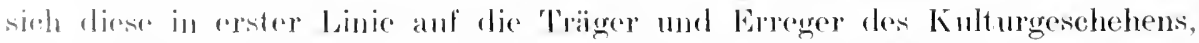

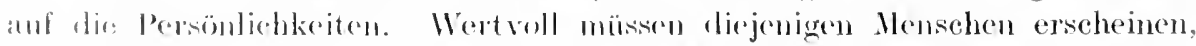

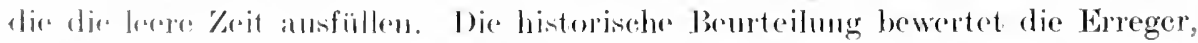

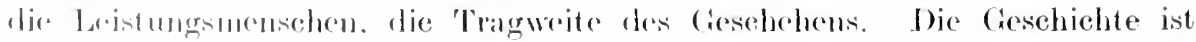

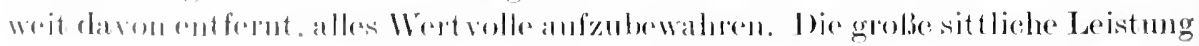

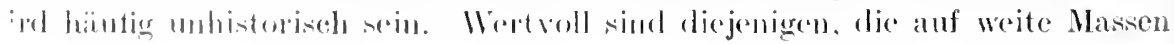


wirken, die ihre Kreise weiter md weiter ziehen, Nahes und Fernes verbinden. Je mehr Kulturgeschehen eine Persönlichkeit aus!öst. 1 m so wertroler scheint sie zu sein.

\section{f) Gegensatz der historischen und geschichtsphilosophischen Benrteilung.}

Úberlegen wir, wodurch sich diese Art der Beurteilung ron der philosophischen unterscheidet. Für die historisehe Beurteihng kommt es auf dis Maß des Kulturgeschehens an. das eine Persönlichkeit anslöst, nicht etwa auf ihren sittlichen Wert. In der philosophischen Betrachtung sind wir geneigt, den Wert eines Menschen vor allem am ethischen Werte zu messen. Für die historische Beurteilung ist der sittliche Wert niemals anssehlaggebend. Die historische Persönlichkeit soll sich so verhalten, dalis sie Kulturgesehehen auslösen kann. Deswegen muß der historisehe Mensch der historischen Beurteilung wissen, was an der Zeit ist, was es in them großen Reiche der Kultur Wichtiges für ihn zu tum gibt. Das Streben nach dem Enerreichbaren können wir wohl ethisch qualifizieren, aber nicht historisch. Die historische Beurteilung liegt jenseits ron gut und böse oder vielleicht richtiger diesseits ron jenen Wertbegriffen. Sie ragt noch nicht in ihre Sphäre himein. Dieser hist orischen Moral, wenn wir so sagen dïrfen, kommt es in erster Linie daranf an, daßs Kulturleistungen ausgeführt werlen. Deswegen ist es ziemlich gleich, in den Dienst welches Wertes sich das Individum stellt, wemn es sich überhaupt nur die Verwirklichung eines Wertes angelegen sein läBt. Die Leistung für den ethischen Wert wird in ihr nicht höher gestellt als die Leistung für den logischen oder ästhetischen. Der Mangel an religiösem Gefühl und ethischem Wollen kann im Sinne der historischen Beurteihng ausgeglichen werden durch künst. lerische Genialität oder durch intellektuelle Größe.

Damit hängt es zusammen, daß für die historische Beurteilung auch das Motiv oder, wie wir vielleicht besser sagen, die Triebfeder des Handelns nieht von entscheidender Bedeutung simr. Ob der Künstler sein Werk geschrieben hat, um Geld zu verdienen, um die Mensehen in ihrer künstlerisehen Anschaumg zu heben, oder ob die reine Liebe zum Schönen in ihm wirksam war, kann seinen Wert im Geiste der historischen Beurteilung mur uncrheblich veränclern. Hat doch Hegel mit Recht darauf hingewiesen, daß die Leidenschaften eine unentbehrliche Triebfeder des historischen Geschehens sind. Jene Leidenschaften. welche die ethische Selbstbesimmung rerurteilt. gerarle sie sind ein historisch Wertvolles $\left.{ }^{1}\right)$.

Gewiß nicht als Selbstzweek. aber als Mittel der Wertverwirklichung. Das historisch Bedeutsame liegt aber nicht in der metaphysisehen Vorstellung. daß die Leidenschaften das Individumm zum Werkzeng einer höheren Macht erheben, sondern darin, daß die Glut und Energie der Leirlensehaften den Reichtum des $K_{u} u$ turgeschehens vermehrt. Alle Passivität und Indolenz, welche nicht die Kraft besitzt, die sprörle Materio zu gestalten. aber auch alle Tätigkeiten der Individuen. die lediglich auf Selbstrerinnerlichmu und Selbstgestaltung abzielen, sie sind ohne eigentliehe historisehe Bedeutung

1) Hegel: Philosophie der Geschichte. 
und höchstens in sekmndärer Weise historiseh wicht'g. Die Betomung des Quietismus führt ja ganz augenscheinlich zur Geschichtslosigkeit. Die historische Beurteilung aber muß sieh mit dem verbinden, was dem historischen Leben Bestand und Dauer sichert. De:wegen ist der indische BüBer gewissermaßen eine geschiehtsfeindliehe Er:cheinung. Für die historische Beurteilung gilt es ganz gewiß, daß die größte siinde der Mangel an Aktivität ist.

Ja, wir können noch weiter geheu. Wem es für die historische Beurteilung lediglich auf die Leistung, auf das Werk, nicht aber auf das Motiv ankommt, und wir möehten glauben, daß eine solehe Anffassung ihrem eigentümlichen Charakter entsprieht, wenn die Tat des rïcksichtslosen Egoismus das Werk einer historisch wichtigen Persönlichkeit sein kann, so kann selbst das Gewebe von Lüge und Illusion. das ganze Völker und Epochen mit kluger und kühler İberlegung ron der Wahrheit abschließt, die Tat historischer Größe sein. Wäre etwa die Religion samt allen Bildnngen kirehlicher Gemeinschaft ein Werk selhstsüichtiger Täuschung, ansgedacht und ausgeklügelt, die unmündige Menschheit zu leiten und zu gängehn, wie es die griechische Aufklärung und später die Anfklärmug des 18. Jahrhunderts in ihrer rationalistischen Einseitiglieit und ihrem Mangel an historisehem Simn behauptet haben, oder wäre sje etwa ein Werk frommen Betrugs, heransgewachsen aus dem Geist des Mitlejds mit den Schwachen und Elenden, die des Gehorsams und der Vergebung bedürfen und mit der Freiheit nichts anzufangen wissen, so würde doch ein solches Gewordensein der Institution der Kirche ihre historische Bedeutung nieht nehmen. Sie würde auch dann nicht aufhören eine große Kulturmacht zu bedenten, da sie durch ihre meisterhafte Organisation Großes sesehaffen. Wir diuffen uns in rein wissensehaftlieher Betrachtung der Geschichte nicht dem Dogma hingeben, daß Wertrolles nur ans reiner Quelle stammt. Allerdings werden wir in der historischen Beurteilung zwischen Werk und Sichöpfer schwerlieh in dem Sinne unterscheiden, daß wir, wemn eine große Kulturtat vollbracht ist, ängstlich nachspüren, ob die Motive auch rein und lauter waren. Ist die Jeistung kulturell bedeutsam, so war es auch ihr Schöpfer. Erst die philosophische Besinnung kann darüber Rechenschaft gethen, dab Wichtigres und Wertrolles auch ron einem an sich wertlosen Indivichum ausgeführt sein kann.

Damit hängt es zusammen, dab der Begriff der Freiheit kein historiseher Bewriff, somelern vichehr ein goschichtsphilosophisehes Problem ist. Nicht in der historischen, sondern in der geschiohtsphilosophisehen Betrachtung grwinnt der Bogriff dor Freiheit Berlentung. Die Freiheit ruht, wie wir vielloicht sagen këmnen, in der Unmittelbarkeit des Lebens und in der gesehiehtsthilosophisehen Jelee. aber in Rejehe der wissensehaftlichen Begriffe hat sie keine Stelle. Man könnte daranf erwictern, dab der Historiker die Menschen $\therefore$ luctrachtet, als ab sige frei wären. Das mag er tun, weil diese Auffassung

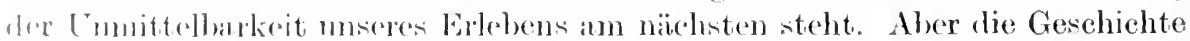
ist. fül don Historiker nicht das Reich der Wreihejt und auch nieht das Rejeh

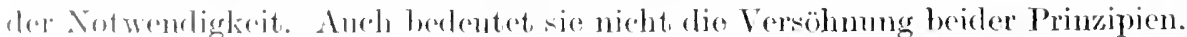

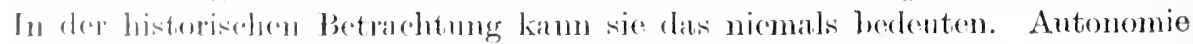

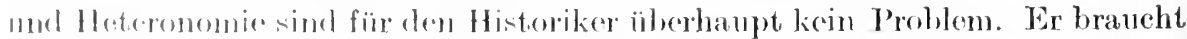

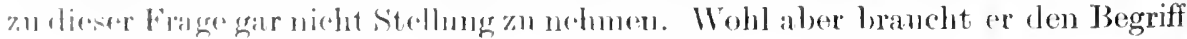


der Kulturleistung. Ohne den Begriff eines simnvollen Ge-chehens wäre die Geschichte sinnlos und überflüssig. Er braucht den Begriff der Wertbestimmtheit. Aber den Historiker braucht nur das , daß" des wertvollen Geschehens zu interessieren. Ihm kann es gleichgïltig sein, welchen Beitrag das Individuum dazu leistet, ob es nur Werkzeng ist im Sinne der Hegelschen Geschichtsphilosophie oder mehr als Werkzeug. Historisch bedeut sam ist das Individuum, das Wertvolles rollbringt, mit dem Eigenwert des Persönlichen hat die Geschichte nichts zu schaffen. Nur durch ihre Leistung dokumentiert sich die Persönlichkeit. Historische Schuld ist nur die Indifferenz oder die sinnlose Zerstörung geschaffener Güter. So ist die historische Moral deutlich geschieden ron dem phmpen Histo. rismus der in doppelter Form aufzutreten pflegt, nämlich einmal in der allgemeinen Anerkennung des Geschehenen und des Faktums ïberhaupt und anderseits in der Bewertung des bloßen Erfolges. Suchen wir uns den ersten Standpunkt deutlich zu machen. Dieser verzichtet im Grunde genommen auf jede Wertunterscheidung; weil etwas da ist, weil etwas geschehen ist, muß es auch respektiert und anerkannt werden. Das bloße Dasein ist gleichbedeutend mit Wert. vollsein. Alles Wirkliche ist wertvoll. Diese Bejahung des Daseienden schlechthin darf nicht verwechselt werden mit Hegels Lehre, daß alles Wirkliche vernünftig ist; denn was Hegel Wirklichkeit nennt, das ist schon nicht mehr das bloße simnliche Dasein, sondern die wahrhafte Wirklichkeit des geistigen Lebens. Jener bloßen Anerkennung des Daseienden verwandt ist die Anerkennung des Erfolges. Etwas soll wertroll sein, weil es sich durchgesetzt hat. Wir huldigen der Nacht, dem Stärkeren in der Geschichte. Nach diesem Standpunkt hat das historische Geschehen mit Recht und Sittlichkeit überhaupt nichts zu tun. Hätte die Macht der Perser das kleine Griechenland überwunden und seine aufblühende große Kultur zertreten, so müßten wir von diesen Standpunkt aus dem Siege des orientalischen Despotismus über das Volk der Freiheit und Schönheit huldigen. Und Beifall jauchzen mülsten wir dem Römertum, weil es die blühende Kultur Siziliens zertreten hat. Der Erfolg ist allemal die Sanktion des Geschehenen. So der Historismus. Wir aber meinen, daß nur dasjenige Geschehen wertroll ist und Anerkennung verlient, das die Kultur rermehrt und bereichert. Deswegen bejaht das historische Bewußtsein noch nicht ein System ron Kulturwerten wie das philosophische, aber es bejaht den Begriff der Kultur, die Idee eines Kulturganzen oder einer Kultureinheit. Deswegen eilt seine Betrachtung in lieberoller Weise immer dorthin, wo iiberall in der Welt im Sinne der Kultur gewirkt und gearbeitet wird. Denn es weiß, daß ein Reich der Kultur werden soll, und daß die Sitze der Unkultur verschwinden müssen. Deswegen ist es mit ganzer Seele immer dabei, wo immer ein schöner Sieg der Bildung und Gesittung errungen wird. Nicht WertsteigeIrung und -verminderung sind Prinzipien der historischen Beurteilung, sondern IKulturvermehrung und Kulturbereicherung. Nur sie treffen den Nerv des historischen Lebens, denn der Untergang der Kultur ist gleich. lbedeutend mit dem Ende der Geschichte.

Hier haben wir nun folgenden Einwänden zu begegnen: schwankt nicht die historische Beurteilung zwischen dem Historismus, der bloßen Erfolgsbeurteilung und der philosophischen Beurteilung, die am Begriff des Fortschritts orientiert ist? Denn: 
1. anch die sinnlose Tat der Zerstörung kann ein nenes, wertrolles Gerchehen einleiten. Die Zesstörung und Vemichtung des Kulturlebens kann Anlaß zu neuer Kunlurherrlichkeit sein. Nenes Leben kann aus den Ruinen tmporblühen. Der Enderfolg ist ja niemals zu übersehen. Wie kamn ich irgendeinen Effekt des Kulturlebens negieren? Muß ich nicht immer erst warten, zu welehem Ziele er endgïltig hintreibt? Ist es vielleicht deswegen gut, alles Geschehen und allen Effekt stillschweigend gutzuheißen. in der Erwartung, daß alles Gexchehen zu einem erwünschten Ziele führt? Diese Art, die Dinge anzusehen. kömnte damn einen gewissen Quietismus heraufbeschwören, sie könnte dahin leiten, daß wir mit ruherollem Sinn all dem mannigfaltigen Geschehen zusehanen und ms den Dingen hingeben mit der sicheren Gewißheit, daß alles, was hier im Kampfe des Lebens und der Welt getan und gewirkt wird. gut sei und wohlgetan.

Tnd 2. Ist nicht Kulturvermehrung gleich Fortschritt? Wird nicht in der historisehen Beurteilung der historisehe Fortsehrittsgedanke gedacht?

Die erste Auffassung kann wohl nur derjenige vertreten, der die alte metaphysische Anschanung besitzt, dab die Geschichte sich die Aufgabe stelle, die Wirklichkeit abzubilken, und daßalleZusammenhänge der Wirkliehkeit historisch seien ofler doch historisch sein könnten. Nur eine solche Anffassung des Geschehens, die keine Wertgewichtspunkte, keine Prinzipien der Auswahl kennt. kamm den erwähnten Torwurf erheben. Diese Abbildtheorie will alles Ceschehen, anch das leere und bedentungslose, reproduzieren. Und indem sie eine zerstörte Kultur durch Stufen der Indifferenz hindurch leitet, kommt sie schließlieh aus der Hand des Kansalprinzips zu der Einsicht, daß der Erwïrser der Kultur auch zugleich ihr Erwecker sej. Für eine einsichtsvolle Geschichtshetrachtung kam jedoch die simnlose Tat der Zerstörung als solche niemals ererehtertigt werlen. T)ie Taten der Vandalen in Rom, die Verwüstung der peruanischen Kultur, die Bluttaten des Dselhengis und Tim ur sind fïr allemal her Vermerteilnug der Geschichte überwiesen. Niemals wird die eine Geschichte die simnlose Zerstörmg der orientalisehen Kultur durch den kulturloxen 'T'im u rexhtfertigen. W'nn aus den Ruinen von Damaskus neue Kultur (rblïht, on wirl das Werturteil der Geschichte ïher den Mongolenhäuptling darburch nicht geäntert. Nieht er ist der Sichöpfer dieses Nenen. Die zum

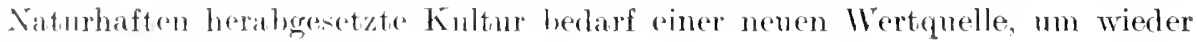
Kultur zur werklen.

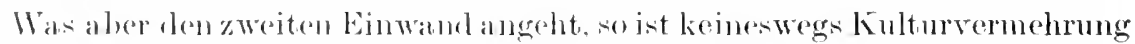
fleich Fortechritt. Zu dem begriff des lortsehritts achöt, wie Rickert klargentellt hat, ein für allemal das Moment der Wertsteigermeg und Wertver-

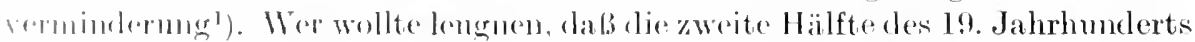

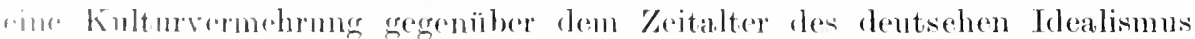

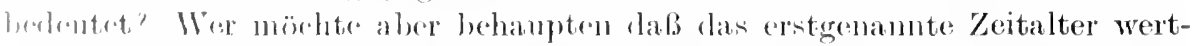

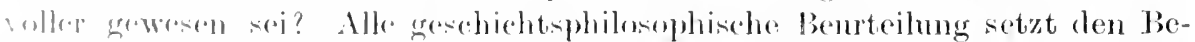

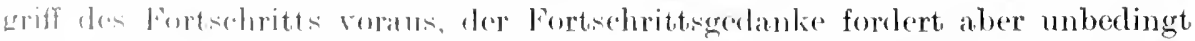

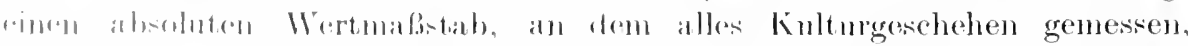

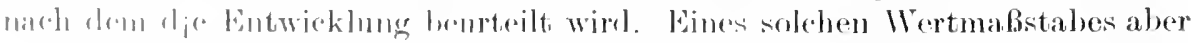

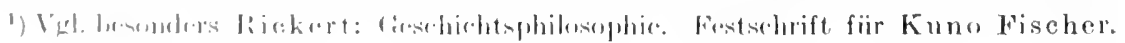

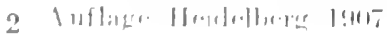


berlarf die Geschichte nicht. Ja. ein solcher Wertmaß-tab, der eine gewisse Srstematisierung und Reglementierung bedeutet, muß sogar dem historisch denkenden Mensehen widerstreben.

Und doch können wir nicht im geringsten daran zweifeln, daß dieser unendlichen Fülle historischer Erteile und den Wertungen, die sich mit diesen Urteilen verbinden. die Bejahung und Anerkennung einer Kultureinheit zugrunde liegt. Und das Charakteristische liegt darin. daß der Begriff der Kultureinheit, der für den Historiker als genamnter und gewollter Maßstab rorliegt. nicht aufgelöst und differenziert wird $z u$ einer Vielheit ron Werten, nicht systematisiert wird zu einem Wertzusammenhang. noch philosophisch gedentet wird als ein Reich absolnter Werte. Der Begriff der Kultur behält hier noch seine Unberührtheit und Naivität, er ist noch nicht problematisch geworden. Wenn wir nach dem Simn und nach den Formen der Kultur fragen, so rerlassen wir das Gebiet der historiseh-wissenschaftliehen Fragestellung. Wohl sind Wissensehaft, Kunst und Religion als Kulturgiiter rorausgesetzt, aber die historische Beurteilung bezieht sich nicht auf bestimmte Kulturwerte, sondern auf Kultur überhaupt. Wo überall eine Leistung vorliegt, wird sie ihre Anerkenmung nicht versagen. Keine bestimmten Werte sei es mun Religion oder Moral oder staatsmännische Kunst, sind für das Ganze der Geschichte in der historischen Beurteilung entscheidend und bestimmend. Der historischen Beurteilung kommt es auf die Leistung an, der Mangel an Leistung ist für sie nieht verwerflieh, aber gleiehgiltig. So öffnet sie bereitwillig ihre Ruhmeshallen dem großen Künstler, sollte er auch ein irreligiöser und moralisch indifferenter Mensch sein. Weun auch die künstlerische Leistung die eine große Einseitigkeit des Individum ist, 1 m ihretwillen wird ihm die Sünde des Terstoßes gegen die anderen vergeben. In der historischen Beurteilung sind alle Güter in gleicher Weise geweiht. Dabei kommt es der historisehen Beurteilung ganz in erster Linie auf die Leistung und nicht auf das Motir an. Es wäre unhistorisch. die Aufrichtigkeit eines Denkers zu bezweifeln. wemn die wertrolle Leistung nun einmal feststeht. Der Historiker konstruiert die Persönlichkeit nach der Leistung. der ethische Mensch ist geneigt, die Leistung nach der Persönlichkeit zu beurteilen, also den entgegengesetzten Weg zu gehen. Nachder h istorischen Mo ral kamn sieh die wertrolle Persönlichkeit oder das Kulturvolk etwas erlauben, was dem unkultivierten nicht zusteht. So erscheint die historische Beurteilung als eine ganz typische Art des Wertens. die sieh auf das engste mit dem Begriff der Kultur als Toraussetzung des historischen Lebens verbindet, aber mit dem Begriff des Fortschritts nichts zu tun hat.

Damit haben wir die Probleme der Geschichtslogik aufgerollt. Es sind in der Hamptsache diese fünf: das Problem des Zieles, des Objektes, das Problem von Form und Inhalt. das Problem der Methode und das Problem der historischen Beurteilung. Diese aber bildet das wichtige Bindeglied zwisehen dem ersten und zweiten Teile der Geschichtsphilosophie. Unterhistorisch und rorwissenschaftich ist die individuelle Wertung, die ron dem persönlichen Standpunkt der Liebe und des Hasses oder ron dem allgemeinen, a ber doch nicht weniger einseitigen der politischen Partei oder der Konfession die Vorgänge der Geschichte wertet, die philosophische Einsicht 
erkennt, wie alles historische Gesehehen seinem letzten Sinne nach in Abhängigkeit gedacht werden muß ron einem Kultursystem. Sie erkennt, wio dieses Kultursytem in die historisehe Bewegung einsehneidet, zur Begründung ihres Bedentungsgehaltes, zur Auswahl des Wiehtigen, zur Erfassung des Wesentliehen führt. Die historische Beurteilung steht in der Mitte zwisehen beiden. Sie weiß niehts ron einem System der Kulturwerte, aber sie weiß den Begriff der Kultur als bedentungsverleihend für die Gesehiehte. Sie bildet den Ủbergang ron der historisehen Betraehtung zur philosophisehen. Sie ist die unentbehrliehe Funktion des ,,philosophisehen“" Historikers und des ,historisehen "Philosophen. So steht die historische Beurteilung ganz ähnlich zwischen Gesehiehtslogik und historiseher Wertlehre, wie diese ihrerseits zwischen Gesehiehtslogik und Universalgesehiehte. Inwiefern aber die Lehre von den historisehen Prinzipien diese Zwisehenstellung eimnimmt, das wird naeh der Anfweisung ihrer verschiedenartigen Probleme dentlich werden.

\section{Zweites Kapitel.}

\section{Probleme der historischen Wertlehre.}

Hit der historischen Wertlehre oder, wie Riekert sie genannt hat, mit der Lehre ron den Prinzipien des historisehen Gesehehens ${ }^{1}$ ) betreten wir ein ganz neues Gebiet (ler Gesehiehtsphilosophie, das bisher nur wenig bearbeitet ist. E. galt bisher überhaupt nur erst eimmal ganz allgemein festzustellen und zu begründen, daß die Geschiehte zwar Wissensehaft, aber keine Naturwissenwissenschaft sei, und daß die Historie ein Allgemeines kennt, das seiner ganzen Sitruktur naeh dem Allgemeinen der Naturwissensehaft dnrehaus entgegengesctzt ist. Dieses Allgemeine der Gesehiehte hat man als Wert, als Norn, als Kulturwert, als Typus bezeichnet. Von denjenigen Philosophen, welehe die historische Begriffshildung in so glüeklicher Weise der naturwissensehaftlichen entgegengesetzt haben, ist ein Teil der Ansieht, daß in den methodologisehen Formen, auf die wir in den Problemen der Geschiehtslogik knr\% hingewieson, dis eigentlieh logische Formung der Gesehichte vollendet sei, laß wir also zur Klarstellung der individualisierenden historisehen Methode nicht übor die methorlologischen Begriffe hinauszugehen bramehen. Dagegen hat man mit leeht den Einwand erhoben, daß der Begriff einer individualisirenelen Wethode ak solcher noch vollkommen unzureichend ist, um die listorische Begriffshildung in ihrer Eigenart dentlich zu maehen; denn es ist ja angenschemlich, dab anch die Naturwistensehaft das individualisierende Verfahren kennt - donken wir mur an dio Entwieklungsgeschiehte der Erde, der P’lanzon und 'Tiere. Aneh hier ist das Ziel der Darstellung die Erfassung the imfividuellen, oinmaligen Gesehehens. Was num den historischen Entwicklungsverlanf zu rinem eigentümliehen macht, das ist, wie Rickert gezeigt

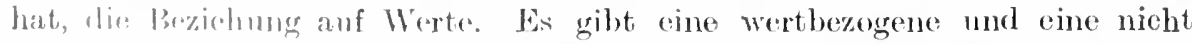

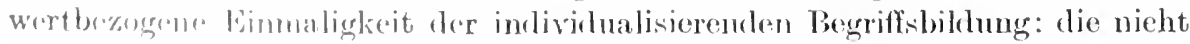

1) Vhl. Rickerts Freschichtsphitosuphie. Festschrift für Kuno Wischer. 
wertbezogene ist naturhaft, die wertbezogene ist wahrhaft historisch. In der geschichtlichenWelt können wir somit drei verschiedene Nomente der begrifflichen Formung unterscheiden, und zwar in folgender Weise: die erste Stufe derFormung war, wie wir gesehen haben, in der historischen Tatsache erreicht, die schon als Resultat eines Erkenntnisprozesses aufgefaßt werden muß. Die zweite Stufe der Formung ist erreicht, wenn die Tatsache in den historischen Zusammenhang eingeordnet und eingestellt ist, wenn ihr Werden, ihre Entwicklung, ihr Verhältnis zı den anderen Ereignissen und Geschehnissen, ihre Verursachung und die Wirkung, die sie ausgelöst hat, ein für allemal feststeht. Aber damit ist der Formungsprozeß noch nicht vollendet. Dazu ist es noch erforderlich, daß das historische Objekt in seinem sinnvollen Bedeuten bezogen wird auf einen Kulturwert, wie etwa die Idee des Staates oder der Wert der Religion. Die Bejahung und Anerkennung der Kulturwerte ist eine logische Voraussetzung aller Geschichtsschreibung. Ohne die Bejahung des religiösen Wertes verliert die Religionsgeschichte vollkommen ihren Sinn, oder sie tritt in eine andere Kultursphäre, etwa die theoretische, hinüber, indem die Geschichte der Religion aufgefaßt wird als die Geschichte unserer menschlichen Irrtümer und Leidenschaften ${ }^{\mathrm{I}}$ ). Was nun der Kulturwert im einzelnen leistet und bedeutet, wie seine logische Struktur beschaffen ist, davon wird später die Rede sein : hier stellen wir nur die Behauptung auf, daß ohne diese Beziehung die logische Formung der Geschichte nicht rollendet ist. Die Geschichte des Unbedeutenden ist eine Paradoxie. Es ist absolut sinnlos, rom wissenschaftlichen Standpunkt aus die Biographie jenes neapolitanischen Fischerjungen zu schreiben, der seinen von der Sonne gebräunten Körper an der Meereskïste wärmt. Die Kulturidee greift auch in alle Phasen des historischen Erkenntnisprozesses ein. Es ist keine Stellungnahme zu historischen Objekten möglich ohne den Kulturgedanken. Wem wir die Kultur verneinen, so vernichten und zerstören wir damit auch zugleich die historische Welt.

Wenn wir das Wort Kultur vernehmen, wenn wir von Kulturgütern und Kulturwerten sprechen, so erhebt sich in uns ein Gefühl mutigen Stolzes und siegreicher Kraft. Und wir verstehen es, daß eine Zeit wie die Renaissance von dem Gedanken der Kulturgröße, von der Vorstellung einer Wiscensmacht und triumphierenden Herrlichkeit des Menschen hier auf Erden aufs tiefste durchdrungen sein muBte. Das Schicksal der Menschheit und die Kuntur sind auf das innigste rerbunden. Sie war ursprünglich nicht da oder doch nicht sichtbar in Erscheinung Getretenes. Sie ist etwas Gewordenes, Erobertes. in schweren Kämpfen Errungenes. Große Opfer hat sie gekostet, Opfer an geistiger und körperlicher Arbeit, Opfer an Jugend und Schönheit, an Leben und Blut. Sie hat aus dem friedlichen Naturwesen Mensch, das wohI dereinst in der Unschuld des Tieres dahinlebte, diesen rücksichtslosen und mächtigen, in seinen höchsten Formen so schön gebildeten Herrn der Erde gemacht. Aber vielleicht ist dieser Sieg und diese Herrschaft des Menschen hier auf Erden, die dadurch erreicht wurde, daß er ans einem Natirwesen zu einem Kulturwesen geworden ist, vielleicht ist sie nur eine scheinbare, vielleicht ver-

$\left.{ }^{1}\right)$ Vgl. hierzu Georg Wobbermin: Die religionspsycholıgische Ifethode in Religionswissenschaft und Theologie, 1913, Kapitel 2. 
mag die Natur jeden Angenblick wieder in ihre alten Rechte einzutreten. Damn wäre unser Dasein hier md jene Kulturblüte, auf die wir so stolz sinı, nur etwas Ephemeres gewesen, das mit keinem Früher oder Später so recht eigentlich zusammenhängt, in der Unendlichkeit der Weltendauer nur eine gleichgültige Minute und in der Unendlichkeit des Weltenrammes nur ein einziges Fleckchen ausfüllt.

Tnd wenn wir hinblicken auf den Kampf, den die Menschheit gekämpft hat. wenn wir all die Opfer bedenken, die sie gebracht hat, 1 m dem Erdenleben die jetzige Daseinsform zı geben, so können wir mit Recht rielleicht diezweifelnde Frage erheben: war demn wirklich das Erreichte diese unendlichen Opfer an Schönheit und Jugend, diesen Verzicht anf ein frohes Genießen simnlicher Seligkeit wert? Haben nicht vielleicht jene recht, die mit Widerwillen und Besorgnis auf diese große Kulturentfaltming schauen? Jene, welche fürchten, daß die Steigerung der Kulturformen die Stärke unseres irdischen Daseins bedroht, da 3 sie uns wohl erst groß und mächtig, dann aber schwächer und weicher macht, so daß wir, der Einfachheit und Śchlichtheit der Natur entwöhnt, zugrunde gehen am Überfuß und an der Fiille des Lebens? Jene, die uns zurückführen wollen die schlichten Wege zu einem ungekünstelten und ungeformten sinnlichen Dasein?

Jene, welche so denken, sind die wahrhaft mhistorischen Menschen. sie wollen das versuchen, was rollkommen ummöglieh ist. Sie wollen das Alte wiederkehren lassen, das unwiederbringlich dahin ist, sie wollen, daß die Menschheit Wege gehe, die sie bereits gewandelt ist, daß sie jene Ablösung, jenen Bruch mit der Natur wieler rïckgängig mache, den sie vollzogen hat, un das zu werden, was sie ist. Jene Menschen, die so entfaltet und so geworden sind. können niemals wieder werlen wie jene, die am Anfang der Geschichte stehen, und anch niemals kömnen ihre Kindeskinder diesen Anfang wieder erreichen. Ausgereift und zur Entfaltung gebracht, müssen sie in der eimmal eingreschlagenen Richtung immer weiter schreiten, um immer wieder nenes und anderes Dascin zu erzengen. So will es die fdee der historischen Entwirklung.

Wenn nun in der Tat der Begriff der Kultur diese beherrschende Stellung in her historischen Welt einnimmt, so dals wir sagen müssen, er allein mache das historische Universum möglich, so fragt es sich, warum man den Gedanken riner Bexichung der historischen Objekte auf Kulturwerte als logisches Fundamont fïr die Geschichte bekïmpft und ahgelehnt hat. Die Schuld liegt vor allem daran, laB nan gemoint hat, diese Bezichung der historisehen Objekte anf lie Kulturwerte sei keine historische Fundamentierung mehr, die historisehthanetische Formmor sei viehmehr in der Formung durch die methodologischen Katregorien vollentrot. Mit dieser Behauptung verkannte man aber sowohl

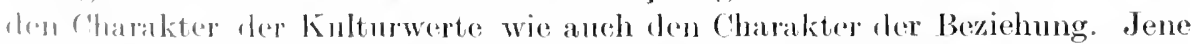
Kinturwerte. lis in dor Goschichte anfreten, wrolen sinseitig als sittliche lobales the l'mos gerfentet, mul in jence Beziehung anf Werte wollte man nicht ein roin fluenetisches Verhältnis, sondern rine praktisehe Stellungnahme

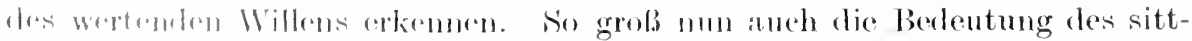

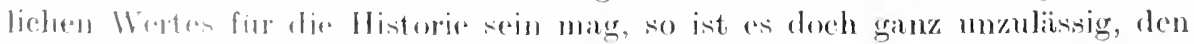

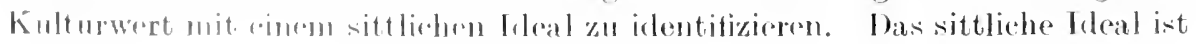


ein Kulturwert, aber deswegen fällt der Begriff des Kulturwerterm noch nicht mit dem Begriff des sittlichen Ideals zusammen. Es ergibt sich, wie wir das schon an anderer Stelle ausgeführt haben, in der Beziehung zu den Fulturwerten die große Gemeinsamkeit zwischen der modernen Philosophie und der Geschichte. Die Philosophie als Kulturphilosophie hat notwendig eine starke Hinneigung zur geschichtlichen Welt. Wie die Philosophie die Fülle der Kulturelemente bejaht und anerkennt, so auch die Geschichte, während die Naturwissenschaft kein Verhältnis zu den Kulturwerten hat, sondern lediglich den zeitlos geltenden Begriff der Wahrheit als höchste logische Bedingung anerkennt. Man kamn die Naturwissenschaft infolgedessen als die absolut theoretische Wissenschaft bezeichnen, sofern sie es nur mit der Wahrheit zn tun hat und in keiner Hinsicht der anderen Werte vorauszusetzen und anzuerkennen braucht. Man kann das auch so ausdrücken, daß in der Naturwissensehaft nur das Theoretische als Wert und Form anerkannt ist, während alle anderen Werte höchstens in Materialstelhung vorkommen und ihre eigentümliche Bedentung rollkommen einbüßen. Dagegen werden in der Philosophie und Geschichte neben dem theoretischen Werte auch andere Werte anerkannt. Nach der Einseitigkeit der Naturwissenschaft hingewendet würde die Philosophie mit der Logik und die Geschichte mit der Geschichte des wissenschaftlichen Lebens zusammenfallen.

Wenn nun aber auch in der Philosophie und Geschichte neben dem theoretischen Wert der Wahrheit, der theoretischen Formen, der Wissenschaft und Erfahrung noch andere Werte anerkannt werden, so ist das natürlich so $\mathbf{z u}$ verstehen, daß diese Werte gleichsam theoretisch überformt sind; denu sie werden hier philosophisch-theoretisch und historisch-theoretisch ergriffen und verstanden. So setzt etwa die Philosophie als Ethik die Anerkennung des sitt. lichen Wertes der Freiheit, des Guten oder der Pflicht voraus, also diese fremden Werte sind von der philosophischen Hethode ergriffen und in den Dienst der Erkemntnis gestellt. Allerdings ist die Form sehr verschieden, in welcher die nicht theoretischen Werte eimmal in der Philosophie und anderseits in der Geschichte erscheinen. Tehmen wir etwa als Beispiel den ethischen Wert. Der ethische Wert verdichtet sich in der Philosophie zu dem Begriff der Freiheit; Freiheit im Simne der Bestimmung des Willens durch das reine Sollen. Ohne diese Freiheit würde sittliches Leben nicht möglich sein, und eine Ethik im Sinne der Philosophie des sittlichen Lebens wäre gegenstandslos. In der Ethik ist der sittliche Wert bestimmend und leitend. Die Tatsache semer Anerkemung ist es allein, die dem Gebiete der Philosophie diese mächtige Erweiterung übor das Gebiet der Logik hinaus zu geben rermag. Diese Anerkennmng des Sollens aber, die Bejahung der Pflicht ist keine theoretische, sondern eine rein ethische Beziehung. Indem dann die philosophische Methode ron der Logik her, wo ihre eigentliche Heimat ist, in das Reich der neuen Probleme übergreift, sucht sie den eigentümlichen, dem theoretischen Verhalten durchans fremden Akt des sittlichenWillens und die aus ihm resultierende Form der sittlichen Gesimnung und der sittlichen Wissensüberzeugung von der theoretischen Beurteilung her zu verstehen, in der die logisch unangreiflare und unfaßliche Willenstat ihren theoretischen Niederschlag gefunden hat. In der theoretischen Form der Benrteilung glaubt die Ethik den an wich nur erlebbaren Akt des sittlichen: 
Willens so nah wie möglich theoretiseh umgriffen zu haben. Es ist damm weiter die Anfgabe der Philosophie als Ethik, diese Tatsache der sittlichen Beurteilung zu deuten und anf ihre Toraussetzungen zu entwickeln. Auf diesem Wege wird -ie zu einem system oder doch wenigstens zur Anfweisung einer Anzahl in ihrem Zusammenhang logisch nicht deduzierbarer Normen oder Werte des sittlichen Lebens gelangen, denen auch sittliches Tun zustrebt, nach denen unsere sittliche Beurteilung sich richtet, von denen unsere sittliche Gesinnung, mser moralisches Bewußtsein erfüllt ist, und die unser Wissen von dem, was gut und recht ist, erleuchten und leiten. Hierbei ist nun ein doppeltes zu beachten, nämlich einerseits dieses, daß die Ethik diese Normen in ihrem zeitlosen ewigen Gelten betrachtet, daß zu ihrem eigentlichen Gebiete keine Reflexion über das Werden dieser Werte und ihrer Beziehung zum historischen Geschehen gehört, daß vielmehr die Geschichte nur als Hilfswissenschaft in der Ethik erscheint. Weiter aber dieses, daß es der Ethik in erster Linie anf die Gesinnung, d. h. auf die Beziehung der sittlichen Normen zur Imerlichkeit unserer Willensüberzeugung und Willensbejahung ankommt, auf daß sich das Gute in dieser Sphäre unseres innersten Erlebens ein Reich der Freiheit aufbaue. Alles kommt darauf an, daß das Gute in mir Gestalt gewinne, und daß die reine und ungetrübte Beziehung zur Pflicht als dem ewigen Sollen aus mir eine Persönlichkeit bilde und so meiner schwankenden, von den Leidencehaften hin und her getriebenen Individualität feste Gestalt verleihe, daß damn weiter in den allgemeinen Verhältnisien des kleinen und großen Lebens, wie sie in Familie und Gesellschaft rorliegen, der sittliche Wille das Sollen auch in der Persönlichkeit der anderen achte und nach besten Kräften immer bestrebt sei, das als gut und recht Erkannte in allen Verhältnissen des Lebens kraftroll zu betätigen.

Ganz anders der ethische Wert in der Geschichte. Er konstituiert nicht wic in are Philosophie ein besonderes Gebiet ron Normen, die unter Vorauscotzung andes höchten Wertes oler eines höchsten Zweckes gelten. Durch die Comeinsankeit des historischen Geschehens, dem ex zugewendet ist, verhindet wich der sittliche Wert hier viel enger mit den anderen Kulturwerten. sic sind alle in gleicher Weise hingegeben der Fülle des historisehen Geschehens, und nur mit einer gewissen liraft der Abstraktion, die allerdings allein hier za fruchtharen Resultaten führen kann, kömen wie diese Gemeinsamkeit do: Vorhandensems auflösen und die Gesamtheit des historisehen Werdens in die vorshiorlenon Reihen wetroller kntwicklung zerlegen. Dann wird also dersittliche Wert eine Entwicklungseihe unter mehreren anderen formieren, niinlich die Ent widklung des moralisehen odes sittliehen Lebens. Dabeisei gleich liver benordit, dab die lisalation nicht sehr einfach ist, dab gerade der moralische

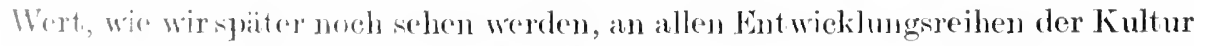

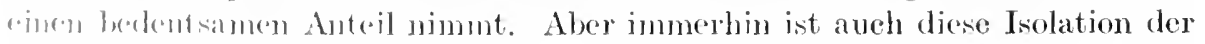
moralischen Estojeklumg gefordert, mag sie anch sehwieriger sein als die

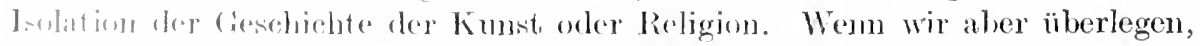
in welcher. Weras sich wohl das sittliche in der Geschiehte offenbaren mag, so

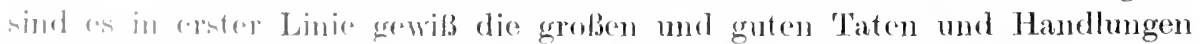
der Mruschene an dire maln denken möehte. Aber wo sind sie nufgezeichnet,

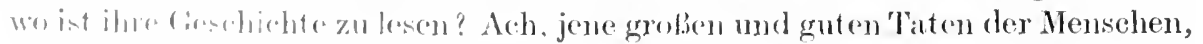

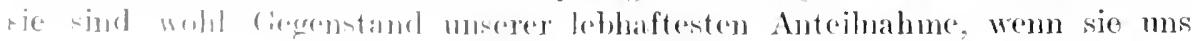


unmittelbar in Leben begegnen, aber gar häufig funden diese Taten großer Pflichterfüllung und aufopfernder Liebe nicht den Weg zur Öffentlichkeit oder wollen ihn auch wohl nicht wandeln, und anderseits würden sie auch wohl nicht genügen, um eine Entwicklungsgeschichte der Moral zu gestalten. Diese Taten tragen häufig ein hohes Maß ron Schlichtheit und Einfachheit an sich, und die Geschichte, sie liebt nun einmal das Großartige und die Pracht. Lediglich eine Geschichte des Wohltuns zu schreiben, ist wenig interessant. Die Wohltäter, ron denen die Geschichte handelt, sollen nicht Wohltäter des einzelnen, sondern Wohltäter der Menchheit sein. Und nicht einmal alle jene Wohltäter und Beglücker der Menschheit gehören der Geschichte an. Augenscheinlich liebt die Geschichte das sittlich Große und Wertrolle nur in Beziehung zu den großen politischen Geschehnissen, den Veränderungen und Umwälzungen des Völkerlebens. Erst wemn es so erscheint, bestimmend für ein Völkerschicksal, erst dann wird das Moralische, der sittliche Wert wahrhaft historisch bedeutsam. Während also die Philosophie in der Ethik den sittlichen Wert so betrachtet, wie er sich in der Beziehung zu einer einzelnen Persönlichkeit in der Imnerlichkeit der Gesinnung, im Wollen und Wissen des Guten offenbart, betrachtet die Geschichte ihn so, wie er sich darstellt im Völkerleben, in den Handlungen der großen Gesetzgeber. in der weisen Fürsorge der königlichen Nacht sowie in dem Heroismus einer Nation, die das Vaterland rerteidigt und der geliebten Heimat die großen Opfer bringt. Hier in der Geschichte also ist es das große politische Tun, in dem die Anerkemmung des sittlich Wertrollen sich offenbart. Jener König, dessen Leben geweiht ist der treuen Fürsorge für die Wohlfahrt seines Landes, und jene Nation, die in der Stunde der Not und Gefahr im Kampf für die Heimat die großen Opfer bringt, sie sind die Guten und Wertrollen, die Helden der Geschichte. Der moralische Kulturwert erscheint in der Geschichte als Begriff des Staates oder als Begriff der Nation.

Der Begriff des Staates oder auch des Volkes bedeutet das Ideal eimer sittlichen Gemeinschaft, die das historische Geschehen verwirklichen soll. Dieser ethische Wert ist in der Geschichte theoretisch geformt, $d$. h. in den Dienst der Erkenntnis gestellt und begrifflich entfaltet. Dort in der Wissenschaft der Geschichte hat er jene einfache und schlichte Gestalt verloren, in der er als moralischer Impuls das jugendliche Herz des jungen Bürgers entflammt, der, des Vaterlandes Gefahr und Elend schauend, auf Hilfe und Rettung sinnt. Der Begriff des Staates ist in der Geschichte verstanden und logisch durchdrungen in der ganzen Fülle seines politischen und sozialen Bedeutens. Und auf diesen Begriff, auf die Idee des Staates wird das sittlich wertvolle Leben bezogen, soweit dieses überhaupt in der Historie zur Darstellung gelangt. Das staatenlose Dasein derVölker gilt als das Jenseits der moralischen Kultur. Die Geschichte, sofern ihr die Entwicklung der moralischen Kultur am Herzen liegt, wird zu zeigen suchen, wie Ordnung und staatliche Gemeinschaft, Recht und Gesetz die ursprünglich so roher und barbarischen sitten und Gebräuche gemildert und reredelt haben. Durch diese Beziehung des historischen Geschehens auf einen Kulturwert wie der Staat, eine Beziehung, die, wie wir noch sehen werden, einen rein theoretischen Charakter trägt, wird erst eine Gliederung und simnrolle Erfassung der historischen Welt möglich. 
Die Lehre ron den Kulturwerten läßt sich. wie wir bereits angedentet haben. in drei Problemgruppen zerlegen. Zuerst kommt es darauf an, zu zeigen, wie das Verhältnis der Kulturwerte zu jenen absoluten Werten zu denken ist, ron denen die Philosophie handelt. Dieses Problem wollen wir als das Gelt ungsproblem der Kulturwerte bezeichnen. Weiter handelt es sich darum, festzustellen, was die Kulturwerte für das historische Geschehen im einzelnen leisten, um das Leistungsproblem der Kulturwerte. Endlieh haben wir zu zeigen, wie die Kulturwerte eigentümlich gebildet und geformt sind, und worin ihre logische Terwandtschaft besteht. Das ist das Strukturproblem der Kulturwerte. Diese drei Probleme ergeben sieh mit Notwendigkeit. Heinrich Rickert hat sich vorwiegend nur mit dem Leistungsproblem, Dilthey mit dem Strukturproblem beschäftigt. Man könnte meinen, daß die erste Frage als eine spezifisch erkenntnistheoretische nicht in die Geschichtsphilosophie hineingehört oder auch mit der zweiten Problemstellung zusammenfällt. Die Grenzen zwischen Erkenntmistheorie und Geschichtsphilosophie kömnen überhaupt nicht so scharf gezogen werden. Soviel ist gewiß, daß die Frage: wie ist Erkenntnis des Wirklichen ïberhaupt möglich, eine ganz allgemein philosophische und erkenntnistheoretische ist, während die Frage: wie ist Geschichte als Wissenschaft möglich, diese beiden Deutungen und Bearbeitungen zuläßt, daß man entweder den Versuch macht, zu zeigen, wie die Kategorien der Geschichte, diese methodologischen Formen, in den reinen konstitutiven Formen der Wirklichkeit verankert sind, etwa die historisehe Kausalität in dem Prinzip der Kausalität überhaupt, so daß hier der Woggegangen wird von der Geschichtslogik zur allgemeinen Logik. Das wäre die erkemntnistheoretische Bearbeitung dieser Frage. Oder aber man zeigt, wie der kulturwert als höchste Form des historischen Lebens angesehen werden muB, und wie sein Verhältnis zu den höchsten und absoluten Werten der Philosophie zu denken ist. Es handelt sich etwa um die Frage, wie verhält sich der Kulturwert der Wissenschaft zur Idee der Wahrheit, und wie das Kunstwerk oder hesser das künstlerische Leben zur Idee der Schönheit. wobei Wissenschaft mol Kunst immer in ihrem lebendigen Dasein, in konkreter Gestalt, im Prozeß des historischen Geschehens gedacht werden. Das ist der Weg. der von der (ieschichtslogik her zur Universalgeschichte führt.

Dab aher das Geltungsproblem nicht mit dem Leistungsproblem zusammenfïllt, ergibt sich aus folgender l'berlegung. Jer Kulturwert kamn entweder so betrachtet werden, wie er zu dem historischen Geschehen, der historischen Wirklichkest und der Erkemntnis dieser Wirklichkeit sich verhält. birse Formung, die der Kulturwert vollzieht, indem or uns die Möglichkeit giht, in die historisehe Welt einzudringen, bezeiehnen wir als seine Leistung. Wir haben aber auch die Höglichkrit zu fragen. wie sich denn eigentlich

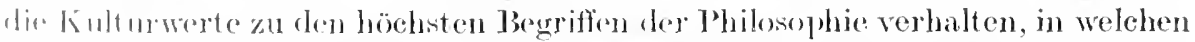

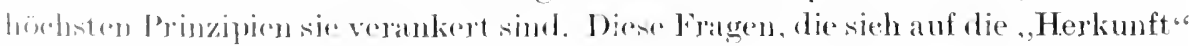

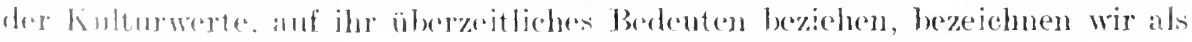

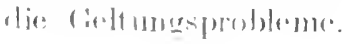




\section{\$ 1. Der erste Problemkreis. Die Probleme der (ieltung.}

\section{a) Notwendigkeit absoluter Geltung zum Verstehen der lieschichte.}

Das Problem der Geltung ist das Problem aller Philosophie. Das Wort ,gelten" bezeichnet in der glücklichsten Weise dasjenige, worauf es in der Philosophie einzig und allein ankommt. Wir wollen wissen, wie etwas gilt, ob es wenig oder viel bedeutet. ob es etwas Bleibendes, Festes und Absolutes oder etwas Flüchtiges, Relatives und Veränderliches ist. Und wenn wir nun auf dieses gewaltige Gesehehen blicken, das wir als Mensehheitsgeschichte bezeichnen, wemn wir das große und wechsehnde Schicksal der Völker und ihrer Helden sehen, ihren Ruhm bewundern und ihren Untergang beklagen, jenen Untergang des Großen und Herrlichen in der Welt, das so viel schöner und besser war als alles spätere Leben ist und jemals werden kann, wemn wir ein grausames Gesetz des ewigen Wandels zu erkennen glauben und Rätsel schauen, die wir nicht verstehen. dam blicken wir wohl manchmal mit Fureht und Sorge naeh einem Ruhepunkt in all diesen Wandel aus. Wozu die Arbeit eines ganzen Lebens, das dem stillen Dienst der Erkenntnis gewidmet ist, wenn diese Erkemntnis selber nicht etwas Bleibendes und Dauerndes an sich hat, wenn sie so flüchtig und vergänglich ist wie mein schwaches Tun, das ich ihrem Dienst geweiht habe? Wozu aufbauen mit sorgsamer Hand in schwerem grüblerischen Simen, wemn alles doch wieder zerbricht und verweht und lieine Stätte hat. Wahrlieh, der Ruhm und der Erfolg sind ein so seltenes und so rergängliches Gut, daß es sich nicht lohnt, um semetwillen der Wissensehaft zu leben. Und die Lust, von der man wohl spricht. dieses hohe geistige Genießen, das mit Freuden verweilt bei dem so schön Geschaffenen und in der stillen Welt der Arbeit sich heimisch fühlt? Ach. wenigen ist wohl nur dieses stille Glück auf kurze Zeit besehieden. Die meisten quält gewiß der Gedanke des nicht Genügens, der verlorenen, der verfehlten. rom Ziele immer gleich weit entfernten Arbeit. $O$, dieses stille und schöne Reich des Wissens. in dem dir vielleicht kurze Stunden reiner Freude vergönnt sind, es ist auch zugleich die Welt des traurigen und schmerzlichen Zweifels an dem Erfolg und den Anssichten unseres schwachen menschlichen Tuns. Denn in diesem stillen Reiche des philosophischen und wissenschaftlichen Lebens, wo die Wahrheit als Hüterin und Richterin bestellt ist, da wird man am schwersten prüfen. am sorgfältigsten wägen und nicht so leicht durch den Erfolg des Augenblickes ergriffen und geblendet sein. Hier ist die Stätte des einsamen Simens, wo immer wieder das Urteil gefällt wird über den Sinn oder Nichtsinn des historischen Geschehens.

Wozu, so werden wir weiter fragen, dieser gewaltige Aufwand ron hraft, den ein Heldenleben erfordert, das neue Formen des Daseins und des sozialen Lebens schaffen will, dessen gewaltiger Wille sich auflehnt gegen das Bestehende und diese große Sünde der Negation an dem Vergangenen rollzieht, die alten Gesetzestafeln zerbricht und neue Rogeln schafft, die das menschliche Dasein bestimmen? Woher nimmt er das Recht, als Richter aufzutreten über die Vergangenheit? Was treibt ihn dazu, diese großen Opfer an Kraft und Arbeit zu bringen und sich und riele Tausende anfzuopfern für eine nene Idee? Magr sein, daß3 das, was ihn erfüllt und zu so großen und begehrlichen T'aten hinreißt, 
in sehr viclen Fällen der wilde Ehrgeiz, die rasende Leidensehaft ist, die nur um ihrer selbst willen diese großen Szenen des Krieges, der Verfolgung, der sozialen und politisehen Umwälzungen heraufbeschwört. Mag sein, daß eine wilde, verzehrende Kraft in ihnen lebt, die sie hindrängt und fortreißt auf den Sehauplatz der Taten, daß sie ihr Eigenes wollen und ungewollt das Wertvolle sehaffen. Möglich wäre es ja, daß diese großen Naturen, die Weltgeschichte machen, im Grunde nur ihren Leidensehaften frönen. Aber aueh dann gilt für sie, die wenigen Auserwählten, Hegels Wort: die Heroen sind nicht glüeklich'1). Sie sterben in der Jugendblüte ihrer Schönhejt wie Alexander oder fallen getroffen ron des Fremndes Hand wie Cäsar oder leben ein Riesenleben gewaltiger Kämpfe, um dann zu sterben einsan und rerlassen auf St. Helena. Cnd der Augenschein lehrt etwas anderes. Die Auffassung, daß alle Heroen, wie ron einem Dämon besessen, nur ihren Leidenschaften folgen, ist eine Konstruktion, die für einige große Erscheinungen gilt, für andere aber nicht. Mäehtig war die Sorge für des Reiches Wohlfahrt bei Naturen wie ('äisar, dem Frankenkaiser Karl und dem großen König ron Preußen. Und dieses ewige Sinnen und Trachten, des Reiehes Herrliehkeit zu wahren und Glïek und Frieden ihren Tölkem zu bringen, hat ihre Haare vor der Zeit ergrauen lassen und ihren Nächten den Schlaf geraubt. Wozu all die Arbeit, wozu all die Opfer, wenn die politischen und sozialen Schöpfungen der Heroen nur da sind, um wieder zerstört zu werden?

Und nun ror allen Dingen jene religiösen Naturen, jene großen Lehrer und Erzieher des Mensehengeschlechtes, die das Reich Gottes auf Erden vorbereiten wollten, und jene Millionen, die ihnen naehgelebt haben, wie törioht und simmlos war doch das Leben, das sie führten, wenn nicht jenen Lehren, die sie rerkünden, irgend ein Wahrheit,gehalt, irgend ein überindividuelles Bedeuten zukommt, mag dieses hier auch noch so sehr in verschleierter und -ymbolisher Form gegeben sein. Wem wir auf die großen Religionslehrer blicken, die vielfach ihr Leben an ihre Lehre setzten, auf die großen neuartigen Schöpfungen ihres Geistes, an die Begeisterung und den Fanatismusdenken, den sie erwcekt, an das Blut, das man um sie vergossen, an all die Seligkeit und Uncoljgkeit von Schuldgefühl und himmlischer Ekstase, die im Gefolge dieser Lehren und religiösenşchöpfungen über dieMensehen gekommen sind, so möehten wir an dem Gosantsinn des historisehen Geschehens zweifeln, wemn diese mächtigen Bewegungen und Impulse dureh eine Illusion bestimmt waren.

Es scheint so, als ob das Gehict des küustlerischen Lebens das einzige ist, das anch ohme den Gedanken des ewigen und danernden Bedeutens auszukommen vermag. Der Gedanke der Relativitit und des bunten und ewigen Wechsels scheint sich noch am crsten mit dor Irlee der Kunst zu vertragen. Die Welt, bje: sir. orichtet, soll nicht jene Art von Bestand und Daner haben, die der pulitiche (bramisator scincm Werke verleihen möehte, denn er baut nieht. in die Mirklichkoit ein, wie joner es tut, sondern sehaffe eine freie Welt des Unwirklichen, dia bis zu einem gewisien Grarke unabhängig ist von dem Sinn des historirchen Gerehehens. Dor Kïustler hat die Virtuosität, auch dem

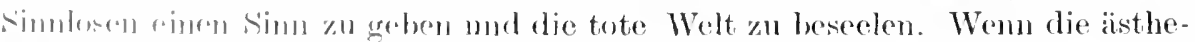

1) Hrgen: Philusuhlie dur Geschichte. 
tische Vernunft das Göttliche zu begreifen sucht und die künstlerische Qualität dem Wirklichen verleiht, so verbindet sie mit dem Gedanken eines höchsten Weltprinzipes gar gerne den Gedanken des freien Spieles. Die Vorstellung des Göttlichen, wie sie etwa aus einer ästhetisch gerichteten Metaphysik sich ergibt, ist frei und losgelöst von dem Gedankell irgendeiner moralischen Verantwortung. Sie liebt nicht, sie begehrt nicht und kennt kein Gesetz. Sie ist der spielende Aion, von dem Heraklit spricht, der in regellosem Spiel sich mit den Dingen der Welt befaßt und jenem Kinde am Strande des Meeres gleicht, das Sandhaufen aufbaut und wieder einreißt ${ }^{1}$ ). Auch ist der Küustler nicht so entfernt von jener blühenden Lebensfülle, die Freude in unser Dasein trägt. Ihm ist es noch am ersten gegeben, die Arbeit und das Streben mit schönem Lebensgenuß zu verbinden. Er hat seine Welt, die er liebt, für sich im Kunstwerk isoliert, deswegen gehören er und sie nicht so sehr dem großen Strome des Gesamtgeschehens an. Auch steht der Charakter des wahrhaften Kunst. werkes, das immer ein Vollendetes und Abgeschlossenes bedeutet, in einem gewissen Gegensatz zu den anderen Formen der Kultur, die in ihrem niemals erfüllten und abgeschlossenen Charakter ron dem Geist des Vorwärtsstrebens erfüllt sind.

Und doch vermag auch die Kunst und der Künstler, der mit aufrichtigem Herzen das Schöne sucht, nicht zu großer und unsterblicher Gestaltung vorzudringen, wenn er nicht in irgend einer Weise durch den Gedanken des Ǔbersimnlichen bestimmt wird. Jene sinn- und bedeutungslose Kunst, die als Produkt unserer modernen Kultur vor allem im Impressionismus sich entfaltet hat, mag als anmutige Spielerei unser Wohlgefallen erregen, aber den Namen Kunst im hohen Sinne des Wortes verdient sie nicht. Die Anerkennung eines Überindividuellen und Übersinnlichen oder doch zum mindesten die Stellungnahme zu diesem Problem, sei es auch nur so, daß das Úbersinnliche gesucht oder zweifelnd gehofft oder gar verworfen wird, führt erst jenen Geist des wahrhaft künstlerischen Lebens herauf, den wir aus tiefstem Herzensgrunde und mit seliger Freude bejahen.

\section{b) Anfang der Geschichte.}

Wenden wir unsere Blicke nummehr nach dem Anfang und dem Ende der Kulturentwicklung hin, um ihr Antlitz etwas genauer zu schauen und die Frage ihres Geltens besser und sorgfältiger zu verstehen. Zuerst die Frage des Anfangs: hat es immer Kultur gegeben in dem Sinne, daß Wertrolles geleistet wurde bis zu dem Grade, daß es würdig war, in den Büchern der Geschichte aufgezeichnet zu werden? Historisch-entwicklungsgeschichtlich werden wir diese Frage verneinen, ohne lange zu zögern. Wir wissen ja, daß es eine Zeit gegeben haben muß, die noch nicht erfüllt war ron höherem menschlichen Leben, in der der Mensch als solcher noch eine Art tierischen Daseins führte. Und auch dieser tierähnliche Mensch muß einmal geworden sein, vielleicht ist er hervorgegangen aus niederen Lebensformen. Und dieses Leben selber, das große Wunder der Natur? Ist auch das Leben geworden, oder war

Diels: Fragmente der Vorsokratiker. Heraklit. 
das Leben immer da? Viel leichter wird man sich wohl entschließen, die Kultur als das höhere Leben aus dem niederen Leben herznleiten, als diesen weiteren Schritt zu gehen und das Leben als Produkt des Nichtlebens zu begreifen. Es scheint so. als wenn wir es erst jetzt mit zwei ganz verschiedenen Reichen zu tum haben. Die Kultur gilt als eine Provinz des Lebens und liann aus Leben überhanpt rerstanden werden. Wenn einmal Leben da war. so kamn dieses Leben sich entwickeln und höhere Gestalt gewinnen, wie das Kind zum Knaben und der Knabe zum Jïngling reift. Aber es ist doeh wohl schwierig, das Leben als eine Provinz des Nichtlebens und als ein Produkt des Anorganischen zu begreifen? Wie kann so radikal Entgegengesetztes auseinander geworden sein? So hat man sich dem wohl entschlossen, das Leben als ein immer Daseiendes zu betrachten und die empfindungsbegabte Naterie an den Anfang des Weltprozesses zn setzen. Aus ihr kam man flamn alles heransholen. was man will. Logisch konsequenter Weise aber muß man weitergehen und den Tersuch machen, das Leben ans dem Nichtleben abzuleiten. Damm war also am Anfang aller Dinge das Nichtleben, und ans dem Nichtleben ist das Leben und jenes hölsere Leben, das wir Kultur oder anch verniunftiges Leben nennen, geworden. Ins aber nicht auch das Nichtleben. diese letzte Form des Wirklichen. zu dem wir gelangt sind, einen Lreprung haben? Ist nicht auch das Nichtleben Produkt einer weiteren Sphäre, aus der es begriffen werden muß? Dieses Weitere und Andere. um das es sieh hier handelt. kalnn aber nur das Unwirkliche sein, und so ist das Wirkliche aus dem Nicht: geworklen. Beachten wir die seltsame Dialektik, die in diesem Ent wicklungsgedanken steckt. Das allgemeine Prinzip muß clarin gesehen werden, dals das Rejchere auf das Ärmere, das Zusammengesetzte anf das Einfache zurüeliführt. so daß man schlieBlich die ganze Kinltur aus dem Nichts begreift. Kultur jst eine drt des Lebens. kann also aus Leben überhaupt begriffen werden, Leben ist eine Art des Wirkliehen. kam also aus Wirklichlieit überhaupt begriffen werden. Die einfachste Form des Wirklichen ist aber die unorganische liaterie. die am wenigsten zu raten und zu denten gibt. Ind doch erhebt sich aneh bei ihr. so gle ichgültig und minteressant sie anch sein mag, die primitive Frage nach dem Crsprung. Fïr ihre Herkunft aler bleibt dam nichts anderes iibrig als das Nichts. Fnd um dentlich zu mathen, dals so entgegengesetzte und repschiedenartige Dinge wie Kultur, Leben, Nichtelen und Niehts in fincm hausalen Zusammenhange stehn, legte man grobe /eitintervalle zwischen

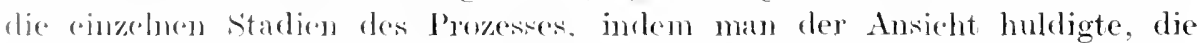
fomen kömnten es ropständlich machen. dab das Entgegengesetzte zum Ent-

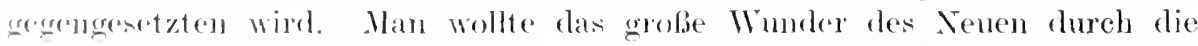

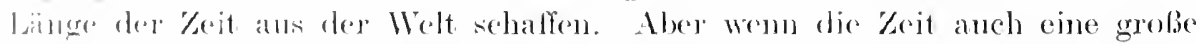

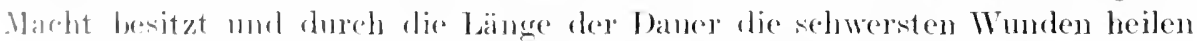

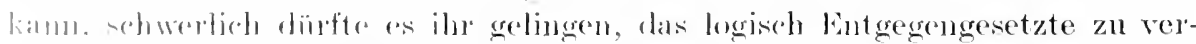

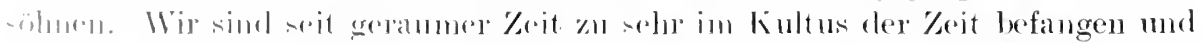

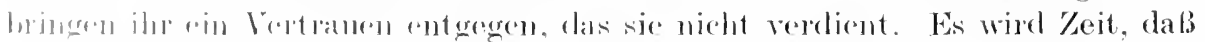

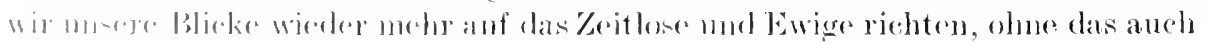

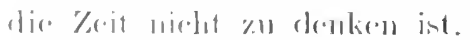

Gegend den Versueh, die Kultur ans der Materie und ans dem Niehts

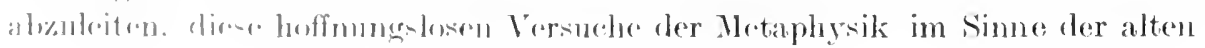


Kosmogonie, die noch immer wiederholt werden, lassen sich gar mancherlei Einwände erheben. Zunächst einmal der durchaus plausible Einwand, der jedem nachdenklichen Menschen mit einer gewissen Selbstrerständlichkeit kommen muß. Wozu soll ich die Fülle der Kultur, diese gesteigerteWirklichkeit auf das Minimun des Wirklichen oder gar auf das Nichts zurïckführen? Es ist nicht sehr wahrscheinlich, daß das Mächtige und Große so ohne weiteres aus dem Nichts hervorgeht. Die Scholastik kannte einen Satz, der auch bei den Demonstrationen Descartes' in den Meditationen bei der Entwicklung des Gottesbeweises eine gewisse Rolle spielt. Er lautet dahin, daß in der Crsache immer mehr oder doch mindestens die gleiche Kraft enthalten sein müsse wie in der Wirkung. Natiirlich handelt es sich hier um eine ganz metaphysische Auffassung des Kausalprinzips, die unbeweisbar und von der Erkenntnistheorie längst widerlegt und überwunden ist. Aber einer anderen. weitaus plumperen Form der Metaphysik gegenüber besteht dieser Satz rollkommen zu Recht. Ist es nicht viel einleuchtender anzunehmen, daß das Vollkommene am Anfang steht und das weniger Tollkommene herrorbringt? Ist es nicht viel leichter einzusehen, daß das Göttliche die Materie herrorbringt, wie umgekehrt die Materie das Göttliche? Wollen wir aber leugnen. daß es etwas Großes und Göttliches in Kultur und Natur gibt? Wozu damn die Verehrung des Kunstwerkes und die Tergötterung der Wissenschaft. Oder will die Menschheit hier nur einen Kúltus ihrer selbst treiben und nicht über sich hinausgehn? Wozu aber macht man den Anfang des Geschehens zu einem Nichts? Nur un desjenigen Begriffes willen, der unser Zeitalter berauscht und zum Schlagwort geworden ist. der alle Fragen mit einem Schlage lösen soll. nämlich der Begriff der Entwickhnng. Man vergißt zu leicht, daß doch etwas dasein muß, das sich zu etwas entwickelt. Und daß dieses große Resultat und das Werden, das unseren Stolz und unsere Freude bildet, dem Gedanken der Entwicklung gemäß ein Etwas roraussetzt, das alle diese Gestaltungen in irgendeiner Weise als ungeworden und unentfaltet in sich trug. Sonst läßt die Entwicklungsgeschichte immer wieder ein Nenes als ein ursachloses Etwas ans dem Nichts auftauchen und macht den Gang des Geschehens zu einem ewigen Rätsel. Der Gedanke der Entwicklung darf nicht überspannt werden. Wir dürfen der Idee des Werdens nicht das Sein und der Idee des Seins nicht das Werden aufopfern. Wir werden später bei den Problemen der Universalgeschichte mit einer gewissen Notwendigkeit vor die Frage gestellt werden, wie denn mun eigentlich der Gedanke der Entwicklung und des Werdens mit der Idee des Bleibenden. Ewigen und Geltenden zı rersöhnen sei.

Eine große Schwierigkeit der alten Kosmogonie liegt dann weiter in dem Begriff der Zeit. Nehmen wir an, daß das Wirkliche geworden sei, so gelangen wir zu der Vorstellung einer Zeit ohne Wirklichkeit, ohne Objekte, ohme Leben, also zur Vorstellung eimer leeren Zeit ${ }^{1}$ ). Und ich möchte wohl wissen, was man sich unter einer leeren, einsamen, brütenden Zeit vorstcllen soll. Schon diese Vorstellung führt uns dazu, das Wirkliche als ewig zu denken oder besser nicht nach dem Anfang des Wirklichen zu fragen; denn auch die Torstellung.

1) Das berühmte Problem der Antinomientehre Kants. Kritik der reinen Vernunft. Kants Schriften. Werke. 3. Band. Akademieausgabe. 
dab das Wirkliche ewig sei, führt, wie Ka n t gezeigt hat, zu unlösliehen Schwierigkeiten auf dem Standpunkt einer naiv realistischen Hinnahme der Dinge. Ob, ich das Nichts oder die Materie an den Anfang des Weltgeschehens setze, ist logisch in gleicher Weise unsinnig und widerspruchsvoll. Denn was soll ich ron einer Materie halten, die einsam in der Zeit ist? Von ihrer Entwieklung kann ieh ïberhaupt niehts aussagen, denn von einem Zeitverlauf können wir nur reden, wenn Bewußtsein gedacht wird, das den Stoff anffaßt und dentet. Wenn man ron Gott gesagt hat, daß vor ihm tausend Jahre sind wie ein Tag, so kann man diese Hyperbel, die ein Ausdruck ist für die Unbegreifliehkeit eines Etwas, das von unserer Organisation so ganz versehieden ist, mit demselben Reehte auch auf die Materie anwenden. Mensehlich erlebbare Zeit können wir nieht messen und vergleiehen mit dem Dasein der Materie in einem problematisehen Etwas, das dann noeh den Namen der Zeit haben soll, obwohl von mensehlichem Auffassen und mensehlicher Anschaumg nieht mehr die Rede sein kann. Weitaus logiseher ist es dann noch, die Auffassungsweise des menschlichen Intellektes an einer höheren Bewußtseinsorganisation zu messen, für die Millionen von Jahren soviel bedeuten wie für uns ein dauerloser Augenbliek.

Es ist ein ganz eigentümlicher Prozeß, den diese Art der entwicklungsgeschichtlichen Betrachtung am Wirklichen ausiibt. Die Wirklichkeit, wie wir sie erleben und unserer Organisation gemäß einzig verstehen können, diese Wirkliehkeit wird zersetzt und aufgelöst. Alles wird fortgenommen und fortgedacht, was ihr das Anreeht auf Dasein und Bedeutung gibt, und dieser letzte schale und einförmige Rest, der übrigbleibt, dieses absolut Bedentungslose, soll dann noch als bloße Materie die Wirklichkeit bedeuten.

Und wie steht es mit jener seheinbar so selbstverständlichen Amnahme, laß3 das höhere Leben der Kultur aus dem niederen Leben der primitiven Daseinsformen geworden sei, daß man ohne große Schwierigkeit die Kultur als eine Provinz des Lebens aus dem allgemeinen Leben begreifen kann? Als ob nicht der Übergang des wertfreien, des bloßen Lebens schlechthin zum Kulturleben nicht zum mindesten ein ebenso großes Wunder wäre wie das Werden des Lebendigen aus dem Toten. Jener erste Zustand der kulturlosen Menschheit, vor dem wir so gut wie gar niehts wissen, nieht einmal, ob ihre soziale Gruppierung die Isolation oder das Herdenleben war, ob der einsam dureh die Wälder sehweifende Wilde oder die zusammengedrängte Masse eine bessere Vorstellung von ihrer Daseinsform gibt, man kamn sie noch nieht ais oin volles Leben be\%eichnen, weil diescm Leben noch dio Bewegung und die Entfaltung fehlt. Ehonso seltsam und wnndertar wie das Werlen des Lebendigen aus dem Toten ist der Cbergang res trammhaft bewegungslosen Daseins zu dem bewegten urıl schöpferisehen Johen der Handlung nnd der Tat.

Das liätsel des Anfangs rer historisehen Bewegung hat die Gesehiehtsphibosphin der groben metaphrsisehen systone in mannigfaltiger Weise zu druten gesncht. Das Problen war immer, wiodenn wohl eigentlich die Bewegung in dicse lelundig-tote Masse gokommen sein möehte. Unl das zu verstehen, wandten sich die Blicke meistens der religiösen Uberlieferung zu und suchten ansihr gowiso Auhaltspmkte für die Einleitung des Geschehens zu gewinnen. Inter der Iditung hoherer Naturen sollten die Mensehen von ilurem dumpfen 
Simnenleben erlöst sein, und diese höheren Naturen wurden dlann später von der dankbaren Mensehheit als Helden und Götter verehrt ${ }^{1}$ ). Irgendwo auf der Erde sollte der Wohnsitz eine; Tolkes gewesen sein, das von vornherein im Besitz aller Küulturgüter sich befunden haben sollte. ein göttliches Tolk, im Zustande höchster menschlicher Tollkommenheit, mit paradiesischer Schönheit geschmückt. Alle anderen Tölker der Erde befanden sich dagegen im Zustande rauher Wildheit und Barbarei. Das göttliche Tolk wurde äber die Erde zerstrent und ist dann überall zum Kulturträger geworden. E- rerkörperte das Prinzip der tätigen Vermunft und setzte die trägen Massen in Bewegung ${ }^{2}$ ). Wir sehen, wie in diesen Vorstellungen der Gedanke des Paradieses lebt, mit dem sich im dentschen Idealismus die Apotheose des Griechentums verbindet. Es wird hier der Versuch gemacht, den Anfang der Kulturbewegnng so weit wie möglich zurückzuschieben. An irgenteiner Stätte der Welt muB ein Asyl der Kultur immer gewesen sein. Hier war rlie Kultur am Anfang des historisehen Geschehens konzentriert. und indem nun die Vertreter dieser Kultur über die Erde sich verbreiteten, leiteten sie durch die Macht ihrer Aktivität. durch ihren Schöpferdrang, durch ihre Bejahmng newer und höherer Lebensformen das historische Geschehen ein.

Diese Lehre. wie sie etwa ron Fichte vertreten ist, beweist eine große Tiefe des geschichtsphilosophischen Verstehens. Fichte kemnt den unversöhnlichen Gegensatz ron Leben als bloßem Dasein und Leben im Simne ron hohem und rernünftigem, bildendem und schaffendem Leben. Dieses kann aus jenem nicht hervorgegangen sein, und so muß dem die Geschichtsphilosophie an dem Anfang der historischen Bewegung die Tatsache der Kultur einfach registrieren.

Anch wir wollen so tun und die Geschichte begimnen lassen mit dem Rätsel einer Kultur. die in irgendeiner Form schon gegeben war. ohne daß wir über ihre Genesis irgend etwas Bestimmtes sagen können. Es muB einmal ein ungeheurer Anstoß, ein gewaltiger Impuls die Welt durchbebt haben. gleich jenem, Anstoß des vo', ron dem der alte griechische Denker Anaxagoras spricht. und ron diesem Augenblicke an gab es Kunltur auf Erden. Jerle historische Darstellung setzt das Dasein der Kultur schon vorans und rechnet mit der Tatsache ihrer ursprünglichen Gegebenheit. Wie für den Phrsiker die Materie und für den Biologen das Leben überhaupt, so ist für den Historiker rernünftiges. gestaltetes, kulturerzengendes Leben eine ursprüngliche Tatsache: denn erst unter der Toraussetzung seiner Wirklichkeit kann ron einer Wissenschaft des historischen Lebens gesprochen werden. Ohne den Begriff der Natur als eines Inbegriffs ron mannigfaltigen Phänomenen, die durch gesetzliche Notwendigkeit bestimmt sind, keine Naturwissensehaft. und ohme Kultur im simne eines höheren, vernünftigen, werterzengenden Lebens keine Geschichtswissenschaft.

\section{c) Ende der Geschichte.}

Und richten wir unsere Blicke nummehr für kmrze Zeit auf das Ende der Geschichte, das gleichbedeutend ist mit dem Ende der Kinlur. Dem mit

I) So bei Herder: Ideen zur Philosophie der Geschiehte der Mensehheit.

$\left.{ }^{2}\right)$ Vgl. hierzu besonders die Idee des Normalvolkes in Fiehtes Grundzügen des gegenwärtigen Zeitalters.

M ehlis, Goschichtsphilosophie. 
dem Ende der Kinltur hört auch die historische Bewegung auf. beide sind unanflöslich miteinander verbunden. Wenn sehon der Anfang des Geschehens in nächtiges Dunkel gehüllt ist, durchdrungen von Mythologie und Sage die dämmernde Torzeit, so gilt das noch in weit höherem Maße für das Ende der Geschichte. Gewiß. mit der Aufhebung der Kultur hört anch die Gosehichte auf, denn die ursprüngliche Wildheit des bloßen Daseins oder das Idyll des bloßen Zusammenseins bilden noch kein historisches Leben. Wie aber das Ende beschaffen sein möchte, anch darüber hat die alte metaphysisehe Gesehiehtsphilosophie verschiorknartige Theorien aufgestellt, und zwar meistens in dem Simne, daß die Kultur und mit ihr das historisehe Leben gewissermaßen an ihrer eigenen Nacht zugrunde geht. In fortgesetzter Steigerung wird die Kultur immer mehr des Gleichgïltigen und Indifferenten ungestalten und mit wertvollem S̈ein erfüllen, bis schließlich das Werden stoeken muß am eigenen ỦberfluB. und lie Tollendung das Fragmentarische des historischen Geschehens fiir immer äberwindet. Dann wird das Ende der Gesehiehte sein, wenn die treibenden Wertimpulice des historischen Geschehens kein nenes Formungsmaterial mehr fasien und ergreifen können, weun das historisehe Universum zu den geworlen ist. was es seiner Natur und Entfaltungnmöglichkeit nach werden und sein sollte.

\section{d) Kann ein Kulturwert den anderen ablösen?}

In unserer Zeit macht sich eine eigentïmliche Stellungnahme geltend zu der Dincrhaftigkeit der Kulturwerte. Es hat den Ansehein, als ob das moderne Kulturbewntsoin in seiner Einsoitigkeit nur noch zu bestimmten Werten sich bekennen kann. die anderen aber der Vergessenheit und dem Untergange anheimfallen lassen will. Die Werte aher, von deren Danerhaftigkeit das moderne Konlturbenubtisein ïbrenengt ist, das sind in exster Linie die Wissensehaft, die Teehnik und der Wert der politisch-sozialen Organisation, Werte, mit denen sich. wio es scheint, in besonders hohem Maße der Gedanke des Fortschritts verbiulet. Thagesen sind nach der Auffassung dieses ZeitbewnBtseins rinem frihheren oder späteren Untrerang geweiht Religion. Philosophie und achließlich die Kumst, also diejenigen Werte, die nach der Auffassung einer wherflüchlichen Psychologre mehr dem Gefühl ak dem Intellekt zugewendet sind, und die damn weiter anch das gemeinsam haben, dabs sie von der Idee dos Fortschritts nur leise berïhrt wevelen. Alles das ist wohl ein Anzeiehen

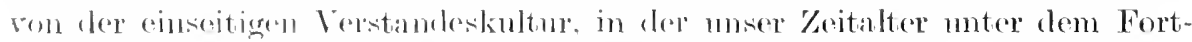
wirken der Aufklärunger noch immele lefangen ist.

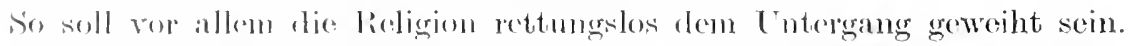

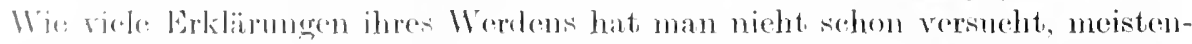

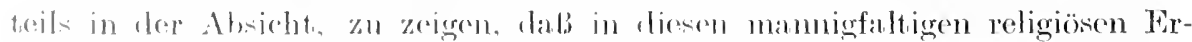

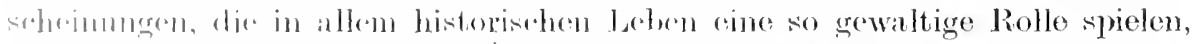

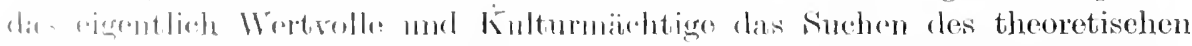

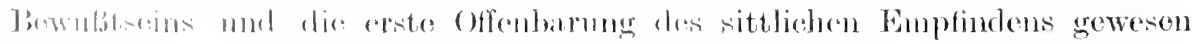

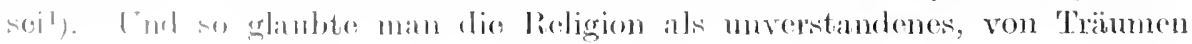

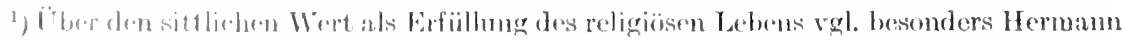

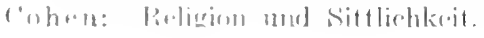


der Phantasie umhülltes theoretisches und religiöses Leben verstehen zu sollen ${ }^{1}$ ). Tor der leuchtenden Helle des erhöhten Külurbewußtseins muß der religiöse Phantasietramm, der dem Kindesalter der Menschheit so angemessen ist, in nichts zergehen. und es bleibt die Stäre des sittlichen Wollens und der hohe Flug des Erkemntnisstrebens als das Wahre und Wertrolle nach vollzogenem Länterungsprozelb zurück. Lnd so sah man die Intensität des religiösen Lebens ohne Schmerz erlahmen und glaubte etwas Höheres und Besseres an seiner Stelle gewonmen zu haben.

Auch der Philosophie hat man zeitweilig ein sellständiges Daseinsrecht nicht einräumen wollen. Auch sie sollte etwas Vorläufiges und Transitorisches sein wie die Religion. Sie sollte eine Überspammung des Erkenntnisstrebens bedeuten, einen aussichtslosen Tersuch, in das verborgene Wesen ther Dinge einzudringen. Sie sollte jenem schönen Alter seliger Jugend entsprechen. diss mit wundervollen und mächtigen Bildern die Wirklichkeit verklärt, die Herbheit der Realität im feurigen Enthusiasmus äberwindet und in dem Vollhewnßsein seiner frischen Kraft anch ror dem Unmöglichen nicht zurückbebt. Was aber als Gutes mol Tüchtiges. als danernd Wertrolles in der Philosophie rorhanden war, das sollte die ermsthafte und rerstandesklare Naturwissenschaft entweder schon selbst in den Kreis ihrer Probleme gezogen haben oder doch in nicht gar langer Zeit zu ihrem unveräußerlichen Eigentum machen. Unu so sollte die richtig rerstandene Philosophie wie die richtig rerstandene Religion in ihrem wahren Wertgehalt nach gründlicher sänbermng und Reinigung ron allen Zutaten jugendlicher Phantasie wissenschaftliche Erkenntuis bedenten.

Und wie man von der Endlichkeit und Vergänglichkeit der Religion und Philosophie überzeugt war, so hat man auch der Kunst ein Ende vorhersagen wollen. ,Die Kunst stirbt." Es naht eine Zeit, die kein künstlerisches Leben mehr kemnen wird ${ }^{2}$ ). Eine Zeit wird kommen, wo rlie Kinst anfgehört hat mit mit ihrer Schönheit und Freiheit das geistige Leben zu erfüllen. Wemn man aber ohne allzu großen Schmerz jene beiden anderen scheiden und schwinden sah, so konnte man anf die Idee der lebendig wirkamen Schönheit nur mit Wehmut und Traner verzichten, als ob man ron der trïben thnung erfüllt war. daß eine Kultur ohne künstlerisches Leben allen Glanz und alle Herrlichkeit verlieren würde. Cnd weiter glaubte man auch zu wissen. daß die Kunst unersetzlich sei. daß Religion und Philosophie rielleicht in der Wirienschaft ein höheres Leben gewimnen können, claß aber die Kunst nicht anfgenommen und aufgehoben werden könnte in einem anderen Kulturwert. Wit dem Ende der Kunst würde dann also in der Tat ein Teil der Kultur mwiederbringlich zu Ende sein, und was alsdann noch zurückbleibt, ist keine rolle und ganze Kultur mehr. Die Kunst findet nicht wie Religion und Philosophie eine willkommene Aufnahme in einem anderen Kulturgebiet, die Kmst wird grawam remichtet, und zwar soll es ror allem die Entfaltung der mollernen Technik sein, die

1) Hume: Naturgeschichte der Religion. Auguste Comte: Cours de philosophie positive.

") Vgl. hierzu besonders I. MI. Guyeau: Die ästhetischen Probleme der Gegenwart, 2. Kapitel. 
in ihrems stetigen Wachstum mit der Kunst unvereinbar ist und früher oder später ihren Tntergang herbeiführen wird.

Was damn endlich das sittliche Leben betrifft, so befindet sich das moderne Fulturbewиßtsein gerade diesem Werte gegenüber in einer gewissen Befangenheit. Einerseits bringt man den sittliehen Qualitäten ein hohes Maß von Anerkennung entgregen und will etwa die Religion durch Moralität ersetzen. Anderseits chämt man sich anch etwas der Moralität und will sich über ihre Steifheit und Philistrosität beklagen. Als Wertmaßstab sucht man sie soweit wie möglich ron der Beurteilung des politischen Lebens fernzuhalten, indem man die L̉berzengung rertritt, daß die Ethik mit Politik nichts zu tun habe. Gewisse ummoralische Bestrebungen zielen daranf ab, den sittlichen Wert seiner beherrschenden Stellung in allen Verhältnissen des Lebens zu berauben und an seine Stelle die Normen des Geschmackes, das Gebot der Schönheit zu setzen, -o da 3 nach diesen mannigfaltigen, verworrenen und wunderlichen Vorstellungen ron der Dauer oder Vergänglichkeit der Werte Religion und Philosophie zur Wissensehaft und Sittlichkeit zur Kunst werden soll, während die Kunst als solche der Technik zmm Opfer fällt. Es sind also vor allem diese beiden, die aus dem Kampf der Kulturwerte als unbedingte Sieger hervorgehen, und denen unser Zeitalter den größten Respekt entgegenbringt: die Wissenschaft und die Technik. und die Anerkennung und Erhebung gerade dieser beiden Werte dureh das moderne Kulturbewußtsein ist natürlich und berechtigt, weil das rorige Jahrhundert eine so große Entfaltung von Wissenschaft und Technik gebracht hat, weil es in erster Linie ein Zeitalter der Wissenschaft und Technik war. Das moderne Kulturbewnßtsein würde sich also vielleicht auch damn noch zur Kultur bekennen, wenn ihm nur diese beiden Lieblingswerte dauernd erhalten hlieben.

Die Hervorhebung eines besonderen Kulturwertes unter Herabsetzung und Geringschätzung anderer gibt einem Zeitalter seine besondere Physiognomic. So hat das Griechentum vor allem dio Philosophie, das alexandrinische Zeitalter die Religion, die Romantik die Kumst gewertet. Und man kamn viellejeht behaupten, daß die einseitige Hervorhebung und Akzentuierung geviser Werte gegenüber den anderen in der Regel mit einer großen und -tarken Küulur zusammengeht; denn diese Anerkenmung verbindet sich gar häulig mit eincm eindringlichen Verstehen gerade dieser Geisteserscheinmng und mit großer Leistung anf dem gewïhlten Gebiet. Ein Zeitalter, das, ohne solche Intersehiele zu machen, der Totalität der Kulturwerte in ihrer ungeheuren Verschienlenheit in gleicher Weise zugewendet ist, liuft immer Gefahr, in eine geswisio, fileichgïltigkeit mol Indifferenz zu verfallen, so sehr auch eine solche

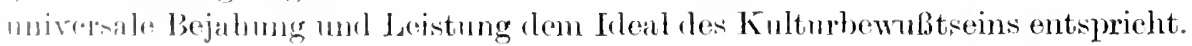
lats miverate bewnlisein, das mit vollendeten Verstehen der Ganzheit zugrandet ist, jet pine irlealo Form des Kulturdaseins, die bisher noch nieht rrovisht ist. Ind so schoint mit einer grobon historischen Bewegung notwonlig alie Tngerechtigkeit und die Sïnde zusammenzugehen, indem die Be-

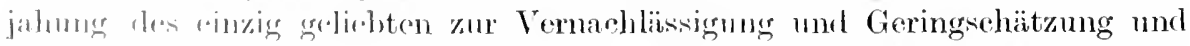

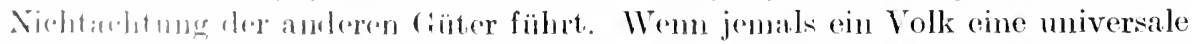
Kolturbegabmeg besessen hat, so war es grewils das Griechentum, und doch vermorhto anch diese Nittion nicht die: ginze Bürde der Kultur za tragen. 
Die Besten und Schönsten dieses Volkes haben der Philosophie, der Kunst und einer weisen Gesetzgebung ihr Dasein geweiht, ohne mit gleicher Höhe der Auffassung das religiöse und sittliche Leben zu bilden und zu formen. Groß und bedentend war auch hier ihre Leistung, doch vor allem groß die künstlerische und philosophische Tat, und wie vermöchten wir an diesem Tolke den Mangel der Ungerechtigkeit und Schwäche zn tadeln, weil seine Schönheit nicht imstande war, die ganze Welt der Kulturwerte zu ertragen!

Gegenüber diesen Vorstellungen und Vorurteilen des modernen Külturbemußtseins muß die Philosophie immer wieder die Blicke auf clas. Ganze richten und, soweit wie das möglich ist, die zeitlich bedingten Wertungen zu überwinden suchen. Sie tut das aber, indem sie prinzipiell den Standpunkt der absoluten Geltung und Gleichwertigkeit der Kulturwerte vertritt. Das ist die eigentümliche Position, mit der die Philosophie an das historische Geschehen herantritt. Die Kulturwerte gelten unabhängig von der Anerkennung eines Zeitbewußtseins. Wenn etwa die Aufklärung in ihren radikalen Erscheinungen den religiösen Wert rollkommen gelengnet hat, so ist dadurch dieser Wert selber nicht im geringsten geschädigt. Er kann die Bejahung enthehren, er ist unabhängig ron ihr, aber die Bejahung kam des Wertes nicht cntbohren, sie ist abhängig ron ihm. Eine Philoscphie, welche die Werte himimmt, wie sie das Zeitbewußtsein erfaßt. steht so sehr in der Zeit, daß es für sie unmöglich ist. in irgendeiner Weise über die Zeit hinausukommen. Eine solche Philosophie, die man in engerem Sinne als Kulturphilosophie bezeichnen kann, will uur die Motive und Wertschätzungen der eigenen Zeit deutlich machen. Sie gibt das Bild einer bestimmten Zeit. Sie erläutert und rerdeutlicht ein bestimmtes Kulturbewußtsein und kann unter Lmständen zur genialen Interpretation dieser Epoche der historischen Entwicklung führen. In einer solchen Philosophie will das BewuBtsein einer Zeit sich selber begreifen und verstehen. Durch sie können wir zum schönsten Geschichtsrerständnis gelangen. wie das zum Beispiel die Philosophie der Romantiker beweist, aus der wir ablesen können, was dem damaligen Zeitalter vor allem als wertroll gegolten hat. Für eine solche Philosophie bleibt es immer charakteristisch, daß hier der Begriff in den Dienst des Kulturverstehens gestellt wird. nicht aber rom Kulturgeschehen her der Weg zum Transzendenten und Uhersinnlichen gesucht wird.

Kann nun die Philosophie die zeitlose Geltung der Werte beweisen? Einen eigentlichen Beweis hicrfür kamn sie nicht führen. Sie kann die abcolute Geltung der Werte nur wahrscheinlich machen. Ihr Ausgangspunkt aber wird im sime erkenntnistheoretischer ṫberlegungen immer die Wis-enschaft sein. Sie wird zeigen, daß eine wissenschaftliche Erkemntnis ohne Anerkenmung des Wahrheitswertes sinnlos ist, und wird damn zuerst die logisehen Formen entwickeln, in denen der Wahrheitswert im Verhältnis zn einer bestimmten Materie sich darstellt. Hat sie das Gebiet der wissenschaftlichen Erkenntnis durchmessen, so wird die Philosophie zu zeigen suchen, daß die Dentung der wissenschaftlichen Erkenntnis noch kein abschïießendes Weltbild geben kam, daß aber die Reflexion jetzt mit aller Tacht anf andere Probleme gezogen wirl, die an der Peripherie der wissenschaftlichen Erkenntnis anftanchen. daB die Probleme der wissenschaftlichen Erkenntnis zu den Problemen der Sittlichkeit. der Kunst und Religion hinleiten. dab ein unverstandener Rest in der sphäre 
des Theoretischen zuriickbleibt, der nur in einer anderen Wertsphäre erläntert und rerdentlicht werden kann. So sehr nun aber anch die Philosophie bemïht sein wird. den notwendigen Znsammenhang der Kulturgebiete zu zeigen, so wird sie doch anch wieder mit aller Entsehiedenheit anf den unversöhnlichen Gegensatz der Kulturwerte hinweisen und dadurch ein für allemal mit dem Irrtum anfrämmen, daß ein Kinlturwert, wie etwa die Religion, dureh einen anderen Kulturwert ersetzbar sei und in ihm aufbewahrt werden könnte

\section{e) Verhälnis der absoluten Werte zu den Kulturwerten.}

Fnd nmm wollen wir sehen, wie das Verhältnis der absohuten Werte, von denen die Philosophie handelt, und die wir als das Wahre, das Sittliche, das Sehöne muldas Heilige bezeichmen, zu den Gebilden rler Philosophie und Wissenschaft, des politiseh sozialen Lebens. des Rechtes, der Kunst und dex Religion zu denken ist.

\section{Wissensehaft und Wahrheit.}

Wir wisen nicht, wer es wohl gewesen sein mag, dessen Geist zucrst einem (s) hohen Wug tat, daß er den Begriff der Wahrheit fand. Wir meinen hier nicht Wahrheit im Simne der Wahrhaftigkeit oder Aufrichtigkeit. eine Norm des Redens und des Handelns, die für unser sittliches Leben bedeutungsroll ist, wir denken hier an den rein theoretisehen Begriff der Wahrheit, den höchsten Begriff der Philosophie, dem unsere theoretische Leistmng ewig zugewendet, ewig fern bleibt. Ein hoher Aufschwung des Geistes muß es gewesen sein, der zuest zu diesem Begriffe hingeführt hat. Wenn wir ein Wort suchen, um das Göttliche zu bezeichnen. so ist der Begriff der Wahrheit vor allem geeignet, das höchste Wesen zu nemuen, weil a' anf allen Kulturgebieten seimen Simn behäl. Jeh kann von dinel whren Erkenntnis spreehen und ebensogut aueh in ïhertragenem simm ron einer wahren Gesimnme, einer wahren Kunst mul riner wahern Religion. Wemn nach dem Wertempfinden des Griechentums wohl der Begriff des futen ror allen anderen geeignet war. Gott zn nemnen,

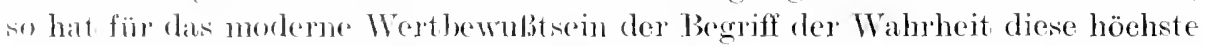
mal heiligste Borlentrung crlangt. Ind wenn wir ms über seine Bedentung klar zu werden suchen. so sohen wir hald ein, dab as ummöglich ist, den Begriff lex Wabrheit zu defunieren, weil jede Defunition als solebe ein Satz, ein Urteil

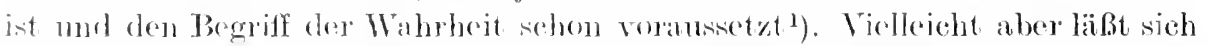

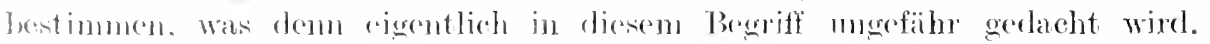

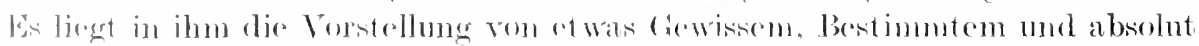

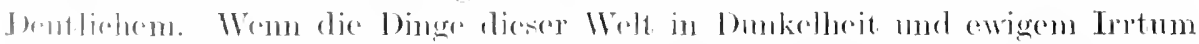

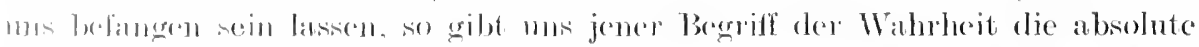

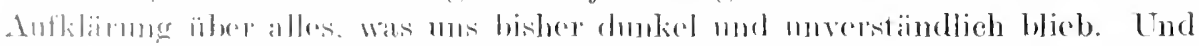

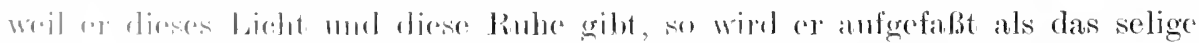

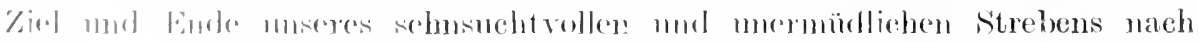

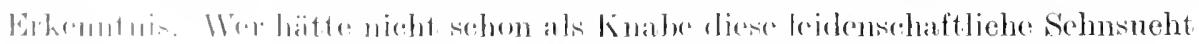

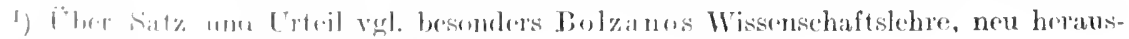

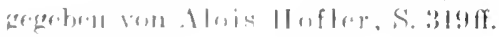


empfunden, ein Wissender zu sein? Wir haben die Hoffnung, daß unsere schwachen und für die Tiefen des Lebens blinden und verschleierten Augen dann plötzlich aufgetan werden, daß sich des Lebens Rätsel und die eigentümlichen Verkettungen menschlichen Schicksals lösen, daß wir das ,Wozu" unseres Daseins erkennen und wissen. Warum diese Welt so gut und so böse, so schön und häßlich, so sinnvoll und so simnlos ist. Anf all diese Fragen erwarten wir Antwort von der Wahrheit, die ïber alle Dirge herrscht und ihr Dasein bestimmt. Diese ewige Wahrheit, die nuabhängig st von aller Zeit, dieimmer gegolten hat und immer gelten wird, werden wir sie jemals ganz erreichen, oder wird uns nur beschieden sein eine kleine Amnäherung an ihren großen. für sterbliche Menschen unfaßbaren Sinn?

Wahr ist in erster Linie immer ein Satz oder ein Lrteil. Das Urteil will die Wahrheit und ist ohne sie vollkomenn sinnlos und unverständlich ${ }^{1}$ ). So haben es alle ernstgemeinten Urteile immer mit der Wahrheit zu tun, mögen sie mun wahr oder falsch sein. Einige Urteile aber stehen der Wahrheit näher und haben etwas von ihrem Sinn erfaßt. Das Gemeinte, was sie behaupten, ist wahr. Eine Aufgabe der Erkenntnis ist gelöst worden, ein Teil des mendlich großen sinnrollen Zusammenhanges der Dinge ist zu einem menschlich Verstandenen geworden. Das Gebiet aber des theoretisch Verstandenen und Begriffenen ist vor allem die Wissenschaft. Nicht immer dienen die Urteile des Lebens der Wahrheit. Hier gibt es Sätze, die um der Schönheit und um des Vorteils willen mit lächelndem Nunde gesprochen werden, sätze ohne Gewicht und mutigen Ernst. Sie sind das flüchtige Geschöp̣f des Augenblickes und wollen gehört und rergessen sein. Aber die Wissensehaft ist jenes Reich des ernst. haften Wägens, des sorgsamen Forschens und Prüfens. Wo jedes Wort und jeder Gedanke nach der Ewigkeit hintönen und hinklingen soll.

Die Wissenschaft ist etwas Gewordenes, die Wahrheit nicht. Wissenschaft ist menschliches Werk und menschliches Tum, ist eine Leistung menschlichen Strebens. Erst solange es Menschen hier auf Erden gibt, kann ron Wissenschaft die Rede sein. Die Wissenschaft will sich der Wahrheit bemächtigen. Sie will wissen, wie alles ist in Wirklichkeit und in Wahrheit. Wäre die Wahrheit etwas Gewordenes, damn wäre der Mensch der Schöpfer der Wahrheit. dann hätte er die Wahrheit erfunden, sie wäre eine Idee, die er' in der F'reiheit seiner Phantasie gebildet hätte. Demn so ist die Grenze des Menschen gezogen, daß er immer mur dam Schöpfer ist, wenn er Verzicht leistet auf die Wirklichkeit, die Wahrheit ist aber mit dem Gedanlien des Wirklichen unzertrennlich rerbunden. Das Wirkliche hat seine Wahrheit im Gegensatz zu den Schöpfungen der Phantasie auf dem Gebiet der Kimst und auf rlem weiten Felde der Illusion. Die Illusion ist der Wissensehaft Feind, die Illusion, welche die Liebe liebt. Die Wahrheit umsehließt und umklammert das, was war oder ist oder sein wird, was geschah, geschieht oder geschehen wird oder doch eine notwendige Beziehung zur Wirklichkeit hat. Es ist num einmal der Wissenschaft nicht gegeben, dieses Wirkliche als Ganzes zu rerstehen und zu deuten. Sie muß immer der Philosophie dieses Ganze zur Simndeutung überlassen und den Ter. such machen, anf dem Wege einer bestimmten Begriffsbildung der Wirklichkeit

1) Vgl. hierzu besonders Rickert: Gegenstand der Erkenntnic. 
zu nahen. Die Wissensehaft setzt an die Stelle des Wirklichen einen Urteilszusammenhang. einen Begriffszusammenhang, und dieser hat, wie die Erkenntnistheoric zu zeigen vermag, eine notwendige Beziehung zur Wirklichkeit und somit auch seine Wahrheit. Es ist ein fortgesetzter Prozeß der Umbildung und L'msetzung, den die Wissenschaft rollzieht, indem sie das Wirkliche in ihre Sprache der Begriffes zu übertragen sucht. Nehmen wir an, die Wissenschaft wäre am Ziele. die Wissensehaft in ihrer Vollendung hätte die ganze Wirklichkeit in Begriffe umgesetzt. Dam hätte dieser gewaltige Urteilszusammenhang gewiß seme Wahrheit. Aber das Ganze ist geschrieben und gesprochen in der sprache des Begriffes als der sprache mensehlicher Erkenntnis und kann nur ein endlicher Ausdruck für das Ewige und Unendliche sein.

So ist der Urteilszusammenhang der Wissenschaft nur ein Äquivalent für den wahrhaftigen Zusammenhang des Wirklichen. Das Wirkliche ist hier auf eine endliche Weise, d. h. in der alstrakten Form des wissenschaftlichen Begriffes ansgedrückt und rorhanden. Die Wirklichkeit in ihrem Reichtum kamn nur zum geringen Teil in die sprache des Begriffes eingehen, und das Unendliche ist beschränkt und getrübt durch die Formen der endlichen Reflexion. Wemn aber anch dieses zugegeben werden mul um der Wirklichkeit willen, die unserer mensehlichen Einsicht und Erkenntnis überlegen ist, so müssen wir doch gleich hinzufügen, daB der Kampf, den die Wissenschaft um die Wirklichkeit führt. durchaus nieht den Charakter eines hoffnungslosen und rergebliehen Beginnens an sich trägt. Wird auch die Wissenschaft nicht die ganze Wirklichkeit und die ganze Wahrheit erreichen können, so wird sie doch dieses Zugest änduis könnenì wir vielleicht derWissenschaft machen - das Wesentliche des Wirkliehen und seiner Wahrheit, jener, Wahrheit an sich", von der Bulzano sprieht, dio tejweise noeh nie gedacht ist und teilweise auch nie sedacht werden wird, in endlicher Form mehr und mehr sich zu eigen machen. Was sie nicht auf einmal haben und besitzen. anch nicht voll und ganz sich zu eigen machen kamn, das wird dem uncndlichen Prozeb der wissenschaftlichen Erkenntnis anheingegeben. 1 m allmählich und teilweise in der mensehlichen lieflexion dargestellt zu werden.

Wir minsion also dem Wirklichkejtsusammenhang in semer Wahrheit als Inhegriff von , sätzen an sieh". den nur das (qütlliche weib und versteht, droll loteikzusammenhang entgegenstellen, der in der wissensehaftlichen Retlexion grogenen ist. Allerdings kann der Begriff ejnes Zusammenhanges

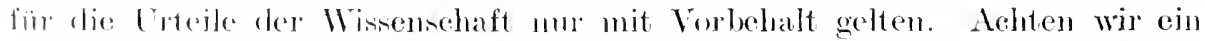

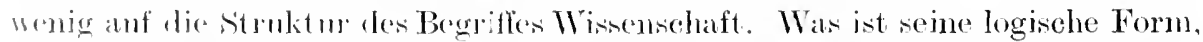

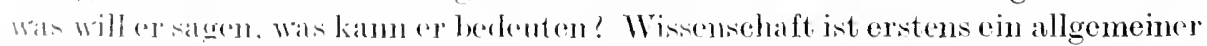

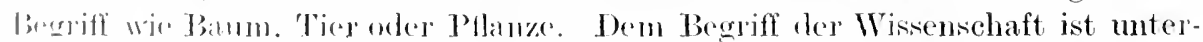

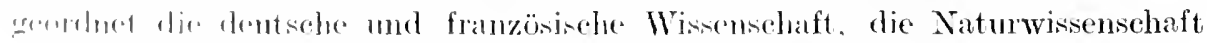

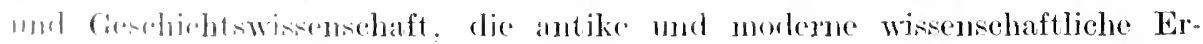

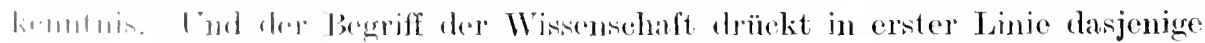
at1- Wan allend lieren mamigfaltigen Formen des wissensehaftliehen Lebens

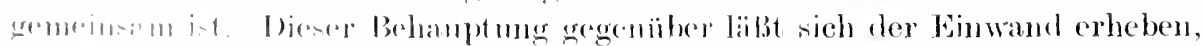

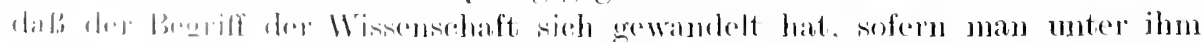

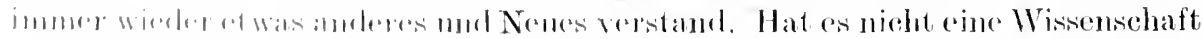

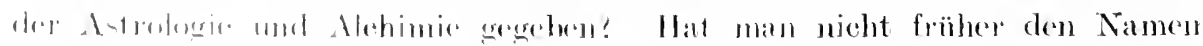


der Wissenschaft auf menschliches Tun und menschliche Benchäftigung angewandt, die nach unserer modernen Auffassung nicht nur unwissenschaftlich. sondern sogar wissensehaftsfeindlich war? End dennoch hat sich der Begriff der Wissenschaft mit immer größerer Festigkeit herausgebildet, und es besteht zu unserer Zeit nicht mehr so sehr die Gefahr: daß das Unwürdige mit diesem ehrwürdigen Namen genamnt wird. Was für den Begrift der Wissenschaft nummehr merläBlich ist, das ist dieses, daf sie einen gesicherten und zuverlässigen Weg der Erkenntnis aufzuweisen vermag. Ohne Methode keine Wissenschaft, und je strenger, präziser und exaliter die Methode, je geringer an Zahl und je evidenter die Propositionen sind, ron denen her der Treg zur Erkemntnis des einzelnen herabführt, um so höher ist der Rang der Wissenschaft. So kömmen wir doch etwas aufweisen, was als gemeinsames Kennzeichen alles wissenschaftliche Leben charakterisiert: die Methode. und die Methode ist es anch, durch welehe die Wissenschaft, wie wir noch näher sehen werden, mit der Wahrheit und den Wirklichkeitsusammenhang verbunden ist.

So ist das Methodirche recht eigentlich jenes Allgemeine, das in den einzelnen Formen des wissenschaftliehen Lebens sein besonderes Dasein gewimnt. so etwa in der Historie eine andere Gestalt annimmt wie in der National. ökonomie. Aber der Begriff der Wissensehaft ist nicht damit erschöpft. da f.j wir in ihm einen allgemejnen Begriff ror uns haben, der in eine Mamigfaltigkeit besonderer Arten zerfällt. In dem Begriff der Wissenschaft steckt noch eine ganz andere Art des Allgemeinen, die wix als die Allgemeinheit des Ganzen im Verhältnis zu seinen Teilen bezeichnen. Es ist das die historische Allgemeinheit im Gegensatz zn der naturwissenschaftlichen. Einerseits ist die Wissenschaft etwas, was sich über die Zeitlichkeit erhebt und das zu allen Zeiten Gleiche zum Ausdruck bringt, und damn bedeutet die Missenschaft auch wieder einen Zusammenhang. ein gegliedertes Gefüge, das mehr oder weniger mit der Zeit rerflochten ist. Wir sagen mehr oder weniger. demn der Begrift dieses Zusammenhanges wissensehaftlicher Trteile kamn seh' verschieden gedacht werden. Soll dieser Zusammenhang, so könnte man etwa fragen, alles das umfassen, was jemals im Geist der Wissenschaft gedacht und gewollt ist? Sollen wir überall dort Wissenschaft konstatieren, wo das menschliche Erleben jemals ron dem Geist und Sim dieses Wertes in zweckvoller Weise erfüllt war, oder sollen wir auch dort sogar von Wissenschaft reden. wo ungewußt und ungewollt die Erfüllung der wissenschaft. lichen Forderung in irgend einer Weise sich rorbereitet hat?

Ich glaube, wir werden unter Wissenschaft immer cin bewist gewollten Tun und Erkenntnis im Sime einer lichtrollen Retlexion über die selbstgewählten Gegenstände des Wissens verstehen. Deswegen scheidet das dunkle Tasten nach Erkenntnis und das ungewollte und ungesuchte Finden des wissenschaftlich Bedeutsamen aus dem Begriff der Wissensehaft ans. Wir rerstehen also jetzt unter Wissenschaft alle jeren ungeheuren Erlebnisusammenhänge, die in der Zeit sich gebildet haben, durchkreuzt ron mancherlei anders orientierten Erlebnisgefügen, in denen in zweckroller, zwecksetzender und hew'uster Art der Wille zur Wahrheit und zum Sein der Frkenntnis in einer gewissen ordnung und im methodischen Fortgang sich offenbarte. Dieser ungehene, 
vielfach $z^{+} 1^{\prime} k$ hïtete Zusammenhang des menschlichen Erlebens, der unmittelbar in die Zeit hineingestellt ist mit der Seligkeit des erreiehten Zieles, mit dem Zweifel. der zwischen versehiedenen Möglichkeiten der Lösung hin und wieder geht, und der Terzweiflung, die keinen Rat mehr findet und keinen Weg mehr sieht, aus diesem Meer des Irrtums aufzutauchen, umfaßt das Wissen, wie es in der Zeit lebt und in rastloser Tätigkeit und unermüdlicher Arbeit seinem Ziele zugewendet ist.

Von diesem Zusammenhang des wissenschaftlichen Lebens müssen wir (-inen anderen wissenschaftlichen Zusammenhang abheben, der weit abstrakter und nicht so unmittelbar lebendig ist wie die Wissenschaft, von der zuvor die Rede war. Ich meine den Zusammenhang der wissenschaftlichen Resultate, wie er in den wissenschaftlichen Werken niedergelegt ist als die reife Frucht dieses ungeheuren Strebens und nimmer müden Tuns. Dieser Urteilszusammenhang lebt nicht mehr ummittelbar in der Seele des Schaffenden. Er hat sich abgelöst von ihm, ist gleichsam objcktiviert und hat ein selbständiges Dasein gewonnen. Zum Leben kehrt er erst dam wieder zurück, wenn der Geist des Verstehenden aus den toten Buchstaben den ewig lebendigen Sinn ergreift und ihn in den eigenen Erlebniszusammenhang einbezieht. Aber auch hier läßt sich wieder unterscheiden, indem unter dem wissenschaftlichen Zusimmenhang entweder alle wissenschaftlich bedentsamen Werke verstanden werden in den mancherlei Beziehungen, die zwischen ihnen bestehen, mögen diese Werke anch noch so veraltet scin; das wäre ein für die Historie durchaus branchbarer und notwendiger Begriff von Wissenschaft. Oder aber man faßt den Begriff der Wissenschaft enger, trifft eine Auswahl und wirft manehes beiseite, indem man wieder den Begriff einer le bendigen Wissenschaft geltend macht. Jan wird etwa sagen, daß manche wissensehaftliche Werke sich ïberleht haben und fïr die gegenwärtige, die moderne Problemstellung keinerlei Borloutung mehr besitzen. Diese alten Bücher sind tot und nicht mehr hesecelbal. Dagegen ist in den anderen whrhaft wissenschaftliche Erkenntnis niedergelegt. Der Begriff aber, durch den diese Auswahl wissenschaftlicher Frkenntnis zusammengefïgt wird, ist das wissenschaftliche Idealbewußstsein der fiegenwart, von dem alle rege Tïtigkeit der gegenwärtigen Arbeit mit freudigem Schimmer ausstrahlt. Während der vorige Begriff der Wissenschaft schou relatir der Zoit entronuen zu sejn schien, kehrt der jetzige Begriff, der so stark von dem Moment der Gogenwart affült ist, ganz angenscheinlich in sröberem Umfange wieler zur Zeit zurück.

Lis gibt abey noch rinen lotzten Begriff des wissensehaftlichen Zusammenhauger, drer vom der Bezichung zur Zoit gänzlich orlöst ist. Das ist der idealo Zusammenhang der wissenschatiehen Lrteile, wio ihn der vollendete Stand

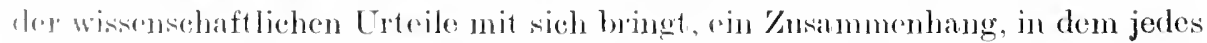

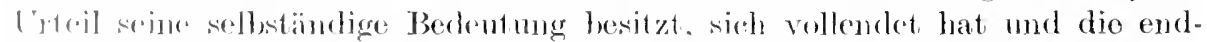

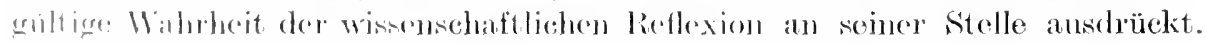

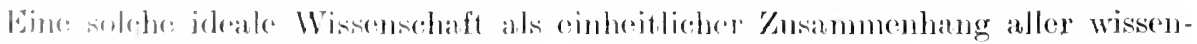

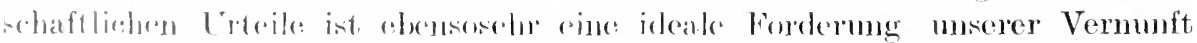

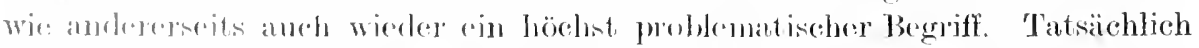

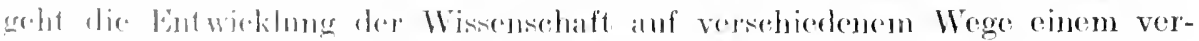

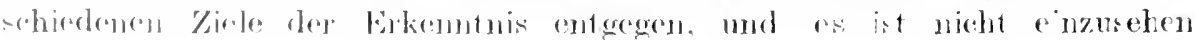


wann der ideale Lrteilszusammenhang einer miversalen Wi-senschaft jemals ereicht sein soll.

Der Begriff der Wissenschaft bedeutet somit, wie wir gesehen haben. 1. ein Allgemeines im Sinne des naturwisenschaftlichen Gattungsbegriffes, das Methodische ist das Gemeinsame und Gleiche in all den varchiedenen Formen der wissenschaftlichen Arbeit, und 2. ein Ganzes. einen Zusammenhang ron Urteilen, dessen logische Struktur sich mehr oder weniger won dem zeitlichen Gebundensein abhebt. Aber damit ist die logisehe Form rlieses Kulturbegriffes Wissenschaft noch nicht erschöpft. Wir müssen hinzufügen, dals der Begriff der Wissenschaft ein Wertallgemeines ist im Gegensatz etwa zu dem Begriff des Gravitationsgesetzes oder des Säugetieres, daß sich hier mit dem Gedanken des Allgemeinen und Ganzen der Wert verbindet. so daß wir ein Wertallgemeines oder ein Wertganzes ror uns haben.

Und so stehen sich nun diese beiden gegenüber: das Wahre. das ewig galt und gilt, das mit dem Begriff des Wirklichen unablöslich zusammenhängt, und der Kulturbegriff Wissenschaft als ein Crteilszusammenhang, der in seiner Formierung fortgesetzten Veränderungen in der Zeit mterliegt, aber als ein Wertallgemeines oder Wertganzes doch eine notwendige Relation zu den absoluten Werten besitzt. Diese Beziehung müssen wir noch deutlich machen, denn unsere Frage lautete so: wie rerhält sich der absolute Wert, von dem die Philosophie handelt, und speziell der Begriff der Wahrheit zu dem Kulturwert, der uns in der Geschichte entgegentritt und speziell auch zu dem Kulturbegriff der Wissenschaft? Der Zusanmenhang des Wirklichen, der durch den Begriff der Wahrheit bestimmt ist, gilt ron jeder menschliehen Anerkemnung und bedarf zu seinem ewigen und unveränderlichem Sein der Tätigkeit und der Handlungen der Menschen nicht. Wissenschaft ist dagegen ohne menschliche Tätigkeit nicht denkbar, Wissenschaft bedentet die zeitliche Verwirklichung ewiger Wahrheit. Alle wissenschaftliche Betätigung rollzieht sich in der Zeit, und auch das Resultat, die wissenschaftliche Leistung, die den Anspruch auf überzeitliche Bedeutung erhebt, bleibt immer das in der Zeit Verwirklichte, dasjenige, was durch die Zeit hindurchgegangen ist und aus dieser Beziehung zur Zeit niemals ganz erlöst werden kann. Die Wahrheit und Wirklichkeit gehört dem Reiche des reinen Geltens an, die Wissenschaft aber der Sphäre dessen, was sein soll. Wissenschaft ist diejenige Form der Wahrheit. die menschlichem Erkenntnisstreben zuteil werden kann.

Stehen so diese beiden, Wahrheit und Wissenschaft, einander gegenuber wie das aller Zeit entrückte ewig Geltende. von aller menschliehen Tätiglieit Freie und Unberührte und das an die Zeit Gebundene, durch menschliche An. erkennung Konstituierte, durch menschliche Tätigkeit Verwirklichte. so ist das so weit Getrennte doch anch wieder eng rerbunden, sofern die wissenschaftliche Erkenntnis durch die Wahrheit und die Formen des Wirklichen begrüudet ist. Wenn wir die Wahrheit denken wollen. so dïrfen wir nicht die Torstellung haben von etwas Dunklem und Cnbestimmtem wie etwa in der religiösen Forstellung das Göttliche erscheint, vielmehr werden wir immer darauf hingewiesen. die Wahrheit und das Wirkliche als die Einheit einer gegliederten Mannigfaltigkeit zu denken. Alle Wahrheit ist srnthetische Einheit einer Mamigfaltigkeit. Die Wahrheit ist werler das Homogene. das der Mannigfaltigkeit 
entbehrt, noeh die Mannigfaltigkeit, die bloße Menge, die der Einheit entbehrt. Wahrheit bedentet einheitliche Ordnung und Gliederung der Mamnigfaltigkeit, und das Prinzip dieser Gliederung nemnen wir Form. Mannigfaltig sind die Formen der Wahrheit. die den verschiedenen Teilen des Wirklichen zucewendet sind. Identität und Verschiedenheit, Kausalität und Inhärenz, Sein und Werden. Räumlichkeit md Zeitlichkeit, sie sind in ihrer eigentümlichen logischen Bestimmtheit immer einem besonderen Material zugewendet. so bestimnt etwa die Wahrheit das Wirkliche duch den Begriff der Kausalität. Das will heißen, das Wirkliche soll kausal verbunden gedacht werden. Jede Retlexion. dic auf das Unirersum sich richtet und bei ihrem Versuch, das Wirk. liche zu erfassen, ron diesem Prinzip keine Xotiz nimmt. muß unbedingt zu einer falschen Auffassung des Seienden gelangen. Notwendig muß das Prinzip der Wahrheit in der wissenschaftlichen Reflexion in den Formen der Methode sich darstellen. So erscheint z. B. das allgemeine Vernunftprinzip der Kausalität, diese Kategorie des Wirklichen in der naturwisenschaftlichen Methode als Cresetzesbegrift. Jan kam somit sagen, daß die Wissenschaft, deren logisch Allgemeines dic Methode war, durch die rerschiedenen Formen der Methode mit der Wirklichkeit und der Wahrheit verbunden ist, sofem dieiWahrheitsforn des Wirkliehen in der einzelnen Wissenschaft diese besondere Gestalt gewinnt und etwa der naturwissensehaftliche Gesetzesbegriff in der Kausalität iuberhaupt als seiner allgemeinen Wahrheitsform begründet ist. Und ähnlich nun, wie sich die methodologischen Formen der Wissenschaften zu den Formen des Wirklichen, den konstitutiven Kategorien verhalten, verhält sich schließlieh auch ler Begriff der Wissenschaft überhaupt zu der Idee der Wahrheit. Die Geltung der Wisensehaft ruht in der Wahrheit, und in der Wissensehaft bat die Wahrheit eine bestimnte Gestalt gewomnen. Die Wertbetontheit, die auf allen ihren Urteilen liegt, das Moment des Geltens oder des Geltensollens int ein Zeitliches und Ewiges. das die mermeBliehe Leistung rollzieht, das Substrat unsers monschlichen Tuns mit dem Göttlichen zu rerbinden. Frst so (rhält der Begrift der Kultur jene Würde, dic ihm in ganzen Zusammenhang unserer Meltanfinsing notwendig zukommen mub. Die Kultur ist weder cinc rein götliche noch eine rein mensehliche Angelegenheit, aber sio int der Treffounk ewiger Weste mit zielbewubem manshlichron T'un.

\section{Kunst und șehönheit.}

[ind wio die Waluheit als der höehste theoretinehe Wert das Gewand

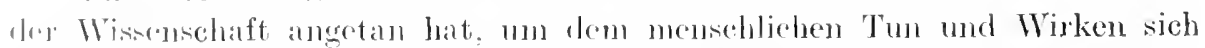

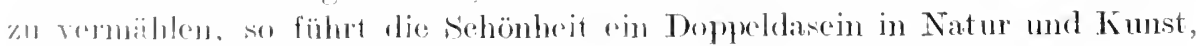

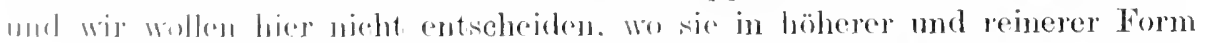

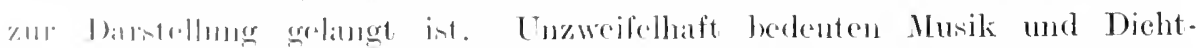

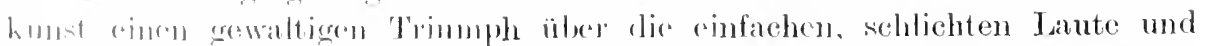

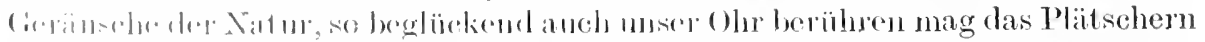

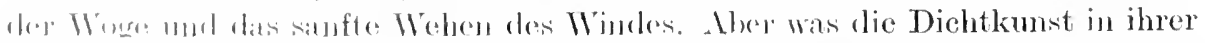

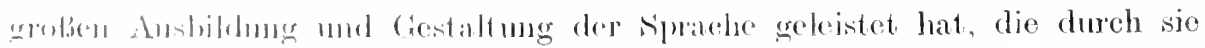

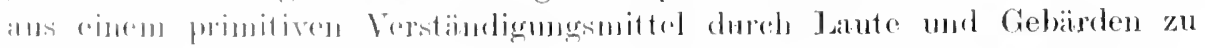

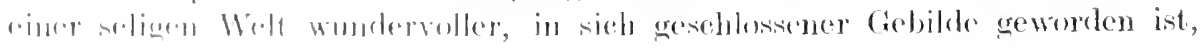


umhüllt von dem Wohlklang flutender Rhythmen und der Verse weiehem tönenden Klang, durchdrungen von der symbolisch verklärten Idee, die an das Geheimnis der Welt zu rühren scheint, das ist ein Sieg der Kunst über die Natur, wie er ähnlich nur noch in der Musik zum Ausdruck gelangt, wo das störende und rerwirrende Geräusch, durch das Maß der Harmonie gebändigt, die schöne Welt der Töne hervorgezaubert hat. Zweifelhafter erscheint der sieg der Kunst gegenüber der Natur auf dem ganzen Felde dex bildenden Kunst. siegreich steht der stille schöne Tempel in Segesta gegenüber Siziliens wilden Felsenbergen da. Und doch ist es wohl der Arehitektur versagt, in dem Großen, Gewaltigen und Erhabenen die Satur zu übertreffen. Wam hätte sie auch den Versuch gemacht, Piesenpaläste zu bilden. zu denen der Arco naturale und die wilden Klippen, die ihn ungeben, als Fassade dienen kömnte? Und vollends auf dem Gebiet der Skulptur und der Malerei scheint dieser Sieg zweifelhaft zu sein. Der Skulptur ist es gegeben, den menschlichen Körper in seiner Form am rollendetsten wiederzugeben, aber ihr fehlt der Reiz der Bewegungr in dem sanften Spiel der Muskeln. ihr fehlt die zartgetönte Mannigfaltigkeit in der Farbe der Hout und vor allem der Glanz des Anges in reinem schönen Lenchten. Die Nalerei dagegen kann uns nur alnen lassen die Bedentung der Form durch die Sehönheit ihrer Linienführung, dagegen hat sie Macht und Gewalt über Austruck und Blick und über Reiz und Schmelz der Farbe. Das gerade ist das Eigenartige der Kunst, daß sie in ihrer hohen Harmonie doeh immer zerklüftet bleibt, daB ihr durch das Material gewisse Grenzen gesetzt sind, welche ihre Möglichkeit so beschränken, daß es ihr immer nur gegeben sein kam, in einer gewissen Richtung die Natur zu übertreffen, niemals aber ganz und in jeder Beziehung. Das Gesantkunstwerk bleibt eine Forderung, die niemals erreicht wird, die Idee der Kunst rollendet sich immer nur in der Begrenzung.

Wenn nun die großen Meisterwerke der Skulptur und Malerei in einer gewissen Hinsicht mehr zu bedenten scheinen als dic Natur, und der Apollo Sauroktonos schöner genamnt werden darf als der schönste unter den griechischen Jünglingen, der jemals gelebt und geatmet hat, so ist dieses Mehr des großen Kunstwerkes gegenüber der Natur durch die tiefsimnige Symbolik des Küunstlers hervorgebracht, der das Ewige und Zeitlose, die ästhetisehe Idee in den Marmor hineinbildet. Wenn daher die moderne bildende Kunst in mancher ihrer Erscheinungen zu einer ideenlosen geworden ist, so hat sie damit zugleieh auch endgültig darauf verzichtet, im Sehönheitskampf über die Natur den Sieg davonzutragen.

Das macht also zunächst eimmal das Charakteristisehe des schönheitswertes aus, daß er eine doppelte Verwirkliehung, eine Terwirklichung in zwei Sphären findet, in der Welt der Natur und in der Welt der Kunst, so daB die kritische Philosophie im Verhältnis zu ihm auch dementsprechend zwei Fragen zu beantworten hat, nämlich 1., wie ist schöne Natur möglich, und 2., wie ist schöne Kunst möglich ? $\left.{ }^{1}\right)$ Der Begriff der Schönheit hat also nieht nur in dem Kulturwert der Kunst Gestalt gewonnen, sondern ihm gehört noch ein anderes Gebiet, das von mensehlicher Kulturtätigkeit unabhängig ist, ein stilles Peich,

2) Vgl. Kant: Kritik der Urteilskraft. Werke, Bd. V. Akademieausgabe. 
wo er verwiklicht sein kann, ohne daß die Tätigkeit des Mensehen bereits die große Bahn der Kulturentwickhng betreten hätte. Uns kann hier nur das Verhältnis des Schönheitswertes zur Kunst interessieren, sein Verhältnis zur Natur scheidet aus unserer Betrachtung aus.

Was die schönheit eigentlich sei, läßt sich niemals auf eine bestimmte Formel bringen, ich kamn diesen Wert in seiner transzendenten Abgesehiedenheit nicht beschreiben und definieren. Er bleibt ein Rätsel, ein undurchsichtiges Geheimnis. Ich kam immer nur anfweisen und aufzeigen. wo die Schönheit simnlich wirklich geworlen ist, und dann aus voller Überzeugung sprechen: „Siehe. hier ist Schönheit. was bedürfen wir weiterer Zengnisse“. Hier ist der Beweis geliefert, daß ein umbedingt Wertvolles gilt, daß ein unbedingt Wertrolles wirklich ist. Die simnliehe Schönheit, die wir erleben, ist der dentliehste und sichtharste Beweis ron der Wirklichkeit des Transzendenten.

Versuchen wir uns eine ganz allgemeine Torstellung ron dem Begriff der Schönheit zu machen. Wenn wir von Schönheit spreehen, so denken wir natürlich nicht nur an das klassische Ideal. Der Begriff der Schönheit ist sehr viel weiter als dieses, birgt Tausende von Möglichkeiten in sich. Anch jenes, was man wohl im Gegensatz zur Antike als das Charakteristische und Intressante bezeichnet hat, kann sehr wohl den Namen der Schönheit verdienen. Man soll aber nm nicht den Versuch machen, die Aufgabe der Kunst durch fälschliche Orientiermug an anderen Werten zu verwirren. Wenn ich den ästhetischen Wert am theoretischen orientiere, so kamn ich zu der Behamptung gelangen, daß es die Aufgabe der Kunst sei, die sinnliche Wirlichkeit so darzustellen, wie sie ist. Das ist die Forderung des Naturatismus gewesen, der als höchste Verständnislosigkeit auf dem Gebiet dor asthetischen Theorien hezeichnet werden kanm, und der doch praktisch in seinem Kample gegen gewisve Verstiegenheiten und Sentimentalitäten der alten sehulo Gutes geleistet hat. Das Sehwelgen in dem Phantastischen, Zauberhaften, sinnlich Tuwirkliehen und t'berwirklichen muß für die Kunst ebenso roxderblich sein wie die rücksiehtslose Hingabe an die Realität. Immer muldie Kunstrom simulieh Wirklichen in seiner Anschaulichkeit und Lebendigkeit zugewendet soin, immor muB der Künstler ron Leidensehaft und Enthusiamm erfüllt sein zu den schönen Körpern und Gestalten des Wirklichen, und doch darf er anch niemals jene andere Nelt aus den Augen verlieren, die seinem Schanen und Sehaffen erst die hoho Weihe gibt. Und so ist dio Kunst dasjenige Gelbiet. Wo das Sinnliche und das Tnsinnliche immer in gleieher Weise betont worden sollen, wo weder das Simnliohe dem Unsimnlichen noch das Cnsimnlicho dem Simmliehen anfgeopfert werten darf. Der Kïnstler jot vom rohen Gemubmensehen und rom lsketen gleich weit entfernt.

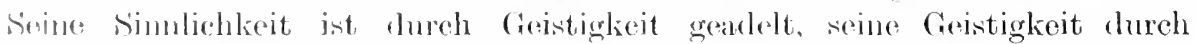

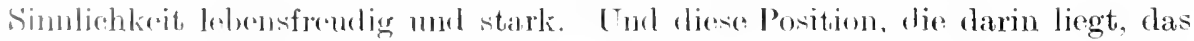

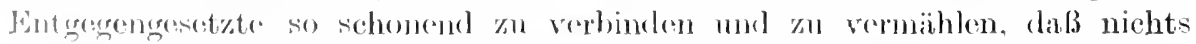

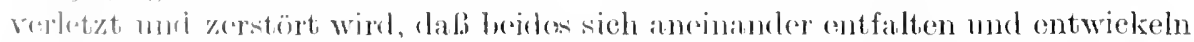
kann, las gilot dam für unsere mensehlicho Vorstellung den Begriff des Vollandreten. Wohl mö̈ren wir anf alen moralischen Mensehen mit Achtung und

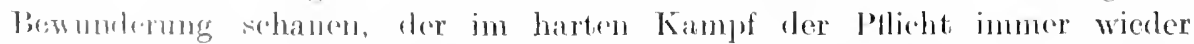

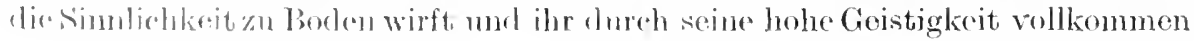


obzusiegen trachtet, aber unsere Liebe gehört dem ästhetischen Menschen, der beide Sphären zwanglos vereinigt und auf diese Weise nicht die Torstellung des Unvollendeten und Fragmentarischen wachruft, sondern in seiner eigenen Persönlichkeit sowie in dem, was er schafft, die Harmonie und den Frieden des Universums andeutet. Die Vorstellung der Schönheit und des Kunstwertes ist vor allem bestimmt durch den Godanken des in sieh Puhenden, sich selbst Genügenden.

Deswegen mußte aneh die Orientierung der Kunst an den moralisehen Werten zu herben Mißrerständnissen führen. Zur Natur des sittlichen Wertes gehört die ungelöste Spannung, hier muß das Sollen, die Fordernng immer im Gegensatz zum gegenwärtigen Zustand stehen, so daß das Sein nicht bleiben und beharren darf, sondern auf die Bahn des mendlichen Prozesses fortgetrieben wird. Die romantische Kunstheorie hatte ihrerseits recht, wenn sie erkannte, daß den Werken der Zeit die Tollendnng fehlte, was nichts anderes sagen wollte. als daß diesen Sehöpfungen einer unsicheren, schwankenden, neue Formen und Ausdrucksmittel suchenden Kunst dasjenige fehlte, was sie erst zu einem wahrhaften Kunstwerk großen Stils erheben komnte. Aber die romantisehe Kunstheorie hatte mrecht. Wenn sie den romantischen Sitil und die romantische Kunst als die Kunst des Unvollendeten und Fragmentarischen, die auf den mendlichen Prozeß hinleitet, der objektiven antilien Kunst gegenüberstellte. Alle große Kunst ist objektiv in dem Simme, daß sie selbständig und anf sich angewiesen ist, frei und abgelöst ron ihrem schöpfer, dessen intime Stimmungs- und Gefühlswelt in dem großen Werk sieghaft überwunden ist, frei und abgelöst aber auch von dem Beschauer, ron dem es kein Zntmm und Mithelfen verlangt, sondern nur Verstehen und Anerkennen. Bei ihrer Betonung des Fragmentarischen verzichtete die romantisehe Kumst anf den wahrhaft ästhetischen Wert. Wahrseheinlieh lag bei den romantischen Kumsttheoretikern eine gewisse V'erweehslung ron Form und Inhalt vor. Das Gefühl, das die Kunst damals zur Gestaltung hringen wollte, war das Sirammungsgefühl der Sehnsucht nach dem Wunlerbaren. Weil das stofflieh Gegenständliche antinomisch war, glaubte man anch die Form entsprechend wählen zu müssen, indem man meinte, daß gerade der Charakter des Unvollendetsein. einen neuen Typus in der Kunst abgeben könnte. Man beaehtete nicht, daß es zum Wesen des Kunstwerkes gehört, keine Anweisung mehr auf eine spätere Zukunft zugeben, sondern für sich, in schöner Vereinsamung eine kleine Welt zu sein. Jedes Kunstwerk ist eine Monade, die, für sich abgeschlossen. dureh nichts mehr beeinflußt wird und nicht mehr über sich himausgeht, oder wie jene aristotelisehe Gottheit , mmbekümmert $u m$ die Welt, selig in ihm selbst": Der interessante Begrifi der Ironie als Kinstprinzip muß trotz aller geistreichen Verteidigung der romantischen Schule als kunstfeindlich und kunstzerstörend aufgefaßt werden, nämlich deswegen. weil er das Kunstwerk dauernd an die Stimmungsqualitäten des Subjektes bindet und den Dichter das Kunstwerk nicht freigeben läßt. so daß das Kunstwerk niemals zur Ruhe kommt und immer ein anderes werden soll als es ist.

Das also ist des Schönheitswertes eigentümliehe Art, daß sich mit ihm der Gedanke der Isolation verbindet. In der Irlee der Sehönheit liegt der Gedanke einer seligen Finsamkeit. So hat Plato seinen Weltengott im Timaios ge- 
dacht, der, alles unfassend. keine Einflüsse mehr von außen erfährt und deswegen ewig jung ist und schön, nieht altern und und sterben kann. Es ist wohl nicht zufällig. daß wir mit der Kunst so gern den Gedanken des Jugendlichen unct "wig Gegenwärtigen rerbinten.

Weiter ent-steht sodam die Frage. ob sich das Schönheitsmoment lediglich mit der Form oder auch nit dem Inhalt verbindet, was zu der philosophisch nmmöglichen Unterscheidung zwischen Fomästhetik und Gehalts- und Beleutumgsästhetik geführt hat. Die Vertreter der Gehaltsästhetik stellten -ich in einen gewissen Gegensatz zu ler Ästhetik Kants, dem man in der miBrerstehenden Auffassmng seiner Lehre den billigen Vorwurf des Formalismus machte. indem man die Form als etwas ansah, das ïberhaupt keinen Inbalt und keine Bedentung hat. während doch im Gegenteil aller höhere Inhalt und alle Bedentung nur durch Form möglich und das Formlose gleichbedeutend ist mit dem Indifferenten und gänzlich Gehaltlosen. Die Anhänger der Formästhetik konnten damn zu der Behauptung kommen. daß der Inhalt gänzlich gleichgïltig sei, mol die Kimst infolgedessen alles darstellen kömnte, anch das Gemeine und Häßliche mut Ekelhafte, indem man sich ohne Schwierigkeit über die tiefsimnigen Cnternchmngen les Meisters hinwegsetzte, der im Laokoon die Möglichkeit des Darstellbaren und die Angemessenheit der Stoffwahl entwickelte. und zwar aus flen verschiedenen Darstellmgsmitteln der naeh dem Gesetz der Sukzession sich ausbreitenden Diehtkunst, die in der Handhung ihren würdigsten Gegenstand sieht, und der nach dem Gesotz des rämmlichen Zusammenseins geordneten Skulptur mul Malerei, der manches verboten ist, was jener offensteht. Mit einem gewissen Úbereifer stürzte sich die Kunst auf die Darstelhung des Widerwärtigen, um ihre Emanzipation von der Antiko darzutun und den Beweis zu liefern, daß die Souveränität des Kunstsehaffens anch aus dem Nichts, ja sogar aus dem Sehönheitswidrigen ein Kunstwerk formen kam. Anderseits rerlangten dic Gehaltsästhetiker, daß die Kunst nur solehe ()bjekte bilden sollte, die ein Moment des höheren Bedentens in sieh schlössen. Gegen den Kultus der Nichtigkeit und der bloßen Spielerei wendete sieh hier eine toilweise ron ernsthaftem Kumstsinn getragene ästhetisehe Úberzeugung.

Nou ist en leicht einzusehen, daß dieser ganze Widerstreit in der Hampsache loch auf einem ]hilosophischen Mißrerständnis heruht. Der Begriff der Form ist jedenfalls, vor allem in der Kumst, ein vieldentiger Begriff. Nehmen wir als Beispiel ein Drama, etwa Ibsens Rosmershoh. Was ist an diesem Drama Form, und was ist Lnhalt? Von Form in Simne der Verskunst kann hier nieht dio Rerle sein, dem die hat der I)ichter in soinem Drama versehmäht, um der Wirklichkeit näher \%u kemmen. Aber ist etwa die Prosa rlieses Dramas form los? Gerato das Gegenteil ist der Fall, wir haben es hier mit einer außerordentlich foin stilisierten Prosa zu tun. Die Eigenart des Auschucks, besonders in der gefofon Szene zwischen Rosmor mul Robecka ist so auBorordentlich, daB wir die sprache dieser Menehen nicht vergessen können. Wundervoll handhal, \%. P. der Diehter das kïnsterische Ausdrueksmittel der Wortwiederholung, und so sehon wir seine Mensohen, von dor Ahmug eines sehreeklichen lerhängnises argriffen, mürle unl ver\%weifhumgsvoll dio letzte Bestätigung for gransamon Wahtheit ausoinander herausholen, indem die letgtgesprochenen llorte des einen der ambere wioderholt, als mïbte er noch oin wenig anf ihnen 
auswhen und bei ihnen rerweilen, um sie in der ganzen Furchtbarkeit ihrer unerbittliehen Konsequenz zu begreifen. Und weiter ist Form der ganze Aufbau des Dramas in seiner wundervollen stejgrerung. und Form ist die eigentümliche Bildung und Gestaltung dieser Charaktere, dieser Mämmer und Fraucn in der unvergleichliehen Eigenheit ihres Wesens, und Form ist ror allem die tiefsimnige Srmbolik, die hinter dem Ganzen steht. Wie schwer ist das Leben zu tragen, wemn śchuld mud schicksal so mär.htig sind, daß über den hellen Mittag des Tages immer jene gespentinchen Wolken jagen, diese weiben Rosse ron Rosmersholm! Und so groß war Dein Wollen des Guten. Rosmer. und so schwer der Kampf, den die Leidenshaft mit einem stoken moralisehen BewuBtsein auszufechten hatte. Aher ob Thu nun wieger wler Be-iegter genannt werien mußt: wemn Du mit der Frau. die Du hurch Liehe zur schönheit gebildet, den Weg zmm hohen Steg des GieBbaches wandelst. niemant wird Dir. Du müder Lebensstreiter. seine Anerkemmung ressagen. Ruhe in Frieden. Rosmer, Du hast etwas Grobes gewollt: Adelsmenschen wolltert Du bilden!

Und num erimnern wir an jene Unterscheidnng, die wir in einem anderen Zusammenhang bereits rollzogen haben, als wir darauf hinwie-en. dab wir zwei versehiedene Arten ron Form merscheiden minsen. nïnlich erstenjene. die in der Diehtkmnst sthon im Rhythmus der sprache zum Ansdruck kommt, welche in der Ge-talt der Strophe, len Charikter de- Ver-es. in Bild und Metapher. in der Wahl de- Reimez. in Alliteration unl sprechtakt sowie in wer ganzen Technik des Aufhans zum Auslrutk kommt. Die-c Form ist immer mehr oder weniger abhängig zu denken ron der Zeit. lie -ie geschaffen. ron dem Lande, in demsie geworken. von der Volksindividhalität. die sieh in ihr zu enthüllen sucht. To besteht gewis ein imniger Zu-ammenhang zwischen dem Hexameter, der sapphischen Strophe und iter griechi-chen sprache und dem griechischen Tolke. und derAlexantriner offenhart das Zeitalter Lud wig s XII., und der Jambu ist vor allem die Form des dent-chen Verses. wöhrem die Stanze nach Italien und der Trochäms nach spanien hinzuweisen scheint. Alle diese vershiedenen Anstrucksormen. wie sie in Dichtkum-t. Musik und den bildenden Kün-ten zutage treten. weiven auf eine Formeinheit hin, die man am besten alsstil bezeichnet. S.) kömmen wir ron antikem Stil, ron romantischem Stil, vom realistischen und materialistischem stil, rom stil der Renaissance. des Rokoko, des Empire und Barock sprechen; immer int hier tie Wahl der künstlerisehen Ansdrucksmittel. rom Geist eines bestimmten lollses oder einer bestimmten Zeit erfüllt, und man liamn die Physiognomie einer Zeit an ihrem Kunststil ablesen.

schon diesem Formprinzip gegenüber besteht eine gewise schwierigkeit für jene radikalen Verehrer des l'art pour lart. die da meinen. w müs-e sich für alles, anch für das Widerwärtige und Ekelhafte irgendeine Form der Darstellung finden lassen. Diese radikalen Anhänger cines allgenteinen Formprinzips lassen sehon hier die große Tatsache ants den Angen, das alle wahre Kunst doch immer die Selbstarstellnng und (rfenbarmng einer Indiridualität sein muß. Dem feingebitheten grieehivenen Geiste wäre es ak eine Perrersität und Paradoxie erwehienen. dab der Freund des schönen im Wielerwärtigen und Ekelhaften sich darstellen und objektivioren -ollte. Dieser Wille zur Allgestaltung ist nur scheinbar ein Ansdruck der kïn-tlerischen Freiheit, in Wahr-

Mehlis, Geschichtsphilosoptie. 
heit rielmehr Willkür und Zwecklosigkeit, das Signum für einen atomistischen Individualismsus, der nieht mehr im Geist des Allgemeinen schaffen und gestalten will und deswegen, dem ureigensten Leben seines Volkes und seiner Zeit entfremdet, isoliert und heimatlos ist.

Aber weit größere Schwierigkeiten ergeben sich für die Freunde der Allgestaltung, wenn sie nunmehr auf den zweiten und höheren Begriff der ästhetischen Form blicken, den wir als die ästhetische Idee bezeichnen, die unabhängig von dem Charakter einer bestimmten Zeit und eines bestimmten Volkes, in rerschiedensten Stilformen erscheinen kann.

Eine solche ästhetische Idee ist auch in Ibsens Rosmersholm zu finden, wenn es auch ummöglich ist, diese Idee auf einen scharfen begrifflichen Ausdruck zu bringen. Man hat immer mit Vorliebe die individualistisch geformten Charaktere des morlernen Dramas der typenhaften Auffassung der Gestalten etwa in Schillers großen Dramen entgegengesetzt. Man pflegte wohl zu sagen, Wallenstein ist nicht eigentlich eine individualistisch durchgebildete Erscheinung, er ist der allgemeine Repräsentant des Realismus überhaupt, wie etwa Max Piccolomini den Typus des Idealismus darstellt. Dagegen sind Ibsens Charaktere von dieser vagen Allgemeinheit befreit. Ibsen will Menschen darstellen, wie sie wirklich sind, ein buntes Gemisch der mannigfaltigsten Eigenschaften werthafter und wertfeindlicher Natur.

Das ist bis zu einem gewissen Grade richtig, aber wir dürfen nicht vergessen, daß diese so außerordentlich kompliziert gebildeten Menschen des Ibsenschen Dramas auch ihrerseits Träger eines allgemeinen Sinnes sind, und dieser sinn ist die isthetische Idee. Wir wollen versuchen, dieser ästhetischen Idee uns mit einigen Worten zu nähern, sie ist das allgemein MenschJiche und ewig Geltende in diesem großen Kunstwerke. In Rosmer lebt eine mächtige sittliche Úberzengung von ungeheurer Kraft, die sich in Gegensatz stellt zu der kleinlichen und erbärmlichen Moral seiner Zeit. Er will ein neues, höheres Geschlecht, ein nenes, höheres Menschentum, die freien Adelsmenschen, die Träger einer höheren Sittlichkeit. Rosmer ist der Prophot eines neuen, höheren sittlichen Evangeliums. Und nun tritt er zu der Frau in eine nähere Lebensgemeinschaft, die mit der natürlichen Wildheit und Ungebmolenheit ihrer Instinkte den Mann ihrer Jiebe begehrt, lor an ein krankes Weib gefesselt ist.

Rosmer muß schuldig werden und Liebe mit Liebe erwilern, und die kranke Fran ist den Wog zum Gießbach gegangen und hat sich geopfert und ihn freigemacht. Welch ein tief tragriseher Konflikt! Und so ist das moralische Bewußtsein dem Sinnentrieh unterlegen? Doeh nieht so ganz. Denn indem es hexiegt wurde, hat es geschaffen und eine neue Walt aufgebaut. Aus dem primitiven Geschöpf ler Sime hat os einen sehönon Nensehen gebiletet, hat, - elber irrend und fohlend, das andere Bewubtevin geweekt. Auch der fehlende und irrende Rosmor hat das geloistet, was er wollte, einen Adelsmensehen sebildet, der den stolzen Mut hat, die Konsequenzen seiner Handlungsweise zu tragen, und sei es auch der bittere Weg des Todes. Anch im Fehlen und Irren bleibt der moralisehe Mensch, was er war, Schöpfer nnd Sieger. Mit diesen Worten haben wir otwas angedentet von dor ästhetisehen Idee, die uns in Rosmorstolm so gewaltig ergreift. 
Wenn nun aber die ästhetische Idee als die ästhetische Form im höchsten Sinne, als die wahre Seele des Kunstwerks für die ästhetische sichöpfung unentbehrlich ist, dann kömnen wir auch mit Bestimmtheit sagen, claß nicht jeder Stoff zum Kunstwerk tauglich ist: denn nicht jede Materie ist geeignet, der Träger und das Substrat eines hohen Sinnes zu sein. wie es im Wesen rler ästhetischen Idee begrïndet ist.

In ihr haben wir aber vor allem das Glied gefunden. welches den reinen und absoluten Begriff des Schönen mit dem K'imstwerk als dem Pesultat menschlicher Kulturtätigkeit verbindet. Es gibt gewisse allgemein logisehe Kategorien, die. vermittelt durch die philosophische Reflexion, auch im Kunstwerk erscheinen, und auf die der Verfasser der Kritik der Urteilskraft einen hohen Wert gelegt hat. Solche sind etwa der Begriff der ästhetichen Harmonie, der dem theoretischen Begriff der Einheit entspricht, und der nach Kant das Gebiet des Schönen im engeren Sinne konstituieren soll. Ferner der Begriff der Antinomie, die hohe ästhetische Spannung, der mit dem Begriff des Erhabenen zusammenhängt, und weiter auch der Begriff des Reichtums, der Fülle, der Freiheit im Sinne des schönen Spiels. Aber diese allgemein logischen Formen. welche die Welt des schönen mit dem allgemeinen Reiche der Vernunft verbinden, können uns ebensowenig zur seele des Kunstwerkes hinleiten wie die zeitlieh bedingten Formen des Stils. Die ästhetische Idee ist es allein. die uns den Zugang zum Kunstwerk öfinet, sie, die begrifflich niemals zu meistern ist. weil sie dem ewigen Begriff der schönheit so nahe steht.

Hier muß nun aber sogleich ins Auge fallen, daß die ästhetische Idee eine enge Beziehmung zu anderen Werten hat. So ist ja ohne Zweifel die Idee von Posmershohm mit einem Problem des sittlichen Lebens verbunden. Die Idee eines Kunstwerkes kann einen moralisehen Charakter tragen, das ist unbeschadet der Autonomie des Kunstwerkes sehr wohl möglich. Ebensowohl kann der theoretische oder der religiöse Wert die ästhetische Idee erfüllen. Kant hat vielleicht bei der Entwicklung des Ideals der Kunst als der, ,anhängenden" Schönheit und in seiner Lehre von der Schönheit als Symbol der Sittlichkeit') zu viel Wert und Nachdruck auf den moralischen Faktor gelegt. Theoretische und religiöse Werthaltungen können ebensowohl in die Seele des Kunstwerkes eingehen. Niemals aber bleiben sie das, was sie zuvor waren. vielmehr sind sie für das bildende und gestaltende ästhetische Bewubtsein nummehr zum Material geworden. Die eigentümliche Umbildung aber, die der fremde Wert in cler Sphäre des Ästhetisehen erfährt, ist vor allem darin zu suchen, daß er hier in seiner Unbedingtheit eine endlich begrenzte Welt des Unwirklichen leitet. Er wird zum Gesetz dieser einsamen Welt. So etwa jenes moralische Bewußtsein, das nach höheren Werten rerlangt, die den freien und stolzen Adelsmenschen der Zukunft leiten sollen. Dieses Bewußtsein muß hervorzaubern den tragischen Konflikt zwischen Leidenschaft und hohem Willen, der das Drama bewegt, und muß den Helden als siegreich im Untergange zeigen, untergehend, weil er der Macht der Leidenschaften unterlag, und siegreich, weil er niemals aufgehört hat, das Große und Edle

1) Kant: Kritik der Urteilskraft. Werke, Bd. V, S. 351. Akarlemieausgabe. 
zu bejahen, und durch diese danernde Bejahung auch immerfort im Sinne des Schönen und Wertvollen gewirkt hat.

In der Welt des Lebens und der Wirklichkeit vermissen wir häufig die strenge Logik der Tatsachen, wohl hauptsächlich, weil es für uns unmöglich ist, das verworrene Netz so bunt durcheinander gesponnener Fäden zn durchdringen. Hier erscheint etwa das hohe moralicehe Bewußtsein als Sieger, oder es erscheint ałs ein besiegtes und untergehendes. und es möchte uns häufig so scheinen. als ob der Mensch nicht mit Notwendigkeit schuldig würde, sonden dureh eine Laune des Zufalls, und ats ob der Nenseh nicht gezwungen wäre, die Konsequenzen seiner Handlungsweise zu tragen. Dieses Wechselnde des manchmal ...Ja" und manchmal, ,Nein" macht die Kunct zu einem Reich strenger Notwendigkeit. wo notwendige Schuld zum notwendigen Untergange treibt. Lnd die Gleichgiiltigkeiten des nur trimmphierenden oler blob mntergehenden Bewnbtseins maeht fle Kunst wertroll und interessant dureh jene eigentümliche Konbination, die wir als tragisehen Konflikt bezeichnen Was soll das aber heißen und bedeuten? Wemn wir das Gute siegreich und mühelos trimmphieren sehen, so wird mser sittliches Bewubtsein dachreh gestärkt erhoben. aber für unser ästhetisches Gefühl kam dieser siegergang unter Umstämden sehr wenig berlenten. Und der kampflose, hoffunngslose Untergang des Wertrollen ist blok schmerztich, aber nicht tragiseh. Dann aber wird unser ästhetisches Empfinden mächtig erregt, wem wir das hohe Wertbewnßstein. das an sich Große mul Mächtige ins Unrecht gesetzt sehen chreh wikle Triebe und Leidenschaften mler durch ein feindliches Geschiek, und wir nun erlehen jenen mächtigen Kampf, den ein stolze; Herz anszufechten hat. und in dem es ats Besiegter doch schließlich immer noeh sieger bleibt.

\section{Freiheit und sittliches Leben.}

Der theoretische and astheticche Wert hatten das gremeinam, daßsie woch ïber die Kultur hinaus eine Stätte der Verwirklichung finden; so hat die Wirklichkeit ihre Wahrheit, mahhängig von mensehlieher Kultur, und die Schönheit der Natur besarf zu ihrem Dasein der kïnsterisehen Betätignng nicht. Jetzt aber nähern wir ms einem Wertgebilde, das in eminenter Weise mit mensehlicher Kulturtaitigkeit zusammenhängt, das in allem mensehlichen deben unl in aller mensehliehen Kinltur die entseheidende Rolle spielt, einem

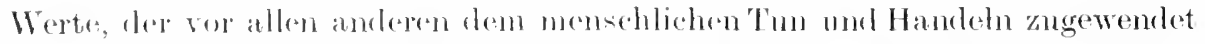
ist, wir meinen den sittlichen Wret der Freiheit. Diraceseltsane Begriff der

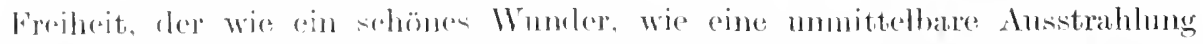

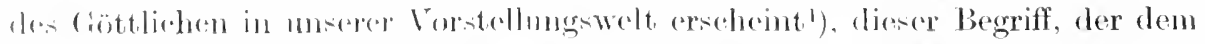

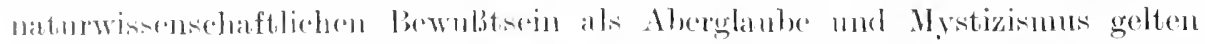

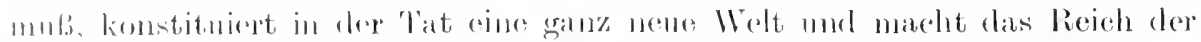

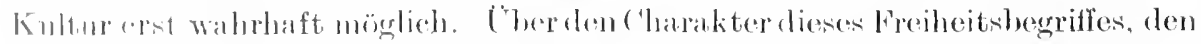

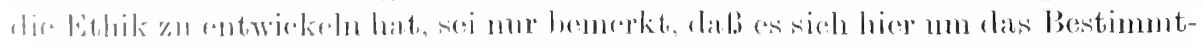

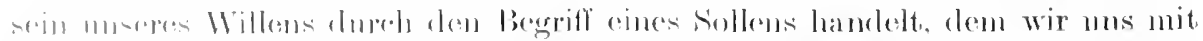

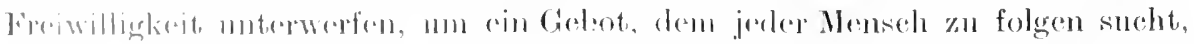

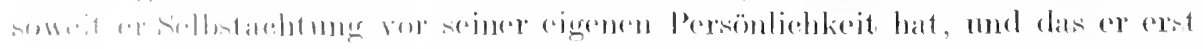

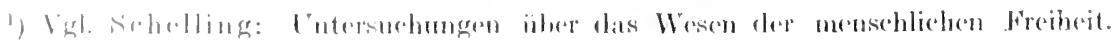


damn remichtet und begräbt, wemn er sich selbst wegwirft. Es ist angenscheinlich, daß diesem Begriff in der Wertung des persönlichen Lebens und auch in der Wertung des Völkerdaseins eine hohe Bedeutung zukommt, daß dasjenige, was wir eines Menschen Charakter und eines Volkes Tüchtigkeit nemnen, für uns einen Maßstab höchster Wertbeurteilung hergibt. Es ist seltsam, daß diese Freiheit und das Gefühl des Verantwortlichseins für mein Tun und Treiben sich unmittelbar mit meinem Lebensgefühl verbindet, und daß ich aufhören müßte, der Idee der Menschheit nachzuleben, wenn dieses Gefühl in mir zugrunde ginge. Die Freiheit ist derjenige Wert, der die Schwachheit unserer Natur adelt und der das feste Fundament und die Grundlage für die Verwirklichung der anderen Werte hergibt. Und die Gewißheit der Freiheit haben wir in der unmittelbaren Sphäre des Lebens, das noch dureh keine wissensehaftliche Reflexion zersetzt ist. Damn rerschwindet die Freiheit in der Welt der wissenschaftlichen Reflexion, für die dieser Begriff eine Paradoxie sein muB; er verschwindet, um in den letzten C'berlegungen der Philosophie, auf den Höhen der Reflexion wiederzuerscheinen.

Wie ist num im allgemeinen die Torstellung. die wir mit der Freiheit oder dem Guten verbinden. einem Begriff, den sehon Aristoteles aus einer tiefen Einsicht herans als den spezifiseh menschlichen Wert bezeichnet hat? I) Er bedentet in erster Linie eine ungeheure Wertung und Erhöhung des menschlichen Daseins. Die Wahrheit ist eine Irlee, die uns mit einer gewissen Feindlichkeit entgegentritt, sofern sie uns immer wieder vor Augen führt, wie klein und unbedentend die Gaben unserer Erkenntnis sind. Sie läBt es uns immer deutlicher werden, daß wir im besten Falle nur ein schwaches Aquiralent für die ewige Wahrheit gewimnen können. Die großen Philosophen stimmen fast ausnahmslos darin überein, daß wir uns cinen götlichen Verstand prinzipiell verschieden ron allem menschlichen Erkennen denken mïssen. Aber im Willen scheint uns etwasgegeben zu sein, das ron dem höchsten Willen nur graduell. nicht aber prinzipiell rerschieden ist. Und so hat Descartes ${ }^{2}$ ) die potentielle Unendlichkeit des menschlichen Willens dem aktuellen göttlichen Willen entgegengesetzt und Kant den reinen Willen des autonomen Mlensehen in eine nahe Beziehung gebracht zu dem Irleal eines heiligen Willens, in dem der Kampf ron Moralität und Neigung ausgekämpft und rollendet ist. Und so erscheint die Freiheit oder das Gute vor allen anderen Werten als ein Ideal. als eine Aufgabe für den Menschen. Mit dem Guten rerbinden wir die Forstellung eines Zieles, das der Hensch nach einem langen Prozel. des Kampfes erreichen soll. Das Gute ist nicht das freiwillige Geschenk der schönheit, sondern das Resultat eines machtrollen streites, der ausgekïmpft unl ansgelitten sein muB.

Daß das Gute der spezifisch menschliche Wert sei, das zeigt anch besonders deutlich sein Gegensatz zum ästhetischen Wert. Der ästhetische Wert steht in einer absoluten und notwendigen Relation nur zu wonigen Menschen, den Kümstlern und den großen Interpreter der Kunst. Es war ein Trrtum der Romantik anzmehmen, daß die Grundform und Grundgestalt jeder mensehlichen

1) Vgl. Aristoteles: Nikomachische Ethik.

${ }^{2}$ ) Descartes: Meditationes de prima philosephia. 
Seele der Trjeb) nach kïnstlerischer Gestaltung sei. Dieser Trieb nach künstlerischer Darstellung, dieses große Maß des Schaffens wird immer nur die Aufgabe und Leistungsmöglichkeit weniger sein, so dalj man mit Recht von der Exklusivitat des ästhetischen Wertes und von dem aristokratischen Charakter aller Kunst spreehen kann.

Diere unzweifelhafte Tatsache darf allerdings nicht zu der Behauptung führen. dafs dem ästhetischen Wert wohl der Charakter des notwendigen, aber nicht des allgemeingültigen Bedeutens zukomme. d. h. dals der ästhetisehe Wert und das künstlerisch wahrhaft Wertvolle nur für wenige gilt; daß die Kmst nur die Anerkenmung weniger forlere, eben jener kleinen Schar, die das reltene Phänomen des Geschmackes besitzt. für die überwiegend große Zahl der unkïnstlerischen Menschen aber nicht als Ideal betrachtet werden kömne' $)$. Der äs thet ische Wert gilt gewiß nicht , won"allen Erscheinungen, ebensowenig wie der ethische Wert ...ron" allen Erseheinungen gilt. Sein Gebiet jst in dem großen Reiche der Natur und Kultur ein begrenztes. Nieht alle Erscheinungen der Natur sind schön, nicht alle Formen des historischen Lebens haben cine künstlerische Bedentung. Nicht, ron" allen Gebilden der Natur und der Gesehiehte wirl in Beziehung zum KulturbewuBtsein die Anerkemmng der Schönheit verlangt. Nur der Wahrheitswert hat diese unbeschränkte Geltung in seinen Verhältnis zur Wirklichkeit, daß alle Erseheimmgen unter seine Iurisctiktion fallen. Die Welt des Schönen ist ihm nur insofern entrückt, als sie den Verzicht anf Wirklichkeit loistet. Alle anderen Werte haben eine beschränkte sphäre des Geltess, , von". aber eine mbesehränkte Sphäre des Geltens, für". Dab mun ter ästhetisehe Wert noch nicht die Anerkemnung afler gefunden hat, und die weitce Tatsache, daß vielleieht einer Fülle ron Menschen die ästhetische Anlage fehlt, und sie infolgedessen nicht imstande sind, das küustlerisch Wertvolle zu fühlen oder anch zu sehaffen und zu bilden. das kanu gegen die Allgemeingültigkeit des ästhetischen Wertes im simne eincre Forderung, eines sollens nichts beweisen.

Deswegen kimm roch die Forderung bestehn, dab der ästhet ische Wert ron allen anerkannt wird, und so haben ja aueh tatsïehlich das Griechentum

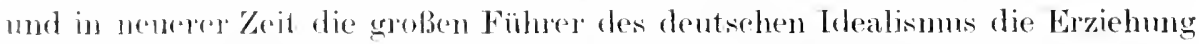
zur Sohönheit gefordert. Wir sehen also hier entgegengesetzte Behauptungen erscheinen, sownhl in bezug auf die Konstatierumg des psychologisehen Befundes

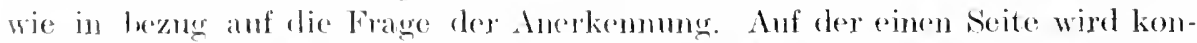
statiert. dab das licefïhl für das Sehöne jedem Mensehen eigen ist, ja, dab er

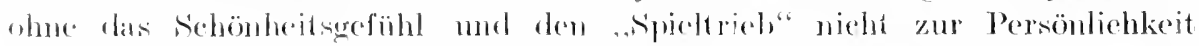

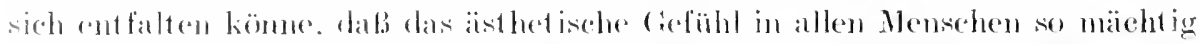

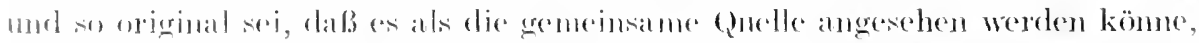

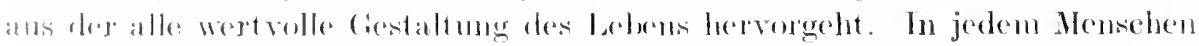

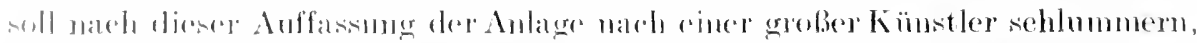

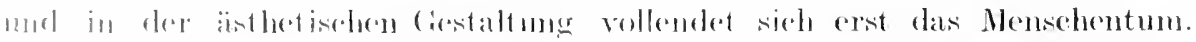

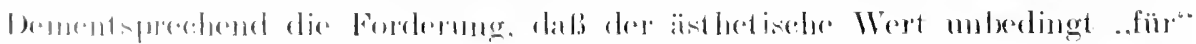

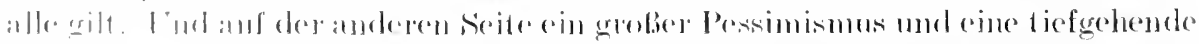

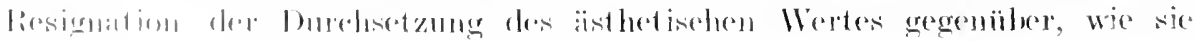

1) Vel. ('hristianson: Philosophire der Kunst. 
in einem Zeitalter der Geschmacklosigkeit und des mangelnden Schönheitssinnesehr verständlieh ist. Nur wenigen Mensehen ist naeh dieser Lehre der Sim für das Schöne eigen. Die Schönheitsliebenden sind die kleine Gemeinde der künstlerisehen Naturen. Sie haben einen Gegenstand der Verehrung, der den anderen fehlt, und den die anderen nieht begreifen. So bleibt das schöne ihnen aufbewahrt, und sie möchten anf die anderen Werte wohl gerne verzichten. wenn ihnen nur das Schöne bleibt.

Von einem solehen Standpunkt aus ist die Idee einer ästhetischen Erziehung des Menschengesehlechtes natürlieh eine Naivität. und man möchte fast meinen, daß diejenigen. die a uf das Verständnis der großen Menge im Verhältnis zum Schönen so unbedingt resignieren, nicht ohne Frende und Stolz das Gebiet des Schönen als ihre besondere Domäne betrachten und auf den Schutz seiner Grenzen sorgsam bedaeht sind.

Wie haben wir zu diesem Gegensatz in der Beurteilung des Schönen Stellumg zu nehmen, der natürlieh ron größter Wichtigkeit sein muß für die Ziele der Kunst in der Praxis des Lebens wie für alle diejenigen Bestrebungen, die in irgend einer Form der Bildung, der Kultirierung und des Unterrichtes auf das Leben und die Entwicklung der Völker zu wirlien suchen? Es handelt sich hier um eine Vermengung der philosophirchen und psychologischen Fragestellung. Ob jeder Menseh ästhetisches Gefühl besitzt ist eine Frage der Psrcho. logie, die ron der Philosophie nicht entsehieden werden kann. Ob der ästhet ische Wert tatsäehlich ron allen Menschen anerkannt wird, ist ebensowohl eine quaestio facti und nicht eine quaestio juris. In all diesen Fragestellungen wird das ästhetische Problem nach der Seite der Psychologie hin verschoben. Wir kömmen in der Philosophie nur die Frage nach dem simn des Kunstwerkes erheben. Wie ist der Anspruch des Geltens zu rerstehen. den das Kunstwerk erhebt? Will die göttliche Komödie oder der Hermes im Vatikan nur als der schöne Freund und Liebling weniger rerstanden sein. zu denen er dam allerdings ein unbedingtes und notwendiges Terhältnis besitzt, so dals das Kunstrerk gleichsam das Medium ist, das eine schöne und stille Schar auserlesener Geister unmittelbar mit dem Göttlichen verbindet? Es mag ein hoher Reiz in dieser Vorstellung liegen, aber ron ihrer Wahrheit kömnen wir mis nicht überzeugen.

Der Anspruch. den das wahrhafte fiunstwerk stellt. ist ein anderer. Es handelt sieh da nicht um das Verlangen, der Liebling einzelner. weniger: aueh noch so erlauchter Geister zu sein. Bei dieser Anffassung und Deutung würde das Schöne rettungslos in das Gebiet des Relativen rerstrickt und ent behrte des zeitlosen und ewigen Bedeutens. Unabhängig ist die schönheit. die sichim Kunstwerk offenbart, von der Laune und dem Geschmack des Tages. von der großen Liebe des einzelnen, und selbst die Kultur einer ganzen Zeit, der Charakter eines Tolkes und einer Epoche rermag nicht restlos die Bedingungen des Kunstwerlies herzugeben. So ist die göttliche Komödie ein Werk, das Ansprueh auf ewige Anerkemmung besitzt, und kommt eine Zeit, die diesem Werke die Anerkennung rersagt, so hat deswegen die götliche Komödie nicht ihren Wert. Wohl aber diese Zeit das Verhältnis zur Kumst verloren. Der ästhetisehe Wert und das Kunstwerk gelten für alle Menschen aller Völker und Zeiten. ïberall gelten sie bort, wo im unendliehen Welten. 
raume vemünftige IVesen wohnen mögen. So allein kam der Wert des Kunstwerkes und der sinn der Kunst gereehtertigt werden.

Cnd demorh ergeht in der Tat die asthetische Forderung in einer ganz anderen Weire an min wie die ethische. Die ethische Forderung richtet sich an jeden einzelnen unter uns. und das Verhältnis zu diesem Wert aufgeben heißt -ein freies Hensehentum verlieren. Die ästhetische Norm ist für alle da und unberlingt gesetzt. aber die Einladung. ihr zu folgen, ist nicht so unbedingt mol nieht so dringend wio auf dem sthischen Gebiet. Auf die Anerkennung den ästhetischen Wertes verzichten. bedeutet nur auf schönes Menschentum verzichten. das sich hier in einer ganz einzigen Art im Verhältnis zum Leben, zur Kunst und Xatur offenbart. Dagegen bedentet der Verzicht auf den ethischen llert den Verzicht auf Menschentum äberhaupt. so schr ist er unter allen anderen für die ganze form wnseres Lebens konstituierend.

So viel num aber auch der ethisehe Wert für wahres Menschentum in der Entfaltung des sittlichen Lebens bedenten mag. su geht doch nicht die ganze Fülle dessittlich Wertrollen in das historische Geschehen ein. Fs ist nicht jene ganze Wolt dej antonomen Persönlichkeiten. von der Kant in der Kritik der praktisehen Vermunt haudelt. die in die historiche Bewegung eingeht, und nicht alle ihre Leistmgen sind für die Geschichtswisisenschaft wichtig und interesant. Fis mus, wie wir gesehen haben, ein Moment hinzutreten, um das sittidh Wortolle zum historiceh Releranten zu machen, und dieses

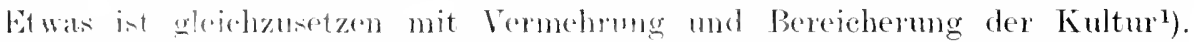

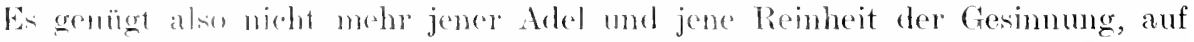
wrehe die Ethik deu gröbten Nachdruck zu logen hat, es genügt nicht jene - rhön Form der inneres Freiheit. dats erhabene Verhältnis zum sittengesetz als dem mbludingen sullen. um das sithlehe damit sehon ohne weiteres in

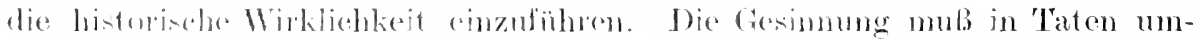

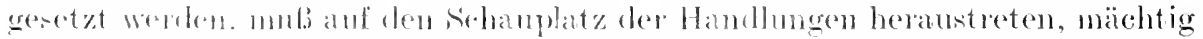

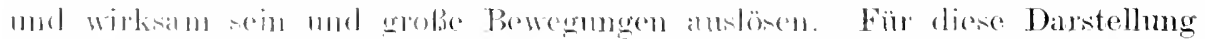

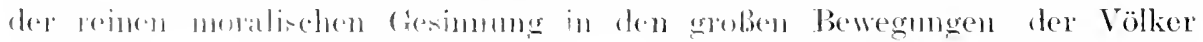

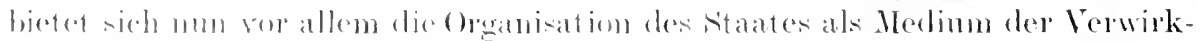

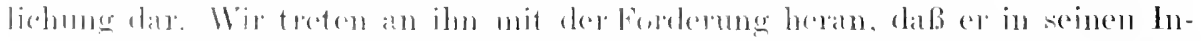

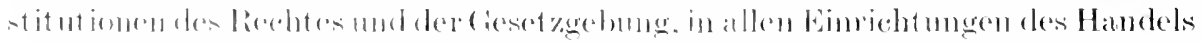

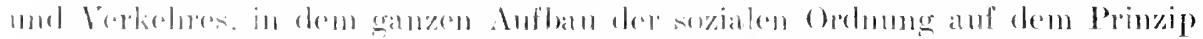

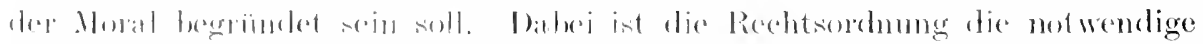

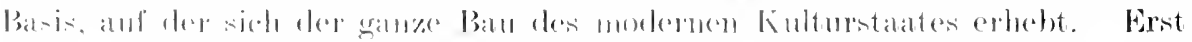

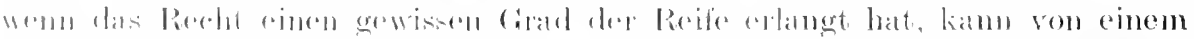

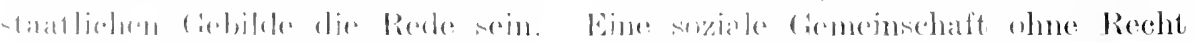

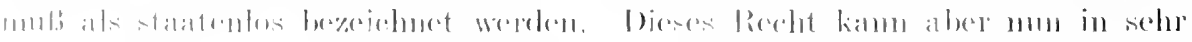

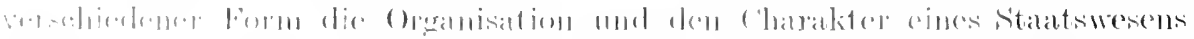

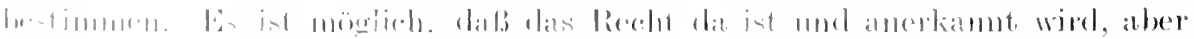

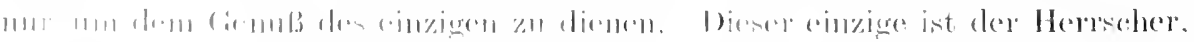

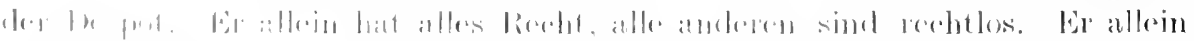

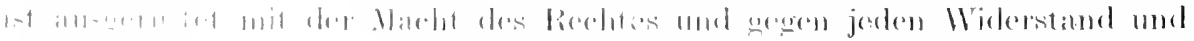

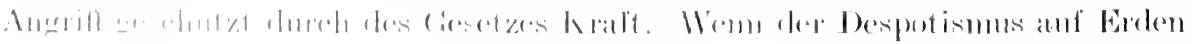


herrscht, damn ist das Recht schon erschienen und wirklich geworden, aber es hat noch nicht den Staat durchdrungen, es haftet lediglich an der Person deseinzelnen. Der Staat des Despoten ist kein Rechtsstaat, sondern ein Gewaltstaat. der die große Masse durch das Recht fesselt und bindet. sie zu Sklaren seines Wilfens macht. Wenn wir allerdings darauf achten, daß für den Despotismus Staat und Herrseher zusammenfällt, dam müssen wir auch die absohute Monarchie als einen Rechtsstaat bezeichnen. Das Pecht hat schon seine organisierende und gestaltende Tätigkeit hegonnen. aber die Form. die es dem Staat gegeben hat, widerstrebt der Moralitat. Der despotische Staat ist tief unmoralisch, weil es allen Forderungen der Gerechtigkeit widerstreitet. Wenu sittlich Wertrolles in ihm geschieht. so wird es nicht durch dienc Staatsform, sondern trotz dieser Staatsform erzeugt.

Das Recht, das mepringhich in der Nacht des einzigen ruht. bleibt nicht bei ihm allein als danelnder Besitz. Früher oder später muB der Trram die kostbare Gabe des Rechtes mit anderen teilen. Anfangs verleiht er vielleicht einzehen das Recht als ein schönes Genchenk seiner Liebe. Er verleiht er. indem er sich das Recht bewahrt, das Geschenkte wieder zurückzunehmen. Allmählich aber wird das Verliehene zu dauerndem Besitz. sei es auf dem Wege friedlicher Entwicklung, sei es als Resultat eines schweren Kampfes um das Recht. Das Recht wird nummehr zum Eigentum der Gemeinschaft und gilt jetzt nicht mehr allein für den Herr'scher. sondern für alle Bürger. Alle Bürger schützt und rerteidigt das Reeht und giht ihmen Ruhe und Frieden. Abernoch ist das Recht in sehr verschiedener Form Schutz mol Besitz der einzehnen. Das Recht ist für alle da, aber dic Rechte sind sehr verschicelen. Den Prozelis aber, der dahin führt, dab die Verschiedenheit der Rechte sich in das gleiche Recht für alle und in einen Zustand des gleichen Rechtsbesitzes rerwandelt. mub man als einen Prozeb der Horalisierung des Rechtes resstehen ${ }^{1}$. Allerdings darf dieser Prozebs nicht in einer rein äuberlichen Regulierung der Besitz- und Eigentumsrerhältnises gesehen werden. Es ist nicht recht, daßs der Besitz für alle der gleiche sei. weil des Besitz in der Hand des einen so viel mehr bedeutet als in der Hanl des anderen. Soll num derjenige, der aus wenig viel machen kam, bevorzugt oder benachteiligt werten gegenüber demjenigen, der aus viel nichts machen kann? Ansdem Begriff des Rechtsstanteund Kulturstaates kamn mur die Fordernng a bgeleitet werden. da Bgleiche Erwerhbedingungen für alle geschaffen werden sollen. Dazu ist vor allem erforderlich. da l.s ein gleiches Bildungsnivea für alle Bürger (-richtet wird, demn die höhere Bitdun wird bei gleichem Maß der Anłage im Kampfe tler Interesen den sieg davon tragen. Daß eine absolute Gleichheit in dieser Hinsicht niemals zu erzielen ist, das ist schom in der Verschiedenheit der Individualität bourundet, die auch bei gleichen Bildungsbedingungen zu einem vernehiedencul Bildungssesnltat führen wisd. Und es ist gut so, dab diese Terschiedenheit rin für allemal gegeben ist und feststeht. weil bei absoluter Gleichheit allor Gerebenheiten und Verhältnisse im Kampe der Interesien niemals eine Entscheidung falten würde und das statswesen so zu einer heibenden Stagnation verurteilt wäre. Eine absolute Gleichheit des Besitzes in woiter ausgeschlosen durch 
die grobe Mamigfaltigkeit der Berufe, die ihrerseits wieder zu den Grundbedingungen des Kulturstaates gehört. Die Verschiedenheit der Berufe beseitigen, hieße an den Anfang der Geschichte zurückkehren. Der Kulturstaat muß sich zur Arbeitsteilung bekennen. Es ist aber billig. daß die größere und höhere Arbejtsleistung den größeren Gewinn daronträgt.

Auch ist es nicht allein die Forderung einer Regulierung der Besitzverhält. nisse im sime einer relativen Gleichheit, die in ihrer Erfüllung eine Moralisiermig der Rechtsordnung bedeuten wïrde. Die Tatsache ungeheurer Besitzunterschiede, wie sie etwa in Sizilien zwischen den reichen Latifundienbesitzern und der jammervollen sozialen Not der Schwefelgrubenarbeiter im Innem der Insel rorliegt, ist nur das sichtbarste Zeichen sozialer Ungerechtigkeit. Menschliches Glïck und menschliche Freude sind nicht allein von Besitz und Habe abhängig. Doch bedarf eine wertrolle soziale Gemeinschaft gesunder Lebensbedingungen; demn wemn der einzelne durch den ständigen Kampf mit den grauen Gestalten des Elends zu sehr hedroht und in Mitleidenschaft gezogen wird, so erlischt in ihm die schöne Liebe zum Ideal der Ganzheit. Auf Glück und Wohlfahrt des Volkes hat das Recht Rücksicht zu nehmen, wemn es einen sittlich wertrollen Zustand unter den Menschen begründen will. Es ist eine moralische Aufgabe les Rechtes, die Glückseligkeit zu fördern, wenn auch der Zweck der sozialen Gemeinschaft eines Staates niemals allein in der Befriedigung der Bedürfnisse und in der Gestaltung behaglicher und schöner Lebensverhältnisse liegen kann. Weit wichtiger ist es, die Aufgabe des Rechtes in seiner moralischen Wirksamkeit dahin zu bestimmen. daß es Möglichkeit md Gelegenheit bieten soll, zur Entfaltung der. Inclividualität, was nicht zum wenigsten durch eine verständnisvolle Ordnung des ganzen Bildmingswesens, der Erziehung, des Berufs- und des Beantenwesens geschehen kam. Die Rüicksichtnahme anf die Individualität ist eine forderung, die wir an das Reeht und an den Stat stellen, die er vermöge seins eigrnen Natur nur widerwillig erfüllen wird. Wir verlangen damit rom Stat cine gewisse Solhstbesehrïnkung, ein Opfer für die emzelnen und rinengewisen Verzicht anf Macht. Nur unter groben Schwierigkeiten und widerstrebend wird sich die Rechtsmaschine so einstellen, dab sie der Entfaltung drer Perönlichkeit dient und auf die Eigenart der Persönlichkeit Rücksicht nimmt. Demm im Wresen des Rechtes liegt es, alles zu uniformieren und einander anzugleichesu. Das ist die Gröbe mol gloichzeitig die Grenze des Rechtes, wenu ro mit der forderumg der Gleichheit an alle Nenschen herantritt und ihre Individualiat zu Persones heralsetzt. Vor dom Pechte sind alle gleich, da gilt der Pupur wicht mehr als dor Kittel des Bettlers. Da muls der Reiehtum

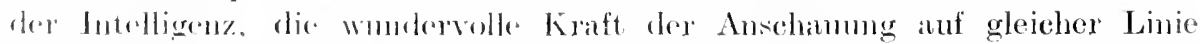
"rocheinen mit dom Goistesinnen mud dem Phantasielosen. Aber diese schoffe Jotommer der G iteichheit und das bestreben. keinen Untersebied zu

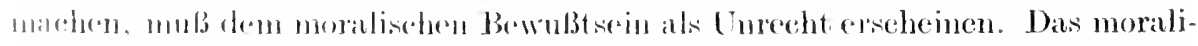
schr. Bewnbtscin kam es nicht verstehon, dals gleiche strafe den einen und den

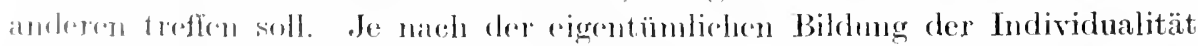

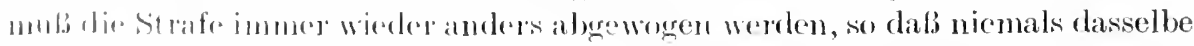

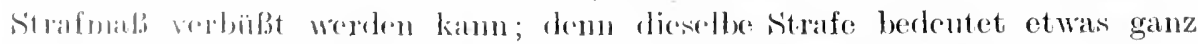

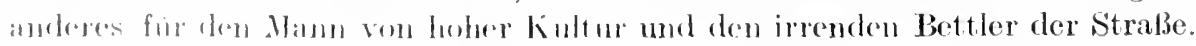

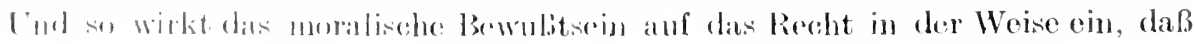


es seine starre Konsequenz zu brechen sucht. Das Recht weicht ron dem Prinzip der starren Uniformierung ab. das anfangs so notwendig war, um die Reehtsordnung erseheinen zu lassen, und berüehsichtigt die Individualität. An sieh liegt im Wesen des Rechtes die Tendenz, aus der Hannigfaitigkeit der Indiriduen eine homogene Masse zu bilden. Die Rechtsordnung bedentet Homogenität ohne Mamnigfaltigkeit. Deswegen ist sie für Hegel das abstrakte All. gemeine, ron dem das Reieh des objektiven Geistes, das Reich der Kultur ausgeht, und das in der Moralität üherwmden wird, die immer auf rlas Persönliche und Individuelle abzielt.

Der moralische Wert tritt uns im historisehen Leben selten ganz rein entgegen. Nur in der wundervollen Erseheinung seltener grober Persönlichlichkeiten wie Christus. Sokrates und Franz ron Assisi offenbart sich in vollem Umfang seine reine Hacht. Wenn das ethisch Wertrolle mit Reeht und Staat in Berührung kommt, dann wird es aus dem Reich der Gesinmung. das seme ureigenste Position bildet. gewaltsam herausgedrängt. dam wird es gezwungen, dem wilden und unbeherrschten Leben Konzesionen zu machen. Democh steht die hohe soziale Bedeutung der lloralitit ein für allemal fest. Die moralische Ordnumg bezieht sich auf das Verhältnis der Mensehen zueinander. Für den einzehnen Mennchen besteht die sittliebkeit nicht. Ein Iensch. der in keiner sozialen Gemeinsehaft lebt, kam ein Terhältnis zum Wahrheits- und Schönheitmwert hahen oder das religiöse Gefühl zum Göttlichen kultivieren, aber das moralische Verlangen kam er nicht stillen. Wird das moralische Gefühl auf Gott gerichtet. so geht es sofort in das religiöse über. Zwischen dem Göttlichen und dem Mensehlichen kann kein PHichtrorhältnigedacht werden, wie es die alte jüdische Religion behauptet hat. Crott darf weder als Richter im simne des Rechtswertes noch als Prinzip der Gerechtigkejt im Sime des ethisehen Mertes gedacht werden. Gott hat keine Pflichten gegenüber der Menschheit, und die Menschheit hat keine PHichten gegenüber Gott. Deshalb kann man mit Recht den ethischen Wert als den spezifiseh mensehlichen und sozialen bezeichnen, der nieht mmittelbar zum Aholnten hinüberführt. Wenn ron Kant die moralisch Persönlichlieit so unmitte?bar auf Gott als den moralisehen Gesetzgeber bezogen wirl. wo handelt esich hier um eine Vermischung ethischer und religiöser Ilomentel ${ }^{2}$.

Der moralische Wert ist es, der durch seine Einwirlimeg auf die rechtliehen und sozialen Verhältnisse äberhaupt wertsolle Gemeinschaften schafft ron denen Familie mnd stat dis historisch bedent-ansten sind. Insofern kann man mit Hegel sagen. dab rlic anfangs starre und äuberliche Rechtoordnung, die zuerst zum schutz des Gemeinsehaftslebens anforichtet war und das eigentich wertrolle Leben der Hensehheit noeh anschloli. durch den moralischen Wert in den Zustand der sittlich wertrollen Gemeinschaft ïber. führt wird. Hegel war nur zu sehr von der Macht des Staat es und der Bedeutung der historischen Verhältnisise durchdrungen, wemn er die Auffasmung vertrat. daß der Begriff des Staates als Idee fer wahhaftigen. konkreten und rerwirklichten Sittlichkeit dem moralisehen Nert überznordnen sei. Vielmehr int es immer der moralisehe Wert in seiner Imerlichlieit. ron dem jede wertrolle

1) Vgl. Kants K̈ritik der praktisehen Vernunft. Werke Bd. 5. Akidemieausgahe. 
Entfaltung in den großen und kleinen Verbänden menschlicher Gemeinschaft ausgeht. Dagegen ist der Staat, wem wir auf seine Verfassung achten, kein werthaftes Gebilkle, so schr er als Träger und Substrat des großen und wert. rollen historischen Geschehens angesehen werden muB. Auch derjenige Staat, der als Ideal des Kultursataates die starren Sätze des Rechtes im Simme höchster Ioralität handhaben würde und höchster Kulturblïte eine Stätte bereitet, ist im Terhältnis zu den anderen Staaten, die seine Existenz bedrohen, immer rom den naturhaften wertfreien Prinzipien des Egoismus und der Gewalt greleitet.

Wir mußten auf das Problem der Geltung der absoluten Werte und ihre Bedentming für die verschiedenen Kulturgebiete und das historische Geschehen überhaupt in dliesem Zusammenhang näher eingehen, weil durch die ganze Art und Weise, wie wir dieses Verhältnis denken wollen und müssen, der Aspekt fer historischen Betrachtung bedingt ist. Der Historiker mus sich immer darüber klar sein, daß die historische Welt auf denselben Grundprinzipien ruht wie die philosophische Erkenntnis. Ist die philosophische Erkenntnis gegenstandslos, dam hat es aneh keinen simn mehr, Gesehichte zu schreiben. Nirr betrachtet die Philosophie die Werte in ihrel Ablösmg rom historischen Geschehen, whiend es die Geschichte mit den konkreten Formen zu tum hat, die das Ewige in einer großen Mamnigfaltigkeit zeitlich beelingter Einzelgestaltungen annimmt. Von drer ganzen Art und Weise, wo das Verhältnis der Kulturwerte zu den absoluten llerten gedacht wird, ist mehr oder weniger die Darstedlung der (ienehichte abhäugrig.

\section{Das Heilige und die Religrion.}

Wirhallan jetzt mur noch in Kürze auf liobeziehmog einzugehen, rlie zwischen der Poligion und jenem alsonuten Werto besteht, den dis Philosophie als das

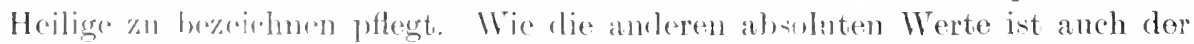

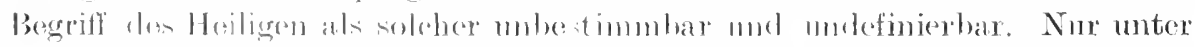

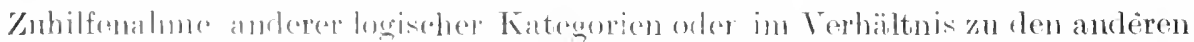

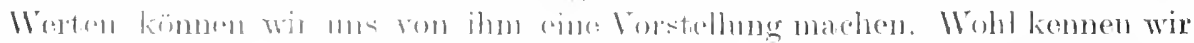

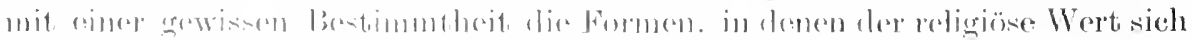

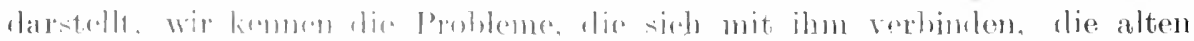

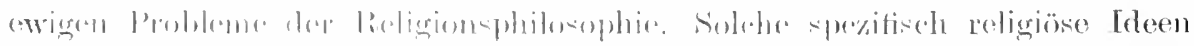

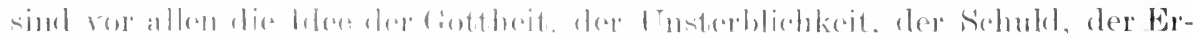

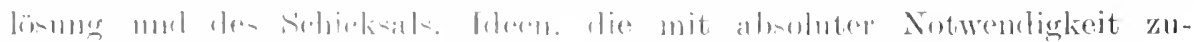

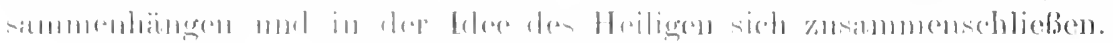

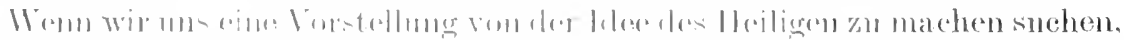

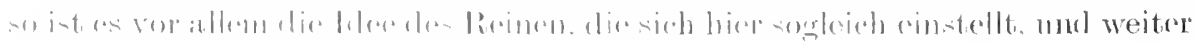

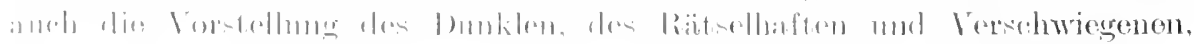

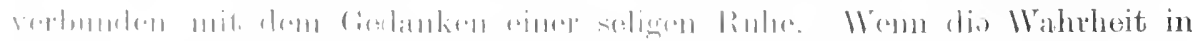

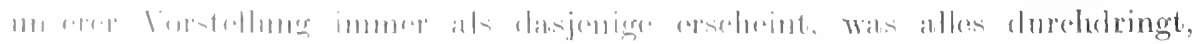

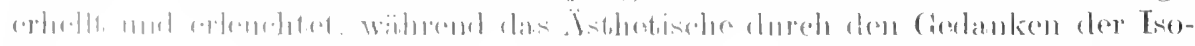

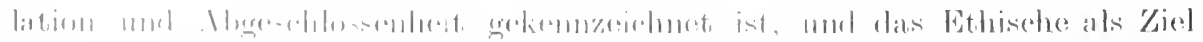

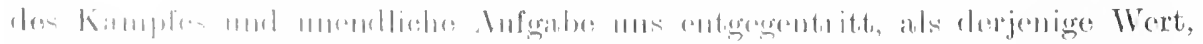

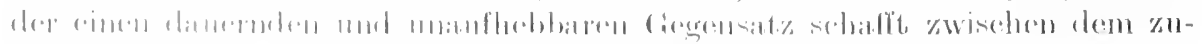

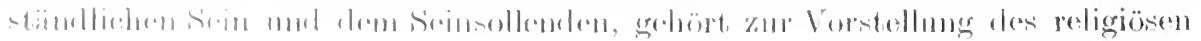


Wertes im Gegen-atz zur Wabrheit die Vorstellung des Dunklen mul Nächtigen. im Gegensatz zmm Schönen die Vorstellung lex L'Terwinlung aller Distanzen und Aufhebung aller Trennung. im Gegensatz zum Ethirchen die Vorstellung des mühelosen Gewimns. Das ethisch Wertsolle leidet nicht mor dem Staub. und Schmutz der Welt nowie mnter der Gewalttätigkeit der Leiclenschaften. Sofern sie nur zerstrent und niedergeworfen uml untergeorihet sind. können sie schon für eine Weile von der menschlichen scele besitz ergreifen. Ja. wir müssen sogar sagen. daß die Leislenschaften zum Ruhm und zur Ehre des sittlichen Wertes notwendig sind. Was aber die Idee des Hoiligen bedentet. das kamn nur derjenige verstehen, der eimmal ron ganzer seele nach absohter Reinheit rerlangt hat. unberüht rom staub ler Welt. Wie anch the Irlee rles Heiligen im übrigen rerstanden und gedentet werlen mag, welche Form mel Gestalt sie auch annimmt für ten menschlichen Geist. dieses ist ihr nach moerer Vorstellung doch ror allem eigen: das Entriektsein und Cuberührtsein rom Stanb der Welt; mol alle groben religiören Ideen sind im Gedanken dierer Reinheit und Unberührtheit veranket. Es gibt ein absolute- Weven, das die Reinheit immer bewahrt, sie nie verloren hat und nie resliertn wird, die Gottheit, und andere Wesen gibt es. welche die Reinheit urspringlich besessn haben. ihrer aber später verhustig gingen duch der sünde Schuld. Jener Prozeß aiver. durch den die befleckte seete wieder in den Zu-tand der ur-prünglichen Reinheit zurückgeführt wird, int der Weg der Erlösmng. In allen großen Religionen haben diese Gedanken ihre Stelle gefunden.

Wir sehen aber sofort, dab das. Heilige orler las Reine ron allen anderen Irleen oder W'erten prinzipiell verscheden int durch tic absolute Behauptung: und Bewahrung der Transzendenz. Wähent wir etwa sagen können. dafs das Schöne wirklich ist und hier anf Erden Ge-talt gewomnen hat, während die Wahrheit in den wissenschaftichen Crteilen zugegen ist, sofern man ron ihrem Wahrheitsgehalt sprechen kann. ist die Natur des Heiligen so beschaffen, dat. kein Gebilde der Kultur im weiten Lmkreis der Welt den Namen des Heiligen rerdient.

Wir können ein simnlich Wirkliches als gut und schön, als wahr un' recht

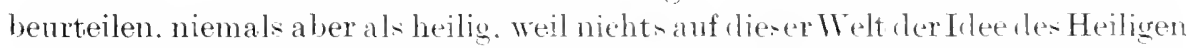
mot Reinen aueh mus ron ferne entepricht. 1)a Heilige verwirklicht sich nicht wie das Wahre oder das Schöne aber die Tor-tellung ron cinem Heiligen bewegt mit Macht die Gemüter ter Menchen und findet in groben heligionssystemen ihren Ausdruck. die alle darin ähereinstimmen. lals se symbole für das Göttliche suchen. Dit soziale Er-cheimung cler (rist theit ist clie lileetler Kirche. die damn ihrerseits wieder in zahlreichen Kultenmen das (rït liche smmbolisiert. So ist eine gewisse Tendenz der Religron mit Ent-chiedenheit der Sichtbarkeit und dem Anschaulichen zngewendet. ein Be-trehen. in dem sie sie sich mit der Kunst berührt, die mit Vorliehe die religione Ldee umi Vorstellung ergreift und ihre Allgemeinheit in der Anchanung zur Darstellung bringt. Diese Pichtung der Religion. die danah -traht sich zu offenbaren, die deutliche symbole schafft, die ats Ganzes ein firstem von filauhen-sätzen ergeben, die in der großen Mrganisation Kirche und in den Kulturformen zur Wirklichkeit drängt, sie ist diejenige Form der Religion. die sich dem Kultussystem eingliedert, sie ist die historisch gerichtete Religion. 
die das Wertrolle der Kulturentfaltung durehaus bejaht und anerkennt. Im Gegensatz dazu gibt es eine andere Form des religiösen Lebens, und wir möchten slauben. daß ihr große Tiefe und weites Bedenten zukommt, die in vollkommener Opposition zur Geschiehte steht und dem historisehen Prozeß als colchem keinerlei Bedentung zuerkemen will. Während jene Form, die nach Wirklichkeit dıängt, von der Gesehichte etwas erwartet, daß sie nämlich ein Ziel, ein Resultat, einen Endzweek ergeben soll, der ihren Erwartungen ent- prieht und jetzt noch fern ist, steht die andere Form der Religion, die naeh Unwirklichkeit drängt, und die wir als Mystik bezeiehnen, mit vollkommener Úberzengung auf dem Standpunkt, dab clie historisehe Erwartung ein Irrtum sei, weil eine solche die ewige und ummittelbare Gegebenheit des Göttlichen verkennt. Die Mrstik rertritt die Auffassung, daß das absolut Wertvolle der wahrhaft smchenden Seele zu aller Zeit gegeben und gegenwärtig sein kann, daß ihr in hohen Stunden der Weihe die Kraft gegeben ist, lie Vereinigung mit dem Göttlichen ummittelbar zu vollziehen, daß die Seele nicht zu warten braucht bis anf das Ende der Gesehiehte. daß sie jederzeit den Durehbruch in die Evigkeit vollziehen kann, daß es im Raum der Seele ein Allerheiligstes gibt, rein und -chuldlos und mberührt ron dem Stanb des Lebens, und daß dieses Heilige der Seele die Vereinigung mit der heiligen Gottheit vollziehen kann, wem Verstand und Wille schweigt mnd zur Ruhe kommt, erlöst vom Strom des Lebens. Eine solehe Anffassung ist religionsfeindlich im Simne der historischen Religion. die in der simnliehen Wirkliehkeit in festen Formen zur Darstellung gelangen will, denn die Mystik ist vollkommen individualistiseh gerichtet, sie versehmäht die sinnliche Wirklichkeit und das Symbol und das Gleichnis zum Verstehen und Erfassen des Göttlichen. Die Mystik ist aber auch in cinem gewisen simne kulturfeindlieh, weil sio dem großen historisehen Werden nicht mit Liebe hingegeben ist, sondern immer die Umdentung des Zeitlichen in das Zeitlos: vollzicht, gegen das Werden Einsprneh erhebt und das Ende der Geschichte verlangt. Diese prinzipielle Kulturfeindlichkeit schließt natürlieh nieht ans, dabolio groben mystischen Naturen eine hervorragende Bedentung fïr die Entwieklung menschlicher Kultur besessen haben.

So schen wir, lab die Kulturwerte überall auf die absoluten Werte der Philosophio hinweisen, deren teilweise Verwirkliehung in der sinnlichen Sphäre beleuten und, was ihren Geltunesscharakter anlangt, in einem Wertsystem begrïndet sind. Der Begriff der Wahrheit geht über die wissenschaftliehe Erkemminis weit hinaus, aber dio Wissencehaft ist die uns zugängliche Stätte der Wahrheit. Wohl ist das Reich des Schönen erbaut und errichtet auch ohne kïnsterisehes Streben, aber in fler Kunst erwacht das Sehöne für den Menseheneroist und erlebt hier seine höghste Blïte. 1)agegen int der ethisehe Wert lor Freiheit anf has engsto verhunden mit menschlichem Wollen und Tun - wive mit, dem Gedanken dex monsehlieh sozialen Gemeinschaft. Das Wahre

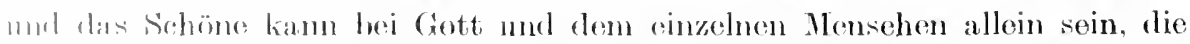

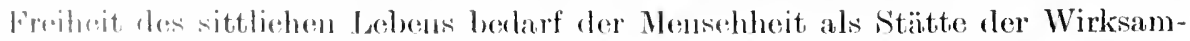

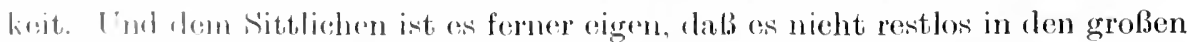

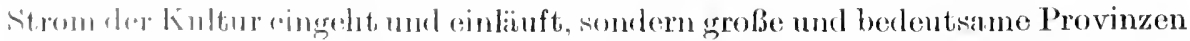

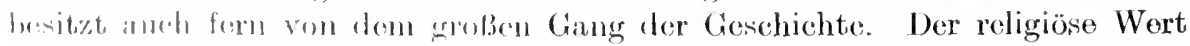
anllich, lon wir in lor Philosophie das Hoilige nonnen, widerstrebt in soiner 
strengen Abgeschiedenheit dem Gedanken der sinnlichen Verwirklichung. In den Vorstellungen aber, die das religiöse Bewußtsein vom Heiligen und Göttlichen sich entwirft, sind diese beiden Richtungen zu finclen, eine wirklichkeitsbejahende, kulturbefreundete und eine wirklichkeitsverneinende, kulturfeindliche.

\section{$\S$ 2. Der zweite Problemkreis. Das Leistungsproblem der Kulturwerte.}

Die Ưberlegungen, welche wir über das Verhältnis der Kulturwerte zu den absoluten Werten der Philosophie ans tellen, haben uns in dem Gedanken, daß der Kulturwert nicht nur im absoluten Wert begründet und verankert ist und von ihm alle Würde und Bedeutung erhält, sondern auch als sinnlich-zeitliche Verwirklichung des Ewigen aufgefaßt werden muß, schon bis zu einem gewissen Grade über das rein methodologische Problem hinausgeführt zu dem universalhistorischen Problem derWertverwirklichung hin. Mit dem Problem der Leistung wenden wir uns wieder einem spezifisch methodologischen Problem zu, das wir anch als die Frage der theoretischen Wertbeziehung bezeichnen können ${ }^{1}$ ). Wir haben diese theoretische Wertbeziehung, die dem Bezogensein der naturwissenschaftlichen Urteile auf Gesetzesbegriffe entspricht, sowohl von aller subjektiven, persönlichenWertung wie auch von dem geschichtslogischenProblem der historischen Beurteilung sorgfältig zu unterscheiden. Die subjektive persönliche Wertung, welche die Geschichte verfälscht, kann darin bestehen, daß ich vermöge einer gewissen gleichartigen Neigung und Gesinnung eine historische Erscheinung über alle anderen erhebe und preise. Weil ich die historische Erscheinung liebe, weilich zu ihr mich sympathisch hingezogen fühle, deswegen werte ich sie so boch. Diese Fälschung der historischen Betrachtung ist außerordentlich häufig und nirgends so verbreitet wie in der molemen Kunstkritik. Hier können wir es tausendfach erleben, daf dem begeisterten Kunstjünger jeder Maßstab zu ruhiger Einschätzung fehlt, und daß er dasGeliebte, was seiner persönlichen Neigung und seinem Geschmack zusagt, vergöttert und den geliebten Meister in die Gesellschaft der Heroen emporträgt. In welch mbelentender und schlechter Gesellschaft mußten sich nicht schon Homer und Sophokles. Dante, Shakespeare und Goethe befinden. Dieselbe subjektive Wertung wird hervorgebracht, wenn nicht persönliche Liebhaberei, wohl aber ein Parteiideal, etwa der Liberalismus oder der Konscrvatismus, für die Benrteilung des historischen Geschehens maßgebend wird, oder wem gar ein einseitig konfessioneller Standpunkt den Aspekt für die Auffassung und Darstellung der Geschehnisse hergibt. Von dieser subjektiven Auffassung und Einschätzung unterscheiden sich historische Beurteilung und theoretische Wertbeziehung. Die Voraussetzung der historischen Benrteihung lildete, wie wir gesehen haben, lediglich die Anerkennung der Kultur überhaupt. Der Begriff der theoretischen Wertbeziehung appelliert an eine Differenzierung des Kulturganzen. Insofern braucht die historische Beurteilung weniger rorauszusetzen wie die theoretische Wertbeziehung. Dieser Begriff der Kultur

1) Der Begriff dieser theoretischen Wertbeziehung besonders deutlich bei Rickert: Geschichtsphilosophie. Festschrift für Kuno Fischer. 
wirl in der historischen Beurteilung als Maßtab aufgestellt. Jede Kulturrermehrung wird als wertroll, jede Kulturverminderung als wertwdrig empfunlen, und ganz allein anf die Leistung kommt es an. Gleichgriltig orler doch zum mindesten nebensächlich ist es. ans welchem Motiv heraus lie Leistung geschieht. Diese historische Beurteilung wirl rom Historiker -elber vollzogen. und die Philosophie hat hier lediglich aufzuweisen, durch welchen Maßstah sein Verhalten gegenüber den Gegenständen bestimmt ist. Daß eine solche historische Benrteilung stattfindet, daß in allen großen historischen Werken zahlreiche Beurteilungen und Wertungen historischer Leistungen und Handlungen sowie des Gesamtge-chehens ïberhampt vollzogen werden. las wird wohl niemand bestreiten kömen. Eine andere Frage ist nur, ob diese historischen Benrteilungen zu Recht bestehn, das heibt, ob sie im Wesen der historischen Wissenschaft hegrïndet sind. Die historische Beurteihng wird vielfach ak eine mwissenschaftliche Beigalbe zur Erkenntnis der historischen Welt anfgefa Bt, und die theoretischeWertbeziehung als das methodisch eigentlich Wesentliche geltend gemacht. Wie etwa die anschanlichen Bilder und Vorstellungen. lureh die der Historiker ïber die individualisierende Begriffsbildung hinans Wirklichkeitsnähe zu errejchen sucht und das Persönliche, Rätselhafte und Cnauflöshare $z$ verdeutlichen unternimmt. als eine kiunstlerische Beigabe, als eine auBerlogische Leistung im simne theoretischer Erkenntnis anfzufassen ist. so sollen auch die Beurteilungen, in denen die Auffassung der historiwhen Erscheinungen und ihre Werteinschätzung ron Seiten des Geschichtsfor chers sich kundgibt. in Iogiseh-theoretiseher Hinsicht irrelevante Zugaben sin. Nach unserer Auffassung ist die historisehe Bemrteilung ron herrorragender theoretikcher Bedentung. da sie recht eigentlich die Geschichte als sollstständige Wissensehaft konstituiert. Der theoretische Wert der Wahrheit, der ein Verhältnis zu dem blob vorstellenden und rein erkemnend sich verhaltenden Menschen besitzt, führt weder in der Naturwissenschaft noch in den einsamen nnd wirklichkeitsfernen Gebiet der Logik zn einem Verständnis der Welt. Nur dort, wo der Mensch in der Fülle aller möglichen Verhaltungsweisen, in der sinzen llannigfaltigkejt seiner Beziehungen zum Universum, in der ganzen Volständigkeit soiner. Wert- und Zielsetzungen berïcksichtigt

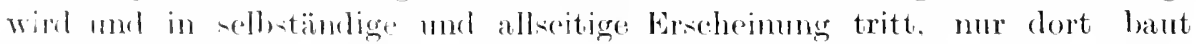

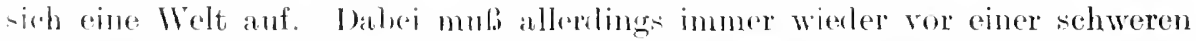

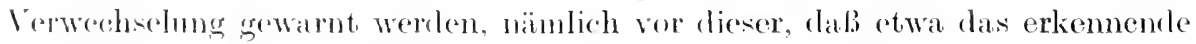
Sinhjekt als der ganze Mensch aufgefabt wirile). In dem erkennenden Subjokt lommot immor mur das einseitig theoretische Verhalten zum Ausdruck.

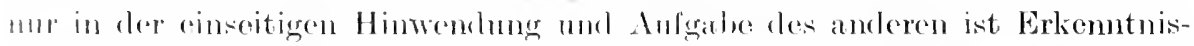

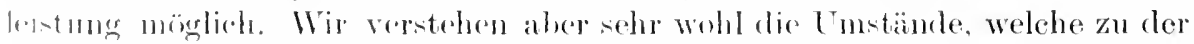

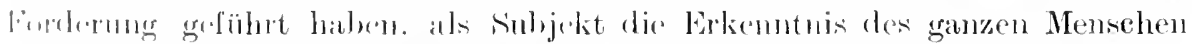

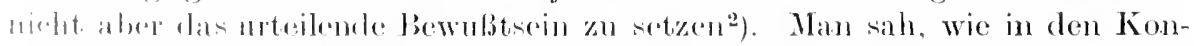

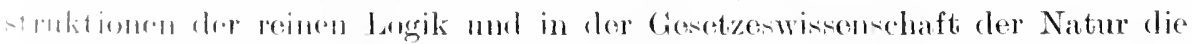

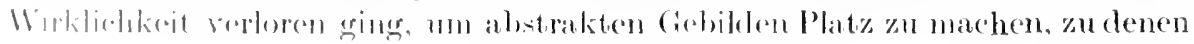

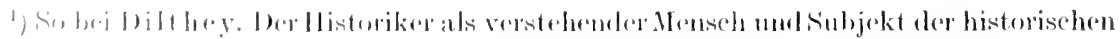

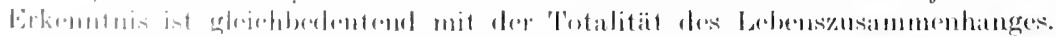

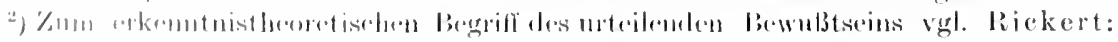

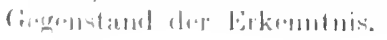


das wertende Gesamtbewnßtsein des Menchen kein Verhältnis mehr gewinnen konnte, die in eine absolnte Ferne gerückt waren. Deswegen erhob man die Forderung, daß nicht der erkennende Mensch erkennen soll, sondern der ganze Mensch in der Fülle seiner Verhaltungsweisen, der in ästhetiseher Anchaunng verweilende, vom sittlichen Pflichtbewußtsein getragene, von der religiösen Sehnsueht und L: ebe ergriffene Mensch. Ein soleher Mensch ist doch erst ein ganzer Menseh. Nur der ganze Mensch kann die Wirkliehkeit erkennen, wiesieist. Der theoreti che Mensch ist eine Abstraktion, und eine Abstraktion vermag nicht zu erkennen. Immer erkennt der wirkliche, lebendige Mensch.

Demgegenüber kann nicht oft genug betont werden, daß gerade dieser sogenannte ganze Mensch in der Fülle seiner Beziehungen mit Rücksicht auf irgendeine Wertleistung, mag es sich da nun um kïnstlerisches Schaffen oder um politisch wertrolles Tun handeln, immer eine Abstraktion ist. Denn der allseitig sich rerhaltende Mensch ist der absolut untätige Mensch. Weder erkennt er, noch schafft er künstlerische Formen, noch gibt er neue Gesetze und Institutionen, noch schöpft er aus der Tiefe seines Gemütes neue Symbole, das Göttliche zu verstehen. Er ruht in sich. Alle Tendenzen der Wertbejahung kompensieren sich gegenseitig. Indem er alles bejaht, bejaht er niehts. Allem zugewendet, ist er in Wahrheit dem Niehts zugewendet. Eine stumme, tatenlose, in sich abgeschlossene Monade. Dieser ,ganze" Mensch ist die Konstruktion des Anfangs von allem Wert- und Weltrerstehen. Dem Wertund Weltchaos, dem absolut Unbestimmten, steht gegenüber das Chaos der menschlichen Seele, das ron allem gleichmäßig ergriffen und deswegen ron nichts ergriffen ist. Erst die Differenzierung der Wertrerhaltens und die einseitige Zuwendung zu einem Gebiet macht Kulturleistung möglieh.

Niemals kann der ganze Mensch das Subjekt der Erkenntnis sein, wohl aber soll das erkennende Subjekt den ganzen Mensehen zu objektivieren mnd zu verstehen suchen und allen Tendenzen, die im menschlichen Wertrerhalten zum Ausdruck kommen, Parm und Stelle verleihen im Ganzen des Meltbikles. Wenn die Erkenntnis nur das theoretische Verhalten berüeksichtigt, nur den theoretischen Menschen und die theoretische Leistung zu objektivieren unternimmt, so kann immer nur ein Weltframent, nicht aber eine wirkliehe unt vollständige Welt entstehen. Diese Universalität aber hat die Geschichte mit der Philosophie gemeinsam, dafs sie im Akt der historischen Beurteilung die Fülle der Werte bejaht und damit die Objektivierung des ganzen Menschen und des Menschlichen ïberhaupt unternimmt.

In der historischen Beurteilung ercheint somit zuerst das Prinzip der Geschichte, dieses Prinzip ist die Kultur. Die historisehe Benrteilung tritt an die Gegenstände, an die gesehichtlichen Erscheinungen überall nah heran und gibt ihnen in der Tersehiedenheit der Werteinschätzung eine gewisse Differenzierung. Ans dem Kleinen und Unbedeutenden heht sich das Große empor, dessen Leistung den Anspruch erhebt anf den Nachruhm der Jahrtausende. Aber eine eigentliche Gliederung der historischen Welt rermag die historische Beurteilung noeh nieht zu rollziehen, dafür ist der Begriff der Kultur noch zu vage und unbestimmt. Anch ist die historische Beurteilung, wie wir gesehen haben, mit Notwendigkeit immer gebannt und gefesselt ron dem Gedanken der Umsetzung des Tuns und Wertrerhaltens in objektive 
Leistıng und ist gern bereit, für großes Tun und Wirken auch das Laster und den Ehrgeiz und die Brutalität der Leidenschaften mit in den Kanf zu nehmen. Wenn das Phänomen der Größe eimmal da ist, kömnen diese Mäichte das Bild nur leise tönen. niemals aber vermzieren und verunstalten. Dagegen bahnt sich in dem Begriff der Wertbeziehung eine höhere Forderung an. In ihr kommt die philosophiche Forderung zum Ausdruck, daß das in der historischen Beurteilung Gemeinte sich zum reinen Wertverhältnis läntern soll.

\section{a) Prinzip der Auswahl.}

Suchen wir nunmehr im einzelnen die Leistung der theoretischen Beziehung zu erspähen. Sie ist ein Prinzip der Auswahl, der Gliederung, der Vertiefung und Erkemntnis der historischen Welt. In erster Linie ein Prinzip der Auswahl. Ihr fällt die Aufgabe zu, das historisch Wichtige, das wahrhaft Historische ans der Fülle des Wirklichen herauszulösen. Ohne sie wäre die historisehe Erkemntnis riehtungslos und direktionslos. Die Besinmung auf sie ist langsam und allmählich gereift, wie in der Naturwissensehaft dieVorstellung von den Gesetzen. Immer wird es gewisse Gesichtspunkte gegeben haben, nach denen die historischen Tatsaehen als wichtig und der Aufbewahrung wert empfunden wurden. Ursprünglich war es das Auffallende, das Ungewöhnliehe, das Außerordentliche, das den Menschen veranlaßte, mit Zeichen und Schrift Vergangenes festzuhalten. Ein schweres Unglück, eine Krankheit, die das Volk heimgesmeht hatte, die Erscheinung eines Kometen, die Torfinsterung der Sonne, ein schönes, segenreiches Jahr, Taten der Rache, Taten der Liebe und des Verbreehens Furchtbarkeit, Buderzwist, abenteuerliche Wanderungen, Krieg und Krieges Schieksal. Die Freude am Ungewöhnlichen war es, die den erstenHistoriker sehnf, und mit lehhaften Bildern schmückt seine Phantasio die geschehenen Taten. Und später mag es dann wohl der Nutzen gewesen sein, der die Auswahl bestimmte. Man wählte diejenigen Tatsachen aus und schrieh sie nieder, die geeignet waren, den späteren Generationen zur Warmung, zur Nachahmung und Belehrung zu dienen. Je mächtiger aber das historische Goschehen wurle, je reicher die Zeiten waren an Taten und Ereignissen, je höher und schöner die Formen des Lebens sich entfalteten, ım so unzweilentiger stellten sich die Kulturwerte als die Auswahlprinzipien für den Historiker herans. Schildern will er, wie Ordnung und Sitte, Rechte und Institutionen, große gesellschaftliche Verbänle, Völker und Völkergemeinschaften gewordon sind.

\section{b) Die moralisehe Auswalle}

Das machtvolle politisch-soziale: Werden drängt sich seinem Geiste auf. Jer Wert aber, der dahinter steht, dor alle seine Uberlegungen leitet, der die Answahl des Wesentlichen bostinme, anf den die großen politisehen Ereignisse bryogen werden, das ist rler Begriff des Reehtes und der Moralitä. Denn was die grofoen Vorbänlo, die groben sogialen Gemeinsohaften bilket und gestaltet, was sio äher dies Stufe dos bloß naturiaftion Dascins in das werthafte Leben dor gronchichtichen Wrot erhob, was die Hordo, die Sippe, den Stamm in die Form rar Finnilie, dos \%weckvorbandes, der bürgerlichon Gomeinschaft, des Volkres, dre Niutionalität, dos Stalates geführt, das ist im Grumle genommen 
niehts anderes wie die Idee der Rechtsordmmg mul der moralisehen Ordnung. Ohne die Idee dieser Ordnung und ohne die Regeln und Einrichtnngen, die diese Ordnmosprinzipien geschaffen haben, wïrle ein politisch-gesellschaftliches Gemeinschaftsleben ummöglich sein. Dabei kann man wohl mit Recht, wie man das Verhältnis zwischen den beiden Ordnungsprinzipien auch denken mag, die juridische Ordnung als die äußere, exoterische und die moralische Ordnung als die esoterische bezeichnen. Wo Recht und Geretz ist, la ist anch staatliche Ordnung und Herrschaft. Der Staat erscheint am sichtharsten und greifbarsten in dem Gesetzesmechanismus. Deswegen hat man zeitweilig die Äußerlichkeit des Gesetzesmechanismus dem Staate gleichgesetzt. Politische Staatengeschichte und Rechtsgeschichte hat man unanflöslich verbunden. Wenn ich die großen politischen Bewegungen beobachte, die in den Wanderungen der Völker, in großen gemeinsamen Unternehmungen, in Angriff und Terteidigung. in dem Anwachsen und der Tergrößerung des einen Volkes auf Kosten der Herabsetzung und Herabmindermng des anderen Tolkes, in der Sehöpfung nener Zweckverbände, in Loslösung und Trennung, in Aufruhr, Empörung und Tyramnenmord bestehen, dann könnte ein aufmerksamer Beobachter und Interpret des historischen Lebens wohl meinen. daß es das Pecht sei, das hier vor allem und in erster Linie seine Veränderung, Entfaltung und Ausbreitung erfährt und so als das leitende Prinzip der Auswahl für die politische Geschichte angesehen werden muß. Wem wir nach dem Gemeinsamen in all diesen politischen Geschehnissen fragen, so handelt es sich doch schließlich immer um die Bildung und Auflösung von Recht, um große politische Bewegungen, neue staatliche Ordnungen, nene Gesetzgebungen. Und wenn aus dem Inneren des staates heraus in gewissen sozialen Bewegungen der Wille des Volkes sich gegenüber dem Herrscherwillen geltend maeht, so ist das Resultat auch hier wiederm Rechtsbildung und Rechtsverändermng, sei es nun im sime der gestellten Forderungen oder sei es in der Absicht, ähnliche Bewegungen ein für allemal ummöglich zu machen.

Und doch ist die Rechtsmaschine weit davon entfernt, alle Verhältnisse in der Lebensgemeinschaft einer Gesellschaft ordnen und gestalten zu kömen. Viele Lebenskreise werden von ihr nur flïchtig berïhrt. Sie richtet sich ror allem gegen diejenigen, die sich in irgendeiner Weise gegen das soziale Verhälnis auflehmen, die durch Taten und Handlungen in Opposition zur Gemeinschaft treten, und gibt so den notwendigen Schutz für Leben und Eigentum. Sie sichert Bestand, Wohlfahrt und Gedeihen des Staatswesens, bestimmt die Rechte ron Volk und Herrscher, gibt dem Verkehr und dem Handel feste Normen und baut so die äußere Form des Staatswesens auf. Aber in die innerlich geweihten Kreise freundschaftlicher Neigung und Srmpathie, in alle jene Verhältnisse, die aus freier Wahl sich bilden, in die Verborgenheit des Sichaus. lebens, in das Walten des Familienkreises, in das Verhältnis des Freundes zum Freunde, des Liebenden zur Geliebten, des Schüler's zum Lehrer, des Herrn zum Diener, sowie in alle jene arderen Kreise von gegenseitigen Abhängigkeiten, in die sich die Menschen aus freier Wahl begeben, um ein persönliches Bedürfnis zu befriedigen oder irgend einem Wunsch, einer Sehmsucht, einem Streben Nahrung zu geben, sowje auch in das weite Gebiet geselliger Beziehungen, in alle diese Kreise und Verhältnisse dringt das Recht nicht eigentlich 
ein, sondern gibt nur ein allgemeines Sehema her: demn jenes starke und persönliche Leben, das gerade in den intimen Zirkeln herscht, entzieht sich in seiner schönheit und Eigenart den allgemeinen Normen des Gesetzes, die immer nur das häufiğ Geschehende regeln kömnen, der Eigenheit und Einzigkeit des tief innerlich bewegten Lebens gegenüber aber notwendig versagen müssen. Und dasselbe gilt auch für das Terhältnis des Rechtes zu allen jenen Betätigungen, in denen der Mensch, ron hohen Aufgaben erfüllt, sein Bestes und Wertrollstes hergibt für die Erfüllung und Vollendung großer objektiven Leistung. Nicht vermag das Gesetz Normen zu geben, nach denen sich die Arbeit des wissenschaftlichen Forschers vollziehen soll, noch hat es jemals dem Künstler Anweisung gegeben, wie er schauen und gestalten soll. All dieses vielseitige Leben aber hat seine Stelle im Staat, und so ist das Recht weit davon entfernt, das ganze Leben des Staates ordnen zu können und zu wollen.

Ton der Innerlichkeit der kleinen Lebenskreice her, jener freien und unberïhrten Gemeinchaften, gehen nun aber andere Bewegungen aus, welche die starre Rechtsmaschine beseelen und eine imnere Ordnung der Dinge aufbauen. Das geschicht in erster Linie vom moralischen Bewußtsein her, das in lebendigem Kontakt mit dem Rechtsbenußtsein der Zeit dieses immer wieder verändert und die alten Normen des Rechtes olssolet werden läßt. Die moralische Ordnung, die eine soziale Gemeinschaft errichtet und dadurch erst ein wertvolles Staatswesen schafft, ist nicht sichtbar und augenfällig. Sie kommt nicht in besonders kodifizierten Sätzen zum Ausdruck, sie hat auch keine Institutionen, Formen und Einrichtungen getroffen, die unmittelbar ihrem Dienste geweiht wären. Is gibt keine moralischen Anstalten, wie es wissenschaftliche und künstleyische gibt. Es gibt keme Belohnungen für moralische Leistungen, wie solche für eine wissensehaftliche oder kïnstlerische Tat dargeboten werden. Der Verstolj gegen dic Moralität findet keine Strafe und die Förderung des sittlichen Lebens keinen John nach festen Regehn und Normen. Die moralische Ordnung ist einc geheime, rerschwiegene und unsichtbare Ordumng der Dinge. Und demnoch ist der Bestand und die Leistungsfähigkeit des Staates ron ihr in erster Jinie alohängig, alles frische Leben und alle Gesundheit und alle Macht ruht auf ihr. Nicht immer dringt das moralisehe 'L'un bis in die Öffentlichkeit des historischen Lebens. Unbekamnt, unverstanden und rersehwiegen wird ('s manchmal sein und hleiben. Aber in den großen Werdegängen, Krisen und Cmüilzungen, dic ein Staatslcben erfährt, wird immer die moralisehe Tüchtigkeit rines Vollios entechejdend für den Ausgang sein. So hat dex stat im Grunde erenomnen sejn wahres leben in der sittiehen Ordnung aller sozialen Verhält-

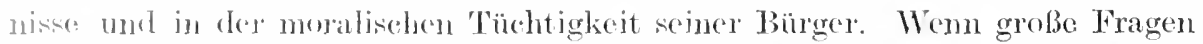

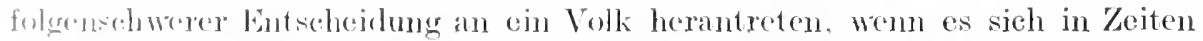
bittere Not den harten Entschlub absolnter Hingabe und Aufopferung für

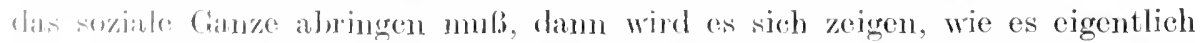

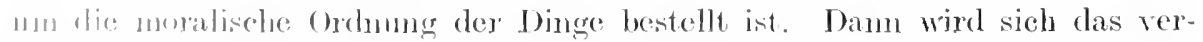

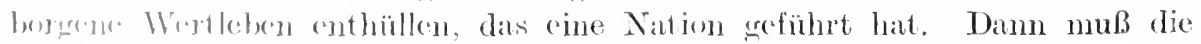

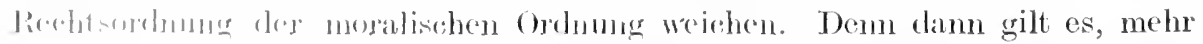

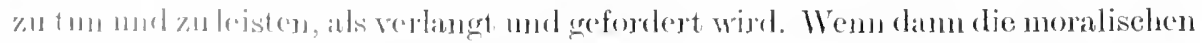
Kräfte die stage liochtsmaschine besecele und alle äuberen Institutionen

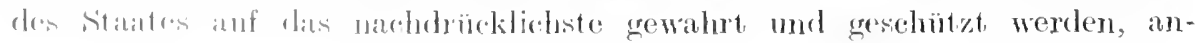


erkannt und getragen von den Heroismus der Nation, dann ist es gut um den Staat bestellt. Unselig ist aber ein Gemeinwesen, wenn in den Stunden der welthistorischen Berufung die moralische Ordnung versagt, wenn der sittliche Wille sich nicht hineinlegt in den staatlichen Organismus und ihn als ein starres und blutleeres Gebilde zurückläßt.

So ergibt sich denn für den Historiker die ungeheure Bedeutung des sittlichen Wertes für die Geschiehte und das Schicksal einer Nation. Er darf sich nicht täuschen lassen durch die stolze Macht staatlicher Institutionen, durch den pompösen Aufbau des Rechtes, durch die ungeheure Organisation staat. licher Kräfte: hohl und nichtig und leer können sie sein ohne die begeistende Kraft des moralischen Willens. Das Rechtshewubtsein eines Volkes rermag niemals die bestehende Rechtsordnung anzuerkennen, es drängt immer über sie hinaus. Es sieht ein Unrecht im Recht. Es sieht eine Terletzung der Gerechtigkeit und damit einen Verstoß gegen die moralische Ordnung. Die Fortbildung des Rechtes ist also vielfach durch das moralische Bewußtsein des Volkes bedingt, wenn auch die rechtlichen Normen als solche nicht das sittliche Leben regulieren, sondern nur eine äußerliche Korrektheit des Handelns.

Bei der großen Bedeutung des moralischen Wertes für das Schicksal der Völker sollte es ja num wohl selbstverständlich sein. daf der sittliche Wert in hohem Maße die Auswahl des historischen Geschehens bestimmt. Und so haben denn auch alle großen Historiker der Stimme gelauscht, die aus den Tiefen des sittlichen Gemeinschaftsbewußtseins eines Volkes herauftönt. Es ist die Kunst des wahrhaft großen Geschichtsschreibers, auch diese Stimme rernehmbar zu machen, die für die äußerliche Betrachtungsweise nur zu leicht verloren geht, da sie nur zu häufig erstickt wird durch die Leidenschaften der Parteien. durch die Härte des Interessenkampfes, durch das Geräusch und den Lärm des Tages. Das sind die wahrhaften Feierstunden der Weltgeschichte. wemn eine Nation sich auf ihren moralischen Wert besinnt und, durch die hohen Werte der Pflicht, der Unabhängigkeit und politischen Freiheit, der Aufopferungskraft, der Trene und der nationalen Ehre bestimmt, rom Heroismus der Vaterlandsliebe geleitet, das eigene Schieksal mutig zu gestalten und zu bestimmen unternahm und sein Schicksal zum Weltenschicksal erweiterte. Besonders schön und glänzend erscheint die Sittlichkeit eines Tolkes. wenn sie sich zum Anwalt großer Kulturgüter macht. Deswegen steht Griechenland so groß und muvergleichlich da, als seine schöne sittliche Kraft sich in den Perserkriegen zum Anwalt der eigenen großen Kultur und damit zugleich zum Anwalt der Menschheitskultur machte. Aber auch dort, wo das sittliche Bewußtsein in weniger glänzender Form mit einer gewissen Schliehtheit zutage tritt, wie in den Anfängen der römisehen Republik oder in den Kämpfen des kernigen Schweizer Bauernvolkes gegen Burgund, aneh dort muB der Simn des Historikers mit Bewunderung und Verehrung weilen, wissend, dab in dieser schönen und heroischen Hingabe an das Vaterland wahrhaft Großes geschieht. Und wie feierte doch die stoische Moral neue Triumphe, als der große Preußenkönig, rings von Feinden umkreist. mit stolzer Beharrlichkeit und Unerschütterlichkeit um sein und seines Staates Dasein kämpfte, ein gemeinsames. unauflöslich verbundenes Schicksal. Und wie schien doch in den 
Anfängen der französischen Revolution die Somne einer höheren Bürgertugend zu leuchten. So erscheint der moralische Wert überall am fernen Horizont der Staaten- und Völkergeschichte und rerklärt mit seinem Schein der Helden und Fölker todesmutige Taten. Und so gibt der moralisehe Wert ein wichtiges Prinzip der Auswahl her, sofern die Anzeichen moralischer Tüchtigkeit für den Bestand der Staatengebilcle einen Befund von größter Bedeutung darstellen.

Wir sind hier an einer Stelle angelangt, wo wir den moralischen Wert als Prinzip der Auswahl, auf das die politisehen Gesehehnisse theoretiseh bezogen wurden, gegen eine Reihe ron Mißrerständnissen zu schützen haben. Tor allem gegen die Auffassung, als ob wir irgendeine moralisierende Tendenz in der Gesehiehte vertreten wollten. In der Geschiehte kann der moralische Wert sehon deswegren keine aussehlaggebende und entseheidende Bedeutung besitzen, weil neben ihm noch andere Werte, wie Wissensehaft Kunst und Religion, als Prinzipien der Auswahl fungieren. Wie aber kann die Geschisehte den Primat irgendejnes Wertes den anderen gegenüber begründen, oder wer wollte ihr jemals die Aufgabe stellen, eine solehe Rangordnung zwischen den Kulturgütern festzulegen? Ist die moralisch-politische Entwicklung die leitende und bestimmende für die Auffassung des historisehen Gerchehens, oder müssen wir etwa der intellektuellen oder der ästhetischen Entwicklung den Vorzug geben? Es könnte auf den ersten Blick so scheinen, als ob der moralisch-rechtlich-politische Wert den Anspruch erheben kömnte, der leitende Wert des historischen Geschehens zu sein. Das moralisch-staatliche Gemeinschaftsleben der Völker bildet ja die Grundbedingung für alle höhere Kulturleistumg. Und doch, wemr wir auf clie Geschichte blicken, wie sollen wir unter diesem Gesichtspunkt die \%eiten und Völker einsehätzen und beurtcilen? In ciner Zeit politischer Schwäche haben die griechische und dentsche Nation anf dem Gebiet der Philosophie und Kunst das höehste geleistet. Sicherlich steht das Zeitalter des Plato und Aristoteles, des Sophokles und I'raxiteles somie das Zeitalter des dentschen Idcalismus an IVürde und Bedentung nicht zurück hinter dem Zeitalter Ludwigs XIV. oder hinter dem Zeitalter der aroßen nationalen Einheitsstaten im 19. Jahrhundert. Für den Historiker gibt es keinen leitenden Wert, sondern versehiedene gleichberechtierte Kulturwerte, die als Prinzip der Auswahl die historische Wirk. lichkeit bestimmen. Eine moralisierencle Geschiehtsaufassung ist ja sehon durch museren Begriff der historischen Benrteilung zurückgewiesen, die lediglieh einen undifferenzierten Bogriff von Kultur überhanpt zugrunde legt und in dem ganzen Charakter ihree Mertabschätzung jenseits ron gut und böse steht. wie wir das in der Idee eince, historisclest" Moral festgelegt haben.

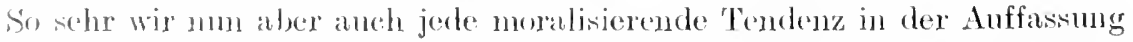

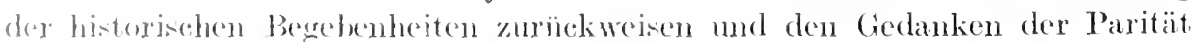

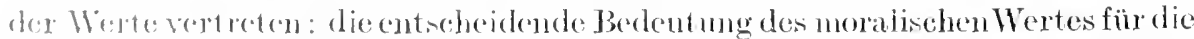

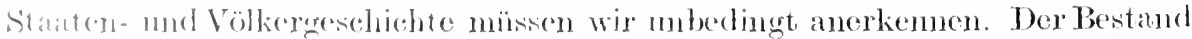

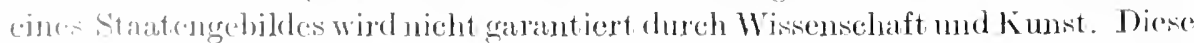

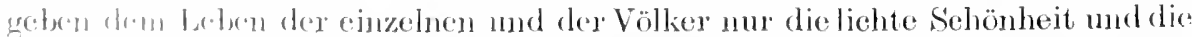

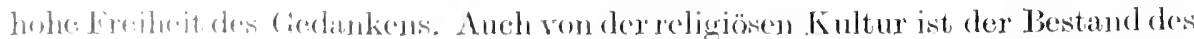

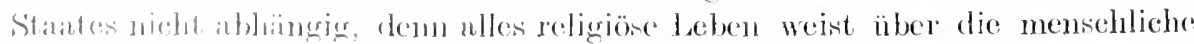

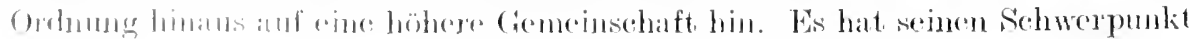


viel zu sehr im Transzendenten, als daß es sich mit absoluter Opferwilligleit in den Dienst irgendeiner menschlichen Ordnung stellen möchte und könnte. Aber der moralische Wert ist es, der die Stabilität irdisch-menschlicher Gemeinschaften begründet, der dem Gemeinschaftsleben der Individuen Festigkeit und Würde gibt. Ton hier aus müssen wir jene realistische Auffassung als Maßstab der Betrachtungsweise ablehnen, die das ethische Homent aus den Hand. lungen des öffentlichen Lebens vollkommen verbannen will und ihm lediglich ein privates Dasein anweist. Daß der sittliche Wert auch ein öffentliches. freies und allgemeines Dasein habe, darauf wird das Bestreben der großen Leiter und Erzieher der Völker und Nationen immer gerichtet sein. Wenn wir die Geschichte so auffassen, als ob es sich hier nur um das Auskämpfen und Ausfechten eines großen Interessen- und Konkurrenzkampfes unter den Völkern handelt, in dem jedes Mittel der Gewalt und der Lüge zur Vernichtung und Ausrottung des anderen gestattet ist, so verliert dureh diesen mibrerstandenen Darwinismus die Historie jede Würde und jeden Sinn. Mag an den Politiker noch so sehr die Forderung der rücksichtslosen Interessenvertretung seiner eigenen Nation gestellt werden: der Standpunkt des Politikers ist nicht die Warte. von der aus der wahrhafte Historiker Menschheitsgeschichte schauen soll. Der moralische Wert ist es doch schließlich ganz in erster Linie, der über die Brauchbarkeit, Festigkeit und Bedentung jedes sozialen Kreises entscheidet und so den letzten Maßstab für die Auswahl der Wertvollen hergibt, mag er auch in der historischen Beurteilung wenig hervortreten und'erst in der philosophischen Besimnung deutlich werden. Daß für die Entwicklung des intellektuellen Lebens der Kulturwert Wissenschaft in jeder Weise bestimmend ist, wird man wohl eher zugeben als das herrschende Verhältnis des moralischen Wertes gegenüber den sozialen Gebilden und der Geschichte ihres Werdens. Man redet häufig ron der Gesundheit eines Volkes oder auch von der Gesundung der sozialen Verhältnisse. Iran glaube nur nieht, durch diese bildliche Ausdrucksweise die große Tatsache verschleiern zu kömen. daß dasjenige. was wir Gesundheit nemen, in erster Linie die moralische Tüchtigkeit eines Volkes ist. Eine Nation mag phrsisch noch so gesund, so fruchtbar und reich an Kräften sein : dem Untergang und Verderben ist sie geweiht. wenn ihr die moralische Kraft der Utberzeugung und der Glaube an sittliche Güter fehlt. Nur die moralische Überzeugung kann ein Tolk dahin führen, große Taten im Interesse der Gemeinschaft auszuführen und freiwillig die größten Opfer zu bringen. wenn es die Sache so will.

So ist in der Tat der moralische Wert ein wichtiges Prinzip del Auswah! für die Staaten- und Völkergeschichte, den der Historikel zwar nur selten in bewußter Weise anwendet, den er sogar als einseitig und rollkommen ungenügend zurückmeist, der aber doch immer im Hintergrunde der Auffassung und Deutung großer politischer Taten steht, da er nun eimmal unzertrennlich mit dem Begriff des Staates rerbunden ist.

Wenn ein Historiker die Geschirhte der griechischen Stadtstaten rom Zeitalter der Perserkriege bis zum Untergange der politischen Sclbständigkeit Griechenlands durch die Hakedonier und später dureh die Römer schreiben will, so legt er als Prinzip der Auswahl den Begriff der griechischen Polis und des grieehischen Tolkes zugrunde. Die Eigentiumliehkeit des griechischen 
Kleinstaates wird er zu schildern haben, der immer wieder neu und anders in Grieehentand aufgebaut wurle und, wie wir ron Aristoteles wissen, über 150 verschiedene Formen der Verfassung gezeitigt hat. Sofern die Rechts. ordnung in Gesetz und Verfassung der Individualität der cinzelnen Volksgemeinschaften auf das glücklichste angepaßt war, mußten Moralität und sittlichkeit hier eine schöne Heimat finden und das ganze öffentliche Leben durehdringen. Die Enge des Staates ergab einen nahen Zusammenhang zwisehen bekamnten und befreundeten Mensehen, und die sehöne und hellleuchtende Flamme der hellenischen Vaterlandsliebe hatte ursprünglich nur in beschränkten und isolierten Verbande für die Nächsten und Liebsten geglüht. Erst später griff sie dann über die engen Grenzen der kleinen Stadtstaaten weit hinaus und leuchtete als präehtiges Fanal im Kampfe gegen die übermïtigen Perser. Über die schöngegliederten Verhältnisse des kleinen Stadtstaates hinaus wendet sich das Interesse immer wieder der griechischen Nation als einer Ganzheit zu. Überall sehen wir den Simn für die Familie, für das traute Heim, die Liebe zur Polis, die fromme Ehrfurcht dem Göttlichen und Unerforschlichen gegenüber, eine edle ma Bvolle Haltung und Lebensführung, Gehorsam gegenüber den Gesetzen des Vaterlandes, Tapferkeit und Gerechtigkeitsgefühl, wahrlich Eigensehaften, die in hohen Maße geeignet waren, das Fundament für die Ordnung eines großen, umfassenden Einheitsstaates herzugeben. Wemn num dieser griechische Einheitsstaat nieht erreicht wurde, so darf man deswegen dem Griechentum doeh nicht den Vorwurf machen, daß es ihm an staatenbildender Kraft gefehlt habe. Gerade das Gegenteil ist der Fall: Ordnungen des Reehtes und Verfassungsformen konnte dieses Volk schaffen wie kein anderes. Ganz verfehlt ist es natürlich, von der Zucht. losigkeit und Disziplinlosigkeit des grieehisehen Volkes zu sprechen. Auch Partikularismus ist ein verfehltes Wort, weil ihm zu sehr der Gedanke des Engherzigen und Kleinliehen anhaftet. Man kann ron dem Individualismus der griechischen Nation spreehen, wenn auch dieser Begriff die griechische Nation nur in einer gewisen Hinsicht kennzeiehnet, da ja das Allgemeine und Gesetzliche in höchstem .laße bewertet wird. Dieser Individualismus des Grieehentums, wie er sieh in ker Anerkemmung bereehtigter Figenart und in der Ausgestaltung des persönlichen Lebens so prïiehtig offenluat, ist ron Unbotmäßigkeit und Anarehismus so weit ent fernt, daB ep sich schr wohl rem Ganzen eines hellenisehen Finheitsstates cingegliedert häite. Nichts ist ungereehtfertigter, als lediglich rom Wrfolg aus ïler ('haraktes und Wert einer Nation zu urteilen. Wem die ldee des griechisehen Winheitsstates sich nicht erfüllt hat, so läßt sich der Grund hiexfür nicht aus dem nationalen Charakter ableiten, und auch das Milieu und die äuloren lomstänrle vermögen nicht alles zu erklären. Es ist ungerecht. fortigt und mugerecht, die Figenschaften einer Nation so zu bestimmen und

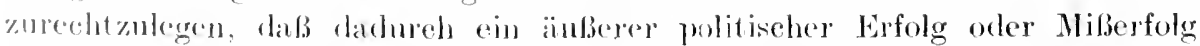
möglichst plansibel und einfach relüntert wirl. Das ist ein historiseher Rationalismm. dro den vopgehliehen Versuch maeht, das Rätselhafte und, Zufüllige"

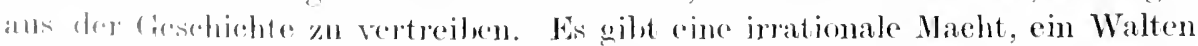
ïber Vilkrer und Stanten, das wir als behickisal bezejehnen, und als tragiseh

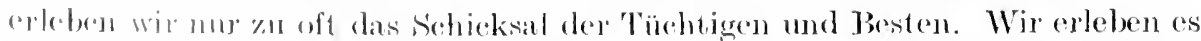

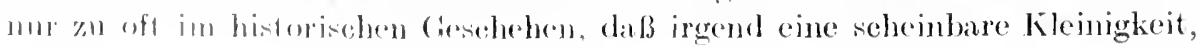


häufig in ganz unerwarteter Weise, den Ausschlag gibt für Vlenschen-und Völlerschicksal. Warum mußte Athen im Peloponnesischen Kriege dem schlechteren Gegner gegenüber unterliegen? War nicht alles danach angetan und darauf angelegt, dem athenischen Volke die Vorherrschaft zu sichern? Diese stolze Flottenmacht, dieses prächtige Soldatenmaterial und gute und erlesene Fïhrer! Und denmoch sollte Athen der so verdiente Erfolg nicht zuteil werden. Warum mußten auch die griechischen Bürger den Nikias zum Felrherrn erwählen. der zurerlässig und tapfer, aber schwerfälligen Geistes war! Warum mußte der freie Geist eines freien Atheners von den Schatten des Aberglaubens umnachtet werden? Warum mußte die Verfinsterung des Iondes der beabsichtigten Heimkehr nach Athen entgegenstehen? Warum mußte die Einschließungsmaver, welche die Athener angelegt hatten, bei Ankunft rles spartanischen Feldherm noch nicht ganz vollendet sein? Welch eine Fülle des Irrationalen steckt doch in all diesen historischen Ereignissen! Wohl ist der moralische Wert eines Staates oder einer Nation für Sieg oder Untergang vielfach entscheidend, aber über allem steht das Walten des Schicksals, das nur zu häufig das Gute und Große dem Schlechteren und Geringeren gegenül)er unterliegen läßt.

Der moralische Wert ist ein notwendiges Prinzip der Auswahl für das politisch-soziale Geschehen, weil seine Verwirklichung im öffentlichen Leben den Staat als Kulturstaat erst möglich macht, und weil seine Wirklichkeit im Leben und Handeh eines Volkes erst den Begriff der Wertindividualität schafft, mag dabei nun die Reflexion mehr auf die Wertleistung der ganzen Nation, auf das gemeinsame Schaffen gerichtet sein oder sich dem Außerordentlichen und Großen im schöpferischen Tun einzelner großer Persönlichkeiten zuwenden. Das moralische Prinzip ist die conditio sine qua non des Kulturstaates und der großen Kulturnation, aber es fehlt viel daran, daß beide durch die Anerkemnung und Verwirklichung dieses einen Kulturwertes schon vollendet wären. Große Denker haben so gedacht, ror allen Plato und Hegel. Für Plato ist die Verwirklichung der Idee der Gerechtigkeit als des höchsten sittlichen Wertes die selbstrerständliche Vollendung der idealen sittlichen Gemeinschaft. In diesem platonischen Staat hat auch die Schönheit, der ästhetische Wert und die Wissenschaft eine politische Aufgabe zu erfüllen. denn alle Bürger sollen zur Schönheit gebildet werden dureh Gymnastik und Musik, und die wissenschaftliche Erkenntnis ist der Staatsleiter wichtigste Tugend. So gehört auch die Wissenschaft dem Staate an, aber schon Plato deutet darauf hin, daß diese Gemeinschaft von Wissenschaft und Staat wohl notwendig. aber nicht ganz freiwillig ist, dem nur ungern nehmen die Weisheitsliebenden die Lenkung des Staates in die Hand. weil sie so abgelöt und getrennt werden von der ruhigen Schau der Ideen. Und wie mächtig und bedentungsvoll der sittliche Wert für den Staat ist, das erhellt schon ans der Tatsache, daß dieser Wert im platonischen Staat zwiefach zugegen ist, indem er eimmal als Tapferkeit das Heldenleben der Krieger leitet mo anderseits als höchster Wert, als Idee der Gerechtigkeit dem ganzen Staate Ëinheit und Vollendung gibt. Hegel. und vor ihm schon teiheise Arist oteles, hat dam die Überzengung vertreten. daß der sittliche Wert als solcher für den Staat konstituierend ist, daß der Staat die Fleisch gewordene sittliche Vermunft bedeutet, und daß der Begriff der 
Wisenschaft sowie anch der Kunst und Religion über den Begriff des Staates weit hinausgeht. Hier liegt num eine Reihe von sehr interessanten Problemen vor. die sich auf das Verhältnis des Staates zu den anderen Kulturwerten beziehen. Diese Unvereinbarkeit des Staatsbegriffes mit den anderen Kulturverten bei Anerkemung seines selbständigen Wertes ist vielleicht von niemand so tief und eindringlich gezeigt worden wie ron Fichte ${ }^{1}$ ). Fichte ist es ror allen gewesen. der im Gegensatz zu den Theorien der Aufklärung wieder zu dem Wertbegriff des staates gelangte, indem er ihn auf das engste mit dem Begriff der Nation verband2). Wenn nun aber auch Fichte den positiven Wert des staates rollkommen erkamte, so wies er doch auch gleichzeitig auf die unversöhnliche Antinomie hin, die zwisehen dem Staat und der Autonomie des wissenschaftlichen und religiösen Lebens notwendig bestehen muB.

Wenn wir uns aber die Frage stellen, was wohl Aristoteles und Hegel veranlaft haben mag, in der Verwirklichung des sittlichen Lebens den Staat vollendet zu denken. so ist es die t'berzeugung. dals sich das theoretische und religiöse Leben in der Beziehung zum Staat nicht erschöpft. In dem moralischen Wert vollendet sich nach inrer Utberzengung der Gedanke der sozialen Gemeinschaft. Er ist as, welcher der Menschheit die höchste Weihe gibt, sofern es auf das regenseitige Verhältnis der Glieder zueinander ankommt. Aber dem ästhetischen, religiösen und philosophisehen Leben tut die Relation zur Mensehheit als endguiltiges und höchstes Verhältnis nicht Genïge. Diese reichen über den Simn irdischmenschlicher Gemeinschaft hinaus und beziehen sich auf das Verhältnis zum Absoluten. Hier macht sich also dic Úberzengung geltend, daß, um ein Beispiel zu nehmen. der wissensehaftliche Wert. weil er in der Beziehung zur sozialen Gemejunchaft nicht restlos anfgeht, ron ihr abgetrennt und als etwas betrachtet werden miibte, das zur Konstitnierung des Statslebens nicht das geringste beiträgt. Disem Standpunkt, der nur den moralisehen Wert für den Staat geltend machen will, tritt cin anderer gegenïber, der alle Kulturwerte ansclucklich auf die Gemeinschaft des States beschränken will, der also geneigt ist, anzunehmen, dal sich alles wertvolle Leben in der Gemeinsehaft des Staates restlos ausirkt und nicht $\ddot{i b e r}$ den Staat hinausreicht. Solche Vorstelhungen funden wir in der (ieschichtsphilosophic des jungen Sehelling ${ }^{3}$ ) vertreten, und vom modernon Gachichtophilosophen huldigt etwa Dilthey dieser Auf-

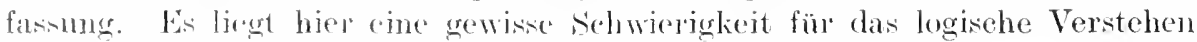

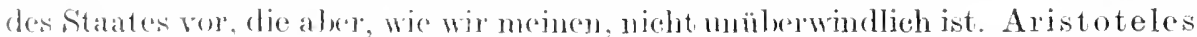

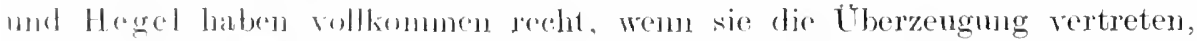

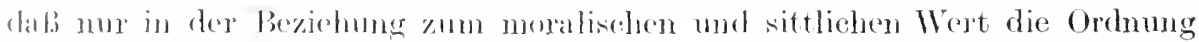

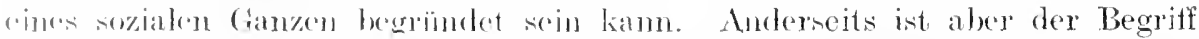
des Kulturstantes in den begriff dor wirklich gewordenen sittiehen Ver-

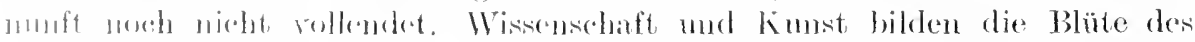

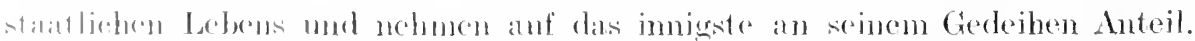

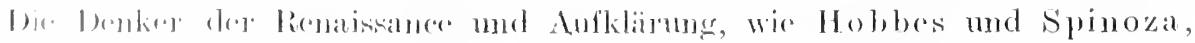

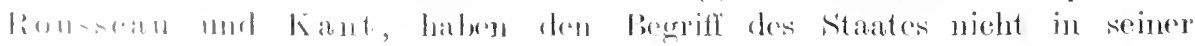

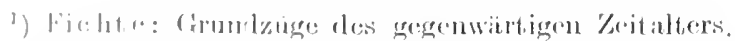

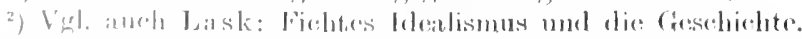

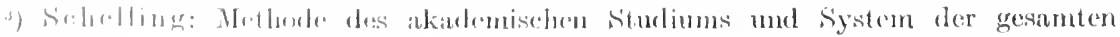
Philısiphin. 
Konkretheit und in der Fülle seiner Beziehumgen ergriffen. Sie verbanden mit ihm die Torstellung einer rein äußerlichen Regulierung der sozialen Gemeinschaft, und selbst damn, wenn sie die Notwendigkeit und Bedentung der staatlichen Institutionen bewunderten und rerstanden, komnten sie sich doch nicht entschließen. ihm denjenigen Reichtum zuzusprechen, der nun ein für allemal zu seines Wesens Art gehört. Spinoza setzt den Begriff des Staates in den Mechanismus der Gesetzesbestimmungen. Hobbes in den Herrscherwillen, Rousseau in den allgemeinen Willen der Volkssubstanz, und auch in der Philosophie Kants verharrt der Staat in einer gewissen Fremdheit gegenüber den höchsten Gütern der Kultur. Es gab eine Zeit, da man die Sphäre des Staates so begrenzt wie möglich zu denken rersuchte. In dem Schutz ron Leben und Eigentum sollte seine Mission erfïllt sein, aber die positive Leitung der ideellen Menschheitsinteressen mochte man ihm nicht anvertranen. Wohl machten in dieser Auffassung bittere Erfahrungen sich geltend, die das Kulturbewußtsein eimmal durchlebt und durchlitten hatte. Unantastbar, unangreifbar und fremd dem Staat gegenüber sollte sich das höheres Geistesleben in der bloß äußerlichen Form der staatlichen Zusammengehörigkeit entfalten. Das Bestreben der großen Denker war damals daranf gerichtet, das ideale Daseinsrecht ron Philosophie und Wissenschaft, ron Kunst und Religion gegenüber dem Staat zu verteidigen. Der Staat soll ein Rechtsstaat sein, indem er Leben und Eigentum schützt und im übrigen die große gewissermaßen negative Mission erfült, daß er Freiheit und Unabhängigkeit gewährleistet dem Denlien und dem Gewissen in der versöhnlichen Toleranz eines guten und rücksichtsvollen Terstehens. Der Staat soll ein moralischer Staat werden, ler über diese Forderungen hinaus das Prinzip der Gerechtigkeit zum Prinzip des bürgerlichen Lebens macht und durch Pflege und Erziehung in all seinen Einrichtungen und Institutionen ein freies persönliches Leben sich entfalten läßt, der schließlich auch über seine eigene Sphäre hinaus mit allen seinen Kräften daran arbeitet, die Idee der Humanität, den allgemeinen großen Menschheitsgedanken zu erfüllen und schließlich alle Gegensätze unter den Völkern in einer idealen Totalität aufzuheben. Die Cmmandlung des Staates in ein moralisches Wesen war die Forderung der großen Idealisten der deutschen Philosophie, und daß diese Forderung in der Schöpfung des modernen Nationalstaates erfüllt sei, hat der Optimismu der Hegelschen Philosophie zu demonstrieren gesucht. So sehr num aber auch Hegel bemüht war. den Staat zu begreifen als das rertiefte und rollendete Leben der Nation und so diesen anfangs so dürren und abstrakten Begriff mit hohem Reichtum anszustatten, er vermochte doch ron einer gewissen einseitig moralischen Auffassung des Staates nicht loszukommen. Wem er auch in der Idee der Sittlichkeit als eines Wertbegriffes sozialer Gemeinschaft über den individualistischen Begrifi der Moralität hinansging, der sich lediglich auf die Bildung des persönlichen Einzellebens bezog. so gelangte er in seiner begrifflichen Prägung doch nicht dahin, dem Staat jene Fïlle und Lebensschönheit zu geben, die etwa die antike Auffassung eines Pla to mit dem Staat rerband. Hegel gab dem Staat alle Nacht, aber nicht hinreichend Leben, Schönheit und Wert, um diese Nacht zu rechtfertigen. Der sittliche Aspekt ist nicht nur der herrschende, sondern der einzig zu rechtfertigende und gerechtfertigte. Nach Schelling ist dagegen der Staat erst in der Verwiklichung aller Kultur- 
werte lebendig. Da lebt die Wissenschaft in der Weisheit der Gesetzgebung und die Sittlichkeit in dem Heroismms der Nation, da ist es die Schönheit, die dem -taatliehen Leben die höchste Weihe und den vollendeten Rhythmus der Bewegung gibt. Niemand hat den Stat so reich und schön gedacht wie Sch elling und dem sozialen Leben der Völker so hohe Aufgaben gestellt wie er. Als der starre Hauch der Moralität dem sozialen Ganzen die höchste Würde verlieh, aber die Liebenswürdigkeit und der berechtigte Reichtum der Bewegungsformen als wertrolle soziale Erscheinungsform negiert wurde, da hat er durch die Idee der Weisheit und Schönheit dem Begriff des Staates ein höheres Leben verliehen. Dabei ist dem Schellingschen Staatsbegriff dieser Doppelsinn eigen, daß einerseits die Kultur in ihm zur Vollendung gelangt, daß er aber anf der anderen Seite auch wieder nur der Boden ist, anf dem die Güter der Knltur einer höheren Bestimmmng entgegenreifen, oder das Substrat der Wertträger für weit überragende Zwecke. So eng Schelling den Begriff der Kulturwerte mit der Idee des States verband, so hat er sie deswegen doch nicht in ein Hörigkeitsverhältnis zmm Staat gebracht. Naeh unserer Auffassung kann das Verhältnis der Kulturwerte zum Stat nur so gedaeht werden, daß Wissensehaft und Kunst den Staat vollenden, ohne sich im Staat zu vollenden. Der Begriff des Staates ist in der Idee der Sittlichkeit noch nicht rollendet, er ist erst dort vollendet, wo die Fülle der Kinltur Leben und Wirkliehkeit und Daseinsrecht gewonnen hat. Aber indem Kulturwerte in Wissenschaft und Kunst den Staat rollenden, weisen sie anch zugleich über den Staat hinaus mit dem Appell an eine höhere und allgemeinere Ordmung der Dinge, der anch der Begriff des Staates dienend unterworfen ist.

Indem wir so von dem Begriff der Moralität als eines Prinzips der Auswahl für die politische Geschiehte handeln, erwächst die Frage, inwieweit demn nm tatsächlich die politischen Handlungen und Ereignisse, von denen hier die Rede ist. als abhängig von einem allgemeinen Prinzip der Moralität gedacht werden können. Wir miissen hier ansdrücklieh betonen, daß diese Frage rein philosophischer Natur ist mol der Tätigkeit und Stellungnahme des Historikers rollkommen fromliegt. Was findet nicht alles seine Stelle in der politischen Grschichte eincr Epoche oder eines Tolkes! Dic Blätter der Geschichte sind crfüllt ron drom liriegerisehen Glanz kämpfender Heere, von dem leisen, klugen gerïnschlosen Gang diplomatiseher Verhandhungen, von kïhnen Fahrten zur Erkmulung der Erde, von Winnlerungen der Völker. von Statengrünllumgen, von dem schaffenden Tun der Gesetzgeber. Und in dieses mä.chtige politische Geschehen wirken hinein anch die anderen Sphären des Kultururechehens. Der religiösc Gedanke entflammt den kriegerischen Sinn, die Weisheit der benker kommt der Gesetzgebmug zugute, und die Morgenröte einer monen Lifoche führt die Kumst heraut. Sehwierig mag es wohl manchmal sein, line gewaltige politische Leben dahin zu verstehen, daß in seinen geheimsten

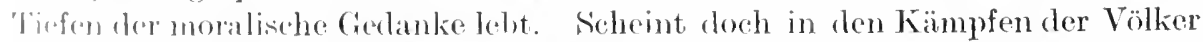

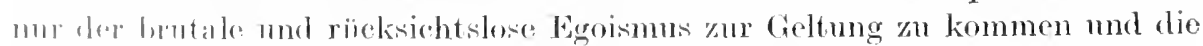
greheimen Fowhandlungen und das gan\%e Tntrigenspiel der Diplomatie weit

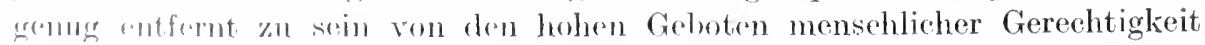

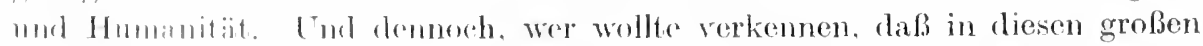

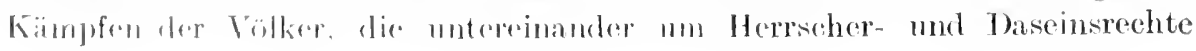


lämpfen, die ihre eigene Position zu erweitern oder zu behaupten streben, die Freiheit fordern oder anch ron dem Gedanken hoher Befreiungstaten erfüllt sind, daß in diesem Ringen um Nacht und Lebenseichtum, in diesem Kämpfen um einen geachteten und ehrenrollen Platz im Rate der Völker anch sittlich Wertrolles in schöner Form zum Ausdruck gelangt. Oder wir müßten aufhören zu beverten das Heldentum der Schlachten und die fromme Liebe zur Heimat und zu der Täter Brauch und Sitte. Tir dürften keine Anerkennung mehr zollen dem Tolke, das seine Autonomie und Selhständigkeit gegen eine Telt zu behaupten bereit ist und der Idee des Vaterlandes die höchsten. Opfer bringt. Cns müßte das Terständnis für nationale Ehre und politischen Freiheitssinn verloren gehen.

Und wie die Kämpfe der Völker weit daron entfernt sind, lediglich das Streben nach Erhaltung des eigenen und brutale Tergewaltigung des fremden Daseins zum Ausdruck zu bringen. so ist auch das Geschäft der Diplomaten nicht nur ein kühles und glattes Ränkerpiel, das mablässig auf Vernichtıng des fremden Lebens bedacht ist. Nicht mit Lnrecht hat Auguste Comte in ihnen die Anwälte und Herolde des ewigen Friedens erblickt. Cnd so taucht wohl überall hinter dem wilden und scheinbar regellosen Treiben des politischen Lebens als simnerleihendes und einheitgebendes Moment das emste und große Antlitz der Moralität hervor. Tieles allerdings, was das politische Iseben mit sich führt, kann keine oder doch nur eine indirekte und äußerliche Beziehung zum moralischen Leben gewinmen, unter dem wir in erster Linie das Werden des persönlichen Einzel- und Gemeinschaftslebens rerstehen müssen. Diese; andere, das dem moralischen Wert fremd bleibt und anch durch keinen anderen Kulturwert ergriffen ist, fällt unter den Begriff des ,relatir Historischen“. Auf Kulturtaten kommt es in der Geschichte ausschließlich an. in ihnen liegt das eigentlich wertrolle historische Geschehen. Aber die Geschichtswerke enthalten auch die Darstellung von Vorgängen und Ereignissen, die zur Erhöhung und Bereicherung der Kultur nicht das geringste beigetragen haben. Das sind einerseits Vorgänge, die im direkten Gegensatz zur Kultur stehen. als Geschehnisce kultuxzerstörender Art, dieTaten der Römer in Sizilien. der Vandalen in Rom, der Mongolen in Bagdad, der Spanier in Granada und Cordora. de: Cortez in Mexiko. Diese Ereignisse borgen ihren historischen Wert natürlicherweise lediglich ron der Bedentung dessen, was sie vernichtet haben. Ihre historische Wichtigkeit liegt in dem negativen Terhältnis zur Kultur. Gerade wel die Kultur den leitenden Gesichtspunkt für die historische Auswhl hergibt, muß anch dasjenige Raum und Erwähmung finden. was dem Werden des Kulturgedankens feindlich entgegenstand. Weiter aber treten uns im Zusammenhang einer Geschichtsdarstellung Ereignisse entgegen, die scheinbar dem Begr ffe der Kultur und jedem bestimmten Kulturwerte vollkommen indifferent und gleichgültig gegenüberstehen. Diese Ereignisse haben keinen Selbstzreck. Sie sind an sich nicht wichtig und nicht wesentlich. Man könnte sie fortlassen. ohne daß dadurch die Historie ihres Reichtnus in geringsten beraubt wïrde. Aber sie sind notwendig als Übergänge, als Zwischenglieder, als Interpolationen. So kennt beispiels reise die Geschichte der Philos ophie und dex Kunst eine Reihe ron Namen, welche Männer bezeichnen, die für das Gebiet, dem sie angehören. wenig oder nichts geleistet haben. Die wert volle Tat war dem Späteren aufberahrt. 
Jene haben rergeblich und nutzlos sich gequält und gemüht, dieser fand das erlösende Wort, Es ist wohl nicht die Achtung und die Dankbarkeit oder das Verständnis für den mutzlos und hoffnungslos um eine große und schöne Sache Kämpfenden. das hier dazu geführt hat, den Namen des Unberlentenden dem Reiche hoher Erinnerungen einzugliedern und anzurertrauen. Es ist die Notwendigkeit, welche für die Geschichte besteht, das Werden des Großen zu erklären und den Trimmph seiner Macht und Schönheit hell und glänzend lenchten zu lassen im spiegel des Unbedeutenden. Thr Dasein in der Geschichte hat also den sinn der Erklärung und des Verständlichmachens. Unbegreiflich erscheint uns das plötzliche Dasein des Großen und Mächtigen. Der Historiker macht uns mit diesem Dasein alhmählich vortraut, indem er uns leise und behutsam an die große Erscheinung heranführt und sorgsam auseinanderlegt, wie sie so geworden ist und zu dieser Schöjfertat gelangte. Das Wunderbare und Rätselhafte des Neuen soll aufgehoben werden durch die sorgfältige und gewiscnhafte Erklärung. die jede Einzelheit der historisehen Erscheinmng auf Gründe und Urrachen zurückführt. Das Große, so will es die historische Erklärung verständlich machen, war nicht an sich selber da, ist keine causa sui. sondern durch etwas anderes verursacht und deswegen auch nicht zu sehmücken und zu krönen mit allem Glanz des Erreichten. Zum Erfolg hat beigetragen die Zeit, das Milieu, das Studimm großer Yorbiker, Erziehmng, Unterricht und Einflüse mannigfaltigster Art. So ist mur ein Teil des Werthaften mit der großen Persönliehkeit verbmelen, anderes weist auf andere zurïck. Und in der Herleitung dieses anderen tritt damn häufig gemug das, ,relativ Historisehe“ hervor, das selleer keine Eigenwertigkeit besitzt, sondern nur der Erläuterung des Wertrollen dient.

Wenn das Unwichtige somit einerseits den Glanz des Werthaften rerminclert, inclem as zeiner Aufteilung und Auflösung Veranlassung gibt. rermag es auch anderseits auf dem Wege des Kontrastes seine Sehönheit und Herrlichkeit zu erhöhen. Damn steht es als das Kleine und Unbedeutende oder als das HäBliche und Gemeine dem Groben gegenïber und löst die Gewißheit in uns aus, wie viel doch ein einzelner zu leisten vermag im Vergleich mit der groben Menge dex Unfähigen mol Unproduktiven.

\section{c) Die logische Iuswahl.}

Soriel ïber den Kulturwert als Prinzi]) der Auswahl und speziell äber len moralischen Wert als Auserenrinzip für das politiche Geschehen. Weit klarer und durehsichtigere ist das Verhälnis des Wahrheitswertes als Ausleverinzi], zur Geschiehte der Philosophie mul Wisenschaft, der Fiunst und

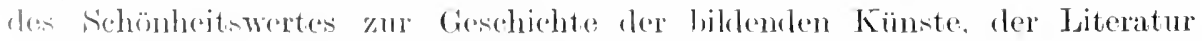

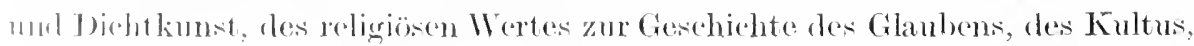
ler bihhung kirchlicher Gemeinsehaften, des Dogmas, des rein mystisehen

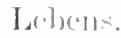

In allerencin aneliame Werte der Wahrheit nimme als Fulturwert

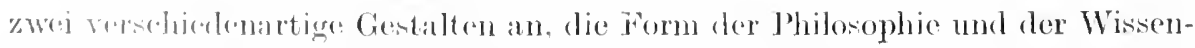

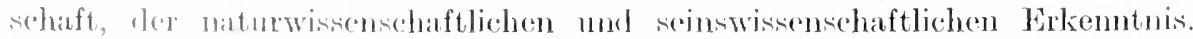
bie Ihilosephie ist nicht als Missenschaft zu begreifen, sondern vielmehr als cin cigentimbliches, won boconderen und andersartigen Kategorien oder Wahr- 
heitsformen getragenes Gebilde anzusehen. Der Begriff der Philosophie leitet die Auswahl in dem einen großen Gebiet der Wahrheitserkenntnis. Wohl werken die meisten Menschen mit dem Begriff der Moralität oder des sittlichen Lebens eine deutlichere Vorstellung verbinden als mit dem Begriff der Philosophie, weil dieser nicht wie jener an alle Menschen als notwendige Forderung sich richtet, sondern nur zu wenigen ein innerliches Verhältnis hat. Der Philosoph wird aber wohl kaum einen ernsthaften Zweifel darïber hegen. was er als Philosophie zu verstehen hat, wenn es auch nicht ganz einfach ist, den Begriff der Philosophie einwandsfrei zu definieren. Es ist ein recht ander geartetes Leben, das der Kulturwert der Philosophie anf sich zieht und rereinigt. ein weit abstrakteres und einsameres Geschehen, als das Werden der politischen Dinge. Waren es in der politisch moralischen Reihe konkrete und sichtbare Handlungen, die ummittelbar das Leben formen und gestalten und ein große: öffentliches Geschehen herbeiführen, so bleibt das intellelituelle Geschehen in der philosophischen Bewegung zunächst weltfern und weltfremd. Der Politiker, der Gesetzgeber, der Sittenlehrer, der Diplomat. sie üben ein praktisches Tun und banen und arbeiten im engen Zusammenhang mit rielen an der sozialen Organisation. Der Philosoph ist für sich, und das Werk seiner Arbeit steht der realen und sichtbaren Welt so fern wie möglich. Aber dieses so weltfernc, in der Abgeschiedenheit erzengte Gebilde seines Schaffens, der Begriff, die Idee und das rollendete Gedankenwerk des Systemes hat doch anch wieder ein hohes Maß an Lebens- und Weltbeziehung, sofern es den Kosmos verständlich macht und das Leben erhöht und bereichert. Denn der philosophische Gedanke, der in der Einsamkeit geboren ist, remag auch, wenn seine Zeit gekommen ist. das öffentliche Leben zu bewegen und das Geschick der Menschheit in nene Bahnen zu lenken. Was der Begriff der Philosophie aus der unendlichen Fülle des Weltgeschehens auswählt. das ist das Leben der Denker, ihre begrifflichen Schöpfungen und der allgemeine Grundzug des Zeitalters, in dem sie gewirkt haben, mit seinen herrschenden Tendenzen und Bewegungen. Manches von dem, was eine frühere Zeit unter dem Begriff der Philosophie verstanden hat. wird gewiß in einer modernen Darstellung keine Aufnahme mehr finden, da cler Begriff der Philosophie weit enger geworden ist, sofern man früher alle wissenschaftliche Erkenntnis als Philosophie bezeichnete.

Man sollte meinen, daß der Begriff der Wissenschaft ein besonders dentliches und zweifelloses Auswahlprinzip für das historische Geschehen ergeben müßte, weil die Welt schon so lange ein wissenschaftliches Leben kennt und mit dem Gedanken der Wissenschaft sich für uns die Torstellung höehster Genauigkeit und Präzision verbindet.

Aber wir wissen ja, wie unsicher und unbestimmt der Begriff der Wissenschaft sein muß in einer Zeit, wo der wissenschaftliche oder nichtwissenschaftliche Charakter der Geschichte noch immer den Gegenstand lebhaftester Diskussionen bildet. Eine Geschichte der Wiscenschaft ist infolgedessen vielleicht problematischer als eine Geschichte der Philosophie. Dagegen werden die Schwierigkeiten erheblich vermindert, wemn sich der Historiker bescheidet, nur die Geschichte einer bestimmten Wissenschaft, etwa der Naturwissenschaft und speziell der Mechanik, zu schreiben. In rerschiedenen Disziplinen der Naturwissenschaft hat die Spezialidee der Wissenschaft eine 
Schärfe und tine Bestimmtheit erreicht, die in hohem Grade die Auslese des Geschehens begünstigt. Wir denken hier ror allen Dingen an die Mathematik und an die exakten Naturwissenschaften. Mit der Philosophie hat es die Wissenshaft gemeinam, daß ihre Geschichte eme Geschiehte des Wissens, des Theoretischen und der Theorie ist. Das muß diesen Formen der Historie ein hohes Maß von Zuverlässigkeit und Gewißheit geben. Hängt doch alles Wissen rom Theoretischen ab, gibt doeh das Theoretische die Mögliehkeit des Wissens ron den an sich wissensfremden Gebieten der Kunst, des Rechtes und der Religion. Wie wir nun in der Logik ein systematisches Wissen rom Wissen haben, so liest in der Gesehichte des Wissens ein historisches Wissen rom Wissen vor. In allen anderen Disziplinen haben wir eine systematisehe oder historisehe Erkenntnis des Erkenntnislosen. Wir leben aber der Úberzeugung, daß das Theoreticche sich selten bescer versteht als die anderen Wertgebiete.

Was nun die Bedentung anlangt, so ist die Geschichte der Philosophie wohl wichtiger als die Geschiehte der Wissensehaft. Die Geschichte der Philosophie ist als Wissen rom Theoretischen nicht nur Geschiehte, sondern auch Philosophie in dem Simne, daß sie eine neme Erkenntnis des Virkliehen herbeiführt. Das hängt damit znsammen, daß erst die Geschichte der Philosophie den notwendigen Znsammenhang enthüllen kann, der zwisehen den Problemen des Denkers besteht. In dieser Riehtung bringt die Geschichte der Wissensehaft dem allgemeinen Begriff ron Wrissenschaft überhaupt nichts Neues hinzu. Weiter aher wird die Philosophie niemals in dem Maße historisch, wie die Theorien der Wiscenchaften historish werden. Jene Theorien der Astronomie, die durch die Lehre von den Sphären oder auch von den Kreisen und Gegenkreisen die Bewegung der Himmelsörper erklären wollten, sincl ein für allemal ïberwunden mul relativ wertlos für das gegenwärtige Forsehen und Denken. Dagegen müssen die platonischen Ideen unvergessen bleiben, weil in ihnen eine unvergängliche Wahrheit liegt.

\section{d) Die ästhetische Auswahl.}

Gegenül) (lor politischen Geschichte und der Geschiehte des Theoretischen hat en die dechichte der Kunst und der Religion sehr sehwer, auch nur einigermaben zиr historischen Beherschung ihrer Gegentände vor\%ndringen. Die Idee dos Känstlerischen, die als Auswhlprinzip für die Geschichte der Literatur wie für die Geschichte der bildenden Kumst in Kraft und Geltung steht, erfrent sich in uncerer Zeit der höchsten Anerkenmung. Lebhaft wünscht matn die Exweiterumg ihros Bezirkes, ihren Eingang in so manche Verhältnisse Jes Lebens als schöno Form moeres 'Tuns und Leidens, als Maßstab unserer

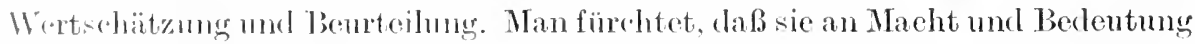
rerlirron könnte, man ist ilı auf das imbigste zugetan. Aber über den Begrife J.e Kunst herrede wenig Einstimmigkeit. Man will ihr viclfach nicht mehr

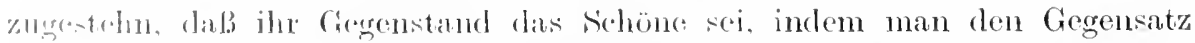
von lorm mol Stoff anf das schärfste betont und die Behauptung anfstellt,

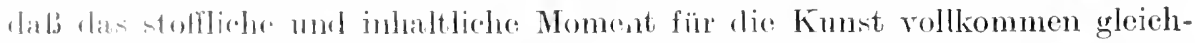

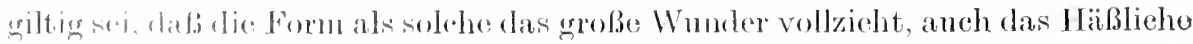

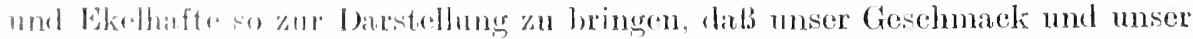

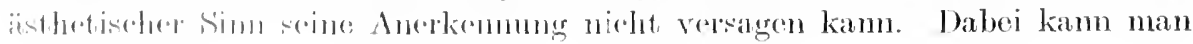


noch unterscheiden zwischen solchen Theoretikern, welche die Beziehung ron Kunst und Schönheit insofern aufrecht erhalten. als sie behaupten, daß die künstlerische Form, gleichgültig wie der Inhalt beschaffen sein mag. schönheitsbildend wirkt, und jenen anderen, die alle authentisehe Dar-tellung ron Wirkliehkeit und Leben als Kunst rerstehen. Da die Kunst unserer Zeit vielfach gedankenlos und ideenlos jeder whrhaften Gröse entbehrt und bei aller Betonung des lart pour l'art gewisse Werke der neueren Kunst nur zu sehr auf müdes, gedankenloses und rerträumtes Genießen zugerichtet sinc, so ist es kein Wunder, daß auch die historisehen Werke über Kunst und Literatur an Ideenlosigkeit leiden. Das gilt natürlich nicht allgemein, wir es ja auch große Erseheinungen der modemen Kunst gibt, welehe die ästhetische Besinnmng gar mäehtig herausfordern. Wenn wir an die früher vollzogene Cnterseheidung zwischen Form im Simne der ästhetischen Idee und Form in Sinne ron Stil erinnern sowie anderseits unter Inhalt das Bedeutungsmäßige als Torwurf, Fabel und Motiv rerstehn, unter Stoff aber las Material oder die Darstellungsmittel, welche den rerschiedenartigen Künstlern zu Gebote stehn, so ergibt sich eine große Mamnigfaltigkeit ron Auswahlprinzipien für die Geschichte der Kunst. Soriel ist deutlich, daß das Material oder der Stoff, daß es die rerschiedenartigen Darstellungsmittel sind, welehe die allgemeinste Gliederung der Kunstwelt rollziehen. Wort, Ton, Farbe und Stein zerlegen die Welt der Kunst in das Gebiet der Dichtkunst, Musik, Malerei und Skulptur.

In jedem einzelnen Gebict bieten sich num aber sehr rerschiedene Prinzipien für die Auswahl des künstlerischen Gesehehens dar, und durch den Charakter des Prinzips ist das ganze Niveau der Darstellung bedingt. So gibt es gewisse Darstellungen der Literaturgeschichte, die das Kunstwerk aus der Erlebniswelt des Dichters zu entwickeln suchen, die immer wieder deutlich zu machen suchen, wie in jedem einzelnen Falle das rein persönliche Erlebnis die ïberpersönliche Weihe erhalten hat und das subjektive, blob individuelle Fühlen und Empfinden zum über]ersönlichen Fühlen erweitert ist. In der Reihe des Objektiven, der losgelösten Kunstformen nud Kunstwerke wird nicht eigentlich eine Terbindung hergestellt, rielmehr rerharren diese in Isolation einander gegenüber. Immer wieder führt der Weg der Erklärung rom Künstlerleben zum Kunstwerk und rom. Kunstwerk zum Küustlerleben. Der Znsammenhang der zwischen Tergangenem, Gegenwärtigem und Zukünftigem gesucht wird, bezieht sich vielmehr auf das Leben und Wirken der Dichter, in rem die historische Forschung den Abhängigkeitsverhältnissen nachgeht, lie der Spätere ron dem Früheren erfahren hat. als daß es sich hier um die Herstellung eines Zusammenhanges zwischen den Kunstwerken handelt. Immer wieder verläuft die Erklärungsreihe aus der sphäre des Objektiven in die Reihe des Subjektiren. Wir wollen die Stimmung, die Gestalten, die cigentimliche Illusionsform einer Dichtung erklären, wir gehen auf das Erleben des Dichters zurück und suchen nach der Möglichkeit verwandter Stimmen. Neigungen und Bewegungen in der Realität seines Leb-ns nahe dem Zeitpunkt der Schöpfung. indem wir ron der Toraussetzung ausgehen, daß nieht alles das, was uns im Funstwerk entgegentritt, freie und absolute Schöpfung ist. Was wir aber in der Erlebniswelt des Dichters nicht wiederfinden kömnen, das sehen wir vielleicht vorgeformt in den Werken eines früheren Dichters. Aus ihm hat der 
spätere geschöpft; or hat jene Stimmung nachgelebt und sie in rerwandter Form wiedergegeben.

Eine ganz andere Form der Darstellung ergibt sich, wenn das Prinzip des Inhalts als Maßstab der Auswahl sehärfer betont wird. Die Diehtung ist anf gewisse Erscheinungen der Sage oder der Geschiehte hingewiesen. Man könnte sich eine Gesehichte der Literatur unter dem leitenden Gesichtspunkt der Stoffwahl denken. Welche Umwandlungen und Veränderungen hat die Siegfriedsage, das Leben des Faust und Don Juan in der Darstellung der Diehtkunst erfahren? Der tötliche Bruderzwist der Braut von Messina weist auf frühere Torbilder hin, und die Entscheidnng des weisen Nathan und das Symbol der drei Pinge wurzelt sehon in Boeeaceios heiterer Simnenwelt. Die Erklärungslinie geht hier ron Motiv zu Motiv, von Inhalt zu Inhalt. Hier läßt sich die Frage erheben, welche Ausweitumg, Bereicherung, Versehärfung, Vertiefung das alte Motiv erfahren hat. Eine solehe bloße Stoffgesehiehte ist noeh keine Problem- oder Ideengeschichte der Kunst; denm der Stoff ist nur der Boden, auf dem das Problem erwachsen kann, und dieselbe künstlerisehe Idee kann sich mit sehr versehiedenartigem Bedeutungsmaterial verbinden.

Beror wir jedoch auf die ,Sinngesehiehte" als die wahrhaftige und höehste Formgeschichte eingehen, müssen wir den Begriff der Stilgeschichte erörtern, der unsere Zeit im hohen Grade zugewendet ist. Wenn wir den Begriff des Stiles und der Stilformen als Auswahlprinzip für das kümstlerisehe Gesehehen aufstellen, so sind wir genötigt, in weitem Umfange auf das allgemeine Kulturgesehehen einzugehen; denn der Stil ist das Produkt einer Epoche, eines Volkes, einer Zeit, nur zum geringsten Teil die Sache des einzelnen, der dem allgemeinen Stilcharakter nur die versehiedene Nuanee und Färbung gibt. Die Werke der Antike offenbaren eine ungeheure Einheit des Stilgefühls. Es besteht eine Verwanlt:chaft zwischen den Versen des Homer, dem Charakter der aleäischen Strophe, den erhabenen Rhythmen des Sophokles, dem Apollo Sauroktouos, dem Torso des Herkules und den Tempeln ron Segesta und Pästum. An diese Einheit des Stilgefühls denken wir, wenn wir von der Kunst der Antike spreehen. Mächtig im Grieehenvolk hat derselbe künstlerische Geist ein Jahrtausend durehweht.

Wir sehen, wie der Stil sieh wandelt mit dem Charakter des Volkes und dem Geist der Zeit. Als deine lichte Schönheit.freude, o Hellas, gestorben war, die ihren Ausdruck fand in jenen säulengetragenen Tempehn, deren sehöne, schlichte, unendlich erhabene Form dem hellflutenden Somenlieht des Südens den Eintritt nicht verwehrte und die WeiBe des parischen Marmors dem tiefblawen Hinmel entgegenhielt - damals als dein Untergang besiegelt war, erhoben sieh groß und ernsthaft die gotisehen Dome, mälehtig hinausstrebend über das Simnendasein. Und doch verrieten sie im lieblichen Blätterwerk, im krausen Gerank und in der Wumlerlichkeit grotesker Zierrate ein starkes mul sinnenfrohes leben, das überall hervorhgte und hervorquoll, ein seltsam gerpaltemes und pararloxes. Dasein. Anderen Warbenkontrast führten sie herbei, indron sic den farbigen Siundstein dem dunkeln Himmel des Nordens entgegenhielten. Jules nene: und schöpferische Volk entwickelt seinen eigenen, mehr oler weniger sellständigen Stil, in dem os sein künstlerisches Empfindon zur Torstellung bringt. Dabei setzt ein grober Kunststil immer ein gowisses 
Maß der Vollendung im Kulturdasein eines Volkes roraus. Sucht ein Volk nach einem neuen Stil, so sucht es nach adäquaten Ausdrucksformen für das, was seine Seele auf das innigste bewegt. Es befindet sich damn immer in einer ungefestigten, kritischen Epoche, in einer Epoche des Uberganges. Der Stil kïndigt sich an im ersten emsthaften Kunstschaffen eines Tolkes. Er verändert sich, er wächst sich vielgestaltig aus, Generationen bilden an ihm, bis er schließlich eine gewisse Starrheit und Festigkeit erlangt, die uns deutlich macht, daß der Kunsttrieb eines Volkes oder einer Zeit zur Erfïllung gelangt ist. Wir bezeichnen den Stil nach ästhetischen Kategorien, wenn wir in der griechischen Skulptur zwischen dem hohen und schönen Stil unterscheiden, nach Volk und Stadt, wenn wir der dorischen Säule das rerschiedenartige Gepräge der ionischen und korinthischen entgegensetzen, nach einem eigentümlichen Kulturprozeß schöpferischer Erimnerung, wenn wir der Renaissance gedenken. Und immer geht derselbe Grundcharakter des Stils durch alle Kunstgebiete hindurch. Es lebt eine rerwandte künstlerische Ausdrucksform in Dantes großem Gedicht, im Moses des Michel Angelo rom Grabdenkmal Julius II. in Rafa els Schule ron Athen, in den Dogenpalästen Genuas und Venedigs. Und wiederum ist es deutlich, daß die kleinen Putten und Engelsgestalten, die aus der goldreichen Pracht so mancher Kirchen des 17. Jahrhunderts hervorleuchten, Ausdrucksformen desselben Barockstils sind, der uns in den Gestalten der Schäferspiele und in den ron prunkenden Wort- und Bildglanz überhäuften Gedichten ron Hoffmannswalda u begegnet. Manchmal allerdings vermag ein neugewonnener Stil sich nur gewisser Kunstgebiete zu bemächtigen. War vielleicht der klassische und romantische Stil, der sich in der deutschen Dichtkunst und Musik so herrlich offenbart hat, zu spirituell gerichtet, $u m$ seinen Niederschlag auch in großen Formen der bildenden Kunst $z u$ finden? Ind weiter gibt es Zeitalter, die keinen Stil finden können. und andere, deren bunte Stilvermischung einen nur zu deutlichen Abdruck gibt ron der großen Verworrenheit und Verbogenheit ihres künstlerischen Empfindens. Alles in allem aber sind die Stilbegriffe außerordentlich wichtige Ausleseprinzipien und Wertbegriffe des Kunstgeschehens.

Es gibt nun aber noch eine höhere Form der Kunstgeschichte und höhere Prinzipien zur Auswahl des Kunstgeschehens und cer künstlerischen Bildung. Diese bezeichnen wir als Sinngeschichte, und ihre Ausleseprinzipien sind die ästhetischen Ideen. Eine solche Form ist der Philosophiegeschichte als Problemgeschichte verwandt. Wie es sich in der philosophischen Problemgeschichte um das Schicksal und die Entfaltung logischer Begriffe wie Kausalität und Substanz handelt, so in der kunsthistorischen Sinngeschichte um das Schiksal und die Entfaltung ästhetischer Ideen. Diese ästhetischen Ideen aber, die als Prinzipien der Simngeschichte fungieren, sind keine formal ästhetischen Kategorien, wie Harmonie, Spannung. Distanz. Gegensatz, Buntheit und Reichtum, sondern Aufgaben und Probleme, die auf dem allgemeinen Boden der Wertanerkennung sich ergeben. Diese Probleme des Wertlebens bilden die höchste geistige Sphäre, in welcher der Mensch rerweilen kann. Der Verstand kann diese Fragen in ihrer dunklen Pätselhaftigkeit nicht lösen, aber die Kunst kann sie darstellen. Sie setzen alle das Mühen und Leiden, das Lieben und Kämpfen des Menschlichen um das Göttliche roraus. Das Suchen nach Wahr- 
heit. das zur Höhe und Tiefe führen kam, ler Weisheit seliger Trimmph, der Káanpf des moralisehen Höhenbewußtseins mit ter niederen Wertempfindung, der sichönheit hingegebenes Genießen und das Sterben an Schönheitsfülle, das Wollen der Freiheit und des Rechtes, die unbefleekte und umberührte Reinheit in Cregensatz zum Staub der Welt, die Erhebung über alle Sinnenwelt hinaus in die reine Sphäre des Geistes und die liebliche Sehönheit des Vollendet-Unvollendeten des knabenhaften, des jünglingshaften Gottes - alle diese Begriffe, die in ihrer Kargheit nur ein reeht flüchtiges Bild, eine höchst unvollkommene Torstelhung von dem Gemeinten geben kömnen, weisen auf ästhetisehe Ideen hin.

Eine Geschichte der Ideen hat es nieht wie die Stilgesehichte mit demjenigen zu tum, was in jeder Epoche zu einem Nenen wird, was den eigentümlichen Kunsteharakter eines Tolkes oder einer Zeit zum Ausciruck bringt. Sie ist vielmehr auf dasjenige gerichtet, was nnabhängig von Zeit und Raum immer wieder in den großen Werken der Kunst erseheint und ihnen Unendlichkeit und Tiefe und sinnvolle Einheit gibt. Während der Stileharakter die notwendige Relation zu einem bestimmten historisehen Individuum hat und die Eigentümlichkeit einer Tolksindividualität in der Art des persönlichen Fühlens und Empfindens zur Gestaltung bringt, ruht die ästhetische Idee in der Bezichung zwischen derNensehheit als der Welt vernünftiger Wesen zum Göttliehen und Absohuten als dem sehlechthin wertvollen und bringt diese höchste Relation zur anschaulichen Darstellung. Der Stil ist das dem Weehsel der Völker und Zeiten Unterworfene, die Idee ist das immer Wiederkehrende, das mit den verschiedensten Stilformen sieh verbinden kann. Während die Stilgeschichte darauf ausgeht, den Ubbergang von einer Kunstform in die andere zu zeigen, verfolgt die Sinngesehichte dieselbe Idee im Flnß der Jahrtausende. Die Ideo erseheint als die Sehöpfung des einzehnen, sie ist das Mysterium der Kumst. Sie erscheint, um niemals zu versehwinden. Der Stil ist die Sehöpfung der Tölker und Generationen und kamn mit ihnen versehwinden und vergehen.

\section{e) Die religiöse Iuswahl.}

Wenn wir dann schlicklich noeh auf das religiöse Leben der Völker blicken, so bictet sich hier, wie es scheint, das Ausleseprinzip mit einer gewissen Selbstverständliehkeit dar. sofern wir unter Religionsgesehiehte doeh wohl niehts ancleres verstehen kömnen als die Entwicklung der religiösen Torstelhmgen ron Cott uml Seele. Wir möehten aber an dieser Stelle noeh eimmal ansirüeklieh anf clie Schwierigkeit hinweisen, die in dem Gexlanken der Auswahl liegt. Vor dem histori-chen Gesehehen äberhaupt stehen wir mit der Frage: was ist kulturhaftes, wertrolles Geschehen und somit der Aufbewahrung wïrlig; vor dem religiösen Gerchehen erheht sich der Gerlanke, welehe Torstellungen über das Vorhältnis von Gott und heole sind historiseh wiehtig. Das trifft die Religionserschichte vor allem deshall, weil ihr Gecenstand so heschaffen ist, daß er in jorler andreren Sorde ein anderes Vorstellungsbild auslöst. In jeder Seele le])t rin andores bilk des Göttlichen, mol zwar uicht nur in dem Sinn, daß ein in soincn Hauptuncrkmalen festutehentes Cedankending, wie der Begriff der Kansalitiat, hurch die auffassonde. Individualitit leise Modifikationen erfährt. J)e Cottenbildre sind in ganz anderer Weise versehieden. Nanche sind wunderbar reich anserstattet, nanche siml irmliche und erbärmliche blasse, nebelhafte 
Schatten, manche haben eine wundervolle Kraft und Schönheit, und manche sind den plumpesten Simnenwesen gleich. Die Gestalt des Gottesbildes richtet sich nach der Seele, die individuell gebildet ist, und deswegen ist es für die Religionsgeschichte garz ummöglich, eine Geschichte der Gottesbilder zu schreiben, ein Unternehmen noch weit hoffnungsloser, als wenn jemand sich aus ästhetischem Interesse die Aufgabe stellen wollte, nachzuweicen, welche verschiedenartigen Bilder und Gefühle die antiken Statuen des Vatikans in den verschiedenartigen Beschauern erregt haben. Diese Bilder der großen Kunstwerke würden mit den Gottesbildern das gemeinsam haben, da 3 sie zum Teil große und schöne Züge tragen, zum anderen Teil aber furchtbar verstümmelt sind.

Wie verhält sich die Religionsgeschichte dieser Fülle ron Gotteshildern gegenüber, die in den Seelen der Menschen wohwen? Nicht alle sind für sie historisch wichtig, sondern vor allem nur diejenigen, die in schöpferkräftigen Seelen gebildet wurden und zu der Gründung mächtiger Religionssysteme hinführten. Die Gottesvorstellungen der großen Religionsstifter haben einen vorbildlichen Charakter gewonnen, sie sind normatir geworden für die Nasse der Gläubigen, sie haben ein gewaltiges Geschehen ausgelöst. Die Religionsgeschichte wird also weit mehr eine Geschichte der Religion als der religiösen Vorstellungen sein, und doch bedeutet, sollten wir meinen, eine erhabene religiöse Torstellung, die ein Mensch besitzt, nicht aber zu einer religiösen Lehre erweitert, viel mehr als ein schöner poetischer Gedanke, der nicht zur Darstellung gebracht ist. Wenn das Religiöse in rorstellungsmäßiger, bildhafter Form auftritt, dann nimmt es in der Seele individuelle Gestalt an, und das Erleben des wahrhaft Religiösen ist schon als solches eine weitaus größere Leistung als das Haben von künstlerischen Gedanken. Für die künstlerischen Gedanken kommt alles darauf an. daß sie zur Darstellung in der Anschauung gelangen, für die großen religiösen Vorstellungen ist es am wichtigsten, daß sie im Herzen getragen werden. Deswegen lehrt etwa die Mystik eine solche Terinnerlichung des religiösen Lebens, daß hier der Utbergang in religiöse Handlungen und Terrichtungen alle Bedeutung verliert.

Die größte Sichtbarkeit und Deutlichkeit gewinnt das religiöse Leben dort, wo es auf Grund einer religiösen Lehre zur sozialen Organisation fortschreitet, Kultusstätten und Kirchen schafft und den Glauben durch Dogmen erhärtet. Durch die Organisation wird die Kirche eine Macht und greift nummehr auch in das politische Geschehen ein. So werden Kriege möglich um des Glaubens willen und politische Machtansprüche erhoben, welche die alleinige Herrschaft des Staatsgedankens bedrohen. Die Kirchen- und Dogmengeschichte gibt in erster Linie das religiöse Leben wieder, soweit es in den festen Formen sozialer Organisationen und Gesetzmäßigkeiten sich bewegt. Der Begriff der Religion ist hier unmittelbar mit dem Begriff der Kirche verwoben. Wo Religion ist, da muß auch Kirche sein. In diesen Formen der Religionsgeschichte, die den Begriff der Kirche als Aus'eseprinzip an das religiöse Geschehen legen, wird immer die Eigentümlichkeit und individuelle Gestaltung des religiösen Lebens zu kurz kommen, da es sich häufig in einer gewissen Opposition zur Idee der Kirche bewegt. Die Kirche ist ron dem Gedanken des Universalismus beherrscht, und es gibt Formen des religiösen Lebens, die ganz 
und gar individualistisch gerichtet sind. Die Kirche glaubt eine deutliche Forstellung rom Göttlichen zu besitzen und fordert die Anerkennung eben dieser Torstellung, sic gestattet dem religiösen Bewußtsein keine eigene Deutung und Interpretation, sie legt dogmatisch fest, wie geglaubt werden soll. Und diese Festlegung bezieht sich nicht nur auf die allgemeinen Züge der Gottesrorstellung, sondern geht tief in das einzelne hinein. Dagegen macht sich in der Mystik eine undogmatische Tendenz geltend, die sich gegen die universalistischen Ansprïche der Kirche rıchtet. Hier wird aller Wert auf das persönlich überpersönliche Verhältnis zum Göttlichen gelegt. Die Kirche mit ihrer Sakramentenlehre, mitihren Heilsverrichtmngen aller Art ist nur eine Stätte der Vorbereitung und nur das äußere Symbol für eine weit höhere und innigere Gemeinschaft. Während in der kirchlichen Religion, die wir auch als die positive bezeichnen können, der Gedanke der Erweiterung und Ausbreitung der Gläubigen über die ganze Erde lebt, das soziale Moment der religiösen Gemeinde, das gemeinsame Suchen des Göttlichen und die öffentliche Verehrung gepflegt wird, lebt in der religiösen Mystik als der negativen Religion der Gedanke der Vereinsamung und Verengung, die Sehnsucht nach den dunklen und abgeschiedenen Wegen, die unmittelbar zu Gott hinführen. Sehr rerschieden wird also wohl eine Religionsgeschichte ansfallen, je nachdem der Gedanke der positiven oder der negativen Religion das Prinzip der Auslese hergibt.

Eine religionsgeschichtlich? Darstellung kann aber noch durch ganz andere Gesiehtspunkte und Auswahlprinzipien bestimmt werden als durch den Gegensatz des kirehlichen und antikirchlichen Lebens und den damit verbundenen Prinzipien des Universalismus und Individualismus, von denen jener das Allgemeine als cine bindende und rerpfliehtende Macht erhebt, dieser der Persönlichkcit größeren Spielraum gewährt in der Freiheit des mystischen Lebens. Wir können die religiösen Phänomene ordnen und erklären nach der verschiedenen Ursache ihres Werdens. In diesem Simne hat man wohl unterschicden zwischen physischer, psychiseher und anthropologischer Religion ${ }^{1}$ ). Die leitenten Begriffe, welche hier verschiedene Formen des religiösen Letens trenneu, sind selber keine Wertbegriffe. Die Determination des religiösen Lebens überhaupt erfolgt rielmehr dureh die Beziehung zu drei verschiedenen Formen des Wirklichen. die als Ursache der verschiedenen Religionsvorstellungen angesehen werden. Die eine Wirklichkeit ist die physische Natur; an ihr entwickelt sich der Glaube an rie Naturgötter, welehe die Gestirne lenkien und leiten, das Meer bewegen, die Tiefen des Waldes mit mancherlei Leben rrfüllen. Die andere Wirklichkeit ist die psyehisehe Natur unserer

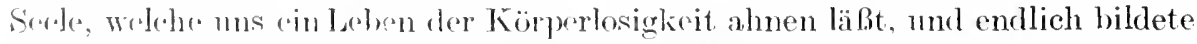
sich an der peycho-physisehen Natur des Mensehlichen die religiöse Form dor Hekdenterehrung. des Ahnenkultus und verwandter Kultformen. Zwischen diessen drei Formen des religiösen Jobens besteht kein Vorhältnis der Entwirklung. Sie gehen anf repsehiedenen Wegen zu einer Gottesrorstellung zusammen unt bezeichnen getrennte Weisen des Werdens voll religiösen Vorstedhneen, in denen sellber eine Futwicklung sich vollzicht, indem z. B. die paychischer Ridigrion aus bescheidenen Anfängen zu hoher Bliite sich entfaltet,

1) Vel. die religionswissenschaftlichen Schriften von Max Mïller. 
ohne daß man jedoch wiederum die psychische Peligion als die höhere Form gegenüber der physischen bezeichnen könnte.

Wir können aber auch, ohne auf den verschiedenen Grund des Werdens zu reflektieren, einfach die verschiedenen Gestalten oder Typen feststellen, die das religiöse Bewußtsein annimmt, und da ist es vor allem wichtig, auf das Verhältnis von Gott und Seele zu achten; denn eine Religion ohne Gott und eine Religion ohne Seele müssen wir prinzipiell ablehnen. Für gewönlich wertet man eine Religion nach dex Peinheit der Gottesvorstellung, so pflegt man z. B. den Monotheismus als Fortschritt gegenüber dem Polytheismus zu bezeichnen; aber der Fortschrittsgedanke gehört überhaupt nicht in die Religionsgeschichte hinein. Und was so selbstverständlich erscheint, der Vorzug des Monotheismus gegenüber dem Polytheismus, ist in dieser Selbstrerständlichkeit doch schwierig zu rechtfertigen. Denn mag auch der Monotheismus aus logisch-theoretischen Gründen höher einzuschätzen sein, so ist doch nicht ohne weiteres klar, warum der Monotheismus in rein religiöser Hinsicht absolut und von vornherein höher zn bewerten ist als der Polytheismus.

Dieser Schwierigkeit entgehen wir in der Religionsgeschichte, wenn wir ganz allgemein das Verhältnis von Gott und Seele zugrunde legen und nur auf die Formen möglicher Bezichung zwischen beiden roflektieren. Hier ergibt sich sogleich eine Dichotomie: Distanz oder Nähe. Entweder bleibt die Gottheit im Verhältnis zur Seele das Ferne, das nie Erreichte, das in sich ruht und der Liebe zum Endlichen entbehrt. Das heißt, die Gottheit ist vollkommen, aber lieblos und weltenfern. Oder aber die Gottheit kann ron rler Seele erreicht werden, und der Liebesbewegung der Seole zur Gottheit hin kommt entgegen eine Liebesberegung der Gottheit zur Secle hin. Das heißt. Gott ist unrollkommen, unvollendet und bedürftig, aber liebereich und weltennah. Man hat bisher noch zu wenig auf diesen Gegensatz geachtet, der für die Beurteilung religiöser Fragen entscheidend ist. Wäre das Göttliche absolut vollkommen, so wäre das Endliche ihm ewig fern. Nur das Bedürftige kann die Liebe haben und mit dem Endlichen vereinigt sein. In jener Lehre aber, die den Gegensatz ron Gott und Seele überwindet, ist wiederum eine doppelte Stellungnahme möglich, nämlich entweder so, daß die Betonung des Göttlichen zum Sterben der Seele in Gott oder die Behauptung des Seelischen zum Sterben dər Gotheit vor der allmächtigen Seele führt: Mystik und Magie.

\section{i) Die theoretische Beziehung als Prinzip der Gliederung.}

Die theoretische Beziehung ist dann in zweiter Hinsicht ein Prinzip der Gliederung. Sie ordnet und formiert die historische Wirklichkeit. Die methodologischen Kategorien der Geschichte wie die historische Kausalität formieren einen Zusammenhang zwischen den Erscheinungen, aber eine Gliederung der historischen Welt können sie nicht herbeiführen. Das geschieht erst durch die historischen Prinzipien, welche die verschiedenen Entwicklungslinien beherrschen und bestimmen. Ohne die Prinzipien des historischen Geschehens würde die geschichtliche Wirklichkeit blind und chaotisch sein. Durch sie wird etras Ähnliches geleistet wie durch die Gesetze in der naturwissenschaftlichen Welt. Dem allgemeinen Begriff des Gesetzes oder der 
GesetzmäBigkeit entspricht in der Geschichte der Begriff der Kultur oder der Werthaftigkeit. Den besonderen Naturgesetzen entsprechen in gewisser Weise die besonkleren Kulturwerte. Wie das große Gesetz der Gravitation imnerhalb dor Natur die besondere Sphäre des Astronomischen begründet, so in der Kulturwelt die ästhetische Idee oder der ästhetische Wert die Sphäre des künstlerischen Lebens. Wie sich der Begriff ron GesetzmäBigkeit überhaupt in der Natur zu der besonderen GesetzmäBigkait spezifiziert, durch die das Stufenreich der Natur geordnet wird ron der Welt des Mechanischen her bis zur Form des organischen Lebens, so spezifiziert sich der Begriff von Kultur iiberhaupt in (ler Welt des historischen Werdens zu den Geschehensketten besondercr Kulturbedeutung ron der Sphäre des wirtschaftlichen Lebens her bis zur Höhe des rein intellektuellen Lebens. Und wie es mmöglich ist, aus dem Begriff der Naturgesetzmäßigkeit die besonderen Naturgesetze abzuleiten, sondern jedes dieser Gesetze dem Begriff des Kausalallgemeinen gegenüber einen irrationalen Faktor aufweist, der durch das Hingewiesensein auf eine besondere Inhaltlichkeit bedingt ist, so daß die Formen des Organischen nur im Verhältnis zu einem besonderen Lebensinhalt rerstanden werden können, so sind auch die besonderen Kulturwerte irrational gegenüber dem allgemeinen Prinzip der Werthaftigkeit überhaupt, das für alles historische Leben unbedingte Geltung hat.

Unangreifbar und unantastbar steht das Leben in seiner unendlichen Fülle dem Menschengeiste gegenïber, die große schweigsame Sphinx mit den schönen ewig weehsehnden Zügen. Was wolltest du mit ihr beginnen, wie könntest du dich ihr nahen, wie solltest du auch nur das leiseste Verstehen gewinnen ohne die Bcziehung zur Wertidee? Wie groß ist doch die Erleuchtung, die von ihr ausgeht, wenn sie die dunklen und nächtigen Gestalten eines chaotischen Werdens mit mildem Lichte umsäumt. Wanderer wären wir ohne Sinn und Zicl auf Pfaden des Schreckens und der Zerstörung, in ewige Nacht gebannt, wenn nicht die Iree des Wertes uns beschieden wäre. Nicht als ob uns die Wertidee zu rinem rationalen Begreifen der Lebenswelt führen könnte, immer bleibt cin Lnergrünfliches, ein Unerforschliches zurück. Aber in feinen Lichtadern zittert der Wertglanz durch dunkle, geheimnisvolle Reiche und erweist das Fremde als belannt und rertraut. Wie wunderbar hat sich durch sie das V'crhältnis des Mensehengeistes zur Welt geklärt! Einstmals glaubte der Menseh den Gesstzen sex Natur rollkommen unterworfen zu sein, später hat sich ihm sein sinnvolles Verhälnis zur Welt der Natur und Geschichte dargetan. Er fand sich der Natur gegenüber als Gesetzgeber, und im Universmm der Geschichte faubl er sich selber wieder.

Was lir historische Welt zu einer Einheit rerbindet, das ist nur der Gedank der. Werthaftigkeit überhanpt. Ein letzter, cin absoluter Wort ist postuliert, dir. Irlee ciner sinnvollen Einheit, eines Welt- und Lebenssinnes wird an ras Gescheluen herangetragen. Kann sich die Wertidee gegenüber dem Leben

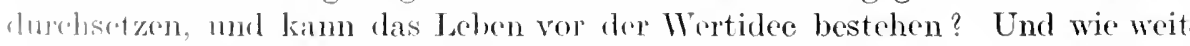
velonag dir denkende. Brotrachtung den simn in was einzehne zu tragen? Demn crst dann wijorlo dis historische Universum als geordnete und vollkommen

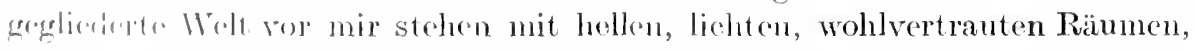
wenn die Simnghnug bis in alle Einzeldinge und Einzelverhältnisse vorgerllungen wäre. 
Hier müssen wir nun allerdings den Irrtum zurückweisen, als wenn die teleologische Ordmung der Dinge, welche die Werticlee rollzieht, gleichbedeutend sei mit der Erklärung der Welt aus dem Gedanken der Vorsehung oder anch nur aus der Idee eines Endzweckes. Der Begriff der Torsehung läßt uns das historische Universum als ein Reich der göttlichen Ordnung rerstehen. Gott hat die Welt sinnvoll eingerichtet, und der sinnvolle Verlauf des Geschehens ist nun entweder lediglich durch Gottes ursprüngliche Schöpfertat bedingt, die ein weiteres Eingreifen in den Lauf der Dinge nicht mehr erforderlich macht, oder durch andauernde Leitung und Lenkung, oder endlich durch radikales Eindringen in den Gang der Begebenheiten. In dem Begriff der Vorsehung wird also die Ordnung des Weltgeschehens im Vergleich mit einer Naschine oder mit einem Staatswesen gedacht. Im ersten Falle wird die Maschine so vorzüglich gedacht, daß sie das Wunder der Technik, das perpetum mobile, zur Wahrheit und Wirklichkeit gemacht hat. Das große sinnvolle Getriebe trägt in sich die unversiegbare Bewegungskraft, die eincm rorgesetzten gottgewollten Ziele entgegenarbeitet. Im anderen Falle ist es das Bild des konstitutionellen und des absoluten Herrschers, das sich mit dem Begriff der Forsehung verbindet. Beide kümmern sich um die Ordnung der Dinge und wirken auf sie ein, aber ersterer verharrt in einer zurückhaltenden und zurückgezogenen Stellung dem Geschehen gegenüber. Nur wenn es notwcndig ist für die Idee des Ganzen, befaßt er sich mit dem Lauf der Welt, ricles der freien Willensentscheidung überlassend, während im anderen Falle sein allgewaltiger Wille alles Geschehen durchdringt.

Auch von der Idee eines Endzwecks kann bei der teleologischen Ordnung der historischen Welt, wie sie durch die Prinzipien des historischen Geschehens herbeigeführt wird, nicht die Rede sein. Die Lehre rom Endzweck erhebt eine bestimmte Wertidee, z. B. die religiöse oder theoretische, zur höchsten und absoluten. Sie ordnet die anderen Wertideen in einem großen tcleologischen System dieser höchsten Idee unter, so daß ihr Wert und ihre Bedeutung zun Mittel wird für den absoluten Endzweck. Die Lehre rom Endzweck macht also den Versuch, einen einheitlichen Simn anfznweisen. Wird der Endzmeck religiös gedacht, so erweist sich als Zicl und Ende der Geschichte die rollendete. Offenbarung und die Heiligung der menschlichen Seele. Wird dor Endzweck moralisch gedacht, so muß das Reich der freien und autonomen Persönlichkeiten als Sinn des Geschehens erscheinen, und unter dem theoretischen Aspekt ist alles wertvolle Leben Weg zur Wahrheit, Weg zur Erkenntnis, und des Gesehehens allseliges Ziel ist das Schanen ihrer mverhüllten Schönheit ron Angesicht zu Angesicht.

Die teleologische Ordnung des Geschehens, wie sie durch die Mertideen als Prinzipien des historischen Werdens hergestellt wird, führt mur zu der Behamptung, daß die Geschichte sinnroll sei, da es allgemein anerkannte und gebilligte Ideale gibt, denen die Menschneit nachstrebt. Nach dem Verhältnis zu diesen Ideen beurteilen wir die Redeutung eines Menschen, nach Grad und Reichtum der Entfaltung gegenüber diesem objektiren Werte bestimmen wir die Größe einer Zeit. Nur die Behauptung eines sinn rollen Geschehens ist durch die Ordnung der theoretischen Wertbeziehung verbürgt, nichts aber weiß sie ron einem letzten Sinn alles Geschehens, und zwar in einem doppelten 
Sinne nicht. Sie vermag weder einen letzen und absoluten Wert aufzuweisen noch auch deutlich zu machen, daß alle Wertbetätigung einem gemeinsamen Zicle entgegeneilt.

Allerdings stellt sich der Begriff der Kultur an dieser Stelle ein und verbürgt eine gewisse Einheit des Zieles und damit zugleich auch eine einheitliche Ordnung des historischen Gesamtgeschehens. Wir können zwar nicht behaupten, daßKultur der Inbegriff alles Wertvollen ist, es gibt wertvolles Leben, das sich im Gegensatz zux Kultur bewegt, doch wird durch diese Tatsache die Ordnung des historischen Universums nicht gestört. Nur haben wir bei dem zweifellosen Gegensatze, der zwischen den sinzelnen Kulturgebieten besteht, vorderhand noch kein Recht, zu behaupten, daß sich diese ganze unendliche Fülle wert vollen Lebens zu einer einheitlichen Ordnung zusammensehließt.

So haben wir den Begriff der Kultur als die unbestimmte Forderung einer letzten Werteinheit, der dann sogleich die großen getrennten Reiche der verschiedenen Kulturgebiete oder, wie wir sie im historischen Gewande besser bezeichnen, die verschiedenen, Reihen“ der Kulturentwicklung unterstehen. Innerhalb dieser Reihen besteht die Forderung einer streng teleologischen Ordnung und Gliederung, und wir wïßten nicht, welche Instanzen die Durchfïhrung dieser Ordnung verbieten sollten. Der Ordnungeharakter des historischen Universums ist so zu verstehen. daß wir die Gliederung des historischen Ganzen in rersehiedene Ordnungssysteme behaupten können, aber das Ganze selber tritt uns nicht als Ordnungss ystem entgegen. Wir wissen nicht, welcher Entwicklungsreihe wir den Vorzug geben, welche wir zur leitenden dec historischen Bewegung erheben sollen. Nur innerhalb eines bestimmten Wertgefüges, otwa in der Welt der Kunst oder in der Reihe des politischmoralischen Jcbens, läßt sich eine Gliederung uml Ordnung schaffen, die auch das Kleinste erfaßst und ergreift, die ron dem allgemeinen leitenden Prinzip her in alle Einzelheiten eindringt. wobei rerschiedene Möglichkeiten der Bearbcitung und Glichlerung der betreffenden Gebiete gemäß der Verschiedenheit der Ausles'prinzipion gegeben sind. So spezialisiert sich die theoretische Bezichung, wom rom allgemeinen Geschehensprinzip Kinst wir vorwätsschreiten zum Begriff d'x bildenden Kunst und weiter zur skulptur der Renaissance bis schlirßlich zu den Werken Michel Angelos und der mächtigen Gestalt seines Mroses.

\section{g) Die theoretische beziphung als philosophische Vertiefung des liulturbegriflies.}

Auch als ain Prinzip philosophischer Vortiefung mu die theoretische Bezichung angeschent werden. Sie lehrt uns dir historische Welt in einem neuen Jichle schen mol führt das in der historischen Beurteilung Gemeinte auf seinen

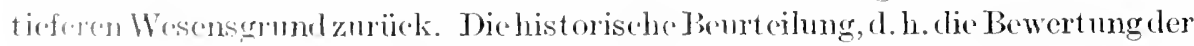

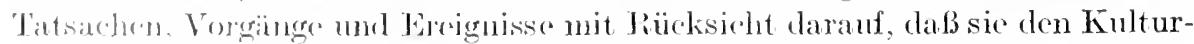

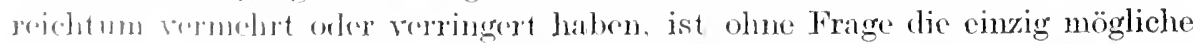
Pesition des Historikers. Dia Finge dre niedelen oder höheren Kultur eines

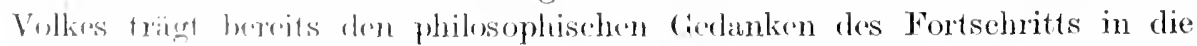

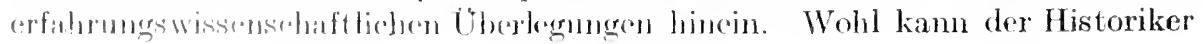


über alte und neue, über reiehe und arme Kultur sprechen, aber der Begriff der Kultursteigerung darf, sofern er streng empirisch-wissensehaftlieh rerfahren will, in seiner Darstellung nieht genutzt werden, weil der Begriff des Fortschritts eine geschichtsphilosophisches Problem ist. Es möchte fast so scheinen, daßdie geschichtsphilosophische Betrachtungderempirisch-historischen nicht so entgegengesetzt und nicht so scharf ron ihr abgesondert ist, wie die naturwissenschaftliche ron der naturphilosophischen. Vielleicht lassen sich auch die Grenzen nur schwerer ziehen, weil die Zeit ihrer innigen Berührung und Verschmelzung noch nicht lange überwunden ist. In jener Zeit ihrer schnellen und wundervollen Entfaltung am Anfang des 19. Jahrhunderts wurde alle große Geschichte zur Geschichtsphilosophie, und das Tatsacheninteresse der Historiker drang in die großen Gedankenwerke der Philosophen ein. Auch jetzt ist die Ablösung der historischen Betrachtung von der geschichtsphilosophisehen noch nicht reinlich rollzogen, was die rerschiedene Auffassung der historischen Beurteilung deutlich erkennen läßt, die nach unserer Ansicht ein notwendiges methodologisches Prinzip des Historikers ist, während nach der Auffassung anderer Wissenschaftstheoretiker die Beurteilung als ein rein philosophisches Prinzip lediglich dem Geschichtsphilosophen eignet. Ferner ist es aber die Universalgeschichte, die alle Geschichtsphilosophie krönt und besonders schwer ron der empirisch-historischen Darstellung zu tremnen ist. Das hängt aber damit zusammen, daß die Universalgeschichte, wenn sie mehr als Programm und Problem sein soll, zu ihrem Gegenstand nicht nur die reinen Formen und Prinzipien hat wie die anderen philosophischen Disziplinen, sondern ror die Aufgabe gestellt ist, deutlich zu maehen, wie sich die Form, das Prinzip des historischen Lebens, mit dem Geschehen verbindet. In gewisser Weise führt also die Universalgeschichte das durch die Abstraktion Getrennte wieder zur Einheit des Lebens zusammen und leitet das Cnwirkliehe zur Wirklichkeit zurück. Während die Philosophie in ihren anderen Disziplinen der statischen Betrachtungsweise und dem strengen Srstemzusammenhang zugewendet ist, verbindet sich in der Universalgeschichte die starre Form mit der ganzen Lebendigkeit des Geschehens. so daß die Universalgeschichte als die Synthese ron wissenschaftlichem und philosophischem Denken erscheint.

Die Schwierigkeit in der Trenmung historischer und geschichtsphilosophischer Betrachtungsweise scheint mir aber noch an einem anderen Faktor zu liegen. Es führt ein geheimer logischer Zusammenhang von der historisehen Beurteilung zum Problem der Universalgeschichte hin, den ich als einen Prozeß derVertiefung bestimmen und charakterisieren möchte. Die aligemeine historische Beurteilung, die über alle Parteigegensätze in wirtschaft licher. religiöser und politischer Hinsicht sowie über die einseitige Betonung des moralisehen Faktors weit hinausgeht, bezieht sich auf die Idee der Kulturvermehrung im sime ron Wertzuwachs. Jeder Historiker bewertet die Kultur, darin sind sie einig, keiner ron ihnen will ihre Vernichtung unr Aufhebung. Der historische Wert einer Leistung bleibt derselbe, mag er num ein Produkt der Notwendigkeit oder der Freiheit sein. Es ist nicht notwendig für den großen Historiker, in die Tiefen der Wertbejahung und Wertverneinung hinabzusteigen. Es ist nieht notwendig für ihn, sich ausdrücklich jener Werte bewußt zu sein. Welche die Anordnung 
und Gliederung seines Stoffes bedingen. Erst die philosophische Besinnung auf die Prinzipien des historischen Lebens vollzieht die Differenzierung der allgemeinen Kulturbewertung. Jedes Tun und Leiden, Wirken und Wollen in der Geschichte steht jetzt in notwendiger Beziehung zu einem bestimmten Kulturwert. Und nun erst wird die Frage aktuell, ob jene religiöse Leistung eine reine Glaubenstat, ob jene große Kunstschöpfung eine reine Künstlertat war, ob sie herrorgegangen ist aus der frendigen Bejahung der Schönheit. Zu bestimmten Kulturwerten, zu bestimmten Wertanerkennungen hat sich der allgemeine Begriff der Kultur vertieft, aber die Einheit, die dem Ursprünglichen eignete, ist jetzt vernichtet. Diese verlorene Einheit stellt sich dann in der miversalhistorischen Betrachtungsweise wieder her. Hier werden wir notwendig hingetrieben zu dem Begriff eines Systems der Kulturwerte, nach einer Wertordnming, zu der Itlee einer Rangordnung zwischen ihnen, denn die Universalgeschichte sucht den Sinn des Gesamt geschehens zu ergründen. Zu den Begriff des Endzwecks sehen wir uns hingeleitet und zu dem Gedanken des Fortschritts, der sich auf das engste mit ihm verbindet und das Maß der Sinn- und Zweckerfüllung zum Ausdruck bringt, während jener im Verhältnis zu diesem den allgemeinen Wertmaßstab und das letzte Beurteilungsprinzip hergibt.

\section{h) Theoretische Wertbeziehung als Erkenntnisprinzip.}

Das Leistungsproblem der Kulturwerte in der Funktion der theoretischen Wertbeziehung kommt dann endlich noch zum Ausdruck in dem Gedanken möglicher Erkenntnis der historischen Welt. Diese Funktion der Prinzipien des historischen Lebens mußten wir schon beriihren, als von der Gliederung der historischen Wolt lurch den Kulturbegriff die Rede war. Hier wurde darauf hingewiesen, dal das historische Geschehen ein unverstandenes und sinnloses Geschehen sein würde. wenn diese Masse des Werdens nicht auf die Wertideen bezogen wïrde. lch stehe ror irgendeiner Tat des Lebens, Leistens und Schaffens, ich lese in alten Schriften rom menschlichen Leben, Handeln und Tun. An Tfre des Albanersees arschane ich das stille Kloster der Franziskaner, las an den seligen Ufern der schönheit ruht. Mönche in bramncn Kutten sammeln Reisig in Walde, am Waldwege steht das kleine Eselgespann, und grïßend schereiten wir woiter. Was berleutet dieses Tun? Die dienenden Brüder des Klostexs sammoln Bremnholz, das Ferer zu zïnden, der Kälte zu wehren, das Mahl zu bereitron. Jirse Arbeit zu verrichten, zwingt sie des Grolens Gebot. Und warnm ist jenes ere bo Gebiude hier gebaut, an dieser ein-

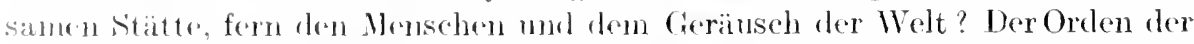
lannziskaner ist rinc Gomeinschaft ron Gottesslirnern. Sie glauben, daß du im

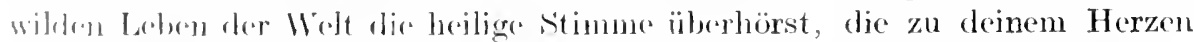
sprjeht. Joshalts sind sio in rle Kinsankeit gegangen, und die Einsamkeit gilt

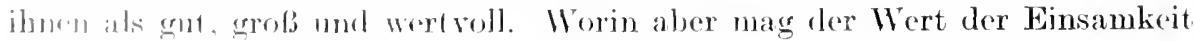

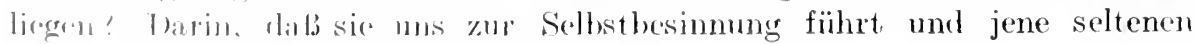

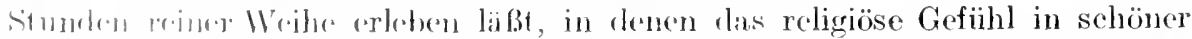

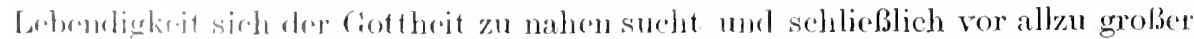

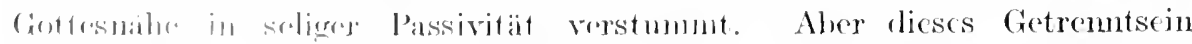

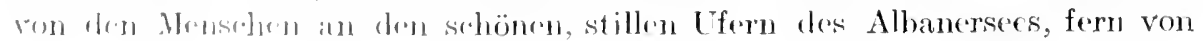


den Wohnungen der Weltkinder, bedentet ein Fernsein ron Leisten und machtrollem Tum, ron sozialer Wirkung und Betätigung. Lnd was will das heißen? Ist demn wirklich dieses Tun und Gestalten im kräftigen Leben ein so hohes unr köstliches Ding? Ist es nicht gerade dieses hastige und geräuschrolle Tun, was uns ron der lebendigen Quelle alles wahren Lebens entfernt? Eine Wertidee lege ich den Erscheinungen an. In ihr liegt etwas von Kontemplation und Passivität und Hingabe an die unbekannte Tiefe der Nelt. Es ist die Idee der weltentzogenen Reinheit, des Unberührtseins rom Staub der Welt. Ich habe den Begriff rer Religion und rermag von ihm aus ohne weiteres dieser Menschen Tun und Treiben zu rerstehen. Wiuden wir ihn nicht haben, so bliebe uns jenes weltentrückte Gesehehen an den Ufern des Albanersees rollkommen unverständlich. Wir würden Begriffe an diests Geschehen legen, die dem eigentïmlichen Charakter des Gegenstandes nicht angemessen sind. Es würde etwas ron jener Unverständlichkeit an sieh habeu, die für uns mit dem Leben andersartiger Gesehöpfe verbunden ist. Wie wir das Leben der Tierwelt deuten und mißdenten, indem wir fremden Sinn in die Erscheinungen tragen: in ganz ähnlicher Weise wird der in religiöser Beziehung unwissende Mensch die Formen des rehgiösen Lebens mißrerstehen nur mit demUnterschiede. daß dort das Höhere das Niedrige und hier das Niedrige das Höhere nicht rerstehen kann. In beiden Fällen aber fehlt die entspreehende Wertidee, die uns den Zugang öffnet für das Verständnis einer rerborgenen Lebenswelt.

Ich lese in alten Chroniken ron einem Wanderer, der einsame Pfarle wandert. Rauhes Gewand bekleidet ihn dürftig, einen Stab trägt er in der Hand und erbettelt oder erwirbt in den Städten und Dörfern der Mensehen im eiligen Vorübergehen ein kärgliches Brot. Er hat, wie es scheint, keine Stätte, da er sein Haupt hinlegen darf. Kirchen und Klöster sucht er auf und verweilt dort und betet und wandert weiter. Mir wissen, daß wir es hier mit einer Erscheinung des religiösen Lebens zu tun haben; wir bezeichnen diese Menschen als Pilger, sie wandern für eine bestimmte Zeit oder wanderu auch wohl für immer, für alle Zeiten. Sie gehen, um eine Schuld zu büßen, sie wandern nach einem bestimmten Gnadenort, wo ihnen Befreiung winkt. Oder sie wandern, weil sie den Sinn des religiösen Lebens in diesem Losgelöst sein von festen Stätten und Wohnungen, in diesem Aufgeben und Hinausgehen aus allen sozialen Bindungen, in diesen Anstrengungen und Enthehrungen um des Heiles und des Friedens willen verstehen. Das Wandern wird ihnen zum Symbol für den irdischen Leidensgang der Seele, und in allen Regungen ihrer Seele und in allen Bewegungen ihres Körpers tun sie den einen großen Willen kund: Gott zu suchen.

Wir leben in einer Zeit, die den Regungen des religiösen Bewußtseins ein hohes Maß von Unverständnis entgegenbringt, oder anders ausgedrückt: unsere Zeit vermag manche historischen Erscheinungen nicht recht zu würdigen und zu verstehen, weil ihr der Sinn für das religiöse Leben verloren gegangen ist . So mag ihr auch das Leben des frommen Nönches, der in die Einsamkeit flieht, um die reine Stimme eines höheren Lebens zu vernehmen, an dem ethischen Ideal gemessen als minderwertig oder unwertig erseheinen. Der Verfechter der ethischen Ideale verlangt, daß jeder Mensch in einen Pflichtenkreis und Berufskreis eintreten soll, der ihn mit anderen Nenschen rerbindet. und or 
perhorresziert das religiëse Ideal der Einsamkeit, weil es seinen ethiseh-sozialen Ideen entgegenstelit. Desgleichen wird ihm der rastlose Wanderer, der seinen Gott sucht, als mwertig exscheinen, weil ex nach seiner Auffassung den Mitmenschen gegeniiber nicht hilfreich nud hilfebietend ist. Er wird ihn vielleieht sogar als eine Landplage des Lebens betrachten und niehts als Bequemliehkeit und Müßiggang in seinem Tun und Treiben erblicken kömmen. Er vergißt, daß jener rielleieht einen großen Verzicht auf das Leben geleistet hat und vieles aufgab und fortgab. 1 m sich einen Weg zu bahnen in jenes Land, das seine gläubige Seele sueht in der festen T́berzeugung, daß cs nur auf diese Weise zu gewimnen sei.

Und dasselbe Verkennen des religiösen Bewußtseins wird vielleicht dahin führen, in dem Tun der Büßer und Asketen, in dem Treiben der Flagellanten und in anderen Erscheinungen religiöser Erregıng nichts anderes zu erblicken als Symptome der Narrheit und des Wahnsinns. Messen wir sie an dem ästhetischen Wert, so beben wir vor ihrer Häßliehkeit zurïck, nnd unter dem Aspekt der sozialen Brauehbarkeit erseheinen sie umnïtz und verwerflieh. Aber der ästhetische Wrort ist jenen Ausschreitungen und Übertreibungen gegenïber nicht kompetent, und der Begriff der sozialen Branchbarkeit vermag ihnen kein Licht abzugewinnen. Wir nehmen so manchen Erseheinungen des historisehen Lebens gegenüber ('ine schiefe Position ein, weil wir sie auf Iaßstäbe und Werte beziehen, die sie nieht auflösen und verdeutliehen können, oder weil wir sie viclleicht gar zu hastig auf moderne Wertauffassungen beziehen und gar zu wenig durchdrungen und erriullt si:d von dem Geist jener vergangenen Zeit, der diese Erscheinungen verständlich macht.

Wenn wir nun aber ïberhaupt bei vielen Historikern eine gewisse Verständnislosigkeit gegenüber den rehigiös'n Bewegungen und eine scharf ablehnende und anklagende Haltung gegenüber ihren Exzessen vorfinden, so hängt das auch wieder mit einem bercehtigten Prinzip zusammen. Denn wir haben bereits an anderer Stelle daranf hingewies'n, daß das religiöse Leben in seiner einen Jimension, wie auch andere an sich wertvolle Erseheinungen, eine gewisse Kulturfoinclichkeit offenbart, soforn sie aus der Goschiehte horansolrängen und ihrer nicht bedïrfen. So gibt es Sphären des menschlich Wertvollen, die von dem aroßen Rhythmus des Fortschrittes nicht cregt werken, und wertvolle Lobrusäuforungen, denen wir nicmals ein wahrhaft historisches Interesse entgegenbringen kïnnen. Auf dem Gebicte des religiösen und auch des sittichen Labens, soforn w dic kloinen Vorhältnisse des Daseins bewegt, wird

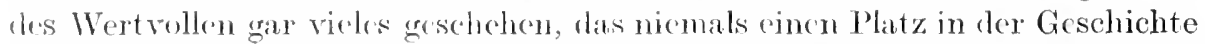
rwirtht, und zwar nicht nur deshalh, weil es mbekamnt mel unverstanden blineb, sontern vor allem anch, wril es nur wenig orter niehts zn tum hat mit den libegriff der historischen Cö̈be.

Mir möchten an rieser. Stclle noch auf cin spezialles historisehes Beispiel hinweism, das mir besonters gerignet arscheint, deutlich zu machen, wie mor das Vorhattnis zu den Wertideen und das Wissen ihrer mögliehen An-

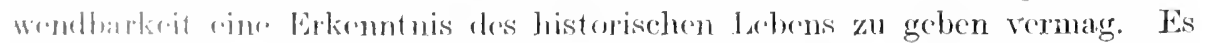

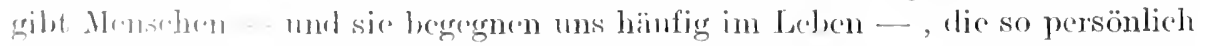
ringestellt sime, dals es fïr sire vollkommen munöglich ist, zu irgendeiner objoktiven Wrotumg vom Persomen und Dingen vorzuldringent. Was ihnen nicht 
sympathisch ist, können sie anch nicht schön finden. Sie können nicht rerstehen, daß man etwas anerkennen und werten kann, ohne es gern zu haben. Daneben aber können wir viele Menschen erleben, denen das Wertrerhältnis zu einer bestimmten Idee, etwa zur Idee des religiösen Lebens, vollkommen fehlt. Solche Menschen können nie Geschichte schreiben, denn in dem großen Historiker muß ein allseitiges Wertrerhältnis lebendig sein, und er muß die Fähigkeit haben, auch die leisen Pegungen wert rollen Lebens in der Tergangenheit zu begreifen. und sich so sehr in den Geist der früheren Zeit hineinversetzen können, daß er jene Doppelentscheidung ruhig zu vollziehen vermag, vor die jeder Historiker gestellt ist, nämlich einmal zu wissen. was das Geschehnis der Vergangenheit für die Vergangenheit bedeutet hat, dann weiter aber auch, wie hoch seine Bedeutung für die Gegenwart einzuschätzen ist. Manchmal ist es nun aber nicht leicht zu entscheiden, welche Wertidee ron ausschlaggebender Bedeutung ist, und die Maßstäbe, die wir der Tergangenheit ent nehmen. geraten in eine unvermeidliche Kollision mit den Wertmaßstäben der Gegenwart.

Das historische Beispiel, das ich hier heranziehen möchte, ist jene bekannte Absage, die Heinrich der Löwe Friedrich Barbarossa hat zuteil werden lassen, als dieser seine Gefolgschaft für einen neuen Römerzug erbat. Die Historie war früher geneigt, Heinrich den Löwen als schuldig zu betrachten, indem man ihm einen Mangel an Lehnstreue vorwarf. Alle Sympathie wendete sich dem edlen Staufen zu, der immer wieder ron neuem das Glück der dentschen Waffen in Italien erprobte. Die Bestrafung Heinrichs des Löwen durch den zurückkehrenden Kaiser erschien als gerechte Sühne seines schuldhaften, treulosen Verhaltens. Derselbe historische Vorgang hat dann später eine ganz andere Auffassung erfahren. Man empfand das Ansinnen, das der Kaiser an seinen großen Vasallen stellte, nicht mehr als ein selbstrerständlich zu erfüllendes Gebot. Man suchte nachzuweisen. daß die Tasallitätspflicht ihre bestimmten Grenzen habe und daß außerhalb dieser Grenzen die selbständige Entscheidung rollkommen zu Recht bestände. Seinen Römerzug hatte der große Welfenherzog geleistet und der italienischen Politik dos Kaisers schon viel geopfert. Andere Aufgaben und Pflichten harrten seiner im Osten des Reiches, Taten der Kolonisation gegenïber einem Volke ron niederer und zurückgebliebener Kultur. Es handelte sich hier weder um einen Bruch der Lehnstrewe noch um einen Akt grober Undankbarkeit gegenüber dem Kaiser, der ihn so mächtig gemacht hatte. Denn zu diesem nenen Römerzuge war der Herzog vermöge seiner Tasallitätsverhältnisse nicht verpflichtet. und mit Bedauern mußte er sehen, wie die italienische Politik der Hohenstaufen so nutzlose Opfer forderte. Im Grunde wollte er des Kaisers eigenes Bestes, wenn er ihn von dieser Abenteuerpolitik zurückhielt und ihn zu reranlassen suchte, im eigenen Lande für Deutschlands Nacht und Größe Sorge zu tragen. Der Herzog hat mehr an die Interessen des Dentschtums gedacht und sie zu wahren gesucht als der Hohenstaufe. Die Hausmachtspolitik des Welfen, der Ländererwerb im Osten fiel mit den Interessen des Reiches zusammen. Erwerbungen in Italien, die eventueil die Hansmacht der Staufen verstärkten, konnten für das Deutschtum nichts bedeuten, da erfahrungsgemäß die höhere Kultur immer die feindlichen Elemente einer niederen Kultur in sich aufnimmt und nach ihrem Geiste gestaltet. Wieviel germanisches Blut war nicht schon 
in Italien für den internationalen Gedanken des römischen Kaisertums deutscher Nation geopfert worden, wie hatte doch die romantische Politik der deutschen Kaiser die gesunde und stetige Entwicklung des Reiches gehemmt. Der Herzog war der Weitsichtigere gegenüber dem Staufenkaiser, dem Idealismus des Romantikers trat die besonnene Politik des Realisten gegenüber.

Betraehten wir dieses Beispiel etwas näher, wm daraus zu ersehen, daß dic hesonnene und berechtigte Anwendung der Wertideen ganz allein zum Terständnis der historischen Begebenheiten zu führen rermag. Der einseitige Jaßstab, den die Vergangenheit an diese große Begebenheit herantrug, war wohl der Gesichtspunkt der Lehnstreue. Herzog Heinrich hatte sich dem Kaiser als treulos erwiesen und mußte dementsprechend büßen. Sein Treubruch führte zum Verlust sämtlicher Lchen, und damit war die Macht des einst so ruhmvollen Welfenhauses vernichtet. Eine mehr realpolitisch denkende Zeit unterwirft den Begriff der Vasallentrene einer näheren Prüfung. Sie findet, daß in ihr nichts mbedingt Bindendes und Verpflichtendes für die Leistung des Römerznges lag. Sie weist auf das freie und lockere, so wenig geregelte Verhältnis hin. das damals zwischen der international gesinnten Kaisermacht und den großen Vasallen in Dentschland bestand. Was darüber hinaus als rerpflichtendes im Terhältnis ron Kaiser und Herzog noch angesehen werden moehte, jene irrationalen Gefühlswerte ron Dankbarkeit. Freundschaft und und Liebe, die zwischen ihnen noch bestanden, und die eine sentimentaler urteilende Zeit so hoch einstellte, indem sie ihnen unbedingte Geltung beimaß und einen Vorstoß gegen sie auch damn verurteilte, wem es sich um die Wahrung und Verteidigung ureigenster politischer Intcressen handelte - jene alle konnten von den modernen Historikern nieht mehr gleichwertig in Rechnung gezogen werden. An dem ethischen Maßstab gemessen, mußte die Tat des Welfen klein und niedrig erseheinen, denn die sittlichen Verpflichtungen beginnen dort recht eigentlich, wo die rechtliehen aufhören. Der Freundschaft harte Probe hat Herzog Heinrich nicht bestanclen. Nehmen wir dagegen den Nïtzlichkcitsstandpunkt des Realpolitikcrs, so hat er klug und rerständig gehandelt, weil er fest und stark im Auge behiclt, was zum Besten seines Volkes dicnlich war. Geändert hat die Geschichte vielfach ihr Urteil über die italienische Politik der dentschen Kaiser. Was früher als unvergängliche Ruhmestat galt und mit marchenhaftem Schimmer das mystische Geheimnis der Kaiserkrone umstrahlte, das gilt in den nïehternen Augen der Gegenwart wohl als ïberspannte, abenterorliche und romantischo Politik. Handelte es sich doch mm ein Objokt, das nur guringe praktische Vorteile dem Besitzer gewährte, Im ein blobes Machtsymbol, das die gröBten Opfer an nationalen Kräften grobuteriseh verlangte. Wir leben in rinem Zoitalter, das sich mit leidensehaftlinerer Lieber zur Idere des nationalen States bekement. Die Idee der Weltnomarehis hat allo Wirksankeit vertoren. Wir glauben nicht melur an die Wolt machestrllung cines cinzelnen Tolkes, und anch der fromme Messiasglaube an dir ansorwithle Sation ist in Sichwindon begriffon. Immer deutlieher rntfalen sich ror don Blicken des IIstorikers die Wertindividualitäten der rinzeluen Vationen, und wom wir die groben Kulturnationen in ihrer Eigenart vorsteluen, so glauben wir, da 3 ihrer keine verloren gehen wird, daB jede ein unersıtzliches Gilied in dem Ganzen der curopäischen Völkergemeinschaft bedeutet. 
Und so ist es denn der Wertmaßstab des Realpolitikers oder vielmehr der Maßstab des Historikers, der „reale" Politik bewertet und den gesunden nationalen Egoismus durch die Idee der Wertindividualität des eigenen Volkes rerklärț, der eine nene Beurteilung jenes welthistorischen Vorganges herrortreibt. Neue Wertideen sind an die Stelle der alten getreten. Die Idee der Weltmonarchie hat ihren Zauber verloren, und die ethische Beurteilung wird abgelehnt. Aus diesem Wechsel leitender Wertgesichtspunkte ergibt sich eine schwierige Aufgabe für den Historiker. Er muß den Wertgesichtspunkt der Vergangenheit mit dem der Gegenwart verbinden. Er darf die Ideen der Vergangenheit, die doch einmal wirksam waren, nicht einfach ignorieren, er darf auch über sie nicht skrupellos zu Gericht sitzen. Denn auch er hat keinen absoluten Wertmaßstab bei der Hand, und er würde einer Zeit unrecht tun, wenn er ihr Ideen imputierte, die sie nie besessen, oder die Handlungsweise historischer Persönlichkeiten an Maßstäben messen wollte, die gänzlich außerhalb des Gesichtskreises der betreffenden Epoche lagen. Immer wieder muß sich der Historiker fragen: , Welche Wertidee ist erkenntnisspendend für den betreffenden Vorgang der Geschıchte, ron welchem Gesichtspunkt aus kann ich die geheimnisreichen Tiefen der Vergangenheit durchleuchten ?" Da müssen uns denn ror allem diejenigen politischen Persönlichkeiten als großmächtig erscheinen, die im Sinne der politischen Ideale ihrer Zeit tätig gewesen sind. Es gab eine Zeit, da die Idee der Weltmonarchie gar mächtig die Gemüter ergriff und ebenso die Idee des Papsttums oder der Kreuzzüge. Dem Mittelalter war eine große universalistische Idlee eigen. Das Germanentum war als Nachfolger der antiken Völker gedacht, soweit es sich um die politische Weltmachtstellung handelte. Der ganze Erdkreis sollte ein Reich sein zum Schutz und zur Entfaltung der einen christlichen Kirche, und zum Anwalt dieser Idee haben sich die Staufenkaiser gemacht. Von den Staufenkaisern eine nationale Politik zu rerlangen, wäre ein Anachronismus ebensogut wie das Postulat der Sklarenbefreiung für den antiken Grundbesitzer. Wir können ebensowenig den Kosmopolitismus der Mittelalters vom Standpunkt des Nationalismus der Gegenwart einschätzen, wie uns der Kosmopolitismus rergangener Zeiten als theoretischer Wertbeziehungsbegriff für das 19. und 20. Jahrhundert dienen kann. Unglaublich schwierig bleibt allerdings, dabei immer zu entscheiden, wieweit die alten Wertideen schon obsolet geworden sind und dem Werden des Neuen sich hemmend entgegenstellen. Es gibt keine Zeit, die von allen möglichen Idealen und Wertideen beherrscht wäre, sondern eine Zeit wird immer nur von einer verhältnismäßig geringen Zahl von Kulturnormen bestimmt, bzw. treten nur wenige leitend und fördernd herror. Die Ideale der Menschheit leuchten plötzlich auf uncl kehren dann wieder für geraume Zeit in die Dunkelheit zurück, um späteren Geschlechtern von neuem zu leuchten.

Wir betonten in diesem Abschnitt die Erkenntnisfunktion der Wertideen. Nur von gewissen Ideen aus können wir ganz bestimmte Erscheinungen verstehen und würdigen. Deswegen ist es ron allergröBter Wichtigkeit, auf welche Normen der Historiker die geschichtlichen Vorgänge bezieht. So mag etwa das Mönchswesen des 4. und 5. Jahrhunderts ästhetisch widerwärtig, aber religiös bedeutsam sein, und die schönen Sünden der Renaissance müssen den Moralisten entrüsten.

Mehl1s, Geschichtsphilosophie. 
Eine logische Schwierigkeit besteht nun aber darin, mit der Erkenntnisfunktion der theoretisehen Wertbeziehung auch tief in die historisehen Begebenheiten einzudringen. Wenn ich von Wissensehaft, Kunst und Religion spreehe, so sind das ganz bestimmt höchst allgemeine und formale Begriffe, die mit gar mancherlei Inhalt in Verbindung gebracht werden können. Wie kann ich die bestimmten Gestalten und Formen des religiösen und künstlerisehen Lebens, die mir in der historisehen Welt entgegentreten, nut meinen allgemeinen Begriffen von Kulturwerten in Verbindung bringen oder gar den Versuch machen, jene aus diesen zu rechtfertigen? Wir stehen hier vor einer der interessantesten und wichtigst on Fragen der Geschichtsphilosophie, die auch für die Universalgeschichte von entscheidender Bedeutung sein muß.

\section{i) Der Typus.}

Dilthey hat den Versueh gemacht, die Formen und Gestalten aufzuweisen, in denen der allgemeine Kulturwert im Prozeß der historischen Entwicklung der Fülle seiner Daseinsmöglichkeiten nach sich ausdrückt und auswirkt. Es ist das ein Problem, das in metaphysischer Gewandung vor allem die Philosophie des deutschen Idealismus besehäftigt hat und mit dem Problem der historisehen Epochen sowie mit der Idee einer Gliederung des historischen Geschehens auf das engste zusammenhängt. Es liegt die Vorstellung zugrunde, daß die Wertidee Grenzen der Darstellungsmöglichkeit hat, daß sie sich im Prozeß des Kulturgesehehens allmählich crschöpft und auswirkt, daß sie sich, fortschreitend von Teil zu Teil, schließlich in ihrer Ganzheit offenbart. So hat etwa die Religion gewisse Formen ihrer Daseinsmöglichkeit, und man hat gemeint, daß das Christentum dic vollendete Form der religiösen Wertverwirklichung sei. So hat auch die Philosophie Formen oder Teilideen, in denen sie zum Bewußtsein der Menschheit gelangt, die num untereinander wieder entweder ein einfaches Fortgehen von Wahrheit zu Wahrheit oder auch eine Steigerung im Prozeß der Erkenntnis sclber bedeuten können. Jede Teilidee hat cine weltgesehichtliche Epoehe, in der sie sich answirkt, nachdem sic neu gefunden and entdeekt war durch die schöpferische 'Tat des großen Mensehen. Es ist nun aber nicht erforderlich, daB die Teilwerte, soweit wir ron ihnen wissen, ein harmonisehes Ganzes bilden, daß im ProzeB der Erkenntnis und des Wissens Glied an Glied sieh reiht, bis wir sehließlich das Ganze in seiner Schönheit ïbersehauen können. Viehmehr besteht in der Regel cin Gegensatz zwischen den Treilideen der Werte. Das neue Menschheitsideal der Kultur mol dos Lebens gerït in Konflikt mit rem, was früher einmal als geltend betraehtet wurke. So stchen im klaffenden Gegensatz die Offenbarung

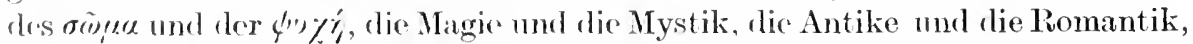
der Naturalisnms und deg Idealismus. Diese Gegensätze treten immer wieder hervor, seitlem sic cinmal zur Wirklichkeit gelangt sind. Natur und Freiheit, unbewaß3t und bewaßt, naiv und sentimental, das sind dann sehließlich ganz allgrmoine Brstimmungen und Kenmzoichen, in denen der Gegensatz, der auf den Trilgeticten anfunweisen ist, zu cinem Gesamtgegensatz vereinigt wird.

Dic Mctaphysik des dentsehen Irlatismus sah in diesen Wortideen reale Kräftr, die das historische Universum mabhängig von unserem endlichen Erkennen formen unel gestalten. Donker wie Fichte und Schelling hielten 
es für möglich, aus dem Begriff der leitenden Wertidee alle möglichen Formen des Wertrollen abzuleiten und auf Grund dieser Formen den historischen Verlauf in seinen Grundzügen zu konstruieren. Seitdem sind die Forderungen der Geschichtsphilosophie erheblich herabgesetzt, aber das alte Problem bleibt in Kraft. Denn nur dann hat es einen Sinn, dem Problem der Unirersalgeschichte nachzudenken, wenn die Möglichkeit besteht, Grundformen des Kulturgesehehens, Gestalten des historisch Wirklichen aufzuweisen, in denen der allgemeine Kulturwert zur Darstellung gelangt, und dann auf Grund dieser Ausdrucksformen ein Bild des historischen Universums zu entwerfen. Diese Gebilde der historischen Wirklichkeit, in denen die allgemeinen Kulturwerte zu einem notwendigen bestimmten Ausdruck gelangen, bezeichnen wir nach Dilthey mit dem Begriff des Typus. Durch den Typus als die bestimmte Gestalt des historisch Wertrollen kommen wir erst zu einem philosophischen Verstehen des historischen Prozesses. Der Typus ist in der Geschichte der Ansatzpunkt für das philosophische Verstehen. Durch dies Medium gelangt die irrationale Geschichte zu einer gewissen Rationalisierung. In dem Begriff des Typus begegnet sich die Arbeit des Historikers mit der Arbeit des Philosophen.

Allerdings ist es rollkommen aussichtslos, diese Typen aus den allgemeinen Wertideen heraus zu konstruieren. Sie können nur in der Besinnung auf den historischen Prozeß an der Empirie der Geschichte aufgewiesen werden. Das gilt aber ebensowohl für die Formen der objektiven Kulturwerte, die niemals aus dem Begriff des einheitlich Wertvollen, überhaupt aus der Idee eines absoluten Wertes entwickelt werden können. Die objektiv'n Kulturwerte sind eine historische Gegebenheit, und wir können uns auf ihr höchstes Prinzip besinnen, aber das Absolute, auf das sie hinweisen, ist uns in keiner philosophischen Erkenntnisform unmittelbar und rollständig gegeben. Die Philosophen sind darüber uneinig, ob der Begriff des Absoluten in die Philosophie gehört. Diejenigen, die in den Bahnen Kants wandeln, kennen nur die objektiren Werte, sofern sie sich auf einem besonderen Gebiet offenbaren, und der Begriff einer absoluten Werteinheit kommt bei ihnen nicht zu einer geschlossenen und rollständigen Darstellung. So kennt die Kritik der reinen Vernunft die Idee der Erkenntnis und Wahrheit und die Vorstellung der intellektuellen Anschanung des göttlichen Verstandes. So kennt die Kritik der praktischen Ternunft den Begriff der Persönlichkeit, der Freiheit und des heiligen Willens, und die Ästhetik findet das Objektire in der Schönheit und Erhabenheit sowie in der Vorstellung ron dem übersinnlichen Substrat der Menschheit. Nirgends aber tritt in einer philosophischen Disziplin das Absolute in seiner schönen Ganzheit hervor, und es bloibt zweifelhaft, ob wir uns der objektiven Terte schon in ihrer Fülle bewußt sind, oder ob es nicht noch andere, unbekannte gibt, die erst nach Jahrhunderten oder Jahrtausenden zum BewuBtsein des Menschengeschlechts gelangen. Denn gar zu kurz ist der bisher zurückgelegte Weg einer vernünftigen Ent wicklung des Mensehengeschlechtes, als daß wir meinen könnten. die Kultur wäre schon in ihren allgemeinen Zügen rollendet und aufgebaut.

Müssen wir aber unsere Erkenntnis der objektiren Tierte als fragmentiseh betrachten, selbst in bezug auf die Frage nach der Zahl der höchsten Prinzipien, so daß es prinzipiell nicht ausgeschlossen ist, daß die Menschheit der Zukunft noch zu der Erkenntnis ganz anderer Kulturgüter gelangt, so kann es kein 
W'under nehmen, daß auch die Gestalten, in denen sich der objektive Wert im historischen Prozeß offenbart, nicht erschöpfend und vollständig aufzuweisen sind. Es bleibt die Möglichkeit bestehen, daß die Religion oder auch die Philosophie und Kunst noch ganz andere historische Gestalt annimmt wie die bisher uns bekannte. Wie uns aber die Möglichkeit einer späteren Entdeckung neuer Kulturmomente nicht hindern kann, einem System der Kulturwerte nachzudenken und jedes Wertgebiet einzeln auf seine Kategorien zu durchforschen, so kann die Geschichtsphilosophie auch an dem Problem der historischen Gestaltung der objektiven Werte nicht vorübergehen, zumal mit ihrer Erfassung die Möglichkeit gegeben ist, ein philosophisches Einteilungsprinzip für das historische Geschehen zu finden.

Wenn wir nun ron den Gestalten des listorischen Geschehens sprechen, denen wir eine Beziehung zu den objektiven Kulturwerten geben wollen, so wird hier nicht an so spezielle historische. Formen wie Christentum oder kantische Philosophie gedaeht, die als durchaus einmalige historische Erscheinungen aufzufassen sind und deswegen der Geschichte und nicht der Geschichtsphilosophie angehören. Es handelt sich vielmehr um Begriffe von weitaus höherer Allgemeinheit, die mit den Kulturwerten das gemeinsam haben, daß sie nicht so unmittelbar und ausdrücklich an eine bestimmte Epoche gebunden sind, sondern einen Ewigkeitsgehalt in sich bergen, der immer wieder nach neuer Wirklichkeit verlangt. Dicse Typen des historischen Geschehens hängen mit den Kulturwerten insofern notwendig zusammen, als sie die verschiedenen Möglichkeiten ihrer Auffassung und Darstellung zu bedeuten scheinen. Zur Rechtfertigung unserer Theorie brauchen wir nur auf die Tatsache hinzuweisen, daß, obwohl die Geschichte die Kategorie des Nenen zu ihren wichtigsten Formen zählt, dennoch immer wieder auf allen Kulturgebieten eine Gemeinsamkeit unter den Wertgebilden der entlegensten Epochen sich offenbart. Ich erimnere nur an die Gemeinsamkeit von Antike und Renaissance, von Christentum und Budlhismus, von deutschem Idealismus und griechischplatonischer Philosophie.

Um nun dicse Gestalten des historischen Geschehens zu verstehen, die den objektiven Kulturwerten so nahe liegen, ist es notwendig, sich darauf zu besinnen, daß jedes Wertgebiet ron einem ursprünglichen Gegensatz getragen wird. Das ist in der theoretisehen Philosophie der Gegensatz von Subjekt und Objekt, der auch für die anderen Gebiete relerant ist, für die Religion und die Religionsphilosophie der Gegensatz ron unendlich und endlich, für die Ethik und das sittliche Ieben der Gegensatz von sein und sollen, und schließlich für die Kunst und die Ästhetik der Gegensatz von Form und Inhalt für die genießende Betrachtung und der Gegensatz von Gestalt und schöpferischem Drang für dic künstlerische Produktion.

Gerale in neuerer Zcit ist man wieder diesen Grundgestalten des historischen Geschehens nacligegangen. So erschöpft sich etwa nach Fichte das Gehict der Philosophie in eine freie idealistische und eine durch das Prinzip der Notwendigkeit beherrschte naturalistische ${ }^{1}$ ), und Dilthe y hat diesen Gegensat\% ïbernommen, wenn er als Typen der Weltanschauung den Idealismus dem

3) Vhl. hesenders Fichtes Einleitungen in dio Wissenschaftslehre. 
Naturalismus gegenüberstellt ${ }^{1}$ ). Verwandt ist der Gegensatz ron subjektivierender und objektivierender Auffassung, den Pickert in seinem Logosartikel aufgewiesen hat $\left.{ }^{2}\right)$. Wenn aller Erkenntnis das Subjekt-ObjektVerhältnis zugrunde liegt, so gibt es scheinbar nur diese beiden Möglichkeiten, daß wir nämlich entweder das Subjekt dem Objekt eingegliedert denken oder aber das Objekt als Inhalt des Subjektes verstehen. Entweder bestimmt, wie Fichte sich in der Wissenschaftslehre ausdrückt, das Nicht-Ich das Ich oder das Ich das Nicht-Ich. Subjektirierende und objektivierende Weltauffassung würden somit Typen des philosophisch-historischen Geschehens sein.

Wir wollen an dieser Stelle vor allem auf den Grundgegensatz hinweisen, der das religiöse Leben beherrscht und die verschiedenen Gestalten des religiöshistorischen Geschehens hervortreibt. Dieser Gegensatz ist das Verhältnis des Unendlichen zum Endlichen, des Unbegrenzten zum Begrenzten.

Setzen wir eine Beziehung zwischen beiden Begriffen, so ergibt sich die Möglichkeit, daß entweder das Endliche als göttlich das Unendliche, oder das Unendliche als göttlich das Endliche bestimmt. Dieser Gegensatz entspricht in vieler Hinsicht dem Gegensatz von antiker und moderner Gottesvorstellung. Es ergibt sich aber noch eine Möglichkeit rerschiedener Gottesrorstellung aus dem Begriff der Distanz und der Einseitigkeit der Wertbeziehung heraus. Das Gött liche kann nämlich entweder so gedacht werden, claß es in rollkommener Abgeschlossenheit und Jenseitigkeit in sich ruht, daß es selig ist in ihm selbst, so daß der sehnsüchtigen Liebe des Endlichen keine Gegenliebe des Göttlichen und Unendlichen entgegenstrebt. Eine solelie Auffassung und Deutung des Gottesbegriffes finden wir etwa bei Plotin. Oder aber es besteht ein gegenseitiges Verhältnis ron Liebe und Geliebtsein zwischen dem Endlichen und Unendlichen, und die Distanz wird rernichtet durch die religiöse Flamme der Sehnsucht. Dann kamn wieder eine rerschiedene Offenbarung des religiösen Lebens kund werden, je nachdem die Macht des Unendlichen durch die Kraft des Endlichen, oder die Kraft des Endlichen durch die Macht des Unendlichen Zwang erleidet. Diese zuletzt aufgewiesenen Typen des religiösen Lebens habe ich in meinem Logosartikel als Magier und Mystiker einander gegenübergestellt. ${ }^{3}$ ) Die mystische Seele ist es, welche in heiliger Passivitiät und Abgeschiedenheit durch die Maeht Gottes bestimmt und betroffen wird, während die leidenschaftliche Aktivität das Magier's in der Bejahung ihrer Individualität und in der Kraft ihrer Gottessehnsucht die Gottälnnlichkeit verachtet, das Gottgleichsein erstrebt und in ihrer Begierde naclı dem Höchsten das Göttliche mit dem Zwang ihres Willens bedroht. In dicsen Gegensatz von Magie und Mystik sind die religiösen Ideen ton Gott und Unstexblichkeit auf das engste verflochten, und beider Gestaltungen finden wir überall dort, wo das religiöse Leben in die Tiefe geht. Es ließe sieh aber vielleicht zeigen, daß der antiken Welt in höherem Maße die Gestalt des ilagiers und der modernen Welt die Gestalt des Mystikers entspricht, doch gehört auch dieser schon dem Reiche der Hellenen und jener noch der Welt der Gegenwart an. Dazwischen

1) Vgl. Diltheys Aufsatz „Die Typen der Weltanschauung“ in dem Sammelwerk Weltanschauung.

$\left.{ }^{2}\right)$ Vgl. Rickert, Vom Begrifi der Philosophie. Logos Bd. I H. 1.

3) Logos Bd. II. H. 2. 
erhebt sich dann immer wieder das religiöse Genie und sucht den unversöhnlichen Gegensatz. der zwischen beiden errichtet ist, durch seine große Liebesmacht zu überwinden.

\section{\$ 3. Der dritte Problemkreis. Das Strukturproblem.}

Die Erkenntnisfrage des Leistungsproblems der Kulturwerte treibt dann schließlich zum Strukturproblem hin. Es ist das die Frage nach der Beschaffenheit der Prinzipien des historischen Lebens. Wir wollen wissen, wie sie aussehen und wie sie sich roneinander unterscheiden. Eine solche Beschreibung der Kulturwerte kann in sehr verschiedener Weise erfolgen, nämlich entweder mehr aus methodologisch-klassifikatorischen Gründen oder mit der Absicht, einen Einblick in das Verhältnis ron Kultur und Leben sowie eine Erkenntnis ihrer universalhistorischen Bedeutung zu gewinnen. In dem ersten Falle kommt es dem Geschichtslogiker nicht so sehr darauf an, die qualitativen Unterschiede zwischen den Kulturwerten in ihrer Eigenart sowie ilure verschiedene Lebensund Geschichtsbedeutung aufzuzeigen, sondern er stellt vielmehr die Frage, welche verschiedene theoretische Formung derselbe philosophische Wertbegriff, z. B. der Begriff des Volkes oder der Nation, gemäß dem verschiedenen Charakter philosophischer Begriffsbildung annehmen kann. Ich denke hier vor allem an das Buch von $\mathrm{Lask}^{1}$ ), welches die Logik der Fichteschen Philosophie und ror allem seiner Geschichtsphilosophie klargelegt und dentlich gemacht hat.

\section{a) Algemeine logische Struktur der Kulturwerte.}

Hier in diesem schönen Werke finden sich Untersuchungen über die Natur des Wertbegriffes. Lask lehnt sich an die von Rickert rollzogene Unterscheidung zwischen generalisicrender und individualisierender Begriffsbildung an. Für die individualisierende Begriffsbldung ist das Verhältnis des Ganzen zu scinen Teilen, für die generalisierende Begriffsbildung das Verhältnis des Allgemeinen zum Besonderen charakteristisch. Lask wendet diesen Gegensatz, der für die logische Beherrschung der sinnlichen Seinswirklichkeit so bedeutsam ist, anf die reine Sphäre des Sinnes an. Auch hier ergibt sich dieselbe Alternative: die Sinnwelt kann wie die Sinnenwelt individualisierend oder generalisierend geformt werden. Zwischen Baum und Eiche besteht gemäß der nat urwissenschaft lichen Formung der Sinnenwelt das Verhältnis des Allgemeinen zum Besonderen als Gattung und Exemplar. Das Exemplar hat seine Werthaftigkeit aufgegeben und gilt nur, sofern es der Gattung sich untergeordnet hat. Rafaels Schule ron Athen verhält sich zur Hochrenaissance wie der Tei] zum Ganzen, wie eine künstlerische Einzelleistung zur Gesamtleistung "iner großen Kulturepoche. Dem Ganzen eingeordnet, verliert die Einzelleistung menals ihren selbstïndigen Wreharakter. Das Verhältnis des Ganzen zu drn 'Trilen stedıt der Wirklichkeit näher, dem gattungsmäßig Allgemeinen schwintut der Wirklichkritsgehalt. Damit hängt es zusammen, daß die große "manalistisch" Logik und Metaphysik in ilhrer Wirklichkeitssehnsucht das brsorulere aus dem Allgemeinen abzuleiten unternimnt, während die erkenntnistherentischr Lesignation anor andytischen Philosophie die Kluft zwischen

1) Liak, Fichtes Idealismus und dio (ieschichte. 2. Aufl. 1914. 
dem Allgemeinen und der Mannigfaltigkeit des besonderen Inhalts auf das schärfste betont. So erweitert sich für Lask mehr und mehr der Gegensatz ron naturwissenschaftlicher und historischer Begriffsbildung, der ja in der rerschiedenen Formung des Allgemeinen zum Ausdruek gelangt, zu einem Grundgegensatz des Denkens überhaupt, der auch in der philosophischen Erkenntnis zum Ausdruck gelangen muß. Der Gegenstand der philosophischen Erkenntnis sind nun aber die Werte. Folglich wird die rerschiedenartige Begriffsbildung auch in der Auffassung der Werte und ihren gegenseitigen Beziehungen zum Ausdruck kommen. Wir können nachweisen, daß die analytische Philosophie Kants die naturwissenschaftliche Begriffsbildung in der Wertsphäre zum Ausdruck bringt. So etwa bei der Auffassung des Wertrerhältnisses ron Wertallgemeinem und Wertexemplar. Die Indiridualität, die Persönlichkeit hat in der philosophischen Begriffsbildung $\mathrm{K}$ ants dem Sollen der Pflicht gegenüber keine selbständige Bedeutung. Das Wertrolle an der Persönlichkeit ist lediglich das Pflichtgemäße. Dagegen ist die Persönlichkeit in der Wertbegriffsbildung des deutschen Idealismus als Eigenwert gegenüber dem Allgemeinen gewahrt. Hier wird die Gesellschaft als das Wertganze gedacht, dem sich die Individualität als Wertteil eingliedert. Dabei hat Lask vortrefflich zu zeigen gewußt, daß diese ganze Wertbegriffsbildung mit dem Gegensatz ron Individualismus und Universalismus ebensowenig zu tun hat wie etwa der Gegensatz ron individualisierender und generalisierender Begriffsbildung berührt wird. Denn die Philosophie Kants, die den Eigenwert der Persönlichkeit rollkommen aufgehen und eingehen läßt in das Wertmoment der Pflicht, gerade sie trägt in ihrer Ethik einen stark individualistischen Charakter, und anderseits denkt die Philosophie Hegels die Wertindividualität so fest eingeordnet in die Werttotalität des Ganzen, daß wir die universalistische Tendenz seiner Wertungsweise nicht bezweifeln können.

Als Beispiel für die mehr formale Wertbetrachtung, die auf Klassifikation hinausläuft, müssen auch die logischen Untersuchungen ron Max Weber gelten, wie sie in seinem Artikel über sozialwissenschaftliche und sozialpolitische Erkenntnis niedergelegt sind. Im Mittelpunkt seiner logischen Erörterungen steht der Begriff des Typischen. Max Weber geht daron aus, daß er zwei Auffassungen des Typischen als bekannt und anerkannt voraussetzt, nämlich typisch im Sinne des Vorbildlichen und Idealen und typisch im Sinne des Durchschnittlichen. Für die erste Form der Bergriffsbildung können wir auch den Begriff des Normativen, für den zweiten den Begriff des Normalen einsetzen. Der Begriff des Typischen im Sinne des Vorbildlichen ist für die Philosophie und Geschichte wesentlich, der Begriff des Typischen als durchschnittlich verstanden ist ein Produkt der wertfreien, naturwissenschaftlichen Begriffsbildung. Wenn wir von dem Charakter Bis ma rcks als typisch deutsch sprechen, so meinen wir, daß die wertvollen Eigenschaften der dentschen Nation vielleicht in einer gewissen Einseitigkeit und Schroffheit, aber doch wieder auch in einer wundervollen Auslese und gesteigerten Form in seinem Wesen ihren Ausdruck gefunden haben. Wir künnen aber auch ron typisch deutsch in dem Sinne sprechen, daß wir darunter diejenigen Qualitäten rerstehen, die allen Deutschen gemeinsam sind. Dann fällt der Begriff des Typus mit dem Gattungsbegriff zusammen. und dieses Gemeinsame ist dann nicht ein Großes 
und Wertvolles, sondern ein verhältnismäßig Kleines und Erbärmliches Das Wertrolle wird durch das Minderwertige kompensiert, und das Resultat ist das allgemeine Durchschnittsniveau. Diese Entgegensetzungen sind so äußcrst wichtig, weil sie es bis zur Evidenz deutlich machen, wie ungeschieden noch in dem Begriff der platonischen Idee das Produkt der naturwissenschaftlichen Begriffsbildung, die Gattung und der philosophische Begriff des Wertes rerbunden war.

Max Weber hat gezeigt ${ }^{\mathbf{l}}$ ), daß die idealtypischen Begriffe, die zum Verstehen der historisehen Wirklichkeit so wichtig sind, von dem Gedanken des Seinsollenden, Vorbildlichen, dem Idealbegriff des philosophischen Denkens zunächst vollkommen freigehalten werden müssen. Es handelt sich hier um ein Gedankengebilde, das wir konstruieren, um iiber die Bedeutung historischer Erscheinungen uns Klarheit zu verschaffen, und ihrem Wert als Erkenntnismittel tut es keinen Abbruch, daß sic im Gegensatz zu den wohldefinierten Begriffen der Naturwissenschaft ein hohes Maß von inhaltlicher Unbestimmtheit mit sich führen. Diese idealtypischen Begriffe dürfen weder als die eigentliche Wirklichkeit angesehen werden noch als Schemata, denen die Erscheinungen des Wirklichen subsumiert werden sollen, sie sind vielmehr ideale Grenzbegriffe, an denen die Wirklichkeit gemessen wird. Eine Verquickung des spezifiseh historisehen idealtypischen Begriffes mit dem philosophischen Begriff des Ideals, des Seinsollenden, ergibt sich aber sehr leicht aus dem Umstande, daß die idealtypischen Begriffe, deren wir zur Bewältigung der historischen Mannigfaltigkeit bedürfen, daß sie selber ursprünglich vielfach Ideale des wissenschaftlichen, künstlerischen oder religiösen Lebens gewesen sind. Aus dieser Tatsache ergibt sich ein interessanter Vergleich zwischen den historischen idealtypischen und den naturwissenschaftlichen Durchschnittsbegriffen. Beide sind gemäß der rein wissenschaftlichen Begriffsbildung zunächst sollensfrei, aber beide werden nur zu leicht einer rein logischen Ausdeutung unterworfen. Die historischen Begriffe mit ciner gewissen Berechtigung, weil sie selber häufig in der Vergangenheit den Idealcharakter gehabt haben. Sie waren Ideale gewisser Lebens- und Kulturkreise oder das Kampfziel gewisser Parteien und Konfessionen oder Forderungen großer wirtschaftlicher, politischer und religiöser Bewegungen. Anders dic naturwissenschaftlichen Durchschnittsbegriffe, wie der Begriff des Lebens, des Organismus oder anch des homo sapiens, die in der naturwissenschaftlichen Entwicklungsgeschichte nur zu häufig die Bedeutung des Tileals annchmen. Ihrem Begriffsprinzip nach vollkommen wertfrei zu denken, gewinnen sie ihre Wertbedeutung erst danlurch, daß sich vermöge einer gewissen Amphibolie dem Begriff des Lebens der Begriff des wertrollen Iebens und dem Begriff des homo sapiens die Idee dris Kulturmenschen unterschiebt.

So gewinnt der Begriff des Typus eine dreifache Grundbedentung. Er ist philnsophiseh Ideal und Vorbile, historiseh idealtypiseher Konstruktionsbegriff ohne normativen Charakter und naturwissenschaftlieher Durehschnittsbegriff. Zwischen rliessen Extremen gibt es num zahlreiche Uhorgänge und in

1) Vul. Mitx Wober, Die Objektivitat soyialwissensenafticher und sozialpolitiseher

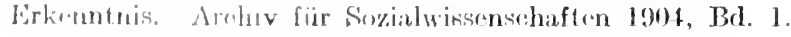


den Begriffen mancherlei Variationen. Nehmen wir etwa den Begriff des Christentums, so können wir darunter die Gedanken oder Ideen verstehen, welche die Menschheit in einer bestimmten Epoche, etwa des Mittelalters, tatsächlich beherrscht haben. Wenn wir dieser chaotischen Masse rerschiedenartig geformter Gedanken, Meinungen und Auffassungen gegenüber nach dem Wesen des Christentums fragen, so bilden wir einen Begriff, der eine Verbindung von Glaubenssätzen, Dogmen, ethischen Normen, Naximen der Lebensführung in sich schließt. und der als idealtypische Konstrulstion anzusehen ist. Wenn wir uns aber Rechenschaft geben über das Wesen des Christentums, so tritt sogleich noch ein anderes komplizierendes Moment hinzu, indem die herausgehobene Form des Christentums, in der ich sein Wichtiges und Wertvolles zu fassen suche, auch zugleich den Charakter des Vorbildichen annimmt. Das eigentlich Wichtige am Christentum, auf das ich die Erscheinungen der Zeit beziehe, jenes Etwas, an dem ich sie messe, ist uns gleichzeitig auch das Ziel, dem die Darstellung Erfolg und Realität verschaffen will, nach dem. sie die Erscheinungen beurteilt. Wieviel Modifikationen der Begriff des Idealtypus zuläßt, und wie ersich mit dem Begriff des Ideals und des Gattungsbegriffes berührt, das haben die Untersuchungen ron Max Weber rorzüglich dentlich gemacht.

Die Probleme, die sich Lask und Max Weber in bezug auf die Struktur der Kulturwerte gestellt haben, sind mehr formal methodologischer Natur. Bei Lask handelt es sich um eine Art Logik der Geschichtsphilosophie, sofern er auf die verschiedene logische Form aufmerksam macht, welche der Kulturwert entsprechend dem Charakter einer analytischen oder emanatistischen Philosophie in den rerschiedenen Systemen annimmt. Max Weber speziell sucht die logische Gestalt des Kulturwertes, sofern er als methodologisches Prinzip fungiert, von dem Idealbegriff der Philosophie und dem Durchschnittsbegriff der Naturwissenschaft abzugrenzen. Beide aber beschäftigen sich mit dem Kulturwert schlechthin und nicht mit der Gestalt, die er auf einem speziellen Gebiet, etwa in der Sphäre des künstlerischen Lebens gewinnt. Auf diese Sonderstruktur der Kulturwerte zielen die Untersuchungen von Dilthey ab, die also innerhalb des allgemeinen Strukturproblems der Kulturwerte wieder eine ganz besondere Frage behandeln. Es handelt sich hier um verschiedene Fragestellungen, die aber doch schließlich dem einen gemeinsamen Ziele dienen, nämlich deutlich zu machen, welche verschiedenartigen Gestaltungen der Kulturwert im Prozeß der Geschichte anzunehmen remag.

\section{b) Sonderstruktur der Kulturwerte.}

Vergleichen wir die Gestalt, die das Strukturproblem bei Dilthey annimmt, mit den zuvor erörterten Fragestellungen, so liegt der Torzug dieser vielleicht in der größeren Schärfe der logischen Formulierung, an deren Stelle bei Dilthey der Reichtum und die Klaft anschaulicher Schilderung und Beschreibung steht, verbunden mit einem feinen Achtgeben anf die eigentümliche Gestalt, welche zur Beschaffenheit eines besonderen Wertgebietes gehört.

Die außerordentlich verschiedenartige Gestalt, die das Strukturproblem der Kulturwerte schon angenommen hat, ist uns ein Beweis dafür, daß hier noch sehr viel unbebautes Land der gesehichtsphilosophischen Bearbeitung 
hal'rt. Es ist aber auch von Wichtigkeit, auf die verschiedenen möglichen Behandlungsweisen aufmerksam zu machen, die alle demselben Ziele der Erkenntnis dienen. und von denen die eine die andere keineswegs ausschließt. Wir müssen jene Unduldsamkeit in der Behandlung philosophischer Probleme beklagen, die nur die eigene Erkenntnisform selig preist und die anderen nicht rerstehen will.

\section{c) Verschiedene Möglichkeiten in der Behandlung des Strukturproblems.}

Wieviel verschiedene Wege läßt doch speziell das Strukturproblem der Kulturwerte zu! Wir können den Kulturwert zu beschreiben suchen, wie er im unmittelbaren Erlebniszusammenhang sich geltend macht. Wir können z. B. die ästhetischen Phänomene als eigenartiges Werterlebnis verstehen, das mit ganz anderen Impressionen die Seele erfüllt wie logische oder ethische Formen. Wir sind dabei weit entfernt, Psychologie im üblichen Sinne des Wortes zu treiben, weil wir die Phänomene so betrachten, wie sie in der auserwählten, der einzigartig disponierten, dem Schönen zugewandten Seele klassische Form gewinnen. Und wenn Dilthe $y^{1}$ ) den Gegensatz von Lebenswerten und Kulturwerten so zu fassen sucht, daß er zwei Pole konstruiert, den objektiven des Gegenstandes und den subjektiven des Ich, und alle Erlebniswellen zwisehen ihnen hin und her fluten läßt und dann den Unterschied so versteht, daß im Erlebnis des Kulturwertes das persönliche Ich ausgelöscht wird in der rücksichtslosen Hingabe an das Objektive, während es im Erlebnis der Liebe hell und stark hervorleuchtet, so ist die Seele, deren Erlebniszusammenhang er zu prüfen unternimmt, selber ein ideales Gcbilde, kein Gattungsbegriff, gewommen durch Abstraktion von der existierenden Individualitäten-Mannigfaltigkeit, sondern um ein typisches Erfassen idealer Inhaltlichkeit handelt es sich hier. Denn es gibt Individualitäten, die den Kulturwert ausbeuten, und andere, die sich in der Liebe vergessen.

Und wieder andere Formen nimmt das Problem der Kulturwerte an, wenn wir uns deutlich zu machen suchen, was denn alles zu einem Kulturausschnitt wie Recht oder Kunst gehört, was für eine Mannigfaltigkeit ron Verhältnissen und Lebensformen dieser Begriff zu ciner Einheit verbindet. Aus den unklaren, verworrenen und widerstreitenden Vorstellungen, wie sie in den Köpfen der Individuen leben, Gedanken, die in versehiedener Schärfe und Idbendigkeit, hänfig nur als bloße Schemen gegenwärtig sind, wird der Begriff des Rechtes gewonnen, arbeitet sich seine wissenschaftliche Bedeutung hervor. Wir gedenken des Gesetzes als eines Komplexes ron Normen, deren Geltung abhängig ist von gesetzgebenden und herrschenden Mäehten. Wir gedenken der Rechtssubjekte, die dureh ihre Zugehörigkeit zu einer sozialen Grmeinsehaft verpflichtet sind, die ganze Lebenshaltung ihnen gemäß zu gestalten. Wir suchen zu bestimmen, wieweit die Rechtssphäre das Leben d'] Individuen umgreift und durchdringt. Wir wissen die Instanzen, die ihre Ausiibung bewahren, und jene, die gemäß ihrer Geltung über normwidrige Handlungen urteilen und entscheiden. Und wieder gibt es eine stille Sphäre in

1) Dilthey, Aufhau der geschichtlichen Welt in den Geisteswissenschaften. Studien \%ur Grundlegung der Geisteswissensehaften. 
dem allgemeinen Wirkungszusammenhang des Rechtes, wo das Recht geprüft und geklärt und weitergebildet und gelehrt wird. Und notwendig gehört dazu das lebendige RechtsbemuBtsein eines Tolkes, ror dem alte Normen obsolet werden und andere als ideale Forderungen und Zielsetzungen erscheiner, und das. selber in ewiger und lebendiger Entwicklung begriffen, an den Neuschöpfungen des Rechtes einen zähen, verschwiegenen, fast lautlosen Anteil nimmt.

Und wieder eine andere Gestalt nimmt das Problem der Prinzipien des historischen Lebens an, wenn wir von der Zugehörigkeit und Beziehung der Wertmomente und Ideen zu real wirkenden Willensmächten und Vorstellungskreisen vollkommen absehen und den Tersuch machen, den idealen Inhalt der Kulturwerte schlechthin auseinanderzulegen, wenn wir etwa die Überlegung anstellen, welche ideellen Einheiten sich zu der religiösen Idee zusammenschließen, und welche Gegensätze und Tertunterscheidungen zwischen den verschiedenen Prinzipien zu machen sind.

Alle diese verschiedenartigen Untersuchungen sind berechtigt und haben uns einen tieferen Einblick in die Struktur der Kulturwerte tun lassen, doch entbehren sie alle eines bestimmten Zieles, solange sie nicht in den Dienst des universalhistorischen Problems gestellt werden. Der Historiker treibt Geschichtslogik, um sich über die Methode seiner Wissenschaft Klarheit zu rerschaffen, der Geschichtsphilosoph, um von ihr aus zur Erkenntnis der Prinzipien des historischen Lebens zu gelangen. Ist er aber zu ihrer Erkenntnis gelangt, ist er in all diesen großen Kultursphären heimisch geworden, dann wünscht er zu wissen, was diese Prinzipien für die Wirklichkeit und das Weltgeschehen bedeuten. Er gelangt also notwendig zu dem Problem der Universalgeschichte Wir heben von vornherein hervor, daß es sehr wahrscheinlich ist, daß die verschiedenen Prinzipien für das welthistorische Geschehen auch etwas bedeuten werden, und daß wir schon früher gezeigt haben, wie gewisse Formen wertvollen Lebens nicht eigentlich historisch sind und auch dem Begriff des Fortschritts einen gewissen Widerstand entgegensetzen.

Das führt uns dazu, nunmehr zu einer Aufteilung der Werte überzugehen, die für die Lösung des universalhistorischen Problems eine entscheidende Bedeutung gewinnen wird. Man kann in erster Linie zwischen statischen und dynamischen Werten unterscheiden. Das heiBt, es gibt gewisse Werte, die nur unter der Voraussetzung eines lebendigen und wertvollen Geschehens Bedeutung haben. Es sind das die eminent geschichtsphilosophischen Begriffe, die das neue Problem stellen. Zu ihnen gehört zunächst der Begriff des Fortschritts, der selber der höchste Ausdruck des dynamischen Prinzips ist. Er würde in einem rein statischen unbeweglichen Weltbild, wie etwa dem spinozistischen, alle seine Bedeutung verlieren. Er findet seine nähere Untersuchung erst in der Universalgeschichte. Nit ihm hängen eine Reihe von anderen Begriffen zusammen, die deswegen gleichfalls für das Problem der Universalgeschichte aufbewahrt werden, nämlich der Begrıff des Endzwecks, der seinerseits wieder mit dem Begriff des Wertmaßstabes der quantitativen und qualitativen Wertordnung zusammenhängt. Ferner des Begriff der Wertverwirklichung, der Erfüllung, der historischen Epoche, der Persönlichkeit als Wertträger, der Freiheit in allgemein geschichtsphilosophischem Sinne und der Notwendigkeit im Sinne einer bestimmten Wertfolge. Dahin gehört ferner 
denn auch noch ganz besonders der geschichtsphilosophische Begriff der Antinomie. der schon in der Lehre von den Prinzipien des historischen Geschehens seinen Ausgang nimmt.

\section{d) Die statischen Werte.}

Wir haben in diesem Abschnitt nur die Struktur derjenigen Kulturwerte zu untersuchen, die man im Gegensatz zu jenen, die so unmittelbar mit dem historischen Geschehen verschmolzen sind, auch als die statischen Werte bezeichnen kann, sofernsie ablösbar gedacht werden können von dem historischen Prozeß und wie die erstarrten Ideen Plat os aufgefaßt werden als das Absolute und an sich Wertrolle, das allem Geschehen zugrunde liegt, und zu dem alles Geschehen hinstrebt. Fortschritt kann unmöglich ein letzter Wert sein, denn er hat nur Sinn im Verhältnis zu einem Ziele. Fortschritt um des Fortschritts willen hebt jedes Ziel und jeden Endzweck auf und läßt das ewige ruhelose Geschehen das Letzte sein. Der Begriff des Fortschritts vollendet sich erst in dem Gedanken des Zieles, dem er entgegeneilt, und erhält auch durch dieses Ziel erst seinen Wertcharakter. Anders steht es dagegen mit der Wertidee der Schönheit. Warum sollte das Schöne nicht Ziel und Krone des Lebens sein? Und ebenso ließe sich die Idee der Menschheit als Endzweek des historischen Geschehens denken. Fragen wir nun mit Rücksicht auf einen letzten Wertmaßstab der historischen Entwicklung, ob wohl eine Anordnung zwischen den Werten möglich sei, so ließe sıch diese in doppelter Richtung denken, nämlich einmal als quantitative und dann als qualitative Wertordnung.

\section{e) Quantitative Wertorduung.}

Bei der quantitativen Wertordnung gehen wir von der Spannung aus, die zwischen dem Begriff des Individualismus und des Universalismus liegt. Unter Individualismus verstehen wir die Auszeichnung des Individuums, unter Universalismus die Auszeichnung des Allgemeinen, der Gesellschaft, des Gattungsmäßigen. Dieses Spannungsverhältnis kamn schon in primitiven Fïhlen und Stellungnchmen aufgewiesen werden, wo es sich noch um keine philosophisch wichtigen Wertsctzungen handelt. Es gibt in der Tat nur dicse beiden extremen Möglichkeiten, nämlich entweder so, daß das Individuum oder das Soziale alles bedentet. Bedeutet das Individuum alles, so ist die Gesellschaft für das Individuum da, bedeutet die Gesellschaft alles, so ist das Individuum für die Gescllschaft da, und die Gesellschaft kann mit ihm machen, was sie will.

Dic Auszcichnung des Individuums kann dann wieder eine doppelte From annehmen, je nachdem das Individuum als solehes, mag es noch so erbairmlich sein, als cine letzte Position angesehen wird, über die man nicht hinanserhon kann und darf, oder aber die Auszoichnung nur den starken und mairhtion lexemplaren der Gattung zuteil wirt. Dex Kultus des Individuums schlectuthin fülurt in seinen lotzten Konsequenzen zun Anarchismus, der dic

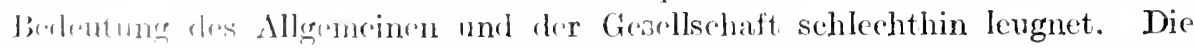
Auszrichume la großrn. starken Gatungsindividuen führt zum Despotismus unel \%ul (imaltsherrsehift. Anderseits ist die Nichtachtung jecler Form fres Individurllen. dir alsolutr und rinscitige: Auszeichnung rles Sozialen gleich- 
bedeutend mit einem herdenmäßigen Aufgehen in ein Allgemeines. Die vollkommene Nivellierung des Persönlichen löst alle Cnterschiede auf. Alle Individuen sind gleich nichtig und bedeutungslos gegenüber dem Gesetz der Allgemeinheit.

Von diesen Verhältnissen und Beziehungen, die noch unterhalb der Schwelle des Wertbewußtseins liegen, muß wohl unterschieden werden jene bewußte Herausarbeitung des Allgemeingültigen und Objektiren, welche dahin führen kann, entweder die Persönlichkeit oder die Gesellschaft mit hohen Wertmomenten zu umgeben und zu verklären. Wenn wir die Persönlichkeit als schlechthin wertvoll betrachten, so sprechen wir von Individualismus, rerbindet sich dagegen das Wertmoment mit einem sozialen Ganzen, so haben wir es mit einer universalistischen Wertungstendenz zu tun. Die Extreme können auch hier so weit auseinandertreten, daß in dem einen Falle die wertrolle Persönlichkeit alles bedeutet, der gegenüber die soziale Gemeinschaft nichts mehr gelten kann, sofern ja das Gemeinschaftsleben nichts anderes ist als das Leben der wertvollen Persönlichkeiten, oder aber die Persönlichkeit nird als etwas fast Unwirkliches betrachtet, das erst in der Gemeinschaft wahrhaftes Leben und Realität gewinnt und ohne sie nicht imstande wäre, irgendeine Leistung zu vollziehen. Dann verbindet sich der Wert ausschließlich mit dem Allgemeinen, und während nach der ersten Auffassung der wertrolle Mensch allein es ist, um dessentwillen die Gemeinschaft und die Weltgeschichte Berechtigung hat, indem ihre ganze Tendenz darin gesucht wird, auch unter Darbringung von noch so viel Opfern die große Persönlichkeit als die reife Frucht des historischen Geschehens zu erzeugen und zu erhalten, erhebt der extreme Universalismus, der die soziale Gemeinschaft mit aller Wertauszeichnung belegt, die Forderung, daß sich das Indiriduum rückhaltlos aufzuopfern habe für die Gemeinschaft, der es sein Wertleben schuldet.

Zwischen diesen verschiedenartigen Standpunkten gibt es dann eine Reihe von Ubergangsformen, je nachdem die Persönlichkeit dem sozialen Ganzen gegenüber an Bedeutung zunimmt oder das soziale Ganze im Verhältnis zur Persönlichkeit an Absolutheit verliert. Zwischen den Gegensätzen aber, die einer quantitativen Wertordnung hemmend entgegenstehen, kann die Entscheidung sehr verschieden ausfallen. Extrem und einseitig ist eine Lösung, die zur Alleinwertung des Persönlichen oder zur Alleinwertung der Gemeinschaft gelangt. Die Versöhnung aber kann in verschiedener Richtung erfolgen, je nachdem der Versuch darauf gerichtet ist, die Idee des allumfassenden Ganzen als Menschheit, Gott, Welt, historisches Universum mit der Idee des Persönlichen auszusöhnen, oder die Lösung darin besteht, daß die beiden extremen Positionen gewissermaßen geopfert werden. und ein Wittleres als das Berechtigte anerkannt wird. Unzweifelhaft gehen unsere Wertungstendenzen, wenn sie den quantitativen Gesichtspunkt anlegen, nach der Weite und Enge. So erscheint einerseits die Persönlichkeit als ein Letztes, Unangreifbares und anderseits die Menschheit. Zwischen beiden liegen jedoch eine Fülle von sozialen Kreisen, wie der Liebe und Freundschaft, der Familie, der Korporation, des Berufsstandes, der Stadtgemeinschaft, der Landsmannschaft, des Staates, der europäischen Zivilisation usw. Es kann nun sehr wohl sein, daß die Wertung unter Vernachlässigung der äußersten 
Gegensätze eins von diesen Mittleren ergreift und etwa zu der Behauptung gelangt, daß es nicht auf die Pcrsönlichkeit und auf die Menschheit ankomme, weil der Begriff ron jener zu eng und von dieser zu weit sei, sondern die höchste Wertgemeinschaft sei das Liebesverhältnis oder der Staat oder der adlige Stand. Dann müßte der Liebende zum Opfertod bereit sein dem Verhältnis der Liebe gegenüber, das für ihn am meisten gilt, so wie der Bürger dem Staate und der Baron der Adelskaste gegenüber. Und ebenso bereit müßten sie sein, die weiteren Verhältnisse deswegen zu opfern: den Staat der Liebe. die Menschheit dem Staat und die europäische Kultur der Adelskaste. Vor allem ist es immer wieder die Idee des Staates gewesen, die der Enge des Persönlichen und der blassen Weite der Menschheit gegenüber als das wahrhaft Wertrolle geltend gemacht wurde.

So ist ron dem Gedanken der quantitativen Wertordnung aus, die in der Universalgeschichte eine so wichtige Rolle spiclt, der Widerstreit der Tendenzen zu beobachten, die auf Verengung und auf Erweiterung gerichtet sind, die Spannung zwischen dem Persönlichkeitswerte und dem sozialen Werte. Das ganze Problem erhält aber noch eine Verschärfung, wenn wir die Wertbegriffsbildung selber betrachten, die sich auf das Verhältnis des Persönlichen und Individuellen zum Allgemeinen bezieht. Dies Verhältnis kann nämlich entweder als das des Allgemeinen zum Besonderen oder als des Ganzen zu seinen Teilen gedacht werden. Im ersteren Falle verliert das Individuelle die Eigenbedeutung; so gilt etwa die Persönlichkeit im Sinne Kants nur als wertvoll, sofern sie unter den allgemeinen Begriff der Pflicht subsumierbar ist, wertlos aber erscheint die Sondergestaltung, die unwiederholbare und einzigartige Form, zu der sich das Leben des Individuums gestaltet hat. Und um noch ein anderes Beispiel anzuführen: das staatliche Leben hat im Sinne der Geschichtsphilosophie nur soweit Bedeutung, als es unter den Begriff einer weltbürgerlichen Gesellsehaft subsumierbar ist. Ganz anders wenn wir das Verhältnis des Ganzen zu seinen Teilen anwenden. Diese Begriffsbildung rermag den Eigenwert der Persönlichkeit zu retten. Denn wenn das Individuum im Verhältnis zum Allgemeinen gedacht wird als Teil zum Ganzen, dam ordnet es sich als besonderer und rigenartiger Gliedwert einer unfassenden Totalität ein, die den Lebensgrunil ihrer besonderen Form bildet, ohne doch selber das zum Ausdruck zu bringen, was die Persönlichkeit im Vergleich nit anderen Persönlichkeiten in bezug anf ihr. Wertleben Gemeinsames hat.

Aber wie gesagt, die individualisierende Auffassung des Wertverhältnisses von Persönlichkcit und Gesellschaft gibt nur dic Möglichkeit für eine Rettung des cigentïmlichen Persönlichkeitswertes. Aueh diese Formung der Begriffsbildung kaun das Individuum aufheben und vernichten, je nachdem die Idee Jer Ganzheit und 'lotalität so mächtig betont wird, daß die Individualität sich anflëst und dahingibt wie der Tropfen in Mecre, oder als fester Kern in sellstinnliger Position gegenüber dem Allgemeinen erhalten bleibt.

\section{f) Qualitative Wertorduung.}

Zur Trollendung fler Wertordnung tritt dann die qualitative Abstufung der Werte hinzu. Es gilot noch eine ganz andere Ordnung der Werte, die mit Irm Gregensatz von Persönlichkeit und sozialer Gemeinschaft nichts zu tun 
hat. Hier handelt es sich nicht um Weite und Enge, nicht um den Wertzuwachs, der mit der Idee größerer Nähe oder Weite sich verbindet, hier handelt es sich vielmehr um das Verhältnis zwischen den allgemeinen Kulturformen, der Wissenschaft, Kunst, Religion usw., also um ein Verhältnis zwischen dem schlechthin Allgemeinen, das in jeder seiner Formen den Anspruch auf Universalität und restlose Wirklichkeitsbeherrschung erhebt. Es soll eine Einheit zwischen den rerschiedenen Kulturformen hergestellt werden. Nur so kann eine allgemeine Deutung der Welt und des Lebens sich ergeben. Eine Kulturform etwa die Wissenschaft oder die Kunst, muß zum dominierenden Wert erhoben werden. Dann haben wir eine Hierarchie der Werte, die vielleicht in der Idee der Religion sich vollendet. Wir nennen sie die qualitatire Wertordnung, weil es sich hier um die verschiedenen großen Wertqualitäten handelt, die in sich absolut sind und die Welt der Dinge und Individuen in der rerschiedenartigsten Beleuchtung hervortreten lassen. Setzen wir die qualitative Mertordnung in ein Verhältnis zur quantitativen, so kommen wir zu Begriffen wie ethischer Individualismus, der eine Entscheidung für den Persönlichkeitswert und dieIdee der Sittlichkeit bedentet, oder wie ästhetischer Universalismus, darin die Entscheidung für das Soziale oder Allgemeine und für das Schöne gefallen ist.

Die Herstellung der qualitativen Wertordnung begegnet nun sehr großen Schwierigkeiten, sofern die Überordnung eines Wertes iiber die anderen gleichbedeutend wäre mit einer Aufhebung und Zerstörung ihrer Absolutheit. Außerdem sind die Kulturformen ja spezifisch verschieden und dulden nichts Gemeinsames über sich als höchstens die blasse und gänzlich umbestimmte Vorstellung des Wertes überhaupt. Dieser Schwierigkeit, die in der Herstellung einer Wertordnung liegt, ist die große Metaphysik seit $\mathrm{Kant}$ dadurch entgangen, daß sie zeigte, wie das Problem der wisscnschaftlichen Erkenntnis nicht zur Auflösung des Wirklichkeitsproblems führt, sondern daß da ein irrationaler Rest bleibt, der seinerseits wieder das Problem des sittlichen Lebens stellt, und daß etwa die Probleme des sittlichen Lebens in den Problemen der Religionsphilosophie und Ästhetik sich rollenden. Es besteht aber noch die Möglichkeit, daß die Struktur des emheitgebenden Wertes selber ein Prinzip hervortreibt, das zu einer einheitlichen Wertordnung führt. Dabei ist auf den Gegensatz zu achten, der jedes Wertgebiet konstituiert. So hat Schelling etwa die Kunst als Einheit des Bewußten und Unbewußten begriffen und, indem er das Bewußte der Freiheit und dem sittlichen Leben, das Unbewußte aber der Natur und der Wissenschaft mit ihrem Prinzip der Notwendigkeit gleichsetzte, das Ästhetische als Einheit ron Natur und Geschichte, ron Sollen und Müssen und somit auch als Harnonie der moralischen und wissenschaftlichen Weltanschauung begriffen.

Es fragt sich nun, ob es nicht möglich ist, zwischen jenen Kulturwerten. welche in ihrem Zusammenhang die qualitatice Wertordnung bilden, eine Unterscheidung zu vollziehen, welche ganz bestimmte Bedeutungssphären der Werte schafft. Diese Frage können wir bejaben, und die Entwicklung der Philosophie im 19. Jahrhundert hat manches zur Entscheidung dieser Frage getan. Es wird sich nämlich zeigen, und nur die Universalgeschichte kann es deutlich machen, daß die objektiren Werte der Kultur ein ganz ver- 
schiedenes Verhält nis zum historischen Prozeß haben, und daß ihre Bedeutung dementspreehend varschieden ist. Sie zerfallen aber in zwei Gruppen: auf der einen Seite stehen Religion, Kunst und Philosophie, und auf der anderen Seite Wissenschaft, Sittlichkeit, Recht, Wirtsehaft und Technik. Hegel hat jene ersten drei Werte als die Werte des absoluten Geistes den Werten des objelitiven Geistes entgegengestellt. Will mar den Begriff der Kultur als höehsten Wertbegriff festhalten, so kann man jene ersten drei als Kulturwerte der. anderen als Zivilisationswerte gegenüberstellen ${ }^{1}$ ). Verbinden wir dagegen den Begriff der Kultur besonders eng mit dem Begrnff des Fortschritts und der Geschichte, so können wir behaupten, daß jene drei Wertgebilde über die Kultur hinausragen.

\section{g) Absolute und objektive Werte.}

Es gibt nun eine große Reihe von Gegensätzen zwisehen den beiden Wertgruppen, die unsere Unterseheidung rechtfertigt Das, was zuerst in die Augen fällt, ist die Tatsache, daß eine Spannung nur zwischen den beiden Wertgruppen liegt, daß aber die Spannung innerhalb der einzelnen Grupp s stark reduziert ist. So besteht etwa zwischen der Moralität und dem Ästhetischen eine gewisse Feindseligkeit. Zeiten und Menschen, die das Schöne so freudig zu genießen vermögen, befinden sich sehr häufig in einem gevissen Gegensatz zur Moralität, und Zeiten hoher religiösen Kultur haben sehon manehmal die freie Entwicklung des wissensehaftlichen Lebens gehemmt. Dagegen vermag das religiöse Leben sehr viel leichter mit Philosophie und Kunst zusammenzugehen. Wenn wir ferner die Geschichte als das Reich des Antinomisehen verstehen, sofern sie so sehr auf den Gegensatz von Sein und Sollen gespannt ist, weswegen man sie im Zeitalter der idealistischen Philosophie dem Reich der Moralität und der Freiheit gleichsetzte, so kann man sagen, daß Werte wie Wissenschaft, Sittlichkeit und Recht weit mehr als Philosophie, Religion und Kunst dem historischen Leben und der Idee des Fortsehritts hingegeben sind. Bezeichnen wir die erstgenannten Werte als die objektiven und di letztgenannten als die absoluten Werte, so ist die Idee des Fortsehritts vor allem nur für die objektiven Werte, nicht aber für clio absoluten Werte maßgcbend. Sofernsich dann mit der Idee des Fortschritts, wie wir noch dentlieh zu machen haben, die Idce des Endzwecks und der nie crreichbaren Aufgabe verbindet, ergibt sich von dieser Úberlegung aus ein höchst interessanter Eimblick in jenen Antagonismus der geschichtsphilosophischen Spekulation, wie er in klassiseher Form vor allem in dem Gegensatz von Kant und Herder bzw. der Bewertung des Endzweeks zum Ausdruck kam. Während Kant die Prinzipien des historischen Geschehens mit der Idce des Endzwecks verband und sämt liche Kulturwerte als regulative Ideen auffaßte, die richtung- und ziclgebend die geschichtliche Entwicklung bestimmen, so daß las ganze gewaltige Menschheitsgesehehen nur der Erfüllung jenes fernen Zieles zu dienen hätte, meinte Herder, daß das Ziel der Kultur überall dort erfüllt sei, wo (rine Nation sich selbst in vollendeter Gestalt mit allen ihren Gaben und Fähigkeiten zur Darstellung gebraelıt und so dıc Idec der Humanität in einer sehönen

1) Vgl. (. Fwald, Kultur und Terhnik. Logos Bdl. 3, Heft 3. 
Form verwirklicht habe ${ }^{\overline{1}}$ ). Eine unfaßliche Härte und Grausamkeit würde nach Herders Auffassung darin liegen, wenn der Aufwand an Glïick und Menschenleben durch die Jahrtausende hindurch einer Werterfüllung zu dienen hätte: die dem fernsten Grschlecht der Zukinft eimmal zuteil wird. Dieser Gegensatz zwischen Kant und Herder, die Theorie des Enrlzweelis und die Theorie der Allgegenwärtigkeit des Wertrollen, jene, welehe den Begriff des Fortschritts so sehr bejaht, und diese, welche in jeder hohen Blïtezeit eines Volkes ein denkbar Höchstes rerwirklicht sieht, lassen sich sehr wohl rereinigen, wenn wir unsere Unterseheidung ron objektiven und absoluten Werten denken.

Kant ist in seiner Theorie ror allem an dem sittlichen Leben, an Wissenschaft, Recht, Staat, Wirtschaft und Technik orientiert, jenen Prinzipien cles Geschehens, die wir auch als Fortschrittswerte bezeichnen können. Deswegen legt er alles Gewicht auf das Ziel des Prozesses, dem jene zueilen. da sie ein für allemal mit dem Gedanken des fortschreitenden Prozesses auf das engste rerbunden sind. Dagegen denkt Hercler an Religion, Kunst und Philosophie, für die der Fortschrittsgedanke nicht in derselben Weise gültig ist, wie für jene. Kunst, Religion und Philosophie scheinen rielmehr Werte zu sein, die in verschiedenartiger Form und Pichtnng zu höchsten Gestaltungen hindrängen, ohne da 3 wir imstande wären, sie nach einem höchsten Maß der Vollendung einzuordnen. Solche in ihrer Art vollendeten Kulturformen waren etwa die Plastik der Griechen. das Epos Homers und der italienischen Renaissance, der dorische Tempelbau, die Halerei des Cinque en to, das Drama Shakespeares, die Poesie und Nusik im Zeitalter der deutsehen Renaissance, die Philosophie des deutschen Itealismus, die Mystik des Mittelalters. Denken wir an die rersehiedenen Kulturwerte, so hat weder die Theorie des Endzwecks nocb die entgegengesetzte rollkommen recht, sondern das Problem gliedert sich entsprechend der ron uns gemachten Wertunterscheidung. Nicht für alle Werte ist die Idee des Endzwecks wichtig, sondern nur für die objektiven Werte. Das eben war de Irrtum und die Einseitigkeit der Geschichtsphilosophie ron Kant und Herder, daß jener nur an che objektiven und dieser nur an die absoluten Werte gedacht hat.

Die Gemeinsamkeit, die zwischen den objektiren okler auch zwischen ren absoluten Werten besteht und zu einem scharfen Wertgegensatz zwisehen den beiden Gruppen führt, läßt sich noch durch eine Reihe ron Gegenüberstellungen erläutern. Man wird zuer'st darauf aufmerksam, daß es sich bei den objektiren Werten immer um ein Werk der Gemeinschaft handelt. während die absohten Werte dieses sozialen Cluarakters entbehren. Die Wissenschaft ist nur zu denken als Leistung einer Gesamtheit. An ihr wird immer weitergebildet, sie reift allmählich zu einem Gesamtwerk ans. Das Kunstwerk ist immer die Leistung des Einen und immer ein Vollendetes. So ist jene auf den Prozeß und auf die Unendlichkeit angewiesen, während diese das Vollkommene und Fertige immer mieder in das Dasein einführen. Das Kunstrerk ist paradox genug. ein Unendliehes in der Begrenzung zu sein, die Trisscmschaft muß notwendig

$\left.{ }^{1}\right) \mathrm{Kant}$, Idee zu einer allgemeinen Geschichte in weltbürgerlicher Absicht. Herder, Ideen zu einer Philosophie der Geschiehte der Menschheit. Vgl. auch ,.Roussean und the deutsche Geschichtsphilosophie" ron Richard Fester, und F. Medic us, Kant und Ranke.

Mehlis, Geschichtsphilosophie. 
unendlich bleiben, denn die Inhaltserkenntnis der sinnlichen Wirklichkeit ist eine Aufgabe, die niemals ganz erfüllt sein kann.

Die absoluten Werte stehen dem Begriff der Einheit näher, während die objektiven Werte von dem Prinzip der Spannung beherrscht sind. Wir können uns das sittliche Leben als die Stätte der Tätigkeit und des Handelns ohne den Gegensatz von Sein und Sollen nicht vorstellen. Und auch im Recht sowie in Wissenschaft und Technik tritt der Gedanke der Forderung und der Aufgabe streng und ernsthaft hervor. Aber das religiöse und ästhetische Bewußtsein kann den Gegensatz überwinden und zur Einheit führen, ja, in den höchsten Formen des religiösen und künstlerischen Lebens wird diese Uberwindung und Aufhebung immer erreicht. Der Widerstreit in der Seele des formenden und schaffenden Künstlers wird getilgt und alle Disharmonie wird durch Harmonie überwunden. Die Unruhe und Bewegtheit aber des religiösen Bewußtseins schweigt in der ekstatischen Hingabe an den Weltengrund.

Dieses höhere Maß von Freiheit gegenüber dem historischen Geschehen, das den absoluten Werten eigen ist, macht sie zu Abschlußwerten aller Kultur. Sie brauchen nicht auf das Ende der Weltgeschichte zu warten, sie können jederzeit eine bestimmte Erfüllung erhalten. Und auch noch in einer anderen Weise kommt ihre Gemeinsamkeit gegenüber den Fortschrittswerten zum Ausdruck. Sie haben nicht dieses strenge und feindliche Verhältnis gegenüber der Natur, mehr ein Verhältnis des Liebhabers und Freundes als des Herrschers und Gebieters. Darauf hat Ewald ${ }^{1}$ ) sehr sehön hingewiesen. Die Kunst will die Natur verherrlichen, die Philosophie sie denken und verstehen, die Religion sie zur Schaubühne der Gottheit machen. Die objektiven Werte sind ihr feindlich gesinnt. Die Sittlichkeit will sie bekämpfen, die Wissenschaft und Technik sie beherrschen, und das Recht muß immer wieder ihr Ankläger und Verfolger sein.

Wir haben hier nur auf rereinzelte Probleme hinweisen können, die sich mit der Frage nach den Prinzipien des historischen Lebens verbinden. Das Strukturproblem der Kulturwerte weist am sehärfsten auf die Universalgeschichte hin, der wir uns nunmehr zuwenden wollen.

\section{Drittes Kapitel.}

\section{Die Probleme der Universalgeschichte.}

Jede: neue Disziplin der Philosophic erfordert ein neues Prinzip. So gilt ('s in crster Ininic das Prinzip der Universalgeschichte im Verhältnis zu der Johre von den Prinzipien des historischen Lobens festzustellen. Auch die Lnivorsalgeschiehte handelt ron den Kulturwerten, aber in einem anderen Sinnes als die historische Wertldhe. Thr kommt es nicht sowohl auf die Erkenntriskleistung, Besehaffenheit und Geltung des Kulturwertes, sondern auf auf das J'oblon der Vorwirklichung an. Ferner treten aber in der Uni-

1) O. Ewald, Kultur und Technik. 
versalgeschichte noch ganz neue Wertformen hervor, welche in der Logik keine Stelle finden können, sondern die erst dann zum Ausdruck kommen, wenn von der Lebendigkeit des Geschehens die Rede ist. Dahin gehört der Begriff des Fortschritts und die ihm zugehörigen Begriffe des Endzwecks, des Wertmaßstabes, der Wertbeurteilung, der Wertordnung, dahin gehört aber vor allem auch der geschichtsphilosophische Begriff der Antinomie.

Wenn wir den Gegenstand der Universalgeschichte auf eine einheitliche und höchste Formulierung bringen wollen, d. h. auf eine Bestimmung, die der Weite und Bedeutsamkeit ihrer Probleme den umfassendsten Ausdruck verleiht, so bezeichnen wir als ihr Prinzip die für die systematische Philosophie im engeren Sinne, nämlich für die Logik, Ethik und Ästhetik unlösbaren Antinomien der Vernunft.

\section{a) Antinomien.}

Um diese Aufgabe etwas deutlicher zu machen, müssen wir einen Vergleich mit den Erfahrungen des Lebens ziehen. Wenn wir einen Menschen in seinen Handlungsweisen, Gewohnheiten, in seinen Gedanken und Vorstellungen, in der Mannigfaltigkeit seiner Gefühls- und Wertungsweisen beobachten, so werden wir nur selten imstande sein, das Gegensätzliche zu einer Einheit zu rerbinden. Verwundert fragen wir uns : ist es denn möglich, daß ein Mensch so gut und so schlecht, so fein und so geschmacklos, so weise und so töricht sein kann. Und indem wir ihn zu bestimmen suchen und einen Merkmalskomplex von ihm ablösen, finden wir, daß zwischen den mancherlei Bestimmungen überall der Widerspruch steht. Aıch im Nachdenken über uns selbst können wir zu ähnlichen Resultaten gelangen. Und hier ist es wohl die Schroffheit, Derbheit und Allgemeinheit der begrifflichen Bestimmungen gegenüber der Kompliziertheit und feinen Nuancierung des persönlichen Lebens, die den Widerspruch heraufbeschwört. Was in der Sphäre des Allgemeinen durch den Widerspruch zerrissen wird, das vermag, in der Sphäre des Lebens als Wirklichkeit nebeneinander zu bestehen, und es ist nicht einmal so, daß der Widerspruch in der Sphäre des Allgemeinen durch zeitliche Auseinanderlegung im Leben gelöscht wird, sondern das Widerspruchvolle und Antinomische scheint der Form und dem Stil mancher Individualitäten notwendig zuzugehören. Wir können auch so argumentieren, daß der Widerspruch, den das Allgemeine nicht erträgt, durch das Leben getragen und ertragen wird. Nun hat es die systematische Philosophie lediglich mit einem Verhältnis zwischen dem Allgemeinen zu tun. So gelangt sie zu Antinomien, die sie nicht versöhnen kann. Wie sollte sie etwa den Begriff des Allgemeinen mit dem Begriff des Besonderen oder dell der Form mit dem des Inhalts versöhnen? Die Universalgeschichte hat es nicht mit einem Verhältnis zwischen dem Allgemeinen zu tun, wenigstens ist dies Verhältnis nicht ihr entscheidendes Grundverhältnis. Sie steht vielmehr vor der Frage, was wohl das Verhältnis der allgemeinen Formen zu der Individualität des historischen Lebens sein möchte, und wie sich das Allgemeine in der Sphäre des Individuellen zueinander verhält, und was es füreinander bedeutet.

Es könnte ja wohl sein, daß jene Antinomien, die in der systematischen Philosophie zu keinem Austrag kommen, in der Universalgeschichte irgend- 
eine Lüsmug finden. mag dicse Lösung auch im Unendlichen liegen. Auf jeden Fall hat das Terhältnis der Spannung und der Gedanke des Zweckes, der Aufgabe und der regulativen Idce nur dort einen Sinn, wo es sich um die Lebendigkeit des historischen Geschehens handelt, nicht aber dort, wo die Inhaltlichkeit zı (inem Grenzbegriff rerflïehtigt wird. Die Antithetik, der Gegensatz, die Dualität ist, so kamn man sagen, das höchste Prinzip der Philosophie. Ohne Gegensatz ist kein Wissen möglich. Auf dicsem Gegensatz ruhen aber auch die großen Antinomien der menschlichen Vermunft. Man kann nun sagen, daß die Antinomien, sofem sie über den Gegensatz der Wertgebiete hinausgehen, zn einer gewissen Einheit hinleiten. Der Gegensatz ist das überall Anzutreffende und infolgedessen dasjenige, was allem einen einheitlichen Charakter gibt, nämlieh den des Antinomisehen. So wird durch die Antinomien die Einheit der Universalgeschichte rerbürgt. Sie sind ja auch das Nene und ihr besonderes Prinzip) gegenüber der Geschichtslogik und der historischen Wertlehre. Dagegen kommt in den Kulturwerten das Prinzip der Mannigfaltigkeit in der Universalgeschichte zum Ausdruck. Die Universalgeschichte rermag zu zeigen, daßsich der Gegensatz in allen Gestalten des historischen Lebens wiederfindet.

Dic universalhistorische Betrachtungsweise vermag jenen Gegensatz aufzuheben, der zwischen dem Prinzip der Naturwissensehaft und Geschichte besteht, sofern ist auch die Geschichtslogik bezïglich der Auflösnng und Säuberung ihrer Probleme unmittelbar auf die Gesehichtsphilosophie im engeren Sinne, nämlich auf die Universalgeschichte hingewiesen. Die Universalgeschichte rersöhnt die [dee des ewig Gleichen, das hier als Wert erkannt wird, mit der Idee dos ewig Neuen, das hicr als Sinn verstanden wird. Sie führt uns zu der Einsicht, daß der Inhalt des wertenden Bewußtseins, das letzthin Gemeinte immer gleich ist, und daß3 nur die Dentung, die wir ihm zuteil werden lassen, der Sinn, den wir mit ihm verbinden, immer versehieden ist.

\section{b) (ieschichte als Organon der Philosophie.}

Die Geschichte kam unter dem Aspekt der Universalgeschichte als das Grganon der Philosophie bezeichnet werden. Sie beweist, daß die Probleme der Philosophic ewig und notwendig sind. Das gilt in erster Linie für die Philosophiegeschichte, aher anch für die politische und religiöse Geschichte sowie für die Geschichte des künstlerischen Lebens. Wie Sehelling ${ }^{1}$ ) (lie Kunst als clas wahthaftige Organen aller Philosophie bezeichnet hat, sofern sie nns die Cewibhreit des Absoluten gibt, so möchten wir in cinem ganz ähnlichen Sime dic Gosehichte als das Dokmment für die Wirklichkeitsbedentung der hörhsten philosophischen Probleme anfassen. Was die Logik in den reinsten nun! höchsten Formen bewegt, das bewegt das historische Jeben in weitaus komkiroterer (Eestalt ${ }^{2}$ ). Das Form-Inlualt-Jroblem ist ein Grundproblem

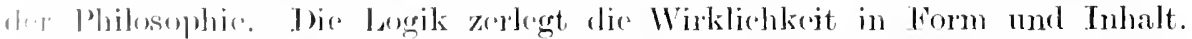

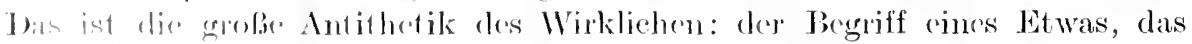

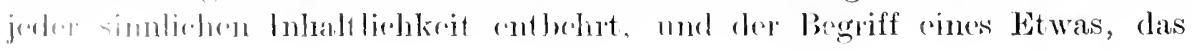

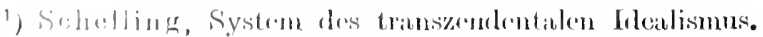

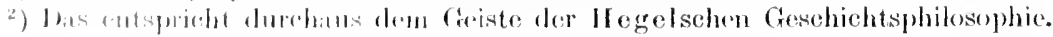


jeder Formung und Wertgestaltung rerhstig gegangen, das gänzlich unbestimmt und unbegriffen und unbegreiflich ist. In dicse Komponenten, die beide unwirklich sind, zerlegt tie Logik die Wirklichkeit. Und beide Prinzipien, Form und Inhalt, wachsen auf dem Felde der Gesehichte zu konkreten Gedankengebilden aus, zu Typen philosophisehen Weltverstehens, die notwendig miteinander in Kampf und Fehdle liegen müssen, da sie von entgegengesetzten Gestalten beseelt sind. Der Rationalismus bejaht einseitig die Form und meint, Alaß der Begriff alles durchdringen und auflösen kann. Der Irrationalismus bejaht einseitig ten Inhalt und meint, taß ex ewig unbekannt und verschwiegen bleiben müsse. Und ähnlich spiegelt sich ter rein logische Gegensatz, der zwischen dem Allgemeinen und dem Besondern besteht. im historjschen L eben überall dort wieder, wo ron Universalismus unt Individualismus die Rede ist.

Die Universalgeschichte treibt notwendig zu dem Problem ron Individualismus und Universalismus hin, zu der Frage, welehen Anteil am historischen Geschehen wohl das Allgemeine und das Besondere habe. Die philosophische Überlegung sneht sich darüber Klarheit zu versehaffen, was die Persönliehkeit an eigener und selbständiger Leistungsfähigkeit gegenüber den allgemeinen Wertideen und ihrem bestimmenclen Einfluß wohl bedenten möchte. Es könnte ja sein, daß Cie Persönlichkeit das blinde Werkzeng der Wertiflee bilket und zur absoluten Ohmmacht verurteilt wäre, oder aber daB die Wirksamkeit tles Allgemeinen sich als Illusion heransstellen wïrde, und die Persönlichkeit ihr eigenes Schicksal und das Schicksal der Welt zu tragen und zu gestalten hätte. Vielleieht aber rermag flie Universalgeschichte ten Anteil festzustellen, welcher jedem einzelnen Faktor als Erreger des Weltgeschehens zukomnt.

Die Universalgeschichte hat es nicht mit den Kulturwerten als Ansileseprinzipien, sondern mit den Werten ïberhaupt zu tun, sofern sie in einer lebendigen und wirksamen Beziehung zum historisehen Geschehen sich befinden. Wichtig ist dabei die Frage, ob es die Universalgesehichte mit der ganzen Wirklichkeit zu tun habe. Wir wissen ja, daß die Geschichte nur cine Auswahl des Wirklichen zur Darstellung bringt. Wird in der Universalgeschichte dieser Gegenstand noch mehr beschränkt oder erweitert? Dazu möchten wir schon an dieser Stelle unsere Auffassnng vertreten, daß nämlich die Universalgeschichte alles wertrolle Geschehen in sich schließt, also nicht das relativ Historische, dasjenige, was lediglich rorgetragen und aufbewahrt ist, um das Werden des Wertrollen zu zeigen oder L̇bergangsgebilde zu schaffen, sondern nur das absolut Historische, was Eigenwert besitzt und an sich etwas bedeutet. Anderseits aber gehört zu Universalgcsehichte anch manches, was für tlie empirisehe Geschichte wenig Bedeutung bcsitzt oder gar ihrem höchsten Prinzip, der historischen Beurteilung, widesstrcitet. Ich denke hier besonders an Erscheinungen des sittlichen Lebens, tie sich nur in kleinem Kreise ausgewirkt haben, und an das große Gebiet des Mystischen, das die absolute Nichtigkeit des Zeitlichen rerkünclet.

Die Antinomien sind das Kernproblem der Universalgeschichte. Kant hat ihren logischen Ort ganz anders orientiert. Sie erscheinen bei seiner erkenntnistheoretischen Grundlegung der Naturwissenschaften dort, wo es sich darum handelt, zu zeigen. daß dem kategorialen Verstehen der Weg 
in die übersinnliche Welt ein für allemal verlegt ist, und daß sie widersinnig und unrerständlich wiıken, wenn wir an ihre Anwendung auf eine vom Bewußtsein abgelöste sinnliehe Wirklichkeit denken. Unter der erkenntnistheorctischen Besinnung erblaßt das Truggebilde der widerspruchs vollen Antinomien: die spekulative Vernunft vermag den transzendentalen Schein aufzulösen. Anders in der Hegelschen Philosophie, die den Begriff der Antinomie zum Grundbegriff ihrer Methode macht, der uns in allen Disziplinen der Philosophie entgegentritt und auf ein höchstes Prınzip der Vernunft hinweist. Für Hegel sind die Antinomien in der Logik lösbar. Wir vermögen nicht einzusehen, wie solches möglich sein soll. Wohl aber meinen wir, daß das Antınomienproblem in der Universalgeschichte seiner Lösung entgegengeführt wrd. Was unserer Auffassung gemäß die systematische Plilosophie im äußersten Falle zu leisten vermag, das wäre die Herstellung eines Zusammenhanges zwischen den verschiedenen Kulturgebieten, etwa in der WVeise, daß sie zeigen würde, wie die Probleme der Wissenschaft zu den Problemen des sittlichen Lebens und diese wieder zu den Problemen der Kunst überleiten'). Vermöehte aber auch die systematische Philosophie diesen Zusammenhang herzustellen, so würde sie doch nicht imstande sein, den Gegensatz zu überwinden, der jedes einzelne Kulturgebiet trägt.

In dem Begriff der Antinomie liegt ein rationales und irrationales Moment verborgen. Es liegt ein Gegensatz vor, und der Gegensatz spaltet das Reich der Vernunft und erregt Unruhe und Bedrängnis. Der Widersprueh, der in das Logische hineingetragen wird, macht uns die Sphäre des vernünftigen Denkens fremd und unbegreiflich. Er duldet kein System und keinen Zusammenschluß der Glieder. Aber die Antinomie selber ist für uns auch wieder nichts Unbekanntes. Im Verhältnis etwa des Allgemeinen zum Besonderen kennen wir die heilen Glieder, und zwar kennen wir sie nur durcheinander, das eine macht uns das andere deutlich, ohne diese Gegenseitigkeit würden uns beide verborgen bleiben. So haben wir ein Wissen durch das Antinomische von dem Antinomischen. Weiter aber involviert auch der Grolanke des Cirgensatzes die Idee seiner Auflösung. Wir wissen, daß der Gegensatz aufgelöst werden soll, aber wir kennen nicht die Lösung. Sollte der Gegensatz num einmal zum Wesen der Sinnenwelt gehören, so fordert sic notwendig ihre Ergänzung und Erfüllung durch ein sinnliches oder übersimnliches Einhritsprinzip, das wir mit dem philosophischen Begriff des Absoluten orler mit dem religiösen der Gottheit bezciehnen. So wird das Sinnliche mit dem Unsinnliehen in eine notwendige und enge Verbindung gesetzt: das eine kann ohne das andere nicht sein, das cine ist auf das andere angewiesen. Cud so sehwindet auch der allzu schroffe Gegensatz dahin, welcher in der Vorstellung rine rom Sinnlichen völlig unahhängigen Sphäre des Unsinnlirehen liregt.

In ror systematischen Philosophie wissen wir die Antinomien als letzte notwendige Voranssotzungene. Mir wissen, daß koin Kunstwerk schön sein kinn, whne das Sparmmesverhält nis von form und Inhalt, von Freiheit und Notwentigkrit, cin Sipanmungsverhiiltnis, das scino gewaltigste und gewalt-

1) Div: Hfrstollung rines soleben Zusammenhangs wïrde ein System der Werte ergeben. 
samste Form im Drama erhält. Die Antinomie ist anch das Prinzip der Werte, zwischen denen gleichfalls notwendige und für die Logik unüberwindliche Gegensätze bestehen. Die Antinomie ist also das auch den Werten übergeordnete Prinzip, das ihr gegenseitiges Verhältnis erst konstituiert und möglich macht. Die Geschichte trägt die Antinomien in sich, oder die Antinomien formen die historische Entwicklung, aber die Geschichtsforschung reflektiert nicht ausdrücklich auf diesen Gegensatz. dor das gesamte Kulturleben beregt. In der Universalgeschichte werden die Gegensätze ausdrücklich gedacht. Die Geschichte ist nicht das friedliche Reich der Wertverwirklichung, sondern der Schauplatz für den Kampf der Vernunftantinomien, in denen alle Wahrheit ruht. Und für die Universalgeschichte erhebt sich das Problem, ob es eine Synthesis zu dieser Antithesis gibt, oder ob sie ein unüberwindliches Letztes bedeuten, wie die absoluten Werte, die keine Unterordnung unter ein Allgemeines dulden.

Jede Wissenschaft als solche glaubt, daß sie in der Welt rollkommen allein, daß sie einzig sei. Sie kïmmert sich nicht darum, ob ihr Geist einer anderen Wissenschaft widerspricht. $\mathrm{Zu}$ den wichtigsten Aufgaben der Philosophie gehört die Aufweisung eines Prinzips, das die Einheit zwischen den verschiedenen Gestalten des wissenschaftlichen Lebens herzustellen rermag.

Diese Einheit des Wissens kann niemals in der Sphäre der Wissenschaften liegen, die durch rerschiedenartige Begriffsbildungen zucinander in Gegensatz gesetzt sind. Die Einheit des Wissens ist niemals das Allgemeine der Wissenschaften. Auch liegt die Einheit nicht im Inhalt, etwa in einem gemeinsamen Erkenntnisresultat, zu dem alle Tege der Reflexion hinleiten müßten, sondern in der Form und gewissermaßen auch, so paradox es klingen mag, in dem Formgegensatz, der sich als das Prinzip aller Kultur- und Wissensgebicte offenbart.

Das Grundprinzip alles werthaften Lebens ist die Dualität, und die Universalgeschichte ist der Beweis dieser Dualität zugleich mit der Idee ihrer Úberwindung. Die Antike kannte dieses Grundprinzip noch nicht und rermochte deswegen auch zu keinem philosophischen Verstehen der Geschichte rorzudringen.

c) Unirersalgeschichte im Verhïltnis zu Philosophie und Wissenschaft.

Es erhebt sich nun die Frage: was bedeutet die Idee einer T'nirersalgeschichte im Verhältnis zur Wissenschaft einerseits und den grundlegenden philosophischen Disziplinen anderseits, wie ist ihr logisches Terhält nis zu denken, oder: welche Stellung nimmt die Universalgeschichte im Ganzen des wissenschaftlichen Lebens ein? Da ergibt sich nun folgende Utberlegung: alle Philosophie bedeutet ein systematisches Wissen, folglich auch die Geschichtsphilosophie. Die Geschichte ist eine unsystematische Wissenschaft, zu ihrem Wesen gehört das Fragmentarische, das Unbegrenzte. Niemals wird sie imstande sein, den Kreis der historischen Urteile zu schließen. Die Trniversalgeschichte ist das systematische Wissen rom Unsystematischen. Hier erhebt sich nun weiter das Problem: ist eine solche Wissenschaft eine Absurdität. oder handelt es sich hier nur um eine scheinbare Paradoxie. und ist vielleicht gerade diese Wissenschaft befähigt, zu einer Einheit der Weltansicht zu führen. 
Ist vielleicht die Lnivosalgeschichte qualifiziert, die Antinemien der Vomunft zu äberwinden und das Systematische mit dem Unsystematischen, das Abstrakte mit dom Konkretcn zu versöhnen?

\section{d) Idee des Fortsehritts.}

Tir haben als Gegenstand der Universalgesehichte zunächst ganz allgemein die Antinomien lezeichnet, wil sie das Nene, Leitende und Bestimmende sind, was zu den Prinzipien des historischen Geschehens hinzutritt, wenn wir uns ron der historischen Wertlehre zur Universalgcsehichte wondon. Aber gowiß spielen auch die Kulturwerte in enger Verbindung mit dom Prinzip der Antinomie erst hier ihre entscheidende Rolle. Sie werden aber nun nicht mehr nach ihrem Geltungs- und Leistungswert betrachtet, sondern sofern sie im Prozeß des historisehen Gesehehens zu fortsehreitender Verwirklichung gelangen. Damit haben wir gleich wicder einen nenen Begriff der Universalgeschichte ausgesprochen, der erst hicr Bcdentung gewinnt, und der mit dem dem der Antinomien auf das engste zusammenhängt, nämlich den Begriff des Fortschritts. Allerdings ist der Begriff dos Fortsschritts nicht der absolute konstituierende Wert für die Universalgeschichte, weil nicht alle Prinzipien dem Begriff des Fortschritts unbedingt unterliegen, sondern wie wir noch dentlich zu machen haben, nur eine begrenzte Zahl von Kulturwerten. Mit dem Begriff der Antinomien einerseits und mit dem Begriff des Fortschritts anderseits hängen dann die übrigen Grundbegriffe der Universalgcschichte, wic der Begriff des Endzwecks, des Wertmafstabes, der historischen Epoche und andere. zusammen.

\section{e) Die lebendige Inhaltlichkeit.}

Indem wir hier den Gegenstand der Universalgesehieht e bestimmen, spre chen wir in crster Linie nur von Formbegriffen, die keine simnliche Inhaltlichkeit in sich tragen. Die Form ist ja auch, wie wir wissen, der Gegenstand der Philosophic, währ' nul die Erkemntnis der simnlichen Inhaltlichkeit der Wissenschaft überlassen bleibt. Demnoch hat es die Universalgeschichte nicht wie die anderen philosophisehen Disziplinen lediglich mit der Form zu tun. Sie hat es mit dem wert vollon historischen Leben in scine' Lebondigkeit zu tum, ebenso wie die historische Wisscnschaft. Sie löst das Wirkliche nicht in zwei Begriffe, Form und Inhalt, auf, dic selber unwirklich sint, um dann dem System eines Unwirkliehen naehzugehen, sond'r'n für sie ist die Form nur so weit interessant, als sie im Verhältnis zum Inhalt rerhar't und im Leben wirklieh ist. Deswe gen fratg sie nach dem Sim der Geschichts. Dor Sim ist aber der Wert, sofern or im Lelen Gestalt gewinnt, dir psychischen Akte der Anerkcmmung und

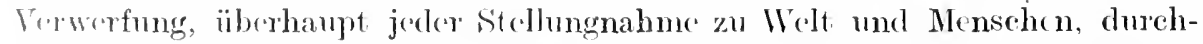

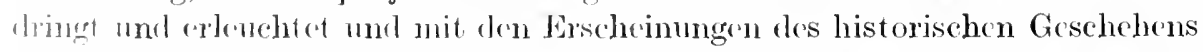
sowio mit den ganzen Einsichtungen der mensehlichen Gesellselaft ummittelbar

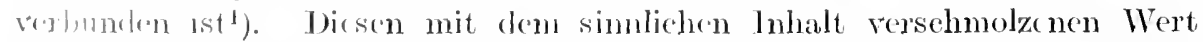

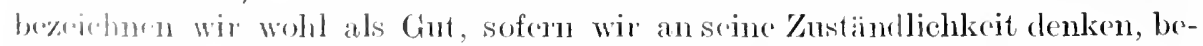
trathen wir ihn abre in chger Verbindung mit den Geschehen sclbst, so sprechen wis anch wohl vont den Gistalten des historisehen Ledrens.

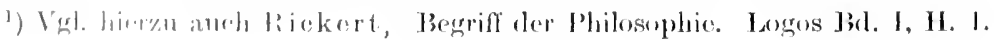


Da die Universalgeschichte sich also mit einer lebondigen Inhaltlichkeit befaßt, verläßt sie die Bahmen erkenntnistheoretischer Überlcgungen, und somit besteht für sie eine Gefahr, die in der Geschichtslogik und in der historischen Wertlehre nicht anzutreffen ist, nämlich die Kollision mit don Aufgaben der historischen Wissensehaft. Daß nun diese Gefahr zu rermeiden ist, erhellt aus folgenden Überlegungen:

1. hat es die Geschichte nur mit der Entwicklung der menschlichen Kulturbetätigung und ihrer historisehen Beurtelung zu tun, die Cnirorsalgeschichte aber mit dem Fortschritt der historischen Entwicklung und ihrer philosophischen Wertbedeutung.

2. Die Geschichte will den Zusammenhang des historischer Leberis nach dem Verhältnis von Ursache und Wirkung exklären, die Univcrsalgcschichte suelıt den Sinn des historischen Gesehehens zu deuten.

3. Die Universalgeschichte liefert keine neue Inhaltscrkenntnis in dem Sinne, daß sie das Gebiet des historisehen Wissens bercichert, wohl aber erfaßt sie den Idealgehalt historiseher Gronzbegriffe und kommt daduch zur Einsicht in den vernüftigen Zusammenhang des histcrischen Ganzen.

4. wird die Universalgesehichte niemals den Anspruch erhe ben dïrfen; daß sie apriori aus der Idee des Endzwecks heraus die historische Entwicklung zu konstruieren rermag, sondern sie wird dicse ron der Goschichtsforschung enthüllte historisehe Wirklichkeit als eine $G \in g \in b \in n h e i t$ roraussetzen nnd lediglich eine neue Frage an diese Gegebenheiten richten, wodurch nicht die historische Erkenntnis, wohl aber die philosophisehe Erkomntnis des Wirklichen bereichert werden kann.

\section{f) Der Begriff der Entwicklung.}

Die Begriffe Entwicklung und Fortschritt werden vielfach promiscue gebraucht. Man legt den Gedanken des Fortschritts in den Gedanken der Entwicklung hinein, da dieser Begriff nun eimmal dem Gebiet der Biologie entstammt, das vor allen anderen naturwisscnschaftlichen Gebieten am schwersten von dem Wertgesichtspunkt freizuhalten ist. Cnd doch ist das Leben als solches kein Wertgebilcle, weder pflanzliches noch tierisehes, noeh menschliches Dasein, noch der Prozeß, der dieses Dasein ron der früheren zur späteren Gestaltung weiterleitet. Das Leben als solches bleibt in der bloßon Materialstellung stehen und wird erst durch das Tun und die Leistung dos Menschen $\mathrm{zu}$ einem wertvollen Gebilde. Mag nun dieses Tun sich auf die Gestaltung des eigenen Lebens richten und ein höher's Vermunftleben daraus erzcugen, mag es die Beziehung zu anderen Individuen, die als solche auch nur etwas naturhaft Gegebenes ist, mit Sinn und Bedeutung erfüllen oder ïber die Sphäre sozialer Zusammenhänge hinaus ein Verhältnis zum Absoluten gewimnen, das in den Formen der Kunst und Religion, der Philosophie und Wissensehaft, des Rechtes und der Moralität in das große Gebiet menschlicher Leistung, das wir Kultur nennen, als ideeller Gegenstand hineinragt.

In dem Begriff der Entwicklung liegt über den Begriff des Geschehens und der Veränderung hinaus auch der Gedanke des Zieles als Zweck des Prozesses. Die Pflanze soll sich entwickeln, die Knospe entfalten, die Blüte soll welken, um der Frucht Raum zu geben, die wicderum in sich den Keim zu neuen Bil- 
dungen pflanzlichen Lebens trägt. Ziel und Zweek ist überall gesetzt und gegeben, aber immer wird das alte Ziel durch ein neues iiberholt und schließlich alles in den Ḱreislauf einer ewigen Wiederkehr gezogen. Und wo ist das Ziel, wenn wir auf die Entfaltung des einen Pflanzendaseins schauen: ist es die Knospe, die Blüte oder die Frucht?

Die Entfaltung des mensehlichen Lebens kann wie die Entfaltung jedes anderen Organismus rein entwicklungsgeschichtlich ohne jede Wertbeziehung begriffen werden. In der Entwicklung der Körperlichkeit wird immer wieder die alte Zielsetzung durch eine neue überholt: das Kind wird gebildet, und das Kind wird zum Knaben, zum Jüngling, zum Mann, zum Greis. Und was ist Ziel und Höhepunkt des Prozesses? Ist es der gereifte Mann, der Mann in der Bliite seiner Jahre? Aber an ihm sind ja auch schon wieder Zeichen des Verfalles bemerkbar. Oder bedeutet Knabe und Jüngling die höchste Form des menschlichen Lebens, weil es ja sie im Grunde genommen sind, die wir mit den höchsten Prädikationen der Schönheit umkleiden? Vielleicht aber ist der Greis das Ziel der menschlichen Entwicklung, der sich das köstliche Gut der Seelenruhe errungen und dem irrenden und fehlenden Kämpfertum des Mannes gegenüber ein Weiser und Vollendeter ist? Vielleicht aber vermag die Form der Körperlichkeit, die sich in den Lebensaltern offenbart, überhaupt nicht als Symbol für das Wachstum des Geistes zu dienen, darauf es in der mensehlichen Entwicklung doch vor allen anderen Dingen ankommt. Denn der menschliche Geist trägt immer neue Entwicklungsmöglichkeiten in sich und kann niemals als ein vollendeter gedacht werden.

\section{g) Wertzuwachs und Wertsteigerung.}

Nun haben wir es in der Geschichte nicht mit der Entwicklung schlechthin, sondern mit einer werthaften Entwicklung zu tun. Diese Entwicklung äußert sich in der Anknüpfung und Vermehrung wertvollen Lebens oder, wie wir auch sagen können, in einem Wertzuwachs. Dieser Begriff der historischen Entwicklung muß von dem Begriff des Fortsehritts wohl untersehieden werden, zu ressen Wesenscharakter nicht nur das Moment des Wertzuwachses, sondern auch der Wertsteigerung gehört. Nicht nur daß zu lem zeitlich früheren Wertrollen ein zeitlich späteres Wertvolles hinzutritt, sonderm es kommt vor allem darauf an, daß dieses Spätere als Produkt des Fortschritts das zeitlich Frïhere an Wertbedeutung übertrifft. So bedeutet etwa die Philosophic des 19. Jahrhunderts einen Wertzuwachs gegenüber der Philosophie des deutschon Trlealismus, sofern eine ganze Reihe von Problemen, die jene große Zeit bewegte, in der Philosophic cines sehopenhauer. Lotze, Nietzsche, Elluard von Hartmann weitcrgchildet wurde. Aber ob die Philosophie las 19. Jahrhunderts unserer großen klassischen Philosophie gegenüber als Fortschritt bereichnet werken kann und darf, das möehten wir billig bezweifeln.

Von besonderer Komplikation wird die Unterscheirlung von Fortsehritt und Entwicklung, wenu wir anf die Entfaltung des persönlichen Lebens sehen. Man kann von einer Futwicklung der Leistung und der Fähigkeiten und von

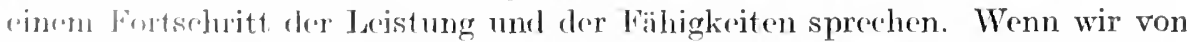
L dristung sprerhen, so denken wir an den objektiven Niedersehlag der Kulturbogabung und Kulturfähigkeit: an das Werk. Tn der Analysis der Leistung 
wird es nicht schwierig sein, das Neue gegenüber dem Alten als interessante Weiterbildung und somit als Wertzuwachs anzuerkennen, ohne doch von einem höheren Bedeuten des Neuen gegenüber dem Alten sptechen zu wollen, eine Einschätzung, die allein den Begriff der Wertsteigerung rechtfertigen könnte. Denken wir aber nicht an den objektiven Niederschlag der Kulturleistung, sondern an die Entfaltung des persönlichen Lebens, so ist die Scheidung von Entwicklung und Fortschritt weitaus schwieriger zu vollziehn. Das Aufklärungszeitalter in seiner individualistischen Tendenz hat den Begriff der unendlichen Vervollkommnungsfähigkeit des Menschen als höchsten Wertbegriff geprägt. Das Werden neuer Gaben und Fähigkeiten, neuer Funktionen, die Welt zu bilden, die Verfeinerung der Simnesorgane, das Wachstum der Intelligenz, der höhere Schwung phantasievoller Gestaltung - alles das bedeutet doch nur Entwicklung, wenn sich mit der Bereicherung der Natur- und Geistesgaben nicht auch eine persönliche Leistung verbindet. Fs ist sehr schwer zu entscheiden, ob die noue Gabe und Fähigkeit unserer mensehliehen Natur gegenüber den anderen Fähigkeiten, die wir besitzen, ein Plus im Sinne des Fortschritts oder Entwicklung als Wertzuwachs bedeute. Daß diesem Mehr gleichzeitig auch eine höhere Bedeutung zukommt, das ergibt sich erst aus der Leistung, welche dies Neue entweder in der Gestaltung des persönlichen Wesens oder in ,objektiren“ Kulturleistungen vollzieht.

Wie alle Philosophie will die Unirersalgeschichte nicht erklären, wie eine historische Erscheinung aus der anderen geworden ist, sondern sie will die historische Entwicklung deuten. Das historiseh Erklärte ist für den philosophischen Gesichtspunkt noch immer ein Unverstandenes. Ich weiß, wie Grieehentum, Renaissance und Romantik geworden sind, aber ich weiß deshalb noch nicht, was sie für die Menschheit bedeuten. Bei diesem Deuten kommt es in erster Linie darauf an, einen Gesamtsinn des historischen Geschehens oder des historischen Universums zu finden, der allen großen Gestaltungen des Menschlichen gerecht zu werden vermag. Diesen Gesamtsinn wird man dann in den einzelnen Reihen der Kulturentwicklung, so z. B. in der Entfaltung des religiösen und ästhetisehen Bewußtseins. wiederfinden, natürlich in einer ganz bestimmten Modifikation, die nun so ohne weiteres aus der Wertidee des Ganzen nicht abzuleiten ist.

Dabei handelt es sich nicht um eine Bereicherung der inhalt liehen Forschungsergebnisse der Historie. Die Universa lgeschichte vermag die empirische Geschiehte nicht zu bereichern oder zu ergänzen. Sie übt aueh keine Korrektur an ihr aus. Sie wird das Bild, das die Geschiehte ron Kaiser Friedrich dem Zweiten und von seiner Tätigkeit in Sizilien entrollt, soweit es als Ergebnis eines sorgfältigen Quellenstudiums mit Notwendigkeit sich ergibt, rollkommen unangetastet lassen. Sie wird niemals mehr, wie das wohl frïher geschehen ist, den historischen Tatsachen Gewalt antun, und sie mit Rücksieht auf irgendeine Konstruktion ummodeln und umbiegen. Sie weiß aber anch, daß die historische Beurteilung, die für den Historiker unentbehrlich ist, und die ror allem den Gedanken der Kulturvermehrung, der Zeiterfüllung, der Wirksamkeit und des intensiven gesteigerten Lebens so stark bejaht, von der Wertbeurteilung auf Grund des Fortsehrittsprinzips vollkommen verschieden ist. Auch ist es augen- 
scheinlich und selbstrerständlich, daß das Beurteilungsprinzip der meisten Historiker ein begrenztcs ist. So ist, wie wir sehon in einem anderen Zusammenhang betont haben, der Gesichtspunkt einer realen Politik für die meisten modernen Geschichtsforscher der entscheidende. Und desgleichen hat die Stärkung, die der nationale Gedanke in der ganzen Weltlage erfahren hat, dahin geführt, die Leistung für die eigene Nation als Grundmaßstab für eine historische Persönlichkeit zu betrachten. Dagegen wird die Universalgeschichte, die mit dem Begriff des Fortschritts die Erscheimungen wägt, über die realpolitische Tat hinaus anch Gesinnungswerte kultivieren. Sie wirt den persönlichen und nationalen Egoismus nicht unbedingt billigen. Friedrichs II. Bild wird vielfach verdunkelt dureh die Schatten und Begrenzungen einer spezifisch nationalen Einwertung. Aber wenn er Sizilien mehr geliebt hat als Deutsehland und den Schwerpunkt der Weltmonarchie zu sehr nach dem Siiden legte, wem er, umgeben von dem Glanz sarazenischer Pracht, seinschlichtes schwäbisches Rittertum rerga 3 , so ist er doch der geniale Schöpfer der modernen Staatsorganisation, so bleibt er doch der weitblickende Anreger und Förderer ron Philosophie und Wissenschaft, und seine schlanke Gestalt wird immer ein ästhetischer Glanz umleuchten, ihn, der so ritterlich mit dem Schicksal gerungen hat, und den noch hente in Sizilien ein trenes Godächtnis in licbevoller Erimnerung aufbewahrt, wie die bunten sizilianischen Banernkarren beweisen, auf denen man häufig des großen Staufenkaiseıs Bild erblicken kann. Ihn, den ein beschränkter nationaler Irertgesichtsyunkt rielleicht gering wertet, weil er die Interessen des Peiches nicht immer genuigend gewahrt, nird die Universalgesehichte dex Mensehhcit immer zu ihren Helden zählen.

So ergibt der universalgeschicht liche Standpunkt in Verhältnis zur Historie niemals cine Bercicherung der inhaltichen Forschungsresultate, sofern die Geschichtsphilosophie durch cigene Erforschung die Fakta nicht rermehren kann und noch viel weniger durch eine phantasievolle Konstruktion die Fakta vermehren darf. Wohl aber ändert sich durch den philosophischen Aspekt, unter dem die Universalgeschichte in der Historie erscheint, der Bedeutungsgehalt von Persönlichkeiten und Epochen, sofern sie mit der Idee des historischen Ganzen unmittelbar verbunden und über jede Partikularität hinausgehoben werden. Denn die Universalgeschichte formt den Begriff der welthistorisehen Individuen und der welthistorischen Epochen und will den absoluten und notwrongen Bedeutungsgehalt aus der Geschichte herausheben. Dicse notwendige Brelentung aber erhalten die Erscheinungen, Tatsachen, Epoehen, Nationen, Prrsönlichkcitcn dlureh ihr cigentïmliehes Verhältnis zu den absoluten Wertirle'n. Der Charakter oder 'Typus einer Zeit ergibt sich aus ihrer Stellungnahme zu den Kulturwerten. Sir kann sich kulturbejahend oder -verneinend verhalin. So bejahte Julian Apostata die Kultur und rerneinte das Christrutum. J)ie 'Tragik des Kaisers aber lag darin, daß er eine Kultur festhaltrn wolle, dren Kräfte crlosehen waren, gegenuiber einer Unkultur, die kulturnatichtige Potrozen in sich trug. So gilut es Zciten und Persönliehkeiten, dir anf ainr ganz brstimmte Wertkombination ringestellt sind, wie etwa die lemantik anf an ästhretisch-roligiösen Wert in Verbindung mit der Geschiehte,

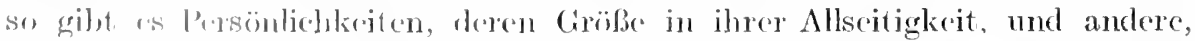

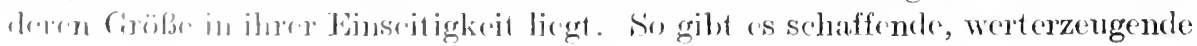


Nationen und Völker von welthistorischem Beruf, Träger großer Kultur und Vernichter großer Kultur. Es gibt ein Ideal des Griechentums und des gricchischen Menschen, der Renaissance und des Renaissance-Menschen, der Romantik und des romantischen Menschen. Alle sie sind niemals wirklich gewesen, aber es handelt sich hier um Ideale, die das Lelen bestimmt haben. Alle diese Typen sind für die Universalgeschichte ron größter Bedeutung, weil sie mit ihrer Hilfe sich des historischen Lnivers ms bemächtigt.

Der Historiker wird immer sagen: diese griechischen Menschen und dieses Griechentum hat es nicht gegeben. Vielleicht, daß in Athen im Zeitalter des Perikles einzelne wenige cin ähnliches Ideal rerkörperten. wie os die enthusiastischen Verehrer des Griechentums denken und gedacht haben. Vielleicht aber war diese schöne Einheit ron Geistigkeit und Sinnlichkeit nur das Ideal jener fermen Kultur. Darauf möchten wir erwidern, daß dann rliese wenigen für die philosophische Betrachtung Griechenland sind und immer sein werden, und daß das ,nur" Idealsein für den Philosophen mehr bedentet wie die ganze Fülle der Tatsachen. Denn auf die Geschichte der Wertideen, auf ihr Bewußtwerden im menschlichen Geiste, auf ihre Darstellung in Kultur und Leben kommt es ihm ja allein und aussehließlich an.

Dem Historiker werden die Typen des historischen Lebens nicht viel mehr bedenten wie Anzeichen eines intensiren Kulturlebens, das twa den Trp' des Renaissancemenschen oder des Romantikers geschaffen hat, oder auch als Begriffe, die sehr geeignet sind, einen bestimmten Zeitraum historischer Entwicklung festzulegen. Indem das historische Bewrßtsein über eine nur zahlenmäßige Feststellung der historischen Epochen hinauskommen will, sucht as den spezifischen Bedentungsgehalt einer Epoche durch ideale Grenzbegriffe zu bestimmen und macht dann die Erfahrung, daß es außerordentlich schwierig ist, Begriffe wie Renaissance oder Griechentmm auch nur einigermaßen ziffernmäBig festzulegen. So hat man z. B. den Anfang der Renaissance-Epoche immer weiter zurückgeschoben, weil man schon weit früher wie im 14. Jahrhunfert charakteristische Anzeichen eincs neuen Kulturgeistes zu entdecken glaubte. Aber man muß wohI unterscheiclen, ob der Geist einer nenen Zeit erst an der Arbeit ist. oder ob er sich bereits in ganz nenen Leistungen und Schöpfungen zur Darstellung gebracht hat und darlurch cine neve Epoche inauguriert. Ferner kömnen ja auch die rerschiedenen Kulturgebiete zu rerschiedener Zeit die neue geistige Formation erfahren, etwa die Philosophie frïher wie die Kunst, und das eine muß dann notwendig als Dominante betracht et werden. Auch erkennt die philosophische Besinnung sofort, daßs alle Lebensideale und Kulturideale ein Moment des Tnvergänglichen an sich haben, so daß der Geist des Griechentums noch in der Gegenwart fort lebt.

Für die philosophische Besimmng bedeuten die Typenbegriffe weit mehr als Abgrenzungsbegriffe für historisches Leben oder als Begriffe, die einen bestimmten Bedeutungsgehalt gewisser Epochen mit einem höheren oder geringeren Maß ron Deutlichkeit herrorheben. Sie schließen auch mehr in sich ein als die allgemeine Stimmung eines Zeitalters oder als das Wollen und die Ziele der kulturellen Oberschicht einer Nation oder einer Epoche. Das philosophische Bewußtsein, das sich der Geschichte nähert, lebt in der Hauptsache nur in diesen Begriffen und ist daron übcrzeugt, daß der Gesamtsimn und das 
eigentlich Werthafte und Eigentümliche einer Zeit darin zum Ausdruck gelangt, bzw. verbindet es den ganzen Wertgehalt einer Epoche mit diesen Begriffen. So besteht ein erheblicher Unterschied zwischen der historischen und philosophischen Bedeutung von Romantik oder Renaissance. Romantik im philosophischen Sinne bedeutet ein Wertbewußtsein eigentümlicher Natur, eine ganz eigenartige Stellungnahme zu Welt und Leben, das sich einmal in der Zeit gebildet hat und dann als Form des Bewußtseins dauernden Bestand gewinnt.

Diese Formen desKulturbewußtseins, diese großenGestalten des historischen Lebens hängen mit den absoluten Werten der Philosophie notwendig zusammen. Sie bedeuten eine einseitige Stellungnahme zum Wertreich, wie sie durch Geist, Charakter, Bildung, Natur und Eigenart einer Nation oder einer Epoche bedingt ist. Dabei ist es vollkommen unmöglıch, diese Gestalten des Bewußtseins aus den objektiven Werten abzuleiten, wenn auch der Inbegriff möglicher Gestaltungen schließlich in jenem Grundgegensatz verankert ist, der die prinzipielle Voraussetzung irgendeines Kulturgebietes bildet. So kann die universalhistorische Entwicklung der Philosophie nur verstanden werden, wenn wir dabei den entscheidenden Gegensatz von Form und Inhalt, ron Subjekt und Objekt beachten. So ist die Entwicklung des religiösen Bewußtseins durch das Verhältnis des Unendlichen zum Endlichen und ihre gegenseitige Determination eindeutig festgelegt. So muß die Entwicklung des künstlerischen Geistes vor allem in dem Wandel der ästhetischen Ideen und in der Entwicklung der Stilformen gesehen werden. Weiter aber geht die sichtbare Beziehung zwischen den Grundprinzipien und den lebendigen und wirksamen Gestalten des historischen Lcbens nicht. Uberall müssen wir die Gestalten des Kulturlebens der historischen Wirklichkeit entnehmen, und das Neue besteht nur in dem Bezogenwerden auf ein Allgemeines und in der andersartigen Orientierung und Einstellung.

\section{Spezialprobleme der Universalgeschichte.}

Nachdem wir so das Verhältnis der Universalgeschichte zur Geschichte crörtert hahen, um ein für allemal dem Verdacht zu begegnen, daß es jene in älınliche Weise wie diese mit historischer Inhaltlichkeit zu tun habe, wenden wir uns nunmehr den Śpezialproblemen dieser höchsten geschichtsphilosophischen Disziplin zu. Was nun da von den anderen philosophischen Disziplinen her vorausgesetzt werden muß, ist dieses, daß dem Wert als solchem, so etwa dem Wert der Wahrheit oder derSchönheit, eine von der Zeit unabhängige Geltung zukomme. Die Zeit ist die Form unserer Endlichkeit, durch die wir von dem Absoluten wissen. Ohne das endliche Bewußtsein bedeutet sie nichts. Die Formen, in denen uns das Göttliche und Aboslute zugängig ist, sind die Kulturwerte. Sic sind nicht rollkommen unabhängig von der Zeit, sie stehen vielmehr in der Zeit und sind für rlas endliche Bewubtsein. Wissenschaft und Kunst haben sich in der Zait entwickelt, d. h. sie sind nicht ohne Zutun des endlichen Bewußtscins da, orler sic haben cinen gewissen Anteil am Endlichen. Es würde aber cin Irrtum sein, zu behaupten, daß die Kulturgüter nichts anderes seien wie Mcrischenwerk, renn das Objektive und Algemeingültige an ihnen ist nicht das Werk unserer Sehöpfung. Das Wahre und das Schöne sind nicht durch 
uns bestimmt, wir geben ihm nur eine Anwendung, indem wir es mit der Fülle des Sinnlichen verbinden, oder anders ausgedrückt: unsere Leistung ist darauf gerichtet, daß sich das Wertrolle offenbare und an dem Endlichen entfalte.

Das Resultat aller erkenntnistheoretischen Untersuchungen läßt dieses beides als widersinnig erscheinen: daß alle Entwicklung sich nur im Absoluten und durch das Absolute rollziehe, denn dadurch wird der Sinn des Sinnlichen und die Position des Endlichen überhaupt rerneint. Anderseits kann aber auch die historische Entwicklung nicht bloß als Sinnenwerk und Tun des Endlichen verstanden werden. Vielmehr nimmt in der historischen Entwicklung das Absolute und Unsinnliche, das Werthafte und Unendliche an dem Relativen und Sinnlichen, an dem Irrationalen und Endlichen teil.

Das menschlich Große und Persönliche ist, wie es uns scheinen möchte, der Mittler zwischen den beiden Welten. Es ist das, was am Endlichen und Cnendlichen Anteil hat. Ohne die Wertindividualität würde das Reich des Unsinnlichen und Utbersinnlichen in transzendenter Abgeschiedenheit verharren. Das Sinnliche aber würde allein sein. Erst durch den Menschen steht das Göttliche mit der Natur im Bunde. Das Reich der Natur bleibt sinnlos und unverstanden ohne die Erkenntnisform, die der Mensch ihr auferlegt hat. Und das Mysterium der Kunst reredelt die Natur durch die Macht seines Geistes. Nicht das Gelten des Werthaften, aber seine sinnvolle Terwirklichung im Sinnlichen ist die Leistung menschlichen Tuns.

Der philosophischen Betrachtung der Historie muß es so scheinen, als ob dieVerwirklichung des Werthaften in einer bestimmten Ordnung sich vollziehe. Gott mußte als endlich gedacht werden, beror das menschliche Bewußtsein zu der Vorstellung des Unendlichen gelangte, Gott mußte in der zerstreuten Vielheit gesucht werden, beror der menschliche Geist sich zu der Idee des Einen erhob. Diese Ordnung ist ron logischer Notwendigkeit erfüllt und entzieht sich der Macht menschlichen Wirkens, aber mag nicht eine freie und selbständige Sphäre des menschlichen Leistens dort bestehen, wo es sich um den Zeitpunkt der Wertverwirklichung handelt?

Das zeitlich Bedingte ist es ja, in dem sich das Zeitlose erfüllen soll. Wie kann das Unendliche im Endlichen, das Zeitlose in Zeitlichen wirklich werden? Wie steht der Wert zur Zeit. Diese Frage wird hier in einem ganz anderen Sinne gestellt wie in der Erkenntnistheorie; denn dort handelt es sich nur um eine rein logische Auseinanderlegung des Wirklichen, die zu seiner absoluten Entwirklichung führt, zu Teilen, die niemals ein Ganzes formieren können, denn nur aus Wirklichkeiten läßt sich eine Welt aufbauen. Wenn Kant das Wirkliche in Begriff, Anschauung und reinen Inhalt zerlegt, so handelt es sich hier um Unwirklichkeiten, zwischen denen ich alle und jede Beziehung denken kann, und Kant hat bekanntlich die Anschauung als das Bestimmende im Verhältnis zum Inhalt und den Begriff als das Bestimmende im Terhältnis zur Anschauung gedacht.

In der Universalgeschichte liegt die Sache von vornherein anders, weil die sinnliche Wrklichkeit nun nicht wehr in ihre Komponenten zerlegt, sondern als Wirklichkeit belassen wird. Gleichzeitig weicht der statische Gesichtspunkt, der für die Philosophie charakteristisch ist, sofern sie die Wirklichkeit in Begriffe zerlegt, dem dynamischen. Der Begriff der Bewegung 
und des Geschehens rerbindet sich hier ummittelbar mit dem sinnlichen Inhalt. Der Inhalt hat seine Wirklichkeit in der Bewegung. Aber die Werthaftigkeit des sinnlichen Geschehens weist uiber die sinnliche Wirklichkeit hinans auf eine Sphäre des Geltenden hin. und es erhebt sich die Frage, wie das Verhältnis des Wirklichen zum Úberwirklichen zu denken ist, durch das die Wirklichkeit des sinnlichen Geschehens erst eine notwendige und allgemeingültige Bedeutung erhält.

Das erste Hauptproblem der Universalgeschichte wäre also das Verhältnis des Geltenden als des Úberwirklichen zur sinnlichen Wirklichkeit und zur Zeit als der Bedingung des sinnlichen Daseins. Ohne eine solche Beziehung und Verbindung würde die historische Bewegung simnlos sein. Ist sie aber sinnreich, so erhebt sich die Frage, wclche rerschiedenartigen Sinngebungen mit der historischen Bewegung verbunden werden können, und welche Form als die wahre und maßgebende angesehen werden muß. Ist aber das Problem einer eindeutigen Sinngebung gelöst, dann ergibt sich die Frage der geschichtsphilosophischen Konstruktion auf Grund dieses Prinzips und wir haben festzustellen, wieweit wohl die Universalgeschichte als rollendende und abschließende philosophische Disziplin gedacht werden kamm.

\section{§ 1. Das erste Problem der Universalgeschichte: das Verhältnis von Wert und Zeit.}

Es mag Menschen geben, die umbedngt und unbekümmert dem Kultus der Zeit ergcben sind und dic den Gedanken eines Geltenden, das die Zeit äberlanert, nicht anerkennen wollen. Diesen Menschen gilt die Zeit als unborlingte Sicgerin, dic alles überwindet. Das ist für sie vollkommen selbstvorständlich, daß alles der Zeit unterliegt und daß nichts daucrt.

Durch den nenen Zeitangenblick wird der alte überholt und abgelöst. Er hat num nichts mehr zu bedeuten. Die Worte, die ich einst gesprochen, das Urteil, das ich einst gefällt, sie weichen der neuen Situation, welche dee Zeit herbaigcoührt hat. Die Zcit ist die unbedingte Herrscherin, die alles verändert. Sic Jäbt mir nichlts ron dem, was jeh einst besessen. Es gibt nichts Persönliches was dic Zeiten ïberdanert. Auch keine Werte und Leistungen gibt es, denen Anerkennung bleibt. Jeder neue Zeitaugenblick stößt um, was bisher gegolten, und auch meinc Liebe und brhnsucht ist cin Kind des Augenblicks. Widerstandslos treihen wir dahin in der Zeit und genügen ilner Forderung des ewig Neuen. Dicser Kultus des Zait, wie wir ihn socben andenteten, ist eine Absurdität. Dry Gedanke Jes Geltens lïBt sich niemals ausschalten. Auch wenn wir der Zeit diesen ungrehomen Vorrang zuerkennen, gilt über alle Zcit hinaus der Satz des ewigen Wechscls, dab nichts Daner und bestand hat. Eine vernünftige mol hesomnene. Ulorelegung weist aber auch üherall auf dasjenige hin, was die

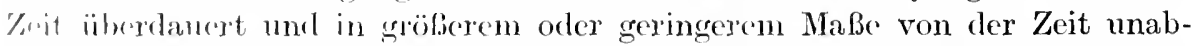

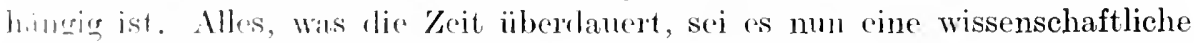

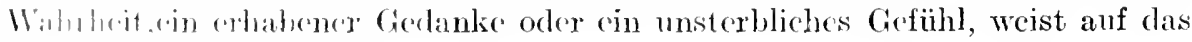
liwiere und zerilose hin.

Wir mïssen numment die wichtige fiage cheben, wie die versehiedenen Kuldurgiils?. Jirligion und Kunst, und die leitenden Werte, von denen sie ahhängen, lic formendes lleiligenund Sehönen, wiesie sich wohl zur historischen 
Wirklichkeit oder zum historischen Leben und damit zur Zeit rerhalten. Auch für die naturwissenschaftliche Betrachtung ist die Zeit notwendig und bedeutsam. Denn alle Bewegung kann nur in der Zeit gedacht werden. So ist ja auch für Kant die Zeit Bedingung aller Erfahrung. Aber schon Kant hat die Zeit vermöge ihrer engen Beziehung zum geistigen und damit auch zum historischen Leben als die Form des inneren Simnes bezeichnet und ihr den Raum als die Form des äuBeren Sinnes entgegengesetzt. Die Zeit ist die Voraussetzung der physischen Natur, die Voraussetzung aller Körperbewegungen, aber die Zeit ist auch ror allem ein Rhythmus unseres imneren seelischen Beziehens. Und wenn Kant tie Phänomenalität ron Raum und Zeit lehrt, wenn er die Behauptung ausspricht, daß sie nur Formen der Erscheinungen sind, aber das wahre Wesen der Dinge nicht berühren, so sollten wir meinen, daß die Zeit doch in einem anderen Simne phänomenal sei wie fler Ramm.

Die Zeit scheint in gewisser Weise unauflöslicher mit der Wirklichkeit verwoben zu sein als der Raum. Wir können uns vielleicht einen Zustand denken, wo die räumlichen Terhältnisse aufgehoben sind, wo der Raum nur als Zeichen gilt für ein raumloses Geschehen. So gehen ja auch die Monaren der Leibnizschen Philosophie dem Ranme roraus. Das geistige Leben der Monaden erzengt den Raum als ein notwendiges Produkt der Erkenntnis. Nur die körperliche Welt bedarf, wie es seheint, des Raumes, nicht aber die geistige Welt. Wir können uns einen Lebenszustand denken, gewiß nur denken, aber nicht rorstellen, dem ron der Raumanschauung kommen wir niemals los, einen Zustand können wir uns denken, wo es keine Entfernungen mehr gibt und das ,hier" zugleich das, ,dort" ist. Nanche metaphysischen Systeme postulieren dies Reich raumloser Dinge. Wir können uns einen Zustand denken, wo alle räumliche Trennung schwindet, wo alles allem gegenwärtig ist. und in einem solchen Zustand wäre noeh geistiges Geschehen elcnkbar. So ist etwa für die platonische Weltvorstellung tie Zeit wichtiger als der Raum. Gewiß steht die Ideenwelt jenseits ron Zeit und Raum, aber tie Seele bedarf ror allem der Zeit. Schuldig wird sie in der Zeit und muß als Strafe für ihre schuld auf eine ganz bestimmte Zeit die Schar der seligen Götter rerlassen, die im Anschauen der Ielee leben.

Alles Geschehen fordert Zeit. Zeit und Geschehen sind Begriffe, die sich nicht trennen lassen. Ein Geschehen in der Zeitlosigkeit ist ein Widersinniges und Unverständliches. In tem Zeitlosen ist keine Veränderung möglich. Dort bleibt alles, wie es ist. Dort gibt es kein Entstehen und Vergehen. Dort hat alles Daner und Bestand. Auch das Neue, an dem das historische Denken festhält, hat dort keine Stelle mehr.

Nicht nur das körperliche, sondern auch das seelische nund geistige Geschehen bedarf der Zeit. Das Zeitlose ist das Bewegungslose, die Melt, die sich nicht rerändert. So denkt etwa die Naturwissenschaft ein ruhiges Reich ron Gesetzen, das zeitlos und ewig gilt. Und aus dieser Vorliebe fiur das Zeitlose ergibt sich die Tatsache, daß die Naturwissenschaft in systematischer Hinsicht so eng mit der Philosophie zusammenhängt. Die Naturwissenschaft stößt in gewisser Weise die Zeit ron sich ab, denn sie trachtet nach den Gesetzen der Körperbewegung. Diese Gesetze aber sind Urteile, die an kein Zeitmoment gebunden sind. So soll etwa das Gesetz der Gravitation oder der Energie für alle Zeiten 
gelten. Es soll über den Rang einer Hypothese erhaben sein. Das wird immer das Verlangen der naturwissenschaftlichen Erkennt nis bleiben. Wenn aber das Gesetz für alle Zeiten gilt, so spielt die Zeit keine Polle. Die Zeit ist damit in die Sphäre "des Gleichgültigen gesetzt. Dagegen kann die Naturwissenschaft die Ablösung rom Räumlichen weit schwerer vollzichen. Sie scheint mehr des Raumes als der Zeit zu bedürfen. Denken wir an ein System der Naturwissenschaften, so denken wir an den Raum als den Ort aller körperlichen Dinge, auch der letzten körperlichen Substanzen, die doch immer raumerfiillend gedacht werden miissen. Zwischen diesen letzten Dingen bestehen Bezichungen, die in gewissen Lageverhältnissen, einer Konstellation der letzten Dinge oder Substanzen, zum Ausdruck konmen. Diese Anordnung der Substanzen im Raume bedingt alles mögliche Geschehen, das sich als Orts veränderung im Raume rollziehen kann. So waren für Demokrit leerer Raum und Atom Grundprinzipien der Naturauffassung. Das Naturgesetz aber, wie es die moderne Naturwissenschaft denkt, läßt sich auffassen als das Prinzip aller möglichen Lagerungsverhältnisse der Substanzen im Raume. So kann das Gesetz anch gedacht werden als der Inbegriff aller Beziehungen, die zwischen den Substanzen bestehen. Unter diesem Gesichtspunkt erscheint dann alle Bewegung als ein Sekundäres gegenüber der Ordnung, die im System der räumlichen Substanzen zugrundeliegt. Die Naturwissenschaft tendiert nach einem statischen Weltbild hin. Sie kommt in der Vorstellung von gesetzmäßig geregelten Beziehungen zwischen letzten Dingen zur Ruhe. Die Zeit aber, von der die Naturwissenschaft handelt, ist zu einer Funktion, zu einer Abstraktion geworden, aus tauschbar gegen Paum nnd Kraft und Masse. Sie ist die Form eines ideellen Geschehens, wie es als solches sich niemals vollzieht. Die naturwissenschaftliche Begriffshildung hat die Zeit rationalisiert und verränmlicht und damit gleichsam entwirklicht. Sic hat die Form eines individuellen und wirklichen Gesehehens zur Form ideeller und unvollziehbarer Bewegungen gemacht und damit das Verhältnis zum historisehen Leben eingebüfot.

Dagegen hat die Zeit zur Geschichte ein unentbehrliches Verhältnis, weil sie mit ihrem Grundbegriff des Geschehens sich zusammenschließt, und die historischen Objelite cine notwendige Bezichung zur Kultur besitzen. Der Begriff der Zeit ist von den Kulturwerten unabtrembar. Denn Religion und Wissenschaft sind Wirkliehkeiten des Kulturlebens, das nur in der Zeit sich vollziehen kann. Alles historisehe Leben fordert den Begriff der Entwieklung, nnd in rem Begriff der Entwicklung loistet die Zeit gleiehsam etwas für dir Wirklichkrit. Sie ist die Mögliehkeit ihrer Weiterhildung oder auch ihrer Aufhebung, je nachosm die Philosophie rlies Verhälinis deutet. Dagegen ist die Keit als form der Bewegung in der naturwissensehaftlichen Auffassung nur das gleichgültigr Substrat des immer gleichen Geschehens. 1) ir historischr. Ent wicklung leistet etwas an der Wirklichkeit, nnd dazu bedarf sir. Are zeit. Dir naturwissensehaftliche Bewegung läßt rlie Wirkliehkeit so, wireste ist. Unel deswergen ist die 7ejt in ror Naturwissenschaft nur Substrat abrer nicht Faktor'.

So strhen wir also in rer Geschichtsphilosophie von vornherein vor der

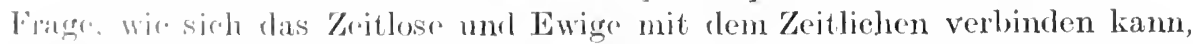
nder wir sich Zritanschaumng mol Wrltanschaumg verbindet, oder wie das 
Verhältnis von Wert und Leben zu denken ist. Wenn nun eine solche Verbindung gefordert und nach ihrer Möglichkeit gefragt wird, so setzt das allerdings schon vollzogene Vorurteile voraus, nämlich diese, daß es wertvolles Leben und Geschehen gibt, und daß weder der Wert noch das Leben Schein sei. Daß es wertvolles Leben gibt im Gegensatz zu dem Indifferenten und Gleichgültigen, das wird wohl im allgemeinen zugegeben werden.

Sehen wir von jenen ab, so ist der Gegensatz von Wert und Nichtwert doch «weifellos das Grunderlebnis jedes Menschen. Dagegen ist es mit den beiden anderen Vorurteilen schwieriger bestellt. Man hat nämlich auf der einen Seite behauptet, das Leben sei ein bloßer Schem, eine pure Illusion, kein Zustand des wahrhaftigen Wachens, sondernein Traumdasein, ein Höhlendasein. Dieses unserLeben ist dann viellelcht etwas, was gar nicht ist und sich rollzieht, sondern nur ein trügerischer Nebel, der die wahreWirklichkeit verdunkelt, nämlich die Welt des Ewigen, wo es keine Veränderung und kein Geschehen gibt, sondern alles von Anfang an sich gleich bleibt. Diese Auffassung ist z. B. die Konsequenz der Schopenhauerschen Philosophie. Was Veränderungen erleidet, ist der Zeit unterworfen, denn es hat einen Anfang gehabt und muß ein Ende haben. Es ist notwendig ein Sterbliches und Vergängliches, nicht aber ein Ewiges. Eine Verbindung und Vereinigung des Unvergänglichen und Vergänglichen wäre ein Wunder, und das Wunder ist unmöglich. Wie sollte eine Vereinigung absoluter Werte mit der Zeit gedacht werden? Ton vornherein ist es klar, daß wir keine Mittel besitzen, uns dies Verhältnis deutlich zu machen. Der Begriff, der sich uns aufdrängt, ist der Gedanke der Kausalität oder der Wirkung, aber dieser Begriff gilt, wie $K$ ant nachgewiesen hat, nur für das Verhältnis von Objekten in der Zeit. Er bestimmt ein Verhälnis in der Zeitlichkeit, aber wir können nichts mehr mit ihm anfangen, wenn es sich un ein Verhältnis zwischen dem Zeitlosen und dem Zeitlichen handelt.

Dem Ewigen gegenuiber, das Dauer und Bestand hat, muß die Zeit in der Fliichtigkeit ihres Wechsels als das Minderwertige, ja als das Wertfeindliche erscheinen. Diese Wertfeindlichkeit der Zeit hat Karl Joël mit folgenden Worten charakterisiert: ,Der Kultus des Raumes mag die Universalität des Göttlichen aufheben und es verkleinern zu hellenischen Tempelstatuen, aber auch in ihnen noch lebten die Unsterblichen. Doch der Kultus der Zeit hebt mit der Unvergänglichkeit auch die Gottheit auf. Er läßt die steinernen Dome rersinken und die ewigen Lampen verlöschen, aber verlöscht el nicht auch die ewigen Ideen, zerreißt er nicht schließlich auch die starren Ketten der Logik, die ewig gïltigen Schlüsse, die noch fester sind als alle Dome? Denn die Kirche stützte sich auf Aristoteles, nicht umgekehrt. Der Raum ist human. Er verstattet ein Nebeneinander. Die Zeit aber ist grausam. Sie lebt nur von dem Mord ihrer, Glieder und duldet keine Auferstehung. Der Kultus der Zeit ist der Kultus des Wechselnden und Neuen"'). So Karl Joël. Und dieser Gedanke der Schlechtigkeit der Zeit widensetzt sich dem Yersuch, eine Verbindung zwischen ihr und dem Ew:gen zu denken. Ewigkeit und Zeitlichkeit schließen sich aus. Die Einsicht in ihre Grausamkeit führt dahin, sie selber

1) Karl Joël, Weltanschauung und Zeitanschauung. Ans dem philosophischen Sammelwerk: Weltanschauung. 
und alles Leben, das in ihr sich regt, vollkommen zu verneinen. Es gibt ein Reich eriger Wahrheit und Schönheit, aber dieses Reich ist unerreichbar. Das dem Wechsel in der Zeit Unterworfene kamn niemals dorthin gelangen.

Auf der anderen Seite steht die bloße Zeitanschaunng, die nichts gelten lassen will, als das, was in der Zeit lebt und der Zeit unterworfen ist, die alle Werte rollkommen relativiert. Was wir schön, gut und wahr nennen, das ist nach der Auffassung dieser Anbeter der Zeit nur Geschmacksache. J)em wenn sich clas Neue an die Stelle des Alten gesetzt hat, so hat das Neue unberingt recht. Was wahr und gut ist, das hängt von der Zeit ab, in der wir uns befinden. Die Zeit macht das Wahre zum Wahren und das Gute zum Guten. Die Zeit bestimmt den Wert. Damit ist dann allerdings die Absolutheit des Wertes aufgehoben. Der absolute Wert ist die 1llusion, die sich eine bestimmte Zeit über die Bedeutung der Wertsetzungen macht. Eine solche Weltauffassung, die rollkommen in der Zeit stehen bleibt, die nichts anerkennt, was nicht nur jetzt, sondern immer gilt, sie gräbt bei ihrem Kultus des Neuen an ihren eigenen Wurzeln, indem sie das Vergangene immer wieder vernichtet und nicht gelten läßt, was einst gegolten hat. In dieser ewigen Versündigung gegen die Tradition, die uns als Zeitanschauung heilig sein sollte, wird sie das Prinzip eines haltlosen Dahinlebens. Eine solche Zeitanschaung ist im Grunde genommen eine Augenblicksanschauung. Denn wenn die Zeit wertvernichtend ist und die Geltung der Werte ron der Zeit abhängt, so vermag in der Tat jeder neue Angenblick den alten zu töten. Was der Augenblick als wertroll rrschcinen läßt, das gilt, das ist das Recht, das mir der Augenblick entgegenbringt.

Diesen Relativismus gegenüber, der sich auf dem Gedanken der Zeit aufbaut, sucht die Philosophie auf den verschiedenen Kulturgebieten die absoluten Werte aufzuwcisen, inclem sie das Leben vernichtet und in Begriffe auflöst. In der Tniversalgeschichte aber tritt das Leben wieder herror, und diese philosophische Disziplin ist is allein, welche das Verhälnis ron Wert und Leben in dem Begriff dou Wortrerwirklichung zum Problem stellt. Dieses Verhältnis aber ron Wert und zeitlicher Entwicklung oder auch ro.x Wert und Leben kann rersehieden gedacht werden. Augenscheinlich ist auch das Verhältnis bei den verschiedenen Werton ein rersehiedenes. Der Kulturwert der Religion stelst nieht so zur Zeit wie Wissenschaft und Teehnik, und anders als Kimst und Religion steht das sittliche Leben zum historischen Werden.

Wemn wir darauf reflektieren, wie sich dic versehiedenen Wrate zur Zeit verhalten, so müssen wir zwei Hauptgruppen ron Werten unterscheiden. Auf der rinen Serite Kunst, Roligion und Philosophic, auf der anderen Seite Lecht, Sittlichkeit und Wissenschaft. Der Gegensatzaber zwisehen den kejolen Wrotgrupen liegt zumächst darin, diaß mur die este Gruppe weltanschaumg-

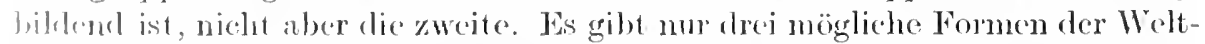

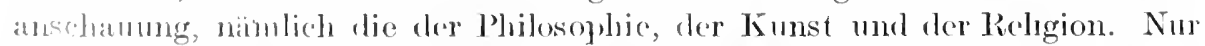
dicse sanz allein vollzichen die notwerulige Hinwendmg rum Absoluten, inrlan siresich dio Aufuabostellon, das Universum als Ganzes zu denten. In.

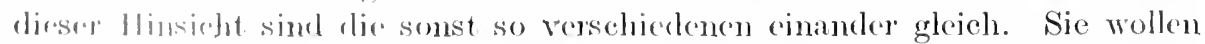
das Absohnta med suchen sich soiner in verschiedener Form zo bemächtigen.

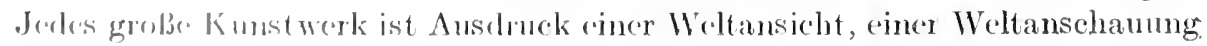


ebensowohl wie Religion und Philosophie. Und jene drei, die am Anfang der menschlichen Entwicklung rerbunden waren, sind auch nach ihrer Trennung noch durch zahIreiche Beziehungen verknüpft. So gibt es etwa Künstler, deren Werke reich sind an philosophischen Gedanken, und andere, in denen sich das künstlerische Schanen mit religiöser Begeisterung verbindet. Weiter ist ihnen allen dreien ein gewisses Moment des Asozialen gemeinsam. Dagegen beziehen sich die sittlichen Normen und Pflichten auf mein Terhältnis zu anderen Menschen, und bei dicsem Verhältnis kann ich entweder das ,mein“ oder das ,,andere Menschen"stäıker betonen und so von Pflichten gegen mich selbst und ron Pflichten gegen andere sprechen. Und dasselbe gilt für das Gebiet des Rechtes. Das Recht reguliert die menschlichen Dinge und Verhältnisse. und es ist eine anthropomorphe Vorstellung, zu meinen, daß anch Gott sein Recht und seine Pflicht haben müsse. Was nun die Wissenschaften angeht, so ist auch ihnen der Gedanke der Sozialität anfgeprägt. Sie sind nicht das Werk des einzelnen, sondern das Werk der Generationen. Insofern sind sie ein soziales Produkt. Die einzelne Persönlichkeit schafft keine Wissenschaft. wie et wa der einzelne ein Kunstwerk schafft oder eine Religion stiftet. Wissenschaftliche Leistung reiht sich an wissenschaftliche Leistung. Der wissenschaftliche Mensch leistet ron rornherein Verzicht, die wissenschaftliche Wahrheit als Ganzes zu finden, die Erkenntnis in vollendeter Form zu geben. Jeder wissenschaftliche Mensch ist ein Beitragender, einer der beiträgt und hinzufügt zu dem, was andere geleistet haben. Etwas ähnliches gilt auch für den sittlichen Menschen, sofern er tätig und reformatorisch wirkt. Alle seine Handlungen sollen helfen und Richtung geben der menschlichen Entwicklung. Es scheint aber bereits ein großer Gewim zu sein, wenn es gelingt, nur um ein ganz geringes und kleines die Entwicklung in bessere Bahnen zu lenken. So ist die sittliche Leistung ihrem Wesen nach eine beitragende Leistung. Sittliche Tat reiht sich an sittliche Tat, wissenschaftliche Leistung an wissenschaftliche Leistung. Und all dicses Leisten ist bestimmt und erfüllt durch die Idee, daß ein Reich der Sittlichkeit und ein Reich der wissenschaftlichen Erkenntnis sowie auch schließlich ein Reich der idealen Rechtsordnung sich herausbilden wird im Lauf der Entwicklung. Gerade dieses ist es, was dem emsigen Forscher mit dem Freunde des Guten und Rechten das frohe Bewußtsein einer nicht vergeblichen Arbeit und Mühe gibt. Unmöglich kam der einzelne vollenden, aber es besteht die Forderung und Erwartung, daß die späteren Generationen der Enkel rollenden werden, was die Täter gedacht haben. , Gib der Welt nur den Anstoß zum Guten, so wird der ruhige Rhythmus der Zeit die Vollendung bringen." So stehen gerade diese drei: Sittlichkeit, Wissenschaft und Recht, in einem besonders nahen VerhäItnis zur Geschichte. Hier muß die Zeit die Vollendung herbeiführen. Und von ihnen aus ergibt sich auch eine gewisse Pflege der Tradition, weil der eine Beitragende den anderen ergänzt, und der spätere immer bewußt und ausdrüicklich auf den früheren aufbaut. Wenn wir genauer zusehen, so gilt die Zeit hier nicht nur als das Mittel der Verwirklichung des Wertes, als Schaustätte seines Wirkens, sondern auch als dasjenige, was das Wertvolle einem letzten Ziele entgegenführt. Die Zeit ist also das Mittel der Verwirklichung und zugleich Mittel der Vollendung. Dazu kommt endlich noch ein drittes Moment. Die drei Werte, mit denen 
wir es hier zu tun haben, nehmen aneh in ganz besonderer Weise an dem Gedanken des menschlichen Zieles teil. Das Rechtsbewußtsein setzt Normen, und diese Normen haben nur dann Sinn, wenn die Mögliehkeit eines Verstoßes gegen die Norm besteht. Wäre die Mensehheit dahin gelangt, daß sie prinzipiell legal handelte, so verlören die Gesetze ihre Bedeutung. Und dasselbe gilt für das sittliehe Bewußtsein. Das sittliche Bewußtsein lebt in dem Gegensatz ron Sein und Sollen. Es muß immer etwas da sein, was anders sein sollte. Das gilt sowohl für die Leistung, die der sittliche Mensch an sich selber vollziehen soll, wie auch für die sozialen Verhältnisse, auf die zu wirken er sich berufen fühlt. Wäre alles so, wie es sein sollte, so hätte das sittliche Bewußtsein niehts mehr zu tun. Und so ist die Aufgabe des sittlichen Bewußtseins notwendig unendlich. Das sittliche Bewußtsein ist nie am Ziele. Das Ziel ist für das sittliche Bewußtsein eine regulative Idee. Erfüllung kann ihm nie ganz zuteil werden, dem würde ihm absolute Erfüllung zuteil, so wäre es selber aufgehoben. Und etwas ähnliches gilt nun auch für die wissenschaftliche Erkenntnis. Auch die Wissenschaft ist unendlich. Am deutlichsten ist das in der historisehen Wissenschaft. Sofern immer neues Geschehen sich auslöst und dieses neue Geschehen immer wieder begriffen und mit der Vergangenheit in Einklang gesetzt werden soll, kann die historisehe Wissenschaft niemals am Ziele sein. Wäre die historische Wissensehaft am Ende, so wäre auch das historisehe Leben am Ende.

Betrachten wir mun jene anderen Kulturwerte und Kulturprinzipien, die ein prinzipiell anderes Verhältnis zur Zeit und zum historischen Leben annehmen: Philosophie, Kunst und Religion. Daß ihnen eine Ausnahmestellung zukommt, diesem Umstande hat Hegel dadurch Rechnung getragen, daß er sie in die Sphäre des absoluten Geistes versetzte, und ihrem, ,überhistorischen" Charakter, wemn wir so sagen wollen, wurde er dadurch gerecht, daB diese Werte, wic er sie im Zusammenhange seines Systems entwickelt, die Weltgesehichte hinter sieh gelassen haben. Mit dem Begriff der Weltgeschichte vollendet sich nach Hegel die Sphäre des objektiven Geistes, die Hegelsche Kulturphilosophie. Kunst, Religion und Philosophie heben die Geschichte anf. Was soll das bedenten? Nach Hegel doeh wohl, daß die wahre Kunst, Religion und Philosophie, die es mit dem VerhäItnis des Mensehlichen zum Göttlichen zu tun habcn, das Ende der Gesehichte, die Aufhebung des historischen Prozesses bedenten, daß in ihres wahren und wahrhaftigen Gestalt alles Endliche aufgehoben wird. Ein absolutes und endgültiges Durchbrechen des historischen Prozesses scheint sich in ihnen zu vollziehen, und dabei versteht Hegel diese drei als immer höhere Stufen dor Gotteserkenntnis und zugleich der Gottesoffenbarung.

Wohl hat as niemals einen Denker gegeben, der so ïberzeugt war von der Wiirle der Philosophir wic Hegel, dor mit soleher Entschiedenheit und wunderrollem Vorstehen den Borlingungen ihres Scins und sinnes nachgedacht hat wic ('). Dorr philosophisehr'n Erkronntnis muß ein Wissen rom Absoluten möglich scin, sonst gibt as krino Philosophic, und der Gegensatz, der zwischen den letzten Bregriffril lustclst, zu denen wir vorzudringen vermögen, die Tatsache der

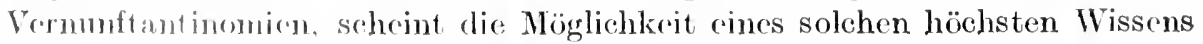
zul hewahrhritrn. Dann wir sollen wir den Begriff des Endliehen verstehen 
ohne den Begriff des Unendlichen, und wie sollten wir den Begriff des Relativen ergreifen ohne den Gedanken des Absoluten. Jene, die da bchaupten, daß alles relativ und nichts absolut sei, haben rein dogmat isch von einem Vernunftgegensatz sich die eine Behauptung zu eigen gemacht. Alles muB relativ sein, denn wir können den Gedanken des Absoluten nicht mit dem Gedanken des Relativen zur Einheit bringen, ebensowenig, wie wir den Gedanken des Endlichen mit dem Gedanken des Unendlichen rersöhnen können. Wenn der Relativist jedoch konsequent wäre, so würde er bemerken, daß auch zwischen den Begriffen von Einheit und Mannigfaltigkeit, von Sein und Werden Gegensätze bestehen, deren Úberwindung ganz ähnliche Schwierigkeiten bereitet wie etwa der Gegensatz des Absoluten und Relativen. Wollen sie aber als Anhänger der Vielheit und des Werdens darum auch jede Einheit und jedes Sein verleugnen?

Ohne Zweifel ist das Absolnte ein notwendiger Begriff für die Philosophie, aber ein anderes ist es, das Absolute wissen, und ein anderes, das Absolute in der Fülle seiner Formen begreifen und verstehen. Gott ist mehr als das Absolute. Gott ist das Absolute, mit dem ich leben kann, das ich nicht nur nachdenke, sondern auch nachlebe. Gott gehört nicht in die Philosophie. Gott gehört, wie es die Romantik formuliert hat, nur in die Religion, nicht aber in die Philosophie und Kunst. Auch Goethe weilte, wie Friedrich Schlegel sagt, nur in den Propyläen des Tempels. Kant hat gezeigt, da $B$ das Absolute notwendig gedacht werden muß, aber niemals kann dieser Begriff für das philosophische Bewußtsein die Lebendigkeit und Gegenwärtigkeit gewinnen, die er für das religiöse Bewnßtsein besitzt.

Hier ist nun aber auch der Ort, wo wir auf die Seltsamkeit der Hegelschen Geschichtsphilosophic hinweisen müssen, die in ihren Konsequenzen dahin geführt hat, zu behaupten, daß mit Hegel die Weltgeschichte am Ziele sei. Sie erwächst aus der ïbermäßigen Betonung des Endzwecks. Es handelt sich im Grunde genommen um den eschatologischen Gedanken, daß mit dem Erscheinen der wahren Religion, bei Hegel der wahren Philosophie, die Weltgeschichte am Ende sei. Hegel hob die absolute Erkenntnis für das Ende der Geschichte auf. Weun das Ende der Geschichte sich naht, dann rollendet sich das Evangelium des Geistes. Dann erhält die religiöse Torstellung ihren wahren Inhalt und die künstlerische Anschaung ihren vollendeten Gehalt. Das bedeutet aber noeh nicht das rollendete Kulturgeschehen. Das vollendete Kulturgeschehen offenbart sich in der vollendeten Form des Wissens. Diese vollendete Form des Wissens gibt die absolute, die vollendete Philosophie. Unter diesem Gesichtspunkt sind Religion und Kunst Wissensformen, untergeordnet der philosophischen Form, die ihre Einheit bedentet. Das Wissen vom Absoluten wird zur absoluten Philosophie und verbindet sich mit dem Gedanken des Endzwecks. Das führt aber zu der großen Paradoxie, daß mit der Hegelschen Philosophie die Weltgeschichte am Zicle ist im vollendeten Wissen des Weltgeistes. Hegel suchte die Philosophie zu verstehen. wie die Wissenschaft verstanden sein will, nämlich als Beitragswert, dessen Vollendung von der Zeit abhängig ist. Er wußte, daß die philosophische Wahrheit in doppelter Weise an die Zeit gebunden sei, einmal, sofern die Zeit das Substrat der Wechselwirkung bildet, und einmal, sofern die Zeit die Vollendung des 
philosophischen Bewnßtseins herbeiführt. Er meinte, daß die Zeit der philosophischen Erkemntnis in der Weise Widerstand entgegensetzte, daß ein Plato notwendig zum Halbwissen verurteilt war, und nur dem vollendeten Menschengeschlecht das wahre Wissen zuteil werden sollte. Die Wahrheit läßt sich Zeit, sie wartet auf das Ende der Geschichte, und rergeblich sind alle Versuche des zu zeitig geborenen Genius. Den Spätgeborenen fällt die Wahrheit als reife Frucht mïhelos zu. Vergeblich ist das Ringen und Kämpfen des früheren Menschengeschlechtes. Und doch meinte Hegel, daß in der Philosophie wie in Religion und Kumst ein unmittelbares Verhältnis zwischen dem Menschlichen und Göttlichen gegeben sei.

Wenden wir denselben Gedanken anf das religiöse Gebiet an, so würde dasselbe Phänomen darin zum Ausdruck kommen, daß alle religiöse Sehnsucht der früheren Menschengeschlechter niemals zu einer wahren Gottesvorstellung sich zu erheben vermochte, daß sie notwendig im Irrtum befangen bleiben muB, bis das Ende der Geschichte erreicht ist. Das Ringen und Kämpfen einer vicltansendjährigen Menschheit ist also notwendig a priori erfolglos, und nur dem gereiften und rollendeten Menschengeschlecht wird nach dem Plane des Weltgesehehens die Erfüllung ihrer religiösen Sehnsucht und Erwartung. Und so ist die ganze Weltgeschichte mit dem Fluche des Vorläufigen belarlen, und die Mïhe und Arbeit der Nationen kommt nur den letzten Menschen zugute. Die Härte und Grausamkeit, die in dieser ganzen Weltauffassung liegt, die schon ron Herder in seiner Opposition gegen Kants Geschichtsphilosophie cingesehen ist, ist dann hesonders ron Hermann Lotze aufgewiesen werden. Unter diescm Gesichtspunkte sind in der Tat Menschen barmherziger als Götter $\left.{ }^{1}\right)$.

Anch Lessing, der vor allen anderen in Dentschland zuerst in der modernen Philosophie das geschichtsphilosophische Problem gestellt hat, ist über diesen Gesichtspmnt dles Vorlänfigen nicht hinausgckommen. Seine Auffassung fler religiösen Erkenntnis in cliesem Simne ist niedergelegt in dem berihmten Glcichnis von den drei Ringen. Allerdings ist hier der Bann der Zeit insofern abrochen, als anem Teil der Menschheit die wahre Religion offenbart ist. So wirkungsoll aber" anch Lessing in seinem "Nathan" die alten Motive genutzt hat, sosthr widerstrebt doch dem religiösen Bewnßtsein der Gedanke, dals dic wahre Religion nur einem Tril dor Menschheit als Erbteil beschieden sein soll, die anderen aber, von der Wahrheit ausgeschlossen, dem Irrtum preisgegeben sind. Und darïber fïhrt anch die schöne lösung nicht hinweg, hic Lossing der alten Parabel zu groben weiß, wenn Nathan erklärt, der wahre Ring als symbol der wahren liceligion habe die Eigenschaft, vor Gott murl Mlonsehren angenchn zu mache'n. So sohön das sittliche Motiv anch ist, las von dassing in die Fabel eingeflochten wirl, so nugenïgend ist es in

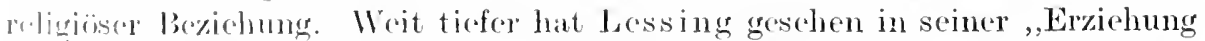

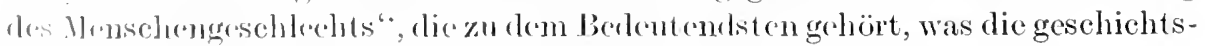

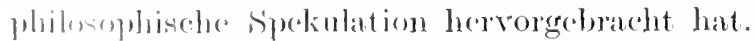

L ist niwht schwor zu "utschoiden, worin diese ïbermäßige Bewertung der $\%$ ait, lis botomung des Fortsehritts und der Kultus des Endzwoeks seinen 
historischen Grund hat. Die ersten großen geschichtsphilosophischen Konstruktionen der Apologeten. der Gnosis und des Origines suchten die Bedeutung der religiösen Offenbarung und ihrer großen Kulturinstitution, der Kirche, zu demonstrieren. Die christliche Gemeinde sah in der Erscheinung Christi die absolute Erfüllung. Sie lebte in der Erwartung des Weltunterganges. Dieser eschatologische Standpunkt wurde durch die Religionsphilosophie des dritten und vierten Jahrhmolerts ïbermunden. Die Apologeten ließen der antiken Welt einen gewissen Anteil an der religiösen Wahrheit. Die religiöse Ủberzengung der alten Welt sollte eine teilweise Offenbarung der religiösen Wahrheit bedenten, das Christentum aber die rollendete Offenbarung und damit das Ende der Geschichte. Origines ist viel weiter gegangen. Er vertrat die Idee eines dritten Erangeliums. eines Christus nach Chris tus, eines Erangeliums des Geistes, und in dieser Vorstellung wurzelt die Geschichtsphilosophie des deutschen Idealismus. Wir rerstehen die eminente Bedeutung dieser Lehre, ohne die sittliche und wissenschaftliche Bildung nicht rerstanden werden könnte. Aber wir behaupten, daß sie nicht selbstrerständlich und unbedingt gilt. Es gibt eine Form des religiösen Lebens, die gegen diese Geschichtsauffassung, die allen Nachdruck anf das Ende der Geschichte legt. Protest erhebt, und diese religiöse Lebensform ist viel zu wichtig, als daß wir so ohne weiteres an ihr rorbeigehen könnten. Ich meine die Mystik. Die Mystik steht in einem ganz anderen Verhältnis zur Zeit als die Offenbarungsreligion oder, richtiger gesagt, die Mystik gelangt zu einer ganz anderen Auffassung über das Verhältnis des religiösen Wertes zur Zeit als die Offenbarungsphilosophie.

Der Mystiker pflegt die Zeit als solche für die Form des Endlichen zu halten. die notwendig durchbrochen werden muß, um zum Absoluten vorzudringen. Schon in diesem Leben ist eine absolute Befreiung ron dem Zustand der Endlichkeit möglich. Damn tritt die Seele in ein Verhältnis ein, da Ram und Zeit, die in Gott gesetzt sind, ihre Berleutung verloren haben. Die Seele kann also den Zustand der Torwelthchkeit wiedergewimen. Sie hat gleichsam die Möglichkeit, die ganze Schöpfung wierler rückgängig zu machen. Sie kam Gott so auffinden. wie er vor aller Welt war. Auch sie selber ist nach der Lehre des größten Mystikers nichts Geschaffenes. Das Durchbrechen der Zeitlichkeit und der freie Zugang zur Ewigkeit ist der Sinn rer mystischen Ekstase. Diese Lehresteht ganz augenscheinlich im Gegensatz zu der geschichtsphilosophischen Lehre rom Endzweck. Der religiöse Mensch braucht nicht zu warten auf clas Ende aller Dinge, sondern er vermag die religiöse Tereinigung mit Gott und die Gotteserkenntnis jederzeit zu vollziehen. Die Mrstik deutet alle zeitlichen Verhältnisse in ewige Verhältnisse um. Für sie hat die Zeit überhaupt keine Bedentung. Sie ist ein Etwas, das durch einen unbegreiflichen zeitlosen Akt gesetzt ist, den die Seele im Zustande der Ekstase wieder rückgängig machen kann. In der mystischen Auffassung der Religion ist die Zeit gänzlich belentungslos, in der historischen Auffassung kommt alles anf die Zeit an. Dazwisehen steht der Gedanke der Wert verwirklichung, wie wir ihn für Philosophie. Religion und Kunst in Anspruch nehmen, nämlich so, daß das zeitlos Geltende in die Zeit eintritt, ohne von der Zeit abhängig zu sein, daß also in der religiösen Erfahrung weder die Zeit aufgehoben wird als ein Etwas, das gänzlich hedeu- 
tungslos ist gegenüber dem allmächtigen Wert, noch auch so, daß das Wertvolle erst durch die Zeit in mühseliger Entwicklung vollendet wird. Der Wert bestimmt die Zeit, aber er hebt sie nicht auf; so ist das Verhältnis im Grunde genommen ja auch ron $\mathrm{K}$ ant gedacht. Fassen wir es in dieser Weise, so ist die Erfïllung der religiösen Sehnsucht nicht mehr rom Ende aller Dinge abhängig.

Und etwas ähnliches scheint mir auch für das Schöne zu gelten. Hier stehen wir vor der auffallenden Erscheinung, daß das Kunstwerk ein in sich Tollendetes bedeutet. Deswegen hat es auch geschichtsphilosophisch gar keinen Sinn, die großen Kunstwerke unter den Gesichtspunkt des Fortschritts zu stellen. Der Fortschritt trifft hier höchstens die Technik des Schaffens. Aber auch bei mangelnder Technik beleutet bereits die griechische Kunst eine Höhe des Kunstschaffens, die niemals übertroffen ist. Die moderne Kunst ist anders als die Kunst der Antike, aber wir können nicht behaupten, daß sie einen höheren Anspruch auf Schönheit besitzt. Auch Platos Symposion bedeutet vollendete Schönheit. Damit aher tritt die Kunst auf die Seite jener Kulturgüter, die dem Prinzip des Endzwecks nicht unterliegen.

\section{§. Das zweite Problem der Universalgeschichte: die möglichen Sinngebungen des historischen Geschehens,}

Eine Sinngebung der Geschichte setzt eine Werttheorie voraus, und zwar in der Regel so, daß die Werte zu einem System verbunden sind, und daß sich somit irgend ein Wert als leitender Wert oder Abschlußwert ergibt, von dem gleichsam alle Sinndeutung ausgeht und der als Endzweck des historischen Geschehens die Gesamtentwicklung durchleuchtet. In der Regel wird die Auffassung vorliegen, daß dieser eine Wert der entscheidende sei, daß es auf seine Entfaltung und Entwickhung recht eigentlich ankommt, daß er auch den anderen Wrertformen sein Gepräge geben soll, und daß die Gliederung der historischen Welt von der Initiative dieses einen Wertes abhängig ist.

Entsprechend den Werten ergeben sich somit 4 Grundformen der geschichtsphilosophischen Spekulation als reine Formen der Universalgeschichte:

1. die religiöse Universalgeschichte: der Sinn der Geschichte ist Erlösung, wher auch: ihr Sim ist das Offenbarwerden der Geheimnisse Gottes;

2. die spekulative Universalgeschichte: der Sim der Geschichte ist die alsolute hzw. relative Erkennt nis;

3. die ethisehe Tniversalgeschichte: der Sinn der Geschichte ist das Bewnktsein der Freiheit;

4. lie ästhetische Univcrsalgeschichte: die Geschichte bedeutet eine (offenbarung göttlicher Schönheit.

Denken wir diesen Sinngebungen nach, so wirl es uns sofort deutlich, dals hier immer wieler ein amberes Kultur-orlor Wertinteresse an der Arbeit

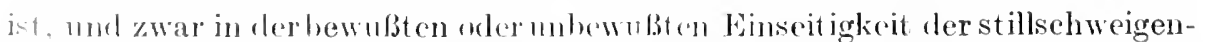
den Voraussetzung, dal3 ein ganz best immutes Wertgebilde, z. 13. das Schöne, das

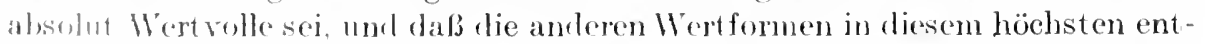

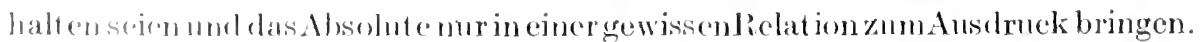
Weiter ist es vom größten Interesse, zu schen, wie die Simugehungen der ver-

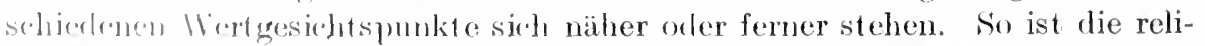
groise Sohnsudelt nachloffonbarung, ter Winsch, daß Gottes Wille kund werde. 
dem Ziel des theoretischen Strebens, dem absoluten Wissen, ganz augenscheinlich verwandt. Aber vielleicht ist das Wollen der Offenbarung anch keine rein religiöse Forderung. Sieht es doch manchmal so aus, als ob das religiöse Bewußtsein wisse und wünsche, daß Gott in seiner Pätselhaftigkeit und Dunkclheit verharre. Vielleicht bedeutet die Sehnsucht nach dem Wunder nur ein

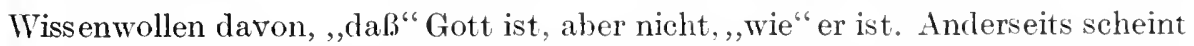
die religiöse Sinngebung der Erlösung der ästhetischen einer Verklärung der Sinnenwelt durch das Schöne zu widerstreiten. Denn der Erlösungsgedanke will das Schwinden der Sinnenwelt, der Gedanke einer ästhetischen Verklärung aber bejaht doch das sinnliche Dasein. Das Gruntproblem der Universalgeschichte aber muß darin gesucht werten, eine Formel zu finclen, die den verschiedenen Forderungen genïgt und das religiöse Interesse befriedigt, ohne das ästhetische zu verletzen.

Wir wollen die ,möglichen" Sinngebungen an typischen Beispielen erläutern, indem wir darauf hinweisen, daß sie nur selten rein in Erscheinung treten. So verbindet sich etwa die religiöse Universalgeschichte mit einem spekulativen Gedanken, wie in der Gnosis. oder auch die ästhetische Universalgeschichte hat eincn religiösen Einschlag, wie bei Schelling. Wir wählen aber als Beispiel der religiösen Universalgeschichte die Gnosis, der spekulatiren Hegel und Comte, der ethischen Kant, der ästhetischen Schelling.

\section{a) Die religiöse Sinngebung.}

Die Gnosis ist für uns ron besonderem Interesse, weil sie als der Anfang aller großen metaphysisch-geschichtsphilosophischen Spekulation angesehen werden kann. Weil diese Form des religiösen Bewußseins die Irłee der Menschheit entdeckt hatte, vermochte sie das Ganze des historischen Geschehens mit einheitlich religiösem Sinn zu erfüllen.

Zwei große religiöse Grundbegriffe sind es, auf denen die Geschichtsphilosophie der Gnosis ruht, nämlich der Begriff der Schuld und Erlösung. die einander mit Notwendigkeit fordern, von denen der eine ohne den anderen nicht bestehen kann. Es ist die ticfe Überzeugung des religiösen Bewußtseins, daß das Menschengeschlecht eine gemeinsame Schuld zu tragen und zu bïßen hat. Ja, nicht nur das Menschengeschlecht, sondern die ganze Natur ist in diese Schuld verstrickt und ein sichtbarer und fühlbarer Ausdruck dee Schuldigseins. Das große Leiden der Welt ist die Trennung. Die ganze Natur ist durchdrungen von diesem Trennungsweh. Losgerissen ist die Natur rom Ursprung ihres Seins, und der Weg zum Göttlichen ist ihr verschlossen. Alles Leid der Welt ist Trennungsweh. Ein Dualismus besteht zwischen der transzendenten Welt der Äonen und der sinnlichen Natur. Dieser Dualismus, dieser Gegensatz, der das ganze Leid der Welt trägt, verdankt seinen Ursprung einer Sündenschuld. Diese Sündenschuld ist aber nicht in dieser Welt der Zeitlichkeit begangen, sondern geht vielmehr der Welt der Zeitlichkeit voraus. Die Gnosis wird also hingetrieben zu dem Gedanken eines intelligibelen Sündenfalles, eines Aktus der Sünde, der sich im Reich des Ewigen vollzogen hat. und dessen sichtbarer Ausdruck die Natur ist. Wenn die Gnosis dem Reich der Äonen nachdenkt, so stößt sie auf den Begriff des Urgrundes alles wertvollen Lebens, die tiefe rätselhafte Gottheit, an deren Geheimnis nicht gerührt 
werlen darf. Aus ihr ist jene Welt des Transzendenten geworlen, die charakterisiert wird als die Welt der Wahrheit und Vernunft, des Lebens und der ewigen heiligen Gemeinschaft. Jene Welt der Werte, an der auch der Mensch seinen Anteil hat. Am Ende dieser Aonenreihe, welche die religiöse Phantasie des Gnostikers erschant, an der Grenze des himmlischen Reiches, steht ein Prinzip, las er ouçi, nennt: es ist die sehnsïchtige Liebe nach Erkenntnis, der Wunsch, das Rätselhafte, Dunkle und Unbekannte der Gottheit in dentlicher Gestalt zu verstehen und zu lieben, die Sehnsucht, das Mysterium zu enthïllen, die tragische Schuk der Erkenntnis. Tragisch ist diese Schuld, weil ihr schmerzvolles Leid in der Notwendigkeit des Weltgeschehens und anf uralter Wertfeindlichkeit ruht. Das Spekulative muß sich gegen das religiöse Geheimnis versündigen, aber dieser Form der Schuld erwächst ein newer Wertcharakter, las Tragische als eine Form des Schönen.

Diese sündige Erkenntnisliebe, lie keine Grenzen und kein Maß halten kann. dies unendliche Streben der Liebe ist schuld an der Trennung der Welt. Un der Erkenntnislicbe und der sündigen Sehnsucht willen trat der Gegensatz in die Welt. Dieses grumllose Streben der siundigen Weisheit wird mit dem Sturz in die Endlichkeit gebüßt. Und so entsteht uns clie Natur, die der sichthare Ausdruck dieser geheimen sündigen Sehnsucht, dieser großen Erkemntnisliebe ist. Die Bäche sind die 'Tränen der Weisheit, und die gegen den Himmel starrenclen Felsen symbolisieren ihr schmerzliches Erkennen. Die sanze Natur, wie sie sich ror uns ausbreitet, ist ihrem innersten Wesen nach erstarte Sehnsucht.

Der Sinn der Geschichte aher besteht darin, den starren Bann der Natur zul lösen und die Welt wieler zul Gott zurtickzuführen. Diese welterlösende That ist das Werk der göttlichen Termunt, des heiligen vo's. Immer mehr wird die heilige Geistesmacht den starren Widerstand der schuldhaften Welt brexiegen, die Irrationalität der sïndigen Sehnsucht läutern und alle Trennung ïherwinden. Ton dieser großen Tat cler Erbösung ist niemand ausgeschlossen: der ganzen Welt soll sie zuteil werden. Die Geschichte ist der Prozeß, durch den diesiindige Welt geläntert und zu Gott zurïckgeführt wird. Die Natur bedentet Entfernung und Abwendung von Gott, die Geschichte Rüickkehr und Vereinigung mit Gott.

b) Die, ,wissenschaltlicher sinngebung.

Ganz anders jene Simngebung, die das spekulative Bewußtsein aus der firchichte vollzioht. Der logische Wert kann aber als Form des philosophischen mol wissensehaftliehen Bewubtseins sich mit der Geschiehte verbinclen. Als beispiel einer spezialwissensehaftlichen und spezicll naturwissensehaftlichen simgehming mag die Geschichtsphilosophie von luguste Comte gelten ${ }^{\mathbf{1}}$ ). Jor Sinn der Geschichte ist hier der fortschreitende ProzeB positivistisoher Silfurelklärung. An Anfang der Geschichte ist die Natur für den Mensehen

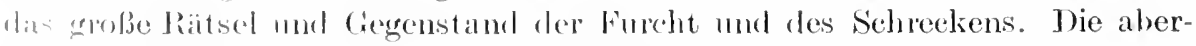

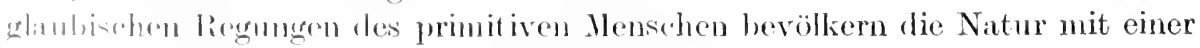

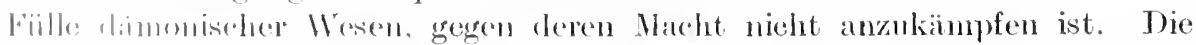

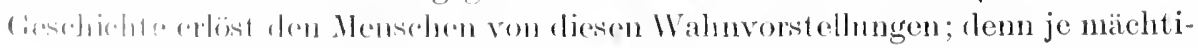

1) Anguste 16unte, Cours de philosephie positive. 
gersein Wissen wird, um so mehr erkennt er, daß diese Torstellungen von Göttern und Dämonen, welehe die Natur beseelen, vollkommen unhaltbar sind. Die Logik des Menschen klärt die Natur auf. Sie maeht das Chaos wilder Naturgewalten, das Reich des Wunders und der Willkür zu einer bekannten und wohnlichen Stätte, die einer ruhigen Gesetzmäßigkeit unterliegt. Sie macht den Mensehen, wenn aueh nieht zum Herrn der Natur, zum Gott der Erde. wie es der naturwissensehaftliehe Enthusiasmus der jugendfrischen Renaissance gehofft und erwartet hatte, so doeh zu einer kraftrollen Potenz, die wirksam eingreifen kann in das Naturgesehehen und ihrer GesetzmäBigkeit nieht mehr hilflos und bedingungslos unteriegt. Denn die Erkenntnis der Gesetze zwingt sie in den Dienst und Nutzen des Menschen. Das alver, was uns der Natur überlegen macht, ist die Fahigkeit unseres Geistes zu immer höheren Abstraktionen. Und so ergeben sich naeh Auguste Comte drei Starlicn in der Entwicklung des Mensehengeschleehtes, die ebenso vie'e Stufen der logischen Virtuosität bedeuten: der theologische, der metaphysische und der positive Zustand.

Für den Positivismus ist der Sinn der Geschichte gleichberleutend mit einem relativen Wissen ron der Natur. Theologie und Metaphysik, die sich ein absolutes Wissen ron den letzten Dingen ammaßen, haben nur ein Nichtwissen. und Unwissen. Um stabile Gesellschaftszustände anf Grund einer einheitlichen Weltansicht zu schaffen, sollen die Gesetze der Naturwissenschaft kanonisiert werden. In der positivistisehen Religion erstart die Naturwissenschaft zum Dogma, und die Kunst soll das große positivist ische Dogma ron der Mensehheit als dem großen Wesen rureh Schönheit verklären. So ist die Naturwissensehaft für Auguste Comte die einzige Wissensform, alles andere ist mur ein Almen, Deuten. Umdichten und Verklären des rorliegenden Wissensinhaltes.

\section{c) Dic philosophisch-theoretische Sinngebung.}

Für Hegel ist der Simn der Geschichte das absolute Wissen rom Absoluten $\left.^{1}\right)$. Dieses absolute Wissen ist hegrifflicher Natur und nur in der Philosophie, in seiner rollkommenen Reinheit aber lediglich in der Logik zu finden.

Wertroll ist das Wissen ron der Natur, wichtiger das Wissen des Geister. ror allem aber das Wissen des absoluten Geistes. Diese Erkenntnis läßt die Gesehiehte hinter sich und geht über alles Endliche hinaus, sie läßt die durch den sittliehen Wert beherrschte Sphäre der Kultur weit hinter sich zuriick. Je wertroller der Gegenstand, um so mäehtiger das Wissen. Das Absolute ist das Ziel aller sehnsüehtigen Erkenntnis. Alle Erkenntnis leitet zum Ahsoluten hin, und ron der Erkenntnis des Absoluten geht alle Gewißheit aus. Kunst, Religion und Philosophie sind die drei Wissensformen des Absoluten. In der Kunst weiß ich das Absolute in der Form der Anschaunng, in der Religion in der Form der Vorstellung, in der Philosophie in der Form des Begriffes. Der Apoll ron Belvedere bedentet ebensowohl ein Wissen rom Göttichen wie die Vorstellung der Trinität. Die Religionsphilosophie und Kunstphilosophie wäre nun ihrerseits wieder ein begriffliches Wissen ron einem unbegriffliehen Wissen. Dies begriffliche Wissen tritt aber hinzu, sofern dic

1) Hegel, Enzyklopädie. 
Philosophie deutlich zu machen versteht, wie sich in Kunst und Religion ein unbegriffliehes Wissen mit Vernunftnotwendigkeit zu immer höherer Form in Ansehauung und Torstellung erhebt. Und so bringt die Universalgeschichte den großen Gang der Erkenntnis zurDarstellung, die sich in niederen. und höheren Wissenssphären zu einem immer reineren Verstehen des Absoluten und Göttlichen unter Aufhebung des Endlichen entfaltet.

\section{d) Die moralische Sinngebung.}

Hören wir nummelir Kant und seine Sinngebung des historisehen Prozesses. Alle reale Erkenntnis, alle fruchtbare und erfolgreiche Erkenntnis dieser unserer Wirklichkeit unterliegt den Grundsätzen und Prinzipien der Erfahrung.

Unser theoretisehes Wissen von den Gegenständen der Natur vollendet sich in den mathematisehen Naturwissensehaften. Und die Prinzipien dieser Erkenntnis sind so besehaffen, daß sie nur in der Besehränkung auf die Formen unserer Endlichkeit, auf Raum und Zeit, Macht und Wirksamkeit besitzen und darïłser hinans jecles angebbaren Sinnes entbehren. Die Kausalität und das Gesetz sind die Prinzipien dieser unserer Welt. Aber die Bedingungen des Naturgeschehens sind gefestigt. Eine höhere Ordnung der Dinge, die von dem theoretischen Bewußtsein der wissenschaftlichen Erkenntnis niemals eingesehen werden kann, ist für das sittliche Bewußtsein unabweisbare Forderung und unbezweifelbare Realität. In dem Erlebnis des Sollens ist eine höhere Wertorlnung der Dinge verbürgt. Und nur aus dieser Wertordnung heraus ist der Sinn der Welt zu verstehen. Die historisehe Welt widerstrebt der exakten naturwissenschaftlichen Erkenntnis. Hier handelt es sich um einen Prozeß, der die an sieh wertlose Natur zu einer wertvollen macht, der die Natur über sieh selbst hinausführt. Jenes Ziel aber, da die Natur nieht mehr Natur ist und dureh die Idee der übersinnliehen Welt überwunden wird, ist erreicht, wemn die Mensehheit sich so weit von der Natur emanzipiert, daß sie den Gedanken der freien und autonomen Persönliehkeit verwirklieht.

Anfangs lag die Mensehheit in den Banden der Natur und wurde durch ihre sinnliche Triebhestimmtheit rüeksichtslos beherrseht. Die Leidensehaften hielten die Individuen fest in der Ordnung des bloßen Seins. Aber ebendieselben Jeidenschaften, die der Grund unserer Niedrigkeit sind, sie werden auch gleichzeitig der Grund unserer Größe. Denn lurch die Leidenschaften entfaltet sich ،lie ungehenre Bewegung der historisehen Welt. Die Leidensehaften werden zu Triehferlem des historischen Gesehehens. Die Mensehheit vollzieht den Abfall yom der Natur. Sie tritt aus der natürliehen Gebundenheit, dem Stand der Unschuld heraus. Das ist die Sehuld des Mensehengesehlechts, dalj es den Stand der Natur verlassen hat, nm ein Reich der Kültur und Vernunft zu erstuchen. In seinem tierisehen und sinnlichen Dasein war der Honsch thue schmkl, als vernïnftiges 1 tesen ist er sehuldig geworden. Seine irhmlal ature bülst er mit lem Verzicht auf das Glïek des sinnlichen Daseins. Jie Kultur maelnt das Menschengeschlecht nieht glüeklicher, aber sie gibt ihm eim Anfgabe les Handelns, nach deren lirfüllung sich sein Wert bestimmt. lnel so) ist der grolue Sinn des historisehen Geschehens nach Kant das Werden ler antomomen l'ersönlichkeit, die in dem lingen und Kämpfen um große kinlturzicle withlst und wird. 


\section{e) Die ästhetische Sinngebung.}

Es könnte so scheinen, als ob im Tergleich mit den erwähnten Formen der Geschichtsphilosophie die ästhetische Deutung zurïckstehen müßte, weil sie am wenigsten an den letzten Sinn der Geschichte rïhrt. Die Geschichte als Offenbarung göttlicher Schönheit, die Geschichte als das Epos im göttlichen Geist gedichtet, als das große Drama der Darstellung Gottes in der Welt, das alles kann leicht als ein romantischer Ïsthetizismus aufgefaßt werden, wie das schöne Wort, das schöne Bild über den Nangel an wahrem Wertverständnis hinwegtäuscht. Deswegen müssen wir auf das Problem hindeuten, das hinter der ästhetischen Geschichtsphilosophie eines Schelling gesucht werden mu $B^{1}$ ). Das Berechtigte einer ästhetischen Geschichtsphilosophie liegt vor allem darin, daß sie die augenscheinlichen Kontraste des Lebens, den Gegensatz von Sinn und Unsinn, von gut und böse am leichtesten überwindet. Mit einem Worte, weil ron ihrem Standpunkt aus eine Versöhnung des Rationalen und Irrationalen am leichtesten denkbar erscheint. Ton ihrem Standpunkt aus ist das höchste Prinzip, das die Religion als Gott bezeichnet, ganz anders zu verstehen wie in der religiösen Geschichtsphilosophie oder in ihrer spekulativen und ethischen Form. Das wesentlich andere aber liegt darin, dals das Absolute oder die Gottheit gänzlich unbekümmert ist $u m$ das Schicksal des einzelnen, da das einzelne ihm Mittel ist und nicht Selbstzweck. Nach der religiösen Auffassung kommt es darauf an, daß die Sünde der Welt gebüßt und das einzelne erlöst wird. Nach der spekulativen Auffassung soll die dunkle Irrationalität durch das Licht der vollendeten Erkenntnis durchleuchtet werden. Die dunklen, verschwiegenen Wege sollen lant und hell werden. Das Rätsel von Tod und Leben wird uns gelöst. Die Lösung der Rätsel ist die spekulative Form des Erkenntnisgedankens. Und die ethische Geschichtsphilosophie? Hier handelt es sich um das Werden der ethischen Persönlichkeit, um die Erlösung von der Sinnlichkeit der Natur und der Indifferenz. des Naturhaften.

In der ästhetischen Geschichtsphilosophie ist das einzelne nur da, um den immer höheren Ruhm des Ganzen zu verkünden. Gewiß, das Kulturgeschehen ist reich an Leiden, wenn wir uns auf den Standpunkt des einzelnen Inrlividuums stellen, aber vom Standpunkt des Ganzen aus schwindet dieses Leiden, wird es sogar ästhetisch wirksam, tragisch und damit sinnvoll. Tom ethischen Standpunkt aus muß ich imner wieder fragen: wozu das Unrecht? Wozu ror allen Dingen das Leiden der Unschuldigen, das den sittlichen Menschen empören und den Anwalt des Göttlichen und Menschlichen Iran Karamasow zu dem paradoxen Bekenntnis kommen läßt: ,Gott muß ich anerkennen, aber seine Welt nehme ich nicht an."

All diesen Schwierigkeiten vermag die ästhetische Geschichtsphilosophie zu entgehen. Die große Entwicklung des historischen Lebens ist nur unter dem Gesichtspunkt des Schönen zu verstehen. Die großen Kriege empören das sittliche Bewußtscin, denv sie kultivieren das Unrecht dles Tötens, das weder die Heiligkeit des moralischen, noch des rechtlichen Wertes dulden bis 1804 .

1) Vgl. hierzu mein Buch: Schellings Gesehichtsphilosophie in den Jahren 1799 
kann, aber wer wollte das ästhetisch Imposante des kriegerischen Enthusiasmus leugnen? All die furchtbaren Grausamkeiten und Opfer ler Weltgeschichte, ror denen Religion und Sittlichkeit zurïckbeben, an denen teilzumehmen der Gedanke der Terantwort lichkeit uns erbleichen macht, sie alle sind versöhnt und ausgeglichen, wenn die Geschichte nichts anderes bedeutet als ein spiel, wenn wir die Geschichte in das Zeichen des ästhetischen Wertes rücken clürfen. Das Spiel ist immer ïsthetisch relerant. Das Spiel hat anch einen Simn, aber clas Eigentümliche dieses simmes liegt darin, daß er nicht ernst genommen werden larf - wohl tragisch, aber nicht wirklichkeitsernst. Große Künstler haben ihr eigenes Leben so angesehen und große Denker das Weltleben unter diesen Gesichtspmnkt gestellt. Schon Plato spricht von dem großen Trauerspiel und Lustspiel des Lebens, schon Heraklit verherrlicht den spielenden Aion. Schelling hat die Geschichte ästhetisch zu denten versucht und ihr dabei die höchste kïnstlerische Würcle zugesprochen. Im Anschluß an Schillers Geschichtsphilosophie faßt er die Entwicklung des Menschengeschlechtes als den Wreg ron der mbewnßten Schönheit des natürlich-sinnlichen Lebens zur bewußten kïnstlerischen Beherrsehung aller Lebensverhältnisse. Die Anfänge des Menschengeschlechtes und die antike Welt erscheinen unter dem Gesichtspmkt der natürlichen Schönheit als der Einheit vor der Trennung. Dann krmmt die tragische Epoche des Abfalles, der Zerstörung jener ursprïnglichen Einheit. Die letzte Epoche, die dem Menschengeschlechte bevorsteht, ist eine Wiederherstelhng der verlorenen ursprünglichen Einheit in einer höheren, bewnBten Einheit. Diese ganze Entwicklung sucht Schelling aus dem Wesen und ler Natur des Kunstwerkes zu rerstehen, das selber eine solche Einheit nach der Trenmung belcutet. Wir können diese Gedanken hier nur flüchtig anteuten, sehen aber bei allen Cberspannungen eine Wahrheit in lem Gedanken, daß in gewisser Hinsicht nur die ästhet isehe Sinngebung mit dem Lehen und mit dem Tode fertig werlen kam.

\section{Problem einer umfassenden und einheitlichen Sinngebung.}

J)an rerschiedenen möglichen Simngebungen des historischen Lebens :regenïber erwächst fiir jele Lniversalgeschichte die Aufgabe, die Versehiedenhoit d.es Simnes zu einem gemeinsamen sinn zu verbinden, was erst dann geschehon kamm, wemn wir mos hesonnen haben, was die einzehen Kulturwerte in ihrer simgehemelen Funktion für die Gesehichte bedenten, welche Dentungsmöglichkeiten das religiöse, othisehe usw. Bewubtsein im Verhältnis zur Geschirdite besitzt.

Survel ist aber von vomberein dentlieh, dals eine cinseitige Sinngebung, of wa unter dem Aspekt des ethischen oder wissensehaftlichen Bewubtseins, drom Problem der Eniversalgeschichte nicht gereeht zu werten vermag; denn

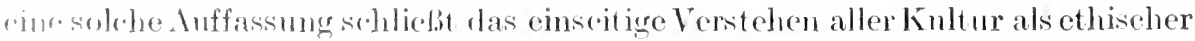
odro wiscmsedaftlichor Kultur in sich. Wis ist das genau so einseitig, als wollto man otwa den (iesirhtspmnkt rler Kunst gesehichte oder der Religionsgeschichte \%om absulut dominicrenten madhon um die Behamptung vertreten,

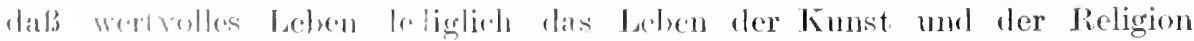
sei, mul lats alles andere leben mur insofern Bedentung habe, als 
ein Reflex jenes wahrhaften Wertlebens auch auf andere Formen des seelischen Erlebens und Beziehens fällt. Der Begriff einer Kultureinheit selber, den die historische Beurteilung voraussetzt, bedentet bereits eine Überwindung dieser partikularen und einseitigen Auffassung. Kultur bedentet für die Historie den Inbegriff alles wert vollen Lebens, und vor der Idee der Kultur erseheinen Wissenschaft, Kunst und Religion als gleiehwertige Glieder. Mag anch, miversalgesehiehtlich betrachtet, sich eine gewisse Verschiedenheit der Wertformen im Verhältnis zur Zeit offenbaren, so ist damit doeh nieht eigentlich eine Auszeichnung der einen Wertgruppe vor der anderen, sondern im Grunde genommen nur ein Gegensatz konstatiert. Die Werte verhalten sich versehieden zur Zeit, für einige Wertformen ist die Idee des Endzweekes relevant, für andere nicht. Daraus ergiht sich dann weiter, daß die Idee des Endzweeks nicht das konstitutive Prinzip für alle Kulturformen hergeben kann, daß also die Idee der letzten Werteinheit nicht mit dem Begriff des Endzwecks zusammenfällt, der nur für die Entfaltung des sittlichen, staatlichen, rechtlichen, wissenschaftlichen und wirtschaftlichen Lebens, also für die im eminenten Sinne sozialen Werte maßgehend ist.

Immerhin muß es als Aufgabe der Philosophie erscheinen, den Gedanken der Kultureinheit, der in der Historie so unbestiumt bleiht. und der alles St reben, Leisten, Schaffen, Formen und Billen in gleicher Weise bejaht, zn einer Werteinheit zu vertiefen, die nun erst allen Kultubetätigungen ihr besouderes Recht zugestelit, ihre gegenseitigen Beziehungen enthïlt und einen Gesamtsinn offenbart, der auf festgesctzter Ordnung ruht. Dabei wird sich zeigen, daß diese letzte Werteinheit, die wir meinen, nicht nur den Gedanken der Kuntureinheit rertieft, sofern sie ihren tiefsten simn offenbart, sondern gleichzeitig auch an inhaltlichem Bedenten ïber dies Prinzip der Historie hinausgeht, was damit zusammenhängt, daß die Universalgeschichte nieht nur die Vollendung der Geschichtsphilosophie, sondern anch die Vollendung aller Philosophie überhaupt bedeutet, und zwar besonders deshalb, weil sie den Gegensatz philosophiseher und wissensehaftlicher Fragestellung in höherer Einheit aufhebt, weil sie die Idee des Unsystematischen mit dem Systematischen versöhnt und endlieh jene Antinomien und Gegensätze, anf denen jerle einzelue philosophisch-systematisehe Disziplin anfgebant ist, und die in ihrer reinen nnd abstrakten Form unversöhnlieh sind, als konkrete Gestalten und Typen des historisehen Lebens einer Versöhnung entgegenführt. Der systematischen Philosophie fehlt die Bewegung, der Naturwissenschaft der Wert, der Geschichte der Systemgedanke. In der Tniversalgeschiehte ist das Wertsystem auf lehendiges Geschehen bezogen. Sucht doch die Universalgeschichte dentlich zu machen, wie die in sich ruhende Wertordnung anch wirkam seiu kann in den Gestalten des historischen Geschehens. Liegt doch ihr wor allem auch der Gedanke am Herzen, daß das Ringen und Kämpfen der Persönlichkeit um Erkenntnis und Erlenehtung und Erlösung nicht a priori ein aussichtsloses und hoffnungsloses sein muB, daß erst das Ende der Geschichte die Wahrheit zu bringen vermag und die Wirkliehkeit des Schönen un die Einswerdung mit dem Göttlichen. In dem Gedanken der absoluten Werte wahrî sie die Freiheit der Persönliehkeit, in dem Gedanken der objektiven Werte das Recht der Notwendigkeit.

Mehlis, Geschichtsphilosophie. 
Und endlich jener harte Gegensatz der Prinzipien, auf denen jedes Kulturgebiet ruht. Immer widerstrebt der Inhalt in seiner bloßen Gegebenheit der rationalen Form, und die bloße Zuständliehkeit des Seins empört das Sollen, und das Endliche steht dem Unendlichen rätselhaft gegenüber, und das Material und bloß Bedeutungsmäßige widerstrebt der Bildung und Gestaltung; aber jedes große Kunstwerk versöhnt das Material und den bloßen Bedeutungsgehalt mit den formfrohen Stil und der Tiefe der ästhetisehen Idee, in den Werken des religiösen Genies gelangen Magie und Mystik zu einer Einheit, und selbst der harte Kampf von Pflieht und Neigung ruht wohl vorübergehend in dem Kunstwerk sittlicher Bildung. Und so ist der Sinn der Geschichte wohl nicht nur die Erlösung des Wertvollen von dem Wertindifferenten und Wertfeindlichen, noch das absolute Wissen und Verstehen, noch die vollendete Rechtsordnung unter den Menschen, sondern vielmehr die Versöhnung - nicht etwa die Aufhebung und Tilgung - jener Gegensätze, darauf die Dialektik der versehiedenen Kulturgebiete ruht, und in denen ihr eigentiimliehes Leben besehlossen ist.

\section{\$ 3. Das dritte Problem der Universalgesehichte: die universalgesehicht- liche Konstruktion und die Idee einer absehließenden philosophischen Disziplin.}

Eine geschichtsphilosophische Konstruktion hat mit dem Vorgehen der systematischen Philosophie dies gemeinsam, daß sie sie sich auf den Grundgegenastz besinnt, der das betreffende Kulturgebilde konstruiert. In der Philosophie und speziell in der Logik ist das etwa der Gegensatz von Form und Inhalt, der ja auch wohl den anderen Disziplinen der Philosophie untergelegt wird, aber seine eigentliche Heimat in der Logik hat. Jede Logik wird in ihrer Analysis der Wirkliehkeit von diesem Gegensatz ausgehen und festzustellen suchen, wieriel Wirklichkeitsgehalt wohl dem Denken oder der Form und dem Denkfremalen ${ }^{1}$ ) oder dem Inhalt zukommen möge. In der reinen Sphäre des Begriffes kann dieser Gegensatz nicht versöhnt werden, wohl aber wird er überwunden in der Gestalt des Systems, das ihn nicht zum Schweigen, aber zur Versöhnming führt. Jeller einseitige Empirismus oder Rationalismus kann ron vornherein als ein verfehlter Versuch bezeiehnet werten; denn ein Problem wird nicht gelöst, indem man den einen Hauptfaktor als quantité négligeable betrachtet. Die Geschichtsphilosophie der Philosophiegeschichte wirl daher zu zeigen haben, daß der frlealismus es ist, der von allen Gestalten des philosophisehen Bewubtseins bisher den vollkommensten Versuch einer Versöhnung des Gegensatzes von Form und Inhalt geleistet hat, indem or cin System bildete, das sowohl den Forderungen unserer Vernunft wie anch unserem sinnlich-irchischen Wirklichkoitsgefïhl entspricht.

Indem mun die Philosophie von System des ldealismus ans diese Konstruktion versucht, wirl sie den Vorstufen ihrer relativ höehsten Erfülung

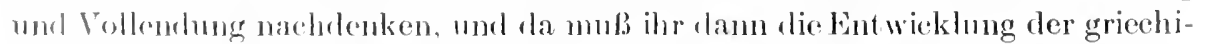

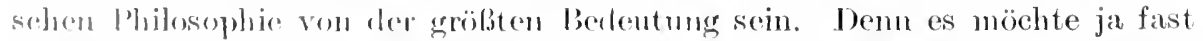
so sclurinan, als ob die buwegung, die das Ganze der Mensehheit ergreifen

y) Cohn, Voranssetzungen und Zielo der Erkenntnis. Leipzig 1908. 
soll, schon einmal die Seele des griechischen Volkes erfaßt hätte, als ob es das Los der Menschheit sei, nachzuleben, was Griechenland vorgelebt hat. Gewiß aber hat die Entfaltung des theoretischen Denkens dort eine Stufe erreicht, die uns die Möglichkeit gibt, von der Philosophie eines Pla to oder Aris to teles aus das Frïher und Später der philosophischen Bewegung zu ordnen und zu verstehen. Ende und Anfang zugleich bedeutet des A ris to teles großes System. Von ihm aus wird man am besten wïrdigen können, was einst gewesen und was werden sollte. Unser Interesse nimmt aber vor allem die Entwicklung der Logik in Anspruch, weil das philosophische Bewußtsein in ihr am prinzipiellsten zum Ausdruck gelangt. Die Philosophie der Kunst und die ästhetischen Theorien der verschiedenen Zeitalter werden wir in erster Linie für die Entwicklung des ästhetischen Bewußtseins in Anspruch nehmen, während uns Ethik und Staatsphilosophie einen Einblick in das moralische Bewußtsein der Völker gewähren können. Wir vertreten zugleich die Auffassung, daß die theoretisch-philosophische Bewegung den Charakter eines Zeitalters und einer Menschheitsepoche so entscheidend bestimmt, daß alle anderen Gestalten des Kulturlebens ihr großes und ruhiges Licht reflektieren, indem wir es dahingestellt sein lassen, ob die philosophischen Gedanken in ihrer systematischen Bindung und Fesselung durch die anderen Geistesbewegungen erzeugt und gebildet werden, oder ob vielmehr umgekehrt der Kulturcharakter ein Resultat rler philosophischen Ideen ist. Jedenfalls ist es rollkommen angemessen, wenn eine universalgeschichtliche Konstruktion den theoretischen Wert als die eigentliche Dominante des Kulturgeschehens betrachtet.

Was dann den Wahrheitsgehalt unserer Konstruktion betrifft, so ist, dieser natürlich relativ, sofern jede Problementscheidung eine einseitige Hervorhebung gewisser Denkformen und Denkmotive anf Kosten der anderen bedeutet. Jede Urteilsentscheidung tıit dem Ganzen unrecht und läßt dort, wo das Allgemeine ruhig und bedingungslos herrschen sollte, das Persönliche eintreten. Die Zuruickhaltung des Urteilens ist die weltfremde Forderung einer müden Skepsis, aber sic erhält einen gewissen Glanz, wenn wir bedenken. daßsie vor der Verletzung und Sünde gegen das einzelne bewahrt. Jede Systembildung ist eine rohe Gewalttat, doch was als moralisches Unrecht erscheint, ist theoretische Größe. Die Stellung und Ordnung der Probleme kann als derjenige Teil philosophischer Untersuchungen betrachtet werden, wo eine gemeinsame Anerkennung denkbar und möglich ist. Wir können gemeinsam lernen, die Probleme zu sehen, wir werden eine Problemstellung als einleuchtend und ïberzeugend empfinden; wenn aber die Entscheidung gefällt wird, rlamm müssen sich die $W^{r}$ ege trennen. Nicht als ob wir behaupten wollten, daß die große theoretische Systementscheidung zwecklos und sinnlos sei und das Persönliche nichts für die Wahrheit leiste. Wir meinen viehmehr, daß allen großen Systemen der Philosophie ein unverlierbarer Wabrheitsgehalt zukomme, und daß wir das Allgemeine nur verstehen können am Abglanz der Persönlichkeit. Aber die Taten der Versöhnung, welche die Philosophie zu vollziehen vermag, reichen nicht an die selige Vollendung heran, die dem Kunstwerk eigentümlich ist. Hier ist immer vollkommen erfïllt, was dort nur teilweise gelungen ist.

Wir hatten die Versöhnung von Form und Inhalt ganz allgemein als die Aufgabe des theoretischen Bewußtseins bezeichnet. Das Problem der Philo- 
sophie muß in gewisser Hinsicht anch das Problem des wissenschaftlichen Beиา ßtseins sein. Hier tritt uns der Gegensatz in Form und Inhalt als das Verhältnis des Allgemeinen zum Besonderen entgegen, der in dem Widerstreit ron Naturwissenschaft und Kulturwissenschaft sich spiegelt, von denen jene das Allgemeine und diese das Individuelle zum Gegenstand der Erkenntnis erhebt. Für die Naturwissenschaft gilt es, daß nur im System Wahrheit sei. Die Geschichte muß die Wahrheit des Unsystematischen behaupten. Die Geschichte behauptet das ewig Nene, die Naturwissenschaft das ewig Alte. In der Richtung der Geschichte liegt angenscheinlich die Idee der Freiheit, in der Richtung der Naturwissenschaft die Naturnotwendigkeit. Denn die Gesehichte fordert die Anerkennung freier, zwecksetzender Wesen, eine Forderung, die für die Naturwissenschaft sinnlos ist. Ferner sind die naturwissenschaftlichen Gesetze an die Idee einer beschränkten Wirklichkeit gebunden, während für die Geschichte die Unendlichkeit des nferlosen Geschehens maßgebend ist. Wir sehen also, daß gewisse einander widerstreitende Vernunftsbegriffe an Naturwissenschaft und Geschichte verteilt sind, daß sie unter dem Aspekt entgegengesetzter Kategorien die Wirklichkeit zu begreifen suchen, und daß die Nöglichkeit und der Erfolg ihres Fortschreitens durch die Vernachlässigung des Gegensatzes erzielt wird. Innerhalb der natırwissenschaftlichen Sphäre ist (ler Gegensatz vielleicht aufzulösen. Vielleicht' ${ }^{1}$ ) ist es möglich, alle anorganischen und organischen Erscheinungen der Natur dereinst von einem naturwissensehaftlichen Grundgesetz aus zu begreifen, aber die Antinomie zwischen dem historischen und naturwissenschaftlichen Denlien ist a priori unauflösbar.

Die Antinomien als Gegenstand der Universalgeschichte geben der Philosophie cinen nenen und eigenartigen Aspekt. Fïr K ant waren sie ein erkenntnistheoretisches Problem, das durch den transzendentalen Idealismus gelöst werlen konnte, fiir Hegel in der Hauptsache ein Problem der reinen Logik, das durch das Prinzip, der Dialektik iiberwunden werden soll. Doch muß der Hegelsche Lösungsversuch in der Logik als rollkommen verfehlt betrachtet werten. Jede Synthese der Hegelschen Logik ist ein hoffnungsloser Versuch der C'herwindung und keine Lösung. Die seheinbare Rationalität geht in Irrationalität unter. Für das endliche Bewußtsein entspringt hier keinerlei einsichtswolle Erkenntnis. Der Weg der Dialektik bleibt rätselhaft und unbegreiflich, und die ursprïnglichen Gegensaitze sind nur scheinbar beseitigt, in Wahrheit hieben sie in ihrer ganzen Herlogkeit und schroffheit hestehen. Nein, nicht in sler Logik kömnen diese gewaltigen und räitselhaften Antinomien iiberwunden werlen, wie iiberhange cine rationale lösung ihrer Unbegreiflichkreit durch ansgekliggelte Konst ruktionen mmögrieh ist. Aber die Gesehichte ist das weite Reich, wo Göttliches und Menschliches an der Arbeit sind, um in groben lacistungen mol behöpfungen den schuncrzliehen Gegensatz zu versïhnen, den die Yermunft in ihrer Dialekt ik offenbart. Dieser Gegensatzliegt min

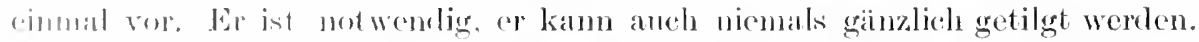

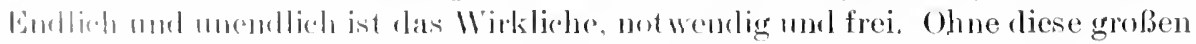

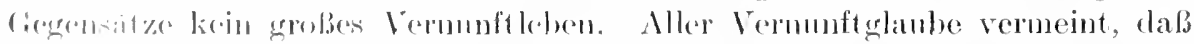

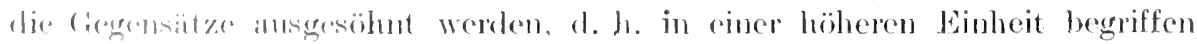

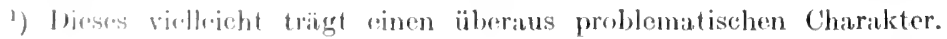


werden können, nicht etwa, daß sie getilgt werlen sollen, ansgelöscht in Gleichartigkeit. Es seheint aber, als ob unserem analytischen Denken diese große Synihesis ewig verborgen sei. Das endliehe Bewulstsem ist analytiseh. und nur das göttliehe kann wahrhaft synthetiseh gedacht werlen.

Wie ist nun das Verhältnis der Universalgeschichte zu den anderen philosophisehen Disziplinen und zur Wissensehaft zu denken? Alle Philosophie ist systematisches Wissen, auch die Geschichtsphilosophie. Die Gesehichte selber aber ist die spezifisch unsystematische Wissenschaft, zu ihrem Wesen gehört das Fragmentarisehe, das Unbegrenzte. Niemals wird sie imstande sein. den Kreis der historisehen Urteile zu schließen. Die Lniversalgeschichte aber ist das systematisehe Wissen rom Unsystematischen. Das weist auf ihre Aufgabe hin, das Antinomienproblem einer Lösung entgegenzufïhren. Wie das Leben des einzehen den Widerspruch ïberwindet. so versïhnt die Lniversalgeschichte die Antinomien des Geistes, nicht in der Weise, daß sie eine logische Auflösung des Antinomienproblems zu geben vermöehte, sondem in der Universalgesehiehtesind die Antimomien ausdrïcklich an die Irrationalitiat und an die Unendliehkeit des historischen Prozesses rerwiesen. Die Cnirersatgeschichte hat es so mit den Antinomien als den unlöslichen Aufgahen der Vermunft zu tun. Man kann sagen, daß sie es sind, welehe der Universalgeschichte das einheitliche Prinzi] geben. Diese eigent ïnlichen, notwendigen und starren Verhältnisse des Gegensatzes, zu denen alle Erkenntnis in letzter Instanz getrieben wird, sie weisen auf das höchste Prinzij) der Philosophie und rler philosophischen Geschichte hin.

In gewisser Weise scheint dabei die Universalgeschichte den Gegensatz von Naturgeschichte und Geschichte zu rersöhnen. Das ewig Gleiche. das die Naturwissenschaft sucht und in der Form des Gesetzes zu begreifen unternimmt, hier erscheint es in der Form der ewig gleichen Werte. Und jenes ewig Nene, das die Gesehichte meint, erst hier wirt es vollkommen rerstanten als der immer nene Sinn des historischen Lebens.

Die Romantik hat die Kimst als das Organon der Philosophie bezeiehnet, als das Doknment ihrer Wahrheit mm Wirklichkeit. Wir möchten viehmehr der Geschichte diese Bedentung beimessen. demn die Geschichte liefert den Beweis dafür, daß die Prohleme der Philosophie ewig und notwendig sind. Cberall, wo in der Geschichte der Gesensatz ron Rationalismus und Irrationalismus herrortritt, handelt es sich nm das Form-Inhalt-Problem. No wir ron Tniversalismus und Intivinualismus sprechen, kündigt sich das Verhältnis des Allgemeinen zum IBesonderen an. Und so leben in den mannigfaltigen und reichen Formen des Kulturlehens die letzten großen logisehen Antinomien, die jene spannmesterhälnisos erzengen, ohne welche die historische Wirklichkeit nicht bestehen kann.

Fïr Kant waren die Antinomien in der Hauptsache nur ein naturphilosophisches Problen. Die kritische Philosophie setzte sich nit ihnen anseinander und suchte ihre Schärfe teils durch den Gedanken eines möghiehen Dritten, teils durch Verteilung auf rersehiedene Gebiete zu ïborwinden. Hegel meinte, daß die Logik anf alle Antinomien eine Antwort zu geben remöchte. Das war ein Irrtum. Aber er hat die Erkemntnis vorbereitet, daß in der Antinomie die Einheit ron Wissen und Nichtwissen hegt. Wir wissen die Antinomie. 
aber wir wissen nieht ihre Lösung. Es bedarf des Rätselhaften und Problematisehen um unserer Aufgabe und Bestimmung willen. Diese Deutung drängt sich uns unwilkürlich auf, wemn wir auf das große Vermunftgesetz des Antinomischen schauen.

In der systematisehen Philosophie treten uns die Antinomien als letzte notwendige Toraussetzungen entgegen. Wissen wir doeh, daß keine Kunst sein kann ohne das Spanmungsverhältnis ron Form und Inhait, von Freiheit und Notwendigkeit. Die Antinomie ist auch das Gesetz der Werte, da ja der Gegensatz auch die Versehiedenheit der Werte trennt. Die Geschichte trägt diese Gegensätze in sich. Sie reflektiert nicht ausdriicklich darauf. In der Universalgeschichte werden die Gegensätze ausdrücklich gedacht. Durehsie wird der Charakter der Geschichte geändert demn die Historie ist nun nicht mehr das friedliche Reich der Wertverwirklichıng sondern der Schauplatz für den Kampf der großen Vernunftantinomien, in denen alle Wahrheit ruht. Keine philosophische und wissenschaftliche Reflexion remag dureh dialektische Kunsigriffe rliese Gegensätze zu einer Einheit zu versöhnen. Keine Synthesis des endliehen Geistes hebt diese Antithesis anf. Die wahren Antinomien sind, weil sie ein Letztes bedenten, ebenso unïberwindlich wie die Werte, die keine Unterordnung duklen. Die Behautpung der Lösbarkeit der Antinomien ist ähnlich paradox wie der Versuch, die Versehiedenheit der Kulturwerte einem höchsten Werte unterzuordnen. In beiden Fallen handelt es sich um das Bestreben. eine Rationalisicrung und Relativierung am Absoluten zu vollziehen. 


\section{Zweiter Teil.}

\section{Die Geschichte der Geschichtsphilosophie.}

\section{Einleitung.}

Die Geschichte der Geschichtsphilosophie in kritischer Absicht bildet selbst ein eigentümliches Problem. Wir haben die Probleme der Geschichtsphilosophie in dem ersten Teile unseres Werkes vom modern kritischen Standpunkt aus auseinandergelegt. Wir übersehen nummehr ihre Gliederung, die Teilprobleme, zu denen wir hingeführt werden, wenn wir dem philosophischen Simn der Geschichte nachdenken. Wir haben dadurch die Möglichkeit gewonnen, zu den Antworten, welche die Vergangenheit auf das Problem der Geschichtsphilosophie gegeben hat, kritisch Stellung zu nehmen. Wir können die Vergangenheit an der modernen Problemstellung orientieren. Dabei ist unser Hauptblick nach wie ror auf die Universalgeschichte gerichtet. weil ja in ihr die Geschichtsphilosophie sich vollendet und selbständig und autonom wird. Als Geschichtslogik und als Prinzipienlehre dient die Philosophie dem Verständnis der historischen Wissenschaften. Als Universalgeschichte nimmt sie erst eine eigentümliche und nene Gestaltung gegenüber der Wirklichkeit an.

Augenscheinlich ist diese Geschichte der Geschichtsphilosophie selber keine rein historische Betrachtung, da ja in ihr nicht alles zur Darstellung gelangen soll, was mit Rücksicht auf die Weiterbildung geschichtsphilosophischer Probleme wichtig ist, sondern nur die großen Hauptlinien dieser Bewegung, die zu einer kritischen oder idealistischen Geschichtsphilosophie hinführen, die sich anf einem Srstem der Werte anfbaut. Es wird roransgesetzt, daß der Sinn der Geschichte auf der Verwirklichung allgeneingültiger Werte beruht, deren GesetzmäBigkeit selber in dem Prinzip eler Antinomie liegt, die jede Wertwirklichkeit ergreift und zwischen den einzehnen Wert. gebilden einen Gegensatz anfrichtet, der in der reinen Systematik nie gan\% ausgetragen werden kamn, aber in den Gestalten oder Typen des Kulturleben. konkrete Wirklichkeit gewinnt und num in dem Schatten dunkler Irrationalität einer Entscheidung entgegengeführt wird. Somit ist die Geschichte der Geschichtsphilosophie, welche wir hier zur Darstellung bringen, systematisch orientiert und somit eine Geschichtsphilosophie der Geschichtsphilosophie, scheinbar ein Paradoxon, daß jedoch anflösbar ist und eine Verwandtschaft mit gewissen Problemen der Logik hat. Ein wichtiger Teil jeder Logik, die Nethodologie, beschäftigt sich mit den Formen des spezifisch wissenschaftlichen Denkens. Nun ist aber doch auch die Philosophie ein theore- 
tisches Gebilde, das eine gesicherte Methode hat oder doch haben sollte. Folglich können wir uns eine Untersuchung über die philosophische Methode denken. Diese Untersuchung wäre selber Methodologie, sofern sie die Frage nach den Formen des philosophischen Denkens erhebt. Da nun alle Methodologie unter den Begriff der Logik fällt, so kommen wir mit Notwendigkeit zu dem Problem einer Logik der Logik. Etwas ähnliches liegt in der Geschichtsphilosophie der Geschichtsphilosophie ror. Wir postulieren eine philosophische Betrachtung aller Geschichte, also auch der Philosophiegeschichte. Einen Tril der Philosophie bildet num auch die Geschichtsphilosophie, folglich muB es eine Geschichtsphilosophie der Geschichtsphilosophie geben. Die Geschichtsphilosophie, die der Vergangenheit angehört, wird hier systematisch orientiert und auf die moderne Auffassung einer Philosophie der Geschichte rom Standpunkte der Wertphilosophie bezogen. Allerdings rermag in der Darstellung spezialphilosophischer Probleme der Gestaltenzug der Philosophie nicht rein und groß zu erscheinen, weil dic besondere Form, welche die Wertidee gewimnt, sich ror allem in den großen systematischen Zusammenhängen einer philosophischen Lehre offenbart und in den Spezialproblemen nuw schwach nachdämmert. Es gilt in dieser Hinsicht die Auffassung Hegels und des ganzen deutschen Idealismus, anch in der Übertragung ans der politischen Geschichte in die philosophische Geschichte, daB der Weltgeist nur in den großen Begebenheiten ruht. Unsere Darstellung wird daher nicht den Charakter ciner philosophischen Konstruktion, sondern einer kritischen Darstellong tragen.

Die Giliederung mserer Darstellung der geschichtsphilosophischen Entwicklung hat Rücksicht zu nehmen anf die Entfaltung und Bildung der einzolnen Probleme und muB deswegen problemgeschichtlich sein. Die leitenden Gesichtspunkte aber sind in der vollendeten Geschichtsphilosophie, in der Eniversalgeschichte zu suehen. Dabei kamm nur das Große mnd Prinzipielle Berieksichtigung finden. Wenn nun anch das ordnungsprinzip unserer barstellung in der Hauptsache das Problem hergibt, so kömen wir doch die Enfüllung des geschichtsphilosophischen Gedankens in den großen Epoehen der Menschleitsgeschichte nicht unhetont lassen.

Es bieten sich für die Entwickelung des geschichtsphilosophischen Gedankens drej Hauptalsschnitte dar:

1. die Geschichte seines Werclens bis zu seiner Entfaltung in der christlichen Patristik.

2. lie Geschichte seiner Entfaltung bis zu seiner Vollendung in der Geschichtsphilosophie des dentsehen Idealismus.

3. dir Gesehichte seiner Vollendunge.

bie Geschichte des Worelens ist die Geschichte eines langsamen Wath-ros mol lieifons, die sieh fast mbemerkbar in aller stille vollzicht. Wir würden

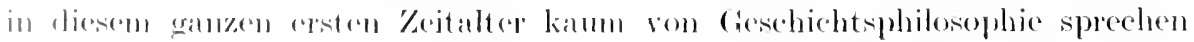

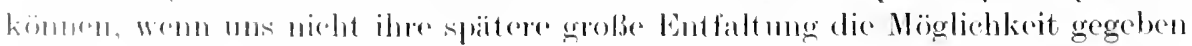

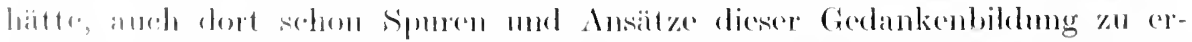

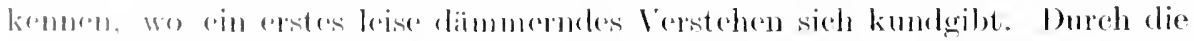

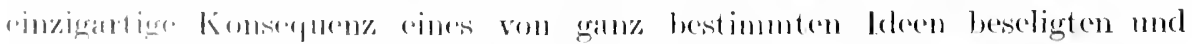

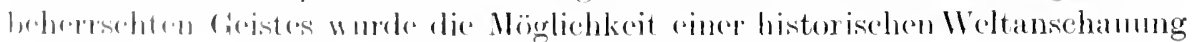


bei den Griechen verhindert. Dann bildet sich die historische Weltansehaunng in der christlichen Patristik und speziell in der Gnosis. Der Aspekt, unter den die Geschichtsphilosophie hier tritt, ist der rein religiöse. Die Gesehiehtsphilosophie entfaltet sich an der religiösen Wertidee. Diese einseitige Betonung einer religiös historischen Weltanschammg führt zur Gegnerschaft in der Renaissance und Aufklärung, bis dann die croße Zeit des dentschen Idealismus eine allseitige Entwicklung und Vollendung der geschichtsphilosophisehen Idee herbeiführt, deren Wirksamkeit in der morlernen Bewegung des Nenidealismus nachtönt. Den großen Bildnen des geschichtsphilosophischen Gedankens gegenüber rerhält sich die moderne Bewogng anfnehmend und kritisch zugleich und strebt danach, die grandiose Einseitigkeit der spekulativen Lösungen, die dort gegeben sint, dureb eine möglichst allstitige Erfassung und Durchdringung der historischen Wirklichkeit zu rersöhnen.

\section{Erstes Kapitel.}

\section{Das Werden des geschichtsphilosophischen Gedankens in dem griechischen Kulturkreise.}

a) Die Idee des Griechentums.

Wenn es sich um das Werden eines Gedankens handelt, so wissen wir sogleich, daß nun bald der Name Hellas genannt wird, und wemm wir diesen Namen hören, so unterliegen wir immer einem Zauberbann. Die in jeder menschlichen Seele ruhende Sehnsucht nach Sehönheit faßt uns dam gewaltsam an und wir fürchten ihr zu unterliegen. Hin- mol hergestoßen, nach den resschiedensten Seiten gewendet sind die Völser und Zeiten durch die Idter des Griechentums. Man hat diese ferme Kultur gehal bt und rerachtet und damu anch wieder tief und sehmerzlich geliebt. Der römische Kaiser Julian und der deutsche Diehter Hölderlin haben beite mit ihrer heiBen sude den Gedanken des Griechentums ergriffen und wollten es wieder haben. weil sie nur mit ihm leben konnten. C'nd wenn der Kaiser die gricehischen Gö̈ter und ihre Priester zurückrief und die festliche Schönheit antiker Labendremde wiederzugewimnen strebte, so stchte der junge Dichter dieste rorlorente schöne Welt mit all den herrlichen Gestalten, dic sie dereinst herölkerten, in der Welt der Phantasie, im Trammland der Kunst wieder zu arweeten, bis (‘) an dieser großen Sehnsucht und Liebe dahinstart).

Gegenüber gewissen Zeiten und Persönlichleiten. die das Griechentum nicht nur reridealisierten, dem diese reridealisierende Funktion ist nun einmal ron der Tätigkeit des Künstlers und des Historiker's unablösbar, sondern vielmehr vergötterten, macht sieh in unsarem Zcitalter wieder eine son mehr nïchternen Erwägungen beherrschte stellungnahme gegeniiber der griechischen Kultur geltend. Man will ror allen Dingen dem griechischen Tolke seine Ausnahmestellung nehmen. Es soll ein Volk wie andere Völker gewesen sein. Man sträubt sich, in den Hellenen das Genie unter den Vöhern zu sehen. 
man läßt dunkle Schatten auf diese Züge fallen, an deren strahlender H lligkeit man sich einst berauschte. Dieses Volk soll nicht der Schöpfer von Philosophie und Kunst gewesen sein, es hat für sie gewirkt als ein Volk unter anderen Völkern. Auch war ihm jene Freudigkeit nicht eigen, die nach der Auffassung seiner Verehrer aus ewiger Jugend und starkem Schönheitsgenuß emporwachsen sollte. Jene hohen Götterbilder lasten unter dunkler Schwermut. und häufig klingt aus hellenischer Dichtung ein Klagelaut des Schmerzes zu uns herüber.

Wenn nur jene düstereu Schatten, die in der modern historischen Betrachtung auf den Götterbildern der Hellenen ruhen, nicht zum größten Teil der Melancholie unseres modern nordischen Empfindens entspringen, so daß wir in jenem Schönen und Fremden unser eigenes trübes Antlitz erschauen, wenn nur jene Minderschätzung ihrer Kulturleistung sich nicht vielleicht weniger als Resultat eines ruhig abwägenden Urteils ergiebt, das auch den anderen Völkern gerecht werden möchte, sondern viehmehr als Äı Berung eines gewissen Mißbehagens und einer Feindschaft gegenïber dem Wunderbaren und Außerordentlichen! Wir glauben, daß dem so sei, wenn wir auch bis zu einem gewissen Grade die Korrektur anerkennen, die das I9. Jahrhundert am Bilde des Griechentums rollzogen hat. Daß aber dieses Volk nicht nur in gelassener, freudiger Haltung zmm Bildner eines einzigartigen Lebens geworden ist, sondern daß es anch von großen Leidenschaften durchwüht und zerrissen war, und daß es anch ein Verständnis besaß für den Schmerz und die Sinnlosigkeit des Lebens, das alles kann uns diese geliebten Züge nur noch teurer machen.

Eine philosophische Betrachtung der geschichtsphilosophischen Entwicklung steht nm aber diesen Volke gegeniiber vor der unleugbaren Tatsache, daß jenes hochbegahte und verstehende Volk das große Gebiet des historischen Lebens, das für die modeme Philosophie eine Quelle so wichtiger Anregungen bildet, nicht rerstand und auch nicht verstehen wollte. Und so stehen wir demn gleich am Anfang vor der Frage, wie es möglich war, dab das Griechentmm an den Problemen der Geschichtsphilosophie im allgemeinen rorïborgegangen ist?

\section{h) Ias (harakteristische des griechisehen línlturbewuBtseins.}

Man kïnnte viclleicht meinen, daß dic Bildung der historisehen Wissenshaften in jence Zeit noch zu wenig vollendet war, als daß die geschichtsphilosophische Spekulation mächtig einsetzen konnte. Gewib. die Gesehichte war damals trot\% aller Größe und Bedeutung der antiken Historiker noch nicht zol einel reinen Wissenschaft herangereift. Aber das gilt in ganz ähnlicher Wrise anch für die Naturwissenschaft, obwohl doch hier die naturphilosophische Sipeknlation so miachtig cinsetzte. Wenn sich die Kunst der Gesehiehtsforsehung vorband und die groben Leistmugen ihrer Darstellung mit dem Zauber der Sirbonheit schmürkte, so folgte dir Naturwissensehaft dem großen Zug der Hetaphysik mol lag gan\% in ihren Banden. Ws ist nicht so ohne weiteres einzusehen. weshalb die vohialtnismäBig große Reifo der historisehen Forsehung

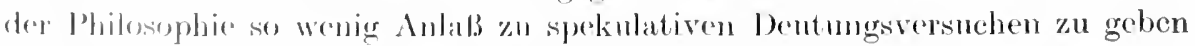

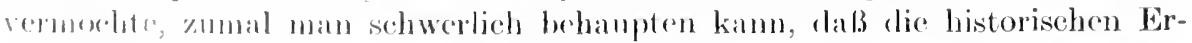

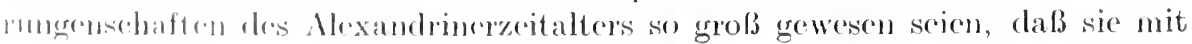


einer gewissen Selbstrerständlichkeit zu geschichtsphilosophischen Konzeptionen führen mußten.

Untersuchen wir, welches stillschweigende Vorurteil diesen Erwägungen zugrunde liegt, so ist es wohl die Annahme, daß die Entfaltung irgendeines Zweiges der Wissenschaft oder der Kultur sogleich die Aufmerksankeit des philosophischen Denkens auf sich lenken müsse. Diese Vermutung wird hier noch verstärkt durch die Annahme, daß dem griechischen Tolke ein allseitiges Verstehen und Interesse eigentümlich gewesen sei, und es tritt die Tatsache hinzu, daß damals alles wissenschaftliche Leben in einem innigen Zusammenhang mit der philosophischen Reflexion sich befand. Aber diese Toraussetzung. welche man wohl als ein regulatives Prinzip der Geschichte bezeichnen mag. unterliegt doch auch wiecler sehr notwendigen Einschränkungen. Gewiß, man kann wohl im allgemeinen sagen, daß das Aufblühen des wisscnschaftlichen Lebens die philosophisehe Spekulation auf sich zieht, und daß die Theorie an der Theorie erstarkt. Und doch können wir auch immer wieder beobachten, daß philosophisch gerichtete Zeitalter, die ron dem Drang nach Synthese getrieben sind, mit anderen Epochen abwechseln, in denen das spezialwissenschaftliche Interesse der Einzelforschung vollkommen überwiegt. So folgt auf das Zeitalter der großen griechischen Metaphysik ein Zeitalter des Spezialistentums in der alexandrinischen Epoche, so ging der große Zug umfassender Spekulation, wie er im deutschen Idealismus und in der Romantik sich offenbarte, in der wissenschaftlichen Kleinarbeit des 19. Jahrhunderts verloren. Noch weit weniger trifft es dam zu, daß jede mächtige und große Form des Kulturlebens sogleich das philosophische Interesse auf sich ziehen muß. Die Gegeninstanz hierfür bildet die griechische Kunst und die griechische Religion, von denen die erstere sehr spät und die letztere nur in sehr beschränkten Grenzen der philosophischen Spekulation unterworfen wurde. Die philosophische Spekulation der Griechen kennt keine große Form der Kunstphilosophie und Religionsphilosophie. Und doch lebten beide damals ein gewaltiges Leben: die Kunst ein sichtbares und die Religion ein rerborgenes nud unsichtbares Dasein. Stand num etwa der griechisehe Philosoph der Kunst und der Religion feindlich gegenüber? Wir wissen, daß Denker wie Protagoras. Aristipp und Demokrit den Wert der Religion remeint haben. Xenophanes hat sich gegen den Schönheitskultus seines Volkes gewendet, und gewiswe Formen der Kunst sollten im platonischen Staate keine Stelle haben. Denken wir den Gründen nach, so kommen wir zu der Vermutung, daß liemächtige, ron leidenschaftlicher Liebe zum Begriff erfüllte Philosophie der Grieehon in der Religion und Kunst Gegner erblicken mußte, die wie sie selber ron den Bestreben erfüllt waren, eine Weltanschanung zu bilden. Nur daB diese Wultanschauung nicht durch den Begriff erhellt werden sollte, sondern in der dunklen und undurchsichtigen Sphäre der Anschauung und der Vorstellung verblicb. Wenn die griechischen Philosophen in der Form des Begriffes das Höchste und Wertrollste erblickten, dam mußten sie wohl ron einer gewissen Feindschaft gegen das Irrationelle in Kunst und Reỉgion erfüllt sein. Wir kömnen das aber auch anders rerstehen. Es brauchte nicht eigentlich Feindschaft zu sein. Plato, der Größte mnter ihnen, war ja im Grmnde genommen ein leidenschaftlicher Liebhaber des Schönen, wie auch die Mrsterien der Religion ihn 
auf das imigste bewegten. Vielleicht erschien den Philosophen Griechenlands die Macht des Irrationalen in Kunst und Religion gar zu groß, als daß sie auch nur den Versuch gewagt hätten, jene Unbegreiflichkeiten dem strengen Gange logischer Deduktionen zu unterwerfen. Und so blieben jene beiden für sich. Die Religion führte ihr unsichtbares geheimnisvolles Leben in den Mysterienkulten und die Kunst ein absoht sichtbares und offenkmoliges Dasein in den Wimderwerken des Marmors und der Dichtkunst. Die Kunst hatte aber anch the Geschichte in ihren Bannkreis gezogen und entzog sie dadurch der philosophischen Durchdringung. Die Philosophie wollte die Welt anders sehen als die Kunst und die Religion: schärfer und dentlicher und bestimmter. Sichöne Bilder, Symbole, VerheiBungen und Gleichnisse konnte sie nicht anerkennen - und die Anschanung muBte sie zerstören. Weit entfernt aber war die griechische Hetaphysik ron cler Frage, was dem so ein ganz andersartiges Eingestelltsein gegenüber dem Universum zn berleuten habe, wie es zu verstehen sei.

So ist as dem der griechischen Philosophie in der Tat nicht gelungen, las Ganze der Kultur der philosophischen Erforschung zu unterwerfen. Ja, man muß sogar sagen, daß die Philosophie der Gricehen ron dem Gedanken einer allseitigen Kulturphilosophic etwa in Sime Kants sehr weit entfernt war. Die griechische Philosophie war weit mehr eine Philosophie der Natur und des lebens als gerade der Kultur. Was letztere betrifft, so beschäftigte -ich die Philosophic in der Hauptsache nur mit dem theoretischen Sinn des wiscuschaftlichen Denkens, sowie mit Recht, Horalitä, Erziehung und Redekinust.

Diesc Einseitigkeit der griechisehen Philosophie, die sich in der Vernachläsigung so bedentender Kulturfragen clokmmentiert, gibt den antiken Sysemen rin hohes Mab ron Einheitliehlseit mol Geschlossenheit. Weil das antike Denken unhistorisch war, deshalb besab es die Möglichkeit, zu einem grechlosenem System zu gelangen, in dem alles anflewahrt schien, was der philosophischen Durehdringung zugänglich war. Weil das philosophisehe Bewnstein der Antike den Gegensatz nicht kannte, der sogar in der Sphäre des theoretiseh-wisensehaftliehen Denkens in dem Antagonismms ron Ge-rhichte mol Naturwisensehaft sich kumblgibt, gerade deshalh remochte es

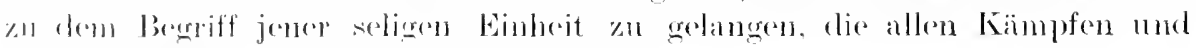
allere Solmoneht vollkommon entrïclit ist.

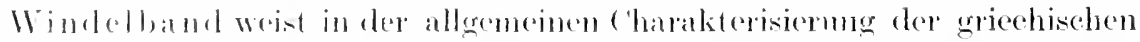

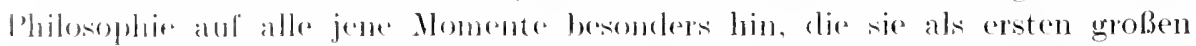

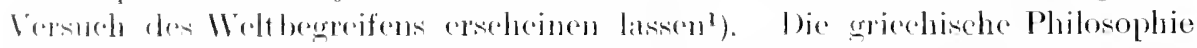

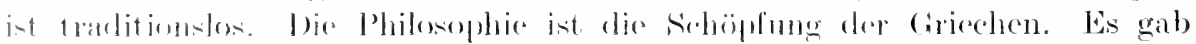

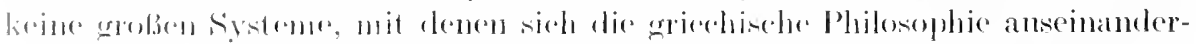

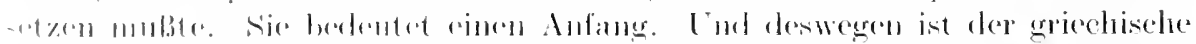

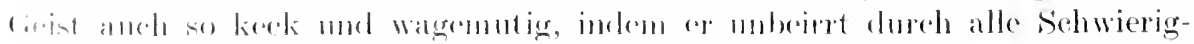

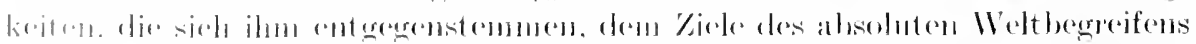

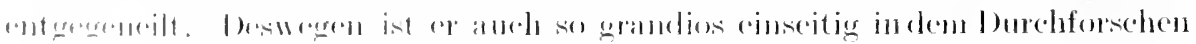

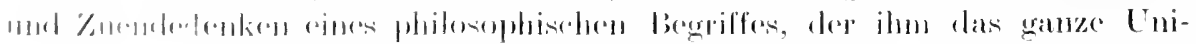

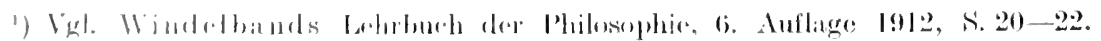


rersum deutlich und rerständlieh maehen soll. Das Wesen dor Welt ist das Sein. oder das Werden, oder das Lngeteilte, oder des ewiq Teilbart. es ist das Absolute oder das Relative. Es ist Harmonie oder Gegensatz oder beides gleiehzeitig. Alles. was dem leitenden Begriff des srotems widerstreitet. gilt als mwirklich. Für den Eleaten ist das Werden Illu-ion und Trug. für den Relatiristen das Absolute. für den Atomi-ten das Teilbare. für Anaxagoras das Lnteilbare. Wenn man so die Philosophie der Griechen als Philosophie des Anfangs betrachtet. dann läßt sich wohl rerstehen. daf die geschichtsphilosophische spekulation in diesen Volke über die ersten Anfänge nicht hinaus kam.

Da die griechische Philosophie keine Geschichte hatte, so konnte sie auch nicht über ihre Geschichte philosophisch reflektieren. und sie schaltete zum mindesten die Philosophiegesehiehte aus dem Kreis der reschiehtsphilosophischen Probleme aus. Aber das antinomische Verhältnis zur Geschichte. das für die griechisehe Philosophie so bezeiehnend ist. wird uns noch deutlieher, wenn wir einmal der eigentimlichen Struktur des einzigartigen griechischen Kulturbewußtseins naehdenken.

\section{c) Die Bewertung des Allgemeinen.}

Wir wollen der Natur des griechisehen Kulturbemßtseins nur so weit naehgehen, als es sich in der Philosophie offenbart. Gewiß kömen wir seint Wertungsweise aneh ummittelbar an den politisch-sozialen. ethischen. ästhetisehen und religiösen Phänomenen erkemnen: aber da es sich für uns un die Frage handelt, warum der Geschichte in Griechenland eine philosophisehe Deutung nieht zuteil geworden ist. so können wir das griechische Wertbewßsein ans seiner Philosolhie zu rerstehen suchen. sofern wir es hier mit einer eigentümlichen Begrenzung der Reflexion zu tun haben. Wir müssen sor ufältig auf alles achten. was den besonderen Charakter der grieehischen Philosophie gegenüber den Philosophien anderer Zeitalter bedingt, und da die großen systeme der griechischen Philo-ophen. die das Zeitalter beschließen. die Motive und Gredankenbildungen des Anfangs mehr oder meniger in sich aufgenommen haben. kommt es un ror allem auf diese srsteme an. deren relative Universalität die Mögliehkeit gibt. uns über die Crenzern und Einseitigkejt des hellenischen Denkens Pechenschaft zu geben. Achten wir num auf das Besondere dieser Peflexionscestaltung. so int es vor allen der Kultus des GattungsmäBigen. Trpischen und GesetzmäBigen. die ums hier in die Augen fällt. Diese Wertung de- Gattungsmäßigen al- des Allqemeinen kommt ebensowohl in der Philosophie der ioni-chen Natmphilosophie wie auch in der Ideenlehre Platos zum Ansdruck. Gedenken wir Heraklits. Er hat die cers:s bestimmt dem Grunde des Wesens nach als ewior lebendige Berregung, flüehtig wie Zeit. fließend wie Waser und in der Hastigkeit mul Plötzlichkeit ihres Wirkens der züngelnden Flamme gleich. dem leuchtenden Fener, das höchste Lebendigkeit mì Geschehenstärke und gleichzeitig auch simmolles Streben und remünftiges. Tum bedeutet ${ }^{1}$ ). Diese Bewegung ruht

1) Tgl. Diels. Fragmente der Torsokratiker. Desgleichen Diels, Heraklit. Bernars: Abhandlungen. Ed. Pfleiderer. Die Philosophie des Heraklit ron Ephesus. 
a uf dem Prinzip des Gegensatzes, der alle Welt beherrseht, und verläuft in vollkommen geordneten, gesetzesbestimmten Bahnen, Das Fließende und Flüchtige der Natur wandelt sich und steigt empor von niederen zu höheren Stufen des Seins. Schwer und mühsam ist jenes Geschehen, das der naive Mensch als Sein der Erde versteht, frischer und leichter des Wassers Form, selig des Feners Bewegung. Die Gesetzmäßigkeit der Elemente aber verlangt diesen Weg und diesen ewig gleichklingenden Rhythmus, daß Erde zu Wasser und Wasser zu Feuer werde und daß des Feuers Form dureh des Wassers Gestalt zur irdischen Erscheinung zurückstrebe. Immer aber müssen die Wandlungsstufen in gleichen Verhältnissen geordnet sein. In einem ganz bestimmten, unüberschreitbaren Verhältnisse tritt Erde dem Wasser und Wasser dem Fener entgegen, und immer sehreitet die Bewegung denselben Gang.

So lehrt Heraklit die ewige Wiederkehr aller Dinge nach des Gesetzes Macht. Immer wieder steigt das Irdische und Sterbliche zu höheren Lebensformen empor, mm dam aus seiner Göttlichkeit und Schönheit in niedere Sinnenform zurückzukehren. Nicht steht etwas Göttliches über des Gesetzes Kraft, sonderu Sterbliches und Unsterbliches sind ihm gemeinsam unterworfen und bei diesem gleichen Schicksalsanteil auch nicht prinzipiell von einander geschieden. Nit voller Klarheit formt sich so bei Heraklit der Gedanke, daß das Gesetzmäßige, das ewig Wiederkehrende, der immer gleichmäßige Rhythmus des Geschehens das Wertrolle und Schöne sei. Heraklit verneint die Nöglichkeit und Wirklichkeit des bloßen Seins, das Dasein eines Dinges, welches auch nur für einen Augenblick unveränderlich bliebe. Alles ist in unaufhörlicher Veränderung begriffen. Es ist Torheit, zu sagen, daß nur die Erscheinming des Dinges sich rerändert, sein Wesen aber nnveränderlich bliebe. Auch das Wesen ist ergriffen von des Geschehens Macht. Und cliese große Bewegung, in der sich die Welt auswirkt, bejaht Heraklit mit Genugtumng und Froude. Aber ohne Regel und Ordnung würde ihm der Weltenlauf erschcinen, wenn die Bewegung nicht in sieh zurückkehren und somit zur Geschlossenheit gelangen würde. Wemn in inmer fremdem und neuem Geschehen sich das Lniversum offenbarte, dann würde die denkende Betrachtung der Welt zu keinem Zicle gelangen. Immer Neues und Unrorgesehenes würde der Woltauf bringen. Dann wäre das Denken, in dem doch nun eimmal unsere höchste Lust liegt, gar klein und gering. Dann wäre es wohl selber veränderlich und somit ohne Wahrheit. Ind so kommt das Denken erst zur Ruhe und vernatg sich selber Glauben zu schenken, wenn es von der GesetzmäBigkeit der bewroung mel von der ewigen Wiederkehr aller Dinge äberzengt ist. Und der Gerbanke dieser ewigen Wieckerkehe aller Dinge, der nach dem Vorbild der lythagoriischen Lehe bis in das Kleinste durehgedacht wurde, so daB schlirblich jeder Mensed in ein und derselben Gestalt wiederkehren und jecle Situation sich wiedroholen sollte, ar hatte fïr den griechisehen Geist angenwhroulinh nichts Sohreckliches und Furehtbares. Da dieser sehöne und helle

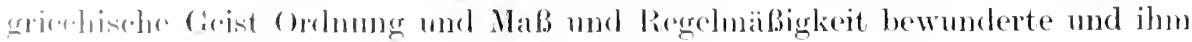

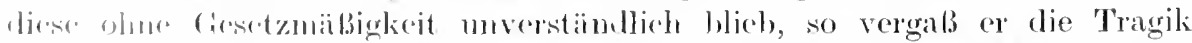

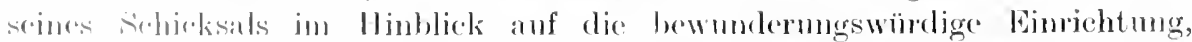

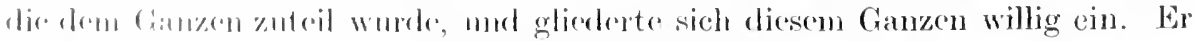

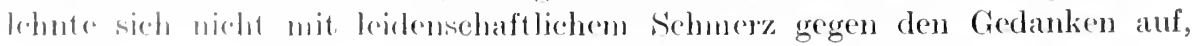


daß dem Wechsel der Jahreszeiten gleich auch seine Blüten und Früchte wechseln und wiederkehren müßten. Er trieb den Gedanken der Wiederkehr so weit, daß er meinte, es müsse im Werden des Weltalls auf Grund derselben Elementenkonstellation immer wieder die Zeit kommen, die denselben Baum, der früher einmal war, mit denselben Früchten bilde.

Und diese Wertung des Allgemeinen zeigt anch die weite metaphysische Welt, die Plato entdeckt hat. Das Individuelle ist dem Wechsel unterworfen und kann nicht zur Ruhe kommen. Auch für die schönste Gestalt des sinnlichen Lebens, für die menschliche Individualität, gilt dieses Gesetz des Wandels und des Wanderns. Nur die Gestalten der unsinnlichen Welt, die in sich ruhenden, von aller Qual des Sinnlichen abgeschiedenen und abgelösten Ideen wechseln nicht und verändern sich nicht, sondern bleiben sich immer gleich und treu. Sie sind das Vorbildliche, das Ideal und gleichzeitig auch das Allgemeine als das Gattungsmäßige. Das Schöne und Wertvolle ist das, was der Vielheit der eimzelnen Dinge gemeinsam ist. Nicht auf das Eigentümliche, sondern weit mehr auf das Allgemeine und Gemeinsame ist diese Philosophie gerichtet, wenn auch das, was in der Sinnenwelt so zahlreich und häufig anzutreffen ist, in der übersinnlichen Welt nur einmal vorkommt und darin doch anch eine gewisse Bewertung des Einzigartigen sich kundgibt. Nur das eine Schöne gibt es und das e ine Gute. Wie große unvergleichliche und nie erreichte Götterbilder ruhen die Ideen in der transzendenten Welt.

Nur das Allgemeine und Gattungsmäßige ist wertvoll, weil es Konstanz und Dauer hat, das Individuelle ist dem Wechsel unterworfen und deshalb ohne objektive Bedeutung. Auch die hellenische Kultur ist ein individuelles Gebilde, das zugrunde gehen muß und den Keim des Todes in sich trägt. Nirgends prägt sich diese Úberzeugung Platos durchsichtiger aus als in dem berühmten Mythos von der Insel Atlantis ${ }^{1}$. Es gibt kurzlebige und langlebige Völker. Zu den ersteren gehören die Hellenen, zu letzteren die Ägypter. Diese entwickeln allmählich und sorgsam eine lang anhaltende und verweilende Kultur, jene entfalten in drängender Hast all die reichen und schönen Gaben ihres Geistes, sie finden Jugendlichkeit und sterben den Tod der Jugend, nachdem sie eine kurze Zeit mit der Fülle des Neuen und Schönen geschmückt haben. Der Vertreter des jugendlichen Volkes, das jugendlich bleibt und jugendlich stirbt, der Athener Solon erforscht Weisheit und Belehrung von dem Sohn des alten Volkes, dem Priester der ägyptischen Gotheit. Wir erfahren, daß die einzigartige Tat der Perserkriege, auf welche das griechische Nationalbewußtsein so stolz war, im Grunde genommen nur der schwache Abglanz einer weit größcren Tat des politischen Heroismus gewesen sei, ausgeführt an einem Volke, das einst die athenischen Fluren bewohnte. Damals nahte der Feind von Westen, das mächtige Heeresvolk der sagenhaften Insel Atlantis, weit größer an Zahl als der Perser zahlreiche Scharen, und besiegt und vernichtet wurden sie durch der Athener Vorgänger, die Bewohner einer einzigen Stadt, weit schwächer als die Scharen, die das vereinigte Griechenland den Persern entgegenstellte. Die Insel Atlant is ist im Meere versunken. und furchtbare Überschwemmungen haben auch die Wohnstätten der früheren

1) Vg!. die Darstellung des Timaios. 
Athener zerstört. Aber in den Tempeln ägrptischer Gottheiten sind Dokumente aufbewahrt. welche die alten Gesehichten erzählen.

Was sich aus dieser Auffassung des historischen Geschehens bei Plato ergibt, ist höchst eharakteristisch für die ganze geschichtsphilosophische Auffassung der Griechen. Es gibt keine Kontinuität der Kulturentwicklung, demn die Völker altern und sterben, und alles Geschehen wiederholt sich in ähnlicher und verwandter Form. Das sind alles Behauptungen, gegen die sich das modeme Kulturbewußtsein empört und auflehnt. Demn dieses behauptet einen engen und notwendigen Zusammenhang des Kulturlebens und das Werden des Neuen und Einzigartigen. Immer wieder ist naeh platonischer Auffassung die Kultur der Vernichtung und Zerstörung ausgesetzt, ihr fehlt es an jeder Stabilität.

\section{d) Die Nation als höchster sozialer Wert.}

Gerade die Blüte des Kulturlebens, die schöne Vollendung. sie ist vor allem dureh Vernichtung bedroht. Das Höchste und Schönste ist dem Untergange geweiht. Es wurde so schön, 11 nun bald zu sterben. Kein Ersatz ist vorbereitet, der an die Stelle des verlorenen Volkes treten kömnte, denn die Sehönheit ist doch wohl mersetzlich. Das griechische Kulturbewußtsein kemnt noch nicht die Idee des nenen welthistorisehen Tolkes, das an die Stelle des alten tritt und die überkommenen Ideale und Zielsetzmngen weiter bildet, ihnen eine nene Heimat gibt und ihmen auf newem und andersartigem Boden ein nenes schönes Wachstum crwirbt. Nit der Kraft des schaffenden Volkes müssen auch wohl scine Götter und Ideale sterben. Nur die griechische Seele kann griechische Götter verstehen. Mit dem Meister stirbt anch sein Werk. Denn nur der Meister kamn das Werk offenbaren. Nach seinem Tode wird (es stumm.

End so dachte das Grieehentmm über die Idee der Nation nicht hinaus umcl wollte auch nicht darïber hinausdenken. Daß jenes Vertrolle, was es sclber geschaffen, nach seinem eigenen Untergange einmal für andere Völker Iranchbar und wertroll sein könnte, diese rorstellung konnte ihm nichts bedruten. Der Hellene schätzte sich selber und seine Bedentung für das Ganze viel zu hoch ein, $u m$ mainen zu können, daß seine Nation ersetzlich sei. Vielleicht hiclt sich dereinst jeder Menseh in seinem simnlich-irdisehen Dasein für uncrsctzlich und clamm jedes Volk in seinen ersten großen Anfängen. Plato aber meinte, daß das griechische Volk das verniunftige sei, das einzig zur Staatenbildung befähigte, das Logos-Volk. Was sollte wohl ans der Kultur und Gesehichte der Menschheit wedeln, wemn dieses Volk zugrunde ging?

Wrij den griechisehen Volke die Idee der Menschheit mbekannt blieb. Mril rin gemeinsanes Schicksal der Menschheit ihm ein mgedaehtes und unenolles Zusimmonenfasisen des Terschiedenartigen war, leshalb konnte die Sirekulation der Griechen kroine Geschichtsphilosophie formen. Viel schon g.horito dazn, dals sich das grichische Volls in allen seinen Teilen als Einheit

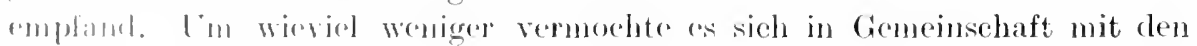

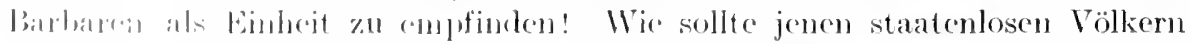

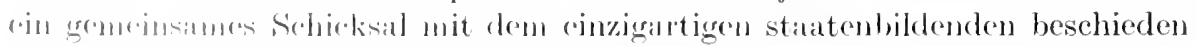
sein! Denn math der griechisehen Vorstellung konnte jenen nienals das zuteil 
werden, was den Hellenen ein für allemal eignete, diese sieghafte, kulturschaffende Vernunft. Jene sind zum Dienen bestimmt, zum Mittel und Werkzeug. Frei und herrschend zu sein ist die Bestimmung der Hellenen.

\section{e) Fehlen des Fortschrittgedankens.}

Wenn nun aber die Idee einer höheren sozialen Einheit, die über die Nation hinausgeht, dem griechischen Volke fehlte, dann mußte auch die Idee des Fortschritts ihm notwendig fremd bleiben. Denn wenn das grichische Denken davon überzeugt war, daß keiner Tolksindividualität Dauer und Bestand beschieden sei und es gleichwohl bei dem Begriff der Nation als höchster sozialen Einheit Halt machte, dann mußte wohl die Idee des Fortschritts ihren Sinn verlieren. Dann entfaltet sich Nation neben Nation, und was die eine leistet, bedeutet für die andere nichts. Wohl steigert sich die eine in ihren Leistungen und bringt dem Geschaffenen und Erworbenen neues Wertvolles hinzu. So scheint sie in sich fortzuschreiten. Aber dieses Fortschreiten in sich hängt an der Vergänglichkeit ihres eigenen Daseins. Die Idee ist hier gebunden an ein einzelnes sinnliches Substrat und kann nicht ron ihm loskommen und muß mit ihm zugrunde gehen. Und so hat der Fortschrittsgedanke keinen wahrhaften Bestand, solange er von der sinnlichen Vereinzelung eines einzigen Volkes abhängig gedacht wird. Seiner Natur ist es angemessen, daß er über die Idee der Nation weit hinausgreift und mit dem Begriff der Völkergemeinschaft und eines allgemeinen Kulturganzen sich rerbindet. Denn was sollen wir von dem Fortschreiten des einen sagen, wenn der Rückschritt des anderen ihm parallel geht und zwischen diesem ,Vor- und Rückwärts" kein sinnvoller Zusammenhang besteht? Das eine kümmert das andere nicht. Sie gehören nicht zusammen. Den Fortschritt können wir nicht behaupten, sondern höchstens sagen, daß hier ein Volk fortschreitet und dort ein Volk zurückgeht. Ist dieses aber der Fall, so läßt sich über die Zeit, über die Epoche, in der diese beiden Völker ihr Schicksal erfahren, nichts Bestimmtes aussagen. Wir können auf Grund der Entfaltung des einen Volkes nicht sagen, daß die betreffende Epoche einen Fortschritt bedeute. Denn wir wissen nicht, welches Volk für den allgemeinen Charakter der Epoche bestimmend ist, welches Völkerschicksal ihr Wert oder Unwert verleiht. Jedes Volk bleibt für sich, und so bleibt die Epoche charakterlos, d. h. ohne philosophischen Sinn. Man kann da nur von historischer Entwicklung reden, indem man dem Leben der einzelnen Nation nachgeht, das Werden seiner Macht und Größe deutlich macht und den Gründen seines Unterganges und Zerfalles nachspürt.

Die Idee des Fortschritts kann dann erst aufleuchten, wenn die Betrachtung der einzelnen Volksgemeinschaft einer Auffassung weicht, die da meint, von der Idee des Ganzen aus Ordnung und Sinn in das Geschehen bringen zu können. Dann ist, wie es scheint, jedes Volk ersetzlich und entbehrlich. Der Sinn des Geschehens enthüllt sich, wenn wir die Toraussetzung machen, daß alles irdisch-sinnliche Dasein der Idee ihren Tribut zollt, die, ron diesem Untergange nicht berührt, der Möglichkeit nach immer neues Leben findet und immer wieder in neuer Gestalt dem sinnlichen Das in die schöne Form ihrer Bildung rerleiht. Ohne den Gedanken eines immer neuen Substrats wertroller Entfaltung kann die Idee des Fortschritts nicht wirksam sein.

Mehlis, Geschichtsphilosopihie. 


\section{f) Rationalismus des Griechentums.}

Und so ist die ganze Weltanschauung des Griechentums vollkommen unhistorisch. Seine Größe und seine Schwäche liegt in der Negation des Geschichtlichen. Seine Größe, weil der griechische Geist, an der Idee der Natur orientiert, zu einer so geschlossenen und absolut fertigen Systematik gelangen konnte; seine Schwäche und Einseitigkeit, weil ein so großes Gebiet menschlichen Lebens wie die historisehe Welt von der philosophischen Durchdringung ausgeschlossen blieb. Auch der historischen, von Naturgesetzen nicht bestimmten Welt eignet ja nach griechischer Auffassung ein erkenntnisfeindliches Moment in Unbegreiflichkeiten und Zufälligkeiten, die sich der wissenschaftlichen Durchdringung verschließen. Soll es eine absolute Erkenntnis der Wabrheit geben, dann muß das Erkenntnisfeindliche herabgesetzt und entwürdigt werden. Dann darf Geschichte nicht gelten, dann darf Geschichte nichts bedeuten. Nur von dem Bleibenden und Dauernden ist Erkenntnis möglich, nicht von dem unruhig Bewegten und immer Neuen. Nur von dem Begrenzten und Endlichen wissen wir, nieht aber von dem Unbegrenzten und Unendlichen. Und so sind jene wertvoller wie diese, weil jene unserer Erkenntnisliebe entgegenkommen, diese aber von der Seligkeit gottschauender Erkenntnis uns ausschließen. Das philosophische Bewußtsein der Griechen neigt immer dahin, das theoretisch Unwertige und Alogische zu rerneinen. Dahin führte es der logische Enthusiasmus und die Sehnsucht nach System und Einheit.

Wie ein Mensch, der die Schönheit liebt, das Häßliche übersehen und vergessen möchte und mit der Maeht seiner Phantasie aus allen Dingen den Zauber des Liebenswerten und Reizenden hervorlockt, oder wie der gottliebende Mensch das Böse aus der Welt fortdemonstrieren möchte, weil es dem Ruhme des Göttlichen feindlich entgegensteht, so hat die schöne griechische Seele die Wahrheit geliebt bis zur Schuld und Sünde, indem sie ın ihren Besitz so leidenschaftlich rang, daß sie in der Verkennung und Verwerfung des Irrationalen dem so sehr Geliebten Zwang antun mußte.

Der Glaube an die theoretische Vermunft war so mïchtig in Griechenland, daf. das philosophische Bewußtsein vermeinte, es sei wohl möglich, die Elemente des Wirkliehen vollkommen und restlos zu ergreifen. Das ist das Vorrecht der Netaphysik, daß sie allein die logisehe Schnsucht zu erfüllen vermag, und wäre es auch nur durch eine Illusion. Und diese griechische Metaphysik ist nun ganz in erster Linie eine Metaphysik der Natur und keine Metaphysik der Geschichte. Die platonischen Ideen verharren in ihrer Ruhe und Abgesehiedenheit gegenüber dem sinnlichen Gesehehen. WohI nehmen die Dinge an den Ideen teil, aber die Ideen nehmen keinen Anteil an den Dingen. Und wenn Aristoteles die Formen des Wirkliehen weit unmittelbarer auf den Inhalt wirken läßt, so nimmt dic Form doch auch wieder gerade in seiner b.hre einen Charakter an, der sie von der Bedeutung einer Wertidee sehr zu

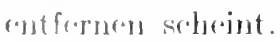

\section{g) Kontemplatives Lehen.}

Mit dor Bewertung des Naturhaften, Begrenzten und Algemeinen, mit dem Kultus der theoretisehen Vernunft geht zusammen eine hohe Bewertung 
des Kontemplativen und eine geringe Auffassung von Tum und Tat. Neben den aristokratischen Vorurteilen des Griechentums gibt sich in dieser Geringschätzung und Ablehnung auch ganz gewiß der geschichtsfeindliche Charakter der griechischen Weltansehauung kund. Denn es ist kein Zufall, daß in der Philosophie Spinozas sub specie aeterni die Welt so starr und bewegungslos erscheint, während die Metaphysik des deutschen Idealismus die Starrheit der logischen Formen zerbricht und den Gedanken der Bewegung und Entfaltung auch mit der Natur des Begriffes verbindet. Der Spinozismus hat das historische Problem nicht beachtet, er hat von naturwissenschaftlichmathematischen Begriffen aus das Universum konstruiert. Die Geschichte ist in ihm nicht aufgehoben und begriffen, sondern beiseite geschoben und als wissenschaftlich und philosophisch unbedeutsames Gebilde verkannt und negiert. Die Wertschätzung der Kontemplation und die Geringschätzung des Tuns weist auf ein ruhiges Reich der Gesetze hin und mißachtet den Schauplatz leidenschaftlicher Bewegung, der in der historischen Welt sich vor unseren Blicken auftut.

Ganz anders die Philosophie des deutschen Idealismus, die das Problem der Geschichte in seiner tiefsten Bedeutsamkeit erfaßt und nicht nur einseitig an naturwissenschaftlichen Begirffskonstruktionen, sondern vor allem auch an dem konkreteren Reichtum der historischen Begriffe orientiert ist. Unter ihrer Herrschaft ergreift die Bewegungsmacht des historischen Lebens die Ruhe und Starrheit der philosophischen Begriffswelt und treibt sie dahin, die Idee der Kontinuität und des ewig Bewegten zum Ausdruck zu bringen.

Diese Werthaltung des Kontenplativen und die Verachtung von Zweck und Tun in dem geschichtsfeindlichen System Spinozas ist augenscheinlich die Erbschaft des Griechentumes an den größten Philosophen der Penaissance. Nicht umsonst hat sich die Philosophie des deutschen Idealismus, welche die neue Weltanschauung zum ersten Mal in umfassender Weise philosophisch begründete, im Gegensatz zum Spinozismus entfaltet. Indem sie zum Gegenbild des Spinozismus wurde, wurde sie gleichzeitig auch zum Gegenbild der antiken Philosophie.

Es ist nur augenscheinlich, daß die Nichtachtung des Tuns, die dem kontemplativen Zuge des Griechentum entsprach, sich auch noch auf einem anderen Gebiete geltend machte, das ähnlich wic die Geschichte Begriffe w ie Tun und Handeln in den Mittelpunkt ihrer Ủberlegungen stellt, ich meine die Ethik. Dies geschah aber in der Weise, daß die ethischen Úberlegungen keine Freiheit erlangten, keine selbständige Behandlung erfuhren, sondern immer von theoretischen Problemkreisen umschlossen blieben.

\section{h) Keine Philosophie der Kíultur.}

Die Orientierung des Griechentums an Naturwissenschaft und Natur ließ sie in ihrem Antagonismus zur Geschichte und Geschichtswissenschaft auch nicht den philosophischen Sinn der Kultur und die Bedeutung der Kulturwerte verstehen. Das klingt paradox, da es sich bei den Griechen um das größte aller Kulturvölker handelt. Aber es ist etwas anderes. Kultur schaffen und Kultur verstehen in dem Sinne, daß wir zum vollen Bewußtsein ihrer Be- 
deutung gelangen. Es liegt wohl etwas Richtiges in der Auffassung Hegels, daß eine Kultur erst dann begriffen wird, wenn die schönen Gestalten des Lebens alt geworden sind. Das Schöne und Lebensvolle begreift nicht und will nicht begriffen sein. Ist aber in Griechenland erst eine große Kultur geworden, so wollte und konnte diese noch nicht zum Wissen ihrer selbst gelangen.

Seltsam ist ja vor allem das große Faktum, auf welches Windelband ${ }^{1}$ ) hinweist, daß das Griechentum erst so spät sich darauf besonnen hat, was wohl das Schöne in dem ganzen Zusammenhang seines sozialen Lebens bedeuten möchte. Erst Epikur hat das Schöne zum Prinzip der Lebensführung erhoben, erst Plotin hat dem Schönen in einem großen System metaphysische Weihe gegeben. Allerdings müssen wir hier unterscheiden zwischen dem Naturschönen, dem Kunstschönen und dem metaphysisch Schönen als Idee des Sehönen. Die Schönheit und Ordnung der Natur wird in der philosophischen Reflexion der Griechen immer auf das höchste gewertet, und die Gestalten jugendlicher Schönheit leuchten mit ihrem heiteren Glanz in die ernste Gedankenarbeit der Philosophen hinein. Und wenn die Platonische Sehnsucht die Idee des Schönen auch noch nicht in ihrer Reinheit zu erfassen vermochte, so hat er ihr doch in seinen Jugenddialog Phädros den höchsten und leidenschaftlichsten Tribut gezollt. Also das schöne sinnliche Gebilde der Natur und das, was jenseits der Welt liegt, sie sind es, welche die Platonische Liebe entflammen, nicht aber das, was zwischen beiden liegt, nicht das Schöne, sofern es in menchlicher Leistung, im Schaffen des Kunstwerkes zum Ausdruck kommt. War es den großen Denkern der Hellenen doch gewiß und sclbstrerständlich, daß das, was Menschenhände schaffen konnten, etwas Relatives und Vergängliches sei. Schön vielleicht für mich und dich oder auch für eine bestimmte Zeit, niemals aber für alle Zeit. Das, was menchlicher Satzung und Setzung entstammt, ist vergänglich und unvollkommen. Niemals hat sich das Griechentum zu einem hohen Pathos menschlichen Leistens erhoben. In dem Kunstwerk glaubte Plato nur cinen schwachen Abglanz des Schöhnen zu schen. Schöner als das Marmorbild ist die lebensvolle blühende Gestalt in dem frischen Glanz jugendlicher Schönheit. Sie erinnert unmittelbar an das Ewige und Göttliche, das Kumstwerk aber nur mittelbar.

Wie die Kunst, so ist auch die Religion und das sittliche Leben nicht philosophisch selbständig gewürdigt. Die Religion blieb im wesentlichen außerhalb der Sphäre des philosophischen Nachdenkens, und das Hauptprinzip der Ethik, die Idee der sittlichen Freiheit, blieb dem Gricchentum unbekannt. Die philosophische Durchlringung der Wissenschaft blicb in ihren ersten Anfängen, nur der Staat und das Precht haben in der Philosophie der Griechen schönste Würrligung und Verständnis erfahren.

Ls ist fast verwunderlich, daß in einem Kulturkreise und bei einem Volke, das seiner ganzen Struktur und Begabung nach der Geschichte so fremd, ja fast feindlich entgegenstand, nun dennoch die ersten Anfänge geschichtsphilosophischer Spckulation sich gelilklet haben, dic dann später mehr oder wroniger für flie ganze folgeentwicklung bestimmend geworden sind.

1) Vut. Lohrbuch, \& 20, ‥ 107 . 


\section{i) Anfänge der geschichtsphilosophischen Spekulation bei den Griechen.}

Am Anfang der griechischen Philosophie erträumt das mythologische Bewußtsein die beiden Formen eines welthistorischen Prozesses, die denkbar und möglich sind. Die alten griechischen Kosmogonien intonieren das Thema der Weltgeschichte. Die Reflexion richtet sich darauf, wie der Anfang wohl war und wie das Ende wohl sein möchte. Da kann man nun in der Tat von einer optimistischen und einer pessimistischen Lösung des Problems durch das mythologische. Bewußtsein sprechen, von einer optimistischen, wenn man auf die Gigantomachien, von einer pessimistischen, wenn man auf die Lehre vom goldenen Zeitalter reflektiert. Nach der ersten Vorstellung stand am Anfang das Chaos und die Herrschaft der ungebändigten und mitleidlosen Naturgewalten. Aus ihnen entfaltete sich siegreich die heitere und schöne Welt der olympischen Götter und stellte Ordnung und Recht an die Stätte ron Willkür, Wildheit und Unrecht. Immer schöner und blühender entfaltet sich die Welt aus dem trüben und dumpfen Anfang. Nach der anderen Auffassung stand am Anfang das goldene Zeitalter der Seele. Schöne und glückliche Menschen im Besitze der herrlichsten Geistesgaben, von einer gütigen Vorsehung geleitet. Aber das Material der Menschen verschlechtert sich, je länger das Geschehen währt, der historische Prozeß ist ein Prozeß der allmählichen Degeneration. Am Anfang waren die Menschen so gottähnlich, je länger das Werden währt, um so gottfremder und unseliger. Nicht zu den Höhen des Geistes führt die Geschichte, sondern zu Untergang und Tod.

\section{k) Problem der beiden Wege.}

Man kann vielleicht sagen, daß in diesen Vorstellungen des mythologischen Bewußtseins schon jenes Problem angeschlagen ist, aus dem der geschichtsphilosophische Gedanke hervorwuchs, sofern er in dem allgemeinen Gedanken des Weltwerdens eingebettet war, und das man wohl am besten als das Problem der beiden Wege bezeichnet, ein Problem, daß in den mannigfaltigsten Formen und Abstufungen die ganze Philosophiegeschichte durchdrungen hat, das von Heraklit bis Hegel und über Hegel hinaus in der Geschichte der Philosophie gelebt hat und noch lebt. Die Geschichtsphilosophie als Universalgeschichte war ursprünglich eine Geschichte der Welt und gleichzeitig auch der Überwelt und Unterwelt. Neuerdings verstehen wir unter Universalgeschichte eine philosophische Deutung des Kulturgeschehens. Früher handelte es sich hierbei nicht nur um eine Geschichte der Menschheit, sondern gleichzeitig auch um eine Geschichte der Erde, der Götter und Dämonen. Das Problem der beiden Wege ist ein religionsphilosophisches und beschäftigt sich mit der Frage, wie wohl diese drei Potenzen zueinander stehen möchten: Gott und Welt und Seele. Wird die Seele als ein besonderer Faktor neben der Welt genannt, dann ist sie allerdings schon in besonderer Weise vor ihr ausgezeichnet. Die philosophisch-mythclogische Úberlegung ist nun schon früh darauf gerichtet, wie das Göttliche, das Prinzip des Anfangs, die do\%r der alten ionischen Naturphilosophie, wie es zur WVelt und Seele wird, wie es aus dem Zustand des Unbestimmten zum Bestimmten, aus der Verfassung einer umfassenden Allgemeinheit zu den mannigfaltigen Bildungen des Weltlebens 
gelangt. Dieser Prozeß, der dann später als Egressusgedanke für die Religionsphilosophie ron Bedeutung wird und die verschiedenartigsten Formen annimmt, gehört ursprünglich dem Problem der Weltgeschichte an. Ihm wird dann später ein anderer Prozeß zur Seite gestellt, in dem das Endliche aus seiner Vereinzelung zum Göttlichen zurückkehrt. Dieser Regressus ist dann immer mehr das eigentliche Thema der Weltgeschichte geworden. Sehon in dem Thema der griechischen Mythologie, in der Lehre vom Chaos, das Form und Gestalt annimmt, und in der Lehre vom goldenen Zeitalter, das seinen Wertglanz rerliert, ist das Motiv der beiden Wege zu erkennen, nur stehen beide unverbunden und umbezogen nebeneinander. Es gibt einen Prozeß der Entwertung und der Wertverklärung in der Welt. Der Prozeß der Entwertung ist der Weg der Individualisierung, der Abweg von Gott, und der Prozeß der Wertrerklärung ist der Weg der Entindividualisierung, der Zugang zu Gott. So kann man schon in jenen beiden Weltbildungslehren, die das mythologische Bewußtsein der Griechen erzengt hat, den Ansatzpunkt für die wichtigsten religionsphilosophischen und geschichtsphilosophischen Probleme entdecken. Das erhellt auch noch unter einem anderen Gesichtspunkt. Wenn in der späteren Zeit das Werden der Welt aus Gott mit Notwendigkeit begriffen werden sollte, ohne daß man auf einen freien schöpferischen Willensakt der Gottheit zurückgreifen wollte, so stellten sich dem philosophischen Bewußtsein immer zwei Formen des notwendigen Weltwerdens dar: die Emanation und die Evolution. Der Gedanke der Emanation schließt aber die Vorstellung in sich, daB das Wertvolle am Anfang steht wie in der Idee des goldenen Zeitalters; was aber ans diesem ersten hervorgeht, steht an Bedeutung hinter ihm zurück. Je weiter das Werden dringt, um so geringer sind die Formen, die es zeitigt. Wie sich das ausströmende Licht in die Dunkelheit verliert, so wird Wert und Sinn durch die Macht des Irrationalen immer stärker und mächtiger gehemmt. Der Gedanke der Evolution entspricht dem Werden des Kosmos aus tem Chaos. An Anfang steht das Ungestaltete, das relativ Unwertige, und aus ihm erwachsen dam erst die höheren Formen des Weltlebens.

Die alten ionischen Naturphilosophen, die man unter dem Namen der Jilesischen Naturphilosophie oder auch der Hylozoisten zusammenfaßt, spreehen das Thema der Weltgesehichte in dem Gedanken des Prinzips aus, das am Anfang war. Am Anfang war keine schaffende Kraft, aber aueh keine tote Materie. Am Anfang war vielnelır cin lebenerfüllter Stoff, ein stoffumwobenes leben. Dieses Prinzip bestand schon für sich allein, als die Welt der gegljederten Dinge moch fohlte: Wasser und Kraft wird es genannt, Gott morl Lnendlichkeit. Anaximander ist wohl der erste grobe Naturphilosoph gewesen, Ior dem Gerlanken des Wroltwerdens tiefer nachgedaeht hat ${ }^{1}$. Mit ihm beginnt die Geschichtsphilosophie in weitesten Simne des Wortes. Ehe alle I biner und ihre Elemente waren, lebte das Unendliche sein einsanes Dasein. Es trum nieht dic Djuge orker die Elemente in sich, etwa als Misehung der verschicelencen 'T'rile, somdern in dieser Urauftinglichkeit war überhaupt noch

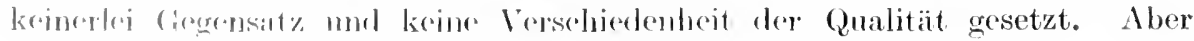


der Möglichkeit nach trägt dieses mendliche Etwas alles das in sich, was noch werden und sich entfalten soll. Es ist die nnerschöpfliche Fülle als fruchtbarer Schoß der ganzen Welt, und es ist die still in sich gekehrte Armut, die keine Mannigfaltigkeit und keine Formen aufzuweisen rermag. Wie konnte dieses Etwas sich zur IVelt bestimmen? Nur dadurch, daß jene beiden Kräfte an ihm und aus ihm hervortraten, die Anaximander als das Warme und Kalte bezeichnet. Das Warme ist das Prinzip, welches die Dinge ausdehnt, das Kalte, welches sie zusammenzieht. Unter den konvulsirischen Bewegungen und Zuckungen, in Zusammenziehung und Ausdehnung rollzog sich die schmerzhafte Geburt der Welt. Anziehung und Ausclehnung, die dem $\mathrm{Cr}^{\top}$ wesen entstammen, sind das notwendige Prinzip aller Dinge. Die Kraft der Attraktion führt die Dinge zusammen, die Kraft der Repulsion treibt sie auseinander. In Liebe müssen sich die Dinge mmarmen oder feindlich begegnen und fliehen.

Diese Welt der individuellen Dinge, die aus dem Urwesen geworden ist, ist nach der Auffassung der griechischen Weisen keine selige und glïckliche Welt. Denn ron einem solchen Zustand der Seligkeit und Freude kann doch wohl nur dann die Rede sein, wenn kein Makel und keine Schuld der Indisidualität anhaftet. Nun aber verdankt nach der Auffassung des Anaximander das Universum seinen Ursprung einer rätselhaften Schuld. Der sündige Trieb nach Formung und Gestalt ist es gewesen, der das Göttliche zerrissen und zerstört hat. Dieser Formungstrieb, diese Schönheitssehnsucht führte zur Bildung des ron Gott Getrennten, der Individualität. Individualität bedeutet Gottesferne. Strafbar ist die Ablösung und Lostösung von dem Alleinen. Die Individualität muß ihre Schuld büßen. Das geschieht aber durch die Rückkehr in den Crsprung aller Dinge, durch die Wiederauflösung in das Absolute.

Deutlich ist schon hier das Prinzip der beiden Wege zu erkennen. Der Weg rom Unendlichen bis zur Indiridualität ist der Egressus, die Abwendung ron Gott. Die Schuld der Tremmung erwuchs aus der Schönheitssehnsucht nach Gestalt und Form. Der Weg ron der Individualität zum Unendlichen ist der Regressus, die Rückkehr zu Gott. Diese Rückkehr zu Gott, die gleichbedeutend ist mit Auflösung und Vernichtung der Individualität und der ganzen gegenständlichen Welt, erscheint jedoch nicht als Ziel der mystischen Sehnsucht. Die Rückkehr zu Gott ist nichts Gehofftes und Gew ünschtes, sondern viehmehr eine gerechte Strafe für die Ruchlosigkeit des Endlichen. Diese starke Formbejahung, welche den Untergang des Individunms im Alleinen nicht als Seligkeit, sondern als Buße empfindet, offenbart die durchaus antimystische Haltung des Anaximander. Ob nun Anaximander gelehrt hat, daß immer wieder das Individuelle aus dem Unendlichen wird, l:m nach Ablauf bestimmter Zeiten zu ihm zurückzukehren, das können wir aus den wenigen Bruchstücken, die uns ron ihm hinterlassen sind, nicht erraten. Erst ron Heraklit wissen wir mit Sicherheit, daßerden Egressus und Regressus des Weltgeschehens nicht als einmaliges Werden, sondern als ein immer sich Wiederholendes gedacht hat.

Heraklit ist der große Denker der Hellenen, in dem die spezifisch unhistorische Weltanschanung der Griechen ron der ewigen Wiederkehr des 
Gleiehartigen wohl am reinsten zum Ausdruck gelangt, und dennoch hat er den Gedanken der Geschichtsphilosophie nicht unerheblich bereichert, indem er den Gedanken der beiden Wege so mächtig betonte. Zwei Wege gibt es, in denen das Weltgeschehen sich bewegt. Der eine führt von oben nach unten, aus dem feurigen Weltleben der Gottheit zu den niederen Erscheinungen sinnlicher Wirklichkeit. Die Bewegung des vernünftigen Weltlebens nimmt drei rerschiedene Gestalten an, die in rastloser Veränderung immer wieder neu erzeugt werden. Die höchste und wertvollste Gestalt ist die Gestalt des Feuers, in der sich das Göttliche am reinsten offenbart. Der feurige Gluthauch nimmt dann die Gestalt des Flüssigen an, die an Wert und Schönheit hinter jenem weit zurücksteht, um dam schließlich in der Gestalt des Erdigen am meisten entäußert zu sein und das Göttliche am tiefsten zu verbergen. Aber aus dieser Entfremdung kehrt das Wirkliche durch des Flüissigen Gestalt nach oben zurïck zu der Feuergestalt der Gottheit. So bewegt sich das Göttliche hin und her in ewigen Wandlungen, 1 m dam schließlich auf alle Bildung und Gestaltung Verzicht zu leisten und, wenn die Zeit sich erfüllt hat, zum Ursprung zurückzukehren, wo es dann keine Welt mehr gibt und keinerlei Gestaltung und Bildıng, sondern nur das fenrige Urleben der Welt, das alles in sich zurückgenommen hat, $u$ wiederum in einer ganz anderen Weltwirklichkeit scin Flammendasein zu offenbaren.

In dieses Weltgeschehen ordnet sich die Seele ein. Dem innersten Wesen nach eignet auch ihr die Gestalt des Feners, und sie verleugnet ihre Natur, wenn sie die Form niederer Stofflichkeit annimmt. Zur Dimension des Feners gehört sic selber, bis zu ihr strahlt die Gottheit in ihrer Reinheit aus. Daß aber die Scele, welche Heraklit auf das höchste bewertet, und deren Rätselhaftigkeit sein Staunen erweckt, als etwas so Selbständiges und Individuelles der Gottheit gegenübertritt, das ist nach Heraklit durchaus nicht ein Zeichen ihrer Sehuldhaftigkeit. Vielmehr liegt es in der ganzen Lebensanschaunng des gricchischen Weisen, diese Position des Individuums gegenüber der Gottheit als eine unwiederrufliche cinfach festzuhalten. Deswegen bedeutet das Individum als starkes Mensehenleben und als Persönlichkeit auch nieht den Cmkehrungspunkt im Prozeß des göttlichen Weltlebens, von dem aus num der Weg der Pïckkehr, der Weg der Erlösung beginnt, sondern in rer ursprüngliehen Form seines eigensten Wesens formt sich das Göttliche zur menschlichen Secle, indem es herniedersteigt, und formt sich das Seelische zur göttliehen Hoheit, inflem es trimmphierend sieh erhebt.

\section{1) IDr Bogriff dre Entwirklumg bei Empedokles.}

War num b×j drn bisherigen Dankern die geschichtsphilosophische Vorstellung wohl schon vorhamlen, aber clurch die Strenge der naturwissenschaftlich'n Anschammng vollkommen getremnt und zurückgedrängt, so zeigt

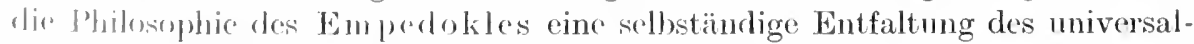
historischen J'roblems; denn dor große Sizilianer ist es gewesen, der znerst den

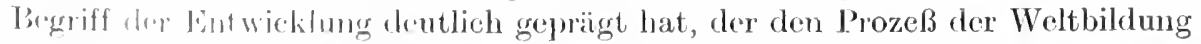
mul Welfonformung sicher muterschied, indem or Epochen und Phasen des Wreltgeschelurens foststellte mol jenen Absehnitt res Wordens begrifflieh fixierte, 
da der Weg der Rückkehr, der im engeren Simne weltgeschichtliche Prozeß, seinen Anfang nimmt ${ }^{1}$ ).

Der allgemeine Charakter dieser Weltgeschehenslehre steht im Zeichen des religösen Wertes. Empedokles konstruiert einen rorweltichen Zustand des Seins, da nur das Göttliche als absolute Harmonie und Einheit herrscht in der Gestalt des seligen Sphairos. Damals fiel alle Wirklichkeit zusammen mit dem in sich ruhenden Gott, der alle Elemente der Dinge in rollkommenster Mischung barg. Dinge gab es nicht, keine Gestalten und Gegenstände, sondern nur die eine Substanz, die eine herrliche Gestalt. In ihr war alles rollkommen verbunden in chaotischer Fülle und kannte keinen Gegensatz und keinen Streit. Und das Göttliche freute sich seiner erhabenen Einsamkeit. Fassen wir diese Vorstellung etwas begrifflicher, so war am Anfang das rollkommen Undifferenzierte, das Weder-Noch aller Gegensätze, wobei der Gedanke des Gegensatzlosen sowohl die räumliche Scheidung der Dinge wie auch jeden Wertgegensatz, vor allen den ron Gut und Böse, von Schuld und Heiligkeit verneint. Dieses Göttliche, nach dem die religiöse Sehnsucht des sizilianischen Propheten so tiefes Verlangen trägt, das seine Künstlerliebe als vollkommen preist in seiner Isolation und Abgeschiedenheit, in der Vollendung der Gestalt, es mußte aus seiner erhabenen Ruhe in den Prozeß des unseligen Werdens und in den Zustand des Streites gerissen werden. Der göttliche Sphairos, in dem das Prinzip der Harmonie und der Liebe unbedingt herrschte, trug in tiefster Tiefe verborgen das Prinzip des Gegensätzlichen und Wertfeindlichen in sich. Durch einen unbegreiflichen Anlaß getrieben, taucht es aus den Tiefen empor und zerreißt und vernichtet die Harmonie und Einsamkeit des schönen seligen Sphairos.

Indem der Gegensatz oder der Streit mächtig wird, lösen sich die Elemente aus ihrer engen Umschlingung und Verbindung. Feindlich scheiden sich die Kräfte, und eine Welt der Gegenstände entsteht. So hört der Sphairos auf einsam zu sein, er findet sich nunmehr in der Gemeinschaft der Dinge. Noch aber ist das Prinzip der Liebe und Harmonie dem Prinzip des Hasses übergeordnet, und so entsteht kein chaotisches Durcheinander der Erscheinungen oder ein Unverbundenes, Getrenntes und Gelöstes, sodern eine Welt gegliederter Dinge. Damit ist, so scheint es, die Idee des Eg res s u s erfüllt. Der ungegliederte und undifferenzierte Weltgott hat sich zur Welt der Dinge entfaltet. Die Stufe der Individualität ist erreicht. Aber die Konstruktion des sizilianischen Philosophen sieht sich zu der Konsequenz getrieben, auch das zweite Prinzip, das Prinzip des Gegensatzes, zu absoluter Herrschaft gelangen zu lassen. Und so lehrt er einen Untergang der dinglichen Welt, der keine Rückkehr zu Gott bedeutet, sondern vielmehr als ein Stadium absoluter Wertfeinllichkeit und vollkommener Gottlosigkeit angesehen werden muß, in dem das Prinzip der Harmonie und Liebe alle Wirksamkeit und alle Kraft verliert. Es ist das eine Zeit der vollkommenen Sündhaftigkeit, in der sich die Elemente feindlich scheiden und in wildem Gegensatz sich fliehn. Die Ordnung der Welt bricht zusammen, jede dingliche Bindung und Tereinigung, jede organische Bildung wird durch das wütende Rasen des Streites unmöglich gemacht.

1) Vgl. Diels. Fragmente der Torsokratiker. 
Es ist das der absolut unsoziale Zustand der Welt, der auch kein mystischer Einheits- und Tereinigungszustand ist, weil die göttliche Liebe gebunden ist und scheinbar aufgehört hat, noch weiter zu sein. Es gibt im Grundegenommen diese drei Zustïnde der Welt:

1. den mystischen Einheitszustand, da es keine Dinge und keinerlei Individualitäten gibt, da das Ganze ungesellig und asozial ist, weil absolut göttlich, da die Elemente sich nicht verbinden zu partialen Einzelerscheinungen mnd ron Sympathie und Antipathie zueinander hingetrieben und voneinander abgestoßen werden, sondern die relative Bindung zugumsten einer absoluten Bindung aufgegeben haben, sofern sie nicht Elensente der Individuen oder Elemente und Teile der Welt, sondern Elemente Gottes sind. Dieser Zustand des Sphairos ist der absolut wertvolle und selige Zustand des Seins, der das selbstverständliche und leidenschaftlich gesuchte Ziel aller religiösen Sehnsucht bildet;

2. ren antinomisehen Zustand der Welt- und Gottlosigkeit, da es keine Dinge und Individualitäten gibt, da das Ganze absolut ungöttlich ist, da die Elemente in einem Gegensatz zueinander liegen, der nicht mehr ein Gegensatz ist ron Individuum und Individumm, also ein Gegensatz, der zugleich das Moment einer Einheit in sich schließt, sondern eben dieser absolute Gegensatz, der jede Einheitsidee aussehließt und die Grundfesten des Seins in atemloser Spannung erhält. Dieser Zustand des Hasses ist der dämonisehe Zustand der Wirklichkeit, die jedes Haltes und Sinnes entbehrt und Welt und Gottheit vernichtet hat.

Dazwischen steht nun ein dritter Weltzustand, der alle Kennzeichen des Relativen an sich trägt. Er ist weder absolute Bindung, noch ist er absolute Trennung, er ist weder absolut wertvoll, noch vollkommen sinnlos. Er ist der einzige historisehe und soziale Zustand der Wirklichkeit. Nur wenn Einheit besteht in der Trennung, nur wenn Sinn mit Widersinn sich rerbindet, nur dann ist eine Welt denkbar, eine Welt simmlicher Formen und Gestalten. Das Wesen aller sinnlichen Wirklichkeit und Endlichkeit besteht in diescr Relativität. Geht das Relative miter, so ist entweder alles Cintt oder alles Dïmon.

Man kann anch, wemn wir uns an einem neneren Gesehiehtsphilosophen orintieren, sagen, daß der Sphairos die absolute Thesis sei, das Prinzip des I mmittelbaren und des Ursprungs, während der dritte Zustand des Wirklichen dic absolnte Antithesis zmm Ausdruek bringt. In dem mittleren Zustand "Aber, der zwischen bejden stcht, tritt das Prinzip der Synthesis hervor, inden del Gegensatz mit der Eimheit sich zu einer synthetischen Mannigfaltigkcit verbiuslet.

In dieser Unterschejdung der deej möglichen \%ustände des Seins tritt jerloch noch nieht der agentiche geschichtsphilosophisehe Charakter der

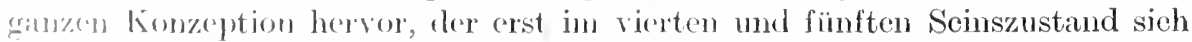

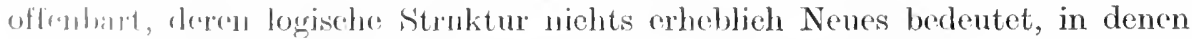
dir andhehtsphilosophisehe Ider aber erst recht eigentlich zum Durehbruch gardamgt.

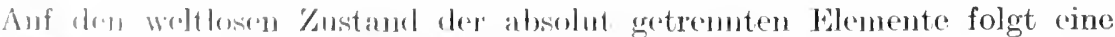

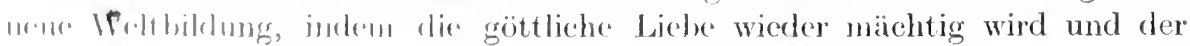


Haß zusehends an Kraft und Wirksamkeit einbüßt. Wie das Werden des Hasses aus der Liebe Schoß zur Weltbildung treibt und dann zur absoluten Katastrophe, indem die Liebe erlischt und der Gegensatz triumphiert, so ist es in dieser neuen Phase des Weltwerdens die Entfaltung der Liebe aus Kampf und Widerstreit heraus, welche die neue Welt erstehen läßt. Die erste Welt war ein Produkt des werdenden Hasses, die zweite Welt ist ein Produkt der werdenden Liebe. Und wie das Werden und Wachsen des Hasses schließlich die Welt zerstört, so zerstört auch das Werden der Liebe am Ende die Welt, indem der alte selige Zustand des Sphairos zurückgewomnen wird. Der Weg ron Sphairos bis zur Feindschaft der Elemente ist der Weg der Entgöttlichung, der Weg von jener Elementenfeindschaft bis zum Sphairos ist der Weg der Gottwerdung. Auf dem Wege der Entgöttlichung wird das Individnum, um zu vergehen, und desgleichen auf dem Wege der Gottwerdung wird das Individum, nm zu vergehen. Aber jenes Werden und Entwerden bedeutet Unseligkeit, und dieses Werden und Entwerden bedeutet Seligkeit.

Leise erwacht in diesen Vorstellungen des großen sizilianischen Propheten die Idee des Fortschritts und der Gedanke der religiösen Universalgeschichte. Der bestimmende Wertgesichtspunkt ist ja augenscheinlich der religiöse, dem der ethische Gegensatz von Gut und Böse untergeordnet ist. Deutliche Phasen des Weltgeschehens beben sich heraus, die mit bestimmten Wertakzenten verbunden sind. Tom Sphairos bis zum Reiche des Hasses herrscht das Prinzip der Wertverminderung und also die Idee des Rückschritts, rom Reiche des Hasses bis zum Sphairos das Prinzip der Wertsteigerung und die Idee des Fortschritts. Noch aber steht der Gedanke des Rückschritts dem des Fortschritts unvermittelt gegenüber, beide vereinigen sich nicht zu einem Gesamtgeschehen, die Position des Endlichen und Urpersönlichen ist nicht in ihrer Bedeutsamkeit erkannt, der Gedanke der Kulturentfaltung ist in dem Gedanken des Naturwerdens rollkommen eingeschlossen und hebt sich nicht über ibn hinaus, und schließlich ergreift die Idee des Wiederkehrenden den ganzen Entwicklungsprozeß. Immer wieder wird die Natur entgöttlicht, um von neuem göttlich zu werden. Der Kreislauf des Geschehens schließt das Wertziel des Werdens immer wieder mit dem Anfang zusammen.

In die allgemeine geschichtsphilosophische Konstruktion tritt der Gedanke herein, was wohl die gegenwärtige Zeit bedeuten möchte in dem Gesamtablauf des Werdens. Da zweifelt num Empedokles nicht, daß er selber in der Zeit der Heimkehr, in der Zeit der Gottwerdung lebt. Er ahnt und fühlt das Wachsen und Werden des Göttlichen und ist selber Prophet der kommenden Gottheit. In jenem vierten Stadium befindet sich nach seiner Lehre die Menschheit der vorsokratischen Zeit, da die Individualität und die dingliche Wirklichkeit wieder mal überwunden wird und die Menschheit zu Gott zurückkehrt oder selber zum Göttlichen und Freien wird.

\section{m) Der Weltprozeß des Anaxagoras.}

Noch ein anderer Denker dieser eigentümlichen Zeit, die zwischen Heraklit und den Eleaten rermittelt und die höchste Blüte der Naturphilosophie bedeutet, hat ein geschichtsphilosophisch interessantes Prinzip aufgestellt, 
nämlich Anaxagoras ${ }^{1}$. Er fragte nach dem Ursprung des Seins und nach dem Anfang des Geschehens, indem er die Ủberzeugung vertrat, daß die Bewegung des Weltlebens nicht von Ewigkeit her bestanden, sondern einen ganz bestimmten Anfang genommen habe. Es gab also einen Weltzustand der Bewegungslosigkeit, der den Gegensatz ausschloß, und wo die Vernunft un. beschränkt herrschte. Sie ist es dann auch selber gewesen, welche die Bewegung und das Weltwerden herbeiführte, indem sie zu einer ganz bestimmten Zeit und von einem ganz bestimmten Punkte des Raumes aus mit unendlicher Kraft einen mendlichen Anstoß erteilte.

Dieses göttliche und vernünftige Prinzip des Anfangs hat nun aber nicht in wilder Willkür das Weltwerden herbeigeführt, sondern vielmehr nach einem vorbedachten Plane. Das gewollte Ziel war die schöne und vernünftige Ordnung der Welt, die in der Bewegung der Gestirne und in dem Reichtum des organischen Lebens ihren vollen letzten Ausdruck fand. Sinn und Vernunft ist nach der Anffassung des Anaxagoras ganz ohne Zweifel in der Welt enthalten, aber der göttliche Anreger ist mit dem gewaltigen Meisterstreich, den er ausführte, doch nicht ganz durchgedrungen, sondern manches blieb dem Göttlichen doch fremd. Nachdem er aber einmal den großen Anstoß gegeben und aus seiner erhabenen Ruhe zum Wirken überging, hat er wohl überall seine heiligen Spuren in der Welt zurückgelassen, die an ihn gemahnen, aber selber wirkt und leitet er nichts mehr. Wic vor allem Weltleben ruht die göttliche Vernunft in sich beschlossen, wie das ihrer Schönheit und Heiligkeit geziemt. Das Weltgeschehen aber verlänft nach dem strengen Mechanismus jenes Rhythmus, den das Göttliche durch Wirbelbewegung nun einmal in die Welt gebracht hat.

Mag nun die Idee der Vernunft, wie sie Anaxagoras gedacht hat, auch wn simnlichen Elementen noch nicht ganz gereinigt scin, so kamm man doch sagen, daß dieser große Denker zuerst das Prinzip der reinen Form als den Begriff des Unsinnlichen deutlich gefühlt und geahnt hat. Bei der begrifflichen Bestimmung der Weltvernunft kann or von gewissen stofflichen Merkmalen nicht los, daß er aber etwas Stoffremdes entdeckt zu haben vermeinte, das verkündet schon allein der Begriff des vor̃s. Nicht als fenerartig noch als luftartig wird das Göttliche bezeichnet, noch erschcint es in der paradoxen Gestalt des Seins und des Werdens, sondern als Geist und Vernunft wird es von Anaxa goras gedacht. Gott ist unser höheres scelisches Leben, das nach Einheit verlangt, dlas etwas Gemeinsames zum Ausdruck bringt und von der Idee rines notwendigen Geltens erfüllt ist. So erwacht hicr in Griechenland die Idre des Idealismus, unter dessen Aspekt allein eine Geschichtsphilosophie möglich ist; denn immer wird sie getragen von dem Gedanken eines sinnvollen Werlens. Dr. Sinn aber ist das Unsinnliche, das als Idee dir Geschichte erfïllt.

Das Problem des Anfangs hat or anfgeworfen. Nieht war die Bewegung und das Wrodrn immer und ewig cin simnloses Spiel kleinster Wirklichkeitstrilr. Lis muls ein Prinzip rles Anfangs gewesen sein, ein sinnvolles Etwas, las rirs grolbe und gewaltsame Sehauspiel des labens und Leidens inszeniert

1) Vhl. I)inls, Fragmento der Vorsokratiker. 
hat. Richtung auf Sinn zum mindesten ist in diesem großen Leben zu spüren, wenn auch dieser Sinn nicht das Ganze erhellt und verklärt. Nach mechanischer Gesetzmäßigkeit verläuft das Leben der Welt in Natur und Geschichte, aber dieser Mechanismus ist ins Leben gerufen von einer vernunftreichen Macht. Und so suchte Anaxagoras die Idee der Zweckmäßigkeit mit dem Gedanken des Mechanismus zu verbinden, indem er ein teleologisches Prinzip an den Anfang der Bewegung stellte, die seinem ersten Impuls gehorchend aus schweigender Ruhe ward, und dann in gleichmäßigem und gesichertem Ablauf, ungestört und ununterbrochen durch Einwirkungen und Bestimmungen irgendwelcher Art, ablaufen muß im gesetzmäßigen Werden.

Die Macht des Denkens hat in Anaxagoras das Grundprinzip aller idealistischen Philosophie und aller Geschichtsphilosophie gefunden in dem Gedanken der Teleologie, der allerdings bei ihm noch in wunderlichen materialistisch-metaphysischen Umhüllungen erscheint. Er hat, wie ihm das ja auch Aristoteles rorwarf, von diesem Großen und Neuen nur wenig Gebrauch gemacht. Nicht betrachtet er das Geschehen der Natur und Geschichte als das Erfülltwerden eines Endzweckes, als einen Prozeß der Wertverwirklichung. Nur am Anfang steht der Sinn als Impuls, und wir wissen nicht, ob dieses unsinnliche Etwas seinen verborgenen Wilien zur Erfüllung bringt, oder ob nicht vielleicht doch schließlich diese große Aufbietung von Kraft, die eine Welt erschuf, einen Stoß ins Leere bedeutet. Teilnahmlos und lieblos verharrt das Göttliche gegenüber seiner Welt. Nicht steht es zu ihr in starker und lebendiger Beziehung. Es hat der Welt sein Antlitz gegeben, um sich wieder von ihr abzuwenden. Nur erraten können wir in der sinnlichen Wirklichkeit des Gottes Spur. So hat Anaxagoras Großes und Folgenschweres gedacht und ist doch über die starre Form des Naturalismus nicht hinausgekommen.

Von den Gestalten der drei großen Denker, welche die Geschichte der griechischen Philosophie beschließen, sind nur Plato und Aristoteles für die Geschichtsphilosophie von Interesse. Der dritte steht ihren Problemen absolut kalt und feindselig gegenüber: Demokrit. In dem Weltbild, das er mit kühler Meisterhand geschaffen, hat die Geschichte keinen Platz. Ist er es doch gewesen, der zuerst die Welt des Materialismus geschaut hat, jenen starren, durch das Gesetz der Notwendigkeit bestimmten Mechanismus.

\section{n) Der Platonische Idealismus.}

Ganz anders Plato, der dem Idealismus die erste große Form gegeben hat. Durch ihn sind die Grundbedingungen für eine Wertung der Geschichte und eine geschichtsphilosophische Konstruktion gegeben. Hat er doch das reine Sinngebilde des Wertes in der göttlichen Idee geschaut ${ }^{1}$ ). Ist doch die geschichtsphilosophische Leistung des deutschen Idealismus vor allem so zu verstehen, daß er Platos Begriff der Idee mit der lebendigen Bewegung der Geschichte verknüpfte. Das aber, was eine Lösung der geschichtsphilosophischen Fragen im Rahmen der Platonischen Philosophie ausschloß, das war die scharfe Trenmung zwischen den beiden Welten, die der große Verkünder des Idealismus errichtete.

1) Vgl. Windelband, Lehrbuch, 1912, S. 96. 
Es war dieses, daß er seiner ursprüngliehen Konzeption naeh alle Bedeutung und allen Wert mit dem Zeitlosen und Transzendenten verknüpfte und der armen Simnenwelt der Bewegung so gut wie nichts zurüeklie $\left.\beta^{1}\right)$. Eine gesehichtsphilosophische Anschauung der Welt fordert die enge Verbindung von Wert und Wirklichkeit, sie verlangt eine Sinndurehleuchtung der sinnliehenBewegung. Diese geschiehtsfeindliehe Tendenz hat Hegel in Plat o erkannt, und deswegen fühlte er seine Ansehaungen der Aristotelischen Philosophie so weitaus verwandter.

Sehen wir abergenauer zu, so ist bei Pla t o der für die Gesehiehtsphilosophie unentbehrliche Begriff des reinen Wertes oder der Idee viel größer und deutlicher herausgearbeitet als in der Aristoteliselien Philosophie. Der tiefste Grund dafür, daß Plato den Gedanken der Wertverwirkliehung ursprünglieh seinem System so fernhielt, muß darin gesueht werden, daß er den Begriff des reinen Wertes, obwohl er aueh bei ihm mit der naturbegriffliehen Vorstellung des GattungsmäBigen verbrämt erscheint, so seharf und so absolut zu fassen suchte, daß er vor dem Gedanken einer Verbindung dieses Holien und Reinen mit der sinnliehen Welt des Begehrens und der Bewegung zurüekschauderte. Er hat den seheinbar unversöhnlichen Widersprueh zwisehen Wert und Wirklichkeit erkannt, der ihm in primitiver Form zuerst entgegentrat in der Philosophie der Eleaten und der Philosophie Heraklits als der Gegensätze von Sein und Bewegung. Muß das metaphysisehe Wesen aller Dinge als Sein oder als Bewegung gedacht werden? - so lautete das Problem, das ihm entgegentrat. Es kanu nieht gedaeht werden als das Sein der Bewegung noeh als die Bewegung des Seins. Beide schließen sich aus. Nun verband sich für Heraklit mit dem Begriffe der Bewegung der Begriff des Lebens, und zwar die Idee eines wertvollen und schaffenden Lebens, während das Sein für ihn gleiehbedeutend war mit dem Unproduktiven, mit dem Starren und Toten. Das Sein ersehien ihm als ein Grenzfall der Bewegung. Heraklit glaubte zu erkennen, daß das Wertleben der Welt Tätigkeit und Bewegung sei, und deswegen besteht eine gewisse Verwandtschaft zwisehen ihm, dem jungen Sehelling, Fichte und Hegel. Anderseits verband sich für Parmenides mit der Idee des Seins die Vorstellung des Vollkommenen und Absoluten. Dasjenige, zu dessen Wesen 'Tun und Bewegung gehört, das kann noch nicht vollendet sein, ihım mangelt und fehlt noch etwas, das es dureh seine Täigkeit erst erreiehen will. Von Liebe und Jegehren ist es get rieben odor, wenn wir die höehste Forin eines Bewegungszieles behaupten, von Sohaffensdrang. Das Göttliche aber ist bedïrfnislos und hat auch nicht den Munsch zu wirken und zu schaffen. Es ist das absolut Tollendete und in sirll Jieschlossene. Nicht zient der Gedanke irgendweleher J3cwegung seiner crhabenen Ruhe ${ }^{2}$. Lwig lebendiges Werden oder starres unbewegliches Sein, flas war die grolie Alternative, vor die sieh die Philosuphlie der Griechen nach Ileraklit und Parmenides gestellt sah.

Nun hatten ja vor Plato Vermittlungsversuche stattgefunden durch Anaxagoras und seine Zeitgenossen, die an die Stelle des einen Seins die

1) Windelband, Lehrbuch, 1912, S. 105ff.

$\left.{ }^{2}\right)$ So iuch die platonische Auffassmng, besonders im Timaios in der Schilderung des giottlichen Wolt. 
Vielheit des Seienden setzten und die Ortsveränderung als die wahrhaftige Form der Bewegung gegenïber cler täuschenden Eigenschaftsveränderung zu erkennen glaubten. Die Wahrheit des Seienden und die Wahrheit der Bewegung glaubten sie erkannt zu haben. Plato aber konnte diese Form der Versöhnung nur wenig bedeuten. Denn wenn er auch mit jenen eine Vielheit des Seienden annahm und der Vorstellung des einen Seienden widerstrebte, so konnte er doch unmöglich den Bewegungsbegriff mit jenen teilen. Denn die Bewegung widerstrebte auch nach seiner Auffassung der Würde des Göttlichen. und wenig einsichtsvoll und begrïndet erschien ihm die Behauptung, daß die quantitative Bewegung die Wahrheit der qualitatiren sei. Tor allem aber sah er ein, daß die Natur des wahrhaft Seienden als des Ewigen und Unveränderlichen den Gedanken des Sinnlichen als des Relativen vollkommen ausschloß. Und so war er der erste, der den Gedanken des Simnlichen und Unsinnlichen ganz rein zu fassen vermochte ${ }^{1}$ ). Er schaute die unsinnliche Ordnung des Vernunftreiches, den erhabenen Zusammenhang der Ideen, jenes Reich der Zwecke und Werte, dem wir als Vermunftwesen in unseren Begriffen zustreben, und er schaute das sinnliche Werden und Vergehen, jene empirische Ordnung der Begebenheiten, der wir als Sinnenwesen mit unseren Sinnen gehören. Er faßte den Gedanken einer zwiefachen Realität. der wahrhaftigen und ewigen der Idee und der sekundären der sinnlichen Dinge. Das Sinnliche ist nach Plato nicht realitätslos, ein bloßer Schein, sondern es bedeutet vielmehr neben dem gleichbleibenden und unveränderlichen Faktor des Logischen und Geltenden den veränderlichen und modifizierenden Faktor. Auch ist das Sinnliche das Prinzip der Mannigfaltigkeit im Verhältnis zur Einheit der logischen Form. Letzter Instanz ist die Welt des Sinnlichen in der Welt des Unsinnlichen begründet und durch sie bestimmt.

Wenn nun aber auch die Welt des Sinnlichen nicht das Wirklichkeitslose ist, so entbehrt sie doch nach der ursprünglichen Lehre Platos jedes Wertcharakters. Sie ist die Welt der Unwahrheit und der Täuschung, die schwere Kerkerhöhle, die uns umfangen hält. Wo wäre in ihr Gerechtigkeit und Heiligkeit zu finden und der Schönheit seliger Glanz? Im Grunde genommen bedeutet die Sinnenwelt für die Welt des Unsinnlichen nichts, diese ist nicht auf jene angewiesen, wohl aber jene auf diese.

Mit dieser scharfen Entgegensetzung der beiclen Welten hat Plato das Größte für die Philosophie und speziell auch für die Geschichtsphilosophie geleistet. Ist er es doch gewesen, der zuerst das Problem der Antinomien gestellt hat, das jedem Bezirk der Vernunft zugrunde liegt, und das allein zu einem philosophischen Verstehen der historischen Bewegung gelangen läßt. Verteilt er doch auf die beiden Welten den Gegensatz ron Wert und Wirklichkeit, des Absoluten und Relatiren, des Unsinnlichen und des Sinnlichen, der Einheit und der Mamnigfaltigkeit, des Wesens und der Erscheinung, des Einen und des Vielen, des Begrenzten und des Unbegrenzten, der Puhe und der Bewegung, des Zweckes und Mittels, des Ewigen und Zeitlichen, des Raumlosen und Räumlichen, des Allgemeinen und Besonderen, des Tollendeten und Bedürftigen, des Rationalen und Irrationalen,

1) Vyl. Windelband, Lehrbuch, 1912, S. 96. 
der Form und des Inhalts, des Unsterblichen und Sterblichen. Indem er aber diese Gegensätze erkannte, hielt er sie für unüberwindlich in der rein logischen Sphäre, im Gegensatz zı Hegel, der gerade die Anflösung dieser Antinomien zum Grundproblem seiner Logik machte. Daß Plato sie für unauflöslich in der Sphäre des Logischen hielt, ist ein Dokmment einsichtsvollsten Verstehens und kennzeichnet die Anerkennung des Irrationalen und die Verwerfung jedes einseitigen Rationalismus. Anderseits aber vermochte Plat o nicht zu erkennen, wie das später vor allen $\mathrm{H}$ e gel erkannte, daß es sich anch bei den Bestimmungen, die er so ohne weiteres mit der Sphäre des Sinnlichen v́erband, um Bestimmungen der Vernunft handelt. Das den allgemeinen Bestimmungen der Ideenwelt Entgegenstehende, das Relative, das Unbegrenzte, die Vielheit, das Besondere und Individuelle, sind keineswegs Merkmale, die sich mit dem sinnlichen Gegebenheitsinhalt so ohne weiteres als Anzeichen seiner Nichtigkeit verbinden. Vielmehr handelt es sich hier $11 \mathrm{~m}$ Bestimmungen der Vernunft, um Kategorien des Denkens, die jenen anderen notwendig zugeordnet sind. Plato sah, wie unnachgiebig, schroff und unversöhnlich sich diese so rerschiedenartigen Gedankengebilde und die mit ihnen verbundenen Wertungen gegenübertraten. Er konstatierte deshalb nur ihre Unvereinbarkeit, indem er clie eine Gruppe ron Denkformen der Welt des Unsinnlichen und die andere der sinnlichen Materie verschmolz.

Aber diesen Standpunkt der Unvereinbarkeit der beiden IVelten hat Plato nicht behauptet und festgehalten. Immer mächtiger wird in ihm der Gedanke, daß eine Beziehung und Verbindung zwischen den beiden Welten gedacht werden müsse, daß sie unmöglich in dem Verhältnis einer vollkommenen Exklusion stehen kömmen. Besteht aber eine solche Verbindung, so wird das Sinnliche zum Material, an dem sich die Form offenbart, zum Stoff, der von der Form unklammert und ergriffen wird. Damit stürzt sich die Platonische Philosophie in die größten Schwierigkeiten und lockt das gesehichtsphilosophische Problem herror. Denn solange das Göttliche nnd absolut Wertrolle so gedacht wird wie in der ursprünglichen Konzeption Platos, nämlich abgeschieden von allem sinnlichen Sein, in vollkommener Passivität und in sieh ruhend, umı das Simnliche als die wertlose Hast der Bewegung erschien, solange trat Plato noch nicht ror das Grundproblem aller geschichtsphilosophischen Erkenntnis: wie dem das Zeitlose und Abgeschlossene auch gleichzeitig in der Zeit sich offenbaren und entfalten könne, wie mit einem Worte sinngemäß vereinigt werden könnte der Gedanke des Wert- und Vollendetseins mit der Idee des Wert- und Vollendetwerdens. Denn das ist ja zunächst gar nicht rinzusehen und auszurlenken, wie das Göttliche und Wertvolle, das außer aller \%eit steht und vollkommen mangellos ist, dahin gelangt, zeitlich und endlirh zu werden, um im Prozesse der Endlichkeit einem Ziele entgegenzureifen. Hier möchtcn wir nun gleich jenes Hindernis hinwegräumen, das in der Virstellung liegt, daß das Zeitlose, Göttliche gleichzeitig in der Zeit sich voll'met. Hier steckt ja scheinbar ein unauflöslicher Widerspruch, daß etwas

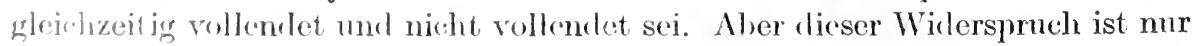
"in s.']rinharer, lenn ras ,gleichzeitig“ gilt in Grumle genommen für diese Vorstellmugsw rise nicht. Fs ist gewiß3 nmmöglich, dab jenand gleichzeitig hier und dort ist, wher dab ciner im selhen zeitmoment seinen Charakter vollendet und 
nicht rollendet habe, aber das gilt nur für den Fall, claß heide Zustände als in der Zeit befindlich betrachtet werden. Zu gleicher Zeit kann etwas hier und dort geschehen, nicht aber kann ein Identisches hier und dort sich ereignen. In dem Beispiel, auf das es uns ankommt, gilt aber die Zeit nicht für beide Zustände, da ja das Vollendete ausdrïcklich als zeitlos betrachtet wird. Nur das Unvollendete ist in der Zeit und kann mit einem anderen in rer Zeit Befindlichen verglichen werden. Das Zeitlose kann nie zu gleicher Zeit sein, das ist eine contradictio in adjecto. Das Verhältnis zwischen dem Zeitlosen und Zeitlichen ist eben nicht das Verhältnis zu ,,gleicher Zeit:, sondern ein ganz andersartiges, und deshalb kann diese Beziehung auch nicht durch den Satz rom Widerspruch bedroht werden.

Doch immerhin: die ganze Schwierigkeit der geschichtsphilosophischen Fragestellung tritt hervor, wenn die Frage aufgeworfen wirl, wie denn der Gegensatz zwischen den beiden Welten zu überwinden sei, und der Versuch gemacht wird, von der Sinnenwelt her zu jenem jenseitigen Land Brïcken zu schlagen. Hat die Sinnenwelt keinen Anteil an der Welt des Wertes, damn bedeutet das Geschehen und die Bewegung nichts und ist rollkommen sinnlos. Hat es aber an der Welt des Transzendenten Anteil, so erhebt sich auch sofort das große Problem des Werdens, was denn das Werthafte für die Sinnenwelt und die Sinnenwelt für das Werthafte bedeute, und was das Göttliche reranlaßt haben möchte, sich in der Sinnenwelt zu offenbaren.

Plat o hat dasVerhältnis zwischen den Ideen und der Sinnenwelt immer wieder anders zu bestimmen gewußt, und dieursprünglich naturalist ische Auffassung dieses Verhältnisses nähert sich immer mehr einem geschichtsphilosophischen Verstehen. Ganz naturalistisch als Abbildverhältnis wurde ursprünglich ron Plato die Beziehung zwischen der Welt des wahrhaften Seins und der Welt der Genesis gedacht. Vorbildlich ist die Welt der Ideen, nachbildlich die Welt der Genesis. Die Welt der Genesis verhält sich zur Wertwelt, wie sich die Kopie zum Original verhält. Dann hat im Grunde genommen die Welt des wahrhaften Seins mit der Welt des Werdens nichts gemeinsam als eine gewisse Ähnlichkeit. Nicht aber hat die Idee an der Sinnenwelt oder die Sinnenwelt an der Idee wahrhaften Anteil. Die absolute Kluft bleibt noch bestehen, wemn auch die Vorstellung des $̈$ hnlichen die Frage auf wirft, was denn wohl eigent lich das Gemeinsame sei, das die Ähnlichkeit des an sich rollkommen Entgegengesetzten herbeiführte.

Allerdings ist in gewisser Weise das feindliche Verhältnis ron Idee und Sinnenwelt schon überwunden, wenn die Relation von Vorbild und Nachbild zu ihrer Verdentlichung benutzt wird. Denn nunmehr eignet der Welt der Bewegung ganz augenscheinlich Wertcharakter, ein Abglanz jener höheren Welt ruht auf ihren flüchtigen und rergänglichen Gestalten. Nach jener ist. sie gebildet, und die absolute Fremdheit ist getilgt.

Aus dem Gedanken des Ähnlichseins wird der Gedanke des Teillabens in der Weise, daß das Verhältnis ron Idee und sinnlicher Wirklichkeit gedacht wird wie das Verhältnis des Allgemeinen zum Besonderen. Wie im Verhältnis des Gattungsbegriffs zum Artbegriff und dieses wieder zur simnlichen Erscheinung das Besondere durch das Allgemeine eine ganz eigentümliche Bestimmung erfährt, die von jeder physischen oder anch psychischen Einwirkung prinzipiell 
rerschieden ist, so soll auch zwischen den beiden Welten diese rein logische Beziehung bestehen. Wenn Plato das Verhältnis der beiden Wirklichkeiten durch die Beziehung des Gattungsbegriffes zum Artbegriff verdeutlieht, so weiß er natürlich sehr wohl, daß es sich hier nur um einen Vergleich, um eine Analogie handelt; denn die Idee ist nicht der Gattungsbegriff, sondern nur das in der Form des Gattungsbegriffs Gedachte. Die Welt der Ideen ist nicht gleichbedeutend mit dem Inventar logischer Werte oder mit dem Zusammenhang zwischen den verschiedenartigen Formen der Vernunft oder gar mit der Summe aller Gattungsbegriffe, sondern ganz in erster Linie handelt es sich bei Plato, wenn er von der Welt der Ideen spricht, um eine unsinnliche Materie, die ron der sinnlichen vollkommen verschieden.

Für diese unsimnliche Materie gelten Wert bestimmungen, die dem Charakter des Sinnlichen durchaus entgegengesetzt sind. Das Verhältnis von Gattungsbegriff und Artbegriff ist ein Sinnverhältnis zwischen Formen. Der Artbegriff ist das die Unbestimmtheit des Gattungsbegriffes Determinierende, das den Unterschied hervorlockt. Oder auch der Gattungsbegriff ist das Bestimmende für all die möglichen Formen, in denen er sein Wesen entfalten kann. Eine analoge Art von Bestimmen und Bestimmt werden soll zwischen der unsinnlichen Idleenwelt und der sinnlichen Genesiswirklichkeit bestehen.

Immer wieder anders und neu hat Plato das Verhältnis zwischen den Welten zu denken versucht, bis er schließlich seine große, endgültige Lösung fand. Einmal erprobte er die Lösung des Anaxagoras an seinem Weltsystem und sprach von dem Beiwohnen der Ideen, von ihrem Kommen und Gehen an den Dingen. Diese herben und gezwungenen Vergleiche sollten deutlich machen, wie es zu verstehen ist, daß aus dieser Welt der Nichtigkeit uns manchmal ein Rausch der Schönheit entgegenflutet. Wohl hält sich das Ideelle und Schöne seinem gewohnten Verhalten gemäß vollkommen fern von der Niedrigkeit und Flüchtigkeit der Simmenwelt. Aber es gibt gewisse seltene und auserlesene Feierstunden des Geistes, da die beiden getrennten Welten gleiehsam eine Vermählung feiern, und das Ewige und Schöne sinnliche Gestalt annimmt, da es zu der Sinnenwelt kommt, um Licht in ihre dunklen Tiefenzu tragen, bald aber wieder geht und entschwindet, um unendliche Sehnsucht zurickzulassen.

Die endgiiltige Lösung Platos ist dann die teleologische Beziehung, die er sowolı im Reich des Unsinnlichen anfzuweisen unternimmt, wie er denn vor allem auch rlas Sinnliche mit dem Unsinnlichen teleologisch verknüpte und darlurch den gesohichtsphilosophischen Gerlanken der Wertverwirklichung zwerst in großer und vorbilllicher Form konzipierte. Indem der Platonische Gedanke diese ganz newe Beziehung st ift et, reründert die Simmen welt vollkommen ihrc Struktur. Vorher war sie gänzlieh wertlos ocler mur flüchtig und vorübergehend ılem Land cler Schönheit vermählt, jetzt aber ist das Schöne zum dauernlen Gast hier auf Erden geworden. Ehendasselbe Schöne, das in jener Welt ganz und ungeteilt vorhanden ist, ist in clieser irdischen Welt in zerstreuter Vereinzelung zu finden. Daß dlas ideelle Schöne aber sinnlich wirklich geworden ist und das Ewige sich somit rem Zeitlichen vermählt hat, das beweisen vor allem rie suhönen Gestalten des Lebens, die glanzvollen Körper jugendlicher Gestalten, dic: unsere Sehnsucht und Liebe erwecken ${ }^{\mathbf{1}}$ ).

1) Sin besonders im Phädros. 
Plato gelangt zu seinem höchsten Prinzip, durch das er die Welten verbindet, indem er die Frage erhebt nach einer letzten Einheit in Reiche der Ideen. Es muß etwas geben, was die Erkenntnis der Gegenstände des Denkens in ähnlicher Weise möglich macht, wie die Sonne uns die Erkenntnis der sinnlichen Dinge vermittelt. Dieses Etwas, diese Sonne für das Auge des Geistes, bezeichnet Plato als das Gute, ohne bei dieser Bestimmung den spezifisch sittlichen Wert im Auge zu haben, der sich vielmehr für ihn in dem Begriffe der Gerechtigkeit vollendet. Das Gute ist der Begriff eines letzten Wertes, einer höchsten Werteinheit, sofern alle Gegenstände des Denkens auf dieses absolut Wertvolle sinnvoll bezogen sind. Das Gute macht alle Probleme der Erkenntnis in letzter Hinsicht zu Problemen des Guten als des Göttlichen. Dieses Göttliche formt die getrennte Welt der Ideale zu einem einheitlichen Wertreich. Man kann das Gute auch als die Form der Ideen bezeichnen, sofern es den Grund ihrer Erkenntnismöglichkeit und ihrer Wahrheit bedeutet. Da es rerschieden ist von allen anderen Ideen, ist auch der Begriff des Seins von ihm fernzuhalten ${ }^{1}$ ).

So ist die übersinnliche Welt organisiert und verbunden, und ein Wertsystem kann gedacht werden, das jene Welt des Ewigen treulich wiedergibt und abbildet. Noch aber fehIt die Brücke zwischen den beiden Welten, das, was das Sinnliche und Unsinnliche zusammenführt, dasjenige, was die Möglichkeit hergibt, daß die übersinnliche Form der sinnlichen Erscheinung sich verknüpft, und was auf der anderen Seite dem Sinnlichen diese Läuterung zuteil werden läßt, daß es der Welt des Reinen entgegengefülırt wird. Dieses Verbindende muß in der Mitte stehen zwischen dem Sterblichen und Unsterblichen, d. h. es muß an beiden Welten gleichmäßig Anteil haben. Der Welt der Ideen gehört er an, deswegen muß der Mittler unsterblich sein, der Welt der Genesis muß er zugerechnet werden, deswegen muß der Mittler sterblich sein. Also gehört es zu seiner Natur, unsterblich zu sein wie die Ideen und sterblich wie die sinnlichen Dinge. Dieser Mittler zwischen den Welten ist die Liebe.

Die Liebe steht zwischen dem Unsterblichen und Sterblichen oder auch: sie ist unsterblich und sterblich zugleich. Sie ist nicht unsterblich in dem Sinne, daß sie, von blühendem Leben erfüllt, ewig unrerändert bliebe. Vielmehr ist sie dem Schicksal der Veränderung und des Todes hingegeben, wenn auch nur für kurze Zeit. Sie, die noch eben jetzt uns beglückte als eine helle und starke Erscheinung, mit aller Liebenswiirdigkeit des überreichlich Schenkenden geschmückt, sie ist heute bleich und erstarrt. Kein Wort mehr vermag sie zu reden. Die Liebe ist tot. Aber die Liebe ist nicht sterblich in dem Sinne, daß sie der Bewegungslosigkeit und Starrheit des Todes danernd anheimfallen könnte. Sie stirbt, um wieder zu erwachen. Sie ist also das Unsterbliche im Sterblichen. Sie hat nicht das dauernde helle Unsterblichkeitsleben des Göttlichen, an das der Tod nicht herantritt, sie hat aber auch nicht das Los und das Schicksal des nur Endlichen: die Vergänglichkeit. Sie hat an beidem Anteil, am Tod und am ewigen Leben. Der Idee menschlicher Unsterblichkeit auf das engste vermählt, der Unsterblichkeit, die durch die Nacht des Todes hin-

1) Vgl. hierzu besonders 6. u. 7. Buch der mohıszía und Lask, Die Logik der Philosophie und die Kategorienlehre, Tübingen 1911, S. 225ff. 
durchgeht, gewinnt der Begriff der Liebe tiefste religionsphilosophische Bedentung und schließt die Welt der Antike mit dem Christentum zusammen. Dies Unsterbliche im Sterblichen, das Unendliche im Endlichen, diese Verbindung des Göttlichen und Menschlichen hat ihr hohes religiöses Symbol gefunden in der Gestalt des Dionysos, des schönen Lichtgottes, der zerrissen wurde von den Söhnen der Nacht, und aus dessen Blut und zerrissenen Ghiedern das Geschlecht der Menschen emporblühte. Alle sind sie Teile ron ihm, das Göttliche wohnt dem Menschlichen bei. All die verschiedenen Teile des Göttlichen streben aber nach der früheren Einheit. Und in Rausch und Orgasmus kehrt das Getrennte und traurig Geschiedene zur seligen Einheit zurück. Dionysos, der starb, um das Menschliche mit dem Göttlichen zu verbinden, der den Tod erlitt, um mit der Menschheit zu verschmelzen, er ist ein religiöses Symbol der Platonischen Liebe. Und an eine andere, weit größere religiöse Gestalt werden wir erinnert, die an der Scheidegrenze der beiden Weltkulturen steht: Jesus von Nazareth. Göttlich und menschlich zugleich ist sein Ursprung. Er ist der Sohn der Fülle und der Armut: Gottes und des Menschen Sohn. Er ist das wahrhaft Endliche, das in der notwendigen Bezichung zum Unen llichen ruht und so die Macht besitzt, die schlechte Endlichkeit des Sinnlichen mit dem Unendlichen zu versöhnen. So ist er der Mittler zwischen den Welten, der den Opfertod erleidet, der stirbt, um wiederaufzuleben nach der Liebe Art $^{1}$ ).

Mit Platos Lehre von cler Liebe, die verkïndet, daß das Göttliche simnliche Gestalt annimmt und sich in den höchsten Formen des irdischen Daseins offenbart, beginnt die Idee der Universalgeschichte wirksam zu werden. Denn das eben ist ja die Grundroraussetzung jeder universalgeschichtlichen Konstruktion, daß ein reales, sinnvolles Werden stattfindet, das auf irgendein Ziel gerichtet ist. Das religiöse Bewußsein deutet dieses Ziel als Wiedereinswerdung des Menschlichen mit dem Göttlichen durch des Mittlers, durch der Liebe Macht. Das ist die Tat der Erlösung. Der Erlösungsgedanke aber konstituiert sogleich die beiden Wege, den Weg der Schuld und den Weg der Entsündigung. Und so treten denn gar bald nach Plat o die großen geschichtsphilosophischen Konstruktionen hervor, die das Thema von Sündenschuld und Erlösung stellen.

In der großen Platonischen Metaphysik haben allegeschicht sphilosophischen Konstruktionen ihren Anfang und Ursprung. Noch fehlt dio Idee der Menschleit, der Gedanke des Fortschritts und die Vorstellung ron einen gemeinsamen S'chicksal des Menschengesehlechts: alles andere aher ist so rein und klar wio nur möglich geschaut. Diese psychophysische Wirklichkeit, der wir angehören, dieso selt same Vereinigung so heterogener Dinge wie Geist und Körper verdankt ihren Ursprung einer Süudensehuld. Daß diese Verbindung von Seele und Körpor otwas Rütsehaftes und Paradoxes ist, schließt nach der Platonischen Vorstellung allerrings nicht ans, daß eino so seltsame Verbindung auch die sipuren dor Shö̈nheit tragen kann. Nicht wird der Körper als das Vorunstalfonde mud fomeine bot rachtet, sondern in der Haupt sache nur als ein Etwas, das don freien Aufstieg des Geistes hemmt und der Soole den nmmittelbaren

1) Vigl. Ire Jethere ven der Liebe als Woltprinzip im Symposion. 
Eimblick in der Erkenntnis seliges Land rerschließt. Aber so muB doch diese Vereinigung angesehen werden, daß sie die Folge eines Frevels ist, daß sie da ist und besteht, weil einmal etwas Heiliges getrübt, ewas Wertrolles zerbrochen wurde. Es gibt nach Plat o eine Welt der Bewegungslosigkeit als das Reich des reinen Sinnes und eine WeIt der Bewegung als sinnliche Wirklichkeit, die sich ihrerseits wieder gliedert in eine psychische und eine psycho-physische Welt. Ursprünglich allerdings war das Psychische rom Physischen getrennt, so daß die Totalität des Wirklichen ursprünglich in drei Sphären zerfiel, in die logische Sphäre der Ideen, in die psychische Sphäre und in die physische Sphäre als das Reich der groben Materialität. In der Sphäro der groben Materialität war nur niederes Leben wirksam, aber das Vernunftleben, das Psychische im engeren Sinne des Wortes, war nicht mit ihr verbunden. Jene Sphäre rles höheren psychischen Lebens, das Reich der Götter und Menschen, war lediglich der Ideenwelt zugewendet und empfing ihr Leben und ihre Nahrung von dem Göttlichen allein. Die Macht und Kraft der Erkenntnis hielt die menschlichen Seelen in solcher Höhe, unter Anspannung ihrer höchsten Geistesgaben konnten sie sich dort behaupten. Als die Menschen aber lässig wurden in dor Ideenschau und der heilige Eifer um Erkenntnis erlahmte, da konnten sie bei ihrem Verlust an Intellektualität den Zustand der reinen Kontemplation und des Schauens nicht länger bewahren. In der menschlichen Seele ist ein Teil, welcher der Sphäre des niederen Lebens zugewendet ist, das ist die simnliche Leidenschaft und Begierde. Sie hat den vernünftigen Teil der Seele gestört und verwirrt und ihren Fall in die Tiefe verschuldet. Und so hat die Seele diese Gottesferne erreicht, daß sie, den niederen Lebensformen vermischt, in grobe sinnliche Materie eingekerkert und eingemanert ist.

Soweit der Egressusgedanke. Und wie ist der Heimweg möglich ? Wio kann die verlorene Seligkeit wiedergewommen werden? Nur durch die Liebe allein. Der Eros als Mittler ist auch gleichzeitig das Prinzip der Seele. Dies metaphysische Grundprinzip der Platonischen Plilosophie ist den vernunftbegabten Teilen der Seele zugeordnet. Dort ror allem hat es seine Stelle, wo das Vernüntige sich mit dem Enthusiastischen verbindet. So verbindet es die vernunftentflanımte Tätigkeit mit den Urbildern des vernïnftigen Lebens. Diese Platonische Liebe ist Sehnsucht nach dem Absoluten, ist Sehnsucht nach Unsterblichkeit. Die Liebe vollbringt nach Plat o das Werk der Erlösung, während nach den Vorstellungen der Gnosis die Liebe der Erlösung bedürftig ist. Von sehr verschiedenen Seiten aus können wir den Heimweg gewinnen, je nachdem wir als theoretische Menschen der Wissenschaft oder als ethische dem Guten oder als ästhetische dem Schönen zugewendet sind. Prinzipiell hat keiner dieser Wege einen Vorzug vor dem anderen, denn trotz der großen Verschiedenheit ihrer Struktur leiten sie doch gleichmäBig nach dem einen Ziel der religiösen Sehnsucht. Den Weg der Erlösung aber finden wir am leichtesten durch das Schöne. Denn das Schöne ist von allem Werthaften dasjenige, an dessen sinnïicher Wirklichkeit wir nicht zweifeln können. Wohl mag uns das Gute hier auf Erden verborgen bleiben und die Wahrheit sich vor uns verhiillen, aber das Schöne schauen wir in den lebendigen Gestalten des Lebens $\left.{ }^{1}\right)$. Wer nun die schöne Gestalt erschaut, der wird ron einem heftigen

1) Vgl. hierzu die Darstellung des Phädros. 
Gefühl der Sehnsucht und des Heinwehs ergriffen. Seltsam bekannt mutet sie ihn an die liebe schöne Gestalt. Und die Erinnerung bewegt seine Seele, die Erinnerung an eine Zeit, da ihm das Höchste zuteil wurde, da er die Schönheit nackt und unverhüllt geschant am übersimnlichen Ort. Damals wußte sich dio Seele ror Glücksgefühl kaum zu fassen, in seligem Staunen erblickte sie damals die herrlichste aller Gestalten. An diese heilige Schan wird der Liebende erinnert, wenn er die sehöne Gestalt des Geliebten erblickt. Dunkel erinnert wird er an Momente himmlischer Seligkeit, die er genossen hat. Sowie er sich dem Geliebten nähert, wird dieses Glücksgefühl in ihm erregt. Damit gibt ihm der Geliebte aber immer die Richtung auf die übersinnliche Welt und läßt die Sehnsueht nach den Ideen immer größer und nächtiger in ihm werden. Und ein Wunder vollzieht sich nummehr mit der Seele des Liebenden, eine vollkommene Umbildung und Wandlung erfährt sein innerstes Wesen. Seine Seele, die einst in der Gemeinschaft der Götter lebte und selber herrlich war, hatte ja durch Lässigkeit in der Ideenschau die Schwungkraft des Geistes eingebüßt. Ihr Flügelkleid hatte die Seele eingebüßt, das sie so weit hinaushob iiber das Niedrige und Gemeine der bloßen Sinnenwelt. Indem nun der Liebende den Geliebten schaut und genießt, wachsen seiner Seele neue Flügel und heben ihn hoch hinaus über das Trübe und Dumpfe der Sinnenwelt. Liebe ist Liebe zur Schönheit, Sehönheit ist der Liebe Reiz, und indem wir die sehöne Gestalt des Geliebten lieben, betreten wir den Pfad der Erlösung.

Aber als wahrhaft erotische Mensehen könmen wir nicht verweilen in der Liebe zu der einen sehönen Gestalt, sondern werden dahin getrieben, alle schönen Gestalten zu lieben und so, indem wir dem Einzelnen untreu werden, dem Ganzen und dem Prinzip tren zu sein. Zwischen den verschiedenen Wertformen best eht dann auch fraglos eine enge Verwandtsehaft, so daß der Liebhaber der schönen GestaIten zum Liebhaber der schönen Sitten und Handlungsweisen wirl. Und ron den sehönen Sitten und Handlungsweisen sehreitet er fort zu deı schönen Künsten und Wissensehaften, bis er sehließlich dahin gelangt, das Urbild der Schönheit selber zu schanen, fortgerissen in heiliger Sehnsucht zu iiberhimmlischem Ort, wo ihm vergönnt wird wiederzuschauen, was er dereinst im Zustande der Freiheit und Körperlosigkeit täglich zu sehauen vermochte.

In dieser Platonischen Peligionsphilosophie steekt ein bedeutsames geschichtsphilosophisches Moment. Ja man könnte mit einem gewissen Rechte behaupten, daß Plat o der Begrïnderder religiösen Universalgesehiehte gewesen sei, denn fast alle ihre Elemente finden sich bei ihm ror; und dennoch fehlt oben Plato zur Universalgeschichte dio Geschichte und die historisehe Auffassung der Dinge. Denken wir an den Sündenfall der Seele. Wio unglaublich tiof ist diese ganze Lehre und doch anch wieder wie absolut unhistoriseh. Eikennt nisschuld hat uns aus dem Reiche der Schönheit vertrieben, Erkenntnislicbe führt uns dorthin zurïk. Aber das Schuldigwerden ist kein gemeinsannes Schicksal. Nicht et wa werlen clurch gemeinsame Schuld die Soelen der Monschen in dio simnliche Sphäre versuben, sondern sporadisch verfält bald diese, hald jone der siinde gegen das Göttliche und damit auch zugleich dem Jas der bindlichkeit. Und in ähnlich individualistischem simne ist von Plato and dic hiuckkchr der Seelen zu Gott gedacht. Nicht durch eine große Erlösungs- 
tat, die das Ganze der Wirklichkeit angeht, sondern je nach dem persönlichen Begegnen der einzelnen Individualität vollzieht sich das Erlösungswerk des Menschen. Jedem Menschen erwächst zu seiner Zeit ein besonderer Erlöser.

Ganz im geschichtsphilosophischen Sinne aber ist die Art und Weise, wie Plato den teleologischen Gedanken ron der höchsten Idee des Guten bis zu den niederen Formen des Lebens herableitet. Zeigt er doch, wie durch die ganze Natur ein Sehnen hindurchgeht, und für den philosophisch Verstehenden bedeutet diese Sehnsucht Sehnsucht nach Unsterblichkeit. Ihre primitivste Form ist bei den Tieren zu entdecken, die auf die Erhaltung der Gattung so ängstlich bedacht sind. Weit höher offenbart sie sich in der Rubmsucht des Helden, der von dem sengenden Wunsche erfüllt ist, daß sein Name aufbewahrt bleiben möchte in der Erinnerung seines Volkes. Und der Liebende schöpft den Ewigkeitsgedanken aus der Liebe und der Schönheitsfreund aus der Schönheit. Alle diese Leidenschaften und Sehnsüchte streben dem Wertreich zu. Dieses selber aber wird geeint durch die Idee der Ideen, durch die Form der Formen, welche die Probleme des Guten, Wahren und Schönen in letzter Hinsicht zu einer Gottesfrage macht. Dieser Sonne im Reiche der Ideen strebt aller lebendigen Wesen Sehnsuchtsliebe $\mathrm{zu}^{1}$ ).

\section{o) Der Begrifi der Entwicklung bei Aristoteles.}

Das System des Aristoteles, das die Philosophiegeschichte der Griechen abschließt, kann in einer Geschichte der Geschichtsphilosophie sehr leicht eine verschiedenartige Deutung erfahren. Es kamn als Abfall von der Platonischen Grundidee oder auch als Weiterbildung aufgefaßt werden. Im Gegensatz zu einer geschichtsphilosophischen Auffassung der Wirklichkeit steht fraglos die Naturalisierung des Formbegriffs, von der nur der Begriff der Gottheit ausgeschlossen ist. Weiter dann auch vor allen Dingen die Absage an jede mögliche Frage nach dem Ursprung und dem Schicksal der menschlichen Seele. Dagegen scheint der geschichtsphilosophischen Fragestellung entgegenzuführen der ganz neue Begriff der Entwicklung, den Aristoteles aufgestellt hat, das Stufenreich der Natur und die erotische Materie.

Es besteht eine sehr enge Beziehung zwischen dem System des Arist oteles und dem System Hegels, welche von dem deutschen Philosophen auch vollkommen eingesehen ist, der Aristoteles durchaus im Sinne seines Systems verstand. Bei aller Verschiedenheit und Gegensätzlichkeit liegt doch eine tiefinnere Verwandtschaft vor, was kaum denkbar sein würde, wenn das Aristotelische System der Idee der Geschichte rollkommen fremd gegenüberstände, der Geschichte, die in Hegels Philosophie so mächtig zu Worte kommt.

Das Neue, was das Aristotelische System der Philosophie der Vergangenheit gegenüber gebracht hat, ist vor allem der Gedanke der Entwicklung. Innig verbunden sind in der Wirklichkeit immer Form und Materie, Unsinnliches und Sinnliches, Geistiges und Materielles. Da die Form als das Unsinnliche Prinzip derBewegung ist, so darf sie, wenn Bewegung wahrhaft und wirklich stattfinden soll, auch nicht getrennt ron der sinnlichen Wirklichkeit in einem

1) Vgì. die Darstellung des Symposion. 
Reich des Transzendenten gedaeht werden ${ }^{1}$ ). Denn das absolut Getrente kann ummöglich aufeinander wirken. Beide Elemente der Wirkliehkeit: die Mögliehkeit und die Kraft des Seins berühren sieh auf das engste. Indem sie aber einander berühren, wird das Mögliche zum Wirklichen. Das gesehieht durch den ProzeB, durch die Entfaltung, durch das Werden, das die beiden Grundelemente der Welt dureh ihr Zusammenwirken hervorrufen. Dem Stoffe oder der Materie wohnt inne die Sehnsucht nach Form. Ihre Liebe und Begierde ist darauf geriehtet, gestaltet zu sein. Diese Liebe der Materie, diese Liebe des Simnlichen ist keine zeugende und schöpferische Funktion wie der platonische Eros, sondern sie ist bloße Sehnsueht und Begehren, der es an jeder erlösenden Kraft fehlt. Dagegen ist mit dem Formprinzip der Charakter der Aktualität verbunden, und wenn die Materie nach Gestaltung begehrt, so begehrt die Form zul gestalten. Der Erosbegriff der Aristotelisehen Philosophie ist also in Gegensatz zur Platonischen Liebe mehr der hingebenden Sehnsueht des Weibes zu vergleiehen. Aber diese hingebende Liebe des Sinnliehen ist nicht ohne Macht, sofern sie die Umklammerung und Umarmung der Form herbeizwingt. Nun darf der Formbegriff des Aristoteles keineswegs im Sinne eines naturwissensehaftlichen Begriffes, etwa als Naturkraft, verstanden werden. Es handelt sich hier nicht $u$ etwas, das im Ramme stoßen und treiben kann, es handelt sich überhaupt nicht um etwas materiell Wirkendes. Bewahrt ist durchaus der Grundcharakter der Platonischen Idee. Es handelt sich um ein intelligibeles Prinzip, um ein Ziel, um eine Aufgabe, die dem Werden gestellt ist. Nur ist dieser Wertbegriff des Aristoteles clurch Gleichsetzung mit dem Allgemeinen des Artbegriffes in ähnlicher Weise naturalistisch entstellt wie die Platonisehe Idee durch Gleichsetzung mit dem Gattungsbegriff. Diese Aufgabe, die dem Werden gestellt ist, dies Ideal des Seins gelangt in keiner sinnliehen Gestalt des Lebens jemals zum vollkommenen Ausdruek. Niemals erreichen Pinie und $\mathrm{zy} y$ resse die vollkommene Form, immer wird die reine Form getrübt durch die Macht des simmliehen Faktors, der nie die vollendete Linie deutlich hervortreten läBt, der immer die reinen und hellen Konturen des Wirklichen trübt und verdunkelt. Und, so sind alle Produkte der Natur unvollkommene Versuche, das Ideal darzustellen, das in keiner Erscheinung der Sinnenwelt vollkommen realisiert ist. Die reine Form gelangt niemals zu adäquater Darstellung, ja der Gedanke der Darstellung und Entfaltung der Form in der Materie seheint schon den Gedanken der adäquaten Wertverwirklichung auszusehließen, da ja die Materic als Möglichkeit des Seins immer wieder tausendfältige Abwege und Abirrungen versehuldet. Dennoeh muB eine adäquate und restlose Darstellung der idealen Form wenigstens der Irlee nach denkbar sein. Das wäre dann der Fall, wenn die sinnliehe Materie restlos von der Form durchdrungen wäre, oder wem die Sinnlichkeit durch die Gristigkeit absolıt verklärt wäre. Das ist aber nur in Gott als deu Vollkommenen und Vollendeten der Fall. Die ganze Sinnenwelt behält den Charakter les liuhelosen und Fragmentarisehen.

In diesem Begriff der Entwicklung ist der für die Geschiehtsphilosophie so hrdentsance Gerlanke der Wertvorwirklichung logisels vorgebildet. Die

1) Vhl. die Kritik der Platonisehen Ideenlehre in dor aristotelisehen Metaphysik. 
Vorgänger des Aristoteles hatten die Idee der Entwicklung noch nicht deutlich gedacht, ,sondern nur die Form der Veränderung und Bewegung. Und so weit dieser aristotelische Begriff der Entwicklung von dem historischen Entwicklungsbegriff auch noch entfernt sein mag, so strebt er doch unverkennbar der historischen Gedankenrichtung zu. Was ihn aber von dem historischen Entwicklungsbegriff trennt, das ist vor allem dieses, daß das Verhältnis zur Zeit für ihn vollkommen gleichgïltig ist. Der Aristotelische Begriff der Entwicklung ist unabhängig von der Zeit gebildet. Nicht als ob Aristoteles behauptet hätte, daß es eine Entwicklung gäbe, die unabhängig von der Zcit verläuft, aber in dem Stufenreich der Entwicklung, das er gelehrt, spielt die Zeit keine wesentliche Rolle.

Diese Stufen der Natur, in denen Aristoteles den Gedanken des Wirklichen gedacht hat, beginnen bei der bloßen Materie und enden bei Gott. Aber dieses Beginnen und Enden ist kein zeitliches Beginnen und Enden. Nicht soll dargetan werden wie Stufe auf Stufe zeitlich folgt, wie die Materie zu Gott wird, oder wie Gott sich aus der Materie entwickelt. Niemals wird die Materie zu Gott. Sie bleiben ewig geschieden. Und mit dem modernen naturwissenschaftlichen Entwicklungsgedanken, der zu zeigen sucht, daß alles höhere Leben aus niederem Leben sich entfaltet hat, mit der großen Historisierung der Naturwissenschaft, wie sie vor allem Darwin verkündete, hat die Lehre des Aristoteles nichts zu tun, ja sie ist gerade der feindliche Gegenpol dieser Theorie, sofern sie die Festigkeit der Arten, die Starrheit und Unveränderlichkeit der Formen lehrt, die niemals zueinander sich entfalten, die niemals ineinander übergehen, aufgehen und untergehen, sondern ewig bleiben, was sie sind. Insofern sieht Aristoteles die Natur vollkommen unhistorisch an, und doch treten in seiner Naturphilosophie Momente hervor, die geschichtsphilosophisch recht bedeutsam sind, vor allem in der Idee des einen teleologischen Zusammenhanges, der das Höchste mit dem Tiefsten verbindet.

Wenn wir die Natur aller Formen und Gestalten entblößen, so kommen wir zu dem Begriff der unbegreiflichen irrationalen Materie, die selber nicht ist und existiert, weil lediglich das Geformte Seincharakter hat, und ohne die auch wieder nichts existieren könnte, weil die Form des Stoffes bedarf, um wirklich zu werden. Diese erste Materie ist der allgemeine Boden, auf dem sich die Natur aufbaut $^{1}$ ). Sie ist Naturfaktor, sie ist Naturbedingung. Aber sie ist als allgemeines Fundament der Natur doch nicht zugleich ihr erster und allgemeiner Grund. Aristoteles stellt die Frage der Naturentstehung überhaupt nicht. Im Geiste seiner Philosophie ist die Natur nie entstanden, sondern ewig. Ewig ist Materie von Sehnsucht nach Form ergriffen, ewig Form von dem Drang nach Gestaltung erfüllt. Wunderbar ist es zu erkennen, wie das Universum, bildlich gesprochen, von oben und von unten gestützt wird und zwischen reiner Form und reiner Materie als den letzten Bedingungen des Wirklichen ruht.

Die Materie schlechthin ist das Wertfreie, aber notwendig auf den Wert Bezogene und in den teleologischen Zusammenhang Eingestellte. Was wir so

1) Vgl. zur Bestimmung der Aristotelischen Grundbegriffe besonders Prantl, Ge. schichte der Logik Bd. I und Zeller, Philosophie der Griechen II, 2. 
im allgemeinen als wertfeindlich empfinden, kommt nach Arist oteles auf Rechnung der Materie. Jede Form ist werthaft, aber die Formen haben einen versehiedenen Wertcharakter und einen verschiedenen Wertrang.

Der ersten Materie als dem Unmittelbaren und Gottfernsten stehen am nächsten die Formen der mechanischen Welt. Sie sind es, welche die erste und rohste Arbeit an ihr vollziehen. Wer die Unwirklichkeit aller Formen behauptet, sieht die Welt als Chaos an, wer lediglich von der Geltung der mechanischen Gesetzmäßigkeit und ihren Formen überzeugt ist, sieht die Welt als Mechanismus an. Auch diese Welt des Mechanismus, die durch den dunklen Begriff der j̇úxæy, sich so eng mit der Materie berührt, diese Welt einer kühlen Abstraktion trägt bereits ewige und unvergängliche Formen in sich, die niemals aus der Vergänglichkeit des Stoffes abgeleitet werden können. Aber die mechanische Welt ist noch nicht die vollendete, $d$. h. die absolut geformte Welt. Sie ist erfüllt von Sehnsueht nach höherer Formung. Diese Sehnsucht findet ihre Erfüllung in den Formen des Physikalischen. Ihnen gegenüber ist die Welt des Mechanischen bloßer Stoff. Diese Welt des Physikalischen bedeutet der mechanischen Welt gegenüber eine Wertsteigerung, denn sie ist mit höheren Formen geformt. Man kann niemals sagen, daß die mechanische Welt zur physikalischen geworden ist, denn in der mechanischen Welt sind die Formen des Physikalischen nicht enthalten. Die Formen des Physikalisehen sind der mechanischen Welt gegenüber das absolut Neue und Unableitbare. Umgekehrt sind auch die Formen des Mechanischen nicht in den Formen des Physikalischen enthalten und aufgehoben, wie etwa bei Hegel die niederen Formen in den höheren enthalten sind. Sie verharren in einer gewissen Disparatheit zueinander. Was man von ihrem gegenseitigen Verhältnis behaupten kam, ist ledighich dieses, taß die höhere Form die niedere Form und das von ihr Geformte als Zweek- und Zielsetzung bestimmt. Und so wird immer Niederes durch Höheres bestimmt, bis schließlich die immanente sinnliche Wirklichkeit ihre höchtse Formung durch die tätige Gattungsvernunft der Menschen erfährt. Höher kann das Sinnliche dann nicht mehr hinauf, denn damit ist die Welt zu dem Punkt gelangt, wo sie der Gottheit so nah wie möglich kommt und sich loch immer noch ganz prinzipiell von ihr unterseheidet.

Wenn wir nun diese versehiedenen Weltsphären betrachten, die in einem Verhältnis zueinander stehen, das cin für allemal fest geordnet ist, und das durch kcine Zcit angefochten werden kamn, so ist dieses ganze Stufenreich seinem logischen Aufbau nach mit einer universalhistorischen Gliederung des historischen Prozesses vergleichbar, nur daß die Zeit, welche für die Geschichte wesentlich ist, hier keine Rolle spielt. Die Stufen des Wirklichen sind vielmehr so geflarht, wie sie, in der Vernunft" von Ewigkeit zu Ewigkeit sind.

Ein Endzweck ist als bestimmend gedacht, ein höchstes Formprinzip, die schöjferische Tätigkeit der Vernunft, in der sich die Sinnenwelt vollendet. Man kann das auch so ausdriicken: Ger Enrkweck der Natur ist die rastlos tätigr. Gattungsvernunft, welche die höchsten Werke der Kultur leistet. Von ihr aus sind alle Phasen der Natur als Vorstıfen zu verstehen. Der Sinn der Natur muls darin gesucht werden, daß mensehlich Wertrolles geschaffen wird. Jrodr Naturstufe: dient diesem Zicle, jede Naturstufe nähert sich diesem 
Ziele. Schon die Materie ist dazu bestimmt, daß sie Kulturmaterial werde. Immer höher steigt der Wert, immer größer ist das Maß der Vollendung.

Will sich aber die Sehnsueht, die aus der Materie hervorströmt, niemals zur Ruhe begeben? Wird sie immer weiter geführt und getrieben, oder gibt es eine höchste Erfüllung? Nach der Philosophie des Aristoteles kommt die Sehnsucht in der Sinnenwelt nie zur Ruhe. Auch in den großen Kulturleistungen auf sozialpolitischem, künstlerischem und wissenschaftlichem Gebiet ist noch immer ein Vorläufiges zu erblieken. Sie sind noch nicht der letzte Sinn der Erde. Der Sinn der Erde geht über die Erde hinaus, wie wir vor allem in der höchsten theoretischen Vernunfterkenntnis deutlich erfahren. Die Sinnenwelt weist auf eine übersimnliche Welt hin und wäre selber haltlos, fragmentarisch und unverständlich olne diese höchste Sphäre. Diese übersinnliche Welt ist, um mit Meister Eckhart zu sprechen, , lauter Gott". Dort gibt es nichts anderes zu finden als ihn. Nichts Einzelnes und Vereinzeltes hat dort Platz und Stelle. Der Sinn der Natur ist nur zu rerstehen als Sehnsucht nach Formung und als relative Erfüllung dieser Sehnsucht. Wäre die Natur restlos von Form durchdrungen, dann würde der Impuls der Materie verstummen und der Form keine Aufgabe mehr gestellt sein. Dann würde alle Entwicklung aufhören und die Natur in eine absolute Ruhelage übergehen. So ruht das Kunstwerk in seiner Vollkommenheit, nachdem die Tätigkeit des Künstlers das Größte darangesetzt, daß Größte daran getan und nichts Ungeformtes zurückgelassen hat. Aber es gehört zum Wesen der Sinnenwelt, daß sie niemals zur Ruhe gelangt. Die Formen der irdischen Wirklichkeit sind nicht mächtig genug, das Simnliche und Sterbliche so weit zu läutern, daß es in die Reinheit und Unvergänglichkeit ihres eigenen Wesens rollkommen aufginge und verschwände. Selbst in dem Höchstgeformten der Sinnenwelt, in dem menschlichen Individuum, ist die Sinnlichkeit nicht ron Vernunft durchdrungen, sondern höchstens ron Vernunft geleitet und beherrscht. So fehlt der Sinnenwelt die Vollendung, aber sie fühlt diesen Mangel und strebt ihn zu überwinden. Jene beiden Faktoren, die in der Simenwelt einander zustreben, aber niemals sich so vollkommen finden und rerbinden, daß der Gegensatz getilgt wäre, in jener anderen Welt schließen sie ihren Frieden. Das kann aber nur so geschehen, daß die Liebessehnsucht der Waterie vollkommen erfüllt und sie ganz von Form gesättigt wird. In der Sinnenwelt gibt es immer wieder neue Möglichkeiten des Werdens. Mag das Leben noch so hoch sich entfaltet haben, es kann immer wieder zu einem anderen werden. Die Sphäre des Ủbersinnlichen und Reinen kennt keine Entwicklungsmögliehkeit mehr. Hier ist alle Möglichkeit zur Wirklichkeit geworden. Dort ist nichts weiter zu finden als der in dem Schauen seiner selbst verlorene Gott (Gott Narkissos), der das Vorbild zu der Vorstellung des göttlichen Gegenbildes hergab und der so ganz und völlig ron seiner eigenen Vollkommenheit in Anspruch genommen ist, der so selig in seiner Einsamkeit ruht, daß er sich um die ganze Sinnenwelt nicht im geringsten kümmert, und doch in dieser Teilnahmlosigkeit noch so viel Macht besitzt, daß er die ganzeWelt bewegt, so wie das Geliebte das Liebende bewegt $\left.{ }^{1}\right)$.

1) Vgl. das 12. Buch der Metaphysik. 
In der Philosophie des Aristoteles sind sehr viele Momente aufbewahrt, die später eine geschichtsphilosophische Formung angenommen haben. Der Begriff des unerreichbaren Endzwecks, die absolute Idee, in welcher die Sinnen-

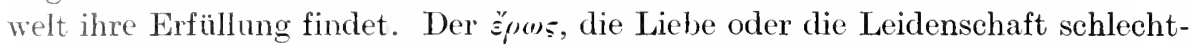
hin. als treibendes Motiv des Geschehens, die Stufen des Wirklichen, von denen jede neue einen höheren Grad der Werterfüllung in sich schließt. Alles das liegt vor. Und demnoch schließt das Aristotelische Weltbild jede historische Anschauung der Dinge aus. Das Stufenreich der Natur ,folgt" in keiner Weise, weder zeitlich, wie in der historischen, noch unzeitlich, wie etwa die Äonenreihe der Gnosis. Für den einzelnen Prozeß des Geschehens ist natürlich Zeit erforderlich. Aber die Vorstellung der ,Stufen" ist lediglich naturwissenschaftlich gedacht, als ein Úbereinandergelagertsein und -geschichtetsein, wobei immer das ,Untere" als Lebensbedingung für ,das Obere" und das ,Obere" als Wertbedingung für das ,Untere“ gedacht wird. Charakteristisch für Aristoteles in Gegensatz zu Hegel ist dann auch der Verzicht auf das Kontinuitätsprinzip hinsichtlich des Formenzusammenhanges. Die Materie steigt gleichsam in die verschiedenen Etagenstufen hinauf und wird immer geformter und immer kultivierter. Aber dieFormen sperren sich gegeneinander und gehen nicht incinander über, sondern werden als fest bestimmte in sich ruhende Begriffe gedacht. Das höhere Prinzip tritt zu dem alten als ein Nenes hinzu und hebt das frühere nicht in sich auf, so daß es vollkommen ausgeschlossen wäre, das alte Prinzip aus dem neuen oder das neue aus dem alten logisch zu entwickeln.

So können wir alles in allem in der Philosophiegeschichte der Griechen nur ein leises Werden des geschichtsphilosophischen Gedankens bemerken. Die Elemente bilden sich und schließen sich hier und dort zu Gebilden zusammen, die für die Bereitstellung des geschichtsphilosophischen Gesamtmaterials von Wichtigkeit wurden, sobald ein neuer Geist sie berührte, der nun nicht mehr wie der Geist der antiken Welt von dem Prinzip der Endlichkeit und Begrenzung, von der Idee des Seins und der Naturwerdung, von dem Gedanken des Typischen und Allgemeinen vollkommen beherrscht war, sondern in neuen Formen des Denkens die Idee der historischen Weltanschauung verkündete. Das war der Geist des Christentums.

\section{Kweites Kapitel.}

\section{Die Entfiltung des geschichtsphilosophischen Gedankens in der christlichen Philosophie.}

\section{\$1. Die christliche Geschichtsphilosophio.}

Her "Zoit nach Aristoteles bedentet für die Geschichte der Philosophie,

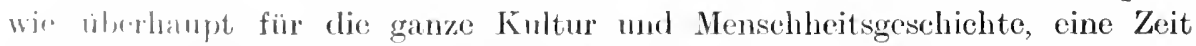
des Untrenumes, ren vollkommenen Zersetzmng und des Zerfalls. Es ist der Infergang dre griechisehen Welt, der sich damals vollzog, und der dann spirler durch den Untergang der römischen Welt abgelöst wurde. Dic Zeit 
ron 300 vor Christus bis 500 nach Christus ist die tragisehe Epoehe der Mensehheitsgeschichte, weil in ihr so viel Großes und Herrliches grausam zerstört wurde, und sie ist doch anch gleiehzeitig wieder eine eminent positive und synthetische Zeit, weil in ihr eine ganz neue Welt sich aufbante. Es war das eine Zeit, da man wohl meinen konnte, daß die Menschheit am Ende ihrer Leistungsmöglichkeit angelangt sei, und daß nummehr eine vollkommene Katastrophe ïber sie hereinbreehen würde. Man hatte den Glauben an die theoretische Vernunft vollkommen eingebüßt, ja man war auch nieht mehr imstante. die großen griechischen Metaphysiker zu begreifen. Alle U'berzeugung und alle theoretische Gesinnumg war verloren geangen, eine müde und resignierte Skepsis hatte die Gewüter ergriffen, und wo, wie in der Stoa, noeh ein gewisses theoretisches Pathos vorhanden war. da erwies sich doch der Verstand als vollkommen hilflos, mit den theoretischen Problemen fertig zu werden. Niemals ist so viel über Logik gesehrieben worden. und niemals die Logik so wenig gefördert wie gerade in jener Zeit.

Dabei war die Menschheit jener Zeit ron einer großen Besorgnis, Angst und Unruhe erfüllt. Sie wußte nicht mehr, was sie mit dem Leben anfangen. und was sie von ihm erwarten sollte. Das Leben war von tausend Gefahren bestïrmt, und ein finsterer Abgrund sehien sieh zu öffnen, der alles zu rerschlingen drohte.

In jener Zeit, welche man die alexandrinisehe zu nennen pflegt, war der Glaube an das Wissen, der Glaube an die theoretische Vernunft rollkommen verloren gegangen. In schwerer Bedrängnis ertıug man die Härten des politisehen Lebens, den Zwang und die Brutalität der römisehen Weltherrsehaft. Man floh aus dem politisch-sozialen Leben mit seinen erbarmungslosen Realitäten in eine stille Schönheitswelt, die man mit gleiehgesinnten Freunden teilte, wo man ein verfeinertes Kulturdasein genoß und die Häßlichkeit der Massen und die Grausamkeit des Staates in gleicher Weise rerachtete. Oder aber man wurde angelockt durch die Stimmen der Propheten, die nene Götter verkündeten, und wurde Myste jener geheimen Kreise, die sich damals an zahlreichen Orten bildeten, und die darauf ausgingen, den Mensehen von dem Jammer des irdischen Daseins zu erlösen. In jenen geheimen Kreisen wurde der junge Myste auf rerschwiegenen Pfaden langsam der Gottheit entgegengeführt, die ihn liebend erwartete. In Rausch und orgiastisehem Tammel, in wilder simnlicher Verzückung glaubte man der Umarmung der Gottheit teilhaftig zu werden. Und immer wieder waren es andere Götter, denen das geängstigte religiöse Bewußtsein sich zuwandte. Da die alten Götter, wie es schien, ihre Maeht verloren hatten, wandte man sich den seltsamen und phantastischen Gottheiten des Orients zu, deren Kultus sich vielfaeh mit perversen Grausankeiten und wilden sinnlichen Ausschweifungen rerband ${ }^{1}$ ).

\section{a) Dit Messiasidee.}

In dieser Zeit wurde die Messiasidee lebendig, wolehe die erste große geschichtsphilosophische Perspektive gegeben luat und in der Regel mit der

$\left.{ }^{1}\right)$ Vgl. über das alexandrinisehe Zeitalter Erwin Phodes Psyehe und die Philosophie der Kunst ron Schelling. 
Idee des anserwählten Volkes zusammengeht. Eine religiöse Idee von höchster Innigkeit und Tiefe, die Vorstellung, daß der große Gott der Welt sein auserlesenes Püstzeng sendet, um die sündige und elende Mensehheit zu befreien und zu erlösen. Der Messias ist der Liebling Gottes, der ihm am nächsten steht im All der Welt. Er soll das Getrennte verbinden, die gestörte und gelockerte Einheit ron Menseh und Gott wiederherstellen. In ihm vereinigt sieh die Idee der Menschlichkeit und Göttlichkeit. Er ist das Göttliche, sofern es sich simnlich und mensehlich offenbart und doch zugleich aneh wieder in dieser seiner Menschlichkeit Proben und Beweise seiner Göttlichkeit liefert. Er ist die Erfüllung der Platonischen Liebe.

Der Messias erscheint als Mensch unter anderen Menschen. Er ist der Sohn eines bestimmten Volkes. Dieses bestimmte Volk, in dem der Messias geboren wird, dem er sich in ummittelbarer Liebe kundtut, aus dem er seine Jünger und Helfer wählt, ist das auserwählte Volk. Dies anserwählte Volk ist das historisch unersetzliche Volk. Vergleichen wir den Begriff des auserwählten Volkes mit Hegels Begriff des welthistorischen Volkes, so ist jenes absolut und dieses relativ bedeutsam. Der Untergang des anserwählten Volkes würde gleichbedentend sein mit dem Untergange der Mensehheit, der Untergang des welthistorischen Volkes bedeutet nur das Ende einer großen Epoche. Ein neues Volk erscheint auf der Weltbühne, das die Idee des Weltgeistes weiterführt, das sich als neues Werkzeug seiner absoluten Macht darbietet: das neue welthistorische Tolk. Das auserwählte Volk ist nur einmal da, zum Wesen des welthistorisehen Volkes gehört keineswegs die Einzigkeit.

Mit der Idee des Messias erseheint das Universum als Geschiehte. Der Messias bedeutet, daß Gott sich in der Gesehichte offenbaren will. Zuvor hatte sich nach den religiösen Erinnerungen der Menschheit das Göttliehe nur in der Natur offenbart. Jetzt offenbart sich Gott in einer bestimmten historisehen Persönlichlicit und maeht das Schieksal eines einzelnen Volkes zum Mensehheitssehicksal.

Wrenn las Göttliche zu einer bostimmten Zeit, in einem bestimmten Volke durch eine bestimmte Persönlichkeit sich offenbart und dureh diese seine Offenbarmug dic Erlösung der Mensehheit vollzieht, so läßt sich von dieser Zeit der Erfüllung eine Zeit der Erwartung und Vorbereitung unterscheiden. I'nd weiter muB nach der Zcit der ummittelbaren Erfüllung sich die Ausbreitung des Erlösmugswerles rollziehen. Das, was in einer großen metawhysischen Tat geleistet ist, muß sieh historisch in einer Fülle von Wirksamkeit atuseinauterlegen.

Nicmals ist die Schnsucht nach Eviösung so mäehtig gewesen wie in jener

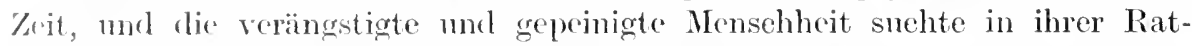
und Hilflosigkeit naeh Gestalten, die sie in glänbiger Liebe umfassen konnte,

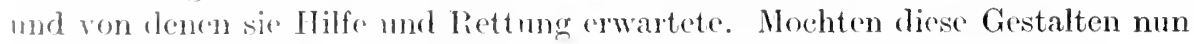
Hrensehendeiber oder Marmorbilder sein.

I)anals crwachte der Glaube an Autoritaiten, der lem Kindheitsalter der Mr'nschheit angehörte, so mïchtig wie nie zuvor. Nicht an die vernünftige Cherlegung richtet sich rler Appell der Menschen, sondern an die vom Glanz dror Vergangrenhejt mimstrahlte Gestalt. Nicht weil es dem eigenen Bewußtsein ron wahr uncl recht (ntsprach, wurde etwas bejaht und anerkannt, sondern 
weil es ein großer Lehrer der Vergangenheit so gesagt und rerkündet hatte. Autorität, Offenbarmng und Geschichte, das sind augenscheinlich Begriffe, die eng zusammenbängen, und die in jener Zeit sieh zu einer geschichtsphilosophischen Einheit formten. Denn die Idee der Offenbarung führte in der religiösen Universalgeschichte zur Gliederung des historisehen Universmms, und der Glaube an autoritative Mensehen als Träger der göttliehen Offenbarung schloß die Vergangenheit mit der Gegenwart zu einer sinnvollen Ordnung der Begebenheiten zusammen ${ }^{1}$ ).

\section{b) Prinzipien des Wertgeschehens.}

Dieser Gliederung des historischen Universums in einer universalgeschichtlichen Betrachtung nach gewissen Prinzipien wertvollen Geschehens hatte die Psychologie der Alexandrinerzeit vorgearbeitet. Schon Plato hatte zwischen dem Physischen, dem Psychischen und dem Werthaften und rein Vernünftigen zu unterscheiden gewußt. Diese Unterscheidungen aber, die in dem großen System des Aristoteles in Kraft blieben, gingen in der Entwicklung der griechischen Philosophieschulen rom 3. Jahrhundert vor Christus bis in das erste Jahrhundert nach Christus vollkommen verloren. Da ist es nun die dritte Phase der Stoa, die sogenannte religiöse Stoa, gewesen, welche die Wertunterschiede des Wirklichen wieder herauszuarbeiten bemüht war. Seneca hat auf das schärfste zwischen dem Psychischen und dem Physischen unterschieden und die Idee des Werthaften allein mit der Seele verbunden. Das Physische ist nur Hemmnis und Hindernis für die Seele. Ein Kerker, eine Fessel für den Geist. Epiktet bezeichnet Vernunft und Leib als die beiden Bestandteile des Menschen. Das Schöne und Wertvolle ist im Menschen unmittelbar mit den Häßlichen und Gemeinen verbunden.

Marc Aurel gelangt zu einer Dreiteilung des Wirklichen. Es gibt für ihn, entsprechend dem Grundgedanken derstoischen Metaphysik eine niedere und eine höhere Gestalt des Sinnlichen. Den groben Stoff des Sinnlichen bezeichnet er als $\sigma \tilde{\omega} \mu \%$, die feinere Form des Sinnlichen als $\approx \nu \approx \dot{\nu} \mu \alpha . \quad$ Diese beiden Faktoren konstituieren die sinnliche Wirklichkeit. Ton dem $\pi$ sinu unterscheidet er aber scharf die eigentliche Seele als ein unkörperliches, nicht an die Sinnenwelt gebundenes Wesen und bezeichnet sie als voís oder als óćivor

Diese Unterscheidungen, welche für die Gliederung der Universalgeschichte so wichtig geworden sind, erhalten später noch eine Verschiebung, sofern in der christlichen Philosophie das Gebiet des Psychischen an Macht und Bedeutung gewinnt und das Gebiet des Simnlichen sich mehr und mehr rerengt. Es werden nunmehr einander gegenübergestellt das Simmliche und das Unsinnliche. Das Sinnliche ist das Somatische, die niedere Sphäre der Körperlichkeit. Das Unsinnliche gliedert sich dagegen wieder in zwei Gebiete, in das Gebiet des Psychischen und in das Gebiet des Pneumatischen. Das Pneumatische gilt nun nicht mehr als sinnliche Form, sondern vielmehr als die höchste Form des seelischen Lebens, die wir auch im modernen Sprachgebrauch als Geist oder Vernunft bezeichnen. Damit hat der Begriff des Pneuma eine große Wandlung erfahren. Er, der frïher seine Abkunft rom

1) Vgl. Windelband, Darstellung der religiösen Periode in seinem Lehrbuch der Philosophie. 
Simnlichen nicht verbergen konnte, wird nun als reines geistiges Leben gedacht und aufgefaßt.

Das Problem der Geschichtsphilosophie entwickelt sich jetzt im engen Zusammenhange mit der großen religionsmetaphysischen Frage, wie denn das Sinnliche und Endliche, die irdische Welt und all das Böse und Wertfeindliche, das in ihr ruht, wie es aus Gott geworden sein könne, der doch das reine Prinzip des Guten und Wertvollen ist. Die andere Frage aber ist die für den Menschen so eminent wichtige und entscheidende, wie denn er selbst, der von der Sinnlichkeit so mächtig Ergriffene, der doch immer wieder das Unsinnliche verlangt, sich reinigen und befreien könne von der Schwere der Materie und von dem Staube der Welt.

\section{c) Apollonius von 'Tyana.}

Auf das schroffste stellt die Religionsphilosophie der Alexandrinerzeit Gott als das Prinzip der reinen Form der Materie gegenüber. Gott ist das absolut Transzendente, das, an sich genommen, nicht die geringste Gemeinschaft mit der Sinnlichkeit hat. Gott ist nach Apollonius von Tyana reines Selbstbewußtsein. Gegenstand dieses göttlichen Selbstbewußtseins sind aber die Ideen als die Urgestalten des Ewigen und Wertwollen. Auf der anderen Seite in absoluter Gottesferne die Materie als das schlechthin Sinnliche, als Grund des Unvollkommenen und des Bösen. Sie ist nicht von Gott geworden, hat mit seinem heiligen und reinen Wesen nichts zu schaffen. Sie ist ein Etwas, das immer war und vollkommen rätselhaft und nubegreiflich bleibt. Sie ist der Urzufall, die absolute Gottesferne. Wie kommt nun Gott zur Welt, und wie ist das Rätsel des Menschen zu erklären?

Ausgeschlossen wird von dem großen Neupythagoräer der Gedanke der Schöpfung. Nicht bewußtes Wollen ist es, was das Göttliche dahin geführt hat, Welt und Menschen zu bilden. Die Analogie mit dem sittlichen Tun des Menschen wird vollkommen verworfen: die Welt ist nicht das Werk der Güte. Sie kann aber auch ebensowenig in Analogie zu der Kunstbetätigung des Menschen als cine freie Schöpfung aus dem Nichts begriffen werden. Gott hat die Welt nicht gewollt, weder als Wirkender noch als Schaffender. Vielmehr mußte die Welt aus Gott werden, mochte er wollen oder nicht.

Das Göttliche, wie es Apollonius anffaßt, ist rein kontemplativ zu denken und hat mit Tun und Wirken nichts zu schaffen. Nur für sich ist es da und selig im Schanen der Ideen. Aber Fülle und Úberfluß ist mit ihm verbunden, und so wirl es notwendig zu einem Gebenden und Verschwendenden. Nicht aus Güte gibt die Gottheit, sondern weil sie ihren unendlichen Überfluß nicht bewahren kann, deswegen wirft sie ihre Strahlen in die Welt. Das ist der Emanationsgerlanke, der, schon von Apollonius von Tyana vorbereitet, in Neuplatonismus sich vollendet hat. Bei dieser Emanationsvorstellung steht das 11 ertvollste am Anfang des ganzen Prozesses. Das absolut Wertvolle ist der Cisprung. Die folgenden Gestalten sind Abschwächungen dieses Ersten und schwrllen und klingen immer mehr ab, je weiter sie vom Ursprungentfernt sind ${ }^{2}$ ).

1) Verl. ijher den begriff der Jimation Windelband, Lehrbuch, S. 204 und Kuno Fischer, simura, $S$. 409. Dazu die feinen Bemerkungen von Giordano Bruno in soinem Pancla: Dialoghi dolla eausa, principio ed mo, dentseh von Lasson, Berlin 1872. 
Und so strahlen die ewigen Gedanken Gottes die ióyo: aus, die zwar der Sphäre des Unsinnlichen entstammen, aber doch auch wieder den Sinn der reinen Vernunft als den Geist der ruhigen Betrachtung eingebüßt haben und zu tätigen Prinzipien geworden sind. Die Entfernung vom Göttlichen hat ihnen selbständige Aktionsfähigkeit verliehen. Indem sie der Materie sich nahen, haben sie an Feinheit und Geistigkeit eingebüßt. Lebenbildende Kräfte im Sinne der Stoa sind die Ausstrahlungen der göttlichen Ideen geworden. Indem sie nun mit der Materie in Berührung gelangen, üben sie ihre gestaltende Funktion aus und formen die Telt.

$\mathrm{Zu}$ diesen $\lambda u_{\gamma o \iota}$, welche die Verbindung zwischen dem Unsinnlichen und dem Sinnlichen herstellen, gehört auch die menschliche Seele. Sie steht an Würde hinter den reinen Formen und Urbildern des Wirklichen weit zurück. Aber andererseits steht sie an Rang und Bedeutung hoch über der Materie. Es war im Grunde genommen ein furchtbarer Zwang, der diese Abkömmlinge der reinen Geistigkeit dahin trieb, sich mit der trüben und dumpfen Materie zu befassen und eine Welt zu bilden, welche sie ihrer höheren Natur gemäß doch notwendig rerabscheuen und verachten mußten. Diese Welt, welche die ióyo gestaltet haben, wird ihnen selber zum Kerker und Grab. Sie bleiben in die Sinnenwelt gebannt und können den Rückweg zu Gott nicht finden. Das ist die äußerste Entfernung von Gott: dies Eingesponnensein in die sündige Sinnenwelt. In ihr eigenes Werk haben sich die Seelen rerstrickt. Sie können nicht mehr loskommen. Gar zu hart und fest sind sie gefesselt und gebunden.

Niemals würden die Gestalten des Unsinnlichen den IVeg zu Gott zurückfinden, wenn nicht der Prophet, der Wissende, als eine Offenbarung des Göttlichen in der Sinnenwelt erschienen wäre. Apollonius von Tyana weiß und fühlt sich als Messias und Helfer der sündigen und hilflosen Menschheit ${ }^{1}$ ). Seine Seele ist mächtig und stark, stärker als alle anderen Seclen. Sie hat schon einmal in gewaltigem Aufschwung die Kraft besessen, sich von allen Hüllen des Irdischen zu befreien und den Weg der Erlösung zu gehen. Das war an den großen Anfängen des Griechentums, damals trug Apollonius den Namen Pythagoras. Jetzt ist er wiedergekommen, freiwillig wohl, um dem ratlosen Menschengeschlecht den Weg zur Wiedererwerbung des verlorenen und ersehnten rein geistigen Lebens zu weisen.

Für alle Menschen besteht eine Möglichkeit derErlösung, aber sie müssen erst über den Weg und über die Mittel unterrichtet werden. Diese Mittel aber bestehen nach Apollonius vor allem in den Reinigungen. In den Säften unseres Körpers pocht ein wildes Begehren, das auf simnlichen Genuß gerichtet ist. Die Bejahung dieses sinnlichen Genusses und die Stärkung aller Fleischestriebe gilt es zu verhindern. Um das zu erreichen, muß der Mensch auf gewisse Speisen verzichten, die unserer Simnlichkeit Vorschub leisten, so vor allem auf die Fleischnahrung. Er muß seinen Körper an Terzicht gewöhnen und in ernsthaften Übungen daran arbeiten, sein geistiges Leben unabhängig vom Körper zu gestalten. Ja, er muß ernsthaft daran arbeiten, eine Ablösung des geistigen Lebens ron der Niedrigkeit des Simncnlebens zu vollziehen. Dann wird im Tode der Moment gekommen sein, wo die freie Seele

1) Vgl. hierzu Chr. Bauer, Apollonius und Christus. 3 Abhandlungen.

Mehlis, Geschichtsphilosophie. 
nicht mehr auf den Körper angewiesen ist und von seiner Schwere nicht mehr mitgerissen und mitgezogen wird, sondern den kühnen Flug ins Geisterreich zu tun rermag.

Der Weg der Erlösung und Befreiung von der Sinnenwelt, das große religionsphilosophisehe Problem, aus dem die Idee der religiösen Universalgeschichte hervorgewachsen ist, hat in der Metaphysik des Apollonius von Tyana noch eine rein äußerliehe Behandlung erfahren, sofern die Erlösung der Seele nicht dureh Erhöhung desWertlebens erzielt wird, etwa durch Stärkung des sittlichen Bewußtseins oder durch Erhöhung der theoretisehen Einsicht, sondern im Grunde genommen nur negativ durch Schwächung und Herabsetzung der Simnlichkeit. Ferner ist das Schicksal der Mensehen noch nicht als ein gemeinsames gedacht. Die Strafe der Inkarnation muß unter dem ethischreligiösen Gesichtspunkt aufgefaßt werden als die Schuld des einzelnen, und ebenso vollzieht sich die Erlösung als eine rein persönliche Angelegenheit. Wer auf den Meister und Propheten hört und sich dem Kreis der Jünger und Mysten zuwendet, dem steht der Heilsweg der Seele offen. Alle anderen sind dem Verderben geweiht und müssen dauernd in den Fesseln der Sinnlichkeit schmachten.

\section{d) Die beiden Wege bei Philon.}

Weit mächtiger ringt sich schon der geschichtsphilosophische Gedanke bei Philo, dem Juden, hervor, wenn es auch dem Christentum vorbehalten war, die Idee der Geschichtsphilosophie vollkommen zu realisieren ${ }^{1}$ ). Er setzt an den Anfang des zeitlosen Prozesses der Gottwerdung den unbekannten, eigensehaftslosen, unendlichen Gott, den keine Namen nemmen. Gott ist hier die reine Potentialität des Seins, das Wirklich-Unwirkliche. Keine Qualitäten eignen ihm, weil er sich restlos ausgegeben und verschwendet hat. Er hat sieh aber verschwendet an das zweite Prinzip, als den zweiten Gott, der die Fülle der Ideen in sich trägt, und der sich infolgedessen zu dem Anfangsprinzip verhält, wie Reichtum sich verhält zur Armut, Aktivität zur Passivität und Wirklichkeit zur Möglichkeit. Das Weltwerden aus Gott wird dann ähnlich gedacht wic bei Apollonius. Scine Eigenart aber entfaltet das philosophische Denken in vollem Maße bei dem Wege der Rückkehr, in der Erlösungsidee.

Noch ist die Erlösung kein gemeinsames Sehicksal und wird in dieser Hinsicht noch unhistorisch gedacht, aber Philon kennt eine Stufenfolge der Erlösung und faßt ihren Sinn viel tiefer und innerlicher. Die Frage, welche Philon aufwirft, ist diese: ,Wie kann sich der Menseh von der Simnlichkeit befreien?" Beider Beantwortung dieser Frage geht Philon von dem Gedanken aus, daß der Menseh, der so tief in Sünde und Schuld verstrickt ist, nicht nit rinem Sehlage aller Fesschn ledig und ein freier und seliger Geist werden kann. Wie der Myste allmählich dem Zustand des Wissens von den göttlichen Gehrimnissen naht und nit jeder neuen Wreihe würdiger wird, das Göttliche zu umfangen, so mul3 auch nach seiner Lehre die Seele sich vorbereiten, um drer Cuarmung dor Gotheit und damit der Erlösung von der Welt teilhaftig zu Werden. Dir erste Stufe anf diesen IVege ist die politische oder praktische. Hior hat der Mcosch don Simn und die Bedeutung des Tuns erkannt. Er

1) CYher Philon vel. Liwald, Gesehichto des Volkes Israel. 
ist num nicht mehr bloßer Sinnemmensch, der den Reizungen der Triebe folgt. Er rermag sie zu beherrschen. Dureh Tun entfaltet er seine wertrollen, rernünftigen Anlagen und stellt sie in den Dienst des staatlichen Gemeinsehaftslebens. Sofern er seine rohe Sinnennatur überwunden hat und der Gemeinschaft dient, ist der Mensch schon bis zu einem gewissen Grade ein Erlöster und ein Befreiter.

Der Mensch ist von den gröbsten Fessem seiner Simnemnatur befreit, und zwar dadureh, daß er an den Staat gebunden wurde. Die Seele aber, welche den Weg der Erlösung num eimmal betreten hat, strebt auch über diese Bindung hinaus. Diese Befreiung rom Staate aber findet sie in der Beschäftigung mit der Philosophie und Wissenschaft. In der Beschäftigung mit Philosophie und Wissensehaft nehmen wir, wie sehon Aristoteles gelehrt hat, teil an der Seligkeit Gottes. Nun bedrängt und bedrückt uns nicht mehr der Zwang sozialer Normen und Gesetzgebungen, num sehweigt auch das Terpfliehtetsein dem anderen gegenüber, der mit uns in den gemeinsamen Lebenskreis gestellt ist. Nun quäIt mich nieht mehr die Last eines bestimmten Berufes. Nun höre ich endlich einmal auf, ein ethisch-soziales Wesen zu sein und rerpflichte nieht mehr und werde aueh nicht verpflichtet. Nun bin ich volliommen zugewendet dem höchsten Prinzip der Welt und nur mit ihm beschäftigt und ron seinem Glanz erfüllt. Ich lebe auf dieser Stufe in der Sphäre des rein Theoretisehen und habe mieh sehon gar weit von der Simnenwelt entfernt und bin schon fast ein Erlöster. Noch aber empfinde ich den Zwang einer Bindung und eines Gebotes. Meine gottsehauende Seligkeit ist noch nicht rollkommen. Denn ich bin dem Zwange der logisehen Normen unterworfen und unterliege der ganzen Herbigkeit und Strenge des Begriffes. Diese Bilder der Anschaumn, die ich erfahre, sind so stark geformt und gebildet, daß sie ror meiner leidenschaftlichen Erkenntnisliebe noeh nieht in ein süßes Nichts zergehen. Diese höchste Stufe der Freiheit und die Abstoßung und Aufhebung aller Simnliehkeit ist erst in der religiösen Ekstasis möglich.

In der religiösen Stufe vollendet sieh der Weg der Rüickkehr. Die Seele erreicht nunmehr einen Zustand, der sie ron allem Simnlichen entfernt. Das ist der Zustand der Ekstase, in dem die Seele gleichsam außer sich gerät. Die Seele gibt ihr eigenes Leben auf, ihr eigenes Wollen und Fühlen sowie auch die Lebendigkeit der Vorstellungsbilder. Der Begriff, dem die Seele bisher zugewendet war, dem sie unbedingte Anerkennung zollte, und der ihr ein helles Verstehen gab, er ist in Nacht und Sehweigen untergegangen und führt nieht mehr die gottsuchende Seele. Alle Wallungen, Strebungen, Bilder. Gleichnisse Anschauungen, Begierden, Torstellungen und Begriffe sind untergegangen. Die Seele ist dieser ganzen Fülle und Mannigfaltigkeit vollkommen ledig und befreit. Alle Bande sind fortgefallen, und die Seele ist nummehr zu jenem Zustand reiner und rollkommener Passivität gelangt, da die Gottheit in ihr unmittelbar zu wirken remag. So ist sie num in diesen Zuständen höchster Ergriffenheit wahrlieh erlöst und erreicht sehon in ihrem simnlieh-irdischen Leben ihr ursprünglich göttliches Dasein wieder. Wer aber dieses erreicht hat, daß er imstande ist, die Sinnlichkeit so weit zu überwinden, daß niehts ihn mehr fesseln und binden kann in Zustande höchster Weihe als das Göttliche selbst, der wird durch den Tod, der das Simnliche bedroht, in seinem wahren Wesen 
nicht berührt, sondern im Gegenteil, der Tod ist für ihn eine willkommene Hilfe, ron nun an für immer mühelos in jenem Zustande der Gottseligkeit zu weilen, den seine leidenschaftliche Sehnsucht sich bisher mühevoll erkämpft hatte.

e) Die drei Stufen der Riiekkehr.

Diese Gliederung des Heimweges, der Rückkehr und Rückwendung der Seele zu Gott, die ron Philon angedeutet wird, ist das große Thema der ersten religionsphilosophischen Geschichtskonstruktionen geworden. Vor allem hält man an den drei Stufen der Rückkehr fest, indem man jene Stadien der persönlichen Erhebung in der christlichen Patristik mit den drei Offenbarungen des Göttlichen vermählte. Allerdings wurden nunmehr die drei Stufen der persönlichen Erhebung und Läuterung zu drei Stufen des historischen Fortschritts, und das Politisch-Ethische, Theoretische und Religiöse, was den Wertcharakter der Stufen hergab, wurde in dieser Form nicht aufrecht erhalten, sondern wich zunächst einmal der Gliederung in somatisch, psychisch und pneumatisch.

\section{i) Christentum und Universalgeschichte.}

Wenn nun aber auch die philosophiegeschichtliche Entwicklung, wie wir sie bisher betrachtet haben, voller Andeutungen und Fingerzeige ist für eine begriffliche Beherrschung des historischen Universums, so bestehen diese Hinweise doch nur für denjenigen, der vom Standpunkt des Christentums her in die griechische Welt zurückschaut. Das Problem der Weltgeschichte wurde erst durch das Christentum aufgerollt ${ }^{1}$ ). Diese Frage der Weltgeschichte aber ist die Frage nach dem Sinn des historischen Geschehens. Wohl hatte das Römertum als politischer Aufgabe der Idee eines Weltstaates nachgestrebt. und war damit über die Enge des griechischen Nationalismus hinausgegangen. Wohl war der kosmopolitische Gedanke in diesem Volke gereift. Lehrte doch die Philosophie der' Stoa eine Gemeinschaft der Edlen und Weisen aller Völker und Zeiten, eine Gemeinsehaft, die mit den engen Bindungen der Nationalität vollkommen aufräumte und die große geschichtsphilosophische Idee von der Einheit des Menschengeschlechtes vorbercitete. Aber diese Gemeinschaft unfaßte doch nur die großen und starken Persönlichkeiten und formte sich nicht zu der Idec ciner allumfassenden 'Totalität des Mensehlichen.

Die Patristik ist es gewesen, welehe sich zu der Idee einer Einheit des Menschengeschlechts erhob. Diese christliche Religionsphilosophie ist eine Verbindung von christlicher Religion und gricehischer Philosophie ${ }^{2}$ ). Die Jdee der Menschheit, die dam immer mehr im Lanfe der Zeiten sich zum Ideal und Vorbild, zum Inbegriff des menschlich Wertvollen herausarbeitete, hedentetc ursprïnglich nur cine schlichte Zusammenfassung alles menschlichen Lrbens unter den Gedanken, daß ihm ein gemeinsames Los beschieden sei. Nicht mehr geht der cinzelne gesondert und für sich den Weg von Schuld nud Sühne, sondern der Gang ist ein gemeinsamer geworden. Nicht mehr steht dir Nation ler Nation ohne jede religiöse Bezichung unverbunden gegenüber.

1) Vgl. Windelband, Lehrbuch, S. $212 \mathrm{ff}$.

2) VGl. I'. Wendland, Christentum und Hellenismus. 
Mögen sie unter allen anderen Gesichtspunkten sich frend und feindlich gegenüberstehen, mögen die politischen und sozialen Gegensätze noch so groß sein. mag die Idee der Schönheit das eine Tolk zu einer wundervollen Einheit zusammenführen, während das andere, ron allen Gestalten des Sehönen rerlassen, ein rohes barbarisches Dasein führt, der Idee der Religion eignet diese Macht. daß sie alle Gegensätze in einer inneren metaphysischen Einheit verbindet. Wenig will im Grunde genommen alles andere Wertleben gegenüber der Religion bedeuten. Auf die religiöse Stellungnahme kommt es ganz in erster Linie an, denn mit ihr ist ja allein der Seele Schicksal und der Sinn des Geschehens rerbunden.

\section{g) Die Stufen der Offenbarung.}

Das sinnvolle Weltgeschehen aber rollzieht sich im Geiste der Patristik in drei Phasen, die als Stufen der göttlichen Offenbarung aufzufassen sind und immer höhere Formen der Vollendung bedeuten. Die erste Stufe dieser Offenbarung ist der primitiven und sinnlichen Natur der jugendlichen Menschen angemessen. Die weiteren Stufen entsprechen der höheren geistigen Reife des Menschengeschlechts, das nummehr imstande ist. die göttlichen Wahrheiten in reiner und unverhüllter Form entgegenzunehmen.

Es erscheint also die Weltgeschichte als Erfüllung des göttlichen Heilsplanes. Die göttliche Vorsehung hat beschlossen, die sündige Menschheit zu erlösen. Diese Erlösung rollzieht sich stufenweise dadurch, daß sich das Göttliche den Mensehen kundgibt. Zuerst appelliert das Göttliche mit starken Bildern, Verhüllungen und Einkleidungen an die sinnliche Natur des Nensehen, später spricht Gott zu dem reinen Termunftwesen. Die Gliederung des Erlösungsprozesses in drei Stufen entspricht der Trinitätslehre. Dabei wird die Summe aller Menschen stillschweigend aufgefaßt wie ein einzelner Mensch, der ununterbrochen lemt und an Kräften und Fähigkeiten zunimmt. Seinem Lebensalter angemessen verkehrt die Gottheit mit ihm. Zu dem Kinde sprieht sie mit der Sprache des Kindes, zum Jüngling mit der Sprache des Jünglings, zum Manne mit der Sprache des Mannes. Diese Torstellung ron dem einen Menschen führt über die Schwierigkeiten hinweg, welche in dem Gedanken einer mehrfachen Offenbarung liegt. Denn wenn sich die Offenbarung nicht an eine Einheit richtet, sondern verschiedenen Menschen, Tölkern und Zeiten zuteil wird, so wird man sich fragen, ob jeder Offenbarung schon ein endgültiger Erlösungserfolg innewohnt oder nicht. Wäre das der Fall, so mïßten die Formen der Offenbarung gewissermaßen als gleichwertig angesehen werden, weil die frühere für den sinnlichen Mensehen genau dasselbe leistet, was die spätere für den kultivierten und geistigen erreicht. Oder aber die früheren Offenbarungen sind ron rorbereitender Natur. Dann haben sie anch nicht die Kraft, den Menschen zu erlösen, sondern leiten nur zu dem Erlösungswerke hin, das sich in der letzten Offenbarung rollzieht, und das nun seinerseits auch rückwirkende Kraft besitzt, indem es nachträglich diejenigen erlöst, die der vorbereitenden Offenbarung gefolgt sind. Ja, die Wirksamkeit der vollendeten Offenbarung kann auch so gedacht werden, daß sie nicht nur für die Vergangenheit, sondern auch für die Zukunft sich als gültig erweist.

Dieser Gliederung des historischen Prozesses durch eine dreifache Offenbarung kamen die Begriffe der spekulativen Psychologie entgegen, wie sie ror 
allem in der religiösen Stoa ihre Ausprägung gefunden hatten. Diejenige Form der Offenbarung, die an den rohen Simnenmenschen sich richtet, ist die somatische Offenbarung, deren Prophet Moses ist. Ihr folgte damn die psyehische Offenbarung, welche an die ethische Natur des Mensehen appelliert, und deren Prophet Christus ist. Die Offenbarung, die Moses zuteil wurde, ist die Offenbarung des Vaters, die Offembarung durch Christus ist die Offenbarung des Sohnes. Noch aber steht eine letzte und höchste Offenbarung bevor: die Offenbarung des Geistes. die an den Menschen als theoretisches Vermunftwesen sich wendet. Die Idee der dritten Offenbarung als einer noch bevorstehenden ist nicht zum dauernden Eigentum der christlichen Kirche geworden, aber damals lebte sie mächtig auf und ergab sich auch mit einer gewissen Notwendigkeit aus der Úberwindung der eschatologischen Vorstellungen ${ }^{1}$ ).

\section{h) Die Gestalt Christi.}

In den Mittelpunkt aller geschichtsphilosophischen Konstruktionen steht die Gestalt Christi. Er ist das Göttliche, das mensehliche Gestalt annahm. Er war ron Anfang an Gott und ist nicht etwa erst durch sein großes Leiden und Sterben zur Göttlichkeit erhöht. Das Göttliche und Übersinnliche ist seine ursprüngliche Natur. Aber das Menschliche und Sinnliche ist auch an ihn keine zufällige Erscheinung und Hülle, wie etwa für die griechischen Götter die menschliche Form und Gestalt, die sie gelegentlich annahmen, um mit den Erdenkindern zu verkehren, eine Art Maskerade war. Die Menschwerdung C'hristi machte die Erlösung der sündigen Menschheit erst möglich. Das Göttliche hat in Christus nicht nur menschliches Gewand angelegt, sondern in der Idee des Gottmenschentumes liegt es beschlossen, daß Christus ebensosehr Gott wie auch Mensch ist. Er ist absolut göttlich, weil er von Ewigkeit her in der Gemcinschaft Gottes lebt, und er ist absolut menschlich, weil er alle Qualen des Menschlichen bis zum Sehreeken des Todes fühlt und erträgt. Diese Idee des göttlichen Mittlers ïberwindet den Gegensatz des Sinnlichen und ('bersinnlichen und bringt zu absoluter Erfüllung, was in der Idce der Platonischen Liebe geahnt und gefordert war. Sie reißt die Gotheit aus ihrer erhabenen transzendenten Ruhe heraus und führt sie deun sehmsüchtigen Liebesdrang der Kreatur zu seliger Umarmung entgegen. Durch den Gedanken aber dieser Verbindung des absolut Wertvollen und Göttlichen mit dem Leben und dem historisehen Géschehen wird die Idee Christi zu der beherschenden geschichtsphilosophischen V'orstellung der religiösen Universalgeschichte. Ja, man kann sagen, daß die Idee Christi es gewesen ist, welche die Menschheit gelehrt hat, das Universum als Geschichte zu sehen.

So steht denn die Gestalt Christi im Mittelpunkt aller geschichtsphilosophisehen C'berlegungen der alexandrinisehen Epoche. Und diese stille und schönc Gestalt des göttlichen Dulılers hat das Verhältnis von Gott, Welt und Inensch rollkommen rerändert. Früher war das Göttliche dem Menschlichen frond und forn. Jetat aber ist nicht nur das Monschliche auf das Göttliche, sondern anch das Gö̈tliche anf das Menschliche angewiesen. Die Idee des

\footnotetext{
1) Jire von() rigines verkündete, von Lessing in der Erziehung des Menschengesehlechts anfer:nommeno Lerhe ven den drei Evangelien.j
} 
Menschen ist mit der Idee der Gottheit und der Idee der Welt in Einklang gebracht. Als eine große sinnrolle Einheit erscheint nunmehr das Universum, und im Mittelpunkt des Geschehens und alles werdenden Interesses steht der Mensch. Nicht mehr ist er ein Glied der Natur, sondern das einzig Werthafte ron allem Geschaffenen, für das die Natur da ist. Um ihn ist die Gottheit bekümmert und in ihrer unergründlichen Liebe bereit, das größte Opfer für ihn zu bringen. Indem das Göttliche um das Menschliche leidet, das als Geschöpf Gottes so schwere Schuld auf sich geladen hat, geschieht der Gerechtigkeit Gottes ein für allemal Genüge, und das All der Welt ist mit sich selbst versöhnt.

\section{i) Die Weltgeschichte als Drama von Sündenfall und Erlösung.}

So tritt die Weltgeschichte in Erscheinung als das große Drama ron Sündenschuld und Erlösung. Dabei wird die Tat des Schuldigwerdens aufgefaßt als eine Handlung, die der Entwicklung des Dramas und damit der Geschichte vorausgeht. Das Schuldigwerden geschah in einer Zeit, da der Mensch noch ein reines Naturwesen war, es geschah zu einer Zeit, da überhaupt noch kein historisches Geschehen war. Es geschah also zu einer unhistorischen Zeit, oder, nach einer anderen Auffassung und Deutung, der Akt des Schuldigwerdens ist ein zeitloser, intelligibeler Akt, der nicht nur dem historischen Geschehen, sondern auch der Weltbildung vorausgehend gedacht wird. Während das Drama als Kunstwerk in der Regel die Tat des Schuldigwerdens in sich schließt, geht in dem großen göttlichen Drama der Weltgeschichte die Schuld der dramatischen Handlung roraus.

Die christliche Geschichtsphilosophie, wie sie sich in der Patristik entwickelte. war nun anfangs noch ganz erfüllt ron der Idee des nahen Endes, ron jenen eschatologischen Vorstellungen, die durch die Worte des Herrn selber begründet zu sein schienen. Denn der Messias hatte davon gesprochen, daß er wiederkommen würde, und durch diesen Gedanken seiner Wiederkehr die trostlosen und verlassenen Jünger getröstet. Die Frage nach dem Sinne des Geschehens wurde daher anfangs nur auf die Vergangenheit, nicht aber auf die Zukunft bezogen. Man suchte die Zeit vor Christus zu deuten und zu rerstehen. Man verstand sie aber als eine Zeit der Vorbereitung. Das Erscheinen Christi in der Sinnenwelt bedentete die absolute Erfüllung. Er schloß nach der Vorstellung der Apologeten die Tore der Weltgeschichte. Über ihn führte kein großes Geschehen mehr hinaus. Nach seinem Tode blieb nur noch übrig eine kurze Zeit der Erwartung. Dann würde er wiederkommen zu den Seinen und all ihren Kummer stillen. Wohl aber fiel von seiner erhabenen Gestalt ein heller Glanz auf die Geschichte der Vergangenheit. Christus bedeutet die absolute Offenbarung Gottes. Dieser absoluten Offenbarung gehen andere relative Formen voraus, welche das Ziel der Weltgeschichte vorbereiten. Von vornherein muB unterschieden werden zwischen einer natürlichen und einer übernatürlichen Offenbarung. Die natürliche Offenbarung kamn zu aller Zeit erfolgen, die übernatürliche tritt zu einer ganz bestimmten und rorgesehenen Zeit in Erscheinung.

Die natürliche Offenbarung wird allen Menschen in gleicher Weise zuteil. Sie zerfällt in eine äußere und innere Offenbarung. Die äußere Offenbarung vollzieht sich in der Natur. In der zweckmäBigen Ordnung der Welt vermögen 
wir das Dasein eines höchsten Wesens zu erkennen. Die innere Offenbarung gibt sich kund in dem ruhelosen Trieb nach Wahrheit und Erkenntnis, von dem unsere Seele erfüllt ist, und der sich nicht bei der Sinnenwelt beruhigt, sondern immer wieder über sie hinausgeht und der Welt des Übersinnlichen zustrebt. Diese natürliche Offenbarung hat für die Geschichtsphilosophie keinerlei Bedeutung.

Die übernatürliche Offenbarung zerfällt in eine relative und absolute. Die übernatürliche Offenbarung richtet sich immer an auserwählte Persönlichkeiten, die ein eigentümliches und unmittelbares Verhältnis zur Gottheit haben. In der relativen Offenbarung gibt sich die Gottheit nur teilweise den Menschen kund, sie enthüllt noch nicht die Fülle ihrer Geheimnisse. Sie enthüllt sie auch nicht als Mysterien, sondern läßt von ihrer Rätselhaftigkeit nur Weniges und Vereinzeltes dic Menschen wissen. Die relative Offenbarung bereitet die absolute Offenbarung vor. Sie muß aufgefaßt werden als ein Hinweis auf die Erfüllung des historischen Geschehens, als eine Andeutung der welterlösenden Tat, die sich nach Gottes Ratschluß vollenden soll.

Eine solche relative Offenbarung des göttlichen Heilsplanes und der göttliehen Geheimnisse ist nach der Auffassung der Apologeten vor allem die Offenbarung, welche Moses durch Gott zuteil geworden ist. Aber das jüdische Volk ist nicht das einzig auserwählte, mit dem sieh die göttliche Liebe beschäftigt. Auch das griechische Volk hat Lehrer und Propheten des Übersinnlichen. Den verschiedenen Formen der Patristik ist mit Ausnahme der Antignostik eine freundliche Haltung gegenüber dem Griechentum eigentümlich. Jene alexandrinische Epoche bewunderte die griechische Philosophie, die ihr die Möglichkcit gegeben hatte, das religiös Gefühlte und Gewertete in die Form des Begriffes zu übertragen und es so dem theoretischen Verstehen deutlichzumachen. Sie erkannte damit die ungeheure Bedeutung der Griechen für die Geschichte der Menschheit. Den großen Männern des Hellenentums war schon ein Wissen von den übersinnlichen Wahrheiten gegeben, wenn auch nur ein begrenztes und unfertiges Wissen. So müssen Pythagoras, Sokrates, Plato und Aristoteles als Vorläufer Christi angesehen werden. Mit dieser Einsicht war eine gewaltige Leistung für die geschichtsphilosophische Spekulation vollzogen. Die im Werden begriffene neue Welt, deren Kulturträger mehr und mehr die germanischen Völker wurden, schloß sich nunmchr mit der alten Welt des Abendlandes und des Orientes zusammen. Die Wege Gottes fïhrten durch das Judentum und Griechentum über das Römertum hin zu den neuen Staatenbildungen der germanicehen Völker. Durch die Idee der Offenbarung vereinigt, die Moses und Sokrates zuteil geworden war, konnte das Germanentum die große Tradition der alten Kulturländer für sich in Anspruch unchmen. Anfangs verachtete der religiöse Geist dieser Zeit noch das neue Werden nind verachtete die Kultur der Wissenschaft und Kunst, nur erfüllt von dem V'rlangen nach dem Ende der Geschichte und der Wiederkunft des Herrn. Als aber die Vorstellung des nahen Endes mehr und mehr erblich, da bejahte man anch dic Kultur der Vergangenheit und vermochte in ihr etwas Wertvolles und schünes zu erblicken, inckem man gleiehzeitig fragende und suchende blicke inf tais Gessehehen richtete, das der Mensehheit noch bevorstand, und scincrn sinn zu crforschen suchte. 


\section{k) Die Geschichtsphilosophie der Guosis.}

Für jede Wissenschaft und für jede Form des Kulturlebens überhaupt kommt einmal der Zeitpunkt der Erfüllung. Vielleicht trat dieser Moment für das Epos mit Homer, für die Plastik mit Phidias, für die Logik mit Sokrates-Plato ein. In der Geschichtsphilosophie war es die Gnosis, die den Geist der Vollendung in all dasjenige hineintrug, was vorher doch noch mehr oder weniger Stückwerk war. So war die Geschichtsphilosophie eine Form der philosophischen Spekulation, von der Sehnsucht und Kraft des religiösen Geistes erfüllt, die im Orient ihren Ursprung nahm und rom Geist des Griechentums den schönsten Ausdruck empfing. Es handelt sich in der Gnosis nicht um streng begriffliche Philosophie, sondern um eine metaphysische Spekulation, die symbolische Verhüllungen liebt und im rauschenden Gewande der Schönheit daherschreitet.

Die Geschichtsphilosophie der Gnosis ist die erste große Form der religiösen Universalgeschichte. In ihr lebt der religiöse Gedanke absolut, und deswegen muß sie auch als der reinste geschichtsphilosophische Ausdruck des religiösen Bewußtseins angesehen werden. Die Universalgeschichte der Gnosis ist typisch für die religiöse Universalgeschichte.

Die Pole, um die sie sich dreht, sind die religiösen Wertideen der Schuld und der Erlösung. Das Schuldigwerden wird als eine zeitlose Geistertat gedacht, nicht sowohl als Tat des Menschlichen und Individuellen, sondern als Tat des Göttlichen. Dies Schuldigwerden vollzieht sich in dem zeitlosen Geschehen des Äonenprozesses. Neben dem zeitlichen Geschehen gibt es nach der Vorstellung der Gnosis ein zeitloses oder auch rorzeitliches Werden der übersinnlichen Welt. Die Theogonien des Griechentums gewimnen hier neue Gestalt. Noch ist die alte Vorstellung der sinnlichen Zeugung aufbewahrt in der Zuordnung von zwei Prinzipien, die immer einen Äon erfüllen, doch besteht er nur noch als symbolische Hülle. Denn keine anschaulichen menschenähnlichen Gestalten von Göttern sind es, die im Prozeß der Evolution anfeinanderfolgen, sondern viehmehr die höchsten Wertbegriffe der philosophischen Spekulation, die später Hegel im Prozeß der Dialektik miteinander zu verbinden suchte.

Am Anfang stehen diese beiden mystischen Begriffe: die Tiefe und das Schweigen, in denen die alte Vorstellung des Chaos anklingt. Aus dem tiefen schweigenden Abgrund der Gottheit ist die Ideenwelt herrorgegangen. Dieses Prinzip des Anfangs ist noch nicht bewußt und gestaltet, sondern vielmehr das Unbewußte, das träumende Spiel des Geistes, sein phantastisches, ungeordnetes und schöpferisches Dasein. Ist unter dem Urgrund der ursprüngliche Zustand des Seins zu verstehen, so ist das Schweigen, das auch als Denken,

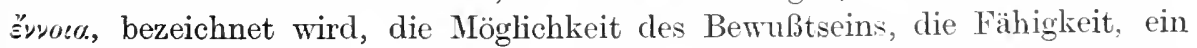
bewußtes Vernunftleben zu erzeugen. Wie Philon geht also auch die Gnosis hinter das Prinzip des Selbstbewußtseins, das Aristoteles als das höchste Prinzip aller Philosophie aufgestellt hatte, zu einem Prinzip des Unberußten zurück.

Aus dem höchsten Prinzip des Unbewußten geht als zweites Gestaltenpaa r das Bewußtsein oder die Vernunft hervor, welche die Gnosis als vois bezeichnet. Es ist die theoretische Vernunft, deren Gegenstand die Wahrheit ist. So hat 
sich die Möglichkeit des göttlichen Wissens zur Fülle des schöpferischen göttlichen Denkens offenbart. Ton den Gestalten aber, die dieses Bewußtsein schöpferisch erzeugt, und die ihrem Wesensgrunde entsprechend ewig und unvergänglich sind, steht damn an erster Stelle der Logos und das Leben. Der Logos ist im Sinne der Stoa als Lebenskraft gemeint, als jene göttliche Funktion, deren Ziel und Gegenstand das Leben ist. Jene beiden aber erzeugen danm ihrerseits die höchsten Gestalten des Lebens in der Idee des Menschen und der wertvollen menschlichen Gemeinschaft, in den Gedanken der Persönlichkeit und des sozialen Ganzen. Und so folgen sich, aus dem Urgrund alles Seins emporsteigend, die Fülle der himmlischen Gestalten, und Ewigkeit schließt sich an Ewigkeit an. Bis schließlich am Ende des Äonenprozesses, an der Grenze der Ewigkeit als späteste Idee die Weisheit sich bildet, die sehnsüchtige Liebe nach Erkenntnis. Diese Weisheitsliebe ist zugewendet dem Ursprung ihres Werdens und erforscht all die leuchtenden Gestalten, die sie von diesem Ursprung tremen, und dringt bis zum Urgrund alles Werdens vor. Und da steht sie dann plötzlich vor dem Rätsel der Welt, vor dieser schweigenden Tiefe der bloßen Gottheit. Und indem sie das Gestaltlose und Namenlose schaut, wird sie von sündiger Liebe zu diesem Quell alles Seins und dem Wunder ihres eigenen Werdens ergriffen. Als Strafe für ihre Sündenschuld wird die Weisheit von der Sphäre der seligen Gestalten in die Tiefe geschleudert und bildet, so zur Tätigkeit getrieben, die Welt.

In dieser Lehre von der Schuld der Weisheit hat die Idee des Sündenfalles wohl ihre tiefste symbolische Verklärung gefunden. Sie bildet gewissermaßen eine Verbindung zwischen der Vorstellung des Judentums und der Lehre Platos. Nach der Auffassung des Judentums wird die Menschheit in den ersten Menschen schuldig, weil sie zuviel wissen wollen. Dies ,Zuvielwissenwollen" offenbart sich aber in der Gestalt einer naiven Neugier. Nach Plato werden die individuellen Scelen schuldig, weil sie in der Erkenntnis lässig sind und nicht hingebend genug an der Ideenschau teilnehmen. Dort ist die zu große, hier die zu geringe Erkenntnisliebe sündhaft und strafbar.

In der Auffassung der Gnosis vom Sündenfall waltet das jüdisch-christliche Moment entschieden vor, erhält aber durch die griechische Vorstellungswelt eine erhabene Tiefe. In der Idee der Woisheit finden wir die Platonische Liebe wieder, die die Welt des Ewigen und Unsinnlichen mit der Welt der Sinnlichkeit rerbindet. Deswegen steht auch mach der Lehre der Gnosis die Gestalt der Weisheit an der äußersten Peripherie des Äonenreiches. Sie bedeutet den Ubergang aus der Sphäre der Geistigkeit in die Sphäre der Sinnlichkeit.

Anfünglich allerdings ist sic der Schar der ewigen Gestalten zugewendet und gan\% von ihren lichte erfüllt. Sic ist der Prototyp alles Wissens, und zwar speziell jenes endlich-menschlichen Wissens, das seiner ganzen Art nach nirmals \%un Ziele gelangen kaun und von den göttlichen Geheimnissen streng

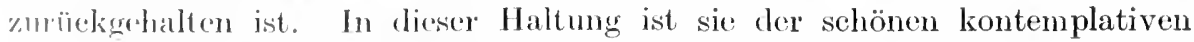
Milserele des Plotin rergleichbar, nur collicher und beschränkter als sie, mril mit rom Sehnsuchtsverlangen des ïntbehrenden behaftet. Dieser Mangel troibt sie ï)er die ruhige Sehönhejt des Schauens hinaus, die ihrer göttlichen Herkunft angenurssen wäre. Ein qualvolles Verlangen steigt mächtig in ihr 'mlor, sich mit dem Göttlichen zu vereinigen, aus dem sie hervorgegangen 
ist, und den Kreis des Geisterreichs zu schließen, das Ende zum Anfang zurückzuführen. Ein solches Verlangen ist unangemessen, weil ein leidenschaftliches Begehren der Würde des Geisterreichs nicht geziemt. Frevel aber ist es, weil blutschänderisches Begehren nach dem Ursprung des eigenen Seins. Jene strenge Sphäre des Göttlichen duIdet das leidenschaftliche Verlangen und auch die weiche mystische Liebe nicht, die mit dem Göttlichen eins zu werden trachtet. Sie fordert vielmehr eine strenge Bewahrung der Distanz und gibt das göttliche Geheimnis der Geburt nicht preis. Will doch diese sündige Liebe das notwendig Verhüllte entschleiert und nackt sehen. Wagt sie es doch in ihrem frevelhaften Erkenntnisdrange, an den heiligen Rätseln der 'Tiefe zu rühren.

In dieser Liebe sündigt alles Menschliche. Die $\sigma o \varphi$ í $\alpha$ der Gnosis symbolisiert die Idee einer gemeinsamen Schuld, der nun sogleich die rächende Strafe der beleidigten Gottheit folgt. Die sündige Liebe wird in die Leere und Wüste des unendlichen Raumes geschleudert und bildet aus diesem Nichts die Sinnenwelt. In ihr kommt das leidenschaftliche und unruhige Streben der Weisheit vorläufig zur Ruhe. Sie erstarrt wie Niobe in ihrem tiefen Schmerz. Die ganze Sinnenwelt ist erstarrte Sehnsucht, deutlicher und sichtbarer Ausdruck eines unerfüllten Liebesdranges. Und so gewinnt die ganze Natur für den Wissenden eine symbolische Bedeutung. Die Bäche sind die Tränen der Weisheit, und die Felsen bedeuten ihr schmerzliches Erkennen.

So weit führt und leitet der Weg der Weltwerdung, der Abweg von Gott, der Egressus. In der äußersten Gottesferne steht der Mensch als Vollendung des Individuellen. Weiter kann die Entfernung ron Gott nicht gehen, in ihm ist die äußerste Entfremdung erreicht. Von ihm aus tritt die rückläufige Bewegung ein, die unter Aufgabe der Individualität und der sinnlichen Gestalt zum reinen Geisterreich zurückführt, der Weg der Erlösung, der universalhistorische Prozeß, die Weltgeschichte. Durch diesen Prozeß wird die erstarrte Natur gleichsam aufgelöst, die Bande der Sehnsucht fallen ab, und das Vereinzelte und Getrennte kehrt zu Gott zurück.

In dem Mittelpunkt der universalhistorischen Konstruktion der Gnosis steht derMensch, der Gottentfernte. Er ist für die übersimliche Welt von hoher Bedeutung, deswegen kämpft und ringt das Geisterreich um ihn. Was in den religiösen Mythen der Völker lebt, das ist kein Gebilde der Phantasie, sondern eine metaphysische Realität. Wenn das jüdische Volk seinen Gott Jehovah verließ und sich dem Gotte Baal zuwandte, so wandte es sich nicht ron der einzig wahrhaften Realität einem wesenlosen Scheingebilde zu, sondern dieser Úbergang des religiösen Bewußtseins bedeutete nur dic Abwendung ron der höheren und die Hinwendung zu der geringeren Realität. Wie die rerschiedenen Völker und Nationen, so haben auch ihre Götter ein wahrhaftes Dasein. Und wenn diese Götter auch nicht dem reinen Geisterreich angehören, so sind sie als Dämonen, die ihrem Realitäts- und Wertcharakter nach zwischen dem Sinnlichen und Unsinnlichen stehen, doch nicht ohne Macht und Wirksamkeit. Alle kämpfen sie den schweren Kampf um die menschliche Seele. Denn der Mensch ist das sinnlich-geistige Wesen, auf dessen Gefolgschaft und Verehrung es ihnen ankommt. Den Kämpfen der Völker und Nationen, die das Leben der Weltgeschichte erzeugen, liegt, wie den Kämpfen der homerischen ,Helden, 
der Kampf der Götter, der Streit der Dämonen zugrunde. In dem siegreichen Volke triumphierte der Gott, dem der Kultus der betreffenden Nation geweiht war. In diesem Kampfe, der die Bewegung der Weltgeschichte leitet, gewinnen aber mehr und mehr die höheren Vernunftmächte die Oberhand. Ihr Triumph bedeutet den Verfall und Untergang der Sinnenwelt und die Wiederherstellung des reinen Geisterreichs. Mäehtig wird die Individualität mit ihrem trotzigen und auf sich selbst gestellten Willen der Macht des Allgemeinen unterworfen, und je mehr sie sich selber aufgibt, um so näher kommt sie dem Ziel der Erlösung. Von diesem Ziele der Erlösung ist niehts ausgeschlossen. Die ganze Natur wird erlöst, die ganze Natur wird zu Gott zurückgeführt, so daß eine absolute und vollkommene Einheit wiederhergestellt wird. Und dieser Prozeß ist ein Weg innerer Offenbarung, eine aufsteigende, fortsehreitende Bewegung. Wenn die Apologeten in der Erscheinung Christi die absolute Vollendung erblickten und von ihr aus die Geschiehte der Vergangenheit als eine Zeit der Vorbereitung konstruierten, so steht für die Gnosis die absolute Offenbarung noch zu erwarten. Die Offenbarung vollendet sich in der Idee des voũs, der wissenden Vernunft, welehe die Sinnenwelt verklärt und zu Gott zurüekführt als die reine Offenbarung des Geistes.

So ist der Bau der Universalgeschichte in der gnostischen Lehre tatsächlich vollendet. Ein gemeinsames Schicksal der sinnlich-sündigen Welt, ein gemeinsames Ziel : die Erlösung dureh die Macht des Geistes. Der Gedanke des Fortschritts kommt zum Ausdruek als Stufen in der Entfaltung der religiösen Idee, welehe die Glieder und Epochen des universalhistorisehen Zusammenhanges bilden. So hat die Gnosis dic Universalgesehichte recht eigentlich gesehaffen und eine ganz nene Idee des Weltlebens verwirklicht.

\section{l) Die Geschichtsphilosophie des Origines. I}

Dic alexandrinische Katechetenschule und ihr großer Meister Origines, welche die Gnosis so bitter bekämpften als eine falsche und trügerische Lehre rom Wissen, haben die gnostische Lehre von der Erlösungsgeschichte der Menschheit teilweise vertieft, und zwar vor allem durch ihre Auffassung des Verhältnisses von Mensch und Gott, teilweise aber auch die kaum gewonnene universalhistorische Idee wieder in Frage gestellt ${ }^{1}$ ). Origines sieht den tiefsten Sinn der W'elt in dem Verhältnis der unendlichen göttlichen Persönlichkeit zu den endlichen mensellichen Persönlichkeiten. Gottes unendlicher Wille, der mit seiner absoluten Schöpfertätigkeit zusammengeht, ist dem endlichen Willen des Menschen zugewendet, der sehnsuchtsvoll nach Gott verlangt. In clem Willen liegt nach Origines das Wertmoment des Lebens und schließlich auch das Wertmoment der Welt. Der endliche Wille ist der auf Gott angewiesene berlürft ige Wille, der enthehrend nach Gott verlangt. Der unendliche Wille ist der ïber seine Grenzen hinausgetriebeno göttliche Wille, der weit melir hat, als er bedarf, und der infolgedessen im Ủberstrom seiner Fülle immer geben und schaffen nnrl crlösen kann, um so an Ende aller Bedürftigkeit abzuhelfen und all dies Vereinzelte und Unvollkommene zu einem schönen Ganzen z"1 'rgänzen. So hat er zuerst einen tiefen Einblick in das Wesen der

¡) Vgl. Winrlelband, Lehrbuch, S. 211. 
guten Endlichkeit als des Persönlichen und Eigentümlichen getan, das Gott zu Welt ergänzt.

Die Unirersalgeschichte des Origines berichtet uns, wie der unendliche Schöpferwille der Gottheit, dessen Sein und Tun gleichbedeutend ist mit Schaffen, immer neue Welten erzeugt und bilclet, so wie nach der Torstellung etwa des Heraklit immer wieder neue Welten aus dem göttlichen Urfeuer hervorleuchten. Niemals kann dieses schöpferische göttliche Tun zur Ruhe kommen. Immer wieder wirkt es sich in neuer Betätigung aus, und seinem unendlichen Reichtum entsprechend sind alle Welten, die der göttliche Geist geschaffen, vollkommen rerschieden gebildet. Niemals wiederholt sich der göttliche Künstler, immer wieder vermag er etwas Nenes zu geben. So ist die Weltschöpfung das Wiederkehrende, aber dem historischen Gedanken wird Rechnung getragen, sofern nie dasselbe wiederkehrt. Setzen wir einmal Gottes Wesen gleich mit dem unendlichen Willen, so kann auch das Geschehen keine Grenzen haben, und es ist eine unmögliche Vorstellung, daß die Menschheit in der einmal geschaffenen Telt einmal schuldig und einmal erlöst wird. Vielmehr wird das Endliche in der immer wieder geschaffenen Welt immer wieder schuldig und immer wieder erlöst. So vermochte Origines die griechische Vorstellung von der ewigen Wiederkehr der Dinge mit der christlich-modernen ron der Unwiederholbarkeit des historischen Geschehens zu rersöhnen. Es entspricht dieser Torstellung des Origines, daß auch die Offenbarung Christi für ihn keine absolute Bedeutung besitzt, sofern in der Zukunft noch darüber hinaus die reine Vernunftoffenbarung des heiligen Geistes liegt.

Das Wichtige dieser ganzen Lehre für die Entwicklung der geschichtsphilosophischen Probleme muß wohl darin gesucht werden, daß Origines zuerst die Welt als das Feld zwecksetzenden Wollens begriffen hat und somit die Auffassung der Geschichte als Welt der Freiheit und der Tat rorbereitete.

\section{m) Regressus bei Plotin.}

Das überragende System dieser ganzen Epoche, die große Erbschaft des Griechentums, das System Plotins, ist zu sehr im Geiste der Antike gebildet, als daß es die Fähigkeit besessen hätte, dem universalhistorischen Gedanken ernsthaft Rechnung zu tragen. Nur der Regressus-Gedanke, der sich neben der Idee des Egressus, wie in allen religionsphilosoplischen Systemen der Zeit, so auch bei Plotin findet, rerdient ein gewisses Interesse. Allerdings bedentet der Prozeß der Rückkehr, geschichtsphilosophisch betrachtet, eimen erheblichen Rückschritt gegenüber der Gnosis und Origines, sofern von einem gemeinsamen Schicksal der Erlösung keine Rede sein kann. Vielmehr vollzieht sich der Prozeß der Befreiung rom Sinnlichen und Endlichen ohne Assistenz der Gottheit und ihres großen Offenbarungswillens als selbständige und isolierte Handlungsweisen der Individualitäten. Aber dieser Prozeß der Rückkehr ist in seiner ganzen Stufenfolge noch reicher und komplizierter geworden und offenbart all die verschiedenen Wege, die zu Gott himleiten. Deutlich ist bei Plotin der Gedanke ausgebildet, daß es die Kulturwerte sind, welche die Sinnenwelt überwinden und das Endliche zum Unendlichen zurïckführen. In der Beschäftigung mit Kunst und Wissenschaft, mit Staat und Religion 
betreten wir den Heilsweg der Seele. Nicht aber sind diese Trege im Verhältnis zueinander selbständig gedacht und vollkommen gleichwertig, so daß man es der Seele freistellen kann, ob sie den Weg der theoretischen Erkenntnis oder den Weg der Schönheit geht. Vielmehr schließen sich die verschiedenen Wege zu einem einzigen zusammen, sofern sie so gedacht sind, daß sie ineinander ïberleiten.

Die niedrigste Stufe auf dieser Skala bildet die politisch-sittliche Betätigung, das Wirken für den Staat und die Gesellschaft. Gewiß wird schon in diesem Tun der kleinliche Individualismus und Egoismus überwunden, aber noch wird die Seele gar zu sehr verstrickt in das unruhige Treiben des sinnlichen Lebens. Von überstaatlichen und übersozialer Bedeutung ist jenes Streben, das anf die Erkenntnis der Natur gerichtet ist, die selige Theorie, in der die wilde Qual des sinnlicher Begehrens und die rastlose Tätigkeit des Wirkenden und Schaffenden zur Ruhe gelangt. Doch ist das theoretische Schauen noch nicht die höchste Form der geistigen Schan. Höher als alle theoretische Vernunft erhebt sich die ästhetische Theorie, welche dem kontemplativen Geiste erst die süßesten und seligsten Geheimnisse der Welt enthïllt. Denn in der ästhetischen Schan sieht er die schöne Seele der Welt durch die Sinnenwelt hindurchblicken.

Und auch hier ist das Höchste noch nicht erreicht. Es gibt eine Schau des Gestaltlosen und Unbestimmten in glühender Ekstasis, da die Seele die Welt überwunden hat und nummehr, nachdem sie sich aller Dinge entäußerte und vollkommen ruhig geworden ist, nackt und arm in seligem Entziicken die erhabene Armut und Nacktheit der Gotheit empfängt. Der WVeg der Rückkehr muß verstanden werden als ein Wandern lurch die Stufen der metaphysischen Ordnung. Es gibt ein Denken getrennt rom voüs, und ein anderes, höheres, da die Seele mit dem voús sich ummittelbar vereinigt hat ohne Preisgalse der Individualität. Das Sehönste aber ist die absolute Entäußerung des Persönlichen im Alleinen ${ }^{1}$ ).

\section{n) Iugustins Lehre von den beiden Staaten.}

Wenn somit die Geschichtsphilosophie in der alexandrinisehen Epoche in der religiösen Sphäre noch still verharte, und das Schicksal der Seele nach dem Tode ganz einzig die Gemiiter ergriff und dic Universalgeschichte heranfbeschwor, so wird mit dem beginnenclen Mittclalter, an dessen Grenze uns die überragencle Ciestalt Augustins entgegentritt, die philosophische Betrachtung dahin geführt, narh dem Sim des politisch-sozialen Lebens zu fragen und zu mutersuchen, in welchen Organisatiomen und Finrichtungen der Geist Gottes hier anf Erden sichtbare Gestalt angenommen hat. Wenn man nach dem Zicle der Geschichte die Frago stellte, so dachte man nicht sowohl in erster Linie und ganz aussehließlich an die vollkommene Ubberwindung der Sinnenwolt unt an len Kusammonschlub der entsühnten Menschheit mit der überwollichon und unsimnlichen Gottheit, sondern man dachte ror allen Dingen an die Einswerdung der Menschen hier auf Eron. Die Einheit des MenschenS. 5.5.

1) Ves. hierza Cieschichte der mitrelalderlichen Philosophie von Maurice de Wulf, 
geschlechts, die Idee der Gemeinschaft, welche ron Anfang an im Geiste Gottes beschlossen war, sollte durch den historischen Prozeß zur sinnlichen Entfaltung und Verwirklichung gelangen. Erst in dieser Fragestellung lag die Aussöhnung der christlichen Idee mit den Zielen und Plänen einer großen Menschheitskultur. Das Gottesreich galt nun nicht mehr allein und ausschließlich als eine Sphäre reiner Geistigkeit, sondern auch als Ziel der irdischen Entwicklung, als geistig-sinnliche Wirklichkeit.

Allerdings ist diese Wendung von den Sphären reiner Geistigkeit zu den Typen des sozial-politischen Lebens hier eine zögernde und allmählige, die in A ugustin ihren Anfang nimmt und sich in Dant e vollendet. Diegroße Sehnsucht des Augustin gehört dem Gottesstaat als der seligen Gemeinschaft des Himmels. Illa civitas, in qua nobis regnare promissum est $\left.{ }^{1}\right)$. Gelangen wir doch in jenem Staate zur freudigen und ungestörten Schau der Herrlichkeit Gottes. Das selige Leben der Seele in der Gemeinschaft der Götter, wie es Plato schildert, ist immer wieder gefährdet und bedroht. Ein Nachlassen in der großen Anspannung des Erkenntnislebens kann die Seele wieder in all die Qual und Unruhe des Sinnenlebens zurückstoßen. Aber den christlichen Seelen, die zur himmlischen Seligkeit und zum Anschauen der Gottheit gelangt sind, kann niemals wieder das traurige Los des irdischen Daseins drohen. Sie haben ein für allemal die Not und Qual der Sinnenwelt überwunden. Sie ruhen in Gottes Gnade. Wie unendlich erhaben ist doch der himmlische Staat, das Reich Gottes, die civitas Dei, gegenüber dem irdischen Staat als den sinnlich-reltlichen Organisationen der Menschheit. Sie stehen roneinander ab wie Himmel und Erde, wie zeitliche Frenden und ewiges Leben, wie die Gemeinschaft der Engel und die Gemeinschaft der schuldvollen Menschen.

Wenn nun aber auch die ungeduldige Liebessehnsucht des Augustin den Pforten des himmlischen Reiches entgegendrängt und sein Auge noch nicht mit Ruhe und Vertiefung die großen Gestalten der historischen Wirklichkeit betrachtet, so gibt es doch eine sichtbare Organisation. die seinen Blick gefangen hält, da ihr eine unbedingte Beziehung zum Übersinnlichen innewohnt, und das ist die Kirche. In ihr baut sich Gott auf Erden ein Haus, zu dem er alle diejenigen hinführt, die seiner Gnade teilhaftig werden sollen, jener Gnarle, die ron Anbeginn der Welt an über allem Geschaffenen waltet und ihr Los bestimmt. Der Sinn des historischen Geschehens ist die Erlösung der simnlichen Welt und ihre Aufhebung in der civitas dei. Aber an diesem höchsten Ziel des Geschehens nimmt nicht alles Geschaffene teil. Augustin lehrt nicht wie die Gnosis ein absolutes Erlösungswerk, an dem die ganze Natur Anteil hat, das selbst die gefallenen Engel zu Gott zurückführt, sondern nach seiner religiösen Auffassung gibt es Auserwählte der göttlichen Gnade, denen die ewige Seligkeit zuteil wird, und andere, welche durch Gottes unerforschlichen Ratschluß zur ewigen Verdammnis bestimmt sind. Die Sünde der ersten Menschen bedeutete einen unverzeihlichen Frevel an ihrem gütigen Schöpfer. Die von jenen Erzeugten und Geborenen sind in ihrem sündhaften Tun und Treiben eine ständige Kränkung und Beleidigung für die Reinheit

1) De eiv. Dei 5, 17. Vgl. Die Staats- und Soziallehre des hl. Augustinus ron Otto Schilling. 
und Schönheit des höchsten Wesens. Diese Menschheit, für welche die Sinnenlust das Höchste bedeutet, und die nur in den Anschauungen und Vorstellungen einzelner sich zum Úbersinnlichen erhebt, sie hat im Grunde genommen ohne jede Ausnahme das Schicksal des Sinnlichen, den Tod verdient.

Die Kirche als ein Wertgebilde, das sich der Sinnenwelt vermählt, nimmt nun die Stelle im göttlichen Heilsplan ein, daß nur durch sie der Zugang zum Göttlichen gewomnen werden kann. Nur wer zur Kirche gehört, kann sich dem mystischen Leibe des Herrn vermählen, aber nicht alle, die sich zur katholischen Kirche bekennen, gewinnen die Seligkeit der civitas Dei. Denn es gibt nun eimmal nach der Úberzeugung des Augustin zwei Reiche, die um die Weltherrschaft ringen, und ron denen das eine zum ewigen Triumphe, das andere zur ewigen Strafe im Sinne der Gottesferne bestimmt ist: das Reich Gottes und das Reich des Teufels. In der Sinnenwelt aber haben beide ihr Reich begründet, das mit keiner sinnlich sichtbaren Institution zusammenfällt: die civitas coelestis und die eivitas terrena. Die himmlische Gemeinschaft ist diejenige, welche, der Sinnenwelt abgewandt, dem Gottesstande zustrebt und das Gebot der Liebe betätigt. Die irdische Gemeinschaft bejaht ausschließlich das sinnliche Leben und betont die Selbstsucht und den Egoismus. Die civitas coelestis ist das begnadete, das anserwählte Reich, die civitas terrena ist das verworfene Reich.

Die civitas coelest is liegt in der Sphäre der Kirche, nicht aber fällt die Kirche, wie man wohl gemeint hat, mit der civitas coelestis zusammen. Ebensowenig ist der Staat gleichbedentend mit der civitas terrena. Nur durch die Idee der Kirche ist die himmlische Gemeinschaft möglich, an dieser kann aber sehr wohl auch das staatliche Leben teilnehmen. Die weltliche Gemeinschaft des Staates kann überformt werden durch die Normen der himmlischen Gemeinschaft und so an ihrem reinen und unschuldigen Lichte Anteil haben.

Der Gegensatz ron civitas coelestis und civitas terrena meint im Grunde genommen nur den metaphysischen Gegensatz von gut und böse. Der Gottesstaat, die Gemeinschaft der Auserwählten, und der Teufelsstaat, die Schar ler Verworfenen, kämpfen miteinander in der großen Bewegung der Weltgeschichte. Dabei ist das Streben des Göttlichen auf die Aufhebung des Sinnlichen gerichtet. Gott nimmt sein Werk zurïck. Die Gestalten des Lebens, leren or sich entäußert hat, (lie er zu selbständigem Dascin erhob, er will sie wieder in sich zurücknehmen. Sein Organ in der Simnenwelt ist die Kirche als civitas Dei, dic Pilgerstadt, der Sammelplatz für alle diejenigen, die auf rem Wege zu Gott sind. Diese Starlt Gottes auf Erden arbeitet an der Aufhet)ung der Simnenwelt dureh dic Pflege der Liebe und Bekämpfung der sinnlichen Selbstsucht. An ihre Stelle tritt in der Ewigkeit die unsichtbare Kirehe, las himmlische Jerusalem. So ist die civitas coclest is diejenige Gemeinschaft, welche das Ewige liebt und zun liwigen und Götthehen hindrängt, während die civitas terrena das Zeitliche und Irdische festzuhalten sucht.

Dagegen kann die sichthare Kirehe, welehe wie dic unsichtbare als eivitas Dei bercichnct wird, mit der eivitas coelestis nicht gleichgestellt werden, da ja nicht alle Glietler rer sichtharen Kirche in dio unsichtbare eingehen. Innnerhin aher lat die religiöse Idee in ihr einen Körper gewonnen. Die sichthare Kirche ist der Inbegriff alles Wertvollen hier anf Erden. 
Was nun aber den Staat betrifft, so hat er im Grunde genommen keinen Eigenwert. Er empfängt sein Licht und seine Schönheit von der Kirche. Demn ron der Kirche als Stathalterin des Herrn geht alle Gnade aus. Wertroll sind die Einrichtungen und Gesetzgebungen des Staates, wertroll ist das Tun und Lassen seiner Bürger nur, sofern es im Geiste der Religion geschieht. In den Sakramenten als Mittel des Heils hat die Kirehe Gnarlen- und Wertgeschenke zu vergeben. Denken wir die Kirche fort, so bleibt der Staat als ein rollkommen wertloses Gebilde zurück.

Je mehr die Idee der Kirche mit dem Begriff des Werthaften verschmilzt, um so mehr gilt sie als Prinzip des Úbersinnlichen gegenüber dem Staat als Prinzip des Sinnlichen. Die Kirche rertritt das geistliche Leben, welches das wahrhaft geistige ist. Der Staat rertritt das weltliche Leben. Dann liegt das Böse und Wertwidrige auf seiten des Staates, das Gute und Wertvolle auf seiten der Kirche. Dann konkretisiert sich der Kampf der Guten und Bösen, der limmlischen und irdischen Stadt, in dem Kampf ron Kirche und Staat.

o) Die Konstruktion des welthistorisehen Prozesses bei Augustin.

Der universalhistorische Prozeß als Erlösungs- und Heilsgeschichte der Menschheit gliedert sich in sechs Stufen, die immer mehr den Triumph des Geistigen ïber das Sinnliche und den Sieg der unsichtbaren Kirche offenbaren. Diese sechs Stufen entsprechen den sechs Schöpfungstagen. Was in sechs Tagen geschaffen ist, wird in sechs Tagen zu Gott zurückgenommen und erlöst. Und wie den sechs Welttagen der Schöpfung der Sabbath der Gottheit folgt, so folgt den Welttagen der Erlösung der Sabbath der Menschheit. Gottheit und Menschheit sind die Pole des Weltgeschehens.

Die Konstruktion dieses universalhistorischen Prozesses beginnt mit $\mathrm{K}$ ain und $\mathrm{Abel}$, in denen sich der Gegensatz entfaltet zwischen den Kindern Gottes und den Kindern der Welt. In der Gliederung der fünf ersten Stufen des Weltgeschehens knïpft August in an Daten des alten Testamentes an. Die sechste Stufe der historischen Entwicklung ist charakterisiert durch das Erscheinen des Herrn. Somit rerhalten sich die ersten fünf Epochen des Weltgeschehens zu der sechsten Epoche als eine Zeit der Hindeutung, Vorbereitung und Erwartung. Auch damals war schon die Idee der Erlösung best immend und entscheidend für den ganzen Ablauf des Werdens, schon damals hatte die Gottesstadt ihre Streiteı. Aber diesen Kämpfern fehIte der Führer, der die zerstreuten Streiter des Herm unter seiner Fahne versammelt hätte. Damals war infolgedessen herrschend der Herr der Welt, und seine Söhne bedrohten die Kinder Gottes. In den Weltmonarchien des Heidentums ron Babylon bis Rom triumphierte die civitas terrena. Alle Furchtbarkeit der siinde brach unter ihrer Herrschaft aus. In ihren maßlosen Lastern trimphierte das Prinzip des Bösen.

Mit Christi Erscheinen beginnt die Zeit der Erfüllung. Nunmehr gewinnt die civitas coelestis das Úbergewicht. Die zerstreuten Gotteskinder organisieren sich in der Kirche. Die civitas terrena büßt ihre mächtige Organisation in den Weltmonarchien ein. Der Geist der Liebe, der Versöhnung und des Friedens ergreift die welttichen Staaten, die bisher ganz allein dem 
Geiste der Gewalt und des Egoismus gefolgt waren. So ist das Bollwerk der Sünde auf Erden ernsthaft bechroht, an dessen Stelle sich mehr und mehr die civitas Dei erheben wird. Wenn der weltliche Staat, zu dem sich die eivitas terrena organisierte, sich in den christlichen Staat verwandelt, dann muß er auch das Liebesgebot der civitas coelestis erfïllen und die Gebote Gottes befolgen.

In Augustin erblicken wir die Geschichtsphilosophie des Mittelalters, das große, ïberragende, die ganze Entwicklung bis zur Renaissance überschattende Werk. Die religiöse Idee der Erlösung, die den ganzen Entwicklungsprozeß bestimmt, hat feste Gestalt gewonnen in der Idee der Kirche als der sichtbaren Kirche, die auf dem Wege des Heils erbaut ist und die Erlösungsbedïrftigen, die frommen Pilgerseharen umfaßt, und der unsichtbaren, welche die Welt überwindet, die als Ziel gesetzt ist und die jubelnde Schar der Seligen in sich vereinigt. Alle anderen Kulturerscheinungen haben noch keinen selbständigen und autonomen Wert, nur im Lichte der Kirche können sie etwas bedenten. Die Idee des Fortschritts offenbart sich sowohl in der Hauptgliederung des historischen Geschehens, in dem Gegensatz der Epoche der Vorbereitung und der Epoche der Erfüllung, wie auch in der Vernichtung der historischen Weltreiche und der Begründung des christlichen Gottesstaates, in dem Trimmph der civitas coelestis über clie civitas terrena.

In ihrer grandiosen Einseitigkeit hat die Universalgeschichte Augustins etwas Lastendes. Vor allem deshalb weil das Dogma von der Gnadenwahl, das in die geschichtsphilosophische Konstruktion mit verflochten ist, das große Willensleben in der Geschichte nicht hervortreten läßt und den Glanz der Freiheit von ihr entfernt. Was soll das Ringen und Kämpfen der Menschheit in dem großen Geschehen der Geschichte, wenn all dies leidenschaftliche Tun an dem feststehenden Pesultat nichts ändern kann, daß nun einmal diese zur Seligkeit und jene zur Verdammnis bestimmt sind? Durch den Gedarken der göttlichen Gnadenwahl wird die Idee der mensehlichen Freiheit vollkommen illusorisch gemacht. Úber clen Menschen wird nur verfügt. Die bloße Tatsache seines Daseins entscheidet schon über sein Schicksal. Die Gewalt des Cottesgedankens lastet so auf dem historischen Universum, und die Idee der Menschheit vermag ihr gegenüber noch nicht deutlich zu Worte zu kommen.

Das Mittelalter hat drei große Gestaltungen der Geschichtsphilosophie hervorgebracht. Augustin steht am Anfang, er hat der mittelalterlichen Geschichtsphilosophie die typische lorm gegeben, Otto von Freising beleutet die Höhe der mittelalterlichen Weltanschauung, Thomas von Aquino und Dante das letzte große Wort der mittelalterlichen Philosophie. Un die thilosophische unt kulturelle Situat ion zu verstehen, aus der diese drei Formen ller Geschichtsphilosophie hervorgegangen sind, ist zu beachten, daß die Cieschichtsphilosophie Augustins nach den Untergang des weströmischen Jieiches, die Otto von Freisings nach Canossa und diejenige des Thomas von Aquino urel Dantes nach den Untergang der Staufen geschrieben ist. In allen drei Fälen hatte das Imperium Schiffbruch erlitten, und das Sarerdotium hatte 1 rimmphiert. Und doch liegt in jeder politischen Situation rin erhellicher Unterschied vor. Zur Zeit Augustins war das alte heidnische Weltreinh ler Rïncer zorlorochen, das erst vor kurzer Zeit sich der Idee des 
Christentums gebeugt hatte. Zur Zeit Ottos von Freising beugte sich das neue römische Kaiserreich deutscher Nation ror dem gewaltigen Papste Gregor VII., und die Idee der Kreuzzüge, welche des Papsttums höchster Glanz heraufbeschwor, bewegte damals die europäische Welt. Endlich neigten sich zu Dantes Zeiten die beiden großen Gewalten ihrem Untergange zu. Das Papstthum hatte dem gewaltigen Staufenkaiser obgesiegt, aber seine eigene Macht war nun am Ende. Es hatte die nationalen Kräfte gegen das Imperium entfesselt, und eben diese nationalen Nächte schlugen nunmehr das Papsttum selber in Fesseln und machten es schwach und ohnmächtig. So hatte die universale Idee sich selber zerstört, indem das Sazerdotium als das geistliche Prinzip des Universalismus die nationalen Gewalten gegen las Imperium als das weltliche Prinzip des Universalismus entfesselte.

\section{p) Die Weltgesehichte Ottos von Freising.}

Otto von Freising ist wie Augustin ron Sehnsucht erfüllt nach der übersinnlichen Welt. Aber der Gedanke der Verneinung der Sinnenwelt hat doch Augustin gegenüber schon erheblich an Schärfe und Schroffheit eingebüßt. Auch nach seiner Lehre ist das Ziel der Geschichte zu suchen in der Erhöhung der civitas Dei und in cler Erniedrigung der civitas terrena, und Kirehe und Staat treten auf als die konkreten Gestaltungen, in denen die himmlische und göttliche Stadt soziale Gewandung annimmt. Bei seiner sehroffen Betonung der Welteitelkeit ist er doch auch erfüllt von der Bedeutung der Kulturbewegung. Er verweilt mit Nachdruck und Ausführlichkeit bei dem politischen Geschehen und läßt die transzendente Welt weit mehr in den Hintergrund treten. Er erweist den natürlichen Faktoren des Geschehens weit mehr Gerechtigkeit als Augustinus ${ }^{1}$ ). Er hat Sinn für Individualität und Familie, Nationalität und Staat, Wissenschaft und Kunst. Vor allem ist es die Entfaltung der politischen Macht und der Wissenschaft, die bei ihm eine ausführliche Behandlung und Würdigung erfährt. Als Anzeichen seiner feinen Beobachtungsgabe und des Interesses, mit dem er dem Gang des Kulturlebens nachspürte, mag gelten, daß er in der Entfaltung des athenischen Staates die Disharmonie erkannte, welche zwischen dem politischen und wissenschaftlichen Fortschritt liegen kann²).

Während das Staatsleben Athens unaufhaltsam dem Untergang entgegenging, erreichte seine Philosophie und Wissenschaft die höchste Blïte. Allerdings haben wir den Eindruck, daß Ot to ron Fre ising die nicht religiöse Kultur nur historisch, aber nicht eigentlich philosophisch wichtig nimmt. Das religiöse Leben ist für ihn unmittelbar im Utbersinnlichen und Göttlichen verankert, aber das wissenschaftliche und staatliche Leben reicht ïber die Sinnenwelt nicht hinaus. Wissenschaft ist Menschenwerk, und der Staat ist häufig das Werkzeug gottfeindlicher Mächte. Auch die Philosophie ist wohI nur das höchste menschliche Gut, auf natürlichen Faktoren beruhend, so wie für Aristoteles der Staat das höchste menschliche Gut bedeutet

1) Vgl. Dr. Joseph Schmidlin, Die geschichtsphilosophische und kirchenpolitische Weltanschauung Ottos von Freising, S. 19.

2) A. a. O. S. 21 
und nicht in die Sphäre des Göttlichen himeinreicht. Alle nur menschliche Kultur steht im Zeichen des Relativen, oder dieses Relative ist bedeutsam im Dienste des Absoluten. Die religiöse Potenz ist entscheidend für die menschliche Gattung, nicht ihre materiellen wirtschaftlichen, sozialen und politischen Bediirfnisse, nicht ihre weltliche Geisteskultur. Deshalb darf auch die historische und geschichtsphilosophische Betrachtung nicht in erster Linie bei diesen verweilen, sondern muß an der Idee der Kirche orientiert sein, die dem religiösen Leben die soziale Form verleiht. Sie ist das allumfassende universale Prinzip, die das zerstreute menschliche Geschehen zu einer Einheit verbindet, von welcher aus das Ganze geordnet und gewertet werden kann, je nach der innigen Zugehörigkeit zu ihr oder cler Fremdheit in Feinclseligkeit und Geschiedenheit. Die weltliche Kultur wird nicht mehr als etwas Gleichgültiges behandelt, aber sie hat noch keinen selbständigen Sinn und bleibt auf die Sinnenwelt eingeschränkt. Doch muß ein wesentlicher Unterschied August in gegenüber darin gesehen werden, daß die Idee der Menschheit nach Otto von Freising für den historischen Prozeß einzig maßgebend ist. Während bei Augustin Himmel und Hölle in das historische Geschehen einbezogen sind, bilden nach Otto nun die Menschen in ihren Kämpfen und Leiden das Objekt der Geschichte. Alles menschliche Schicksal wird zu einem Gesamtgeschehen vereinigt, und die Völker der fernsten Zeiten sind mit den Kämpfen der Gegenwart verbunden. An Stelle der polemischen Haltung, die in Augustins Gottesstaat hervortritt, der als die glänzendste Apologie anfgefaßt werden kann, welche die christliche Kirche jemals gefunden hat, ist eine ruhig abwägende moralische Beurteilung getreten, ja manchmal wird anch bei großen welthistorischen Tatsachen die geschichtsphilosophische Beurteilung ganz zurïckgchalten.

Charakteristisch ist es für die Wertungsweise Ottos von Freising, daß die aktive Rolle, welche die Persönlichkeit in welthistorischen Geschehen $\mathrm{zu}$ spielen hat, eine sehr geringe ist. Wohl ist die Individualität für das welthistorische Geschehen wichtig, sofern ja der Mensch im Mittelpunkt dieses Geschehens steht, das ihn erlösen und von der Simnenwelt befreien soll, aber dic Persönlichkeit vermag für dieses große Werk und das hohe Ziel der Weltgeschichte so gut wie nichts zu tun. Die Individualität ist dahingegeben der leitenden Gotteshand und den großen sozialen Institutionen, in denen sich die göttliehe Fïgung kundgibt, der Kirche und dem Staat. Die Weltgeschichte ist lediglich ein Ausclruck für die Größe und Herrlichkeit Gottes, nicht aber für die Größe mnd Herrlichkeit des Menschen. Gott leistet alles für las Weltgeschehen, und der Mensch leistet niehts. Er vermag nichts zu leisten. Fr ist das hilfluse und sehuldbeladene Wesen, das dahin geführt wird, Wohin ihn das Maß seiner Schuld und der göttliche Wille führt. Noch ist die Fremde an großen historischen Persönlichkeiten nieht erwacht, noch wird der horlentende, ïberragend. Mensch nicht als Held verstanden.

Jie Glichlernng des historischen Universums vollzicht sich unter einem doppelton Gesichtspunkt, nämlich nach dem Prinzip der sechs Weltalter, las sich ja sehon boi Augustin finclet, und dem Prinzip der vier Monarchien. Jiese sint das assyrisch-babylonische, das medisch-persische, das mazedonisch-grichische mul rlas römische Reich. Von diesen sincl weitaus die wiehtig- 
sten Babylon und Pom, während die beiden anderen bloße ,Zwischenreiche“ sind $^{1}$ ). Die Monarchie des Anfangs und die Monarchie des Endes, Babylon und Rom stehen im engsten Verwandschaftsverhältnis, in dem Verhältnis ron Vater und Sohn. Die letzte dieser vier Weltmonarchien, die römische, besteht noch und wird bis an das Ende der Welt bestehen bleiben. Das Imperium Romanum dauert bis an das Ende alles Weltgeschehens. Es trägt das Schicksal des sechsten Weltalters ïber alle Schicksale, Revolutionen und Katastrophen hin zum Ende aller Dinge. Seit dem Erscheinen des Herrn weehselt nicht mehr die Weltmonarchie, das römische Kaisertum bleibt bestehen, es handelt sich nur um Herrscher aus verschiedenen Völkern, die zu dem einen selben imperium gelangen ${ }^{2}$ ). Wenn nun aber Otto von Freising in diesen historischen Zusammenhang die eigene Zeit einzugliedern sucht, so vertritt er wio später Hegel eine Geschichtsphilosophie des Endes. Er vertritt die Auffassung, daß seine Zeit das Greisenalter der Menschheit bedeute. Aber dieses Greisenalter ist nicht wie Hegels Greisenalter des Geistes eine Epoche des höchstentfalteten Kulturlebens, sondern vieImehr eine müde und kraftlose Zeit. Die Herrlichkeit der Welt neigt sich ihr m Ende zu, und das Symbol für diese dem Untergang geweihte Zeit sind die tönernen Füße des Kolosses mit dem goldenen Haupte, den Daniel geschant hat. Ưberhaupt ist die ganze Vorstellung des mittelalterlichen Geschichtsphilosophen an Herodots Lehre von den Weltaltern orientiert. Das goldene Zeitalter steht am Anfang, und die Menschheit stemert dem Verfall entgegen, sofern es sich um die Herrlichkeit und Schönheit dieser Welt handelt. Aber indem die weltliche Kultur in Philosophie und Kunst und staatlichem Leben einem tragischen Untergange zustrebt, triumphiert die wahrhafte Geisteskultur in der vollkommenen Entfaltung des religiösen Lebens und in der Ausbreitung der Gottesstadt. Das Weltende steht nahe beror, und dieses nahe Ende gibt sich kund als schärfste Spannung des Gegensatzes. Die Tugenden der Gotteskinder haben sich mächtig offenbart und stehen im schärfsten Gegensatz zu den Lastern der Gottesfeinde, der Kinder der Welt, deren $\Lambda a ß$ bis zum Utberfließen roll ist.

Indem der historische Proze $\beta$ sich entfaltet, macht er eine Teränderung des Schauplatzes durch, der das historische Leben von Osten nach Westen führt. Im Osten, in den weiten asiatischen Reichen, erblühte die Kultur, im Westen wird sie untergehen. Von Hast und Unruhe ist das ganze historisehe Treiben erfüllt, und immer wieder ist die Menschheit ron Katastrophen und Revolutionen gequält, so daß sie, wie Otto sagt, einem Fieberkranken gleicht, der, von dem Wechsel der Lage Ruhe erhoffend, sich hin und her wirft und dennoch bloß Mühen und Schmerzen findet, wohin er sich anch wendet ${ }^{3}$ ). Das ganze Leben der Kultur ist beherrscht von dem Gesetz des Wechsels und der Veränderlichkeit. In dem Gedanken dieser Veränderlichkeit liegt ein Doppeltes beschlossen, nämlich einmal im Simne der mutatio rerum: nichts hat Dauer und Bestand, andererseits aber auch im Sime der Schwäche und

1) Dr. Joseph Schmidlin, Die geschichtsphilosophische und kirchenpolitische Weltansehauung Ottos ron Freising, S. 30.

$\left.{ }^{2}\right)$ A. a. O. S. 32 .

3) Chron. V, 36. Eece enim ut... hue et illuc (228,26, kl. A. 251). 
Hinfälligkeit der Welt, der miseria mundi $\left.{ }^{1}\right)$. Typisch für die Hinfälligkeit aller irdischen Größe ist ihm das Römerreieh, wie es den Meereswogen gleicht, bald Völker und Reiche zermalmend sich bis zum Himmel erhebt, bald von Senchen, Krieg und innerem Unfrieden zerrissen im Abgrunde liegt ${ }^{2}$ ); wie die größte und mächtigste Nation almählich tiefer und tiefer sinkt bis zur Schändung und Zertretung durch die Barbaren ${ }^{3}$ ).

Der beständige Wandel und Wechsel ist das Element der Geschichte, und dieser Wandel nimmt in der Regel die Gestalt des Tragischen an. Selten nur löst sich die Spannung des historischen Lebens zum Glück ihrer Helden auf. Alles Heldenhafte in der Geschichte ist einem schmerzlichen Untergange rerfallen. „Die Heroen sind nicht glïcklich.“ So hat später anch Hegel gelehrt. Und in der leidenschaftlichen Anteilnahme Ottos an der Tragik des Geschehens drückt sich ein wahrhaft historisches Mitgefühl aus.

Irclische Grückseligkeit kamn unmöglich der Sinn des Weltgeschehens sein. Was die Mensehheit hier anf Erden erreichen soll, das ist die Läuterung und Heiligung ihres Lebens. Der Mensch als moralisches Wesen ist der Endzweck des irdischen Daseins, die civitas Dei in höchster Erfïllung ist das Ziel seiner überirdischen Existenz. Dennoch ist der mittelalterliehe Chronist weit davon entfernt, diesen moralischen Läuterungsprozeß etwa im Sinne Kants als dic Uberwindung der heteronomen Moral und das Werden der Autonomie oder überhaupt nur als die Entfaltung eines moralischen Zustandes der Menschheit zu denken. Wenn er das Moralische in der Geschichte betont, so geschieht es mehr in lehrhaft pragmatiseher Absicht, so will er zeigen, daß das Laster bestraft und die Tugend belohnt wird. Die Geschichte soll bessern und belehren. Damit wird sie aber in den Dienst des Lebens gestellt und ihrer selbständigen Bedentung beraubt. Die Idee der Freiheit und des persönlichen Lebens bestimnt nicht als Wertidee das historische Geschehen, indem die Menschheit fortschrcitend diesem Ziel sich nähert und in der Erreichung des Zicles ihr Schicksal erfüllt, sondern so sehr die Reflexion darauf gerichtet ist, daß in der Betätigung des sittlichen Lebens der Erdonsinn des menschlichen Daseins sich erfüllt, so bringt sie doeh auch wieder das Moralische als ein Fremdes an die Geschichte heran, das nicht mit ihrem inneren Leben verbunden ist und wärhst und fortschreitet. Unter dem Gesichtspunkte der Moralität rïckt die Geschichte nicht vom Fleck, zumal nicht in tem Sinne, daß alles Wertrolle und menschlich Große in dem Gedanken einer sittlichen Ordnung der Dinge zusammengefaßt wird, und das Sittliche wird nicht zu ciner verklärenden und rersöhnenden Macht hier auf Erden. Was vichuchr im Laufo der Enfwisklung immer dentlieher wird, das ist die unïberbrückbare Kluft, welche die beiden Reiche und damit anch das Gute und das Böse von einander trennt. Denn das Gute, dem ein bleibender Wert innewohnt, das lebt in der Gotfosstarlt. in der sichtbaren und unsichtbaren Kirche. Die Kirche bedeutet lie Zusammenfassung aller werthaften Kräfte. Die Zugchörigkeit zum Gottes-

1) Vgl. ('hron II, 30: Rerumque mutationes tam miseras texui quam multiplices (15., 10, kl. A. 90).) Prol. 11: Superiore libo promisisse me recolo de rerum mutatione at: miserii, seripturum $(1.44,2, k+$ A. 61$)$.

2) ('hron. II, 51.

3) (hrom. IV, 31 . 
staat rermag einzig und allein bleibenden Wert zu verleihen, nur durch sie können wir an das Absolute und an die Pforte der Ewigkeit herantreten.

Für die Enttaltung des historischen Geschehens zu dem immer mächtiger anschwellenden Gegensatz zwischen den beiden Kirchen ist das Erlösungswerk Christi entscheidend. Denn mit ihm erlischt der göttliche Zorn den Gläubigen gegenüber und seine Gnade beginnt zu walten. Auch vor der Geburt Jesu gab es Gotteskinder, aber ihre Zahl war gering, und keine feste Organisation hielt die Geliebten des Herrn zusammen, die wenigen, die im jüdischen Volke sich als wahre Gottesknechte bewährten. Das unsichtbare Jerusalem vor Christi Geburt umfaßte nur wenige Glieder, die sämtlich dem jüdischen Volke als dem auserwählten Volke Gottes angehörten. Dagegen war die Gesamtheit des Heidentums unter die Herrschaft des Bösen gebengt. Nur auf die Gotteskinder der heiligen Stadt Davids konnte ein Strahl rückwirkender Gnade fallen, das ganze Heidentum war der Gottesferne und der Verdammnis anheimgegeben.

Sollte sich mun das Gottesreich auf Erden ausbreiten auch ïber die Grenzen des auserwählten jüdischen Volkes hinaus, dann war es notwendig, daß in den heidnischen Völkern der Boden bereitet wurde für die Ankunft des Herrn. Das geschah in zwiefacher Weise, nämlich eimmal so, daß das Hellenentum durch Philosophie und Wissenschaft die Seelen der Menschen für das Hohe und Göttliche empfänglich machte, und andererseits dadurch, daß die Menschheit gebeugt wurde unter die harte und riicksichtslose Gewaltherrschaft der Römer und aus dieser Knechtschaft und Unseligkeit hinaus nach dem Úbersinnlichen verlangte. So hat sich die Gottheit des Hellenentums und des Römertums in sehr verschiedener Weise bedient, um ihren Heilsplan zu verwirklichen. Sie hat das Hellenentum genutzt in positiver Weise, um den geistigen Gesichtskreis der Menschen zu erweitern, das Pömertum aber in negativer Weise, um Schrecken und Furcht vor dem Sinnlichen zu erregen.

Nach dem Erscheinen des Herm ist der Gottesstaat allmählich der herrschende geworden, und die Idee dieses Gottesstaates fällt für Ot to von Freising weit mehr als bei Augustin mit der Kirche in ihrer konkreten Gestalt und ihrer politischen Organisation zusammen, während jener auf die mystische Einheit der Kinder Gottes den größeren Nachdruck legt. So treten die großen Gestalten des politischen Lebens in ein helleres Licht der geschichtlichen Wirklichkeit hinein, und es handelt sich nicht mehr nur um einen Kampf abstrakter Prinzipien, sondern um den Kampf innerlicher Realititen, die diesen Prinzipien hingegeben und von ihnen organisiert und beherrscht sind.

Der Weltstaat ist jetzt zum christlichen Staat geworden und steht nicht mehr in absoluter Gottesfeindschaft, und die Kirche, der geistliche Staat, ist nicht mehr die reine Gemeinde der Heiligen. Der weltliche Staat hat an der Kirche Anteil und der geist liche Staat an der Welt. Wenn aber die Simnenwelt aufgelöst ist am Ende der Geschich+e, dann wird die reine Gestalt der Kirche offenbar werden und auch die reine Gestalt der Welt. Dann wird das ewige Jerusalem die wahren Gotteskinder umfassen, und die Kinder der Welt werlen endgültig der Verdammnis dahingegeben sein. 


\section{q) Dantes Geschichtsphilosophie und Thomas von Aquino.}

Wir kommen nummehr zu derjenigen Form der mittelalterlichen Geschichtsphilosophie, die das Wesen der mittelalterlichen Kultur am reinsten zur Entfaltung gebracht hat, , der Stimme ron zehn schweigenden Jahrhunderten", der Geschichtsphilosophie Dantes. Sie ist in erster Linie dureh das große System des Thomas ron Aquino, daneben aber auch durch den Teuplatonismus bestimmt. Der große Kampf zwischen den universalen Mächten, zwischen Papsttum und Kaisertum, war ausgekämpft. Das imperium war unterlegen, aber auch dem sacerdotium waren unheilbare Wunden geschlagen. Indem die universalen Mächte des Mittelalters sich so leidensehaftlich befehdeten, erstarkte die nationale Idee und nahm dem imperium und sacerdotium seine Bedeutung. 'Thomas' ron Aquino großes System hat das Verhältnis der beiden universalen Mächte im Sinne des Mittelalters endgiiltig bestimmt ${ }^{1}$ ). Er hat es verbunden mit dem Grundgedanken seines ganzen Systems, mit dem Reiche der Natur und dem Reiche der Gnade. Das Reich der Natur ist die sinnliche Wirklichkeit, die sich in einem Stufenreich der Entwicklung bis zum Menschen entfaltet, das Reieh der Gnade ist die übersiunliche Wirklichkeit, welches sich in den Gestalten der Intelligenzen zu immer höheren Sphären erhebt. Und der Mensch ist gestellt als ein Übergang zwischen diesen beiden Reichen. Seine Seele ist wie die Platonische Weltsecle nach zwei Seiten gewendet. Als forma separata strebt sie der unsinnlichen Welt, dem Geisterreiche zu, als forma inhaerenz, als Kraft (les Lehens. ist sie der Welt des Sinnlichen zugewendet. Bürger zweier Welten ist der Mensch und auch Bürger zweier Städte; denn der Sinnenwelt entspricht auf Erden als menschliche Organisation das imperium und der Welt des Übersinnlichen das sacerclotium.

Dabei gilt nun aber der Staat nicht mehr als das Wertfeindliche und Böse, nicht mehr als die Stadt der Weltkinder im Gegensatz zu der Starlt der Gottes- ' kinder, auch nicht als das Wertindifferente gilt jetzt der Staat, sondern als ein relativ Werthaltiges. Wenn er auch nicht die Bedeutung eines absoluten Wertes besitzt wie die Kirche, so hat er doch eine bestimmte Mission im göttlichen Weltplan zu erfuillen. Er ist die Stätte der Vorbereitung und der Läuterung, durch welche der Mensch hindurehschreitet, bevor er der heiligen Gemeinschaft der Kirche angehört. Der weltliche Staat ist somit eine Station auf dem Heilsweg der göttlichen Gnade. Wie die Natur mit ihren niederen formen sich zu der hohen Gestaltenwelt des Himmels verhält, so verhält sich der irdische Machtbereich des Staates zur leuchtenden Herrlichkeit der einen katholischen Kirche.

Nicht laat 'Thomas von Aquino eine Geschichtsphilosophie gesehaffen, lie noch einmal die grolien Tendenzen des Mittelalters in monmentaler Weise zustummenfaßte. Jas ist erst (Jurch J)ante geschehen, den man deshalb mit ficcht, ,lie Stimme ron 10 schweigenden Jahrhunderten" genannt hat. Er strht, wie es scheint, an der Grenze zweier Zeitalter und faßt noch einmal die

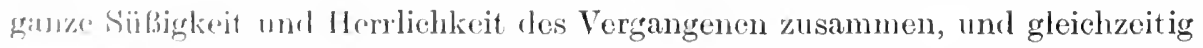

1) Vel. iiber Thomas von Aquino: Maurice de Wrulf, Geschichte der mittel. altorlichen Philusophite. 
spüren wir in seinen Werken das Wehen der neuen Zeit, die schnell heraneilt und ein neues Werden rïstet.

Dante geht von dem Gedanken aus, daß die Menschheit eine Einheit bildet, daß sie notwendig zusammengehört und in dieser Einheit ruht, aus der ja schließlich all ihr Schicksal quilt. Diese Einheit verdichtet sich bei ihm zu der metaphysischen Vorstellung einer Substanz, an der alle Menschen Anteil haben. Die Einheit, an der wir teilhaben ist das Göttliche im Menschlichen. Die Einheit der Menschheit ist die Idee der Menschheit, wie sie Gott als Uridee innewohnt. Gottes Vorsehung ist darauf gerichtet, die ganze Welt sich so ähnlich wie möglich zu machen. Sie soll ein Bild bedenten, das ihm gleich sei. Die Gemeinsamkeit des Menschlichen und Göttlichen liegt aber vor allem in der Idee der Einheit. Die Einheit ist eine Eigenschaft Gottes: Deus est unum, und die Einheit ist eine Eigenschaft, welche die Menschheit noch nicht besitzt, aber erwerben soll. So stellt die Idee der Einheit die Beziehung zwischen Mensch und Gottheit her ${ }^{\mathbf{1}}$ ).

Die Einheit als Endzweck der göttlichen Torsehung ist einerseits ethischreligiöser Natur und dann auch wieder politisch-sozial. Diese Einheit des Menschengeschlechts, welche ron Gott geschaffen und erzeugt wurde mit den ersten Menschen, diese ursprïngliche, gottgewollte Einheit ist durch die Sünde zerstört. Die Geschichte aber kann philosophisch nur so verstanden werden, daß ihr ganzes Werden darauf abzielt, jene erste ursprüngliche Einheit wieder herzustellen und somit die Wirkung der Sünde aufzuheben und zu zerstören. Da nun aber die Einheit sowohl politisch-sozialer wie ethischreligiöser Natur ist, so kann man den Endzweck des Weltgeschehens auch in diesem Doppelsinn begreifen, daß er die Wiederherstellung beider Einheitsformen in sich schließt. Dieses Ziel hat seine rorlänfige Verwirklichung erfahren durch die Menschwerdung Gottes in der Idee der christlichen Gemeinschaft und durch die Einigung der Menschen im römischen Weltimperium.

Es gibt nach Dante ein auserwähltes Tolk im Sinne der religiös-ethischen Einheit und ein auserwähltes Folk im Sinne der politisch-sozialen Einheit des Menschengeschlechtes. Das Volk der religiösen Einheit sind die Juden, das Volk der politischen Einheit sind die Römer. Beide sind Werkzeuge der göttlichen Vorsehung. In ihnen ist der Weltgeist tätig. Sie sind die welthistorischen Völker. Während die anderen großen Weltmonarchien, die vor den Römern nach der Weltherrschaft st rebten, not wendig unt ergehen mußten, weil sie dem Willen Gottes entgegenstrebten, ist das römische Imperium zu dauernder Herrschaft berufen und wird Bestand haben bis an das Ende der Welt. Gewiß meinten die Römer, als sie den Erdkreis unterwarfen, ihren eigenen Zwecken zu dienen, und waren doch nur Werkzenge in Gottes Hand und erfüllten die Pläne des Weltgeistes. Was nun diese eigenen Absichten und Zielsetzungen des Römervolkes betrifft, so waren sie allerdings auch vornehmer und edler Natur und von den Gewalt- und Herrschaftsgelüsten der früheren Weltmonarchien erheblich verschieden. Die Römer strebten nach der Weltherrschaft, um das allgemeine Wohl der Menschheit zu fördern, um

1) Vgl. Dantes Geschichtsphilosophie von Otto Fr. Miller S. 16. 
Ordnung, Recht und Freiheit unter den Völkern der Erde zu verbreiten ${ }^{\mathbf{1}}$. Sie dienten blind der göttlichen Vorsehung, aber als würdige Werkzenge vermöge des Adels ihrer Gesimnung. Wie er dem auserwählten Volke der religiösen Einheit durch Wunder sieh kundgab, so hat Gott auch die Schicksale des Römervolkes durch Wunder und Zeiehen gelenkt. Nach ihrer Würdigkeit oder Unwürdigkeit verfallen die Völker dem Gericht. Rom war es würdig, das Weltimperium zu erwerben. Unter Kaiser Augustus ist die politischsoziale Einheit erreicht. Die Welt war unter ihm so würdig geordnet, daß nummehr das Werk der Erlösung in der Geburt des Messias sich vollziehen konnte. Die Geburt des Heilandes wirkte sich ans in der Begründung der religiösen Einheit, und so wird die Weltgeschichte nunmehr zur Geschichte der großen beiden Weltinstitutionen, des imperium und sacerdotium.

Mit der Formierung dieser beiden Institutionen ist ein vorläufiges Ziel der Menschheit erreicht, die große Atempause des historischen Lebens, das damn hastig weitereilt, der endgüItigen Vollendung entgegen. Dieses Ziel des historischen Geschehens aber erblickt Dante in der Ausbreitung der Kultur dureh Papsttum und Kaisertum und in der Herstellung eines großen Friedensreiches. Diese Entwicklung wird in erster Linie gelenkt durch die Kausalität Gottes. Got bestimmt als höehstes Ziel und Endzweek alle Dinge, und der irdischen Welt Sehnsucht strebt ihm zu. Aristoteles hatte den göttlichen Enflweek der Welt so charakterisiert, daß er die Welt bewege als das selbst Bewegungslose, wie das Geliebte den Liebenden bewegt. Gott erweekt die menschliche Sehnsucht, aber das schöne und vollkommene Geliebte bleibt selber ungerührt. Nach Dante erscheint die sehnsuchtserfüllte Welt unter dem Bilde des Meeres. das von einem Ufer zum anderen flutet und zum ersten Ufer zurückwallt. Von Gott geht diese Bewegung aus in dem Prozeß des egressus, und zu Gott kehrt diese Bewegung zurïck in dem Prozeß des regressus.

Teben Gott als der ersten Zweekursache gibt es nun auch sekundäre Nebenursachen, die Intelligenzen oder Engel, die formbildenden Kräfte, die

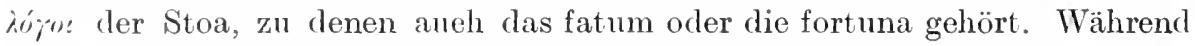
Gott in der Kausalität des Endzwecks oder der Vorsehung das Ganze des Weltgeschehens umfaßt, übernehmen die Intelligenzen als sekundäre Ursachen die Verteilung der göttlichen Kausalität auf die einzelnen Epochen und verbinden das Uhersinnliche mit dem Sinnlichen. Unter ihnen ist speziell der fortuna die Ordnıng der äußeren Güter überlassen, die für die höhere Kultur der Menschen gleichgïltig sind, und der heroische Mensch in seiner Ireiheit erscheint als eine Macht, lie unbekümmert um die Laune der fortuna ihre Zielsetzungen rerfolgt.

Dantes Geschichtsphilosophie offenbart ganz augenscheinlieh einen groben lortschrit gegenüber dem Gesehichtsbild Augustins und Ottos von lineising, wohl vor allem deswegen, weil ilum die Religion nicht mehr als das einzige Kind Gotes gilt, sondern daneben auch die anderen Kulturmiandite. so besomlers das imperium, eine sellständige Wertbedentung gegen-

) Jintes (irsehichtsphilusophie von Miller, S. 19; Mon. II, 3. Conv. IV, 4, Mon. II, $\therefore-i$. 
iiber der Kirche gewimnen. Das imperium ist ein Repräsentant Gottes auf Erden so gut wie die Kirche. Jenes ist das Prinzip der politisch-sozialen, materiellen Ordnung, diese das Prinzip der ethisch-religiösen Ordnung. Beide Gewalten aber können nur daun im Sinne der göttlichen Vorsehung ersprießlich wirken, wenn ihre Sphären vollkommen getrennt bleiben. Das imperium hat die absolute Herrschaft ïber alle weltlichen Güter, das Papsttum über alle geistigen Güter. Jenes ist höchste Autorität in Sachen der irdischen Herrschaft, dieses dagegen die höchste Instanz in moralischen und religiösen Angelegenheiten. Weder darf der Staat in die Sphäre der Kirche, noch die Kirche in die Sphäre des Staates eingreifen. Imperium und sacerdotium sind rollkommen gleichgeordnete Mächte. Und das Schwert des Priesters soll nicht. das Schwert des Fürsten ïberragen. Wenn das Papsttum um irdischen Besitz bekümmert ist, dann verliert es alle seine Würde. Und wenn das Kaisertum nach Hoheitsrechten über den Priesterstand trachtet, dann durchbricht es die von Gott gesetzten Schranken. Die Geschichte der Welt ist die Geschichte dieser beiclen Mächte, die das Gottesreich in sich tragen und bewahren. Bis an das Ende der Geschichte werden imperium und sacerdotium bestehen. mag es auch zeitweilig so aussehen, als ob ihre Macht dahinschwinde. In der universalen Idee ruht nach Dante das Heil der Menschheit. Durch sie wird jene ethische Kultur erzielt, zu der das Weltgeschehen ausreifen soll, die Freiheit, das Recht und der Friede.

\section{\$ 2. Die Geschichtsphilosophie der Renaissance und Infklärung.}

Mit Dante verklingt die letzte Stimme der mittelalterlichen Geschichtsphilosophie, deren allgemeiner Charakter dahin rerstanden werden muß, daß es sich hier um eine religiöse Form der Universalgeschichte handelt, welche die anderen Kulturwerte noch nicht selbständig gelten läßt und die Macht der göttlichen Vorsehung so sehr betont, daß die Gestalten der historischen Persönlichkeiten daneben vollkommen verblassen. Sie sind nur das Werkzeng, dessen sich der Weltgeist bedient, um seine Pläne zu erfüllen. Aber sie haben kein eigenartiges Interesse. So bleibt die mittelalterliche Geschichtsphilosophie befangen in einer einseitigenWertung des religiösen Lebens, in der Identifizierung von Wert und Religion und in einer Betonung des allgemeinen göttlichen Waltens und der Schicksalsmächte stehen, die ein deutliches Hervortreten und eine klare Anschauung menschlichen Heldentums rollkommen zur Seite drückt, und auch die Ansätze zu einer Úberwindung dieser Einseitigkeiten, wie sie sich bei Dante finden, der das sittlich-politische Leben stark unterstreicht und im Römertume das Heldenhafte erschant, rermag dies allgemeine Bild nicht zu ändern. Eine Wandlung gibt erst die Geschichtsphilosophie der Renaissance, und fast entscheidend für die neuc Wendung der Probleme ist hier die Erschemung Machiavellis geworden.

a) Iachiavelli und die Idee der Nation.

Das Neue bei Machiarelli gegenüber der christlichen Geschichtsphilosophie ist vor allem die Ablehnung des Universalismus und die Betonung des Na- 
tionalen. Er sucht nicht mehr die Einheit des Imperiums und Sacerdotiums mit der Einheit der Menschheit und diese wieder mit der Einheit der göttlichen Substanz in Bezichung zu bringen. Er bewertet vor allem die Nationalität und ist gleichgïltig und fremd gegenüber der Idee menschlicher Einheit und göttlicher Macht. Dennoch hat er nicht eigentlich die Wertindividualität der Persönlichkeit und des Volkes im philosophischen Sinne des Wortes entdeckt. Das Individum, wie es von Machiavelli gedacht wird, ist weder selber ein eigentümliches Wertgebilde, noch ist es der berufene Träger sittlicher Werte, ein Individnum etwa, welches das sittlich Wertvolle oder den religiösen Gedanken freiwillig anerkennt und sieghaft bejaht. Die historischen Individuen, wie sie Machiavelli preist, besitzen als dominierende Eigenschaft ihres Wesens virtı̀ ${ }^{1}$ ). Diese virtı̀ ist gleichbedeutend mit Tüchtigkeit, mit Vitalität, mit Lebensmacht. Die Persönlichkeiten, die der große Florentiner meint, sind die gewaltigen Herrenmenschen und Leistungsmenschen. Sie vor allen machen Geschichte, diese Menschen mit rücksichtslosem Willen und starker gesunder Kraft. Das, wohin ihr Ehrgeiz und ihre Liebe sie treibt, fällt doch immer mit den großen Aufgaben der Kultur zusammen. Sie sind die Fortbeweger des historischen Geschehens, und im Verhältnis zu jener rohen und plumpen Masse, zu der die Alltagsmenschen gehören, sind sie die Bildner der Geschichte. Machiavelli vertritt die Auffassung, daß die Geschichte in der Hauptsache nur von großen Persönlichkeiten, von machtvollen Individuen gebildet wird. Diese Individuen aber wachsen für ihn zu gewissen Typen aus, mit denen er dann die Vorstellung von historischer Größe verbindet. Ein solcher Typus ist etwa für ihn Cesare Borgia, aus dem Machiavelli das Bild eines Fürsten geformt hat, so wie er es bejaht. Alles ist mächtig gesteigert, und wir erleben an ihm den Typus des gewaltigen Herrenmenschen, der vor nichts zurückbebt, wenn es sich um große Ziele handelt. Diese Typendes Ma chiavelli sind vollkommen rationalisiert, sofern sie so gedacht werden, daß das Werden des historischen Lebens aus ihnen abgeleitet werden kann. Sie haben keine rätselvollen Tiefen. Wie sie selber der vernünftigen Einsicht hingegeben sind und so das Geschiek bemeistern und die Zufälligkeiten des Lebens überwinden, so sind sie auch der historischen Erkenntnis vollkommen zugängig, welehe die Frage erhebt, was wohl das verständigste und zweckmäßigste Verhalten in einer gegebenen Lage sein möchte. Wir haben das Recht, auf das V'rnünftige und Einsichtsvolle als Grund zu schließen, weil wir wissen, daß sich jene Heroen trotz ihrer gewaltigen Lcidenschaften von den Leitsätzen der vernünftigen Einsicht bestimmen ließen. So tritt nummehr der Gedanke der göttliehen Kausalität ganz zurück, und das Schicksal verliert an Macht und Würde gegenüber dem Helden, der bei aller Lamnenhaftigkeit und Verändrichkeit der fortuna immer derselbe bleibt, keinem Gesetz der Entwicklung unterworfen, seine starre und unbeugsame Art bewahrt.

Ifahiarelli bedeutet somit in seiner Geschichtsanfassung den denkbar griblon Gegensatz zur. Geschichtsphilosophie des Mittelalters. An die Stelle Hor Kansalitit Gottes tritt nmmmehr die Kansalität dor großen Gattungs-

$\left.{ }^{1}\right)$ Über den Begriff drr virtì vgl. Eduard Wilholm Meyer, Studien zur Geschichtsauffassungr Marhiave!lis. München 1912. 
individuen. Der rücksichtslose Leistungsmensch an die Stelle der göttlichen Vorsehung, der blanke Naturalismus an die Stelle einer religiösen Metaphysik. Der Wertgesichtspunkt weicht im allgemeinen einer wertfreien Betrachtung, wenn auch die Idee der Nation wertend anerkannt wird und in der Betonung des Erfolges sich die richtige Einsicht kundgibt, daß für die historische Beurteilung in der Tat die Leistung entscheidend ist. Nicht aber ist deutlich, daß als allgemeingültige Toraussetzung der Leistung doch immer die Idee der Kulturwerte zu gelten hat, nach denen sich die Leistung als historisch bedeutsam oder nicht bedeutsam bestimmt. Auf jeden Fall ist für die geschichtsphilosophische Konstruktion nunmehr ein neuer wichtiger Faktor gewonnen oder wiedergewonnen, nämlich die historische Persönlichkeit; aber die Persönlichkeit und die soziale Gemeinschaft des Staates werden noch nicht als Wertindividualitäten ron unwiederbringlicher Einzigartigkeit, sondern in naturwissenschaftlicher Auffassung als Gattungsindividuen begriffen. Sie sind den Naturmächten verwandt, hochgespannte Lebenskräfte von gewaltiger Intensität, furchtbar, schön und gefährlich. Erst der Weiterbildung der Geschichtsphilosophie ist es gelungen, dem Begriff der Persönlichkeit und des Staates jene naturalistischen Züge zu nehmen, die das Zeitalter der Renaissance ihnen verliehen hatte. Die naturalistische Gesichtsmaske, welche die Individualität des einzelnen und der Gesamtheit tragen mußte, hing bekanntlich mit der Wertung der Naturwissenschaften zusammen, die clamals zu hoher Entfaltung gelangten. Aus dieser Übertragung naturwissenschaftlicher Torstellungen und Begriffe auf die Gegenstände der Kulturwissenschaft entsprang jene abstrakte, mechanische, wertfreie Auffassung des Staates, wie sie ihren bezeichnendsten Ausdruck bei Hobbes gefunden hat, und die Auffassung der Persönlichkeiten als kondensierte Lebensmächte. Und die Offenbarung einer gewaltigen Lebensmacht als Ausdruck des staatlichen Willens und der staatlichen Ommipotenz entsprach in jeder Hinsicht den Grundwertungen dieser Zeit.

\section{b) Methodologische Probleme.}

Um diese Zeit traten nun auch die methodologischen Probleme der Geschichtsphilosophie leise herror. Alles Interesse war zwar in der Hauptsache auf die Naturwissenschaften und die Mathematik gerichtet, und es herrschte das Verlangen, in einer Universalmetbode den gemeinsamen und untrüglichen Weg aller wissenschaftlichen Forschung festzustellen. Der Weg der Mathematik und Naturwissenschaft sollte auch in der Philosophie und Kulturwissenschaft, betreten werden. Daneben aber finden sich doch auch Überlegungen, die für die Sicherstellung einer besonderen historischen Methode ron Bedeutung geworden sind. Ich denke hier ror allen an Bacon, Spinoza und Leibniz.

\section{c) Bacon.}

Bacon ging darauf aus, neue Gegenstände missenschaftlicher Erforschung zu finden und zu konstruieren. Er glaubt an die Almacht des naturwissenschaftlichen Denkens. Es gibt nur eine Form der Verstandeskenntnis, und diese ist die naturwissenschaftliche. Nicht aber erschöpft sich alles Wissen in Ver- 
standeserkenntnis. Neben dem intellectus gibt es die memoria; neben der eigentlich urteilsmäBigen Erkenntnis eine Erkenntnis durch Bilder und Vorstellungen, welche auf das Vergangene der historischen Wirklichkeit gerichtet ist. Das Land der Erinnerung, das Reich der Mnemosyne ist das Gebiet des historischen Verstehens, das durch Bilder und Gestalten lebendig gemacht wird ${ }^{1}$ ).

\section{d) Spinoza.}

Spinoza hat die mathematische Methode auch auf die Philosophie angewendet, und sein wertfeindlieher Naturalismus läßt keinen Raum für selbständiges historisches Leben ${ }^{2}$ ). Dennoch hat er eine Unterscheidung getroffen, welche für die Entwicklung der historischen Methode eine große Bedeutung gewann; es ist das die Unterscheidung von endlicher und unendlicher Kausalität $\left.{ }^{3}\right)$. Nach der metaphysischen Auffassung Spinozas ist jedes endliche Ding doppelt bestimmt, nämlich einmal durch Endliches und dann wieder durch Unendliches. Jedes Ding ist endlich bestimmt, sofern jedes Einzelding und jeder Zustand von Ruhe und Bewegung, in dem es sich befindet, immer wieder bestimmt ist durch andere Dinge und andere Bewegungszustände endlicher und begrenzter Art. Jedes Stückchen psychischer Wirklichkeit ist dureh ein anderes Stück psychischer Wirklichkeit, ebenso wie alle physische Wirklichkeit wieder durch Physisches verursacht und darin begründet ist. Aber gleichzeitig unterliegt auch jedes Ding der Bestimmtheit durch ein Allgemeines. Dieses Allgemeine ist für den Körper die Raumgesetzmäßigkeit und für das seelische Geschehen die Bewußtheit der eogitatio. Die menschliche Kansalität ist die Bestimmung der endlichen modi durch die unendlichen Attribute. Die endliche Kansalität ist die Bestimmung der endlichen modi durch andere endliche modi, cine Bestimmung, die niemals auf ihren letzten Grund zurückverfolgt werden kam, sondern uferlos in das Unendliche geht.

Wenn wir diesen beiden Begriffen von Kausalität eine moderne Deutung geben, so kommen wir zu dem Prinzip der historischen und naturwissenschaftlichen Kausalität. Denn jene Kausalität, da Endliches immer Endliches bestimmt, la das nur Individuelle immer wieder von einem anderen Individuellen abhängig gedacht wird, ist der historischen Kausalitätseinmaligkeit zu vergleichen, die für alles historische Gesehehen bestimmend ist. Jene andere Kausalität aber, die Spinoza als die mendliche Kausalität oder als die Kausalität der Altrihute bezeichnet, ist als Kausalitätsallgemeinheit der naturwissenschaftlichen Kausalität vergleichbar, die als das Allgemeine der Gattung oder des Gesetzes das individuelle Einzelgesehchen und die Totalität aller Bewegnng bestinmt. Der Kausalitätseinmaligkeit in ihrer Besonderheit und Individualität tritt die Kausalitätsallgemeinheit in ihrer Gleichartigkeit cntgegen.

\section{(1) Lejhni\%}

Dersell) Gegensatz von Kausalitätscinmaligkeit und Kausalitätsallgemeinhrit, wie er in der condlichen uni unendlichen Kausalität Spinozas

1) Iacon, Instauratio magna. Vgl. Friedrich Überweg, Grundriß 3. Teil., S. 67.

2) Vgl. Kunn Fischer, Spinozas Leben und Werke, Heidelberg 1898.

3) Vgl. Windolband, Roktoratsredo, Straßburg 1894 . 
zum Ausdruck kommt, findet sich in einer für die Geschichtsphilosophie noch weitaus bedeutsameren Form in Leibniz' Unterscheidung der ewigen und tatsächlichen Wahrheiten wieder. Es gibt nach Leibniz ewige Wahrheiten, welche unmittelbar begründet sind im göttlichen Intellekt, ron denen Gott selber nicht lassen kann, weil er als vernünftiges Wesen das Vermünftige bejaht und die Wahrheit anerkennt, die sein eigenstes heiliges Wesen ausmacht. An diesen ewigen Wahrheiten hängt die ganze Organisation der Welt, so vor allen Dingen ihr Grundverhältnis, die Beziehung des Endlichen zum Unendlichen. Unmöglich konnte die Gottheit die Monaden unendlich schaffen. Um ihrer eigenen Unendlichkeit willen mußten sie endlich sein und begrenzt und unvollkommen; denn die Gottheit erträgt nur die eine Unendlichkeit, die sie selber bedeutet. Das logische Prinzip der Welt verlangt das eine Unendliche und die unendlich vielen Endlichen. Die rein logischen Wahrheiten hängen aber schließlich ab ron dem Prinzip des Widerspruches. Für das Gebiet des Begriffes und für das Reich des Systematischen gilt das Gebot des Widerspruches unbedingt und ist hier vollkommen entscheidend. Durch die Norm des Widerspruches wird die philosophische und naturwissenschaftliche Erkenntnis bestimmt. Neben den ewigen Wahrheiten der systematischen Erkenntnis, die für alle Zeiten unverschiebbar feststehen, gibt es die tatsächlichen Wahrheiten der sinnlichen Wirklichkeit. Hier handelt es sich um das Gebiet der Erfahrung, vor allem auch um die historische Tatsächlichkeit. Es ist die Wahrheit des Soseins, der ganz individuellen Gegebenheit. Die allgemeine Form und Struktur eines Gegenstandes wird ron dem Satz des Widerspruches bestimmt, der für das Allgemeine mit Notwendigkeit gilt. Dagegen ist die individuelle Ausgestaltung dem Allgemeinen gegenüber gewissermaßen etwas Zufälliges, was, wie es scheint, auch anders hätte sein kömen, ohne daß dadurch die Struktur des Wirklichen und die Beziehung des Cnendlichen zum Endlichen merklich verschoben wäre. Das Prinzip dieser Tatsächlichkeitswahrheiten ist nach Leibniz der Satz rom Grunde, der im göttlichen Willen wurzelt. Während die ewigen Wahrheiten, die nach dem Prinzip des Widerspruches verlaufen, unveränderlich im göttlichen Heilsplan ruhen, vermag der göttliche Wille die tatsächlichen Wahrheiten des Gegebenen zu modifizieren. Die Wahrheiten der Tatsachen stehen somit an Würde und Bedeutung hinter den ewigen Vernunftwahrheiten zurück $\left.{ }^{1}\right)$.

Damit ist Leibniz nicht nur auf den wichtigen Unterschied aufmerksam geworden, der auch ron Spinoza konstatiert war, sofern er eine doppelte Art der Bestimmtheit, nämlich die von unendlicher und endlicher Káausalität annahm und damit auf die beiden Sphären des naturwissenschaftlich Philosophischen und des historisch Erfahrungsmäßigen hinwies, eine Unterscheidung, in welcher schon bis zu einem gewissen Grade der Gegensatz ron naturwissenschaftlicher und historischer Begriffsbildung vorbereitet war, sondern vor allem wichtig ist auch die Einsicht ron Leibniz, daß der Satz des Widerspruches für die Geschichte keine tntscheidende Bedeutung besitzt. Der Satz des Widerspruches ist das höchste Prinzip aller mathematischen Wissenschaften. Er gilt für die Sphäre allgemeiner Begriffe und drückt Beziehungen

1) Vgl. auch Windelband, Lehrbuch S. 332 ff. und 355. 
aus, die zwischen ihmen bestehen ${ }^{1}$ ). Er lehrt die Unvereinbarkeit gewisser Merkmale. Er gilt für jene Sphäre, die dem sinnliehen Leben relativ fremd ist. Dagegen scheitert seine Nacht an der historischen Wirklichkeit, und zwar aus einem doppelten Grunde. Einmal ohne Zweifel, weil die Begriffe der Historie so sehr mit Rücksicht auf das Individuelle gebildet sind, daß der Begriff des Widerspruchs in einer Fülle von Irrationalität den Gedanken des Gegensatzes immer wieder auslöscht und zum Schweigen bringt. Wie das Leben Gegensätze tragen kann, so scheint auch die historisehe Wirklichkeit, zumal in der Gestalt der historischen Persönlichkeit, Gegensätzliches in sich vereinigen zu können²). Dazu kommt dann weiter noch, daß der Begriff des Widerspruches in der Sphäre des Unsystematischen seinen Sinn verliert. Denn der Widerspruch hat nur dort einen guten Sinn, wo sich das Reich allgemeiner Begriffe zu einem System von Grund und Folge zusammenschließt. Nicht aber kann er dort eine beherrschende Bedeutsamkeit gewinnen, wo die individualisierende Begriffsbildung der Historie den unendlichen, niemals abgeschlossenen Prozeß der geschichtlichen Wirklichkeit zu gestalten unternimmt.

\section{f) Yeue Ausdrucksformen des Wertlebens in der Renaissance.}

So hat die Renaissance bei aller Bejahung des Wertfreien und der naturwissenschaftlichen-mathematischen Methode doch auch wiederum Gedanken gebildet, die der Idee einer historischen Methode entgegenkommen, wenn auch dieses andere, das neben dem Philosophisch-Naturwissenschaftlichen sich geltend maehte, in dem Zusammenhang ihrer Gedankenwelt nur etwas Geringes und Nebensächliches bedeuten konnte. Und dieselbe Renaissance, die in ihrer naturalistischen Gesinnung dem Wertbegriff feindlich entgegentrat, die vor allem den ethisehen und ästhetischen Wert in ihren philosophischen Überlegungen stark vernachlässigte, die den Begriff der Individualität als Persönlichkeit und Staat jedes Wertglanzes entkleidete: dieselbe Renaissance hat auch wieder dem Wertleben neue Ausdrucksformen verliehen. Das bezieht sich nicht nur auf die Ausbildung des theoretischen Itleals in der lebendigen Erfassung des Wahrheitsbegriffes, auch die soziale Gemeinsehaft des Staates und die Idee der Persönlichkeit gewimnen neben der Renaissance der antiken Wertbeurteilung doch auch gleichzeitig darüber hinaus einen neuen Sondersinn. Auch das Griechentum hatte die Idee des Staates als Vollendıng der sozialen oder auch spezifisch ethischen Gemeinschaft auf das höchste gewertet. Aber die nationale Idee hatte damals noch keine Geschichte, sic war höchstens ein stummer Protest gegenüber den Weltreichen des Barbarentums, gegenüber jenen großen orientalischen Despotien, in denen sich das Prinzip der Weltherrschaft fast unmittelbar mit der geistigen Gewalt vermählte. Scitrlem hatte eine Rönerherrschaft geblüht als Herrschaft eines Kulturvolkes, das an der Verbindung der beiden Gewalten in wesentlichen festhielt. Und die Herrschaft des Römertuns war dann abgelöst von der Herrsehaft des deutschen Imperiums, dem in Rom die Macht des Sacerdotiums gegenübertrat. Die große mniversalistische

1) Vgl. iiber den S'atz des Widerspruches Bolzanos Wissenscbaftslehre S. 200-212.

2) Obluer das Paradoxe historischer Porsöulichkeiten vgl. Fritz Wittels, Tragische Motiva, lim lin 1911. 
Bewegung hatte sich in dem Gegensatz der weItlichen und geistlichen Gewalt versteift. und der Konflikt dieser beiden, die so sehr aufeinander angeriesen waren, hatte dann schließlich ihren Untergang herbeigeführt. Nun erwuchs der Gedanke ron dem eigentümlichen Wert der Nation, die etwas für sich bedeutet und für sich bedeuten will. Die fremde Wertbekleidung wird abgelehnt oder doch stark zurückgedrängt. Das Tolk ist nicht wertvoll als auserwähltes Volk, als Tolk Gottes, auch nicht als Erbe fremder Güter. noch schließlich als Tolk im Dienst eines ethischen Sollens, sondern um seiner Eigenheit und Unvergleichlichkeit willen ist es wichtig, und sein eigentuim liches Kulturschicksal zeichnet ihm besondere Wege vor. Lnd wie in allen Reflexioncn, die sich auf die Persönlichkeit beziehen, der große Mensch erfordert wird als der Universalmensch, der alles rersteht und zu leiten rermag, so erhoht sich auch die Forderung der großen, eigentümlich gebildeten Nation.

Allerdings treten diese Postulate nur gelegentlich hervor, während die Frage nach dem Prinzip des Kulturgeschehens weitaus am meisten in der Besinnung auf die Natur des Staates zum Ausdruck gelangt. Dabei sind Staat und Volk als zwei durchaus disparate Dinge gedacht, die wohl niemals miteinander in Einklang gesetzt werden können. Je nach der politisehen Haltung der Staatsphilosophen dieser Zeit wird der Staat entweder als ein allmächtiges Wesen aufgefaßt, das rücksichtshos befehlen und bestimmen kann, oder aber es wird der Versuch gemacht, die Sphäre des Staates so eng wie möglich zu ziehen und das wertvolle Kulturleben in Religion, Wissenschaft und Sittlichkeit aus seiner Sphäre auszuschließen.

Auf jeden Fall bleibt der Renaissance das große Verdienst, daß sie neben der einseitigen Betonung des Allgemeinen, wie es der mittelalterlichen Geschichtsphilosophie eigentümlich war, die Individualität als den zweiten großen Geschehensfaktor energisch geltend machte. Allerdings ist die Indicidualität noch nicht als Tertindividualität gefunden, sondern nur als Machtpotenz erkannt.

\section{g) Entdeckung des Fortschrittsbegriffes in der Aufklärung.}

Die Bewegung des Aufklärungszeitalters wird in allgemeinen dahin charakterisiert, daß es kein Terhältnis zur Geschichte gehabt habe, und seine geschichtsfeindliche Haltung dadurch motiviert, daß der rationalistische Charakter des Zeitalters, der sich durch ein L'bermaß ron Kritik gegenuiber allem Geltenden auszeichnete, das Verhältnis zur Tradition lockerte und löste. Handelte es sich doch um ein Zeitalter, das auf allen Gebieten unerhört Neues wachsen und werden sah. und das ron dem stolzen Gefühl seiner sieghaften Triumphe erfüllt war. Dennoch würde man dem Auflelärungszeitalter sehr unrecht tun, wenn man es als eine für Geschichte und Geschichtsphilosophie unfruchtbare Epoche bezeichnen wollte. Wohl führte die Kritik an Religion, Kunst und Staat schließlich zu einem gewisen geistigen Anarchismus, in der die theoretische Vernunft, welche die große revolutionäre Kritik an allem Bestehenden geübt hatte, am Ende auch das Fundament ihrer eigenen Benrteilung untergrub, aber der wahrhaft spekulative Geist dieser Epoche hat doch auch wieder neue Wertgebilde aufgewiesen, so besonders den für die Geschichtsphilosophie ganz unentbehrlichen Begriff des Fortschritts. Der 
Fortschrittsbegriff ist geradezu entscheidend für die Stimmung und Haltung des Aufklärmmgszeitalters, und zwar kommt dieser Begriff in zwei verschiedenartigen Formen hier zur Entfaltung, sofern er einerseits mit dem Leben des cinzelnen und seiner Persönlichkeit, anderseits mit dem Algemeinen desGattungslebens sich verbindet. Der Individualismus dieses Zeitalters verkündet, daß die Individualität in ständigem Wachstum einem Ziele höchster Vollkommenheit sich nähere. bezw. anch da B die Persönlichkeit bis ins Unendliche sich steigere und entfalte. Wenn die Idee des Fortschritts so ummittelbar mit der Einzelpersönlichkeit verbunden wird, dann wird weniger anf den Fortschritt der Knlturarbeit reflektiert als den objektiven Niederschlag der persönlichen Entfaltung, sondern das Interesse ist vielmehr darauf gerichtet, inwiefern die Qualitäten des Menschen in ihrer Weiterentwieklung eine Werterhöhung bei sich führen. Es ist gemeint, daß die Mensehen der Zukunft höher und wertvoller sein werden als die Menschen der Gegenwart. Aber diese Steigerung der Wertqualitäten am einzelnen braucht noch nicht notwendig zusammenzugehen mit einer Wertsteigerung der Kulturleistungen überhaupt. Es könnte ja sein, daß die Wertindividnalität behindert wäre, sich auszudrücken und zn offenbaren. Wie auf der anderen Seite auch die Möglichkeit besteht, daß das Wertvolle und Bedentsame von dem relativ Unbedentenden geformt und geleistet wird.

Ganz anders, wenn dic Behamptung aufgestellt wird, daß die Menschheit fortschreite, sofern sie wächst und steigt, um einem Ziele der Vollendung entgegenzugehen. Denn mit dem Fortschrittsgedanken verbindet sich immer ein gewisser Zielgedanke. Dieses Ziel kam nicht der Fortsehritt selber sein; dem daß die Menschheit im ganzen fortschreitet, dieser große Gedanke des Aufklärungszeitalters, hat doch nur damn einen Sinn, wenn etwas Feststehendes angenommen wird, dem das Gesehchen zugewendet, ist und in dem es seine Erfüllung findet. Was wäre ein steiker Felsenpfad ohne Grad und Gipfel und eine Himmelsleiter, der der Himmel fehlt. Diese msere irdische Wolt solt gebildet nnd gestaltet werden. Wir sind wohl gern bereit, diese Last und Mühe der Arbeit zu tragen. Vielleicht verlangen wir keinen anderen Lohn als den, der in unserer Arbeit liegt, aber ein Zicl wollen wir wissen. Das Banen in das Cferlose hinein ist plan- und simnlos. Die Ordnung der Welt entfaltet sich, und immer fügen dis späteren Geschlechter den Leistungen der früheren las Größere und Bedentsamere hinzı. Der WVert der Beiträge steigt, aber schlicßlich muls doch eimmal der Vollender kommen, der das Unvollendete krönt. So sehr num aber anch der Gedanke des fortsehrit ts als Wertsteigerung simgemäB mit dem Gedanken des Endzwecks verbunden ist, so vermochte doch das Anfklärungszoitalter in seinem starken Lcbonsgefühl auch den Fortwhehitt un des Fortsehritts willen zu bejahen. Von der Neuheit und Größe

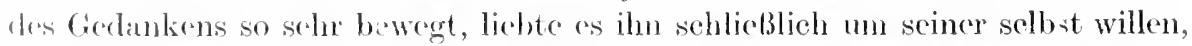
mol die Betonmen der Aktivivät wonde so mähehtig in diesem Zeitalter, daß die Vorstellung fockend erschim, immer weiter in uncudliche Fernen und Woiten hinaus zol hilden wud zu schaffen an cinem Werk, das niemals seinen Abschluß (rhält. Dannit feicete das Aufkliarmesseitalter ganz angenseheinlich die Gesehirhte, zu derm logischer Struktur ja 11 m cimmal das uferlose Gesehehen, las Anfangshose mol Endlose grehört. 
Wenn wir aber von dem allgemeinen Charakter des Aufklärungszeitalters sprechen, so müssen wir uns immer darauf besinnen, daß das Zeitalter von zwei sehr entgegengesetzten Strömungen bewegt wird. Die rationalistisehe Oberströmung, die in Frankreich ror allen durch Toltaire repräsentiert wird, findet ihren Gegensatz in dem Pathos des Irrationalen und Affektiven, wie es Rousseau vertrat. Die irrationale Unterströmung geht über Herder zur Romantik hin, und sie hat ja vor allem die Geschichte geliebt und gestaltet.

In dieser Zeit hatte die Gesehichtsphilosophie die schwere Auseinandersetzung mit dem Begriff der naturwissensehaftlichen GesetzmäBigkeit zu rollziehen, der seit dem Zeitalter der Renaissance immer mehr an Geltung und Bedeutung gewonnen hatte. Das gedanklich Wirksamste, was sie den Herrschaftsansprüchen der Naturwissensehaft entgegenzustellen vermochte, das war in der Tat dieso Idee des Fortschritts, die ihrem letzten Sinne nach mit dem Gedanken der Wiederkehr vollkommen unvereinbar ist. Die Unvereinbarkeit dieses Gegensatzes wurde jedoch nicht sogleich offenbar, und so versuchte man denn zunächst einmal, die Idee des Fortschritts mit dem Gedanken der naturwissensehaftlichen Gesetzmäßigkeit als dem großen Erbteil der Renaissance zu versöhnen. Die wichtigsten Vertreter dieses Gedankens sind Tico und Condorcet. Thnen entgegen stehen diejenigen Gesehichtsphilosophen, die das Naturgesetz in der Geschichte von vornherein ablehnen. In dieser Tendenz verbindet sich die mirersalhistorisehe Tendenz des Mittelalters, wie sie in der Gesehichtsphilosophie eines Bossuet noch weiterlebte. mit den individnalistischen Tendenzen der neuen Zeit, die in Rousseau und Herder zur Sprache kamen.

\section{h) Die Geschichtsphilosophie Vicos.}

G. B. Vicos Werk ${ }^{1}$ ) hat der modernen Gesehichtsphilosophie und Völkerpsychologie die Wege gewiesen. Zwei ganz versehiedene Gesichtspunkte wissenschaftlicher Betrachtung sind hier noch rollkommen ungetrennt. Benedetto Croce will in Vico schon die Geschichtsphilosophie des deutschen Idealismus und speziell die Geschichtsphilosophie Hegels vorgebildet sehen ${ }^{2}$ ). Das ist nur in begrenztem Sinne der Fall. Die Terwandtschaft zwischen Vico und der Philosophie des dentsehen Idealismus ist wohl ror allem darin zu sehen, daß Vieo wie jene den Begriff der Wertidee mit dem historischen Geschehen rerbunden hat, der Gegensatz aber in der rollkommen unkritischen Vermischung des Psychologischen und Logischen, die für den Vorläufer Kants ja selbstverständlich ist. Dazu kommen eine Fülle ron mittelalterlichen Vorstellungen, die vor allem in dem Tersmeh eines Ansgleichs ron Offenbarung und Vernunfterkenntnis sich geltend machen.

Vico geht in seiner Geschichtsphilosophie ron dem Gedanken aus, daß es möglich sei, das Leben der Völker nach wissensehaftlichen Prinzipien dar-

1) Gesamtausgabe Vicos von Ferrari, 7 Bände, Noapel 18.58-65. Vgl. auch G. B. Vico als Geschichtsphilosoph und Völkerpsychologe von Dr. Otto Klemm. Leipzig 1906.

$\left.{ }^{2}\right)$ Benedetto Croce. L . Filosofia di Criambattista Vico. XX. Il Vico e lo suolgimento posteriore. Bari. 
zustellen, wenn es gelingt die beiden Erkemntnisquellen des Menschen in einer großen Synthese zu rereinigen und das Wesen der Dinge aus ihrer Entstehung zu begreifen. Er geht also von dem erkenntnistheoretischen Problem aus, wie eine Erkenntnis des historischen Lebens möglich sei, als dessen Stoff und Substrat ihm das Tölkerdasein, die Gegebenheit großer sozialen Zusammenhänge entgegentritt. Die mittelalterliche Gebundenheit seines Denkens sieht eine Lösung dieser Frage dann vor allem in der Versöhung des theologischen Offenbarungsgedankens mit der philosophisch-geschichtlichen wissenschaftlichen Vernunft. Es gilt als ein doppeltes Erkenntnismittel für ein Wissen von der historischen Wirklichkeit auf der einen Seite die Vernunft, auf der anderen Seite die Offenbarung, auf der einen das verum, auf der anderen das factum. Mit diesen Erwägungen stellt sich Vico prinzipiell auf den Standpunkt des Thomismus, der sich in ähnlicher Weise die Aufgabe stellte, die Forderungen des theoretischen Denkens.mit dem religiös-kirchlichen Offenbarmngsglanben zu versöhnen.

Der rationalen Erkenntnis sind in der simnlichen Wirklichkeit des historischen Lebens keine Grenzen gesetzt. Sie vermag sich mit der wirklichen Ordnung der Dinge in Einklang und Úbereinstimmung zu setzen. Von der Ordnung der Dinge ist eine Erkenntnis möglich, dem diese Ordnung ist ein für allemal feststchend, nnverändrrlich und ewig. Die Wissenschaft kam sich ihr aber auf doppelte Weise nahen, nämlich entweder auf dem Wege einer apriorischen Konstruktion, darin die eigentliche Aufgabe der Geschichtsphilosophie gesucht werden muß, oder unter Heranziehung der Gegebenheiten und Tatsachen auf nur empirischem Wege.

Diese historische Wirklichkeit und das, was ihr zugrunde licgt, die ewige ideale Geschichte, die in immer wieder nenen Modifikationen sich simnlich ausdrückt, läßt sich num aber auf rein rationalem Wege und vollkommen unabhängig von den cinzelnen Tatsachen konstruieren, in ähnlicher Weise wie die Geometric ihre Größen schafft, indem sie Elemente konstruiert und entfaltet. Der Geschichtsphilosoph hat die Idee der ewigen Geschichte und kamn a us der allgemeinen Idee des IVeltplanes heraus die Einzelphasen der historischen Entwicklung begreifen. Auch ist eine Kenntnisnahme des historischen Lebens durch den Umstand schr erleichtert, daß der Handelnde mit dem Erzählenden gewisscrnaben zusammenfällt, soforn der Kulturmenseh die historisehen laistungen vollführt und sie in Werken und Institutionen mancherlei Art befestigt und der Kulturnensch wielerum die objelstivierte historische Termunft z/1 varstehen mutrummut. Zwischen dem Historiker und den Kulturwerken brsteht gewissermaben keine Heterogenitait, sofern im Prozeß des historischen Vorstehens das Kultursubjekt dem Kultmohjekt gegenübersteht. Danit ist rin wichtiges Argmment für die Möglichkeit der historischen Erkenntnis herheigrzogrn. Dam Mistoriker sind dem Völkerleben gegenüber gesicherte Mittel

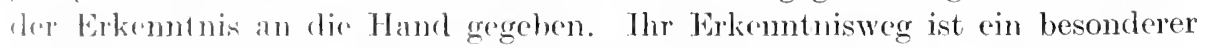
mel rigentïmlicher. Wegr. Vireo tritt der Wissenschaft der Renaissance entgerenen, soforn sie cine Tuiversalunethode lehrt. Lis gibt so vicle Methoden, als

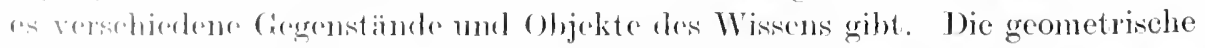
Mretherde, dir Descartes als Thiversalmethode proklamiert hat, unterliegt

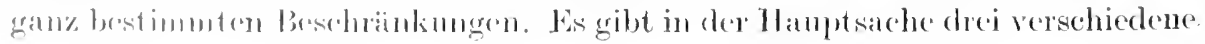


Sphären der menschlichen Erkenntnis, die für sich bestehen und nicht auf einander zurückgeführt werden können:

1. die Welt der Nationen, mit welcher sich die Menschen vor allen anderen Dingen besehäftigen, auf der ihr Hauptinteresse ruht;

2. die Welt der Natur, welche die Physiker beobachten;

3. die Welt des Geistes und Gottes, zu deren Betrachtung sich die Metaphysiker erheben.

Die Welt der Nationen ist nach Tieo die noeh unentdeckte und unrerstandene Welt, welche die scienza nuova zum Gegenstand ihres Studiums. machen soll. Von allen Wissenschaften ist sie die höchste und umfassendste und rermag ihren Gegenstand auf dem Wege einer strengen Deduktron zu erschließen. Sie beginnt mit dem Lautwerden und Hörbarwerden der Vernunft. mit dem ersten Gedanken an die Gottheit. Sie will eine Entwicklungsgeschichte des rernünftigen Lebens geben. Die nene Wissenschaft ist zugleich Geschiehte und Philosophie der Menschheit, Universalgeschichte und Kulturphilosophie. Sic will zeigen, wie die icleale ewige Geschichte, die im Plan der göttlichen Vorsehung enthalten und für alle Völker die gleiche ist, wie diese Geschichte in dem historischen Leben der verschiedenen Völker sich immer wieder ron neuem manifestiert. Sie bestimmt den Entwicklungsgang des einzelnen Tolkes als eine Entfaltung zum Standpunkt der Humanität und legt von allen Werten des Kulturgeschehens besonderen Nachdruck auf das Prinzip der Moralität, der Politik und des Rechtes als wichtigste Elemente für die Entwicklung des Völkerlebens.

Das Prinzip des Weltgeschehens stellt sich in den einzelnen Nationen in sehr verwandter und ähnlicher Form dar. Sie erleiden ein ähnliches Schicksal, und so ist es sehr wohl möglich, das Prinzip des universalhistorischen Geschehens an der Entwicklung eines einzelnen Tolkes, z. B. der römischen Nation. abzulesen. Die soziale Welt, zu der die Völker sich entfalten, ist von Menschen gemacht, und da die menschliche Natur überall die gleiche ist, so trägt auch die gesellschaftliche Welt aller Völker und Zeitcn eine verwandte Physiognomic. Auch ist in dem Leben der Völker eine verhältnismäßig große Stabilität zu bemerken, sofern sich die menschliche Natur und dementsprechend der Charakter der Nationen nicht plötzlich und überraschend verändert, sondern immer die Spuren des früheren Stadiums und der ersten Gewohnheiten anfbewahrt. Der Grundsatz, daß die Natur keinen Sprung macht, gilt erst recht für die Welt der Kultur. In einem kontinuierlichen Geschehen lösen die Gestalten des Völkerlebens einander ab.

Mit dem Gedanken der auserwählten Völker hat Vieo gebrochen. Es gibt keine Völker, die das Geheimnis des göttlichen Lebens ror allen in sich trügen. Es gibt keine Völker als große Lehrmeister für alle Zeiten, solche, über die hinaus kein Fortsehritt mehr denkhar und möglich ist. Man hat bisher ganz übertriebene Vorstellungen von der Weisheit und Wacht der alten Völker gehegt. In der Hauptsache ist die Kultur eines jeden Tolkes sein eigenes Werk gewesen, und die Tradition war ihm nichts anderes als Material für eine nene Schöpfung. Und so vermag uns die Geschiehte eines einzelnen Volkes in der Gesamtheit seines Kulturlebens in Verfassung, Sitte und Lebensweise als Typus des gesehiehtliehen Ablaufes zu gelten. 
Wemn Tico ein Ziel der Tolksentwicklung und der Mensehheitsgeschichte denkt, so ist es ror allen dieses, daß es ein Reieh sehöner Mensehlichkeit bilde, und daß die Idee der Gerechtigkeit zur Herrsehaft gelange.

Indem nun Vieo der Kausalität des historisehen Geschehens naehdenkt, erseheint ihm der mensehliehe Wille als Substrat der Wertrerwirkliehung, als der große Impuls des Mensehlichen, der dem Plane der göttliehen Vorsehung entgegenkommt. Wäre nicht diser große und starke menschliche Wille, so mangelte der Gotheit das Werkzeng der Offenbarung.

Allerdings ist es ausgeschlossen, die Kausalität des historisehen Gesehehens vollkommen zurüickuführen auf mensehliehe Willenshandlungen. Der große gemeinsame Entwicklungsgang der menschliehen Kultur, die Gesehichte des menschliehen Erfolges ist nieht aus der unendlichen Mamnigfaltigkeit verschiedener Willensrichtungen zu erklären. Es bleibt unbegreiflich, wie bei dieser Mannigfaltigkeit der Willensimpulse ein vernünftiger Simn und die Erreichung eines gemeinsamen Zieles möglieh sein sollte.

Aus diesen Gründen lehrt Vi co neben den individuellen Willenshandlungen Ursachen allgemeiner Natur. Das sind die Ideen als die allgemeinen Gesetzmäßigkeiten, die den historisehen Prozeß bestimmen. und dazn treten als weitere Faktoren die göttliche Torsehung und das. was er die natürliehen Bedlingungen nemnt. Aus den natürlichen Bedingungen ist zu ersehen, warum (lie historische Verwirkliehung der Ideen gerade diese bestimmte Form angenommen hat. Man kann sagen, daß diese natiurlichen Bedingungen Mitte] der göttlichen Torsehung sind. Die göttliche Vorsehung bedient sieh ihrer zur Errejehmng eines Zweekes, und der Plan der Vorsehung fällt mit den Ideen zusammen, ans denen die ileale ewige Gesehiehte hervorgeht. Die Geschiehte, wie sie sich in der simnlichen Wirklichkeit rollzieht, ist cin Abbild der idealen Geschichte. Auch unterliegt das Verhältnis der natürlichen Bedingungen zur Vorschung einer gewissen Einsehränkung, sofern ein Irrationales und Wertfeindliches angenommen werden muß, das nieht als Werkzeng der Gottheit verstanden werlen kam. Ein ungöttlicher Rest bleibt zurück. und der Sïndenfall als Auflehnmng gegen Gott ist ein Teil dieses irrationalen Restes.

Wir finden bei Vico manche Momente, lie auf eine Auffassung cier Geschichte als wertbezogene Eimmaligkcit hinzuführen scheinen. Er postuliert eine Wertordunng des historischen Gesehehens und betont den Gedanken des Fortschritts. Aber die historische Betrachtung weicht dem naturwissenwhaftlichen Aspekt, sofern auf das Wiederkehrende so grober Wert gelegt wird und ein allgemeines Gesctz als Bestimmung dieses Wioderkehrenden, djeser gleichartigen und verwandten Entwirklung behauptet werden mulb. Hlo Völker machen eine verwandte Entwicklung durch, jecle Volksentwicklung ist ain Fall konkreter und sichtbarer Dasstellung jener idealen Gesehiehte,

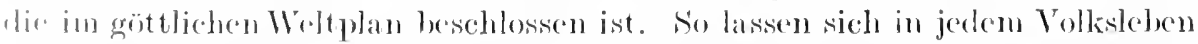

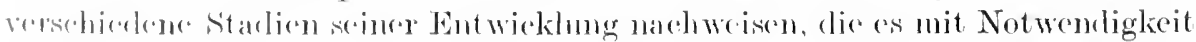

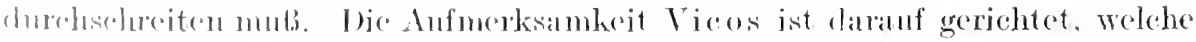
Wandlungen der Volkscharakter, der Typus der groben Persönlichkeit in

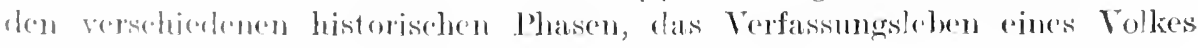

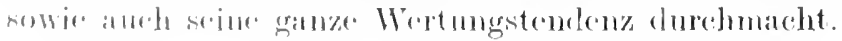


So ist die Natur des Menschen in der Woise eingerichtet, daß er zucrst auf las Notwendige achtet, dann auf das Nïtzliche, dann auf das Angenehme und sehließlich der Schwelgerei und Tergeudung anheinfällt. So sind die Helden eines Tolkes, wenn wir etwa an die Entwicklung der Griochen und Römer cenken, anfangs wild und barbarisch wie Polyphem, damn grol, mütig und stolz wie Achilles. dam gerecht wie Aristides und Scipio Africanus, dam gleich mächtig im Guten wie im Bösen wie Alexander und Cäsar, dann grüblerisch und trübsimng wic T'iberius und cnıllich ausschweifend wie Nero. Und das Terfassungsleben eines Tolkes wird nacheinancler repräsentiert duch das Prinzip des Despotismus, der Aristokratie. der Volksfreiheit und der Monarchie.

Die Kulturentwicklung eines Tolkes läßt sich dann ihrerseits wiecler in Teilentwicklungen zerlegen, bei denen es sich immer um die Entfaltung eines bestimmten Gutes, so etwa des staatlichen Lebens, der Verfassung, der Sitte, des Rechtes, handelt. Auch diese Teilentwicklungen wiederholen sich in jedem Volke. Faßt man aber sein Gesamtleben ins Auge, so lassen sich drei Hauptstadien in der Entfaltung der Menschheit unterscheiden. nämlich das göttliche, das heroische und das menschliche Stadium. Die göttliche Natur des ersten menschlichen Zustandes ist charakterisiert clurch die Herrschaft der Phantasie.

Das erste Stadium der Menschheit, ron dem dieUniversalgeschichte handelt . ist der Herrschaft der Phantasie unterworfen, die $u m$ so stärker und freier sich entfaltet, je schwächer das Denken ist. So war der Mensch am Anfang der Weltgeschichte poetisch und schöpferisch gesinnt. Mensch und Natur waren noch göttlich. Die große menschliche Phantasie belebte und rergöt lichte die materiellen Dinge nach der Vorstellung, die sie sich von den Göttern bilcete.

Das zweite Stadium der Menschheit ist das heroische. Die Heroen nahmen die Natur für sieh in Anspruch und begründeten ihr Privilegim durch den Hinweis auf ihre göttliche Herkunft. War in dem ersten Stadium das Gefühl und die Phantasie herrschend, so dominierte nummehr der tatenfrohe Wille.

Seine Erfüllung aber findet das Menschengeschlecht in der remünftigen und verständigen Natur, ein Zeitalter, in dem das Wohlwollen mit allen Menschen und die Anerkemmng ron Vernunft und Pflicht sich sieghaft Bahn bricht. Das erste Zeitalter war ein Zeitalter des Gefühls und der Phantasie, das zweite des Willens, und das dritte bedeutet ein Zeitalter des theoretisch TorstellungsmäBigen. Oder anders ansgedruiekt: das erste Zeitalter trägt cinen religiösästhetischen Wertcharakter, das zweite ist naturhaft ethisch ohne theoretische Emsicht, das dritte ist zur bewußten Anerkemmung der ethischen und theoretischen Trerte gelangt.

Diese Zeitalter, welche die Menschheit durchschreiten mul., wiederholen sich immer von neuem. In göttlichen Zustande der Menschheit gehen die geistliche und weltliche Vacht rollkommen Hand in Hand. Die geistliche wirkt im Sinne der welt lichen und die welt liche im Sinne der geist lichen. Ihre Spaltung und Trennung tritt im heroischen Zeitalter der Menschheit ein. welches das Prinzip der Tasallität und des Lehnswesens zur Entfaltung hringt. 
Das dritte Zeitalter ist das Zeitalter der idealen Terfassung in Monarehie oder Republik.

Und wenn wir an Ziel und Ende dieses Entwicklungsverlaufes denken, so rreist dieses Ziel nach Vicos Auffassung ganz augenscheinlich über die Sinnenwelt hinaus. Das wahrhaftige Ziel der Mensehheit liegt im Transzendenten. Der Grundgedanke seiner geschichtsphilosophischen Konstruktion ist doch religiöser Natur. Nach Vico ist dem Menschen ganz im Sinne der Philosophie Campanellas ein endliches posse, nosse, velle eigentümlich. Diese Trennung und Abspaltung des endlich begrenzten Wollens rom allgemein göttlichen Willen ist durch den Sündenfall herbeigeführt. Die Trennung wird als Mangel und Unvollkommenheit empfunden, und so strebt die menschliche Sehnsucht nach der Einheit des Anfangs zurïck. Dureh Klugheit, Maß und Tüchtigkeit wird die Rückkehr zu Gott hergestellt. Diese Erlösung von der Wirklichkeit rollzieht sich immer wieder von nenem. Sie hat sich immer wieder vollzogen. wenn eine Nation die typischen Stadien des Völkerlebens durehlanfen hat.

Als irdisches Ziel des Geschehens denkt Vico die ,große Republik“" in der die widlerstreitenden Willensriehtungen zur Ruhe kommen. Als, ,ewige und natüliche Republik" bezeichnet er sie, sofern sie teil hat an der ewigen Ordnung der Dinge und der Natur des Menschen als vernïnftigen Wesens entspricht. Die ,natïrliche" Republik ist die nach dem Gesetz der Vernunft geordnete Republik. Es handelt sich um eine ideale Form des sozialen Lebens, wie sie dann später Kant in der Idee einer weltbïrgerlichen Verfassung geforlert hat.

Innerhall, einer jeden Epoche, wie sie sich darstellt in dem Entwicklungsgang einer bestimmten Nation, die drei vorgezeichnete Stadien durehläuft, herrscht ein strenger, unverbrïchlicher Kausalzusammenhang. Innerhalb einer solchen Epoche läßt sich alles kausal erklären. Damn aber wird der natürliehe Zusammenhang der Dinge zerrissen, und die Vorsehung der Gotheit greift ummittelbar in das Geschehen ein. Zwischen zwei Epochen tritt also jedesmal das Wunder ein, sofern die Kausalitit Gottes sich ummittelbar des Geschehens annimmt und die Naturgesetze suspendiert. Der nene Anfang einer Entwicklungsepoche schließt sich nicht so ohne weiteres dem Ende der alten an, sondern zur Eischeinung des Nenen bedarf es der Werktätigkeit Gottes. Die Gesetze, welche das historische Gesehehen bestimmen, sind Mittel in Gottes Hand. Gott bedient sich der Gesetze, um die Welt zu gliedern und zu ordnen. Dureh tie Gesetze wirkt Gott mittelbar auf das Gesehehen ein, aber er vermag anch ummittelbar nnd olne Zwischeninstanzen das historisehe Geschehen zu bestimmen. Indem nun die Individnen die Zweeke der Vorsehung erfüllen. hrsteht eine gewisse Heterogenie zwischen den Zwerken, die sich der Menseh s.tzt, den Zielen scines persönlichen Ehrgeizes, und lem Resultat, das erreieht wirl, sofern er, ohne as zu wollen, den ihm verborgenen Absichten der Vorsolung dicnt. Tach Vicos Anfassung nut\%t lic Vorschung die Absiehten dre Mroschen, dire in der Regel immer anf Befriedigung der eigenen Wïnsche

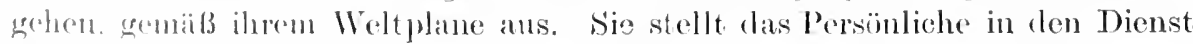

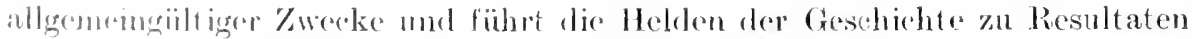
hin, lir ihrer hesmorn Absicht vollkonmen forn lagen, aher dem sinne des (iinzen zumutzo limmmen. 
Das Bedeutsame der Geschichtsphilosophie Vicos liegt in dem Versuch. die Gesetzeserkenntnis der Naturwissenschaft mit dem Wertgesichtspunkt historischer Auffassung zu rersöhnen. Es gibt ein allgemeines Gesetz des Fortschritts, welches die normative Abfolge der menschlichen Gesellschaftsordnung im Völkerleben zum Ausdruck bringt. und das in Gottes Weltplan ruht und enthalten ist. Das Schicksal der Völker ist im wesentlichen dasselbe. die ideale Ordnung der staatlichen Zustände in ihrer bestimmten Reihenfolge konkretisiert sich immer wieder aufs nene. So kommt die naturwissenschaftliche Auffassung der Geschichte ror allem in dem Gedanken des Cesetzes der Wiederkehr und der typischen Allgemeinheit der historischen Persönlichkeiten zum Ausdruck. Aber anderseits ist das Gesetz des Völkerlebens, ron dem die Geschichtsphilosophie Vicos handelt, kein Naturgesetz im sinne der Naturwissenschaft wie etwa das Gesetz der Trägheit oder die Gesetze der Wärmelehre. Und zwar nicht nur deswegen, weiles ihm an Exaktheit und mat hematischer Formulierbarbeit fehlt - diese Art ron .,Vollkommenheit "könnte ja für das Verstehen dieser GesetzmäBigkeit noch der Zukunft rorbehalten sein - , sondern vor allem deshalb, weil es wertbehaftet und nicht frei im Sinne einer höchsten Instanz ist. Gleichgiiltig walt et das Naturgesetz ïber Gut und Böse, aber die Gesetze Ticos sind Gesetze zur Erreichung eines wertrollen Zieles und begründen eine Skala der Wertsteigerung. Auch ist das allgemeine Gesetz Vicos nicht ein selbständiges Prinzip des Wirkens und der Naturerklärung, sondern Mittel in der Hand eines Wertwesens, Werkzeug des göttlichen Prinzips. Und damit hängt zusammen, daß auch der Schauplatz der historischen Entwicklung nicht ungeteilt diesen Naturgesetzen gehört, und der Gedanke der unverbrüchlichen Naturordnung nicht durchgeführt ist, weil die Kausalität Gottes als die Kansalität des Wunders immer wieder den Ablauf des Geschehens durchbricht, und zwar allemal damn, wemn das Neue in der Gestalt und dem Werdegang eines neuen Tolkes in der Geschichte der Kultur erscheint, nachdem es den sïndenfall in der Abwendung ron dem lautlosen Leben des naturhaften Daseins rollzogen hatte. Was die Gesehichtsphilosophie Vicos bis zur Evidenz zeigt, das ist ror allem dieses. daß die Idee des Fortschritts als geschichtsphilosophisches Prinzip mit dem Begriffe des Naturgesetzes unvereinbar ist.

\section{i) Condorcet.}

Die Gedanken Vicos sind rou C'ondoreet weitergebildet, aber noch strenger in die Bahn der Gesetzeserkenntnis gewiesen ${ }^{1}$ ). (Condoreet ist ein Sohn der Aufklärung. Religiöse und theologische Ideen, wie etwa der Gedanke der Offenbarung und des Wunders, können das wissenschaftliche Bild nicht trüben, das er uns ron der Entwicklungsgeschichte der Menschheit gegeben hat. Er betrachtet das historische Geschehen in streng wissenschaftlieher Weise, wenn wir auch das gewaltige Agens dentlich spïren, das all dicse Gestalten offenbart hat. Es ist das der große und unzerstörbare Glaube Condorcets an den Fortschritt des Menschengeschlechts. Allerdings ist dieser Glaube nicht auf ein bestimmtes Tolk bezogen, vielmehr macht Condorcet.

1) Esquisse d'un tableau hisorique des progrès de l'esprit humain. 1795. 
indem er das Vöłkerleben betrachtet, die Konstruktion eines einzigen Volkes, zu dem sich die ungeheure Summe menschlicher Kräfte zusammenschließt. Dieses Gesantrolk, die Mensehheit, sehreitet vorwärts, wenn auch die einzelnen Teile untergehen müssen. Die Menschheit als Ganzes schreitet vorwärts einem Reiche des vernïnftigen Lebens zu.

Diesem großen Fortschrittsgesetz gegenüber hat das Wunder keine Stelle mehr. Cond ore et lehrt die unverbrïchliche Nat urordmung, die alle Ent wicklung bestimmt und keine Ausnahme duldet, so daß auf Grund der gewonnenen Resultate auch eine Voraussicht der Zukunft möglich ist. Der Mensch ist Her des historischen Geschehens, die Irrationalität der Geschichte ist nicht so groß3. wie man wohl gemeint hat. Auf Grund einer überreichen historischen Erfahrung ist es möglich, siehere Schlüsse in bezug auf die Zukunft zu ziehen. Wir sind imstande, msere cigene historische Situation zu verstehen, indem wir sie als Glieder einer typischen Entwicklungsreihe begreifen. So wissen wir etwa, daß im wirtschaftlichen Leben ganz bestimmte Formen in der Organisation der arbeitenden Klassen aufeinanderfolgen. Wie für die antike Welt die Sklavenwirtschaft charakteristisch und notwendig war, so etwa für las. Mittelalter die Leibeigenschaft und für den modernen Staat der freie Arbeiterstand.

In seiner geschichtsphilosophischen Konstruktion, die eines großen Zuges nicht entbehrt, führt der aufk]ärerische Rationalismus Condorcets gerade hinsichtlich der Auffassung des Mittelalters zu manchen Mißdeutungen. Was aber den Gesetzesbegriff betrifft, so hat er zwar cinerseit s an Bedeutung gewonnen, sofern er in seiner Tubedingtheit aufgestellt ist, aber anderseits tritt der Gelanke der Wiederkehr, der bei Vieo noch scharf betont wurde, doch weit mehr hinter der Idee eines einmaligen wertrollen historischen Geschehens zuriick, da das Interesse des französisehen Gesehichtsphilosophen ror allen ler Entwicklung der Mensehheit in ihrer Ganzlieit und weniger der Entwicklung einzehner Völker zugewendet ist.

\section{k) Bossuet.}

Gegenïber der Gruppe jener Gesehichtsphilosophen des aufkläres ischen Rationalismus, die den Gedanken eles Naturgesetzes anch für die Geschichte nutzhar machen wollen, steht cine andere Gruppe von Philosophen, die, den Gertanken des Fortscheits mehr oder weniger betonend, das Gesetz im naturwissenschaftlichen Simme als Prinzip der Geschichte ablehnt. Sie gehören zu jener irrationalen Luterst römmng des Aufkliamgszeitalters, die sich gegen die Hersehaft des, leeren" Verstandes auflehnt. Der Fortselurittsgedanke in theologischer Gebmulenhert, wio or ans der Geschichtsphilosophie des Mittelalters sich rmporgermugen hatte, enthüllt sich in deg Gesehichtsphilosophie w) bossuet. In Mittelpunkt seiner geschichtsphilosophisehen Konstruktion

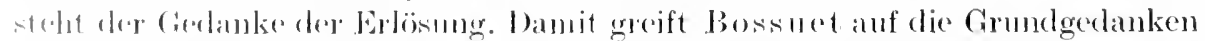

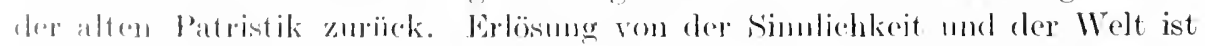

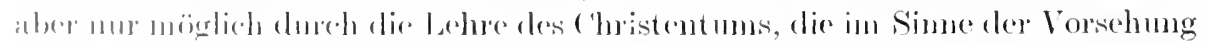

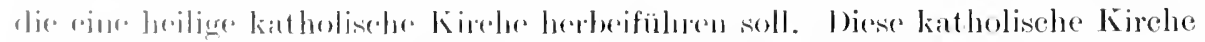

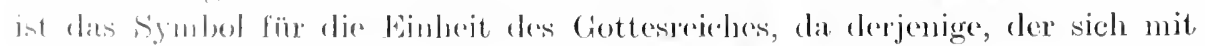
ihe verbmelen hat, anf Gualde holfen darf. Wie concloreet betont auch 
Bossuet das gemeinsame Schicksal des Menschengeschlechtes und nicht wie Vico die Sonderentwicklung ron Nationen, die dureh keine ableitbare kansale Beziehung verbunden sind. Tiehmehr kommt es ihm vor allem darauf an, das Ineinandergreifen des Tölkerschieksals zu zeiger. Das gemeinsame große historisehe Schicksal der Mensehheit will er zeigen, wie es sich allmählich enthüllt und erfüllt. Die Gliederming und Ordnung des Geschehens rollzieht sieh dabei entsprechend dem Reifwerden und Siehvollenden der Erlösungsidee. Gewiß ist der entscheidendste Einschnitt, der in Weltgeschehen gemaeht werden kann, das Geburtsjahr Jesu Christi, aber diese Zeit der Erfüllung ist noch keine Zeit der absoluten Vollendung. Die Erlösungsidee muBte sich erst ein Werkzeug und eine Stätte bereiten, von der aus sie dann über alle Welt sich verbreiten konnte. Dieses Werkzeug und Instrument wurde für dic ehristliehe Kirehe und ihre erhabenen Zielsetzungen das Reich Karls des GroBen. das sich auf den Trümmern der abendländisehen Welt aufbaute. Diese Völker Westeuropas mit ihrer großen gemeinsamen Kultur, sie haben in sinne der Weltgeschichte das Werk der Christianisierung zu vollenden. Sie sind gleichsam eine Station und ein Úbergang zu dem Ziele der Allherrschaft des Christentums. In dem Reiche Karls des Großen verdichtet sich und erstarkt der religiöse Geist cles Christentums, um sich dam später ïber alle Lünder der Welt auszubreiten.

Jener irrationalistischen Strömung, die jede naturalistische Bindung des historischen Geschehens ablehnt, gehören im Zeitalter der Aufklärung dann endlich noeh die überragenden Gestalten ron Roussean und Herder an.

\section{1) Rousseall.}

Rousseaus Schriften sind ron erheblieher Bedentung für die Entwicklıng

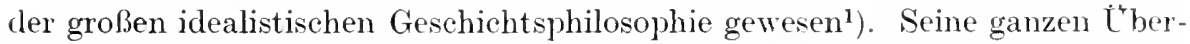
legungen rüeken den Begriff der Kultur in den Mittelpunkt der gesehichtsphilosophischen Spekulation. Rousseau hat zuerst die Frage nach dem Simn und der Bedeutung der menschliehen Kultur erhoben. Er hat ihn der Forderung der menschliehen Glüekseligkeit entgegengestellt. Wollen wir unsere Individualität zum Ziele einer wahrhaften Glückseligkeit bilden, die natürlich ron niederer Sinnenlust weit entfernt ist, damn müssen wir dahin gelangen. diء Kultur bis zu eimem gewissen Grade zu verneinen. Tor allem ist Rousseau aufmerksam geworden auf die Wertfeindlichkeit, die zwisehen den verschiedenen Kulturgebieten besteht, so etwa zwisehen der Sphäre des noralischen und des künstlerischen Lebens. Er hat die großen kontemplativen Werte Wissenschaft und Kunst in ihrer moralitätsfeindlichen Tendenz deutlieh zu machen gewußt, und indem er den Begriff der Kultur ror allem mit der Entfaltung dieser beiden verknüpfte, gelangte er zu einer relativen Verneinung der Kiultur. Mit großer Entsehiedenheit stellte er dem Begriffe der Kultur überall den Begriff der Natur entgegen. Dabei lassen sich ganz augenseheinlich zwei sehr rersehiedene Begriffe ron Kultur bei Rousseau unterscheiden. Der eine Naturbegriff trägt keinen Wertcharakter. Hier handelt es sieh m den Ummenschen. der einsam die Wälder durehsehweift und dessen remmftloses Tun noch

\footnotetext{
1) R. Fester, Rousseau und dio deutsche Geschichtsphilosophie. Stuttgart 1890.
} 
diesseits ron gut und böse liegt. Der andere trägt sozialen Charakter und meint ‘ie natürliche Sozialität einer schlichten und einfachen Kultur, die noch von den Rauheiten und Gefährdungen der Zivilisation bewahrt ist. Auf dieser Stufe der Entwicklnng lebt die Mensehheit in friedlieher Gemeinschaft, gegliedert in kleine Tolks- und Familieneinheiten unter einem ruhigen md gerechten patriarchalisehen Regiment. Liebe und Verständnis herrscht hier ïberall, da das Eigentum allen gemeinsam ist und die Arbeit noch keine einseitige Spezialisiermng erfahren hat. In diesem Zeitalter konnte sich der Mensch in der Totalität seiner Kräfte auswirken, da die schöne Mannigfaltigkeit seiner Termunftanlagen noch nieht dureh enge Berufsziele gehemmt ist. Dieses Zeitalter kennt noch nieht den Despotismus der Fürsten, welche die großen Staaten, die sie mit eherner Kraft beherrsehen, zum Werkzeug ihres schrankenlosen Ehrgeizes maehen. Noch steht die unpolitisehe Gemeinsehaft an Stelle der sozialen Organisation, der Altruismus herrseht über den Egoismus, und die Einfachheit der Lebensgewohnheiten und Sitten erblüht zu einer reinen Moralität, in der die Güte der mensehlichen Natur, durch keinerlei Schranken getrennt, frei und sehön sich offenbaren kann. Der Naturzustand Rousseaus ist somit ein Zustand unverdorbener sittlicher Kultur. Man kann somit nieht sagen, daß Rousseau die Kultur radikal verneint hat; denn der Naturzustand der Mensehheit, den er als höchst wertvoll anerkennt, und über den die Menschheit nicht hinausgehen sollte, ist bereits ein Kulturzustand, sofern höheres sittliches Leben geformt und gebildet ist. Roussea u verbindet ren Begriff der Kultur vor allen mit der Wissensehaft und der Kunst, jenen geistigen Mächten, die der Ursprünglichkeit einem verhältnißmäßig (infachen und primitiven Lebens am meisten feind sind und die Verfeinerung des Lebens nit allen Segnungen und Nachteilen der Zivilisation in Gefolge hahen. Er wendet sieh also nur gegen gewisse Formen der Knltur und zwar segen diejenigen, die naeh seiner Auffassung der Kultur eines wahrhaft sittlichen Lebens am meisten entgegenstehen. Er wendet sich also nur gegen die durch ein C'bermaß ron Zivilisation verdorbene Gegenwartskultur und erhebt dir Forklerung der Rückkehr zu einfacheren und sehöneren Formen des sozialrn Daseins, die durch die Hast der Úberkultur entstellt sind.

In dieser ginzen Tendenz Rousseaus liegt es beschlossen, daß er sich dem sozialen Fortschritt feindlich entgegenstellt. Von einer Vervollkommmung der gesellschaftlichen Zustände im Sinne der Zivilisation darf nach seiner Lehre nicht gesprochen werlen. Der Fortsehritt in Wissensehaft und Kunst, dre sich in der reichen und kostharen Ausgestaltung des staatlichen Lebens bemerkbar macht, zerstört das ruhige mol reine Wesen der sittliehen Gemeinschaft, the dureh die harten Forderungen des Egoismus, der sieh in Kampf In! lixsit\% mol Ejgentum änBert, noeh nicht ans ihrer schönen Ruhelage gerisen ist. Domoch jst auch Romsseau, wie alle groben Vertreter des Auf-

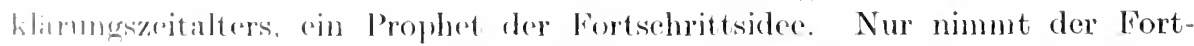
rhritserelanke bei ilm keine geschichtsphilosephische Gestalt an, inden "r anf dir grolsen Kulturzusammenhänge bezogen wird, sondern er wirel vielmehr oinseitig anf rle individuelle Entwicklung beschränkt. Von des ursprüng-

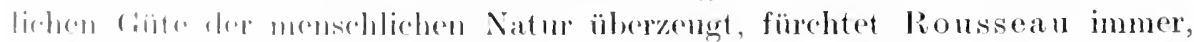

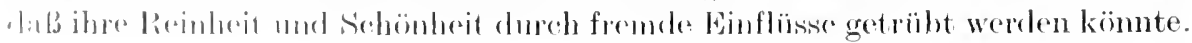


Die Individualität hat die Möglichkeit, einen unendlichen Reichtum guter und schöner Anlagen aus sich zu entfalten, und das wird auch geschehen, wenn dem Individuum in den sozialen Terhältnissen keine allzu schroffen und hemmenden Schranken entgegenstehen. Die sozialen Terhältnisse so zu gestalten, daß sie die Entfaltung der Individualität und eine Wertsteigerung des Personenlebens ermöglichen, ist die erste Pflicht des sozialen Gesetzgebers.

\section{m) Herders Geschichtsphilosophie.}

Ủber das Aufklärungszeitalter hinausweisend, schließt die Geschichtsphilosophie Herders gleichzeitig die große Epoche der Torbereitung $a b^{1}$ ). Seine Auffassung der Individualität ist der Auffassung Rousseaus rerwandt. und auch sein Begriff der Natur hat mit dem Naturbegriff Rousseaus manches gemeinsam. Aber alles ist so sehr vertieft und erweitert und zu einer so großen universalhistorischen Auffassung zusammengeschlossen, daß wir in Herder den Anfang der vollendeten geschichtsphilosophischen Systeme erblicken müssen. Er stellt den unverlierbaren Typus einer Form der Geschichtsphilosophie dar. der vor allen Dingen den Werteharakter der Individualität betont und gegenïber der Idee des Endzwecks und des Fortschritts, welche die enige Torläufigkeit alles wertrollen Geschehens zum Ausdruck bringen, den Gedanken des Tollendetseins und der Allgegenwart des Wertrollen auf das äußerste rertritt ${ }^{2}$ ).

Herder kann sich nicht entschließen, einen schroffen Gegensatz zwisehen Natur und Kultur zu setzen. Der Begriff der Natur ist bei Herder allumfassend. Nicht nur die niederen Formen des Daseins, sondern auch die höchsten Formen des geistigen Lebens umfaßt sein Begriff der Natur. Wir dürfen im Sinne der Herderschen Philosophie keinen schroffen Gegensatz denken zwischen dem. was ursprünglich gegeben war, und dem, was geworden ist. Das engere Gebiet der Kultur ist aus jenem Frïheren allmählich hervorgegangen, hat sich aus ihm heraus in vollkommener Kontinuität entwickelt. Nieht hat es sich gewaltsam ron ihm losgerissen, noch sich in Streit und Unrecht gesetzt. Aus dem mütterlichen Schoße der einen großen Natur ging alles herror, diese unendliche Mannigfaltigkeit des bloß natürlichen und geistigen Daseins.

Indem dann aber Herder nach dem Simne des historischen Gesehehens fragt, kam er ihn nur in der Terwirklichung der Humanität erblicken. Diese Humanität, zu der sich die Menschheit als Gegenstand der miversalhistorischen Betrachtung entwickelt, darf nicht mit dem abstrakten Begriff eines Endzwecks rerwechselt werden. Die ungeheure Arbeit und der Kampf des historischen Lebens darf nicht lediglich so aufgefaßt werden, als ob er nur im Dienste kommender Geschlechter stände und seine Bedeutung nur daher bekäme, daß eine ferne Menschheitsgesellschaft am Ziel einer endlosen Entwicklung die schwer erkauften Früchte mühelos ernten sollte. Ein unerträglicher Gedanke liegt darin. daß all unser Tun und Leisten nur rorläufige Zwecke rerwirlichen kamn, und daß uns niemals etwas Endgültiges und Tollendetes beschieden ist.

${ }^{1}$ ) Vgl. Auch eine Philosophie der Geschrchte der Menschheit: Ideen zur Philosophie der Geschichte der Menschheit. 1893.

2) Vgl. E. Kühnemann, Herders Persönlichkeit in seiner Weltanschauung. Berlin 
Trostlos ist der Gedanke, daßs unser Leben von der Wahrheit und Schönheit ausgeschlossen bleibt, weil jene sich erst am späten Horizonte der Menschheit offenbaren werden. Nein, immer und überall, das ist die geschichtsphilosophische Auffassung Herders, kamn das Wertvolle in Erscheinung treten und das Vollendete zur Darstellung gelangen. Die Zeit bchindert die Offenbarung des Göttlichen in der Wirklichkeit nicht. und so ist es zu all und jeder Zeit und immer wierler in nener Schönheit zugegen.

Dic Idee der Menschheit umfaßt die Summe alles wertrollen Lebens, sofern es zu eigentümlicher und vollendeter Entfaltung gelangt ist. Uberall dort ist Humanität rorhanden, wo ein Volk seine eigentümlichen Gaben und Anlagen rollkommen ansgewirkt und entfaltet hat. Jedes Volk realisiert somit auf eigentïmliche Weise die göttliche Idee der Wenschheit, und man kann nicht sagen, daß jene alten Kulturen, die jetzt vergangen sind oder nur noch mit wenigen Trümmern z11 uns herüberragen, von der Vollendung ausgeschlossen gewesen wïren. Tielmehr brachten sie das Vollendete in einer mwiederholbaren, nur als Produkt ihrer Indivichualität möglichen Weise in schönster Eigentümlichkeit zur Erscheinung. Anch kann man nicht sagen, daß alles das. was jene Völker der Vergangenheit Vollendetes geschaffen haben, daß dieses alles rollkommen vernichtet mol begraben sei, vielmehr lebt das Vollendete als danernder Bestand in der Gegenwartskultur weiter, solange überhaupt ron höheren Daseinsformen die Rede sein kann.

Der geschichtsphilosophische Begriff der Individualität tritt uns bei Herder vor allem als Wertindividualität der Nation entgegen. Weder vereinzelte große Persönlichkeiten noch auch die politischen Organisationen der Staatswesen stehen im Mittelpunkt seiner Betrachtung. Das eigentliche Objekt seiner geschichtsphilosophischen Üherlegung bildet die Nation. Die Nationen, in denen das Ganze der Menschheit immer wieder nene Gestalt gewinnt, sind 'Träger des Kulturgeschehens. Die Universalgeschichte, wie He rde r sie denkt, ist werler eine Geschichte der Persönlichkeiten noch eine Geschichte Ier Staaten. Er legt der Persönlichkeit gegenüber den Nachdruck anf die Gomeinschaft. Ton den Formen der Gemeinschaft aber scheint ihm jene Einheit am bedeutsamsten zu sein, die sich in Splache, Sitte, in gemeinsamer Lehensauffassung, in verwandten Bildungen des geistigen Lebens bekundet, berleutsamer als jene amlere, deren Grenzen durch große politische Geschehnisse rrrichtet und gezogen sind, Grenzen, an denen der Wechsel der Ereignisse immer wieder neut Verämlerungen vollzogen hat. Die Wertindividualität Ifor Nation, rio Herder der staatlichen Gemeinsehaft gegenïberhält, ist gleichsan das Ursprïngliche, durch natürliche Sozialität Verbundene, gegenüber from Gewordrnen und lurch politische Kunst Geordnoten mol Gemachten. In ler Nation finlet sieh alles freiwillig und fremlig zusammen, im Stat ist dir "zusammengehörigkrit rine gesollte.

Indem Horder 1301 so dio Natjon zum Trä̈ger des Kulturgeschehens mandlt. Hetont ar anch in seiner universalhistorisehen Konstruktion weit weniger dir starlor politiuche Machtrntfaltung, lie Kämpfo und Eroberungen, welche dic

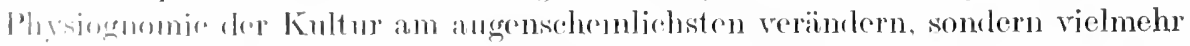

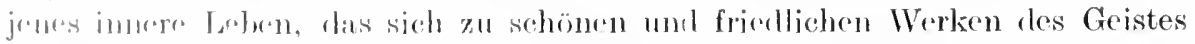

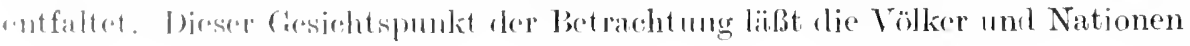


nicht in einer schroffen Ordnung des Nacheinander erscheinen, wie etwa bei Hegel die einzelnen Tolksgeister durch die Idee des absoluten Geistes bestimmt sind, der immer wieder ein anderes Volk zur welthistorischen Macht erhebt, sondern jedes Volk hat bei Herle reine unverlierbare Eigenbedentung. die danernd bestehen bleibt, und die auch durch seinen politischen Untergang nieht in Frage gestellt werden kann. Das Tölkerleben erseheint somit von rornherein unter dem Gesichtspunkt, daß es sich in einem Tebeneinander friedlich gliedern und ordnen soll. Es erscheint naturhaft, bildnerisch und demoliratiseh. Naturhaft, sofern dem Geschehen in Herders geschichtsphilosophischer Betrachtung nicht die dominierende Herrscherrolle zufällt wie in ter Curuhe der dialektischen Bzwegung, die chrch die großen Systeme des deutschen Idealismus strömt, sondern mehr gedacht wird als ein Mittel zur Herstallmur einer schönen Seinsordnung des Lebens, die ïberall und immer hergestellt werden kann und ist. Das Zuständliche, die Seinsordnung beschäftigt Herder in erster Linie, das Pathos des Gesehehens ist ihm fremol. Daher auch die starke Unterstreichung des Bleibenden und Zuständlichen als dos Wertrollen und Bedeutsamen. Wie ein Bildner ordnet Herder die Geschiehte. mehr ein Plastiker und Maler als ein Dichter. Er läßt das historisehe Leben von allen Seiten und mehr in seinem Zusammensein schanen als in dem Nach. einander der epischen Erzählung oder gar in der seharfen spanmung einer dramatischen Handlung. Demokratisch aber läßt sich seine Auffassmng rom Völkerleben nennen. weil ihr die Idee eines auserwählten Tolkes vollkommen fehlt, das der Weltgeist zum schicksalsmäehtigen Werkzeng seines Willens auserlesen hätte. Vielmehr verweilt die universalhistorische Betrachtung Herders mit gleicher Liebe und Hingabe bei allen Völkerindividualitäten und ist nicht allein $u m$ das Schicksal der ganzen Mensehheit, sondern auch um das Schicksal jedes einzelnen besorgt. Diese Betonung des Zuständlichen und die Parität in der Behandlungsweise der rerschiedenen Vollssgemeinsehaften konnte Herder kein Prinzip an die Hand geben, um das Welt geschehen in Epoehen zu gliedern und zu ordnen. Er ist ein Gegner aller scharfen Trennungen und schroffen Bewegungen. Wie er in der Sammlung seiner Wolkslieder die Lierler des hohen Nordens, die Liedehen der Letten und Finnen mit den Liedern gepart hat, welche Griechen und Römer dereinst gesungen, ohne daß er den kïnst. lerischen Wert der einen über die anderen erhoben hätte, so läBt er auch in seiner Geschichtsphilosophie den amerikanischen Wilden und den soln Griechenlands als eigentümliche und selbständig schöne Gebilde nebeneinander bestehen.

Typisch für die Auffassung Herders ist anch die starke Betonung der Kontimuität, die Ablehnung jeder dramatischen spannung. Während der dialektisehe Gedanke in der Auffassung des dentseben Idealismus immer Extreme konstruiert, deren Überwindung das Wesen des historisehen Geschehens ausmachen soll, geht nach der Anschanung Herders eine Form iles historischen Labens ruhig aus der anderen hervor, lösen sich die Gestalten in bunter Fiille ab, treibt das eine Weltleben der Natur immer wieder nene Blüten und Früchte.

Bei dieser ruhigen und kontemplativen Stellungnahme gegenüber dem Geschehen, bei dieser Universalität des Nachfühlens mol Nachempfindens gegenüber jeder Form des historischen Daseins, scheint es nun in der Tat schwierig zu sein. einen Maßstab anzugeben, nach clem das historische Geschehen 
gewertet und beurteilt wird. Der Herdersohen Gesehichtsphilosophie liegt augenscheinlieh keine Wertordnung zugrunde. Wir können nicht eimmal vermuten. wie sich Herder etwa die Bedeutung des wissensehaftlichen Lebens im Verhältnis zur Kunst gedaeht hat.

Nur soviel ist gewiß, daß er die Entfaltung des politisehenLebens rerhältnismäßig gering gewertet hat. Aneh ist der Begriff der Kultur, der für jede geschichtsphilosophische Konstruktion entscheidend ist, von Herder noeh nicht deutlich heransgearbeitet. Das Reich der Natur und der Kultur sind anf das engste ineinandergeschlungen, und es findet sich keine entschiedene Bejahung des Kulturlebens gegenüber dem bloßen Dasein der Natur.

Das Prinzip der geschichtsphilosophisehen Beurteihng ist die Idee c.er Humanität, deren allgemeiner Charakter wohl eine großzügige und unbefangene Wertung der historisehen Erscheinungen möglich maeht, die aber anderseits auch wieder den Nachteil in sich schließt, daß es ron ihr aus sehr sehwierig ist, Höhen und Tiefen des historisehen Lebens festzustellen. Wenn schon dasjenige Tolk das Ziel der Gesehiehte erreieht hat, das in einem stillen und friedrollen Dasein. fern ron den großen Bewegungen der Gesehichte das wenige, das ihm die Natur verlieh, frei und mbefangen in beseheidenen und idyllischen Grenzen entfaltete, clamn ist es in der Tat schwierig, der ungehenren Leistung gerecht zn werden, welche ein so geniales Volk wie das grichische für die Kultur der Mensehheit rollbrachte. Aueh das stille Volk der fernen Tropenwelt, das ein träumerisches Leben lebt, in naiver Cnbefangenheit das Dasein genieBt und in harmloser spielerischer Weise seinen Kunstrieb in primitiven Schnitzereien und in der Freude an buntem, derbem Farbenschmuck äußert, es ist nach Herders Prinzip ebensogut zur Humanität gelangt wie jenes schicksalsmächtige Volk, das in Marmorbildern ron unvergleichlicher Schönheit der Mensehheit ein Ideal des Göttliehen sehuf, und das aus tausend Trunden bluten mußte und zugrumde ging, weil es so schön und heldenhaft auf seinem Posten gestanden. Wenn Herler demmgeaehtet das griechische Tolk als clas Genie unter den Völkern gefeiert hat und ihm eine Darstellung von seltener Follendung gab, so hat er das im Grunde genommen nicht rom Prinzip rer Humanität aus getan. Das Prinzip der Humanität hat sich in jedem Volk erfüllt, das sein Eigenes entfaltet und dargestellt hat. An dieser Darstellung des Figenen kamn es behindert werden. Diese Hemmungen aber crlcidet es nicht rermöge seiner Natur, sondern infolge der Roheit und Brutalität fremcler Völker. So muB Herder mit Notwendigkeit diejenigen Vïlker verurteilen, die mit roher Gewalt sehöne stille Werke des Friedens zerstort haluen. Deswegen wird ihm das Römertum zu einer wertfeindliehen Macht. Es steht in der Hatuptsache seinem P'rinzip entgegen, und da Herder lic politischen Leistungen verhältnismäbig gering einsehätzt, so findet die rönische Nation ane sehr begrente brwertung.

[mmerhin ist jerloch Herler nicht dabei stchen geblicben, seine Wertmetcrschicele lodiglich in dem begremzten Sinne von Humanität zu setzen, Ire auf die Entfaltung der eigenen Individualitat im Stile Rousseaus hinandianft. Er wortet alleh die grobe, dic hesonders reiche mel mächtige Indivi-

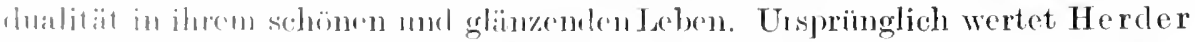

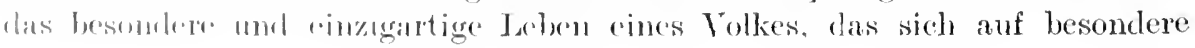


und einzigartige Weise erfült und darstellt. Schließlich aber wertet er doch über alles das große und schöne Völkerleben, das sich in großer und schöner Weise darstellt. Ist dies aber der Fall, so tritt auch der Begriff der Kulturleistung schärfer hervor. Der Wert einer Nation liegt damn nicht mehr in ihrem bloßen Dasein, in dem Charakter ihrer Lebensgestaltung, in dem schönen Stil ihrer Lebensführung, sondern in dem Großen, was sie getan und erduldet hat.

Alle großen Probleme der Geschichtsphilosophie klingen bei Herder an: das Verhältnis der Natur zur Kultur, das VerhäItnis der Individualität in ihrer Besonderheit zum Allgemeinen der Welt und der Wirklichkeit, das Verhältnis ron Endzweck und Fortschritt zu der Idee einer rollendeten Gegenwart, die Bedentung der Individualität als Lebenserscheimung und als Kunturträger. Dabei geht vieles noch unausgeglichen nebeneinander her, und große Entscheidungen sind noch nicht gefällt. Mit voller systematischer Kraft sind dic Probleme der Geschichtsphilosophie erst rom deutschen Idealismus angegriffen und haben hier eine einzigartige Vollendung gefunden.

\section{Drittes Kapitel.}

\section{Die Vollendung der Geschichtsphilosophie in deutschen Idealismus.}

Wie es Plat o gewesen ist, welcher der Philosophie den großen Zug gegehen und ihr das königliche Antlitz rerlieh, so ist die philosophische Betrachtung der Wirklichkeit unter dem Aspekt des historischen Geschehens und die freie und königliche Auffassung des historischen L'niversums die unvergleichliche Tat des deutschen Idealismus.

Wenn wir bei der Betrachtung des dentschen Idealismus an Plato erinnerten, so liegt darin keine Zufälligkeit, denn ohne Frage ist der Geist der Platonischen Philosophie für die Entwicklung des deutschen Idealismus bestimmend gewesen und immer noch bestimmend. Der deutsche Idealismus ist es vor allem gewesen, der den Begriff der Platonischen Idee mit dem Begriff der Kultur und der historischen Wirkhichkeit rerhunden hat. Die Platonisehe Idee trägt einen sehr allgemeinen Charakter. Es gibt Ideen aller Dinge. Der dentsche Idealismus erkennt das Werthafte der Idee ror allem in den großen Offenbarungen des geistigen Lebens. Und wenn die Bewegung der Simmenwelt nach der Platonischen Vorstellung die Gegenwart der Idee mur leieht und flüchtig erfuhr. hat der deutsehe Idealismus eine feste und notwendige V'rbindung zwischen den beiden Welten hergestellt und das historische Geschehen betrachtet als erfüllt ron dem Leben des Geistes und als Sehanplatz und Werkstätte ideeller Mächte.

Indem num aber der deutsche Idectismus von dem Begriff der Idee und der Kultur aus das Problem der Geschichtsphilosophie in Angriff nahm, wurde er infolge seiner großen Systematik mit Notwendigkeit zu der Frage getrieben. auf welchem Wertgebiet der Kultur wohl das historische Geschehen seine Toll-

Mehlis, Geschichtsphilosophie. 
enrlung finden möchte. Das war eine Frage, welche in der gricchischen Philosophie noch nicht zum Austrag gekommen war. Denn das griechische Denken ruhte in der Einheit aller Werte. Die Geschichtsphilosophie des deutschen Idealismus ist nun dahin zu verstehen, daß nacheinander die verschiedenen Werte als leitend und bestimmend für die Universalgeschichte geltend gemacht werden. Und zwar war es zuerst, dem nahen Verhältuis zur Auflklärung entsprechend, der moralische Wert, der in der Geschichtsphilosophie Kants geltend gemacht wurle. Dieser moralische Gesichtspunkt als sittlicher Endzweck alles Kulturgeschehens, wie er ron Kant in einer Reihe kleiner Schriften zur Geschichtsphilosophie behauptet war, erhielt seine Vertiefung und systematische Erweiterung in der Geschichtsphilosophie Fichtes. Gegenïber cler Erhebung des sittlichen Wertes zum Einheitsprinzip und Trertmesser des historischen Lobens wurde dann rom der Romantik und ihrem Philosophen Joseph Schelling der ästhetische und religiöse Gesichtspunkt geltend gemacht. Schließlich wurde dann auch die Bedentung des theoretischen Wertes für alles historische Leben festgestellt, und zwar ist es Hegel gewesen, der, die Philosophie des deutschen Idealismus abschließend, auch die Universalgeschichte unter den Maßstab der logisch-theoretischen Erkenntnis gestellt hat, während der französische Geschichtsphilosoph Auguste Comte die Idee der naturwissenschaftlichen Weltanschammg znm Prinzip des historischen Geschehens machte. Wir müssen also folgende Formen der Geschichtsphilosophie unterscheiden:

1. die moralische Auffassung des historischen Universums (Kant, Fichte),

2. lie ästhetisch-religiöse Auffassung (Schelling).

3. clie theoretische Auffassung (Hegel, Comte).

Disser Weg von der Erhebung des ethischen. ästhetischen, religiösen Wertes bis zur endgültigen Feier der theoretischen Erkenntnis als höchstes Gut des Lebens ist wohl zu verstehen, wenn man berlenkt, daB die Philosophie jener Zeit in ihrem leidenschaftlichen Erkemntnistrieb bei der Durchdringung der anderen Kulturgebicte sich anfangs sclbst vergessen hatte und erst später in der Reflexion auf ihre eigene Laistung zum Bewußtsein ihres Erkenntniswertes gekommen ist. Gewiß folgte auch jedesmal der Wertcharakter der Geschichtsphiksophic mit Notwendigkeit aus dem Charakter des Systems, das von den rerschiedenen Denkem vertreten wurle. Wir begimnen unsere Darstellung rieser großen Zeit mit der ethischen Geschichtsphilosophie.

\section{§1. Die othische Geschichtsphilosophie Kants.}

\section{a) Deutung des historischen Geschohens aus dom Bogriff dor Kúltur.}

In Kant labt der geschichtsphilosophische Gedanke der modernen Welt, nimlich eine Dentung des historischen Geschehens von dem Begriff der Kultur hro, zum erstenmal in klarer und entsehiedener Form anf ${ }^{1}$ ). Wine frühere Geschichtsphilosophie hat te tem irdischen Dasein nur geringen Wert beimessen kïmnen. Nach ihr konnte der Mensch froh sein, wenn er so bald wie möglich

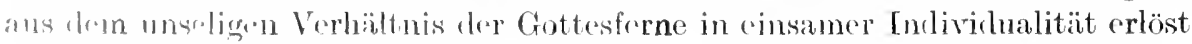

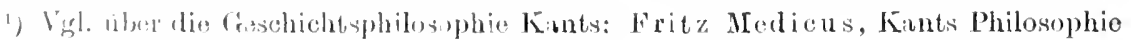
A.r Gesohirhte, Barlin 1902. 
und zu dem einheitlichen Weltgrunde zurückgeführt wurde. Unter der Dominante des religiösen Wertes wurde der Wert des Gesehehens in der Aufhebung des irdischen Daseins, nicht aber in dem Aufban der Kulturmacht und in der Durchdringung der Sinnensphäre mit geistigen Gütern erblickt. Indem num von $\mathrm{K}$ ant der sittliche Wert als der entseheidende gedacht wird, tritt die Wertung der Kulturleistung, des Handelns und des Tuns mächtig herror, der Gedanke der positiven Mitarbeit des großen Menschen an der göttlichen, sinmreichen Welt. Die Geschichte wurde gedentet von der Idee einer sittlichen Kultur aus. Die Kultur aber gipfelt nach $\mathbf{K}$ ant in dem Persönlichkeitsideal der Freiheit. Die Gewißheit der Freiheit und des Sollens hatte die praktische Philosophie ergeben. und die Teleologie der Urteilskraft hatte ein Reich der Zwecke aufgebaut. Wenn die Kritik der reinen Vernunft auf den theoretischen Menschen und sein Vorstelhungsleben, die praktische Vernunft auf den wertenden Menschen und sein Willensleben, die Urteilskraft auf den fühlenden Menschen. sofern er im Reich der Kunst und Natur Beurteilungen vollzieht, reflektiert hatte, so ergab sich für die Geschichtsphilosophie das Verhältnis des Naturmenschen und des Kulturmenschen als Ausgangspunkte der Úberlegung ${ }^{1}$ ). Indem num aber in der Geschichte ganz ähnlich wie im sittlichen Leben das Verhältnis ron Notwendigkeit und Freiheit, als das Verhältnis des ron seinen Trieben und Affekten geleiteten Menschen zu der freien und autonomen Persönlichkeit, vorzuliegen schien, wurde die Geschichte sogleieh unter den Gesichtspunkt der Moralität gestellt.

\section{b) Vollendung der moralischen Probleme in der Geschichtsphilosoplie.}

So ist die Geschiehtsphilosophie Kants auf das engste mit seiner Ethik verbunden, und seinem großen Torbilde entsprechend ist das nahe Verhältnis ron Ethik und Geschichtsphilosophie auch in der Folgezeit bis auf die Gegenwart noch vielfach behauptet worden. So etwa aueh in dem sinne, daß die ethischen Probleme in der Geschichtsphilosophie ihre Erfüllung finden. WVie die Idee der Gesellschaft und der Nation, sofern sie der sozialen Ethik angehört. dem rein formalen Sollen, das die autonome Persönlichkeit sieh zu eigen gemacht hat, einen Inhalt verleiht, der ihm Anweisung gibt über (las , Was". des Gesollten, so wächst wieder aus der Idee der Menschheit als leitendem Begriff der Geschichtsphilosophie der sozialen Ethik eine Inhaltlichkeit zu, die sich auf das ,Was" der Pfliehten bezieht, sofern sie für die Völker bestehen und gesetzt sind. Diese Vollendung der Ethik durch die Geschiehtsphilosophie liegt der Auffassung Kants noch rollkommen feru. Erst Hegel hat zu begründen unternommen, daß die Probleme der Ethik sich in der Gesehichtsphilosophie vollenden. Kant hat seinen geschiehtsphilosophischen Spekulationen nicht den Rang jener philosophischen Beweiskraft zugestehen wollen. die er für seine Kritiken in Ansprueh nimmt. Seine Geschiehtsphilosophie hat nur den Rang einer wissenschaftliehen Hypothese, tie mehr oder weniger unbeweisbar ist. Schließlieh kandelt es sich in der Geschichtsphilosophie doch nur um eine gut fundierte Meimming und Auffassung, und dort, wo ctwas gemeint wird, da ist es natürlich anch möglich und erlanbt, etwas anderes zu

$\left.{ }^{1}\right)$ Vgl. besonders: Idee zu einer allgemeinen Geschichte in weltbürgerlicher Absicht. 
meinen. In der Geschichtsphilosophie treten wir nach Kants Auffassung aus dem srstematischen Begründungszusammenhang der Philosophie heraus, und im Gebiet des Unsystematischen gibt es keine Gewißheit. Hier sind alle Formen des Denkens zu tief mit der Empirie verwoben und leisten einer reinlichen philosophischen Scheidung zu heftigen Widerstand. Die Kritik der reinen Vermunft hat es mit dem wohlgeordneten Erkenntnismaterial der Naturwissenschaft zu tun, die Geschichtsphilosophie dagegen mit dem ungegeordneten Material der Geschichte, die nicht als Wissenschaft im strengen simne aufgefaßt werden kam. Erst indem die philosophische Reflexion sich auf die Geschichte richtet. wird aus ihr etwas, was wissenschaftliche Bedentung besitzt, und zwar glaubte Kant durch das Prinzip der Urteilskraft als teleologisch reflektierender Betrachtung ein Prinzip zum Verständnis der Geschichte geowonnen zu haben. Wie das Kunstwerk aus dem Prinzip einer subjektiven Zweckmäßigkeit heraus verstanden werden soll, so läßt sich das Prinzip der objektiven Zweckmäßigkeit auf das Leben der Natur und Kultur anwenden. Wir sehen hier ganz deutlich, wie die doppelte Beziehung der Kantischen Gesehichtsphilosophie zur Ethik und zur Kunstphilosophie seinen Nachfolgern die Möglichkeit gestattete, den geschichtsphilosophischen Gedanken entweder im Anschluß an die Moralphilosophie (Fichte) oder im Anschluß an die Kunstphilosophie (Śchelling) zu vollenden.

Wenn wir übrigens auf den moralisehen Aspekt der Kantischen Geschichtsphilosophie hinweisen. so darf das nieht so verstanden werden, als ob Kant einer moralisicrenden Auffassung der Geschichte in einseitiger und engherziger Weise zugestimmt hätte. Der ethische Gesiehtspunkt, unter den Kant in seiner geschichtsphlosophischen Deutung dic Geschichte stellt, ist vielmehr so allgemein und so groß wie möglich. Er ist so sehr ans den innersten Tiefen seiner Philosophie hervorgewachsen, daß dic kleinen moralischen Richter des historischen Leleens, die Hegel in seiner Geschiehtsphilosophie so treffend gegeißelt hat, ror ihm verstammen müssen.

\section{c) Natur und Kullur.}

Der Ausgangspunkt der Ka $n$ tischen Gesehichtsphilosophie, die im Anschlu13 an Roussea usche Gedanken und doeh auch wieder im ent scheidenden Gegensatz zu ihnen sich gebildet hat, ist der Gegensatz ron Natur und Kultur. Am Anfang des historischen Geschehens hahen wir uns einen Naturzustand der Mensehen zn denken, fer in mancher Weise dem Rousseanseben Ideal entspricht. Iamals lebte der Menseh in vollkommenem Einklang mit der Natur, selber ein Tril von ihr. durch ihre Krifte unbedingt hestimmt, ihrer Gewalt sehut zlos preisgegeben, aher auch wiederum lichevoll vom ihr umsehlossen und durchdrungen. Inmals hatte der Mrnsch noch keine Sehärlen der Zivilisation zu erleiden, stark und gesumt. mit denstärmischen Gefahrender Elemente vertraut. Damals kinnte er moch krinc grolix. Freucke und keinen großen Sehmer\%. Die starken laidenschaften waren noch nicht arwacht. Er fährte ein regetatives Leben, nur ron loisen Willumgrn des Fendigen und Sohmerzlichen berïhrt. Mensch

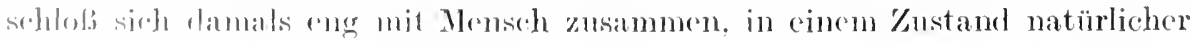

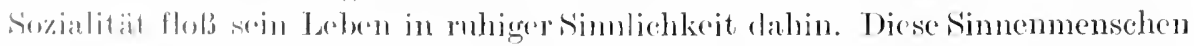

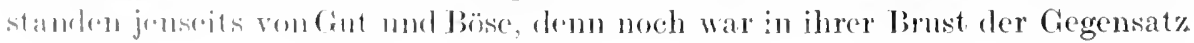


ron Pflicht und Neigung nicht zum Bewußtsein gelangt. Sie handelten instinktiv, dem Zuge ihrer simlichen Regingen folgend. Sie handelten im Banne der Gewohnheit und ihrer primitiven Sitten und Gebränche. Ihr Zustand war ein Zustand der Stabilität und Bewegungslosigkeit, denn noch war der Mensch von Tat und Listung weit entfernt. Nur um tie Bafrieligung seiner primitiven Bedürfnisse war er bemüht mel dachte noeb nicht dar.n. unvergängliche Werke und Tollendetes zu schaffen. Er führte ein bloßes Gegenwartsleben. kein Zukunftsdasein, von Träumen einer naiven [uschulel umsponnen. Damals gab es noch keine Geschichte, denn zur Geschichte gehört cin waches und ron Gegensätzen durchfurchtes Leben. Damals aber warein Tag wie der andere. Das Spätere hatte vor dem Frïheren nichts rorans. Alles rer'ief in cinem ruhigen Rhythmus der Wiederkehr.

Dieser idyllische und paradiesische Zustand der Menschheit, ohne Schöpfung und Leistming, das Glïck des ruhigen Sinnenlebens, muBte notwendig ein Ende erreichen, als der Mensch zu dem ersten schwachen Bewntsein der Freiheit erwachte, als er in sich den Gegensatz von Simncnwesen und Vermuftwesen empfand, als neben dem Instinkt tie Reflexion sich geltend machte, und der Mensch immer mehr zu der Gewißheit gelangte, daß ihm nicht alles erlaubt sei. was ihm gefiel. Damals, als er zuerst ten Gott in scinem Innern rerspiirte und das Sittengesetz in seiner herben Majestät ihm ror Angen trat; damals hatte der Frieden seines tränmerischen Daseins ein Ende, das historische Leben. die Geschichte der Menschheit begann. Demn das Sollen trieb den Mensehen zur Tat, es stellte Forilerungen an ihn, die er erfüllen mußte. Nun gehörte er nicht mehr sich und dem friedlichen Kreise einer primitiven Gemeinschaft an. Jetzt mußte er dem Rufe Gottes folgen. der zu ihm gedrungen war. Tond indem er nummehr begam, im Kreise der Pflicht und des Sollens zu handeln, und den Anforderungen zu entsprechen suchte. die an ihn gestellt wurden, la begann er anch das Große zu tun und Dinge zu rerrichten, die der Aufbewahrung und Erzählung wert waren. Die Leistungen aher. die der Mensch rollzog. bezogen sich auf eine Ungestaltung des bloß natürlichen Daseins, anf die Schaffung eines höheren Lebens. Staatenbildung und Gesetzgehung unl Orhnung. Recht und milde Sitten waren das Result at und der Erfolg des großen menschlichen Tuns. Das Große aber, das geleistet war, wirkte als Vorbild weiter. und das ruhmvolle An lenken der Heroen lchte in dem Herzen einer liebenden Nachwelt fort.

\section{d) Die Bedentung der Leidenschaften.}

Doch nicht nur das Sollen allein führte den Menschen zur wertrollen Leistung hin, sondern auch das andere. was nummehr im Gegensatz zum Sollen groß und mächtig wurde, die menschlichen Leidenschaften: Ehrgeiz, Liebe und Ruhmsucht, die bisher nur in schwachen Andentungen unt auf kleine Zicle gerichtet im Menschen wirksam waren. Durch die Erkenntnis des Sollens und dureh das Bewußtsein der Freiheit wurde nummehr der brütende Instinkt und die kleine Neigung zu großer Leidenschaft entflammt. Und so standen einander zwei große Mächte gegenüber: die ideelle Macht der Idee, die ihre schweren Forderungen an den Mensehen richtete und bedingungslose Hingabe son ihm verlangte, und die große Macht der Leidenschaft, die sich anf große Ziele persönlicher Wrunscherfüllung richtet, jene Leidenschaft, in der die Natur ihre 
höchste Steigerung und Vollendung fand, und die zugleich darauf gerichtet war, die ursprünglich gegebene Natur zu zerstören. Diese Leidenschaft kämpfte rielfach gegen das Sollen und führte dadurch zur höchsten Spannung in der Natur der großen historischen Persönlichkeiten, manchmal aber auch stellte sich die große Leidenschaft in den Dienst der Idee.

\section{e) Bedeutung des Gegensatzes.}

Wir sehen hier die außerordentlich fruchtbare und folgenreiche Anwendung, die Kant von dem Problem der Ethik her auf die Geschichte gemacht hat. Im Sinne der Kantischen Philosophie liegt das Wesen des sittlichen Lebens in dem Gegensatz von Pflicht und Neigung, von moralischem Trieb und Sinnentrieb, ron Sollen und Sein. Solange dieser Gegensatz nicht hervorgetreten ist, solange ist auch noch kein sittliches Leben vorhanden; wenn aber dieser Gegensatz wieder überwunden ist, dam ist aneh die Menschheit am Ziele, bezw. ist die Menschheit dann über sich hinausgegangen, denn die absolute Harmonie ron Pflicht und Neigung gehört dem göttlichen Willen an. Auf dem Verhältnis von Pflicht und Neigung als dem von Idee und Leidenschaft baut sich auch das historische Leben auf. Nur besteht eine Verschiedenheit der Beurteilung in der moralischen und historischen Auffassung. Vom Standpunkt der Ethik aus müssen die Leidenschaften ganz unbedingt niedergedrückt und niedergezwungen werden, damit das moralische Gesetz in seiner Reinheit sich durchsetzen kann. Nur dort kamn in moralischem Sinne von einer Persönlichkeit, ron einem Charakter gesprochen werden, wo die Idee der Pflicht den reinen Willen bestimmt. In historischen Leben sieht es anders aus. Hier treten die Leidenschaften der Erfüllung des Wertvollen nieht immer hemmend entgegen, wie das für den sittlichen Beurteiler der Fall sein muß. Vielmehr dienen die Leidenschaften hier der Erreichung des wertrollen Zieles. Ihr Sinn und ihre Bedeutung wird erst in der Gerchichte kund. Sie sind das e'gentliche Agens des historischen Geschehens.

\section{i) Der historisehe Sündenfall.}

Wollen wir die Geschichte verstehen, so müssen wir sie auffassen als einen Bruch mit der Natur, als einen Sündenfall. Von demPrinzip der Dualität ergriffen, hat der Mensch die naive Einheit scines ursprünglichen Lebens preisgegeben. bas war gleichbedeutend mit einem Verzicht auf das reine Glück des Sinnenwesens. Dieses Glüek zerstört die Kultur. Wenn wir unter Glück die Freuden eines ruhigen Sinnenlebens verstehen und dieses Glück unter allen Umständen crstreben, dann müssen wir allerdings auf die Kultur verzichten. Aber in dem Glïck des Sinnenwesens kann auch die Aufgabe und der Zweck der Menschheit ummöglich beschlossen sein. Ein Verzicht auf die Freuden des animalischen Lathens wird unbedingt gefordert. Der Mensch soll ein Opfer bringen, um das Girofire zu vollenden.

\section{¿) Jas Zice des historisehen Geschehens.}

Was ist mun aber das Ziel, dem soviel (O)fer und Verzicht auf Eigenglück gelejistet werdensoll. nund dem die Mlitted der Leidenselalften zutreiben? Das Ziel 
der Geschichte kann nicht in der Gegenwart liegen, noch hat die Tergangenheit schon das Ziel besessen. Das Ziel rollendet sich in ferner Zukunft. Auch rollendet sich das Ziel nicht in jedem einzelnen, aber die Gattung bringt das Tollendete hervor. Vieles muß verloren und zugrunde gehen, damit die Geschichte ihr Ziel erreicht. Tom Standpunkt des einzelnen Menschen oder auch rom Standpunkt einzelner Nationen aus können wir mit der Geschichte keinen Sinn rerbinden. Denn wie die einzelnen Menschen, so werden und rergehen auch die Völker und Staatengebilde. Sie schreiten vor, aber sie schreiten ihrem Untergang entgegen. Die Idee des Fortschritts kann nur mit der Idee der Menschheit verbunden werden. Wenn auch die einzelnen Völker zugrunde gehen, die Menschheit als Ganzes schreitet fort. So ist all unser Tum und Leisten ein vorbereitendes Tun. Wir selber sollen wie das Tolk Israel in der Wüste das gelobte Land nicht sehen, aber unseren späten Nachkommen wird es beschieden sein. So wird in der Tat ein großes Opfer von uns verlangt, sofern wir gänzlich auf das Vorläufige beschränkt sind. Aber wenigstens ist uns der Trost gegeben, daß wir nicht umsonst gelebt, sofern wir liünftigen Geschlechtern rorgearbeitet haben. Wir sollen ein Gebäude aufrichten mit emsigem Fleiß, und das Werk ist so groß, daß wir nur die ersten Crundsteine mit Aufbietung unserer besten Kraft zu setzen rermögen. Wir werden nicht die stolz gekrönten Zinnen erblicken. Langsam reift das Menschheitswerk. Doch können wir versichert sein, daß unsere gute Arbeit nicht rergeblich war. Wir sollen der Welt die Richtung zum Guten geben, so hatte schon Lessing gelehrt. dann können wir zuversichtlich hoffen, daß der rubige Strom der Entwicklung die Erfüllung bringen wird.

Das wahre Ziel des Menschengeschlechts kann aber nach Kant nur in der Entfaltung des persönlichen Lebens liegen. Die Menschen der Gegenwart sind so beschaffen, daß sie noch zu keiner wahrhaften Freiheit gelangt sind. In ihrem Tun und Handeln sowie in ihrem ganzen Gesinnungsleben sind sie heteronom bestimmt, denn sie folgen äußeren Geboten und Rïcksichten und den weichen Gefühlen der Sympathie, der Liebe und des Mitleids, nicht aber dem inneren Gott, der in ihnen wohnt. und dem stolzen Geboteder Pflieht. Sie wissen eben nicht, daß das, was sie rielleicht manchmal als lästigen Zwang empfinden, der Zwang ihres eigensten Tesens ist. Demn das, was sie stark und selbständig und nuabhängig ron der Welt macht, das ist mit der Natur des Sollens auf das engste rerbunden. In Kampfe mit dem Despotismus. jencr Form des Staates, da dieser noch als blinde Naturmacht erscheint, hat sich der Mensch allmählich zu freieren Formen des bürgerlichen und politischen Lebens durchgerungen. Aber noch mangelt es ihm an jener Freiheit, die mns erst zu wahren Herren des Lebens macht und ganz allein auf uns selbst stellt, jener Freiheit, durch die wir uns selber das Gesetz des Lebens gegeben, die Autonomie der sittlichen Freiheit. Wohl mögen im einzelnen schon Taten der Freiheit geschehen, aber eine freie Tat macht noch kinen freien Nenschen. und bei weitaus den meisten Menschen ist das Sittengesetz noch nicht zum Durchbruch gelangt. Der Mensch ist ein freies Wesen, sofern er die Möglichkeit besitzt, dem Gebot des Sollens Folge zu leisten, noch aber fehlt viel daran, daß alle Menschen die Idee des Sollens bejahen und sich ron ihm in ihrer Gesinnungsweise und ihren Handlungen bestimmen Iassen. Daß nun eine spätere Menschheit 
in allen ihren Teilen das Sittengesetz in sich realisiert, das ist ein Ziel, auf das die Menschheitsentwicklung hinzuarbeiten scheint. Die Menschen sollen sich durch eigene Tat zu freien Wesen bilden. Nicht der Affekt, sondern das stolze und ruhige Gebot der Pflicht soll sie in all ihrem Tun und Leisten leiten und führen. Die Affekte mußten einmal hervorbrechen, um den Menschen aus seinem gleichgiiltigen und indifferenten Leben zu erwecken. Losbrechend im Widerstreit mit dem Sollen, haben sie die Menschheit weitergeführt. Die Leidenschaften in ihrer ungezügelten Stärke tragen diestarke Bewegung in das historische Geschehen, und insofern sind sie cin Mittel zur Erreichung des Wertrollen, zur Hervorbringung eines Reiches freier Persönlichkeiten. Aber in diesem Reiche selber darf daun die Leidenschaft nicht mehr die Herrschaft führen. Sie muß cin für allemal in den Dienst der menschlichen Vernunft treten. Sie mußte sich so gewaltig entfalten, um in einem Größeren unterzugehen.

Das Reich freier Persönlichkeiten ist cine ideelle Gemeinschaft, die mit staatlicher Organisation nichts zu tun hat. Wie müssen wir uns nun den politiseh-sozialen Kulturzustand der Menschheit denken, die zu einer so hohen Stufe sittlicher Reife gelangt ist? Die äuBere Ordnung der Menschheit, welche Vorbedingung für ein wertrolles Personenleben bildet, ist die weltbürgerliche Gesellschaft. Die weltbürgerliche Gesellschaft, wie Kant sie meint, bedentet die Moralisierung des staatlichen Lebens. Unsere politische Organisation ist vorläufig so beschaffen, daß die Idee des Kulturstaates, die den Menschen zum Bewubtsein gekommen ist. nur im Innern eines Staatsverbandes zur Anwendung gelangt und mehr oder weniger erfolgreich durehgeführt wird. Dagegen befinden sich die Staaten untereinander noch im Naturzustande. Wohl gibt es ein Recht der Völker, aber meist mehr der Idee als der Wirklichkeit nach. Denn nur ron den vorgeschrittenen Nationen wird (s) anerkannt, und es handelt sich $u m$ eine Bindung, die leicht wieder abgestreift werden kann. Die Nationen können straflos gegen das Völkerreeht rerstoßen. denn es gibt keine Instanz, die den Bruch des Rechtes rerhindern oder verfolgen könnte. Es steht rollkommen im Belieben der Völker, das bindende und verpflichtende Verhältnis den anderen Staaten gegenüber jederzeit aufzugeben und zu kündigen. Damn bricht der Naturzustand wieder zwischen den Völkern aus, und jeder hat die Vollmacht, den andern zu töten und zu vergewaltigen. Solange diese Sitten bestchen, ist auch kein freies Persönlichkeitsleben möglich, denn der Barbarismus des Krieges widerspricht der Idee des sittengessetzes. Damit das Reich der freien Persönlichkeiten werde, ist es notwendig, immer mod überall auch die andere Volksindividualitat als Persönlichkeit anzurerkennen. Diesen Zustand wirk die weltbïrgerliche Verfassung herbeifïhren, welche die Vöhkex der Welt zu riner Gemeinsehaft zusammenschlicßBt und aino Instanz begrïndet, anen (ierichtshof der Nationen, von dem Jas liecht ansgeht, und ror den die Schuldigen geladen werden, um Strafe

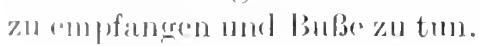

Das licich der P'ersönlichkeiten und die weltbürgerliche Verfassung als Vittal, as hurbeizuführen, sind regulative Ideen des historischen Geschehens. Sire sinel lirinc motaphysischen Wirklichliciten, wohl aber Prinzipien, die fïr

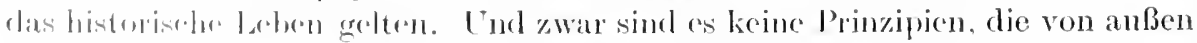
her an bas historischr. Loben herangetragen wären, sondern solehe, die ibm 
selbst entnommen sind, und die auch ganz allein imstande sind, es deutlich und verständlich zu machen. Diese regulativen Ideen sind Richtpunkte des historischen Lebens. Ton ihnen aus wird es verstanden, von ihnen aus verstehen wir die Gliederung des Geschehens.

\section{\$2. Die ethisch orientierte Geschichtsphilosophie Fichtes.}

Der Endzweck des historischen Geschehens, wie ihn die Gesehichtsphilosophie Kants denkt, verbindet sich unmittelbar mit der Idee der Persönlichkeit, und die Ordnung des politischen und sozialen Lebens erscheint nur als Mittel ihrer Herrlichkeit. Fichte ist es gewesen, welcher die Vermunft zuerst über die Persönlichkeit hinaus in allen Kulturverhältnissen aufsuchte und den Reichtum ihrer Ziele feststellte. Er betont nicht nur das wertvolle Persönlich keitsleben, sondern anch das wertrolle Gemeinschaftsleben. Er geht ren Beziehungen der großen Persönhichkeiten zu den verschiedenen Kulturgütern nach, während Kant lediglich auf die sittliehe Kultur reflektiert hat ${ }^{1}$ ).

Dennoch bleibt auch bei Fichte der sittliche Wert als der leitende be. stehen, ganz entsprechend dem Primat der sittlichen Vermunt, wie er ihn in seinem System der Philosophie vertrat. Nur zeitweilig tritt die Betonung des sittlichen Lebens hinter der Idee der Religion zurïck. Denn die Geschichte ist philosophisch verstanden auch für Fichte die Geschichte der Freiheit.

\section{a) Geschichte und Geschichtsphilosophie.}

Nach Fich te ist die eigentlich wissenschaftliche Behandlung der historischen Ereignisse nur die philosophische. Die Tätigkeit des Chronisten, der die Begebenheiten aufzeichnet und berichtet, leistet noch keine eigentlich wissenschaft liche Arbeit, sondern gibt nur das Material dafür her. Die wissenschaftliche Leistung muß darin gesucht werden, daß der Philosoph den Zusammenhang zwischen den Ereignissen herstellt. Der Philosoph sucht das historische Geschehen aus der Idee eines Wertzusammenhanges zu verstehen. Die Grundvoraussetzung hierfür ist. daß Vernunft und Simn in den historischen Begebenheiten anzutreffen ist.

\section{b) Vernunftereiheit als Endzweek.}

Die Vermunft ist die Macht des Geistes, welche die historischen Geschehnisse hervortreibt und wandelt. Diese Vermunft des historischen Cniversums zielt auf einen Endzweck ab, der dem philosophischen Denken auch unabhängig von der Kenntnis der historischen Fakten klar und deutlich ist. Der Endzweck des historischen Geschehens kann in nichts anderem gesucht werden, als darin, daß die Menschheit alle Verhältnisse mit Freiheit nach der Vernunft einrichtet. Menschheit, Freiheit und Vernunft sind apriorische Voraussetzungen der Geschichte. In ihnen ist alles Wesentliehe beschlossen. Vernunft und Freiheit sind Grundbegriffe des idealistischen Systems. das Fichte in seiner Wissen-

1) Von Fichtes Schriften kommen hier besonders in Betracht: Grundzüge des gegenwärtigen Zitalters, 1806; Über das Wesen des Gelehrten, 1805. 
schaftslehre ent wickelt hat. Das System der Vernunft, wie er es dort konstruierte, ergab sich als ein System der Freiheit. Die fortschreitende Menschheit ist der neue Gegenstand der geschichtsphilosophisehen Spekulation, die das Leben der Vernunft untersucht, sofern es sich in der Zeit darstellt. Die Vermunft soll in den menschlichen Verhältnissen zur Herrschaft gelangen, alles soll nach ihr geordnet sein.

\section{c) Ursprung der Menschheit.}

Damit das soziale Leben der Menschheit nach der Vernunft geordnet werde, muß sie ein Wissen von der Vermunft besitzen. Sie muß zum Bewußtsein der Freiheit gelangt sein. Das setzt voraus, daß die Menschheit ursprünglich noch kein Wissen von der Vernunft besaß und deswegen auch ihre Verhältnisse der Natur der Vernunft nicht entsprachen. Es mußte auch etwas angenommen werden, das der Natur der Vernunft widerstrebt, ein Vernunftloses, Irrationales, ein bloß Gegebenes, ein bloß Naturhaftes, Simnliches, ron Vernunft und Sinn noch nicht Durchdrungenes, die Materie des historischen Lebens. Anderseits aber muß für die geschichtsphilosophische Úberlegung die Vernunft immer dagewesen sein. Ist das aber der Fall, so war sie ursprünglich latent rorhanden und noch nicht wirksam. Desgleichen hatte die Menschheit noch kein Wissen ron ihr. Anfang und Ende des historischen Lebens stellt sich uns also als dieser Gegensatz dar: am Anfang ein Zustand der bewegungslosen Vernunft und gleichzeitig ein Nichtwissen von der Vernunft, daneben das Dasein des bloß Naturhaften, des Irrationalen. Da die Ternunft num damals schon vorhanden war, ohne gewußt und verstanden zu sein, ohne Selbstbewußsein und ohne Freiheit, so kann man das Zeitalter der unbewußten Vernunft auch als das Zeitalter des Vernunftinstinktes bezeichnen.

Denn das bewuBtlos Tätige ist das Instinktive. Zum Wesen der Vernunft gehört die Bewußtheit. Ist die Vernunft aber selber noch nicht reflektiert, so ist sic gleichsam im Naturzustande. Und diese Vernunft mit Naturcharakter bezeichnct Fichte als Vernunftinstinkt. Wir müssen also unterscheiden zwischen einem Naturhaften, Instinktiven, das jeglichen Wertes entbehrt, und einem Instinkt der Vernunft, in dem das Werthafte noch schlummert und unbewußt waltet.

\section{d) Die fünf Stadien.}

DicWeltgesehichte begimt mit dem Zeitalter des Vernunftinstinktes und endet mit dem Zeitalter der Vernunftreiheit. Wenn nun aber der Vermunftisstinkt ursprünglich die Menschen boherscht und geleitet hat, und wir an Ziel des historischen Lelens cine von Prinzip der Freiheit geleitete Menschheit erblieken, so mub einmal eine Zeit gewesen sein, da sich die Mensehheit vom V'rmunftinstinlst emanzipierte, ohne jerloch schon zum vollen Bewußt-

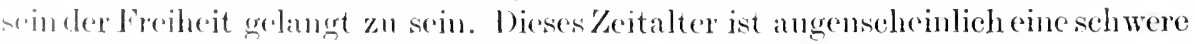

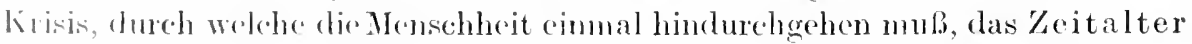

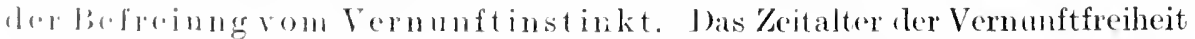
yliedert sich mon seinerseits wirder ganz deutlieh in zwei Periolen. Wird das Kirel dre nensehlicheon Entwicklumg darin geschen, dals alle mensehlichen

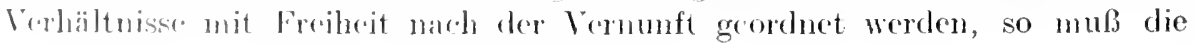


Menschheit, beror sie die Verhältnisse mit Freiheit ordnet. zumächst erst einmal zur Einsicht in die Natur der Ternunft gelangt sein. Fichte unterscheidet daher zwischen einem Zeitalter der Vernunftwissenschaft, da die Menschheit die Bekanntschaft mit den Vernunftideen machte. und einem Zeit alter der Vernunftkunst, da sie alle Verhältnisse nach dieser Einsicht gestaltet und bildet. Für den ersten Zustand der Menschheit aber besteht noch das Problem, wie demn die Menschen eigentlich dazu gekommen sind. den Vernunftszustand des Instinktes aufzugeben und sich dem Vernunftwissen zuzuwenden. Denn dás Zeitalter der umbewußten Ternunft ist im all gemeinen ein glückliches Zeitalter für die Menschen, die rom Vernunftinstinkt sanft geführt und geleitet werden und die schweren Gegensätze des Lebens noch nicht kemnen. Hier läßt sich nun aber ein Tnterschied feststellen. Solange der Vernunftinstinkt gleichmäßig verteilt in den Menschen tätig ist, so lange führt er sie zu innigster Gemeinschaft zusammen und wird als schön und beglückend empfunden. Nun wird es aber geschehen, daß diese gleichmäßigc Verteilung nicht mehr bestehen bleibt, sondern daß der Vermunftinstinkt in einzelnen Individuen besonders mächtig wird. Dam fordert die unbewußte Ternunft, sofern sie in einzelnen großen Individuen sich darstellt, Bengung und Unterwerfung. Das ist das Zeitalter der Vernunftautorität, in dem die Menschheit allmählich ihre Liebe zum Termunftinstinkt verliert und ihn in den großen autoritativen Individuen hassen lernt. So gilst es also fünf rerschiedene Zeitalter der Menschheit, nämlich das des Vernunftinstinktes, der Vernunftautorität, der Befreiung von der Vernunft, der Vernunftwissenschaft und der Vernunftkunst. Das erste Zeitalter ist ein Zeitalter kindlicher Unschuld und Naivität, ein natürlicher Altruismus führt hier zum innigsten Gemeinschaftswesen. Im zweiten Zeitalter bäumt sich der Egoismus in einzelnen Individuen auf und zerstört die Bande frommer Gemeinschaft. Als Antorität stellt er sich den anderen feindlich drohend entgegen. Das ist das Zeitaltel der beginnenden Sünclhaftigkeit. Wenn aber die unterdrückte Masse gegen den Vernunftinstinkt streitet, sofern sie ihn als Last und Bedrückung empfindet, und der Kampf gegen die Vernunftautorität schließlich zu einem Kampf gegen alle Vernunft und Ordnung führt, und die siegreiche Unvernunft rorübergehend zu einem vernunftlosen Zustand hinleitet, so muB man ein solches Zeitalter das Zeitalter der vollendeten Sündhaftiglieit nenner, weil es in seiner Entfremdung von der Vernunft alles Göttliche vergaß. Wagegen ist das Zeitalter der Vernunftwissenschaft, in dem die Menschheit bckannt wird mit den großen Vernunftideen das Zeitalter der anhebenden Pechtfertigune. Und schließlich muß das Zeitalter der Vernunftkmst, da die Vernunft wieder das ganze Leben und alle Terhältnisse der Menschen durchdringt, und zwar als wissende, sich selbst verstehende Ternunft, als das Zeitalter der roll. endeten Rechtfertigung bezeichnet werden.

\section{e) Der rationale und der irrationale Gescliehensfaktor.}

Betrachten wir zuenst den Anfangszustand der Menschheit, wie er sich aus der Idee des Zieles er gibt. Damals ist die Vernunft noch nicht zum Bewußtsein ihrer selbst gekommen. Sie waltet als Instinkt. Die Tennunft ist da im 
Naturzustande. im Zustande der Unbewußtheit. Daneben ist aber auch ein anderes rorhanden, das keinen Anteil an der Vernunft hat, das Irrationale, das dem vernünftigen Leben entgegensteht. Diese beiden Faktoren verteilen sich nach Fichtes Theorie auf zwei verschiedenartige Gestalten des Völkerlebens. Wir haben uns am Anfang des historisehen Geschehens ein auserwähltes Volk zu denken, in dem die Vermunft als Instinkt heimisch war. In diesem Volke ist das Zentrum aller Kultur zu suchen. Die anderen Völker entbehren des vernünftigen Lebens. Wohl ist die Anlage zur Vermunft in ihnen vorhanden. Aber dieseVernunftanlage als solehe erzengt noch keine Form des sozialen Lebens. Das Volk, das sich im Besitz des Vermunftinstinkts befindet und von ihm geleitet wird, bezeichnet Fichte als das Normalvolk. Der Zustand dieses Volkes fällt so ziemlich mit dem Wertbegriff der Natur zusammen, wie ihn Rousseau aufgestellt hat. Sein Zustand ist sehon ein Kulturzustand, wenn man unter Kultur alles wert volle und gepflegte Leben versteht. Aber dem Nomalvolk fehlt noch die Einsicht in die Natur des Guten und Wahren. Absichtslos und ohne es zu wollen, führt as ein sittlich wertrolles Dasein. Ton den sympathischen Instinkten der Liebe und des Altruismus ist es geleitet, aus denen alle sittliche Kultur emporwächst. Das Normalvolk ist aber noch kulturlos, wenn man unter Kultur die großen bewußten Formen des sozialen Lebens wie Staat und Recht und Freiheit sowie anch die Güter der Wissenschaft und Kunst versteht. Das Normalvolk ist durch Bande der natïrliehen Sozialität, der Sympathie, Terwandtschaft und Liebe verbunden. In diesen innigen Bezichungen des Altruismus, der noch keinen Gegensatz und keine Feindschaft kennt, liegt das Gilück dieses Volkes, das eine fromme und gläubige Tradition unter dem Bilde des Paradieses aufbewahrt hat. Alle Möglichkeit großer Kulturgestaltung ist in dieser auserlesenen Menschheit beschlossen.

Diesem paradiesischen Naturzustande gegenüber befanden sich die anderen Tölker in ciner durchans kulturlosen Verfassung. Wild und einsam schweiften sie durch die Wïlder dahin, von dem Prinzip des Egoismus und des Hasses anscinandergetrieben, so daß keinerlei wertrolles Gemeinsehaftsleben sich bilden konnte. Mit dem Normalrolk teilen sie das Schicksal der Bewegungslonigkeit und Geschichtslosigkeit, den Zustand eines immer gleiehmäßigen und sich nicht woiterbildenden Dascins, bis dann durch ein Ereignis, dessen ("harakter und Ursache sich in einzelnen der wissensehaftlichen Erforschung entzieht, cinc Vermischmng des beiden Völkertypen eintrat, indem das Nomalrolk auscinandergerissen mol ïber die Sitze der Unkultm zerstrent wurde. Mit diesen Ereignis beginnt die Weltgeschichte.

Nummehr mischen sich Form und Stoff Ior Mensehheit, und das Kulturl.len nimmt seinen Anfang. Dio Söhne des Normalvolks erscheinen bei den wiklen Natmriblken, die keine Ordnmeng und Sitte kennen als die weit äberlogenen Grister. Sie sehen, daß jene in einem unwördigen Zustande leben, und selfort machen sice sich ans Werk. Sie geben Recht und Gesetz, sehaffen gute

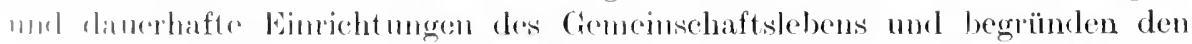

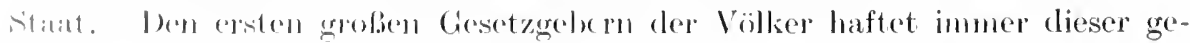

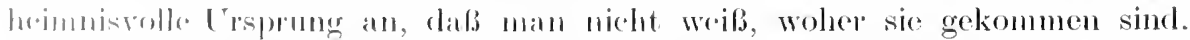

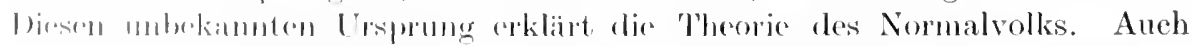

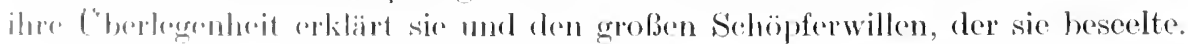


Derm die Kinder der Vernunft fanden Verhältnisse ror, die ihnen unleidlich erscheinen mußten, da sie mit so ganz anderen Formen des Daseins vertraut waren. Und so schufen sie Kultur. Das Bild jener Frendlinge aber, deren Kom men und Gehen etwas Geheimnisvolles hatte, wurde von den dankbaren Nachkommen zu den Göttern erhoben. Die wache Vernunft der Kinder des Normalvolkes ließ auch in den wilden Naturkindern die vernünftige Anlage zur Entfaltung kommen. Lichtträger waren sie, wie es Prom ctheus gewesen.

\section{f) Der Sïndenfall der Geschichte.}

Solange nun der Vernunftinstinkt der geschaffenen Ordnung gemäß das Völkerleben still und friedlich regierte, solange wurde er geliebt und seine Herrschaft als ein Segen empfunden. Solange die Wohltaten der Verumft allen zugute kamen, fühlten sich die Völker frei und glücklieh. Aber es kam eine Zeit, da große und mächtige Naturen die Segnungen und Wohltaten der Vernunft für sich in Anspruch nahmen. In ihnen war der Ternunftinstinkt so mächtig geworden, daß sie ihren Mitmenschen gegenüber sich weit überlegen fühlten. Und ebenso wurden sie ron ihren Mitmenschen als die weitaus überlegenen empfunden. Die Stärke des Vermunftinstinktes, der ihnen gegeben war, machte sie zu Autoritäten. Solange nun die Autoritäten die Macht, die ihnen gegeben war, in den Dienst der anderen stellten, solange waren sie Wohltäter des Menschengeschlechts. Aber es konnte nieht ausbleiben, daß Selbstsucht und Ehrgeiz herrorbrach, als sie die Kluft bemerkten und empfanden. die sie ron jenen anderen trennte. Cnd damn nahmen sie alle Rechte für sieh und zwängten die Tölker in den Sklavendienst.

Dieses Zeitalter der Autorität umfaßt nach der Auffassung Fichtes das Altertum und das Mittelalter. Fs umfaßt Gestaltungen ron verschiedenstem Wertcharakter. Wohl mochten im Zeitalter der Autorität sehon rereinzelte Denker zum Zustand der Vernunftwissenschaft rorgedrungen sein, aber die Masse der Menschen blieb in Vernunftinstinkt befangen. In bezug auf das politische Leben hat dieses Zeitalter die so ungleichwertigen Formen des Despotismus und des Kulturstaates hervorgebracht. Es erzeugte die großen asiatischen Dynastien, in denen das Recht ron der Willkür des Herrschers abhing. Es erzengte aber auch die griechischen Staatenbildungen, in denen das gleiche Recht für alle geschaffen wurde. Nach Fichtes Auffassung wird sich der Kulturstaat darin vollenden, daß nicht nur das gleiche Recht für alle gilt. sondern da $B$ auch allen gleiche Rechte eingeräumt werden. Diese gleiehen Rechte können sich allerdings nur auf das bïrgerliche Leben, nicht anf das politische Leben beziehen. Ferner ist dies ganze Zeitalter eharakterisiert durch seinc universalhistorischen Tendenzen, wie sie in der Idee der Weltmonarchien und in der Idee der einen katholisehen Kirehe zum Ausdruck kommen.

Gegen die großen Autoritäten auf politischen und kirehlichen Gebiet hat sich das Zeitalter der vollendeten Sündhaftigkeit empört, das gegen die Herrschaft des Vernunftinstinktes sich auflehnte. Es griff zu den Waffen der Kritik und wandte sich zuerst in berechtigter Weise gegen manche Schäden des sozialen Lebens. Aber das Zeitalter begnügte sich nicht. an Eimriehtungen und Ordnumgen zu rütteln, an denen gewiß in Laufe der Zeiten manches alt und rerbesserungsbedürftig geworden war. Statt zu reformicren, verfiel 
man sehließlich darauf, der ganzen Tradition den Krieg zu erklären und alles das zu bekämpfen, was alt und verehrungswürdig erseheinen solltc. Von blindem Haß gegen die Tergangenheit erfüllt, wollte man die IVeltgeschichte von neuem anfangen. Man wollte etwas sehaffen und leisten, was noch nie gewesen war. und ersehöpfte das Denken mit den kühnsten und fabelhaftesten Utopien. Die Kritik begnügte sich nicht damit, die Unzulänglichkeit des politisehsozialen Lebens naehzuweisen, sie wandte sich auch gegen Peligion und Moralität und gelangte zu dem Resultat, daß anf diesen Gebiet ein Allgemeingültiges überhaupt nicht zu finden sei. Schließlich stellte die maßlose Kritik der Zeit auch die Gültigkeit des theoretischen Denkens in Frage und zerstörte damit das Fundament seiner eigenen Behauptungen. So sagto sieh das Zeitalter überhaupt ron der Vernunt los, die nur in der Idee eines Allgemeingültigen gesucht werden kann. An die Stelle der Vernunft trat der sogenannte gesunde Menschenverstand in seiner Borniertheit und Leerheit und anderseits eine phantastischeSchwärmerei. Denn nachdem der kahleVerstand demMenschen alle Werte und Ideen genommen hatte, jene alten liostbaren Güter, von denen er durch die Jahrtansende hindurch gelebt, snehte phantastische Schwärmerei und Leidenschaft eine nene Lebenswolt aufzubanen. Dieses Zeitalter ist das der Aufklärung, welehes sieh erhaben dünkte über alle früheren Zeiten. Jedes Individuum glaubte damals so riel Fähigkeit zu besitzen, daß es über alle Dinge richten und alle Verhältnisse beurteilen könnte. So groß die Gelehrsamkeit dieses Zeitalters war, so groß war aneh die Leere seines Geistes und Herzens. da es kein Verhältnis zu dem Ubersimnlichen und den Ideen besaß.

Das Zeitalter der rollendeten Sündhaftiglseit ist notwendig ein Zeitaltel schwerer Krisen und Revolutionen; denn es handelt sich um einen großen I'hergang, dren die Menschheit in Verlauf ihrer Fntwicklung eimmal vollziehen mußte. Die Mcnsich heit mußte einnal den V'ernunftinstinkt opfern und aufgeben und sich der bewußten Ternunft zuwenden. Einmal mußte das gesehehen. Tnd Fichte hat das Zeitalter, in clen er lebte, so gedeutet, daß es an der Firenze liege zwischen den Zeitalter der Befreinng ron Vernunftinstinkt und dem '/eitalter der beginnenden Rechtfertignng oder der Vernunftwissenschaft. So hat er die eigene große Zeit, die Zeit des deutschen Idealismus und der liomantik, als die Zeit eines gewaltigen Úberganges verstanden, in der ain unerhört Nones sieh $711 \mathrm{~m}$ erstemmal der Nenschheit offenbarte.

\section{g) Der Aubau einer neuen Geisteskultur.}

In Zoitalter der Tromunftwissensehaft gelangt die Vernunft zur Erliementnis ihrer selfst, oder, was dasselbe bedentet, die Menschheit gelangt zum

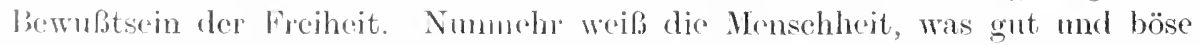

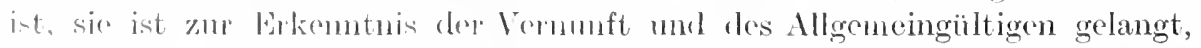
jotzt ist sio in den Kustand dor Roifo oingetreton. Nieht mehr folgt sie blind

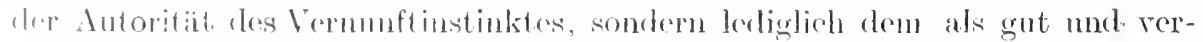

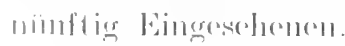

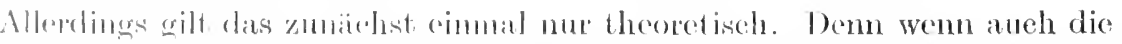

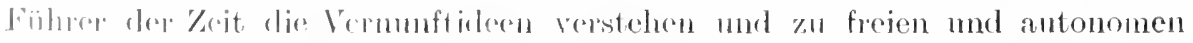

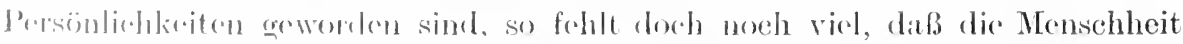

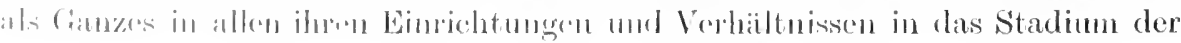


bewußten Vernünftigkeit eingetreten sei. Vielleicht wird im Zeitalter der Vernunftwissenschaft, dem die große Offenbarung zuteil geworden ist, der Gegensatz am schärfsten hervortreten zwischen der Größe der Vernunft und der Kleinheit und Trübheit, der Dumpfheit und Enge der gegebenen Verhält nisse. Die Unvernunft des bloßen Daseins und die Größe des geschauten Ideals muß mit Notwendigkeit eine gewaltige Spamnung erzengen, und so wird die Geschichte ein mächtiges Leben durchfluten und die Menschheit zu den größten Taten hingerissen werden.

Das Zeitalter, in dem sich dann die Umwandlung dər gegebenen Verhältnisse im Simne der Vermunftideen rollzieht, ist das Zeitalter der Vermunftsunst. In diesem Zeitalter wird das Irrationale rollkommen ron Sinn und Geist durchdrungen. Die Menschheit kämpft ihren schwersten Kampf, indem sie das als gut und recht Erschaute nun auch im Sinne der Termunft zur Darstellung und Wirklichkeit bringt. Mit diesem Zeitalter erreicht die Geschichte ihr Ziel. Die Sinnenwelt ist vom Geiste durchdrungen, von dem einen göttlichen Leben erfüllt. Alle Hemmungen und Schranken sind fortgefallen: und in freier Schönheit ist die Menschheit zu dem gerrorden. was in der Totalitä ihrer Natur von Ewigkeit her rorgezeichnet rar.

\section{h) Die Ternumfideen.}

Die Mächte aber, welche diese Entwicklung hørbeiführen. sind die Ideen und die großen Persönlichkeiten, die Heroen der Geschichte. Das göttliche Leben ist eins und unteilbar, aber im Verhältnis zu den verschiedenen Materien des Geistes wirkt es sich rerschieden aus. Anders in der Kunst, wo es zun großen Schauen hinleitet und in dem Werke der Schönheit seine geheime Stätte findet, anders in Staat und Pecht, wo es die Beziehungen der Menschen zneinander im Sinne eines würdigen und erhebenden Gemeinschaftslebens normiert und ordnet und so eine reine Liebe zum Vaterlande und die freiwillige Tat der Aufopferung für das heimatliche Land erregt und großwerden läßt. Die höchsten Ideen jedoch, in denen das eine göttliche Leben ausstrahlt und sinnliches Dasein gewinnt, sind Philosophie, Religion und sittliches Leben. In der Erkenntnis des reinen Begriffes, im Verstehen des religiösen Srmbols und in der urpersönlichen Tat der Freiheit gibt sich das Göttliche am reinsten und lautersten kund, erfassen wir am ummittelbarsten den wehenden Geist der Gottheit. Die Ideen werden also von Fichte als göttliche Kräfte gedacht, die das Wirkliche gestalten.

\section{i) Die Helden der Geschichte.}

Die zweite Potenz, welche zur Verwirklichung des historischen Geschehens erforderlich ist, ist der Held, die große Persönlichkeit, der Religiöse, der Denker, der Künstler, der Staatsmann, der sittliche Reformator, der Prophet. Seine große und einzige Erscheinung bringt hervor das Nene, das nie Dagewesene. Er besitzt ein inniges und unmittelbares Terhältnis zu den Ideen. Er ist der wahrhaft göttliche Mensch. Durch seine Beziehung zu den Ideen wächst er zur Größe heran und spürt in sich die weltbewegenden Kräfte und erkennt das Einzigartige, das in ihm liegt, das berufen ist, der Telt etwas Nenes zu offenbaren. Er läßt die schlummernden Kräfte entstehen, die in ihm ruhen. 
und die Schönheit seiner Individualität macht er der Welt zum Geschenk. Er ist immer ein Wissender und seinem Zeitalter weit roraus und ron einem großen Glauben und einer großen Liebe zu seiner Mission erfüllt. Er ist kein blindes Werkzeng der Ideen, so daß sie ohne sein Wissen mit ihm schalten und walten können, wie es ihnen gefällt. Er ist kein blindes Instrument in der Hand einer listigen Vernunft, die seine Leidenschaften nutzt, um ihrem eigenen rerborgenen Plane zu dienen. Er ist der Liebhaber und Freund der Ideen, der teilhat am göttlichen Leben und ihre dunklen und schicksalsschweren Wege erspäht. Und so eignet ihm in der Tat eine fast übermenschliche Größe, weil or ein bewuBter Diener der Gotheit und ihr Vertrauter ist, weil er ihre ewige Stimme in sich artönen läßt und in verständnisvoller Liebe und Einsicht nach ihrem Wohlgefallen handelt. In der Auffassung des heroischen Menschen trennen sich besonders scharf die Gesehichtsphilosophien ron Fichte und Hegel.

\section{k) Konkrete Auffassung der historischen Individualitäten.}

Es ist deutlich, wie sich bei Fichte der Geschichtsphilosophie der Aufklärung gegenïber eine vertiefte nnd weit konkretere Auffassung der' historischen Individualität anbahnt ${ }^{1}$ ). Für Fichte ist (lie Persönlichkeit als Wertindividualität nicht nur Träger des Sittengesetzes. Sie führt vielmehr ein eigenes Wertleben. Der große Mensch, der im Dienste der Idee das umerhört Nene hervorbringt, er ist auch abgesehen von seiner Leistung für sich schlechthin etwas Wertrolles in seiner idealen Organisation. Er ist seinem metaphysischen Sinne nach gewiß ein Teil des einen göttlichen Lebens, aber selbständig und eigentiumlich gebilclet. Und wie Fichte den Begriff der Einzigartigkeit und des Nenen mit dem Helden verbindet, so anch mit der Individualität groben Stiles, dem Staat und der Gemeinschaft. Die Aufklärung hatte zwischen Staat und Volk anf das schärfste unterschieden. Der staat galt ihr im allgemeinen als die bloß äuberliche Normierung und Regelung des gesellschaftlichen Lebens. Das eigentlich wertwolle Lehen in Kinst, Religion, Sittlichkeit und Wissenschaft, las führt (ler Meusch auBerhall, der staatlichen Sphäre und vollkommen von ihr getrenut. Der Mensch führt ein Doppelleben. Eimmal sofern er Bürger ist unl den Sohutz seines Idehens und seines Eigentums verlangt, gehört er dem Staat an mul ist velpflichtet, ihm dafür gewisse Leistnugen zu entrichten. I) Mensch schätzt diesen staat nicht sonderlich. Wr nimmt iln als ein notweruliges (bel hin, das ihm gar manche Unbequemlichkeiten bereitet, dafür aber ihon anch eine ruhige gesellschaftliche Position gewïhrt. Seine Frende und sein Giliok findet er nicht im stante, und lie Loistumgen, die er etwa anf wissenschaftlichem mol kïnstlerischem Gebicte vollzogen hat, sie sind gewils

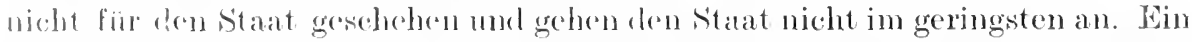

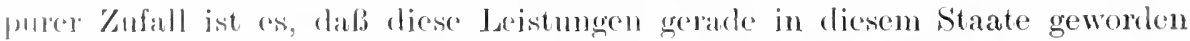
simel. Alls wertvolle Tum gehört dex Persönlichkeit, der Menschheit und Gott.

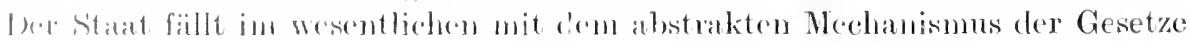

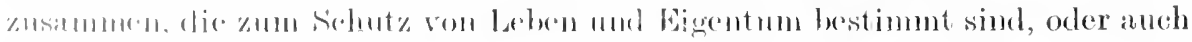

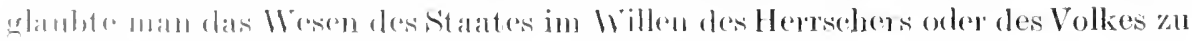

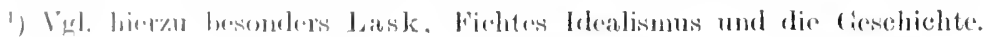


erkemnen, von dem alles Recht abhängig ist. So blieben Staat und Recht dem eigentlichen Tolksleben äußerlich und fremd. Der kosmopolitische Geist der Zeit fand in der Enge und Beschränktheit staatlicher Verhältnisse eine Fessel und Grenze für alles höhere geistige Leben. Die universalistischen Tendenzen des politisehen Lebens waren mit dem Mittelalter zu Grabe getragen. Die Nationen waren an die Stelle des Imperiums, die Konfessionen und Sckten an die Stelle der einen katholisehen Kirche getreten. Noch aber konnte sich der menschliche Geist in diesen Grenzen nicht zurechtfinden. Er strebte darüber hinaus und verknüpfte die Werte des Lebens ganz ausschließlich mit der Idee der Menschheit. Anf der Persönlichkeit und den ganz nahen Beziehungen des Lebens in Freundschaft und Liebe - und dann anderseits auf der denkbar umfassendsten Gemeinschaft der Menschheit und der vernünftigen Wesen. überhaupt ruhte in jener Zeit alles Interesse und alle Wertbeziehung, und man vernachlässigte jenes Zwischenglied, das die Terbindung des einzelnen mit der Ganzheit herzustellen berufen ist, den Staat, die Nation.

Diese abstrakte Auffassung des Staates finden wir bei Fichte völlig verändert. Er hat den Begriff des Staates dem der Nation genähert und ihn in dieserVerbindung viel konkreter verstanden. Der Staat hört auf, ein Mechanismus und ein blutleeres Gebilde zu sein. Der Staat ist die Schöpfung und Leistung der Nation, die eigentümliche Lebensform, welche sie sich selber bestimmt und gibt. Allerdings ist dicser Standpunkt in den Grundzügen des gegenwärtigen Zeitalters noch nicht erreicht. Dort erscheint der Staat für die Heroen der Geschichte, die sonnenverwandten Geister noch nicht so sehr wichtig. Geht das heimatliche Staatengebilde zugrunde, so ist der große Mensch darum nicht heimatlos. Denn er wird sich immer als zugehörig empfinden zu jenem Volke, das an Energie des Schaffens und an schöpferischen Kulturtaten alle anderen überragt. In diesem Tolke hat der Genius immer seine wahre Heimat.

\section{l) Der Staat und die Ińulturwerte.}

Dieser relativen Geringschätzuug des Staates entspricht es denn auch, daß von den höchsten Kulturwerten nur die Kunst in eine intimere Beziehung zum Staat gesetzt wird, während Fichte zwischen Wissenschaft und Staat, Staat und Sittlichkeit, Staat und Religion ein gegensätzliches Verhältnis konstruiert. Der Staat ist der Kunst wohlgesinnt. Seine Macht und Stärke bedeutet auch eine Hilfe für ihr Gedeilhen und eine sorgende C'nterstützung ihrer blühenden Schönheit. Die Herrlichkeit des Staates geht zusammen mit der Herrlichkeit der Kunst. Ganz anders sieht es aus, wenn wir auf das Verhältnis von Staat und Wissenschaft reflekticren. Beide müssen sich immer bis zu einem gewissen Grade als Gegner betrachten. Denn die Wissenschaft nimmt für sich in Anspruch das Reeht ciner freien und unbefangenen Kritik an allen Verordnungen und Einrichtungen des Staates sowie anch an der ganzen Tradition, aus der der Staat herrorgegangen ist. Sie nimmt für sich in Anspruch das freie Wort, die Freiheit des Denkens und Lehrens. Diese Freiheit kann dem Staat unbequem sein und unter Umständen seiner Politik Schaden loringen. Ihn interessiert die Wissenschaft ror allem, sofern sich ihre Ergebnisse praktisch verwenden lassen. Das Interesse der Wissenschaft aber liegt nicht in der Anwendbarkeit ihrer reineu Prinzipien. Sie fragt aus

Mehlis, Geschichtsphilosophie. 
rein theoretischer Anteilnahme nach den Gegenständen der Wirklichkeit, sie lebt in der reinen $9 \varepsilon \omega \rho$ ó́.

Auch zwischen den Prinzipien der Moral und den Prinzipien des Staates scheint nach Fichte ein Gegensatz zu bestehen, der niemals ganz überwunden merden kann. Kant hatte diesen Gegensatz in dem Verhältnis von Moralität und Legalität gesehen. Für das Recht als Prinzip des Staates ist die Handlung von ausschlaggebender Bedeutung, für die Sittlichkeit die Gesinnung. Jede wertvolle soziale und politische Leistung wird vom Staat ancrkannt, der sich wenig darum kïmmert, welchem Motiv diese Leistung ihren Ursprung verdankt. Die Moralität ist ein Prinzip, das sich nur bedingungsweise dem Rechte unterordnet. Der moralische Mensch erkennt das Recht an, solange es ihm gut, wertvoll und sinnvoll erscheint. Wo aber die Idec der Freiheit und der Selbstbestimmung durch das Recht gekränkt wird, da lehnt er sich gegen das Recht auf und bekämpft es bis aufs äußerste. Das moralische Bewußtsein und das Recht stehen niemals in vollkommenem Einklang, denn das Recht verlangt nur ein Minimum und setzt voraus, daß eine bestimmte Norm etwa der Strafe angemessen sei dem begangenen Vergehen. Die Moralität dagegen verlangt das Äußerste und erkennt in dem Verhältnis von Strafe und schuldhafter Tat, so wie es im Rechte normiert ist, immer das Unzulängliche und Ungenügende.

Am radikalsten aber widerstrebt vielleicht die Idee der Religion dem festen Gefüge der staatlichen Ordnung. Immer wieder zeigt die Geschichte, wie das religiöse Prinzip mit dem Staat im Kampfe liegt. Die Religion will den Gottesstaat an die Stelle des irdischen Staates setzen. Sie will alle Schranken der Sinnlichkeit zerstören und die Welt überwinden. Das Work des religiösen Menschen in seiner Ganzheit paßt niemals in die strenge, auf zcitliche Verhältnisse und zeitliches Wohl bedachte staatliche Ordnung hinein. Es muß diese Ordnung notwendig sprengen. Will die Religion im Staate existieren, so muß sie ihm notwendig Konzessionen machen. Das kann entweder so geschehen, daß sie cin ruhiges Immendasein lebt und 1 m das öffentliche Leben des Staates unbekümmert ist. Dann hat sie ihr Dasein im Staate, ohne doch an seinen Verwaltungen und Einrichtungen teilzunchmen. Oder aber sie söhnt sich in der Form cler Kirche mit lem Staate aus und verzichtet auf die strenge und absolutc Befolgung ihrer eigensten Irleale mol Forderungen.

In dem Verhältnis des Staates zu den höchsten Kulturwerten hat somit Fichte das für die Geschichtsphilosophie so ungemein wichtige Problem der Wertgegensätzlichkeit borührt. Der Simn des Kulturlebens ordnet sich nicht so ohne weiteres zu einer Einheit, sondern tritt in schroffen Gegensätzen unseinander. In den , Grundzügen" erscheint nun der Staat in der Hauptsache noch als Mittel gegenüber dem selbstherrlichen Zweck der Kulturwerte. In fon Perlen an die deutsche Nation hat sich dieser Standpunkt geändert.

Hier verbinclet Fichte auf das innigste die Idee des Stantes mit der Irlen der Nation. Fr vorstaht die Nation als Staat, als politische und kulturelle Winheit, und re versteht den Staat als großes nationales Leben. Fr faßt hier lie Vution als cin eigentïmliches Wertgebilcle, las mersätzlich ist, indem er spminll den mersotyharen Eigenwert der deutselen Nation betont. Würde sie jemals von der bilrflïehe des politischen lebens versehwinden, wärde sie ansgelöscht mul ansgotilgt und cin Ranh, der fremulen Mächte, dann würde 
das Schicksal des Menschengeschlechtes auf das ernsthafteste bedroht sein; denn ohne die selbständige Kulturentfaltung dieses besonderen Tolkes kann dic Menschheit nicht rorwärtsschreiten. Die ideale Kulturgemeinschaft stellt sich somit für Fiehte dar als eine Gliederung der Mensehheit in eigentümlich wertvolle Gebilde, von denen jerles einen notwendigen Beitrag leistet für die Schönheit des Ganzen, und jedes ein notwendiges Glied bildet, das nicht verloren gehen darf.

Der Staat, durch den das Leben der Nation flutet, ist nun nicht mehr ein Etwas, das leicht entbehrlichist, und von dem sich der Genius fortwendet, wenn ihm neue und größere Ziele winken, sondern auf das engste ist die Individualität mit dem Wohl und Wehe des heimatlichen Staates verbunden, und deswegen soll sie auch bereit sein, ihr Bestes für ihn zu opfern. In Fichte ist die Idee des nationalen Staates als eigentümliches Wertgebilde erwacht. An die Stelle der alten umiversalistischen Wertgebilde einer früheren Zeit, des Imperiums und des Sacerdotiums, setzte er den Ewigkeitswert eines eigentümlichen nationalen Lebens und die klar erkannte IVertgenossenschaft des nationalen Staates.

Die Kulturphilosophie des deutschen Idealismus, wie sie ron Kant inanguriert war, hatte das Problem des sittlichen Lebens zum Weltproblem erhoben und von hier aus auch den Sinn der Geschichte zu deuten unternommen. Fichte war Kant auf diesem Wege gefolgt. Er hatte von cler Idee der Freiheit ans in umfassender Weise das historische Universum gedeutet. Für die Geschichte, in der Leistung und Tat und Schaffen und Wirken eine so große Rolle spielt, schien der sittliche Wert vor allen anderen befähigt zu sein, als Ordnungsprinzip zu dienen. Von ihm aus schien sich die bunte Mannigfaltigkeit des historischen Geschehens am einfachsten und selbstverständlichsten zu ordnen und zu klären. Nicht zu einem ruhigen Pflanzendasein sind wir bestimmt, sondern unsere Aufgabe liegt in der Leistung: Tun und Handeln bestimmt unseren Wert. Und in dem großen Leben der Geschichte wird unser Tun und Leisten geadelt dureh das große Ziel, das es zu verwirklichen gilt. In den Dienst dieses Zieles werden wir gestellt, und dadurch empfangen wir Würde und Bedentung. Wir sollen einen Beitrag dafür leisten, daß eine schöne und freie Menschheit wird, die alle ihre Verhältnisse nach der Vernunft gestaltet.

\section{\$3. Die romantische Geschichtsphilosophie.}

Gegen diese Geschichtsphilosophie der Moralität und der Freiheit wandte sich die romantische Geschichtsphilosophie, die in Schelling ihre Vollendung fand $^{1}$ ). Sie wandte sich, indem sie in den Spuren Herders weiterschritt, vor allem gegen die Betonung des Endzweckes und die einseitige Betonung der sittlichen Kultur. Sie tat das, indem sie Werte geltend machte, deren Struktur von der Struktur der Moralität sehr verschieden ist, indem ihr philosophisches Interesse ganz in erster Linie auf Kunst und Religion gerichtet war, Wertgebilde,

1) Für Schellings Geschichtsphilosophie kommen besonders folgende Schriften in Betracht: 1. System des transzendentalen Idealismus, 2. Philosophie der Kunst, 3. Methode des akademischen Studiums. Vgl. darüber mein Buch: Schellings Geschichtsphilosophie in den Jahren 1799-1804. 
die ganz zweifellos unter sich eine tiefe innere Verwandtschaft verraten. Sie unternahm es, ron ihnen aus der Geschichte einen Sinn zu geben, und wir können ihre Tendenz vielleicht am besten verstehen, wenn wir bedenken, daß die Vorstellung Kants und Fiehtes das historisehe Leben der Gegenwart immer wieder zur Torläufigkeit verurteilte. Der Mensch ist dazu verurteilt, ewig beizutragen, nicht aber zu vollenden. Und so bleibt er ein Opfer und eine große Hingabe für die Kultur der Zukunft. Aber es gibt Werte, aus deren Tiefen wir die Gewißheit schöpfen können, daß das Yollendete zu aller Zeit gegenwärtig sein kann. Und zu diesen gehört in erster Linie die Kunst. Weiter aber scheint eine ästhetische Rechtfertigung der Welt am meisten unserem Bewußtsein von der Tatsache zt entsprechen, daß in dieser Welt so viel Sinnvolles mit so viel Sinnlosem zusammengeht. Anch dürfen wir vielleicht an Plato erinnern, der ebenfalls (ler Idee der Schönheit diese Auszeichnung zuteil werden ließ. Die sinnliche Wirklichkeit des Schönen unterliegt nicht dem geringsten Zweifel, in der anorganischen und organischen Natur begegnen wir immer wieder ihrem holden, beglückenden Antlitz, während wir manchmal verzweifeln möchten, ob Wahrheit und Gerechtigkeit in dieser Simnenwelt vorhanden sei. Dazu kam, daß Kant in der Kritik cler Urteilskraft die eigentümliche Zwisehenstellung offenbart hatte, die clie Kunst im Terhältnis zum theoretischen und praktischen Gebiet einnimmt. Das Problem der Schönheit entsteht, wenn die Kategorie der prakltischen Vernunft, die Idee des Zweckes, Anwendung findet auf den Gegenstand der theoretischen Ternunft, auf die Natur ${ }^{1}$ ). Während das Problem der theoretischen Ternunft die ïbersimnliche Welt als das räitselhafte und unauflösliche Ding an sich bei Seite schiebt, und anderseits die Ethik in ler Natur als Instinkt und Trieb und Neigung nur Hindernisse für die Erreichung des Wertvollen erblicken kann, nühert die ästhetische Problemstellung die beiden so schroff getrennten Welten. Der Gegensatz der simnlichen Eimbildungskraft nnd des Terstandes wird überwunden in der Idee ciner harmonischen Zusammenstimmung dieser beiden Grundfaktoren aller Erkenntnis, er wird überwunden in der Ansehaumug des Sehönen. Der Gegensatz ron Einbildungskraft und Terstand ergab die Begrenzung der Wirkliehkeitserkenntuis. Beide weisen auf eine gemeinsame Wurzel hin, und der göttliche Geist als intuitiver Terstand rermag sehauend zu verstehen und rerstehend zu schauen. Ihm ist der ïsthetische Zustand rerwandt, weil in ilsm die einsritige Torherischaft der einen oder andern Geistesfunktion getilgt ist und somit keine auf Kosten der anderen leidet, sondern eine Versöhmung erzielt wird, dic unser ganzes Wesen crhöht und besceligt. Die Romantik, welche in ter liebevollen Versöhnmng aller Gegensïtze das Zicl des mensehliehen lebens und in der Harmonic unserer mannigfaltigen Geisteskräfte die Schönheit und las Gilizck des Daseins zu erkennen glaubte, konnte faher den ästhetischen Zustand, ron cinem hohen metaphysischen standpunkt aus gesehen, wol, als Wiorlergewinnung jener ursprimglichen Einheit betrachten, die in (ioft ron Fwigkejt an und (lanernd vorhanden ist ${ }^{2}$ ). Die Unseeligkeit der sinn-

1) Vel. Windelband. Lehrbuch st. 471.

2) Cher dits Lelwensgeföhl und die P'hilosophie der Romantik vgl. besonders Erwin

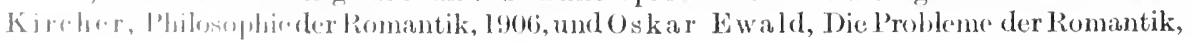
$19(9)$. 
lichen Wirklichkeit liegt in den Gegensätzen unserer eigenen Natur und ebenso auch an dem Gegensatze, der die äußere Natur bedrückt und ängstigt. In Gott ist bleibende Vollendung. Die Natur ist das evig Unvollendete, das große Fragment Gottes, das nicht zu Ende gedichtete Gedicht, über das der Weltgeist träumt und sinnt. Wir aber sind Bürger zweier Welten und haben sowohl am Vollendeten wie am Unvollendeten Anteil. Gott ist ewig vollendet, die Natur ewig unvollendet, wir sind rollendet und unvollendet zugleich. Im allgemeinen müssen auch wir das schwere Los des Unzulänglichen und Fragmentarischen ertragen. Aber in seltenen Weihestunden des Lebens erreichen wir durch die künstlerische Tat die Vollendung, sei es nun, daß wir das Kunstwerk schaffen oder es nachschaffend verstehen. Wir sind zum Künstlertum berufen. Schaffen ist göttliches Tun, Schöpfer ist der Künstler, künstlerisch schaffend nähern wir uns Gott und nehmen teil an der großen Bewegung und dem heiligen Sinn der Welt. Auf die unvollendete Wirklichkeit richtet sich des Künstlers Tätigkeit und hilft der Gottheit ihr Werk rollenden.

Auch in Kants Lehre rom Genie war ein Ansatzpunkt gegeben, um im Ästhetischen die Versöhnung aller Wertgebilde zu denken. War doch das Genie nach Kants Auffassung allein auf kïnstlerischem Gebiet zu finden. Besaß es doch die Fähigkeit, aus den Tiefen des Unbewußten heraus das Große und Mächtige zu schaffen. ohme Absicht, das Zweckmäßige hervorzubringen, das unser ästhetisches Gefühl so mächtig ergreift, und Regeln zu geben, die für alle Zeiten gelten. Der Künstler ist der Schaffende, der Gesetzgebende. wie die Natur bringt er ohne bewußte Absicht das Sinnvolle herror, und lediglich aus seinen Werken lassen sich die Gesetze der Schönheit entwickeln, denn die Originalität des künstlerischen Genies bringt immer wieder ein nene Form und Gestalt des Schönen herror. In dieser Idee des Genies, wie sie Kant aufgestellt hatte, schien in der Tat die Einseitigkeit der moralischen und theoretischen Menschen überwunden, und damit war der Gedanke gegeben, daß sich die Menschheit nur im Künstlertum, die Kulturwelt allein in der ästhetischen Sphäre rollenden könne.

\section{a) Schillers Philosophie der Kunst.}

Schiller hat zuerst die Erhebung des ästhetischen Wertes über alle Werte vollzogen und seinen ästhetischen Idealismus auch für die Geschichte nutzbar gemacht ${ }^{\mathbf{1}}$ ). Während der moralische Mensch notwendig im Kampf mit der Natur liegt, ist der Kü̈nstler der Liebling und Günstling der Natur, dem sie ihre Geheimnisse verrät. Auch ist es möglich für den hochkultivierten Menschen, den Kampf ron Pflicht und Neigung, der den sittlichen Menschen so sehr bedrängt und quält, zu einem glücklichen Ende zu führen. Es gibt einen ästhetisch-sittlichen Zustand des Menschen, da Pflicht und Neigung nicht mehr miteinander streiten, sondern in rollkommene Harmonie gesetzt sind. Das ist die Erscheinung der schönen Seele, die in frendiger Liebe die Pflicht erfüllt

1) Vgl. Schillers philosophische Abhandlungen, vor allem: Anmut und Würde, 1793; Briefe über die ästhetische Erziehung des Menschen, 1795̃ Über naive und senti. mentalische Dichtung, 1796. E. Kühnemann, Kants und Schillers Begründung der Ästhetik. 
und ihren schönen und zarten Neigungen ruhig und vertranensvoll nachgehen darf. Der vollendete Zustand des gesellschaftlichen Lebens kann nur im Sinne des Ästhetischen gedacht werden. Anfangs gilt Schiller das Schöne als Mittel zur Herbeiführung eines moralischen Zustandes, aber immer mehr gewinnt es für ihn an selbständiger Bedeutung. Zwei Triebe des Menschen stehen im schroffen Gegensatz, der Stofftrieb und der Formtrieb, von denen uns der eine in die sinnliche Sphäre niederzwingt, der andere zn den Sternen emporreißt. Auf ersteren grïndet sich das Sinnenleben der Natur, auf letzteren die Gestalt des moralischen Lebens. Zwischen ihnen ist der ästhetische Trieb gestellt, der anfänglich als bloßer Spieltrieb wirkt und den Menschen von der Not des bloßen Naturzustandes befreit, der ihn veranlaßt, über jene Handlungen hinaus, die der Erhaltung des Daseins dienen, das in praktischer Hinsicht Zwecklose und Unnütze zu tum, nämlich den Körper zu schmücken und den eigentümlichen Bau und die Bildung und Gestaltung der Glieder durch rhythmische Bewegung zu offenbaren. Aus diesem Spieltrieb, dessen Erwachen immer ein Beweis dafür ist, daß die Menschheit gewillt ist, über die Natur hinauszuwachsen, aus diesem in seinen ersten Gestaltungen durchaus primitiven Lebensgefühl ist alle große Kunst hervorgegangen. So baut sich auf ihm einerseits das selbständige Reich der Kunst und der Schönheit auf, anderseits aber macht das Spiel auch die Menschen weicher und gefälliger und für die Aufnahme höherer Gesinnung und Gesittung empfänglicher. Die künstlerische Betätigung wird zn einer Schule der Moralität. Wenn der Mensch sich ron der drmpfen Brutalität des bloßen Simnenlebens abgewandt hat und empfänglich geworden ist für die weichen mul lieblichen sowie auch für die stillen und großen Formen des künstlerischen Lebens, dann ist er auch so weit vorgeschritten, daß ihm nummehr bald in unverhüllter Form die großen Gestalten des sittlichen Lebens nahen dïrfen, claß er mit Verständins ihnen begegnen kann. Hat er nun aber das Reich der Moralität gewonnen, wo die Persönlichkeit durch den strengen Glanz des Sittengesetzes geweiht ist und im Verhältnis des einen zum andernein ernstes Sollen, die gewissenhafte Befolgung der Pflicht verlangt, so soll deswegen doch die Schönhcit in seinem Leben weiter daucrnd ihre Stätte finclen, sie soll nach wie ror auch über die stillen Stätten der Kunst hinaus das menschliche Leben gestalten. Wenn auch das staatliche Leben und die bürgerliche Gesellschaft sich niemals clen Gesetzen der Schönheit fügen dürfen und können, weil hier die Moralität und das Recht ein für allemal die verpflichtenden Instanzen sind, so soll doch die Sichönheit dauernd unsere Liebe und unsere Freundschaft schmiicken und in den Formen des gesellschaftlichen Lebens unberlingte Herrscherin sein. In ten Kreis wahrhaft schöner Geselligkeit werken wir uns flüehten, wenn uns der strenge Dienst der Pflicht mïrle gemacht hat. T)enn im geselligem Lchen, da ist das Gebot der Pflicht

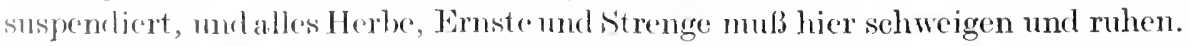
Hirer darf der Mensch dem Menschen nur als Gestalt begegnen, nur als Objekt rines froich spicels gegeniiberstehen.

Immer tiofor dachte Siehiller dem Verhältnis der Kunst zum Leben nach. Fr mutrsuchto ihre grobon Gestaltungsmöglichkeiten und brachte sie in enge Vorbimlung mit dor historischen Entwicklung. So hat er zuerst eine große Konstmktion los kïnstlorischen Universums gegeben, d. h. er hat die Fnt- 
wicklung der Kunst geschichtsphilosophisch zu deduzieren gesucht. Sein Ausgangspunkt war der von Kant aufgestellte Gegensatz ron Notwendigkeit und Freiheit sowie auch die Unterscheidung zwischen dem Schönen und dem Erhabenen. Ganz augenscheinlich kann der Mensch und speziell anch der Künstler in einem doppelten Verhältnis zur Natur stehen. nämlich entweder so, daß er mit ihr in Einklang und Harmonie steht. daß er tatsächlich der Günstling der Natur ist und mit ihr in engster Gemeinschaft lebt. Das ist das Zeitalter des naiven Dichters, der unbewußt zweckmäßig schafft wie die Natur. Dio naive Dichtung ist augenscheinlich der große Anfang der Kunst, aber es besteht keine so enge Gemeinschaft zwischen ihr und den Zeitverhältnissen, daß sie nicht zu aller Zeit möglich wäre, daß nicht immer wieder der naive Dichter als der eigentliche Dichter der Schönheit unser Herz gewinnen könnte.

Dem nairen steht der sentimentalische Dichter im sentimentalen Zeitalter gegenüber. Er ist der Sohn einer Zeit, die das enge Verhältnis zur Natur aufgegeben und sich von ihr emanzipiert hat. Er schöpft nicht mehr so unmittelbar aus den Quellen der Natur, er ist ihr fremd geworden. Er empfindet den Gegensatz von Ideal und Wirklichkeit und sofern er diesen Gegensatz kennt und weiß, ist er der Wissende in seinem Verhältnis zu dem nairen Dichter. Indem er nun aber zu künstlerischem Schaffen übergeht, wird er immer wieder eine große Sehnsucht offenbaren nach dem, was er verloren hat. So ist er der Dichter des Gegensatzes gegenüber dem naiven Dichter als dem Dichter des vollkommenen Einklanges. Dieser scharfen Spannung entspricht Kants ästhetisches Ideal des Erhabenen. In dem Gefühl des Erhabenen sind nach Kants Lehre Verstand und Einbildungskraft in Widerstreit gesetzt, während sie in dem Gefühl des Schönen zusammenstimmen. In dem Gefühl des Erhabenen stellt die anschauliche Kraft der Einbildung die Natur als dasjenige vor. was in der Unendlichkeit seiner Ausdehnumg ron dem Verstand nicht zu beherrschen oder aber anch in der Macht und Größe scines Scins durch die Schwäche unseres Willens nicht $\mathrm{zu}$ überwinden ist. Ton diesen verschiedenartigen Momenten, die das Gefühl des Erhabenen rorbereiten, hat Schiller in der Hauptsache nur die Idee der Spannung beibehalten. Doch weist er nicht den Kontrast auf zwischen den rerschiedenen ,Kräften des Gemütes“, sondern stellt das Gemüt des Dichters in Gegensatz zur Natur. Auch ist die Natur im Verhältnis zum Dichter nicht sowohl das Ưberlegene und Überwältigende, sondern vielmehr das Ersehnte, in unerreichbare Ferne Gerückte. Und wie sich bei $\mathrm{K}$ a n $\mathrm{t}$ die Tollendung des Erhabenen in der Úberwindung des Gegensatzes yom Verstand und Sinnlichkeit durch die V'ernunftideen vollzieht, so baut Schiller über den Zustand des Sentimentalen und Naiven den vollendeten Zustand des künstlerischen Fühlens auf, in dem die Dichtkunst ihre höchsten Schöpfungen entfaltet.

Dem Zustand des naiven Dichters, der den Gegensatz nicht kennt, der noch vollkommen im Einklang ist mit sich selbst und der Natur, der seine Sinnlichkeit nicht als Last empfindet, sondern sie durch schöne Geistigkeit verklärt, entspricht im allgemeinen die epische Ruhe und Besonnenheit, während mit dem Gefühlszustand des sentimentalischen Dichter's eine leidenschaftliche Bewegung zusammengeht. Úber diesen Gegensatz hinaus kann eine Dichtung gedacht werden, in der sich leidenschaftliche Bewegung und Erregung mit erhabener Ruhe vereint, eine Dichtung, die mit der Dissonanz beginnt und in der 
Harmonie sich vollendet. Wir können uns den Weg der Menschheit und ihres künstlerischen Bildungsganges so vorstellen, daß sie ursprünglich ein Leben unbewußter Schönheit gelebt hat, das die Phantasie des Menschen als das verträumte Arkadien und als die Unschuld des paradiesischen Zustandes rorstellt. Diesem reinen Boden der Natur ist die naive Dichtkunst erwachsen. Aber die Entwicklung des Menschen ging dahin, daß Sinnlichkeit und Moralität miteinander in Streit gerieten, daß der Mensch aufhören mußte, den beglücken. den Regungen seiner sinnlichen Natur sich hinzugeben. Uber die Natur hinausgegangen, ersehnte der Mensch den ursprünglichen Zusammenhang zurück, und es erwuchs die große Form der sentimentalischen Dichtung. Noch aber steht die höchste Form des Lebens und der Dichtkunst aus, die nur darin gesucht werden kann, daß die Menschheit die verlorene Einheit in einer höheren Form wiedergewinnt. Das ist die Idee einer Schönheit, die den Gegensatz hinter sich gelassen und überwunden hat.

Wir sehen in dieser Deutung, die Schiller dem Universum der Kunst gegeben hat, alle Voraussetzungen der romantischen Geschichtsphilosophie enthalten, die von seinen Gedanken ihren Ausgang genommen hat. In der Lehre ron Friedrich Schlegel und Novalis begegnet uns noch eine gewisse Beschränkung der geschichtsphilosophischen Fragestellung auf das künstlerisehe Leben, während Schelling zuerst unter dem ästhetischen Gesichtspunkt das Ganze des historischen Universums gedentet hat.

\section{b) Novalis.}

Novalis geht ron der Anffassung aus, daß das geistige Leben, das er ganz in erster Linic als künstlerisches Leben versteht, auf zwei verschiedenen Kräften des Geistes beruht, nämlich auf Instinkt und Reflexion, in denen wir unschwer den ron $\mathrm{K}$ ant aufgestellten Gegensatz von Sinnlichkeit und Verstand wiederfinden $\left.{ }^{1}\right)$. Am Anfang des historischen Lebens gehen beide zusanmen, mit ihrer Trennung erst beginnt die Geschichte. Und das historische Leben zeitigt uns Erscheinungen, in denen entweder der Instinkt oder der Verstand dominiert. Der Kultus des Instinktes führt zur Bejahung des Formlosen. Es ist das Zeitalter des rohen, intuitiven Dichters, der Form und Gestalt haßt. Die frei ausströmenden Leidenschaften werden gefeiert oder auch die mystisehe Schwärncrei oder die cinseitige Kultivierung des Willenslebens. Dieser Geistesrichtung entgegengesetzt ist die Herrschaft des leeren Verstandes oder der bloßen Reflexion, die in der Scholastik zum Ausdruck kommt. Immerhin aber haben die beiden entgegengesetzten Geistesrichtungen, wie sie sieh in dem rohen intuitiven Dichter und im Scholastiker offenbaren, dieses gemeinsam, daß sir von der Geltung und Bedeutung einer ïbersinnlichen Welt erfüllt sind. I)anit stchen sie in einschneidendem Gegensatz zu dem bloßen Empirismus, der. nur am Gegebenen haftet und weder den göttlichen Instinkt noch die rein. Lorn des Verstandes gelten lassen will. Das Ziel der Geschichte aber muB darin gesucht werden, daß die beiden getrennten Zweige des mensehliehen Geistestabens wiorler zu einer Einheit verbunden werden. An die Stelle der

1) Übar Novalis vgh. besonders H. Simon, Der magische Idealismus, Heidelberg 1906. 
unbewußten Schönheit, die den Anfang aller Geisteskultur bezeichnet, soll an Ende der Geschichte die bewußte Schönheit treten.

\section{c) Friedrich Schlegel.}

Tiefer und allseitigerals Novalis hat Friedrich Schlegel das geschichtsphilosophische Problem ergriffen ${ }^{1}$ ). Für ihn zerlegt sich das historische Universum in zwei Hauptepochen, in die antike und die moderne oder romantisehe Welt. Antike und Romantik bedeuten zwei entgegengesetzte Typen des Geisteslebens, die sich als Inbegriff ganz versehiedener IVertungsweisen enthüllen und auch notwendig eine ganz verschiedene Form der Kunst erzeugen müssen. Auf der einen Seite steht die heidnisch-antike Welt, auf der anderen Seite die romantisch-christliche Welt. Das Prinzipdes Griechentums ist die Begrenzung. Es ruht in sich und ist in sich vollendet. Die Schönheit in der Begrenzung ist sein Ideal. Dieses Volk hat sich selber vollkommen zur Darstellung gebracht. Es hat alle seine reichen und vielseitigen Möglichkeiten in Wirklichkeit umgesetzt. Es konnte nichts mehr geben, als es zugrunde ging. Es hatte eine geschlossene, in ihrer Weise unerreichte Kultur erzeugt. Das Symbol für diese große antike Kultur ist der Kreis, der in sich selbst zurïckgeht. Das ganze Leben dieser alten Welt ruht in der Natur und ist von einer hohen Kontemplation geleitet. Die historische Auffassung der Dinge ist ihr fremd. Der griechische Denker lehrt die ewige Wiederkehr der Dinge, und still ordnet sich die Schönheit des nairen Menschen dem Ganzen der Natur ein. Die Kunst einer solchen Zeit muß die allgemeinen Züge der Gesamtkultur wiederspiegeln. Es ist die Kunst der Begrenzung, die ihren höchsten Ausdruck in der griechischen Plastik gefunden hat. Diese Kunst des Griechentums kamn niemals übertroffen werden. Sie ist in ihrer Art unerreicht und unerreichbar und verdient deswegen den Namen der Klassik. Die Klassik ist die höchste Blüte im Leben der Schönheit, ihre absolute und freie Entfaltung.

Das Prinzip der christlichen romantischen Welt ist dem der Autike durchaus entgegengesetzt. Dieses romantische Prinzip ist das Unendliche. Nicht die Begrenzung und die Einheit, sondern die Unbegrenztheit und die Dualität ist für die moderne Welt charakteristisch und bestimmend. So wind die Gottheit in der modernen christlichen Welt als das Unendliche gedacht, und der Gegensatz von Geistigkeit und Sinnlichkeit wird auf das schärfste empfunden. Das Symbol für diese ganz andersartige und neue Kultur ist die unendliche Linie. Die neue Zeit hat sich das Prinzip des Fortschritts zu eigen gemacht, und wenn die griechische Welt das Prinzip der Kontemplation vertrat, so vertritt das romantische Zeitalter ganz unbedingt das Prinzip der Tätigkeit und Bewegung. Ferner ist die moderne romantische Welt der Herrschaft der Natur entwachsen. Sie hat dafür ein unlösliches Verhältnis zur Geschichte. Aus dieser neuen Kultur muß die romantische Kunst verstanden werden, deren Geist die Sehnsucht nach dem Unendlichen offenbart, und die als progressive Universalpoesie in der Dichtung hervortritt. Diese neue Kunst ist nicht sowohl eine Kunst des

1) Vgl. auch besonders Schlegels Kritik von Condorcets, ,Esquisse d'un tableau historique des progrès de l'esprit humain" in Niethammers Philosophischem Journal Bd. III, H. 2, und über Schlegel: Fr. Steppuhn, Friedrich Schlegel. Logos Bd. I., H. 2. 
Schönen als vielmehr des Charakteristischen und Interessanten. Aber einmal wird eine Zeit kommen, und sie steht nach der Auffassung Schlegels nahe bevor, da auch die romantische Kunst zu einer Kunst der Klassik wird. Das ist dann die große objektive Kunst der Zukunft, die sich in den Werken Goethes zu enthüllen beginnt.

\section{d) Schellings Geschichtsphilosophie als Vollendung der romantischen Idee.}

Alle diese verschiedenartigen Motive, aus dem Einheitsgefühl hervorgewachsen, daß Kunst und Künstlertum das Größte sei, was wir erleben können, und die alle auf rerschiedenem Wege dahin führen, das historische Geschehen von der Idee der Schönheit aus zu begreifen, sie haben sich in Schelling, dem Geschichtsphilosophen der Romantik, zu einer großzügigen Konstruktion des historischen Lebens zusammengeschlossen.

\section{e) Der tragische Charakter der Geschichte.}

Das Grundgefühl, daß er der Geschichte entgegenbringt, ist das Gefühl des Tragischen. Nicht tritt er mit einem freudigen Fortschrittsoptimismus an die Geschichte heran, sondern das, was ihn am meisten erfüllt und ergreift, was er als simnlos und schwer vereinbar mit einer göttlichen Weltregierung empfindet, das ist ror allem der Untergang des Großen und Schönen vor dem verhältnismäßig Kleinen mond Unbedeutenden. Und da ist es vor allem der Untergang des Griechentums, der diese schöne romantische Seele mit tiefstem Schmerze ergreift. Daß diese einzig große Kultur vergehen mußte, scheint die Tücke eines finsteren Schicksals zu sein. Hier ist der große Riß zu spüren, dar die historische Welt zerklüftet. Hier ist ein Untergang von gewaltiger GröBe, der eine Welt in Stücke brechen läßt, um einer neuen Welt Raum zu geben. Trotz aller Kraft des Sinnlosen ist aber auch des Sinnvollen so viel in dor Welt, daß wir die Geschichte nicht ohne ein übcrindividuelles Einheitsjrinzi] verstehen können, das die so verschiedenartigen Zweeksetzungen der Ir'nschheit zu einem Zicle führt. ,So sehr diese auch glauben, ihre eigenen Wïnsche und Hoffnungen zu realisicren, und so ausgelassen sie auch ihre Willkür üben, so werden sie doch durch eine höhere Notwendigkeit gezwungen, eine Entwicklung des Schauspiels herbeizuführen, das sie selber nicht gewollt md beabsichtigt haben. Sie müssen dahin, wohin sie nieht wollen."

Diese Uberlegungen über die sinnvoll sinnlose Welt, der in hohem Maße das Moment der Schönheit eigentümlich ist, haben zu der Gestalt des Schellingschon Weltgoistes geführt, der dic Natur und auch die Geschichte unbewußt zwecknäßig gestaltet. Schelling versteht die Gottheit in Analogie zum genialen S'haffen des Kïnstlers. Sic wirkt dio Gestaltungen der Weltgeschichte aus mhlewuliten rätsclhaften Tiofen heraus. Und zwar erseheint die Gotheit anfangs in der Geschichte als dic horbe Notwendigkeit und Schönheit des Schieksals, das flic notwendigen Ordmungen des sozialen labens unbeabsiehtigt, aber sinnvoll hervorenft, un tann schlieBlich im Laufe des historisehen Werdens zu planvoll brw $\%$ offenbaren. 


\section{f) Der ideale und der reale Faktor.}

In der Natur des göttlichen Wesens, das das große Weltgedicht ersinnt und erschafft, sind diese beiden Elemente gesetzt, die Sehelling als das Ideale und Reale oder auch als das Unendliche und das Endliche bezeichnet. Gott ist die ungetrennte Einheit alles wertvoll geistigen und natürliehen Lebens. Es gibt in letzter Hinsieht niehts Ungöttliches in der Welt. Und in der idealen Paarung des Sinnlichen und Geistigen liegt die Sehönheit der sehaffenden Weltkraft, die die zerstreute Mannigfaltigkeit des Lebens zu sinnvoller Einheit verbindet. Während nun in der bloßen Natur das reale Moment einer strengen Notwendigkeit herrsehend ist und das geistige Prinzip sich dem Sinnlichen unterordnet, ist in dem historisehen Universum das geistige Prinzip das überwiegende gegenüber dem materialen Faktor. Das Unirersum der Kunst abcr soll es nach Sehellings Lehre sein, in dem die höchste Harmonie der Weltkräfte zu finden ist.

\section{g) Die drei Welten.}

Es gibt eine dreifache Betrachtung des geistig-sinnliehen Universums, oder, wie Sehelling sich auch wohl ausdrückt: das Universum kann unter drei versehiedenen Potenzen stehend gedacht werden, es gibt eine naturphilosophische, geschichtpshilosophische und kmustphilosophisehe Betrachtung der Welt. Von diesen ist die gesehichtsphilosophisehe Betrachtung speziell dadurch charakterisiert, daß das ideale Prinzip als dominierend im Verhältnis zum realen gedacht wird. Die Welt der Kunst wird von der Gesehiehtsphilosophie im engern Sinne des Wortes geschieden, weil anfangs noeh für Schelling der politische Gesiehtspunkt und seine großen Bildungen in Reeht, Kirehe und Staat für das eigentlich historisehe Leben die entseheidenden Instanzen waren. Das höehste Wertprinzip aber, das ihnen zugrunde liegend gedaeht wird, kann kein anderes sein, als die Idee der Sittliehkeit, die in dem Begriff der Freiheit ihren höehsten Ausdruek findet. Eben weil der Gedanke der Freiheit für die Welt des sittlichen Handelns entscheidend ist, behauptet Schelling, daß die Geschichte dureh das Überwiegen des idealen Prinzips charakterisiert ist. Geschichte liegt für Sehellings Auffassung ursprünglich nur dort vor, wo feste und sichtbare Institutionen und Ordnungen des sozialen Lebens geschaffen werden, dort, wo es sich um das Gebiet der praktisehen Tat handelt. Aber sehon früh verbindet sich für ihn auch das religiöse Leben mit der historisehen Welt, und es ist schließlich nur eine Form der äußeren Darstellung, daß die Kunstphilosophie nicht auch unter den Aspekt der Gesehichtsphilosophie tritt.

\section{h) Geschichtsphilosophische und empirische Betrachtung des Geschehens.}

Jedenfalls kann nur dort von einer philosophisehen Betrachtung des historischen Lebens die Rede sein, wo das Geschehen auf einen absoluten Wrert bezogen wird, oder, metaphysischer gesprochen, wo die Gesehichte als Darstellung des Absoluten in der empirisehen Wirklichkeit gedacht wirc. Eine solehe Betrachtung trennt sich auf das schärfste von einer empirisehen Betrachtung des historisehen Lebens. In der empirisehen Betrachtung kommen wir über ein gewisses Moment des Zufälligen nicht hinaus. Wir suchen hier das Gesehehen aus den Motiven, Plänen und Absichten der Personen zu verstehen, 
aber es bleibt rätselhaft, wie aus dieser Fülle entgegengesetzter und vielfach sieh durchkreuzender Zielsetzungen ein vernünftiger Gesamtsinn sich entwickeln komnte. Und indem Schelling von der Methode der Geschichte, ron ihrem Begriff und ihrem Gegenstand handelt, wendet er sich mit aller Schärfe gegen jede pragmatische Geschichtsschreibung, die das historische Leben unter den ihm ganz fremden und äußerlichen Gesichtspunkt des Nutzens und der Belehrung stellt. Gewiß wird die Darstellung des historischen Lebens nicht objektiv in dem Sinne sein können, daß die Persönlichkeit des Historikers an ihr keinen Anteil hat. Wir können unser individuelles Ich nicht auslöschen und die Gegenstände so darstellen, wie sie vor Gottes Auge ruhen; immer wird die historische Darstellung die Spuren des persönlichen individuellen Lebens in ihrer ganzen Bildung, Auffassung und Deutung verraten. Schwerlich aber kann der Gesichtspunkt der Betrachtung jemals zu groß und zu feierlich genommen werden, und nichts ist verwerflicher in Schellings Augen, als wenn das Bild der Geschichte etwa mit Rücksicht auf konfessionelle, soziale oder parteipolitische Rücksichten entstellt wird; ,denn unter dem Heiligsten ist niehts, das heiliger wäre als die Geschichte, dieser große Spiegel des Weltgeistes, dieses ewige Gedicht des göttlichen Verstandes: nichts das weniger die Berührung mreiner Hände ertrïge"1).

Die empirisehe Geschichte hat kein Prinzip der Allgemeingültigkeit, und das Absolute bleibt verhüllt. Sie weist nicht auf eine überindividuelle Notwendigkeit hin, sondern erfreut sich der bunten Mamnigfaltigkeit der Tatsachen und sucht aus den Zwecksetzungen, Handlungen mo Motiven der einzelnen Individuen das Ganze der Gesehichte zu verstehen. Ihr schroff entgegengesetzt ist die geschichtsphilosophische Betrachtung, welche die Geschichte als Darstellung des Absoluten in der Welt zu verstehen sucht und alle großen Formen und Gestalten des historischen Lebens bewußt und ausdrücklich anf cine Wertidee als Ziel und Sinn des Gesehehens bezieht, von der aus sie zugleich auch einen Maßstab für die Beurteilung der historischen Ereignisse gewinnt.

\section{i) Die historische Kunst.}

Zwischen diesen beiden entgegengesetzten Formen der historischen Darstellung steht, ,die historisehe Kunst". Diese bleibt nieht bei der bloß empirischen Darstellung der Begebenheiten stehen, aber anderseits bezieht sie die Geschehnisse auch nieht ausdrücklich auf eine höchste Wertidee. Sie vollzieht keine strenge Answahl des historischen Wertlebens, sondern verhart bei der bunten Fülle der historisehen Ereignisse; aber sie begnügt sich auch nicht mit der psychologischen Erklärung der Tatsachen, sondern sie läßt hinter der bunten Bilderflucht der Erscheinungen das Schieksal alınen, das Ziel und Einheit in das Leben bringt. Sie läßt das Allgemeine und die Idee nur ahnen und verrät niemals ihre geheime Gestalt. Die Erklärmng erfolgt vielleicht aus psychologisehen Ursachen, aber wir wissen genau, daß linter diesen Geschehnissen rin höheres Walten steht.

In rler eigentlichen Geschichtsphilosophie handelt es sich dagegen um die bryirhung d(r historisehen Begebenheiten auf cin sorgfältig herausgearbeitetes

1) Silselfing. Methode des akademischen studiums, Worke, Auswahl in drei

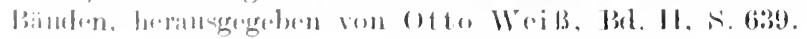


Wertsystem und ihre Rechtfertigung durch diese Beziehung. Dabei erscheint die Wertidee als das übersinnliche Etwas, das zögernd und allmählich in Erscheinung tritt, das in dem großen Prozeß des historischen Lebens immer sichtbarer und deutlicher wird, sofern die Idee in allen ihren Teilen allmählich in einer festgesetzten Ordnung zur Wirklichkeit und zum Dasein gelangt.

\section{k) Der kïnstlerisclie Wert als leitend.}

Es ergibt sich num aber für Schelling, daß der leitende Wert dieses geschichtsphilosophisch betrachteten Weltgeschehens der künstlerische ist, und zwar in diesem doppelten Sinne, daß eimmal das künstlerische Leben als das vollendete Leben allem anderen voransteht, und dann auch in dem Sinne, da B Schelling aus der logischen Struktur des ästhetischen Wertes die Möglichlkeit gewinnt, das historische Geschehen sinnvoll zu ordnen.

Einmal also steht das ästhetische Leben allem anderen Leben voraus, anderseits aber rollendet sich auch das andere Leben, etwa das Leben des Staates, der Gesellschaft, des Rechtes, der Wissenschaft der Moralität in der Form des Ästhetischen.

Schelling zeigt schon in seinem genialen Jugendwerk, dem System des transzendentalen Idealismus, daß der moralische Wert ebensowenig befähigt ist wie der theoretische, dem geschichtlichen Leben die Vollendung zu geben. Das theoretische Werk ist wie das moralische seinem ganzen Wesen naeh notwendig immer ein fragmentarisches. Es gehört zum Wesen der Wissenschaft und Moralität, daß sie immer unvollendet bleibt, während zu der Natur des ästhetischen Wertes, der sich im Kunstwerk offenbart, notwendig die Tollendung gehört. Kann doch der Sinn des wissenschaftlichen Lebens in nichts anderem gesucht werden, als daß die Wissenschaft bemüht ist, ein Srstem ron Begriffen an die Stelle der irrationalen Natur zu setzen. Diese Irrationalität aber ist für den menschlichen Geist niemals vollkommen zu überwinden. Immer wieder bietet sich den Forderungen des Denkens ein neuer Gegenstand der Erkenntnis dar. Die unendliche Mannigfaltigkeit der anschaulichen Wolt leistet allen Bemühungen des diskursiven Denkens danernden Widerstand. Nicht nur daß es unmöglich ist, die Totalität der Welt in ihrer unmittelbaren Anschaulichkeit und Fülle restlos zu begreifen; auch der Proze 3 der Umsetzung dieser anschaulichen Welt in die Sphäre der begrifflichen Erkenntnis ist notwendig ein unendlicher, da der erkennenden Funktion inmer wieder nene Objekte entgegentreten und so die Bestimmung des Unbestimmten niemals beendet ist. Und diesem großen, niemals vollendeten Prozesse der wissenschaftlichen Erkenntnis hat Schelling einen tiefen metaphysischen Sinn gegeben, wenn er das Ziel der wissenschaftlichen Erkenntnis dahin auffasst, daß der in der Natur heimlich verborgene und gefesselte unbewußte und träumende Weltgeist durch die Tat des wissenschaftlichen Denkens seiner Erlösung und Befreiung entgegengeführt wird. Auch die Natur ist ilnem imnersten Wesen nach gottrerwandtes geistiges Leben, das nach Klarheit und Bewußtsein ringt. Die wissenschaftliche Erkenntnis des Menschen aber kommt, diesem Ringen des Weltgeistes entgegen, indem sie überall an die Stelle des Dunklen und Unverstandenen das Lichtrolle und Sinnreiche setzt. So erlöst das bewußte geistige Leben der Kultur das unbewußte geistige Leben der Natur. 
Und wie der Prozeß der Erkenntnis niemals zum Ziele gelangt, so bleibt auch das sittliche Leben immer fragmentarisch. Denn alles sittliche Leben baut sich auf in dem unüberwindlichen Gegensatz von Sein und Sollen. Diese Spannung ist notwendig, damit überhaupt die Idee der Pflicht und der menschlichen Freiheit zu Recht bestehen kann. Die Idee der Pflicht wäre sinnlos, weun dieser Gegensatz getilgt wäre, denn in einer vom Sollen vollkommen durchdrungenen Welt würde es keine sittlichen Aufgaben mehr zu erfüllen geben, und in einer menschlichen Gemütsverfassung, in welcher der Gegensatz von Pflicht und Neigung vollkommen getilgt wäre, gibt es keine Erhebung und Utberwindung, keine moralische Verfassung und sittliche Leistung mehr. Die Einheit von Sein und Sollen bleibt wie die Úberwindung des Gegensatzes von Begriff und Anschauung eine regulative Idee, und das ganze wissenschaftliche und sittliche Leben der Menschheit ist in dieser Welt zu einem Zustand der Vorläufigkeit verurteilt. Niemals kann es die Vollendung erreichen.

Ganz anders auf dem Gebiete der Kmust. Jedes Kunstwerk wird zweifellos aus einem Gegensatz heraus geboren, aus einem Gegensatz, der in dem Künstler vorhanden ist und der zur Versöhnung drängt. Es ist das der Gegensatz zwischen unserer bewußten reflektierenden Natur und unserer unbewußten instinktiven. Nit jener hängt vor allem die Welt des Denkens, mit dieser die Welt der Handlung und der Tat zusammen. Weder kann die bewußte noch die unbewußte Tätigkeit allein das Vollendete erreichen, aber durch ihr inniges Zusammengehen wird es erreicht und nach schweren Leiden und inneren Kämpfen das Werk der Schönheit geboren. Denn wir dürfen den Künstler nicht so verstehen, daß er mühelos aus dem ihm gegebenen Überfluß das Werk erzeugt, sondern die Harmonie, die wir im Kunstwerk finden, ist aus dem Gegensatz geboren. In dem Kumstwerk ist dieser Mangel und Widerstreit vollkommen getilgt, und in der Vereinigung der Gegensätze tut sich im wahrhaften Kunstwerk das Göttliche kund. In ihm empfinden wir das Unendliche und Ewige als sichtbar und gegenwärtig. Während also für die Wissenschaft und Kunst das Unendliche als Ziel gesetzt ist, gehört die Unendlichkeit zu jedem wahren Kunstwerk. Wir schen in ihm dic paradoxe Forderung erfüllt, daß das Unendliche im Endlichen erscheinen soll, wir erleben in der fragmentarischen Welt der Sinne das Vollendete und Vollkommene. Während also dic Wissenschaft und die Sittlichkeit immer wieder auf ein Nenes hinweisen, ist dic Wclt des Schönen in jerlenn Kimstwerk vollendet.

Dic Superiorität des ästhetischen Wertes gegenüber dem theoretischen und ethischen bofähigt ihn. als Wertmesser des historischen Geschehens zu dienen. Und zwar macht Schelling in doppelter Weise von diesen Charakter des Sehrinen Gebranch. Eimmal, sofern er zeigt, daß der theoretische und moralische Wret in ästhetischen aufgehoben sind und so im Grunde genommen scinc. Grenze und Einseitigkeit bedeuten; anderseits aber auch, indem er dentlich macht, dals jede form des Kulturlebens Stufen zu durehlaufen hat, die dem 'Thern'etischen, MIoralischen und Ästhetischen entsprechen. Oder, noch allgemeiner in r.r. 'T'rminologie Sehellings ausgedrückt, daß das Kulturleben, das als Gimzes natïrlich die idealo Potenz des Universums bildet, in seiner Entwicklung zunerst die Form des relativ Realen, dann die Form des relativ Idealen und schlirolich als Ilarmonic des Idealen und Realen, ein Verhältnis, das Schelling 
auch wohl als Indifferenz und Identität bezeichnet, die Gestalt der Schönheit annimnit.

Indem nun Schelling die historische Entwicklung unter dieses Schema stellt, macht er folgende Ineinssetzungen, die ihm aus der Vorgeschichte der Geschichtsphilosophie gewissermaßen entgegengetragen wurden. Er verbindet den Begriff des Theoretischen mit der Idee des Naturhaften, des Instinktiven und Unbewußten und vereinigt sie zu dem Begriff des realen Faktors. Anderseits vereinigt er den Begriff des Moralischen mit der Idee des Kulturhaften, Historischen, Reflektierten und Bewußten zu dem Begriff des idealen Faktors. Wenigstens kann man sagen, daß es für die Geschichtsphilosophie auf diese Ineinssetzungen hinauskommt, während die Logik Schellings ursprünglich im Gegensatz zu Fich te das ideale Prinizip viel mehr mit dem Theoretischen als der begrenzenden Tätigkeit und dem Prinzip des Bewußten rerband, indem er das Gebiet des Praktischen als das Reich des zunächst und an sich noch unbewußten IVillenslebens und des Instinktiven, Grenzenlosen rerstand, das er dann unter dem Begriff des realen Faktors zusammenfaßte.

\section{l) Stadien der Menschheitsentwicklung.}

So ergibt sich für Schelling das Schema, daß alles Kulturleben zuerst in der Form des Theoretischen, Naiven, Instinktiven und Cnbewußten als seinem relativ naturhaften Zustand, sodann in dem Charakter des Moralischen Sentimentalen, Reflektierten und Bewußten als seinem relatir historischen Zustand erscheint, um schließlich in einem künstlerisch harmonischen Zustand. der weder den einen noch den anderen Faktor überwiegen läßt, zu enden.

Wenn er an den Anfang des Menschengeschlechts denkt, so faßt er ihn als einen Zustand der naiven Schönheit und Unbewußtheit auf, in dem der Instinkt die unbedingte Herrschaft hatte. Dieser Auffassungszustand spiegelt sich wieder in dem ersten großen Kulturzentrum der Menschheit, in der Mittelmeerkultur der Griechen. Hier erscheinen in der 'Tat alle Institutionen und Einrichtungen geschmückt mit dem Zauber einer naiven Schönheit in der ruhigen Einheit des Sinnlichen und Geistigen, ohne Gegensatz und Widerstreit. Gleichzeitig aber stand in diesem Zeitalter alles in Zeichen des Theoretischen. sofern das kontemplatice Leben als das Höchste gefeiert wurde, eine strenge Einordnung in das Walten der Natur erfolgte und die ewige Wiederkehr des Gleichartigen als etwas Selbstverständliches erschien. In diesem Sinne kann man gewiß sagen, daß die naive Schönheit des Griechentums Natur bedeutete, sofern die Natur idealisiert und verklärt wird und als der einzig würdige Gegenstand der Betrachtung gilt.

Diese ursprüngliche Einheit der unbewußten Schönheit, in der der theoretische Wert seinen leuchtenden Glanz über alle Dinge fallen lie 3 ; mußte notwendig zerstört werden, um dem Prinzip des Gegensatzes Platz zu machen, das nun in dem Verhältnis ron Sein und Sollen, ron Pflicht und Neigung als die moralische Form der Kultur hervortrat. Das Glück der Sime, das den naiven Zustand der Menschheit verschönt hatte, ist in seiner Unschuld ein für allemal dahin; denn die Reflexion und das Wissen haben die simnlichen Triebe schuldig gesprochen, und das Sollen hat sich zum Kampf gegen die sinnliche Natur des Menschen erhoben. Da nun die Schönheit des Lebens notwendig auf Einheit 
und Harmonie beruht, so kaun der neuen romantischen Kultur, die durch das Christentum inauguriert wurde, nicht das Prädikat der Schönheit zugesprochen werden. Sie ist eine große Zeit des Úberganges, denn unmöglich kann der Gegensatz die menschliche Entwicklung abschließen. Durch das siegreiche Prinzip der Moralität wird das Tun und Leisten zum Ideal des menschlichen Lebens erhoben. Auf allen Gebieten der Kultur tritt der Gegensatz her ror, nieht zum wenigsten auf politischem und sozialem Gebiet, wo es zu sch weren Konflikten und revolutionären Bewegungen führt. Das ideale Prinzip ist nunnehr im historischen Leben das relativ herrsehende, und die romantische Kunst, welche überall Zerrissenheit und Sehnsucht nach dem Unendlichen offenbart, ist ein getreues Spiegelbild dieser großen, von sehweren Kämpfen und Gegensätzen erfüllten Menschheitsepoche.

Das Zeitalter der Erfüllung steht noch beror, es liegt in ferner Zukunft. Der endgültige Zustand des Mensehengesehleehts wird der ästhetische sein, demn der ästhetische Wert hat ganz allein die Macht, die verschiedenen Formen des Kulturlebens zu allumfassender Eimheit zu führen. Im ästhetischen Staat rollendet sich das Menschengesehlecht, denn in der Schönheit liegt die höehste Form des Lebens. Die endgültige Kultur und Lebensform aber ist die bewußte Schönheit, die sich zum Anfangszustand der Menschheit verhält wie die Schönheit der Kunst zur Schönheit der Natur.

\section{m) Politische Entwicklıng.}

Verfolgen wir dieses allgemeine Schema der Menschheitsentwieklung auf dem Gebiete des staatlichen, küustlerischen und religiösen Lebens. Der Staat der Griechen als die erste große Entfaltung der politischen Kultur zeigt das sittliche Leben nach all seinen Richtungen hin in vollkommener Einheit. Damals führte die Sittliehkeit gleichsam ein öffentliehes Leben und war nicht nur die versehwiegene Angelegenheit der einzehen Persönlichkeit, sondern, aus Sitte und Recht groß und stark herausgewachsen, umsehloß sie gleiehsam als Substanz das geistige Leben der Individualität. Die Noralität stand nieht in Gegensatz zu Reeht und Staat, sondern jene schmiegte sieh an diese und diese an jene an, so daß eine gemeinsane, ungeteilte Atmosphäre des Lebens weschaffen wude. Das staatliehe Leben entfaltete sieh zu Kunst und Wissenschaft und Nation. Ws bot jenen großen jenseitigen Mäehten keinen Widerstand, sondern lieberolle Pflege. Höehster sozialer Wert war damals der Staat und dic Religion; demn zur Hec der Mensehheit hatte sich der griechisehe Gerst noch nieht erhohen. Wemn somit das Prinzip der Nation in Griechenland las mafogebende war, so blieb es doch als Wert noch gleiehsam ungewußt und merkannt. Denn nur den Eigenwert der eigenen Nation umfaßte das (x)icehentmm mit Hingroung und Liebe. Nicht aber vermochte es das Prinzip rer Nationalität in seiner allecmeinen Bedeutung zu verstehen und auch in dem fremelen Volko die Ideeder Nation zu chren und anzuerkenuen. So hatte das Gicchentum auch kein bewulsste Verhältnis zur Kunst, insofern die Reflexion ïlxer dir Berlentung des künstlerisehen Lebens in ihren ersten Anfängen stehen b)lich). bist als die griechische Nation zugrunde gegangen war, erkannte der grierhische. Wrisc, welehe Berlentung die Kunst für den ganzen Zusammenhang der grierbisehen Kultur besessen hate. 1)anals hat Epilum die Schönheit zum 
Prinzip der Lebensführung erhoben und der große Denker Plotin das Schöne als den Geist verstanden, der durch die simnliche Hülle leuchtet.

Diese naive Sehönheit des staatlichen Lebens fand im christlich-romantisehen Zeitalter ihren Untergang. U̇berall traten jetzt entscheidende Gegensätze hervor, denn das Prinzip der Moralität verlangt den Kampf und die Ǔberwindung. Der geistliche Staat stellte sich dem weltlichen Staat, die Wissenschaft der Religion, die Religion der Wissenschaft entgegen. Die Kunst wurde in ihrer freien Entfaltung gehemmmt, und Reeht und Moralität traten sich feindlich gegenüber. Der Staat erschien nunmehr als das absolut Äußerliche, für die Entwicklung des geistigen Lebens nur in dem Sinne Bedeutsame, daß er Schutz und Schirm für Leben und Eigentum gewährte. Er war zu einer abstrakten Wesenheit geworden und wurzelte nicht mehr in dem tiefen Gefühl der Nation.

Dieser Zustand findet sein Ende im ästhetisehen Staat, der nicht nur das gesellschaftliche Leben, sondern alle politisehen und sozialen Verhältnisse und Einrichtungen sowie aueh die Fülle des Kulturlebens umfaßt. Jetzt ist der Staat wieder die Substanz, welche das geistige Leben trägt, dessen Wurzeln tief in seinen fruchtbaren Boden hineinleiten. Jetzt ist die Nation zum Staat und der Staat zur Nation geworden, die mit rollem Bewußtsein ihren eigenen Wert und den Eigenwert der anderen Nationen begreift. Nummehr gewinnt jede Form der Kultur in enger Verbindung mit dem Staat ihr eigentümliches Leben. Die Wissensehaft lebt in Gesetzgebung und Recht, die Sittlichkeit in dem Heroismus der Nation und die Kunst im öffentlichen Leben, das sie zur harmonischen Einheit fülırt, bis ins Innerste durehdringt und rhythmisch bewegt als die Schönheit seiner Erseheinung.

\section{1) Religiöse Entwicklung.}

Die Entfaltung des religiösen Lebens sucht Schelling aus dem religiösen Grundverhältnis des Endlichen zum Unendlichen zu verstehen. Nach der Vorstellung des Grieehentums ist das Unendliche und Göttliche im Endlichen als der Natur vollkommen gegenwärtig und rorhanden. Das Göttliche durchdringt die Welt und steht nicht im Gegensatz zu ihr. Es lebt mit ihr in vollkommener Eintracht. Im Endlichen und Begrenzten wird das Göttliche erschaut. In dieser Wertung offenbart sich das theoretisch-ästhetische Kulturbewußtsein des Griechentums.

In dem modernen romantischen Zeitalter ist das Endliche und Begrenztc dem Göttlichen als dem Unendlichen entgegengesetzt. Das Endliche ruht nicht mehr in der Einheit mit dem Unendlichen, sondern hat an ihm seine Schranke. Die beiden Welten stehen einander gegenüber, die reine geistige und die trübe sinnliche Welt. In der Idee des göttlichen Sohnes ist der Gedanke der Weltversöhnung gegeben. Mit ihm tritt das wahrhaft Endliehe in die Welt, die höchste bewußte Schönheit in dem Charakter seiner Liebe, welche die Welt nieht verklären, wohl aber erlösen und zu Gott zurüekführen will.

\section{o) Künstleris:he Entwicklnng.}

Am weitesten ausgebaut hat Schelling die geschichtsphilosophische Betrachtung der Kumst. Hier geht er von der Toraussetzung aus, daß der Stoff 
und Boden aller wahren Kunst die Mythologie sei. Die Mythologie ist der fruchtbare Boden, aus dem die Werke der Kunst hervorgehen. Ist doch die Mrthologie selber, dies flutende Chaos bunter, bewegter Gestalten, die ursprünglichste Werterscheinung der Menschheit, das Werk der produktiven Phantasie des schaffenden Weltgeistes. Nicht nur daß die Mythologie als Stoff der kïustlerischen Gestaltung ein reiches und bildungsfähiges Material liefert, sondern der Wert des Kunstschaffens ruht selber in den mythologischen Elementen und ihrer Gestaltung, weil sie allein dem Werke des Künstlers jene Tiefen geben, die bis zum letzten Weltgeheimnis herabreichen. Indem die romantische Sehnsucht die verschiedenen Lebensgebiete des Geistes zu einer großen Synthese führen wollte, mußte ihr die Mythologie gleichsam als Symbol dieser gesuchten und erhofften Einheit erscheinen. Denn in der Mythologie ist alles geistige Leben noch in ursprünglicher Einheit vorhanden. Hier atmen Religion und Sittlichkeit denselben Geist, und Wissensehaft und und Kunst berühren sich hier ummittelbar und sind noch nicht getrennt. Aus clieser schönen ursprünglichen Einheit mußte die Kunst in jener ersten großen Gestaltung, die ihr das Griechentum gegeben, Kraft und Stärke schöpfen. Was für die Philosophie der Griechen die Ideen bedeuteten, die Plat on entdeckt hat, das bedeuten für die griechisehe Kunst die Gestalten der Götter. Sie sind die künstlerisch geschauten Ideen. In ihnen ist der heilige Weltensinn umhüllt und umschleiert dureh ein schönes Gewand der Sinnlichkeit. Zum Wesen aller großen Kunst gehört das Geheimnis und die Umsehleierung und Verhüllung. Und das Wesen der kïnstlerischen Gestaltung ist darin beschlossen, daß durch die Fülle der Anschauung ein unendlicher Sim sieh verbreitet.

Aus der verborgenen Welt der Mythologie ist das Reich der griechischen Götter herrorgewachsen, eine sehön gegliederte und geordnete Welt, die von einem einheitlichen Prinzip beherrseht wirl. Sie ist so ruhig und sehön aufgebaut und kemnt keinen Kampf und schmerzliehen Gegensatz. Die griechischen Götter sind selig. Sie haben das Prinzip der Moralität hinter sich gelassen und wohnen jenseits von gut und böse. Jenes Unendliehe aber, das im Gewande der Mythologie verborgen liegt, nimmt in den typisehen Gestalten der Götter immer wieder eine nene Form an. All diese Göttergestalten bedeuten das Tnendliche, aber immer in einer ganz bestimmten Begrenzung. So ist etwa A pollo das Ideal der jungen mämnlichen Sehönheit, während das reife Alter ler vollendeten Männlichkeit in der erhabenen Gestalt des Zeus seinen adïquaten Ausclruek gefunden hat. Diese hohe Götterwelt hat die Plastik der (iriechen offenbart, und dureh die epische Dichtung Homers schreitet derselbe Geist, der in letzter Hinsicht durch das Gebot cincer sanften Notwendigkeit beherrscht wird.

Dic gricehische Kumst hat sich volliommen ausgelebt und entfaltet. Sic hat das clenkbar Höchste in einer ganz bestimmten Richtung erreicht und rrolient deswegen den sehönen und seltenen Namen des Klassisehen. Für die (hristlich-ronantische Kunst liegen die Verhältnisse zunächst weniger günstig. I lonn esf fohlt jene's ge'schlossene Reich des Mythologisehen, aus dem die griechische Kunst hervorgegangen ist. An ihrer Stelle steht hier das Legendarisehe, das von dem Mythologischen sich vor allem dadureh unterscheidet, daß es eine ilubliche Beziehung zur Zejt und zum historischen Geschehen hat, wie. 
der Mythos mit der Idee der Notwendigkeit und der Natur in ewigem Bunde steht. Die Legende geht dagegen mit dem Prinzip der Freiheit zusammen und ist von der Torstellung des Wunders erfüllt, das für die moderne romantische Kunst maßgebend ist, sofern ja ilir eigentlicher Gegenstand im Wunderbaren gesucht werden muß. In dieser modernen Kunst ist das Endliche nicht mehr in der Begrenzung restlos dargestellt, sondern riclmehr vom Endlichen distanziert und von der Form niemals erreicht und umschlossen. Insofern trägt diese Kunst ein Moment des Mangels in sich, das sich in der Gewalt ihrer Bewegung und in der Größe der Leidenschaft und Erregung ankïndigt, die in ihr zur Sprache kommt. Feiert doch diese Kiunst in ihren größten Gestaltungen clas rastlose Streben und die nimmer mïde Sehnsucht nach dem Unendlichen. Dieses Unendliche aber als der ästhetische Sim des Kunstwerkes überragt augenscheinlich die künstlerische Form des Griechentums. Was der romantische Dichter schaut und zu gestalten unternimmt, das ist so groß und mächtig, daß die Ausdrucksmittel ihnen ge genïber bis zu einem gewissen Grade rersagen müissen. So bleibt eine Spanmung, ein Dualismus bestehen, der nie ganz ausgefüllt ist, und der auch damit zusammenhängt, daß die Welt der Legende kein einheitliches Reich der Götter geschaffen und die Beziehung zum Historischen als dem immer Fragmentarischen besitzt. So fchlen der modernen Kunst die großen Symbole der Antike. Eine klassische Kunst ist nach Schellings Auffassung nur dann zu erreichen, wennn neue Symbole erzengt werden, die in derselben Weise auf ein theoretisches, einheitlich geordnetes Reich der Wahrheit hinweisen, wie die griechischen Götter als künstlerische Umschreibungen ron Ideen und Naturkräften aufzufassen sind. Dieses in sich ruhende und geschlossene Reich der Erkenntnis hat der deutsche Idealismus gecrliatfen, und in der Naturphilosophie liegen die Symbole für eine künstlerische Bewältigung des Universums bereit. Dennoch wird dicse neue Kunst der Klassik, die als Ziel des romantischen Zeitalters zu erwarten ist, nicht als Fortschritt gegeniiber der Antike aufzufassen sein. In der Entwicklung des staatlichen Lebens kann man ron Fortschritt sprechen, sofern der ästhetische Staat den nairen Naturstaat und den sentimentalen Staat der Moralität an Wert und Bedeutung ïbertrifft. Dagegen ist die klassische Kunst der Pomantik, die noch berorsteht. wohl ein Gleichwertiges gegenïber der Klassik der Antike, aber keineswegs ein wertvolleres Gebilde. Vielmehr vollendet sich die Entricklung der Kunst in zwei ganz rerschiedenen Dimensionen. Der eine Höhepunkt ist schon erreicht, der andere soll noch erklommen werden.

\section{p) Ende der Geschichte.}

Das Endziel der Entwicklung muß darin gesucht werden, daß alle Formen der Kultur wieder einmïnden in die Urform, ans der sie herrorgegangen sind, in den Ozean der Poesie. Schelling macht hier die Toraussetzung, daß alle Geistesgebiete in einer ursprünglichen Einheit standen. Diese ursprüngliche Einheit des geistigen Lebens kömnen wir auf allen Gebieten noch deutlich spüren. So ist es augenscheinlich. daß die verschiedenen Formen der Dichtkunst einen gemeinsamen Ursprung haben, daß eine ursprüngliche Form der Dichtkunst dramatische, epische und lyrische Elemente in sich enthielt. Auch ist es evident, daß eine auffallende Ähnlichkeit und Verwandtschaft zrischen den rerschie- 
denen Kunstformen besteht. Die Affinität zwisehen Plastik und Malerei ist ja mïhelos sichtbar. Es gibt eine malerische Plastik und eine plastische Malerei. Die Beziehung zwischen Musik und Dichtkunst ist leicht zu entdeeken. Auch haben wir eine Form der Diehtkunst, die mehr nach der Seite des Unanschaulichen und Musikalischen geht, und eine andere, deren plastischer Charakter sich nicht verkennen läßt. Schließlich haben die Romantiker sogar zwischen zwei scheinbar so entgegengesetzten Kunstformen wie Architektur und Musik eine Verwandtschaft herausgefühlt, wenn sie die Architektur eines gotischen Domes als gefrorene Musik bezeichneten.

Aber nicht nur zwischen den internen Gebieten der Kunst besteht die Terwandtschaft: Wissenschaft und Kunst weisen anfeinander hin, wie das Beispiel der Gesehichte lehrt, die ursprünglich in der Hauptsache ein Werk der schaffenden Phantasie war, und weiter auch aus der engen Beziehung ron Religion und Sittlichkeit und schließlich aus der ursprüngliehen Einssetzung des Guten und Schönen deutlich wird. So war der Ursprung gemeinsam und einheitlich, und zu diesem gemeinsamen und einheitlichen Ursprung wird sich der Gang der Entwicklung zurückwenden. Das romantisch moderne Bewußtsein ist gespalten. Es stellt das Universum unter versehiedene Potenzen und gelangt nicht zu einer einheitlichen Erfassung des göttlichen Wesens. Die Wissenschaft rermag in der Welt nur die Idee der Gesetzmäßigkeit zu entdecken, das sittliche Bewußtsein das Moralgesetz, die ästhetische Auffassung das, ,übersinnliche Substrat der Menschheit", das Rechtsbewußtsein die Gerechtigkeit, die Philosophie das Absolute, die Religion den unbekannten Gott. In immer wieder neuen Stellungen zur Welt rermag das Bewußtsein dem Göttlichen immer wieder neue Seiten abzugewinnen, sieht sich aber außerstande, die Gottheit in ihrer Totalität zu erfassen. Würden nun alle die Schranken fortfallen, die etwa das sittliche Bewußtsein rom ästhetischen und dieses wiederum vom wissensehaftlichen trennen, dann würden wir als ganze und ungeteilte Menschen dem einen und ungeteilten Universum gegenüberstehen. Damn wïrde ein eil1heitliches Wertbewußtsein die Totalität des Wertlebens verstehen. Dann würden für uns die Unterschiede dahinschwinclen, die wir m Absoluten setzen, weil unser Gesichtspunkt einseitig und besehränkt und unscre Einstellung immer wieder eine andere ist : dann würde die Wissensehaft Kunst und clie Kunst Wissenschaft sein. Damn würden wir im grenzenlosen Aufschwung unseres Lebens das Göttliche in seiner Totalitait verstehen und erfassen kömmen.

q) Die religiöse Geschichtsphilosophie des spïteren Schelling.

Diese ästhetische Geschichtsphilosophie des jungen Śchelling, in der das Wertbewnßsein der Romantik seinen vollendeten Auscluck ampfangen hat, wird rurch lie religiöse Geschichtsphilosophie des gereiften Maunes abgelöst. Ganz allmählich rollzicht sieh bej schelling diese Wendung von der Kunst zur Religion hin. Tud wemn die ästhetische Geschiebtsphilosophie zum 'Teil rine religiöso Phlysiognomie träigt so sind in cler roligiösen noch gewisse ästhetiseher Zü̈ge: zol erkemmen.

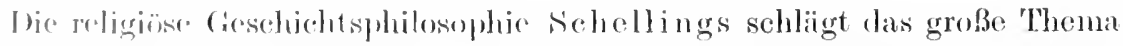

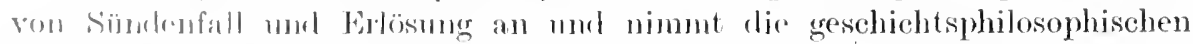
Sigckulatiunch of acob Bölumos und der Guosis auf. Dor Gegensatz, weleher 
bisher nur im Wertbewußsein der Menseheit rorhanden war, wird nummehr in das göttliche Wesen selber verlegt. Das religiöse Grunrlverhältnis ist das Verhältnis des Endlichen zum Unendlichen. Wir müssen aber unterscheiden zwisehen der sehlechten Unendlichkeit der simmlichen Dinge und der wahren, sehrankenlosen Unendlichkeit des göttlichen Wesens und desgleichen zwisehen der schlechten Endlichkeit des simnlichen Einzelwesens und der wahrhaften Endlichkeit der göttlichen Individualität und Begrenzung. Das Grieehentum hatte die Gottheit als das Ideal der Begrenzung und des Schönen, das ehristlichromantisehe Zeitalter als das Ideal der Unendlichkeit und des sittlichen Sollens verehrt. Die Gottheit ist die Einheit dieser beiden Gegensätze, des wahrhaft Endlichen und des wahrhaft Unendlichen. Beicle befinden sich in ursprünglieher Einheit und Harmonie. Das wahrhaft Endliche ist das Gegenbild der göttliehen Unendlichkeit. Sie sind die höehsten Prinzipien, ron denen alles Weltliche seinen Anfang und Ausgang nimmt.

Mit der Idee des wahrhaft Endlichen verbindet sich der Gedanke der Freiheit. Individualität und Begrenzung, Persönliehkeit und Freiheit gehören notwendig zusammen und bestimmen sich weehselseitig. Das Urpersönliche des göttlichen Ebenbildes, das nach Schellings Auffassung auch für die Idee der Menschheit typisch ist, hat die Mögliehkeit, im Absoluten zu verweilen und sieh ron ihm zu tremmen. Das Charakteristische der Freiheit ist, daß sie eine doppelte Möglichkeit setzt, zwischen denen eine ungehemmte Wahlentscheidung getroffen werden kamm. Die menschliche Natur ist so besehaffen, daß von verschiedenartigen Möglichkeiten, die ihr gegeben sind, immer nur ganz bestimmte realisiert werden kömmen und andere nieht. Die Sehellingsche Spekulation ist nun auf den Gedanken gerichtet, daß in Gott alle Möglichkeit auch zugleich Wirklichkeit ist. Infolgedessen vermag das göttliche Gegenbild, indem es sich von Gott trennt, doch aueh zugleieh in seiner liebenden Gemeinschaft zu verweilen. Notwendig mit Gott als dem Prinzip des Unendlichen verbunden, tritt er vermöge der Idee der Freiheit aus der Gemeinsehaft mit Gott hervor und trägt so den Gegensatz in dio Welt.

Sofern das Endliche sich rom Unendlichen trennt, entstcht die Simnenwelt, sofern es in der ursprünglichen göttlichen Einheit verweilt, bleibt die ewige Welt der Ideen rein und ungetrübt. Die Welt rerdankt somit ihr Entstehen nicht dem Weltplan der göttlichen Vorsehung, sondern vielmehr einem Akt ursprünglieher besinnungsloser Freiheit, der in der ganzen Natur des Göttlichen angelegt war. Ein plötzliehes Abbrechen der Kontinuität und Verbindung zwisehen den Urprinzipien der Welt läßt das Unicersum in Zeit und Raum entstehen.

In dieser Lehre Schellings tritt die Paradoxie in unverhuillter Form hervor. Das Endliche löst sich rom Unendlichen ab und bleibt doch auch wieder mit ihm verbunden. Das verstößt augenseheinlich gegen den elementaren Satz des Widerspruches. Das kam aber wenig bedeuten, weil das Prinzip des Widerspruches nach der Auffassung des deutschen Idealismus nur für endliche Verhältnisse gilt und in der Anwendung auf das Ewige jede Bedeutung einbüßt. Schelling sehaut, indem er über das Problem der Weltentstehung nachgrübelt, das Universum als Prophet und Künstler an. Dem religiösen 
Bewußtsein macht die Vorstellung, daß Gott jenseits der Sinnenwelt in vollkommener Transzendenz verweilt und doch auch gleichzeitig wieder die Sinnenwelt erfüllt, keine Schwierigkeit. Und ebensowenig stößt es sich an der Vorstellung, daß Christus in der Gemeinschaft Gottes und doch auch gleichzeitig auf Erden weilt. Und wie das Kunstwerk den logischen Widerspruch zu ertragen vermag, so auch nach Schellings Auffassung das religiös-künstlerisch geschaute Universum.

Allerdings liegt eine ungeheure Paradoxie in der Behauptung, daß die Sinnenwelt ist und nicht ist, nämlich existiert, sofern die Möglichkeit der Freiheit zur Entfernung von der Einheit des göttlichen Urbildes führt, und nicht existiert, sofern das Gegenbild die andere Möglichkeit seines Seins erfüllt und in der Einheit mit Gott danernd verharrt. Soviel ist gewiß, daß die Entfermung des Gegenbildes ron Gott die Unvollkommenheit unserer sinnlichen Existenz verschuldet, daß sie uns aber gleichzeitig das Licht der ïbersinnlichen Welt in der Idee der Freiheit gegeben hat, das einzig Göttliche, das unmittelbar in der Sinnenwelt anzutreffen ist. Mit unserer Beschränktheit und Unvollkommenheit, die in der Entfermung von Gott beruht, ist also auch gleichzeitig wieder unsere Größe und Menschlichkeit in der Idee der Freiheit gegeben. Das Eigentümliche dieser geschichtsphilosophischen Voraussetzung, dieses Geschehens im Zeitlosen liegt vor allem darin, daß der „Sündenfall“, der die Welt erschuf, die ureigenste Tat der Gottheit ist, daß das Werden der Erscheinungswelt als das Werden in der schlechten Unendlichkeit und der simmlichen Individualität zugleich das Wertmoment der Freiheit als Dokument des wahrhaft Göttlichen auf die Sinnenwelt verbreitet. Ein radikal Böses kennt diese Philosophie nicht, und der ,Sündenfall“, ,ler sich im Absoluten ereignet, läßt die Harmonie dieser Welt unberührt. Nur wird durch ihn die Erscheinungswelt hervorgerufen, in welche die Individualität ein von Gott getremutes Dasein lebt.

Inrlem nämlich das wahrhaft Endliche, der Idee der Freiheit folgend, aus den Zusammenlang mit dem Göttlichen sich loslöst, entsteht die sinnliche Wrklichkeit, ron simnvollen Kräften gebildet, in welcher die Individualität in einsamer Gottesferne wohnt. Dies Prinzip) der Individualität erreicht seine äußerste Kraft in der Idee der Persönlichkeit des Menschen, welche dem Allgemeinen und Gattungsmäßigen in ilırer Eigentümlichkeit und Originalität an meisten entgegengesetzt ist. Die große Individualität bedeutet die absolute Partikularität gegenüber dem einen göttichen Willen. So cigentümlich eine Persönlichkeit gebildet ist, desto größer ist ihre Gottesferne. Mit der hochcntwickelten Porsönlichkeit ist der Prozes der Entfernung der Welt von Gott vollended, gleichzeitig aber ist auch derjenige Punkt erreicht, da die Welt wieder zu Gott in der historischen Bewegung zurüklehrt. Niemand ist Gott so nah und so fern wie die grofe Persönlichlieit, welche in lem Geschehen der Welt dort ihre Stelle einnimmt, wo dic Ablösung von der göttliehen Einheit, die im Wrolon dor Natur sich offenhart, nicht mehr weiterschreitet, sondern die

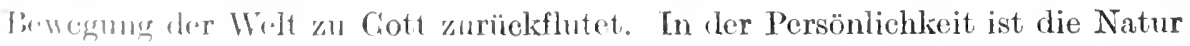
und dianit der Ferressus rollendet, und mit der Persönlichkeit beginnt der Ringersus und dio Geschichte. Das absolut Individuelle in seiner simnlichen (irintalt ist Gott forn, weil es die. Iflee der absoluten Einheit verneint, und 
es ist Gott nahe, weil nur mit ihm sich del göttliche Wert der Freiheit verbindet.

In der Natur vollendet sich der Prozeß der Individuation, die zerstreute Mannigfaltigkeit und Fülle, das Prinzip des Gegensatzes. Es ist die Welt der Ruhe und Bewegungslosigkeit, die das Prinzip des Fortschritts nicht kennt. Wahres Leben und Bewegung beginnt erst dort, wo die vernünftige Persönlichkeit die Gestaltung der Welt übernimmt. Und wenn das schöne Wunder der Individualität erreicht ist, dann kommt das Göttliche unmittelbar dem göttlichen Menschen zu Hilfe. In Kunst, Wissenschaft und Religion offeubaren sich die göttlichen Ideen und führen das Irdische und Sinnliche zum Himmlischen und Übersinnlichen empor.

\section{Die theoretische Geschichtsphilosophie.}

Es blieb der Philosophie des deutschen Idealismus vorbehalten, alle möglichen Formen der Geschichtsphilosophie zu entwickeln, und so finden wir denn nach der ethischen Geschichtsphilosophie Fiehtes und nach der ästhetischen und religiösen Schellings die theoretische Geschichtsphilosophie Hegels als die Vollendung des geschichtsphilosophischen Gedankens in Deutschland überhaupt. Sie ließ ihren großen und mächtigen Schatten auf alle Theorien der Vergangenheit fallen und hat es zeitweilig den Blicken späterer Generationen rollkommen entzogen. Wie das gewaltige System Hegels alle Leistungen der Tergangenheit noch einmal zusammenfaßte, aber nicht als leeres Konglomerat, sondern indem es ihnen eine neue Seele gab, so hat auch seine Geschichtsphilosophie die Arbeit der vergangenen Jahrhunderte in ihren Kreis gezogen und sie in einem ganz neuen Lichte erglühen lassen. Das höchste Wertmoment aber auch für das historische Geschehen konnte für Hegel nur die Erkenntnis des Absoluten sein, in diesem Doppelsinne, daß die absolute Erkenntnis Gottes von seiten der Menschheit auch gleichzeitig das absolute Wissen der Gottheit ron sich selber bedeutet. Das ist die Position und der Ausgangspunkt der Hegel schen Geschichtsphilosophie, die den Triumph und unerreichbaren Wert der theoretisehen Erkenntnis offenbart. Und wie nach Spin o z a die sehnsüchtige Erkenntnisliebe des Menschen mit der Liebe Gottes zu sich selber zusammenfällt, so spiegelt sich auch nach Hegel in der logischen Erkenntnis des Menschen ron den höchsten philosophischen Wahrheiten das Sichselbstverstehen und -erkennen des absoluten Geistes wieder.

a) Stellung der Geschichtsphilosophie im System.

Wenn wir in dem großen Hegelschen System den logischen Ort der Geschichtsphilosophie suchen, so finden wir sie dort, wo sich die Entwicklung des objektiven Geistes vollendet. Die Philosophie des Geistes zerfällt in drei Teile: in die Philosophie des subjektiven, des objektiven und des absoluten Geistes. In der Philosophie des subjektiven Geistes wird die menschliche Seele gedentet und verstanden, sofern sie noch nicht in ein rerstehendes Verhältnis zu absoluten Werten getreten ist, und sofern sie noch nicht die Kraft und die Tätigkeit besitzt, in Sehöpfungen der Kultur die Vernunft auf Erden heimisch zu machen. Ihr weitaus bedeutsamster Teil ist die Phänomenologie 
des Bewrußseins, die uns die mannigfaltigen Stellungen des Ich zum All deutlich macht. In dieser Phänomenologie handelt es sich um die Entwicklung des naiven Bewußtseins zum wissenschaftlichen und philosophischen hin. Wenn die Geschichte der Philosophie die Entwicklung des philosophisch-wissenschaftlichen Bewußtseins gibt, also die Geschichte der Weltanschauungen, Lebensbeurteilungen und Koulturdeutungen, die der spekulative Geist an den Erscheimmgen rollzogen hat, wenn die Geschichtsphilosophie ihrerseits die Gesamtheit der Kulturphänomene, also auch die philosophischen selber, ron einem gemeinsamen Wertmaßstab aus zu rerstehen und zu deuten unternimmt, so hat es die Phänomenologie mit der Unmittelbarkeit des seelischen Erlebens zu tun, das ohne philosophisehe Reflexion in ursprünglicher Naivität zu den Erscheinungen des Weltlebens Stellung nimmt. In der Phänomenologie handelt es sich um eine Darstellung und Beschreibung der Deutungen und Auffassungen, welche der Volks- und Mensehengeist gebildet hat in der Betrachtung der Sinnenwelt über Dasein und Wirklichkeit, in der Betrachtung des Lebens über Ziel, Sinne und Zweek, in der Ahnung einer übersinnlichen Welt von Gott und Jenseits, in der Hingabe an soziale Verbände über Familie, Herrschaft und Knechtsehaft, in dem Bewußtsein einer Naturordnung ron Gesetz und Kraft. Diese Wandlungen in den Wertsetzungen und in der Stellungnahme des naiven Bewußtseins zur Wirklichkeit überhaupt sowie speziell zu den einzelnen Gebieten des Lebens und der Kultur sucht die Phänomenologie als eine philosophische Disziplin in ihrer Notwendigkeit zu erweisen und in ihrem Zusammenhang zu konstmieren. Das naive Bewustsein steht unmittelbar den Erfahrungen gegenüber, die es gemacht hat, und vermag das Entgegengesctzte nieht zusammenzureimen. Der Philosoph vermag hinter den Rïcken des naiven Bewußtseins zu sehen und die Entwicklung der Vernunft zu erkennen, die sich für jenes insgesammt in einheitlich großem Zusammenhang vollzieht. Und so stellt er zwisehen der bunten Fülle der Impressionen und Einfälle, die das phänomenologische Bewußtsein erlebt, einen simnrollen Zusammenhang her, der einem bestimmten Ziele zustrebt. Diese Jugendgesehichte des theoretischen Bewubtseins, diese dilettantisehe Auffassung ron Welt und Jeben, die zu immer neuen Paradoxien führt, muß in rer Reife des wissenschaftlichen Bewristeins ihr Ziel und Ende haben. So sind alle diese Auffassungen und Deutungen, die das historisehe Leben der Menschheit erzeugt hat, als eins Torschule des gereiften Kulturbewußtseins und speziell auch des wissenschaftliehen Lebens anfzufassen. Dabei ist die phänomenologische Botrachtung der Bewußseinsentwicklung nicht eigentỉch eine historische, sofern sie immor nach neuen Stadien des Bewußtseins ausschaut und diese nicht schon dort registriert, wo sie sporadiseh auftreten, sondern erst damn von ahnen Gebranch macht, wenn sic ihre Reife und Tollendung erreicht haben.

\section{b) Die Sphäre des objoktiven Geistes.}

Die Juhre rom ohjektiven Grist ist dic Kulturphilosophie Hegels. Sie hat as mit der kulturschaffonden 'aitigkeit dor Mensehen zu tum, mit der sinnvollen Formung und Oremmer des Lchens, und zorfällt in die Lehre vom Recht, won cker Joralitiit und der Sittliehlecit. Die Lelure von der Moralität handrelt von drer Individualethik und gipfelt in dem Begriff der Persönlichkeit, 
weleher dem juristisehen Begriff der Person als des Reehtssubjektes scharf gegenübergestellt wird. Die Lehre rom Begriff der Sittlichkeit hat es mit den objektiven Erseheimungen des sittlichen Lebens in Familie, bürgerlieher Gesellschaft und Staat zu tun. Der Staat ist die konkrete, objektiv gewordene sitt. liche Vernunft, und an ihn knüpfen die gesehichtsphilosophischen Betrachtungen Hegels an, der gerade in der Bewegung des staatliehen Lebens den wesentlichen Gegenstand für die gesehiehtsphilosophisehe Betrachtung zu erkennen glaubt.

Die Geschichtsphilosophie folgt auf die Staatsphilosophie. Diese sucht einerseits die innere Struktur des Staates zu verstehen. Dann betrachtet sie weiter das Verhältnis der Staaten unter einander. Und dieses Verhältnis ist trotz aller völkerrechtliehen Abmachungen ein Verhältnis des Gegensatzes und Kampfes. Indem die großen Staaten gegen einander crregt und bewegt werden, entsteht das Problem der Weltgesehichte. Die großen Völker ringen um ihre Existenz und um die Eigentümlichkeit ihres nationalen Daseins. Sie kämpfen um Macht und Herrschaft, um irdisehe und himmlische Güter. Was aber ihre Größe und Kraft ausmacht, das ist ohne Frage in erster Linie die Energie des sittlichen Lebens, das sie führen. Solange die sittliehe Vernunft in einem Volke mächtig ist, solange sie in ihm eine wahre Heimstätte gefunden hat, solange hat das Volk ein Anrecht auf welthistorisches Leben. Fehlt dem Volke die sittliche Kraft, so ist aneh sein Dasein gefährdet und beclroht. Denn die sittliehe Kraft allein kann Zucht und Ordnung und Sitte in einem Staatswesen herstellen und ein Volk dahin führen, dem Genius des Vaterlandes die sehwersten Opfer zu bringen. Der Geist des Staates und die Seele des Volkes ist die sittliehe Substanz. Kunst und Wissensehaft können im Verhältnis zum Staat nur als Sehmuck und Zierde, nieht aber als Lebensbedingung betrachtet werden.

Mit dieser Lehre Hegels, daß die nationale Größe eines Tolkes von seinem sittliehen Charakter abhängt und daß der Nangel an sittlicher Gesimnung den staatlichen Untergang nach sich zieht, rermag seine andere Auffassung sehr wohl zusammenzugehen, daß die Beweggrimde, welehe dic historischen Persönlichkeiten und Tölker leiten, wenn sie zu welthistorisehen Taten sich erheben, nur in den seltensten Fällen deutlich gesehaute sittliehe Itleale, sondern in der Regel Motive der Leidensehaften und des Ehrgeizes, des rüicksichtslosen Egoismus sind. Tenn Hegel in der Nation und im Staate die sittliche Vernunft verwirklicht sieht, so bezicht sieh das vor allem und in erster Linie auf die von der Liebe und Anerkenmung der Nation getragene Ordnung der sozialen Verhältnisse, auf den Geist des Gehorsams und der Aufopferung gegenüber dem sozialen Ganzen. Deswegen kann doch der einzelne und ror allen der Große und Mäehtige, das auserlesene Werkzeng für die großen Erregungen des historischen Lebens, deshalb kann auch das welthistorisehe Tolk in seinen nach auswärts gerichteten Taten ron dem Prinzip einer rüeksichtslosen Machtpolitik und ron dem brennenten Feuer des Ehrgeizes getrieben sein.

\section{c) Hegels absolute Werte.}

Wenn nun die sittliche Termunft für das Wesen des Staates entscheidend ist und der Begriff der Gesehichte sich anf das engste mit der Idee des Staates 
rerbindet, so haben augenscheinlich Religion, Philosophie und Kunst nicht dieselbe innige Beziehung zum historischen Leben wie Recht und Staat. Einerseits hat Hegel die Idee einer allgemeinen Kulturgeschichte betont, indem er auf das sorgfältigste den verschiedenen möglichen Formen der historischen Darstellung nachging, anderseits hat er die vorher genannten Werte doch einer besondere Sphäre zugesprochen und in seiner geschichtsphilosophischen Betrachtung ihre Entwicklung nur in sekundärer Weise der Entwicklung des politischen Lebens hinzugefügt. Religion, Kunst und Philosophie sind nach Hegel die absoluten Werte, die über die Sphäre des objektiven Geistes, die sich im Staat vollendet, hinausgehen. Er konstruiert sie im Sinne einer fort. schreitenden Entwicklung, aber er vermeidet es, ihnen eine feste Beziehung zum historischen Geschehen zu geben und sie so dem geschichtsphilosophischen Gedanken unterzuordnen. Bis Hegel hat sich also jene Kantische Idee behauptet, daß die Geschichte, und dementsprechend auch die Geschichtsphilosophie, in erster Linie mit dem Staat und der moralischen Idee der Freiheit zu tun habe.

In dieser Höherschätzung der absoluten Werte gegenüber dem sittlichen Wert liegt die tiefc Einsieht verborgen, daß es sich hier um eine ganz andersartige Struktur des Wertvollen handelt, sofern es nämlich der sittliche Wert immer mit der Idee des Fortschritts und des Endzwecks zu tun hat und das Reich der Vollendung einer späten Zukunft aufbewahrt, während zu der Natur der absoluten Werte ohne weiteres die Vollendung gehört. Jede sittliche Tat ist eine Anweisung auf das Reich der sittlichen Vernunft und der Freiheit, das da eimmal kommen soll, aber in jedem wahren Kunstwerk ist die Vollendung vorhanden. Wenn Hegel somit die absoluten Werte über die Geschichte hinaushebt und ihre Entwicklung gesondert in der Lehre rom absoluten Geist als Kunstphilosophie, Religionsphilosophie und Philosophie der Philosophie bchandelt, so läßt sieh doch sehr wohl ein weiterer Begriff der Geschichtsphilosophie bilden, dem auch diese Gebiete angehören. Ferner ist es ganz deutlich, daß trotz der won Hegel gestifteten Bezichung zwischen sittlicher Ternunft, Staat und Gesehiehte der Charakter der historischen Begebenheit nicht im Lichte der Moralitït, sondern im Lichte der Erkenntnis betrachtet wirl.

\section{d) Die Objektivität der Geschichte.}

Wohl wenige Denker haben so tiefe Blicke in den Gang der IVeltgeschichte getan, wenige wie er den Geist und Simn der historischen Forschung und Auffassung verstanden. Er hat die cinfache Lösung für die noch heute vielumstrittene Frage gefumlen, ob der Historiker vollkommen interresselos und kontemplativ wie der Aristotrlische Gott dem historisehen Geschehen gegeniibrorstehen oder Partei ergreifen soll. Scharf zugespitzt ist clas clie Frage, ob dar Historiker sein cigenes Ich, seine Persönlichkeit auslöschen oder seine Prö̈nlichkeit in dir historischen Ereignisse in licberoller Gestaltung hineinlougn soll. Auslöselien soll der. Historiker nach Hegels Lehre jeden kleinlich(en) Jarteistandpunkt, indem er den sinn für wahrhafte Größe kultiviert murl groli, unl ïberlegen scinen Standpunlet der Betrachtung wählt. Aber anderseits muls or glibend interressiert sein für die Sache und absolut Partei 
sem für die Kultur, genau in derselben Weise wie der Piehter Partei ist für das Recht.

Niemand ist so scharf wie er einer einseitig moralischen Auffassung der Geschichte entgegengetreten. Die Helden der Geschichte dïrfen nicht mit moralischen Maßstäben gemessen werden. Der Historiker muß sich hüten, ihre Leistungen vor das Forum der bürgerlichen Moral zu ziehen. Die Helden der Geschichte stehen jenseits von gut und böse. Historische und moralische Größe fallen sehr häufig weit auseinander. Auch muß sich die historisehe Betrachtung vor einer gar zu peinlichen und kleinlichen Analyse hüten. Immer wirl es sich in der Geschichte um einen großen Stil der Idlealisierung handeln. Immer muß der Historiker die Gestalten des geschichtlichen Lebens aus einer gewissen Ferne erschauen. Denn ror seinem Kammerdiener mus auch der Helcl notwendig klein erscheinen. Wir diurfen beim Helden nicht anf diejenigen Dinge Gewicht legen, die er als sterblicher Mensch mit allen anderen gemeinsam hat, sondern vielmehr auf dasjenige, was ihm vor allen anderen eigen ist und auszeichnet.

\section{e) Die Verunnit des historischen Geschehens.}

Und wie stellt sich nun dem großen Denker das Bild der Geschichte dar? Unmöglich ist es nach Hegel, das historische Leben ohne Annahme und Toraussetzung einer überindividuellen Vernunft zu verstehen. Wie sollte es sonst möglich sein, daß diese ungeheuere Fülle entgegengesetzter Zielsetzungen und Pläne zu einem sinnvollen Ganzen zusammenstimmt? Denn jedes Individuum begehrt doch im Grunde nur das, was ihm zuträglich ist. Seinen Vorteil und Nutzen will es erreichen. Wie sehr aber führt auseinander persönliehes Glüeksstreben und eigenmächtiges Verlangen. Niemals würde eine rernünftige Ordnung der menschlichen Verhältnisse entstanden sein, wenn nicht eine starke und unwiderstehliche Macht die widerstrebenden Elemente zu einer Einheit verbunden hätte. Diese Macht der Vermunft erscheint num aber in der Geschichtsphilosophie Hegels weder als sittliche Idee noch als ästhetische schauende und schaffende Kraft noch als die planvolle und fürsorgende Absicht einer gnädigen und gütigen Gottheit, sondern gewappnet und gepanzert als ein rücksichtsloser, brutaler und kriegeriseher Geist. In clieser Auffassung der Vernunft liegt die Verwandtschaft zwischen Hegel und Heraklit. Da. mit ein großes und gewaltiges Geschehen sich auslösen kann. ist der Gegensatz erforderlich und der Krieg. Wahrlich, von Liebe und Harmonie können wir wenig in der Geschichte erblicken. Um so mehr aber ron Streit und Gegensatz, von Kampf und Sieg und Untergang. Wild und kampffreudig erscheint die Vernunft in der Geschichte. Sie ist nicht planlos, sie arbeitet auf ein bestimmtes Ziel hin. Aber von diesem Ziele können wir nur eine unbestimmte Idee haben. Im einzelnen bleiben uns die Pläne des Weltgeistes rerborgen. Wenig Rücksicht nimmt er auf die Individuen. Er tut mit ihnen nach seinem Gefallen. Ohne Mitleid scheint er zu sein, kalt und grausam. Über Leichen und traurigen Untergang geht sein Triumphzug. Er bemächtigt sich der Indiriduen und Völker und stellt sie in seinen schweren Dienst. Denn nicht ein leichtes und schönes Spiel, sondern eine harte und saure Arbeit bedeutet die Weltgeschichte. 
Der absolute Geist, wie er in der Geschichte erscheint, gleicht den großen Cäsaren, welche die Individuen skrupellos in ihren Dienst zwingen, oder die Helden der Geschichte gleichen dem absoluten Geist. Úber Leichen und Schlachtfelder geht er dahin und zwingt die Individuen zu Taten, die sie niemals beabsichtigt und gewollt haben. Er nutzt die Individuen aus und läßt sie ihre besten Kräfte einsetzen, um sie dann später, wenn sie ausgenutzt und aufgebraucht sind, wegzuwerfen wie leere Hülsen. Die Individuen glauben ihren eigenen Plänen zu dienen, in ihrem eigenen Interesse glauben sie zu handeln und dienen den ihnen verborgenen Absichten des Weltgeistes. Das ist die „List der Vernunft".

Wenn so die Vernunft in der Geschichte dem flüchtigen Beschauer roh und gewaltsam und hinterhältig erscheinen muß, so erschließt sich bei genauerer Betrachtung ihr tiefes und bedentsames Wesen. Der Geist der Geschichte, wie er anfangs erscheint, ist noch ohne Kenntnis seiner eigenen ab. gründigen Natur. Durch das historische Geschehen wird das Bewußtsein zum Selbstbewußtsein. Indem der Geist zum Bewußtsein seiner selbst gelangt, bildet er ein vernünftiges und geordnetes Leben. An die Stelle der Unkultur setzt er Recht und Sitte. Je besser er sich versteht, um so schöner baut er seine Welt auf. Alle Formen der Kultur werden von Hegel in letzter Hinsicht als Formen des Wissens aufgefaßt. In der Idee des Staates ist das Absolute noch nicht verstanden und hat sich auch das Absolute noch nicht begriffen und verstanden. Höher ist die Erkenntnis des Absoluten in der Kumst, wo der Weltgeist vollkommen erschaut wird, aber lediglich geschaut und noch nicht vorgestellt. Die wahre Vorstellung von Gott gibt erst die Religion als eine höhere Stufe des Wissens der Gottheit von sich selber und der Mensehheit ron Gott. Und die rollendete Gotteserkenntnis findet sich in der Philosophie, wo das Absolute sich selbst begreift und begriffen wird. In den großen Werken der Kunst wird Gott immer vollständiger und schöner gesehaut, in der Entwicklung der Religion mit immer reicheren und tiefsinnigeren Symbolen vorgestellt und schließlich in der Philosophie immer mehr begriffen und verstanden.

In der Geschichtsphilosophie Hegels dominiert also mehr wie in jeder anderen Form der Geschichtsphilosophie des deutschen Idealismus einseitig ein bestimmter Wert, und zwar in diesem Falle der theoretische. Fühlen, Ahnen, Glauben, sittliche Überzengung, sie alle sind in letzter Hinsicht untergeordnete Formen des Wissens, das sich nur in der Form des Begriffes vollkommen rein offenbart. Die höchste Wissensform ist die durch den Begriff vermittelte, nicht etwa ein unmittelbares religiöses Gefühl. Weit mehr bedeutet die scharfe und klare Begriffserkenntnis wie jene Fülle des Lebens, die von den religiösen und kïstlerischen Symbolen angedentet ist. Hegel geht von der Voraussetzung aus, dals der ticfste Sinn der Welt in cler Idee der Erkenntnis ruht, und daß anch die anderen Kulturformen niehts anderes wollen können wie eine Art des Wissens zu geben von Gott und der Welt. Er schließt die Möglichkeit aus, disls das Ziel der Kulturwerte in verschiedenen Dimensionen liegt, so daß liv Lristung etwa der Kunst und des theoretischen Wissens unmöglich zu vaglachen sink. Anch kommt er nicht zu der Lösung, daß da ein Drittes sein komme, in dem die Werte zusammenstimmen, das aber nieht als vorwirgend zugrenduret cinem bestimmten Wertgebiet betrachtet werden darf. 


\section{f) Die Freiheit als Ziel der Vernunft.}

Wir haben somit als das Allgemeine und Bestimmende für das historische Geschehen den absoluten Geist der Welt, der zum Bcwußtsein seiner selbst gelangt. Die Vollendung dieser Selbsterkenntnis bezeichnet Hegel als Idce der Freiheit, die er somit durchaus im theoretischen Sinne als Einsicht und absolute Gewißheit versteht. Hegel meinte, daß dieses Ziel der Geschichte nummehr erreicht sei, sofern die Menschheit in das Alter der Reife eingetreten ist und, nachdem sie zuvor im Christentum die absolute Religion geschaffen, nunmehr in der Philosophie des deutschen Idealismus auch die absolute Philosophie zur Darstellung gebracht hat. Ebenso schien Hegel in der Form des gemäßigten Despotismus, der in der Ständevertretung ein Organ des Volkes besitzt, die Vollendung des staatlichen Lebens im wesentlichen gegeben zu sein, so da B nach seiner Auffassung am Anfang des 19. Jahrhunderts der Weltgeist sein Wesen erkennt und am Ziele ist.

\section{g) Das Ende der Geschichte.}

Da diese Lehre vielfach so aufgefaßt ist, als ob nach Hegels Meinung die Weltgeschichte mit seinem Tode zu Ende sei, so sehen wir uns an dieser Stelle gezwungen, auf ihren durchaus vernünftigen Sinn etwas näher einzugehen.

Es war immer ein billiges Vergnügen der Aufklärung, die tiefsinnigen Paradoxien großer Denker zu verhöhnen, deren Bedentung sie vermöge einer glatten Oberflächlichkeit des Denkens nicht mehr verstand. So hatte die Aufklärung der tiefsinnigen Ichlehre von Fichte den Vorwurf gemacht: daß dieser Denker in der Tat die Vorstellung habe, sein Ich umspanne die Welt, und es gäbe überhaupt nichts außer seinem individuellen Ich. Man glaubte in sehr feiner und geistreicher Weise ihn von der Unmöglichkeit seiner Lehre überzeugt zu haben, wemn man ihm die Vorhaltung machte, daß ja dann schließlich auch die Nahrung, die er zu sich nähme, von seinem eigenen Leibe sei. Das Essen müsse ihn doch dann überzeugen, daß er nicht allein auf der Welt sei.

Und derselbe Geist der Aufklärung hat anch an Hegels Lehre von der Vollendung des Geistes seine witzige Kritik geübt. Man empfand es als sehr anmaßend, daß Hegel die Ansicht vertreten habe, die Weltgeschichte wäre mit ihm zu Ende. Und man lachte sich ins Fäustchen bei dem Gedanken, was wohl Hegel sagen würde, wenn er als homo redivivus bemerkte, daß die Welt auch nach seinem Tode ruhig weiterging.

Abgesehen von dem totalen Mißverständnis, das hier vorliegt, rersteht der Aufklärer auch natürlich nicht, was es für die Geschichte der Welt bedeutet, wenn der Genius scheidet. Er sieht, daß nach wie vor Kinder empfangen, geboren und erzogen werden, daß die Menschen froh und elend sind, daß sie alt werden und sterben. Weil er das Leben so gewöhnlich sieht, wie er es gewöhnlich empfindet, glaubt er, daß das Leben mit dem Abscheiden des Genius unverändert sei. Und doch scheint es im Augenblick zu sein, als wemn der Atemzug Gottes nicht mehr die Welt durchweht und der Geist in scinen Ursprung zurückgekehrt ist. Jeder Deutsche, dem die Kultur seines Volkes 
nicht fremd ist, muß es verstehen, welch ein ungeheurer Abschnitt der deutschen Kulturentwicklung mit dem Tode Hegels sich vollendet hatte.

Aber die Lehre des großen Denkers will ja im Grunde etwas ganz anderes besagen. Er hat die Unterscheidung zwischen den Werten des objektiven und des absoluten Geistes gemacht. Die Werte des absoluten Geistes sind gewissermaßen überhistorisch. Sie könmen sich vollenden, ohne daß damit die historische Entwicklung aufhört. Auch müssen wir zwischen Fortschritt und Ent. wicklung unterscheiden. Fortschritt bedeutet Wertsteigerung, Entwicklung Wertzuwachs. Im Christentum ist nach $\mathrm{Hegel}$ die absolute Religion geschaffen worden, was natürlich nicht hindert, daß diese absolute Lehre, die in ihren Grundzügen nicht mehr übertroffen ist, noch im einzelnen ausgebaut und ausgestaltet wird, daß sich eine Entwicklung vollzieht, geleitet von dem neuen Prinzip, das Jesus ron Nazareth aufgestellt hat, beherrscht von dem neuen Gebot, das er den Menschen rerkündete. In der Philosophie des dentschen Idealismus und speziell in der Philosophie des absoluten Geistes hat sich nach Hegel die Philosophie vollendet, weil das Absolute niemals tiefer begriffen werden kamm wie als Inbegriff und Einheit aller Vernunftwerte. Das hindert natürlich nicht, daß sich die Philosophie des deutschen Idealismus noch weiter entwickelt, wie sie das ja auch tatsächlich getan hat. Deswegen bleibt die Philosophie des deutschen Idealismus doch die absolute Philosophie, und wer wollte behaupten, daß das letzte Jahrhundert einen Fortschritt gegenüber dieser Philosophie gebracht hat? Und was schließlich die Vollendung des Staates in der konstitutionellen Verfassung betrifft, so werden wir gewiß die persönliche Parteinahme Hegels gerade für die ständische Verfassung als zeitlich bedingt betrachten, immerhin aber doch viclleicht mit ihm übereinstimmen, daß nur in einem Kulturstaat mit geordneten Rechtsleben gesuncles sittliches Leben möglich sei. Daß nun sehr wohl das Verfassungsleben cines Staates in der Hauptsache vollendet sein kann, sofern die Nation eine bestimmte Regierungsform ein für allemal als die ihr adaequate sich zu eigen zemacht hat, und trotzdem das sittliche Leben der Bürger sich weiterentwickelt, darin kann unmöglich ein Widerspruch gefunden werden.

Was also Hogel behauptet hat, ist keineswegs so paradox wie die Form seiner Austlucksweise. Und dazu kommt noch etwas anderes, was die Natur des religiösen Bewußtseins mit sich bringt, das nach Erfüllung des eigenen Todes unmittelbar die Ewigkeit zu empfangen meint, und das auch schon in dirstem Jeben immer von den Gesichten der Ewigkeit umleuchtet ist. Die Ifee des Todes als der Vollendung des eigenen Lebens muBte für Hegel unmittelbar mit der Vollendung des historischen Lebens zusammengehen. Wi* komte ar cine Wrelt noch deuten und verstehen, die nicht mehr von der Allgregenwirtigkeit scines Bewnßtseins begleitet. war. Und so setzite er die Idee dr's Endes dort fest, wo dir Möglichkeit seines Verstehens ihre notwendige Sichranke findron mußte. Für den Genius der Geschichte ist es vollkommen brrohtigt, das historische Loben so zu deuten, daß das gegenwärtige Zeitalter als das Zoitalter der Vollendung dadurch deutlich und verständlich

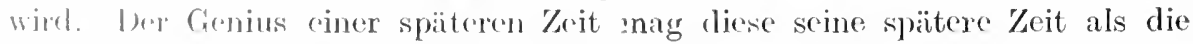

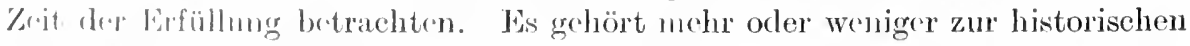
Be+trachfung der Begebenheitron, dir Gegenwart als Erfüllung der Vergangen- 
heit anzusehen. Wenn auch die regulative Idce eines Endzwecks über die eigene Zeit hinaus konstruiert werden kann, so schöpft diese Idee bei dem Mangel jeder Voraussicht die Evidenz, mit der sie sich der menschlichen Überzeugung aufdrängt, doch lediglich aus dem Leben der Gegenwart und der Vergangenheit.

\section{h) Die vernünftige Wirklichkeit.}

Man hat den eminent geschichtsphilosophischen Charakter der Weltdeutung Hegels geleugnet, indem man seine Lehre von der Allgewalt der Vernunft als unhistorisch empfunden hat. Hegel hatte gelehrt, daß die Welt ihrem Wesen nach vollkommen vernünftig sei. Er hatte somit das Irrationale geleugnet, und in einer solchen Welt, die den Mangel und das Wertfeindliche nicht kennt, hat, wie es scheint, das Handeln keinen Sinn, und rozu soll Entwicklung bejaht werden, wenn die Erfüllung schon da ist. Hier trifft nun allerdings die Philosophie Hegels der Vorwurf, daß sie in ihrem großen Vernunftoptimismus die Idee des Irrationalen nicht schwer und ernst genug behandelt hat. Immerhin ließe sich aber auch so noch einiges Prinzipielle zur Rechtfertigung der Hegelschen Geschichtsphilosophie anführen. Einmal könnte man sagen, daß Hegel lediglich das Wesen der Welt als vernünftig bezeichnet hat, das will sagen die wahrhaft wirkliche Melt. Nur das wahrhaft Wirkliche ist also rernünftig. Wirklichkeit und Vernünftigkeit decken sich nicht. Es gibt auch eine Scheinexistenz des Wirklichen, die Leben vortäuscht, ohne Leben zu besitzen, und mit Lug und Trug die Erkenntnis bedroht. Diese Scheinbilder der Wahrheit gilt es zu zerstören, um das klare Reich des Wissens aufzubauen.

Auf einem anderen Wege kommen wir zu demselben Resultat. Man kann sagen, daß die Vernunft der Welt die Idee des Ganzen sei, und daß diese Vernüntigkeit des Ganzen die Unvollkommenheit des Einzelnen nicht nur erlaubt, sondern, streng betrachtet, sogar fordert. Die Unvollkommenheit des EinzeInen stimmt zur Vollkommenheit des Ganzen zusammen. Oder jener Gegensatz, den die Welt aufweist, und den wir als gut und böse oder als schön und häßlich interpretieren, ist zwar für sich allein genommen eine Unvollkommenheit, nicht aber im Zusammenhang des Ganzen; denn in diesem Ganzen findet jede Art Gegensatz seine Auflösung. Eine solche vernünftige Welt des Gegensatzes kann sehr wohl in sinnvoller historischer Bewegung gedacht werden.

Schließlich könnte man auch zwischen dem Unvollkommenen als dem Vernunftwidrigen und dem Unvollkommenen im Sinne des Unvollendeten und Fragementarischen unterscheiden. Dieses Unvollendete kann durchaus vernünftig sein. Die Hegelsche Geschichtsphilosophie bietet das Bild der werdenden Vernunft. Diese Vernunft wird nicht etwa aus einem Etwas, das nicht Vernunft ist, also aus einem Unvernünftigen, sondern aus der unbewußten Vernunft entfaltet sich die sich selbst wissende Vernunft.

\section{i) Die Bedeutung des Helden.}

Die Vernunft, die sich als absoluter Geist in der Geschichte entfaltet, ist vollkommen selbstherrlich und souverän. Den großen Helden der Geschichte und den Volksgeistern, die der Weltgeist zum TVerkzeug seines Ruhmes und 
zum Gefäß seiner Taten macht, ist kein Einblick in die geheime Werkstätte des Geistes beschieden. Nicht ist der Held der Vertraute Gottes, der Inspirierte, dem die Gottheit ihren Willen kundgetan hat, der da weiB, um was es sich handelt, und der diesem großen göttlichen Wissen freudig das Opfer des Todes bringt. Eine solehe mystische Gemeinschaft zwischen Gott und dem Helden, der ron der göttlichen Idee erfüllt ist, kennt die Geschichtsphilosophie Hegels nicht. Im allgemeinen ist den Helden, vor allem den großen Helden der Tat, das Sehicksal des Nichtwissens gegenüber dem göttlichen Weltplan beschieden. Insofern erheben sich jene Gewaltigen nur wenig über die Masse des Menschengeschlechts. Auch sie sind zur Blindheit verurteilt, denn sie meinen in stürmischer Begierde und Leidenschaft, ihren eigenen Zwecken zu dienen, und erfüllen, doch nur die geheimen Absichten des Weltgeistes. Was sie aber über das Niveau der anderen so weit hinaushebt, das ist nicht sowohl ihre Hellsichtigkeit als vielmehr die ungeheuere Erregung und Bewegung, die von ihnen ausgeht und ein historisches Geschehen auslöst. Denn inmer sind die Heroen mit dem Großen, Gefährlichen und Außerordentlichen beschäftigt. Sie dringen gewaltsam auf den Schauplatz des öffentlichen Lebens, und die gewaltige Bewegung ihrer Glieder löst große Werke aus, mögen sie nun zum Sieg oder zum Untergange führen. Ihr großes wirksames Leben ist im allgemeinen nicht freudig zu nennen. Die Heroen sind nicht glücklich. Sie sterben früh in der Blüte ihrer Jugend wie Alexander, fallen unter dem Messer der Mörder wie Cäsar oder sterben einsam und verlassen auf einer Felseninsel wie Napoleon.

\section{k) Die Volksgeister.}

Und wie die Heroen, so müssen auch die Volksgeister als unwissende Werkzeuge der Weltherrschaft betraehtet werden. In diesen Sinne gibt es für Hegel kein auserwähltes Volk. Das auserwählte Volk ist das einzige und bleibende Tolk Gottes. Es ist anch das wissende, weil sich die Gotheit ihm offenbart hat. Die Werkzeuge, welche sich der Weltgeist unter den Nationen auswählt, das sind die welthistorischen Völker. Diese Völker, in die sich der Weltgeist gleichsam hineinlegt, um sie mit höehstem Geist zu erfüllen, leisten am meisten und dulden am meisten. Sie begründen alle Kultur, sie lenken eine Zeitlang die Gesehicke der Welt, bis sich ihre Zeit erfüllt hat, dann müssen sie von jenem Schauplatz weichen, den sie nit großen Werken der Ordnung und des Aufbaus, der Schönheit und Weisheit, aber auch mit Blut und Tränen, mit Untrorgang und Vernichtung erfüllt haben. Thre Zeit hat sich erfüllt, nunmehr sind sie selber dem Untergange geweiht und mit dem Weltgeist verläßt sie Glück und Erfolg. Nunmehr ist ihnen alles Strahlende und Bedeutungsvolle genommen, das sie als Werkzeug des Weltgeistes, als welthistorisches Volk bosaßen, und sie sinken wieder in clas Unbedentende und Alltägliehe zirriick.

\section{1) Stadien des Weltgeschehens.}

Wir der rinzelne Mensch, so hat auch das Leben der Völker seine Jugend und scin Alter. Man kann das Lehen ler Menschheit mit dem Leben eines cinzelnon Mrnsehon vergleichen. Damn müssen wir vier Zeitalter unterseheiden: das zeitalter dor Kindheit oder des Knabenalters, das Jünglingszeitalter, das 
Mannesalter und das Greisenalter des Menschengesehlechts. Jedes Zeitalter ist durch ein Volk oder auch durch mehrere Völker von welthistorischem Charakter repräsentiert. Es gibt also Völker, die im Knabenzeitalter der Menschheit, und andere, die im Greisenalter des Menschengeschlechtes welthistorische Bedeutung gewinnen.

Das Knabenzeitalter der Menschheit ist das Zeitalter der großen Despotien in Asien und Afrika: des babylonischen, assyrischen, indischen, ehinesisehen, ägyptischen Reiches. Der absolute Egoismus und Despotismus, die Freude am wilden kriegerischen Spiel entspricht dem Knabenalter des Mensehen. Etwas Schwerfälliges und Ungefüges haben diese Staaten, was sich auch in der geographischen Lage und Formierung des Landes ausdrückt. Noch fehlt die Organisation und Differenzierung, die erst im welthistorisehen Tolk der zweiten Menschheitsstufe sich ausdrückt.

Die Griechen sind es, die im Jünghingszeitalter der Menschheit welthistorische Bedeutung gewinnen und somit recht eigentlich das schönste Lebensalter repräsentieren. Den Griechen eignet die leichte Beweglichkeit und der Enthusiasmus des Jünglings, der hohe idealistische Flug, die tiefe metaphysische Sehnsucht. Wenn im Kindheitsalter der Menschheit und des Mensehen vor allem der religiöse Wert dominiert und die größte Bedeutung besitzt, so entspricht dem Jünglingsalter von Menseh und Menschheit der ästhetische Wert der Schönheit. Vielleicht läßt sieh das Leben der ältesten Völker am besten von den Formen ihrer Religion aus verstehen, während die griechische Kunst uns am besten das Leben der Griechen erschließen kann.

Das Alter der gesetzten Reife und der vollendeten Kraft, das Mannesalter des Menschengeschlechts, wird dureh das Römertum dargestellt. Während bisher eine blühende Phantasie und das Gefühlsleben herrschte, ist jetzt der reifevoll entwickelte Verstand ans Werk getreten. Und jene Bewegung des Willens, die sich im Jüngling als stürmischer Enthusiasmus und sehnsüchtige Liebe äußert, sie hat sich nummehr zu einem großen und ernsthaften Streben nach sittlichen Gemeinschaftsformen entfaltet. Und so hat das Römertum die Rechtsordnung geschaffen und damit auch die Grundlage für eine sittliche Gestaltung des Staatslebens gegeben. Recht und Gesetz, Staat, Moralität, soziale Ordnung und Sittlichkeit, das sind Begriffe, die in naher und nächstcr Beziehung zu einander stehen. Daß sie wirklich geworden sind und alle Kultur durchdrungen haben, das ist in erster Linie das Verdienst des Römertums. Wenn das Römertum in Erfüllung dieser seiner hohen Mission die andern Völker zum Teil unterdrückt und mißhandelt hat, wenn es die blühende Kultur Siziliens zertrat und mit Krieg und Schrecken den Erdlkreis erfüllte, so dürfen wir darum dieses Volk nicht etwa, wie Herder das getan hat, ron einem weichen Standpunkt der Humanität aus gering werten. Der Krieg ist nach Hegel kein absolutes Úbel, denn er entfesselt, und cntflammt die Geister und trägt die große Bewegung in das Leben der Manschheit hinein. Die Leidenschaften sollen nicht getilgt werden noch in dumpfer Untätigkcit dahinbrüten. Die Leidenschaft dient dem Großen und ist mit der bedeutenden Persönlichkeit untrennbar verknüpft. Wie St. Sim on behauptet auch Hegel, daß nichts Großes in der Welt ohme Leidensehaft gesehehen sei. Und der Krieg ist sicher die Geburtsstätte großer Leidensehaften, als da sind Liebe und Haß 
und Ehrgeiz. Das griechische Tolk war von seiner weltgeschichtlichen Mission zurückgetreten - damals, als das Römertum seinen Siegeszug durch die Welt hielt und nun auch Hellas die Freiheit nahm. Griechenland hatte sein Recht rerloren, es war zum Untergange reif. Die Römer vollzogen das Weltgericht an dem schönen und unglücklichen Volke.

Darin liegt die Gerechtigkeit der Weltgeschichte, daß auch die Richter immer wieder zu Gericht geladen werden. Und so mußte sich das stolze Römertum vor dem Gericht der germanischen Tölker bengen. Indem die Germanen zum welthistorischen Volke werden, beginnt das Greisenalter des Menschengeschlechts. Allerdings darf das Greisentum der Nationen nicht mit dem Greisentum des einzehnen Menschen gleichgesetzt werden; denn das Greisentum des einzelnen bedentet Verfall und nahes Ende, das Greisentum der Menscheit aber fällt zusammen mit dem Greisentum des absolıten Geistes, das heißt es bedeutet seine Vollendung, seine Macht und Herrlichkeit. Dieses Greisentum währt, solange die Menschheit dauert, bis ans Ende der Geschichte; denn es liegt nicht im Sinne der Hegelschen Geschichtsphilosophie, daß die Menschheit noch eimmal den mühseligen Gang der Weltgeschichte von neuem beginnt und rollendet. In Reich der reinen Formen, das die Logik darstellt, schließt sich Anfang und Ende zur Form des Kreises zusammen, das heißt im Reich der ewigen Wahrheit gibt es ïberhaupt weder Anfang noch Ende. Anders in zeitlich historisch-geschichtlichen Werden. Dort lehrt Hegel den eimmaligen Lauf der Entwicklung. Das Greisenalter der Menschheit kann niemals wieder zum Kindheitsalter werden.

Das Schema der Menschenalter ist häufiger in Sinn einer geschichtsphilosophischen Konstruktion gebrancht, niemals aber vielleicht mit einer so tiefen Sinngebung verbunden wie bei Hegel. Das Leben des Geistes wirkt. sich anfänglich in der Hauptsache nu in religiösen Vorstellungen aus, das ist die Knabenzeit der alten Völker, welche die Kultur einleiten. Im schönen Jünglingsalter der Menschheit herrscht das ästhetische, in Mannesalter das moralische Bewußtsein. Hat aber das Menschheitsleben seine Vollendung erreicht, so dominiert das theoretische Interesse, und die Geschichte der modernen Philosophie lehrt uns am besten das moderne BewuBtsein verstehen. Wras jene alten Völker auf das innigste bewegte, das drïckten sie in religiösen S'rmbolen aus. Die Sprache der Griechen war die Kunst, die der Römer Moralität und Recht. Dor tiefste Ausdruck für das Geistesleben der germanischen Völker ist die Philosophic.

Wenn num aber auch das griechische Volk das Volk der Kunst und das römische Volk das Volk der Moralität war, so ist damit noch nicht gesagt, daß dir Kunst ihren denkbar höchsten Ausdruck im Griechentum und die Moralitit im Römortmm gefund(m hat. Es soll lediglich damit gesagt sein, daß diese Werte damals in jenrn Völkern am meisten wirksam und lebendig waren. Demmograchtet kömnen wir cinen Fortsehritt etwa in der Entwicklung des moralischen Wertes auch ïher das moralische Volk der Römer hinaus luhinuteris.

()rintioren wir uns noch cimmal an: dem Endzweek des historisehen Ge-

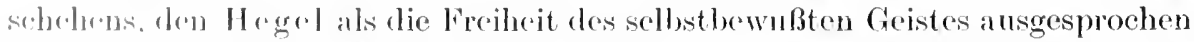
hat. Dir. Kinmbeit des Menschrongeschlechts, wie sie in den asiatischen Despotien 
zum Ausdruck kommt, ist von diesem Zustand an weitesten entfernt. Fetischismus, Ahnenkult, Zauberei und Magie sind die Formen ihren religiösen Verehrung. Alles wird ihnen zum Gotte, aber nicht im Sinne von Meister Eckhart. der das große Antlitz der Welt sich auch in den kleinen J)ingen spiegeln sah, sondern vielmehr in dem Sinne, daß ihnen jedes noch so unbedeutende Ding zur Fratze der Gottheit und damit auch zum Gegenstand der Fureht und des Aberglaubens werden mußte. So sehr das religiöse Leben damals ausgebreitet war und so sehr es die Gemüter ergriff, so weit war es auch ron wahrhafter Tiefe entfernt. Sinnlich und irdisch, nieht aber geistig und transzendent wurde das Göttliehe empfunden. Die Moral dieser kindlichen Menschheit war durchaus heteronom, durch die Furcht vor Strafe und Vergeltung und dureh die Hoffnung auf Lohn gelenkt. Das Recht war noeh wenig entwickelt und ron der Gunst der Starken und Mächtigen abhängig. Die Kunst lebte in ihren ersten Anfängen in inniger Verbindung mit der Religion und entwickelte Formen, die auf das Kolossale hinausliefen, ohne den Reiz der Sehönheit und die Würde des Erhabenen zu besitzen. Eine ausschweifende und ungebildete Phantasie ergötzte sich an einer fabelhaften Tiersymbolik. Von Philosophie und Wissenschaft konnte noch keine Rede sein.

Mit den Grieehen beginnt alle wahre Kultur. Ihre Religion erhob sich zu der Form eines ästhetischen Polytheismus. In den Gestaiten der Götter bauten sie sich die Ideale der Schönheit auf, wie überhaupt der künstlerische Wert an allen Institntionen Anteil hatte. Die Griechen sind das Yolk der schönen Individualität, die aueh den Staat und das öffentliehe Leben zum Kunstwerk gestaltet. Damals offenbarte sich die Freiheit in ihren ersten schönen Zügen. Sie trat noch nicht in voller Selbständigkeit hervor. Sie blieb noch unentwickelt und unentfaltet, gleichsam in Zustande der Knospe stehen. Sie blieb noch zu eng an die Sinnliehkeit gebunden. Der Gegensatz von Pflieht und Neigung war noeh nicht hervorgetreten, aber sehon tat sieh die Freiheit kund in vernünftigen Taten und edler Sitte. Die Kunst, die das Grieehentum geschaffen, trägt mit Reeht den seltenen Namen der Klassik und wird in ihrer Art stets mübertroffen bleiben. Philosophie und Wissensehaft sind ron diesem genialen Volke recht eigentlieh geschaffen.

Das Römertum hat seine ganze Kultur recht eigentlieh naeh der Seite der Moralität hin entwiekelt. Die Religion nahm eine ernstere und strengere Gestalt an, und der moralische Begriff der Pflicht stellte sich der Neigung entgegen. So kam es zu der Begriundung eines gewaltigen Staatswesens, das auf Reeht und Ordnmng begründet war und die Idee des Imperiums rerkündete. welches die gesamte Menschheit umfassen und zur Einheit führen sollte. In der Kunst blieben die Römer im wesentlichen Nachbildner des Grieehentums. und auch in Philosophie und Wissensehaft sind ihre Leistungen den Grieehen nicht ebenbürtig.

Das letzte Zeitalter des Mensehengeschlechts wird dureh die christliche Religion eingeleitet, die das Bild der Welt und die Kultur der Mensehheit mehr verändert hat als irgendein ancieres Weltereignis. In der ehristlichen Religion wurde Gott als Geist verstanden und jener einseitige Sollenscharakter ihr genommen, der für die jüdische Religion so bezeichnend ist, die in der Gottheit immer nur den strengen Richter und eifersïchtigen Wächter und 
Schirmherrn seiner Gebote erschant. Die christliche Religion hat an clie Stelle des moralischen Gottes den Gott der Liebe als den einzig möglichen und wahrhaftigen gesetzt. Nummehr ist die strenge Schranke zwischen Gott und Menschen eingerissen, und das Göttliche findet sich im Menschlichen, das Menschliche im Göttlichen wieder. Und diese Erhöhnng des religiösen Lebens findet auf allen Kulturgebieten deutlichen Nachhall. Das sittlicheLeben vollendet sich in der Idee der Freiheit. Der Mensch hat nunmehr die volle Einsicht in den Gegensatz ron Sein und Sollen erlangt. Nicht aber tyrannisiert er die Neigung und behandelt sie hart und grausam, sondern läßt sie leicht und frendig mit dem Sollen zusammengehen. Durch die christliche Religion hat die Kunst einen ganz neuen Inhalt bekommen, demn die Religion hatte ja Gott als Geist oder als das wahrhaft Unendliche rorgestellt. Dieser neue Gegenstand war für den modernen christlichen Künstler anfangs viel zu groß und stellte an ihn so ungehenere Anfordernngen, daß seine Leistung mit Notwendigkeit hinter der Leistung der alten Kunst zurückblieb. Immer mehr aber ist es der Kunst gelungen, ihres neuen Gegenstandes Herr zu werden, und wenn sie das Göttliche vollkommen in Anschaumng bilden kann, dann hat sie ihre Vollendung erreicht. Die Philosophie endlich ist zum umfassenden Organ des Kulturverstehens geworden und findet in den Grundrorstellungen der Religion ihre eigenen philosophischen Prinzipien wieder.

\section{Die Geschichtsphilosophie im 19. Jahrhundert.}

In der Geschichtsphilosophie des deutschen Idealismus hat sich die Geschichtsphilosophie vollendet. Es wird schwerlich jemals größere Systeme geben als die von Fichte, Schelling mol Hegel gesehaffenen Formen, und die moderne Geschichtsphilosophie lebt durchaus noch von den großen Problemstellungen jener Zeit. Die Probleme aber, die noch nicht recht zum Austrag gekommen waren und dic Folgezeit beschäftigten, das war eimal dic Frage nach dem leitenden Kulturwert des historischen Geschehens, die von jedem der drei großen Geschichtsphilosophen eine verschiedene Beantwortung erfahren hatte, und dann weiter die Frage, ob das Allgemeine der Irlec order das Besondere in der Gestalt der Persönlichkeit für die Weltgeschichte mehr bedente, cin Problem, das in der modernen Geschichtsphilosophie zur Fragestellung Milien bzw. Masse oder Individualitä geführt hat. Wir sahen, raß Fichte und Hegel in der Boantwortung dicser Frage weit auseinandergingen. soforn Hegel der Weltremunft alle Macht zusprach, während nach Fiehte die grolie. Proünlichkeit eine sellständige Bedeutung besitzt. Ferner abur blieb, dir Frage nach dem Wert der Geschichte Gegenstand einer beständigen J)iskussion, und las führte zu ciner cingehenden Durchforschung ihrer methodologrisehon Struktur. Schlie.Blich war es natïrlich, daB dic iclealistische Geschichtsphilosophie mit ihrer Voraussetzung allgemeinginltiger Werte auch Gingurer find. Eud so sehen wir dem bald nach Hegel und teilweise auch schen zu scinculdereiten den Positivismus und Materialismus zu eigenen

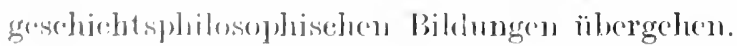




\section{a) Die Philosophie des Positivismus.}

Der bedeutendste und relatir selbständigste der Geschichtsphilosophen des 19. Jahrhunderts nach Hegel ist der französische Geschichtsphilosoph Auguste Comte, auf dessen Philosophie sehr entgegengesetzte Einflüsse gewirkt haben und an dessen Geschichtsphilosophie Aufklärung und Romantik gleichen Anteil hatten. So zeigt sich etwa der aufklärerische Charakter seiner Philosophie in dem Bestreben, das historische Leben durch Gesetze zu rationalisieren, in der Feindseligkeit gegen Theologie und Metaphysik und in dem Wunsche, sie durch die exakten Naturwissenschaften zu ersetzen, während der romantische Charakter seiner Welt-und Kulturauffassung vor allem in der Verherrlichung des Mittelalters, in der Forderung einer absoluten Autorität auf moralischem Gebiet sowie auch in der Cuterstreichung einer kontinuierlichen Entwicklung und in der Ablehmung einer allzu freien Kritik als gefährlich für die sozialen Verhältnisse sich kundgibt. ${ }^{1}$ )

In seiner ganzen Wertsetzung ist Auguste Comte ursprïnglich mehr den theoretischen Werten und speziell den Naturwisseuschaften zugewendet. Immer mehr wird ihm jedoch die Geschichte zur höchsten und bedeutsamsten Wissenschaft. Indem aber die Geschichte für ihn so wichtig wird, steigert sich für ihn gleichzeitig auch die Bedentung des moralischen Wertes, dessen enger Zusammenhang mit der Geschichte ron Comte behauptet wird. Schließlich werden ron ihm die affektiven Eigenschaften, die sich speziell auch im Gefühlsleben des Menschen kundtun und hier zur Bildung des künstlerischen und religiösen Lebens führen, unbedingt berorzugt.

Comte entwickelt den Begriff der Geschichte, indem er sie mit den anderen Formen der Wissenschaft vergleicht und ihr einen Platz in seiner Hierarchie der Wissenschaften anweist. Soviel ist für Comte gewiß, daß alle Wissenschaften Gesetzeswissenschaften sind, und daß auch die Geschichte hiervon keine Ausnahme bildet und bilden darf. Diese Gesetze des historischen Lebens sind bisher noch nicht erkannt worden. Auguste Comte glaubt das Gesetz der historischen Entwicklung gefunden und dadurch die Geschichte zu einer objektiren oder positiven Wissenschaft gemacht zu haben. Eine positive Wissenschaft ist eine exakte Wissenschaft, die in ihrer ganzen Auffassung und Methode dem klaren Vernunftzustande einer rorgeschrittenen Menschheit entspricht. Indem num Comte die Behauptung aufstellte, daß jede Wissenschaft ihrem vollendeten Zustande gemäß Gesetzeswissenschaft sein müsse, hat er vor allen Dingen den heftigen Kampf un die historische Methode heranfbeschworen, der bis zur Gegenwart fortdauert und noch keine endgültige und allgemein anerkannte Entscheidung gefunden hat.

Auguste Comte hat ein System der Wissenschaften aufgestellt, das unter dem Gesichtspunkt der Einfachheit bzw. Kompliziertheit der wissenschaftlichen Phänomene geordnet ist. An den Anfang des Systems tritt dicjenige Wissenschaft, welche die einfachsten und allgemeinsten Phänomene anfzuweisen hat, nämlich die Mathematik. Am Ende steht die Wissenschaft von den kompliziertesten und speziellsten Phänomenen : die Geschichte. Zwischen diese beiden Extreme schieben sich die anderen Naturwissenschaften ein,

1) Vgl. hierzu mein Buch: Die Geschichtsphilosophie Auguste Comtes, Leipzig 1909. 
cin Begriff, der nach Comtes Auffassung ja auch für die Geschichte als Physik des sozialen Lebens gilt. Sie ordnen sich in der Reihenfolge: Astronomie, Mechanik, Physik, Chemie, Biologie. Das Verhältnis zwisehen den Wissenschaften muß dahin betrachtet werden, daß die früher genannten die Voraussetzungen und Grundlagen der später genannten bilden. Die ,einfacheren“ Wissenschaften, die es mit den allgemeineren Phänomenen zu tun haben, sind gleichzeitig auch diejenigen, die früher den positiven Zustand exakter Wissensehaftlichkeit erreieht haben. Die Mathematik ist zuerst, die Gesehichte zuletzt eine exakte Wissenschaft geworden. In den Phänomenen der komplizierteren Wissensehaften ist nach der Lehre Comtes das Objekt der einfacheren Wissenschaft immer vorhanden und rorausgesetzt. Zu ihrem Objekt tritt damn immer eine gewisse Komplizierung in der Gestalt von etwas Neuem hinzu, was nur den besonderen Gegenstand der späteren Wissensehaft konstituiert. Dieses Verhältnis der Phänomene zueinander schließt es vollkommen aus, daß etwa der Gegenstand der Biologie aus dem Gegenstand der Chemie \%u begreifen wäre. Vielmehr ist clas neu hinzutretende Element, wie etwa in der Biologie das Leben rom Standpunkt der früheren Wissensehaft, die von dieser Erseheinung abstrahieren muß, etwas durchaus Unbegreifliches. Es bedarf immer wieder eines neuen Prinzips und einer nenen Methode, um dieses Neue zu verstehen.

Die Anordnung und Gruppierung der Wissenschaften, wie sie Auguste Comte vollzogen hat, will nun keineswegs besagen, daß die Wissenschaft, welche an der Spitze steht, also die Mathematik, etwa die wertvollste und dic anderen beherrsehende Königin unter den Wissensehaften sei. Man kann ebenso gut die Geschichte wie die Mathematik als die erste der Wissensehaften auffassen, da dic Vorzüge und Nachteile beider Wissenschaften in entgegengesctzter Richtung liegen.

Die Naturwissensehaften der einfachen Phänomene sind durch die strenge Notwendigkeit ihrer Gesetze charakterisicrt. Die Naturwissensehaften der komplizierten Phänomene und vor allen dic Gesehichte haben es dagegen mit Gesetzen zu tun, die mehr oder weniger modifizierbar sind. Die Gesetze der Astronomic haben einen anderen Notwentigkeitseharakter wie die Gesetze der Geschichte. Jenen gegenüber ist der Menseh vollkommen ohmmächtig, auf diese kann er seinen EinfluB ausüben und ihre Wirkungen modifizieren.

Schon aus dieser Tnterscheidung erhellt, daß der Gesetzesbegriff bei Auguste Comte einen sehr allgemeinen und dehnbaren Charakter hat, und dals ar sehr Verschieclenartiges darunter begreift. Er versucht den Gesetzeshegriff als dic cinheitliche Zusammenfassung von Tatsaehen zu beschreiben, die auf clem Wege der Induktion festgestellt sind. Im Gegensatz zu den besomeleren 'latsachen sind die Gesetze die allgemeinen Tatsaehen. Der Begriff Jor Kansalitït und der Begriff des Zweckes mul3 von jenem logisehen Gebulde, das Comte als Gescotz bezeichnet und das dureh cin eigentiumliehes Moment Ace linativitat charakterisiort ist, sorgfältig ferngchalten werden. Dabei

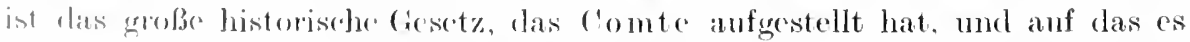
mus in linsom Kusammonhang alloin ankommt, anch nicht ohne dic Voraus-

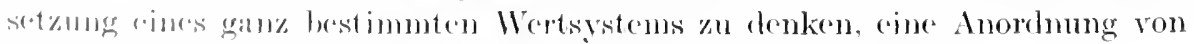
Kulturformen, die vem ihn ginz ausetrücklich vollzogen ist. 
Das Gesetz der historischen Entwicklung. das Comte anfgestellt und an der Gesamtentwicklung der Menschheit deutlich zu machen gewnßt hat, ist das Gesetz der drei Stadien. Die Menschheit muß drei verschiedenartige Stadien der geistigen Entwicklung durchlanfen. um im letzten Stadium am Ziele zu sein: den theologischen Zustand, den metaphysischen und schließlich den positiven. Der theologische Zustand ist vor allem dadurch charakterisiert, daß die Menschheit auf dieser Stufe ihrer Entwicklung alles Geschehen in der Welt durch die Leistung von Göttern zu erklären sucht. Wir sehen also, daß dasjenige, was nach Comtes Lehre für die geistige Physiognomie der Menschheit charakteristisch ist, zunächst eimmal die Art ihrer Welterklärung ist. Das scheint im ersten Moment ein rein intellektualistisches Merkmal zu sein. Dennoch läßt die allgemeine Form der Welterklärung augenscheinlich anch wichtige Schlïsse anf die ästhetische und ethisch-religiöse Natur des Menschen zu. Der zweite Zustand des Menschengeschlechtes ist der metaphysische, in dem an die Stelle der Götter als Prinzipien des Weltverstchens gewisse Entitäten nnd real wirkende Zwecke oder Ideen treten. Die Vorstellung der Götter ist verblaßt, und das, was als Residumu geblieben ist, sind gewisse Begriffe, die zu Realitäten hypostasiert sind, wie der Begriff einer Substanz oder Kraft, mag sie num in spiritualistischem sinne als geistige oder in materialistischem Simne als simmlich-materielle Wesenheit gedacht werden. Der letzte Zustand des Menschengeschlechtes ist dann endlich der positive Zustand, in dem alle Erscheimungen in naturwissenschaftlichem Sime dmeh Gesetze als allgemeine Tatsachen und Feststellungen erklärt werden.

Durch diese verschiedenartigen Erklärmngsprinzipien dokmmentiert sich in erster Linie die intellektuelle Entwicklung, welche die Menschheit durchgemacht hat oder noch durchlaufen wird. Dem der positive Zustand der Menschheit ist noch nicht erreicht, wemn er auch ron Comte als nahe berorstehend gedacht wird. So notwendig dieser Gang des Menschengeschlechtes vom theologischen zum positiven Stadium anch sein mag, so ist es auch wieder deutlich, daß nicht die gesamte Menschheit im selben Tempo vorwärts schreitet, sondern die begabteren Rassen und Nationen des Menschengeschlechtes erreichen ihn weitaus früher. Comte beschränkte daher die Darstellung der Entwicklung und den Nachweis des von ihm gefundenen Gesetzes anf die Elite der Menschheit, anf die großen Nationen Westeuropas, die durch die gemeinsame Kultur der Griechen und Römer bestimmt sind. und die er, entsprechend der Innigkeit ihrer geistigen Gemeinschaft, auch gerne als die west europäische Republik bezeichnet. Was aber für diesen großen und vorbildlichen Kulturkreis gilt, das gilt auch notwendig für die Kultur der anderen Erdteile, deren Völker sehr bald dem Beispiele der westenropäischen Nationen folgen werden.

In der Entwicklung der Menschheit lassen sich in der Hauptsache vier Reihen unterscheiden, nämlich die intellektnelle. die moralische, die ästhetische und die materielle, oder anders ausgedrïckt: die Gesamtentwicklung der Menschheit gliedert sich in die Entwirklung der Philosophie und Wissenschaft, der Moralität und des politischen Lehens. der Kunst und schlieBlich des Wirtschaftslebens und der sozialen Organisation. Die Religion wird ron Comte nicht als besonderes Entwicklungsgebiet aufgefaßt. Er faßt sie in der Haupt- 
sache nur als eine Form der Welterklärung. Was abgesehen von den theoretischen Bestandteilen an ihr noeh kulturbedeutsam ist, das fällt für Comte unter den Begriff der Moral.

Zwischen diesen versehiedenen Reihen bestehen notwendige Beziehungen. So entspricht etwa der metaphysisehen Welterklärung eine ,,metaphysische" Moral und eine bestimmte Form des politisehen und sozialen Lebens. Aber Comte geht diesen Abhängigkeiten im einzelnen nieht naeh, was ja auch ohne Frage die Übersiehtlichkeit und Klarheit seiner Darstellung stören würde, sondern betrachtet die vier großen Formen des Kulturlebens jede für sich in einer künstlichen Isolation. So sehildert er etwa die moralisehe Entwieklung in der Hauptsaehe so, als wenn sie aus sich selbst heraus geworden wäre. Ja, es liegt ihm sogar niehts daran, im einzelnen zu zeigen, wie die spätere Form des ästhetisehen oder moralisehen Lebens aus der früheren sieh entwickelt hat, sondern dem Positivismus kommt es nur darauf an, festzustellen, daß diese ganz bestimmte Form, dieser besondere Typus des Weltverstehens oder der sozialen Organisation auf jenen anderen gefolgt ist.

Yon den vier Reihen ist die intellektuelle Reihe die dominierende. Um uns darüber klar zu werden, welehen Zustand der Menschheit wir vor uns haben, müssen wir immer in erster Linie auf die Form der Welterklärung aehten. Daneben ist vor allem der moralisehe Zustand entseheidend, aus dem das höehste Wertleben der Mensehheit hervorgeht.

Neben diesem allgemeinen Schema der Entwieklung: theologiseh, metaphysiseh, positiv, macht Auguste Comte noeh einen anderen wichtigen Gesichtspunkt für seine Darstellung geltend. Im Grunde genommen gibt es nur zwei mögliehe Weltauffassungen, die theologische und die positive. Jene entspricht dem Kñbenalter der Menschheit, diese seinen reifen Mannesjahren. Das metaphysische Zeitalter mit all seiner Skepsis und Kritik ist im Grunde nur ein Úbergangszeitalter, da es vollkommen außerstande ist, wirklieh etwas Positives zu geben. Man kann somit das metaphysisehe Zeitalter als jene Ubergangszeit der Mensehheit betraehten, in welcher die alten Ideale vernichtet und zerstört und dadureh die neuen Ideale vorbereitet wurden. Dann läßt sich die Mensehheitsgesehiehte in einer zwiefachen Entwicklung begreifen, einer negativen und einer positiven. Die negative Entwicklung bedeutet die Errichtung des theologisehen Systems, aber ihm gegeniiber sind von vornherein sehon die positiven Instanzen an der Arbeit. Auch die seheinbaren Fortschritte des theologischen Systems, das seine höehste Vollendung im Mittelalter erreicht, bedeutet unter einem höheren philosophisehen Gesiehtspunkt schon ein Nachlassen des theologischen Gedankens. Deswegen folgt auf das uroße Zeitalter des Monotheismus so bald die Vernichtung der Theologie dureh dic Jraphysik. welche in der französisehen Revolution ihre Vollendung erreicht. Gleichzoitig mit dem Untergang des theologisehen systems baut sieh flas pritive System unter der Leitung des naturwissensehaftliehen Denkens auf. das ein neue, höhere sittliehkeit, eine neue Kunst, eine neue politiseh syzialn. Organisation und eine nene Religion im Gefolge hat. Diese Elemente des nenon positiven Sisstems verfolgt die Darstellung der positiven Menschheitsgeschichtre ans ihren ersten Anfängen heraus. Die positive Entwicklung führt $\%$ rinem Ziele. das endlich der Gespaltenheit des menschliehen BewuBtseins 
ein Ende bereitet, das schon so lange unter dem Gegensatz von theoretischer Einsicht und religiös-ethiseher Úberzengung leidet. Es gilt die Forderung unserer intellektuellen Eigenschaften mit denen unserer affektiven zu versöhnen. Es handelt sich darum, Religion und Moralität auf dem Borlen einer naturwissenschaftlichen Weltauffassung neu zu begründen. Nur so kann einc vernünftige Ordnung der menschlichen Gesellschaft herbeigeführt werden. die auch gleichzeitig stabil gemug ist, um aller Kritik und allen Angriffen seitens revolutionärer und anarchischer Bestrebungen erfolgreichen Widerstand zu leisten. Um eine einheitliche und vernünftige Verfassung der menschlichen Gesellschaft zu begründen, ist in erster Linie eine einheitliche Organisation des Wissens erforderlich. Diese ist in der von Comte aufgestellten Hierarchic der Wissenschaften vollendet, durch die nummehr alle Disziplinen menschlicher Erkenntnis ein für allemal den Einflüssen der Theologie und Metaphysik entzogen sind. Damit steht die Bahn für eine Nenordnung der menschlichen Gesellschaft frei und offen vor uns.

Es erhebt sich nun allerdings die Frage, welche Bedeutung die Tätigkeit des Reformators in einer von unverbrüchlichen Gesetzen geordneten Welt noch besitzen könne. Hier kommt Comte der von ihm geprägte Begriff des modifizierbaren Gesetzes zu Hilfe, der vor allem für das soziale Leben wichtig ist. Die Macht der Gesetzmäßigkeit als des Allgemeinen muß darin gesehen werden, daß die drei Stadien des Menschengeschlechtes mit Notwendigkeit aufeinanderfolgen, so daß der positive Zustand eines Kulturkreises erst dam sich erfüllen kann, wenn die Menschheit den metaphysischen durchlaufen hat. Deswegen ist aber die Individualität, der Held und Reformator, nicht ohne eigene Wirksamkeit. Seine persönliche Leistung muß darin gesucht werclen. daß er die Entwicklung beschleunigt und die Phänomene des gesellschaftlichen Lebens mit größerer Stärke und Intensität in Erscheinung treten läßt

Der Gegenstand der philosophischen Geschichte, die Comte als Soziologit bezeichnet, ist die Menschheit. Die Menschheit bildet eine absolute Einheit und ist als solche eine rollkommene Realität. Das Individuum ist im Grunde genommen nur eine Abstraktion, nur die Menschheit ist wirklich. Das Individuum führt nur soweit ein wahrhaftes Leben, als es an der Idee der Menschheit teilnimmt und für die Mensehheit et was leistet. Die Menseheit führt ein ewiges Leben, während die einzelnen Individuen sterben. Dem wertvollen Menschen aber ist es beschieden, in der Idee der Menscheit weiterzuleben. Mit seinem Tode tritt er in die imnigste Gemeinschaft mit dem ,Großen Wesen " ein, das weit mehr aus Toten wie Lebendigen besteht und durch die großen Toten immer bestimmender und ausschlaggebender für die Entwicklıng der Mensehheit wird.

Die Idee der Menschheit ist die religiöse Idce der Geschichtsphilosophic von Auguste Comte. Die Menschheit ist das wahrhaftige große Wesen und soll an die Stelle der Gotheit treten. die das theologische System zum Mittelpunkt aller seiner Überlegungen gemacht hat. Die Gottesreligion soll abgelöst werden ron der Menschheitsreligion. Insofern ist die Menschheitsgeschichte Religionsgeschichte, weil sie von den Kämpfen und Leiden des großen Wesens. von seinen schmerzlichen Siegen und mutigen Kämpfen erzählt. Nichts vermag so sehr die sozialen Gefühle zu steigern und zu erheben wie die Beschäftigung 
mit der Geschichte, da sie das Gefühl einer vollkommenen Solidarität und eines gemeinsamen Schicksals erweckt, was uns dazu führt, die egoistisehen Triebe immer mehr zu überwinden und die altruistischen Neigungen zu pflegen.

Mit der Betonung des Menschheitsganzen als wahrhaftiger Realität hängt es zusammen, daß die Idee der Pcrsönlichkeit nicht so stark zum Auslruck kommt, wie es ihren ron Comte behaupteten Leistungsn gemäß hätte sein sollen. Dauernd steht das Ganze der Kulturbewegung und die allgemeine Situation des sozialen Milieus im Tordergrund der Betrachtung und läßt dic Heroen der Geschiehte als Organe der Massenbewegung erscheinen.

Das erste Stadium der Mensehheitsentwicklung zerfällt in drei Epochen, die Epoche des Fetischismus, des Polytheismus und des Monotheismus. Der Fetischismus beseelt und vergöttert alle Wclt. Die theologisehe Idee hat hier augenseheinlich ihre größte Macht. Der Begriff des Naturgesetzes war noch nicht gefunden. ja kaum geahnt. Ursprünglich von Comte gering eingesehätzt wegen der Primitivität der ganzen Naturerklärung, gewinnt dieses Stadium für ihn immer höhere Bedentung, je mehr ihm zum Bewußtsein kommt, daß die affektiven Eigensehaften des Herzens und der Phantasie sehr viel größeren Wert besitzen als die Gaben des wissenschaftliehen Intellekts. Der Zustand des Fetischismus ist als vollkommene Einheit, als innigste Verbindung der Menschen zu einer sozialen Gemeinschaft zu denken. Ohne bewnßte Moralität werden sic doch in dieser Zeit von ciner natürlichen Sozialität geleitet. Comte glanbt wie Rousseau an die natürliche Güte des Menschengesehleehts und malt das Anfangestadium der menschliehen Entwicklung in lenehtenden Farben aus. So sehr die Beseclung der ganzen Natur durch Göter auch die Besehränktheit der intellektuellen Tätigkeiten in dieser Epoche beweist, so verrät sie doch auch wieder cinc reiche Begabung der Phantasie und zugleieh eine gewisse Tiefe des kïnstlerischen Empfindens. Der Zustand des Fetischismus ist ein Zustand ursprïnglicher Harmonic und der spezifisch ästhetische Zustand der Menschheit.

Aus ihm geht cler Zustand des Polytheismus hervor, indem die intellektuclle Begabung der Menschheit erstarkte. Die Abstraktionskraft des Menschen war gestiegen, mod diese Abstraktionsfähigkeit ist es in der Tat, welche die raligiösen Vorstellungen immer mehr äberwindet. Der Fetischismus hatte sieh jodes Ding besecelt gedacht. So war jeder Banm des Waldes einer Gottheit heilig und ron dieser bescelt und bewohnt. Nun fabte der Menseh das gemeinsanc Göttliche zusammen und setzte an die Stelle der vielen Waldgötter den Gott des Waldes. Damit wurde das Wunderbare sehon bis zu einem gewissen Garde beschränkt. Es blicel, Ram für cin anderes Prinzip der Welterklärung, das sich damals schom in dem griachischen bogriff der pusson ankündigte, dats pesitive Prinzip) der Naturgesetzmäbigkeit. Wem somit auch die Theologie des Polytheismus als die reifere mol höhere Form der Welterklärung angesehen

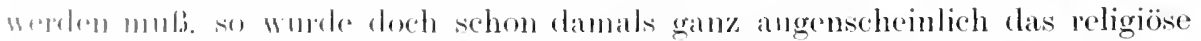

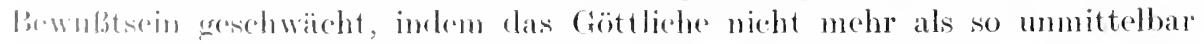

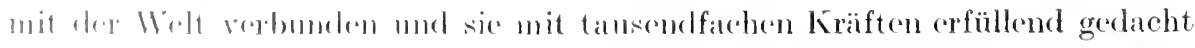

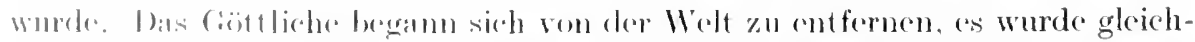

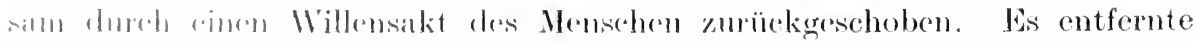
sich von $13 m$ an immer mehr, mus sehbeblich als pure Illusion zu versehwinden. 
Die intellektuelle Begabung dieses Zeitalters war bedentend. Dennoch war die wissenschaftliche Leistung nicht groß, weil die ruhige Feststellung der Tatsachen durch metaphysische Spekulationen immer rewirrt und rerdorben wurde. Die Kumst entfaltete eine erste Blüte, aber in ter Hauptsache nur auf dem Gebiet der Architektur, Skulptur mo Dichtkunst. Auch fehlte es dieser Kunst vermöge der [ngunst der sozialen Situation durehans an Stabilität, so daß sie einem frühzeitigen Verfall anheingegeben war.

Die Moralität dieses Zeitalters llieb auf ciner niedrigen Stufe, wenn es ihm auch nicht an tüchtigen moralischen Instinkten, an Vaterlandsliebe und Heroismus gefehlt hat und speziell im Römertum zeitweilig ron einem echten Geist der Moralität erfüllt war, der sieh an schönsten in seiner großartigren Rechtsschöpfung offenbarte. Was jedoch ein gesmmelesmoralisches Leben und greordnete soziale Verhältnisse erst ermöglicht, das fehlte diesem Zeitalter. nämlich die Errichtung zweier ron einander deutlich geschietlenen Gewalten, einer weltlichen und einer geistigen mit absoluten und universalistischen Tendenzen.

$\mathrm{Zu}$ einer vollendeten sozialen und politischen Organisation gehören nach Comtes Theorie zwei universalistische und zentralisierende Gewalten, die unabhängig roneinander sind. Die weltliche Zentralgewalt hat das äußere politische Leben des Staates zu leiten. Die geistige Gewalt ist die höchste Autorität in Fragen der Moralität unel Erziehung. Das polytheistische Zeitalter hat schon einen schwachen Anfang zur Herausbilelung dieser Prinzipien gemacht. So deutet das Orakel in Delphi, das eine so große Bedentung für das politische Gesamtleben Griechenlands besa B, anf das Prinzip der geistigen Gewalt und das römische Imperatorentum auf das Prinzip der weltlichen Gewalt hin. Dennoch zeigte sich der moralische Tiefstand tieser Epoche in den barbarischen Eroberungskriegen und ter abscheulichen Institution der Sklarerei. die selbst von den besten Männern dieses Zeitalters ancrkannt wurde.

Zwischen den Führern der geistigen und materiellen Bewegung, dem Priesterstande und dem Kriegerstande, die als notwentige (roane des theologischen Zustandes angesehen werden müssen, bestand damals noch kein Zusammenarbeiten in der Richtung auf große gemeinsame Kulturideale. Die große Erfüllung des theologischen Srstems brachte erst der monotheistsche Zustand der menschlichen Gesellschaft.

Allerdings darf man nicht verkennen, daß die bewunderungswürlige Entfaltung des theologischen Systems, welche das Nittelalter offenbart, auch gleichzeitig schon den Todeskeim dieser ganzen Weltanschanng in sich barg. Der Monotheismus war eine ungeheuere Tat der logischen Abstraktion. An die Stelle der vielen Götter trat nun der eine Gott, und dieser eine Gott wurte in absoluter Jenseitigkeit gedacht. So wurde das ganze große Feld der Natur für die naturwissenschaftliche Erklärung frei. Anfänglich hegte man die Ċberzeugung, daß diese transzendente Gottheit des Monotheismus ihren Willen durch Wunder kundtäte und imstande sei, die Ortnung ter Natur, die ron ihr gesetzt war, überall und jederzeit zu durchbrechen. Aber das Wunder wurde immer mehr beschränkt und schließlich auf die dunkle Vergangenheit zurückgeschoben, so daß die Gottheit, von der Welt getrennt, durch die Bedingtheit des Natumechanismus die Welt regierte. Die Gottheit wurde somit an den Naturmechanismus gebunden und rerlor schließlich alle Bedeutung. 
Lnvergleichlich groß aber ist die Bedentung dieses Zeitalters für die Organisation des politischen und moralischen Lebens sowie für die sozialen Einrichtungen der Menschheit. Es begründete das Prinzip der beiden Gewalten im Papsttum und Kaisertum, ron denen das erstere die geistige Wohlfahrt der Tolker und das letztere ihre materielle Wohlfahrt begründen sollte und tatsächlich anch in hohem Maße begründet haben. Denn ihre Leitung und Regierung war gut und segensreich, solange sie ihre Kompetenzen nieht überschritten, solange das Papsttum auf jede weltliche und das Kaisertum auf jede geistliche Macht Verzicht leistete. So hat vor allen Dingen das Papsttum (lie Gewaltätigkeiten und Kriege rermindert. Die plumpen und grausamen Eroberungskriege wurden gemildert. Es war nun nicht mehr allein das Interesse der Gewalttätigkeit und des rücksichtslosen Egoismus, was die Kriege herbeiführte. Weit mehr, als das früher der Fall war, wurde um ideale Güter gekämpft. So war es vor allen Dingen das religiöse Interesse und die religiöse Sehnsucht, welche die Menschen zu kriegerischen Taten trieb. An die Stelle der Eroberungskriege traten die Religionskriege, die besonders in den Kreuzzügen ihre höchste Blüte fanden. Segensreich wirkte das Christentum und seine Spitze, die päpstliche Gewalt, auch in sozialer Hinsicht. Der rücksichtslose Egoismus der Großen und Mächtigen wurde gedämpft und gemildert dureh eine Lehre, rlie den Altruismus zum Prinzip erhob und das große Gebot. der Menschenliebe rerkündete. Auch trug das Papsttum nach Kräften dazu bei, daß die unwürdige Lage, in welcher sieh die niedrigen Volksschichten befanden, die zum großen Teil noch in den Fesseln einer unwürdigen Sklaverei schmachteten, gemildert wurde, und wenn es ihm auch nicht gelang, die armen Heloten zu vollkommener Freiheit zu führen, so milderte es doch ihr Los, indem es die Sklaverei in Leibeigenschaft wandelte.

Auch das Imperium und die mittelalterlichen Institutionen der Vasallität und les Rittertums dienten im allgemeinen dem moralisehen Wohle der Mensehheit. Denn wenn auch das System der Feudalität manche Härten in sich trug, so begünstigte doch anch wieder der Franenkult der ritterlichen Licbe die Erstarkung der altruistisehen Moral in der Erweckung der affektiven Fihigkeiten.

Dir geschichtsuhilosophische Konstruktion weiß dann weiter dentlich zol maehen, dals dic Zeit des Mittelalters auch der kïnstlerischen Entwicklung zolgeneigt war. So fand die Arehitektur in der Gotik eine neue große Ausdrucksform, mut das größte Epos aller \%eiten, tle göttliehe Konödie, wurde in Mittelalter geschaffen.

Un die Mrende des 1:3. Jahrhunderts hat diese große Epoche der Mensehfreitsgeschichte ihr bute erreicht. Gegen don Universalismus erheben sich die partikularen Gewalten. Auf die grobe synthetisehe Epoche des Menschengreshlechlis folgt mmmehr die amalytische mul kritische. Es ist das große I'hergangweitalter, las ('omte als dic metaphysische Epoche des Mensehen-

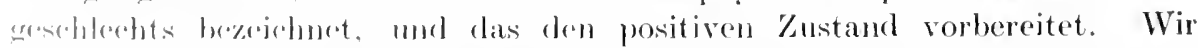

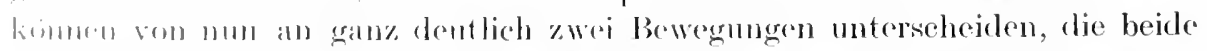

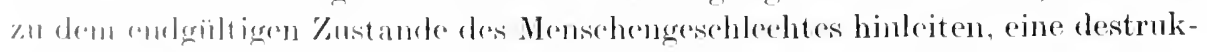

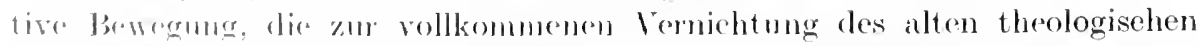
Sistoms dureh dir motaphysische Kritik führt, und eine positive, welehe die 
Elemente der neuen Gesellschaftsordnung entwickelt. An der Grenze zwisehen dem positiven und metaphysisehen Zustand liegt das große weltgesehichtliche Ereignis der französisehen Revolution.

Die intellektuelle Entwicklung führt im metaphysischen Zustand zu' vollkommenen Zertrümmerung der Gottesvorstellung. Sehon der Protestantismus hat die Wundermacht des höchsten Wesens auf das empfindliehste gesehwächt, und im Deismus ist die Gottheit zu einer abstrakten Wesenheit verflüehtigt. Die ganze große Bewegung der Philosophie dieser Zeit läuft darauf hinaus, an die Stelle der lebendigen Gottesvorstellung abstrakte Entitäten zu setzen. Und diese philosophische Kritik an dem alten System nimmt immer radikalere Formen an, je mehr an die Stelle der Philosophen, die ursprïnglieh als die Leiter der intellektuellen Bewegung angesehen werden müssen, die Rechtsgelehrten und die Literaten traten. Diese philosophisehe Kritik, die. mit dem Protestantismus und seinen Vorläuferm beginnend, im Aufklärmng:zeitalter ihre Vollendung erreicht, wandte schließlich die Waffen der Kritils gegen sich selber, indem sie die Mögliehkeit aller Erkemntnis bestritt und so sehließlich in einem haltlosen Skeptizismus endete.

Weiter ergriff die metaphysische Kritik aber auch das Gebiet des moralisch-sozialen und politisehen Lebens und zerstörte ron Grund aus die alte Gesellschaftsordnung. In Zeitalter der Renaissance trat das Laster in furchtbar großer Gestalt hervor und Reeht und Sitte wurde mit Füßen getreten. Die moralisehe Gewalt des Papsttums wurde in die allgemeine Korruption mit hineingerissen und befleckte die Reinheit und Hoheit ihres Amtes durch Ländergier, Grausamkeit, Wollust und Simonie. Die Autorität des Papsttums ging vollkommen verloren. Diese ursprïnglich so hoehstehende und segensreiche soziale Institution sank zu einem klägliehen Sehattengespenst herab. Auch das Imperium verlor allen Glanz, und an die Stelle der universalen Mächte traten nunmehr die nationalen Gewalten, indem die zentripetale Bewegung jetzt dureh eine zentrifugale abgelöst wurde. sei es num daß die Fendalität wie in England oder die Monarehie wie in Frankreich die weltliehe Diktatur an sieh riß.

Die metaphysische Tendenz war der künstlerisehen Entwicklung im allgemeinen nicht günstig, sofern die Rückkehr zu den Idealen der Antike und das ungehenere Ansehen, welehes speziell das Griechentum im Geiste dieser Weltanschauung genoß, die gesunde moderne realistisehe Entwicklnng der Kunst beeinträehtigte und störte. Die Niederlage, die das theologisehe Srstem durch die Metaphysik erlitt, offenbarte sich auch auf materiellem Gebiete. So ist es ja deutlich, daB der militärisehe Geist gleichzeitig mit der Maeht und dem Einfluß der Theologen Bankrott erlitten hat, sofern es nieht mehr die rein militärischen Instinkte sind, die zum Kriege treiben, sondern nach den religiösen Ideen nummehr in erster Linie die wirtschaftliehen Interessen aussehlaggebend zu werden beginnen.

Der Metaphysik war es nicht gegeben, eine neue Ordnung der menschlichen Gesellschaft zu begründen. Sie konnte nur zerstöreu, aber nicht aufbanen. Gleiehzeitig mit der destruktiven Bewegung der Metaphysik setzt die anfbanende Tätigkeit der positiven Philosophie ein. Sie entwickelt die positiven Elemente der neuen Gesellsehaftsordnung in Wissensehaft, Kunst und In- 
dustrie. Die Wissenschaft, welehe nummehr die metaphysischen Systeme ablöst, ist die Naturwissenschaft, die an die Stelle der vagen metaphysischen Ideen den Begriff des Gesetzes stellt. Ausgehend von Mathematik, Astronomie und Mechanik, erweiterte sie immer mehr den Kreis des positiven und gesetzmäBigen Weltverstehens. Am längsten leisteten die Biologie und die Geschichte Widerstand, aus denen die metaphysischen Begriffe am schwersten zu vertreiben waren. Die Hierarchie der Wissensehaft, wie sie von Comte aufgestellt wurde. ist als Abschluß dieses ganzen Prozesses anzusehen.

Die Entwieklnng des künstlerischen Elements, das ebenso wie die moderne Philosophie und Wissenschaft ein notwendiges Glied der positiven Gesellschaftsordnung werden sollte, beginnt schon im Mittelalter in der Bildung der modernen Sprachen, in denen der neue Geist der Dichtkunst sein adäquates Ausdrucksmittel fand. Es bildete sich die moderne Kunst heraus, die sich in das Gewand eines kräftigen Realismus hüllte und als Dichtkunst im Roman ihre höchste Vollendung fand. Die neue Kunst ist vor allen Dingen durch ihre enge Beziehung zu dieser irdischen Welt und dureh ihr nahes Verhältnis zum sozialen Leben und zur Geschichte ausgezeichnet. Vor allem die Gesehiehte wird für die positive Kunst ein unendlich reicher und kostbarer Stoff der Bildung und Formung sein. Die Kunst wird verherrlichen das Leben des großen Wesens, der Menschheit, ihr sehweres Schicksal, ihr tragisches Leid, ihren schmerzlichen Untergang und ihre endgültige siegreiche Erhebung.

Das Werden der positiven Gesellschaftsordnung ist dann sehließlich ganz besonders durch die Entwieklung der Industrie und des Wirtschaftslebens charakterisiert. Der industrielle Geist ist das ganz nene Element gegenüber dem alten theologischen System. Denn kein Kulturelement ist der alten theologischen Ordnung so feindlich gesinnt wie die Industrie, die $1 m$ ihres eigenen Daseins willen den militärischen Geist bekämpfen muß und die Menschheit zmm Frieden führt, indem sie die verschiedenen Nationen immer enger aneinander schließt und cine Gemeinsamkeit der Interessen begründet, von der das alte Wirtsehaftssystem weit entfernt war. Die Entwicklung des Handels ınd der Indıstrie hat dahin geführt, daß schließlich die sozialen Hemmungen der Leibeigenschaft überwunden worden und ein freier Arbeiterstand sich horansbildete, der nummehr als notwendiger, mentbehrlicher Faktor für alles ficmeinschaftsleben angesehen werken mul.

Am schlimmsten war es in dem ganzen metaphysischen Zeitalter um den moralischen Wort bestellt. Die philosophische Kritik hatte zur Zerstörung allar moralischen L'barzengung geführt und die politische Kritik dann vollends jerles AntorititshewnBtsein ausgelöscht nud dadurch die staatlich-soziale

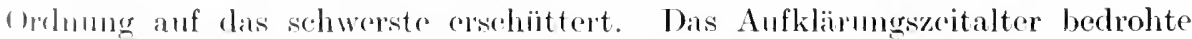
lie menschliche Gesellschaft mit vollkommenor Mnarehie. So bleibt denn dem pesitirem \%ostandr vor allem die politische und moralisehe Organisation der fiescllschaft vorbehalten. Ws gilt die gesanten positiven Kulturelemente Jer .Hemschlorit zusammenzufassen, die Theorie der modernen Gesellsehaft

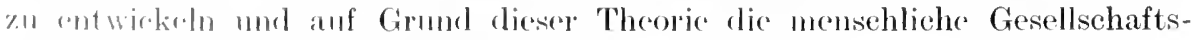

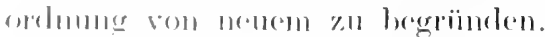

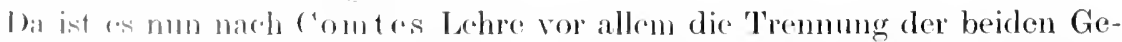

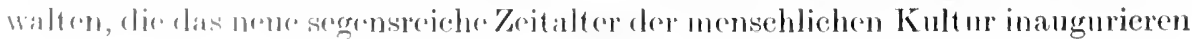


wird. Eine moralische Gewalt sold errichtet werden, frei ron allen theologischen Vorurteilen, die nur die unbedingte Befolgung der großen sittlichen Gebote im Ange hat und ron dem Geiste reinster Menschenliebe geleitet wird Diese moralische Gewalt soll dem Kultus der nenen Religioin rorstehen, die sich nicht mehr auf ein fabelhaftes göttliches Wesen, sondern ganz ausschließlich auf die Idee der Menschheit beziehen wird. Die moderne Religion ist dem Kultus des großen Wesens geweiht und rerkïndet die Herrschaft des Affektiven, die allgeneine Menschenliebe und die Idee des ewigen Friedens.

Diese moralische Gewalt, welche gleichzeitig auch die höchste Autorität des Wissens bildet. wird die Yölker der abendländischen Republik unter ihre geistige Antorität bengen, und ihre Geltung und ihr Ansehen wird sich allmählich über den ganzen Erdkreis verbreiten, was durch den Umstand wesentlich erleichtert ist, daß sie die Heterogenität des Wissens und des Glaubens zu rersöhnen weiß. Die Kräfte aber. auf die sich diese geistige Macht vor allen Dingen stützen wird, sind die Frauen und das Proletariat der Arbeiter. Während sie selber das Prinzip der Intellektualität vertritt, bedeuten die Franen im ganzen Haushalt der menschlichen Natur ror allem das Prinzip des Gefühls und des Phantasielebens, während die Potenz des Willens hesonders durch den Arbeiterstand rertreten wird.

Neben dem geistigen Machthaber, aber mabhängig ron ihm sollen die weltlichen Mächte stehen, die aus der modernen materiellen Macht, der Industrie herrorgehen werden. An die Stelle der militärischen Machthaber sollen die industriellen Gewalten treten.

Der positive Zustand als der endgïltige Zustand des Menschengeschlechtes ist durch die Idee der Moralität im engen Zusammenhang mit dem Prinzip des Universalismus bestimmt. Com te vertritt die Auffassung, daß die Religionen der Menschheit als eigentlich wertrollen Ker'n moralische, ästhetische und intellektuelle Momente enthalten. Das bedentsamste dieser Elemente ist das moralische, das in der Idee der Menschheitsreligion seinen Ausdruck findet. Wenn der englische Geschichtsphilosoph Carlyle dahin neigt, die Persönlichkeit zu vergöttern, so ist für Auguste Conıte die Menscheit in ihrer Totalität ein geheiligtes Wesen. Der Endzustand der Menschheit ist durch das absolute Übergewicht der altruistischen Neigungen über die egoistischen charakterisiert, die sich mit Freudigkeit in den Dienst des Ganzen stellen nnd in der selbstlosen und reinen Gesinnung der Frau sowie in der Tüchtigkeit und Auffassungsfähigkeit des Proletariers ihre stärksten Stützen finden. Wenn wir eimmal feststellen, welche Stellung die einzelnen großen Kulturfaktoren im positivistischen Zustande einnehmen, so finden wir, daß die Wissenschaft mnd die Philosophie, die Verallgemeinerung der wissenschaftlichen Ergebnisse in einer großen organischen Zusanmenfassung, daß diese beiden es sind. Welche, indem sie die Gesetze der Natur und des sozialen Lebens feststellen. damit anch gleichzeitig diejenigen Normen verkünden, die notwendig gelten und Anerkennung finden müssen. Auf der wissenschaftlichen Erkenntnis baut sich dann die moralisch-soziale Ordnung auf. Der Philosoph weiß. Was ist, er kennt die große Tatsache der Welt. Alles menschliche Tun und Leiden ist angenscheinlich von dieser großen Tatsache abhängig. Die Aufgabe des moralischen Lehrers und des sozialen Reformators kann infolge dessen nur darin gesucht werden, 
die Gesellschaftsordnung im Einklang mit der Natur aufzurichten. Die moralische Ordnung ist damit für alle Zeiten fest begründet. Denn es hat keinen Sinn, sich gegen eine Bestimmung aufzulehnen, die ihren Grund und Ursprung in einem Gesetz der Natur hat. Damn ist ein für allemal der unselige Zwiespalt zwischen Glauben und Wissen beseitigt. Ist es doch der Glaube, der immer auf moralische Forderungen sich beruft, während der wissenschaftliche Mensch auf die Tatsachen des Naturgeschehens hinweist. Glaube ich an das, was notwendig ist, so ordne ich mich dem großen Zusammenhang der Natur unter und lehne mich nicht dagegen auf. Das theoretische Bewußtsein der unverbrüchlichen Naturordnming erzeugt eine Resignation, die einen hohen moralischen Sinn in sich schließt. Wir fügen uns in das Unvermeidliche und sehließen uns eng an das Ganze an, aus dem alle Quellen unseres Lebens hervorbrechen. Unsere eitle Selbstüberhebung wird getilgt, und wir führen unser Leben nur als Teil des großen Weltlebens, das uns alle umsehließt und umfängt. Wir wissen auch wohl, daß die individuelle mensehliche Seele, die ja im Grunde genommen eine Abstraktion ist, ımmöglich fortdauern kann, sondern daß ihr ein Weiterleben nur beschieden ist, wenn ihre Leistung jene Höhe erreicht, die in der Idee der Mensehheit das wertvolle Gattungsleben umsehließt.

Die Religion hat im dem positiven Staat ihre Stelle, sofern die Idee der Mensehheit zum Gegenstand des Kultus erhoben wird. Die Idee der Mensehheit soll die Stelle Gottes einnehmen. Ihr allein gelten die Gebete der Gläubigen. Durch Priester in hohen, stillen Tempeln soll das Schicksal der Mensehheit rerkündet, ihr hoher Triumph gefeiert werden.

Die höchste Aufgabe der Kunst aber ist darin zu suchen, daß sie diesem religiösen Kultus der Menschheit Glanz und Schönheit gibt, in hohen Licdern ihr großes Sein verrherrlicht und auch die stillen Stätten ihrer Verehrung mit Bildern der Schönheit schmüickt.

So sehen wir, daß die Gesehichtsphilosophie Auguste Comtes ron einem Wertsystem beherrseht wird, in dem der moralisehe Wert den höehsten Maßstab hergibt. Dabei wird die Selbständigkeit der einzelnen Werte mehr oler woniger zorstört; denn wenn auch Auguste Comte von einer positiven Moral spricht, so ist doch der Inhalt von dem, was geglanbt werden soll, in der Hauptsache theoretische Einsicht und ein Komplex moraliseher Maximen, die sich aus dieser Einsicht ergeben. Die Kunst hat rollends alle Autonomie (angebülst, indem sie so ganz in den Dienst des Moralkultus gezwungen wird. Auch rerkennt C'omte durchaus das Wesen der Moralität, das in dem Begriff des Sollens gipfelt, wenn ar meint, daß die moralische Ordnung sieh aus der S'rinsordmung ableitrun lasse. Von besonderem Intcresie ist scine Auffassung des besetzosbegriffes, der sich hier an die Stelle ciner ideellen Wertverwirklichung schiebt mol sowohl cinen simnollon Endzweck der mensehlichen Whtwikklung wie auch ein Feld freier und ziclbewubter Tätigkeit für den somialen lieformator zuliibt.

Dir Lahe von Augusta Conte bedented die letzte grobzïgige Konstruktion des gesannten Menschhoitsprozesses. Wohl finden wir bedeutsame

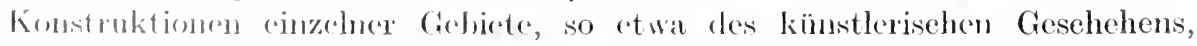
nicht aber wird dergesante Prozebrler Menscheitsgeschichteder philosophisehen brutung mitcrworfen. Die geschiehtsphilosophisebe Spekulation richtet 
sich besonders auf die Fragen der Geschichtslogik. Sie fragt nach der Methode und nach Begriff und Wert der historischen Wissenschaft. Ton besonderem Interesse wird dann die Frage, ob die Persönlichkeit oder die Masse oder weleher bestimmte Kulturwert für den historischen Prozeß maßgebend sei, ob etwa den materiellen Verhältnissen eine größere Macht innewohne oder dem ideellen geistigen Leben.

\section{b) Die materialistisehe Geschichtsphilosophie.}

Die deutsche Gesehichtsphilosophie, wie sie ron Schelling, Fichte und Hegel vertreten wurde, hatte, so schien es, die Bedentung des geistigen Lebens überschätzt, und so erfolgte dann in der Geschichtsphilosophie des Marxismus, der von Feuerbach der Weg gebahnt war, ein heftiger Gegenstoß gegen den deutschen Idealismus. Nicht die Werticleen sind kulturbildend und lebenerzeugend, sondern vielmehr die wirtschaftlichen Kräfte. Der wirtschaftliche Wert war von der Philosophie des deutschen Idealismus stark ignoriert worden. Er wurde jetzt im Gegensatz zu Wissenschaft, Kunst und Religion als das eigentliche Agens des Weltgeschehens betrachtet. Für das, was auf der großen Weltbühne geschieht, ist die ökonomische Lage sehr viel wichtiger wie die philosophischen Ideen oder die moralische Überzeugung. Denn die stärkste Forderung, die das Leben stellt, geht auf die Erhaltung der Existenz, auf Nahrung. Wohnung und Kleidung, auf die Befriedigung der sinnlichen Bedürfnisse. Der deutsche Idealismus hat den Kulturidealen eine metaphysische Realität zugesprochen, die sie in Wahrheit nicht besitzen. Er hat das wahre Verhältnis zwischen den Dingen umgekehrt. Die materiellen VerhäItnisse und die ökonomischen Faktoren, wie sie in den Terhältnissen ron Angebot und Nachfrage, ron Produktion und Konsumtion zum Ausdruck kommen, bilden die Grundbeziehungen des sozialen Lebens, denen die denkbar größte Realität innewohnt. Materielle Gütergewinnung, materieller Gütergenuß sind für die Entwicklung der Menschheit entseheidend. Sie bereiten den Boden vor, auf dem dam allererst das Interesse für die geistigen Güter und Werte entspringen kann.

Das wirtschaftliche Leben ist also nach Marx ron entscheidender Be. dentung für die Mensehheitsgeschichte ${ }^{1}$ ). Er sucht es in seiner historisehen Entwicklung zu verstehen. Indem er es aber geschichtsphilosophisch betrachtet. kommt er mit Notwendigkeit zu dem Begriff einer wertvollen Wirtschaftsgemeinschaft und damit zu der Idee eines wirtschaftliehen Wertes überhaupt. Diesen Wert des wirtschaftlichen Lebens sieht er in dem sozialdemokratischen Zukunftsstaat erfüllt. Die rollendete Wertform, die das soziale Wirtschaftsleben annehmen kann, ist gerade diese Gestaltung. welehe die kapitalistische Wirtschaftsordnung zerstört und begräbt. Marx fragt also nicht nach den Gesetzen, die ein gleichgïltiges Geschehen regulieren, sondern nach dem Fndzweck eines wertvollen Prozesses. Auch seiner Konstruktion des historischen Geschehens liegt ein Wertsrstem zugrunde. in dem der wirtschaftliche Wert die Dominante bildet. Beine Gesehichtsphilosophie unterscheitet

1) Marx, Kapital, 1867 ff. Vgl. L. Woltmann, Der historische Materialismus, 1900.

If ehlis, Geschichtsphilosophie. 
sich ron der sciner großen Torgänger zunächst einmal nur durch den verschiedenen Wertgesichtspunkt.

Allerdings rerbindet sich bei Marx mit dem neuen Wertgesichtspunkt des wirtschaftlichen Lebens auch gleichzeitig eine materialistische Metaphysik, und erst dadurch tritt dieser Geschichtsphilosoph in einen strengen Gegensatz zu der Geschichtsphilosophie des deutschen Idealismus. Es ist nicht nur allein ein Maximum an Kulturbedeutung, was den wirtschaftlichen Wert ror den anderen Kulturwerten auszeichnet, sondern die wirtschaftlichen Ideen und Maximen sind auch gleichzeitig die wirksamsten Ursachen für den historischen Verlauf. Das wirtschaftlich wertvolle Leben hängt am innigsten mit der Realität der Welt zusammen. Es läßt sich auf metaphysische Kräfte zurückführen, die gerade diese Zielstrebigkeit auslösen. Die Wirklichkeit der Dinge ist absolut simnlich und materiell zu deuten, und aus dieser metaphysischen Materialität läBt sich am besten das Streben nach sinnlichen und materiellen Gütern begreifen. Die geistigen Giiter und das ihnen zugewandte Streben basieren, wenn wir ihre Trsache erforschen, anf dem materiellen Wertempfinden und den ihnen korrespondierenden materiellen Grundkräften.

Mit dieser Bevorzugung des wirtschaftlichen Wertes hängt es dann auch wieder notwendig zusammen, daß die Massen und und nicht die einzelnen großen Persönlichkeiten für das historische Geschehen entscheidend sind. Denn aus den ökonomischen Grundkräften geht alles starke und wirksame Leben hervor, und an diesem Ringen und Kämpfen um die Notdurft des Lebens nimmt jedes Individuum in größerem oder geringerem Maße teil, während die hohen wissenschaftlichen und künstlerischen Ideen mur die einzelnen bewegen und nicht imstande sind, in gleicher Weise das soziale Leben in seinen Tiefen zu erregen und zu erschüttern. Schließlich ist doch die Gesamtheit des religiösen, kïnstlerischen und wirtschaftlichen Lebens durch die ökonomische Lage bedingt wnd erhält von ihr aus ein besonderes Gepräge. Die Religion der kapitalistischen Gesellschaftsordnung muß von der des sozialistischen Zukunftsstaates grundverschieden sein, da sie ja mit dem Wirtschaftssystem in cinem unentfliehbaren Zusammenhang steht.

\section{c) Naturwissenschaftliche Auffassung der Geschichte.}

Der englische und französische Positivismus, der mit dem Materialismus der fünfziger. Jahre Hand in Hand geht, bedroht die Selkständigkeit der historischen Wissenschaften und ihre cigentümliche Prinzipienbildung, die im Zeitalter des Irtealismus und der Romantik herangereift war. Die einsichtsvollon Lnterscheidungen rines Fricolich Sichlegel in bezug anf die verschiedene Aufgabe und Methode rom Naturwissenschaft und Geschichtswissenschaft war vergessen worden, mol das bestreben richtete sich daranf, dir Creschichte zu ciner Naturwissensohaft zu, erheben", ein Bestreben, das dams später in Darwins 'Theorien übor die Entwicklungsgesetze des or-

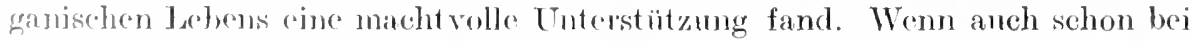
Anguste Comtr das Bestroben vorby, die Geschichte durch Gesetzeshestimmungen zmm Range cince ohjektiven Wissenschaft zu erhöhen, so wahrte Hoctl seine Herausarbeitung des historischen Gesetzesbegriffes der

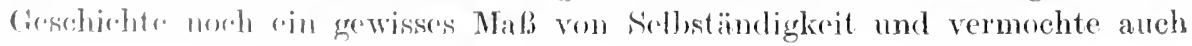


der Eigentümlichkeit der historischen Phänomene und der Besonderheit menschlicher Kulturentwicklung noch in hohem Grade gerecht zu werden. Der Versuch, die Geschichte nun tatsächlich zu einer Naturwissenschaft zu ,erheben", ist erst ron Comtes Schülern, besonders ron John Stuart Mill und Thomas Buckle. unternommen ${ }^{1}$ ). So suchte letzterer die Gesetze des Völkerlebens, ihres Wachsturms und ihres Verfalls zu crgründen, und hier erschien num die Statistik als ein ungemein wertyolles Mittel, um das Schicksal der Menschheit in ihrer Gesamtheit kennenzulernen. Wenn uns der alte Chronist ron den Taten und Schicksalen eines Königs oder Hecrführers erzählt, so mögen solche Erzählungen uns erfreuen und einen interessanten Stoff für künstlerische Darstellungen gewähren. Aber wie ïbcrans wenig bedeuten sie doch für das Ganze der Menschheit. Einen ganz anderen Einblick in das Leben der Menschheit erhalten wir, wenn wir etwa statistisch feststcllen können, daß die Geburtenziffer eines Volkes immer mehr zuruickgcht oder die Zahl der Eheschließungen sich vermindert, wenn dic Kindersterblichkeit zurückgeht oder die Zahl der Selbstmorde steigt. So wird uns rer Rückgang der Geburten davon überzeugen, daß mit den Jahren ein Verfall der betreffenden Nation eingetreten ist, daß sie sich überlebt hat und dekadent geworden ist, so daß nun bald ein anderes Volk an ihre Stelle treten wird. Die Geschicke des Völkerlebens sind dem Leben des einzelnen analog. Die Völker wachsen aus roher Naturkraft empor und werden in ihrer starken Gesundheit das willkommene Werkzeug müder, überlebter Kulturen. Später werden sie von dieser fremden Kultur ergriffen, sie nehmen sic auf und sind ihre bewnßen Bekenner und Verfechter. Sie unterjochen die Bildner und Schöpfer, denen sie einst gedient, und errichten ein neues Kulturwerk auf den Trümmern der alten Welt. Aber auch ihnen droht der Feind in einer ungeschwächten Volkskraft, deren Vitalität einmal später den Sieg über ihre nüde Kulturschönheit davontragen wird. Geht die Geburtenziffer zur̈ück, so wissen wir, daß die Volksgesundheit geschwächt ist, und daß die Zcit bald nahen wird, wo sie aufhören muß, ein selbständiges Dasein zu leben.

Von diesen Standpunkt aus erscheint das Ganze der Menschheit, besonders aber die Masse eines cinzclnen Tolkes als das historisch Relevante. Nicht so sehr liegt das Interesse auf den großen Leistungen als der Vollendung und Krönung des Volkslebens, sondern die Gesundheit und Kraft des Volkskörpers, an der ja alle mehr oder weniger Anteil haben können, wird ganz besonders unterstrichen. Die Masse als Masse wird nunmehr interessant. das bloße psychophysische Dasein in Kraft und Stärke wird historisch wichtig, da ja die Kräfte dieses Massenlebens im Grunde genommen alles produzieren. Auch die Schöpfung des sogenannten Genius ist doch schlicßlich ein Produkt der Massen, wie überhaupt diese positivistischen Geschichtstheorien dem Begriff des Genialen außerordentlich skeptisch gegenüberstehen. Der Begriff des Genies mußte diesem Naturalismus als eine Art asylum ignorantiae erscheinen. Das Unerklärte und Rätselhafte galt bisher als das Geniale. Das Unerklärte kann aber erklärt und das Rätselhafte gelöst werden, wenn wir uns nur nicht zu sehr an das alte Dogma von der Höhen-und Tiefendifferenzen

1) Thomas Buckle, History of civilisation 1875. 
unter den Tensehen klammern und uns entsehließen, alle Erseheinungen an dem Begriff eines durchschnittlichen und normalen Menschen zu messen. Wir werden dann selır bald zu der Einsicht gelangen, daß alles viel durchsehnittlicher ist, als es auf den ersten Blick erscheinen möchte, und daß der größte und kleinste Mensch nicht so gar weit voneinander entfernt sind. Auch in dem sogenannten Genie sind alle Komponenten enthalten, die wir in dem Durchschnittsmenschen rorfinden. und es hat nichts Ausschließliches und Einzigartiges, das bei niemand weiter anzutreffen wäre. Höehstens ist sein psychophysischer Mechanismus etwas komplizierter anfgebaut, wenn nicht gar die Abweichung rom Tormalen als eine gewisse Degeneration bezeichnet werden muß. Jedenfalls aber kamn dieses Anßerordentliche und Ungewöhnliche nur zum geringsten Teil den einzelnen Menschen selber zugereohnet werden. Vielmehr sind es nach Taine die Unstände, das Milien, die allgemeinen Lobensbedingungen, die uns zu dem machen, was wir sind. Der Mensch ist das Produkt der Verhältnisse und ist notwendig so. wie or num einmal ist. In den Kultus des Außergewöhnlichen und Genialen haben wir noch Rudimente alter mythischer Vorstellungen zu erblicken. Es ist das ein letzter Rest jenes Glaubensinhaltes, đaß gewisse auserlesene Naturen ein persönliches Verhältnis zu einer übersinnlichen Welt haben, und daß Gott ihnen seine Absichten durch Inspiration unmittclbar kundtut.

\section{d) Schellings Philosophie der Mythologie nud Offenbarung.}

Gegenüber der starken positivistischen und materialistischen Bewegung trat die Geschichtsphilosophie des deutschen Idealismus rollkommen zurück. Sic lebte weiter in der Hegelschen Schule, die besonders um das geschichtsphilosophische Verstehen der Entwicklung des ästhetischen Bewußtseins sich hohe Verdienste erwarb. Sie fand noch einmal einen großartigen Ausdruck in dem Alterswerk Schellings, in der Philosophie der Mythologie und Offenbarung ${ }^{1}$, die als eine Art Geschichtsphilosophie des religiösen Bewußtseins aufgefaßt werden muß, und in der Schelling zu den tiefsinnigen Spekulationen der Gnosis zurückkehrt. Der Gegenstand sciner Spekulation sind die mythologischen und religiösen Vorstellungen der Menschheit, die immer höhere und reinere Gestalt angenommen haben. Was bedeuten diese religiösen Vorstellungen, in denen wir ein Wissen von der Gottheit zu haben glauben? Sie sind Kundgebungen und Offenbarungen des Göttichen. Aber nicht nur dieses. Der Stufengang der Offenbarung drïckt auch gleichzeitig einen Stufengang des göttlichen Lebens aus. Sie sind Anzeichen des göttlichen Werdens, das jorle Stufo seiner Sellostentfaltung mit einer immer höheren Kundgelung und Offenbarung an das Menschliche begleitet. Das Menschliche aluer hat für das Göttliche diese Bedentung, daß es in ihm sich wiederspicegelt und anschant und so zur belhsterkenntnis gelangt. Der Geist berkarf les firistes, $10 \mathrm{~m}$ sich selhst $\%$ verstehen.

1)ic Bawegung ales mythologischen Bewubtseins belentet also für Sicholling dic Solbstontfaltung Gottes in der Wolt. Die mythologisehen Vorntellungens sind woit mehr als phantastisele Dentungen des Universums,

1) Ausgewahlt, Worke, Bul. IIt. Helix Moiner, Loiprig. 
in ihnen drückt sich das tiefe Werden der Gottheit aus. Und diesem Werden der Gottheit folgt Schelling in einer grüblerischen Konstruktion bis zum Anfang des Anfangs, da die Grundprinzipien der Welt sich zur göttlichen Einheit zusammenschließen.

\section{e) Schopenhauer.}

Dem Kreise der idealistisch romantischen Denker gehört auch die einsame Gestalt ron Schopenhauer an, der, ganz vereinzelt in jener historisch gerichteten Zeit, die Bedeutung der Geschichte nicht einzusehen rermochte. Nach seiner Lehre kann es nur eine Wissenschaft rom Allgemeinen geben, da sich das Besondere und Eigentümliche der erklärenden Erkomntnis entzieht. Deswegen ist die Naturwissenschaft die einzige Form wissenschaftlicher Erkenntnis. Das Individuelle als solches in sciner empirischen Gestalt ist ohme wissenschaftliches Interesse. Die bloße Tatsächlichkeit kam dem verstehenden Geist nicht genügen. der immer nach dem Allgemeinen strebt. Diese Richtung auf das Allgemeine hat auch die Kunst, die. wie schon Aristoteles gesehen hat, viel philosophischer ist als die Geschichte. Das Wesen der Dinge stellt die Kunst dar, das eigentlich Bedeutungsvolle der toten und lebendigen Welt. In ihren großen Symbolen rerstehen wir die Gesetzmäßigkeit der Welt, in den ästhetischen Ideen erschanen wir als subjekt reiner Betrachtung das Ewige und Zeitlose, befreit von den Schranken der Kausalität, welche die phänomenale Welt gebunden hält. Dagegen bleilst die hrstorische Betrachtung in der Phänomenalität stehen und beranscht sich an dem äußeren Glanz großer Geschehnisse, als ob nicht das allgemein Menschliche, wie es die Kunst versteht, und auf das es schließlich allein ankommt, inder Geschichte eines Banernhofes ebensogut anzutreffen wäre wie in der Geschichte cines Königreiches ${ }^{1}$ ).

\section{f) Die Geschichtsphilosophie Carlyles.}

Dieser einseitigen Bewertung des Allgemeinen sowohl mit Rücksicht auf den methodischen Gesichtspunkt der Betrachtung wie auch in Beziehung auf das Objekt der historischen Betrachtung tritt die historische Auffassung Carlyles entgegen. Tief durchdrungen ron der Bedentung des historischen Geschehens, sieht er in den großen Menschen der Weltgeschichte dic Werkzeuge der göttlichen Idee. Als Prophet, als Staatsmann, als König, als Dichter erscheint der Held und erregt die schlummernden Tŕräfte zu gewaltigem historischen Leben ${ }^{2}$ ). Der Held ist die große Individualität, in der das ganze Leben einer Zeit ihr Zentrum und ihre Seele findet. Niemals könnte das Große geschehen ohne den Helden. Er ist rollkommen unersetztlich. in ihm lebt das Schicksal einer ganzen Zeit. Er ist das Wunderbare in dem gleichgültigen und indifferenten Leben, in dessen Wesen uns die Ahnung einer übersinnlichen Welt entgegenscheint. Träge und bewegungslos sind die Massen. Aus ihrer Natur kann das Heldenleben nicht abgeleitet und verstanden werden. Die Massen sind dem Pulverstaub zu rergleiehen, der trüb und dunkel die Erde

$\left.{ }^{1}\right)$ Vgl. A. Schopenhauer, Welt als Wille und Vorstellung.

2) Th. Carlyle, C̈ber Helden und Heldenverehrung. 
deckt. Wohl ruht in ihm ein verborgenes Leben und gewaltige Kraft, aber ans siel selbst heraus kann er niemals zur Entladung kommen. Nutzlos würde er clort aufgespeichert liegen ohne die Erscheimmng des Helden. Plötzlich naht sieh der Held gleich der Erscheinung des Blitzes. Feurig naht er in Flammenschein und erregt den schwarzen Staub der Erde, der dort ein unscheinbares und nichtiges Dasein führte. Lenchtend tritt er ihm entgegen, und siehe, da entflammt er auch. Arme unwissende Mensehen waren die Arabersöhne, die ein ungekanntes und ungenamntes Leben, ein stilles Hirtendasein führten. Da ist ihr Prophet in der Gestalt Muhameds gekommen und hat diese trägen Seelen geweckt und ihnen ein Hohes und Heiliges gegeben, das ihre Herzen in Flammen setzte und den Fenerschein durch die Weit trug. Den Helden ist der Ausdruek, ist die Sprache verliehen, zu sagen und zu tun, was die Menschheit bewegt und leidet. Er hat die Macht, sieh zu offenbaren und, indem er sich selber dentet und versteht, die Menschen zum Verstehen hinzuleiten. so war Dante die Stimme ron zehn schweigsamen Jahrhunderten.

\section{g) Nietzsclıes Bewertung der Individualität.}

In der hohen Bewertung der Persönlichkeit stimmt Friedrich Nietzsche mit Carlyle vollkommen überein. Sein ganzes Wesen und seme ganze Lohre muß aufgefaßt werden als ein flammender Protest der Individualität gegenïber der einseitigen und ausschließlichen Bewertung des Allgemeinen, drs Sozialen und des Milieu. Im Gegensatz zu allen diesen Theorien feiert Nietzsehe clie einzigartige Bedeutung des großen Menschen, die er in einem schrankenlosen Individualismus verkündet. Allerdings hat dieser Individualismus cinen großen Stil. Es handelt sich um die Wenigen, die Auserwählten, die sich ïber die Jahrhunderte hin die Faekel (les Geistes reichen ${ }^{1}$ ). Ihnen gegenüber kömnen die Massen niehts anderes bedenten als bloßes Material oder auch als Stoff und Nahrung ihres Wachstums und Werdens. Ihr niederes I asein, ihr Slklavenlos muB clem Auge des historischen Betraehters als etwas durchaus Nobensächliches erscheinen. Sic bedenten gleichsam die mißlungenen Versuche der Natur, das wirklich Wertrolle zu bilden. Der Genius ist das Meisterwerk der Natur, und die Herdenmensehen sind die Schlaeken und Bruchst ïckי, die niedersinken an der reinen Gestalt. Nır in dem Allerpersönlichsten und Eigentümlichen, wie in den großen und vornehmen Herrennaturen, ist wahres Wertleben zu spoüren, und mur das Werthafte kann Gegenstand der Geschichte sein.

Das was uns in der Botrachtung des Lebens interessiert, ist nicht snohl das Vorgangene ofler auch das Gegenwärtige, sondern das Zukünftige. Die grofise lerspertive der Geschichte liegt in dem, was zu crwarten steht, in llom, was kommen soll. Sielten hat die Sohnsweht so tief geatmet und div Hoffrums so grols und mächtig ihre Fittiche gerïhrt wie in der Phitresphir ron Frichleh Nictasche. Die Geschiehte ist weder der frompel der Mncmosyne, wie Hegel gelelurt hat, noch eine ewige Gegen-

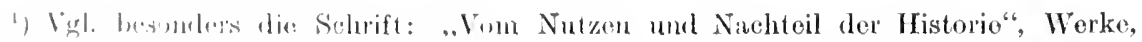
'l'uschen:tu*galle, Birl. JI. Ninumanu. 
wart, wie ein moderner Denker verkündet, sondern eine Vorbereitung der Zukunft, ein Stadium schmerzlicher Erwartung. Fortwenden soll sich die Menschheit von dem, was war und vergangen ist. Ohne Schmerz und ohne Rene soll sie die lange und bange Tradition hinter sich lassen. Nicht unser Vaterland sollen wir lieben, sondern unser Kinderland. Als Mittel und Werkzeuge sollen wir uns denken und fühlen für die große Geburt, mit der die Zukunft schwanger geht. Nicht unsere Nächsten sollen wir lieben, sondern unsere Fernsten, das Fremde, nicht das Bekannte, die Einsamkeit, nicht die Geselligkeit. Denn Einsamkeit ist die Stätte des Großen. Grund und Endzweck alles Geschehens ist das Werden des Übermenschen, das heißt das Werclen eines höheren Typus, der das Allzumenschliche und Kleinliche abgestreift hat. In diesem Sinne ist der Mensch etwas, das ïberwunden werden soll. Und dazu bedarf es nur eines großen und freien Entschlusses, abzustreifen alles Erbärmliche und Enge und die alte Demutslchre. Stolz und frei soll der Mensch sein und werden; der Idee des Jenseits abgewendet, dem Diesseits zugewendet sein, einem starken und mutigen Tatleben hingegeben in der absoluten Bejahung seiner Sinnlichkeit. Dem Körper soll sein Adel wiedergegeben werden, und im Bunde miteinem rornehmen und heroenhaft gesinnten Geist soll er das Ganze und Schöne gestalten. Die Geschichte ist die Werkstätte des Genius.

Das Verhältnis der großen Persönlichkeit zur Masse darf aber nicht so gedacht werden, daß jene für diese da ist, daß für die große Individualität etwa die Sollenspflicht rorläge, die Menschheit zum Licht zu führen. Vielmehr erhält die große Menschemmasse rein teleologisch ihren Wert nur durch die Idee der Persönlichkeit. Für sich betrachtet ist sie gänzlich bedeutıngslos. Die Masse der Menschen ist für die großen Einzelnen und Einsamen da, nicht umgekehrt die Individualität für die Masse. Wie der Organismus der Pflanze seinen Zweck und scine Erfüllung in Blüte und Frucht erreicht und den großen Kräfteverbrauch in die Erreichung dieses Zieles setzt, so ist auch die Kräftebewegung der großen Massen nur für die Vollendung der großen und starken Persönlichkeit da und findet in ihr seine Sinnerfüllung.

\section{h) Der Darwinismus.}

Der individualistischen Tendenz in der Auffassung des historischen Lebens, wie sie sich in Carlyle und Nietzsche ankündigt, stand die großc Anschaumg des Darwinismus entgegen, die, den Anregungen früherer Denker folgend, das Prinzip der Entwicklung zum leitenden der biologischen Betrachtung erhob. Es handelt sich hier zunächst $u$ m einen Triumph des historischen Denkens im weiteren Sinne des Wortes, sofern mit dem Gedanken der Festigkeit der Arten gebrochen und die höheren Lebewesen aus niederen Lebensformen erklärt wurden. Dazu wurden das Prinzip der Vererbung und der Anpassung als Leitsätze für die biologische Betrachtung aufgestellt. Aus den ersten Anfängen heraus erben sich die Eigenschaften der Lebewesen fort. Die Nachkommen zeigen unweigerlich die Qualitäten ihrer Erzenger. Sie müßten ihnen vollkommen ähnlich und als ihr vollkommenes Produkt zu verstehen sein, wenn nicht neben dem Prinzip der Tererbung auch das Prinzip 
der Anpassung gölte und in Kraft stünde. Muß die Vererbung zur Stabilität und Erhaltung des Art- und Gattungscharakters führen, so die Anpassung zur Tariation und Differenziermng der Arten. Das Mulieu macht seinen Einfluß auf das Individum geltend, welches sich seiner Umgebung anzuschmiegen sucht. Da ferner zwischen der Vermehrung der Individuen und ihrer Ernährungsmöglichkeit ein Mißverhältnis besteht, so tritt das Gesetz der natürlichen Zuchtwahl in Kraft. Es ist ein Gesetz der Natur, daß in dem Kampf ums Dasein diejenigen Individuen erhalten bleiben, die sich den Veränderungen der Lebensbedingungen in der Eigentümlichkeit ihrer Organisation am besten anpassen können.

Die große Hypothese des Darwinismus hat auf clas historische Denken zurïckgewirkt und ist auch auf die Kulturgeschichte übertragen worden. Wir sehen clarin den interessanten Torgang, daß ein ursprünglich historisches Prinzip, auf das Gebiet der Natur angewandt, mit neuem Sinn erfüllt wird, und daß es damn wieder mit diesem neuen Sinn auf das alte Gebiet, ron dem es hergenommen war, einwirkt, indem es seine Gestaltung zu verändern sucht. Der Kampf ums Dasein, auf das Gebiet der Kulturentwicklung übertragen, mußte zu einer gewissen Schwächung des miversalen historisehen Mitgefühls führen. Das Interesse des Historikers erregen nummehr in erster Linie die starken und kräftigen Nationen, die, von einem gesunden Egoismus getragen, ihre Partikularität in rücksichtsloser Weise durchzusetzen streben, sowie auch jene Individualitäten. die der Veränderung und der Gunst der Umstände entsprechend ihr Verhalten einzurichten wissen. So gewinnt der politische Egoismus und der Nützlichkeitsstandpunkt allen sozialen Verhältnissen gegenïber an Kredit, sowie anch das Raffinement der Diplomatie, das sich immer wieder der veränderten Weltlage anzupassen weiß. Auch zwischen den Nationen tobt der Kampf ums Dasein, und wenn sie nicht im Schatten stehen wollen, müssen sie sich ihren Platz an der Somne mit schweren Mitteln erkämpfen. Die religiöse Tat der Aufopferung wie auch der politische Idealismus, der auf große gemeinsame Menschheitsziele simnt, erhält unter der naturwissenschaftlich gefärbten Kategorie der Entwicklung etwas Schwaches und Hinfälliges. So ist cler Boden bercitet für eine historische Auffassung des Geschehens, die alles nach dem praktischen Erfolge mißt, die ein Faktum, ein historisches Geschehen nicht deswegen wertet, weil ein Kulturgut in ihm seine Erfüllung gefunden hat, sondern weil in dieser betreffenden Handlung oder Tat der Charakterwille einer Individualität oder die Ansprüche einer Nation sich durchgesetzt haben. Nach dieser Auffassung müssen wir als groß und historisch bedcutsam alles dasjenige anerkemmen, was wirksam gewesen ist und die Massen erregt hat. Es gibt eine historische Beurteilung, die lediglich am Erfolge orientiert ist. Die Völker, die Erfolg gehabt, haben sich durchgesetzt, sif haben sich im Kampf um die politische Existenz als die stärkeren erwiesen, die Völkerrasse, welche die andere ïberwindet, ist auf jeclen Fall immer die collere und bessere Rasse, so dab mit dieser Erfolgsbenteilung notwendig ein historischer Optimisums zusammengeht, der der Geschichte den tragischen Chatakter nimmt. Wemn das Griechentum dem Römertum mnterlag, so ging os zugrunule. weil (s nicht charaktervoll und hinlänglich widerstandsfähig war. 


\section{i) Das Gesetz der Differenzierung.}

Aus dem Prinzip des Darwinismus hat sich aber auch noch ein anderes nicht unwichtiges Prinzip der historischen Betrachtung ergeben. Es ist das ron Herbert Spencer ganz allgemein proklamierte Gesetz der Differenzierung und der Integration $\left.{ }^{1}\right)$. Jede Form der Entwicklung und so auch vor allen die Entwicklung der sozialen Menschheitsgebilde hat einerseits die Tendenz. zur Mannigfaltigkeit und Spezifikation und anderseits zur Gleichartigkeit und Uniformierung. Die unbekannte Weltkraft ist sowohl bestrebt, das Homogene aus einer gemeinsamen Wurzel heraus zu einer bunten Mannigfaltigkeit zu differenzieren und das Individuelle in der Fülle seiner Beziehungen und Unterscheidungsmerkmale zu bilden, wie auch anderseits cliese Vielheiten und Mannigfaltigkeiten dahin getrieben werden, zu neuen sozialen Gebilden sich zusammenzuschließen, die gleichsam Einheiten höherer Ordnung sind, sofern die soziale Gestalt riel reicher gegliedert und in jeder Hinsicht sehr viel komplizierter geworden ist als die Urgestalt. Alles entwickelt sich aus einer relativen Gleichartigkeit durch eine relative Mannigfaltigkeit inclividueller Bildung zu einer höheren Einheit.

Diesen Prozeß kann man sich deutlich machen an der Entwicklung der Kulturgüter, die ursprünglich in einer allgemeinen Werteinheit, in der Gestalt des Mythologischen ruhen, sich dann zu bestimmten Kulturmächten differenzieren und später wieder zu Kultussystemen zusammenschließen. Und lersellse Vorgang kommt zum Ausdruck, wenn auf Zeiten der politischen Zentralisation, für die das Imperium des Mittelalters typisch ist, Zeiten der politischen Dezentralisation folgen, die ron der nationalen Idee beherrscht sind. Tielleicht sind auch diese von der geheimen Idee erfüllt, daß die Torherrschaft des nationalen Gedankens noch nicht das Ende bedeutet, und daß diese große Differenzierung zu Eigenwerten des nationalen Lebens in einer höheren Einheit, clie dem Eigentümlichen vollauf gerecht wird, sich endgültig vollendet; aber im Sinne der Gegenwartskultur bejahen sie den nationalen Gedanken. Aus dem Prinzip der Philosophie, wie es ron Herbert Spencer entwickelt ist, läßt sich dann weiter auch der Gedanke ron analytischen und synthetischen Zeitaltern ableiten, das heißt dieIdee von Menschheitsepochen, in denen das suziale Leben sich in jeder Hinsicht differenziert, nicht nur in bezug auf die Bildung einiger sozialer Verbände und ihrer ausschließlichen Bewertung, indem die Intensität des Erlebens und Bewertens im Verhältnis zum Ganzen abgeschwächt wird und die Richtung auf clas Kleine und Vereinzelte geht. sondern etwa auch mit Rücksicht auf die wissenschaftliche Arbeit. indem dic Gemeinsankeit des Zieles vollkommen zurücktritt hinter (lem Kultus wissenschaftlicher Kleinarbeit.

\section{k) Die Geschichtsphilosophie der Gegenwartskultur.}

Wir haben schließlich noch die Entwicklung der geschichtsphilosophischen Probleme in den letzten Jahrzehnten kurz zu charakterisieren. Wir können hier nur auf die Tatsächlichkeit einzelner Erscheinungen hinweisen, dem diese Zeit ist noch zu new und jung, als daß sie als etwas Vergangenes betrachtet

1) Herbert Spencer, Prinziples of Soziology, 1876-96. 
werden kömnte. mnd so entzieht sie sich der historischen und geschichtsphilosophischen Betrachtung. Wenn es für die geschichtsphilosophische Betrachtung jeder historischen Entwicklung daranf ankommt, das ewig Bleibende und Gegenwärtige aus all den mannigfaltigen historischen Verschlingungen herauszuheben, so ist das Gegenwärtige in diesem Falle ein Etwas, das noch durch keine nenen Formen des BewuBtseins abgelöst, das gleichsam noch nicht über wältigt und überwunden ist und deshalb auch nicht verstanden werden kann. Wir wissen noch nicht, wo das alles hinaus will, wir erheben die Frage: „Was will das werden." Wir schwimmen im Strome, und uns ist die Möglichkeit der Reflexion ïber diese starke und unmittelbare Gegenwart genommen. Denn erst ron einem gewissen Abschnitt der Entwicklmmg aus läßt sich das Tergangene verstehen. Unsere Zeit ist noch unvollendet, und unsere Unkenntnis und Unwissenheit über diese Zeit ist so groß, daß wir nicht einmal wissen, ob es sich in der Geschichte dieser Jahrzehnte um ein müdes Epigonentum handelt, das die erworbenen Schätze der Vergangenheit mit mehr oder weniger Verständnis betrachtet und noch eimmal sich frent, die Kostbarkeiten des Geistes zu schanen, die es selber nicht schöpfen und erwerben kann, oder ob unser Zeitalter in rer Hauptsache ein Zeitalter fler Vorbereitung einer neuen großen Epoche der menschlichen Geistesgeschichte ist. Wir sind nicht imstande, es genauer einzuschätzen mol zu bewerten, noch entzieht es sich allen Vergleichsmöglichkeiten. Noch ist es ein einziges, mübertreffliches Zeitalter, las unsrige, in dem wir leben. Was wir aber als Tatsache konstatieren mïssen, eine Erscheimung ron größter Wichtigkeit für die Entwicklung der Geschichtsphilosophie, das ist das Wiedererwachen des Idealismus, der sich im Kampf mit der ïbermächtigen materialistischen und positivistischen Bewegung immer mehr durehgesetzt hat. Demn nur in Verbindung mit einer idealistischen Philosophic ist eine Geschichtsphilosophic großen Stiles denkbar.

\section{1) Der Neuidealismms.}

Diese nenidealistische Bewegung hat zuerst an den Namen Kant angeknüpft, und es ist das große Verdienst ron Kuno Fischer, daß er das Verstïndnis für die idealistische Philosophie von Kant bis Hegel zuerst wieler erwerkt hat. Denn vor seiner großen Leistung um die Geschichte der Philosophic war die Terständnislosigkeit in Dentschland so groß, daß man das Größte und Weptrollste, was der Genius des deutschen Tolkes gesehaffen, als abstruse Gedankenrerrenkung, als poetische hegriffliche Spiclerei mit ibherlegene Miene abfertigte und sich auf sein Besserwissen viel zugute tat. Kuno Fischer kamn als der philosophische Praceptor Germaniae angeschen werden, sofern er das deutsche Volk, oder vielmehr die Denkenden in diesem Volke, darauf aufmerksam machte, wie groß und ernst das war, was man zur Ziclscheibe des Sipottes aus törichtem Unverstand zu machen grwagt hatte. Inïbertrefflich ist dabei sein ganzes Vorgelen, das die sehwerflijsigen liegriffsmassen in leichtere Bewegung ïberleitet und überall deutlich macht, dafs dort. wo man Willkür und Begriffsphantasic vermutet hatte, rinre logischo Notwondigkroit steckt, die aus dem Ganzen des Systems mit vollendeter Klatheit eingesehen werden kaun. So verdanken wir ihm zu nieht erringrom Treil das Vorstänluis für wnsere große philosophisehe Vergangenheit, 
und daß es uns nicht mehr wie früher so vollkommen an Maßstähen fehlt. um historische Größe zu würdigen und zu verstehen.

\section{m) Lotze und Windelband.}

Zu Lehre und System schritt dann der Neuidealismus in der Philosophie ron Lotze, der den eigentümlichen Charakter philosophiseher Normbegriffe zuerst deutlich machte und dadurch die philosophische Methode und Fragestellung ron der psychologischen zu sondern wußte ${ }^{1}$ ). Der große Begriffsapparat des Neuidealismus wurde dann ror allen durch Wilhelm Windelband herausgearbeitet, der Gesetz und Norm, historische und genetische Fragestellung unterschied und den für die Geschichtsphilosophie so wichtigen Gegensatz des Nomothetischen und Idiographischen herausarbeitete. Die große Anteihnahme an geschichtsphilosophischen Problemen, die uns bei Windelband begegnet, der in seinem Lehrbuch eine klassische Form der philosophischen Geschichte geschaffen, tritt uns schon bei Lotze entgegen. So bringt der Mikrokosmos das für die Universalgeschichte so wichtige Problem wieder in Fluß, wie die geschichtsphilosophische Idee des Endzwecks mit der Forderung eines rollendeten Lebens in Einklang zu bringen sei.

\section{n) Heinrich Rickert.}

In der Philosophie Heinrich Rickerts schreitet der Nenidealismuzu umfassender Systembildung. Im Gegenstand der Erkennt nis ist esihm gelungen, mit der Enge des Kantischen Systems zu brechen, welches das Problem der Erkenntnis in einseitiger Weise mit dem Problem der naturwissenschaftlichen Erkenntnis gleichgesetzt hatte. Erst Heinrieh Rickert hat die erkemntnistheoretische Fragestellung in ersehöpfender und universaler Form erhoben. Das hängt zum Teil auch damit zusammen. daß er die großen Systembildungen des Idealismus in die Sprache der Erkenntnistheorie ïbersetzt, das Berechtigte an ihnen versteht und sie für seinen Systemgedanken nutzbar macht. Pickert hat Kant: erkenntnistheoretische Frage: ,Wie ist reine Naturwissensehaft möglich?.” durch die nene Frage ergänzt: ,Wie ist Geschichte als Wissenschaft möglich?" Rickert bleibt jedoch bei der Frage: , Wie ist Wissenschaft möglich ?" nicht stehen, sondern vertieft sie zu dem Problem: ,Wie ist Wirklichkeit möglich?" Das heißt: . Wie muß die Wirklichkeit gerleutet und verstanden werden?"* Die Frage nach dem theoretischen Simne der Wirklichkeit ïberhaupt war ron Kant noch nicht erhoben worden, und wir sehen mmmehr. wie die metaphrsischen Ausdentungen der Wirklichkeit durch den deutschen Idealismus in der Philosophie Rickerts auf erkenntnistheoretischem Boden neue Bedeutung gewimen.

Ton einer so allgemeinen und erschöpfenden erkenntnistheoretischen Fragestellung ans ist dann Heinrich Rickert anch zu einer Gliederung der geschichtsphilosophischen Problemstellung vorgeschritten. Er ordnet die Geschichtsphilosophie in drei Problemgruppen. Die erste Problemmasse

1) Lotze, System der Philosophie, I. Lugik. 1874. 
umschließt die Fragen der Geschichtslogik oder der philosophischen Methodenlehre. Rickert fragt nach dem Ziel der historischen Erkenntnis und beantwortet diese Frage dahin, daß sie es notwendig mit der Darstellung eines Besonderen und Eigentïmlichen, mit einer eimmaligen Entwicklung zu tun hat, die in dem dunklen Schatten der Vorzeit anhebt und mit der Idee eines unbekannten Zieles schließt. Dieser Prozeß ist in seiner Realität einmalig und imwiederholbar, da es sich doch schließlich um das Menschheitsganze handelt, das mit dem Begriff des historischen Universums sich verbindet. Die historisehe Betrachtung geht über die auf unserem Planeten sich vollziehende Entwicklung nicht hinaus, Weltgeschichte füllt mit Menschheitsgeschichte zusammen. Auch wird ron romherein der Gedanke des Origines abgelehnt, daß immer wieder in sich geschlossene wertvolle Entwicklungen aufeinanderfolgen, Manifestationen des höchsten Wesens, die mit der Schöpfung beginnen und mit der Tat der Erlösung schließen, ohne daß sich das Ende mit einem neuen Anfang rerbindet. Ton clerartigen metaphysischen Spekulationen muß sich der moderne Historiker frei halten. Er hat es nur mit der einen und eimmaligen Nenschheit und ihrer Entfaltung und Gliederung zu tun. Dieser Entwicklungsverlauf, der in allen seinen Teilen mannigfaltig ist und ein rollkommenes Individuum bildet, soll dargestellt werden.

Zum Verstehen dieser Totalität ist einzig und allein die historische Begriffsbildung befähigt, die Rickert der naturwissenschaftlichen Begriffsbildung scharf entgegensetzt. Die historischen Begriffe werden mit Rücksicht anf das Individuelle und Besondere gebillet, die natmrwissenschaftlichen Begriffe dagegen mit Rücksicht auf das Allgemeine. Die Geschichte strebt zur 'Totalitït des Wirklichen, die Naturwissenschaft zn allgemeinen Gesetzen hin. Jene möchte wissen, wie das Ganze der Menschheit sich entfaltet und fortschreitet, in welche Ordnmgen und Beziehungen es sieh gliedert, und wie las geistige Leben seine besondere Gestalt und Form gewinnt, diese möchte feststellen. welche allgemeinen Gesetze die kleinsten Teile des Wirklichen hewegen. Die Gesehichte wertet das Besondere und gliedert es dem historischen Ganzen ein. die Naturwissenschaft subsmmiert das Einzelne als wertindifferentes Exemplar unter ein Allgemeines. Für sie ist ${ }^{\circ}$ m das Allgemeine, das Gemcinsame an der Vielheit des Besonderen, wichtig und interessant. So sind die historischen Begriffe Begriffe von [urlividualitäten, sie wollen das Einmalige rund Lnwiederholbare verstehen.

Gewil, arscheinen in der Geschichte neben Begriffen ron Individuen, Erochen, Handhungen, Begebenheiten auch Gattumgsbegriffe, Gruppenbegriffe, Kollektivbegriffe, die clas Gemeinsane an einer Vielheit anshrieken wollen, aber diese Bespiffe treten durchaus in den Dienst der individualisierenden Therriffobildmus, da sic gebildet sind, um das fudividuclle deutlieher hervortreten \%u hassen mul seine Eigent ïmlichkeit zu offenbaren. So geht der Durchschnitsmensch in Begriffe ron Massenbewegungen cin, gerade deshall, weil "le in seinel Isoliertheit nicht interessiext mul anch nichts beweist. Die

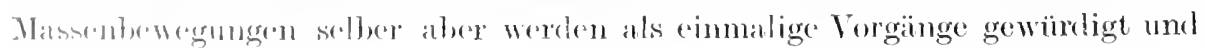
rantitululu

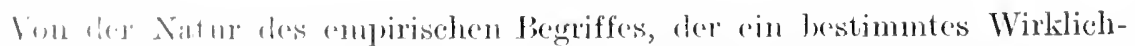
keitestiok meint, geht die lieflexion anf die Begriffsformen, die das ganze 
Gebiet der historischen Wirkliehkeit bedingen. Was sind die Formen, welche die historisehe $W^{\gamma}$ elt sinngemäß gestalten, und wie unterscheiden sie sich ron den Formen der naturwissenschaftlichen Begriffsbildung? Welehe Sondergestalt nimmt etwa der Begriff der Kausalität, der für alle empirisehen Wissenschaften gilt, in der historischen Erkenntnis an?

Von den Formen der Begriffsbildung wandert die Reflexion zu den Prinzipien des historischen Geschehens und erkennt in den Kulturwerten die höchsten Bedingungen der historisehen Wirklichkeit. Nicht Gesetze sind entscheidend für die Auffassung des historischen Lelens. sondern Wertideen wie Kunst und Religion. Wissenschaft und Staat. jene Begriffe also, welche den spezifischen Gegenstand der philosophischen Betrachtung bilden. die von der Philosophie gedeutet und in ihrer charakteristischen Sondergestalt verstanden werden. Daraus ergibt sich der enge Zusammenhang ron Geschichte und Philosophie, der nur in einer historischen Weltansehauung einlenchtent hervortreten kann. Diese Kulturwerte sind das Auswahlprinzip des historisehen Geschehens, denn nicht die ganze Fülle des Gegebenen geht in die historische Begriffsbildung ein. Sehr vieles wird als historisch berleutungslos beiseite gelassen. auch rondem, was der Erkenntnis zugänglich ist. So soll auch die Persönlichkeit nicht in der ganzen Fülle ihres Erlebniszusammenhanges in die historische Wirklichkeit eintreten, sondern nur das ron ihr findet Aufnahme, was die große Tat des Schaffens und Leistens mehr oder weniger erklärlich maeht. Die Kulturwerte sind auch Ordnungsprinzipien, sofern sie die historische Welt gliedern und die großen Entwicklungsreihen konstituieren, an denen alle historische Betrachtung hängt. Endlich können sie als Erkemntnismittel anfgefaßt werden, sofern das Verstehen ihrer eigentümlichen Natur und der Zusammenhänge, die zwischen ihnen bestehen, eine Interpretation des Weltgesehehens in der Form der Universalgeschichte möglich macht.

\section{o) Die Geschichtsphilosophie Diltheys.}

Verwandt und entgegengesetzt ist die Gesehichtsphilosophie Dilthe y's der Rickertschen Gesehichtsphilosophie. Die Terwandtschaft muß wohl ror allen Dingen darin gestucht werden, daß anch er die Frage nach der historischen Vernunft und den Kategorien der Gesehichte erhebt. Nir stellt cr ron rornherein die philosophische Methode der psychologischen Erklärung nieht scharf gegenüber. Die Psychologie soll die Erkenntnishedingungen der Geisteswissenschaften hergeben, allerdings nicht die Psychologie der Elemente, sondern eine Psychologie der konkreten Lebenszusammenhänge. Der Philosoph und Psychologe, der Historiker und Künstler rüeken in der Wissensehaftstheorie Wilhelm Diltheys nah zusammen. Gemeinsam ist ihnen allen die Funktion des Verstehens, die in dem Deuten des Philosophen wie anch in dem Auffassen und Nachfühlen des Historikers. wie schließlich aneh in Intuition des Künstlers und des künstlerisch gesinnten Menschen gleichmäBig. wenn auth in verschiedenartiger Gestalt. sich kundgibt. Der Historiker muB die Seinserscheinungen rerstehen und anffassen, nud es ist gewiß eine philosophische Frage, dieses Verstehen auf seine Bedentung und seine Tragweite hin zu prüfen. Dabei müssen wir von der unzweifelhaften Tatsache ausgehen, daß es die Geschichte ganz in erster Linie mit psychisehen Geschehen zu tun hat. Denn 
was in (ler historischen Entwickhung der Menschheit an Werken mancherlei Art getan, geschaffen und geleistet wird, das muß aus des Schöpfers Geist und Wesen heraus rerstanden werden. Wenn ieh das Kmstwerk verstehen will, so muß ich auch die Individualität des Künstlers denten und verstehen. Ich mul3 mich in ihn hineinleben, in seine imnerste Welt eindringen, sein psyehisches Leben kennen lernen. Das aber ist die Aufgabe des Psycholgen, als des Seelenkemners, wie ihn Dilthey rersteht, mit großer Liebe und Zartheit den feinsten Schwingungen der mensehlichen Seele naehzuspüren, die Ganzheit des Erlebnisses nicht in bedentungslose und wertlose „Empfindungen" aufzulösen. die den Atomen des Physikers verwandt sind, sondern in Erlebniseinheiten. die nach wie ror ron Simn erfüllt sind. Man könnte bei Dilthey roneiner transzendentalpsychologischen oder anch wertpsychologischen Methode sprechen. Denn auf die Kenntnis des Wertlebens oder Geisteslebens kommt es an. Das Erlebnis wird untersucht. sofern in ihm ein Wertrolles erfahren wird. Dilthey sträubt sich ror allem gegen den Gedanken, daß der Wert ron dem Erlebnis abzulösen und einer Sonderbetraehtung unterworfen werlen kömne. Wir können das Werthafte nur verstehen, sofern es in engster Beziehmug zum Erlebnis steht.

Alles können wir verstehen, was vom Geiste geschaffen und aus dem Geiste geboren ist. Wir verstehen das Gebiet des ,objektiren Geistes", die Erzengnisse der Kultur. In der Kultur hat sich der mensehliche Geist kunduegeben mat Teile seiner sellost offenbart. Alle Kultur ist Menschenwerk, und was rom Menschen geschaffen ist, kamm auch vom Menschen verstanden werden. Die Natur ist für den menschlischen Gcist etwas Fremdes, weil nieht von ihm Herrührendes, die Natur kam er nie verstehen, sondern nur dureh Begriffskonstruktion erklären. Aber die Welt der Kultur des Geisteslebens versteht er, weil sie seine Sehöpfung ist.

Das Element der geistesgeschiehtliehen Wirklichkeit ist das Erlebnis als Berleutungseinheit. Jedes Erlebnis ist der Aufbewahrung wert zunäehst eimmal für den einzehen, der es gelebt. Indem sieh damn Erlebnis mit Erkebnis verbindet, entsteht einZusammenhang, den wir als Individualität bezeichnen. Denn wir sind im Grunde das, was wir erlebt haben, und unsererTaten Werk ist unseror Seele Spicgel. In dem Erlebniszusammenhang läßt sich damn wieder eine festere Masse unterscheiden, dic gleichsam reicher und schwerer an Bedeutungsmomenten ist, zu der die Jebenserfahrung cines Menschen sieh verdichtet hat, mot den man als den erworbenen Lebenszusammenhang bezcichnen kann.

Doch das Erlelnnis ist eine Unmittelbarkeit ohne Reflexion und führt nicht äber sich hinans. Wohl hat jecles Gegenwartserlebnis eine Anweisung anf Vorgangenheit und Zuknuft, abor as ist nicht imstande, die Weiten der Vergangunheit zu denten und dex Zakunft Sim zu ersehließen. Erst dureh das Vrestehron golangt der Menschengeist zu einem Wissen von sich selbst und der

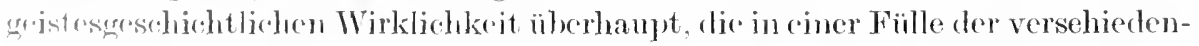

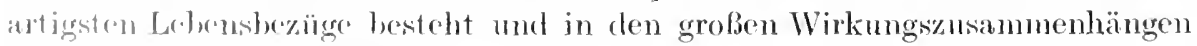
Jer kinltur sich rollemelet.

J) historisehe Wikenntuis ziclt gewiB auf das Individuelle und Einzelue

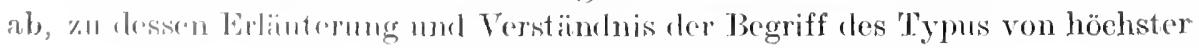


Wichtigkeit ist. Es gibt sehr mamnigfaltige Formen ronTypen. Wir machen ron diesem Begriff schon im alläglichen Leben häufig Anwendung, so z. B.. wenn wir ron einem Willensmenschen, einem Verstandesmenschen, eincm Gefühlsmenschen sprechen. Für das Gebiet der Nationalökonomie bilden wir den Typus des wirtschaftlichen Menschen. Auch dieser ist gewiß nicht der große Mensch in der Fülle seiner Lebensbeziehungen. Der Künstler und der Held sind idealtypische Begriffe. Und nicht nur für den Menschen in seiner eigentümlichen Lebensgestaltung, sondern auch für die großen Komplex* des Kulturlebens gilt der Begriff des Trpus. So lassen sich trpische Formen des religiösen Lebens und Typen der Weltanschaung bestimmen, die in der Eigenart ihrer Gestaltung alle Möglichkeiten des Wertlebens zu erschöpfen scheinen, und von denen ans dann weiter eine Charakterisierung und Bestimmung der tatsächlich historisch rorliegenden Kulturgegebenheiten möglich ist.

Während für Heinrich Rickert ganz in erster Linie das Problem der. historischen Darstellung entscheidend geworden ist, so ist die Theorie Dil the rs auf das Problem der historischen Auffassung gerichtet. Rickert erhebt die Frage: „Welche Form müssen die Produkte der historischen Begriffserkenntnis annehmen, damit eine simnvolle Darstellung des historischen Geschehens möglich ist?": Die Frage Wilhelm Diltheys lantet: .Wie kam sich das historische Bewußtsein die Fülle des gesellschaftlich-menschlichen Leben: zu eigen machen, wie kam es diese Lebensfülle deutend verstehen, und zwar in einer Weise, daß ron einer notrendigen Erkenntnis dieser historischen Wirklichkeit gesprochen werden kamm?.”

\section{p) Georg Simmel.}

Dieses Verstehenwollen der historischen Auffassung ist es auch. was Geory Simmel in seinen Problemen der Geschichtsphilosophie in erster Linie anstrebt. Deswegen ist für ihn ganz ähnlich wie bei Dilthey ein tieferes Eingehen auf psychologische Fragen und auf die Natur des erkemnenden Subjektes erforderlich. Die Leistung des historischen Denkens ist augenscheinlich nicht nur in der eigentümlichen Erkenntnisauswahl und dem Charakter der historischen Begriffsbildnng, sondern anch in der Normativität des Anffassens und Denkens, die von der natmwissenschaftlichen Erkenntnisform so sehr verschieden ist, ungemein wichtig und bedentungsvoll.

\section{q) Die Marburger Schule.}

Im Gegensatz zu den genamnten Denkern ist die Marburger sichnle in ihren Hauptrertretern Cohen und Natorp dadurch charakterisiert, daB für sie der Begriff der Wissenschaft doch in der Hauptsache mit der Idee der Naturwissenschaft zusammenfällt. Demmoch steht dic Geschichte unter dem philosophischen Gesichtspunkt hinter der Naturwissenschaft nicht zuriick. Denn wie die Logik als philosophische Grunddisziplin für die Naturwissenschaften aufgefaßt werden muß, so die Ethik als Wertfundament für die Geschichte. Logik und Ethik sind die beiden Kraftquellen der Philosophie als der Wissenschaft des Geistes. Allerdings ist die Ethik nicht als das einzige Fundament der Geschichtswissenschaft aufzufassen. sondern nur als dasjenige, 
welches der Geschichte ihren Bedleutungsgehalt verleiht und sie zu einer, vom stanulpunkt des Geistes aus gesehen, ebenbürtigen Genossin der Naturwissenschaften macht. Ihrer sprachlichen Unterlage nach wurzelt die Geschichte in der Logik, ihrem Kulturgehalt nach in der Ethik. So ist vor allen Dingen das Recht wie auch Staat und Nation nicht ohne Mitwirkung der Ethik zu renken. Die Ethik ist die positive, schöpferische Bedingung und das Prinzip aller dieser Kulturgïter.

\section{r) Croce und Bergson.}

Die Hegelsche Geschichtsphilosophie hat endlich in den letzten Jahrzehnten eine interessante Neubildung durch Benedetto Croce erfahren, der die Irlee der Geschichte auf das engste mit dem Begriff der Philosophie zusammenschlie $3 \mathrm{t}^{1}$ ), und in dem künstlerisch geschauten metaphysischen Weltbild Bergsons, das von dem Gedanken der schöpferischen Entwicklung getragen wird, ist der Wirklichkeits- und Wertgehalt des historischen Lebens in seiner Fülle und Konkretheit mit äußerster Schärfe den abstrakten Gebilden der Naturwissenschaft entgegengesetzt. Aber mit dieser neuen Metaphysik haben wir auch gleichzeitig den Punkt erreicht, wo eine philosophische Betrachtung der Vergangenheit ror der Stärke und Unmittelbarkeit der Gegenwart rerstummen muß.

1) Vgl. besonders Benedetto Croce, Storia, cronaca e false storie (estr. dagli Atti (lell, Accal. Pontaniana vol. XLII, 1912); Genesi e dissoluzione ideale della filosofia della storia (estr. dall, Annu urio della Biblitec ، filosofiea die Palermo vol. XLIII, 1913); Intorno alla Storia della Storiografia (dalla Critica, maggio 1913.) 
Dritter 'Teil.

\title{
Das System der Geschichtsphilosophie oder inhaltliche Konstruktion der Universal- geschichte.
}

\author{
Erstes Kapitel.
}

\section{Der Simn des historischen Geschehens.}

Das System der Geschichtsphilosophie gibt die Antwort auf die Frage nach dem Sinn des historischen Geschehens. Während der erste Teil unseres Lehrbuches die Elemente der geschichtsphilosophischen Konstruktion in ihrer Isoliertheit betrachtete, der zweite Teil als Geschichte der Geschichtsphilosophie die bedeutsamsten Lösungen der Vergangenheit herrorhob, soll das System der Geschichtsphilosophie die vereinzelten Begriffselemente zu einer Einheit zusammenschließen. Die Probleme der Geschichtslogik und der Prinzipienlehre sinken hier auf die Stufe des Vorläufigen herab. Nur ihr allgemeinstes Resultat geht in die systematische Fragestellung ein. Das Problem der Universalgeschichte selber aber wird über alle wissenschaftheoretischen Erörterungen hinaus zu einer Lösung geführt. Wir wollen jetzt nicht mehr untersuchen, was die begriffliche Grundlage der Unirersalgeschichte ist, we]che Formen des Denkens hier entscheidenden Geltungswert besitzen, sondern wir wollen rom Standpunkte der Wertphilosophie aus das historische Gesehelien deuten.

a) Die Probleme der Geschichtsphilosophie und ihre Lösung.

Die Probleme der Geschichtsphilosophie sind ewig. Wohl niemals wird die Philosophie aufhören, die dort behandelten Fragen zu diskutieren. Immer wird sie in die logische Struktur der Geschichte einzudringen suchen, immer wird sie sich bemühen, die Kulturwerte deutend zu verstehen und ihre Tragweite für das historische Geschehen zu ermessen. Die Richtung aber, in welcher sich diese Erörterung bewegen muß, und die verschiedenen Wege, die abzweigen und zu Sonderresultaten führen, alles dieses ist gewiß nicht willkürlich, sondern ruht auf logischen Möglichkeiten und Alternativen, welche die Problemfülle ausbreiten, der nachzugehen bis in alle Verästelungen hinein eine unendliche Aufgabe sein würde. Gegenüber dieser analytischen Tätigkeit will nun 
das System der Geschichtsphilosophie auf Grund der analysierten Begriffe eine synthetische Konstruktion des Universums versuehen.

\section{b) Wahrheitsgehalt einer universalhistorisehen Konstruktion.}

Der Wahrheitswert einer solehen Konstruktion bleibt gewiß durchaus problematisch. Denn wenn es auch auf Grund der gewomnenen und eingesehenen Prinzipien durchaus möglich erscheint, eine allgemeine Sinngebung des historischen Geschehens zu versuchen und seine Bewegungsrichtung zu verstehen, so unterliegt die Konstruktion des einzelnen doeh in immer höherem Grade der Irrationalität des Gegebenen, und es ergibt sich aus dem eigentümlichen Gegensatz von historiseher und philosophischer Geschiehtsbetraehtung, daß ein Gebilde des geistigen Lebens für die empirische Gesehiehtssehreibung im allgemeinen dureh den Abstand von der Gegenwartskultur an Erklärungssehwierigkeiten zunimmt, während es für die philosophische Deutung an Verständliehkeit gewinnt.

Das hängt damit zusammen, daß die historische Erklärung auf das Wissen und Verstehen des einzelnen abzielt, während die universalhistorische Deutung nur auf das Allgemeine und Typische an den Sondergestalten des historisehen Lebens gerichtet ist: Rein historiseh betraehtet, ist das erst kürzlieh Vergangene leichter zu verstehen, weil es dem Charakter der Gegenwartskultur ähnlieher und verwandter ist. Die allgemeinen Gestaltungen des geistigen Lebens aber bedïrfen einer gewissen Ferne, um ïbersehbar und begreifbar zu sein, wie hohe Gebirgsformationen, die erst von fernen Horizonten aus plastiseh hervortreten. Sie müssen sich erst ausgelebt und ausgewirkt haben, um als Ganzes verständlieh zu sein, und jecle Úbergangsepoche, der ein einheitliehes geistiges Zentrum fehlt, ist von der höchsten Problematik durehdrungen. Je mehr großes geistiges Leben dann weiter eine vorläufige Auswirkung und Erfüllung erfahren hat, $n \mathrm{~m}$ so deutlicher wird auch der Weg, der vor wins liegt, dem von den vollendeten geistigen Einheiten fällt immer ein leises Licht auf (lie Zukunft. So mochte das Sehicksal des Mensehengesehleehtes wcit rätschhafter und unsieherer erseheinen, bevor der griechische Geist sein eigentïmliches Wertleben gelebt und die religiöse Gestalt des Christentums mit neuen Sinngebungen die Welt erfüllt hatte.

\section{c) Das historische und naturwissenschaftliche BewnBtsein.}

Die Probleme der Geschichtslogik interessieren uns hier nur als Resultat. Dieses Resultat ist aber die ganz andere Auffassungsmöglichkeit des historischen Bewubtsens neben dem naturwissenschaftliehen. Fine eigentïmliche Form des Inenkens, die so schr das philosophische Bewnbtsein berüht und in der Auffassung philosophiseher Gegenstände sich hemerkbar macht, daß man fon cincm historisch-philosophisehen Bewnbtsein und cinem naturwissensehaftlindphitosophisehen Bewubscin sprechen kam. So ist etwa Spinoza der Naturwissenschaftler muter den Philosophen, nicht nur sofern seine philoso-

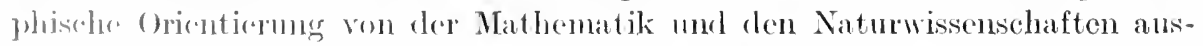
geht, was ja anch hei Kant der Fall ist, sondern sofern in seiner philoso-

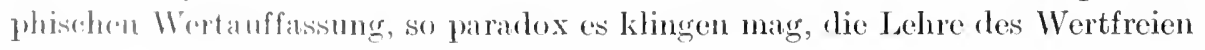


und Wertindifferenten zum absolut Wertvollen wird, während im Gegensatz dazu die Philosophie Fichtes als der Trimmph des historischen Denkens in der Gestalt der Philosophie erseheint. Der Naturalismus ist Naturwissenschaft in der Form der Weltanschaung, Wertwissenschaft als Deutung der Wirklichkeit in Sinne des Wertfreien, der Idealismus ist Geschichte in der Form der Weltanschauung oder historisehe Wcltanschauung, Wertwissenschaft als Deutung des Wirklichen in Sinne des Sollens.

\section{d) Das Irrationale der Universalgesehiehte.}

Weder die Naturwissenschaft noch die Geschichte kann mit ihrer einseitigen Zielorientierung zu einem Verstehen des Universums führen. Dieses Ganze bleibt der Philosophie ïberlassen, die ihrem Wesen nach eine systematisehe Wissenschaft ist. Das Reich des Systems aber ist das ruhige Reich des Begriffes, wo jede Bewegung stockt, wo alles Leben getötet ist. Das philosophische System ist ein teleologiseher Zusammenhang von Vernunftwahrheiten. Das Geschehen wird hier selber zu einer Kategorie des Geistes. Es wird logisch verstanden und fügt sich in dieser seiner Verständliehkeit dem System ein.

Aber durch die logische Dentung ist der Sinn des Geschehens nicht erschöpft. Normen der Vermunft erheben sich, die ihre Erfülhung erst finden können, wenn das Geschehen in seiner Irrationalität erhalten bleibt, wenn wir das Irrationale num nicht mehr selber zum Begriff des Irrationalen verflüchtigen, sondern es in seiner ungeschwächten Macht bestehen lassen. Diese irrationale Wirklichkeit, die mit dem erkenntnistheoretischen Begriff nur den Namen gemeinsam hat, ist Leben, das sich entfaltet.

\section{e) Das universal-historisehe Gesehehen.}

Wir müssen den Begriff des Lebens in semer höchsten Potenz denken, um dasjenige vollauf bezeichnen zu können, mit dem sich in der gesehichtsphilosophischen Vorstellung die Wertidee verbindet. Leben ist es gewiß in simnlicher Wirklichkeit und gleichzeitig mit einer Beziehung zum Unsinnlichen und thberwirklichen, sofern diesem Leben die Möglichkeit zur Gestaltung einer vernünftigen, objektiven Wirklichkeit verliehen ist. Es ist die Totalität des menschlichen Lebens, daranf diese Betrachtung geriehtet ist, wenn auch nicht die Ganzheit dieses Lebens in der universalhistorischen Betrachtung erscheint, sondern nur das bleibend Wertvolle an diesem Leben, der Ewigkeitsgehalt der Gesehichte, der durch die Urbeziehung ron Wert und Irrationalität gesetzt wird. Und dieses Leben darf anch nicht als ein Stagnierendes, einfach Daseiendes gedacht werden, sondern es handelt sich um ein Etwas, das immer neue Formen gewinnt und nie am Zicle ist.

Manches, was in der empirischen Geschichte erseheint, tritt in die Universalgeschichte nicht ein, weil es selber nieht der Aufbewahrung wert ist, sondern nur zur Erklärung des Bedeutsamen dient. Denn die Universalgeschichte hat es lediglich mit dem Wertleben zu tun, mit dem, was Eigenwert besitzt und über alle Zeiten hinals gilt, während die empirische Forschung auch dasjenige in den Kreis ihrer Betrachtungen einschließt, was da lebt, um wieder zu vergehen. Nur mit dem absolut Wertrollen hat es 
die Universalgeschichte zu tun, und dieses wird ihr zum Ausclruck des Ewigen, da sie die historischen Begebenheiten unmittelbar mit den absoluten Werten rerbindet.

In der Universalgeschichte erscheinen nur die allgemeinen Gestalten, die Typen des Kulturlebens. Die Persönlichkeit als Treffpunkt eigentümlicher Wertbeziehungen, als Träger und Substrat leitender Ideen. Wemn irgendwo, so wird hier ihre Unersetzlichkeit und ihre Eigenart eingesehen, dasjenige nämlich, was sie für das Ganze bedentet, und das, was sie für sich bedeutet, sofern sie wertrolles Geschehen auslöst und bedingt, und sofern sie ein in sich ruhendes werthaftes Leben führt. Alle Gebiete des Kulturgesehehens stehen hier unter letzten philosophischen Kategorien, und die großen Epochen der Weltgeschichte offenbaren sich als Komplexe eigentümlicher Werthaltungen, welehe durch den Typus einer besonderen Volksindividualität oder auch eines besonderen Kulturkrcises und seiner Stellungnahme zum Ganzen der Wirkliehkeit bedingt sint.

Andrerseits gehört zu dem miversalhistorischen Geschehen sinngemäß auch eine Fülle desjenigen Wertlebens, das den Prinzipien der historischen Wissenschaft gemä.s, selbst wenn es anch im einzelnen ihrer Begriffserkenntnis zugänglich wäre, beiseite gelassen und ausgeschlossen wird, weil nicht genügend Wirksamkeit von ihm ansgeht. Ich denke vor allem an jene kleinen und stillen Taten des ethischen Lebens, welche die großen Kulturinstitutionen nur leise berühren, die sich in dem engen Kreise des Familienlebens und auf den stillen und leisen Gängen der Liebe entfalten. Ich denke auch an jene Taten der Sellstüberwindung in einsamen Stunden. an all das Schöne, was die Einsamkeit sicht, und das mur ein Ange zn sehen und ein Geist zn verstehen vermag, der das Verborgene schaut und die stillen Wege der Seele kennt. Ich denke an das reine Gottesgeheimnis der stillen Stunden.

So hat es die Universalgeschichte mit dem Größten und Kleinsten zu tun, mit den großen Öffentlichkeiten und den stillen Verborgenheiten. Mit all den Erscheinungen hat sie es zu tum, in denen der lebendige Atem des Weltgeistes weht. Und so wirl es auch weiter gesehehen mïssen, daß jene Werteinschätzung, welehe die Geschichte vollzicht, und die in der historischen Beurteilung sich vollendet, eine leise Korrektur erfährt, indem die Gestalten des Welt Icbens in nenem Lichte erscheiner.

\section{1) Die Idee der Kinltur.}

J)er Ausgangspunkt der universalhistorisehen Uberlegungen ist die Idee der Kultur als Inbegriff des Wertlobens, dem anf diesen Begriff ist ja alles historische Lebent sinngemäß bezogrn. Lnter Kultur verstehen wir ganz allgronein ein Wrethaftes, las dem hlob Natmrhaften entgegensteht. Sie ist ras Gepplegte, das Corformte, das aus der ursprüngliehen Natur geworden ist. Wir

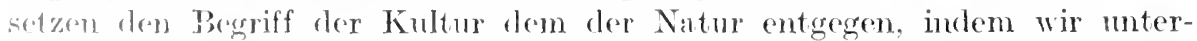

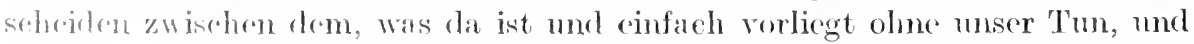
from. Was wir aus riserem Vorliegenden gremacht haben. Das Eigentïmliehe

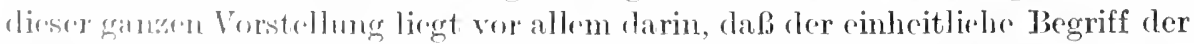

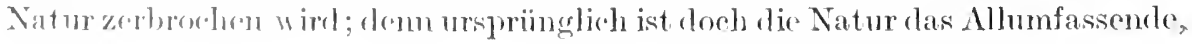


das den Mensehen mit seinem Tun genau so in sich faßt wie das pflanzliche Leben oder auch das Reich des Anorganischen. Genau genommen kann. aber auch nicht alles Tum der Menschen, unter den Gesichtspunkt der Kultur gestellt werden, sondern es gibt gewisse Tätigkeiten, die als rein naturhaft, als Ausdruck seines sinnlichen Daseins aufgefaßt werden müssen, mit denen er gleichsam sich der Natur einfügt und unterordnet und nicht in Gegensatz und Widerspruch zu ihr tritt. Genau betrachtet, gehören nämlich nur jene Handlungen des Menschen der Kultur an, durch die er sich in Gegensatz zu der bloßen Natur stellt und sie zu etwas macht, was durchaus nicht im Sinne ihres natürliehen Gegebenseins liegt. Der Mensch begeht also mit den Kulturhandlungen eine gerisse Auflehnung gegen die Natur. Er stellt sich ans dem Kreis ihres gewohnten Wesens heraus. Er bildete sie nur um und mochte sich, indem er sie ïberwand, wohl vielfaeh als ihr Herr und Meister rorkommen. So gesehah es in der Zeit der Renaissance, jener großen Menschheitsepoche. in der das Individumm so selten nach der Natur stand und gleiehzeitig so weit über sie hinausging. Diesen Gegensatz zu der Natur, in den der Mensch geriet. hat man mit religiöser Betonung als Abfall von der Natur bezeiehnet, als Süinde und Schuld des Mensehengeschlechtes. Jedenfalls hat es zu allen Zeiten nicht an Stimmen gefehlt, welche diese Emanzipation des Mensehen ron der Natur rüekgängig machen wollten und meinten, daß alles Unglüek der Menschheit durch diesen Bruch mit der Natur veranlaßt sei. Das große Rätsel aber wird immer dieses bleiben: wie die Natur dazu gelangte, die gesehlossene Einheit aufzugeben, und wie etwas: das ursprünglich zu ihr gehörte, immer mehr über sie hinauswohs und sieh in Gegensatz zu ihr stellte.

Am Anfang war nur Natur, und dann war etwas, was nicht nur Natur. sondern etwas darüber hinaus ist. Indem aber dieses andere wurde, entstand eine Bewegung, die wir als die Bewegung des vernünftigen Lebens bezeichnen müssen, und die das historische Geschehen hervorbraehte. Der Grund der vernünftigen. Bewegung muß zu dem Naturhaften entweder neu hinzugetreten sein oder als ein Etwas angesehen werden, das immer da war, jedoch anfangs keine Möglichkeit hatte, sich auszuwirken. Alles das liegt vor den Pforten der Gesehichte, und wir wissen keine bestimmte Auskunft darüber zu geben.

Nur soviel wissen wir, daß aus diesem umbekannten Schoße dann jene Mächte hervorgingen, die der Gesehichte ihr Antlitz geben und an denen unser ganzes Tun und Wirken, unsere Liebe und unser Glaube hängt. Anfangs erseheinen sie eingehüllt in den Gedächtnisschleier der Mythologie, dann ringen sie sich mäehtig los. Als früheste tritt die Religion hervor, die immer noch bestrebt ist, alle anderen in ihrer Einheit zu erhalten und zu bewahren. Sie ist es, die sich für das einzige Kind Gottes hält, während alle anderen Formen der Kultur von ihr als Weltkinder betraehtet werden. Dann erheben sich Philosophie und Kunst und Wissenschaft und Recht und Staat und Technik und hohes sittliches Leben. Alle diese reißen den Menschen aus seiner Isolation zur Gemeinsehaft hin. In dem Kämpfen und Ringen um sie gehört er der Ganzheit an. und sein Wert bestimmt sich nur nach der Leistung für jene. Was er für sie getan, das mit Blut und Opfer Erkaufte gehört der Geschichte an. All dieses ist häufig ein Verzicht auf die Pflege des persönlichen Lebens. 
Wenn die Forderungen der Kultur in ihrer Strenge an den Menschen herantreten, dam mag er sie wohl manchmal als Last empfinden. Er möchte wohl gar zu gern in Liebe und Freundschaft verweilen. Immer dem öffentlichen Leben hingegeben, fühlt sein Herz sich vereinsamt und strebt der Stille und Heimlichkeit zu. Wohl sucht er neben jenen noch andere Güter zu pflegen und muß es immer wieder erfahren, daß die Tragik des Leidens in dem Verzicht auf Eigenglück besteht. Will er dem Leben leben, so weist ihn der Mahnruf der großen Kulturmächte schonungslos auf den Schauplatz des Kampfes hin. Jene allein, die für sie gelitten und gestritten, die ihren Anforderungen gemäß Großes und Schönes geleistet haben, können Heimatsrecht in der Geschichte erwerben. In diesen Kulturmächten scheint etwas zu liegen, was über die Menschheit hinausgeht. Sie bedeuten eine Steigerung des Lebens, die daranf ausgeht, den Tod zu überwinden.

\section{g) Kultur, Leben und Tod.}

Den meisten Menschen ist selbstverständlich eine starke Bejahung des Lebens. Jeder Menseh fürchtet den Tod. Der Tod erscheint ihm als etwas ganz Furchtbares, Großes, Sinnloses und Paradoxes. Der Mensch schmückt sein Leben mit Liebesgenuß und mit Freundschaft und Glïck, aber der Tod ist mächtiger als sic alle. Thre leichte Schönheit hält ihm nicht stand. Da sind es nun die Kulturwerte, die ihrer Idee nach den Tod überwinden. Am augenseheinlichsten ist das bei der Religion, die den Tod nicht nur in dem Sinne ïberwindet, daß sie ïber ihn hinausgeht, sondern so, daß sie ihn verklärt.

Der Tod hat zum Leben und zur Kultur eine ganz einzigartige Stellung. Der Tod gehört zum Leben und gehört auch wieder nicht zum Leben. Er gehört dem Leben an, sofern er den Abschluß eines jeden Lebens bildet. Wir kennen nur das Leben, das im Tode erlischt. Jedes Leben endet mit dem Tode, und da das Ende das Ganze erst vollentet, so gehört der Tod zum Leben. Wo Leben ist, da ist auch Tod und umgekehrt. Aber andrerseits ist der Tod auch der absolute Widerspruch und Gegensatz zum Leben. Wo Tod ist, da kann ummöglich Leben sein. Die Idee des Todes schließt die Idee des Lebens aus. Die Idee der Kultur aber scheint es zu sein, welche das Leben mit dem Tode versöhnt.

Die Itee der Religion setzt ein Ziel, das zur vollkommenen Aufhebung des Todesgedankens fïhrt. Welch eine Macht des Geistes kommt in ihr zum Ausdruck! J)er 'Tod ist cloch angenseheinlich das sinnfälligste und Brutalste aller Phänomene. Er liefert den angenscheinlichsten Beweis für die rollkommene Yerstönng des Lcobens. Tnd dennoch läßt die Religion gerade aus den Erscleinungen des Tranmes und des 'lodes neues mächtiges Leben hervorgehen. J) (.er 'Torl ist in ihrem Simue kein Ende, sondern eine Erlösung. Dorthin, wo ainst die Giestalten des Sichreckens und Entsetzens gestanden hatten, wo einst dir. Verzwrillung den ewigen Alschied ersebante, setzt sie die frenndlichen mul grofirn Gestalten der Freude und Hoffnung. Durch ihre Verklairung des

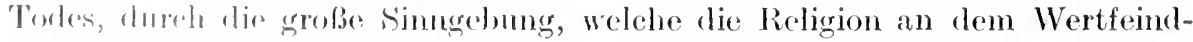
linglisten allor Phämomene vollzoge, hat sic cinen ganz nenen Aspelst der Welt

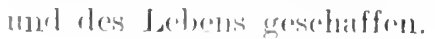


An ihr ist die Kunst aufgeblüht, für die sie einen so überaus wichtigen und so schön gestalteten Stoff geliefert hat. Auch die Kunst ist eine starke und mächtige Uberwinderin des Todes. Auf den ersten Blick scheint sie es nicht zu sein, weil doch die Kunst das Simnliche so sehr liebt und es niemals aufopfert und aufopfern möchte, sondern für immer bewahren. Was aber dem Sinnlichen so sehr zugewendet ist und sich ron seinen Reizen und Verführungen berauschen läßt, das muß, wie es scheint, der Macht des Todes unterliegen. Doch die Kunst remag das Gespenst des Schreckens siegreich zu überwinden, denn sie weiß, daß der Tod nnr für diese Simnenwelt gilt, nur hier allein Macht und Bedeutung besitzt. Und ron diesem großen Wissen erfüllt, bildet die Kunst eine ganz nene Welt, die der Gefahr des Todes nicht unterliegt, weil sie vollkommen unwirklich ist und nur das Wirkliche den Tou erleidet. In dieser Welt der Kunst gibt es kein Altern und Sterben, und ihre besondere Gesetzmäßigkeit wird von der Gesetzmäßigkeit der Wirklichkeit nicht betroffen.

Neben der Utberwindung der Wirklichkeit durch die Kunst steht ihre theoretische Beherrschung und Auflösung. Wie so ganz anders, so ganz verschieden und doch mit Rücksicht anf das letzte Ziel verwandt! Die Kmmst schafft Bilder und Gestalten, die uns die ganze Unseligkeit des Irdischen vergessen lehren. Aus der überströmenden Fülle der Phantasie sind sie geboren, und ihre schöne Form ladet uns zu danernder Betrachtung ein. Die Ċberwindung des Wirklichen bis zu seiner vollkommenen Abstoßung fült der Kunst gar leicht, denn ihre freie Schöpfertätigkeit ist an die Züge des Wirklichen nur lose gebunden. Dagegen geht die Überwindung des Todes, welche die Wissenschaft vollzieht, mit einer gewissen Bindung an die Wirklichkeit und der Verpflichtung einer Rücksichtnahme auf ihre Struktur und Formennotwendigkeit zusammen. Die Wissensehaft und die Sittlichkeit kömmen nicht so tun, als ob die simnliche Wirklichkeit nicht vorhanden wäre. Wohl aber tun beide so, als ob die Idee des Todes nicht rorhanden sei und so führen sie uns über den Tod hinweg.

Verweilen wir noch einen Augenblick bei diesem Gedanken. Die Wissenschaft bildet ihre Begriffe an der Wirklichkeit. Allen inhaltlich empirischen Begriffen entspricht etwas in der simlichen Erfahrung. Sei es num, daß der Begriff ein simnliches Einzelwesen meint, oder daß er als Gattungsbegriff eine Reihe von sinnlichen Einzelwesen zusammenfaßt. Die lö̈hsten Begriffe des wissenschaftlichen Denkens versteht die Philosophie als Form dieser Wirklichkeit, die in der Idee der Erkenntnis begründet sind. Würde das Denken die Formen der Wirklichkeit vernachlässigen und aufgeben, so würde es sich ohne Zweifel selber aufgeben. So bleibt die Wissenschaft gebunden, und doch ist die Leistung der Abstraktion, die sie an der Wirklichkeit vollzieht, auch wieder eine ungeheure Tat der Entwirklichung. Sei es mm, daßsie an die Stelle der farbigen Sinnenwelt das System begrifflicher Beziehmingen in der Naturwissenschaft setzt oder in der Geschichte die großen Bedentungszusammenhänge offenbart oder in den philosophischen Begriffen den letzten Sinn der Welt enthïllt. Daß aber die Wissenschaft ihrem letzten Sinn nach auf das Unendliche abzielt und damit die Idee des Todes negiert, der die Vorstellung des Endes in sich schließt, ist offenkundig. Denn die Anfgabe, welche 
sich die Wissenschaft stellt, ist eine erschöpfende Erkenntnis des Weltinhaltes. Der Reichtum des ansehaulich Wirklichen, der das Weltganze erfüllt, ist niemals zu überwinden. Der Gegenstand des Denkens ist niemals restlos bestimmt. Folglich liegt die Erreichung des wissenschaftlichen Zieles im Unendlichen. Was die Wissenschaft zu erreichen strebt, ist, wie es scheint, ein Unmögliches. Sie will das Unmögliche möglich machen, indem sie das Unendliche begehrt. Sie rechnet nicht damit, daß der Menschheit eine Grenze gesetzt sei. Von der Unendlichkeit der Mensehheit überzeugt, strebt sie dem unendlichen Ziele nach.

Endlich geht aber anch die Irlee des Sittlichen über das Endliche und ïber den Tod hinaus. Das Wesen des Sittlichen in seiner ganzen Hoheit und Reinheit gefaßt, verdichtet sich zu dem Begriff eines absoluten Sollens. Dieses absolute Sollen stellt sich den simnlichen Affekten und Reizungen entgegen. Das Affektive soll vom Geiste des Sollens erfüllt werden. Das Affektive hängt mit dem Klein-Menschlichen und unserer simnlichen Bedürftigkeit zusammen. Dieses Endliche, Enge und Kleine ist das, was überwunden werden soll. Und wenn wir unter dem Kleinen und Engen den bedürftigen Sinnenmenschen verstehen, damn ist der Mensch in der Tat etwas, was überwunden werden soll. Der sittliche Wert gibt die Anweisung auf den unendlichen Mensehheitsprozeß oder, um mit Fichte zu sprechen: immer neue Gegenstände macht sich das Ieh zum Material pflichtmäßigen Handelns.

Lassen wir nun unsere Blicke schweifen auf das nugeheure Gebiet, das der Botmäßigkeit des sittlichen Wertes unterworfen ist, der allerdings nicht, wie man wohl gemeint hat, das ganze historisehe und soziale Leben mit Wertinhalt füllt, sondern nur einen Ansschnitt dieses Lebens. Dabei müssen wir natïrlich zu dieser Sphäre oder zu diesem Wirkungszusammenhang des Sittlichen auch alles das reehnen, was zu ihr in gewollter und bewußter Opposition liegt.

Zu dieser Sphäre des Sittlichen gehört in erster Linie das schwer erkemnbare Reich der Gesinmung. sofern es von dem Gedanken des Sollens bestimmt und ron der Idlee der Freiheit durehgliiht ist. Adel nud Vornehmheit der Gesimmung gehört hierher und das leidensehafthiche Streben, die Menschen zu bessern und zu bekehren, und der Wunseh, aus sich etwas zu machen und scin cigentiimliches Wesen zu bilden und zu behaupten. Solehe Gesinmung l,eibt aber nicht immer als Gesinnming bestehen, soudern setzt sieh in Handlung um. So tritt sie hinaus in das Leben und in die Gesehichte. Wirksam ist sie als Motiv in dem Helden, der für des Vaterlandes Wohl die schwersten ()pfor bringt, und in dem Staatsmann, dessen ruhelose Näehte dem Wohle der sozialen Goncinschaft gewilmet sind. In gar vielem Tun und Handeln wirkt sich die sittliche Idec ans, sei es num in der engen, unsichtbaren Sphäre for Alltäglichkeit oder in den großen Handlungen und Aktionen der Weltgrschichte. Auch dort äberall steht sie auf dem Plan, wo Niedriges, Gemoine und Boshaftes gegen Hohes und Göttiehes ankämpft. Und auch jene grhören der sphäre des Sittlichen m, die als Philosophen ïber ihr Wesen

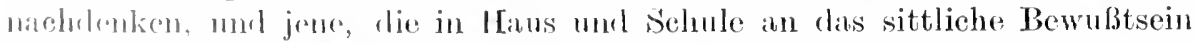
appellieren mol anf P'ilicht und Recht anfmerksam machen. Und es bleibt

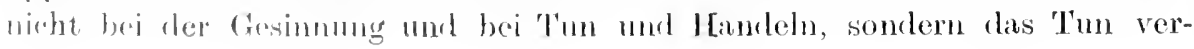


dichtet sich anch zn Einrichtungen und Ordnungen und Institutionen, die einen gewissen Bestand haben. So wird der sittliche Wert aus der Sphäre des freien Tuns in die Sphäre der Zuständlichkeit ïbergeführt. Vieles wird ge. schaffen und geordnet und gebildet, was seinen Simn und sein Leben in der Anschaung des sittlichen Wertes hat.

Und mit diesem Wirkungszusammenhang des sittlichen Lebens hängt dann wieder das Gebiet des Rechtes und des Staates zusammen, das dem Sittlichen eine unendliche Ausbreitung gibt und alle Verhältnisse des Lebens und der Kultur mehr oder weniger angreift und durchdringt.

\section{h) Kultur und persönliches Leben.}

Achten wis auf den Charakter und die Macht der Kulturwerte, so ist es deutlich, daß sie uns dahin führen, das eigene persönliche Ich auszulöschen oder doch wenigstens zu vergessen. In den Verhältnissen der Liebe und deı Freundschaft, die uns wohl ohne Frage die stärkste Lust gewähren, wahren wir das eigene Ich und erhalten es aufrecht. Wir sind uns seiner Freude und seiner Traurigkeit, seiner Schönheit und seines Unglïcks bewußt, auch dann, wenn wir dem Gegenstande unserer Liebe noch so mächtig hingegeben sind.

Wenn wir die Spannung setzen zwischen dem Ich und Xichtich, zwischen Subjekt und Objekt, so betonen wir in minerer Liebe als Liebe zum einzelnen unser persönliches Wesen und rergessen mehr oder weniger die Welt, das Objekt, die Wirklichkeit. Wir nehmen den Gegenstand unserer Liebe in unser Ich hinein und sättigen uns mit ihm und fïllen uns mit ihm aus. Aber in dem Verhältnis zu den Kulturwerten geben wir uns auf und vergessen uns. Diese grenzenlose Hingabe. welche die Geschichte weiter treibt, läßt uns die Idee des Todes überwinden.

Denken wir uns einen Denker. der sein langes und arbeitsames Leben damit ausgefüllt hat, nachzuweisen, daß mit dem Tode alles zu Ende sei. Er reflektierte äber den Tod und nahm ihn immer wieler in seine Sphäre anf und überwand ihn immer von neuem und war der Idee der Kultur und ihrer Lebendigkeit so hingegeben, daf er nicht bemerkte. wie er alt und gra w wrle, und konnte sich im Verhältnis zum Objektiven, das er im Grunde bekämpfte. so vergessen, daß der Tod heramnahte, bevor er ihn recht gewahrte.

\section{i) Die Idee der Zeitlichkeit.}

Der Bedeutung der Kulturwerte scheint nun die Zeit als feindseliges Prinzip entgegenzustehen. Unser Tun und Schaffen ist an die Zeit gebunden. und wir können der Zeit nicht vorauseilen. sondern müssen uns nach ihr richten. Erst im Laufe der Gesantentwickhung wird sich das Göttliche und Wertrolle offenbaren, und erst am Ende der Geschichte hat es sich vollkommen erfüllt. Wo wir auch einen Einschnitt in der Zeit machen, immer stoßen wir auf ein Halbrollendetes. Immer ist die Wahrheit noch nicht erkannt und das Gute noch nicht verwirklicht, immer ist las Schöne noch nicht vollendet. Erst an Ende des ganzen kulturhistorischen Prozesses wird das Wertrolle wirklich sein. Das bedentet aber, daß das schöpferische Tun und Gestalten der Persönlichkeiten an die Zeit gebunden ist. Für Plato war es mmöglich, die Wahr- 
heit zu enthïllen, weil zu seinen Lebzeiten die menschliche Erkenntnismöglichkeit allzu begrenzt war. Die Griechen vermochten das vollkommene Kunstwerk noch nicht zu gestalten, weil der Geschmack noch nicht hinlänglich gebildet war. Die Gegenwart hat mehr Möglichkeiten, das Wertvolle zu entdecken, aber auch wir sind als Kinder unserer Zeit an der Schöpfung und Gestaltung des Größten behindert. Dasjenige, was uns eine überlegene Stellung gegenüber der Vergangenheit gibt, ist die Einsicht, daß wir, vom Prinzip der Zeit beherrscht, immer dara uf angewiesen sind, Relatives zu leisten. Das historisehe Bewußtsein erhebt sich somit über den ganzen Prozeß und ist das Wissende gegenïber dem naturalistisch-dogmatischen Bewußtsein der Vergangenheit, das da immer in der Meinung war, das Absolute erkannt und ergriffen zu haben. Das historisehe Bewußtsein weiß ron der Relativität und Beschränktheit aller endlichen Leistungen und vermag Rechenschaft abzulegen über die rersehiedenen Formen und Typen der Weltanschanung, zu denen die Mensehheit notwendig gelangen muß, wemn sie den Versuch macht, dem Höchstgefühlten und Erkannten irgendeine Gestalt zu geben.

\section{k) Der Standpunkt der schöpferischen Tat.}

Gegen diese mächtige' Betonung und Unterstreichung der Zeit, die das Unvollendete und Unsystematische lehrt, wird der schöpferische Genius Einspruch erheben. Ihm muß diese Bindung an die Zeit als ein trauriges Sklavenlos erscheinen. Keine Kraft der Vernunft und keine Anstrengung des Geistes vermöchte nach dieser Vorstellung die Wahrheit zu erkennen oder das Schöne zur Darstellung zu bringen. Angewiesen ist auch der Genius auf das Ende aller Dinge und dient nur dem Endzweck einer kommenden Menschheit. Er kamn nur be itrag en, aber nicht vollenden. Dadurch wird all seine Kraft gelähmt, weil er doch als Kind seiner Zeit von vornherein verurteilt ist, Unvollkommenes zu leisten. Ja, der Begriff des Genius wird durch diese Theorie aufgehoben und zerstört. Weil das Genie, das seiner Natur nach bestimmt ist, Vollendetes zu leisten, auf das Fragmentarische mit Notwendigkeit beschränkt bleibt.

So tritt hier dem historischen Standpunkte cin anderer gegenïber, den wir yanz allgemein als den standpunkt der sehöpferisehen Tat oder auch der Idee des Systematis chen bezeichnen können. Der religiöse Mensch glaubt an dic Erfüllung seiner religiösen Schnsucht, dab Gott sich ihm offenbaren werte. Der Künstler glanht an sein Werk, der große Philosoph an sein System. Wïrlen sic diese Liebe und diesen Glauben nicht haben, so wären sie nicht das, was sie sincl. The (ibulbe aber ist ganz allgemein gesprochen der Glaube, dals das Vollenden zu aller \%eit möglieh sei, d. h. also, dar die \%eit die absolute Erfïllung des Werkes nicht verhindern köme. Wis ist das der Glaube aller "ahrhaft groben und starken Naturen. Jesus Christus wollte ebensowenig wir. Psuddha rinch Proitrug zur Verwirklichmmg der religiösen Irlee leisten, sondtru ap wollte die ahsolute Religion begründen. Die sixtinische Kapelle ist nirht mit dem beseheidenrm Ansprnch gemalt, der Entwicklnng des Schönen zan dienche somblem wollte viohnehr das heiligste mol herrliehste symbol für dir Wirklienkeit dess hehönen seIber sein. Und als Kant die Kritik der reinen 
Vernunft und Hegel die reine Logik schrieb, da glaubten sie an die absolute Wahrheit ihrer Gedanken. Kant war ebenso fest und sicher überzengt, da B die Erkenntnis begrenzt und auf die Erfahrung beschränkt sei, wie Hegel davon überzeugt war, daß es eine Erkenntnis des Absoluten geben müsse. Für den Philosophen, der sich an die Zeit gebunden fïhlt, kann es kein vollendetes System der Werte geben. Notwendig bleibt es offen und fragmentarisch, so wie die Zeit immer notwendig offen und fragmentarisch bleibt. Dieser Gegensatz, den wir als den Gegensatz des systematischen und historiseh unsystematischen Denkens bezeichnen wollen, die sich mit vollbegrïndeten Ansprüchen einander gegenüberstehen, hat Dilthey mit Recht als die Tragik des Erkennens bezeichnet. Er selber huldigt der Idee des Unsystematischen und der Geschichte, während etwa Eucken mehr der Idee des Systematischen und Schöpferischen huldigt. Beide Auffassungen sind cinseitig. Es ist notwendig, dem verschiedenen Charakter der geistigen Mächte gemäß zwischen diesen Werten selber zu unterscheiden.

\section{l) Vollendungswerte und Beitragswerte.}

Da stehen dann auf der einen Seite diese drei, welche Hegel in die Sphäre des absolnten Geistes verlegt, Religion, Philosophie und Kunst. Auf der anderen aber Wissenschaft, sittliches Leben, Recht, Staat, Wirtschaft, Technik. Nur die letzteren sind auf das engste mit der Idee des Endzwecks verbunden. Niemals wird jemand, der sich im emsigen Studium der Wissensehaft hingibt, die Auffassung vertreten, daß er selber imstande sei, die Wissenschaft, die er betreibt, vollkommen zu vollenden. Das ist vollkommen ausgeschlossen, denn die Idee der Wissenschaft ist ja darauf gerichtet, den immer neu gegebenen Inhalt der Erfahrung vollkommen auszuschöpfen und zu verarbeiten. Eine solche Leistung übersteigt bei weitem die Lebensarbeit eines einzelnen Menschen, sie kann prinzipiell nur als Leistung der Gesamtheit rerstande werden.

Ganz anders steht es mit der Wertidee der Religion, der Philosophie und der Kunst. Sie sind nicht das Werk der Gemeinschaft, sondern das Werk eines einzelnen. Deswegen gibt es auch im Grunde genommen keine Philosophie als strenge Wissenschaft. Deswegen kann das Kunstwerk im Grunde nur einen Meister haben. In der Wissenschaft und den verwandten Kulturwerten gibt es Mitstrebende, Mitarbeiter. Mitkämpfer. In der Religion, Kunst und Philosophie gibt es nur den Meister und die Jïnger. Das eigentiimliche Verhältnis der Jüngerschaft ist nur auf diesen Gebieten heimisch. Denn hier ergeben sich mit Notwendigkeit eigentïmliche persönliche Bczichungen. und ein ganz besonderes Vertrauensverhältnis muß hier bestehen. Die Offenbarung des religiösen Propheten, der Ausdruck des Künstlers und die Lehre des Philosophen, sie verraten viel von persönlicher Lebenshaltung und einer persönlichen Art, die Dinge zu schauen. Der religiöse Prophet lehrt seine Jünger durch Gleichnisse und Symbole die Gesichte und Visionen verstehen, die er in seiner großen Erhebung zum Göttlichen erlebt hat. Der große Philosoph lehrt seine Jünger, die Welt im Begriff zu verstehen. Der große Künstler offenbart seinen Jüngern die Welt, die durch seine Seele hindurchging, die 
durch seine Seele ihre große Schönheit empfing und in unsterblichen Gestalten Anstruek und Spraehe gewann. Und das ITerk des einen Großen erhebt hier immer den Ansprueh, ein Vollendetes zu sein. Das Werk des religiösen Genies duldet keine Weiterbildmug und keine Veränderung. Die Zeit soll und darf fïr die religiöse Lehre niehts bedenten. Sie duldet wohl verschiedene Auslegungen und Auffassungen, aber sie mußs bleiben, wie der Meister sie geschaffen. Und wer dïrfte es wagen, an dem Kunstwerk Veränderungen vorzmnehmen und Umgestaltungen an ihm zu vollziehen? Auch das Kunstwerk ist absolut vollendet und für alle Zeiten so da, wie es einmal geschaffen wurde. Unu dasselbe gilt aneh im Grunde genommen für die Philosophie. Jedes wahrhaft große System ist eine Neuschöpfung und keine Weiterbildung. Schon die kleinste Veränderung zerstört das System. Wohl gibt es Weiterbildungen ron Credanken, nicht aber vou Systemen.

So kanm die Zeit entweder als absolute Grenze gefaßt werden zwisehen dem wertenden BewuBtsein und dem Wert selber, anf den die Werthaltung sich richtet, oder die Zeit gilt als etwas, was in irgendeiner Weise überwunden werden kam. Im ersteren Falle, wemn nämlich die Zeit als Grenze gedacht wird, gibt es wieder zwei Mögliehkeiten, nämlich entweder diese, daß die Zeit überhaupt bestimmend für den Werteharakter irgendeines Gegenstandes ist. Das wïrle damn belenten, daß dem Wert, etwa der Wahrheit oder der Idee les Kunstwerkes ïberhaupt, kein Ewigkeitsgehalt zukommt, sondern daß das Werthafte immer nur für eine bestimmte Zeit gilt. Oder die Zeit ist zwar Schranke für den Wert, doch nicht in der Weise, daß der Wert durch sie rollkommen bestimmt wäre, sondern der Wert bestimmt die Zeit. Dann ist die Erfüllung des Werthaften das Ziel der menschlichen Entwieklung und verhindet sich mit dem Gedanken des Endzweeks, nicht aber vermag der schöpferische Geist zu seiner Zeit das Vollendete zu sehaffen.

Wem wir so den Vollendungseharakter von Philosophie, Kunst und Religion betonen, so soll das etwa nieht bedenten, daß diese Werte iuberhaupt gra line Entwieklung durchgemaeht, und daß ihre ersten Leistungen auf diexem Cebiete schon sogleieh den Stempel der Vollendung an sich getragen Jä̈trn. Das ist natïrlich nieht der Fall. Sie sind allmählich geworden. Aber in einem verhältuismäßig schnellen Wachstum erreichen sie bald die Vollsndming mol gehen nummehr dem Genius die Mittel an die Hand, sich vollkimmen zu offenbaren. Das gilt sowohl für die Begriffe der Philosophie wie anch für die symbole der Kunst und die Gleichnisse der Religion.

Fiir dir Kumst wirl das vollkommen zugegeben. Ws gibt schwerlieh einen lort-chritt im lianstlerischen Grlebnis und eine Verticfung der ästhetischen Irloe mul cine gröbere Kraft dor künstlerisehen Gestaltung, als wir in Griechenliam olde in dem Ttalirn der Renaissance selaten und erleben können. Erl.bmi- (irstaltung und Stil kïnuen wohl anders sein, aber von einem Fort-

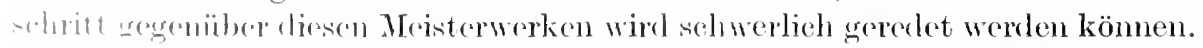
liml liir dir Raligion gilt wohl etwas ähnliehes. Sehwerlich wirl jemand glan-

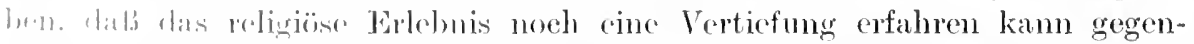

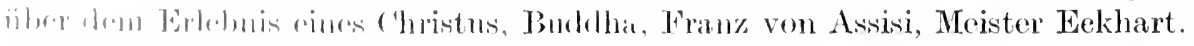

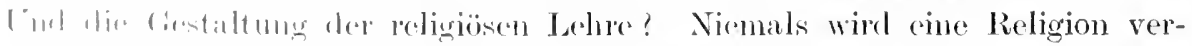

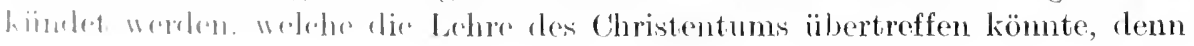


die Lehre des religiösen Genies kamn niemals ïbertroffen werden. Sie ist einzin und ganz vollendet.

Es fragt sich num noch, ob der Fortschritsbegriff auch für die Philosophie eine entscheidende Idee ist. Diese Frage ist viel diskutabler als die Frage der Religion und Kunst. Dem die Philosophie hat es doch ohne Frage mit der Erkemntnis zu tun. Die Erkemmtnis gliedert sich aber in einfache logische Gebilde, die wir als Urteile bezeichnen. Alle diese Urteile schreiten zum Ziele der Wahrheit fort, und die systematische Ordnung dieser Crteile macht das Gebiet der philosophischen Wahrheit ans. Nit der Vermehrung dieser Crteile also oder mit der Vollendung des philosophischen Systems entwickelt sich die Philosophie. Es schreitet aber auch fort das philosophische Wissen, weil das Wissen fortschreitet in den Einzelwissenschaften, dennsiegewähren zum großen Teil das Material für die philosophische Reflexion in den verschiedenen Formen ihrer Methode. Auf sie ist die kritische Besinnung der Philosophie gerichtet und erhebt sich von hier aus zu der Ergründung ihres rigenen Gegenstandes. Endlich aber kamn auch noch das Erlebnis angeführt werden. Der ungehenre Strom des historischen Geschehens bringt immer wieder Nenes hervor, nul aus dieser Fïlle des historischen Lebens kamn immer wieder ein neues phitosophisches Erleben hervorgehen, das dem Unendlichen und Absoluten nähen kommt.

Das scheint so zu sein und ist in ähnlicher Form begrïndet worden ${ }^{\mathrm{I}}$ ). und dennoch dürfte diese Znordnung der Philosophie zu den Beitragswerten verfehlt sein.

Wir müssen dem philosophischen Erlebnis oder der philosophischen Intuition ganz gewiß die höchste Bedentung beimessen. Wir geben zis, daß3 das Erlebnis sich verändert, daß jede neue Kulturlage das Göttliche mond Tertvolle in nener Gestalt erscheinen läßt; daß wir ihm immer wieder eine nene Seite abgewimmen. Aber diese Verändermng des Erlebnisses ist doch mur von relativer Bedentung gegenüber dem philosophischen Grunderlebnis, dem Erlebnis jener leuchtenden Gewißheit, wie es vielleicht zuerst Śokrates-Plato beschieden war. Das philosophische Grunderlebnis ist die Einsicht in den logischen Zusammenhang der Welt. Immer ist mit ihm eine große metaphysische Weihe verbunden. Diese Einsicht, so müssen wir annchmen, war den Größten der Philosophie beschieden. Mit der philosophischen Einsicht deplatonischen Idealismus von der Natur der Wertidee ist die Philosophie gewissermaßen vollendet, bzw. ist es nicht möglich, irgend etwas aufzuweisen. was diesem Erlebnis gegenüber als Fortschritt anfzuweisen wäre. Es ist mit anderen Worten niemals ein Begriff entdeckt worden, der an Tiefe und Bedentsamkeit das Erlebnis der platonischen Idee jemals ïbertroffen hätte.

Ein anderes ist das Erlebnis und die Anfweisung des philosophischen Prinzips, ein anderes seine Anseinanderlegung im System. Gewiß ist mit dem philosophischen Grunderlebnis der Wahrheit die Leistung nicht abgeschlossen. Das System soll erst das Prinzip bewähren, indem es seine Bedentung nach allen Seiten entfaltet und seine Fruchtbarkeit für das ganze Gohiet des Wirklichen, für die Kultur und das Leben erweist. Nun muB aber in dem Gedanken

${ }^{1}$ ) Vgl. Jonas Cohn, Der Fortschritt in der Philosophie Logos, Bd. IV, H. 1. 
des Srstems wieder ein Doppeltes unterschieden werden, nämlich einerseits die Aufweisung der rerschiedenen Grundbegriffe, in we]che der Zentralbegriff sich rerzweigt, und durch die eine vollkommene Beherrschung der Wirkliehkeit und der Kultur gegeben ist, und andrerseits die Gruppierung und Anordnung dieser Begriffe zu einem System. Das eine ist die Aufweisung der Kategorien des Weltrerstehens, das andere das System der Kategorien. Wir meinen nun, daß die großen Systeme der Vergangenheit die Aufweisung der philosophischen Formen schon im wesenthichen geleistet haben und daß nur die sinnvolle Anordnung dieser Formen problematisch ist. Die logischen Diskussionen der letzten Jahrzehnte haben an neuen logischen Prinzipien nicht viel zutage gefördert. Die Diskussion dreht sich vielmehr in der Hauptsache noch $1 \mathrm{~m}$ die logische Tragweite und Bedeutung der gefundenen und anfgewiesenen Prinzipien. Wir möchten ferner meinen, daß sich in der Philosophie des deutschen Idealismus die Philosophie vollendet hat, und daß es auch schon früher Höhepunkte der philosophischen Einsicht gegeben hat, über die hinaus ein unbedingter Fortschritt nicht stattfinden konnte. So ist die Philosophie Platos in gewisser Weise ein Vollendetes, das in seiner Art nicht übertroffen werden kamn. Nur in einer Hinsicht muß ein Fortschritt in der Philosophic behauptet werden. Das ist ein Fortschritt hinsichtlich der Anwendung des Prinzips und seiner Fruchtbarmachung und Erschließung nener Gebiete. Demn die Wissenschaften schreiten ohne Frage fort, indem sie immer nenen Inhalt in begriffliche Form verwandeln. Mit ihrem Fortschreiten werden aber auch der Philosophie immer wieder nene Aufgaben gestellt. Hat es doch die Philosophie mit den Erkenntnisformen der Wissenschaft, mit dem Charakter ihrer Methode sowie mit den Zielen der verschiedenartigen wissenschaftlichen Erkenntnis zu tum.

Wenn wir den Begriff des Fortschritts indieser Weise begrenzen und seine untergeordnete Bedeutung für die absolıten Werte behaupten, dann haben wir in der 'Tat die Möglichkcit, den typischen Gegensatz von Ka nt und Herder, der auch in der modernen Geschichtsphilosophie immer wiederkehrt, zu rersöhnen. D)amn gilt dies Prinzip in der Hauptsache nur für die Annähcrungswerte, nicht aber für die absoluten Werte. Dann ist die Idee der schöpferischen Persönliehkeit gewahrt, weil begrifflich und prinzipiell nichts in Wege stcht, daß sie anf jencn Kulturgebieten das denkbar Höchste leistet. Dann brauchen wir nicht mit tiefer Resignation unseren Zustand als einen Zustand des Vorläufigen zn cmpfinden, sofem uns als den zu zeitig Geborenen der Gemub der Wahrheit und Sichönheit sowie die Offenbarung der göttlichen Gcheimnisse notwendig verborgen bleibt. Dann kamn jedes schöne und mächtigr Kulturvolk zum Genuß der höchsten Kulturgüter gelangen. Dam vertreten die absoluten Kulturwerte gleichzcitig anch die Idee des Systematischen in Sinne der Möglichkeit eines Eintritts ewiger Gïter in den zeitlichen ProzeB,

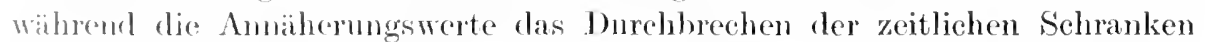
als Zirel (incs nnendlichen Prozesses setzen. Dann wahren die absoluten Werte gerarla ver allem die Idee der sehöpferischen Persönlichleit, da ja ihrem Sinn

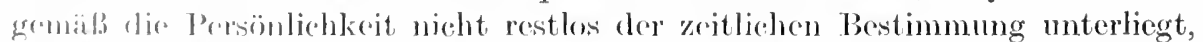
somelaru dre linst immung des Endlichen durch das Unendliehe cine Bestimmung

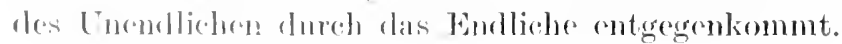


Wemn wir num anch an dieser Stelle die Idee des Fortschritts und des Endzwecks notwendig einschränken mußten, so erkennen wir dabei doch die eminente geschichtsphilosophische Bedentung dieser Begriffe rollkommen an. Es ist ja sicher richtig, daß man das geschichtsphilosophische Problem ron der Idee des Fortschritts her am besten verstehen kamm. In der unirersalhistorischen Entwicklung wird der Simn des historischen Geschehens dadurch garantiert, daß die Menschheit in ihrer Ganzheit trotz zahlreicher Rïckschläge im einzelnen nach einem gemeinsamen Ziele fortschreitet, indem unter Fortschritt Wertzuwachs in Verbindung mit Wertsteigerung rerstanden wird. Je mehr die Menschheit sich entwickelt, um so bedeutsamer und wertroller ist nach dieser Auffassung der Kulturzustand eines Tolkes.

\section{m) Persönlichkeit und Wertidee.}

Als Voraussetzung einer geschichtsphilosophischen Konstrulition ergibt sich also einerseits das Allgemeine in der Gestalt allgemeingïltiger Werte. Diese Werte, welche die systematische Philosophie zu denten und zu rechtfertigen hat, geben der Geschichte ihren Simn. Anf der anderen Seite steht das Besondere in der Gestalt der historischen Individualität, vor allem als historische Persönlichkeit, die als Wertträger angesehen werden muB, sofern ihr in der Hingabe an die Wertideen ein Simn zuteil wird, der über das Allgemeine und Allseitige hinaus noch als ein besonderes wertbildendes Moment aufzufassen ist. Diese beiden sind die metaphysischen Grundelemente der Universalgeschichte, die unmöglich ist ohne den Gedanken der Wertidee und der Persönlichkeit. Ob aber und wie das Endlich-Persönliche aus der übersinnlichen Sphäre des Wertes stammt, und ob es dorthin zurïckkehrt, das sind metaphysische Fragen, welche die Universalgeschichte nicht bcrühren. deren Thema sofort eine Begrenzung erfährt durch den Gedanken, daß sie es mit diesen beiden Grundfaktoren nur zu tum hat, sofern sie sich in der Zeit treffen. Sofern Wertidee und Persönlichkeit unter dem Treffpunkt der Zeit betrachtet werden, entsteht der universalhistorische Prozeß. Denn das Treffen und Berühren dieser Beiden, des Unendlichen und des Endlichen, führt zu dem Phänomen der Kultur, die weder rerstanden werden kamn als das Werk des Allgemeinen, weil sie sonst den Charakter einer vollkommenen Ausgeglichenheit und siegreichen Vollendung tragen wïrde, noch ebensowenig als das Werk des Besonderen anfgefaßt werden darf, weil es ihr sonst an Allgemeingültigkeit fehlen würde und man ummöglich verstehen kömnte, wie aus einer so großen Mannigfaltigkeit entgegengesetzter Willensbestimmungen cin rernünftiges Resultat sich ergeben sollte. Die Cniversalgeschichte macht also auch diese dritte Yoraussetzung, daß das L'nendliche nieht in absoluter' Transzendenz verharrt und sich außerhalb der sphäre der Zeit rornehm zurüekhält, sondern daß das Unsimnliche und Übersinnliche sich in der Zeit rerwirklicht. Das Unendliche und Werthafte wird so nicht mehr im Simne der Griechen als unbek ïmmert um die Welt gedacht, sondern als bek iimmert. Das will sagen: das Werthafte ist in irgendeiner uns verborgenen Weise auf das Endliche hingewiesen und angewiesen, oder anch das Endliche bedentet etwas für das Unendliche. In der Idee der Wertrerwirklichung liegt aber dieses beides, daß 
die Wertidee die Tendenz hat, sich im Sinnlichen und Endlichen zu rerwirklichen, und andrerseits, daß dem Endlichen und Persönlichen das Bestreben imnewohnt, diese Terwirklichung herbeizuführen. Indem sich nun die Kultur als das durch die Arbeit und Leistung der Persönlichkeit in der Sinmenwelt gestaltete Werthafte immer als das Produkt zweier Elemente enthüllt, kann entweder das Allgemeine oder das Besondere als der für die Gestaltung des Sinnlichen zum Sinnvollen bedeutsamere Faktor angesehen werden.

\section{n) Sinn der Kulturberegung.}

Das sind die Voranssetzungen, welche die L'niversalgeschichte zu machen gezwnngen ist, und die natiirlich ron romherein eine Reihe schwieriger Probleme in sich bergen. Die erste Frage, die sich erhebt, ist die Frage nach der Bedeutung des simnlich-wertrollen Geschehens, und zwar zunächst in dieser ganz allgemeinen Form: Bedentet das simlich-werthafte Geschehen, das wir in der Kulturbewegung erschanen, nur etwas für die Sinnenwelt in der Weise, daß es die unsimnliche Welt unverändert läßt, oder lat es auch eine Veränderung der übersinnlichen Welt zur Folge?

Die Idee eines Geschehens in der Zeitlosigkeit, wie es die christliche Patristik lehrt, ist angenseheinlich ein absolut Unverständliches. Zu allem Werden, zu aller Entwicklung gehört Zeit. Ohne das Prinzip der Zeit können wir uns keine Verändermng und kein Geschehen denken. Gegen ein unsinnliches Geschehen, das etwa das simnliche Geschehen parallel begleitet, wie in den alten Mystcrienspielen dem Spiel der Erde ein Spiel im Himmel und ein Spiel in der Höllc entspricht, sprechen aber wn noch andere Gründe als die Paradoxie rincs Eujglieitsgeschehens. Wird nümlich neben dem simnlichen Geschehen cin umsinnliches Geschehen angenommen, dann ist naturgemäß das unsinnliche Gowchehen das wahrhafte Geschehen. Ist dieses aber der Fall, so wird der Prozeß der Kulturbewegung zu etwas gänzlich Bedeutungslosem, zu einem bloßen Reflex von jenem wahrhaften Geschehen. Ihn wird aller Ernst und alle Wiehtigkeit und alle Größe genommen, mnd der Völker Verzweiflungskampf und der große Siegeszug der Heroen wird zu einem Schattenspiel herabervïrligt. Nicht als ob in diesem Falle das Geschehen der Sinnenwelt jedes Wirklichlecitssinnes cntbehrte; clemn ilure Erseheinung und Gestalt ist ja ein Hinweis und ein Anzeichen für einen Prozeß, der wirklich und wahrhaft sich creignet. Aber das simmliche Geselehen wird scines Eigensimes und seiner Sellsitandigkeit berauht. Fs bedentet nur etwas für ein anderes. Es ist im firnele genommen mor symboliseh zu verstehen. All dies farbige und gestaltenreiche (ieschehen ist die weitlïufige Transskription irgendeines dunklen metaphysischen Etwas, das in ihm seine Ubersetzung aus der Sprache des Unsinnliehon in die Sprache de's Sinnlichen erfährt. Hängt aber das Wertmoment vollimmmen mol ausschliefilich an Simnlichen, nud entspricht dem historischen

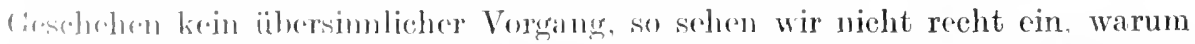

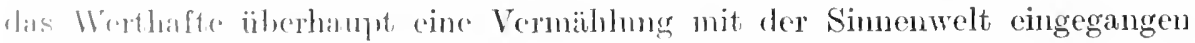

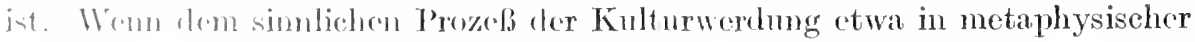

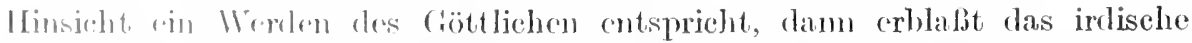

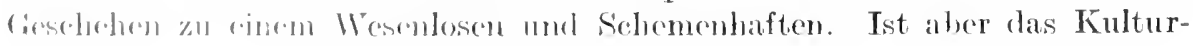


geschehen als ein absoluter, in sich ruhender Vorgang gedacht, der nicht iiber sich hinausweist, der für das Jenseits nichts bedeutet, dann ist auch die Irlee der Kulturwerte und der Begriff des Endzweeks ein Unverständliches; demn wir verstehen das Werthafte und Unendliche in seiner Verbindung mit dem Simnlichen nicht, wemn wir nicht die Voraussetzung machen, daß die Wertideen das Sinnliche verändern und umgestalten, wenn wir nicht meinen, daß sie etwas anderes an ihre Stelle setzen, das mehr als simnliches Leben ist. So muß also im Geiste jeder Universalgeschichte, welche die Verwirklichung des Absoluten und Zeitlosen im Zeitlichen und Endlichen lehrt, der Prozeß des Geschehens sowohl für das Sinnliche wie für das Unsinnliche etwas bedenten. Für das Sinnliche bedeutet die Wertverwirklichung Úberwindung und Aufhebung, für das Unsinnliche Überwinden und Aufheben. So bedentet der historische Prozeß im Sinne der alten Religionsphilosophie eine Offenbarung des Göttlichen in der Simnenwelt, welcher einen Gegensatz, der im Weltall dureh die Schuld des Bösen verursacht war, in erlösender Liebe wieder aufhebt.

Diese metaphysischen Vorstellungen müssen wir hier beiseite lassen und bei dem Gedanken stehen bleiben, da $B$ im Geiste der Universalgeschichte das zeitlos Werthafte für das Sinnliche und das historische Geschehen Ǔberwindung und Aufhebung bedeutet, daß aber andrerseits das historische Geschehen für das Ubersinnliche diese Bedeutung hat, daß es ihm ein Feld der Betätigung ist. Oder um die altreligiösen Begriffe in erweitertem Sinne zn gebrauchen: das Unsimnliche bedeutet für das Sinnliche Erlösung, das Simnliche für das Unsinnliche die Möglichkeit, sich zu offenbaren.

Wird num aber das historische Geschehen als ein Prozeß gedacht, in dem sieh zeitlos gültige Werte verwirklichen, welche die Tendenz haben, sich im Sinnlichen zu offenbaren, das seinerseits auf das Werthafte als Grund seines Unterganges angewiesen ist, so entsteht sogleich das Problem: Wie ist es möglich, daß das zeitlos Geltende, das sich nicht verändert, gleichzeitig anch in der Zeit sich entwickelt und erfüllt? Diese Frage darf nicht so entschieden werden, daß man sagt: In Wahrheit bleibt das Werthafte als das Zeitlose unverändert, und die Entfaltung des Werthaften ist nur ein bloßer Schein. Denn wenn wir die Frage so entscheiden, dann ist es ja augenseheinlich. daB die historische Entwieklung nur eine scheinbare ist. Vielmehr muß die Antwort so lauten: daß die Entwicklung des Werthaften so gewißs sich in der Zeit vollzieht, wie die Zeit als die notwendige Form aller endlichen Erkenntnis angesehen werden muß. Solange endliches Bewußtsein gilt, solange gilt anch die Zeit als die Form des endliehen Bewußseins. Warum aber sollte das Werthafte über sein Gelten für das endliche BewnBtsein hinans nicht noch etwas bedenten, was für uns, die wir alles nur unter der Form der Zeit verstehen, vollkommen rätselhaft ist, dennoch aber seinen guten simn hat? Ferner ist zu bedenken, daß anch das, ,Zngleich“, ron dem die Rede war, sofern die Werte gleichzeitig gelten und sich entwickeln, ein unzutreffender Ansdruck ist, sofern das Zeitlose und Zeitliche ja nie zugleich ist. Von, ,zugleich" kamn nur gesprochen werden, wenn es sich um zwei Dinge oder Vorgänge handelt, die beide dem Prinzip der Zeit mnterliegen, demn nur sie sind miteinander rergleichbar. Nur in diesem Falle kann ich sagen, daß a in demselben Zeitmoment 
sich ereignet, in dem auch b sich ereignet. Ist das Prinzip der Zeit als tertium comparationis vorausgesetzt, dann kann man sagen, daß eine Veränderung mit einem Unveränderlichen zugleich sei. Aber wie sollte das Zeitlose mit einem Vorgang in der Zeit zugleich sein? Das Zeitlose gilt für alle Zeit, der Torgang in der Zeit ist ron dieser als Prinzip abhängig. Die Zeit ist also in diesem Falle nicht dasjenige, was zwei Dingen oder Vorgängen in gleicher Weise übergeordnet ist, sondern sie ist nur dem einen übergeordnet, dem andern aber untergeordnet. Wenn wir die allgemeingültigen Werte als die höchsten Begriffe, zu denen unsere denkende Vermunft sich erhebt, als das Göttliehe bezeichnen, und wir meinen, daß nichts in der Welt so sehr diesen Namen verdient wie sie, dam besteht allerdings immer noch die Paradoxie, daß das Göttliche ein Etwas ist, was nnverändert gilt und jenseits aller Zeit seinen ruhigen Bestand hat, und daß das Göttliche etwas ist, das sich verändert und in der Zeit einem bestimmten Ziele zustrebt. Es handelt sich hier um folgende Antithesen: 1. das Göttliche ist zeitlos absolut und zeitlich relativ, 2. unveränderlich und veränderlich in Entwicklung begriffen.

Die erste Antithese besteht nur so lange, als wir die Zeit im plumpen metaphysischen Sinne als ein Prinzip denken, das unabhängig vom Denken besteht. Fassen wir die Zeit als die Form endlicher Erkemntnis, so muß sich diese Antithese in den Satz auflösen, daß das Göttliche mabhängig von der Zeit sein Wesen hat, dem endlichen BewuBtsein aber als etwas gegeben ist, was (lie Zeit bestimmt; daß das Göttliche etwas sei, was einerseits absolut gilt, umabhängig von der Zeit, andrerseits aber auch für die Zeit gilt und für jede Entwicklungsepoche ein Nenes und Anderes bedeutet. Das Göttliche ist an sich immer dasselbe, zeigt sich aber verschieden in dem Verhältnis zum anderen.

Unabhängig ron aller Zeitlichkeit, die mit der Natur des Endlichen zusammengeht, bestimmt das Göttliche die Zeit. Es gilt über die Zeit himaus und gilt nach der Zeit hin, es ist Wert und Norm zugleich. Durch das Gelten fïr ein anderes wird es aus seiner Unverïnderlichkeit und Unbeweglichkeit erlöst. Es bedeutet ein immer Neues für das endliche Bewußtsein, es gibt sich ihm und erseheint ihm als wertvolles Geschehen. Indem das Göttliche die Zeit bestimmt, wird die Zeit gleichsam von ihrer Relativität befreit und erhält durch die 'Jeilnahme am Zeitlosen eine Art Vollendungscharakter.

Aber was kamn nun dies bedenten, daß das Göttliche die Zeit bestimmt, wenn die Zeit nur eine Form unseres Denkens ist? Ist die Zeit nur eine Form unscres Denkens, dann gibt es doch im Grunde überhaupt keine Bewegung und keine Entwicklung, damn verliert auch die Idee der Wertverwirklichung umd damit die Idce der Universalgesehiehte jeden erkemnbaren Simn. Besinnen wir uns aber doch, was diese Behauptung einsehließt. Wenn wir sagen, daß lic Zeit cine Form unseres Denkens ist, und weiter behaupten, daß wir uns Verïnlcrung nur in der Zeit vorstellen könmen, so ist damit der Begriff des reschehens und der Intwicklung noch keineswegs eliminiert. Wir wissen damm nur, dil l3 dic Sinnenwelt uns notwendig in eincm Nacheinander erscheinen mul.', und dal’s das P'rinzip dor Keit uns daran hindert, ïber das Gegenwärtige hinaus Vrogangrulacit und Zukunft zu schauen und zu wissen. Wir können uns in Ciegronsatz dazu cin Bewußtsein denken, daß das ,Heute“ und ,Morgen“ 
zugleich sieht und dessen umbegrenztes Denken Fernen der Erinnerung mit entlegener Zukunft verbindet. Damit ist der Begriff des Geschehens so wenig verworfen, daß vielmehr die Unterscheidung zwischen eine mendlichen und unendlichen Bewußtsein durch die Idee des Geschehens erst möglich ist.

Ferner ist die Zeit in dieser Vorstellung kein bloßes Phantom. Sie gilt für jedes endliche Bewußtsein. Infolgedessen gilt sie, solange endliches Bewußtsein besteht. Mag aber unsere Phantasie noch so weit reichen, und mögen die Aspirationen unseres religiösen Bewußtseins noch so hoch hinausgehen: wir können uns doch kein Schicksal der Seele vorstellen, nach dem sie den Charakter des Endlichen vollkommen aufgeben würde und, zu dem Zustand des absoluten Wissens gelangt, Gott gleich wäre. Solange aber unser Bewußtsein ein beschränktes ist und den Charakter des Endlichen bewahrt, solange gilt auch die Zeit als Erkenntnisform alles Endlichen.

Das Geltende verändert sich nicht, das Göttliche ist das Vollendete. Alles andere ist der Veränderung und dem Geschehen unterworfen. Das Geschehen ist selber nicht von der Zeit abhängig, sondern lediglich die Erkenntnis des Geschehens für ein endliches Bewubtsein. Wenn wir sagen, daß das Werthafte die Zeit bestimmt, so meinen wir damit, daß die Mertidee das sinnliche Geschehen bestimmt, das für unsere Erkenntnis immer der Zeit als der Form unserer Anschauung unterworfen ist.

\section{o) Die doppelte Bestimmung des historischen Gesehehens.}

Wenn wir das welthistorische Geschehen mit Rücksicht auf die Faktoren, die seinen Ablauf bestimmen, jene Faktoren, die wir zeitlich als das Verhältnis von Ursache und Wirkung bezeichnen, zu verstehen suchen, so unterliegt der historische Prozeß einer doppelten Bestimmung: der Bestimmung durch die Wertidee als das Allgemeine und der Bestimmung durch die Individualität als das Besondere. Diese Bestimmung durch das Allgemeine kam man auch als die GesetzmäBigkeit des historischen Geschehens bezeichnen, wenn man sich von vornherein darüber klar ist, daß die Gesetzmäßigkeit, von der hier die Rede ist, mit der Gesetzesvorstellung der Naturwissenschaft nichts zu tun hat. Denn die Gesetzmäßigkeit der Universalgeschichte reguliert einen eimmaligen Verlauf. Es ist der Prozeß, welcher das Menschengeschlecht zu einer allmählichen Erfahrung der Wahrheit und zu einem Verstehen des Schönen führt. Das Allgemeine begibt sich in die Form der Anschauung und gibt unserem Denken und Fühlen die Richtung. Die Wertidee, etwa der Erkenntnis, tritt aber nicht auf einmal in Erscheinung, sondern gelangt nach und nach in dem historischen Prozeß zu ihrer Erfüllung. Immer neue Teile der Wertidee verwirklichen sich in der sinnlichen Sphäre, und jede stellt sich in der Form und Gestalt eines besonderen Typus dar. Durch eine Reihe von immer neucn typischen Formen und Gestalten, die immer wieder eimen anderen Ausdruck für das Schöne finden, bewegt sich die Entwicklung der Kunst einem bestimmten Ziele zu, und der Weg des Wissens führt durch eine Reihe ron ganz verschiedenartigen Formen der Weltauffassung und Lebensbeurteilung hindurch, durch wechselnde Ziele der Einzelforschung einem allgemeinen Verstehen entgegen. Die Reihenfolge aber, in der diese Gestalten in Erscheinung treten, ist augenscheinlich eine festgesetzte und bestimmte. Das Unsinnliche begibt sich in die Gestalt 
der Ansehammg nach einer festgesetzten Ordnung. Diese Ordnung kann durch die Tätigkeit der Individualität nicht durchbrochen werden, sie ist an die Ordnung des Geschehens gebunden. So offenbart sich also die Kunstwelt in einer Reihe typischer Gestalten. Eine solehe typisehe Gestalt ist etwa der schöne Stil, wie er bei Praxiteles zum Ausdruek gelangt, der das Gesetz fiir eine ganze Kulturepoche gegeben hat: das Gesetz der griechisehen Sehönheit. Ein solcher Typus der Weltansehamung ist etwa der Materialismus des Demokrit als die erste große Form der naturalistisehen Weltauffassung. Die Reihenfolge in der Offenbarung des Wertgeschehens seheint nicht durchbroehen werden zu können. Wie ist nun das Verhältnis der großen historischen Individualitäten zn dem Wertgesehehen zu denken? Werden sie bedingungslos von ihm erfaßt und getrieben als blinde Werkzenge des Weltgesehehens, oder ist ihnen noeh eine gewisse Selbständigkeit gegenüber dem Typus ihrer Epoche, der sich im Zeitgeist ansdrïckt, verliehen?

Ein Beispiel mag unseren Gedanken erläntern. Zn dem Typus der griechi . sehen Verfassung und der ganzen Gestaltung, welche der Stadtstaat, die rókı, als Form des politischen mol sozialen Lebens angenommen hatte, gehörte anch die Sklaverei. Aristoteles, der mmfassendste Geist, den die griechisehe Kultur hervorgebracht hat, konnte den freien Arbeiterstand als Ingredienz einer politischen Gemeinsehaft nicht denken und noch viel weniger wiinschen. Wohl ist in Griechenland die Vorstellung von einem Staat, der die Sklaverei nicht kemnt, als flüchtige Intuition erwacht, aber nnmöglich komten Ansehaumgen dieser Art Daner und Bestand haben. Und vor allen Dingen war es rollkommen ausgesehlossen, daß diese Vorstellungen ihre Verwirklichung in irgendeinem sozialen Verhältnisse gefunden hätten. Weder vermochte die Idee eines freien Arbeiterstandes damals in dem System eines Philosophen Platz zu gewinnen, noch hat sie ror allen Dingen sich in simnliche Wirklichkeit umgesetzt. Denn aus der Form der Sklaverei muBte erst die Form der Hörigkeit und der Leibeigensehaft hervorgehen, bevor sich die wirtsehaftliche Entwieklung in dem Typus des freien Arbeiterstandes vollendete. Wir pflegen diese Tatsache in empiriseh-historisehen Erwägungen anf die allgemeine Kulturlage zuriickzuführen, wenn wir etwa sagen, daß die ganze politische und kulturelle Situation damals so besehaffen war, daß die Idee der freien Arbeit unmöglich Gestalt gewimnen konnte. Fragen wir, was das bedeutet, so kommen wir dahin, anzunehmen, da $\beta$ clie ganze Wertungsweise des damaligen Zeitalters dic Idce der freien Arbeit nicht ertragen konnte. Die Sklaverei war (in notwendiges Ingrediens des antiken Wirtsehaftssystems. Und wemn ihr moralisches Unrecht anch damals schon teilweise empfunden wurde, so wurde diese Wertung, wolche rein ethischen MLotiven entstanmte, doeh rollkommen zuriickgchalten und zurïckgedrïngt dureh die Wertung des Staates, der als unberlingter Se]bstzweek im Zusammenhange der alten Kultur eine so entscheidendr. Rolle spielte. Tor allem in der griechischen Kultur maehte sich in der Wratung des kontemplation Jabens mul dor Geringsehätzung des praktischen 'Thus rino Gefühlsposition mol Wertstellnng bemerkbar, welehe der Idee des morlormen Sitantes drar Arbcit stark widerstrebte.

Fragen wir somit nach dor Heltung, die unter dem geschiehtsphilosophischen Bewnlatsein das Allgemeine der Wertidee annimmt, so kommen wir 
zu dem Resultat, daß die Gestaltenfolge der Wertrealisierung festgeordnet und bestimmt sei, so daß es etwa möglich ist, daß die Idee des nationalen Staates früher in Erscheinung zu treten vermoehte als die Idee des universalen Staates. Wenn wir aber von der Idee des nationalen Staates und ihrer Verwirklichung sprechen als der politischen Situation, in welche wir hineingeboren sind und ron der jede große politische Behandlung der Dinge ausgeht, so sprechen wir natürlich ron einer bewußten Erfassung dieses Gebildes. Erst dann kamn man davon sprechen, daß die nationale Idee Gestalt gewonnen hat, wenn in dem ganzen politischen Tun und Treiben der Völker eine Abstoßung der universalen Ideen zum Ausdruck kommt und die t'berzeugung sieh Bahn gebrochen hat, daß nur auf der eigentïmlichen Gestaltung der Tolksindiridualität ein wertrolles politisches Gemeinschaftsleben sich aufzubauen vermag. Dagegen ist etwa im griechischen Tolke die Idee des nationalen Staates noch nicht verwirklicht worden, weil im Griechentum wohl ron einer Hochschätzung der eigenen Tolksindividualität, nicht aber ron einer Anerkennung des Wertcharakters der Nation gesprochen werden darf. Auch ist das griechische Tolk weit daron entfernt, auf den Gedanken der Weltherrschaft zu verzichten. Diese universalistische Idee war für das Griechentum noch gar nicht aktuell geworden. Hat sie doch ihren großen bewußten Ausdruck erst durch Alexander den Groben erhalten.

Wenn nun die Reihenfolge der Wertgestalten des historischen Lebens feststeht, so fragt es sich, welche selbständige Bedeutung demn eigentlich der Persönlichkeit und der Volksindividualität gegenüber der GesetzmäBigkeit des Allgemeinen zukommt. Sie kann im Sinne der Geschichtsphilosophie nicht als das ruhige Gefäß für die Aufnahme wertroller Gedanken, nicht als das blinde Werkzeng der Ideen verstanden werden. Die Persönlichkeit ist es, welche an der Verwirklichung der Wertideen arbeitet, und es ist eine tiefsinnige metaphysische Frage, darüber nachzudenken, wie weit ohne ihr Tun das Heil überhaupt in die Welt gelangen konnte. Die Größe der persönlichen Leistung aber scheint ror allem darin zu liegen, daßsie das Seinsollende, welches der religiöse Mensch als das Gottgewollte bezeichnct, mehr oder weniger schnell, mehr oder weniger groß und mächtig zur Entfaltung bringt.

Solange die große Persönlichkeit fehlt, die heldenhafte, so lange bleibt das Werthafte für sich, so lange gibt es sich nicht der Menschheit hin. Still ruht die heilige Ordnung, und kein großes Geschehen löst sich ans. Die Zeit wartet auf ihren Helden. Nicht immer ist der Held da, wenn ihn die Zeit roller Sehnsucht erwartet. Es giłt heldenlose Zeiten, da die Gefahr eines allgemeinen Unterganges vorzuliegen scheint, ohne daß ein Retter sich naht. Es giht heldenlose und würdelose Zeiten, da der Gang der Weltgeschiehte zu stocken scheint. Es ist der Held und das Heldenhafte ïberhaupt, das an den großen Wendepunkten der Geschichte so gewaltig in Erscheimung tritt und die weiherollen Momente heraufbeschwört, da das Irdische sich zum Himmlischen erhebt und schweigende Jahrhunderte ron einem unerhörten Glanz erfïllt werden. Der Held beschlemigt das Ende der Weltgeschichte, indem er alles menschliche Streben und alle menschliche Sehnsucht durch Gröbe zur Ruhe bringt.

Wenn die Geschichte ihren Helden feiert, so feiert sie damit einen Festtag des historischen Lebens, einen vorläufigen Ruhepunkt auf dem arbeitsmüclen 
Weg der Entwicklung, die vorzeitige Erfüllung des Zieles. Sie feiert auch ein Vollendetes im Unrollendeten und die Anwesenheit des Höchsten in den kleinen Dingen der Welt.

\section{p) Die Typen des Kulturlebens.}

Die Gestalten des Weltlebens, die der Held zu verwirklichen sucht und die in der Ordnung des ganzen Kulturgeschehens, in ihrer GesetzmäBigkeit begründet sind, bezeichnen wir am b esten als die Typen des Kulturlebens. Solche Typen finden wir auf allen Kulturgebieten. Um gleich ein großes Beispiel zu wählen, so sind etwa Typen der griechischen Kunst, die selber ein Typus des künstlerischen Gesamtlebens ist, die von Winckelmann uncersehiedenen Formen des alten Stils, des erhabenen und des schönen Stils. Oder auf philosophischem Gebiet Naturalismus und Idealismus, Romantik und Realismus als Kulturerscheinungen besonderer Art, Magie und Mystik als Grundformen des religiösen Bewußtseins. Oder auf dem Gebiet des politischen Lebens der nationale Staat und die Universalmonarchie. Diese historischen Wertbegriffe, welche wir Typen nennen, haben eine Allgemeinheit, welche die Mitte hält zwischen der Allgemeinheit des Kulturwertes überhaupt, wie Staat und Kunst, und allgemeinen historischen Begriffen, wie Republik und Königreich als Formen des Verfassungslebens oder Protestantismus und Katholizismus als Formen der christlichen Lehre.

Wir haben mit Absicht hier zwei ganz verschiedenartige Begriffspaare gewählt, die doch das gemeinsam haben, daß sie philosophisch unwertig sind oder dort ihre Stelle haben, wo das philosophische Interesse an der Geschichte aufhört. Unter Typus wollen wir nämlich eine Form der sinnlichen Gestaltung des Kulturwertes verstehen, die sich ummittelbar aus dem Gegensatz ergibt, der einem jeden Wertgebiet zugrunde liegt und noch nicht zu sehr mit den Einzelheiten des simnlich-historischen Lebens belastet ist. In dem Typus sollen nur die allgemeinsten Gestaltungen des Weltlebens begriffen sein. Nur ihr allgemeiner Rhythmus soll sich kundtun und offenbaren - nicht mehr. Begriffe verschiedener Verfassungsreformen oder auch die Formen der christlichen Lehre sind schon zu tief in die Empirie verstrickt, als daß es möglich wäre, sie noch in ein unmittelbares Verhältnis zur Wertidee zu setzen. Deswegen sind diese auch keine geschichtsphilosophischen Begriffe, sondern gehören vollkommen der historischen Forschung an.

\section{1) Gliederung des universahistorischen Geschehens.}

Ton den 'Typen res Weltlebens her ist eine Gliederung des universalhistorischen Prozesses möglich. Fïr jęle Epoche der Weltgeschichte oder auch für jarlen Kulturkreis wird cine bestimmte Gestaltung etwa der religiösen Idec typisch und wichtig scin. Von gesehichtsphilosophischem Interesse ist aber niclıt sowohi die Gestaltung der Religion als eines positiv dogmatisehen, kirehlichen (iehildes, wie das im sime der alten Geschichtsphilosophie lag, die von dor Thloe des christentums ans das Weltgeschchen zu begreifen suchte, sondern violnehr die Gestaltung des religiöscn Bewußtscins mabhängig von jorlere kirchlichen longmatik. 
Wenn nun auch ein bestimmter Typus ganz in allgemeinen als charakteristisch für eine Epoche angesehen werden kann und die Physiognomie eines Zeitalters mehr oder weniger bestimmt, so ist es doch vollkommen ausgeschlossen, auf Grund dieser Typen eine scharfe Gliederung der geschichtsphilosophischen Welt vorzunehmen. Neben dem leitenden Prinzip treten immer wieder nene Prinzipien hervor, und die alten behaupten sich neben den neuen. Die Typen sind nicht vergänglich und kömnen nicht obsolet werden wie Rechtsnormen, die veralten, sondern es handelt sich um Gestaltungen, die der schaffende Geist immer wieder von neuem erzengt. Wenigstens gilt das für diejenigen Werte, die wir als die absolnten bezeichnet haben, für Religion, Philosophie und Kunst, wenn auch für alle wieder in verschiedenem Sinne. So läßt der Fortschrittswert in seinen späteren Gestaltungen das Frühere als ein Überwundenes zurïck. Hat sich der Sinn des Kulturstaates erfüllt, so muß der despotische Staat notwendig als wertgeringer erscheinen. Dagegen. ist die Schönheit der griechischen Plastik ein Vollendetes, das nicht übertroffen werden kann. Hier besteht nur die Möglichkeit, daß Gleichwertiges in einer ganz anderen Form gestaltet wird.

Den Kulturwerten entsprechend, gliedert sich das historische Universum in verschiedenartige Reihen von typischen Gestalten. Wenn auch zwischen diesen Gestalten ein korrespondierendes Verhältnis anzunehmen ist, sofern einer bestimmten Form des künstlerischen Lebens sine bestimmte Form religiöser Gestaltung entspricht, so muß doch jede geschichtsphilosophische Betrachtung zunächst einmal auf die Sondergestalten einer bestimmten Sphäre gerichtet sein.

Dabei ergeben sich dann wieder sogleich zwei Probleme, nämlich:

1. die Frage, welcher Kulturwert wohl der eigentlich dominierende in einer Kulturentwicklung sein möchte, und

2. wie wohl das Verhältnis zwisehen den verschiedenen Kulturgebieten zu denken sei.

Wir müssen annehmen, daß das menschliche Geistesleben sich auf e in e m Wertgebiet am höchsten entfaltet, daß es sich in einer bestimmten Form vollendet, so daß das Leben des Geistes eine geschlossene Einheit bildet, deren begriffliche Ưbersetzung das System ist. Zum mindesten ist das eine Vermunftforderung, die immer wieder erhoben wurde und zu der wir immer wiecter hingetrieben werden. Was ist denn nun das Eine, das not tut? Worauf kommt es vor allen Dingen an? Vollendet sich alles Geistesleben in der Religion? Sollte sie es sein als die älteste Form der geistigen Fntwicklung, in der aller Gegensatz menschlicher Beurteilungen und Wertungen ruht und schweigt? Oder bedeutet für den historischen Prozeß mit Rücksicht anf den Wertgehalt und den bestimmenden EinfluB, der ron ihm ausgeht, der logisch-theoretische Wert mehr als der religiöse? Vollendet sich das Geistesleben nicht in der religiösen, sondern in der wissenschaftlichen Kultur?

Wenn wir die Frage naeh dem leitenden Wert des historischen Geschehens erheben, so haben wir zu unterscheiden zwischen seiner Wirkimkeit auf geistiges Leben und seiner Wirksamkeit in materieller Hinsieht. So können wir etwa die Frage verstehen, ob die Schönheit der griechischen KuItur in ihrer eigentümlichen Prägung abhängig zu denken ist in erster Linie ron 
der großen griechischen Metaphysik, in der das theoretische Bewußtsein seine ersten großen Trimmphe feierte. Sind es die philosophischen Ideen in ihrer unvergleichlichen Neuheit, Frische und Kraft, die das große Leben der Kunst entscheidend bestimmt und auch das sittliche Leben gestaltet haben? Wenn in der Philosophie eines Volkes ein Streben nach Gottweisheit, nach Weltund Lebensweisheit zum Ausdruck kommt, das imnige Bedïrfnis, alles Rätselhafte zur Klarheit und alles Getrennte zur Einheit zu führen, wenn so Wertvolles und Großes von der Philosophie erhofft, erstrebt und geleistet wird, und die griechische Philosophie eime der denkbar höchsten Formen philosophischer Bildung bedeutete, damn muste wohl von ihr ein lebendiger Strom ausgehen, der die gestaltenreiche Welt der Kunst mit Ideen befruchtete und anch dem staatlichen Loben einen schimmenden Glanz verlieh.

Diese Wertbedeutsamkeit ist es recht eigentlich, welche die Geschichtsphilosophie interessiert. Wenn wir davon sprechen, daß die theoretische Kultur entscheidend ist, dann meinen wir, daß sie der Gesamtkultur ihr Gepräge gibt. Mehr von historischem Interesse ist dagegen die Frage, welche Giiter es sind, die große kriegerische Entwicklungen und Bewegungen hervorrufen. War der Grund der Kriege ursprïnglich in Liebe, Haß und Ehrgeiz gelegen, so wurden später bestimmte Kulturmächte ron ausschlaggebender Bedeutung. Im Geiste ästhetischer und theoretischer Steale hat $\mathbf{J u l i a n}$ seinen Kampf gegen das Christentum geführt. Die Idee des freien Kulturstaates hat oft die Herzen entflammt. Religiöse Motive haben in den Krenzzügen einen mächtigen Ausdruck gefunden. Ind den Charakter der modernen Kriege bestimmt in der Hanptsache das wirtschaftliche Interesse.

\section{r) Die Wertfeindlichkeit.}

Erheben wir damn weiter die Frage nach dem Verhältnis zwischen den verschiedenen Kulturwerten, so ist hier vorallem das Problem der Wertfeindlichkeit wichtig. Unter Wrertfeindlichkeit verstehen wir das Faktum, daß zwischen den verschiedenen Kulturmächten, die anzuerkennen wir genötigt, sind, kein Einklang besteht. Es handelt sich la um die Konstatierung eincs Gegensatzes, und dieser Gegensatz ist Vorbedingung für alles Kulturgesehehen. Behaupten wir den Wertgegensatz, so behaupten wir damit, daß das Reich der Vermunft, wie es sich im Kulturgeschehen entfaltet, eine Spaltung anfweise. Das Leben des Geistes, wie wir es erleben, ist zerkliiftet und zerrissen, die Vermunft ist mit sich selbst in Widerstreit gesetzt. Die eigentliche Größe und 'Tragik der Kultur liegt nicht sowohl darin, daß das Verniunftige mit d('m Simnlichen im Streit liegt und der Geist mehr und mehr dir. Herrschaft übor die Natur gewimst. Gewils wiol anch durch den Gegensatz von V'ermunft mol Natur ein Gesehehen alusgelöst, aber das große historische fieschehen ist nur selten ein Kampf der Vermunft mit der Unvernmet. lïn soldher Kample molet ja in der Regel mit dem Siege der Vernunft und lablat rinc optimistische Auffassmug des historisehen Gesehehens zu.

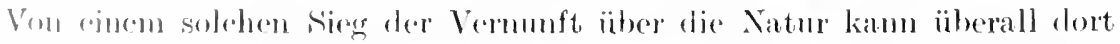

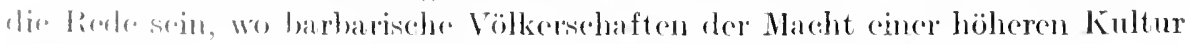

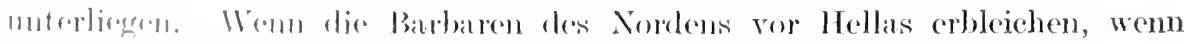
l'arther, Kinfen, (iallior, Germanen dem siegreichen Rom erliegen, dann 
feiert der Genius der Geschichte. Und wie hier mit Feldhermkunst und überlegenen Waffen der Sieg errungen wird, so trotzt die Wissensehaft der Natur, dem Gebiete des bloß Simmlichen immer neuen Boden ab und belanseht ihre Geheimnisse und macht sie sich zu eigen. Frendig jubeln wir stets dem Genius der Geschiehte zu, wenn das Volk des Wissens und der Schönheit, das Gottgeliebte, die Sitze der Unkultur überwindet.

Freilich mag man sich fragen, ob das Volk des Wissens und der Kultur anch immer das Volk der Sehönheit ist. Es möehte ja fast so aussehen, als ob jene Völker, die selber schöndas Schöne leisten wiedie Griechen, selten sind, und dann diese sehmerzliche Antinomie besteht, entweder sehön zu sein oder da. Schöne zu sehaffen. Mit der Steigerung der Zivilisation seheint ein Verlust an natürlicher Körpersehönheit zusammenzugehen. Und so verstehen wir einen Dichter wie Baudelaire, der seinen frommen Hymnus dem Tolke der naekten Kraft und Sehönheit weiht, dem Kultur nieht mur Abfall, sondern auch Verfall bedeutet, und dem Gesichter, die von imneren Kämpfen ergriffen sind, in ihrer müden und sieehen Sehönheit keinen Ersatz bieten können für die frische Schönheit der jungen Völker.

Nur ist eine solehe Beurteilung so mhistoriseh wie möglich, denn alle Geschichtsphilosophie bedeutet eine Apotheose der Kultur. Sie setzt das bewußte Kunstwerk an die Stelle des naiven. Sie liebt die geformte und wissende Schönheit. Jene naive Schönheit konnte sich selber noch nicht als schön genießen, und es ist vollkommen unerfindlich, warum die Höhe der Kultur notwendig mit dem Terfall der Sehönheit zusammengehen muß.

Ebensowenig wie in dem Sieg der Vernunft ïber die Natur, welcher als allgemeines Schema zugrunde liegen mag, der entseheidente Gegensatz des historischen Lebens gesehen werden darf, ebensowenig läßt sich umgekehrt behaupten, der Sinn des Gesehehens müsse darin liegen, daß immer wieder die Kultur der Cnkultur geopfert wird. Es gibt ja Freunde der derben und starken Natur, Freunde der Volksvermehrung und Fanatiker der Gesundheit, welehe die Kinderproduktion auf das äußerste zu steigern wïnschen, jene sozialen Naturalisten, die immer befürehten, daß Bildung des Lebens zum Untergange führen möehte. Sie sehen die Kultur der Griechen und ihren Untergang, sie sehen, wie die europäische Kultur kräftige Naturvölker degeneriert und verweiehlicht hat. Den Rückgang der Geburten in Frankreich sehen sie und prophezeien den romanisehen Tölkern baldiges Ende. An die Stelle des Romanentums wird das Germanentum, an die Stelle des Germanentums das Slaventum treten. Alle Kultur führt zur Überkultur. Die Ủberkultur macht die Völker dekadent. Die dekadenten Völker miissen untergehen. Die Bewegung des historisehen Lebens wird hier also in dem Gegensatz ron Kultur als roll ausgereiftes müdes Leben und Barbarei als frische, ursprïngliehe Taitkraft gesehen. Die Barbarei bekämpft die Kultur und ïberwindet sie, sobald die Kultur alt geworden ist, wie das Junge immer über das Alte trimmphiert. Dann aber wird das ganze siegreiche Volk durch die Kulturkrankheit angesteckt und muß zugrunde gehen wie das Volk der alten Kultur.

Dieser Theorie und Auffassung hiaben wir ein Doppeltes entgegenzuhalten:

Erstens fragt es sieh nämlich, was dem eigentlieh dazu berechtigt, anzunehmen, daß die Kultur die Völker tötet und vernichtet. Doch wohl ledighich die 
Erfahrungstatsache, daß Kultumationen wie die Griechen und Römer zugrundegegangen sind. Lag dieser Untergang aber nicht vielleicht daran, daß mit den Mitteln der alten Kultur dem Staatswesen noch nicht die Stabilität verliehen werden komnte, die den modernen Staaten gegeben ist? England, Deutschland und Frankreich bestehen als modeme Staatengebilde schon fast so lange wie das Römerreich. Und sie sehen nicht danach aus, als ob sie schon Zeichen des Verfalles an sich trügen. Gegen die Angriffe des Barbarentums ist das moderne Europa viel geschützter, wie es das alte war, weil die Stätten der Uukultur an Macht und Ausdehnung erheblich verloren haben. Es ist doch nur eine rohe und plumpe Analogie, wenn man von dem Altwerden der Völker spricht. Das Einzelindividuum, die Persönlichkeit, wird alt in dem Sinne, daß sie ihre Grenze erreicht und dem Tode entgegengeht. Aber in der Nation, die sich durch Zeugung immer wieder ersetzen kann, liegt die Möglichkeit eines unendlichen Lebens. Warum sollte den modernen Völkern der,,westeuropäischen Republik", die trotz aller Feindseligkeit durch ein gewisses Solidaritätsgefühl und gemeinsames historisches Sehicksal verbunden sind, warum sollte ihnen notwendig der Untergang durch das Barbarentum drohen, weshalb besteht für sie nicht die Möglichkeit, fortzudanern bis zum Ende der Geschichte? Sollen wir wirklich ammehmen, daß die Völker Westeuropas durch die Slaven und diese wieder durch die Mongolen abgelöst werden? Fast möchte man meinen, daß die Irlee der Menschheit gerade in diesen hochkultivierten Völkern eine notwendige Gestalt angenommen hat, und daß sie durch ihr historisches Schicksal sich wïrdig erwiesen hätten, ihr Dasein bis ans Ende aller Dinge zu behaupten.

Weiter aber stellt sich die Erwägmng ein, daß vielleicht die Menschheit die Idee der Kultur auf sich nehmen mußte, um an ihr zugrunde zu gehen. Welches Interesse könmen wir vom Standpunkt der Geschichte daran haben, ob Menschen in naturhaftem Zustande auf diesem Planeten kürzere oder längere Zeit ihr Dasein fristen? Ist doch der Mensch im Geiste der Geschichte immer etwas, was überwunden werden soll. Nicht ihm soll Bestand und Dauer beschieden sein, sondern, wemn die Geschichte überhaupt einen Sinn hat, so liegt dieser Sinn in der Úberwindung des bloßen Sinnenwesens Mensch. Was liegt denn so Schreckliches in der Idce dieses Unterganges der Menschheit dureh die Kultur? Ist es nicht sehön, an der Weisheit, an der Schönheit und an der Tugend zu sterben? Ist nicht cin soleher Untergang weit erstrebenswerter als das lange vegetative Dascin in bloßer Natürlichkcit?

Weder jene, die den wahren Sinn der historisehen Bewegung vor allem in der Uberwindung der Natur durch die Kultur verstehen wollen, noch jene, (lie mmgekehrt in dem Siege der Unkultur iiber die Kultur das Wesen llor Gesehichte erlolicken, denken wahhaft historiseh. Jene verstehen wohl, donken al)er nicht tief genng; diese denken ganz naturwissensehaftlich und sinrl von jocler historischen Auffassung weit entfernt. Die große Bewegung Her Gieschichte ruht nicht sowohl auf dem Gegensatz von Kultur und Unkultur als violmehr auf dem Gegensatz von Kultur und Kultur. Und weil es sich 1 m diescen Gegensatz handelt, gerade deswegen bietet anch die Geschichte (in so märohtiges und tragisches Schauspicl dar, an dem wir nieht ohne Rüh-

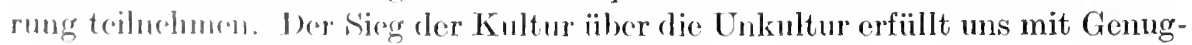


tuung, der Sieg der Unkultur über die Kultur mit Trauer und Entsetzen. Aber wenn das Große und Schöne mit dem Großen und Schönen kämpft, wenn gleichwertige Mächte auf den Walplatz treten und wir erleben müssen, wie das Schöne und Vornehme im Kampf mit dem Schönen und Vornehmen zugrunde geht, dann erst werden wir von einem Gefühle hoher Tragik ergriffen. Dann erst erleben wir die Macht und Herrlichkeit des historischen Geschehens, wenn das Große mit dem Großen streitet: Griechenland gegen Rom, Julian gegen das Christentum, die Staufen gegen die großen Päpste, Napoleon gegen das Nationalitätsbewußtsein des deutschen Volkes, Friedrich I, gegen Heinrich den Löwen.

Kleinlich ist die Beurteilung, welche bei einem solchen Wettkampf des Großen und Schönen einseitig Partei ergreift und nicht vielmehr in der ruhigen Anerkennung der Leistung verharrt.

Die Gnosis hat recht, wenn sie die Auffassung vertritt, daß es sich in der Bewegung des historischen Geschehens um einen Kampf der Götter handelt. Wahrlich, um einen Kampf der Götter handelt es sich in der Weltgeschichte, und diese Götter sind die Wertideen.

Wir sind natürlich weit davon entfernt, zu behaupten, daß nicht auch die wirtschaftlichen Momente eine wichtige Rolle im historischen Geschehen spielten. Die Not des Lebens ist es gewesen, die Sorge um künftige Generationen, welche die Nomadenvölker zum Wandern trieb. Aber schwerlich waren es diese materiellen Instinkte allein, welche die kräftigen Völker Germaniens an die Grenzen des römischen Reiches herantrieben. Ein dunkler Instinkt und eine Sehnsucht nach dem Schönen und Wunderbaren mag es gewesen sein und das Gebot des Schicksals, dem sie gehorchen mußten.

Wenn Kultur mit Kultur in Streit gerät, dann ist es immer ein Kampf um Götter im Sinne ron Wertideen. Und mag der Ehrgeiz und die Leidenschaft noch so mächtig die Führer erregen, immer tun sie das Große im Dienste ihres Gottes, mögen sie nun den Gedanken des Imperiums rerteidigen oder der nationalen Idee Opfer bringen, mögen sie wie Julian die Sinnenschönheit der Antike und ihre Philosophie und Wissenschaft gegen den rermeintlichen Barbarismus des Christentums zu retten suchen oder im Dienste einer religiösen Ủberzeugung ihr Leben zum Opfer bringen.

\section{s) Die Doppelheit des Vernunftgegensatzes.}

Wenn wir nun die Behauptung aufstellen, daß die große dramatische Bewegung des Kulturgeschehens auf Wertgegensätzen beruht, daß es sich hier vor allen Dingen um einen Kampf der Ideen, um einen tiefen Gegensatz des Wertens und Anerkennens handelt, so haben wir, um uns den Sinn der Geschichte deutlich zu machen, in diesem Wertgegensatz ein Doppeltes zu unterscheiden. Der Wertgegensatz, der die historische Bewegung hervorruft, kann nämlich entweder darauf bernhen, daß verschiedenartige Ideen, Ideen verschiedenartiger Wertgebiete miteinander in Konflikt geraten, so die Idee des wissenschaftlichen und religiösen Lebens, oder daß die Wertidee mit sich selber in Konflikt gerät, daß ihre sinnlichen Erscheinungsweisen miteinander streiten. Das wird etwa dann der Fall sein, wenn sich zwei verschiedenartige Formen des religiösen Lebens gegencinander wenden. 
Unser praktisch gerichtetes Zeitalter ist immer sehr geneigt, die ideellen Mächte zu verkennen. Steht etwa in Rußland dem westlichen Europa der Agrarstaat dem Industriestaat, die slavische Rasse der germanischen und romanischen gegenüber, wie es die Geschichtsphilosophen der Nationalökonomie und der Rasse vermeinen? Liegen nicht viehmehr noch ganz andere Kulturgegensätze vor zwischen dem tief religiösen Rußland, dem Rußland der Theokratje. das nieht ohne Vorwurf und Granen auf den sündigen Westen blickt, und der westeuropäischen Repmblik, die als gemeinsames großes Schicksal die Renaissance erlebt und dadureh zur Freude am rein theoretischen Denken und zur Frende am simnlich Schönen erzogen wurle?

Wir konstruieren unsere Formel des Weltgeschehens mit Rïcksicht anf den doppelten Wertgegensatz:

1. den Gegensatz versehiedener Wertideen,

2. den Gegensatz innerhalb der Sphäre ein und derselben Wertidee.

Wer hätte nieht sehon die Qual empfunden, die darin liegt, nicht verstanden zu werlen? Dieses Nichtrerstandenwerden liegt in erster Linie an dem Gegensatz der Wertideen, von denen die Mensehen beherrscht sind. Für den Toren haben wir das Lächeln gutmütigen spottes, für den amusischen Menschen das wegwerfende Crteil: Banausentum, für den Sittenlosen die scharfe Aburteilumg. Wie aber, wenn in zwei Menschen das Religiöse in einer bestimmten Form mit dem Theoretischen in Streit gerät oder das Ethische mit dem Ästhetischen? Dann fühlen wir gar bald, daß aus dem anderen eine Utberzeugung spricht, der wir unsere Anerkemmung nicht versagen können, und die wir doch bekämpfen müssen; und dieser Kampf bereitet uns Sichmerz. Und wir selber sind aneh manehmal durch diesen Kampf zerrissen und zerstört. In dem hochkultivierten Menschen kïmpft nicht sowohl in erster Linie das ernste (iewissen mit dem leichtfertigen Laster. Das Wertrolle selber hat sich die Brust des Menschen zur Walstatt erwählt. Wer hätto nicht selber den harten Kampf zwisehen theoretischer Einsicht und religiöser tberzeugung durchgeciimpft! Tor allem hleibt jenen dieser Kampf nicht erspart, die den Wegg der Wissenschaft gewählt haben. Und im Gewande ter Schönheit vermas das simnliehe gar leicht mus abzulenken von dem strengen Gebot der I'flicht. Cmmöglieh seheint es uns, von so Entgegengesetztem bestimmt, mnser Leben in Einklang zu führen, die Harmonie zu finden, die wir erstreben, da man, wic es scheint. nicht mehroren Göttem dienen kamn. So ist es also der Polytheismus der Worte, weloher dem Leben die größten und sehwersten Konfliktsmöglichkeiten sehafft. Und eine Versöhmung zwischen ihnen herbeizuführen, ist muser höchstes Ziel. weil wir nur so zu einer wahrhaft geistigen

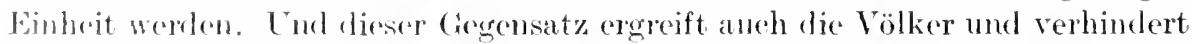
rin grogensoitigas Vorstrhen, das nicht nur dureh die Vorschjedenheit der

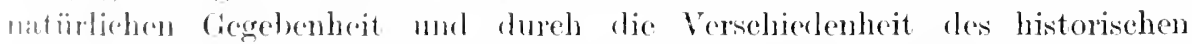

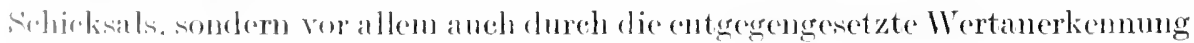
undrommt ist.

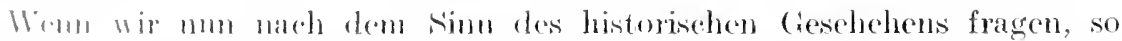
veptretoll wir mit allere Geschichtsphilesephie die Ctherzengung, dab in ihr die

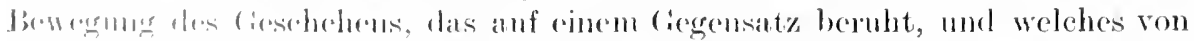

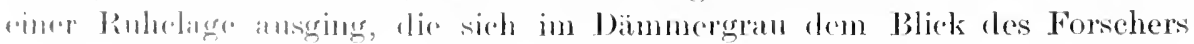


entzieht, daß dieser Gegensatz zu einer Einheit geführt und rersöhnt werden soll. Der Gegensatz aber, den wir in erster Linie zu betonen hatten, ist der Gegensatz ron Wert und Wert oder ron verschiedenen Formen des vernünftigen Lebens, deren Widerstreit so hart ist, daß niemals die eine in die andere übergeleitet, die eine in der anderen aufgehoben werden kamn. Das Ziel des Weltgesehehens kamn somit auch nur die Herstellung einer Werteinheit in dem Sinne sein, daß diese Antinomien, die das Leben zerreißen, zur Versöhnung gebracht werden.

Dann ist das Ziel des historisehen Geschehens erreicht. wenn der Kompetenzenstreit der Vemunft erledigt ist und die Götter des Kulturlebens ihren Bezirk abgegrenzt, ihr Reich in Besitz genommen haben. Wenn das sittliche Leben, durch keine Ansprüche fremder Mächte beleidigt, sein eigentïmliehen Dasein lebt; wenn das Sehöne an seiner Stelle selig ist; die Wissenschaft froj und ungekränkt an ihrer Stelle sich entfaltet, und der Religion ihr heiliges Imnenreich gesichert ist; wemn der Staat nicht mehr rerlangt, als ihm gcbührt, und die Rechte und die Freiheit des Persönlichkeit ebenso gut gewahrt wird wie das Reeht der Gemeinschaft; wenn das Recht selber dem gesteigerten ReehtsbewuBtsein der Menschheit vollkommen entspricht und mit dem Bewußtsein höherer Sittlichkeit nieht mehr im Konflikt liegt: damn ist ein Zustand der Mensehheit erreieht, den wir als den Zustand der irdischen Glüekseligkeit bezeiehnen können. Eine harte Arbeit der Geschiehte ist erforderlieh, um dieses Ziel zu erreiehen. Denn wenn es schon schwierig ist, daß Menschen gegeneinander ihre Rechte abgrenzen und sich ihr Gebict bestimmen, wie viel sehwerer ist es dann, daß die Verträglichkeiten und Unrerträglichkeiten zwisehen den Wertideen bestimmter Entscheidung unterliegen, so daß sie friedlieh und ungestört beisammen wohnen können in den Herzen der Einzelnen und im Leben des Ganzen.

Indem nun aber die Kulturmächte dureh das historische Gesehehen sehließ lich im Mensehheitsganzen die Stelle gewinnen, die ihnen gebührt, vermögen sie anch an ihrer Stelle dem Vernïnftigen zum Siege zu verhelfen. Denm das Vernünftige, an falseher Stelle angewandt, führt zur C'nvernunft, und so jst mit der Herstellung der irdisehen Glückseligkeit aueh ein Sieg des rernünftigen Lebens verbunden.

Unsere Argumentation ist also in Kürze diese:

Ohne Kultur keine Geschichte, denn alle historische Beurteilung hängt an dem Begriff der Kultur. Aus der Idee der Kultur kamn allein der Sinn der Geschichte erschlossen werden. Wir erleben den Wertgegensatz und müssen die Wertfeindlichkeit der Kulturmächte konstatieren. Auf dieser Wertfeindlichkeit beruht die Hochflut des historischen Geschehens. Der Sinn der Geschichte liegt nieht sowohl in der Uberwindung der Natur als viehmehr in der Versöhnung der Antimonien, welehe zwisehen den Wertideen oder ihren konkreten Erfüllungen im historisehen Leben bestehen. Am Eude der Geschichte sollen sie rersöhnt sein. Thr Gegensatz ist zum Austrag gekommen. Nicht sowohl die Utberwindung der Natur ist das Ziel der Geschichte - diese ist ja zum großen Teile schon geleistet und wird auch weiter geleistet werden —; sondern das Ziel der Geschiehte ist vielmehr die Utberwindung der Kultur. Das erste faßliche und deutliehe Ziel aber ist die Vereinheitliehung der Kultur, die Ver- 
söhnung der Kulturmächte. Bald wird die Zivilisation den ganzen Erdkreis durehdrungen haben, und immer mehr wird die Natur in den Dienst des Menschen getreten sein. Aber in diesem Prozeß als dem sichtbaren und augenfälligen, den wir erleben, können wir unmöglich den heiligen Sinn der Geschichte erblicken. Dieses brutale Beginnen der Vernunft gegenüber der Natur, das nur hart und notwendig ist, muß uns als etwas Vorläufiges erscheinen. Die Äußerlichkeit der Ưberwindung, die in dem Gedanken eines bloßen Zivilisationsprozesses liegt, erfüllt nicht den Sinn des Geschehens. In dieser äußerlichen therwindung der Natur erscheint die Vernunft selber als eine Art Naturkraft, nur listiger und überlegener als die nackte Natur. Die erste große Sinnerfüllung liegt vielmehr in der Herstellung jener Ordnung und Gliederung des Vernunftlebens, die jede geistige Unterdrückung meidet, in der Herstellung eines Vernunftstaates, der weder die intellektualistischen Züge der griechischen Kultur noch die religiös kirchliche Physiognomie des Mittelalters aufweist, sondern ein ganz neues Antlitz enthïllt, das seine Schönheit vor allem dem Cmstande verdankt, daß keine Form des geistigen Lebens mehr zum Dienen verurteilt ist, weder die Wissenschaft gegenüber der Religion noch die Religion gegenüber der Wissenschaft.

Dennoch kann die Herstellung der irdischen Glückseligkeit, wie wir die erste Sinnerfüllung eimmal bezeichnen wollen, nicht das Ende der Geschichte genannt werden. Bedentet doch diese Einheit des Kulturlebens erst die höchste Steigerung der Kulturmächte. Wie viel Kraft der Vernunft war doch bisher verschwendet worden! Versehwendet im Kampfe der Kultur mit der Natur und verschwendet im Kampfe der Kulturmächte untereinander. Hatte nicht die Moralität das simnlich Schöne verfolgt, und hatten nicht die Anhänger des Schönen über die Moralität gespottet? Hatten nicht Religion und Wissenschaft cinen verderblichen Kampf gekämpft? Die Wissenschaft num das einzig heilige Gut des Wahren willen und die Religion um das einzig wahre Gut des Heiligen willen. Diese Kämpfe haben ihr Ende gefunden iu dem Zustande der irdischen Seligkeit der Kultureinheit. Die Kräfte, die bisher im Kampfe mit anderen Mächten versehwendet und vergendet waren, sie kömnen sich nunmehr auf die Steigerung und Erhebung des eigenen Wortgcbietes richten. Alles Interesse der Kunst kann nun den Gegenstïnden der Schönheit und alle Kraft der Wissenschaft der Erkemntnis Jer Wirklichkeit und ihrer Formen gewidmet werden. Sie sind alle zu freien Herrschem im eigenen Reich geworden.

Aber noch ist die Kultur nicht am Zicle, sondern der Gegensatz lebt in den einzehnen Kulturmäehten fort und treibt sie gewaltig empor. Nicht mehr steht das wissenschaftliche Bewußtsein im Gegensatz zum religiösen Bewußtsein, alyer zwischen den Gestalten der Religion und ebenso zwisehen den Gestalstalten dar Philosophie und Wissenschaft, zwischen den verschiedenen Gestaltungen des kïnstlerischen Lebens, des Rechtes, des Staates, sowie den verschindenen Formen des sittlichen Bewubtseins dauert ein innerer Gegensatz weiter, der nach Vertilgung und Aufhebung ringt. Jedes Kulturgebiet ist anf rinem rirgensat\% anfgebant, und dieser Gegensatz ist Bedingung für das Jascin de's l'roblems. Nit seiner Lösung wäre anch der innere Kampf an Ziele, unel die deschichte wïrde lautlos und stumm. 
Sobald der Streit der Kulturmächte geschlichtet ist und jede große Form des menschlichen Geisteslebens ihren eigenen Zielen leben kann, dann ist die Harmonie der Welt in dem schönen Ausgleich geistiger Kräfte hergcstellt. Die Auflösung der ersten großen Antinomie bedeutet die Harmonie der Welt. Die Auflösung der zweiten Antinomie, des inneren Gegensatzes zwischen den einzelnen Kulturmächten bedeutet das Ende der Welt. Diese paradoxe Behauptung müssen wir jetzt deutlich zu machen suchen.

Legen wir den Zustand noch einmal fest, in dem sich der ProzeB des Weltgeschehens nummehr befindet. Getilgt sind die uralten Feindschaften, welche die Götter des Kulturgeschehens in Zorn und Haß gegeneinander getrieben. Nicht mehr greift der Staat in die Rechte der religiösen Organisationen ein, und die Schönheit darf ungehindert in ihrem stillen Reiche walten. Nicht mehr wendet sich die Wissenschaft in leidenschaftlichen und heftigen Demonstrationen gegen die Allgewalt des Staates, noch verfolgt die religiöre Organisation die Freiheit des Denkens. Und auch jener schroffe Gegensatz wird schweigen, der das politische Leben so sehr verwirrt, den wir als den Gegensatz zwischen der Wertung des Persönlichen und der Wertung des Sozialen bezeichnen möchten, jener Gegensatz, unter dem unsere Gegenwartskultur vor allem leidet. Steht doch anf der einen Seite die Fordernng, daß die Individuen sich vollkommen an das soziale Ganze anschließen, ja, daß sie in diesem Ganzen aufgehen sollen, da sie ja keine Berechtigung und keine Bedeutung haben ohne dieses Ganze, das die Persönlichkeit erzeugt und bestimmt. Liegt doch dieser Forderung die Auffassung zugrunde, daß nur das Soziale Wirklichkeit besitze, daß das Individuum eine Abstraktion sei. Soll doch infolgedessen auch die Geschichte nur als Bewegung der Massen verstanden werden, von der das Leben der großen Menschen nur erhoben und getragen wird. Organ der Masse ist er und nicht mehr.

Und dieser Betonung des Sozialen steht entgegen die Hochhaltung und Wertschätzung des Persönlichen, des Heldenhaften in der Geschichte, jene Úberzeugung, daß der Held für das historische Geschehen so gnt wie alles sei. Er ist der große Erreger und Beweger. Was wäre die plumpe Nasse ohne ihn. Wir müssen an Carlyles Worte denken, die er dem Andenken Mohameds widmet: „,Diese Araber, der Mann Mohamed und jenes eine Jahrhundert, - ist es nicht, als ob ein Funke gefallen wäre, ein Funke auf eine Welt, die schwarzer, wertloser Staub zu sein schien; aber siche, der Staub erweist sich als explosires Pulver, er flammt himmelhoch von Delhi bis Granada. Ich sagte, der große Mann sei immer wie ein Blitz aus dem Himmel, die übrigen Menschen warteten auf ihn wie Feuerung, und dann entflammen sie auch."

Der Gegensatz in der Wertung des Individuellen und Sozialen, auch er wird im Zustand der irdischen Glückseligkeit zu einem Ausgleich gelangt sein.

Dieser Zustand wird ein Zustand höchster Entfaltung und Bewegung sein, weil so viele Reibungsflächen geschwunden sind. Der Kampf, der jetzt in die inneren Zentren getragen ist, lockt Schönes an Schönem und Gutes an Gutem hervor. Solange die Welt besteht, besteht dieser Gegensatz.

Soll das endgültige Ziel der Geschichte erreicht sein, so muß auch diese Bewegung aufhören und verstummen. Wie kann das geschehen? Untersuchen wir die Struktur der Kulturwerte, so bemerken wir, daß sie auf einem Gegen- 
satz beruhen, der einen sehr verschiedenen Charakter trägt. In der Wissenschaft mnd überhaupt in der theoretischen Erkenntmis handelt es sich sicherganz allgemein um den Gegensatz von Form und Inhalt. Die Form ist der Begriff als das Allgemeine, Bestimmte und Geltende, und der Inhalt ist das Unbestimmte und Cnerforschte, das Irrationale. aus dem immer wieder nene Aufgaben der Erkenntnis heranswachsen. Man liebt es, dieses Rätselhafte und Unergrïndliche gleichzusetzen mit Natur als dem Inbegriff aller möglichen Gestalten. Der Begriff soll die unendliche Fülle überwinden. Ist es nicht die Vermunft in der Form des Begriffes, die der bloß simnlichen Natur obzusiegen trachtet? Tnd doch liegt der Schwerpunkt des Streites nicht sowohl in dem Gegensatz ron Ternunft und Natur, die nieht Natur ist, sondern vielmehr in einer verschiedenen Tendenz und Auffassung der Vermunft. Nach der einen Auffassung ist das Irrationale ein Unbegreifliches mol Unïberwindliches. Alle Macht des Begriffes muß an ihm zuschanden werden. Nach der anderen Auffassung vermag der Begriff der Wirklichkeit vollkommen obzusiegen, und es gibt keine ewigen Geheimnisse und Rätsel für den Menschengeist. Hier stehen wir vor dem typischen, dem grundlegenden Gegensatz aller Erkenntnis. Hier handelt es sich um typische Formen der philosophischen Weltanschamung und überhaupt der theoretischen Erkenntnis. Die eine Anschanung ist getragen ron einem schönen Glauben an die Macht der menschlichen Vernunft, die alles durchlenchten und durchdringen kann. Schön und mächtig muß diese Vermunft erscheinen, wenn sie an letzter Stelle immer das Große und Heilige sieht, trostlos und schwäehlich aber, wenn ihr im Innersten der Welt ein kalter Mechanismus, ein sinnloser Wille, eine leere kalte Höhle der Armut und des Sehreckens entgegengrinst. Die andere Anschaung ist getragen von einer hohen Andacht nnd Pietait gegeniiber dem Rätselhaften in der Welt, und sie vermeint, daß der Erkenntnis von Gott Grenzen gesetzt seien, daß er für sie der Dunkle, Rässclhafte mol Verschwiegene bleiben soll. Schön und herrlich ist diese typische Form des Irrationalismus, wenn sie besagen will, daß wir das Letzte nicht schauen können, daß wir warten mïssen, his unsere Augen anfgetan werden. Schwächlich und erbärmlieh ist er jedoeh, wenn er vermeint, daß es iiberhaupt nichts zu schauen gibt, wenn das Wissen in der müden Haltung der Skepsis verharrt.

Rationalismus mol Irrationalismns bedenten eine Form der Erkenntnis und gleichzeitig rine Strellmug zum Erkenntnisproblem. Del Rationalismus vermoint, die Natur mul die Wolt gänzlich in Erkenntnis auflösen zu können. fïr den Irrationalismus ist das Göttliche din Gehemuns. Wiehtig ist für die Historio nicht sowohl das Verhältnis dieser beiden zur Natur, sondern ihr Verbitltuis zareinandrer.

Wir das philosophiseh theoretisehe Laben anf einem Wortgegensatz ruht, der in lom Gegronsatz von Form und huhalt zmm Austruck gelangt und in den

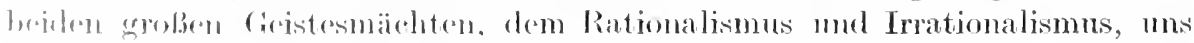

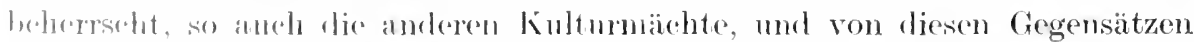

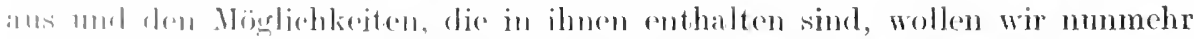

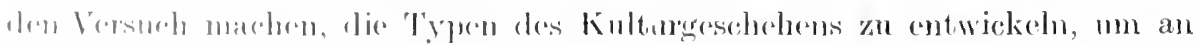

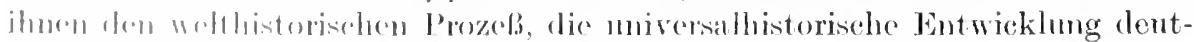
rh zh matelist. 
Die Universalgeschichte hat es mit den logisch unlösbaren Antinomien zwischen den Kulturmächten zu tun. Die Antinomien trägt die Entfaltung des historischen Lebens einer Auflösung entgegen, die gleichbedeutend ist mit dem Ende des Weltgeschehens. Tollendung des Weltgeschehens und Auflösung des Gegensatzes sind synonyme Begriffe. Der Simn der Geschichte ruht somit in der Versöhnung des Gegensatzes, der zwischen den Kulturmächten und in ihnen selber besteht.

\section{Zweites Kapitel. \\ Allgemeine Konstruktion des universalhistorischen Prozesses.}

\section{a) Der Anfang des Menschengeschlechts.}

Der Anfang des Menschengeschlechts ist für die Geschichtsphilosophie ein undurchsichtiges Dämmergran, der Nebel der Vorzeit. Das Vorzeitige ist das Unhistorische, das Bewegungslose, das Unvernünftige. Mit ihm rerbindet sich die Seligkeit des tierischen Daseins, das bloße Gegenwartsleben ohme Vergangenheit und Zukunft. Es ist der Naturzustand des Menschen. ein durch die Bedürfnisse des Augenblicks ausgefülltes Leben, reich vielleicht an Cefahren, reich vielleicht aber auch an primitiver Lust. Der Naturzustand ist das Glück des primitiven Menschen, eine einfache, homogene Lebenswelt. Ein stilles Leben ohne Tat und Ereignis, ohne starke imnere Erschiittcrungen. Ein Leben unter Vorherrschaft der Phantasie oder vielmehr ein Leben, das haltlos hinund herschwankt zwischen dem herben Bewußtsein der Realität und den Ankündigungen und Verheißungen einer imaginären Traumwelt. Ein reiches, volles, ausschweifendes Leben, das noch keine Ordnung und GesetzmäBigkeit kemnt. An diesem Leben hatte der Geist noch keinen Anteil. Er hatte noch nicht an ihm geformt und gebildet, sein Denken und Verstchen noch nicht. in die Natur hineingelegt, um das Schöne, das er geschaffen, aus ihr herauszulesen. Der Mensch ist ja selber nur Natur und steht als Natur in dem natürlichen Zusammenhang der Dinge. Noch remag sich seine Reflexion nicht über sie zu erheben, noch reichen seiner Seele Kräfte zur bildenden Tat nicht aus. Er ist Gegenstand unter Gegenständen, Stein unter Steinen. Noch geht kein Leben von ihm aus in die Dinge, sondern das Leben wohnt in ihm still in sich zurückgezogen. Und sofem der Mensch schauen und sehen kamn, sieht und schant er alles nur mit seinen Augen ohne jede Tradition und Bindung durch das Allgemeine. So ist die Welt für jeden eine andere, sofern sie überhaupt als ein rom Ich Getremntes erschant wird. Jeder glaubt an seine Welt, und abgeschlossen von allem Tun ruht das Ich in der Hülle des Scins.

\section{b) Die Bewegung des rernünftigen Lebens.}

Diese Welt der Natur in ihrem schlichten und einfachen Seinscharakter hat durch die kulturschaffende Venunft etwas unendlich Kompliziertes und Problematisches erhalten. Von dem Beginu ihres rätsellıften Werdens an erfüllt sie mit tausend mannigfaltigen und entgegengesetzten Formen die Welt. 
Es ist aber in ihr ron romherein diese doppelte Tendenz, für sich zu bleiben und sich auszubreiten. Das remünftige Leben geht sowohl auf Abschließung und Absonderung ron der bloßen Natur, anf Isolation und Aufbewahrung der nenen Werke und Leistungen für den engen Kreis ihrer ursprüngliehen Schöpfer. wie es auch andererseits auf Ausbreitung gerichtet ist, bestrebt, den Entbehrenden und Ohmmächtigen mitzuteilen von dem großen Reichtum des Geschaffenen. Mit dem Werden der Vermunft wurde der Mensch zum Schöpfer und zum Leistenden. Die Schöpfung war das Nene, das Unerhörte, das Wunder, welches ihn trennte von der Natur. Frïher von der Natur bestimmt, bestimmte er nummehr die Natur. Und ihren dunklen Rätseln gegenüber vollzog er zuerst die große Tat der Sinngebung, indem er zeigte, was sie bedeutete, und wie sie ward. Er bildete das Kunstwerk, das wohl dem Interesse am Stofflichen entsprang, aber das Stoffliche anch gleichzeitig ïberwand und es in freierschaffener Form von dem natürlichen Zusammenhang der Dinge abhob und absehnitt. Und schließlich stellte die Vermunft Forderungen auf, die der Selbstverständlichkeit der Instinkte mit ihrem primitiven Lmstverlangen sehroff und herb entgegentraten, und das alles in dem Bestreben, eine Ordnung aufzurichten, die der Naturordnung durchaus entgegengesetzt war, nämlich die moralische Ordnung der Dinge, die der frei waltenden Willkür und dem Recht des Stärkeren ein Ende bereitete.

\section{c) Die ILeroen.}

Sofern die Schaffenden den nenen Yermunftgewimn für sich bewahrten, schlossen sie sich zu einer geringen Zahl ron Anserwählten zusammen. Sie hatten ein Recht auf das von ihnen Gefundene und Entdeckte und wollten es für sich bchalten, weil es ihnen zn köstlich und zu gefährlich schien für die anderen. Ziı köstlich, deswegen sollte es ihnen gehören, welche die Kraft besaßen, es immer wieder von neuem zu gestalten und zu erwerben, ihnen, den Helden und Königen der Geschichte. Sie entdeckten in der Vernunft und ihren Gïtem und Geschenken eine Quclle höehster Erregung, alle Möglichkeiten ciner gesteigerten Lebensform. Sie waren bereit, dem Leben der Sinnlichkeit so weit zu entsagen, als es dic Aufrechterhaltung und Erwerbung des Neuen verlangte. Sic waren bereit, Opfer zu bringen. Als Bildende und Gestaltende opfrom sie dem Allgemeinen gar viel von blühender Simnlichkeit. Sie writen auch wohl, dak dieses nene Vermunftleben, das sie zu leben begammen, Gefahnen in sich barg, sofern es den Mensehen aus der alten gewohnten Ordnung herausrils. End wemn anch das nene Erlehnis der Vermunft ihnen so herrlich erschien, daßs ihr Auge nicht aufhören mochte mit Schaucn und ihre Lippen sich immor wieder öfncten zur Lobpreisung der erfahrenen Schönheit, die, durch rigenc Kraft erworben, ihnen zugleich anels wieder als ein Geschenk

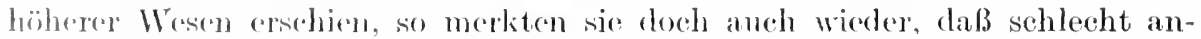

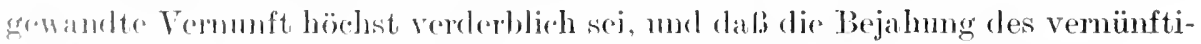

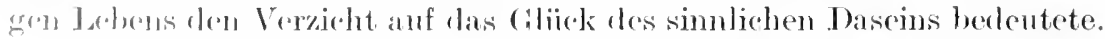

Solange die kultursehaffende Vermunft noeh nicht in Wirksamkeit getreten

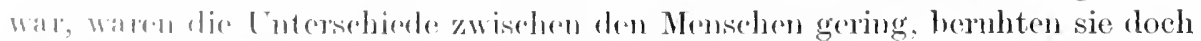
lerlighede anf ldifferenzen rein physischer Kraft. Num aber trat eine Potenz in Tatigkrit, die das psychische Leben in der mamigfaltigsten Weise ge- 
staltete und eine Fülle ron Unterschieden setzte, als Stufen in der Erfüllung des remünftigen Daseins, als Ansätze zur Bilalung eines persönlichen Lebens, als Möglichkeiten und Fähigkeiten zu schöpferiseher Tat. So offenbarte sich gar plötzlich eine ungeheure Kluft ron Mensch zu Mensch. Auf der cincn Seite jene, welche die freie Entfaltung des Vermuftlebens zu den Höhen der Menschheit trieb, und anf der anderen Seite jene, die nieht aus eigener Kraft in das neue Leben eintreten konnten, sondern der L'nterweisung bedurften und ohne diese verurteilt waren, ein bloßes Sinnenleben weiter zu führen. Ton der hohen Warte des Erreichten übersah der junge Kulturmensch des anderen Not. Lnd entscheidend für die Entwicklung der Menschheit mußte es nun sein, wie sich die andern Kulturträger, die von den Menschen als Heroen angestaunt wrulen, zur Frage der Vernunfausbreitung verhielten. Sowohl die ahsolute Konservierung des Vermunftlebens für ihre Entdecker, wie auch seine freie und ungehemmte Ausbreitung war erheblichen Schwierigkeiten unterworfen. Die Aufbewahrung der Kulturgüter für wenige gestattete eine einheitliche (organisation des Vernunftlebens. Auch blieb das Wertvolle so vor Profaniermng geschützt, und, mit dem Schleier des Mysteriums umgeben, konnte es zur Anfrichtung einer Autorität des geistigen Lebens führen. Andererseits blieb das Vernünftige in dieser Isolierung und Hemmung ron vielen Möglichkeiten der Entfaltung abgeschnitten. Es konnte sich in dieser Zurïekhaltung und Abtremmung nicht differenzieren. Die bewahrende und zentrierende Haltung im 'T'un der Heroen mußte das Ganze des Vernunftlebens in relativer Einheit und Gleichartigkeit halten. Auch ließ ein solehes Verhalten eine schroffe, nü̈berwindliche Kluft entstehen zwischen den wissenden Kulturmenschen und der Masse der Kulturlosen, dem Sinnendasein Hingegebenen. Jene äbernahmen den Konflikt von Simnlichkeit und Vermunft, sie nahmen ihn anf sieh und hatten die Kraft, gleichzeitig so tierisch und göttlich zu sein. Den anderen aber trauten sie diese Kraft nicht zu; deswegen ließen sie jene in der Armut des Geistes. Der Gegensatz aber zwischen der kleinen Zahl der KnItivierten und der großen Zahl der Schwachen und Kulturlosen barg in sich die Gefahr, daB das sïBe Geheimnis der offenbarten Ternmft den Menschen wieder verloren gehen konnte mit dem Tode der Schaffenden. Auch blieb die Lage der Lenkenden bedroht, solange sie als die einzig Wissenden der großen Zahl der Lnwissenden gegenüberstanden. Das Vernïnftige in semer Isoliertheit komnte Fureht, aber auch Haß erregen. Das Werthafte war durch die Fülle des Wertlosen mit ständigem Untergang bedroht.

\section{d) Der Typus des Herrschers.}

Der Typus jener Heroen, welche in der Alternative zwisehen Anfbewahrung und Ausbreitung des Vermmftlebens mit voller Entschiodenheit soine Zentralisierung und Isolierung bejahten, erfüllt ron dem Mrunsche, ihm eine einheitliche Organisation zu geben und das Kostbare ron den Schwachen und Elenden zu entfemen, ist der Typus des Herrschers. Sie lebten dem Gedanken. daß die Sinnenlnst, die rein materiellen Frouden und Genüsse für den schwachen und hilflosen Menschen Glücks genug seien, während sie selber das große Opfer der Entsagung und Entbehrung anf sich nahmen, den Gegensatz ancrkannten und so das Ernsthafte und Tragische in das Geschehen trugen. 
Es ist die Idee des Herrschers, diese große Einheit des Vernunftlebens herzustellen und die kalte und stolze Abgesehiedenheit und den Kampf und den Streit auf sich zu nehmen, um ihn für sich zu tragen, um ihn in sich durchzukämpfen und zum Austrag zu bringen. In der Abgeschiedenheit und Einsamkeit ihres stolzen Herrenlebens ist eine große Möglichkeit allgemeinster Stellungnahme zum Leben der Vemunft wirklich geworden Die Natur des Herrschers kann in jedem Vernunftgebiet hervortreten. Es gibt ebensowohl religiöse wie politische Herrschernaturen. Von den großen Griechen gehörten Heraklit und Plato zu ihnen, Perikles und die hohen und stolzen Gestalten der Stoa. Es kann aber in diesem Typus wieder ein Doppeltes unterschieden werden. Wir sahen, daß er im Verhältnis zur Vermunft und den Gütern, die sich mit ihr verbinden, die Absehließung und Aufbewahrung bejaht. Das kann aber einerseits geschehen in dem Wunsche, sie für sich zu haben und sich in sie zu versenken und in ihr zu leben. Andererseits kann sich mit diesem Wunsche auch das Bestreben verbinden, das isolierte Wertvolle, das sein Besitz geworden ist, in praktischer Hinsicht nutzbar zu machen, indem das Vernünftige das immer mächtig ist, zu einer sichtbaren Macht ausgebaut wird und nunmehr als Autorität erscheint. Es gibt Könge im Reiche des Gedankens wie Spinoza und Fichte und Herrscher der Tat und des politischen Lebens wie Napoleon. Gemeinsam aber ist ihnen in besonders hohem Maße das Los der Einsamkeit und Abgeschiedenheit. Sie haben sich von den anderen entfernt und getrennt, wie der Kaiser Tiberio, der auf Capri seine einsamen Marmorpaläste baute, oder wie Karl V., der im Kloster von St. Just Ruhe suchte. Sie könmen nichts Gleichwertiges und Gleichberechtigtes neben sich dulden, das Königliche in ihnen fordert das Alleinsein. Dieses Herrschertum kann Eigentum und Privilegium eines Einzelnen oder einer Klasse oder anch eines ganzen Volkes sein. Wenn die Idee der Auswahl und des Aufbewahrens sich mit dem politischen und sozialen Leben eines ganzen Volkes verbindet, so entspringt die Idee des auserwäh Iten Volkes, die als die erste große bewußte Form des nationalen Daseins anzusehen ist, und die im Charakter des griechischen Volkes ebenso deutlich hervortritt wie in der Idee des Hellenentums. Das Vermunftleben, sofern es auf Einheit, Isolation und Abgesehiedenheit gerichtet ist, führt zur Konstituicrung und Bildung von Zeitaltern, die wir als synthetische bezeichnen kömnen. Das Vermunftleben ist streng organisiert und zu einer einheitlichen Wertauffassung verbunden. Schon das Grieehentum hat trotz aller partikularen fegensätze cin solches gemeinsames, eng ungrenztes und geschlossenes Wertleben offenbart, wie eine Analyse des hellenischen KulturbewuBtseins deutlich prachen kam; aber erst im Mittelalter können wir die Vollendung des großen synthetisehen Gedankens erblieken.

\section{a) Die Symbole des Endes.}

Erinnem wir uns nummehr an das Prinzip der Geschichtsphïosophie als Aro Endzwed des historischen Geschehens, von dem aus wir die großen Anfaugscerscheiumgen des Kulturlobens zu verstehen suchten, so fanden wir, dal.s der Simn des historisehen Geschehens darin erbliekt werden mußte, daß dic Wertfeinfliclukeit, die sowohl zwisehen den einzolnen Kulturwerten 
besteht, als auch jeder Kulturwert selber auf einer Antinomie beruht, durch die historische Bewegung getilgt und ausgelöseht wird. Suchen wir nun die synthetische Tendenz der großen Herrschernaturen, jener auserwählten Völker, die ron demselben Gedanken erfüllt sind, und der Zeitalter, die ihre Physignomie tragen, zu verstehen, so erscheinen sie uns als die großen Symbole jener Einheit, die einst werden soll. Sie sind die sichtbaren Zeichen des Endes und tragen in sich das große Gefühl der Zukunft. Sehen wir aber genauer zu, so ist jene Einheit, die sie verkïnden und in Leben und Tun zum Ausdruck bringen, noch nicht jene Einheit, welche die Wortfeindliehkeit überwinden soll, ja sie hemmt sogar die Erreichung des notwendigen Zieles. Die ,Herrscher" halten die Gegensätze zurïck und lassen sie nicht dentlich hervortreten. Sie bleiben in der Knospe rerschlossen. Es liommt zu lieinem Austrag und keiner Erfüllung. Sie dulden nicht die Tremung der Wrertgebiete und halten damit auch die Entfaltung der einzelnen Vermunftformen zurïck. Die von ihnen hergestellte Einheit ist eine trügerische, unter der verborgene Gegensätze lauem. Sie erreichen die Einheit, indem sie nur ein Minimum des Wertlebens verlangen. Wohl gewinnt in ihnen das Vernünftige hohe und höchste Gestalt. Sie sind ja die großen Wissenden, die das Drohenrle und Gefährliche der Vermunft und des vernünftigen Lebens anf sich genommen haben, und die der Menschheit das große Leid des Zweifels und der Verzweiflung ersparen möchten, wie Dostojewskis Groß-Inquisitor Kardinal. Der Rationalismus der Aufklärung hat diese großen synthetischen Naturen, diese priesterlichen und königlichen Herrscher, die von einem hohen Stolz umkleidet sind, in ihrem leidenschaftlichen Hasse wohl als Betrüger und Verräter hingestellt. da sie der Masse das nicht gaben, was sie von ihnen verlangte, und sie, wie behauptet nurde, über die Wahrheit täusehten, demjenigen eine Anerkennung zollend, was sie im Grunde ihres Herzens verachteten. Es hat gewiß wahre und falsche Herrscher gegeben. Die Aufklärung hat mit den falsehen die walnen verkannt, weil ihr der Sim dieses Typus notwendig verhüllt bleiben muBte. Die Herrseher bewahrten die Kulturschöpfung, weil sie ihnen zu kostbar erschien für die Verständnislosen, sie verhüllten sie, weil ihrem Glanz Gefahr drohte. Sie hatten Mitleid mit den Erbärmbiehen und ließen ihnen das Giliek der Tiere. Sie trugen das, was jene niemals zu tragen rermoehten.

\section{f) Der Typus des Propheten.}

Dem Typus der Herrscher steht gegenüber der 'I'ypus der Propheten. Wenn jene die Schönheit des vernünftigen Lebens für sich bewahren und sie und sich abheben und abtremen ron dem gemeinen Haufen, sind diese ihre Verbreiter und Ausbreiter. Das Kostbare, was ihnen zuteil geworden ist. ron dem sie ein Wissen haben, wollen sie mit den anderen teilen. Sie sehen jene in ihrer Unvernünftigkeit und Erbärmlichkeit und werden ron tiefen Mitleid ergriffen über die Trostlosigkeit und Enge ihres Daseins. Denn ihre Liebe und ihr Mitleid ist größer als ihr Stolz. Sie wollen und müssen sich offenbaren, und sie können sich auch offenbaren, demn sie sind die Herren der Weltgesehiehte. Sie achten das Geschaffene und Geschante nicht so hoch, daß sie nicht bereit wären, es fortzugeben und zu versehenken. Sie sind die großen Gebenden und 
Schenkenden, aber gleichzeitig auch diejenigen, die viel verlangen und fordern. Denn sie dulden nicht das Glück der Tiere. Das Glïck der Tiere ist für sie nicht ein einfach Wertloses, rom Wert noch nicht Erfülltes, sondern ein ewiger Vorwurf, ein Kerker der Seele, die ganze Unseligkeit des Sinnendaseins, die nach Erlösung rerlangt, das stumme Senfzen der Kreatur nach Befreiung. Und so geben sie das Große und Schöne preis, bringen es bereitwillig zum Opfer, setzen sich ans mit liebender Tat den Gefahren des Verkanntseins. Denn wenn sie von jenem Schönen sprechen, das sie bewegt, so laufen sie ja Gefahr, verhöhnt und rerspottet zu werden. Sie schonen weder sich noch die anderen, noch anch selbst das Göttliche, das ihnen zuteil wurde. Sie entbehren die Einsamkeit und wandern in der Menge. Sie schonen die Ärmlichen nicht, sie stören ihr primitives Crlïck und regen ihre Seele anf. Sie sind bereit, sich selbst zu opfern und zum Märtyrer ihrer Lehre zu werden. Sie hejahen den Untergang und die Katastrophe. Sie sind bereit, anch das Heilige möglicher Profanierung preiszugeben, damit es in jenen armen dunklen Seelen ein leises Licht und eine leise Brwegung entzïnde.

Die Propheten sind die Verschwender der Vermunft. Sie wollen, daß das Gute allen zuteil werde. Sie bejahen die absolute Mannigfaltigkeit der Vemunftgestaltung und sind rielfach der irdischen Ordnung gram. Thre große Liebe zur Vernunft geht so weit, daß sie zu Verächtern des Leibes und der Sinnlichkeit werden können. Sie wollen nicht die Anerkennung und Verehrung der Ditmensehen, sondem vielmehr ihre Liebe. Sie wollen nicht herrsehen, sondern dienen. Sie wollen nicht Sklaren, sondern Jünger. Es ist dentlich, daß die Idee der Entwicklnng und anch des Fortschritts von ihnen repräsentiert wird, während dic Herrscher mehr das Prinzip der Ordnung betonen. Gehen sie doch anf Termehrung der Kultur ans. Differenzicren sie doch die schwere und homogene Masse der Vermunfttradition.

\section{g) Formen dieser Typen.}

Der Typus des Propheten kann anf jedem Wertgebiet erscheinen. Es gibt prophotische Philosophen, prophetische Priester und prophetische Könige. Empedokles mol Sokrates waren Propheten, ebensogut wie Mohamed. Wio Gregor VTI. ein Herrseher-Papst war, so Joseph II. ein Propheten-König. Großs ist die Kahl der Dichter, die zu ihnen gehört. End zahlreiche Männer der Wissensehaft mol Aposted der Sittlichkeit stehen in ihrem Dienst. Es lassen sich aber in der Reihe der Propheten ämlich wio in der Reihe der Herrseher zwoi verschiedene Klassen unterscheiden. Das Herschertum kamn einen, wir können fast sagen ïberictisehen Charakter annchmen, wenn die Idee einer rohabenen Einsamkeit und Abgesehiedenheit im Besitz des Wertrollen bejaht wirl. I)as ist die grolbe Solbstbejahnug und Selbsthehauptung in der Vernunft,

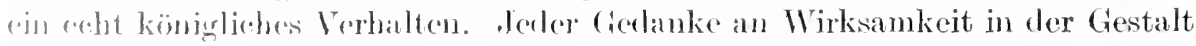

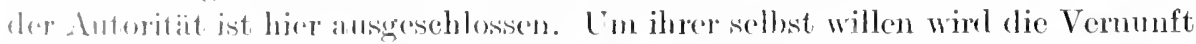
bewahrt. Iniesem Typus in der Reihe der Iferseher entspricht die Gestalt

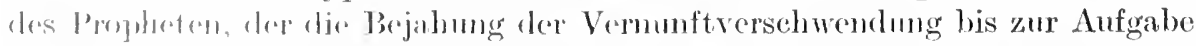

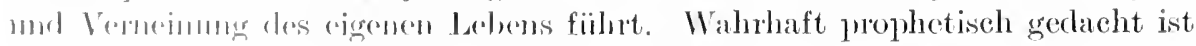

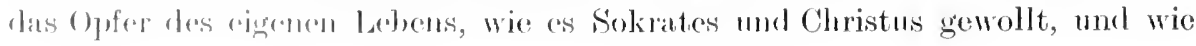


es anch meter den Geringeren ein Giordano Bruno gebracht. Er verschwendet die Vermunft mm der Vernunft willen mol stellt sie nicht in den Dienst irgend einer irdisch-sozialen Ordnung. Der andere Typus des Propheten entspricht jener Form des Herrschertums, die wohl das Prinzip der Isolation und Abgeschlossenheit auf das strengste aufrecht erhält, aber auch ans clem Vernunftleben etwas macht, sofern es diese mit Symbolen umhüllt, die dem sinnlichen Menschen verständlich sind und seine Reinheit in simlich-irdische Institutionen eingehen läßt, die damn als autoritative Verordnungen und Einrichtungen dem Herdenmenschen gegenüberstehen. Diesem Typus des Herrschors entspricht jener Typus der Propheten, denen die Vermmnt als das grobe Heilmittrol erscheint, welches den Körper der Menschheit ron allen Gebrcehen mol Krankheiten genesen läßt, und die sein dnnkles und unverstandenes schicksal erlenchtet. Jene Aufklärer im guten Sime des Wortes, die eine helle Vernunftcinsicht zur Beherrscherin des Daseins erheben möchten, ron der ein ruhiges Licht ausgeht, in dem alles sich versteht und erkennt. Sie wollen nicht eino bestimmte und geschützte, sondern eine frei ausstrahlende Termmftmacht, die bis zum Schmutz der Gasse und zur Trivialität des Alltags reichen soll. Es soll nichts Kaltes, Fremdes und Liebloses zurückbleiben.

\section{h) Analytische und synthetische Zeitalter.}

Wie es nun Zeitalter, Epochen und Perioden gibt, in denen das Herrschertum und die Idee der Termunftbehütung dominiert, Zeiten, dic dureh die Betonung der Einheit und Ordnumg besonders charakterisiert sind, wie das Mittelalter, und die wir als synthetische bezeichnet haben, so gibt es nun auch analytische, in denen das Prophetentum dominiert, wie im alexandrinischen Zeitalter,und im Zeitalter der Aufklärung. Diese Zeitalter, welche die Vernunftrermehrung und -ausbreitung bejahen, sind an dem Primzip der Entwicklung und des Fortschritts orientiert. Doeh müssen wir gleich hier erwähnen, daß die idealtypischen Begriffe synthetisches und analytisches Zeitalter viel zu allgemein sind, als das von ihnen aus anch nur amähernd der Typus einer bestimmten Epoche der Mensehheitsgeschichte charakterisiert wäre. L'm die Wirklichkeit einer historischen Epoche zu verstchen, bedarf es weit eingehenclerer Spezialisierungen. Wohl aber ist in diesen Begriffen das allgemeine Schema für die Bestimmung eines Kulturabschnittes gegeben. Es gibt keine ahsolut synthetischen und analytischen Zeitalter, und doch ist nur von diesen Beyriffen ans der Sinn einer Zeit zu verstehen. Wir mïssen hei dieser Gelecrenheit anf die absolute ÄuBerlichkeit hinweisen, die in den historischen Lnturscheilungen von Altertum, Nittelalter und Neuzeit liegt. Dal3 diese Cnterseheidnngen in ihrer Absolutheit für die Entwicklnng der westeuropäischen Kultur bestimmt sind und diese zum Typus der Menschheitsgeschichte gemacht wird, soll noch nicht einmal als Argument geltend gemacht werelen, weil ohne Zweifel in ihr das größte und wertvollste historische Geschehen flutet. Aber wie dïrftig und wie wenig bezeichnend sind diese Namen: Altertum, Mittelalter und Neuzeit. Alt und neu und das, was in der Mitte liegt. als ob nicht das Alte anch eimmal neu gewesen wäre und das Nene vor dem Geschick des Alterns bewahrt werden könnte. Wir können ms einen Typus des mittclalterlichen Menschen denken, 
weil dieses Zeitalter begrenzt ist, aber die alte und neue Zeit, die ohne denkbaren Abschluß die Jahrtausende umfassen, wie kömmen sie uns die Möglichkeit geben, einen gleichwertigen Typus zu bilden, es sei denn, daß man unter dem alten Mensehen den Hellenen im Zeitalter des Perikles, und unter dem neuen Menschen den Sohn des 20. Jahrhunderts versteht. Natürlich soll deswegen nicht geleugnet werden, daß Geschehnisse, wie der Untergang des römischen Reiches und die Vorherrschaft der germanisehen Völker ebenso wie Renaissance und Reformation von höchster Bedentung für die Entwicklung des Menschengeschlechtes gewesen sind.

\section{i) Bedeutung der Typen für den Sinn des Geschehens.}

Wenn wir nummehr den Begriff des analytischen Zeitalters und die Idee des Propheten an unserem geschichtsphilosophischen Begriff des Endzwecks messen, nach dem die Wertfeindlichkeit überwunden werden soll, so ist seine Bewegung darauf gerichtet, die Wertunterschiede hervortreten zu lassen und jene starre Einheit zu brechen, in der das Wertleben der Vernunft ursprünglich ruht. Der Prophet verneint, daß der Vernunftentfaltung irgend eine Grenze gesetzt werde, er bejaht die Entwicklung unbedingt und ist der Mannigfaltigkeit und Fülle so sehr hingegeben, daß er die Einheit gar häufig aus den Augen verliert. Er ist es, der die Weltgeschichte dem Ende zutreibt, sofern die schnelle Entfaltung der Kultur gleichbedeutend ist mit der Beschleunigung ihres Unterganges.

Denken wir die synthetische Bewegung als die einzig vorhandene und alles Weltleben durch die Herrscher bestimmt, so wïrde das Geschehen in einer starren Ordnung der Dinge ankern. Würde dagegen das analytische Prinzip das cinzig wirksame sein, so wïrde die Entwickhng im rasenden Tempo sich vollziehen und die Stabilität und Ordnung der mensehlichen Gesellschaft berlroht sein. In allen mensehtichen Dingen und zu allen mensehlichen Zeiten lebt diese Doppelbewegung der Vermunft, und die Ganzheit des sozialen Lcbens erhält durch sie ihr eigentümliches Gepräge.

\section{k) Vernunft und Natur.}

Denken wir, bevor wir uns die große Kulturbewegung des Menschengeschlechtes doutlich maehen, noch eimmal an den Gegensatz ron Vernunft und Natur, so lïßt ihr gegenseitiges Verhältnis folgende Alternativen zu: Entwerkr sie stchen beziehungslos neben einander, odersie treten in eine notwendige Beziehmig. Bleiben sie beziehungslos, so ist das Simuliche nur das zufällige und gleichgültige Material, der bedeutungslose Schauplatz, wo sich das Große abspiclt. Das Vernünftige wird dureh das Simnliche nicht versehlechtert und das Simnliche durch das Vernünftige nicht verbessert. Setzen wir aber eine lingiclung zwischen beirlen, so kann ihr Verhältmis friedlieh oder feindlich sein. Ist dis VirhäItnis friedlich, so entschließt sich die Vermunft, die Simnlichkeit rïrklal1hs zu hojahen mud anzuerkennen. J)ic Vermunft sieht ein, daß das Simmonleben anch ihr höheres Dascin trïgt. Sio erkemt im Simnlichen der Natur, in den mughrochenen und starken Leidensehaften die dunkle Geburtsstäte fïr das S'chomes und Anserwählte. Die Vermunft läßt die Simnliehkeit, 
wie sie ist, und liebt sie wohl gar als den freundliehen, glïekspendenden Cienossen, mit dessen Schwäche man Nachsicht haben sollte. Oder aber die Vernunft ist der Sinnliehkeit Feind, so kamn das eine doppelte Bedeutung haben. Der Gegensatz und die Feindseligkeit kann nur an dem jetzigen Zustand der Sinnlichkeit liegen. Die Simnliehkeit wird in ihren Gegenwartsdasein nicht bejaht, aber es besteht die Hoffnung und Erwartung, daß die Simnliehkeit ihren Charakter verändert und sich bessert. Es besteht die Hoffnung, da B sie gereinigt wird ron ihrem Mangel, daß das Sinnendasein verklärt und geläntert wird. Anders, wenn das Sinnliehe ron der Vernunft als das absolute Hemmnis. ihres Seins, als das Böse und Wertfeindliehe erkannt wird. In diesem Falle verneint die Vernunft die Simnliehkeit absolut und sueht sie vollkommen auszutilgen und zu remiehten. In diesen Werthaltungen gegenüber der Natur haben wir Grundverfassungen des Kulturtypus zu erblieken.

\section{1) Die urspriingliche Einheit der Wertgegensätze.}

Da unsere universalhistorisehe Betrachtung sieh auf die Mittelmeerkultur und ihre Entwicklung besehränken soll, die einzige, die uns bis zu dem Grade vertraut ist, daß wir imstande sind, ihrem Sinngefüge im einzelnen nachzugehen. so erledigt sich die Frage, in welcher Reihenfolge die Kulturmäehte in Erscheinung getreten sind. Dem so viel ist augenseheinlieh, daß eine geringe Differenzierung des Vernmftlebens sehon ror dem Eintreten des Hellenentums in die Gesehichte sieh vollzogen hatte. Wir können über den Gang dieser Differenzierung nur Vermutungen haben. Möglieh, daß, wie Sehiller gemeint hat. die selbständige Entfaltung des moralisehen Bewnßtseins die Entfaltnng cles ästhetisehen Lebens voraussetzt. Aber es fragt sich immer, welches Maß ron Vollendung und Selbständigkeit wir annehmen, um das Dasein eines besonderen Kulturwertes zu behaupten. Lebt etwa die Wissenschaft mit dem ersten selbständigen Erkenntnisurteil oder erst dann, wenn sie Methode und Theorie gefunden? Lebt die Kunst mit der Sehönheit der ersten Intuition, dem ersten zarten Verstehen beglïckender Formgebilde, oder muß das große Kunstwerk rollendet sein, um die Wirkliehkeit des Sehönen zu dokumentieren? Nur soviel ist gewiß, daß das Vermunfteben ursprünglieh als Einheit gegeben war, und daß die Herrseher diesen Sehatz behüteten. Úberall bemerken wir noeh die Spuren dieser ursprünglichen engen Verbindung, da alles Tun und Werten der Mensehen von einem Einheitsgrundgefühl getragen war, da der Mangel an Reflexion die großen Vemunftantinomien noeh nieht als solehe erkennen ließ, da alles sich so eng zusammenfand, daß Konflikte und Gegensätze ausgesehlossen schienen und die stille Substanz des geistigen Lebens noeh ror großen Erschüttungen bewahrt wurde oder einige wenige diese Konflikte auf sich nahmen. Das war die vorphilosophisehe Zeit, da die Propheten hinter den Herrschern noch ganz zurüektraten, wenn sie aueh damals schon ihre Forderungen geltend machten und heimlich an der Arbeit waren.

Diese ursprüngliche Einheit der Wertgegensätze ist in der Mythologie gegeben. Daß im Mythos tatsächlieh eine ursprüngliche Einheit rorliegt, erhellt schon daraus, daß er eine Interpretation von sämtliehen Wertgesichtspunkten aus gestattet. Daß religiöse und ethisehe Momente im Mrthos vorliegen, ist 
ja immer gesehen und nie bezweifelt worden. Daneben ist er als rein theoretischer Tersuch der Welterklärung von $\mathrm{Hume}$ und Comte aufgefaßt, und Schelling hat in dem Mythos den wahren Stoff aller Kunst gesehen. Hier im Mythos haben wir in der Tat noch die ungeteilte Vernunft. An dieser bunten Gestaltenwelt hatten alle Kräfte des Geistes gemeinsam Anteil. Die Welt der Mythologie war eine Welt der Vorstellungen und entbehrte vollkommen der Klarheit und Bestimmtheit des Begriffes. Dieser Mangel an Bestimmtheit kommt sehon darin zum Ausdruck, daß die mythologischen Vorstellungen einem ständigen Wandel unterliegen. Die freischaffende Phantasie hat das Recht, an ihnen weiter zu bilden. Nieht nach bestimmten Regeln erfolgt diese Umbildung, nicht nach festen Zielsetzungen der theoretischen Erkemntnis, sondern um Aufschluß über einen. Gegenstand des Wissens zu geben, ist die schauencle, gestaltenbildende Phantasie auf das emsigste an der Arbeit. Sie arbeitet aber auch weiter an diesem ungeheuren Komplex von mythologischen Vorstellungen, lediglich $1 \mathrm{~m}$ ihrer Freude an künstlerischer Gestaltung willen. Die mythische Gestalt soll ein Wirkliches ausdrücken und ist gleichzeitig ein Produkt des asthetischen Bewußtseins. Ferner sind aber diese Gestalten des Mythos anch gleichzeitig Gegenstände der religiösen Verehrung, es sind Götter, angefleht in Kultus und gefeiert durch Opfergaben. In ihrem Verhalten untereinander und zu den Mensehen drückt sich damn aueh weiter ein moralischer Sinn aus. Zeus ist der gereehte Vater der Götter und Mensehen, und Forderungen werden erhoben, die der gute und fromme Mensch erfüllen soll.

Wenn wir nun an jene Wertfeindlichkeit denken, deren Überwindung das historische Geschehen vollzichen soll, so ist es deutlich, daß die Wertgegensätzlichkeit zwisehen den verschiedenen Gebieten der Kultur in der Form des Mythos noch verhüllt und verschleiert ist, während der in jeder Wertsphäre angelegte Dualismus schon hervortritt, denn sonst kömnte man iiberhaupt von kxinem Wertleben spreehen, nicht einmal von einem heteronomen. W'ir müssen also im Mythos den religiösen, theoretischen, ethisehen und ästhetisehen Gegensatz anfweisen kömnen, die das religiöse, theoretisehe, isthetische und ethische BewuBtsein kontituieren. Un sie in ihrer Ursprïnglichkeit zu finden, wenden wir uns der Welt des Diehters Homer zu. Dieser Ansgangspunkt unserer Kon rtuktion bedarf noch einer näheren Rechtfertigung.

\section{iiI) Der hellenische Mythos.}

Wir gehen von dem hellenischen Mythos aus, weil wir msere geschichtsphilosophische Konstruktion auf die Kultur des Mittelmeeres beschränken wollen. Wir haben ein gewisses Recht, uns anf diese Kultur zu besehränken, rincescits weil sich in ihr dic höchste Bewegung des historisehen Denkens entfallot lat, und daun anch, weil uns dieser Kultur gegenüber, aus der unscre "vigene. Kultur horvorging. die höchste. Verstehensmöglichlseit beschieden ist. Hir whihlon den Mythos Hor Hellenen, weil or am Anfang der ganzen west-

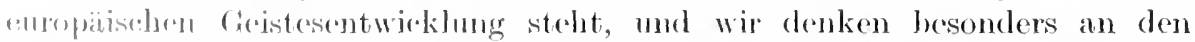
Mylhos Homers, weil dio zorstreuten Gestalten des mythenbildenden Bewnbtscins dureh die Kraft des ästhetisehen Bownbtseins in den groben Ge-

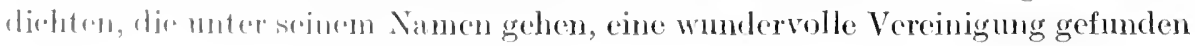


haben. Sollte es nie einen Homer gegeben haben. so ist der Mythos der Ilias und Odyssee für uns um so wichtiger. Wir hätten dann die Gewißheit, daß die Götterwelt des Ho mer nicht so sehr die künst lerische Schöpfung eines einzelnen, die Leistung des ästhetischen Genies wäre, sondern daß die verschiedenen Dichter der verschiedenen Gesänge an einen Stoff gebunden waren, der schon durch das Volksbewntsein der Hellenen gebildet und organisiert war. Die Götterwelt Homers lag dann schon als mehr oder weniger gegebenes Produkt des mythenbildenden Bewußtseins in einheitlicher Gostaltung ror. und diese schon vollzogene Gestaltung ist dam ron den Dichtem der homerischen Epen im hohen Maße respektiert worden. Hat es keinen Homer gegeben. sondern sind die Epen, die unter seinem Namen gehen, das Werk einer größeren Zahl von Volksdichtern, so muß die ästhetische Leistung als geringer. um so höher aber die Leistung des mythisehen Bewßtseins eingeschätzt werden, die der ästhetischen vorherging.

\section{n) Theoretischer Gehalt.}

Im theoretischen Sinne erscheint die Götterwelt Homers als eine Wirklichkeit, die das theoretische Bewußtsein geformt hat, und ruht auf dem Cregensatz ron Form und Inhalt. Dasjenige aber, was die gegebene Wirklichkeit formt, sind nicht Begriffe, sondern bildliche Vorstellungen. Als Crsache etwa einer Krankheitserscheinung, z. B. der furchtbaren Pest, die das Griechenheer befällt, wird Apollo, als Crsache des trojanischen Krieges die Göttin Eris gesetzt. Dort also, wo die moderne naturwissenschaftliche Erklärung ron einem umpersönlichen Gesetz sprechen wïrde, steht die Gestalt des Gottes oder der Göttin, die als Ursache gilt. und zwar als eine Crsache, die ein hohes MaB ron Selbständigkeit besitzt, sofern es in ihr Belieben gestellt wird, zu wirken oder nicht zu wirken. Die göttliche Gestalt ist Trsache theoret ischer Erklärung, aber sie bedentet noch etwas darüber hinaus. Trotz aller Wilkïr hat sie nicht die Macht des Gesetzes, weil sie an höhere Instanzen ganz anderer Art gebunden ist. Die eine dieser Instanzen ist der Herrscherwile des Zeus. der eine mora lische Ordnung zum Ausdruck bringt, die sich über die Gewalt und Willkïr der einzelnen Götter erhebt. Durch den Willen des Zeus ist die Willkür der Göttorwelt beschränkt und zur Einheit geführt. Dieser Wille selber aber ist wieder gebunden an ein Etwas, das Schicksal, die minu, gegen welche anch der Wille des Zeus nichts auszurichten rermag. Anf Grund des Schicksals ist etwa der Stadt Troja der Untergang beschieden. Zeus kann diesen L'ntergang nicht verhindern, aber er hat dem Schicksal gegenïber eine modifiziercndo Gewalt; er kamn etwa den Untergang verzögem oder der Untergang des dem Tode geweihten Volkes mehr oder weniger ruhmroll gestalten. Er ist derjenige, der das Schicksal weiß und auf Grund dieser Schicksalsstimme die Götterwelt leitet. Er ist sich der t'berlegenheit dieses Schicksals bewnt und weiß. daß aneh seiner Herrschaft dereinst der Untergang beschieden ist. Der Sehicksalsgedanke erscheint als die dunkle Notwendigkeit, die das All bestimmt. So hell und glänzend die Vorstellungsbilder sind, welche das theoretische Bewußtsein der Griechen in den Göttergestalten geschaffen, so mbekannt und rätselhaft verbleibt jenes dunkle Schicksal, dem alles sich bengen muB. Unbekannt, hart 
und schonungslos erscheint die $\mu o i f o$, es liegt in ihr kein Prinzip der Voraussicht für menschliche Erkenntnis wie in dem Begriff des Naturgesetzes. Die Menschen kemmen das Sehicksal nicht. Zeus weiß von ihm, kann aber seinen Gang nicht aufhalten und rerhindern. So ist der schicksalswissende Zeus sehr weit entfernt von der christlichen Idee der göttlichen Vorsehung. Denn die Vorsehung liegt in Gottes Hand, die Gottheit Zeus aber steht in des Schicksals Hand.

Die griechische Idee des Schicksals muß wohl in erster Linie als Leistung des theoretisehen Denkens betrachtet werden. Es liegt in ihr ein Hinweis anf die Naturgesetzmäßigkeit der Welt, sie vertritt die Notwendigkeit des Miissens. Die moralische Ordnung, wie sie in Zeus sich offenbart, wird der Idee der NaturgesetzmäBigkeit untergeordnet, die selber jenseits von Gut und Böse steht und ohne Recht und Billigkeit mit eiserner Konsequenz verfährt. Demnach ist die Idee des Schicksals nicht einfach als Vorläufer des modernen Naturgesetzes aufzufassen. Das moderne Naturgesetz ist der Triumph des Rationalismus und zeigt den hellen Punkt der Gewißheit, von dem aus das Naturgeschehen begreiflich ist. Dagegen ist das Schicksal der Inbegriff des Rätselhaften und Geheimnisvollen, der dort in Aktion tritt, wo die Erklärung dureh göttliche Wesen versagt, wo dann immer mit stummer Bewegıng auf ein Übergöttliches hingewiesen wird. Sofern damn auch der Gedanke des Tragischen sich mit ihm vorbindet, eine Vorstellung, die dem modernen Begriff des Naturgesetzes so fermliegt, hat auch das ästhetische Bewußtsein seinen Anteil an der Bildıng rles höchsten Prinzips. Auf jeden Fall aber erscheinen die Götter, soweit es sich bei ihnen um Erklärungsgrïnde des Naturgeschehens handelt, als Formgebungen des theoretischen Bewußtseins, während das Sehicksal den irrationalen Grund des Wirklichen zum Ausdruek bringt.

\section{o) ̈̈sthetischer Gehalt.}

Wie hoch der ästhetische Wert der homerisehen Götterwelt ist, darauf brauchen wir kaum im einzelnen einzugehen. Das geht ja schon daraus hervor, daß die Göttergestalten Vorbilder und Ideale geworden sind für die große Entwicklung der bildenden Kunst in Griechenland. Die griechischen Göttergestalten sind als Ideale der Kumst Typen des Vollendeten in mannigfaltiger Weise. So ist etwa Apollo typisch für die schlanke hohe Jünglingssehönheit. Seine (iestalt und scin Antlitz ist licht und hell, demn er ist der weissagende und liehts]ruclende Gott, kräftig, sofern er ja im Bogen das Geschoß des Todes führt, withrend die sehlanken schmalen Hände verraten, daß er des Saitenspieles kurdig ist. Der Typus des Hermes ist der Gestalt des A pollo entgegengesetzt. Anch rliese Gestalt eines jugendlichen Mannes ist in ihrer Art vollendet sehön. 1) Je Brust ist breiter, die Gliedcr sind kräftiger gebildet, doch nicht ins Úberkriftigr herein, wo angespannte Schnen und hoeh hervortretende Muskelteile lin schwere mol crmsthafte Arbeit des Kampfes verraten, wie in der Gestalt dr:s][crkules. J or mäunliche Gott darf in scincr Erscheinung nichts verkünden, was an die quälonde Arbeit der mühebeladenen Sterbliehen erinnert. Alles

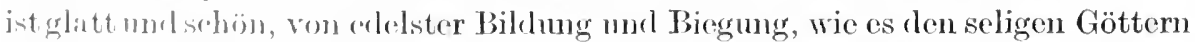
zicint. In rliesen Götergestalten sind Idcaltypen herausgebildet, an denen 
die große Entwicklung der griechischen skulptur festgehalten hat. Sie rerlangten nach der Darstellung des in seiner Art einzig Schöncn. Hochgewachsene lichte Jünglinge mit schmaler Stim und stolzem, gebietendem Auge kennt die Wirklichkeit gar viele. Das Eigentümliche und Herrliche dieses Jünglingstypus aber ist herausgebildet in der Gestalt des Apollo. Und es gibt viele Jünglinge, die kundig sind des eiligen, dahinfliegenden Laufes, deren starke und breitgebildete, schöngewölbte Brust sie zu weiter Fahrt und Wanderung befähigt, und deren sinnendes Auge träumcrisch die Tiefe sucht. Der schönste unter ihnen aber ist gewiß der schnelle Bote des Zeus, der sanfte Führer der Toten in das Reich des Unbekannten: der jugendliche Gott Hermes.

Die Aufgabe, die der griechischen Kunst im Verhältnis zur homerischen Götterwelt erwuchs, war vor allem diese, eine besondere Körperlichkeit zu wählen, die geeignet war, in ihrer ganzen Erscheinung die Irlee des bestimmten Gottes zum Ausdruck zu bringen. Die Kunst geht von der Beobachtung aus. daB die Natur gar oft ihren Zweck verfehlt, daB sie etwa einen hohen, schlanken Oberkörper mit breiten Hüften und plumpen Beinen rerbindet. Die griechische Kunst mußte darauf verfallen, diese Verirrungen der Natur zu korrigieren; der Typus veridealisierte dic Natur, indem er ihr einen Sinn und Zweck unterschob, diesen Zweck zu Ende dachte und die Erfüllung des Sinnes in Marmor und Bronze festhielt. Dic Idee der homerischen Götterwelt führte auch weiter dahin, nach den verschiedenen Charakteren, Abstufungen und Möglichkeiten der Schönheitsgestaltung zu forschen, wie sie durch rerschiedenes Alter und verschiedenes Geschlecht gegeben war. Es gibt nicht nur eine Schönheit des Mamnes und des Weibes. sondern auch eine Schönheit des Knaben, des Jünglings und der Jungfrau. Es gibt nicht nur eine Schönheit des Jünglings, sondern auch eine solche des hohen, schlanken und des mehr kräftigen, untersetzten und innerhalb dieser wieder verschiedenartige Modifikationen. Die Götterwelt Homers ist eine Welt rollendeter und gesteigerter Gestalten, welche die Mängel und Bedürftigkeiten abgestreift haben, die durch Altersgrade und durch den Geschlechtscharakter bedingt sind, die also das betreffende Alter und Geschlecht veridealisieren. So ist den Körpern von 12- oder 13 jährigen Knaben rielfach eine gewisse Herbheit und Eckigkeit eigen. Diese wird zur schönsten Rundung und Flïssigkeit abgetönt in der Gestalt des jungen Apollo.

Die homerische Götterwelt ist ja selber schon eine aus dem mythischen Stoffe gestaltete und poetische Welt; aber wir wissen nicht genan, wie groß der Anteil des ästhetischen Bewußtseins an der Bildung dieser Mythen gewesen ist. Vielleicht lagen diese mythischen Gestalten und die Bezichungen, die zwischen ihnen bestehen, schon fertig vor als das Produkt eines Bewußtseins, das in ungeteilter Geistigkeit schaffte, das noch nicht ästhetisch oder theoretisch eingestellt war. Vielleicht müssen diese Göttermythen aneh im eminenten Sinne als Produkt der Gemeinschaft angesehen werden, so da B sie schon dadurch des auszeichnenden ästhetischen Charakters entbehren. Cnbedingt aber lag in ihnen eine starke Anweisung anf das ästhetische Bewnßsein, denn sie sollten in ihrer ungetrübten Seligkeit und Ruhe auch das ästhetisch Vollendete bedeuten. 
Alles kïnstlerische Leben ruht auf dem Gegensatz und dem Verhältnis zwischen der Gestalt und der zeugenden Kraft der Liebe, die entweder auf die Erhöhung der Gestaltung oder anf ihren Untergang gerichtet ist. Die Götterwelt des Homer trägt dieses Prinzip der Gestalt in höchster Vollendung zux Schau. Während die Götter und Naturkräfte in der Vorstellung der Orientalen zu Fabelwesen anwachsen, die ïber alle mensehliche Bildung hinausgehen, sind die Götter für die Hellenen Menschen in gesteigerter Gestalt. Diese Art der Torstellung machte sie so dankbar und darstellbar für die Kunst, die dem ungegliederten Chaos und Vorstellungen des Abnormen, Fratzenhaften und Unmenschlichen gegenüber notwendig versagen muß. Die Götterwelt des Homer ist nur zu verstehen als das Produkt einer schöpferischen Liebestat, welche, das Schöne in cler menschlichen Gestalt ersehanend, sie zu seligen Göttern erhob. Als das Schönste im Reich der irdischen Gestaltung erschien dem Griechen der menschliche Körper, und dieser Körper ist es denn auch, den seine zeugende Sehmsucht zu der seligen Gestalt der Götter erhob

\section{p) Religiöser Gehalt.}

Es bleibt noch übrig, anf die religiöse und ethische Bedentung der homerischen Götter hinzuweisen. Augenscheinlich sind sie ron vornherein auch in roligiöser Hinsicht sehr ernst gemeint, während sie damn später immer mehr zu Göttern dex Poesie, zu schönen Fabelwesen wurden. Was bedeuten sie in religiöser Hinsicht für den Mensehen? Sie sind für das religiöse Bewußtsein clas Vollendete und Selige. Die Götter Homers sind heiter und glücklich, weil sie ron Krankheit, Alter und Tod, Kummer und Sorge niemals ermsthaft gequält werden. Thre Seligkeit liegt vor allem in cler Unsterblichkeit. Von allen Mängeln des Menschlichen sind sie zwar nicht befreit. Not und Krankheit bleibt ihnen wohl fern, doch können sie Schmerzen leiden, im Kampfe verwundet werden, Verlangen nach Nahrung verspüren oder ron schnsïchtiger Liebe zı den schönen Gestalten der Menschen ergriffen werden. Die Welt der Götter ruht nicht vollkommen selig in sich selbst, sondern sie ist auf das Menschliche lingewjescn. Besonclers ist es das Schöne der irdischen Erscheinung, was das V'rolangen der Götter reizt. Die schönen Menschen gelten deswegen als die hesonderen Liehlinge der Götter. Dic Liebe des Göttlichen zu dem Mensehliehen ist erotisch betont, während das Liebesgefühl, das der Menseh den Göttern entgegenbringt, (in Gefïhl der Bewunderming und Verehrung ist, durehaus verwandt denjenigen Empfindungen, die wir dem Fromd entgegenbringen,

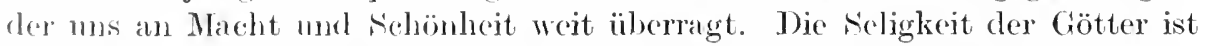
dann anch zeitlich begrenzt, sofern einmal die zeit kommen wird, da die ihre: Herschalt rin Ende areicht und sie von anderen Gewalten abgelöst warlen, mm nun ihrerseits in den Tiefen des Tartarus zu ruhen. Tnsofem ist

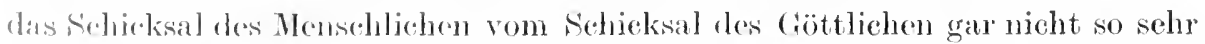

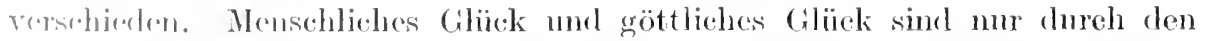

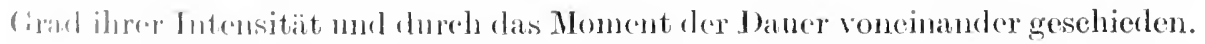

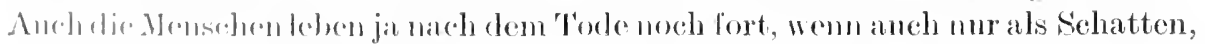
d. h. als herabgesedzte Körperlichkeit, botänbt und mbewußt, während die

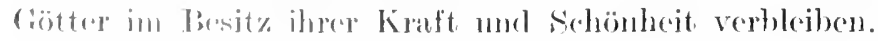


Die Götterwelt des Polytheismus, die sich dem Mythos rermählt, bedeutet als solehe eine ganz besondere Phase in der Erseheinumg des Gottesbegriffes und trägt ein hohes Maß von Notwendigkeit in sieh. Wollen wir. wie es üblich ist, in der Entwieklung des Gottesbegriffes diese drei Phasen: Fetischismuss, Polytheismus und Monotheismus unterseheiden, so hat hier jede Phase ein gewisses Reeht für sich, und man kamn nieht sagen, daß der Monotheismus als soleher die überlegene Religionsform gegenüber dem Polytheismus oder aneh dem Fetisehismus sei. Daß an die Stelle der zahlreichen Götter der eine Gott getreten ist, kamn ebensowohl als Schwäehung wie als Erhöhung des religiösen Bewußtseins aufgefaßt werden. Die zahlenmäßige Terringerung der göttlichen Ursachen ist nur ein Triumph des logisehen, nicht aber des theoretischen Bemußseins. Das einheitliche Weltprinzip, das dem Fetisehismus noch fehlte, liegt ja aueh in der Götterhierarchie des Polytheismus, welche die christliehe Mystik dureh die Hierarchie der Engel ersetzte. Die Vertiefung. welehe der Gottesbegriff im Monotheismus erfährt, hängt mit dem Problem der Zahl nur lose zusammen. Der seltsame pantheistisehe Gottesbegriff, den Xenophanes gegenïber der homerisehen Götterwelt bildete, und der mit sittliehem Pathos die Idee des einen Gottes den zahlreichen Göttern des Homer entgegenstellte, kann noch nicht ohne weiteres als ein Fortschritt in der Entfaltung des religiösen Bewußtseins begriffen werden.

So viel ist gewiß, daß der Polytheismus diejenige Form der Gottesvorstellung ist, die für Kunst und Gesehichte die größten Möglichkeiten gewährt. Auch der Mythos, in dem die verschiedenartigen Wertgebiete miteinander rersehmolzen sind, rerträgt weder den Fetisehismus noeh den Honotheismus. Der Fetisehismus ist ein romythiseher Zustand des Wertbewniseins. Der Fetisch hat keine Geschichte, denn er ist fïr sich allein in den Gegenstand eingesponnen und hat keinen Zusammenhang mit der unendliehen Zahl der anderen Götter. Jedes Ding ist beseelt und für sich da. Aneh das Kleinste hat seinen eigenen Gott. Das ist der größte Mißbrauch, der mit. dem Namen der Gottheit getrieben werden konnte. Was sich bewegte ouler zu bewegen schien, war ron einem besonderen Gott erfüllt. Diese Vorstelhung des Fetischismus darf natürlich mit der Torstellung des Pantheismus nieht rerwechselt werden, der ein unpersönliches göttliches Prinzip lehrt. das als das Eine und Einheitliche dureh alle Dinge hindurehgeht.

Untersuchen wir den Werteharakter des Fetischismus, so wird er wohl in allgemeinen als Ausdruck der theoretischen Ohmmacht, die zu keinem Prinzip der Einheit und Notwendigkeit gelangen kann, andererseits aber auch wieder als Beweis für ein stark entwiekeltes Phantasieleben und ein hohes Maß ron religiöser Scheu und Verehrungsbedürftigkeit erscheinen. Das religiöse Gefühl sieht in allen Dingen lauter Gott, wenn auch nieht den einen ciott in allen Dingen, und das ästhetische Bewntsein übt die grolie Tat der Beseelung an allen Dingen aus. Ist es doeh seine Art, die Steine reden zu lassen.

Das Zeitalter des Fetischismus bedentet im allgemeinen einen großen Mangel gegenüber dem Polytheismus, weil die Entfaltung les theoretischen und moralischen Bewußtseins damals moch fehlte. In dem Polytheismus ist die gleichmäßige Entfaltung allex Wertgebiete gegeben, aber so, daß sie noeh nicht zur Differenziermng gelangt sind. Sofern nun alle Geschichte mit dem Werden 
der Verrunft beginnt, trägt das Zeitalter des Fetischismus, in dem die bedeutsamsten Fortschrittswerte Wissenschaft und Sittlichkeit noch nicht entfaltet sind, und die Phantasie zwar mächtig erregt ist, aber noch nicht zu künstlerischer Gestaltung vordringen kann, den Charakter des Vorläufigen und Vorzeitigen an sich.

Uberlegen wir dann weiter, daß das religiöse Verhältnis in der Beziehung des Endlichen zum Unendlichen liegt, so scheint im Zeitalter des Fetischismus das Göttliche in einer eigentiimlichen Verbindung des Endlichen und Unendliehen gedacht zu werden. Der Fetisch, der den Gegenstand erfüllt und beseelt. erscheint in dieser notwendigen Bindung an das Einzelne als das Endliche und Begrenzte. Deswegen wird ja auch dic Primitivität dieser religiösen Vorstellung so stark unterstrichen. Anderseits erscheint der Fetisch als unpersönlich und unbegrenzt, als die geheime Kraft, die den ganzen Gegenstand erfiillt und zwar an ihn gebunden ist, aber anch wieder als unerschöpflicher Erregungsquell angesehen werden muß. Diesem Mangel und der Begrenztheit des einzehnen Fetisches wird vor allem dadurch abgeholfen, daß ihre Zahl mendlich oder beliebig groß gemacht wird, aber so, daß kein Zusammenhang zwischen den einzelnen Göttern besteht. Geht doch nicht die eine göttliche Weltseele durch dic Fülle der Dinge hindurch, sondern die beliebig große Zahl göttlicher Seelen besteht vollkommen atomistisch für sich in strenger Isolierung. Die Macht des Fetischgottes ist der Kraft des Menschen nicht unendlich überlegen, die Distanz ist nicht so groß, daß ein gegenseitiges Verstehen ausgeschlossen bliebe. Auch besteht keine Kluft zwischen Mensch und Gott. Der Gott kann durch Versprechungen gewomnen, auch wohl durch Drohungen zu einer bestimmten Entscheidung gezwungen werden.

In der Anfteilung der religiösen Grundbestimmungen von Endlichkeit und Unendlichkeit zwischen Gott und Mensch gibt der Fetischismus noch ein sehr undeutliches Bild. Das hängt damit zusammen, daß die Idce des Unendliehen ïberhaupt noch nicht reeht deutlich geworden ist. Es offenbart sich schon im Fetischismus die schwere Dialektik des religiösen Bewußtseins. Wird Gott als das Endliche und Begrenzte gedacht, so verbinden wir mit ihm einen Begriff, welcher unserer Vorstellung von Persönlichkeit und Individualität nahe kommt. Die Götter der Begrenztheit und Endlichkeit sind die Götter unserer Liebe und die Vertrauten unserer stillen Stuncken. Jeder Menseh verlangt nach seinem Gott, den er lieben, zu dem er beten, und ron dem er ein ganz besonderes Interesse für seine eigenen Angelegenheiten erwarten kamn. J) Fetischgötter sind im eminenten Sinne die Götter des einzehnen, so wie die Laren Familiengötter sind. Die sozialen Einheiten verlangen nach Göttern, das Individuum, die Familie, das Volk und schließlich die Menschheit. Die Fotischgötter sind Einzelgötter; die Götter des Polytheismus, die ihr Dasein im Mythos haben, sind Volksgötter.

Wirl dic Gottheit aber endlich und begrenzt gedacht, so scheint sie auch lamit zuglcioh am allgemeincn Sehicksal der Endlichkeit, am 'Tode teilzunehmen. Sïr ist lreschränkt an Kraft und an Lcistungsfäliggkeit und läuft Gefahr, an Wiirde mud Ansehen zu verlieren. Deswegen erhält sie das rätselvolle Wort der Inendlichkeit in der Fïlle seiner weehselnden Berleutung. Denn das

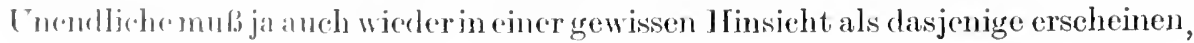


was den Mangel der Abgeschlossenheit in sich trägt, und anderseits wird durch den Begriff der Unendlichkeit das Menschliche als das Endliche vom Göttlichen so weit entfernt, daß es Gefahr läuft, sich gänzlich zu verlieren.

Der Polytheismus, wie er uns in der Götterwelt Homers entgegentritt, faßt nun augenscheinlich das Göttliche als das Endliche und das Begrenzte und tritt darin wohlimallgemeinen dem Charakter der orientalischen Religionen entgegen, die dahin neigen, das Göttliche als das Unendliche zu betrachten. Nirgends ist das göttliche Wesen ungeteilt zu finden, auch nicht in Zeus, etwa in der Weise, daß seine hohe Erscheinung alles das zusammenfaßte, was dic einzelnen Göttergestalten in zerstrenter Form enthielten. Vielmehr ist auch Zeus eine begrenzte Gestalt als Vater der Götter und Menschen, als typisch königliche Herrschergestalt. Es fehlt viel daran, daß Zeus im Verhältnis zu den anderen absolut gedacht werden könnte. Er ist nur der erste unter Gleichon. unter Gleichberechtigten. Auch er drïckt nur eine bestimmte Seite des religiösen Wertes aus, mit dem sich gleichzeitig eine ethische Vorbildlichkeit und die Idee einer wirkenden Naturkraft verbindet. Dieses Reich der Götter, das eine bestimmte Seite des Wertlebens in jeder einzelnen Gestalt in höchster Vollendung offenbart, hat in dem Epos des Homer und in der Marmorwelt der griechischen Staaten den höchsten Ausdruck gefunden. In der platonischen Ideenwelt sind diese Götter und Marmorbilder wieder zu finden, nur daß 3 die Leiber der Götter noch Sehnsucht empfanden nach Nektar und Ambrosia. während die zu Ideen gewordenen übersinnlichen Gestalten der irdischen Wirklichkeit vollkommen abgesagt haben. Soviel bleibt gewiß, daß die in der Götterwelt Homers zum Ausdruck gebrachte Auffassung ron den Göttern, die Behauptung ihrer Endlichkeit und Begrenztheit typisch geworden ist für die Bildung und Auffassung des göttlichen Gegenstandes im ganzen Bereich der griechischen Kultur.

\section{q) Ethischer Gehalt.}

Es erübrigt, die Götterwelt Homers auf ihren ethischen Gehalt hin zu untersuchen. Der ethische Gehalt offenbart sich in dem Gegensatz ron Sein und Sollen. Tritt diese fundamentale ethische Beziehung im griechischen Mythos schon deutlich hervor, oder ist sie hier noch verborgen und in andere Wertbeziehungen eingehüllt? Wir möchten meinen, daß der Dualismus von Sein und Sollen in der mythischen Torstellungswelt nur sehr schwach entwickelt ist, daß somit die Entfaltung des ethisehen Lebens hinter der des religiösen und ästhetischen weit zurïcksteht. Da der scharfe Dualismus, der nun cinmal mit dem Prinzip der Sittlichkeit notwendig zusammengeht, noeh nicht zur Entfaltung gekommen ist, so kann die mythologisehe Welt eine schöne Einheit und Geschlossenheit bewahren und einen gewissen Wertausgleich vollzicher. Da ferner das moralische Prinzip notwendig zu den Beitrags- oder Fortschittswerten gehört, so verstehen wir, wie das historische Lcben unter der Herrschaft des Mythos noch nicht in großen Formen hervorbreehen kann. Eine gewisse Stagnation und Ruhelage bleibt bestehen, die noeh kein leidenschaftlich bewegtes Volksleben hervorbrtihen läBt.

Die Geschichte der Philosophie belehrt uns, daß gegen die Ethik Homers von den griechischen Denkern und Reformatoren auf das heftigste angekämpft

Meblis, Geschichtsphilosophie. 
und gestritten ist. Dieser Kampf ist einerseits ein Beweis dafür, daß das sittliche Bewußtsein seit Homer die größten Umwandlungen erfahren hat, anderseits mag uns diese Polemik als ein Anzeichen dafür gelten, daß in den Mythen Homers auch das sittliche Leben, wenn auch im engen Zusammenhang mit den anderen Wertgebieten, schon in eigentümlicher Formung gedeutet ist. Wenn damn die Ethik des Homer von Denkern wie Xenophanes und Platon als im höchsten Maße unsittlich empfunden wurde, so beweist das eine bedeutsame Wandlung im Kulturbewußtsein und richtet unsere Aufmerksamkeit darauf, nachzuforschen, worin denn wohl das Unsittliche der griechischen Götterwelt und ihres Verhältnisses zu den Mensehen gesucht werden müsse.

Für die Götter Homers bestehen keine Pflichten und Normen, höchstens das Gebot des Gehorsams dem Göttervater gegenüber. Ihnen ist keine höhere Moralität eigen, weder im Verhältnis zueinander noch im Verhältnis zu den Menschen. Die Götter suchen sich untereinander zu täusehen und zu hintergehen wie die Menschen, lediglich mit dem Unterschiede, daß diese Strafe leiden müssen oder wenigstens häufig erleiden, wenn sie andere gekränkt und geschädigt haben, die Götter aber nicht. Das heißt mit anderen Worten: Für die Götter gibt es keine Bindungen irgendwelcher Art, keine Pflichten und Normen, nach denen sie sich zu richten hätten. Sie können tun und lassen, was sie wollen, ohne dafür gestraft und geschädigt zu werden. Die Götter haben keine höheren Pflichten als die Menschen, sondern sie sind von der Pflicht befreit und handeIn nach Willkür. Sie dürfen nicht so angesehen werden, als ob ihre Neigung dermaßen geläutert wäre, daß sie mit Notwendigkeit das Gute tun, daß sie freiwillig und gern dem Sollen folgen, daß Pflicht und Neigung in ihnen zum vollkommenen Einklang gebracht sind. Sie sind von dem unwillkommenen Joch der Pflichten befreit, das den armen Sterblichen auferlegt ist. Sie können tun und lassen, was sie wollen. In dieser Ungebundenheit und Willkür liegt dic Seligkeit der Götter. Diese Seligkeit, die darin besteht, daß die Götter nur Rechte, aber keine Pfliehten haben, daß ihnen ein müheloses Dasein beschieden ist ohne Sorge und Alter, daß sie dem heiteren Sinnengemuß sich hingeben können, ohne ein schmerzliehes Erwachen aus den Träumen sinnlicher Seligkeit befürchten zu müssen. Ein Sollen gibt es für den Menschen aber nicht für den Gott. Das Vernunftgebot ist nicht etwas Göttliches, was uns adelt, sondern etwas Menschliches, was im Verhältnis der Götter zueinander alle Bedeutung verliert.

Dagegen sind den Menschen von den Göttern Pflichten auferlegt, deren Nichtbefolgung sie streng bestrafen. Und die Furcht vor dieser Strafe ist es allein, die den Menschen sittlieh handeln läßt. Als Ziel des menschlichen Daseins erschcint das Wohlleben in Kraft, Gesundheit und Macht Und den armen Siterblichen befällt manchmal Fureht, daß cin zu hohes Maß von WohlJeben den Zorn der Götter herbeiführen möehte. Die Moral der homerisehen $1 \mathrm{Hclt}$ ist also vollkommen ledonisch gefärbt und weist noch nicht das geringste Zajehen eine'r freien Autonomie und Selbstbestimmung auf.

Fïr die ('inzclnen Sphären des sittlichen Lebens ist bezoichnend die freie Auffassung des Geschlechtslebens, das selbverständliche Recht des Mannes, scinter simblichen leidensehaft iiberall nachzugehen, eine Auffassung, die sich rigcntïnlich ábhebt gegen die schön herausgearbciteten Verhältnisse der 
Freundschaft und Liebe, wie sie vor allem in der Beziehung des Achill zu seinem schönen Freund und in der Liebestreue der Penelopeia zum Ausdruck kommt. Die Sphäre des Geschlechtslebens ist als die Quelle notwendiger Lust in hohem Maße der Willkür preisgegeben. Götter und Menschen suchen, von heißem Verlangen erfüllt, den Trieb der Natur zu befriedigen.

In dem Trieb der Natur wird eine Notwendigkeit anerkannt, der zu widerstreben von vornherein hoffnungslos ist. Es ist natürlich und selbstverständlich, der Liebessehnsucht zu folgen, die ein Gott im Herzen erregt hat. Es ist natürlich und selbstverständlich, die Tränen fließen zu lassen, wenn wir von Schmerz bewegt sind. Die Leidenschaften in ihrer Macht und Größe werden nicht durch ein strenges Vernunftgebot beherrscht. Es ist natürlich und selbstverständlich, daß auch der Held die Flucht ergreift und Furcht empfindet, wenn ihm in der Gestalt des überlegenen Gegners das Verderben naht. Sogar an dem armen Leichnam wird der Heros seinen Zorn und seinen Schmerz über den Tod des Geliebten noch auslassen.

Wenn so eine große Sphäre des Affektiven der Sollensregulierung ïberhaupt nicht unterstellt wird, so wachsen anderseits auch aus dem bloß auf Nutzen und Vorteil gerichteten Streben normative Bestimmungen hervor. Das führt dahin, die List und die Verschlagenheit als Norm zu preisen und gelten zu lassen, die Lüge zu verherrlichen, wie Platon gesagt hat, und so bleibt das Sollen klein und schwach der ungeheuren Gewalt und Macht des Affektiven gegenüber. Ein nur anthropologisch gedachtes Sollen als Befehl des Gottes, der nur für Menschliches gilt, tritt der Hochflut des sinnlichen Lebens gegenüber und setzt ihm gelinde Schranken, ein Sollen, das immer wieder Gefahr läuft, in dem Meer des Seins unterzutauchen. So sehr der Göttermythos des Homer als Ganzes vor allem im ästhetischen Sinne die höchste Wertanerkennung erwirbt, so sehr forderte er auch durch unklare Wertverminderung die schärfste Kritik heraus, und deshalb hat die große Entwicklung der griechischen Kultur vor allem in der Opposition zur homerischen Götterwelt sich entfaltet.

Diese Opposition ging wohl in erster Linie vom theoretischen und ethischen Bewußtsein aus, der sich dann später, rom Orient ausgehend, eine Bewegung des religiösen Bewußtceins hinzugesellte mit der gemeinschaftlichen Tendenz, die Götterwelt Homers zu zerstören. Diese Bewegung war erfolgreich, die einheitliche Substanz des mythologischen Bewußtseins wurde aufgelöst, und die Geschichte der Griechen entfaltete sich in großem, leidenschaftlichem Zuge.

Die Götterwelt Homers hatte nicht nur eine ästhetische Bedeutung und ist wohl auch in der letzten großen Fassung und Gestaltung, die sie in der Ilias und Odyssee erfahren hat, nicht nur ästhetisch gemeint. Ursprünglich gab sich in diesen Gesängen die Fülle des mythologischen Bewußtseins kund. Diese Gesänge sollten nicht nur ästhetisch erfreuen, sie verherrlichten auch das Walten der Götter und belehrten über geheime Zusammenhänge der Natur wie auch über die Taten der Vorfahren. Und endlich brachten sie eine Herrenmoral zum Ausdruck, der Herodot in seinem Gedicht die Bauernmoral entgegengesetzt hat.

Für die Anfänge der griechischen Kultur ist die Herrentendenz so sehr bezeichnend, die Aufbewahrung der Vermunft und ihrer Gïter für wenige Auserlesene und ihre Weitergabe an den engsten Kreis der Zugehörigen. Durch 
die Vernunft gestärkt und gehoben, blïhte jetzt empor die Macht der Heroen in jenem Zeitalter, das man so gern als die schöne Jugend des Menschengeschlechts wertet und bezeichnet. Das Göttliche bewahrt das Wertvolle für sich gegenüber dem Menschentum, und das Herrentum der Menschen ist ein Göttergeschenk gegenüber dem Sklaventum. Die schönen und vornehmen Menschen führen ihr Geschlecht auf die Götter zurück und dürfen wie Götter ïber die Menschen schalten. Frevelhaft ist die Tat des Propheten, der die Torrechte des hohen Himmels, das schöne Licht der Vernunft, den armen Sterblichen schenkte und den hohen Göttern entzog. So mußte Prometheus sein Prophetentum mit den schwersten Qualen büßen.

Es findet sich num aber angenscheinlich in der letzten großen Gestaltung der homerischen Götterwelt eine schöne Freiheit in der Beziehung des Dichters zu seinem religiösen Stoff. Der kultische Charakter der Gesänge ist vollkommen zurïckgeteten, und der Ton des Dichters ist nicht nur auf Verehrung und fromme Hingabe gestimmt. Der Dichter erzählt von den Göttern, als ob er es mit mensehlichen Dingen von höchster Bedeutung zu tum hätte. Manchmal erlaubt er sich ihnen gegenüber den Ton einer zart ïberlegenen Ironie, so etwa dort, wo er berichtet, wie schlimm es der Liebesgöttin ging, als sie sich in die rauhen Händel des männermordenden Kampfes mischte.

Daß die homerische Götterwelt nicht nur ästhetisch, sondern anch ethischreligiös und theoretisch gemeint war, das zeigen die heftigen Angriffe, die von den griechischen Denkern gegen sie gerichtet wurden. Der künstlerische Genius eines Platon hätte gewiß nicht diese schroffe Haltung gegenüber Homer eingenommen, wenn diese Gedichte nicht tatsächlich neben ihrem ästhetischen Sinngehalt auch eine ethisch-religiöse Bedeutung besessen hätten. Für uns Nachgeborene ist das schwer zu verstehen, weil wir vom Standpunkt einer ferner und fremden Kultur die Götter der Hellenen notwendig als naiv empfinden müssen. Ganz anders aber hat sich gewiß das Zeitbewußtsein zu ihnen gestellt und fromme Schen und Bewunderung empfunden, wo wir nur Liebreiz und Sehönheit sehen.

Die Cötterwelt Homers blieb das Heiligtum der Dichter, welches ihnen den höchsten Stoff zu künstlerischer Gestaltung gewährte. Die Dichter dieser Götterwelt lockten die Marmorgötterwalt ler griechischen Bildhauer hervor. Je mehr aber diese Welt dem ästhetischen Bewußtsein und seiner Willkür überlassen wurde, um so weniger vermochte sie dem religiösen Bewußtsein zn genügen, das nummehr daranf ausging, seinen Gegenstand in dem Gestaltlosen und Cnendlichen zu suchen.

Die Erstarkung des theoretischen und sittlichon BewuBtseins aber ist es rocht eigentlich gewesen, welche die griechische Götterwalt zu Fall brachte. Jic große Tat der griechischen Philosophie liegt in fer Umbildung jener mythischen Ciestaltenwelt zu einem System rler Begriffe. Wie das wissensehaftliche Jaben in scinen ersten Anfängen der réyvy entsprang, so die Philosophie ans drom Mythos stark und gewaffnet wie Athene aus dem Haupte des Zeus.

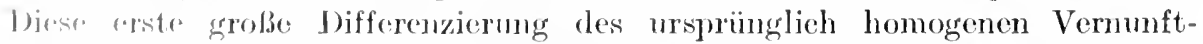
gohaltes, dio BikJung dor versehjedenen Formen des KulturbewuBtseins, ist cin irrationales (ieschehen, durchaus vergleichbar dem ersten Werden der V'rmunft. 


\section{r) Epochen der Menschheitsentwicklung.}

Versuchen wir uns nummehr den Ablauf des Kulturgeschehens in der antiken Kultur in seinen Gesamtzügen deutlich zu machen, ohne auf die Entwicklung der einzelnen Wertreihen, etwa auf die Besonderheit der ästhetischen oder religiösen Entwicklung, näher einzugehen.

Von unserer allgemeinen Bestimmung des historischen Endzwecks her, nach dem der Sinn der Gesehichte in einer Aufhebung der Wertfeindlichkeit in zwiefacher Synthesis zu suchen ist, haben wir den Begriff eines Vernunftlebens gewonnen, das sich entfaltet, um seinen Reichtum zu offenbaren, durch diese Entfaltung aber mit sich in Widerstreit gerät, ein Gegensatz, dessen Austrag und Überwindung als die Aufgabe der Heroen erscheint. Es lassen sich aber zwei Typen des Heroen unterscheiden, je naehdem seine Tätigkeit mehr auf Aufbewahrung der Vernunftgüter und Isolation und Einsamkeit gerichtet ist oder im Gegenteil darauf abzielt, sich und die Vermunft an das Ganze zu verschwenden: Herrscher und Prophet. Nit der Idee des Herrschers hängt der Gedanke eines synthetischen Zeitalters und der Konsolidierung einer strengen und festen Wertordnung zusammen, mit der Idee des Propheten die Torstellung eines analytischen Zeitalters und die Úberzeugung ron der Unvergleiehbarkeit und Unvereinbarkeit der Wertgegensätze. Dabei müssen die Begriffe synthetisch und analytisch immer relativ genommen werden. Das Synthetische kann zweimal absolut gedacht werden, nämlich am Anfang und am Ende des historischen Geschehens, dessen Bewegung von der Einheit ausgeht und in der Einheit sich vollendet. Dagegen ist das Analytische niemals absolut vorhanden, sondern immer relativ, und wir nennen ein Zeitalter synthetiseh oder analytisch, je nachdem das Bewußtsein der Wertfeindlichkeit oder der Werteinheit dominiert. Für die allgemeine Charakterisierung eines Zeitalters ist es dann weiter von höchster Bedeutung, welche Werte in erster Linie bejaht und entfaltet werden, die Vollendungswerte oder die Beitragswerte. Von diesen allgemeinen Bestimmungen aus wollen wir uns das Kulturgeschehen der Antike deutlich zu machen suchen, indem wir gleichzeitig einen Typus der verschiedenen Kulturformen, etwa der antiken Kunst oder der antiken Philosophie bilden und zeigen, welche Wandlung dieser Typus erfährt, ohne jedoch die Einzelheiten dieser Entwicklung zu schildern.

\section{s) Das analytische Zeitalter der Griechen.}

Die griechische Kulturentwieklung, etwa rom Jahre 600 vor Christo bis zur Skepsis der Kaiserzeit, ist in der Hauptsache ein analytisches Zeitalter, ein Zeitalter höchster, leidenschaftlicher Bewegung. Wem wir dies Zeitalter als analytisch bezeichnen, so meinen wir damit, daß diese ganze Bewegung darauf ausgeht, die ursprüngliche feste Wertsubstanz zu zersetzen und aufzulösen in verschiedene Gebiete. Das Resultat dieser Bewegung muß vor allem darin gesucht werden, daß der große Gegensatz von Religion und Philosophie, von Glauben und Wissen dem Menschengesehlecht deutlich wurde. Während die erste große Kultur der Menschheit, die Kultur der Griechen und Römer, unter der Leitung und Aufsicht des theoretischen BewuBtseins erfolgte, indem der Intellekt gleichsam vorschrieb, was als schön gewertet oder als fromm und 
gut anerkannt werden sollte, erfolgte nach der vollkommenen Auflösung und Zersetzung des Denkens eine synthetische Epoche der Entwicklung, die sich in der großen Organisation des Mittelalters vollendete, und in der das religiöse Bewußtsein wertbestimmend wurde. In der Differenzierung der ursprünglich vereinigten Wertgebiete erreichte also speziell im Griechentum das theoretische Denken einen Vorsprung, so daß das Wissen damals viel größer und mächtiger war als der Glaube. Während nun die ästhetische Werthaltung mit der theoretischen in der gemeinsamen Bejahung des Begrenzten unmittelbar zusammenging und diese Kultur verschönte, und das sittliche Bewrußtsein sich der Idee des Wissens vollkommen unterwarf, ging das religiöse Bewußtsein von vornherein besondere und geheime Wege. Es wandelte den Gang der Mysterien und suchte in Rausch und Ekstase jene grenzenlose Einheit zu erleben, von der nach seiner t'berzeugung das theoretische Bewußtsein in der einseitigen Betonung der Grenze nichts wissen komnte.

Der allgemeine Charakter der antiken Kultur ist dann weiter dadurch charakterisiert, daß in ihm die absoluten Werte, Philosophie, Kunst und Religion eine hohe Entfaltung fanden, während die Beitragswerte, mit denen die Idee des Fortschritts auf das engste zusammengeht, noch mehr zurückgehalten waren. Dadurch bekommt die antike Kultur einen gewissen Vollendungscharakter, der im Verein mit der großen inneren Bewegung, die durch ihren analytischen Charakter bedingt ist, ein unvergleichliches Schauspiel gewährt. Wenn sich unsere Seele nach Hellas sehnte und ewige Jugend und Schönheit dort zu finden glaubte, so ersehnte sie die Vollendung, die sie dort ahnungsvoll erschaute.

Die analytische Kultur der Hellenen hat die Trennung der Wertgebicte nicht vollendet, sondern nur angebahnt. Sie blieben in relativer Einheit. Noch fand sich die Schönheit nicht in ihrem eigensten Wesen, und das sittliche Bewußtsein verharrte in der Oberaufsicht der theoretischen Vermunft. Diese relative Vermischung der Wertgebiete in der antiken Kultur ist Mangel und Vorzug zugleich. Sie erweckt in uns die Vorstellung eines seligen und goldenen Zeitalters.

\section{Drittes Kapitel. \\ Die religiöse Entwicklung.}

Versuchen wir nummehr, den typischen Charakter der griechischen Kultur uns deutlich zu machen, indem wir mit der Entfaltung des religiösen Lebens beginnen.

a) Jir Dimensionen des religiösen Bewubtseins.

Das religiöse Bewuftsein hat die beiden Dimensionen der Endliehkeit $n$ un der Tnendlichkeit. Fs setyt den äußcrsten Gegensatz, den es mit den Begriffern $\mathrm{rom}$ Jindlichkejt und Tnendlichkeit umschreibt, und gleichzeitig die Idee sciner (therwindung. Darin liegt die Paradoxie des religiösen Bewußtseins, dals es ciott anf dere cinen seite gar nicht groß und weit genug und anderseits gar nichte eng umel lilein genug vorstellen kann. Ls mub die Gottesferne, das 
Getrenntsein betonen, dann ist Gott gar groß und weit. Es muß die Möglichkeit der liebenden Gemeinschaft betonen, dann kann Gott gar klein und eng vorgestellt werden, um der Vertraute unserer stillen Stunden zu sein. Oder aber die Seele muß sich selber heiligen und groß machen, um der Vereinigung mit dem Göttlichen würdig zu werden. Ist Gott das Unendliche und wird als unendlich vorgestellt, dann ist die Seele begrenzt und endlich. Wohl aber ergeht an sie das Gebot, unendlich zu werden, um so auf immer mit Gott rereinigt zu sein. Ist dagegen Gott das Endliche, dann gehört zu seinem Wesen die Grenzensetzung, und das Menschliche verharrt ihm gegenüber in umahbarer Ferne. Ist Gott das Endliche, das Begrenzte und Schöne, dann ist der Mensch das Unendliche als das Fragmentarische, Sehnsüchtige und Unvollendete. Ist Gott das Unendliche, so ist er der Eme gegenüber der Vielheit irdisch-menschlicher Gestaltung. Ist Gott dagegen das Endliche, so kann er der Eine sein oder ober in der Fülle der Vielheit erscheinen. Ist Gott das Cnendliche, so scheint er aller menschlichen Bildung fern zu sein und die Vereinigung mit ihm durch Untergang und Aufgabe der Persönlichkeit erkämpft werden zu müssen. Ist dagegen Gott das Endliche, so ist er anch Persönlichkeit und Indiviclualität, oder er hat wenigstens die Möglichkeit, individuell und persönlich zu sein. Gliedert sich Gott als das Endliche in eine Zahl begrenzter Gestalten, so kann dieser göttlichen Vielheit deswegen doch ein einheitliches religiöses Grundgefühl entgegenkommen. Wenn im Fetischismus jedes Individuum seinen besonderen Gott hat, dcm er ein einzigartiges religiöses Gefühl entgegenbringt, so daß man hier von einem religiösen Gefühlsat omismus sprechen kamn, so besteht der einheitlichen Götterwelt des Polytheismus gegenüber ein gewisses Gesamtgefühl in der religiösen Stellungnahme. Der Fetischgott ist der Gott des Einen. In ihm gibt sich ein hohes Pathos der Endlichkeit kund. Auch tritt schon an ihm die große religiöse Erscheinung hervor, die wir als Magie bezeichnen, und die sich ausdrïckt in dem Gedanken, daß das Mensehliche das Göttliche in irgendeiner Weise bestimmen kamn. Die Götter des Polytheismus sind die Götter einer Nation. Sie sind für alle Angehörigen desselben Volkes dieselben. Der Gott des Monotheismus kann entweder der eine für ein bestimmtes Volk sein, wie der Judengott, oder der eine für die Menschheit, wie der Gott, den Christus gelehrt hat. Als der Eine ist er aber weit mehr auf die Menschen hingewiesen wie die seligen Götter des Homer, die in der Beziehung zueinander ihr volles Genüge haben und nur ganz gelegentlich um die Menschen bekümmert sind, wenn ihre Leidenschaft und Sympathie erregt ist. Der eine Gott ist auch gleichzeitig mein Gott.

Wird die Gottheit als endlich und persönlich gedacht, wie in der Götterwelt Homers, so wird sie menschlich gedacht oder kam doch wenigstens menschenähnlich gedacht werden. Dieser Prozeßder Vermensehlichung des Göttlichen, der als Anthropomorphismus abgelehnt wird, ist das Anzeichen für eine starke Vertiefung des religiösen Gefühles. Wenn sich der Orient die Götter roh und chaotisch, der Individualität fern, in wunderlicher Zusammensetzung verschiedenartiger Lebensformen vorstellte, so mußte sein Gefühl ihnen gegenüber auch in erster Linie ein Gefühl der Furcht und des Schreckens sein, als deren wertvolles Resultat sich die Demut in der Beziehung von Herr und Knecht offenbarte. Der Anthropomorphismus ist das deutliche Anzeichen dafür, daß der 
Hensch die Erde und ihren Sehöpfer lieb gewann. Es wäre vollkommen verfehlt, die griechisehen Göttergestalten den Fabelwesen orientalischer Kultur gegenüber für gering zu halten. Sie sind viełmehr der schöne Ausdruek eines liebenden Gemütes.

Ferner bestand die Möglichkeit, das Göttliche entweder mehr in der äußeren Natur zu suchen als dasjenige, was die Welt bewegt, oder mehr in der Welt des immeren Erlebens als dasjenige, was die Seele bewegt. Der Gott, der aus der Naturwirklichkeit gebildet ist, dem eignet Form und Gestalt, während der Gott der Mystik, welcher der gestaltenlosen Welt des inneren Erlebens entstammt, gestaltenlos ist wie cliese Welt selber.

Wie ist nun die Struktur des religiösen Bewußtseins zu denken, und welche Wandlumgen erfährt dieses BewuBtsein in der Idee des Christentums? Man kann diesen Weg als den Weg vom Endliehen zum Unendlichen, vom Getrennten zum Vereinigten, von der Magie zur Mystik bezeichnen.

\section{b) Typus der griechischen Religion.}

Die Position des religiösen Bewnßtseins in Griechenland muß im allgemeinen dahin bestimmt werden, daß es in Gott das Endliche und Begrenzte verehrte; dam wird der Menseh notwendig als das Fragmentarisehe und Sehnsüchtige gedacht, dem der Eros eignet. Ferner muß der Typus der griechisehen Religion so gedacht werden, daß zwischen dem Göttlichen und dem Mensehlichen eine unüberwindliche Kluft besteht. Die Seele kann mit Gott keme liebende Umarmung vollzichen. Die Distanzierung von Gott und Mensch ergab sich als Reaktion gegen die anthropomorphen Vorstellungen der homerischen Götterwelt. Cbermenschlich sollte die Gottheit vorgestellt werden; nicht aber so, wie in den orientalisehen Religionen, daß man in Bildern der Körperlichkeit über das schön Menschliche hinausging und so zum Fratzenhaften und Abscheulichen kam, sondern vielmehr so, daß man das Göttliche mehr und mehr erkannte als don alluächtigen Geist, cine Vorstellung, die sich in Aris toteles vollendet hat. 1)er endliche, merreichbare Gott wird als der heilige Geist der Welt gedacht. Das ist die Blüte und Schönheit der gricehischen Religion. Daneben gibt es aber vermöge der dialektischen Natur des religiösen Bewubtseins noch einen anderen Typus, der seinem Sime nach alle Grenzen zwischen Gott und Seele niederreißt. Ihr Verkünder ist der religiöse Magier. Die Idee der Magie ergab sich aus ciner andersartigen therwindung der homerischen Götterwelt. Wenn der Monotheismus des Geistes, wie er in der griechisehen Philosophie ron Xenophanes bis Aristoteles sich entfaltete, der Opposition gegen die simnliche Gestaltung des Göttlichen entsprang, so die Magie aus der Bekïmpefung der alswoluten Grenze. Diese Grenze und Enthaltsamkeit dem Irdischon gegenüber zoigten offenbar die homerischen Götter, die ihre Seligkroit genichen, mulekiimmert $11 \mathrm{~m}$ die Welt. Ihr schönes und frendiges Licht-

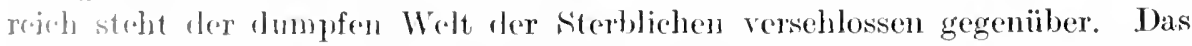

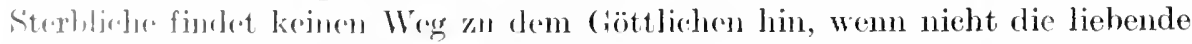

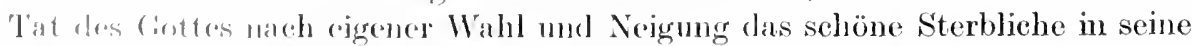
Armo zindt mul ihm das Göttemeschenk der Lnsterblichen verleiht, so wie \%ous don schönon Jirtonknabon dany medes liebend erhöhte. Gegen diese 
Sehranke zwisehen Gott und Mensch bäumt sich das magisehe Bewußtsein auf und sueht die liebende Umarmung des Gottes herbeizuzwingen.

Betraehten wir die Dialektik, in die das religiöse Bewntsein von vornherein verfloehten ist. Gott $m u B$ begrenzt sein, denn nur das Begrenzte hat Individualität, und nur das Persönliehe können wir lieben. Gott muß umbegrenzt und unendlieh sein, denn seine Natur ist von unserer endliehen Natur durehaus verschieden. Gott $\mathrm{mu} B$ vollendet und in sieh ruhend sein, vom Sterbfichen durchaus gesehieden und unbekïmmert $1 \mathrm{~m}$ sein Wohlergehen. Denn wäre die Gottheit bekümmert um die Welt, so litte sie Mangel und müßte entbehren und wäre nieht vollendet. Aueh würde die Idee einer Beziehung zwisehen dem Mensehliehen und Göttliehen die Position der Gottheit bedrohen und den Mensehen allzu göttlich oder den Gott allzu mensehlieh maehen. Anderseits muß doeh notwendig eine Beziehung zwisehen Gott und Mensch gedaeht werden, denn aller Kultus verliert seinen Sinn, wenn die Gottheit in rollkommener Einsamkeit und Lieblosigkeit verharrt. Wird aber ein Verhältnis und eine Beziehung zwischen Gott und Seele gedacht, so kann dies entweder so geschehen, daß die Seele Gott bestimmt. Das führt zur Magie, zur heiligen Tätigkeit des religiösen Herrsehers. Oder aber die Seele wird als bestimmt dureh Gott gedacht. Das führt zur Mystik, zur heiligen Passivität, zum religiösen Propheten. Das religiöse Genie hat mit diesen Gegensätzen zu kämpfen und sucht sie zu überwinden.

\section{c) Pythagoras.}

Die erste große Reaktion gegen die Götterwelt Homers kam man mit dem Namen des Pythagoras verbinden. Er offenbart schon die Spuren des religiösen Magiers, der den absoluten Gegensatz von sterblieh und unsterblich nieht gelten lassen will und die Verwandtsehaft und Ähnliehkeit der Seele mit dem göttliehen Leben behauptet. Das Entseheidende ist dann immer, wie weit die Behauptung dieser Gottähnlichkeit geht. Ist die Seele Gott ähnlich, so kann sie in inniger Gemeinschaft mit ihm verharren, sich ihm ein- und unterordnen, sieh hingeben und aufgeben. Sie kam sieh an die Gotheit verlieren. Oder aber sie kann die eigene Göttlichkeit hegen und bejahen in der Heiligung ihrer Individualität. Sie kann diese Heiligkeit und Göttlichkeit der eignen Individualität so sehr betonen, daß sie im Verhältnis zur Gottheit das Prinzip der Gleichheit setzt und damit jeden Wertunterschied aufgibt. Ja, die Betonung der eigenen Individualität kann so weit gehen, daß die Seele als das Bestimmende gegenüber dem Göttliehen erscheint, das Göttliehe mit ihren Forderungen bedroht und vergewaltigt und sich selber zur absoluten Göttlichkeit erhebt. Im ersten Falle entspringt derTypus des Mystikers als des religiösen Propheten, im zweiten Falle die dunkle und gewaltsame Gestalt des Magiers als des religiösen Herrsehers.

Wird eine absolute Grenze zwisehen der Seele und der Gottheit gedaeht, so wird sie im Grieehentum in der Regel endlieh vorgestellt. Gilt die Grenze als aufgehoben, so erseheint der Typus des Magiers als des religiösen Herrschers. Nur vereinzelt erseheint der Typus des mystischen Propheten, der die Ǔberwindung der Grenze im Geiste einer absoluten Hingabe und Aufopferung betont. 
P y thagoras war ein religiöser Magier und somit ein Nachfolger der Titanen, die das Reieh des Himmels erobern wollten. Er lehrte zuerst der Seele hohen königlichen Gang und ließ die großen Wunderblumen des Orients an ihrem Wege blühen. Er lehrte, daß die Seele nicht, wie Hom er behauptet hatte, ein schwaches Abbild des Leibes sei, sondern etwas Besonderes und Selbständiges dem Körper gegenüber, der für sie nur einen vorübergehenden Aufenthalt bedeute. Er hat zuerst dieses Wunder ihres Daseins verstanden, daß sie niemals zu einer geschwächten Körperlichkeit herabsinken kann und sich nicht so ohne weiteres dem Rhythmus des physisehen Geschehens einordnet. Für ihn war die Seele ein Wanderer auf dem Wege zu Gott. Er hat wohl nicht daran gezweifelt, daß sie Gott erreichen werde. die schöne Heimat des leuchtenden Feuers im Innerster. der Welt. Er lehrte das Endliche bejahen und das Unendliehe verneinen und wollte der Seele helfen, die Zahl derimmer wieder neuen Geburten zu verringern und das irdiseh simnliche Dasein abzukürzen. Denn daß sie in ihrer hellen Sehönheit mur zur Strafe für begangene Schuld an die schwere und dunkle Gestalt des Leibes geknüpft sein könne, daran hat Pythagoras nie gezweifelt. Er zeigte nun den Seinen, wie die Körperlichkeit zu überwinden sei, und lehrte sie das neue Leben leben, das die Individualität reinigt und heiligt und sie wïrdig und geschickt macht, ihren alten Platz im Lichtreich wiederzugewinnen.

Nicht sowohl mit Gott als vielmehr mit der Seele war Pythagoras beschäftigt. Er lehrte, daß sie das ordnende Prinzip des Leibes sei, welehes ihm seine Schönheit gil)t. Sie ist von großer Herrlichkeit und zu den höchsten Dingen berufen. Der Tod, der naeh der Auffassung Homers in harter und mbarmherziger Weise der blühenden Schönheit des Lebens alle Kraft und Energie entzieht und einen bleichen Schatten, ein schwaches Abbild, eine verminderte Körperlichkeit an seine Stelle setzt, die Religion des Pythagoras hat ihn überwunden. Denn der Tod des Mensehen ist nicht der Seele Tod oder Schwächung, sondern ihre Befreiung. Richtig geführt und behandelt, kann sie, rom Körper befreit, den Kreislauf der Geburten durehbrechen und seliger Geister Los gewiunen.

Diese Lehre des Pythagoras war nur für die großen und starken Seelen bestimmt. Die Masse der Menschen hätte sie nicht fassen und verstehen können. Nur wenige haben die Kraft, die große Tat der Überwindung zu vollziehen. Deshalb soll die Lehre des Pythagoras für wenige und Auserwählte, für einen Kreis auserlesener Jünger bestimmt sein, die ihm folgen anf dem steilen Pfade der 'Todesüberwindung durch siegreiche Kraft. Ein dunkles Geheimnis aber umhiillt diesen Kreis gottgeliebter Gestalten, und ein Schwur bindet ihren Mund.

\section{d) Iferaklit.}

In Pythagoras regen sich alle Kräfte des Magiers. Er hat der Seelo Kraft custrlokt, ihre hohe Schönheit verstanden, ihre göttliche Reinheit erstrebt. Hiraklit achtet ihn gering, seinen großen Geistesverwandten. Pythagoras war ihn whl nicht hart und streng und stoly genug. He raklit ist der vollendete Jy7us des Magiers. Nicmand war so stolz in Griechenland wie Heraklit. Hhn war marh seiner innorsten Uberzengung ein absolutes Wissen von allen göttiehon Jingen und von der Welt verborgenem Leben beschieden. Seine Lrhre, die dem gesunden Menschenverstande der großen Masse als überaus 
paradox und unverständlich erscheinen mußte und sollte, lehrte hinter den scheimbar festen Konturen des Wirklichen die große Bewegung eines einheitlich geordneten, nach festen Gesetzen dahineilenden Lebens. Dieses Leben hat Stufen der Wandlung zu durchlaufen. Es nimmt niedere und höhere Gestaltung an. Die höchste Stufe dieses Weltlebens ist das seelische Geschehen. Die Seele ist ein ewiges und großes Geheimnis. Sie rührt an clen tiefsten Grund der Welt und ist ihrem ureigentlichen Wesen nach niemals ganz zu verstehen. Das deutlichste und schönste Symbol für ihren eigentümlichen Charakter ist des Feuers leuchtende Kraft. Die Seele ist Flamme. Sie durchglüht nnd durchwärmt den Leib. Sie wird erlebt in der leidenschaftlichen Kraft des vernünftigen Willens. Wenn unsere Seele auf Erkenntnis geriehtet ist, dann weilt sie in der Region des göttlichen Logos. Aus Heraklit redet unmittelbar die Stimme der Weltvernunft. Heraklit, der religiöse Magier, redet die Sprache des göttlichen Weltlebens, der vermunftbegabten ewigen Gestime. Er ist der Eingeweihte und Wissende den törichten und rerblendeten Menschen gegenüber.

Für die edle und vornehme Seele des Magiers in ihrer heiligen Reinheit gibt es keine Grenzen und Hemmungen. Sie ist die höchste Offenbarung des Daseins, sie ist dem göttlichen Wesen gleich. Zwisehen Seele und Leib liegt ein großer Gegensatz. Alle Schönheit empfängt der Leib durch die Seele. Der seelenlose Leichnam ist häBlich und verächtlich und keiner Aufbewahrung und Pflege wert. Die Seele gehört zu der Götter Gemeinschaft. Zwischen den Sterblichen und Unsterblichen besteht kein absoluter Gegensatz. Dem die sterblichen Menschen tragen in dem Prinzip der Seele ein Bleibendes und Unsterbliches in sich. Feuerstufen gibt es in der großen Entfaltung des Vernunftlebens, da die Seele des Magiers aus eigener Kraft sich zum Range des Unsterblichen erhebt, zu einem göttlichen Dämon sich bildet, zum Wächter der Lebendigen und der Toten. Und diese Gottwerdung der Seele ist kein Geschenk der Gnade, wie etwa Herkules als Lohn für seine Mühe in die Gemeinschaft der Himmlischen erhoben wurde, sondern ans eigener Kraft erhebt sich die Seele zu göttlichem Leben. Die Betonung der Individualität und der Seele geht hier so weit, daß das Göttliche bedroht wird und ernste Gefahr leidet. Das Sterbliche schwingt sich zu göttlichem Leben empor, es wird unsterblich, und das Göttliche verharrt nicht in der Sphäre des Unsterblichen, sondern wendet sich dem Untergange zu und wird sterblich. Und so lehrte He rak lit die Gottwerdung des Menschen und die Menschwerdung Gottes.

\section{e) Empedokles.}

In der Gestalt des Empedokles findet sich zum erstenmal eine Verbindung der mystisehen und magischen Tendenzen. Er ist ein großer Wundertäter und Arzt, Prophet und Herrscher. Der hohe Stolz des Magiers ist ihm eigen und die Úberzeugung ron der Einzigkeit und Schönheit seines Wesens. Er hat die Gewißheit seiner Kraft. Er weiß, daß er die Körperliehkeit überwunden hat, daß er zum letztenmal auf Erden weilt in sterblicher Hülle, daß seine große und starke Seele den Weg zu höheren Welten zurückkehren wird. Wie ein Gott schreitet er durch die Lande, mit Kränzen schmückt man ihm und Tänien das stolze Haupt. Tausende folgen ihm nach, den Weg des Heils 
zu erkunden. Man betet ihn an - und das mit vollem Rechte. Ist er doch so viel mehr wie sie, die sterblichen, dem Verderben geweihten Menschen.

Er weiß, daß er zu den Dämonen gehört, den Auserwählten, die ein ewiges Leben erlost haben. In sich spürt er die große Macht des sieghaften dämonischen Seins. Dieses irdische Leben kann ihm niemals zu danernder Heimat werden. Er geht durch diese Welt als ein Wanderer der fernen Heimatwelt zu. Das irdische Schicksal, was seine Augen hier erschauen, dieses Kommen und Gehen schwacher Menschlichkeit, dieser kurze Gang zwischen Anfang und Ende, dieses Gebundensein an die plumpe Sinnengestalt - natürlich und selbstverständlich ist es für die Armen und Elenden, über die sein stolzer Blick mit Vitleid dahingleitet; aber ihm ist dieses Dasein so wenig angemessen, daß er es als vollkommene Fremdheit empfinden muB.

Das irdische Leben, was für jene natïrlich und selbstverständlich ist, das ist für Empedokles Strafe und BuBe für begangene Schuld. Er weilte im Lande der Seligen. Damals ist seine ungestüme Kraft in Gegensatz geraten zu dem Einheitsprinzip der Dinge. Und num mußte der stolze Dämon eine Fülle sinnlicher Verwandlungen durchleben. Er bewohnte den zarten Leib eines Knaben und Mädchens. Er war Pflanze und Vogel und flutentauchender, stummer Fisch. Aus den seligen Gefilden verbannt und verstoßen, führt er in überdachter Höhle ein freudloses Dasein. Wie viel mehr muß er clen Schmerz des simnlichen Daseins empfinden, da er die Ermnerung an ein höheres Leben bewahrt hat.

Er war ein Herrscher im Reiche der Liebe. Ein Mamm von übermenschlichem Wissen. Alle Kräfte des Geistes waren ihm untertänig, und mamigfacher Künste war er mächtig. Und wenn er sich anf seme mannigfachen Geisteskräfte besann, die ihm auch nach seiner Verbannung aus dem Lande der Seligen erhatten blicben, dann schante er in zehn oder zwanzig Menschenleben, durch die ihn sem dunkles Schicksal geleitete, jedes einzelne Ding in der ganzen $W^{2}$ elt. Ein heiliger und nnaussprechlicher Geist ist die Gottheit, der mit schnellen Giedanken den ganzen Weltban durchfliegt, und der große Magier ist cin Fürst im Reiche des Gedankens und so dem göttlichen Wesen auf das innigste rerwandt.

Jas Schicksal der meisten Mensehen ist Sterblichkeit, absolutes Vergehen odor ein ewiges Wandern durch das Reich niedriger simmlicher Gestalten. Jene abrar, denen ein unsterbliches Los beschieden ist, sie müssen sich anch in ihrem irclisch-sinnlichen Dasein in der Eigentümlichkeit ihrer höheren Lebensform darstellen und offenbaren. Ind so erseheinen sie unter den Mensehen als Seher und Sänger, als Ärzte und Fürsten mol wachsen 'mpon zu Göttern, zu Organen mal Gliedern des einen ungetcilten Weltwesens.

Neben dem Magier kommt aber in Empodokles auch der Mystiker und Prophet zur sijuche. Vor allem in der Fileo des Spheiros, jener absoluten,

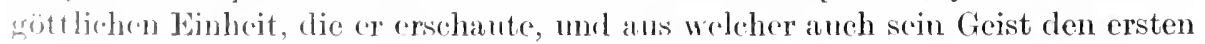

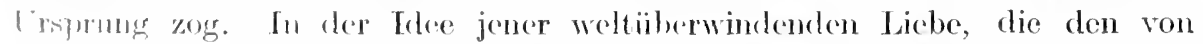

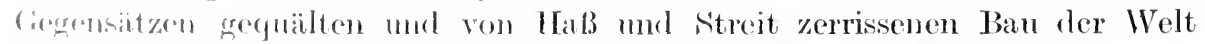

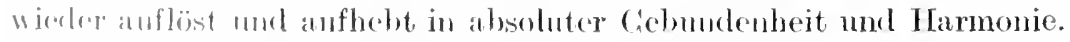

lint w will anch nicht, wie die anderen Stolzen und Einsamen, die ihm heschioflemen Giiter des Godstes vollkommen für sich bewahren mnd behalten. 
Es drängt ihn zur Mitteilung und Verbreitung. Allerdings ist es schwer zu entscheiden, was ihn zu den Menschen geführt, ob er als Gott die schuldigen Opfergaben verlangte, die Huldigungen, die seincr Schönheit zukamen, oder ob der Liebe mächtiges Prinzip ihn zur Hilfe drängte. Ihm, dem Wissenden, mußte es ja Schrecken und Entsetzen erregen. wenn er die blutigen Opfer unter den Menschen sah, die nicht darauf achteten und nichts daron wußten, daß sie vielleicht mit dem Blut des Tieres, das sie rergossen, die schwere Tat des Mordes an Vater und Sohn verübten, da es ja nun einmal der mensehlichen Seele beschieden ist, immer zu wandern. Helfen kam Empedokles den Menschen, ihr Los erleichtern, ihre Krankheiten heilen und sie vor blutigen Taten bewahren. Das Götterlos aber, das ihm beschieden ist, trennt ihn doch von jenen Armseligen gar weit und reiht ihn ein in die unsterbliche schar der Heroen und Dämonen.

\section{i) Aristipp.}

Die Kraft des Magiers strebt zum höchsten Herrschertum empor und duldet keine Macht des Himmels und der Erde über sich. Dicse stolzen Seelen geben sich niemals auf und hüten und bewahren der Vernunft heiliges Fener. Wenn num das Streben nach Gottähnlichkeit sie zu dem Wunsche des Gottgleichseins führt, so kann es auch geschehen, daß die große Erhebung ihrer Seele, die an die Pforten der Geisteswelt pocht, den Himmel leer findet. Es kann sein, daß der Magier zu der Auffassung kommt, daß es nur ein irdisches Götterleben gibt, und daß er sich darauf beschränkt, der Fürst und Gott dieser Welt zu sein. Aller metaphysischen Träumereien bar und ledig. kann sie die Heiligung und Werthaltung ihrer Individualität dahin führen, ein großes. starkes Leben zu leben, das seine Schönheit entfaltet im Rausch der Lust. So hat Aristipp jede Bindung rersehmäht, er wollte nur binden, aber nicht gebunden sein; und schaffend Götterleben wollte er genießen in den großen Momenten des Augenblickes. Er hatte das Leben erwogen und durehdacht mit all seinen Schrecknissen und Gefahren, mit Krankheit, Mühe und Tod. Die große Kraft seiner Seele konnte das alles ertragen und ïberwinden. Deswegen hat er das Leben bejaht, sofern der Weise und Mächtige die Möglichkeit besitzt, es lustroll zu gestalten. Die große tiefe Lust hat Aristip p bejaht und sie als verdientes Geschenk der Vernmft betrachtet. Die Herrlichkeit des Geistes ist es wert, daß ihm die schöne Simnlichleit huldigt. Das Leben der homerischen Götter in ihrer Sorglosigkeit und Ungebundenheit, das nahm er für die Starken in Anspruch, die Herren und Fürsten der Lust. die ihr nicht nach Sklarenart huldigen, sondern ihr Herz so gut bewahren, daß sie mit den schönen Gestalten des Lebens nach ihrem Wohlgefallen verfahren können.

\section{g) Die Stoa.}

Werfen wir noch einen Blick auf dic Nachfolger des Heraklit in seiner Lehre vom göttlichen Logos, auf die Philosophen des römischen Weltreiches, auf die Stoiker. Wie mächtig ist doch in ihnen der religiöse Nagier! Hoch iiber alle irdische Gemeinschaft erhebt sich der göttliche Weise. Der Weise ist ein König, ein Gott, der Herr dieser Erde. In ihm ist der Logos wirklich. 
Geschieden ist er durchaus von den schwachen vernunftlosen Mensehes, der großen Zahl der Toren. Der Weise ist absolut gut, alle anderen Menschen sind absolut sehlecht. Gewaltig ist seine Kraft. Hervorzaubern kann sein Wille aus dem Innersten der Seele die starke, mäehtige Lust, und derselbe Wille kann den gewaltigen Schmerz siegreich überwinden. Und so übt der religiöse Magier den Zauber aus, der auf Kraft beruht, und ist so stolz, daß er sich niemals beugt, und so stark, daß er sich niemals aufgibt. Wandelnd im ruhigen Licht der Vernunft, bejaht er diese Welt als den Sehauplatz seiner Taten. Er ist der Fürst dieser Welt, der zum Gott werden will. Deswegen ist er dem Mystiker Teufel.

\section{h) Anfäuge der Mystik.}

Gegeniiber der großen Entfaltung des magischen Erlebens und der Maeht seiner Gestaltung hatte die mystische Seele bisher nur ein stilles und verborgenes Dasein geführt. Aber ihr bloßes Dasein war schon ein leidenschaftlicher Protest gegen die Sichönheit, die Kraft und den Stolz des religiösen Magiers. Sie konnte nicht ertragen diese Weltbejahung und Selbstbejahung, diesen Kultus der Individualität, diese Heiligung des eigenen Lebens anch in der Begrenzung und Abgelöstheit von der Gottheit. Die mystisehe Seele wollte sich ja im Gegenteil aufgeben und verlieren, sich wegwerfen und begraben lassen in der leeren und wïsten Gottheit. War doch die Gottheit für die Mystik die Armut, die sich vollkommen entäußert hatte und alles fortgegeben und verschenkt, die in überströmender Fïlle gibt und gibt und nichts für sich behalten will und kann. Ist doch nach der Auffassung des Mystikers mit der Gottheit die Sehnsueht verbunden, sich zu offenbaren und allen etwas zu sein und niemand zu vergessen. Für den königlichen Magier ist Gott der Erste unter Gleichen, naeh der Auffassung des Mystikers ist Gott der Herr und die Seele ist Gottes Kneeht, welche ihm die frommen Gesehenke der Demut weilıt. Das Verhältnis, welches der Magier zwishen Gott und seiner auserwählten Sehar und der großen Menge der armen vernunftlosen Mensehen daehte, das setzte der Mystiker zwischen dergottliebenden und gottgeliebten Seele: das VerhäItnis von Herr und Knecht. Und doch ist das Verhältnis von Herr und Knecht, wie es die Mystik und die Magie denkt, auch wieder grundversehieden. Für den Magier sind die Knechte die Unwissenden, die kein Vertrauen verdienen, denen das Vertranen gefährlich ist, die in Unmündigkeit erhalten bleiben müssen. Für den Mystiker ist der Knecht der gute und getreue, der verstehende, dem die Got theit nichts vorenthält, und der dieses Vertrauen durch Dienst und Demut entgilt. Nach ler Lehre der Magic ist der Herr der Fremde und Finsame, nach der Lehre der Mystik der Nahe und Gemeinsame.

Die mystische Secle suchte anfangs einsame Kroise und entfernte sieh von fror Wolt. In den ituon dor optischen und elewsinisehen Mysterien ward ihr Nahrung und Lchensgehalt zuteil. Uralte orientalisehe Vorstellungen ragten in diese Melt der Mysterien hinein. Vor allem die Lehre, daß die Unseligkeit des Mensehen in der Individuation und persönlichen Gestaltung seines Daseins linge. Die Ahlösmng des Endlichen von dem Alleinen, mit der die Bejahung der simnlichrn Tudividualität unserer Gestalt zusammengeht, gilt der mystisehen Ścole als siimle mul Sichuld. Alle Unseligkeit der Welt ist Folge dieser Endlieh- 
keit und Trennung. Und so muß das Bestreben des Mystikers darauf gerichtet sein, die Endlichkeit und Trennung zu ïberwinden. In der klaren appolinischen Gestaitung des Lebens, die nach Form und Grenze strebt, in der Besinnung auf die Eigentümlichkeit des persönlichen Seins, in der Freude an der Buntheit, Mannigfaltigkeit und Fülle, in der Strenge und Herbheit des rationalistischen Unterscheidungsverlangens, das in Kultus des Begriffes zum Ausdruck gelangt, in alle diesem droht der gottähnlichen Seele Gefahr. Sie muB in der Gemeinschaft mit dem Göttliehen und zugleich auch mit den anderen Seelen verharren, und wenn num einnal diese Bande gelöst sind, so muß ihr ganzes Bestreben darauf gerichtet sein, den verlorenen Zusammenhang wieder herzustellen. Das kann aber am besten geschehen, wenn die Leidensehaften und die Affekte erregt werden und nun die Phantasie ihr großes Spiel beginnt. Die große Welt der Gefühle ist auf das Chaotische und Grenzenlose gerichtet und wendet sich von der unruhigen Welt begrenzter Vorstellungsbilder ab. Der Rauseh, der die Sinne verwirrt und die Gestalten verschwimmen läßt, führt die getrennten Verehrer des Gottes zu einem großen Einheitserlebnis zusammen, und in der Einheit dieses Erlebens stellt sich die Lreinheit des einen göttlichen Lebens wieder her, und die Seele genießt die Seligkeit der göttlichen Einswerdung.

Nur leise und schüchtern ist die Stimme der Mystik in der griechischen Welt zu spüren. Von all den großen Denkern der Hellenen, von all den mächtigen, charaktervollen Gestalten, die aus dem Leben Griechenlands hervorgegangen sind, scheint nur Anaximander noch am ehesten als Mystiker bezeichnet werden zu könmen. ther die Daimonionslehre des Sokrates bebt ein mystischer Hauch, in der platonischen Liebe weht ein verwandter Geist, aber vieles andere rückt diese Denker weit von der Mystik ab. Anaximander abel hat als den Ursprung der Dinge das Unendliche gelehrt und die Trennung des Endlichen ron dem Allemen als Sünde und Ungerechtigkeit empfunden. Für diese Emanzipierung muß das Endliche Strafe erleiden, und diese Strafe ist der Weg der Rückkehr zu Gott. Das kleine Fragment, das uns ron ihm geblieben ist, läßt den Sinn seines Weisheitsspruches nicht ganz erraten. Daß unsere Unseligkeit in der Trennung ron Gott beruht, ist deutlich. Das Indiriduum ist nicht von Gott geschaffen. Er hätte es auf immer in liebender C'marmung aufbewahrt. Wenn es nach ihm gegangen wäre, so wäre die Einheit des Menschlichen und Göttlichen bestehen geblieben. Die beiden hätten sich nicht getrennt. Aber das Individuum hat die Trennung von Gott gewollt, und diesem Willen konnte und wollte die Gottheit nicht widerstehen. So ist das Individuum einsam geworden. Das sind gewiß alles Gedanken, die dem Mystiker mehr oder weniger eigentümlich sind. Aber vollkommen fremd ist ihm die Vorstellung, daß die Rüekkehr zu Gott eine Strafe sei. Muß er doch in der Einswerdung mit der Gottheit die höchste Seligkeit erblicken.

Dem Mystiker gilt die Betonung der Individualität als Sündenschuld. Sündhaft ist die Ablösung ron dem Alleinen. Das Gewordene verdankt sein Gewordensein einem Unrecht, einer Schuld. Diese Schuld wird als Auflehnung, als Empörung gedeutet, als sündige Liebe, als das Bestreben, wissen zu wollen rom Urgrund des Seins, also als Schuld der Erkenntnis. Wie viel Deutungen dieser Abtönung und Trennung hat der religiöse Mystiker doch versucht. Ein strenger Richter war er, wenn ihm das Wesen der Individualität als das sündige 
Streben exschien. Gott gleich zu sein, oler auch, wenn er erschaute den unbesiegbaren Hang, an das große Geheimnis der Welt zu rïhren und Geliebter sein zu wollen, wo stilles Dienen ziemt. Aber wie zahlreich auch die Dentungen waren, durch welche der Mystiker das Geheimnis der unseligen Individuation sich verständlich zu machen suchte: Hochverrat, sündige Liebe, pietätloser Rationalismus — sie ror allem sind des Magiers Schuld.

\section{i) Christus.}

An der Scheidegrenze von alter und neuer Welt steht die Gestalt des göttlichen Menschen, in dem die mystische Sehnsucht ihre erste große Erfüllung fand. In ihm wurde das geheime Verlangen des religiösen Mystikers zum deutlichen Wert und zu zwingender Macht. Hier hat die mystische Sehnsucht ihren absoluten Ausdruck gefunden in dem Wollen und Vollbringen des Opfers, in der völligen Hingabe an Gott. In ihm ist der Gedanke der ungöttlichen Trennung, die Schuld der Indiviєlualität überwunden. Bleibt doch die reine, die heilige Seele unlöslich mit Gott rerbunden, sie, die selber göttlich ist. Sein Kommen bedentet keine Trennung, sondern vielmehr Aufhebung aller Tremmung und absolute Vereinigung. Der große Liebesgang der Seele kennt keine Fremdheit und Entfremdung. Dem Menschlichen nicht fremd und dem Göttlichen nicht entfremdet. Absolute Menschemähe und absolute Gottesnähe.

\section{k) Verticfong des religiösen Bewußtseins.}

Bevor wir nun die Entwicklung ron Magie und Mystik in der modernen ehristlichen Welt betrachten, müssen wir noch jener anderen Überwindung der homerischen Götterwelt gedenken, die darin besteht, daß zwar die Idee der Abgeschiedenheit und Begrenztheit aufrecht crhalten wird, das Göttliehe aber aller sinnlichen Bilker bar in seiner höchsten Reinheit verstanden werden soll. J)as Fortschreiten von der simnlieh-körperlichen Gestalt des Gottes zu seiner absoluten geistigen Reinheit hin, diese Bewegung darf nicht so aufgefaßt werden, als ob sich darin lediglich ein Fortschritt des wissenschaftlichen und philosophischen Denkens offenbarte. Hier handelt es sich vielmehr in der Hauptsache um eine Verticfung des religiösen Bewußtseins. Der Intellektualismus ist ja geneigt, zu meinen, daß jede Bewegung des religiösen Bewußtseins gleichbedeutend sei mit seiner L'msetzung in wissenschaftliches Denken, und den roligiösen Vorstcllungen kann er keine andere Bedeutung beimessen, als daß darin die Lebensideale einer Zeit oder eines Volkes sich ausdrücken, so etwa in den homrrischen Göttern das Ideal der Kraft und Schönheit, in dem Begriff der aristotelischen Gottheit das Ideal des kontemplativen Vernunftlebens, in ('H listus das Idral dor Weltflucht mol Entsagung. Dem gegenïber ist festzustellon, dals die höhere mud reinere Auffassung ler Gottheit, wie sie sich im ('hristentum gegrniiber der homerischen Götterwelt offenbarte, die Idee der

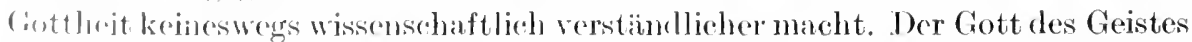

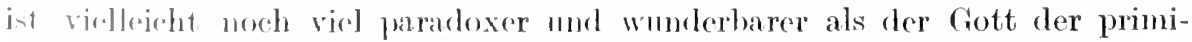
tivn Simonmensehen. Die Irlee ciner mendliehen Persönlichleit ist weit sohwerer \%u verstrlen als dir vätrerliche Gostalt des wolkenersehüttenden

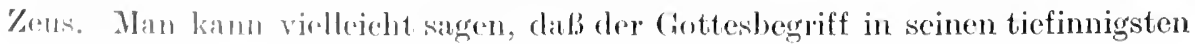


und wertrollsten Formen für das wissenschaftliche Denken am unbrauchbarsten und unsimnigsten gewesen sei. Ferner wird Gott keineswegs immer als Lebensideal in dem Sinne gedacht, daß wir werden sollen, was er ist, oder daß wir wünschen, ihn zu erreichen. Das ist lediglich das Magicrs Art und Verlangen. Für andere Formen des religiösen Bewnßtseins ist Gott gerade das, was nicht erstrebt und erreicht werden soll.

\section{l) Plato.}

Die Erhebung des Göttlichen ïber alles Simnliche hinaus unter Bewahrung ihrer Begrenztheit und Abgeschiedenheit hat sieh in der religiösen Vorstellungswelt Platos vollendet. In den Ideen ist die Götterwelt Homers sublimiert. Sie bilden ein Reich ïbersimnlicher Gestalten. Jedes simnlichen Wirklichkeitscharakters beraubt, dürfen sie weder psychisch noch physisch gedacht werden. Sie haben weder Verstand noch Wille und keine Kraft in materieller Hinsicht. Diese Welt übersimnlicher Gestalten ruht in sich, vollkommen mangellos und vollendet. Alle Schönheit und Herrlichkeit behält sie für sich, und der menschlichen Seele ist nichts anderes beschieden als ein Schanen des Göttlichen von ferne. Dies platonische Schauen ist von dem Schauen des Mystiker: durchaus verschieden, denn Platos Schauen ist ein Schauen des Gestalteten, die des Mystikers aber ein Schauen des Ungestalteten.

Wenn die Seele von der Last der Körperlichkeit befreit ist, dann wird sie die seligen Gestalten im Seelenlande weit heller und ungetrübter und häufiger erschauen als im irdischen Leben, wo nur in seltenen Feierstunden des Geistes dem Blick des starken religiösen Menschen die übersinnliche Welt ihr Geheimmis preisgibt. Niemals aber betritt die Seele das Land der heiligen Gestalten. Von ihnen ist sie ein für allemal ausgeschlossen, und die Ideen betreten auch nicht diese irdische Welt. Wohl vermag die Liebe bis an die Schwelle dieses Ideenlandes vorzudringen, aber der Eintritt ist ihr verwehrt. Sie ist der Mittler zwischen den Welten, aber im Grunde heimatlos, da sie weder jener noch dieser Welt angehört.

\section{iI) Aristoteles.}

Über alle Maßen groß und einsam hat damn endlich Aristoteles das Göttliche geschaut. In seiner Lehre ist die Vielheit der göttlichen Gestalten, wie sic Plato gesehen hatte, vollkommen untergegangen. An ihre Stelle ist das eine göttliche Weltwesen getreten: der in sich versunkene denkende Creist, der nur mit sich beschäftigt ist, vollkommen unbekümmert um die Welt, das großc Geisteswesen, welches der sehnsïchtigen Liebe, die aus den dunklen Gründen der Materie ihm entgegenstrebt, keine Gegenlicbe entgegenbringt. In dieser Vorstellung von Gott als eines denkenden Weltgeistes hat sich die Religion des Griechentums vollendet. Es verkündete in seinem größten Denker die außerweltliche, überweltliche Gottheit, deren Wesen Geist und ein großes Verstehen ihrer selbst ist.

\section{n) Der synthetische Charakter der christlichen Welt.}

Die moderne christliche Welt trägt bis zum Beginn der Renaissancebewegung in der Hauptsache einen synthetischen Charakter. Hatte sich bisher 
in immer steigendem Maße eine Differenzierung der Kulturwerte vollzogen, so strebte die Menschheit nummehr nach einer Organisation des als vernünftig Erkamten. Und zwar geschah dieses, indem man unter der Herrschaft des religiösen Wertes ein einheitliches System zu begründen suchte. War in der griechischen Kultur das theoretische und ästhetische Interesse am stärksten zur Sprache gekommen, so war es 11 m der religiöse Wert, dem die entscheidende Bedeutung beigemessen wurde.

\section{o) Die Lehre Christi.}

Die christliche Lehre, ron welcher die große Umwertung der Werte und der erste mächtige Versueh ihrer Einigung ausging, stand anfangs im Gegensatz zur Kultur. Hatte doch ihr Stifter eine Jüngerschaft und diese Jüngerschaft eine Gemeinde begründet, die täglich und stündlich seine Wiederkehr erwartete. Erwar ron ihnen gegangen, um bald wiederzukehren, und seine Wiederkmuft sollte das Ende dieser Simenwelt bedenten. Groß in ihrer Hoffnung waren sie, diese ersten Christen, und groß in ihrer mystischen Todessehnsucht. Die Liebe zu dem erlösenden Heiland war so groß, die Gewißheit des Glaubens so stark, die Ungeduld, ihn wiederzusehen, so allgewaltig, daß sie mit Frenden len Märtyrertod erhitten, nm nur bald, recht bald wieder bei ihm zu sein. Seine Liebe hatte ihmen das große Wiedersehen und die Einheit des Getrennten in seliger Gemeinschaft gelehrt. Sie fühlten sich als Glieder, ihn als Haupt und wnßten, daß ihnen dereinst eine große und herrliche Schau beschieden sein würde als Entgelt und Ausgleich für ein trübes und schweres Erdendasein. Sie wuBten, daß er kommen würde, wm sie von allen Schrecken der Welt, besonders aber von der Macht des Todes zu erlösen. Das große Gesehenk seiner Liebe für sie sollte die Unsterblichkeit sein.

Seine Lehre, die so nen und tief med rein religiös war, brach mit derästhetischen Vorstellung des weltabgeschiedenen, unlekïmmerten Gottes und machte ladurch der Mystik freie Bahn. Sie brachte den Monotheismus zur Vollendung, indem sie ihn mit der Idee ker Mensehheit verband. Er machte die Vorstellung von Gott so reich, indem er in immer nenen Gleichnissen sein Wesen schilderte, und ließ ihn dam anch wieder ganz verschwinden hinter der einen uroBrn Vorstellung der Liebe. Diese Liebe aber, wie er sie meinte, sollte im Gegensatz zur platomischen Liebe jeder Simnlichkeit entbehren, und um sie in ihrer schlichten reinen Geistigkeit flentlich zumachen, verglieh er sie mit dem Verhälnis der Väterlichkeit, Brïlerliehkeit und Schwesterliehkeit, Kindlichkeit. Die diebe des zens zu Gan ymed ist nicht frei ron simlichem Begehren, und ler platomische Eros zittert vor vorhaltener Glut, Simliehes und Geistiges verbintend; die Liehe aher, die er gelehrt, ist cine kensehe weiße Opferflammone.

Lr war der grölote Prophet, den die Mensehheit gekamt hat, dem er war ganz thingathe mut Opfor. Er wollte alles geben umd versehwenden, er wurde nicht mül, im Austoilon. Keiner hat so herrlich wie er emen köstlichen Besitz verschweludet. Als rer alles gesagt hatte, was er sagen durfte, und nur wenig zuriarkhehalton, was or dem Verstehen seiner Jïnger nieht zugängig machen konnte, dat hat or anch sein Leben geopfert met hingegeben. Er starb als Prophet 
einer neuen Botsehaft, die dahin lantete, daß Gott den Mensehen nieht entgegenstünde wie der Herr dem Knecht, sondem wie der Vater den Kindern. Er hat die Schranke, welehe die alte Kultur zwisehen Mensch und Gott in ihrer ganzen Vorstellungswelt errichtet hatte, endgültig zerbrochen. Er hat ein ganz nenes Verhältnis unter den Mensehen begründet, indem er ihnen sein großes Gebot der Liebe gab.

Zwei große Symbole, die ihm umsehreiben, und die von mendliehem Wert für die Mensehheit gewesen sind, Symbole voller Rätselhaftigkeit und Tiefsim sind die Gottmenschheit und die Idee des stellvertretenden Opfers. In dem Symbol des Gottmensehen ist die Idee der Versöhnumg des Endliehen mit dem Unendlichen ausgesprochen. In ihm ist gegeben, taß die strenge Scheirhung des Mensehlichen und Göttlichen überwmiden ist. Das Unendliche ist auch zugleich das Endliche, und das Endliche und Begrenzte hat an dem Unendlichen und Göttlichen teil. In der Idee des stellvertretenden Opfers ist das religiöse Prophetentum zum vollendeten Ausdruck gebracht. Das Wesen des Propheten bestand ja darin, daß er das wertrolle Leben nieht fü sich behielt. sondern austeilte und versehwendete, daß er nicht wie der Herrscher die Isolation und Abgeschiedenheit betonte, sondern das Mensehliche als absolute Einheit empfindet und nicht nur in sich, sondern anch in anderen lebt. Betont der Prophet in dieser Weise die Einheit des Menschengeschlechts, so macht er sein Sehieksal mit dem Sehieksal der Gesamtheit solidarisch. Damn sind die Schwäehen der anderen Mensehen anch die Sehwächen des reinen und starken Propheten. Er nimmt sie anf sich, weil sie seinem großen Verstehen des Lebens gemäß der Sehieksalsanteil der Gesamtheit sind, und er trägt dort, wo andere nieht mehr tragen können. In der Idee des stellvertretenden Opfers versehwendet sieh somit das Göttliehe an das Mensehliche aus einem großen Liebesgefühl und Einheitsgefühl heraus.

Dem großen Propheten und Mystiker tritt an der Scheidegrenze beider Welten noeh einmal die dumkle Gestalt des Magiers in Judas gegenüber. Thn muß esmbegreiflich und höchst verwerflich dünken, daß Christus das Sehöne so versehwenden komnte. Ihm muBte es verkehrt mud sïndlaft erseheinen, daß jener die Individualität so sehr herabsetzen und verneinen kounte. Er vermochte jene große Erlösertat nieht zu verstehen, die mit den Verantwortliehkeitsgefühl für das Ganze die liebende Hingabe an das Einzelne rerband, und daß der Herr jenes Reich verneinte, das er im Simne ler alten Messiasidee bejahen sollte. Und weil er die Natur des Propheten nieht verstand und anerkemen konnte, so kränkte ihn der Verrat, der an der Idee des religiösen Herrsehers verübt wurde. Und so beantwortete er Verrat mit Verrat und verband sich mit den Gestalten der Finsternis und den rohen Söldlingen der Gewalt. Vielleicht wollte er den religiösen Propheten zwingen, sich auf seine Herrseherwürle zu besimnen. Aber seine Secle komnte die Ablösmng rom Messias nicht ertragen, mid so starb er den Tod der Verzweifhung.

Die große Tat des freiwilligen Opfertodes, wie ihn Christus erlit, erseheint als etwas Ungeheures in der Gesehichte des religiösen Bewnßtseins. Noeh niemals war das religiöse Einheitsgefühl in stiner hingebenden Demut so mächtig hervorgetreten wie in Jesus ron $\mathrm{N}$ a zareth. In der Idee seiner Lehre und seines Lebens waren alle Sehranken zwisehen Menseh und Gott und Menseh und 
Mensch aufgehoben. Und das eine, was alle verband oder verbinden sollte, namnte er mit dem großen Namen der Liebe. Bebte somit das Leben vor den Schuldigen zurück und verlangte ihnen gegenüber sein Recht, so konnte dieses Leben die Schuld seiner Mörder und Verfolger nur als eigene Schuld verstehen, die er zu büßen hatte. Die platonische Liebe ist bereit, ans Liebe zum Geliebten den Tod zu erleiden, und Sokrates starb den großen Tod einer sittlichen Úberzeugung. Der Prophet von Nazareth aber stirbt nicht nur in der Liebe für die Geliebten, sondern in der Liebe für das Ganze, in dem menschliche Engherzigkeit erst das Geliebte ron dem Ungeliebten seheidet.

Sie aber dachten, er wollte Israel erlösen. Sie dachten an die Erlösung der Welt und speziell der klemen jüdischen Welt, er aber an die Erlösung von der Welt. Ihre Vorstellung von der Erlösung war sehr einfach und primitiv. Sie dachten, daß er Israel heilen würde von allen Wunden, die ihm das Schicksal geschlagen. Sie dachten, daß er die alte Herrlichkeit des Reiches Darid wieder herstellen würde, und daß er selber die Krone dieses Reiches trüge. Sie erhofften im Messias den neuen König von Isreal. Alles Elend ihres Volkes schoben sie dem Römertume zu. Nach der Herstellung ihrer politischen Freiheit würde alles gut sein in der Welt, so meinten sie. Er aber hatte der Welt Elend und ihre Ungöttlichkeit eingesehen. Er hatte sich im harten Kampfe von ihr losgerissen. Er hatte die Welt überwunden. Indem er sie aber überwand, ïberwand er sie auch für die Seinen, die er liebte und trennte auch sie von dem bloßen Diesseits dieser Welt, indem er sie dem Úbersinnlichen vermählte.

Die prophetische Natur eines Anaximanders hatte in der Tremnung des Endlichen rom Unendlichen die Unseligkeit der Welt erkannt. Aber des großen Griechen Seele bejahte die sündige Individualität als schön in der starken Gestaltung ihres persönlichen Daseins. Deswegen war ihm die Erlösung im Sinne einer Befreiung und Erhebung fremd. Rüekkehr der Individualität zum All des Unendlichen ist Strafe für schwere Schuld : der unselige Leidensweg der unseligen Dinge. In den Mysterien jauchzte die Seele auf im kurzen Rausch der Befreiung, um nur zu bald wieder ron neuem die große Last der Erdenschwere zu empfinden. Sokrates-Plato hat das sehöne Sinnendasein als Hemmnis für das Erkenntnisleben empfunden, aber die große Negation an der Diesseitigkeit hat er nieht vollzogen. Buddhas Heldenseele hatte das Elend der Welt tief gefühlt und einen Weg der Befreiung gewiesen von ler Dinge täuschendem Wahn, die dem Prinził der Kausalität unterliegen. Doch konnte er nur von den Dingen befreien, nicht zu nenen Dingen die Seele führen. Nach der Verneinung der Diesseitigkeit sah er sich einsam dem Nichts gegenüber. In dieser "Gottlosigkeit" des Buddhismus offenbart sich der 'T'rimmph der Magie.

Er hatte gesagt, daß or gehen wïrde, um ihnen clie Stätte zu bereiten. Er wolle wielerkommen, um sie zu führen, und sie klammerten sich an die Konkretluat seincr Symbole nud Gleichnisse, in denen er sein göttliches Wesen offenbarte. 'Tiefe Einsankeit unfing sic bei scincm Seheiden, und sie erlahmten fiir alles 'Tun. Nur der Frinnerung lebten sie und in der Erwartung der nahen Erfïllnng. Nur dio Schönheit und Wirklichkeit ihres religiösen Lebens spürten sic. Nir ron ilm waren sic arfiillt. Alles andere Kulturleben muBte ihnen 
als unbedeutend, ja als verwerflich erseheinen. Die Religion war für sie das einzige Kind Gottes.

\section{p) Das Johanniserangelium.}

Als er aber nicht wiederkehrte, wie sie es erwartet hatten, suchte das religiöse Bewußtsein der Gemeinde einen Ausdruck in Wort und Schrift, um festzuhalten, was er gelehrt, um seine Offenbarmng aufzubewahren für das Gedächtnis aller Zeiten. So imnig aber fühlten sie sich mit ihm rerbunden, da $B$ sie nichts Selbständiges zu sagen vermeinten, sondern nur das, wozu sie sich getrieben fühlten durch seines Geistes Kraft. Nur einer crscheint selbständiger unter ihnen: der Verkïnder des Johannisevangeliums. Er gehörte wohl zı denen, die den Geist des Christentums mit dem Geiste des Gricchentums versöhnen wollten, und so schmückte er die geliebte Stim des Meisters anch mit dem Diadem hellenischer Anmut und Wïrde. Er erkennt in ihm das Prinzip der Welt, das in inniger Vereinigung mit Gott alle Dinge geschaffen hat, und erhebt ihn so, wie es scheint, in eine Sphäre überpersönlicher Bedentung. Er war ron Anfang an, bevor die Sinnenwelt geworden, und wird sie überwinden und ïberdanern. In ihm ist die Vernunft der Welt. der heilige Logos, zur sinnlichen Wirklichkeit geworden. So ist er das Unendliche, das im Endlichen erscheint, oder auch das wahrhaft Endliche. das Freie und absolnt Persönliche. das von dem wahrhaft Unendlichen zur schlechten Unendlichkeit der simmlich bestimmten. Dinge die Brïcke schlägt, der Mittler zwischen den Welten, dessen Geist die Liebe ist. Er ist nicht nur ein religiöser, sondern anch ein philosophischer Prophet und ein Held und König. Seine Liebe gehörte der gesamten Menschheit, aber diese Liebe strömte nicht mit gleichmäßiger Milde übcr alle aus. Der Gottmensch muBte sich das heilige Recht der Persönlichkeit bewahren, Unterschiede und Stufen der Liebe zu setzen, und diese persönliche Liebe ist nicht nur ein Zeichen seiner Menschlichkeit, sondern gleichfalls eine Offenbarung seines göttlichen Wesens. Ubberwindung aller Grenzen durch die Liebe ist sein Lebenssim. und demnoch bleibt ewig wertroll anch gerade das, was von der Persönlichkeit seiner Gestalt ausgeht, die Innigkeit, mit wetcher er die Seinen mmfaßte, besonders aber jene sanfte Jünglingsgestalt, die seinem Herzen am nächsten stand: sein Johannes-Jünger.

\section{q) Die Idee des tausendjährigen Reiches.}

Als nun das religiöse Bewnßsein in der Wiederkehr des Herm nicht die ersehnte Erfüllung fand, verfiel es auf die Idee des tausendjährigen Reiehes. um die Gestalt des Gottmenschen und sein Verhältnis zur Welt sieh deutlich zu machen. Der Gedanke dieses Reiches ist durchaus religiöser Natur. In ihm ruht die Erwartung und Sehnsucht nach Heiligung und Tollendung. Daß er wiederkehren würde, stand nach wie vor für das religiöse Bewnßtsein fest, aber nicht sogleich, sondern erst nach tausend Jahren. Dicse tansend Jahre waren notwendig, um ein Werk zu besehließen, das von dem Gottmenschen erst begonnen war. Die Tremnung von Gott und Menseh war anfgehoben, das Himmelreich nahe herbeigekommen, das religiöse Leben hatte seine Vollendung gefunden. Aber noch fehlte die Ausbreitung, die Verkïndigung der Botsehaft 
im sinne der religiösen Prophetie. Die Idee des tansendjährigen Reiches riß den engen kontemplativen Kreis der Getreucn auseinander und machte sie zu tatenstarken Verkïndigem seines Wortes. In ihrem menschlichen, dureh seinen Geist geleiteten Tum erstand ein Reich und eine Herrschaft, deren Geist und Charakter ursprïnglich vollkommen unvereinbar war mit dem Charakter dieser Welt.

\section{r) Dic Idee des dritten Reiches.}

Die Idce des dritten Reiches hat die des tausendjährigen abgelöst. Das tauscndjährige Reich sollte das Reich Christi bedeuten, sofern es auf Erden in Erwartung eines feierlichen und crschnten Unterganges vorübergehende Gestalt gewann. Das dritte Reich ist ein Zugeständnis an Geschichte und Kultur. Nummehr galt Jesus von Nazareth nicht mehr als Vollender des religiösen Lebens und die Religion anch nicht mehr als die einzig wertvolle Form der Lebensgestaltung. Immer wieder kchrt das Göttliche bei den Menschen ein, und je mehr es sich offenbart, um so mehr schwindet die Tremnung zwischen den Welten. Christus hat die zweite große Form der Vermunftoffenbarung gegeben, deren Charakter in der Hamptsache einen Appell an das sittliche Bewußtsein bedeutet. Ein neues höheres Evangelium des Geistes stcht noch bcvor. Erst mit ihm waht sich der Welt Ende.

Wir stehen hier vor einem schweren Konflikt in der Entwicklung des religiösen Lebens, der eben damn sich so scharf geltend machte, als dieses gewissemaßen einen absoluten Charakter gewann. In der Gestalt Christi lag der Hinweis anf die Geschichte, sofern er die Idee der Menschheit, die fïr jede geschichtsphilosophische Überlegung merläßlich ist, durch den Gedanken der gemeinsamen Gotteskindsehaft znerst enthiillte und damit die Möglichkeit gewährte, an einen Fortsehritt der Mensehheit zu glauben. Aber die historische Bezichmng und Erfïllung bedrohte das religiösc Leben auch wieder mit angenscheinlichster Gefahr. Dex tiefste Kern des religiösen Bewußtseins hatte sich erwiosen als Uberwindung aller Grenzen zwischen dem GötlichUnendlichen und dem Menschlich-Endlichen. Zeit und Entwicklung verloren dieser Einswerdumg gegeniiber alle Bedentung. Nachdem der Prophet von Nazareth in vorbildlicher Weise das liebeslcben des Göttlichen und Mensehlichen dargestellt, das beiclerseitig anf Erginzung bedacht ist. wie der Kinder Liebo des Vaters Sehutz und des Vaters Liebe der Kinder Frende bedarf, konnte lar 'Triumph des mystischen Bewubtseins nur darin gesneht werden, daß es unter Abstobung mid Verneinme der Simnenwelt der ewigen Liebesmmarmung ler (iottheit entgegeneilte.

Aber dem religiösen Bewubtsein fehlte es nummehr angensehemblich an Kraft, liescon groben liebesgang ler Seele zu gehen, sich zu entiiubern bis zu absoluter Armut und alles hinzugeben und zu opfern. wie or es getan hatte. Vor dem

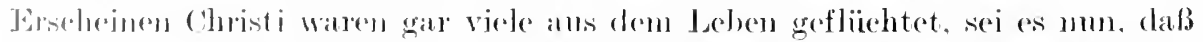

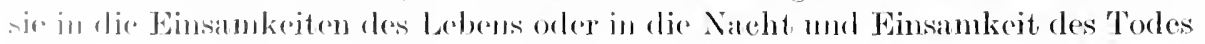

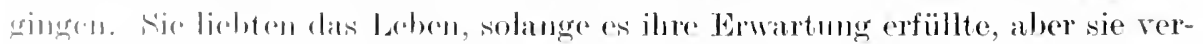

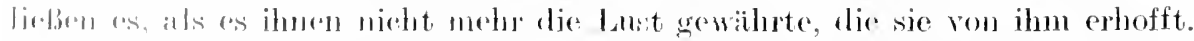

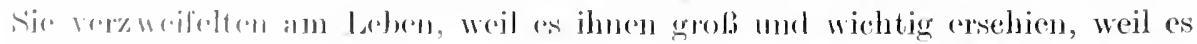

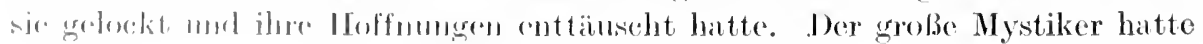


gezeigt, daß dieses Leben überhaupt keine selbständige und eigenmächtige Position bedentet, daß es getrennt vom göttlichen Leben rollkommen unwichtig ist, da $B$ wir schon hier das andere Leben leben kömen, daß unser Leben allen Wert durch das jenseitige erhält. Der Wunsch des religiösen Bewnßstseins konnte infolgedessen nur darauf gerichtet sein, das andere Leben rein und ganz zu führen. Der Tod hatte seine Schrecken verloren. Er war ler willkommene Weg zur Herstellung des reinen und ungeteilten Leben der seele in Gott. Deswegen gingen die Geliebten des Herm auch anfangs mit einer so schönen Selbstverständlichkeit in den Tod. Man kannsich kaum cinen gröleren Gegensatz denken wie den Tod der Selbstanfgabe und Hingabe, den jene christlichen Blutzeugen starben, und den Tod der Selbstbehauptung, wie ihn der stoische Weise starb.

\section{s) Das .,historische. I'hristentum.}

Von der lebendigen Fülte semer persönlichen Gegenwart nicht mehr gespeist, begann jedoch die Kraft der Mystik zu erlahmen. In der Idee des Gottmensehen und der Gotteskindschaft aller Menschen lag die Möghichkeit eines Kompromisses. Die Christusidee hat einen historischen Simn sofern sie das Geschehen adelt. Sein Dasein, seine Offenbarung löste wert rolles Gesehehen aus. Die Welt ersehien nicht mehr als gottrerlassene, wenn auch im höchsten Maße als mangelhaft und unvollkommen. Aber in der mit Gott vereinten Welt. ließ sieh doch leben. Sie war der Schauplatz seines Waltens und seiner liebenden Fürsorge. Das Erdendasein bekam einen Sinn. Es konnte Erwartung und Prüfung und Vorbereitung bedenten, den notwendigen Leidensweg. der zum Heile führt. So schloß tas religiöse BewuBtsein einen Kompromils mit dem simnlichen Leben. und dadurch wurde das Christentum zu einer positiven Religion, die ein Verhältnis zur Kultur zu gewinnen suchte. Dieses, historiseh" gewordenc Christentum ist das ursprïngliche Christentum nicht mehr, das in der Verneinung der Simnenwelt und in der Terklärung des Todes als einziges Ziel seiner Sehnsucht die Vereinigung mit Gott erstrebte.

Wenn das Christentum, historisch" worde in dem sinne, daß es lie Idee der Kultur als Gestaltung und Pflege der Sinnenwelt anf sich nahm und bejahte, so rerstand es sich damit als das Wertmoment des historischen Geschehens und forderte eine Religionsphilosophie heraus, die den historischen Prozeß als die fortschreitende Erlösung des Menschengeschlechtes verstand. Nach wie vor kam es ihm auf die Verbreitung der Lehre, auf die Hingabe der göttlichen Vermmfteinsicht an die Menschen an, niemand sollte sie unbekannt bleiben. Vor allem galt es, die alte Welt des Griechen- und Römertums für die neue Lehre zu gewinnen. Dazu war es notweudig, daB die christliche Lehre eine Form annahm, welehe die Achtung und Anerkennung der alten Kulturvölker erweekte. So mußte das Christentum vor allem die Philosophie und die Kunst, aber anch die anderen Kulturwerte für sich zu erobern und mit seinem Geist zu erfüllen trachten. Es galt, eine christliche Philosophie, eine christliche Kunst, eine christliche Ethik, einen ehristlichen Stat zu schaffen, und das Zentralorgan für alle diese Bestrebungen erwuchs in der Idee der Kirche. Das religiöse Bewußtsein hielt es somit für möglieh, mit den Mitteln des Ceistes schon in der Diesseitigkeit ein Wertleben zu begründen. Wohl sah sie in der 
Religion das einzige Kind Gottes und sehrieb den anderen Kulturwerten keinen selbständigen Sinn zu. Der Wert der Philosophie konnte nun in der Begründung und Verteidigung der religiösen Lehre, die Bedeutung der Kunst nur in der Terschönerung des religiösen Kultus hegen. Sofern sie sich jedoeh als die großen Mittel im Dienste des religiösen Wertes erwiesen, fiel ein schöner Glanz a uf sie zurüek.

So war es das religiöse Bewntsein, welehes die neue Zeit der Synthese lerbeiführte, indem es sich an die Kultur versehwendete. Die antike Welt war ein analytisches Zeitalter gewesen, sofern sie auf die Differenzierung der Wertgebiete abzielte; das Zeitalter, welehes mit der Renaissancebewegung endet, das Zeitalter der tausend Jahre ist ein synthetisches gewesen. Es begründete eine Wertordnung der Dinge, in der die Religion den Vorsitz führte. Alle anderen Kulturformen wurden dem religiösen Werte untergeordnet und verloren dadureh ihre Selbständigkeit und Absolutheit.

Der Vorwand, unter dem dies gesehah, war dieser: daß es sieh munmehr darmm handle, das Reich Gottes anf Erden zu begründen. Das religiöse Bewußtsein vermeinte, ein gutes Reeht auf diese Erhebung zu haben, weil es sich durch die nene große Offenbarmug vollendet fühlte. Es branchte ja im Grunde nicht zu ernewern, sondern nur noch auszuteilen, weil es dureh die Erscheinung des Herm so unendlich reieh geworden war. Sofern in der Religion die Tendenz zur Mystik liegt, hatte sie in der Gestalt des Propheten ron Nazareth ihre Voll('nrlung erhalten. Aber es lagen in ihr noch andere Mögliehkeiten, die sich ansreifen und vollenden sollten. Dabei blieb anch der Religion dieses eigentïmlieh, daß sie niemals ganz in der Kultur anfging, aneh dam nieht, als clureh das Christentum die Welt historiseh geworlen war, daß ihr Interesse wohl mit dem allgemeinen Ziel der Kulturentwiekhung zusammenging, sofern es auf die absolute I'berwindung der Wertfeindlichkeit abzielte, nicht aber mit dem vorläufigen Ziel der irdisehen Glüekseligkeit, das die reinliche Seheidung der Wertgehiete forderte, mul aneh nieht mit jener Bejahung der Simnenwelt, die in der Formgebung des Lebens zur Sprache kommt und durch Festhaltung und Sicherung der Simnenwelt clas Ende verzögert. Denn das religiöse Bewußtsein verlangt doch immer dic Katastrophe und das Ende der Wolt, mag es sieh num 1 m Mystik oder mm Magie handeln. Der Titanenstolz des Magiers stïrmt zum Himmel empor, mol die mystischo Licbe löscht alle Gegensätze ans, und ihre große Sehnsucht fordert das Aufhören der Endliehkeit. Das religiöse Bewubtsein kann also die Kulturentwicklung mur mit einem Vorbehalt bejahen. Es verneint das vorläufige Wude des historischen Gesehehens, die irdische Glïckseligkrit, dio glombedentend ist mit ciner remlichen seheidung der Wortgebiete nicht nur der philosophischen Idee naeh, sondern anch dor Wirklichkeit nach, ain Zicel, mm das die Menschheit sehon lange uncl schwer germugen. Hs vernoint jenes Keitalter der Gerechtigkeit, da jerle. Kulturmacht an ihrer Stelle wirksim ist, moghindert und ungetrennt wom fremelon Märebten, da der Kunst die absolute Freiheit der Gestaltung,

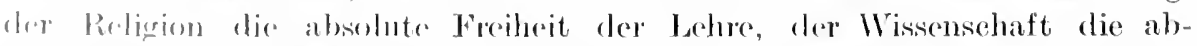

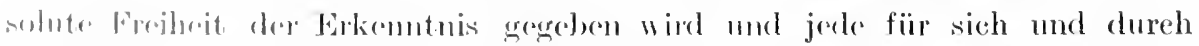

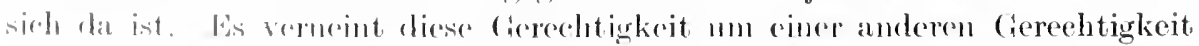

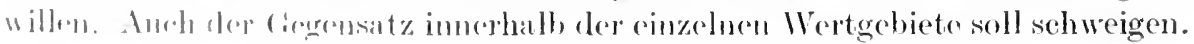


E; soll keinen Kampf und keinen Streit innerhalb der Sphäre der Religion mehr geben. Siegreich soll die eine Lehre trimmphieren. Es soll keine Form des politischen Lebens mehr mit der anderen ringen. Es soll der Kunst nur gegeben sein ein einziger Gegenstand der Gestaltung. Absoluter Friede und Tersöhnung sollen herrsehen. Dieses Schweigen des Kampfes ist aber auch daSchweigen des Lebens. Das religiöse Bewußtsein wünscht den Tod der Simmenwelt und ein newes Leben.

\section{t) Julian Apostata.}

Aus diesem Geist heraus haben wir das große synthetische Zeitalter der tausend Jahre zu verstehen. Bevor wir es jedoch in seinen allgemeinsten Zügen uns dentlich machen, wollen wir das religiöse Bewnbtsein noeh einmal dort erschauen, wo es die Kultur noch nicht auf sich genommen hatte, sondem in sehroffer unversöhnlieher Haltung der Kultur gegenüberstand. Das ist rlas Zeitalter des Kaisers Julian. Damals komnte sich das mystische Bewubtsein. wie es in den christlichen Gemeinden lebte. nicht genug tum in der Verachtung aller Güter, welche die Kunst und die Philosophie mit sich führten. Die Verneinung der anderen Kulturwerte wurde so weit getrieben, dal3 man sich darin gefiel, aus Verachtung der Schönheit das HäBliche zu preisen und a us Opposition gegen die Wissensehaft die Unwissenheit zu verherrlichen. Alles das war ron dem göttlichen Meister nieht gemeint, der die Kampfstellung der Welt gegenïber ausdrücklich abgelehnt hatte. Dennoch hatte diese Haltung der Christen ihren guten Grund, sofern sie um der Auflösung aller Wertfeindlichkeit willen die Anerkennung der Religion als des einzigen Wertes verlangten und das nur religiöse Leben sich zum Ziele setzten, das doch nur in einem Zustand heiliger Passivität sich vollenden konnte und jede Leistung als Befassung mit der Welt und Teilnahme an ihrer Lnw ïrdigkeit und Sündhaftigkeit ansschloß.

Gegen diese Kulturlosigkeit erhob sich num mit aller Kraft die magische Gestalt des apostatischen Kaisers. In ihm sammelten sich die religiösen Kräfte des Magiertumes zu einem gewaltigen Protest gegen die Ungöttliehkeit der Mystik. In seiner stolzen, schönheitsverlangenden und weltbejahenden Seele vereinigte er alle Quellen, die ihm aus dem Reichtum der antiken Kultur entgegenströmten. Aber es handelte sich in dieser Stellungnahme Julians nicht nur nm eimen Protest der antiken Kultur, mit den hohen Gïtern von Philosophie und Kunst, welche sie an den stillen Stätten der Weisheit und Schönheit aufbewahrt hatte, gegenïber dem kulturlosen Christentum. sondern vor allem um die alte Todfeindschaft des Magiers gegenüber dem Mystiker. Er sah die Termunft verschwendet und entweiht, und seine große Herrsehersecle erbebte vor Entrüistung, daß diese Kleinen und Kleinsten es wagten und sieh erkïhnten. seiner Göttlichkeit sich gleich zu fühlen. Er sah, wie sie das Opfer der Indiridualität und Persönliehkeit verlangten, mit denen er den höehsten Wert verband. Tor ihrer Häßlichkeit und Niedrigkeit bebte er zurüek. Er sah, wie sie das köstliche Gut der Freiheit verachteten, mit dem für ihn der Gedanke der Unsterblichkeit vermählt war, und daß sie sieh so gebunden fühlten und in einem anderen lebten, während sein Leben in stolzem und hohem Zuge auf sich selbst gestellt war. Cnd so nahm er den Kampf auf gegen das, was er als sünr- 
haft verwerfen muBte und bekämpfte, die göttliehe Gestalt des Mystikers mit allen Waffen der alten Welt und mußte doeh mitergehen und unterliegen, sieg md Triumph dem Galiläer zuerkemnen.

\section{i1) Organisation des sỵnthetisehen Zeitalters.}

Nimmehr vollzog sich die Organisation des großen synthetisehen Zeitalters, las die schwere Antinomie des religiösen BewnBtseins in sich barg. Der religiöse Wert galt nicht mehr als der einzige Wert, wohl aber als der höchste, dem alle anderen Werte sich unterzuordnen hatten. Das religiöse Bewußtsein verschwendete sich an die anderen Kulturwerte und gab ihnen Weihe und Kraft. Durch diese große Organisation des tausendjährigen Reiches wurde die fortschreitende Entwieklung verzögert, sofem dem Kampfe cler Wertfeindlichkeiten untereinander eine Grenze gesetzt wurde. Diese Gegensätze traten num nicht mehr in der alten Sehroffheit und Feindseligkeit hervor. Sie wurden eingediummt und eingehüllt. Das war die große Liebestat des religiösen Bewußtseins an der IVelt. Aber es war doeh eine Tat, die der Welt gesehah, und so konnte sie nicht in rollkommener Reinheit rerbleiben.

Dieses tausendjährige Reich war ein Symbol für das Endle aller Dinge, für jene vollendete Glückseligkeit, in der anch der Gegensatz immerhalb der einzelnen Wertgebiete ausgetilgt ist, wo die Schönheit verstummt und das sittliche Streben ruht; aher diese Kulturwirkliehkeit war doeh eben nur ein symbol und schloß die große Gefahr aller Verhïllung in sich. Das tausendjährige Reich was errichtet ohne die notwendige Riieksichtnahme auf die notwendige Durehgangsstufe der irdischen Glückseligkeit.

\section{v) Die Illee der Kirehe.}

C'm das grobe synthetinche Zeitalter herbeizuführen, war es notwendig, eine Konzession an die Welt zu machen. Galt es doch, die anderen Kulturwerte mit ihrer weltbejahenden 'Tendenz mit dem religiösen Werte in Einklang zu bringen. Ind so gelangte das religiöse Bewnßsein dahin, sich weltlich zn organisieren mud mit rer Institution der Kirehe in das wirkliche Leben einzutreten. Allerelings sollte diese Kirche in ihrer urspringlichen Gestalt nur das symbol für eine misiehthare Kirche bedenten. End vielleicht mochte es notwendig sein, die sichthare Kirehe als Erimerungsbild an die unsichtbare Kirche anfzurichten. Die unsichtbare Kirche lag ganz in der Richtung des mystisehen Bewulbtseins. Nie berlentete nichts anderes als die große Liebesgemeinschaft dor Foolen mit dem göttlichon Ursprumg, mol das mystisehe Bewnßtstin komnte sich diese Einheit und die Versehnelynng nieht innig genug rorstellen. Sobald $n$ an aber die sichtbare Kirehe hervortrat, wollte sie nicht nux an jonr musichtbare erimem, somelem sic vertrat soglejeh den Gedanken cines \%writroll Mittlertums.

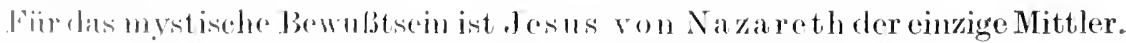
Er hat alle Hemmmise zwischen fott und Seele fortgeräumt. Die Sehranken-

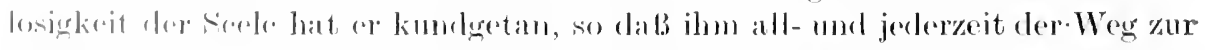

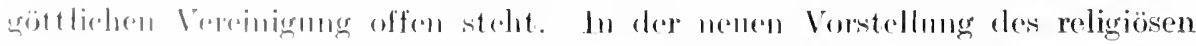

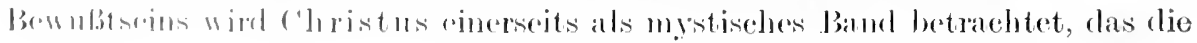


Seelen der wahrhaft Gläubigen znsammenschließt, der ihr Haupt, ihr Herz ihr Blut, der Seelen seele ist. Wemn num aber Christus der Weg zu Gott ist, so erweist sich die sichtbare Kirehe inmer mehr als ter unentbehrliche $W^{\top}$ eg zu Christus. Niemand kann ans eigener Kraft zu ihm gelangen. Jeder bedarf der Assistenz der Kirehe. Damit erhält das religiöse Leben ein hohes Maß von Sozialisierumg, während es zuerst im Geiste des großen Mrstikers ganz intividualistisch aufgebaut war. Naeh seiner Lehre war tie Religion in erster Linie die Sache des einzelnen. Gott ist es, fer dem unendlich rielseitigen und antersartigen Mangel der Menschen abhilft. Gott ist fïr jede seele das, was ihr fehlt. In immer nener nnel andersartiger Gestalt offenbart sich das einzigartige Verhältnis der Seele zu Gott. Nummehr erscheint das Göttliehe weit mehr als das Gleiche für alle und tie religiöse Liebestat des cinzelnen als ein gemeinsamer Schatz der Kirche. Die sichtbare Kirche, als die Cemeinschaft der Gläubigen, die in die Welt hineinragt, setzt aber sogleich noch den wichtigen Unterschied zwischen denjenigen, die immer im Dienste der Kirehe sind, die als Mittler des Herrn die Beziehung zum Göttliehen immer wierler anfs neue eröffnen und selber im engen Zusammenhang gläubiger Liebe verharren, die schon auf Erden das göttliche Leben genießen, denen tie Macht des Wunters gegeben ist, und jenen anderen, die da gehen und kommen. die nicht in dauernder Liebesgemeinschaft mit Gott verbunden sind, die, mit der Simenwelt gar sehr verflochten, das heilige Gebot der Armut und der Entsagung nicht leisten können und so, durch das Irdische gehemmt, immer wieder ron nenem einer helfenden Kraft bedürfen, welche die Fesseln der Seele leichter macht und die Schranken zerbricht. Lnd so sondert sich eine geweihte Sehar ron der mugeweihten, und es reift die magische Sehnsucht, nicht mehr wie frïher alles zu verschwenden, sondern zurückzuhalten und anfzubewahren. Das religiöse BewuBtsein des Magiers erkennt den Abstand, der zwischen den Geweihten und den Lngeweihten liegt. Jene sind doch ohne Frage dem Göttlichen näher, dessen heller Lichtkreis sie ummittelbar umfängt. Cud so erhebt sich innerhalb dieser großen Sphäre tes religiösen Lebens des Nagiers Herrschergestalt mit seinen berechtigten Ansprüchen auf Eigendasein und fromme Bewahrung des eigenen und anvertrauten Gutes neben des Propheten sehnsuchtsvoller und hingebender Gestalt. Ganz groß und stark treten sie in Erscheinung, aber sie ruhen noch in einer Einheit. Die schwere Antinomie, die zwischen ihnen liegt, ist der Menschheit noch nicht bewnt geworden. Erst allmählich gelangen sie dahin, in clen Bewnlstseinskreis ter grolsen religiösen Menschen einzutreten und ihre Seele sieh zum Schauplatz des Kampfes zu erwählen. Indem nun aber dieser Streit innerhalb des religiösen Wertgebietes entbrennt, erscheint dieses Leben erst als reieh nnt wnderbar.

\section{w) Die endliche und unendiche Gotheit.}

Das religiöse Bewußtsein wendet sich in dieser Zeit mit großer Leidenschaft der Bestimmung des göttlichen Wesens zu. Es sehritt damals zu der sieghaften Erkenntnis der Gottheit als des Unendliehen ror. Wem es num Gott als den Unendlichen namnte. so versehmolz wohl in der ursprïnglichen Vorstellungder Gedanke der mendlichen Flucht ron Erscheinungen, die Torstellung ron 
etwas, was weitergeht und niemals aufhört, was sich in das Ungemessene rerbreitet, mnd die Idee ron etwas, was nicht nur in Ramm und Zeit gewaltig ist, sondern was jenseits von Raum und Zeit steht in dem Sinne, daß Raum und Zeit fïr dieses große und ewige Etwas nichts bedenten, daß sie vor ihm niedersinken und zunichts werden, wie schwache Hüllen und Verkleidungen herabsinken von der herrlichen Gestalt. Das religiöse BewuBtsein schwankte aber in seiner ganzen Vorstellungsweise zwisehen Gott als dem Gestalteten und Gott als dem Gestaltlosen. Das magisehe Bewnßtsein wertet die Gestalt, mit der sich alle Schönheit verbindet, und so mußte es wohl auch das Göttliche gestaltet denken. Nicht sinnlich gestaltet, sondern in reiner Geistigkeit, nicht mit des Leibes Augen zu schauen, sondern mit den Augen des Geistes, welche die Tiefen aller rätselhaften Verhüllungen durchdringen. Eine Gestalt, für welehe das Große und Kleine seinen Sim verliert, während die Idee der reinen Form ihm notwendig gewahrt bleiben muß. Und so dachte es sich die Gottheit als die mnendliche Persönlichkeit, deren Wesen Schöpfung, d. h. Gestaltung aus dem Nichts bedentet, die immer wieder das Nene in der Welt hervorbringt. Denn die Idee des göttlichen Schöpfer's ist es, welehe vor allen anderen die magischen Tendenzen des religiösen Bewnßseins trifft. Jene Zauberkraft, die aus dem nichts etwas macht, das ist die selige Wunderkraft des göttlichen Magiers.

Die religiöse Mỵstik dagegen empört sich gegen die Vorstellung einer göttlichen Gestalt. Fïr sie ist keine Bestimmung des Endlichen wert genug, um auf die Gottheit angewendet zn werden. Gott ist der Namenlose, wie sehon Philo gelehrt hat, sein Wesen ist zu groß, als daB unsere stammelnden Lippen ihn verkïnden könnten. Lieber sollen sie schweigen und mögen wir verstehen, daB er ein Niehts für uns sei, in dem Simne, daß wir nicht das geringste von ihm wissen. Gott ist der Seele so fern und doch auch wieder so nah. denn in der menschlichen Seele liegt gleiehfalls ctwas Namenloses, welches der, ,eigenschaftslosen" Cottheit verwandt ist und so ein Verhältnis zwischen beiden möglich macht. Dieses Namenlose und Abgründige in sich soll die Seele betonen, dann reift mal blïht sie der Gottheit entgegen. Wenn aber das mystisehe BewuBtsein in clieser Weise Gott als den eigensehaftslosen daehte, so war doch hier die höchste Armut gleichbeleutend mit der höchsten Fülle.

\section{x) Dir (Hosis.}

Eine Fïlle der versehiedenartigsten religiösen Motive kreuzen sich in der religiösen Lehre der Gnostiker. Alle diese großen religions-philosophisehen Sirsteme der Alexandrinerzeit sind ja im (ipunde genommen Stufen auf dem

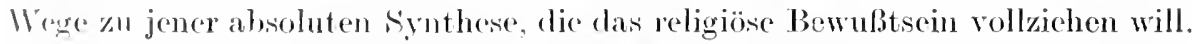
Fis ist nicht das theoretische Interesse des Meltrerstehens, das hier entscheidend ist. sondron die Jösimg der Welträtsel wirl angenseheinlich bestimmt dureh

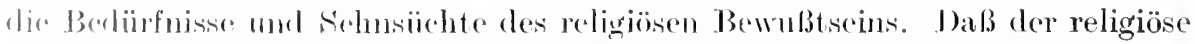
11 cot lop Jorstehende ist und alle Bestimnumgen cles Absoluten im Geiste der religiönds 11 rerthaltung (rfolgen, das ist mzweifelhaft. Ein Gegensatz besteht mur indre Frage. ol, ain Wissen von lem religiösen Wrerte möglich ist, oder ob

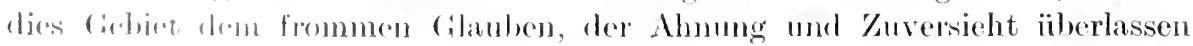

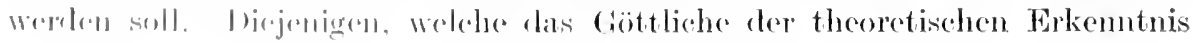


nicht verschließen, sie scheinen damit dem Theoretischen eine zu große Macht einzuräumen und den heiligen Besitzstand der Religion zu gefährden. Anderseits aber machen sie doch auch wieder die Erkenntnis und das Irissen zum Zeugen der Herrlichkeit des religiösen Wertes. Diejenigen dagegen, welche den Gegenstand der Religion in das Gebiet des Unerforschlichen verlegen, sie schützen es damit vor jedem Frevel der Entweihung dureh fremde Augen, aber es seheint doch auch gleichzeitig damit dem Gegenstand der Religion eine Gewißheit zu fehlen, die wir als unendlich bedentungsvoll anzusehen gewohnt sind. Und so gelangt denn das religiöse Bewußtsein zu dem Auskunftsmittel einer besonderen religiösen Erfahrung, die mit der theoretischen Einsicht nichts gemeinsam hat, und welche die Seele über die dumpfen Niedermngen des sinnlichen Lebens zum schanenden Verstehen des Göttlichen erhebt. Das ist die mystische Ekstase.

In der Gnosis sucht das religiöse BewuBtsein den Grund des Werdens und der Schuld in den Gestalten der Ewigkeit zu offenbaren. In mythische Gewänder gehüllt, erkennen wir im Reiche der Äonen jene absoluten Werte, die dem Gesamtleben der Welt allen Simn verleihen. Wie die Götter des Phaedros ordnen sie sich zu einem mächtigen Gestaltenzug. Die Vorstellung, die sie mit dem religiösen Wert verbindet, ist die Vorstellung des absolut $\mathrm{Cr}^{\mathbf{r}}$ sprünglichen, des göttlichen Urgrundes, aus dem alles hervorgegangen ist. Er ist jene schweigende Tiefe, die in sich ruht, deren Rätselhaftigkeit kein Wissen ergründet. Sie ist das Keusche, das Heilige und Reine, das jeder leidenschaftlichen Begierde widerstrebt, das alles wertvolle Leben ans sich entläßt und doch über allem erhaben bleibt. Nach dieser großen und stillen Reinheit, die im Verborgenen bleiben will, strebt die sündige Weisheit. Sie wagt es, in sündiger Liebe an das Mysterium zu rühren. Das ist die Sehuld des Rationalismus, das sündhafte Tun des Magiers, welehes zur Verbamnung der Weisheit aus dem Reiche der lichten Gestaltung und zum Werden ihrer Naturhaftigkeit und Menschlichkeit geführt hat. Das weite Reich der ewigen Wertgestaltungen steht der Erkenntnis offen; aber ihren letzten verborgenen Grund und Sim können wir nicht erraten. Von der Sinnenwelt wissen wir, daß sie die Sünde der liebenden Erkemntnis geschaffen hat, und daß dieses Werk einmal durch die siegreiche Tat der Erlösung dem heiligen Ursprung zurïckgegeben wird.

Immer mehr baut sich das religiöse Bewußtsein im Reiche des Zeitlosen an. Es vermag in ihm Gestalten zu erschanen und weiß ein Geschehen, das aller sinnlichen Weltwirklichkeit voraus in der sphäre des Ewigen verläuft.

\section{y) Plotiu.}

Den Abschluß jener Bewegung, welche das religiöse Bewnßtsein zur Herrscherin erhebt, bilden die Lehren Plotins und Augustins. Was in dem künstlerisch organisierenden Geist des großen Griechen zur letzten Problemstellung führt, das ist nicht sowohl das Verhältnis von Seele und Gott, als vielmehr das Verhältnis von Gott und Welt. Es ist die Beziehung zwischen der schönen

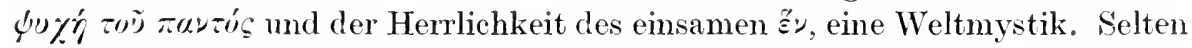
hat die Mystik so schön und kraftroll ein Weltbild geformt wie in der Lehre 
Plotins. Das göttliche Eine steht über allem Begreifen. Es ist die schöne Blïte des noeh nieht erschlossenen und noch nicht getremnten Lebens. Es ist jene absolute Einheit, in welche die Reflexion noch keinen Gegensatz gesetzt hat. Das Göttliche wird nicht begriffen und weiß in träumender Seligkeit auch nichts von sich selbst. Es ist die ewige Jugend des Lebens, die in köstlicher Reinheit und überströmender Fülle sich an die Welt verschwendet, ohne dann doch das geringste zu verlieren. Diese Gottheit des Plotin kann niemals zum Symbol der Armut werden, wie der Gott der Mystik, sondern sie bedeutet ihrem tiefsten Wesen nach mendliehen Reichtum, der durch Geben und Schenken nicht verringert werden kamm.

Wenn $\mathrm{nm}$ dieses eine göttliche Leben sich entfaltet, damn formt es sich zum Gegensatz und gleitet ans der Sphäre des UnbewnBten in die Sphäre der Bewntheit hinïber. Es bildet dam jene Welt schöner und sichtbarer Gestalten, das von Gott ummittelbar Gedachte, die ewigen Ideen, zu denen

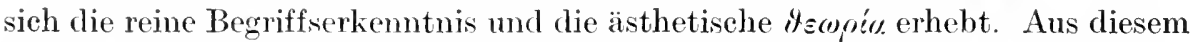
Geisterreiche formt sich mit dem Uthergang in das Sinnliche die Seelenwelt der Weltseele. Diese ist zwiefacher Natur. Einerseits ist sie durchaus kontemplativ und zum Schauren bestel]t. Sie verweilt in der Betrachtung der Gottheit und strebt ihm liebend entgegen. In ihr lebt die große Sehnsucht des platonischen 气̆ Erwarten des göttlichen Liebes- und Lebensstromes, der ihre Kräfte speist. Würde dieser Lichtstrom, der aus dem Ewigen quillt, ihr versiegen, so würde ihre Kraft erlöschen. Sie mïßte zugrunde gehen. Sie lebt im Schauen der Gotheit und empfängt ron ihr die Bilder jener ewigen Gestalten, nach denen sich das Gebände der Simmenwelt fügt und ordnet. Doch bleibt zwischen der Weltsecle und Gott cine gewisse Distanz. Wohl ist der Seele das Schauen der göttlichen Geheimnisse besehieden, und scine Liebe wirkt ummittelbar auf sie cin. Aber niemals ist es ihr erlaulst, zur mmittelbaren Einswerdung und Verschmelzung mit dem Göttlichen zn gelangen.

\section{z) Augustin.}

Diese extreme Wendumg des mystischen Gedankens hat sieh im Mittelalter vollendet und ist von Augustin vorbereitet. Tn ihm regen sich gewaltige religiöse Kräfte, die jedoch in einem mnersöhnlichen Gegensatz auseinanderliaffen. Jas große religiöse Erlebnis, das seiner lehe zugrunde liegt, ist dieses, daß nichts so gewils ist wie die eigene zweifelnde und sehnsiichtig suchende fierele, und dab ans dem Wissen dieser ihrer Hullichkeit das Wissen von der götthehen Unencllichkeit mit. Notwendigkeit sich crgiht. Das göttliche Geisteswescon ist dor mensehlichon G('mütsorganisation vorwandt. Alle Kräite der menseleliehen Soele sind dort, in höehster Steigernng vorhanden. Er ist ein monolliches Reich dor Frimbermes, in dem alles Geschehen der Welt in großen

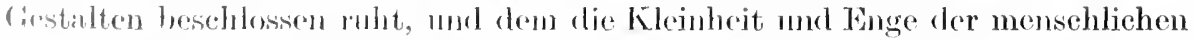

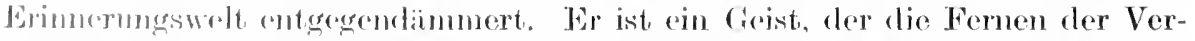

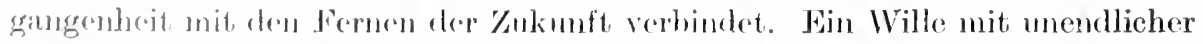

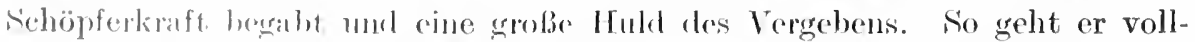
kommen üher dic Kaft des Menschlichen hinaus. Die göttliehen Primalitäten 
sind von den menschlichen Qualitäten prinzipiell verschieden. Dennoch aber ist die Seele ihm verwandt und strebt zu immer höheren und reineren Stufen der Gotteserkenntnis empor, bis sie dam schlieblich zu einem seligen Schanen gelangt, wo sie Gott ron Angesicht zu Angesicht sieht und in stummem Entziicken vor seiner Herrlichkeit verhart.

Das alles vermag sie aus eigener Kraft. wie es scheint, und gewinnt in liebender Sehnsucht die Nähe des göttlichen Her'n und hat den großen starken Willen und die freie Tat. Damn aber erscheint dieser Wille anch wieder als vollkommen gelähmt und gebunden, durch eine alte Tat der Erkenntnisschuld in unzerreißbare Bande verstrickt. Wollte die Seele doch einmal gleich sein mit Gott und wissen, was gut und böse ist. Die freche Erhebung des magisehen BewuBtseins ist ron Gott mit dem Verlust der Reinheit bestraft. L'nd so kann die Seele sich nicht selbst erlösen, auch jetzt nicht. nachdem der große Mrstiker ihr den Weg gewiesen, sondern sie bedarf der Vermittlung dureh die sichtbare Kirche, die mit ihren Gnadenmitteln die gebundene Seele löst und sie auf diese Weise gesehickt mnd würdig maeht, die Vereinigung mit dem Göttlichen zu vollziehen.

In dem großen synthetisehen Zeitalter, das mit Augustin heranfämmert, sehen wir das religöse Bewußsein zur Herrsehaft gelangen. Philosophie und Kunst stehen durehaus im Dienste der Religion, und aneh die Formen des rechtlich sozialen, des sittlichen und politisehen Lebens sind im wesentlichen durch ihren Geist bestimmt. Viele Veranstaltungen, die das religiöse Bewußtsein trifft, dienen ganz augenscheinlieh dem Kultus der Erimerung. Man will das Bild des großen Mystikers lebendig erhalten für die Seele. Und so erzählt und verkündet man immer wieder, was er getan und gelitten hat, findet das große Symbol der Vereinigung mit ihm und dureh ihn in der sancta coena und bildet sein geliebtes Bild in immer neuen Formen und Gestalten. Indem das religiöse Bewußtsein in frommer Feier ihn zum Hohempriester der unsichtbaren Kirche machte, verlangte auch die sichtbare Kirche der Welt, welche die unsichtbare repräsentierte, nach einem Haupt als Nachfolger des Herm, als Bild und Symbol seines Wesens und fand es in der bischöflichen Gewalt, aus der dam später die päpstliche hervorging.

\section{aa) Die Idee des Papsttums.}

Die Idee des Papsttums ist ursprünglich rein religiös und bedeutet eine hohe Blüte des magisehen Bewußtseins. Ein neues Bewußtsein ron Heiligkeit und Reinheit durchdrang die Menschheit, als sie die großen Taten der Liebe und der Aufopferung geschant, welche die christlichen Härtyrer in frommem Clauben an die heilige Gestalt des Herm vollhracht hatten. Die Seele fühlte sich Gott nah und stark und gefestigt in seiner Liebe. Es lag aber in der Lehre des großen Mystikers die Idee eines Strstems ron Kreisen. Wenn anch sein Ruf an alle Mühseligen und Beladenen erging, so kamen sie ihm doch nicht alle glei sh nah und komnten ihm nicht alle gleich nah sein. Dureh die Bewegung ihrer großen Liebe waren ihm am nächsten gekommen die Gestalten der Zwölfe, denen gegenüber er sich am freudigsten offenbarte und verschwendete. Der Prophet von Nazareth war ein religiöses Genie, deswegen konnte er sein eigenes Wesen vollkommen darstellen und offenbaren. Welche aber seiner Gestalt und seines 
Wortes Zauber am meisten ergriff, die mußten seinem Herzen am näehsten sein. Die Lieblingsjünger hatten die innigste Gemeinsehaft mit ihrem Herm. Sie waren die Verstehenden, ohne die er unverstanden und einsam geblieben wäre. Als er sich ron ihnen entfernte, ließ er sie als die Einsamen zurück. Ton ihnen sollte die päpstlich-bisehöfliche Würde überkommen sein. Sie war das Symbol eines reinen und vollkommenen Lebens und einer hohen Einsankeit. Denn der Papst ist der eimzig Verstehende und Wissende. Er vermag zu verkünden, was frei von allem Fehl und irrtumslos ist. Um die apostolisehe Gewalt schloß sich der Kreis der Kardinäle, um jene der Kreis der Bischöfe, um diese die niedere Geistlichkeit. Alle aber glaubten sie im Tempel zu stehen und in der heiligen Arehe zu fahren, geborgen und geschützt durch die Liebe des Herm, mit dem sie in dauernder Gemeinschaft blieben, vor allen Stürmen der Welt. Weit von ihnen getrennt blieben jene, die das Leben der Welt gewählt. Und so erstarkte in diesem mächtigen Kreis die magische Idee des religiösen Herrschertumes. Es erschien als ein Unrecht, jenen Kindern der Welt alles zu geben und aufzuteilen, was doeh an erster Stelle nur für die Geliebten des Herrn bestimmt war. Und so verweigerte man den Kelch den Laien und nahm ihnen die Freiheit des eigenen Ringens und Kämpfens 1 m Gott. Das religiöse Bewußtsein vermeinte, daß jene Schwachen im Geiste nieht imstande seien, das kostbare Gut der religiösen Freiheit zu gebrauchen. Und so ließ es jenen das primitive Glück des sinnlichen Daseins und die Seligkeit eines zweifellosen Glaubens an die bessere Welt, während es sich selber anfangs auf das schärfste von der Sinnlichkeit sehied, um sein priesterliches Kleid rein zu erhalten und die schwere Last der Glaubenskämpfe anf sich nahm. Das religiöse Bewußtsein wollte nummehr aufbewahren und verbergen und verhüllen, weil es die Entweihung der köstliehen Güter fürehtete, die ihm beschieden waren.

Die Idee des Papsttums ist keineswegs nur eine Frage der politiseh-kirchlichen Organisation, sie war von derWeihe eines hohen religiösen Lebens getragen. das in der Nachfolge Christi zum Ausdruck kam. Er war gegangen und entschwunden auf jenem steilen Pfade, der in das Reich der Seligen führt. Seine Getrewen und Geliebten sind alle auf dem Wege zu ihm, gruppiert auf verschiedenen Stufen, ihm näher oder ferner. Eine Seele aber ist ihm am meisten genaht, so wie Johannes ihm im Leben am näehsten gestanden. Ihr Auge schaut die entschwindende Gestalt, und ihr Antlitz leuchtet wider von seinem heiligen Antlitz. Dieser Seele ist alle Macht gegeben. Sie vermag durch ihre Reinheit Wunder zu tun. Sie vermag dureh die Macht ihrer Heiligkeit den sündigen Mensehen von der Liebesgemeinsehaft des Göttlichen auszuschließen und auch diese Gemeinsehaft wieder herzustellen nach ihrem Wohlgefallen.

Und so wurde denn die Gestalt des Magiers gar mächtig in den groben läpsten und führte den'Triumph der Kirche herbei und schuf das große synthe1 ische \%eitalter, in clem die Vertgegensätze zu einer vorläufigen Versöhmung Erobracht wurden. Aher das religiöse BewuBtsein hatte, wie es schien, etwas Inmögliches versucht, wemn es die sichthare Kirche auf der Grenze zwischen den briclen Wolten arrichtete. Lis wurle dadureh zu sehr der Welt hingegeben murl komnte sich nicht mehr in seiner reinen Geistigkeit erhalten. Und so drängte die religiöse. Nagie von der Abtremmung und Sonderung des geistlichen vom welthehen $L_{A}(\cdot) \times$ weiter bis zur vollkommenen Isolierung und Flucht von der 
Welt, die zur Begründung der Klostergeistlichkeit führte. Wenn sie anch später vielfach an der Kulturtätigkeit Anteil nahmen und selbst praktiseh-weltliehe Leistungen verrichteten, so war der Simn des Mönch- und Einsiedlerwesens ursprünglich doch gleichbedeutend mit einem Rückzug aus der Kultur, moehten sie mun die Idee der einsiedelhaften oder der gemeinsamen Einsamkeit vertreten. Das religiöse Bewubtsein entsetzte sich vor der Welt und den maneherlei Gefahren, mit denen sie die Seele bedrohte. Es entsetzte sich vor der Schönheit und Begehrlichkeit der weltlichen Kultur. Es empfand die Einsamkeit als die große Notwendigkeit des Alleinseins mit dem Objektiven und Göttlichen. Solange das religiöse Bewußtsein in der Welt blieb, konnte es die Stimme seines eigenen Herzens nicht vernehmen und das Göttliche nicht erschanen. Viel zu sehr war es hingegeben den äußeren Dingen, und die göttliche Stimme mußte ihm rerklingen in dem Geräuseh der Welt. Und so verlangte der religiöse Menseh danach, einsam zu sein, allein oder auch zu vielen in dem asozialen Zusammensein des stmmmen Gehens und Grüßens.

Die Wendung zur Einsamkeit kann einen sehr verschiedenen Sinn haben. je nachdem der Gedanke der Trennung oder der Vereinigung mehr betont wird. Die Gestalt des Magiers sucht die Einsamkeit, $m$ die mergründlichen Tiefen seiner Seele zu bereichern und seine Individualität abzugrenzen. Er weiß es nur zu gewiß, daß er von den Armen und Elenden nichts gewinnen kann. Auch hält er das Geschenk des göttlichen Lebens für zu reieh und köstlich, als daß er es an jene verschwenden sollte. So sncht er die Einsamkeit, mm sein Wesen zu steigem und groß werden zu lassen. Der Mystiker trennt sich nur ungern von der Gemeinsehaft der anderen Seelen und gibt anch die Beziehung zu ihnen niemals gänzlich auf. Er belauscht die Einsamkeit, um die Stimme dessen zu vernehmen, der im Verborgenen sprieht. Und wenn seine Seele in ihrer reinen Hingabe rollkommen ausgefüllt ist ron dem göttlichen Wort, so wendet er sich zu den anderen Śeelen zurück, um das Verborgene kund zn tmu.

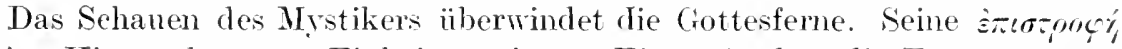
ist eine Hinwendung zur Einheit, zn jenem Einen, in dem die Formen untergehen, die Gestalten erlöschen. Das Schanen ist nicht ein ruhiges Abbilden der göttlichen Wahrheiten. E; schlägt jede Verwandsehaft mit dem sinnlichen Schein aus. Nicht nur weiter reicht das Auge des Geistes. nicht nur feiner bildet es nach. Das mystische Schauen ist dem sinnlichen Leben wesensverschieden. Es handelt sich nicht mehr um ein Schanen der Gestalten, sondern mm ein gestaltoses Schauen. Denn nach Imnen ist das Auge des Mystikers gerichtet. Nicht sncht er hinter den Gestalten der Natur die höheren Gestalten. sondern ans der formlosen Welt des immeren Erlebens wächst ihm der Gegenstand seiner Sehnsucht zu. Und indem die Formen erlösehen und verschwimmen, führt die Sehnsucht des Mystiker's nicht zur. Vielheit des Einzigartigen, sondern zur Einzigartigkeit des Vielen.

\section{bh) Ifugo ron St. Victor.}

Aus der Lehre Hugos von St. Vietor verstehen wir der Mrstik reinen Wesen. Der Mystiker ist der große Schauende und muß als Mystiker der Schanende bleiben. Ist das Schanen Gottes von Angesieht zu Angesicht nicht die Erfüllung aller religiösen Sehnsucht? Aber hinzu tritt der Gedanke der Wahl : 
auserlesen ist die fromme, die dienende Seele von Christus, dem göttlichen sponsus. Christus nimmt die Seele zu sich. Die jungfräuliche Seele ist dem Heiland lieb. Im Anschanen Gottes versunken, stirbt die Bewegung des Geistes, mul die Seele geht in das göttliche Dunkel, geleitet von Christus, ihrem Geliebten und Herm. Und so wird der geliebten Seele die hohe Gnade zuteil, schon im Diesseits teilhaftig zu werden der Offenbarung der ewigen Wahrheit. Wohl ziemt es der mystischen Seele, dem hohen Bilde den heiligen Schleier zu lassen, das Unbekannte still zu verehren. Frevel und Schuld ist das eigenmächtige Streben der Individualität, das göttliche Mysterium zu durchdringen. Aber die Seele, die Gott liebt, darf mit seinem Willen die hüllenlose Wahrheit schanen. Der Eigenwille der Seele geht völlig verloren. Der Wille des Einzelnen geht im Willen des Ganzen anf. Die Individualität geht in Gott unter wie der Wassertropfen im Meer oder wie glïhendes Eisen im Fener.

Un so ähnlicher wird die Seele Gott, je mehr ihre „Kräfte“, Gedäehtnis, Wille und Verstand, überformt werden von der göttlichen Gnade.

\section{ce) Franz von Assisi.}

Diese reine Form der Mystik, die bis Heinrich Suso weiter lebte, hatihre schönste Erscheinung in Franz von Assisi gefunden. Er hat die Idee der Armut mit der Mystik anf das innigste verschmolzen. Wir sollen uns ganz ausgeben und hingeben nicht nur an die Menschen unserer Liebe, die uns verstehen, sondern an alle Menschen und nicht nur an die Menschen, sondern an die ganze lebendige Welt. So hat er nicht nur den Seinen gepredigt und gelehrt, sondem auch den fremden Menschen und den Tieren und Pflanzen. Er fühlte sich allen Geschöpfen verwandt und spürte das eine göttliche Leben in allen Geschöpfen. So mußte ihm die ganze Natur Freund und Bruder sein. Der nährende Strom der Liebe, der ron ihm ausging, umschloß in heiliger Inbrunst alle Kreatur. Nicht nur auf die Erlösung des Menschen, sondern anf die Erlösung der ganzen Kreatur ging seine fromme Liebe aus. Nichts wollte er für sich behalten als ausschließlichen Besitz, alles wollte er hingehen und a rm sein, sowohl an äuBerem Gut wie anch arm in dem Sime, daß er keinen Anspruch anf die Anfbewahrung und Ausnutzung seiner geistig Gaben erhob, sondern sic rein und vollkommenen, in den Dienst der Liebe stellte.

Anf einsamer Bergeshöhe war ihm das Wunderbare begegnet, jenes Wunderbare, das an den Knabenjüngling das dunkle Gebot erlassen hatte, alles zu lassen nul dem Herm nachzufolgen. Damals hatte er die Welthehkeit überwunden. deren verführerische Schönheit ihn einst berauscht. Sogar die Kleider hatte (r von sich getan und war nackt ins Elend gegangen. Nur dem Herm wollte

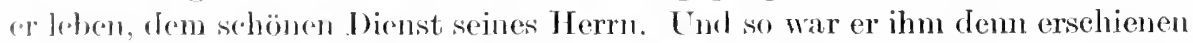
mol hates seine Kraft gestïnkt und sein Geheimnis ihm kund getan. Und nur dre rine Wunseh lehte in ihm, fem Propheten von Nazareth so ähnlich wie mïglich zur wromlen.

J)as rolisciosse bewubtsoin verstand sich nummehr als Armut und Liebe. Dort allein ist roligioses laben vorhanden, wo die liebe so groß ist, daB sie alles anstrilt und fortgiht. Aus besitz und Eigentum entspringt das Unglück

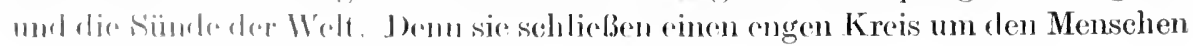


und sondern ihn ab und machen ihn unfähig zu großen Taten der Aufopferung und lieoenden Hingabe. Seine Lehre der Armut war jedoch nicht finster und streng, dem ihm war die glänzende Somne das Symbol für das reine und große Liebesgefühl, das sein Herz erfüllte, die Sonne, der er seinen Hymmus entgegensang. Sonnenhaft sollte die Liebe sein und über alles sich ausbreiten mit leuchtendem Glanz und alles nähren und füllen.

Sein höchster Wunsch aber war, dem göttlichen Meister immer ähnlicher und ähnlicher zu werden. Er begehrte die schrecklichen Wundmale des Herru zu tragen. In brennender Liebe verlangte er danach, bis schließlich an seinem Leibe die furchtbaren Wunden und Nägelmale erschienen. Und so war er selig, daß sein Körper verunstaltet war, daß er das Schreckliche erfuhr, das der Herr gelitten, und war in der Schönheit und Blüte seines starken Lebens der wandelnde Leichnam des Herrn.

\section{dd) Das päpstliche Herrschertım.}

Gegenüber der Zartheit und Reinheit dieser mystischen Gestalt erhebt sich der religiöse Magier gar mächtig und gewaltsam im tausendjährigen Reiche. Er schraubte seine Ansprüche so hoch im Namen Gottes und seiner eigenen Herrlichkeit, daß das große Einheitsgebäude, das er geschaffen, in Stücke brach. Die Päpste vertraten die Idee des Herrschers, und zwar ursprïnglich den Gedanken einer rein geistigen Gewalt, abgelöst ron jeder Weltlichkeit. Sie haben für die Bildung der Kultur, für Wissenschaft und Kunst das Größte geleistet. Aber mehr und mehr verstrickten sie sich in die Idee der Weltlichkeit, ursprünglich, um ihrer moralischen Autorität eine realpolitische Unterstützung geben zu können, um den religiösen Gedanken, der sie erfüllte, in Tat und Leben umzusetzen. Bald aber ergriff der Zauber des Herrschergedankens in absoluter Form die großen Kirchenfürsten und führte sie auf Grund einer eigentümlichen Dialektik zu Forderungen hin, die dem Sinn ihres eigentümlichen Daseins und ihrer hohen Sonderstellung vollkommen widersprachen. Denn der Sinn ihres heiligen Amtes komte doch nur so verstanden werden, daß sie in ihrer ganzen Lebenshaltung dem großen Propheten von Nazareth am nächsten waren. Das Ihm-nahe-Sein aber bedeutete die Überwindung der Welt. Nummehr entschloß sich das magische Bewußtsein in seiner großartigen Bejahung des Herrschergedankens zu einer Überwindung der Welt im Geiste der Unterwerfung. Dem absoluten Jünger des Herrn gebührte im alten Geist des Christentums das Amt des Hohenpriesters, weil er die Welt so weit hinter sich gelassen hatte; jetzt fiel das hohe Amt dem Herrscherhelden zu, der die Fürsten der Welt vor sich niederzwang und Kronen zu geben und zu verleihen hatte. Das Herrscherrecht über die Welt aber glaubte das religiöse Bewbtsein zu verdienen, weil doch geistiges Amt und geistige Macht der welthchen Macht so weit ïberlegen ist, wie die Seele an Würde, Bedeutung und Bestand den schwachen Körper übertrifft. So erhob das religiöse Bewußtsein Ansprüiche auf Weltherrschaft, weil es der Welt obgesiegt zu haben glaubte. Es bekannte sich zur Weltichkeit auf Grund seiner Unweltlichkeit und Überweltlichkeit. 


\section{ce) Bonifaz VIII.}

Diese Entwicklung des religiösen Bewußtseins ist zugleich mit dem Ende des tansendjährigen Reiches in dem großen Papste Bonifazius VIII. vollendet. In ihm feierte die religiöse Magie ihre höchsten Trimmphe. In der Gestalt dieses Greises glühte ein mbesiegbares Fener und das hohe Bewußtsein seiner Göttlichkeit. Als verwerfliche Ammaßung muBte cr es empfinden, daß irgendeine Gewalt der Welt sich ror ihm nieht bengte und das Göttliche in ihm nicht anerkannte mnd verehrte. Mit einem System juristischer Normen begründete und stützte er seiner Göttlichkeit Recht. War er doch der Stellvertreter des Herrn, der in engster Verbindung mit der Gottheit lebte und unmittelbar Anweisungen mot Befehle aus jener Welt empfing. So wie rie ewige Gotheit sich früher des göttlichen Sohnes bedient hatte, um sein Reich anf Erden zu begrïnden. so verkündete er nummehr seinen Willen rlureh die päpstliche Gewalt. Und wie sich der große Prophet von Nazareth eins wuBte mit seinem göttlichen Ursprung, so whte auch der große Papst, daß sein mächtiger Geist im Geiste des Herm rerblieb, und daß Gottes Wille der Wille des Papstes und des Papstes Wille der Wille Gottes sei.

\section{fi) Meister Eckhart.}

Wenn die Gestalten des Magiers und des Mystikers so drohend einander gegenüberstehen, dam muB das roligiöse Genie immer wieder ihren Widerstreit in sich verspüren und daranf ausgehen, ihn zu ïberwinden. Und darin scheint mir mun ror allem die Größe Meister Eckharts zu liegen, da er die Forderungen des magischen BewuBtseins mit den Forderungen des mystischen Bewußseins zu rerbinden woßte. Und tie hohe Tragik seiner Erscheinmng ist darin zu suchen, daß die heiden cwigen Widersacher, jene beiden, die sich niemals verstehen und dulden kömmen. daß der Magier und Mystiker sich seine Seele wählten, um ihren tödlichen Kampf auszukämpfen. All die großen religiösen Antinomien brechen bei ihm gewaltsam hervor: der Gegensatz von Notwendigkeit und Freiheit, von Allgemeinem und Besonderem, von Gott und l'nsterblichkeit.

Sehon in der Siprache des Ee khart kïndigt sich etwas ganz Nenes an. Die zarten Worte der jungfräulichen Mystik weichen der ghtrollen Schönheit leiclenselaftlicher, gewaltiger Rede. Demn die Jungfan ist Weit geworden,

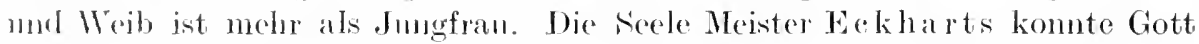
nicht mah genug kommen mol lief so Gefahr, iln ganz zu verlieren. Un Gott llah zu sein, mïssen alle Hüllen fallen. Die Seele muls sich aller Kräfte ent-

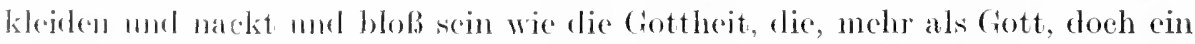
Nichts ist, arm, weil rollkommon mbestimmt, reieh, weil Gund aller Realitiit.

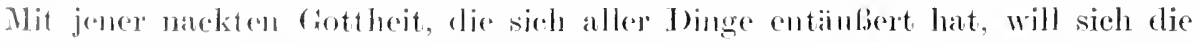

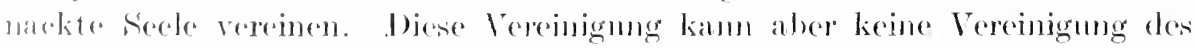

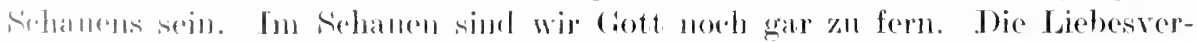

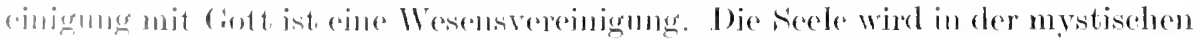
Vereinigung nicht mö̈̈tlich, nieht nur gottibulich. sondern dem göttlichen IIrson merich.

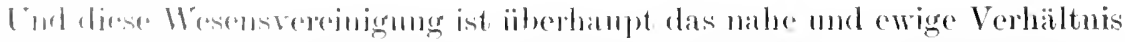

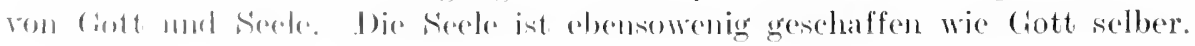


Es lebt etwas in ms. was mehr ist als alle Kreatur. Dieses Etwas, der Funken. war mit Gott eins im ewigen Abgrund der Welt, in der bloßen Cottheit und hat mit Gott die Welt geschaffen. Die Seele ist ungeschaffen mol Gott gleich, nicht nur das Edelste ron allem Geschaffenen, nicht nur gottähnlich. Hier ist die Stelle, wo der religiöse Mystiker zum religiösen Magier wird.

Nicht hoch genng kann Eckhart den Wert der Individualität erheben. Úber die Natur der Engel geht das Wesen der menschlichen Seele. Der tiefo Grund, das ,Nirgend“- der Śeele, in dem der Mensch nicht nur Persönlichkeit, sondern auch Menschheit ist, diese heilige Tiefe der Seele ist dem Abgrund und Urgrund des göttlichen Wesens gleieh.

Die Seele ist nach Eckhart S'chöpfer und nicht nur Geschöpf. Sie ist wic Gott von Ewigkeit zu Ewigkeit. Es giht kein von der Seele unabhängiges Prinzip des Anfangs. Durch die menschliche Seele erleidet Gott Zwang. Dem reinen Zustand ihrer Jungfräulichkeit gegenüber hat Gott keine Wahl. Er muB sich mit der Seele rereinigen. Er mag wollen oder nicht. Und so erwächst ans den entgegengesetzten Forderungen von Magie und Mystik durch die Kraft des religiösen Genius das große, fromme und schuldhafte Verk : Meister Eckhart Lehre.

Der Forderung der Magie genügt die hohe Bewertung der Seele, die nichts ïber sich duldet, die ihrem Wesen nach Gott gleich, anfanglos und grundlos ist wie er. Die Seele ist frei, denn ihre Göttlichkeit kemnt keine höhere Macht; und da sie ungeworden und ungeschaffen ist, so mul die Seele auch notwendig unsterblich und unzerstörbar sein. Die Seele ist so stark, daß sie Gott zu zwingen vernag, und so stirbt Gott vor der almächtigen Seele.

Der Fordermng der Mystik genügt die Betonung des Allgemeinen in dem Gedanken des Begrabenseins in der wüsten und leeren Gottheit, der Untergang in Nichtesnicht, das Fortgezogenwerden in den Urgrund des Seins. Dic Seele ist so mächtig, daß sie den Durchbruch nach der Ewigkeit vollziehen, Gott zur Vereinigung zwingen kamn. Aber indem sie Gott zwingt, erleidet sie selber den Zwang seiner Liebe. In heiliger Passivität erleidet sie sein Wirken, und in dem Gedanken des Gottwerdens erlischt niemals die Sehnsucht des ZuGott-Kommens. Die starke Betonung des Allgemeinen, in dem alles ruht und begründet ist, läßt die Teile in ihrer Selbständigkeit und Abgegrenztheit nicht bestehen. Und so stirbt die Seele ror dem allmächtigen Gott.

Das tausendjährige Reich, welches das religiöse Bewußtsein so groß unr eindrucksvoll geschaffen, in dem der Herrschergedanke sein mächtiges Leben führte, jene Kultur, welche die große Synthese an den feindlichen Wertgebieten vollzog, sie mußte notwendig untergehen, demn sie verkörperte die Idee eines gar zu frühen Endes und einer vorzeitigen Seligkeit. Der Endzweck des Weltgeschehens erfordert die reinliche Scheidung der Kulturgebiete, die sich in schweren Käm pfen vollziehen sollte. Diesen Prozeß, für den das Griechentum das Größte geleistet hatte, als es die mythologisehe Nubstanz zersetzte, hat das tausendjährige Reich aufgehalten. Das soll jedoch lediglich die Konstatierung einer Tatsache und nicht etwa Kritik oder Tadel bedeuten. Notwendig muls ja immer wieder dem analytischen Zeitalter ein synthetisches folgen, welches das Ende der Weltgeschichte aufhält und gheichzeitig ein Symbol des Endes bildet. Gewiß nur ein Symbol, sofern jene Einheit, die es erzielt, nur eine 
scheinbare ist. unter der die Gegensätze der Vermunft schlmmmernd ruhen, um sogleich wieder hervorzubrechen, wemn das schöne Traumbild der Illusion gewichen ist. Die alten Völker hatten sich müde gekämpft, und die neuen Tölker reiften erst langsam einem einsichtsvollen Vermunftleben entgegen. Damals hatte das synthetisehe Zeitalter alle Macht und alles Recht für sich.

\section{gg) Das neue analytische Zeitalter.}

Das nene Zeitalter reicht von der Renaissance bis zur Romantik und schließt somit anch die große Erscheimmg der Aufklärung in sich. Wir wissen nicht, ob die Romantik schon den endgültigen Absehluß jener großen analytischen Epoche bedeutet. aber auf jeden Fall ist der Anfang des 19. Jahrhunderts wieder rom Geist der Synthese erfïllt. Die reformatorischen Bewegungen des religiösen Lebens, die in Dentsehland ihren mächtigsten Ausdruck fanden, lanfen der Renaissancebewegung nebenher, um im Anfklärungszeitalter gemeinsam ihre Vollendung zu finden.

Wie ist mm der Simn der Renaissancebewegung anfzufassen? Es ist ebenso cinseitig, sie als absolute Fortsehrittserscheimmg, wie auch als absolute Reaktionserscheinmo zn denten und zu verstehen. Es gibt ja im Grunde genommen keinen religiösen Fortschritt, wie es einen politischen oder ethisch-sozialen Fortschritt gibt. Vielmehr verbindet sich mit der Religion ummittelbar die Idee der Vollendung. So gibt es wohl keinen Fortschritt über die Lehre Christi und ihre großen Symbole hinaus. Die Bedentung der Entwicklung des religiösen Lebens ist vielmehr darin zu suchen. daß die Religion im BewnBtsein des Menschengeschlechtes frei und abgelöst. ron allen Nebeninteressen erscheint, daß wir rein religiöses Leben verstehen und rein religiöses Leben leben. Sie liegt aber ferner darin, daß das religiöse Genie in immer nenen und höheren Synthesen die unzerstörbaren Gegensätze der religiösen Ideen zı verbinden sucht. Wem wir von immer höheren Synthesen sprechen, so ist ihr Charakter durch das MaB der Entwicklung bestimmt. Niemals aber kömmen wir ausmachen, was wertvoller sei: die reine Gestalt der Mystik oder die schöne Paradoxie jener Lehre, die um eine Ủberwindung des Cregensatzes bemïht ist, und von den Formen der Uberwindung wieder jene, die anfänglich die (iegensätze zu versölnnen. snehte, oder diese, welche daranf ausging, das sehon Verbundene noch enger und tiefer zu verbinden.

Jie Bedentung der Renaissance muls num vor allem darin gesueht werden, daß sie die Solbstänligkeit des theoretisehen Bewnbtseins nen entdeckte und gleichzeitig las fohöne als eine in sich beleutsame Geistesmacht verstehen l(-hrte. Damit rorde das religiöse BewuBtsein zu seiner Reinheit zuriickgeführt, Wom auch in der Wrase, dalo das Religiöse noch auf das engste mit sittlichen Wrertrorstellungen amalgamiert blieb. Die reinliche Selreidung dieser hohen

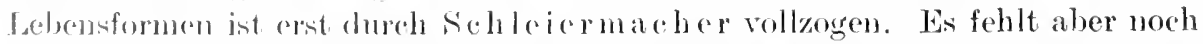

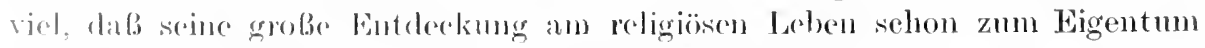

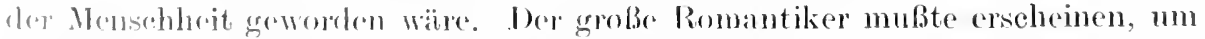

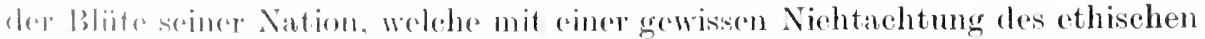

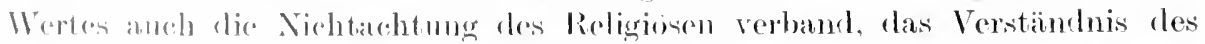

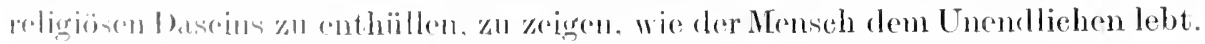


Diesen ganzen Prozeß der Verselbständigung der großen Kulturgebiete gegenüber der Religion hat ein russischer Geschichtsphilosoph als Zerfall und Atomisierung des sündigen Westens verstanden, dem gegenüber in Rußland das heilige Land der religiösen Synthese bestehen geblieben ist. Wir meinen viehmehr, daß Rußland jenes analytische Zeitalter, das mit der Aufklärung endete, noch durchzukämpfen hat, und müssen in dem großen Prozeß der Lösung veralteter Bindungen die Vorbereitung einer höheren Synthese erblicken.

\section{hh) Julius II.}

Mit der Verherrhichung des theoretischen und ästhetischen Geistes, wie ihn die Renaissance mit sich brachte, ging eine starke Bejahung der sinnenwelt und des sinnlichen Lebens zusammen. Die Nachfolger Christi lebten der Welt und der Schönheit. Das Herrschertum und die Macht wurden auf das sehnsïchtigstegeliebt und gefeiert, gerade damals, als die Idee des universalen Herrschertums, von der ein Bonifazius geträumt, unwiederbringlich verloren gegangen war. Der größte der Renaissancepäpste, Julius II., war anderen sinnes und anderen Geistes als der Prophet ron Nazareth. Er bejahte den Stolz und den kriegerischen Sinn und stürmte mit gewaffneter Hand Schlösser und Burgen. Gepanzert konnte man ihn sehen hoch zu Roß mit wehender Fahne. Nicht aber zog er aus. $u m$ das Grab des Erlösers zu suchen und zu gewimnen, sondern $n$ Italien frei zu machen von der Fremrllinge Gewalt, und um seim eigenes Reich zu befestigen und auszubanen.

Den Krenzzügen lag ursprünglich eine rein religiöse Idec zugrunde, die eine schöne Flamme der Begeisterung entfachte. Sie gehören notwendig zu der Kultur des tausendjährigen Reiches und sind eine ihrer gewaltigsten Ausdruckserscheinmugen. Das Zeichen der Schmach und der tiefsten Erniedrigung. das Kreuz des Herrn, die stolzen Ritterheere tragen es demütig in seinem Dienste. Der Kreuzritter ist einer heiligen Minne hingegeben, und dieser Mimne Dienst erfüllt sein ganzes Sein. So gibt es Gottesstreiter, die der irdischen Liebe vollkommen abgestorben sind, geistliche Ritterorden, wie die Templer und Johanniter, die für den Erlöser beten und streiten. Gewiß willersprach anch ein solches Tun der Lehre des großen Mrstikers und war somit rom christlichen Standpunkt ans eine Verimung des religiösen Bewußtseins, sofern der fromme Geist der Nachfolge Christi, der Hingabe und EntänBerung, der Armut und Demut sich mit dem kriegerischen Geist der Zeit vermählte und das gewaltsame Tun zu rehgiös wertrollen Handlungen stempelte. Aber daß alles dieses ursprünglich im tiefsten Sinne religiös gemeint war, cla B es religiöse Liebe und Aufopferung gewesen ist, welche die großen Massen der Krenzfahrerheere in Bewegung setzte, das unterliegt keinem Zweifel.

Ganz anders die Gestalt des kriegerischen Renaissancepapstes. Seine Waffen sind nicht geweiht, noch folgt er anf den fremden Pfaden eines kriegerischen Lebens der reinen Gestalt des Herm. Die Paradoxie des Gottesstreiters liegt ihm fem. Er ist ein Fürst dieser Welt, weleher die größten Werke der Schönheit rollenden ließ und alles in Bewegung setzte zu seines Namens. Ehre und zur Verherrlichung seines geliebten Roms. Ton Macht und Schönheitskultur war seme Seele trunken, und Italien war seine große Liebe, für die 
er litt und kämpfte. In ihm hat das Papsttmm den religiösen Gehalt vollkommen eingebïßt. Nur ein Held und Herrscher, ein Liebhaber und Fremol des Schönen, ein rom Eros besessener, göttlicher Mensch ist geblieben. Dennoch würde diese grobe kriegerisehe und weltliche Erscheimmg nicht so auf uns wirken, wenn ihr der Glanz der Apostelwürle fehlte. Seine kriegerischen Taten würden weniger unsere Bewundermg erregen, wemn sie die Taten eines weltlichen Fïrsten gewesen wären. Gerade bei Papst Julius führt die Einzigartigkeit der Erscheinung zu dem Bewnßsein seines mzerstörbaren Wertes. Daß er ein Wertleben führte, das in so eigentïmlichem Gegensatz zu seiner kirchlichen Stellnng stand, das gerade umgibt diese Gestalt mit dem Zauber des Paradoxen. Ein Mönch. der die Schönheit anbetet, ein Verkünder des göttlichen Friedens, der gepanzert zu Felde zieht, der Vertreter des intemationalen Gedankens, der leidenschaftlich $\mathbf{m}$ nationale Ziele kämpft, das ist gewiß eine seltene und einzigartige Lebenshaltung, die bei diesem großen Papst durch den höchsten Zauber der Persönlichkeit geadelt ist.

\section{ii) Savonarola.}

Gegen den lichten Zauber der Schönheitskultur in Italien erhelt sich eine finstere und dumkle Gestalt, der Mönch Savonarola. Er sieht, wie naektes Heidentum in der Lagmenstadt sich sonnt, wieman nichtmüde wird, die Schönheit des Körper's zu pflegen, die blonden Haare mit Perlen zn zieren und mit iippiger Kunstwerke Pracht Paläste und Kirchen zu schmücken. Er sah die große Sïnde dieser Schönheit ein und erkannte den emsten Mahmruf des Herm in der furchtbaren Krankheit des sehwarzen Todes. Er hat die Schönheitskultur Italiens nicht nur abgelehnt und verachtet, sondern auf das leidensehaftlichste bekämpft. Er wurde zum Zerstörer der Schönheit und Úppigkeit, zu einem unbarmherzigen Verfolger, der ihren zarten Leib dem Flammentode weihte. Er tat es, weil er die Weltlichkeit haßte, die in ihrer äuBeren Prachtgestaltung den religiösen Menschen verriet und sein starkes Gefühl für das Göttliche erstickte. Hingegeben war seine Gestalt der Idee der Armut, er verschwendete sich an das Volk, welches ihn liebte, und scheute nicht der päjstlichen Herrseher drohende Macht. Ciegenüber einem Zeitalter, das Wissenschaft und Kunst als höchste Eigenwerte pries, lehrte er die Religion als das cinzige, was selig machen kam. Er bebte zurïck ror dem weltlichen cieist, der die hohen Kirehenfürsten, die Diencr Gottes ergriffen hatte. Fr liebte des Volkes Armut, und des Volkes Armut licbte ihn. Er war scheinbar cin Reaktionär, sofern er das religiöse Leben wiecler zu cincr ursprünglichen Einfachheit zuriickfïhren wollte, und wies doeh den Weg der Zukwnft, indem er as abriß mol arbiste von dem engen Verwobensein in die simnenwelt. Den Finurtod aber, den er der Schönheit bereitet hatte, muBte er selber erleiden. Stumm und ergriffen schanten die Armen und Elenden muf dem schönen Plat\% Her signoria in Florenz scinem Flammentode zu. Als BewuBtsein und Leben ihm schon dahingeschwmolen mul, vom Flammensturm ergriffen, der arme

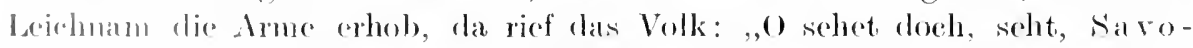

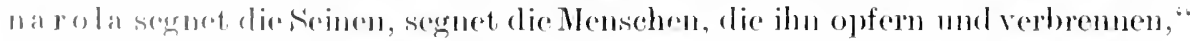
moll seliluchote mol wrinte lant. 


\section{kk) Die Reformation.}

Die analytische Bewegung der nenen Zeit, welche in der Renaissance auf Terselbständigung der Kulturwerte gegenüber dem absoluten Wert des religiösen Lebens alozielte, offenbarte sich aber noch in einer ganz anderen Richtung. Sieging auch darauf aus, das religiöse Leben selber zu spalten und zu entzweien oder doeh zum mindesten die Formen zu zerhrechen. in denen dieses Leben zuvor seine Einheit gefunden hatte. Es gehörte zu der Natur des alten Bekenntnisses, clas Göttliche als das Eine und ewig Gleiche für alle Menschen zu lehren. Anderseits aber lag es in den Simn und Cieist der großen katholisehen Hierarchie, daß das religiöse Leben nieht restlos versehwentet. sondern gepflegt und aufbewahrt wurde, so wie es in der einen heiligen Kirehe eine \%eitlang gar mäehtig gedieh, indem der höehste Glanz auf ihrem (Oberhaupte ruhte. von dem die Fülle der Gnade sich auf das Stufenreich der priesterlichen Ordmung ergoß, um dam als letzten Kreis die Kinder der Welt zu erquicken.

Soweit die Reformation lediglich darauf ausging, die katholisehe Kirehe ron Mißbränehen zu reinigen, bedeutet sie ein Streben nach der Reinheit und Einfachheit der früheren Lehre. Gegen die Weltlichkeit des Klerus wandte sie sich und gegen jene Simonie, die sich in so rerschiedenartigen Formen äußerte und das Heilige für Geld preisgah, das Göttliche in den Dienst des persönlichen Nutzens stellte. Weiter aber wandte sieh die neue Bewegung gegen die Rationalisierung der großen christlichen symbole zu Dogmen und theoretisehen Lehrsätzen. Das Symbol und Gleichnis ist für das religiöse Gefühl und den Glauben bestimmt und bedarf keiner theoretischen Erklärung. Im Gegenteil: eine solehe Erklärung muß den religiösen Simn notwendig mißverstehen und zerstören. Es gibt keine Theologie. keine wissensehaftliehe Lehre von der religiösen Wahrheit, die der Engherzigkeit unseres Begreifenwollens immer entzogen bleibt. Alles das will verstanden sein als die Befreiung der Religion von manchen Hemmungen und Schranken. von Entstellungen und Verunzierungen, die besonders dureh ein Überwehern der theoretischen Reflexion entstanden sind. dic schließlich den lebendigen Geist hinter der Trockenheit und Dürftigkeit des Buehstabens versehmachten ließ.

Das ursprüngliche. unverdorbene religiöse Leben der ersten Christen sollte ernenert werden. und die Bekanntschaft mit den Büchern der heiligen Sehrift erweekte den religiösen Enthusiasmus sowohl zu reiner Gilut der Mystik wie auch zur düsteren Flamme der Nagie. Die gottgeweihte Kämpfersehar der jüdischen Könige und Helden und die Friedensgestalt des leidenden Heilands suchte man in Vorstellungen zu rermählen, die an der ganzen Fülle der alten Tradition gereift waren und der Gegenwartslage des religiösen Bewubtseins gerecht zu werden suehten. Der Gedanke der Wiederkehr und des Endes, der schon im tausendjährigen Reich die Herzen so mächtig ergriffen hatte, erfüllte noch eimmal die Gemüter. Wenn der Herr aber wiederkam, so mußte er doeh von neuem der menschliehen Gestalt sich bedienen, und so mochte demn die Seele des Propheten zuerst als leise Ahmung und Gefühl und dann später mit steigender Dentlichkeit die Vorstellung beschleichen, daß in ihm das göttliche Leben des Herm von neuem der Welt wiedergegeben sei. Wie nah komnte doch in einer solchen Gestalt der Magier neben dem Mystiker stehen. Jener glaubt an den höchsten Anteil und die Gegenwärtigkeit des Herrn 
in mystischen Erleben. Der Herr ist bei ihm alle Tage, und er fühlt sich der geliebten Gestalt so nah, daß schließlich das eigene Wesen vollkommen mit ihm rerschmilzt. Er lebt in Christus und Christus in ihm. Und dieses Leben in ihm, was kam es bedeuten? Der Mystiker lehrt, daß Christus immer wieder ron newem in der Seele geboren wird. Der Magier kamn diese ewige Wiederholung nicht dulden. Sie muß ihm als Nivellierung des Göttlichen erseheinen, das seiner Auffassung gemäß nur selten und groß hervorlenchtet. Er glaubt, daß Christus wiederkehrt als große weltbewegende Erscheinung, und Johann von Leiden vermeinte in eigener Person die seltene Erscheinung des wiedergekehrten Messias zu sein.

\section{1) Protestantismus und Katholizismus.}

Doch ist es nicht allein die Restitution des Alten und der sehönen Ursprünglichkeit, welche die reformatorische und speziell die protestantische Bewegung vor der bisherigen Entwieklung des religiösen Bewußtseins auszeichnete. Viehmehr trat $1 m$ die Wende des tansendjährigen Reiches eine newe große Antinomie in der Natur des religiösen Bewnßseins hervor. Gewiß ist der Protest, wie er sich damals erhoben, vielfaeh ein Protest der Mystik gegen die Magie, sofern sich der Geist der Weltabkehr und Weltverneinung gegen den Geist der Weltbejahung, der Kulturweite und Kulturvollendung erhob. Wenn wir aber von der individnalistisehen Tendenz des Protestantismus spreehen, so ist dieser Individualismus doch keineswegs gleichbedeutend mit der hohen Heiligung der Individualität, wie sie der religiöse Magier verlangte, und die zum Kultus der Persönlichkeit führte. Vielmehr haben wir zwisehen Katholizismus und Protestantismus einen eigentïmlichen Gegensatz in dem Verhältnis von Gott und Mensch in bezug anf Gleiehheit und Ungleichheit zu unterseheiden, den man dahin formulieren könnte, daß3 der Katholizismus die Gleichheit des Inhaltes bei rersehiedener Form und der Protestantismus die Versehiedenheit des Inhalts hei Gleichheit der Form behauptet. Es liegt in der Idee des Katholizismus, ein Stufenreich rles religiösen Wertlebens aufzubanen, clas in der Gnade den Menschen zuteil wird. Die Gnare, als das Göttliche und Befreiende, was zu den Menschen kommt und sic mit Gott verbindet, haftet jedoeh an Amt mul Stellung, an der äuBeren Lehensform. Der Apostelfürst steht dem Göttlichen näher als der Bischof und der Bisehof näher als der Laie. Der Apostelfürst kann die Geschenke der Gnde zurückhalten. Dem Laien wird nieht der Eanze Reichtum der Sakramente zuteil. Deswegen ist er in seiner ganzen Lebensform rom (iottlichen entfenter. Er ist immer und weniger beschenkt. Er lebt glejehsam an der Peripherie der göttliehen liebe, und das hat er anch nicht ander's verdient, form ar leistet woniger für die Gottheit. Dagegen war es groforn Gotteskindern beschioden, mehr zu leisten, als zur Gewinnung eines

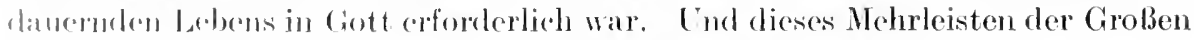

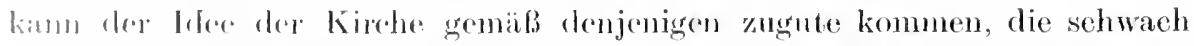

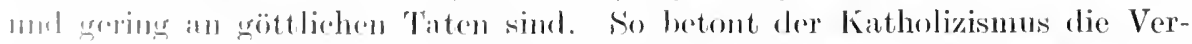

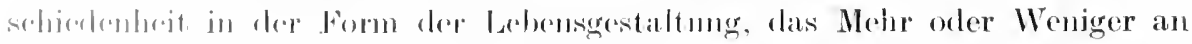

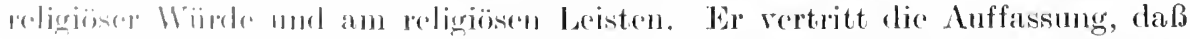

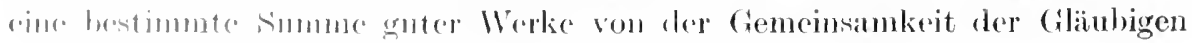


aufgebracht werden müßte, um das große Erlösungswerk des Herm fruchtbar werden zu lassen.

Dem gegenüber betont der religiöse G'eist des Protestantismus, daß wir vor Gottallzumal Sündersind, und daß die Wertunterschiede in bezug anf religiöses Leisten doch viel zu gering erscheinen, als daß man deswegen von einer Sonderposition der Seele gegenüber dem Göttlichen spreehen könnte. Der Priester als Verkünder der Lehre und Austeiler der göttlichen Gnade steht dem Ewigen nicht näher als jeder andere Mensch, dem jeder Mensch ist als Dicner Gottes auch Priester des Herrn und kamn von semen Gnadenmitteln Gebrauch machen. So erwächst aus der eigentïmlichen Lebensform sowie ans tmt und Leistung keine Ausnahmeposition gegenüber dem Göttlichen. Vielmehr können wir ruhig behaupten, daß alle Menschen der Cottheit gleich nah und fern sind.

Verschieden an Wert und Leistung steht die Seele vor Gott — mond democh ist es im Grunde genommen das eine, was alle bedïrfen. So muB die Anffassung des Katholizismus verstanden werden oder die religiöse Idee, welehe ihm zugrunde liegt. Die Heilsbotschaft, wie sie gedentet und anfgefaßt ist von den großen Kirchenlehrern, sie ist es, die das Liebesbediurfuis der Seele und jeden Mangel stillt. In einem ganz bestimmten sinne will das Göttliehe verstanden sein. Immer wieder soll der gleiche Inhalt, die gleiche Botschaft ertönen. Das Eine soll alle Herzen heilen und erlösen, die Bindıug an das L̈bersimnliche sich immer in derselben Weise volziehen. Das Göttliche und die Religion, welche ihr Ausdruck ist, bleibt immer das Gleiche und erleidet keinen Wandel im Laufe der Zeiten, und jene, die ihr zugehören und sich ihr anvertraut haben. sind gebunden und festgelegt für alle Ewigkeit. So ist das Verhältnis der Seele zu Gott gewissermaßen ein umpersönliches, weil das Göttliche anf die Individualität keine Rücksicht nimmt, sondern in die Beziehmug zur Seele und in den Bund, den es mit ihr abschließt, immer dasselbe hineinträgt.

Dagegen ist num in der nenen Lehre, die den Bestand des tausendjährigen Reiches zerstörte, die Religion als Ausdruck einer persönlichen Beziehmug gedacht. Immer wieder richtet sich an die Seele eine andere und nene Botsehaft aus der mendlichen Fülle des göttlicheu Wesens heraus. Glaube und Hingabe ist erforderlich, aber das Bekemntnis wird rersehieden lanten. je nach der Individnalität des Gläubigen. Immer wieder hat das Göttliche einem anderen Mangel abzuhelfen, eine nene Liebessehnsncht zu crfüllen. So geht die Seele mit Gott ein persönliches Verhältnis der Ergänzung ein. Ein Gott, der allen Menschen in gleicher Gestalt gegeniibertritt, kann für den einzelnen nur wenig bedenten. Der Gott, der allen gehört, ist nicht mein Gott, zu dem ich rufe. Gott ist immer das, was mis fehlt. In der Lehre des Katholizismus ist Gott die Ergänzung der Menschheit zur Vollkommenheit und Trïrdigkeit des himmlischen Reiches. In der Lehre des Protestantismus führt Gott das Leben des einzehnen zu einem vollendeten Dasein. So birgt der Katholizismus in sich das Prinzip der Universalität, der Einheit, der Gleichheit. Der Protestantismus dagegen das Prinzip der Dualität, der Spaltung. der Individualität und Ungleichheit. Der Katholizismns hat dem Einheitsgedanken. der Protestantismus der Idee der Persönlichkeit die schwersten Opfer gebracht. Jener hat die Idee der einen Kirehe auf das äuBerste betont und bewahrt, dieser muBte notwendig bis zur Sektenbildung vorwärts schreiten. Das Uniformierungsprinzip de- 
Katholizismus verwies den Protestantismus ans der einen Kirehe. In diese Ablösung und Isolation getrieben, formierte er ein neues Dogma und gab clamit seine Originalität und Eigentümlichkeit preis.

In der Richtung der neuen Beregung, die mit der Renaissance beginut, und die ihren religiösen Ausdruek vor allem im Protestantismus gefunden hat, lag von vomherein eine starke Betomung des Willens und der Tätigkeit, welche sie in Gegensatz bringt zu der kontemplativen Stimmung, die über der antiken Kultur und äber dem Mittelalter liegt. Ans der Verstriekmng mit Affekten und Leidenschaften löst sich allmählieh ein reines und stolzes Willensleben los, das in der Ethik Kants endgültig verstanden wurde. Gleichsam vorbildlich für diese nene Entwicklung ist die große Erseheinung Luthers, dessen Grundpathos doch sehlieBlieh das ethisehe gew esen ist. Unter dem Eindruek seiner Erscheinung steht die Mystik von Jakob Böhme.

\section{mm) Jakoh Böhme.}

Hinter Jakob Böhme steht eine Gestalt, die ihm lauernd über die Schulter sieht, wem er darauf ausgeht, das mystische Verhältnis von Gott, Welt und Seele herzustellen. Sie möchte gar gem das Werk seiner Offenbarming hemmen und verhüten, daß all die Schändlichkeiten offenbar werden, welche Lne if e r. dieser dunkle und schweigende Beohaehter, gegen die göttliche Ciewalt ansgeführt. Dem das Böse und Diabolisehe, das ist für Jakob Böhme nicht bloßer Simnentrug. Wie das die Auffassung von Meister Eckhart war, das Böse ist nieht nur Irrtum und Täuschung, sondern eine furchtbare Realität, welche dem Walten des reinen göttlichen Prinzips sich entgegenstellt. Ersprünglich lebte die Welt in vollkommener Einheit und mystischer Seligkeit mit Gott, damals gab as noch kein Böses und keinen Gegensatz. Dieser Gegensatz ist geworden durch den Stolz des schönsten Engels, den Gott am licbsten hatte, der Gott am nächsten war. Er wollte nieht länger in der göttlichen Einheit verbleiben, sondern eine selbständige Position neben Gott bedenten und so dor zweite Gottsein. Sindiger Ehrgeiz war es, der den Fall des höehsten Gesehöjfes verursachte. Er fiel und sank dahin mit bleichem Antlitz, ein ron (iott Gebannter. Und mit dem Falle Lueifers zugleieh entstand die sündige simnenwelt.

Diese Simenwelt hat all die Eigenschaften, welche die himmlische IVelt in sich trägt, nur sind die Qualitäten versehlechtert und haben ihre ursprüngliche Reinheit eingebiilst. Diese Verschlechterung gilt es wieler gut zu machen; moser Bestreben mul. darauf gerichtet sein. die alte Einheit wiederherzustellen. Fiir die Rïgkgewimmng dieser Finheit kïmpft der gottsuchende Wille. Naeh llejser Eokhart kommt es darauf an, recht stilke zu sein, 1 m die rufende sitimme des Iform zu vermehmen. Der Wille ist fïr ihn von verhältnismäbig

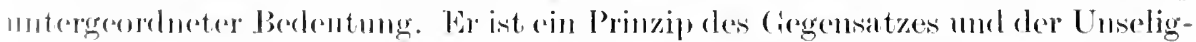

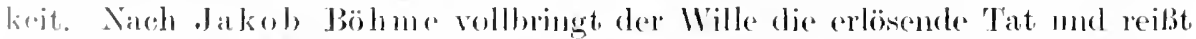
-ieh los von der Macht der Simbliehkeit und des Bösen und gelangt zur Freiheit norl sichönhlatit in cott.

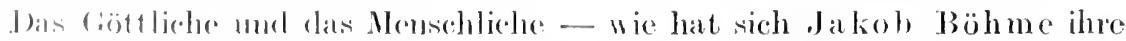

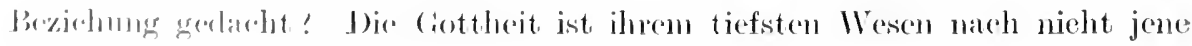


Armut und Wüste, ron der Meister Eckhart redet. Der Lrgrund und Abgrund des göttliehen Lehens ist schlummernde Kraft. Diese Kraft rulst in sich als dunkler Trieb und drängt danach. zu zengen und zu gebären. Die göttliche Urkraft, wie Jakob Böhme sie denkt, hat et was gemeinsam mit der platonischen Liebe. Nur geht diese Liebeskraft des Lniversmms nicht darauf aus, in einem anderen das Schöne zu gebären, sondern diese rätselhafte, in sieh ruhende Kraft drängt danach, sich selbst zu erzengen und darzustellen. Gott ist der sich selbst gebärende, sich selbst erzengende und zum Dasein bestimmende Weltwille, die dunkle, latente Kraft. In dem dumpfen Brüten des Anfangs befangen, ist sie noch ohne wahrhafte Realität. Nun aber geht sie in sich mur erfaßt die Tiefen ihres Wesens. Sie gewinnt ihr eigenes Bill in tiefster Innerlichkeit. Das Göttliche, das, in sich selhst rersunken, zum Bewnßtsein seines Wesens gelangt, dem die Erkenntnis der eigenen Sehönheit in der lautlosen Stille der göttlichen Selbstbesimnmg aufgeht. Diese Gestalt des göttlichen Lebens, diese Phase seiner zeitlos ewigen Entwicklung bezeichnet Jakob Böhme als den , Sohn”. Gottes Sohn ist geboren. nachdem Gott in sich gegangen und sich selbst rerstanden hat. Nun kam das Göttliche nicht mehr als dunkle Schicksalskraft gedacht werden, sondern mub rerstanden sein al ein liebender und wissender Geist. Aber dieser sieh selbst wissende göttliehe Geist ist noch nach Immen gewendet und mit sich selbst beschäftigt, verloren und einsam in sich selbst. Sich selbst hat er geformt und gestaltet, aber die Gestalten seiner Liebe noch nieht heransgestellt und offenbart als Zeugen seiner Herrlichkeit. Das ist die dritte Phase seines Wesens, da das Göttliche, naehdem es in sieh geboren hat, nun die Geisterwelt aus sich herans gebiert. Das ist jener Moment des Gottwerdens, da er lant wird und zum Ausclruek gelangt und seine Tiefe offenbart in freier Sehöpfertätigkeit.

Die erste Phase der Gottheit ist ruhende Kraft der Natur, wie sie sieh ausdrückt in winterlicher Starheit. Die zweite Phase der Innerlichkeit ist dem Safte rergleichbar, der im schönen Frühjahr durch die Adern der Pflanzen rinnt. Ein roll entfaltetes, aber noeh für sich sciendes Leben. Dann erst beginnt dan Schaffen und das Gestalten, das zur bunten Formenpracht des Sommers führt.

So wird Gott als ein zeitloses Wrerden gedacht, das sich in immer höhoren Formen zum Dasein bestimmt. So werden die Formen der Trinität nicht mehr als nebeneinanderbestehende Wesensheiten gedacht, sondern als Gestalten einer ewigen Entwicklung. Dem Gang der Menschheit rom somatischen zum pnenmatischen Evangelium entsprieht ein Werden der Gotheit aus Allaters Kraft zum schaffenden Künstlergeist. Dabei hat das religiöse Bewrisem immer wieder den Versuch gemacht. eine Beziehung zwischen den großen Symbolen der christliehen Religion Gott Vater, Sohn und Geist herzustellen. Sie bedeuten alter und neuer Bund und Bund der Zukunft. Sie haben aber auch eine notwendige Beziehung zum Sein, zum Wisen und zum sittlichen Tum. In diesen großen Interpretationen von Augustin bis Hegel handelt es sich nicht allein $\mathrm{um}$ eine Feinheit religionsphilosophiseher Deutung, sondern um den Lösungsversuch in einem schweren Kampfe. den das religiöse Bewrüsein auszufechten hatte.

Die ursprüngliche Lehre des Christentums war der Kultur völlig abgeneigt. Ja, man kann wohl sagen, daß für sie die Kultur überhaupt nicht bestand. 
Wenn aher die Religion ihren Frieden mit der Kultur machte, dann mußte sie auch die Kultur als gottgewollt verstehen. Und so ist denn seit Augustin eine ganz dentliche Verbindung zwischen den Formen der Gottheit und dem logisehen und ethischen Wert hergestellt. Gott, an sieh" in seiner reinen Lrform ist Macht und Kraft, Christus ist Weisheit und Wahrheit, und der Geist des neuen Bundes ist das Prinzip der Liebe und Güte. Die Formen der Kultur haben neben dem religiösen Wert keine selbständige Bedeutung, sondern erhalten erst dureh die Beziehung zu diesem absoluten Wert ihren unendliehen Sinn. So ist anch bei Jakob Böhme deutlich das Bestreben erkennbar, die Kultur mit einem letzten religiösen Simn zu verbinden, wenn auch die Idee eines machtvollen und schöpferischen Naturlebens, das sich in Gott zeugend entfaltet, die religiöse Kulturdentung zurücktreten läßt.

Und der Gewalt und Vielgestaltigkeit dieses Gottlebens gegenüber die ringende Menschenseele. Sie ist schon deswegen der Gotheit verwandt, weil ihre Urposition der Wille ist. Dieser Wille richtet sieh anf die Zerstörung der schlechten Welt, um dureh eine Tat der Uberwindung seiner Partikularität verlustig zu gehen und an der Versöhnung des Universmms mitzuarbeiten. Die schlechte Sinnenwelt ist nieht wie bei Meister Eckhart ein flüchtiges hi und nu, dem wir durch die Hinwendung zum kontemplativen Leben entgehen können, sie ist eine Realität, die da ist und msere Macht mit ihrer Schlechtigkeit zu überwinden droht. Täglich und stündlich haben wir mit unserem mutigen Willen gegen diese Welt anzukämpfen. Und wir tragen in uns die Kraft der Úberwindung vermöge der göttlichen Natur unseres Wesens. Dreigestaltig ist des Menschen Art: Erdenwesen, Sternenwesen, Geisteswesen. Als Erdenwesen gehört er der Simnenwelt an und ist behersseht von dem grobsinnlichen Charakter der irdisehen Kräfte und Elemente. Als Sternenwesen ragt er in ein Zwischenreich hinein, die Welt der Gestirne, die ein höheres Leben lebt. Und als Geisteswesen gehört er zum Geisterreiche der ungeschaffenen Welt. Ist das Erdenwesen hesiegt und überwunden, dann steht uns der Wreg einer seligen Rüekkehr frei.

\section{nu) Nicolaus von ('ues.}

Im Ausgang der Renaissance hat das religiöse Bewnisein noch einmal einc große Auscinandersetzung mit der Wissenschaft und speziell anch mit der rationalen Wisscnsehaft des Unwirkliehen, mit der Mathematik versucht. Die Religion hat sich immer gern mit der Mathematik verglichen, einmal weil, in ihr die Idee des Unendliehen, der eigentliehe Gegenstand der Religion, eine nicht mwichtige Rolle spielt, weiter, weil dic Mathomatik der vollendetste Ausdruck der wissensehaftlichen Erkemitnis ist, mol schlieBlieh weil der Gegenstand dor Mathematik so etwas Weltentzogenes und Vollendetes hat. Nicolaus von (:ues gelangte im I) nrehmessen des Mathematischen und ihres eigentümlichen Prinzips zu seince Gottesvorstellung, der Coincidentia oppositorum, der dere, dal.3 dis Prinzi], des Widerspruches dem Göttlichen gegenüber notwendig

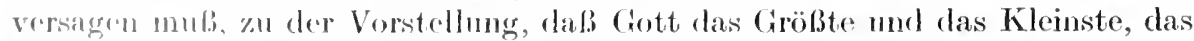
Nahe und das firmo ist. Die mathomatische Unendlichkeit wurde ihm znm Symbol des göttlichen Tesons. 
oo) Pascal.

Anders Pascal. Er sah in der Mathematik eine Wissenschaft ron höchster Gewißheit. Aber dies Wissen der Mathematik bezieht sich auf ein Unwirkliches, nicht auf ein wahrhaft Seiendes. Die Wissenschaften, welche auf Wrirklichkeit abzielen, und vor allem auch die Metaphysik, sie können an Gewißheitswert die Mathematik nicht erreichen. Es hat keinen Simn für die Metaphrsik als theoretische Erkenntnis von den höchsten Dingen, den Kampf des Wissens mit der Mathematik aufzunehmen. Hier muß sie notwendig unterliegen. Besser ist es daher, in bezug auf religiöse Dinge nicht der theoretisehen Einsicht zu vertrauen, sondern sich zu verlassen auf den Zug des Herzens und auf die Stimme frommer Ahnung. Das religiöse Leben tritt als das absolut irrationale Gebiet dem Rationalismus der Wissenschaft entgegen. Beide können sich als Gegenpole vollkommen tolerieren, aber beide haben im Grunde nur wenig miteinander gemeinsam. Was hat das flüchtige und mindere Wissen noch dort zu bedeuten, wo fromme Gewißheit und seliger Glaube wohnt?

\section{pp) Spinoza.}

Im Gegensatz zu Pascal tritt in der Gestalt Spinozas das mathematische Denken noch einmal in engste Verbindung mit der religiösen Liebe. Nicht aber in der Weise, daß die Unendlichkeit des Mathematischen zum Symbol für das Göttliche wird wie bei Nicolaus von Cues, sondern so, daß die Mathematik in ihren Lehrsätzen und Axiomen den strengen und harten Weg der Methode hergibt, auf dem nun das mystische BewuBtsein in glühender Sehnsucht und Leidenschaft dem Göttlichen sich naht. Je näher aber der liebende Geist dem Absoluten kommt, um so leichter und freier wirft er die Hüllen ab, durch welche die Idee der mathematischen Erkenntnis in ihrer Starrheit und Schwere seinen schönen Flug gebannt. Und so kommt er denn durch die Idee des amor dei intellectualis zu einer der bedeutsamsten Auflösungen, die sein innerer Gegensatz jemals erfahren hat. Des Göttlichen Gefahr ist die Liebe, weil alle Liebe einen Mangel bedeutet. Die Idee der Liebe zerstört, wie es scheint, die Vorstellung der in sich ruhenden Gottheit. Deswegen hatte die Religion des Griechentums in ihrer Vollendung das Göttliche gedacht als unbekümmert um die Welt. Das Christentum hatte die Trennung von Gott und Welt überwunden, und das religiöse Bewußtsein mußte nunmehr darauf sinnen, den Gedanken der göttlichen Vollendung mit der Idee seiner Liebe und des notwendig mit ihr verbundenen Mangels zu versöhnen. Diesen Versuch hat Spinoza in der intellektuellen Liebe gemacht.

Unser sinnliches Wesen ist nach Spinoza auf Erhöhung und Ausweitung gerichtet. Während die sinnliche Liebe unsere Macht beschränkt und uns abhängig macht von den Dingen, entfaltet sich in der reinen Erkenntnisliebe, in der leidensehaftlichen Hingabe an den Gegenstand des Wissens unsere Persönlichkeit zur schönsten, vollendeten Form. Für den tätigen Affekt der Erkenntnisliebe gilt aber das Gesetz. aller Liebe, daß sie um so größer und mächtiger sei, je größer und gegenwärtiger die Ursache ist, auf welche sie sich bezieht. Was bedeuten die gedämpften Farben der Erinnerung und die fernen Bilder und Erwartungen der Hoffnung gegenüber dem unmittelbaren Gegenwarts- 
erlebnis der Liebe? Und wie riel größer ist der Liebe Leidenschaft, wemn ihre Ursache vollkommen und mächtig und auch ron anderen begehrt und angebetet ist! Je größer und mächtiger der Gegenstand meiner Liebe ist, um so stärker ist anch mein Liebesgefühl. Es flutet und wächst mit der Größe seiner Lrsache. Nur die große Liebesursache kann die große weiße Flamme der Liebe erzengen. Wrenn mm sehon die duldende Liebe mit der Größe ihres Gegenstandes steigt und gewimnt, so gilt das noch $\mathrm{mm}$ so mehr für jene aktive werbende Erkenntnisliebe. die uns so groß und so selig macht. Je allgegenwärtiger ihre Crsache ist, $11 \mathrm{~m}$ so stärker mol leidenschaftlicher ist sie anch, und ihr Fener wird vergrößert und genährt durch die Macht und Herrlichkeit ihrer Ursache. Was aber kömnte allgegenwärtiger sein als die göttliche Naturordnung, die mich rings umgibt, und welche Ursache größer als die erste göttliche Ursache? Deswegen ist anch keine Liebesleidenschaft so groß und gewaltsam wie die Liebe der Seele zu Gott. Der erkemnende Geist liebt Gott und das Universum. sofem er Ausdruck und Teil dieser Ganzheit ist, sofem in seiner kleinen Welt die göttliche mud ewige Welt sich spiegelt. Das Göttliche wird im menschlichen Geiste offenhar, und dieses Offenbarwerden erzengt die große Liebe. Was offenhar wird und in heiliger Liebesflamme sich erhebt, das ist der Geist Gottes im Menschen. Was in so großer Liebe und Sehnsucht das Göttliche erkennt, das ist das Göttliehe, das sieh selbst erkennt. Des Menschen Erkenntnisliebe zu Gott ist die Liebe Gottes zu sich selber.

Damit ist der Giedanke des Mangels in Gott getilgt. Dem die Liebe Gottes zu Welt und Mensch ist nicht anf etwas gerichtet. was anßerhalb seiner Sphäre liegt. Der erliemmende Menseh ist der göttliche Mensch, und der göttliche Mensch ist eine ummittelbare Ausgeburt der Gottheit. Er ist ein Teil der großen göttlichen Liebe, die sich in seiner Schönheit wiederfindet. Die Liebe der Gottheit findet ihre Erfüllumg in dem göttlichen Menschen, der notwendig zu ihr gehört nnd nicht von ihr abgelöst werlen kann. und die Licbe des göttlichen Mensehen findet ihre Erfüllung in Gott.

Jas Resultat der Renaissancebewegung ist sehließlich doch die Befreiung des religiösen BewnBtseins aus der Vermischung mit dem Theoretischen. 'Theoretische Gesichtspunkte hatten das religiöse Leben mit Rationalisiemng bexhoht. Dieser Abhängigkeit war es entromen. Doeh verblieb es nicht lange in sciner Antonomie. Neus dogmatische Fomen suchten es zn rationalisieren, und ror allem wurde das religiöse Ieben immer mehr im Nime der Moralität verstanden. Da b das Gehiet des frommen Glaubens und des erkenntnismäBigen II issens sehr versehieden war, das hatte man ein fïr allomal eingesehen. Nun aler glanbte man, den Kern des religiösen Lebens und der religiösen Lehre in gewismen ethisehen Fonderumgen anzutreffen. (iewils, auch die theoretisehe Barlonhmg ifer Religion hat noch lange angerlanert. Noch Auguste Comte

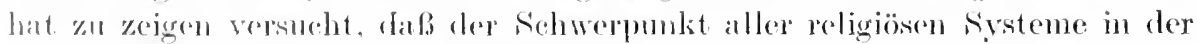
Wraltaliarmug liege, mol der Protestantismus verlor gar viol von seiner Eigen-

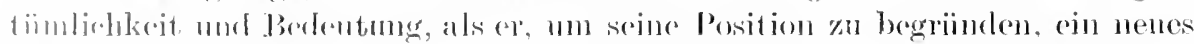

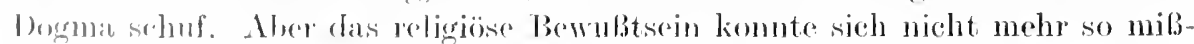

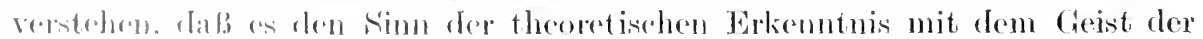

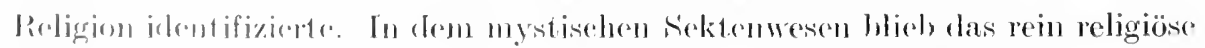

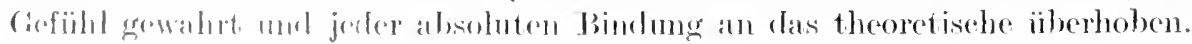


Das religiöse Bewußtsein hatte ein für allemal die Erfahrung gemaeht, daß die theoretische Erklärung und die ganze Beweisführung des theoretischen Bewußtseins seine Ideen und Ideale nicht sicherstellen konnte; daß es simnlos und numöglich sei, einen theoretischen Beweis für das Dasein Gottes, die Cnnsterblichkejt der Seele oder für die Ideen der Schuld, der Erlösung, des Schicksals, der Offenbarung und der Schöpfung zu führen. All diese Itcen wollen religiös und nicht etwa theoretisch und moraliseh rerstanden sein. Sie haben keinen Welterklärungssinn und auch keine Beziehung zu dem ethischen Postulat der Pflicht oder zu dem praktisehen Gesichtspunkt des Nutzens und Torteils. Aus dem eigentümlichen Wesen des religiösen Gefühls, das als Tatsache vorliegt, wollen sie verstanden sein.

Daß das theoretische Bewußtsein dem religiösen Bewußtsein nicht helfen kann, das war eins von den wichtigsten Ergebnissen der Renaissanceberegung. In dem großen analytischen Zeitalter des Griechentums, das ron theoretischästhetischen Wertgesichtspunkten.geleitet war, sind die höchsten Formen des religiösen Lebens den theoretischen amalgamiert und noeh zu keinem Sonderbewußtsein gelangt. Umgekehrt verlor das Theoretische im großen synthetischen ZeitaIter des tausendjährigen Reiches seine Selbständigkeit gegenüber der Religion. Es sollte die Existenz der Religion rechtfertigen und beweisen. Als ob es die Religion notwendig gehabt hätte, ihr Daseinsrecht ron der Wissenschaft begründen zu lassen, und als ob Philosophie und Wissenschaft jemals Halt machen könnten vor einem Reich der Geheimnisse, da es nun einmal, wie das vor allem die Gnosis erkannt hat, ihre tragische Schuld ist, mit gottloser Fand an den Mysterien zu rühren.

Im Zeitalter der Aufklärung, das die große analytische Bewegung, welehe die Renaissance begonnen hatte, weiter führte, wurde das religiöse Leben zwar noch vielfach mißdeutet, aber es hatte doch die Kraft und die Möglichkeit, für sich zu bestehen. Diese Mißdeutungen liegen ror allem in den Erscheinungen des Sozinianismus und Deismus sowie auch in dem Gedanken der Naturreligion und des Freidenkertums.

\section{qq) Die Naturreligion.}

Der Begriff der Naturreligion beruht auf demsennen metaphysisehen Irrtum wie der Begriff des Naturrechts. Wie gegenüber dem Naturrecht die Schöpfungen des positiven Rechtes als Willkür erseheinen, so die positiven Religionen gegenüber der Natur- oder Vernunftreligion. Zu dem Utberhistorischen, Ursprünglichen, durch keine menschliche Satzungen Entstellten will man gelangen. Dieses Ursprüngliche aber ist das, was mit der vernüntigen theoretischen Einsicht übereinstimmt. Diese Lehre setzt voraus, daß die Religion etwas sehr Leichtes und Gemeinverständliches sei, das keine Abgrïnde und Mysterien enthält, sondern hinsichtlich seines Sinnes und Unsinnes ron dem rerstandesmäßigen Denken leicht kontrolliert werden kann. Die religiöse Idee des Wunders und der Offenbarung wird gefährdet. Gott offenbart niemals das Unbegreifliche, sondern nur dasjenige, was begriffen werden kamn, und von dem Begreiflichen nur dasjenige, was der Verstand des Menschen aus eigener Kraft nicht durchdringen kann. So ist die Offenbarung eine sachgemäße 
Ergänzung der natürlichen Erkenntnis. Was wir selber nicht begreifen können, macht uns die Gottheit begreiflich und offenbar. Dabei ist angenscheinlich der Verstand oder die Vernmnft zum Richter über die Offenbarung gesetzt, und die natürliche Konsequenz dieser Lehre mußte dahin gehen, daß das Wunder der Offenbarung vor dem Richterstuhle des theoretischen Verstandes auf die Daner nicht bestehen konnte und somit die Offenbarung gelengnet wurde.

\section{rr) Das Freidenkertum.}

Ein ähnlicher rationalistiseher Zug findet sich anch in dem Freidenkertum der Aufklärung. Teilweise kam man in ihm gewiß eine Bewegung erblicken, welche die Religion von der Starrheit des Dogmatismus erlösen und ihr die freie Beweglichkeit wiedergeben wollte. Aber damit ist die Bedeutung des Freidenkertums doch sehr einseitig gesehildert. Im Grunde bedeutet es im Verhältnis zur Religion weit mehr Freiheitsberanbung wie Freiheitserwerbung. Dieser Standpunkt entwickelt eine Religionsmetaphysik und mißt an ihr die religiösen Erscheinungen. Er findet, daß die religiösen Probleme erst dort beginnen, wo die positiven Religionen aufhören. Das religiös Problematische liegt in einer Sphäre, wo der Unterschied der historischen Religionen jede Bedeutung verliert. Das wahrhaft religiös Bedentsame ist in allen Religionen dasselbe. In dieser Behauptung des Freidenkertums seheint, flïchtig betrachtet, eine gewisse Tiefe und Imnigkeit zu liegen, und menschlich schön wirkt diese Lehre in dem freimütigen Bekemntnis zur Toleranz. Nur kann die Toleranz sehr verschieden gemeint sein. Sie kann aus einem religiösen Bewußtsein quellen, das alles Zeitliche abgestreift und sieh in den Tiefen der Ewigkeit verloren hat, und sie kamn ebensogut das Produkt einer gewissen religiösen Gleichgïltigkeit und Entleerung sein. Das Hinausgehen über das Positive kann das Finden der seligen Armut bedeuten. Das Hinausgehen kann aber auch mit einem Verlieren des spezifisch religiösen Gehalts verbunden sein. Die Aufklärung war gewiß in religiöser Hinsicht mehr Ausleerung als Verticfung. Das Wertrolle sollte das allen Gemeinsame sein, aber das Allgemeine ergab sich als das Flache und Leere, das all seiner Stärke und Wurzelhaftigkeit beraubt ist. Nichts ist leerer und hohler als die religiöse Maxime, da 3 jeder auf seine Art selig werden kam. Es gibt keine Wahl des religiösen Lebens und keine Höhcn und Abgründe. Der eine Weg ist so gut wie der andere, und wir betreten len l'farl, der uns gefällt, der unserer Individualität angemessen ist. Eine solehe Auffassmug der Religion erfordert kein ernstes Simen ïber das, was uns fehlt. ïber die cigene Bedïrtigkeit und Liebe, deren Ergänzung und Erfïllung das (:öttliche ist, sondern hier ist es so gemeint, da $B$ jedes Individuum vermöge sciner Eigenart cine besondere Strabe zieht und auf diescm Wege schon zu Gott gelangen wird, da ja vicle Wege zu Gott führen.

\section{ss) Sozinianismus.}

Tor allem aber riclte die Religionsdentung der Aufklïrung darauf ab, die roligiösen Erscheinungen im Sinne des Rechtes und der Moralität zu interJuetiern. So vermorhte dor Sozinianismus in den religiösen Lehren nichts anderes zu crblirken als eine Gesetzgebung des höehsten Wesens. Gott ist 
Reehtsschöpfer und Richter und Rechtsvollstrecker zugleich. Er stellt dic Gebote auf, die für alles Menschliche notwendig gelten, und wacht eifersüehtig über ihre Befolgung. Klar und sicher hat er den Weg des Rechtes uns gewiesen, so daß wir bei gutem Willen ihn nicht verfehlen können. Für unsere Hancllungen und Taten aber fordert er Rechensehaft ron uns, denn er ist der strenge und unparteijsche Weltenriehter. Wir müssen die Konsequenz unserer Handlungen auf uns nehmen und Strafe dulden für das, was wir gesündigt haben. Er selber vollstreckt diese Strafe über uns und läßt uns seine schwere, aber gereehte Hand fühlen als Vergeltung für alle Verstöße gegen seine Rechtsordinung.

\section{tt) Deismus.}

Ähnlich einseitig interpretiert der Deismus die Religion als Morallehre. Die Mysterien und die großen religiösen Symbole sind Cmkleidungen und Umhüllungen für eine Tugendlehre. Die Größe und Bedeutung einer Religion. etwa des Christentums, liegt in der Größe der sittlichen Anffassung. welche dureh sie vertreten wird. Die religiösen Symbole, Forderungen und Befehle treten in einer eigentümlichen und phantastisehen Gestalt auf, die dem naiven Berußtsein der Mensehheit angemessen ist. Die moderne Menschheit erkennt das klare und einfaehe Soll, das hinter diesen Befehlen steht. Gott kamn nicht anders gedaeht werden als der höehste moralisehe Gesetzgeber. Wer seine Pflicht erfüllt und die Aufgaben löst. die ihm gestellt sind, der schreitet sieher dahin auf dem Wege zu Gott. Die Religion ist nieht sowohl eine Anweisung zum seligen Leben als riehmehr eine Anweisung zum sittliehen Leben. Ind so möchte man glauben, daß ihr Sim darin beschlossen liegt. die Mensehen hier auf Erden dem Pfad der Tugend zuzuwenden und ron dem Weg des Lasters zu entfernen.

\section{uu) Die Romantik.}

Die Befreiung der Religion aus den Umsehlingungen des moralischen Bewußtseins, das war die große Leistung der jungen Romantik. In der Romantik kündigt sich ron neuem ein synthetisches Zeitalter an, aber wir können es noeh nicht ganz verstehen, da wir es noch nicht zu Ende gelebt haben. Nur so viel ist deutlich, daß die Romantik von nenem den Versueh gemacht lat und weiter machen wird, die versehiedenen Kulturgebiete in einer Einheit zu rerbinden. um so ein neues Symbol des Endes zu geben, jener Erfüllung alles Geschehens. das keinen Gegensatz mehr kennt in der großen Liebestat der Versöhnung. Wie ist es num aber möglich, daß die Romantik eine Srnthese herbeiführt und doch gleichzeitig die Selbständigkeit des religiösen Lebens gegenüber der Moralität zu sichern rermochte? Auf jeden Fall war die Einheit, welehe die Romantili erstrebte, nieht die Einheit des lastenden Allgemeinen, die das Mittelalter verkündete. Damals wurdendie Formender Religion zu beherrschenden Mäehten des Lebens erhoben. Dem religiösen Werte sollten alle anderen Kulturgebiete bedingungslos untertan sein. Ihre Individualität und Eigenart mußten sie opfern, weil sie zum bedingungslosen Dienen rerurteilt waren. Ihr Beurteilungsprinzip, das einen letzten Gesichtspunkt der Wertbetrachtung in sieh sehloß. fand seine Korrektur an der religiösen Vorstellungswelt. Die Wissenschaft 
mußte den Trieb nach Wahrheit opfern, wenn das Heilige bedroht sehien, und die Schönheit mußte sich verhüllen, wenn die Gefahr vorlag, claß ihre Nacktheit das mnkïnstlerische Empfinden zn plumper Begierde hinreißen konnte.

Die Synthese, welche die Romantik stiften wollte, trug einen durchaus rerschiedenen Charakter. Die Religion sollte die Kultur verklären, die ernste Weihe, den großen Hintergrund sollte sie ihr geben. Die Einheit in der Religion, welche die Romantik ersehnte, sollte keine lastende Herrschaft des Allgemeinen, sondern eine große Tat der Versöhnung und eine Umarmung der Liebe sein. In dieser Einheit, welche die Romantik begründen wollte, sollte die Individualität des Einzelnen vollkommen gewahrt bleiben, niemals sollte die Religion das strenge Antlitz der Richterin annehmen. Die Religion sollte ein sehöner Gefährte sein, der uns freundlich geleitet und uns das Dasein lieb und wertvoll maeht. Dies Geleitsrecht der Religion ist darin begründet, daß der Rhythmus mseres innersten Erlebens einen religiösen Charakter trägt. Wie die Religion das Urphänomen aller Kultur ist, so sind wir anch im tiefsten Grund der Seele religiös gesinnt und gestimmt. Wir branchen uns nur zu entdecken, so werden wir mus auch als religiöse Mensehen verstehen. Der religiöse Mensch ist also im romantischen Simne weit weniger eine Abstraktion als etwa der wissenschaftliche ofter moralische Mensch. Diese beiden repräsentieren notwendig eine große Einseitigkeit, der religiöse Mensch hingegen eine große Vielseitigkeit, weil er Empfindung für alles und ein Gefühl für das Universum hat.

Die ganze romantische Bewegung bekämpft von vomherein die einseitig moralistische Auffassung des Lebens und der Religion. Die Moralität erscheint als der gemeinsame Gegner der Kunst und des religiösen Gefühls. Man hat die "Genialitätsmoral" (ler Romantik vielfach als UUbersehwang eines jugendlichen Ästhetentums belächelt und anch wohl verurteilt. Man vergaß nur, daß der religiöse Geist sehr versehiedenartige Gewanting annimmt, und daß der Kampf, der hier geführt wurde, nicht nur gedentet werlen darf als ein leichtes und graziöscs Sich-Hinwegsetzen über umbequeme Bindungen und Hemmungen des künstlerischen Gestaltungstriebes, mit dem sich in ciesem Talle die jugendliche Sehmsucht nach Lebensglück und Lebensgenuß verbindet, sondern vielmehr als cin Wunseh und ein Streben, über die Alltagsmoral hinauszukommen und auch über die hohe Moral des kategorischen Imperatives hinweg nach jenem ganz eigenen und in sich geltenden Gesichtspunkt zu gelangen, wo der rcligiöse Menseh in seiner Reinheit dem Göttliehen gegenübersteht.

Das religiöse Bewußtsein hat immer Zeiten gehabt, wo es bei sich war und in Reinheit und Unabhängigkeit lebte. Schleiermacher hat diese religiöse Autonomie wie wenig andere zu verstehen gewußt. Die verstehende secke des grobsen Romantikers entdeckte das Eigentümliche des religiösen Labens, indem er es anf das engste mit den P'roblemen der Kunstphilosophie verhand. Wenn das logische Gefühl der Evidenz und das ethisehe Gefühl der Arhtung die GesctzmäB Bigkeit der Vorstellung und des Willens, die sich in den logischen und ethischen Normen offenthart, $n$ m leise begleitet, so bedeutet das istluetische und religiöse Gofühl cine vollkommen selbständige Melodie. bas logisclan und ethische Gefülı ist leicht zu durehforsehen, während jene anderen beiden I linwrise sind anf ein grobes Unbekanntes, das in ihnen recht rigentlich leht mul in der. Inukelheit scinen Wohnsitz hat. Schleiermacher 
verstand das Gefïhl als die Grundposition des religiösen Bewußtseins und sah gerade darin die Verwandtschaft von Kunst und Religion. Das irrationale religiöse Gefühl in der unendlichen Fülle seiner Beziehungen aber verstand er vor allem als ein frommes Gefïhl der Abhängigkeit rom Weltgrunde. Und damit hatte er in der 'Tat eins der Momente anfgewiesen, die ihm für alle Zeiten charakteristisch sind. Die Furcht- und Erwartungs- und Verehrungsgefühle, aus denen man das religiöse Leben so gern hervorgehen läßt, sie sind noch nicht das religiöse Gefühl selber, und die Oberfłächenbeschreibungen der Psychologie können es nie in seiner Wurzelhaftigkeit erfassen ${ }^{1}$ ).

Nach Schleiermacher steht in dem religiösen Verhältnis das Endliche dem Unendlichen gegenüber. Dieses Endliche ist jedoch nicht das SinnlichVergängliche, sondern die Begrenzung zur Individualität und Persönlichkeit. Diese Persönlichkeit ist nicht der ethische oder theoretische Hensch in seiner Abstraktheit, und auch die weit größere Konkretheit der historischen Individualität reicht nicht an das eigentlich Wesentliche heran, das für die religiöse Persönlichkeit gilt. Der Ausdruck des religiösen Lebens ist in jedem Menschen ein anderer, und durch ihn ist er in semem ganzen Tun und Leiden, Geben und Empfangen bestimmt. Die Sonderart der Begrenztheit, das Eigentümliche der Lebensform bildet die religiöse Persönlichkeit. So begrenzt zu sein, in dieser ganz besonderen Weise, ist Schicksal. In dieser meiner Sonderstellung bin ich einzig und unersetzlich. Niemand vermag den Beitrag zum Lniversum zu leisten, den ich leiste, niemand das Göttliche so zu lieben, wie ich es liebe. Aus der Eigentümlichkeit meines Seins folgt die Idee ciner eigentïmlichen Bestimmung, die ich besitze und die ich ergreife, sobald ich mich selbst rerstanden habe.

Dem Endlich-Persönlichen gegenüber bedeutet das Göttliche die Erfüllung des Mangels und der Begrenztheit, die immer wieder in neuer Form so oft sich vollzieht, als eigentümlicher Daseinssinn in der Welt besteht. Dem Göttlichen selber jedoch dürfen wir keme Bestimmungen geben, die es zum Ideal der Erkenntnis oder des sittlichen Lebens machen. Religiös betrachtet ist Gott weder der Allwissende, moch der intuitive Verstand, und auch der moralische Gesetzgeber und die Idee der Allmacht bilden noch nicht den Gegenstand acr Religion. Die ästhetische Idee als der verhültte Ausdruck des Genialen im Kunstwerk und der Begriff eines übersimnlichen Substrats der Menschheit rühren schon näher an das Eigentïmliche una Selbständige, was das religiöse Bewußtsein meint. Das Göttliche ist für den einzelnen dasjenige, wasihm, dem Endlichen. die Vollendung gibt. Alle bedürfen der Vollendung als der Befreiung oder Erlösung ron der Begrenztheit; der eine bedarf dieses, der andere jenes. der eine mehr, der andere weniger zur Vollendung. Gott ist immer das, was uns fehlt. Alles Irdische ist Stückwerk, und als eine Unendlichkeit des Framentarisehen stellt sich mensehliches Leben und menschliches Wesen dar. Das Göttliche ist diesem Fragmentarischen gegenüber die immer neue Form der Ergänzung, welche die Halbheit zur Ganzheit, den Torso zu Vollstïndigkeit, das Cnzulängliche zum Kunstwerk macht und so in dem großen Zusammenhang des Wirklichen immer wieder neue Harmonicı auslöst. Einsam steht die Scele den anderen

1) Vgl. besonders Schleiermachers Reden über die Religion; neu herausgegeben in der „Dəutschen Bibliothek“ von Martin Rade. 
Seelen gegenüber in vollkommener Abgeschlossenheit. Denn gerade dasjenige, worin ihr eigentümlicher Wertcharakter ruht, vermag sie nicht zu offenbaren. Deswegen wird die Seele immer unverstanden bleiben und auch nur selten zum Ausdruck gelangen, darin der Seele Seligkeit liegt. Nur der geniale Menseh rermag sich zu offenbaren, den anderen aber ist Sehnsucht nach Offenbarung eigentïmlich. Die erlösende Liebestat der Gottheit, die unserem Mangel abhilft. der sich in schweren Hemmungen und Bindungen äußert, in denen wir die ganze Schwere unserer Schuld ertragen, und darin all unser Leiden gesetzt ist. diese sehöpferische Künstlertat Gottes macht uns frei und läßt die Seele zum Ausdruck kommen und gibt ihr die Kraft zur Offenbartung. In dem großen Einsamkeitsrerhältnis ron Mensch zu Mensch, das unter dem religiösen Gesichtspunkt gewiß besteht, ein Verhältnis, dem Leibniz in der Idee der Monade rollendeten Ausdruck gab, kann der eine dem anderen so wenig bedeuten, weil er ohne Verstehen bleibt und niemals weiB, was uns fehlt. In den Verhältnissen der Liebe und Freundschaft allein glauben wir verstanden zu sein, eine Illusion, die unser Dasein sehön macht. In Wahrheit aber ist Gott das Verstehende allein, er ist die ganze Göttlichkeit des Verstehens. Und dies Verstehen ist nicht dic Vollendung der theoretischen Erkenntnis oder die Verabsolutierung des erkemenden Iehs, wie sie in Kants Begriff des intuitiven Verstandes zum Ausdruck kommt, sondern die Erfïllung sehnsüchtiger Liebe.

So hat die Romantik den Versuch gemacht, das religiöse Leben in seiner Reinheit zu erspähen und den alten Symbolen der Religion ein neues Leben yegeben. Wir wandeln woht immer noch auf ihren Wegen und befinden uns in einer Zeit, die eine neue Synthesis rorbereitet. Die Züge dieses neuen Kultursystems rermögen wir jedoch noch nicht zu erschauen, der Sim der nenen Zeit ist noch in Rätsel eingehïllt. Wir warten als religiöse Mensehen auf ein nenes grobes symbol des Endes.

\section{Viertes Kapitel. \\ Die isthetische Entwicklung.}

\section{a) Das ästhetisehe Grundrerhältmis.}

Das ästhetische Grundrcrhältnis offenbart sich in dem Gegensatz ron Eros und (iestalt, eines grenzenlosen Triehes, der von Schnsucht nach Form (rfültt ist. J)ic Kerlegung des Kmotwerkes in Form und Inhalt ist ungenügend, weil unter dieser Aufteihung der Sim des Kunstschaffens überhaupt nicht zur Sprache kommen kamn und das Objekt der kïnstlerischen Liebe selber sehon immer rin irgendwie Geformtes ist. Bilder der Phantasie werlen aus ihrem schwatchen Jämmerleben befreit und zu Wirkliehleiten erhoben, Wirkliehkriton ihrep brutalen livaliät enthoben und zu schönen und flüichtigen Ge-talten rewaicht. Frlebuisseder Vergangenheit, die inder Gestalt von Erimerungs-

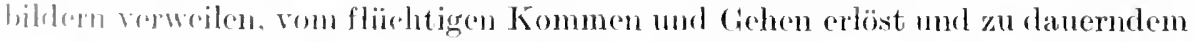

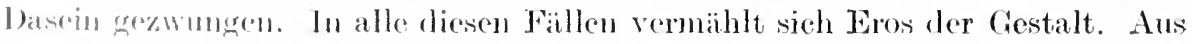

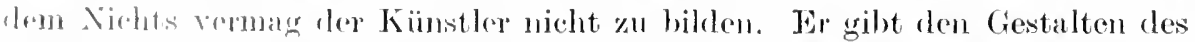

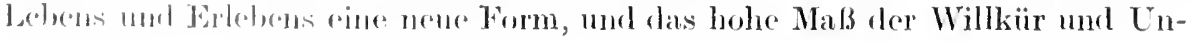


gebundenheit gegenüber dem Stoff, das dem Trieb des Künstlers eigen ist, läßt sein Tun als absolute Schöpfertat erscheinen.

Es gibt aber zwei rerschiedene Wege, welche der Künstler gegenüber der Gestalt einschlagen kann, nämlich entweder so, daß er die Gestalt, der seine Liebe gehört, zur absoluten Gestalt erhöht und zu dem Geformten die nene Form in der Weise hinzufügt, daß er ihre Begrenzung ein für allemal festhält und in dem Bildhaften zum vollendeten Ausdruck gelangt Das ist die Schöpfertat der Plastik. Der andere Weg ist die Befreinng von der Bildhaftigkeit und Begrenztheit, eine Entformung, die jede Spur des irdisehen Daseins vertilgt und dem Chaos zuzueilen seheint, um eine neue ursprüngliche Welt durch eigene Gesetzmäßigkeit zu erzeugen. Das ist die Erlöseltat der Musik, die nicht mit Bildern zu uns spricht, sondern uns viel unmittelbarer ergreift, indem sie unsere Leidensehaften und unser dunkles Gefühl in seinem unendlich wechselnden Reichtum in Tonwellen darstellt.

\section{b) Die ästhetische Idee.}

Wie die niederen Formen des religiösen Lebens zwar für den Historiker der Religion von größter Bedeutung, für den Philosophen jedoch, der ihre Entwicklung deutet, ohne erhebliches Interesse sind, so sind für die Philosophie der Kunst auch nur die großen Meisterwerke wichtig, die das besitzen. was wir ästhetische Idee oder innere Form nemnen. Die ästhetisehe Idee ist dasjenige, was dem Kunstwerk eine imnere Einheit gibt, was ihm Sinn und eigentümlichen Wert verleiht, und zwar einen Sinn, der auch unabhängig rom Kïnstler bestehen bleibt. Es gibt sogenamnte Kunstwerke, die von ihrem Meister niemals vollkommen abgelöst sind, die nur durch ihn verstanden werden können und Umschreibungen seines Erlebens sind, Werke. die kein sclbständiges Dasein besitzen, die keine vollkommenen Objektivierungen, keine selbständigen Schöpfungen sind, weil ihnen die eigene Seele fehlt. Es ist rollkommen verfehlt, das große Kunstwerk nur als Offenbarung des Kïnstlers rerstehen zu wollen, in dem Simne, daß er sich selbst offenbart. Denn so gewiß das Kunstwerk Ausdruck einer schöpferischen Persönlichkeit ist und gewisse Züge seines Wesens verrät, so gewiß ist das große Kunstwerk weit mehr als die Offenbarung des Persönlichen, nämlich Darstellung des Überpersönlichen und Unsinnlichen, und die Darstellung des Unsinnlichen gibt dem Kimnstwerk den Vollendungscharakter.

In der ästhetischen Idee als des Kunstwerks ïbersinnliehem Gehalt ist das Götthiche verhüllt gegeben. Es ist mit der Anschanung verschmolzen und aus der Sinnlichkeit nicht ablösbar. Im Kunstwerk ist clas Simnliche mit dem Ủbersimnlichen versöhnt. Das Unendliche der äst hetisehen Idee, das Lnerschöpfliche und Unergründliche, hat sich hier der Unendliehkeit der Anschaumg hingegeben und flutet durch all ihre Teile hindureh. Das Übersinnliche durehdringt alle Teile des Kunstwerks und läßt niehts Lngeformtes und Gleichgültiges zurück. Die ästhetische Idee hat kein von Kunstwerk abgelöstes Sein. sondern lebt nur im Kunstwerk als dessen Seele und innerster Ciehalt. Sie ist ein Etwas, was nie auf einen Begriff gebracht werden kann, was sich jecler Rationalisierung entzieht, ein Etwas, auf das der verstehende Geist nur hindeuten kamn. Sie ist 
jenes Etwas, das den problematischen Charakter des Kunstwerkes ausmacht. Mit ihr kann sich der absolute Widersprueh und das vollkommen Paradoxe rerbinden. Dabei ist die ästhetisehe Idee niemals eine bestimmte ethische Torm oder eine religiöse Idee als solehe. Sie ist ïberhaupt nichts, was in der Form des Begriffes gesagt werden könnte; denn wäre dasjenige, was das Kunstwerk meint, begrifflieh auszudrüeken, so würde es begrifflieh gesagt sein und nieht in der Form der Ansehauung. Dasjenige vielmehr, was in der Sprache des Begriffes nieht mehr gesagt werden kann, das drückt der Künstler in großen Symbolen aus.

Man möchte nun meinen, daß im Kunstwerk nieht nur die Einheit des Simnlichen und Übersinnlichen, sondern aueh die Einheit oder doch der Zusammenhang der Werte gegeben sei. Jene Aufgabe, die ursprünglieh der Mythos erfüllte, indem er die ungesehiedene Einheit des Wertlebens zum Ausdruek braehte, die Kunst hat sie ein für allemal zur ihrigen gemacht. Die Wertformen der Kultur und des Lebens sind aber entweder in der Form der Einheit oder des Gegensatzes gegeben, je naehdem das Moment der Spannung oder der Lösung dominiert. Die ästhetische Idee in ihrer unendliehen Fülle hat es immer mit der Ganzheit des Wertlebens zu tun. Deshalb fühlen wir der Kunst gegenüber in so hohem Grade die Erfüllung und Erhöhung des ganzen Menschen, weil alles, das für uns etwas bedeutet, im Kunstwerk enthalten ist und auf uns einströmt, so daß das Schöne uns ganz ergreift und in seiner Ganzheit und Totalität den Sinn der Welt versammelt.

\section{c) Die ästhetische Individualität.}

Das Wunderbare, die ästhetische Idee, fordert einen besonderen Stoff, ım sieh an ihm zu offenbaren. Nieht jede Begebenheit, nieht jede Individualität ist gleiehmäßig geeignet, den Sinn der ästhetischen Idee kund zu tun. Hektor, der Sohn des Priamos, konnte, vor allen anderen Gestalten schön, die Größe les Kampfes um die Vaterstadt und den heimisehen Herd offenbaren, und der dunkelhaarige Knabe des alten Karamasow vermochte so besonders gut den Simn des religiösen Bewußtseins und aller mensehliehen Schicksale, die in ihm enthalten sind, zu enthüllen.

\section{d) Typische und charakteristische Kiunstiorm.}

Es bestehen nun aber diese beirlen Mögliehkeiten, daß die Individualität mehr hinter dex ästhetischen Idee versehwindet und das Übersinnliche sich so mächtig ankïnligt, daf die Gestalt als Wolnsitz der inneren Form geneigt scheint, ihre Individualität zu opfern und aufzugeben, oder aber die Idee tritt hinter der straffen Form der Individualität mehr zuriick und kündigt sich nur laise an. Je nachdem peflegt man zwischen cincr iclealistisehen und realistisehen, cincr typischen mul charakteristischen Kunstform zu unterseheiden, inden brisle der isfeculosen Kunst antgegengesetzt werden, die dureh bloß simnliehe Mittel Simuliches erzielen will. 


\section{e) Naive und sentimentalische Kunst.}

Aber auch der Gegensatz ron Kunstwerken, die Wertfeindlichkeit oder Wertversöhnung in der Fülle möglicher Beziehungen zum Ausdruck bringen, scheint eine Unterscheidung zuzulassen. Hier bedarf es jedoch noch einer näheren Bestimmung. In jedem Kunstwerk ist eine Versöhnung des Unsinnlichen mit dem Sinnlichen erzielt, ein absoluter Widerstreit gelöst, und deswegen strahlt von jedem Kunstwerk eine vollkommene Harmonie aus, weil das Kunstwerk das zusammenführt, was im Leben sich ewig fliehen muß. Dennoch kann das Kunstwerk das Übersimmliche oder Geistige so darstellen, daß es entweder freiwillig mit der Sinnlichkeit zusammengeht und das gegenseitige Verhältnis so erscheinen läßt, daß das Sinuliche und die Natur der sichere Besitz des Geistigen sind, oder aber die Natur erscheint als dasjenige, was wir verloren haben und der unsere Erinnerung oder unsere Sehnsucht gehört. Diese beiden Möglichkeiten, die man als Kunst des Schönen und Erhabenen oder des Naiven und Sentimentalen einander gegenübergestellt hat, wollen nichts dagegen besagen, daß das Úbersinnliche in jedem Kunstwerk durch das Simnliche offenbar geworden und zu einer restlosen Harmonie geführt ist. Denn die Versöhnung, die hier gemeint ist, bezieht sich auf die Angemessenheit von ästhetischer Form und simulichem Substrat; also auf das Verhältnis der beiden Elemente, aus denen sich das Kunstwerk aufbaut, während der Begriff des naiven oder sentimentalen Kunstwerkes erst dadurch entsteht, daß das ästhetische Subjekt hinzugedacht wird, und nur die Úberlegung stattfindet, daß im Dichter selber das Sinnliche und das Geistige von vornherein im Gegensatz sich befinden können oder nicht. Mag aber nun das Wesen des Künstlers Harmonie oder Dissonanz bedenten: In dem vollendeten Werk ist jeder Gegensatz des Sinnlichen und Übersinnlichen überwunden und zwar so, daß die sinnliche Individualität als der einzig angemessene Ausdruck der Idee oder die Idee als der einzig mögliche Sinn der Individualität erscheint.

\section{1) Wertgegensatz und Wertharmonie.}

Etwas anderes ist nun der Cnterschied ron Wertgegensatz und Wertharmonie, der im Ideenzusammenhang eines Kunstwerkes rorhanden sein kann. Jedes Kunstwerk trägt die Totalität des Wertlebens in naher Verbindung in sich. Diese Totalität pflegen wir wohl als den geistigen Gehalt des Kunstwerkes zu bezeichnen. Es ist schließlieh dasjenige, was jedes Kunstwerk zum Ausdruck einer Weltanschauung masht, was uns etwa berechtigt, von der Welt Hom ers zu sprechen. Das Kunstwerk ist vollendeter Ausdruck des Wertlebens. Es vermag eine Einheit herbeizuführen, an welcher der Begriff verzweifeln muß. Aber dieser geistige Gehalt des Kunstwerkes, den wir in dem Begriff der ästhetischen Idee zusammenschließen, darf nicht mit dem mythologischen Gehalt des Kunstwerkes verwechselt werden, so daß man etwa mit Schelling zu der Behauptung kommt, in jedem Kunstwerk sei so viel Poesie enthalten, als Mythologie in ihm vorhanden ist. Es wäre vollkommen verfehlt, das ästhetisch Wertrolle in Homers Ilias oder in Goethes Faust nur in den mythologischen Elementen zu sehen. Die ästhetische Idee, wie wir sie 
meinen, in welcher der geistige Gehalt oder das Wertleben des Kunstwerkes seine Einheit findet, braucht keineswegs immer das Mythologische zu sein. Die ästhetische Idee der Ilias entfaltet sich auch in der Beziehung zwischen Hektor und seiner Vaterstadt, umabhängig ron dem Schicksalswort, das Ilias' Untergang bestimmt, und die Sehnsucht des Odysseus nach dem fernen Rauch seiner Heimat verändert ihren Wertcharakter kaum, wenn wir wissen, laß zïrnende Götter seine Heimkehr hemmen. Dennoch liegt in der Gleichsetzung ron Mythos und ästhetischem Wertgehalt eine sehr begreifliche Verwechslung, weil doch der Mythos nun einmal in der Wirklichkeit des Geisteslebens jene ungeschiedene und ungebrochene Einheit bedeutet, aus der sich alles differenziert hat. Trägt nun das Kunstwerk das ungeteilte und ungetrennte Wertleben in sich, ein Umstand, der es zum Symbol der ewigen Jugend des Menschengeschlechtes macht, so ist es gegeben, dieses Getremnte in dem mythischen Stoff des Kunstwerkes zu vermuten. Diese Gleichsetzung wird noch verständlicher, wem man bedenkt, daß auch im Mythos das Übersinnliche in konkreter Form, in der Gestalt der Ansehaumg erscheint, so daß der Mythos aufgefaßt werden könnte als das ursprïngliche Werk der gestaltenbildenden Phantasie, als ein göttliches Kunstwerk, das im Werk des Mensehen neue Gestalt gewinnt.

Das Wahre der Auffassung Sehellings ist dieses, daß im Kunstwerk die Welt noeh ganz ist, daß das Kunstwerk das verlorene Paradies aufbewahrt. Doch das ungeteilte Wertleben des Kunstwerkes bedarf des Mythos nicht zu seiner Verhüllıng. Die Cmhüllung, welcher die ästhetische Idee bedarf, um ihr seliges Geheimnis nieht preiszugeben und zu entblößen, wird durch jede Form der simnlichen Anschaumg gewahrt, mag es sich num oder die des Tones handeln.

Wenn wir von Kunstwerken sprechen, deren ästhetische Idee eine Wertharmonie bildet, und sie von anderen unterscheiden, die einen Wertgegensatz zum Ausdruek bringen, so meinen wir eine Entgegensetzung, die der ron naiv und sentimentaliseh, sehön und erhaben verwandt ist, aber ihre Einseitigkeit ïberwindet. Die Unterscheidung des Schönen und Erhabenen int rou Kant aufgestellt und besagt, daß das Gefühl des Schönen anf einer urpriüghehen Harmonie ron Sinnlichkeit und Verstand beruht, während das (icfühl des Erhabenen dadurch entsteht, daß etwas uns entgegentritt, was die lcistung unseres Verstancles und Willens weit ïherragt, eine Ansehanung, deren Enendlichkeit der Verstand nicht meistern, eine Kraft, die der Wille nicht bïndigen kann, bis die Besinmung anf msere übersinnliehe Bestimmung lic Bewegnng der Secle zur Ruhe fïhrt. Hier ist an das genießende ästhetische subjokt, nicht aber an den Kïnstler und sein Werk gedacht. Die Unterscheidung wn mair mol sentimentalisch denkt an den Kïnstler und sein Werk. Der (irgensatz aber wirl hier cinseitig als das Verhältnis zur Natur gedacht. Der birhtrer, der die Natur hat, schafft das naive Kunstwerk, der Dichter, der die Vitme vertor mud erschut, das sentimentalische. Wie num fïr das historische

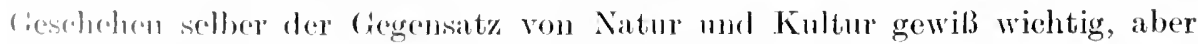

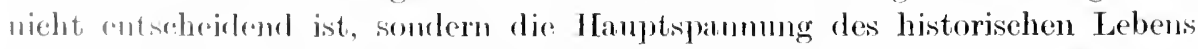
in fen lingrosat\% der Kulturmächte zu suchen ist, so ist es nieht sowohl das Naturharmonische mul Naburgegensïtaliehe, was den Charaliter eines Kunst- 
werkes bestimmt, sondern das Vermuntharmonisehe und das Vernunftgegensätzliche. Das Kunstwerk ist immer der Ausdruek für eine Welt - es trägt die Fülle des Wertlebens in sich. Aber dieses Wertleben kann entweder weich und ungelöst zusammenhängen und in vielen sehönen Akkorden sich verbinden, oder aber es ist von irgendeinem Gegensatz zerklïftet. Im ersteren Falle sagen wir vielleicht: das Kunstwerk atmet eine heitere epische Ruhe, im anderen Falle, daß es von leidenschaftlicher dramatischer Bewegung erfüllt sei. Im ersten Falle nennen wir das Kmnstwerk wohl ruheroll, hoheitsvoll, still und groß, schön, rein, einfach und natïrlich. Im zweiten Falle mächtig, hinreißend, spannend, wild bewegt, interessant, problematiseh, paradox und wunderbar. In beiden Fällen aber ist das Kunstwerk harmonisch in dem Simne, daß es in semem ganzen Aufban, in der Gliederung und Anordnung seiner Teile sowie in allen Einzelheiten der äußeren Form vollendet ist. Jedes große Kunstwerk bedeutet, wie Schelling für alle Zeiten richtig erkannt hat, einen Widerstreit im Künstler, der im Kunstwerk zur Ruhe gekommen ist, eine Erlösung von der Qual des Schaffens. Aber die Lösung dieses Widerstreits kann sowohl in der Form des Gegensatzes wie in der Form der Einheit rollzogen werden.

Es bieten sich somit für eine Betrachtung der ästhetischen Entwicklung eine Reihe ron Gegensatzpaaren zur Charakterisierung des rerschiedenartigen kïnstlerischen Ausỏrueks dar, nämlieh der Gegensatz ron plastisch und musikaliseh, von typisch und eharakteristisch, sehön und erhaben, naiv und sentimentaliseh, wertversöhnlieh und wertgegensätzlich, und man könnte die Frage erheben, ob diese rersehiedenen Gegenüberstellungen nicht vielleicht im Grunde denselben Gegensatz meinen. Soviel aber muß von vornherein klar sein, daß sich diese Gegensätze ebensowenig auf die alte und neue Kultur verteilen lassen, wie etwa die Gestalt des religiösen Magiers oder des Mystikers einseitig dem Altertum oder der Nenzeit zugehört. sondern man wird höehstens zu der Überzengung gelangen, daB die eine oder die andere Form für eine bestimmte Epoche dominierend und entseheidend war.

\section{g) Die versehiedenen Formen des kïnstlerischen Lebens.}

Bevor wir jedoch hier eine Entscheidung fällen, haben wir auf das eigentïmliche Phänomen der Zersplitterung des künstlerisehen Lebens zu achten, das darin zum Ausdruck kommt, daß die Kunst sieh ron vornherein in verschiedene Kunstgattmingen trennt, die dureh versehiedene Ausdrucksmittel und Ziele begrenzt sind, und die sich, wie es scheint. niemals zu einer Einheit zusammenfinden kömmen. Das religiöse Leben zerfällt gewils in ebensoriel Formen, als das religiöse Ideal anders gesticht mud rerstanden wird; aber in der Religion liegt doch unbedingt die Möglichkeit, daß sie als die eine und einzige alles durchdringt und erfaßt, an das eine religiöse Crundgefïhl sich wendet und in einheitlichen Kulturformen und symbolen sich ausdrückt. Dagegen hat die Kunst von vornherein ganz verschiedene Ausdrueksmöglichkeiten. Sie wendet sich an ganz rersehiedene simne und Organe und seheint auch ron vornherein dureh ein gegensätzliches Ziel beherrseht zu sein. Ion Kunst in unserem Sinne kann aber erst dann die Rede sein, wem das Kumstwerk seine Selbständigkeit erreieht hat, wenn das Kunstsehaffen nicht mehr zum bloßen 
Dienen rerurteilt ist, sondern $1 \mathrm{~m}$ seiner selbst willen zur Sprache kommt, wenn die Knusttätigkeit ferner nieht mehr darauf gerichtet ist, aus dem Naturinstinkt der Sinnliehkeit heraus das natürlich Gegebene als solehes darzustellen, die weibliche Brust und die Sehenkel des Pferdes als das, was dem primitiven Mensehen sinnlich behagt, und wenn sie anch anderseits sich nicht in cler bloßen seelenlosen Äußerlichkeit des Dekorativen und Ornamentalen bewegt, sondern dasjenige gewomnen hat, was wir eine ästhetisehe Idee nennen; denn erst von ihrer Innerliehkeit aus wird die äußere Form geweiht, die ohne sie kalt und lieblos bleibt.

Das seelenvolle, ideenreiche Kunstwerk tritt uns nun immer sehon in der Form einer besonderen Kunstgattung entgegen, sei es als Diehtung oder als plastisehe Gestalt. Anderseits ist es eine Forderung der Vermunft, daß die Kunst, die selber ans einer umfassenden Einheit, der mythologisehen Bewristseinswelt herrorgegangen ist, ihrerseits wieder eine ursprïngliche Einheit gebildet hat, aus der sich dann die versehiedenen Kunstarten als Ausdrueksformen dieser Einheit entwiekelt haben. So wird die Entfaltung des Kunstlebens zu einem besonderen Fall der Entwieklung des Vermunftlebens überhaupt. Nur daß das Kunstwerk erst seine selbständige Bedeutung erwarb, als es zu einer besonderen Ausdrueksform gelangt war.

\section{h) Der Geist der Plastik und der Geist der Musik.}

Wenn nun aber anch die Idee der Begrenzung in diesem Doppelsinne für das Kunstwerk gilt, daß es einerseits als das Isolierte und Freie gegenüber der Wirkliehkeit erseheint, als dasjenige, was dem Gesetz der Kausalität nieht unterliegt, und anderseits die eigentiimliche Ausclucksform eine besondere Begrenzung schafft, so kann deswegen doch der Geist einer bestimmten Kunst als der herrsehende in einer bestimmten Epoche erseheinen. Der Geist der Kunst cutfaltet sieh aber in zwei einander entgegengesetzten Ausdrueksformen: in dem Geist der Plastik und in dem Geist der Musik, indem der Geist der Plastik ror allem darin erseheint, daß er die geformte Wirklichkeit noeh einer höheren Formung unterwirft, so daß der Künstler hier im absoluten Sinn zum Sehöpfer und Gestalter wirl, während der Geist der Musik daranf geriehtet ist, alles Bilchafte und alle Schönheit der Gestalt zu verniehten, das Gesetz der Individuation anfzuheben dureh eine Tat der Erlösung, die alle Wirkung anf den gestaltenbildenden Gesichtssimn remeint und an das räitselhafte dunkle Gefühl sich weit ummittelbarer wenclet, die der entwirklichten, ehaotisehen Welt adäquat ist. Sovicl ist wohl dentlich, daB der plastische Künstler als der absolute Schöpfer der Herrsehernatur des Magiers mol der musikalisehe Künstler als der alsohute Erlöser der Prophetemnatur des Mystikers verwandt ist.

\section{i) Eliedromg isthetischer Entwicklung.}

Vit dieser allgemeinen Gegenïberstellung sint wir aber noch vollkommen anforstande, dir Jintwieklung les isthetischen Bewubtscins zu gliedern. Wir

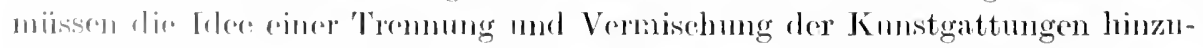
nehmer. die sieh dem von uns anfgestellten Gegensatz zwisehen analytiseher liml syothotischop Epochon des Menselengeschlechtes anschmiegt. Ferner 
mïssen wir den verschiedenen Charakter der ästhetischen Idee berïcksichtigen, welche die Totalität des Wertlebens, die sich in ihr enthüllt, sowohl in Spannung wie auch in harmonischer Einheit offenbaren kann und dementsprechend mehr ron dem Geist der Ruhe oder im Gegenteil ron dem Geist einer leidensehaftlichen Bewegung beherrseht erscheint.

Unter diesem Gesichtspunkt gliedert sich die ästhetische Entwickhung entsprechend der religiösen in drei Hauptepochen. Das große analytische Zeitalter des Griechentums läßt die Kunst entstehen als cine Kunst der Begrenzung, welche die Einheit des Wertlebens offenbart und ron dem Geist der Plastik beherrscht ist. Die Kunst des tausendjährigen Reiches ist gehemmt clureh die enge Bindung an die Religion. Das große synthetische Zeitalter wollte ein absolutes Symbol der göttlichen Einheit errichten und gleichzeitig das Ende der Geschichte rorwegnehmen. Dem Geist der Plastik war es abgewendet, dem es strebte nach absoluter Einheit hin. Deswegen verneinte es die Gestalt und die Idee der Individuation. So hätte der Geist der Musik diesem Zeitalter einen vollendeten Ausdruck geben können; aber die Eutwickhung dieser Kunst, die dem Altertume gegenüber einen großen Fortschritt zu verzeichnen hatte, war auf der polyphonen Stufe stehen geblieben und noch nicht zum absoluten Ausdruck in der Harmonie gelangt. Ihrem synthetischen Charakter gemäß kultivierte infolgedessen das Mittelalter die Zwischengebiete der Kunst, die Architektur, Malerei und Dichtkunst. Anderseits ließ das Mittelalter den Gegensatz der Kunstformen bestehen und rersuchte keine Vermischung, während es im allgemeinen dahin neigte, die Einheit des Wertlebens zu offenbaren. Nur war jene friedevolle Einheit, welche die Kunst des tausendjälırigen Reiches geschaffen hat, nicht die Verkündigung eines frei zusammenkłingenden Wertlebens, sondern vielmehr eine Bindung des geistigen Daseins und seiner absoluten Erfüllung durch die Religion.

Das entscheidend Neue gegenïber dem Altertum hat erst die Renaissance gebracht. Der plastische Geist, der Geist der Schöpfung und Begrenzung trat wieder mächtig hervor. Doch offenbarte er sich in einer anderen Gestalt, sofern dieses nene analytische Zeitalter zuerst in entscheidender Weise die Idee des Wertgegensatzes zum Ausdruck brachte, welche in maneher Weise der modernen Kunst eigentümlich geblieben ist.

Dennoch begimnt in 18. Jahrhundert eine ganz neue Entfaltung des künstlerischen Lebens, die nicht einfach als Resultat und Konsequenz der Renaissancebewegung verstanden werden kann. Das Typische an ihr muß darin gesehen werden, daß der Geist der Musik als der Geist der künstlerischen Erlösung die Herrschaft gewinnt. Man muß sagen, daß die Musik im Leben der modernen Menschheit eine ähnliche Bedeutung besitzt wie die Plastik in der alten Kulturwelt. Diese Macht der Musik zeigt sich auch in den Kunsttheorien einer Zeit. Ist doch in ihr die absolute Uberlegenheit der Kunst gegenïber der Wirklichkeit offenbar geworden. Ist es doch die Musik gewesen mit ihrer göttlichen Freiheit gegenïber der Natur, welche die Nachahmungslehre der Kunsttheorie ein für allemal zerstört hat. Für die plastische Gestaltung scheint die lebensvolle Wirklichkeit ein hohes Vorbild zu bieten. Wir könnten zweifelhaft sein, ob die Marmorgestalt die Schönheit des nackten Lebens erreicht. Daß aber die Musik ein für allemal der Natur obgesiegt hat, davon 
müssen wir überzengt sein. So ist die romantische Kultur, in der die Musik so große Gewalt gewinnt, schließlich ganz konsequent zu der paradoxen Behauptung gelangt, daß die Natur die Kunst nachahmt und nicht umgekehrt die Kimst die Natur.

Endlich ist das neue synthetische Zeitalter der Romantik auch dadurch charakterisiert, daß die Beschränkung des Kunstwerkes, wie sie durch die Torstellung besonderer Ausdrucksmittel und ihrer eigentïmlichen Begrenzung gegeben war, nummehr aufgehoben und eine Dichtung rerlangt wurde, die das Epos mit dem Drama und das Drama mit der Lyrik vereinigt. Ja, man suchte auch die Grenzen zu überwinden, die zwischen Dichtung und Musik und zwischen Musik und bildender Kunst vorlagen. Man betonte den Unendlichkeitscharakter des Kunstwerkes und betonte die sehnsüchtige Hoffnung, daß dermaleinst alle Wertleben zurückfluten möchte in den allgemeinen Ozean der Poesie.

\section{k) Die Dichtung Homers.}

Homers Diehtung ist der große Anfang der Entwickhung des Kunstsehaffens. In der schönen Jugend des Menschengeschlechtes geschaffen, ist sie selber der Ausdruck einer ewigen Jugend. Die Kunst begimnt mit dem Epos und erreicht im Epos sogleich die Vollendung. Niemals ist Homer iibertroffen worden, und nur in dem Epos des Dante tritt ihm ein ebenbürtiges Werk zur Seite. Das Epos ist angenscheinlich der dichterische Ausdruck für ein synthetisches Zeitalter. Als Homer sein großes Epos schrieb, ruhte das Wertleben der Hellenen noch in einer ursprünglichen Einheit. Noch hatte die philosophische Reflexion die Unschuld eines kräftigen Phantasielebens mit ihren hellen śpiegeln nicht gestört. Erde und Himmel waren damals selig, so wie sie der alte Diehter schaute. Ein bestimnter Geist aber ist in diesen Dichtungen zum Ansclruck gekommen: der Geist des dorischen Herrschertums. Es ist der Geist des Adels und der Vornehmheit, der schönen stolzen Kraft. Ritterliche Fahrten und Abenteuer, Wohlhabenheit und freigebige Gesinmming sind Ideale der Zeit, Tätigkeit und Mühe in schwerer wirtschaftlicher Arbeit, jene Mühe, die Hesiod als Anwalt des Banernstandes gefeiert, wirl geringgeschätzt und verachtet. Der Geist der Ritterlichkeit wird gefeiert, Iler auszicht, die Schönheit zu erohern, die dem heimatliehen Hause frevelhaft (ntführte. Die Jiebe des Mannes zu Weib und Kind, der treuausharrende Kampf um die heimischen Penaten, die Liebe des Peliden zu seinem schönen Fremble ist vorherrlicht. Zïge verzeihenden Edelmutes paren sich mit den zajchen cines wiklen und mngezügelten Hasses. Simnliche Leiclensehaft, Stolz mul Wildheit strömt ungrhemmt dahin, und der freie Ausbruch des Schmerzes sheint wohl vercinbar mit der Heldenhaftigkeit dles Manmes. Und neben der Tlias ats lem thig in rie Ferne, dem Fremclen mol Unbekannten entgegen, das Liorl rom der Heimkohr des irrenden Odysseus, das grobe Lied der Gattenschusurht, fler schmerzlich Getrennten, wolche die Wieclervereinigung be-

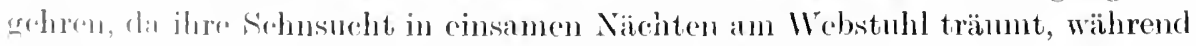
scince dumkle. Sidusucht voun fernen Tusclande aus den Rauch des heimisehen Ilareles iilere woitre Wasserwiiste erspäht. 
Úber alles geht dahin die schöne Bejahıng des Lebens, die Götter und Menschheit verbindet. Wem Dantes großes Gedicht die Jenseitigkeit feiert. so verherrlichen die Gedichte Homers die buntbewegte Fülle des diesseitigen Lebens. Der Weg der göttlichen Komödie verläßt die Welt der sinnlichen Gestalten und läßt nach den Schatten des Infernos ïber dem Berge der Länterung die übersinnliche Welt aufleuchten. Der Weg des homerisehen Epos bleibt in der schönen Sinnenwelt und berührt nur flüchtig und seheu das schweigende Dunkel der Unterwelt. Selbst die Götter sind von Erdensehnsucht ergriffen. Der Weg der Ilias führt zur lockenden Ferne des Fremden und Tnbekannten, und der Glanz ritterlicher Kraft und kïhner Abentenersehnsucht kämpft den jahrelangen Kampf um die geraubte und verlorene Schönheit. Der Weg der Odyssee ist geleitet dureh das Bekamte und Vertrante den heimatlichen Kreises, eine liebe Nähe, die auch den unfruehtbaren Strand der kleinen Ziegeninsel versehönert und der Ferne leuchtendes Ideal hinter einfachen und geliebten Gestalten rerschwinden läßt.

Dieses Epos erscheint num in der Tat als ein absolut Notwendiges, das jenseits jeder individuellen Laune und Willkür steht. In ihm ist das Subjektive und Persönliche vollkommen untergegangen. Nirgends kündigt sich die Individualität des Dichters in persönlicher Stellungnahme, in betrachtender Reflexion unmittelbar an. So erseheint das Epos Homers ïberhaupt nicht als das Werk eines einzehnen Diehters, sondern viehmehr als eine Leistung der Generationen. Und obwohl es keine Tolksdiehtung ist. so erscheint es doch als der kïnstlerisehe Gesamtansdruck der griechischen Nation. Das Epos Homers ist objektir und offenbart die Substanz des Wertlebens in rollkommener Einheit. Noch geht der Geist des Erkennens mit des Künstlers Phantasie friedlich zusammen. Noch erseheint das religiöse Leben der Moralität und die Moralität der Religion nieht als Vorwurf. Sitte und Recht sind von dem ruhigen Lichte des religiösen Glaubens beschienen. Freundschaft und Liebe haben einen seligen Bund geschlossen. Ein freundliehes Los ist den Sterblichen besehieden, ein sinnlich-sehönes Glïck. Und der Schmerz ist nurTraner und unendliehe Wehmut, ein gedämpftes Gefühl, niemals aber nimmt er die herbe Gestalt des Tragisehen oder die starre Form der Verzweiflung an. Fremndlich läehelt die Sonne Hom ers iiber die große irdische Liebe, die sich in allem offenbart. Zwischen Göttlichen und Menschlichen besteht eine Grenze nur in bezug auf Reehte, nicht aber hinsiehtlich des Wesens und der Art. Wohl sind die Götter das Herrsehergeschlecht gegenïber den Helden, so wie die Helden das Herrsehergesehlecht sind gegenüber den niedrig geborenen Sterblichen. Schöne Menschen sind die Götter und die schönen Götter Menschen.

Aus diesem schönen, noch ungeteilten Weltleben, ans dieser göttlichen Harmonie, die dem Ganzen imne wohnt, tanchen Gestalten auf, die diesem Ganzen angehören und ron demselben Geist erfüllt und getränkt sind. Ihre starke Bildung und Formung, ihre lichtrolle Gestalt, die sich dem Gedächtnis der Menschheit für alle Zeiten eingeprägt hat, verrät eine sehrankenlose Schöpferkraft. Die homerisehen Helden sind Repräsentanten eines Allgemeinen und haben insofern einen typisehen Charakter. Aber sie sind nicht Repräsentanten eines begrifflich Allgemeinen, sondern der leitenden Idee des Kunstwerkes, die in ihnen ein besonderes Leben gewinnt. Die Bernfstypen des 1S. Jahrhunderts 
sind rationalisiert und mit wenigen Merkmalen zu erschöpfen; aber in den Gestalten Homers lebt dieselbe namenlose Unendliehkeit, die als ästhetische Einheit das Ganze verbindet.

Das Epos Homers ist das vollendete Epos, das keine spätere Zeit ïbertreffen und ïberholen wird als reines Epos sehlechthin, als Ausdruck eines ungeteilten Wertlebens. Die kriegerisehen Ereignisse, die gefahrdrohenden Abenteuer ruhen in dem künstlerisehen Bann einer beglüekenden Ruhe, gebändigt durch die Meeresstille in der Seele des großen Dichters, in der sich der olympische Himmel und alles Mensehenschicksal so klar und ruhig spiegelt, geschmückt durch die kostbare Formung, die er seinen Gestalten zu geben weiß. So kommt in Homer jene absolute Begrenzung zum Ausdruek, die in der Wahl einer bestimmten Kunstgattung und der durch sie bedingten Mittel sich kund gibt. So wohllautend die homerischen Verse dahinfließen, so führt doch die Betonung des Husikalischen niemals dahin, die Sichtbarkeit zu verleugnen. Vielmehr ist seine große Kunst in unerhörter Weise auf Siehtbarkeit und Gestalt gewendet. Niemals wachsen die plastisch gewählten Beiworte zu lyrischen Stimmungsergüssen aus, und der Gegenkampf der Helden wird nicht zu der Horbheit und Kïrze dramatischer Zuspitzung verdichtet. Und so lebt die Kunst in ihm sein Schöpferleben, erfüllt von dem Geist'der Plastik.

\section{1) Die griechische Lyrik.}

Wenn sich im Epos des Dichters Erlebnis objektiviert mnter Aufhebung des Ich zu einer Gestaltenwelt, so rerklärt die Lyrik des Dichters Liebe zu einem Erlebnis vorbildlicher Natur, in dem wir unsere eigene Liebessehnsueht wiederfinden. Das Epos zeigt ms die Welt in Gestalten, das lyrische Gedicht die Welt in eincr Gestalt. Die griechische Lyrik ist mit dem Ich der Persönlichkeit beschäftigt und in diesem Sinne subjektiv. Während das Epos der Welt hingegeben war, ist das lyrische Gedicht dem Ich hingegeben, und an die Stelle der roflektionslosen Naivität tritt ein mehr bewubtes Künstlertum. Alle menschliehe Sehnsueht lebt in Sa pphos Liedern und ihrer weißen Mädehenschar, und niemals welkt der Kranz, mit dem Alkäos in trunkener Lust die sehöne Schläfe des Freundes geschmückt.

In der griechischen Lyrik tritt dem homerischen Epos ein anderes gegenïber, eine andere mögliche Ausdrucksform, jener ersten gleichberechtigt und vollkommen entgegengesetzt. Homer vergaß sich sellst in der Betrachtung fromder Gestalten, zu denen er als Künstler ein Verhältnis gewommen hatte, dic ihm aber monschlich in Lelben nicht nahe getreten waren in intimen Pianden dor Freundschaft und Liche. Er feierte die Gestalten der Helden und (Gïtcr, lie schon an sich, anch unabhängig von der künstlerischen Gestaltung, anen Wret hedenteten. Der lyrische Dichter hingegen seheute sich nicht, vom "igenon Suhicksal zu singen und zu klagen. Er gal, den Bändern, mit denen "r sein Mäulehen umwand, und den Locken seines jungen Freundes Ewigkeitswret. Cnd wemn or von den Göttern sang, so gedachte er seines persönlichen Verhaibltnisses zu den Himmlischen, und wenn er kriegerische 'Taten kündete, so geelachte or der Kämpfe, die er sellst erlebt. Indem cr num aber das verhältnismäbig Lnberlentrurle zu seinem Gegenstande wählte, mochte seine Schöpfer- 
kraft noch größer erscheinen, da er das Individuelle und Vereinzelte ledighich dureh die Kraft seiner Gestaltung in eine Sphäre erhob, die über alles Endliche hinausreichte.

\section{m) Das griechische Drama.}

Das Drama ist diejenige Form der Dichtung, in welcher die ästhetische Idee am deutlichsten hervortritt, weil sie mit einex straffen einheitlichen Handlung verbunden ist, die sich in wenigen großen Gestalten ausdrüekt. In drei großen Dichtern ist die griechische Tragödie herangereift, deren Geburt aus dem Rauseh und aus dem Tram Friedrieh Nietzsche als erhabene Vision erschaute. In die Welt klar begrenzter Gestalten ragt nach Nietzsches Auffassung durch den Chor ein Entgegengesetztes herein, das das Prinzip dor Unendlichkeit und der Auflösung gegenüber der festen Formung der dramatischen Handlung vertritt. In dem Chor kommt ein Prinzip zum Ausdruck, das die Individuation aufhebt und auf den Einheitsgrund des Wirklichen hinweist. Aber dies dionysisehe Moment spielt doch im attischen Drama eine untergeordnete Rolle im Vergleich mit Wagners Musikrlrama und mußte es notwendig spielen, da ja die Musik damals noch auf der homophonen Stufe stand. Ihre Beseelung empfängt die Musik erst durch die Harmonie, die ihr die Möglichkeit gibt, als gleichwertige Macht dem Apollinischen entgegenzutreten. So ist die Musik in der attischen Tragödie noch niehts Selbständiges. Sie lebt das Leben des Dramas mit und begleitet und reflektiert es in eigentümlieher Weise.

Das Drama offenbart notwendig eine Spannung, einen Gegensatz. Wic verhält sich diese augenseheinliehe Tatsache zu der Bestimmung, daßs dic griechische Kumst das Wertleben in der ästhetischen Idee rolkiommen ungeteilt in seiner Totalität besitzt und so das Gesetz der ruhigen Schönheit zum Ausdruck bringt? Wenn der Gegensatz widerstreitender Anschanungen für das Drama unentbehrlich ist - und daran ist nicht zu zweifeln —, so mu $B$ doch auch wohl der Konflikt in die ästhetische Idee hineingetragen werden und die Idee die Offenbarung des Konfliktes selber sein. Wie kann der notwendige dramatische Konflikt mit der Harmonie des antiken Kunstwerkes zusammengehen?

Es besteht kein Zweifel. daß dureh die grieehische Aufklärung die schöne Einheit des griechischen Wertbewutseins ersehütert war. Tberall klafften Gegensätze hervor zwischen Reeht. Sitte. Gesetz der Väter und den neuen Forderungen der Zeit. Dennoch muß der Dichter in Griechenland cin für allemal die Kraft der Versöhnung besessen haben. Er enthüllt einen Konflikt im Bereich des menschlichen Wertlebens. und zwar hantelt es sich immer um eine göttlieh große Sache und 110 die ganze Skala der Leidensehaften. Dabei eignet dem Spiel eine eigentümliche Gebundenheit. Niemals kämpft rollkommen frei dor Wille mit dem Willen, sondem Spieler mol Gegenspieler sind dureh die Irlee des Sehicksals bestimmt, das sich bald mehr verbirgt, bald offen und dreist herrortritt. Diese übergroße Schicksalsmacht, die rätselhaft und mauflösbar ist, gibt dem griechisehen Drama jene hohe Einheit. welehe uns die ästhetische Idee doch immer wieder als Ausdruck eines ungeteilten Wertlebens rerstehen läßt. Es liegt doch nieht sowohl an der Kraft und rehönheit. an der Intelligenz und Willensmacht des einzehnen, ob ihm Nieg oder Lntergang beschieden ist: 
sondern an der Fïgung des Schicksals, das den Menschen sehuldig werden läßst. sehr häufig gegen seinen Willen durch seltsame Leitung und Verwicklung. Das Sehicksal aber ist Hüter und Bewahrer der Ordnung. Jeden Verstoß gegen die Wertordnung muß es räehen, mag auch in diesem Verstoß der Appell an eine höhere Auffassumg der Werte, an eine nene Offenbarung liegen. Somit drängen im grieehisehen Drama nicht zwei entgegengesetzte Bewegungen aufeinander, die voneinander ganz unabhängig sieh zum Anwalt verschiedener Dinge und versehiedener Ziele und Bestrebungen machen, sondern die dramatische Bewegmng hat eimen ïbergeordneten Beziehungspunkt, in dem doch schließlich alle Bewegung muindet.

Das antike Drama offenbart einen strengen Notwendigkeitscharakter und sehließt jedes Moment des Zufälligen und Willkïrlichen aus. Wenn der Diehter der alten Tragödie die U̇berirdisehen in die Handlung eingreifen und sie die Entscheidung fällen läßt, so handelt es sich dabei nieht um Ursaehlosigkeit und Willkïr, sondern um das Bestimmtsein dureh ühersimmliehe Kausalität. So kommt es, daß die Handlung des antiken Dramas nieht so sehr aus dem Charakter der Personen und aus ihren Motiven und Leidenschaften fließt und rerstanden werden kann, sondern vielfach von außen her bestimmt ist. Sie werden sehuldig dureh einen Verstoß gegen die Wertordnung, mag es sich um bewußte Absiehtliehkeit oder um Täuschung und Irrtum handeh. So muß Ölipus den mgewollten Vatermord und die ungewollte Blutsehande auf das sehwerste büßen. Dadureh ergibt sich eine ganz besondere Modifikation des tragischen Gefühls, welehe man als Leid dem Begriff des Sc h m e r zes entgegensetzen kann. Wir sehen das große vorbildliche Leiden von Mensehen, welehe die Macht des Schieksals bedroht, dem gegenüber sie ohmmäehtig sind, und an dem sie notwendig zugrunde gehen. Dieses Leid verklärt unser Gefühl, regt es aber weniger auf. Dem wir wissen, daß der antike Held doeh sehließlich nur Werkzeug in der Hand des göttliehen Sehieksals ist, das mit ihm umgeht nach seinem Wohlgefallen. Anders der Sehmerz, unter dem wir hier ein Gefiihl des Tragischen verstehen, das hervorgerufen wird durch den für sieh dastehenden und fïr sich verantwortlichen Helden, den Helden, dem niemand helfen kann. I'ir sehen, daß er schuldig wird, weil er so ist, daß sein Charakter zur Ursache des Unterganges wird, und nicht deswegen muß er zugrunde gehen, weil momentane Leidensehaften sein Wesen umhüllen und trüben, sondern an dem Urpersönlichen seines Wesens, an dem, was ihn zu der besonderen wertvollen Erseheinung macht, geht er zugrunde.

Die Gestalten des attischen Dramas und speziell der attischen Tragödie sind im allgemeinen mehr mach der Seite des 'Typischen gebildet, und das Typische ist es ebenfalls, das die besondere Form des tragischen Gefühles, die wir als Lcicl bezoichnen, horvortuft. In dem 'Typischen hat ein Allgemeines, das Inmittchar ans der isthetischen Idee fließt, dic Hersehaft ïber das Besondere "lyriffen, und das Besondere wirl gewissermaBen im Allgemeinen, d. h. als substrat und Träger einer allgemeinen Wertidee schuldig. Nieht als Exemplar orfor Ropräisentant der Gattung tritt dam der Menseh auf, so daß wir im Leiden dre Ifolden das Leiden der Gat,ung und unser eigenes Leid rerspären. Das

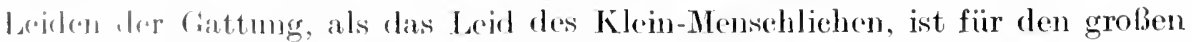

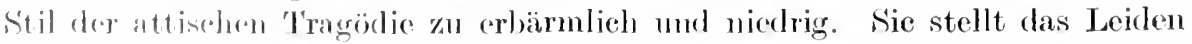


der rom Schicksal gezeiehmeten und der ron Ideen beherrschten Mensehen dar. Der Künstler offenbart das Namenlose, dem Begriff ewig Lnzugängliche in der Form der Anschaumng. In dem Leiden der attischen Tragödie erleiden wir das Groß-Mensehliehe. Nicht aber handelt es sich um ein Schicksal. das aus der Einzigartigkeit einer bestimmten Individualität hervorgegangen wäre, in welchem Falle dann die Individualität von hellem Licht getroffen und das Allgemeine mehr in den Hintergrund treten wïrde. Vielmehr leiden wir in der attischen Tragödie ein allgemeines Schicksal. und nicht empfinden wir Schmerz ïber das eigentümliche Schicksal einer ganz besonderen Natur.

Von den drei großen Meistem der attischen Tragödie, Äschylos, so. phokles und Euripides hat ersterer das Allgemeine am stärksten. letzterer am schwächsten betont. Bei Äschylos rundet sich die Individualität nur schwach, reliefartig, bei Euripides hat sie ihren plastischen Ausdruck gefunden. In dieser Hinsicht bedentet er die Vollendung der attischen Tragödie. Bei Aschylos wird die Individualität durch das Allgemeine noch gestört und gehemmt, die Glieder sind noch gebunden wie in den Anfängen der großen griechischen Plastik, und der Ausdruck der Sprache hat noch etwas Formelhaftes. Es ist die Macht des religiösen Lebens, das sich hicr noch hemmend offenbart. sofern es das Persönliche im Allgemeinen festhält und nieht freiläßt und losgibt. Noch vermag die Kmnst das Religiöse nicht zu meistem und ihm zu einem rein ästhetischen Ausdruck zu verhelfen. Das ist erst bei sophokles der Fall. der das Allgemeine der ästhetischen Idee mit der vollendeten Individualität verbindet.

In der Antigone ist dargestellt der Kampf des göttlichen mit dem mensehlichen Recht. Wer frevelhaft die eigene Taterstadt befehdet, den frommen Altären der Heimat die grimme Kriegsfurie entgegenträgt, dessen nackter Leichnam soll umbestattet liegen bleiben, den Vögeln des Himmels zur speise. So will es das mensehliche Gesetz, dessen Hïter der König ist, das Recht. das geschrieben steht als Menschensatzung, aber geheiligt durch den Willen des Königs als Oberhanpt des Volkes und Stathalter der Götter auf Erden. Aber der Schuldige ist nicht nur schuldig und steht anch nieht nur in Beziehung zur Vaterstadt und der Gesetzgebung der heimischen Penaten. Sein Leben wirkte sich auch noch in anderen Beziehungen aus und gestaltete sich gar reich und wertroll im Verhältnis zu seiner Schwester Antigone. Seine Bruderliebe hat Schwesterliebe erworben. Zwischen ihnen besteht ein besonderes Wertverhältnis. Liebe rerbindet sie und lebt fort in schönen Erimerungen. Aber wäre dieses anch nicht der Fall, muß es nicht hart und gratusam erscheinen, die Rache auch noch an dem armen Leichnam auszulassen und so dem irren Geist den Zutritt zum stillen Schattenreich zu verwehren, so daß er scheu umherirrt an der furchtbaren Stätte des Todes? Ist es gerecht, für endliche Schuld unendliche Strafe zu verhängen? Antigone muß es verneinen. Sie glaubt, daß Endliches nur endlich büßen kann, und daß es etwas Verzeihendes und Versöhnendes gibt, das über den finsteren Geist der Rache sich erhebt und ihn siegreich überwindet. Und so bekämpft sie das Gebot der ewig damernden Rache und rerstößt gegen des Herrschers Befehl. So wird sie als Prophetin einer neuen Wertordnung doch notwendig schuldig, und diese Schuld mußsie mit dem Tode sühnen. 


\section{n) Die griechische Plastik.}

In der griechischen Plastik feiert der Geist der schönen Begrenzung, der reinen seligen Form, der ruherollen Harmonie, der Schöpfergeist des Künstlertumes, der auf absolute Formung geht, seine höchste Vollendung. Viele dieser Gestalten umstrahlt eine hohe Feier, weil sie ummittelbar als Ausdruck des Göttlichen gedacht sind. Das Absolute der Götterwelt teilt sich in verschiedene Formen. und in jeder dieser Gestalten ist das Schöne in einer gewissen Begrenzung vollkommen enthalten. So wird in Zeus die reife Schönheit des Mannesalters, in Apollo die schöne Schlankheit des hochgewachsenen Jünglings, im Dionysos die liebenswïrdige Weichheit und Zartheit des Knaben zur Darstellung gebracht. Die Herbheit des jungfräulichen Wesens offenbart Artemis in höchster Vollendung, und in Aphrodite gibt sich die lachende Schönheit des Weibes der Umarmung hin.

Ein schweres Problem erwuchs jedoch den griechischen Meistem bei der Bildung ihres göttlichen Gegenstandes. Das Gesetz des Kunstwerkes erfordert die absolute Distanz, die Tremnng, das Entrücktsein von der Welt. Der Gegenstand der religiösen Terehrung ist dagegen in einer gewissen Relation zu dem Verehrenden gedacht. Es liegt im Geiste der religiösen Vorstellung, daß sich der Gott dem Sterblichen entgegenneigt, oder daß die absolute Ferne betont wird, die zwischen Gott und Menschen besteht. Neigt sich das Göttliche dem Menschen entgegen, so wird das Werk gleichsam erst durch die religiöse Haltung des Kultïbenden vollendet und bildet keine in sich geschlossene Einheit. So etwa die Gestalt Christi, welcher die Gräber der Entschlafenen segnet. sie widerspricht der Idee des Kunstwerkes. Besteht aber für das religiöse BewnBtscin eine Entfermung des Menschlichen rom Göttlichen, ein unüberwindlicher Gegensatz, so liegt die Gefahr vor, daß die Skulptur zur Formlosigkeit hingetrieben wird und der Mangel an Individualität oder auch das Kolossale res ganzen Aufbaus die künstlerische Wirkung vernichtet.

Die Lösung dlieses Problems ist in Praxiteles vollendet, der nicht ärger mißrerstanden werlen kann. als wenn man meint, daß seine Kunst des tieferen Sinues entlehrte. und daß es ihm nur um wohlgeformte Gliedmaßen zu tun gewesen wïre. Vielmehr ist seine Kunst nicht weniger ideenhaft und göttlich als die Kumst des Plidias. Seine Kunst hat es nur vermocht, höchste Ideenticfe mit schönster Individualität $z$ verbinden.

In der arehäischen Kunst herscht hohe Gebundenheit. Die religiöse Vorstellungswelt tritt hier, so möchte ich sagen, häufig als nackte Religion, njeht aber in Gewande der Kunst hervor. Noeh vermag die Kunst das göttliehe (irheimuis nicht in der Sprache der Kunst individuell anszusprechen, noeh hat sir nieht die Macht, die ïsthetische Idee mit der Fïlle der Ansehaumg vollkommen \%u vermählen. Alles verhart in riner gewissen Startheit und Ungrobstheit. Noch kenut der Körjer nicht dir sehöne Bewegung und Biegung, und ïnsstich haften die schön gearbeiteten Hare an dem staren Haupt. Man kann salgen, ralis in dor archäischen Kunst das Bosondere von dem All-

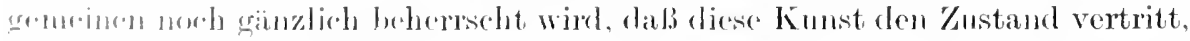

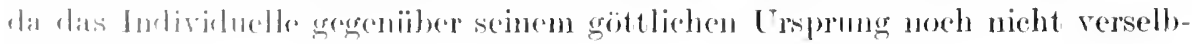
stiburligt. 11 all. 
Phidias hat das Gleichgewicht, den Ausgleich zwischen dem Allgemeinen und Individuellen hergestellt und dadurch tie bikdende Kunst zum höchsten Ausdruck geführt. Stark aber betont er noch das Wesenhafte und zeigt damit eine gewisse Gleichgïltigkeit gegenïber den kleinen individnellen Ansdrucksmöglichkeiten, die häufig so wichtig sind, so mendlich vielsagend, die so manches verraten, was sonst immer versehwiegen wäre. Anch sind seine Gestalten noch nicht von jener sanften Bewegung durchdrungen, welche die süße Lust des Lebens uns vortäuseht. Sie sind gar ruhevoll und menschenfern. Sie sind in einen gewollten Gegensatz zum Menschlich-Endlichen gesetzt. Sie sollen die absolute Uberlegenheit des Göttlichen zum Ausdruck bringen und wohl anch seine Unnahbarkeit; demn die griechisehe Religion hat sich doch schlieflieh in der Vorstelhung vollendet, daß das Göttliche in sich ruht und aller menschlichen Sehmsueht gegenüber vollkommen unbekümmert bleibt.

Alles das ist in der seligen Erseheinung überwunden, die Praxiteles seinen Göttern gibt. Dafür mag als Beispiel unter vielen der junge Apollo mit der Eidechse im Vatikan dienen. Die zarte Jugendschönheit des Knabenkörpers im Alter von 14 bis 16 Jahren, in semer Flüssigkeit und Weichheit. und zwar eines Körpers, der keiner Arbeit front, sondern am lichten sonnensehein im leichten Spiel gewachsen ist, dieses Alter und diesen Körper hat niemand vor Praxiteles in seiner Nacktheit darzustellen rermoeht, und erst Correggio hat auf dem Gebiete der Malerei in der Darstellung der Jünglingsengel an der Domkuppel von Parma Ähnliches erreicht.

Großes Kïnstlertum versucht sich anch gem an einem Stoff ron hoher Lebensbedeutung, weil die Vollendung gerade hier die höchste Lust des Sehauens gewährt, und weil sein verehrender Geist dem so sehr Geliebten in dem erfïllten Werk Dauer und ewigen Bestand verleihen möehte. Auch mag es vor allem den großen Plastiker reizen, das schon an sich so schön Geformte, das sich der künstlerisehen Bildung entgegendehnt, dureh künstlerisehe Formung alssolut zu machen, während der geringere Künstler nach dem Kleinen und L'nbedentenden späht. ob er ihm eine eigentïmliche Bildumg geben kömme.

Daß nun Praxiteles einen Stoff ron hoher Lebensbedeutung gewählt hat, und es ihm gelungen ist, diesen Stoff darznstellen, ihm noch mehr Siehtbarkeit, Gestalt und Ausdruck zu verleihen, wie er als Erscheinung des schönen Lebens offenbart, all das macht Apollo noch nicht zu dem vollendeten Kunstwerk. Das große Kunstwerk des Apollo Sauraktones ist erst zur WirkIichkeit des Unwirklichen geworden, sofern sich in ihm das Allgemeine nit dem Besonderen, das Unsimuliche mit der Anschaumg zu einer ästhetischen Irlee von so seltsamer Tiefe vereinigt hat.

Viele möchten in diesem jungen A pollo nur einen schönen natkten Knahen sehen, der mit einer Eidechse spielt. Sie haben kein anderes Verhältnis zu diesem Werk, als daß sie sich an der Schönheit der jugendlichen Glieder erfrenen oder die hohe Teehnik der Ausführung bewndern. So blcibt ihnen sehon die sehöne Symbolik unverstanden und verschlossen, welche darin liegt, daß dieser nackte Knabe, der spielend das Gesehoß auf die Eidechse zückt, der junge Gott des Todes ist, der dam später eimmal, wie ihn Homer geschidert hat, mit klimendem Köeher von den Höhen des Olymp herniedersteigen wird, um durch furchtbax tödliche Kranklseit die feindlichen Heere zu bedrohen. Daß der sehöne 
Knabe ein Gott ist, zeigt sieh ja vor allem aneh in dem spielerisehen Charakter des ganzen Vorganges. Der junge Gott will nicht töten, wie vielleicht ein irdisches Kind in ernsthafter Weise die Jagd anf das kleine schlanke Reptil aufgenommen hätte. Nur das Gesehoß, von dem schlanken Arm geleitet, bewegt sich leise und spielerisch nach dem Tierehen hin, aber das Ange und die Seele des jungen Gottes sind nieht dabei.

Gewiß hat Praxiteles, als er dieses Werk schuf, zngleieh auch all die Schönheit entdeckt, die in einem jugendliehen Körper ruht, der an der Grenze des Knaben- und Jünglingsalters steht. So kam es, daß er für das, was er zu sagen hatte, die denkbar sehönste und angemessenste Form zn finden vermoehte. Das Unansspreehliehe, was er sagen wollte, läßt sieh aber vielleieht am besten dahin formmlieren, daß der junge Apollo mit der Eideehse das absolut Vollendete im Unvollendeten offenbart. Die Vollendung liegt nieht nur an der äuBeren Gestaltung des Kunstwerkes oder an der adäquaten Form der Verbindung des Allgemeinen mit dem Besonderen der sehönen Erseheinung. demn diese Art der Vollendung ist jedem großen Kunstwerk eigen, sondern sie liegt anch in dem religiösen Simn des Kunstwerkes, das das Göttliche offenbaren will und als Mittel der Sichtbarmaehmug des sehlanken Knaben sieh bedient. Gewiß kam das Göttliehe viele Gestalten amehmen, sich verhüllen in Nacht und Finsternis oder in schlichter Gewandung dahinsehreiten, unbelanseht und unbemerkt. Aber der Apollo mit der Eidechse bedentet das Göttliche nicht, sofern es sieh verbirgt, sondem sofern es völlig offenbar geworden ist. Der jugendschöne Knabe soll seine adäquate Darstellungsform sein.

Das Göttliche im Geiste des Grieehentums ist ohne Anfang und ohne Ende. es stirbt und altert nicht. Deswegen möehte man meinen, daß ihm das Alter gleichgïltig sei. In jeder Altersistufe oder Altersform kann das Göttliche dargestellt werden, und jede drïekt so mrollkommen wie die andere ihr Wesen ans. Aber das Leben der gricehischen Götter hatte feste Gestalt gewonnen, und es war gewil. koine Zufäligkeit, daß der Vater der Götter und Menschen in der vollen Reife der Männlichkeit dargestellt wurde. Der eine Strom des söttlichen Lcbens hatte schon seine besondere Gestaltenfülle gewommen und duldete es nicht, daß die Persönlichkeit des höchsten Gottes, der die neue J) Ynastie der Himmlisehen erzeugte, mit gewaltiger Hand die Titanen bändigt und ren furchtbaren Domner rollt, daß er in weicher Knabengestalt ersehiene. Wie aber das göttliche Leben, sofern es in Zeus reflektiert ist, seinen besten Anstruek findet in kräftigen Mannesalter von vierzig Jahren, so ist die schöne PBiite von 20 Jahren dem Apollo eigen, jenes Alter, in rlem die Jugend ihre selfstindige Kraft gewinnt. Dem Geist der Liebe und des Veines mag es entsprechen, dab er sich in der weichen Gestalt des Kindes oder des Knaben manifest irrt; aber fïr den Gott des Lichtes, derkiinstlerischen Gestaltung und des Todes scherint die Gestalt eines sehbunken Knaben nieht reif und völlig genug zu sein.

so rowiehst der griechischen Kunst in dem jungen A pollo ein ähnliehes

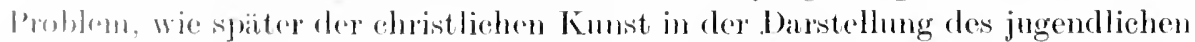
('hlistus. Dic ganze Giottichkeit des Sonnchgottes mub entweder potentiell

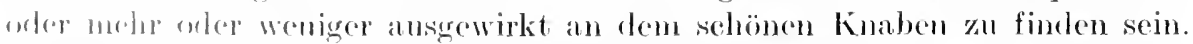

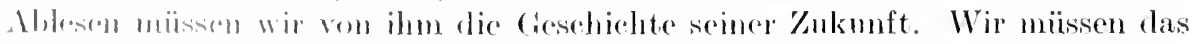

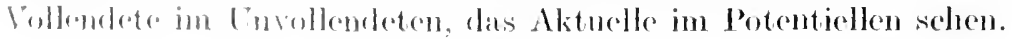


Wenn wir aber das Vollendete im Unvollendeten schanen wollen, so darf das Vollendete das sehöne Werden nicht zu sehr belasten und bedrüeken. E: darf in ihm nur angedeutet sein, damit es dem Charakter des Jugendliehen angemessen und genehm ist. Die Schönheit der knospenden Jugend muB eine Fülle holder Andeutung sein, so daß es unserer Phantasie eine zurerlässige Hilfe gibt, das Ziel des sehönen Wachstums zu erraten. Deswegen glänzt das Ange des heiligen Kindes der sixtinisehen Madonna so ernst und groß, und auch Apollo ist in der ganzen Liebliehkeit seiner vierzehn Jahre mehr als ein nackter Knabe: er ist ein werdender Gott. Seiner Gestalt fehlt all die Herbigkeit und Eekigkeit, die diesem Alter gewöhnlich ist, die sich aber nieht notwendig mit ihm zu verbinden braneht. Die Natur gibt jedem Alter Bildungsmängel und Bildungsvorzüge, doch der große Künstler vermag in der Bildung des göttliehen Körpers all diesen Mängeln abzuhelfen, und so hat auch Praxiteles mit der Gestalt des jungen Apollo getan. Er denkt die Jugendlichkeit dieses Alters zu Ende und gibt ihm so im Simne der Jugendlichkeit den höehsten Zauber der Vollendung.

Und in diesem sehönen Körper sehen wir auch den göttlichen Geist der Vollendung sich zuneigen. Der werdende Gott träumt hier ron dem Traum seiner erfüllten Göttlichkeit. Diese sehlanken Arme, die mit dem. Wurfgeschoß spielen, werden einst mit ermstem Bogenschusse sehweres Sehieksal austeilen. Niemals aber wird anch dann das göttliche Herz der Ruhe entbehren, da es selig ist und ewig fern ron Leid und Lust. Wemn wir ihn spielen sehen, so ist sein Herz doch nieht dabei. Sein Blick schweift ïber den Zielpunkt hinweg in die Ferne. Sein Auge gehört der Welt. Und in dem Traum des Jünglingsknaben kündigt sich sehon an der Gott der Träume und Orakel. der zukunfterschauende, weissagende Gott Apoll.

Jedes Kunstwerk ist sehön, sofern es vollendet geformt ist, mag sein S'toff anch das Häßliche sein. Die Griechen wählten zur Offenbarung der kïnstlerischen Idee mit Vorliebe einen sehönen Stoff. d. h. eine schöne Wirklichkeit des Lebens. Sie haben die Sehönheit des mensehliehen Körpers entdeckt und in der Plastik seine Herrlichkeit offenbart. In einer gewissen Proportion deLeibes gibt sich die Körpersehönheit kund. Hat der ursprünglich derbe. von der primitiven Simlichkeit noch nieht abgelöste Geschmack die plumpe Kraft des Athleten und die weiche zerfließencie Körperfülle als zweekmäßig im Sinne der Zeugung bejaht, so hat die griechisehe Plastik den menschlichen Körper der Gesehlechtsnotdurft entkleidet und ihn dadureh zur freien Sehönheit erhoben. Sie verneinte das Ideal der strotzenden Kraftfülle. der derben Muskulatur, der breiten Hüften und Schenkel, der zerfließenden Weiehheit des Leibes. Eigensehaften. in denen ein barbarischer Gesehmack das spezifiseh Weibliehe und Männliche zu exblicken glaubte, sondern sah das Schöne rielmehn in der strengen Proportion der Glieder zueinander, in der Schlankheit und Festigkeit des Leibes und der Gliedermassen. Dureh diese Betonung wurde der männliche und weibliche Körper einander genähert, der Gegensatz der Gesehleehter trat zurück, und damit wurde eine Form des menschlich Schönen gefunden. die der einseitigen Besehränkung auf das Männliche oder Weibliche enthoben ist. So wurde in der griechisehen Plastik der schöne Mensch zum Symbol des Göttlichen, und wer könnte zweifeln, daß diese Form der Symbolisierung eine 
glïckliche und dem Wesen der Plastik besonders angemessene war. Soll das Göttliche eimmal sichtbar werden, wie es cler Geist der Plastik erfordert, so ist der schöne mensehliche Körper das würdigste und geeignetste Ausdrucksmittel.

\section{o) Die Linnst des Mittelalters.}

Schanen wir aus der Welt der Hellenen in die nene Epoche des Mensehengesehlechtes hinein, so sehen wir die Welt der Kunst anfänglieh vollkommen rerfinstert. Das religiöse Leben hatte durch das große synthetische Mittelalter Erhöhung und Bereicherung erfahren; aber die eigentümlichen Sehöpfungen des Hellenentums. Philosophie und Kunst, waren damals emsthaft bedroht. Der orientalische Geist. der die christliche Religion geschaffen, lehnte sich regen den Geist des Hellenentums auf. Wir verstehen durehaus, daß das Christentum gerade diese Werte auf das schärfste befehtlen mußte, da es sieh in ihnen um die beiden anderen absolnten Werte der Vollendung handelt, die nehen der Religrion noch bestehen. Die Philosophie will die Welt und das Göttliche begreifen, die Kunst will die Welt in der Form der Anschaunng offenbaren, so sind sie beide Konkurrentinnen der Religion. Sie miissen es aber 1 m so mehr sein, wenn die Religion wie im Christentum mit dem Anspruch anftrat, absolut zu sein als das einzige Kind Gottes. Damals sehien mit dem Siege des Christentums auch das Ende der Kunst und ror allem der Plastik besiegelt zu sein. Die Götterbilder wurden durch rohen Vandalismus zertrümmert und begraben. In diesen Götterbildern glaubte man die heidnische Velt der Dämonen zu bekämpfen. und alle Statuen, in denen der Geist der Plastik nach Ansdruek gerungen hatte, erschienen schließlich als Teufelswerk. So offenbarte dieses Zeitalter in seinen Anfängen jene Unseligkeit des Wertgegensatzes, da der Mangel an Verständnis für die Eigentümlichkeit des anderen Kulturgebietes mml die ${ }^{\prime}$ fähigkeit, zu begrenzen, dahin führt, dieSelbständigkeit einer geistigen Lebensform zu bedrohen, die mu und nimmer danernd unterjoeht werden kann, weil Freiheit zu ihrer Natur gehöt und sie allein der Bestimmung ihrer Natur gemäbsich entfalten kam. Wir sehen schon jetzt die Simnlosigkeit eines Ferniehtungskampfes ein. den etwa die Religion gegen die Kunst führt; denn uns ist im Verlauf ler Mensehheitsgeschiehte ein Einblick in rlie Eigentümlichkejt ihrer Strukturgesetze zu teil geworlen.

Lnel damals hat die Religion damn anch selhlicBlich ihren Frieden sehließen müssen mit den beiden anderen Gebieten des absoluten Geistes. Dem synthetischen Charakter des menen Zeitalters gemäb mubten beide zu Gehilfen und bionerimen der christliehen Religion werden. Sehr viel leichter aber war os fïr das ('hristentum, mit der Philosophie Frieden zu sehliefoen als mit der Kunst tres Heirlentums. J)ie msieht baren Sünden der Philosophie komnten der groben

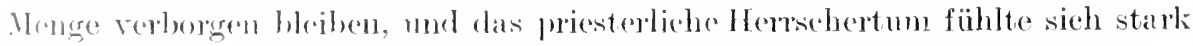

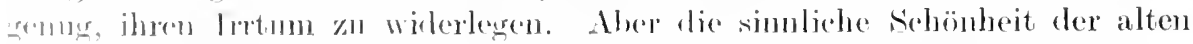

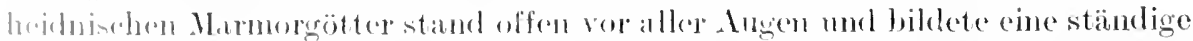

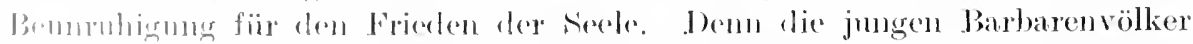

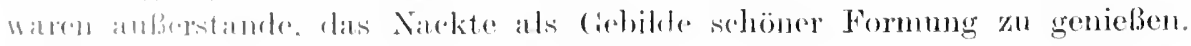

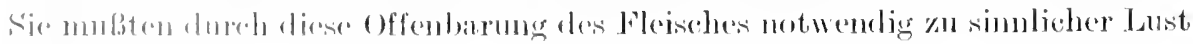

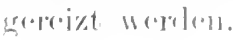


Was aber weiter noch zur Verurteilnng des Plastischen führen muBte, das war der Glanz und die sinnliche Heiterkeit, welche von diesen Marmorbildern ausstrahlte. Das Christentum trug die schweren Falten des Śchmerzes and mußte deswegen von Abscheu und Widerwillen ergriffen sein gegen die nackte Lust der heidnischen Plastik. Die merhörte Idee eines leidenden und sterbenden Gottes und die absolute Verneimung der Sinnenwelt - las waren Momente des Urehristentums, welehe zu einer tödlichen Feindschaft gegeniiber der Kunst und insbesondere der Plastik führen mußten.

Erst damals, als das Christentum aufhörte, absolute Mrstik, Abgeschiedenheit und Erwartung zu sein, komnte es die sinnliche Erscheinung der Kunst dulden. Nur vor der Darstellung des Nackten bebte es zurück. Deswegen mußte die Plastik ganz zurüektreten und ihr Sehöpferwort .. werle. ver'klingen, das die Individualität von allen Umhüllungen befreit und sie ganz frei und offen in der Ganzheit ihres Eigenwesens hinstellt. Die Plastik ist die sichtbarste von allen Künsten, die an wenigsten andentet mud hindentet, sondern alles sichtbar macht und darstellt. Deswegen kann sie von der Religion, die tas Geheimnis liebt, leicht mißrerstanden werden.

Das neue synthetische Zeitalter, das alles Wertleben mnter der Herrschaft der Religion ordnen wollte, bedurfte der Kunst vor allen Dingen, um dem neu geoffenbarten göttlichen Wesen ein Haus zu bauen. Ein großes Blatt in der Geschichte der Architektur ist die Entwicklung von der Gedrumgenheit des alten Basilikenstils bis zur sehlanken Freiheit des gotischen Domes. In dieser Hinsicht vermochte das Mittelalter dem Griechentum etwas Gleichwertiges zur Seite zu stellen, indem es der schönen Proportion des griechischen Tempels und seiner Betonung der Horizontalen gegenüber die Vertikale auf das schärfste betonte. Schöner wohl und einladender zum Verweilen erscheint der griechische Tempel mit seiner lichten Säulenhalle und dem versehwiegenen Geheimnis der Cella. An ihm ist alles ruhig, einfach und schlicht, groß und wïrtig. Hier kann die gottsuchende Seele in der Fülle schöner Formen eine Erfïllung ihrer sehnsticht finden.

Dagegen hat der gotische Dom die Beziehung zur sehön menschliehen Behausung abgebrochen. Sein ungastlicher Piesentum weist zum Himmel. Er hat etwas ron der Poesie des Märehenwaldes, da Riesenbämme. dieht mit Efeu besponnen, die breite Kronen erheben, und alles wirl so ruhig, daß wir das Große und Unvermeidliche nahen fühlen. Gleichzeitig aber waltet auch ein derber Humor und eine trunkene Lust zu allerhand Gestaltung, die selbst das Derbe und Fratzenhafte als Schmuck des Gotteshauses nicht vermeidet. Der gotisehe Dom gibt uns kumd, daß ein ganz nencr Geist in der Kunst geboren ist, daß der Gestaltungswille andere Bahnen geht unt die Schöpferkraft des plastisehen Herrscherwillens sich zur prophetischen Erlösertat rerklärt, wie es die harmonische Musik dam später ansgesprochen hat. Zwischen der Gotik und dem Geist der Musik besteht angenseheinlich eine V'erwandtschaft. Deshalb komte Schlegel die Gotik als gefrorene Insik bezeichnen.

Die Plastik wurde wieder in die Architektur hineingenommen und fristete im Schatten des Gotteshanses cin untergeordnetes Dasein. Hier wrien ihrem Sichtbarkeits- und Offenbarmugswillen Hemmungen bereitet. Nur als Flachskulptur in Nischen und als Relief durfte sie erscheinen. Dem Profaneu 
rollkommen alygewendet, sollte sie lediglich der Illustration einer heiligen Legende dienen. Schwach und schemenhaft, ohne Individualität mußte sie bleiber. Ihre Sehnsucht nach Kraft und Fïlle durfte sie nicht befriedigen, und in die Dichtheit faltiger Gewänder mußten diese Leiber ihre starre dürre Nacktheit verhüllen.

Die Kunst wird umpersönlich. Alle Gebilde der gleichen Zeit tragen ein absolut verwandtes Gepräge. Es handelt sich nicht mehr um Offenbarung des persönlichen Wesens, sondern um die Herstellung eines durch die Tradition gegebenen Schemas. Wie die Plastik remochte anch die Malerei nicht zum vollendeten Ausdruck zu kommen, wenn sie auch jene erheblich übertraf. So schön und liebenswürdig die Fresken von Giotto ansprechen mögen, auch sie verraten noch dentlich den Mangel an persönlichem Leben und eine leise Starrheit und Gebundenheit.

\section{p) Die mittelalterliche Dichtkunst.}

Dem synthetischen Charakter des Mittelalters entsprechend, liegt der Nachdruck der Leistung auf der mittleren der Kïnste, die von fler Musik als der Kumst des Unsichtbaren und der Plastik als der Kunst des Sichtbaren gleich weit entfernt ist, auf der Dichtkunst. Hier hat nun das Mittelalter das große moderne Epos geschaffen, das dem homerischen Epos vollkommen abenbürtig zur Seite tritt: die göttliche Komölie. Jenes war geschaffen worden als die ursprüngliehe Einheit des Wertlebens, wie sie in dem antiken Mythos sich kund tat, nech nicht ron Gegensätzen zerklïftet, dieses wurde geboren, als dic Religion Christi es unternommen hatte, eine neue Einheit als Symbol des Endes zı begrïnden. So spiegelt denn das Dantische Epos die mittelalterliche Welt in ganz ähnlicher Weise, wie Homer in scinem großen Gedieht die griechische Welt widerstrahlt. Am Ende einer großen Epoche fassen beide noch cinmal eine gestaltenreiche Welt zusammen, die durch die Jahrhunderte ging. Während uns aber der griechische Dichter diese Gestaltenwelt unter dem tiefblanen Himmel des Sïdens in der Schönheit des nackten Lebens schanen läßst. und er mur schïchtern und zögermd die Pforten der Unterwelt berïhrt, fïhrt uns. Dante ummittelbar in die schweigende Welt des Todes hinein, indem er der lichten Somme und ihrem farbigen Leben den Rücken wendet. Das Epos Homers ist ein grobes Lied der Lebensfrende und cler Lebensbejahung. 1) antes göttliche Komölie verneint die Sinnenwelt. Sie beginnt mit einer uroben Geste der Abkehr. Der Dichterheld wandelt dureh Nacht und Grauen rinem nenen Liehte \%u. Homer sehildert den Zug in die Ferne, das Aufgeben ler tranten Heimat nm der geraubten simeligen Sehönheit willen und singt dann als notwendige Ergänzmmg das schmerzlich-sübe Lied ron der Wiederkehr

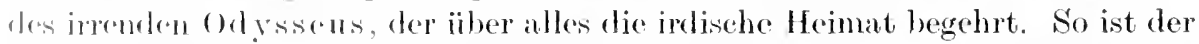
IIrog bri llomer Ansang mol IFeimkehr, bei Dante aber eine Wandermng

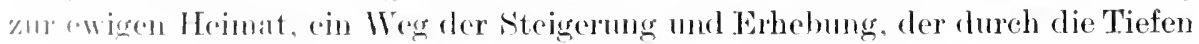
lep Hölle herah den Wrog der Länterung hinauf zu den seligen Höhen des Paraliveses fiihrt.

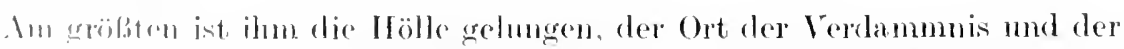

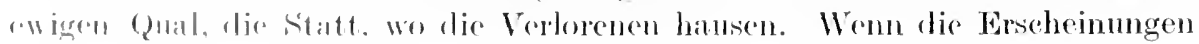


des Infernos auch wie aus quirlendem Nebel emportauchen, so verdichten sie sich doch zu durchaus plastiseher Gestaltung. Das Grauenhafte und Furchtbare geht hier so iber alles gewohnte Maß hinaus, daß die Vorstellung des Diehter: bei jeder neuen Tision immer wieder wie ror einem Rätsel steht. Etwas Grauenvolles, Unfaßbares taneht ans dunklem Grunde herror, eine Bewegung, ein Vorgang, eine Handlung, die allen Gesetzen des Menschlichen Hohn spricht. Lnd dam ertönt eine Stimme leise. sehmerzerfüllt und verzweifelt, die redet ron sich, ihrem Schieksal und der ausgestandenen Qual. Denn eine Erleichterung ist es, das namenlose Leid herauszustammeln und herauszuschreien dem Fühlenden gegenüber. Und indem sie sprieht und redet, wird dem Diehter alles dentlich und verständlich. Die Gesehichte erklärt die Unbegreiflichkeit der Höllenstrafe, deren Furehtbarkeit ror allem darin liegt, daß sie immer die gleiche ist und keinen Weehsel kennt. An die Stelle der immer neuen Gestalten des wechsehnden Lebens ist die eine furchtbare situation getreten.

Dante steht an der Grenze einer großen Mensehheitsepoche. Doeh ist $\mathrm{cr}^{2}$ in der Hauptsaehe zurïekgewandt, zugehörig dem Mittelalter. wem auch dic neue Zeit sich sehon in seinen Werken ankïndigt. Das analytische Zeitalter. das nummehr folgt und bis zur Romantik reicht, hat die höchste Entfaltung des kïnstlerisehen Lebens zur Folge gehabt. Und zwar hat diese Entwickhng. die ron Italien ansging, der Reihe nach alle Kunstgebiete ergriffen, um sieh sehließlich in der Musik zu vollenden. Noch bleibt die Kunst in der Hauptsaehe ron dem Schöpferideal der Plastik geleitet, aber von ferne kündigt sieh sehon das ganz Neue an. Aneh hat die Physignomie der Kunstwelt insofern einc Veränderung erfahren, als das große Kunstwerk im Gegensatz zur Antike nicht mehr die Harmonie des Wertlebens zum Ausdruck bringt in der Gestalt einer ruhigen proportionalen Sehönheit. sondern vielmehr die leidenschaftliche Bewegung des Wertgegensätzlichen. Auch die Spätantike hat diese Form der Darstellung schon gekannt. wenn auch in gedämpftem Maße, sogar auf dem Gebiet der Plastik, wie die Laokoongruppe beweist. Nummehr aber gelangte das neue Prinzip erst zur Tollendung.

\section{q) Die Renaissance.}

Das analytische Zeitalter. das mit der Renaissaneebewegung beginnt. war der Kunst besonders geneigt und ließ ihrer Entwieklung nicht nur jede Freiheit. sondern förderte mit allen Kräften ihren Aufsehwung. Aneh der antike Mensch hatte ein starkes Lebensgefïhl im Verhältnis zur Kumst in seiner starken Bejahung des simnlichen Daseins. aber noch war ihm rerhiillt. "wieviel das Schöne doch fïr das Ganze der griechischen Kultur bedentete. Die Renaissance war der Sehönheit des sinnliehen Daseins zugewendet und wußte. wie groß und unersetzlich die Bedeutung der Kunst fïr die Erfüllung und Tollendung des sehönen Lebens ist. Und so trieb dieses Zeitalter denm einen Kultus mit der Kunst und dem Künstler, der seinem alten Dienst, der Verherrliehung der christliehen Religion, mehr und mehr entzogen wurde und nmmehr das Profane verherrlichte, die sinnliche Schönheit und die geistige und welt liche Macht. 


\section{r) Die Frïhrenaissance.}

T’ber den Gestalten des Quattrocento liegt noch der Goldglanz des Mittelalters. Auch über seiner schönen Erfüllung: Sandro Botticelli. Nichts in der Welt ist ihm an zarter Lieblichkeit zu vergleichen. Es ist, als ob ein weicher Frühlingswind diese Gestalten ergriffen hat und sie in melodischen Rhythmen wiegt. Die armen Glieder, die solange gebunden waren und sich dem Lanc'e der Verheißung entgegendehnten, die schönen bleichen Opfergestalten, zum stillen Schanen bestellt, ergriffen von der großen Offenbarung des Heiligen, sie sind von einem newen Lebensgefühl, von sanfter Daseinsfreucle ergriffen und regen sich in trunkener Lust. Sie haben das dürre Schema abgeworfen, nm Apostel und Heilige zu sein, sie sind zu schönen lebensvollen Wirklichkeiten und Individualitäten geworden. Sie sind, mit des Künstlers Angen gesehen, liebe Gestalten mit schlanken Leibern, hohen Augenbrauen und reich quellendem Goldhaar, Mädchen von Firenze, wie du sie dort noch sehen kannst, und das ganze Leben der Heimat leuchtet in hellen Farben auf. Noch aber sind diese Gestalten nicht absolut geworden und in sich ruhend, noch verraten sie nicht die große innere Bewegung, noeh sind sie nicht von den unendlichen Tiefen der Idee erfüllt. Schöne Blumen sind es, die sich dem Licht entgegen neigen, aber sie vermögen noch nicht dem Größten eine Sprache zu geben, das in schweigenden Tiefen ruht. Das istzuerst und in unerhörter Weise von Mich ela ng e lo geschehen.

In der Kunst des Quattrocento ist der Menseh noch nicht alles. Der Künstler gestaltet ihn in kleineren Verhältnissen und ordnet ihn ein in Landrhaft mnd Ungebung. Der ïppige Fruchtgarten in Botticellis Frühling, in den dio Liebesgöttin ihren Einzug hält, und die schöne Renaissancehalle des Abendmahles von Ghirlandajo umfangen mit Milde den Kreis leichtbewegter Gestalten. Später drängt die menschliche Gestalt die Natur immer mehr in den Hintergrund mo füllt die ganze Fläche des Tafel- und Wandgemäldes aus.

Es war in jener Zeit, da die Plastik wieder mächtig wurde und sich auf die Schönheit der nackten. Gestalt besanu. Damals feierte Donatello den Reiz der jugendlichen Glieder in der Gestalt des Hirtenknaben David. Seine Mcisterhand erschuf die Figur des heiligen Georg als jugendlichen florentinischen Ritter. Erfüllt von dem Geist ciner neuen Zeit, suchte er der Kunst jmmer neven Boden zu gewinnen und wagte sieh mit kïhnem Wrurf an das nir Versuchte.

\section{s) Nichelangelo.}

Jn Cinquecento creichte die bildende Kunst zum zweiten Mal in der

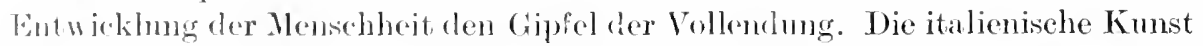

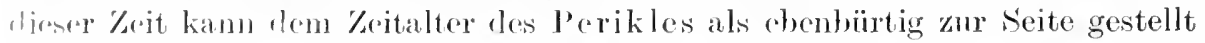
urrolen. Blich anch tie gricehische Plastik merreicht, so crang dafür die

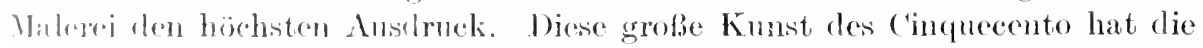
- Intikr zum Vombild genommen, aher niemals in sklavischer Weise sie nachErabunt. So ist flemm damals eine nene Kumstwelt geworden mit einem von der

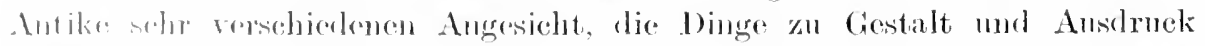

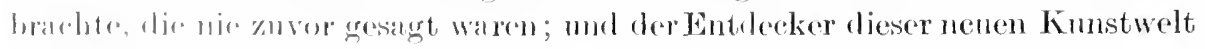

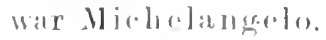


In ihm arbeitete ein nie gahnter Schöpferwille. Der Geist der Plastik war in ihm absolnt, der wie ein Bildhauer malte und doch glcichzeit ig die Gesetze des Malerischen rollkommen beherrsehte und mit den hellen aquarellartigen Farben seiner Riesenwandgemälde mbetretene Pfade wandelte, ror denen jeder andere wie dieser Riesengeist seheu zurückbeben mußtc. Die Kmnstwalt, die cr uns offenbart, ist nicht mehr erfüllt von der Einheit des Wertlebens und somit die Offenbarung der Harmonie, der Schönheit, des Ehenmaßes, der Puhe. sondern im Gegenteil: Michelangelo will als Gesctz der Welt den Wertgegensatz offenbaren.

Seine Gestalten kennen nicht den zarten Ausdruck sinnlicher Schönheit, der junge Sklave des Louvre rielleicht ausgenommen, sie setzen sich über die Gesetze der Proportion hinweg, die das Auge erfreuen und erfrisehen, das der schönen Gestaltung des Leibes nachgeht. Wie ron eincm innerlichen Sturm ergriften, sind sie hingeführt zu leirlensehaftlicher Bewegung unr großer mächtiger Gebärde. Die Glieder in ihrer verschiedenartigen Stellung mol Haltung verraten die innere Erregung und das Gesetz der Polarität, das ihr zugrunde liegt. Daß das Wertreich in sich feindlich zerrissen ist, daß es kein Reich der Ruhe gibt, anch nicht im remünftigen Leben, das sich der gemeinen Sinnenwelt entgegensetzt, das hat Michelangelo kundgetan. Dic Kunst. die hier erscheint, will große und komplizierte Gemütsrorgänge ausclrücken. Wie der große Schauspieler in immer nener Pose und ewig wechselnder Erscheinmug den Sim der Gestalt zum Ausdruck bringt und erfüllt, den der Dichter vorgezeichnet und geschaut hat, so deuten die Gestalten Michelangelos immer wieder etwas neues an. Sie enthüllen die Mysterien des inneren Lebens so absolut dramatisch in ihrer Erscheinung, wie die Marmorbilder der Antike ganz überwiegend dureh den epischen Geist der Ruhe bestimmt waren. Die großen Gestalten der Sixtina, was sind sie anderes als eine Ausdrucksgebärde des religiösen Geistes!

Der künstlerische Schöpfungswille hat dem religiösen Geiste Sprache verliehen. In Michelangelos Werken treten uns religiöse Ideen entgegen. doch sind diese los und ledig aller Beziehung zmm religiösen Dogma und ganz im künstlerischen Sinne verstanden. Man kann ja in den seltsanen und außerordentlichen Gestalten, die Michelangelo geschaffen, etwas Religionsfeindliches rermuten, denn ganz angenscheinlich haben sie alle kem Verhältnis zur übersinnlichen Welt, sofern ihnen der freie Aublick ins Transzendente fehlt, der uns bei Rafael ïberall hegrgnet. All die renchöpfe, die Michelangelo geschaffen hat, stehen unter dem Druck einer ungehenren sichwere. Sie haben alle etwas Lastenr!es. Trostloses mol Einsanes an sich. Sie sind zus einem großen künstlerisehen Leben befreit, aber liese Befreiung ist noch keine vollkommene Erlösung. Sie sind zum Leben erweckt, um in ler sphäre des sinnlichen Lebens das denkbar Höchste zu bedent $\left(\times n^{1}\right)$. Tn der Feliönheit und Kraft ihrer Glieder; in der groloen Formgebung. die ihnen zuteil graterden ist, haftet ihnen doch auch wieder etwas uniberwindlich sohmerzhaftes an. Diese Gestalten sind nicht schön und seligr wie die griechirchen Göttergestalten.

1) Vgl. hierzu Simme ls Auffassung des Michelangelo: Logos Bd. I H. ‥ S. 2016 47. 
Aus dem Marmor soll die künstlerische Erscheinung hervorgehen, die dort im geheimen rorgezeiehnet ist und ungeduldig der Erlösung harrt. In dem weißen Marmorblock werden sehon von der Hand der göttlichen Weltkraft die Linien rorgebildet, in denen einmal der weiße Körper mit seinen leuchtenden Formen. vom Künstler herausgelöst, vor dem staunenden Bliek erscheinen wird. Diese Körper, die Miehelangelo in Marmor und Farbe bildet, sind kräftig, muskulös und athletiseh geformt, ein trotziges Heldengeschlecht, von heroischer Kraft und Leben erfüllt; ein neues Schönheitsideal von Männlichkeit und Weiblichkeit, dem Schönheitsideal des Griechentums entgegengesetzt. Niehts ist verfehlter, als von dem gattungsmäBigen Charakter dieser Naturen zu sprechen; demn das Gattungsmäßige ist das Durehsehnittliehe und Gleichgültige. Sie sind auch keine Typen in dem simne, daß sie etwa das Berufsmäßige bestimmter Menschenklassen zum Ausdruek brächten oder als starre AJlegorien das Persönliche hinter dem Allgemeinen versehwinden ließen. Vielmehr ist in ihnen das Allgemeine und das Besondere auf das innigste verbunden. Sie sind vollkommen inclividuell nach Ausdruck, Gestalt und Gebärde, einzig in ihrer Art nnd unvergeßlich. Und dennoch sind sie allgemein, sofern sieh in ihnen das geistige Leben, so etwa das religiöse und künstlerisehe Bewußsein, in vorbildlicher Weise offenbart und in der Gestaltung seltener und erlesener Gefühlswelten eine so reiche symbolische Sprache redet, daß alle enge menschliche Begrenzung überwunden ist. So ist Jeremias nieht nur die bestimmte historische Erscheinung, durch Rasse und Nationalität begrenzt, sondern er ist der Prophet, wie er überall und immer im dunklen Buch des Schicksals liest und iiber die Furehtbarkeit der Visionen, die er geschaut, zu einsamem Sehmerz erstarrt.

Das Rätsel der Sixtina ist nur zu verstehen, wenn man von der Idee des Gesamtkunstwerkes ausgeht. Das Dargestellte sind die beiden Wege: der Weg der Emanation und der Weg der Rüekkehr, die Idee der Schöpfung und Erlösung. Der Weg der Emanation geht aus von dem einsamen Gott, dem reinen Sehöpferwillen der Gestaltung. Gott Bildner ist allein: die reine Form, die in sich ruhende Weltkraft. Und er sprach das Wörtehen, werde“. Und die Einheit wird zur Viclgestalt reiner schöner göttlicher Wesen, herricher nackter Engelscharen, dic von Allvaters Brust sich niemals entfernen, die sich selig anschmiegen an den Samm seines Mantels. Und sein Schöpferwille dringt weiter und weiter auf dem Wege der Individuation zu immer größerer Vielgestaltigkeit, bis er plötzlich vor ihm liegt, der nackte hilflose Menseh, das große Problem der Wrolt, und das Licht der Vermunft dureh die göttliche. Hand zu ihm hingeleitet wurde. Er, der dann nicht einsam blieb, dem Gott das Weib zur Gefährtin gesellte. Beicle anfangs gar schön und rein, dann aber verunstaltet dureh die Sünde, das contstellte und entweihte Kunstwerk des Lebens. Und wie dann der hohe gättliche /ug in die 'Viefen der Arnseligkeit und Gemeinheit führt. Gegen dir sehnellenden Wogenmassen kämpft mutig ein heroisehes Gesehleeht. Unrortilgbar ist der Mangel, die Sïnde, die Begrenzung. Auch in dem anserwählten (icschlechte Noahs fribt sie weiter fort als die abscheuliche Nengier des cischlochtes, und die hohe Reinheit des göttlichen Sehöpfungsaktes endet als 'Tragikomörlie in riner gemeinen Faree, in neuer Schula, in Noahs Schande.

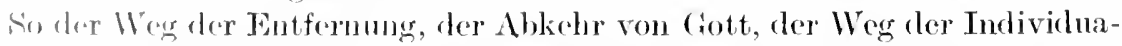
tion, mul tron greseniiber anf den Seitenwänden der Kapelle die Sibyllen und 
Propheten und die Vorläufer des Hauses David in langer Reihe, die Gesehlechter, aus denen seine Göttliehkeit hervorging. Die Sibyllen und Propheten, sie sind die großen Wissenden, die Suchenden, die in den geheimen Büchern lesen, unbewegt in ihrer Abkehr von der Welt, oder plötzlich erregt werden von dem Nahen der Gottheit. Úber ihre Haare geht der Odem Gottes. Aus trübem Sinnen fahren sie auf, ergriffen von der Nähe des Geheimnisses. In Leid versunken sitzen sie, erfüllt von dem Gedanken des mabwendbaren Schieksals. Mit sieghafter Hand weisen sie hin auf das Wort, das gesehrieben steht, das schicksalsschwere, das Wort, dessen Erfüllung so nahe bevorsteht. Sie sitzen die einsame Nacht hindureh, immer in Erwartung des kommenden Heilandes. Ihre Augen sind erfüllt ron dem Rausehe der Ekstasis, und ihre Lippen öffnen sich zu Wunder und Weissagming.

Und dameben jene anderen in den stillen Hütten und Zellen, diese Mïden. von der Last des Alltags hingenommenen Menschen. Sie warten und harren auf das Außerordentliche und Wunderbare, dem die Begrenztheit ihrer Natur sich entgegendehnt. Diese Armen, die sich nicht aus eigener Kraft erfüllen kömnen, die niemais zum selbständigen Ausdruek gelangen, die verurteilt sind, in den Winkeln und Ecken zu sitzen. und aus denen doch das große Geheimnis Gottes hervorgeht. So brüten sie dahin in leerem Schweigen. jene, denen nur die Gebärde des Alltags eignet, die mitgerissen werden von einer dumpfen Gewalt, die nicht mit eigener Kraft ihr Sehicksal formen kömen. Sie, die verurteilt sind, immer zu warten, und an denen das Große vorheigeht, weil sie es nicht verstehen. Die Spreeher und Anwälte dieser vielhundertjährigen Geschlechter sind die Sibyllen und Propheten. Sie forsehen für sie mnd rufen zu Gott und erschauen den Tag der Erlösung.

So der Weg der Entfernung von Gott und jene, die den Weg der Rückkehr bereiten, und die lange endlose Zahl der Wartenden. Wo aber ist das Ziel, das Erlösende? Scheinbar zu rein dekorativer Wirkung herabgesetzt. ist es doch das Bestimmende für jene leidensehaftliche Bewegung, die dureh die hohen Räume geht: die Sehar der Sklaven, jene zwanzig schönen Jünglingsgestalten. Kränze binden sie, um das Wappen des stolzen Priesterfürsten zu schmücken. Sie sind jene Welt plastischer Gestalten, die ihn umschwebte, als er am Juliusdenkmal schuf. Der junge männliche Körper in immer wieder neuer Bewegungsform, das entsprach am meisten seinem Ideal ron sinnlicher Schönheit. Was dem Bildhauer vorschwebte als die vollendete Form, das hat er in diesen unvergleichlichen Gestalten zu maleriseher Darstellung gebracht. Gewiß, die Welt ist entweiht und ihre reine Sehönheit dahingeschwmden. schwer und dunkel ist der Pfad der Erlösung, die Masse brïtet stumm und ausdruekslos dahin, nur um das Kleine und Gemeine bekümmert. In wenig großen Menschen regt sich die große Sehnsucht nach Gott und die bestimmte Gewißheit, daß es ein Erlösendes gibt. Dieses Erlösende selber aber kann im Sinne des großen Künstlers nur das Sehöne sein, das uns ron aller Dumpfheit und Enge befreit und als eine Welt der Gestalten dem sehauenden Bliek erseheint: die nackte Sklavenschar als Typen plastischer Ausdrucksmögliehkeit, als das selige Ziel der Vollendung.

Und dieselbe Idee der Erlösung in ästhetischer Úbersetzung seheint auch als Sinn des Juliusdenkmals gedacht zu sein. In den Stein ist die Statue gebannt. 
im Marmorblocke ruht das schöne Bild und harrt der Befreiung. Der Künstler befreit durch Gestaltgebung. Diese Gestaltgebung weisen die Figuren des Juliusdenkmals in sehr versehiedenem Maße auf. Der Grundstock des Denkmals wird gebildet durch Hemen, an denen Sklaven, Kriegsgefangene gefesselt sind. In der Hermenfigur hat sich nur der Kopf der sehweren Bindung des Marmors entwunden. Die ganze Gestalt ist noch von einem dichten Marmormantel umhïllt. Die nackten Kriegsgefangenen sind aus dem Marmor hervorgetreten. aber an die Hermensäule mit schweren Banden gefesselt. Sie können sich nicht lossingen und brüten in schweigendem Trotz oder sind wie jener eine Schöne der qualvollen Wirklichkeit entrückt, von Müdigkeit ïberwältigt, im Traumesbann. So verkörpert die ganze Unterstufe des Denkmals den Geist der sehwere. der Bindung und Knechtsehaft. Darüber aber thronen die freien Riesengestalten des Petrus und Paulus gewaltig, über menschliches Maß erhaben. Sie gehören zu denjenigen, die von dem Wehen des Geistes erfüllt sind, und ungeheuer ist die Macht, die von ihnen ausgeht. Auf der höchsten Stufe aber sollte sich nach des Meisters ursprünglichem Plan das Wunderbare vollziehen, die Aufnahme des großen Papstes in das Reich der übersinnlichen Gestalten.

\section{t) Corregio.}

Wenn Michelangelo wie ein Plastiker malt und, weil er die Natur verachtete, auch als dekorativen Auf putz und den mensehlichen Körper wählte, wenn er Modellierung und Zeichnung unterstrich, weìl er den Sehmelz der Farbe ein klein wenig verachtete, so in Correggio ein vollkommener und absoluter Maler. Nichelangelo steht in einer Linie mit Shakespeare und Dostojewski. Michelangelo ist nicht nur der Plastiker, sondem auch der Dramatiber unter den Malem, und gerade das dramatisehe Moment tritt anch in den epischen Erzählungen des großen russisehen Künstlers so mächtig hervor. Cier wie Michelangelo die Natur verachtete und nur den Menschen darstellen und rerkïnden will. Die ungeheme innere Bewegung, die Leidensehaft bis zum Wahnsim, sie hat den groben Bildhaner stofflich cbenso gereizt wie den großen Dramatiker und den merreichten modernen Eliker. Canz anders f'orreggio, der Mejster der Farbe, fer nur Maler war und in sehöne Landsehaft die lichlichsten (iestalten gebildet. Er hat die weichen und zarten Gestalten junger Franen. Kinder und Jïnglingsknahen unerreicht vollendet dargestellt. El ist lyrisch bis zur trunkenen Begeisterung der religiösen Ode. Sein grobes Kuppetgemalele in Parma kann den Wandgemälden der Sixtina nach Grobartigkeit res stiks mul dor Anlage vergleichsweise zur seite gestellt werken.

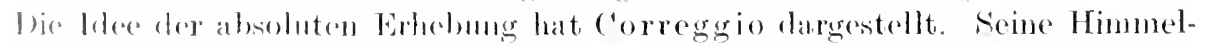

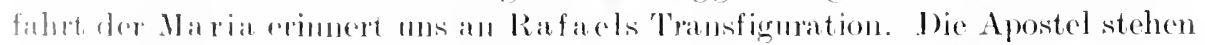

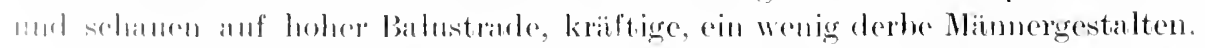

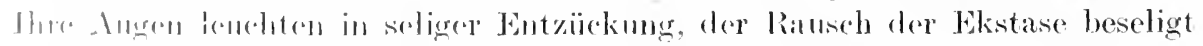

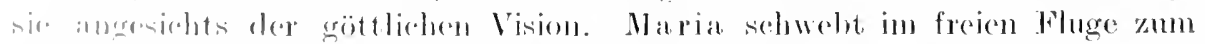

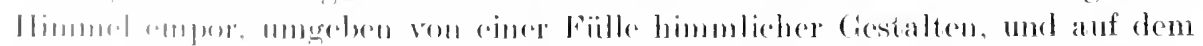

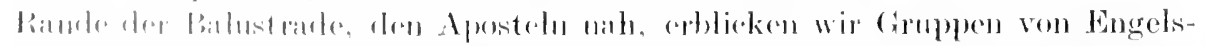

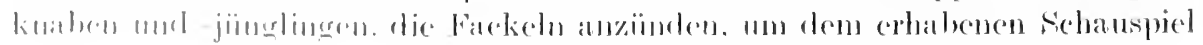


zu leuchten. Diese nackten Knaben und Jünglinge gehören in dem zarten Śpiel ihrer Glieder und in der Lieblichkeit ihrer Gesiehtsbildung zu dem Schönsten, was jemals ein Künstler gemalt hat.

\section{u) Shakespeare.}

Im Zeitalter der Renaissance hat Shakespeare die nene Form des Dramas geschaffen, die das äußere Schicksal in cler Gostalt einer waltenden Gottesmacht in den Kreis der Handlung nicht eimbezieht. sondern höchstens noch das Zwischenreich der Dämonen als Geistererscheinmgen in das Schicksal der Helden eingreifen läßt. Das änßere Sehicksal ist gewissernaßen zu einem imneren geworden, sofem es unmittelhar aus dem Charakter und den Leidenschaften der Personen hervorgeht und so das tragische Gefühl des Schmerzes erweckt. Und indem die Gottheit nicht mehr als bestimmende und rersöhnende Nacht in die Handlung eingreift, kam der Wertgegensatz noeh weit sehroffer und unverhüllter herrortreten. Die Gestalten, die hier geschaffen sind, fordern in ihrer Darstellung zum leidenschaftlichsten Ausdruck und zur höehsten Gebärde anf. Es handelt sich in der Stoffwahl immer um Persönlichkeiten ron großen Dimensionen, die Helden der Tragödie sind gewaltsame und seltene Menschen. Und wem die tragisehe Verkettung ron Sehuld und Schicksal unerträglich wird, dann umhüllt diese Menschen schließlich die Nacht des Wahnsinns. Der Wahnsinn erlöst von der Macht des Leidens. Er setzt den freien Vermunftmenschen wieder zur Natur herab. Dort führt er dam in der Natur das bloß elementare Dasein der Tnstinkte. Das Allgemeine nimmt ihn auf als Brücke zur Nacht des Todes. Eine eigentiimliche Problematik aber bringt der Wahnsinn als Erlösungsmittel mit sich, sofern er, zu absoluter Herrschaft gelangt, die Aktionsfähigkeit des Helden vollkommen zerstört. Deswegen schildert Shakespeare den Helden gern an der Grenze des Wahnsinns, oder wenn er dem Zustand der Reflexionslosigkeit und des Simmlosen verfallen ist, wie König Lear, dam läßt er ans jener schweren, dïsteren, aber schmerzlosen Welt manehmal etwas Sinnvolles hindurchtönen, ein Wort oder eine kurze Redewendung, welche die Seele innig ergreift, so wie uns auf einem zerstörten Instrument der helle und reine Klang einer Saite oder ein sehöner Akkord so tief und ummittelbar berïhrt. Das Srmbol der Rückkehr zur Natur ist für alle diese Menschen, die der Qual der Reflexion los und ledig sind, der Schmuck taufrischer Blumen, der bunte Kranz auf dem remunftlosen Haupt. Kinder werden sie wieder und leben in der Welt der Instinkte friedroll und ohne Sichmerz.

Seltsam. und einzigartig ist aber vor allen anderen die Gestalt des Hamlet, in der Shakespeare sein Größtes gegeben. Es galt den Menschen zu schildern, der ohne Kraft des Willens und der Tat rou bohrender Reflexion besessen ist. Ihn, der sich dazu berufen fühlt, der Welt den spiegel rorzuhalten, dessen zerstörendes Denken schließlieh dahin gelangt, die Welt als ein großes Narrenhaus zu betrachten und ihren Sim zu remeinen. Von all dem Simnlosen, das er erlebt hat, auf das äußerste gequält, zerstört er sich selber auch im ruhelosen Nachdenken über seines Charakters Art. Er vernichtet allen mutigen Entschluß zur Tat und die schöne Welt des Gefühls, die er einst besessen und in der er 
selig war und stark. In ihm, dem zarten theoretischen Menschen, wird also das Instinktive und Impulsive gleichsam durch die Reflexion verzehrt, und dadureh wird die Vermunft, die ja an sich ihre Spannkraft durch die Reflexion erhält, selber aufs schwerste bedroht. In einer furchtbaren Vision, die nur seinem Auge sichtbar ist, erblickt er die Gestalt seines toten Vaters und erhält dureh ihn die Kunde ron dem frevelhaften Mord. Seine abłehnende Haltung gegenüber der Welt verstärkt sieh zu grenzenlosem Ekel. Aber welehe Mächte soll er heraufbeschwören, um die räehende Tat zu vollziehen, da die Kraft seiner Instinkte gelähmt ist? Er muß Gewißheit haben und entsehließt sich, vorlänfig den Tollen zu spielen. Die Tollheit, die er spielt, ist aber nicht das freie Ausströmen dunkler Instinkte, sondern ein berechnetes Spiel der Reflexion. Er spielt mit den Menschen in freier Ironie, ohne sich selber zu schädigen oder zu enthlößen. Gleichzeitig ist aber sein seelisches Gleiehgewicht dureh die furchtbare Erscheinung, die er erlebt hat, aufs äußerste ersehüttert, und in die klare Vorstellungswelt tollironischer Betrachtungsweise brieht der dunkle Strom der gemißhandelten und tief verletzten Instinkte ein mud äußert sieh in grenzenloser Leidenschaft, in wilder Zerstörung, so vor allem in der Szene zwischen $\mathrm{ihm}$ und Ophelia nach dem berühmten Monolog, in der furchtbaren Szene mit der Mutter und in der Handlung an Opheliens Grabe.

So kommt das Seltsame heraus, daß Hamlet dort, wo er den Tollen spielt, klar und gesund und dort, wo er sich gesund wähnt, wahnsinnig ist. Sein (gespielter) Wahnsinn ist Vernunft und seine (niehtgespielte) Vernuinftigkeit ist Wahnsinn. Der Wahnsinn aber ist die Erlösung von der Qual der Dinge. Dort, wo er erlöst scheint, ist er gebunden, und wo er gebunden scheint, ist er crlöst.

Das shakespearische Drama umfaßt die Welt der trüben und der heiteren Dinge. In seinem großen Trauerspiel und Lustspiel des Lebens sind ganz im platonischen Sinne Freude und Leid gemischt. Das. Drama in Shakespeares Geist widerstrebt der engen Auffassung der Tragölie, wie sie Aristoteles gegeben hatte. Er war ein großer Dramatiker und auch ein starker Lyriker. In den hohen Ernst der dramatischen Handlung klingt die Schellenkappe des Tarren hinein und auch der Sehnsmeht und ter Liebe süßes Lied. Sonst aber ist die Verbindung mit dem Musikalischen abgebroehen, dev Chor ist aufgelöst, der dionyische Klang verstumnt. Der hohe Geist plastiseher Gestaltung hat alles zu höehster Sichtbarkeit geliutert.

Man hat wohl den realistisehen Charkter ron Shakespeares Gestalten im Gegensatz etwa zu den idealen Typen der Sehillersehen Dramen betont. Aber Realismus nut Irlealismus sind für rlie Kunst wenig entseheidende Gegensätza. Dir Fintfornung von der Wirklichkeit, die Umbildung der Realität ist für llen Kïnstler sellsstverstiindlich und notwendig. Wird , realistiseh"6 als J)Wretung rincs Kunstwrorks gebraucht, so will rlas Wort besagen, daß die Grestalten des Künstlers ms die Wirklichkeit vortäusehen, daß sie lebenswahr cmpfunden sincl. ,Idealistiseh" ist dam gloichbedentend mit wirklichkeitsfremel. mit mulabudig. (Ailt abor clas Wort idealistiseh als Wertbegriff, so weist

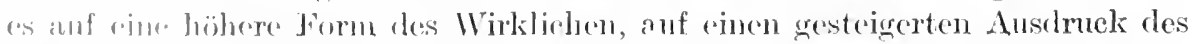

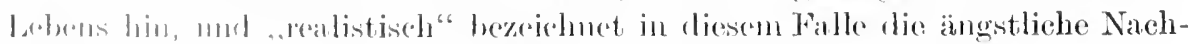
ahmung der Wirklichkeit, das Waften am Nïehternen und Alltägliehen. In 
Wahrheit täuscht alle Kunst über das Leben hinweg, indem sie uns ein reicheres und größeres Leben vortäuscht, als die bedürftige Wirklichkeit kennt. Soll unter idealistisch nicht speziell der klassische Stil verstanden werden. dessen Nenbelebung in einer fremden Kultur ein hoffnungsloses Unternehmen ist, so kann unter diesem Gegensatz nur ein Unterschied in der Stärke und in der Wahl des Ausdrucks verstanden sein. Die Hänfung der Bilder und Metaphern, die kunstreiche Form des Terses im Drama, das laute Aussprechen geheimer Gedankenzusammenhänge in Monolog, alles das hätte dann als Kennzeichen der idealistischen Form zu gelten. Alles das findet sich aber auch bei Shakespeare.

\section{v) Das neue Kunstideal und die Idee der Musik.}

Es möchte fast so scheinen, als ob der Geist der Plastik, jener Geist der strengen Formung, der auf Individuation und dentlichste Betonung der Gestalt gerichtet ist, der in der bildenden Kunst vor allem mächtig wird, der aber auch in der Dichtung in der Dentlichkeit und Sichtbarkeit der Bilder sich kundgeben kamn, als ob jener Geist des Kunstschaffens, der in der antiken Kunst so reich sich entfaltet hatte, in der Kunst des Cinquecento zu seiner zweiten. Vollendıng gelangt wäre. Seitdem wendet sich die Entwicklurg allmählich einem neuen Kunstideal zu, das in der Romantik seine erste große Formulierung gefunden hat, eine Kunstwelt, die beherrscht ist von dem Geist der Musik. Der Geist der Musik ist der Geist der Verbindung und Verschmelzung, während der Geist der Plastik anf strenge S'cheidung und Sonderung gerichtet ist. Die Plastik will alles sichtbar machen, die Musik verhïllen. Plastik heißt offenbaren und deutlich machen. Die Musik will erlösen ron der Unseligkeit des Alleinseins und der Indiridnation. In der Plastik trimmphiert das Indiriduelle, in der Musik das Allgemeine. Die Musik aber fand ihre Erfüllung in der Harmonie.

Die Entwicklung der modemen Plastik bleibt in der Hauptsache rom Geist Michelangelos beherrscht, sofern sie sich bemüht, das Wertgegensätzliche zu offenbaren, in der leidenschaftliehen Bewegung der Glieder, in der Sichtbarmachung starker seelischer Erregungen. Das Ideal der Ruhe und des kontemplativen Versunkenseins, wie es die Blütezeit des Hellenentums gebildet. fand eine unwiirdige Nachahmung in den geistlosen Statuen und Marmorbildern der Barockzeit. Im allgemeinen muß man sagen, daß die bewegten Glieder mehr der Musik entsprechen als das Unbewegte. Träumende und Kontemplatire. wie der Tanz beweist, der die Ruhe der menschlichen Glieder in Bewegung anflöst.

Der Geist der Musik kïndigt sich schon in der Malerei des Correggio an. Diese absolute Ma lerei, die alle schroffen Ubergänge in w underbaren Abtönungen rerschwimmen läßt, ist, wemn man will. die musikaliche Malerei. Jedenfalls ist hier der Punkt erreicht, wo sich die Malerei aufs engste mit der Musik rerbindet. Nicht umsonst sind jene Apostel des Kuppelgewölbes in Parma ron mystischer Entzückung getrieben. Nicht umsonst löst sich die Stärke der Muskulatur und die große Sichtbarkeit der Glieder in schmelzende Weichheit auf. Die mystisehe Verzüickung wird am besten von dionysischer Musik akkompagniert, und die zarten Körper der himmlischen Jïnglingsknaben, die das 
Licht der Fackeln entzünden, sie leben in seliger Hingabe an den versöhnencen Geist der Trelt.

Der neue Geist der Ǩunst äußerte sich damn weiter in der Zurückdrängung der menschlichen Gestalt, welche die Liebe und Sehnsucht des plastischen Schöpferwillens gewesen war. Die Landschaft tritt immer mehr in den Vordergrund, die ron Gestalten mur sehwach belebte Landschaft, in welcher der Mensch als Glied der Natur erscheint oder als Mittel der Naturbelebung. Die Natur ladet zur Rückkehr in das Allgemeine ein. Ja, die von Michelangelo so verachtete Natur wird selbständiger Gegenstand der malerischen Darstellung. In ihr sieht die Kunst einen neuen Weg und eine Erfüllung ihrer Sehnsucht.

Der Geist der Mnsik, der die moderme Welt bewegt, und dessen tiefster Simn zu suchen ist in der Bewegung zum Allgemeinen hin, eine Richtung ces künstlerischen Bewußtseins, der auf religiösem Gebiet der Geist der Mystik und der Prophetie entspricht, dieser neue lebendige Geist äußert sich, wemn man seinen letzten Regungen nachspürt, in einer doppelten Bewegung, die nummehr in immer stärkerem Maße das ganze Gebiet des künstlerischen Lebens ergreift und die aus einer letzten gemeinsamen Wurzel stammt: in Entformung und Versehmelzumg.

Der Sim jeder Kunst ruht auf Gestaltung und Formung, das Formlose kann nie als Kunstwerk gelten, aber innerhalb des kïnstlerischen Lebens gibt es diese beiden Möglichkeiten, daß nämlich entweder die Sichtbarkeit und die Individualität, die eine Qualität dieser Simnenwelt ist, auf das äußerste betont, ja noch höher geformt und noch deutlicher gemacht wird, als sie inder simnlichen Wirklichkeit erseheint; oder aber, die Sehnsueht der Kunst ist darauf gerichtet, diese simnliche Schale zu zerbrechen und eine Welt des Unsichtbaren mit eigentümlichen Mitteln zu gestalten. Das crste ist die Aufgabe des plastischen Geistes, und wir verstehen ron diesem Gesichtspunkt aus, wie das religiöse Bewußtsein der Mrstik, das nach dem Unsichtbaren verlangt und das innere Auge des Geistes lenchten lassen will. diese Welt der plastischen Kunstgestaltung notwendig verneinen mul3. In ihr findet sie die Sünde des magisehen Bewußtseins wieder. Diese Marmorbilder sind Tenfelswerk. Nicht nur wegen ihrer Nacktheit haben finstere Mönche griechische Statuen zersehlagen, noch war es allein der heidnisch polytheische Kultus, als deren Zeugen jene schönen Götter auftraten, die den Verdacht und Widerwillen der christlichen Eiferer erregten. Es war die Ablehmung jener Verherrlichung der simlichen Welt, die dem Geist der Plastik mun cimmal gemäl ist. Der Geist der Musik aber widerstrebt der Siehtbarkojt und Individualität. Er schafft Formen des Gestaltlosen und Namenlosen, die auf die Lnmittelbarkeit des Gefühls und auf die Welt des C'bersinnlichen ohne jede bildliche Vemittlung hinziclen.

\section{w) Die romantische Kumstform.}

Hhre Mittel sind Entformung und Verschmelzomg. Senon in der Entw irklumg der J'rosa, die in Zcitalter der Refornation und Aufklärung immer

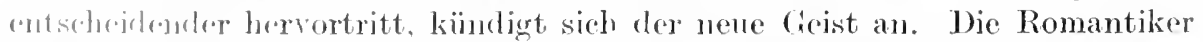

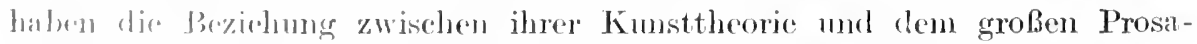
roman wohl herriffen. Der Roman arschejnt als die spezifisch romantische 
Kimstform. In dem Roman liegt seiner ganzen Natur nach ein starkes Zuriicktreten der äußeren Form, sofern von Rhythmus. Ters. Strophenbau sowie ron der Häufung der Bilder, Gleichnisse und Metaphern abgesehen wird. Der Roman ist weniger stilisiert und geformt als das Versepos. Deswegen steht er in seiner Ausdrucksweise scheinbar dem Wirklichen näher.

Das große Prosaepos hat aber auch weiter die Tendenz, alle anderen Formen der Dichtung in sich aufzunehmen. Ursprünglich schien der Behandlung durch das Drama nur ein ganz bestimmter Stoff angemessen zu sein und diesem Stoff nur eine ganz bestimmte Form zu entsprechen. Unter diesen Toraussetzungen steht noch durchaus die große französische Tragödie eines Corneille und Racine. Erst der Geist der Musik hat diese nene Auffassung hervortreten lassen, daß dasselbe Erlebnis dramatisch, lỵisch und episch gestaltet werden kann, und als die Forderung einer besonderen Stoffwahl nicht mehr in ihrer Strenge geltend genacht wurle, sind auch die äußeren Formen der Dichtung einander immer mehr genähert, was dann in der Romantik zu einem rollkommenen Verschmelzungsprozeß geführt hat. Der Prosaroman erschien als die allgemeine Kunstform, der dramatische, lyrische und epische Elemente in sich vereinigen kam. Das Lyrische regte sich in der dramatischen Form, das Dramatische im Epos, das Dramatische drang in das Lrrische ein und das Epische in die dramatische Kunstform. Vor allem erschien eine stark rhythmisierte Prosa als die universale Ausdrucksform des künstlerischen Erlebnisses. So ist in der modernen Kunst die starre Gattungseinteilung von Drama, Epos und Lyrik immer mehr flüssig geworden. Das Dramatische, Lyrische und Epische erscheinen als schwer zu bestimmende Elemente der künstlerischen Formgebung, die Teile desselben Kunstwerkes verschieden abtönen und sich häufig auf das engste berühren und durchdringen.

Immer undurehsichtiger und ssheinbar regelloser wurde die Dichtung und zerstörte auch vollkommen den alten Gegensatz ron Tragödie und Komödie. Soll uns die künstlerische Formung des Lebens vom Leben erlösen. so muß sie in dem neugeschaffenen Reich auch diese ganze Welt verklären. in der immer Leid mit Lust gemischt ist. Jedes Komische in der Welt hat seine ernste Note und jedes Tragische seine heitere. So mußte im Sinne des griechischen Theaters der Tragölie ein Satyrspiel folgen. aber das eine mußte dem ancleren folgen, und so blieben sie zeithich getrennt. Der musikalische. romantische Geist aber forderte ihre gegenseitige, lebendige Durchdringung.

\section{x) Wolfgang Goethe.}

Beror wir jedoch die Idee der Romantik als den Beginn eines nenen synthetischen Zeitalters uns deutlich machen, müssen wir unseren Blick auf die große Gestalt richten, die, wie es uns scheinen möchte, an der Scheiclegrenze zweier Welten steht. Wolfgang Goethe gehört nicht der neuen Zeit an. sofern er sich die Antike zum Forbild nahm und eine ihr verwandte ruhige und hoheitsvolle Gestaltenwelt schuf. und dennoch zählte ihn die Romantik zu den ihren. Das hängt damit zusammen, daß er den Tersuch gemacht hat, jenen plastischen Geist der Kunst, wie er vor allem in Griechenland so groß und schön geblüht, mit dem Geist der modernen synthetischen Kunst zu versöhnen. 
bzw. in der Fülle seiner Leistungsmöglichkeit bald in der Welt der Hollenen, bald in der neuen Welt rerweilte. Wem er in Tasso md Iphigenie über das hellenische Vorbild hinaus Schönes und Unersetzliches schuf, so komnte die Romantik den Faust und Wilhelm Meister als Erfüllung ihrer Sehnsucht betrachten. Denn in beiden schien die Idee der Begrenzung, welche für die ganze alte Kunst so charakteristisch war, vollkommen aufgehoben und das Prinzip der romantischen Verbinclung oder, wie sie selber gerne sagen, Verwirrung verwirklicht zu sein.

Goethe kam ron einem nnkünstlerischen Zeitalter her, das Verstand und Gefühl in Zwiespalt gesetzt hatte, das entweder klug ausgerechnete Gedankenkunstwerke verfaßte oder aber in frei ausströmender Gefühlsinnerlichkeit vollkommen unbeherrscht in seinen Leistungen allen Regeln der Kunst Hohn sprach oder das Regellose zur Regel erhob. Das Zeitalter des Sturmes und Dranges, wie man es wohl genannt hat, mit seinen Idealen der Kraft und des Trotzes bereitete die nene Zeit vor. Und wem der unküustlerische Geist des Sturmes und Dranges das Wilde und Ungeordnete, das chaotisch Unbegrenzte hinausstellte, war der künstlerische Geist der Romantik daranf gerichtet, dem Unendlichen eine Sprache zu geben, das Unsimnliche zu Worte kommen zu lassen und alles Getrennte in liebevoller Unamung zu verbinden.

In der Fausttragödie hat Goethe mit dem Drama alten Stils vollkommen gebrochen und das miversale Kunstwerk geschaffen, in das die Lyrik ihre schönen Blüten gesenkt hat, ohne daß dadurch die dramatische Spannung in geringsten beeinträchtigt wird und daneben noch der ruhige Ton der epischen Erzählung zu Worte kommt. Und hicr hat sich auch das Tragisehe mit dom Komischen verbunden in einer Weise wie nie zuvor. Leise noch klingt dic Idee des antiken Dramas an, jene Notwendigkeit, die sehicksalsbestimmend wirkt und die Irlee der Wertgegensätzlichkeit mildert, weil schon der bloße Gedanke ihrer Bestimmung, die Vorstellung des göttlichen Puppenspieles (ine einseitige Parteinahme verbietet und ganz zur Versöhmung stimmt. Aber dieser Gedanke der göttlichen Bestimmmng muB die handehden Personen als getrennt erscheinen lassen und die Stärke unserer Anteihnahme verringen. So steht das Göttliche wohl am Anfang, und wir wissen seine bestimmende Macht, aber es steht außerhalb der eigentlichen Handlung und greift anch nicht in das Erdenschicksal der handelnden Personen ein, sondem erst dann, als das Erdenschicksal des Faust abgelanfen ist. So steht das Unendliche am Anfang und an Ende und gibt tem universalen Kmnstwerk nur die große Perspektive, ohne die Handlung zu hegrenzen.

Schelling vermeinte, daß es der Mythos sei, der jeclem großen Kunst"re und speziell auch dem Faust den tiefen Kunstgehalt, den immeren Wert, lie ästhetische Tdee vorleiht, weil die mythischen Gestalten eine ursprüngliche Porsie und Symbole des Göttlichen bedenten. Diesen Irrtum haben wir sehon fribler zurückgewiesen. In Faust ist es recht deutlich, dab hier die aisthetische Idere mit dem Mythos nur lose zusammenhängt. Es landelt sich um die Gött-

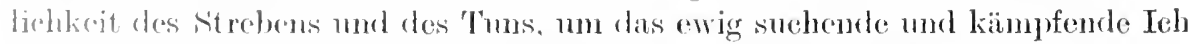
und insoform durchans un das foleal dor modernen zejt. Wertroll ist die Tat, dic am Lufang aller J linge stcht, sie trïgt ihren Wert in sich. In ihrer absoluten Colnankendosigkejt darf sie nie armüden. Mit dieser holen Lebensmacht ist 
aber der Irrtum notwendig verbunden. Dasjenige, was uns als das Göttliche gegeben ist, läßt uns als begrenzte Mensehen schuldig werden. Die große Persönlichkeit hat das Schicksal, über ihre Grenze hinausgehen zu müssen. In dieser Grenzüberschreitung liegt Gefahr und Größe zugleich.

Auf allen Gebieten des geistigen Lebens hat er sich versucht und auch hilfreich und tätig in das Leben eingegriffen, der einsame große Faust. Gar zu schwer hat er die Schranken empfunden, die ihn von der übersinnlichen Welt abschließen. Auch ist sein ganzes Wesen nicht zum seligen Schauen bestellt, denn er kamn die Fülle der Gestalten nicht ertragen. So folgt er dem alten ewigen Lügengeist und wendet sich der Simenwelt zu, um sie wahllos zu genießen. Aber sein Tun wendet sich niemals zum Niedrigen und Gemeinen, sondern bewahrt sich in aller Schuld eme Höhe und Größe, die wir als tragisch empfinden und verstehen müssen. Er leidlet schwer und wïrde den großen Gestaltenzug seines Lebens nicht ertragen, wemn ihm nicht manchmal ein seliges Vergessen beschieden wäre. So aber ist es ihm bestimmt und so hat er sich verpflichtet, daß er verloren sein will, wemn jemals der Genuß mit seinen Fesseln ihn so umstrickt, daß er verweilen möchte in gesättigter Cmarmung simnlicher Frenden. Und so hat ihn seine Liebes- und Schönheitssehnsucht in Gretehens stille Mädchenkammer, in den tollen Spuk der Zaubernacht, in einsame Kerkerzelle und stolze hellenische Schönheitspracht geführt, bis er schließlich durch des Kaisers Macht vor die würdige Aufgabe gestellt wird, als Schirmherr des Landes dem stolzen Meer Boden abzugewimnen. Immer aber begleitet ihn die Schuld bis zuletzt, bis zu jener feierlichen Stunde, da der süße Freiheitsrausch ihn erfaßt und die Idee der Tolksbeglückung, das Wirken und Schaffen für ein großes Ganzes sein Herz mit freudiger Glücksfïlle ïbermannt. In diesem Augenblicke möchte er verweilen, da so hohes Hoffunngsgefühl sein Herz höher schlagen läßt. Dieses Verweilenwollen macht ihn zum Verlorenen, aber nur dem Worte, nicht dem Simne nach. Sein Verweilenwollen ist wirklich schön. Was ihn remichten sollte, hat ihn wahrlich erlöst.

Der Faust und der Wilhelm Meister - an ihnen hat die Romantik sich gesättigt. Ton ihmen ging ein großes Leben aus für das Kunstgefühl der damaligen Zeit. An ihnen rankte die romantische Theorie frei und mäehtig empor. Sie wollte der Zukunft neue Wege weisen, ihr Aufgaben der Bildung stellen, an welche die Vergangenheit nicht gedacht hatte. Ihr kam es darauf an, den Sinn der Kumst und ihre Bedeutung für das Leben zu deuten. Sie stellte sich die Aufgabe, die Beziehungen zwischen den versehiedenen Kunstgattungen zu verfolgen und die Grenzen einander immer mehr zu nähem und schließlich zu verwischen. Sie hat die Auffassung vertreten, daß die Künste sich gegenseitig durchdringen und zu einer Gesamtwirkung vereinigen sollen. Die Erfüllung dieser Sehnsucht schien damn später in Richard Magners Musikdrama gegeben zu sein.

y) Die Musik des bel canto.

Vorläufig aber sollte erst der musikalische Geist zu vollkommener Selhständigkeit erwachen, wie es in cher Kunst des bel canto geschah. Sie ist die absolute Musik, die in Beethoven und Mozart sich offenbarte. Nummehr ist die Musik für sich selbst da und redet ihre ureigenste Sprache. Sie ist nicht 
da. $11 m$ euwa die Wirkung der Dichtung zn erhöhen oder anch, mu das in ihr dargestellte Erlebnis noeh dentlicher zu machen. Sie ruht in sich selber. Und wenn sie mit der Diehtung zusammengeht, so zerstört sie diese vielfach, indem sie zllgumsten reiner Klang- und Tonwirkmuen den Wortsinn und den Gedankenzusammenhang remachlässigt. Der Geist der Musik mußte zuerst einmal bei sich wohnen und bei sich erstarken, um dann die Herrsehaft über die gesamte Kunstwelt anzutreten. Beethoren und Mozart sind in der reinen und absoluten Musik die großen Gegensätze. Es ist gewiß einseitig, die Mozartsche Musik dahin zn interpretieren, daß sie die höchste Offenbarung der sinnliehen Genialität sei, die in Don Juan vollendet ist und in der dämmernden Unhewußtheit des schönen Pagen im Figa ro und in der Beweglichkeit des wackeren Papageno in der Zauberflöte ihre Torstufen findet. Aber soviel ist wohl gewiß, claß keine Musik so sehr wie die Mozarts imstande ist, die sinnliche Erotik in ihren verschiedenartigsten Formen in reichen 'Tonfluten darzustellen. sie gibt die musikalischen $\ddot{A} q u i v a l e n t e$ für den Reichtum unserer Liebesgefühle, für die sie einen merschöpflich weehselnden Ausdruck findet. Das leise Stammeln und Beben der Liebe in seiner Zartheit, Kensehheit und Schlichtheit, das erste Erwachen des simmlichen Verlangens, die romantisehe Liebe, die clureh Fenerströme und Fluten mit leuchtenden Augen dahinsehreitet, ron den weichen Klängen der Flöte begleitet, das derbe Liebesverlangen, das den starken Genuß tes Augenblicks begehrt, und dämonisehe Leidenschaft, die sehließlieh alles zerstört und vernichtet. Mozart hat sie zur Darstelhung gebraeht. Er hat das romantische Wort zur Wahrheit gemacht, daß sïße liebe in Tönen denkt, und sein umfassendes Verstehen dieser Gefühlswelten, die er zu vollendeten musikalischen Ansdrucksformen gebracht hat, erweckt den großen Gegenpol des tragischen Gefühls, die reine Scligkcit der Freude. So hat er die Erfüllung jener romantischen Fordermig gegeben, welehe der klassisehen form der Tragödic, rlie Leid und Schmerz als tragisehe Grundgefühle erregt, die große Form der Komölie entgenstellen wollte, die uns in den reinen Äther der Frende crhebt. Die reine Sphäre des Schmerzes und die reine Sphäre der Freude, das sind zwei große Möglichkeiten künstlerischer Wirknngsweise. Dabei hat es mun angenscheinlich das Wortrama bisher noch nicht rermocht, die große Linie ter Freute vorzuzeichnen. Nur die Tragödie vermochte einen wahrhaft großen stil zu erreichen, nicht aber die Komölie. Der reine Äther der Freute. seheint nur durch die Klangwirkung des Tones hervorgebracht werden zn könne'n.

J) Wirkmng der 'Tonkonödie muß in Vergleich mit der Worttragödie motwentig eine mufassendere Wirkmog ansiiben, weil die künstlerisehe Verklïmug moserer Last zur Fremle nit der Erhöhnng zugleich aneh eine Verstialkming les lustgefïhles belented, wïhrend die kiinstlerische Verklärung mmares sichmerzes zu cinem hohen vorbildichen tehmerzgefühl unseren Leiden ihre 1)mmplheit mo Schwrere nimmt, so dab das tragische Gefühl im Vergleich

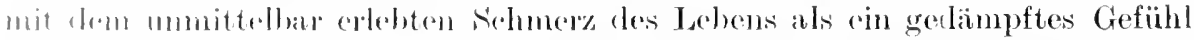

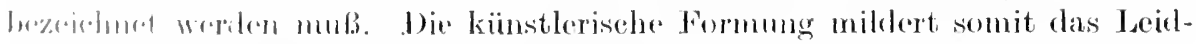

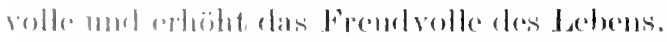

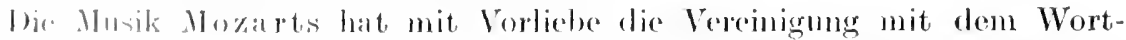

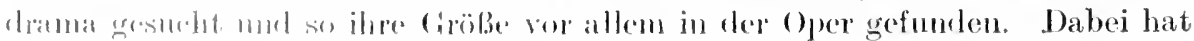


die große Musik eine eigentümliche Lmbildung an dem Wortgefüge des zugrunde gelegten Textes ausgeübt. Sie hat alle Mängel des poetischen Ausdrucks durch ihre nene Formgebung getilgt, sie hat die Dürftigkeit der poetischen Erfindung und Gestaltung zu einem unendlichen Reichtum des musikalischen Ausdrucks geführt. Die Handlung verliert ihre Simnlosigkeit, und die blassen Schemengestalten leuchten auf und erfüllen sich mit frischem Leben. Die Gräfin im Figaro ist aller Sentimentalität enthoben, zu der reinen edlen Frau ist sie geworden, die mit leidensehaftlicher Liebe die verlorene 'T'rene des Gatten zurückersehnt. Und aus dem frühreifen, rerdorbenen und eitlen Kinde des französischen Stückes hat Mozarts Musik die liebliche Gestalt des Pagen erschaffen, in dem die junge Sehnsucht erwacht zu der ersten Ghut einer träumenden Empfindung.

In Don Jua n aber, dem reifsten Kunstwerk des Meisters, ist das Dämonische der simmlichen Liebe geschildert, die ungebändigte Lebensgier. die nicht rastet noch ruht, die nach immer wieder neuen Lebens- und Liebesformen drängt. um in ihnen die Virtmosität des Genießens zu offenbaren. Don $J$ uan ist der Prototyp jener Liebe, die niemals ron der Ganzheit der sehönen Lebensgestalt gefesselt wird und so Gefahr läuft, sich an sie zu verlieren, sondern der an jeder weiblichen Gestalt ein Etwas und immer wieder ein anderes liebt. Er lebt nicht in der Hingabe an die schöne Gestalt des Lebens, sondern in der nimmer mäden Betonung und Ausübung der Liebesfunktion. In ihm ist der ewige Trieb naeh Wechsel, die kaum gestillte Sehnsucht, die schon wieder nach neuer Erfüllung rerlangt. Don Juan ist die grandiose Gestalt des Verführers, dem zur Eroberung des Liebespreises alle Hittel recht sind. Er täuscht, sehmeichelt und lockt und wird doch selber nicht getäuseht, denn er kennt das Ziel seines Verlangens. Er hat nie die schöne Bindung an die geliebte Gestalt begehrt, sondern er will nur seine Liebeserfahrmgen erweitern. Erobern will er und gewinnen. und in diesen Liebeskämpfen wächst seine Kraft. Er kennt nur die flüchtige Sinnenliebe des Augenblicks und läßt sie. wie sie ist, und nutzt sie nicht als Material zu großer Lebensgestaltung. Er müßte notwendig klein erscheinen, weil das Ziel der Verführung klein und niedrig ist, wenn nieht die Dimensionen seiner Erscheinung so ungeheuerlich groß wären. In dem glühenden Optimismus seiner Lebensbejahung, in dem Kultus des Rausches, den er vollzieht, in der ungebeugten Kraft der Instinkte, in der Unbändigkeit seines Trotzes. der keine blasse Fureht und kein Entsetzen kennt, in cler Größe seines Frevels liegt ein Zauber, der uns ergreift und gefangen nimmt. Er sehleppt die schwere Kette seiner Verfehlungen als ein Schicksalsmächtiges hinter sich her, das ihn notwendig vernichten muB, aber er kennt keine Reue und keine Bedenklichkeit. So trifft ihn das Schicksal immitten der wildflutenden Daseinsfrende, beror el stumpf und kalt geworden ist, in der rauschenden Feier des Baechanals.

Die Welt, die Beethoren offenbart, ist nur wenigen verständlich. Er macht sich nicht zum Interpreten jener Gefühle, bei denen wir gern und lange verweilen, die häufiger zu uns treten, und die eine gewisse Skala bilden, so daf auch dem Alltagsmenschen ihre einfache Form zugänglich ist, von der aus er dam die höheren Formen ahnend rerstehen kamn, sondern die Gefühle, die seine Tonwelt offenbart, das sind die seltenen Feiertagsgefühle des Geistes. die wohl am besten solehe verstehen. die sehr schweres ertragen. ruhmroll 
gestritten und schließlich iiberwunden haben, oder auch diejenigen, die sehr einsam waren und sind. Sie erseheint als die denkbar höchste musikalische Offenbarung des Wertgegensatzes. Das Schicksal klopft an - und nun geht es an ein großes Ringen mit dem Notwendigen, das uns bestürmt, bis schließlich die matten müden Hände niederfallen und wir den fremden großen Tod erschauen. Und wir sind wie gelähmt und wissen nicht ein noch aus - und damn auf einmal ungeahnt und ungehofft die große, die sieghafte triumphierende t'berwindung und schließlich die sanfte beglückende Stille, der schöne Abendfriede des Geistes. Durch die Tonwellen seiner Musik geht ein heroischer Zug, dem Geisteszug verwandt, der durch die plastischen Gestalten der Sixtina geht. Der Simn seiner Werke ist schwer zu enträtselı, weil er im allgemeinen die Vermittlung durch das Bild verschmähte und nur selten die ungehenre Nacht seines Tonausdrucks mit dem Wort vermählte.

Die ganze Entwicklung des 19. Jahrhunderts hat in immer höherem Grade den Trimph des musikalischen Geistes offenbart mol dahin geführt, einzuschen, daß es im Grunde genommen niehts Hartes und Sprödes gibt, sondern daß alle kïnstlerischen Ausdrucksformen flüssig sind und ineinander übergehen.

\section{Fünftes Kapitel.}

\section{Die philosophische Entwicklung.}

\section{a) Die Philosophie in Verhiiltnis zu den anderen Werten.}

Wir verweilten bisher bei den Gebieten, die in ihrer Beziehmng zum BewuBtsein am meisten in das Reich des Unbegreiflichen und Irrationalen untertauchen, wo die Reflexion verhältıismäBig uncrgiebig und machtlos ist, wo das Instinktive, die Leidenschaft und das Gefühl gedentet und verstanden sein will. Wir lernten die Mächte kenuen, die hier zu Gestalt und Ausdruck kommen. Wir haben noch die dritte sjphäre kemnen zu lernen, mit der das Reich der absolnten Werte beschlossen ist, das Gebiet der Philosophie.

Mit den anderen absoluten Werten ist dep Philosophie dieses eigen, daß sie (sin nur loses Verhältnis zu der Idee des Fortsehritts hat. Man darf ruhig behaupten, dak alle groben Philosophen ein Vollendetes geschaffen haben, sofern sic das Göttliche in ler Form des Begriffs in notwendiger mel rorbilllicher

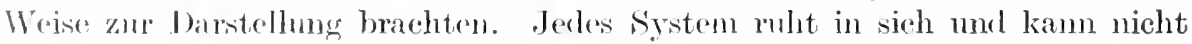

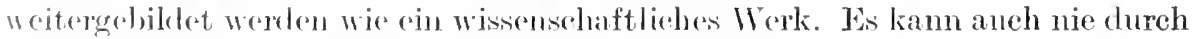
Kritik wielelegt werelen, somelem allein dureh Neuschöpfung.

I) objektiven Wrete orler die Fortsehritswerte sind es eigentlich, welche

dic Vembindung zwischen den Mensehen herstellen; so sind es vor allem die cthicehen Wrote, die cin soziales Verhälnis hegriinden. Das Ethische sehafft

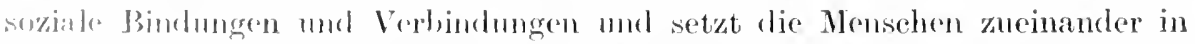

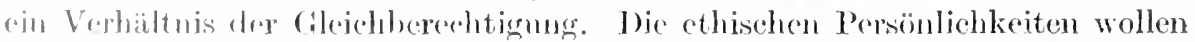
in fejuander w irken, sio wollen sich gegenseitig bilden mul exzichen. Sie arbeiten alliabrall an don l'roblomen der Gemeinsehaft. Wie den absoluten Werten 
die Beziehung zum Fortschritt mangelt, so fehlt ihnen von vornherein auch die Beziehung zum Sozialen. Die, welehe ihnen angehören und von ihnen ergriffen sind, haben die einsame isolicrte Beziehung zum Gegenständlichen als der Idee des Absoluten. Die Verkünder der absolnten Werte in Religion, Kunst und Philosophie sind somit, ihrem ursprünglichen Simn nach, asozial oder übersozial eingestellt.

Wenn sie im Sozialen leben, so kultivieren die Verkünder der absoluten Werte das Verhältnis zu einem engen Kreis, mit dem sie durch das Allgemeine der Idee verbunden sind. Daraus ergibt sich das Verhältnis der Jüngerschaft und Schülerschaft. Abgesehen von diesen höchsten. Wertverhältnissen, eignet dem religiösen Menschen die Einsamkeit, sei es num jene Einsamkeit, die erfüllt ist von der ungeduldigen Sehnsucht der Einswerdung mit dem Göttlichen, wie sie dem Propheten eigentümlich ist, der zu den Menschen spricht und alles hingibt, auch sein Leben, sich aber niemals jenen persönlichen Verhältnissen der Liebe und Freundschaft oder auch den sozialen von Stand, Gesellschaft und Recht so ganz und dauernd hingeben kamn, weil ersichals Werkzeug und Instrument des Göttlichen, als Bereiter eines höheren Lebens fühlt und als der Erlöser von den engen Banden der persönlichen Lebensbeziehungen. Setzt er das allgemeine Verhältnis der Brïderlichkeit und der Menschenliebe, so hebt er damit doch auch zugleich die Eigentümlichkeit der individuellen Wertbeziehungen auf. Oder aber der religiöse Mensch ist Herrscher und Magier, damn wird seine Einsamkeit zur Versumkenheit in sich selbst. Damn glaubt er in sich das Göttliche zu finden, und mit der Heiligsprechung seines Ich entfernt er sich gar weit von den armseligen, viclfachem Verderben geweihten Menschen. Die große Individualität sicht die ungeheure Kluft zwischen sich und den anderen und wahrt für sich das Geheimnis. Den Armen gegenüber bekennt sie sich zu dem Prinzip einer schonenden Duldung. Jene wissen ja nicht, was sie tum. Sie sollen in ihrem Irrtum verbleiben, dem sie können mit der religiösen Wahrheit nichts anfangen, sie würden an ihr zugrunde gehen und die Freude am sinnlichen Dasein verlieren, in dem nun eimmal ihre ganze Seligkeit ruht.

Der künstlerische nud philosophische Mensch haben in dieser Hinsicht viel mit dem religiösen Menschen gemeinsam. Sie müssen sich vou dem Leben entfernen, um es gestalten und begreifen zu kömnen. Wic die Religion, so sondern sich auch Philosophie und Kunst von dem Leben ab und ziehen enge Kreise und kultivieren ein besonderes Verhältnis der Zugehörigkeit. Philosophie und Kunst haben ihre Mysten und Eingeweihten wie rlie Religion, die eine besondere Sprache sprechen, und denen ein besonderes Verstehen eignet, das den Außenstehenden mangelt. Wem aber, zumal in der mystischen Form der Religion, der Wunsch rorliegt, die Draußenstehenden nmzubilden und zu reformieren, so ist die Einstellung des künstlerischen und philosophischen Menschen gegenüber jenen anderen noch umpersönlicher. Für den Künstler sind jene anderen, soweit sie ihm als Objekte interessant sind, Gegenstände des ästhetischen Spiels. Er läßt sie gelten, sofem er ihre Gestalt ästhetisch genießt. Der Philosoph dagegen sucht an jenem anderen Tun und Leiden das Werthafte zu entdecken, dem sein Erkenntniswille zugewendet ist. 


\section{b) Der philosophische Grundgegensatz.}

Die Entwicklung des theoretischen Denkens mht auf dem Gegensatz ron Form und Inhalt. Das Verhältnis zwisehen diesen beiden, die aueh als Bewntsein und Niehtieh einander gegenüber gestellt werden kömnen, kann entweder so gedacht werden. daß das Bew 3 tsein das Niehtieh bestimmt, oder aber in der Weise. daß das Niehtich das Bewußtsein bestimmt. Nur im ersten Falle kann überhaupt ron Erkenntnis die Rede sein, und insofern ist die Idee des W'issens ummittelbar mit dem Idealismus verbunden. Idealismus, Subjektirismus und Rationalismus fallen zunächst einmal zusammen, während sieh auf der Gegenseite der Realismus mit dem Objektivismus und Irrationalismus verbindet $\left.{ }^{1}\right)$. Diejenige Auffassung also, welehe lehrt, daß Geist und Sim in der Welt sei, die will aneh gleichzeitig behaupten, daß nur vom Subjekt aus die Welt verstanden werden kann, und daß ein umfassendes Wissen von dieser Wirkliehkeit möglieh sei. Wir wollen den Vertreter dieser Philosophie einmal als den idealistisehen Typus bezeichnen. Thm steht der realistische oder naturalistisehe Typus gegenïber, der die Körperliehkeit als das eigentlieh Bestimmende in der Welt auffaßt und daher anch notwendig ihre Sinnlosigkeit behaupten muB. Er wird damn ferner behaupten, daß das Subjekt restlos vom Objekt bestimmt wird, und dadureh die Idee des persönliehen Lebens und der Freiheit vollkommen vernichten. Endlich aber ist der realistisehe Typus anch dadurch ausgezeiehnet, daß er kmsequenterweise die Möglichkeit des Wissens verneinen muß und so zu der Vorstellung ciner absolnt irrationalen Wirkliehkeit gelangt. Der idealistische Typus wird immer dahin getrieben werden, zu behaupten, daß die Wirklichkeit Geist sei. wälnend der Realist behauptet, daß sie Ma te rie sei. So rerbindet sich der Idealismus mit dem Spiritualismus und der Realismus mit dem IIaterialismus.

Diese beiden einander so schroff entgegengesetzten Standpunkte haben num aber in sich ihre besondere Angriffsstelle und ihre Gefahr. Der Idealismus liann in Naturalismus und der Naturalismus in Idealismus umsehlagen. So kamm der Idealismus etwa zum Naturalismus werden, solange der Subjektsbegriff dor Erkementis noch nicht als Wertbegriff verstanden ist, und anderscits läBt sich der Irrationalismus, der im Grunde eine Konsequenz der realistischen und ohjektivierenden Weltauffassung ist, sehr wohl mit dem Idealismus voreinget denken. Tnd zwar wird das ror allem dann der Fall sein, wenn ein Standpunlit vorliegt, der die Idec der Transzendenz besonders scharf hervorhebt. (iibt es ein a bgesehierlenes Roich der Werte, so kam das menschliehe BewuBtsein

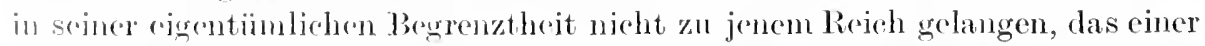
Simmlichlecit nicmals cin ̈̈bersinulicher sitoff gegehen ist. Der Idealismus kamn "1so selor wohl mit cincm gewissen Pathos des Irrationalen zusammengehen²).

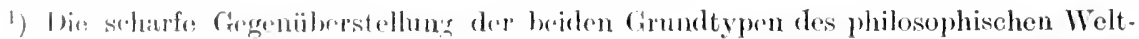
W.phluns zolerst bei Kant: Kritik der reinen Vermuft. Akademicausgabe, Bd. III,

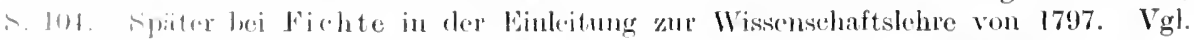

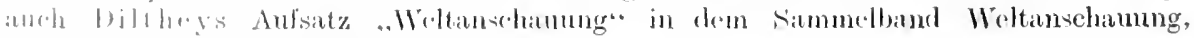

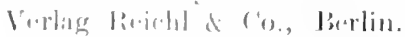

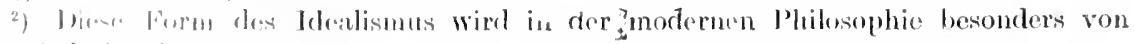

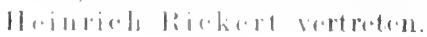


Ja, man kamn vielleicht sagen, daß der für die Philosophie wichtigste Gegensatz in der Sphäre des idealistischen Typus selher wieder entspringt. Und zwar erscheint dieser Gegensatz um so wichtiger und interessanter, weil gemeinsame Toraussetzungen ron Erkenntnismöglichkeiten bestchen. Auch dann, wemn wir in der Sphäre des Idealismus uns befinden, wiederholt sich noch einmal dieser Gegensatz ron Rationalismus und Irrationalismus. Wir stehen auf dem Boden der gemeinsamen Voranssetzung, daß das Subjekt das Objekt. bestimmt. Es fragt sich aber, wie weit die Bestimmungsmöglichkeit des Objektes geht, wo sie ihre Grenze findet. Nun kömnen wir uns einen Standpunkt denken, der die Schrankenlosigkeit der Vermunft lehrt mud behauptet. daß dem Erkenmen die Macht gegeben sei, in die letzten Zusammenhänge des Wirklichen einzudringen. Die Welt ist eine Welt des Geistes, und unser V'erstehen. das selber geistiger Natur ist, stößt somit im Prozeß der Erkenntnis immer auf Gleichartiges und Verwandtes. Das Verwandte ist uns vertraut. Wir können ohne Schwierigkeit seiner Herr werden. Alles ist dem Wissen zugängig, das ummittelbar an die Pforten der Ewigkeit zu rühren vermag. Diesem rationalen Idealismus steht der irrationale gegenïber, der da meint, daß in der Welt des geistigen Lebens schroffe Gegensätze bestehen, welehe die absolute Erkenntnis behindern. Wohl ist das Leben der Welt Geist, aber der endliche Verstand ist so beschaffen, daß er nicht über sich hinansgehen kamn und ihm das Absolute ein für allemal verschlossen ist. Im ersteren Falle ist die Philosophie überzengt von der Macht und der Herrlichkeit der mensehlichen Erkenntnis, im zweiten Falle verehrt sie die Macht der Vernunft, sieht aber in der Natur der menschlichen Erkenntnis eine Begrenzung, die sie daran hindert, das Reich des Úbersinnlichen zu berühren oder gar zu durchdringen.

Wir branchen wohl kaum darauf hinzuweisen, daß ein absoluter Typus des idealistischen und naturalistischen Philosophen oder auch des rationalen und irrationalen Idealisten wohl sehwer in der Wirklichkeit anfzuweisen ist. Beide Faktoren, der rationale nud irrationale, ringen in jedem großen System nach Ausgleich, denn Form und Inhalt sind die Grundbedingungen aller philosophischen und wissensehaftlichen Erkenntnis.

\section{c) Wertfeindlichkeit und Versiöhnung.}

- Der Anfang aller großen Philosophie ist in Griechenland vollzogen, und die geschichtsphilosophische Dentung der philosophischen Entwicklung läßt vor allem anderen die Geschichte der Menschheit, ihrer Kultur und ihres Wissens ron der Kultur als einen Prozeß erscheinen, durch den das ursprüngliche, eng anfeinander bezogene und undurchsichtige Wertleben gelöst wird, ein Prozeß, durch den die verschiedenen wertrollen Formen der Kultur und des Lebens zur Selbständigkeit gelangen. sowohl die Philosophie gegenüber der Religion, wie die Religion gegenüber cler Philosophie. Man kann sagen, daß die Einsicht in die Natur der menschlichen Vernunft und in die rersehiedenartige Struktur der Geistesgebiete durch die Philosophie des dentschen Idealismus in ihren Grundzügen vollzogen ist. Würde das soziale Leben und die Einsicht der einzelnen in gleichem Tempo fortgeschritten sein mil der Entwieklung des intellektuellen Geistes, so müßte die Verschiedenheit von Religion und 
Philosophie, ron Sittlichkeit und Kunst, von Moralität und Staat, von Recht und Wirtschaft, von Wissenschaft und Technik hinsichtlich ihrer Ziele und ihrer Zielverwirklichung eingesehen sein. Das würde aber bedeuten, daß die Menschheit zum Bewnßtsein der Wertfeindlichkeit gekommen sei, die zwischen den einzelnen Kulturgebieten besteht, und deren Ubberwindung ihre Aufgabe ist. So riel ist gewiß, daß die Einsicht in den Gegensatz der Anfang seiner Utberwindung ist. Die Vermmft ist mit sich selber im Zwiespalt, wir sehen es ein, und manches ron dem, was wir für absolut wertwidrig hielten, war weder böse noch häßlich, sondern geschah nur im Dienst anderer Götter, die ihren besonderen Wertcharakter tragen, deren Verstehen uns aber nicht zugänglich war. Wir vermögen noch nicht einzusehen, wie jene Gegensätze, die cler grübehnde Verstand immer wieder in Einklang zu bringen sucht, im Leben ausgeglichen und versöhnt sein sollen und können. Wenn aber irgendetwas in der Welt sie auszugleichen vermag, so scheint es diese Allgewalt des tätigen Lebens zı sein. In die Sphäre des Logischen erhoben, wird der Gegensatz von Kulturbetätigung und dem Ruhen im Persönlichkeitsleben ebenso unversöhnlich erscheinen wie der Gegensatz zwischen dem schaffenden Künstler mud dem Moralisten. Auf beiden Seiten liegt ein Recht. Das eine kann nicht so ohne weiteres an die Stelle des anderen treten. Wie aber sollen die entgegengesetzten Forderungen miteinander versöhnt werden? Ist nicht die Begrenzung und Einschränkung ihres Rechtsanspruches anch gleichzeitig eine Begrenzmng ihrer Absolutheit? Sollte das Getrennte sich nicht vielmebr von imnen durchdringen, $u m$ zu einer wahrhaften Aufhebung seiner Partikularität zu gelangen? - Kant hat die ideale Abgrenzung der Kulturgebiete vollzogen. Wenn früher clumpfes Brüten sieh in wildem Haß verzehrte, so wissen wir num den Grund und die Quelle unserer Mißrerständnisse. So kömnen wir hoffen, daß die Zeit nicht mehr allzuferne ist, da die Kultur mit dem Leben, die Wissenschaft mit der Religion, die Kunst mit der Moralität sich versöhnen wird, nicht im simne des Ausgleiches und des Kompromisses, sondern in Sinne einer gegenseitigen Wertanerkennung, die dem Ziele der Menschheit dient. Bisher hatte die Vernunft mit der Vermunft gleichsam mit versehlossencm Visier gekïmpft und jeder Kämpfer in dem anderen die nackte 'Torheit vermutet. Jetzt sind die Visicre zuriickgeschlagen. Alles ist hell und doutlich. Auch in dem Entgegengesetzten crkennen wir den Schcin des Absoluten. Wir erkemen, daß es eine selbständige Position und aufhellbar ist. Wir wissen, dal3 es nieht ausgetilgt werden kam mol soll. Wir wissen aber anch, daß es unbesieglyar ist, und claß wir unsere Kraft an seiner Bekimpfung verschwenden. Cond so lassen wir von jenem äußeren Kample ab und suchen die (inzelnen Wertsphä̈ren in sich homogen zu gestalten. Dex Kampf ist nummehr gnum in die inneren Zentren verlegt, die Krïfte, die bisher versehwendet waren, sind zum höchsten Kampf der Vermunt aufgebot'n. Nun kïmpft das Leben mit

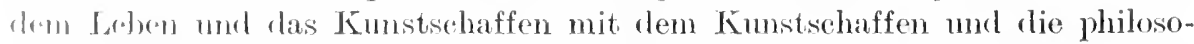
jhiseho Laho mit der philosophischen Iehre. Hier kam es keine gegenseitige

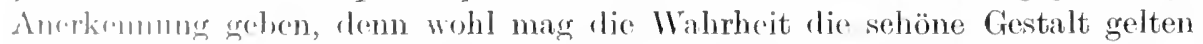
lassen, and rhure sie zu verstehen. Niemals aber darf die Wahrheit eine andere Wahrheit ancrkmmon, dem es giht, nur eine Wahrheit. Hier also kämpft

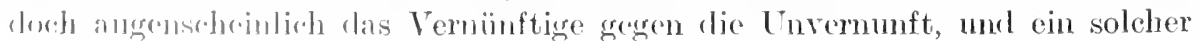


Kampf ist relativ leicht. Aber vielleicht sind bei dieser Gegenüberstellung die Gegensätze nicht absolut, so daß etwa auf der einen Seite clie ganze Walırheit und auf der anderen Seite die Unwahrheit steht, daß die Moralität mit der Sittenlosigkeit, das Leben mit dem Tode, der Schaffende mit dem Unproduktiven streitet. Vielleicht liegt auf seiten des Idealismus nicht das absolute Recht und auf seiten des Naturalismus nicht das absolute Unreeht. Vielleicht gibt es eine Aufhebung clieser Gegensätze, deren rationale Durchdringung der Einsicht unseres Intellektes verborgen bleibt, die aber als nnentfliehbare Forderung gesetzt ist. Vielleicht gibt es eine Versöhnung des plastischen und musikalischen Geistes, der Magie und der Mystik. Sollte sie aber eingetreten sein, so wäre damit anch zugleich die große Bewegung des vernünftigen Denkens am Ziele. Die Aufhebung der Antimomien ist gleichbedentend mit dem Ende der Geschichte.

\section{d) Verhüllung der Wertgegensätze bei den Griechen. Die Vorsokratiker.}

Forschen wir nach der Entwicklung des philosophischen Denkens, so zeigt der Anfang der Philosophie bei den Griechen die absolute Verhïllung der Wertgegensätze. Die Prinzipien, auf denen alles philosophische Denken ruht, sind noch vollkommen unbekannt. Man pflegt diese erste Periode der griechischen Philosophie wohl als die kosmologisehe zu bezeichnen. Damals soll der griechische Geist so sehr von seinem Gegenstande, der Natur g'ja:s oder der Welt 火ю́ $\iota_{0}$ erfüllt gewesen sein, daß er das Ich, das Subjekt der Erkenntmis rergaß. Wohl gab es damals schon eine Plilosophie, weil das Weltganze in der Form des wissenschaftlichen Begriffes erseheint. Die Welt wird gedacht, d. h. sie wird begrifflich geformt. Aber noch gibt es keine Reflexion über diese Formung, kein Denken des Denkens und infolgedessen auch keine Einsicht in seine Grenzen. Ein solcher Standpunkt, in dem das Ich rollkommen außer Rechmung bleibt und alles mit Notwendigkeit in die Natur eingegliedert wird, mu als Objektivismus, als objektivierende Auffassung der Welt betrachtet werden ${ }^{1}$ ). Das ist der Standpunkt der Wissenschaft, die in absoluter Uneigennützigkeit dem Objekt hingegeben ist. So erklärt sich die Behauptung, daß das Interesse dieser alten Philosophen in der Hauptsache ein naturwissenschaftliches gewesen sei, was zugegeben werden müßte, wem die Richtung anf einen besonderen Gegenstand diesen Denkern eigentümlich gewesen wäre. Das ist aber nicht der Fall. Sie alle fragten nach dem Sim der Welt, nach einem einheitlichen Prinzip der Wirklichkeit, und deshalb waren sie Philosophen.

Mit dieser objektivierenden Anffassung rerbindet sich die realistische. Nicht der geringste Zweifel an der Konstanz der Wirklichkeit wird erhoben in dem Sinne etwa, daß sie als Produkt des Ich und der Erkentnis angesehen würde. Die Welt ist ruhig für sich da und ron keiner Form der Erkemntnis überschattet. Wohl ist die Welt der bloßen Meinung dureh das Subjekt verunziert, aber die wahre Wirklichkeit ist mangetastet, ron dem Subjekt der Erkenntnis nicht beriihrt.

1) Über subjektivierende und objektivierende Weltanschauung vgl. Rickerts Artikel: Vom Begriffe der Philosophie, Logos, Band I Heft 1. 
Der idealistische Standpunkt, der die Welt aus der großen Tatsache der Erkemntnis heraus verstehen will, ist im allgemeinen geneigt, die Leistung des Denkens sehr hoeh einzuschätzen. Nach dem realistischen Standpunkt kann das Denken viel oder wenig erreiehen, das Erreichte ist aber nicht sowohl sein Terdienst, seine Leistung, sondern ein Geschenk des Objektiven. Das subjekt der Erkemntmis, wie es die Griechen dachten, ist zum Sehen geboren, zum Schauen bestellt. Und das Objektive ist nicht da, $n$ sich zu verhüllen nnd in faltige Schleier zn verbergen, sondern $\mathrm{nm}$ sich dem Schauenden hinzugeben und das Erkamntsein und Verstandenwerden zu genießen. Es gehört zum Wesen des Absoluten, sich kund zu tun und zn offenbaren.

Diese Betonmng der Passivität, die für die ganze griechische Philosophie eigentümlich ist, und die in der kosmologischen Epoche mit einer reflexionslosen Hingabe an das Ganze zusammengeht als philosophiseher Ausdruck eines pantheistischen Alleinheitsgefühls, hat wohl zu der Auffassung geführt, daß die Torsokratiker Mystiker seien, oder daß ihre Philosophie aus dem Geist der Mrstik geboren sei ${ }^{1}$ ). Die philosophische Absurdität der Mystik liegt wohl ror allem darin, daß sie sowohl objektivierend wie subjektivierend, idealistisch mul realistisch und somit wieder anch keines ron beiden ist. Die Tiefe des Ich, die reflexionslose Vermunft erscheint als Prinzip aller Erkenntnis und alles schanens. So ist die Mystik ganz ichseitig eingestellt. Natur und Welt haben für sie keine oder doch nur sehr geringe Bedentung. Still und heilig steht das Ich da in Erwartung, daß es erfüllt werde von dem Göttlichen. Das Ich scheint das Göttliche in sich aufnehmen zu wollen und das gotterfüllte Ich alles zu sein. In demselben Augenblicke aber verschwindet das Ieh und geht unter und wird begraben in Gott.

Wenn in der kosmologisehen Epoche Form und Inhalt noch nieht deutlich geschieden sind, so besteht hier die Alternative, daß entweder die Vorstellung der Form mehr hinter der Vorstellung des Stoffes oder die Vorstellming des Stoffes mohr hinter der Vorstellumg der Form versehwindet. Form und Inhalt aber müssen wir im Simne der grieehisehen Philosophie so verstehen, wie sie Aristoteles verstanden hat. Da ist die Form das Unsimnliche und gleichzeitig (las Prinzip) (Ior Bewegung, der Stoff aber das Simnliche und an sich Bew egumgslose.

Wemn die milesische Naturjhilosophie das Prinzip der Welt als Wasser chler als Luft bezeichnet, so bildet sie den Begriff ron etwas simulichem. Dem Luft und Wasiser sind simnlich erlebbar. Dies simnlich Erlebbare crhält dann das Attrihnt dor Ewigkeit und dor Sellsthewegnug, die Bestimmungen, die nach Aristoteles der Form gehouren. So ist das Stoffliehe mit den Eigensehaften ler Form ansgestattet. Des Mirkliche wirl in konkret ansehanlicher Gestalt gerlacht.

In (iegensat\% \%и der milesischen Naburphilosophie betonen Heraklit

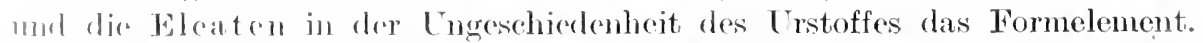
so hat Heraklit das Wirkliche mit dom IV erden, Parmenides mit dem

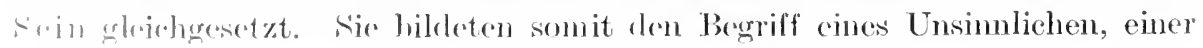

I) Vyl. Kinl Iö̈1, Ursprung der Naturphilosophie aus dem Geist der Mystik. Juna logri. 
kategorialen Form, um das Weltwesen zu bezeichnen. Aber diese Formen wurden noch nicht in ihrer Reinheit und Abgelöstheit rom Sinnlichen gedacht. Denn für Parmenides ist das Seiende gleichzeitig das, was den Raum ausfüllt, und für Heraklit schiebt sich dem Begriff der Bewegung als des Urgeschehens immer wieder die Vorstellung eines simlich-körperlichen Substrats unter.

Erst die letzte Periode ist dahin gelangt, ein besonderes Formprinzip neben dem Stoffprinzip zu behaupten und dadurch den Dualismus als den Standpunkt aller wahren Philosophie zu begründen. Doch waren auch Empedokles und Anaxagoras noch weit davon entfernt, den Begriff der logischen Form in seiner Reinheit und Allgemeinheit zu fassen. Sie lehrten ein Prinzip der Tätigkeit und Kraft neben dem schwerfälligen Substrat der Materie, aber ihr Formbegriff bewahrte aus seiner engen Verbindung mit der Materie noch einen gew issen Sinnlichkeitscharakter.

\section{e) Die Sophisten und Sokrates.}

Die Auffassung der verschiedenen Wirklichkeitselemente ist in Reinheit und Strenge erst durch die sophistische Epoche vollzogen worden. Sokrates wurde zum Entdecker des Begriffs. Das Denken machte sich nummehr sellsst zum wichtigsten und bedeutsamsten Gegenstand des Denkens. Das Selbstbewußtsein wurde zum Prinzip der Philosophie. Die Reflexion schuf den Zweifel und die Kritik, die lebendige Bewegung gegenüber der früheren dogmatischen Starrheit und Gebundenheit. Das Subjekt wurde Ausgangspunkt der philosophischen Úberlegungen, das Ich erschien als das andere, das sich der Objektswelt entgegenstellte. So schien sich als erster Typus der selbstbewußten Philosophie der Idealismus ergeben zu sollen, und in der Tat muß die sokratische Philosophie in diesem Simne verstanden werden. Er hat jene beiden Gesetzmäßigkeiten, die niemals aufeinander zurückgeführt werden können, die Gesetzmäßigkeit des Sollens und des Seins, voneinander zu trennen gewußt. Er hat zuerst Normbegriffe aufgestellt, und zwar speziell auf sittlichem Gebiet, die vom Leben oder, wie wir anch sagen können, im Reiche des Lebens für das Bewußtsein gelten. Er hat das Unsinnliche in seiner Reinheit erfaßt und es dem Sinnlichen entgegengestellt. Wem er aber auch in dieser Weise ein für allemal das Prinzip der reinen Form in der Idee des Sollens entdeckte und damit die erste große Analysis der Wirklichkeit vollzog, so war er doch vollkommen außerstande, das Gebiet des Normativen num selber zu ordnen und zu gliedern. Wie das Ethische von ihm in engster Beziehung zum Intellekt gedacht wurde, so hat er auch das Schöne mit dem Guten identifiziert. Die Harmonie, die wir in der Wirklichkeit des schönen Lebens erschauen, und die unser Dasein beglückt, der Zauber der Form, der Reiz der Gestaltung, sie gehören mit Selbstverständlichkeit der Sphäre des Sittlichen an.

Auch die Sophisten haben das Ich zum Ausgangspunkt ihrer philosophischen Betrachtung gemacht; aber sie haben nicht das ideale Ich der Erkenntnis gedacht, sondern sind vielmehr beim individuellen Ich stehen geblieben, wenn sie nicht das Gattungs-Ieh zum Fundament ihrer Lehre erhoben haben. Diese Position des individuellen Ich konnte die Erkenntnis nicht begründen und die 
Souveränität des Subjekts gegenüber der Wirklichkeit nicht erweisen. Der Sophismus kam nicht über die Tatsache der verschiedenen Auffassungsweisen des Wirklichen himaus. Immer wieder wies er darauf hin, daß die Welt in jedem Subjekt anders erseheint, und war paradox genug, zu behaupten, daß es unmöglich sei, der einen Erseheinungsweise vor der anderen den Vorzug zu geben. Er mußte die Wirklichkeit als das gemeinsame Ziel der Erkenntnis vollkommen verlieren, er mußte überhampt an dem Bestand der gemeinsamen Wirklichkeit zweifeln. Was tatsäehlich nachweisbar existierte, war doch mur die Versehiedenheit der Meinungen bei den versehiedenen Individuen. Über das Reeht dieser Meinmugen läßt sich nicht entseheiden, dem es fehlt durehaus an einem gemeinsamen Wahrheitskriterium. Es gibt kein ideales Schauen der Welt oder einen vorbildlichen Verstand, der das Wirkliche in seiner Wahrheit versteht. Es gibt nur dies rerschiedenartige, immer geteilte Meinen, das auch bei jedem Einzelindividum täglich und stündlich atseinandergeht. So vermag der Sophismus keine philosophische Lehre zu erzeugen. Er sah den Weg rom Ieh zur Welt. Da er aber zu oberflächlich war, um die Natur des Feh einzusehen, so zerram ihm die Wirklichkeit unter den Händen.

\section{i) Demokrit und Plato.}

Es bedurfte em paar Jahrhunderte philosophischer" Entwickìng, um zum erstenmal den idealistisehen und realistisehen Typ in großen Linien hervortreten zu lassen. Demokrit hat die Sinnlichkeit, Plato die Úbersinnliehkeit der Welt gelehrt, oder genauer: Dem okrit hat gelehrt, daß über die Sphäre der Wahmehmung hinaus, unsichtbar und unerlebbar fïr unsere sinne eine Welt sich eröffne, zugängig allein dem Denken, die Welt der rein simnlichen Gestalten; Plato aber lchrte die rein intelligibele Welt hinter den Gestalten des simlichen Lebens. Demokrit lehrte, daß auch alles psychische Geschehen, einschließlich des erkennenden Denkens, auf Atombewegung beruhe. Und die Seclenatome sind ron den anderen Atomen der Natur mur der Gestalt nach rerschieden. Das Objektive ist die ungeheure Impression, welche die Seele erfährt, wenn sie von der Bewegung der Dinge gereizt wird. Sie selber ist keine besondere Position gegenüber den Objekten. Sie ist Ding unter Dingen und gohört schrankeulos dieser Wirklichkeit an.

Fii] Plate ist die Seele und das erkennende Ich das absolut andere, das der simnlichen Wirklichkeit entgegensteht. Aus der Natur der Seele und des Goistes allein lïBt sich die Wirklichkeit verstehen und deuten. Wohl hat I'la to moch nicht gelehrt, dab das Subjekt das Objekt in der Weise bestinmet,

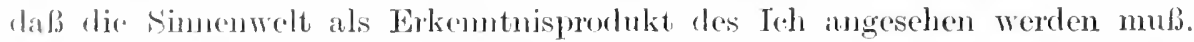
Er denkt das Ich im wesentlichen passiv mol empfangend, aber er verkündet seine absolute Uherlegenheit gexenïber dor Wolt der simbiehen Gestalten. Nur mit unserer simblichen Trichbestimmbheit golı̈ren wir der Welt der sinn-

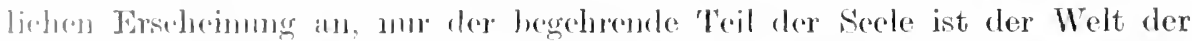

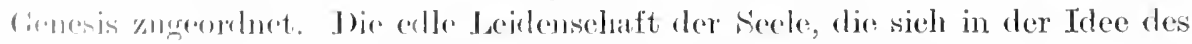

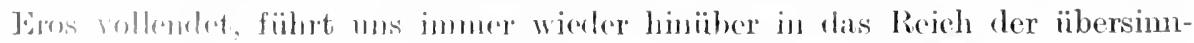

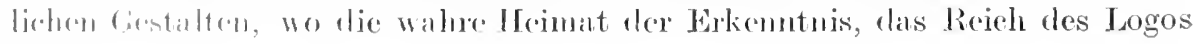
ist. 
Diese Sinnenwelt hat keine absolute Realität, demn sie ruht nicht auf selbständigen sinnlichen Substanzen, die etwa wie die Atome des Demokrit als Ursachen des Gesehehens zu gelten hätten. Es gibt keine Dinge an sich im Sinme des Materialismus. Die Seele ist nicht Produkt der Simnenwelt und kamn auch nicht aus ihr begriffen und verstanden werden. Sie gehört einer rein psychischen Wirklichkeit an und ist nur Gast und Fremdling in dieser Welt des Werdens. Es gibt eine rein psychische Wirklichkeit, die mit der Welt des psychophysischen Geschehens nur lose verbunden ist. In dieser psyehisehen Welt, die dem Gesetz eines rernünftigen Geschehens unterliegt, ist die Seele von all der Erdenschwere und Illusion befreit, die ihrem irdischen Dasein anhaftet. Hier kamm das Ieh der Erkenntnis leben und in roller Reinheit das Absolnte schanen, das es, solange cie Seele an die Körperlichkeit gebunden ist, nur selten und trübe erblickt. $\mathrm{Ja}$, in diesem heiligen Lande lebt die Seele ron der Erkenntuis im Schauen der Ideen. Alle Nahrung und alle Kraft empfängt sie ron den Gestalten des Absoluten. Das Land der Seelen ist der Erkenntnis Land.

Aber weit höher noch führt der große Flug des Idealismus. Das Reich der Seelen, wie es der Pha edros schildert, ist das Reich der Mitte, das zwischen dem Absoluten und dem Relatiren steht. Es ist dem Gesetz des Werdens unterworfen und kann Veränderungen erleiden. A her es ist nicht dem dunklen Zufall und dem teilnahmlosen Schicksal unterstellt, sofem es von einer reinen Wertgesetzmäßigkeit bestimmt ist. Solange die Seele stark bleibt in ihrer Hingabe an das Schöne, solange sie unermüdlich ist im Schanen und das wertrolle Leben der Erkemntnis lebt, so lange gehört sie mit all ihren Kräften dem Lande der Seelen an, in dem sich ihr Wertleben aufbant, in dem sie das Schöne erfährt, und das für sie das Land der großen Erimerung bedentet. Das Absolute kam die Seele nicht entbehren, denn sie bedentet für das Göttliche die Stätte seiner Offenbarmug. Das Göttliche würde einsam bleiben und unverstanden, wenn der sehnsüchtige Auftrieb der Seele ihm nicht entgegeneilte. In der Welt des Physischen liegt keine Mögliehkeit des Verstandenwerdens. Nur die Seele in ihrer Reinheit kann das Göttliche rerstehen. Die sinnrolle Bewegung aber auch der psychophysisehen Welt geht rom Seelenlande aus. Denn wenn die Erkemntnis der Śeele zum Verhängnis wird und sie die Schwere des Erdenlebens auf sich nehmen muB, dann wird auch hier an bescheidener Stätte etwas Großes erzengt, sofern die schönheitsnchende Seele den Kampf mit der Sinnenwelt anfnimmt und, ron alten Tränmen der Erinnerung bewegt, nach ihrer wahren Heimat zurïkzukehren rerlangt.

Über dem Reich der Seelen erhebt sich dann weiter die anßerweltliche Welt, die allem Streit und allem Werden entzogen ist: die ruhende Welt der Ideen. Wenn den Seelen im Seelenlande noch ein Rest der Körperlichkeit anhaftet, ein zart ätherisches Gewand, so ist das ïbersimnliche Prinzip des geistigen Lebens in Platos jenseitiger Welt volliommen anf sieh gestellt. Für jene nackte Welt des Geistes, für jene unsimmlichen Substanzen und Seinswirklichkeiten haben wir Begriffe, die höchste Werte meinen. Diese höchsten Werte erschöpfen sich nicht in der Geltung für das subjekt. Das Gute und das Schöne ist nicht nur für den endlichen Geist da als Norm seines Willens 
und Schauens: die Werte haben einen Gehalt, der in ihnen ruht, der in ihnen begründet ist. Auch ohne das erkennende Subjekt würde ihnen ein unendlicher Bedeutungsgehalt zukommen. Sie bilden jenes Reich, von dem die Seele ihr höchstes Leben hat, in das sie aber niemals eintreten darf. Die Ideenwelt ist ron ihr abgeschieden, und kein Weg führt sie hinein in des Höchsten Land. Die Gebilde der übersinnlichen Welt sind als Realitäten gedacht, die ihr besonderes Dasein leben. Plato behauptet die Erkennbarkeit der ïbersinnlichen Welt. Wir wissen nicht nur von dem Prinzip, das uns die übersinnliche Welt denken lehrt, der reinen Form des Utbersinnlichen, sondern wir wissen anch von ihr in inhaltlicher Beziehung, in den seltenen Stunden des theoretischen Schanens. Wir können diese überhimmlischen Wesenheiten erfahren, und die Schönheit ist es, die diese Bekanntsehaft vermittelt, da das Sinnliche der Diesseitigkeit vor allem nach ihr gebildet ist. Jenes übersinnliche Reich ist der Grund alles Werdens und somit auch der simnlichen Schattenbilder. Alles hat dureh die Beziehung zu den Irleen Leben, Bestand und Gestalt, wenn wir anch äber das Werden des Simnlichen aus seinem Ursprung nichts wissen können. Eine Idee jedoch ist vor allen anderen ansgezeichnet, nämlich die Idlee des Guten. Sie ist jenen anderen so sehr iiberlegen, daß wir es vermeiden müssen, den Begriff der Wirklichkeit anf sie anzuwenden. Diese Idee des Guten ist die Form des metaphysischen Seins. Sie ist das Prinzip, das ganz allein die Erkenntnis dieser höchsten Wirklichkeiten möglich macht. Ohne das Gute vermöehten wir die Ideen nicht zu erkennen, und sie allein ist es auch, die jenen geistigen Substanzen den Wertcharakter verleiht, so daß sie sichtbar und erkembar werden als Ziele der menschlichen Sehnsucht. Ohne das Gute wäre der überhimmlische Ort verfinstert. Durch die Kraft des Guten allein erhalten die Ideen ihren Glanz und treten wie Sterne am nächtlichen Himmel hervor. Damit hat Plato das vierte Reich von ferne geschaut, die Sphäre des reinen Sinnes, die auch das metaphysische Leben noch beherrseht und bestimmt. Er ist absoluter Idealist, sofern er die höchsten Formen des geistigen Lebens als die Urwirklichkeit aller Dinge gedacht hat.

\section{g) Das System des Aristoteles.}

Gegenïber Demokrit und Plato kommt in Aristoteles das Prinzip der Vermitthung zum Austruck. Fr stattet die Natur mit intelligibelen Formen aus und gibt ihr dadurch Festigkeit und Bestand. Indem er aber die intelligibelen, geistigen Formen in eine so nahe Bezichmg zum Stoffe setzte, nahm cr ihnen vieles von ihrer Selbständigkeit mol Wïrde und verschleierte ihren Wertcharaktris. Wenn diese Wescnkrüifte der Natur auch noch vom Sehimmer des Cicistes umlenchtet sind nud den Glanz des göttlichen Ussprungs zugleich mit der Idece der Ewigkeit in die Natur tragen, so seheint das Intelligibele, das Insirhthare dor Natur vermöge der starken biologisehen Orientierung und seiner (Ifrichsetzonger mit dem Arthegriff doch anch wieder dem allgemeinen Begriff des habens stark gonähert an sein. Wohl ist dic form noch immer das wert-

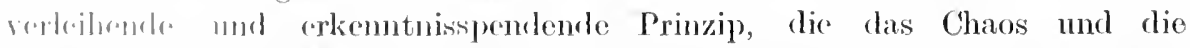

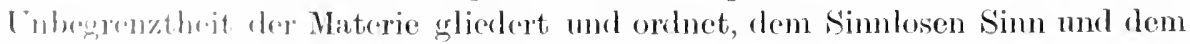
riestaltosen (iostalt giht, aber sie steht in notwendiger Berührung mil dem 
Stoff und kamn niemals ron ihm loskommen. Sic bewegt ihn und bildet ihn, und bewegt und gebildet zu sein, ist der Materie Sehnsucht. Wohl erhebt sich das Reich der Formen in immer höheren Stufen dem Göttlichen entgegen, bewegt durch die Liebe zu dem Geliebten, aber doch bleiben sie durch eine unüberwindliche Kluft rom Göttlichen geschieden. Die absolıte Schönheit der reinen Form ist ihnen nicht zuteil geworden, die Nähe des Sinnlichen hat ihre Unbedingtheit und Reinheit zerstört.

Nur dem höchsten Prinzip, der tiefen einsamen Gottheit, ist der absolute Charakter der platonischen Idlee gewahrt. Sie hat das Sinnliche rollkommen überwunden und aufgehoben. Sie ist die Form aller Formen, sofern in ihr nichts mehr vorhanden ist, das nach höherer Formung verlangt. Sie hat keinen Mangel und keine Liebe zu den simulich-irdischen Dingen. Sie ruht in sich und ist für sich allein, wemn auch die Totalität der Natur notwendig mit ihr verbunden und auf sie bezogen ist. Denn insofern ist das triumphierende Prinzip des Geistes gewahrt. Alle Formen der Natur stehen in teleologischer Beziehung zur Gottheit als dem höchsten Beweger und Endziel der Welt. Das Leben des Geistes leuchtet überall hervor in der Natur und bestimmt und beherrscht die Materie. Über alle himaus als letzter Einheitsgrund der Welt aber erhebt sich das Prinzip der Gottheit in der Sphäre des Úbersinnlichen, die Form aller Formen, das Denken des Denkens, der reinste Ausdruck des theoretischen Wertes.

Dem überwiegend idealistischen Standpunkt dieses Sistems gemäß spielt die ratio hier eine große Rolle. Dem theoretischen Denken sind keine Grenzen gesetzt. Es beginnt mit der Erfahrung, erweist sich aber auch zugleich als das absolut Úberlegene gegenüber der Erfahrungswelt. Denn das Denken hat ein ummittelbares Wissen ron den höchsten Prinzipien. so besonders auch von dem übersinnlichen Prinzip der reinen Gottheit. In der ruhigen Kontemplation, in der seligen Theoria nehmen wir an der Seligkeit des höchsten Wesens unmittelbar Anteil.

Die Beziehung des göttlichen Geistes zur Welt ist eine logisch simnvolle. Gott ist der höchste Bestimmungsgrund des Seins. Er ist das Ziel aller sinnlichen, formbegabten Sehnsucht. Nicht aber wird die Frage erhoben, wie denn wohl das Simnliche mit dem Ủbersimnlichen real zusammenhängen möchte, oder ob etwa die Formen der Natur am Anfang der Sinnenwelt von der Gottheit sich abgelöst haben oder aus ihr hervorgegangen sind als weltbildende Kräfte. So weit die theoretische Erkenntnis reicht, sind Gott und Natur getrennt. Wohl können wir den logischen Zusammenhang der Welt, nicht aber die Geschichte ihres Werdens verstehen. Gottwerdung und Weltbildung sind kein Problem für die Philosophie. Und wenn auch die Welt in teleologischer Hinsicht auf Gott als ihren letzten Sinn bezogen ist, so verharrt doch der göttliche Geist auch wieder in absoluter Sprödigkeit gegenüber der Natur. Die Welt ist nicht der Schauplatz seiner Taten, der Gegenstand seiner Objektivierung und Darstellung, das Reich seiner Offenbarung, das Produkt seines künstlerischen Schaffens, das Objekt seines Denkens, sondern ein Etwas, dem er Sinn verleiht, das aber für ihn ohne Interesse ist, da er nur für sich selbst besteht, nur für sich selber da ist und im Erschauen semer eigenen Herrlichkeit in sich selbst verloren ruht. 


\section{h) Begrenztheit der griechischen Philosophie.}

Die große Entwicklung der griechischen Philosophie lief auf eine Differenzierung der Wertgebiete hinaus und trägt infolgedessen einen überwiegend analytischen Charakter, so mächtig sich auch der Geist der Synthesis in der Bildung großer metaphysiseher Systeme offenbarte. Ton der kosmologischen Epoche mit ihrer vollkommenen Amalgamierung und Verschmelzung der philosophischen Grundprinzipien bis nach Aristoteles hin hatte sich der Gegensatz von Form und Inhalt, von Wert und Unwert, von Sinnlichkeit und Geistigkeit immer sichtbarer und vollständiger vor allem in den großen Systemen des Naturalismus und Idealismus entfaltet. Aber der Gegensatz zwischen den einzelnen Wertgebieten, zwischen den verschiedenen Formen des objektiven Geistes, war noch nicht dentlich herausgearbeitet. So verharrte vor allem der religiöse Wert in einer zu nahen, schier mlöslichen Beziehung zum Theoretischen, wie das besonders in der aristotelischen Konstruktion des Gottesbegriffes zum Ausdruck kommt. Platos wundervoll ordnender Geist hatte das Wertreich gesondert und den Werten ihre besondere Position in transzendenter Abgeschiedenheit gesichert. Doch vermoehte er ihren eigentiimlichen Charakter noch nicht durch spezifische Inhaltlichkeit zu erweisen. Nur dem ästhetischen Wert des Schönen sicherte er im Phaedros eine Sonderstelhng im Reiche der Ideen. Aristoteles hat dann vor allem den Versuch gemacht, die ethischen Werte von den theoretischen zu sondern. Es ist ihm das anch bis zu einem gewissen Gracle gelungen, (loch nur in der Begrenzung, daß er Sittlichkeit und Staat als die spezifisch menschlichen Güter dem theoretischen Wert als dem absoluten, in sich ruhenden, transzendenten Wert gegenüberstellte, der nicht nux eine menschliehe. sondern cbensosehr anch eine göttliche Angelegenheit bedeutet. Denn in rer kontemplativen Erkenntnis erschöpft sich des höchsten Wesens Tum. In Philosophie und Wissensehaft nehmen wir teil an der Seligkeit Gottes. Mit Hegel können wir dies Verhältnis so ausdrüeken, daß Sittlichkeit und Staat in der Sphäre les objektiven. knlturschaffenden Geistes liegen, während die Philosophie rler Siphäre des absoluten Geistes angehört.

Dagegen war der religiöse und kïnstlerisehe Wert in seiner Besonderheit rhurch das philosophische Denken bisher noch nicht verstanden und gedeutet worlen. Unr ebensowenig war das sittliehe Gebiet in seiner Reinheit von der Sphäre des rechtlichen Lebens al)gegrenzt. Das hängt damit zusammen, daß lor religiöse mul kïnstlerisehe Wert ron der [rrationalitït der Gefülnlswelt

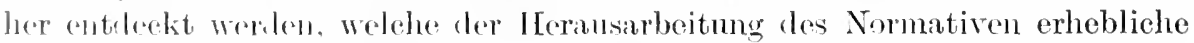
Sehwierigkeiten in (lon Weg logt. Das Denken als Prinzip) dor Rationalität mulste zucrst sich sellst erkentent, um das religiöse mel kiinsterisehe Prinzip

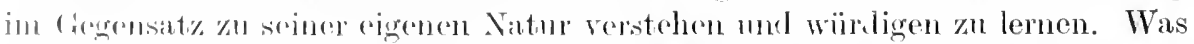

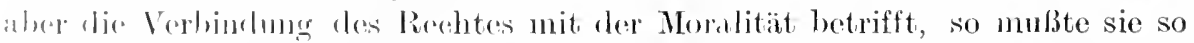

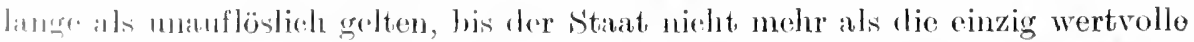
Form des sittliehen labens angeschen worde. Die Trenmung der beiden Wert-

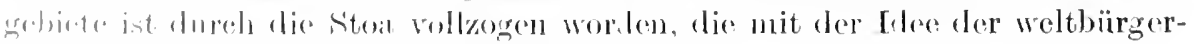

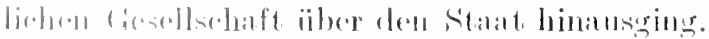




\section{i) Das alexandrinische Zeitalter.}

Die Enthüllung dieser neuen Wertformen geschah in einer Zeit, die, den analytischen Prozeß der Wertdifferenzierung fortsetzend, zugleich durch ein Stadium absolnter Skepsis hindurehging, mm dann ein neues Zeitalter der Srnthese unter der Herrschaft des religiösen Wertes rorzubereiten. Indem das philosophische Bewußtsein an der Macht des theoretischen Wertes, ror allem an der Offenbarung der reinen Logik verzweifelte, versuchte es, von der Erseheinung des religiösen Lebens her die Welt zn verstehen, oder zog sich ron der Welt zurück und begnügte sich damit, ein sinnvolles und seliges Leben in der Diesseitigkeit als Tollendungsmöglichkeit für anserwählte Naturen philosophisch zu begründen.

Die Hinwendung zur Diesseitigkeit und zum Leben, die damals erfolgte. als die großen Typen des Idealismus Plato und Aristoteles nicht mehr nacherlebt und verstanden werden komnten, hat in der Diskussion der Stoa und der Epikuräer dahin geführt, die Form der ethischen Persönlichkeit dentlich hervortreten zu lassen, die ja ihrerseits nur ein Minimum der allseitig geformten Individualität bedeuten kann. Die große Antinomie ron Freiheit und Notwendigkeit trat damals in den Gesichtskreis des philosophischen Bewubtseins. Der Umkreis des sittlichen Lebens wurde nm so besser erforscht. je einseitiger die Philosophie bei den Problemen der Moralität und sittlichen Lebensführung verweilte. Tor allem ist es das Verdienst der Stoa gewesen, daß sie mit großer Härte und Starrheit damals das Bild des moralischen Menschen geformt und in der Gemeinsehaft der Weisen und Guten zum erstenmale in der Geschichte des menschlichen Denkens die Idee einer über den Begriff des Staates hinausgehenden sittlichen Wertgemeinschaft gefaßt hat.

Eigentïmlicherweise wurde num auch in jener Zeit, da das Leben seine Schönheit verloren hatte, der ästhetische Wert erhoben und gefeiert. Die Philosophie Epikurs offenbarte die Bedeutung des Schönen für das Leben. Die schöne geschmackvolle Lebensführung allein rermag das Leben lustroll und reizroll zu gestalten. Und die Bedeutung des Schönen für die Welt hat Plotin kund getan, der das künstlerisch Wertrolle in seiner großen metaphysischen Konzeption als den Geist verstand, der die Materie durchlenchtet.

Das wichtigste Ergebnis dieser Übergangsperiode bedeutet jedoeh die Entdeckung des religiösen Wertes, den die Philosophie nummehr in seiner eigentümlichen Struktur zu verstehen begamn. Sie fand ihn an dem Begriff des Irrationalen. und Alogischen, dem der Form gegenüberstehenden anderen Prinzip, das der Idealismus als das bloß Stoffliche und Erkemtnislose gering gewertet hatte. Ủberhaupt stand der große rationale Zug der griechischen Philosophie in einem feindseligen Verhalten dieser bloßen Sinnenwelt, dem ungeordneten Stoff, dem Chaos der Empfindungen gegenüber. Wemn der Materialismus eines Demokrit den Trimmph des Sinnlichen verkïndete, so meinte er doch nur die Form der Anschamung, Ausdehnmng, Lage, Gestalt und Bewegung. Nur der Sensualismus und Relativismus der Sophisten hatte den bloßen Wahrnehmungsinhalt als das unmittelbar Gegebene, als den einzigen Erkenntnisinhalt gefeiert.

Das Stoffliche, das dem Begriff der Form entgegensteht, galt nach der aristotelischen Philosophie als das Grenzenlose, das an sich keinen Bestand 
hat, sondern nur eine bloße Möglichkeit des Seins, das erst durch die Form zur Wirklichkeit erhoben wird. Der Stoff ist für Aristoteles ferner auch das Unbestimmte, das erst durch die Form Ordnung und Gliederung erfährt. Dies Grenzenlose und Unbestimmte ist es dam weiter, das die Reinheit der Form trübt und ihrer hohen Zielbestimmung gegenüber die dumpfe und blinde Totwendigkeit in das Weltgeschehen hineinträgt. Es ist der Grund aller Unrollkommenheit, alles Leidens und aller Annomalität in der Welt. Dennoch ist es kein wertfeindliches Prinzip, da es ja in seiner Schwäche und Haltlosigkeit von Liebe und Sehnsucht nach Gestaltung erfüllt ist.

In dem Begriff dieses Unendliehen, das für die theoretische Philosophie der Griechen nur die Bestimmung des Stofflichen und Sinnlichen sein konnte entdeckte nummehr die philosophische Besinnung der Alexandrinerzeit die wahrhaftige Prädikation des religiösen Gegenstandes. Bisher war die Gottheit gar zu sehr durch die Macht der ästhetisehen und theoretisehen Wertungsweise naeh der Seite der Gestalt und der Begrenzung geformt und gebildet worden. Der Geist der Schönheit ließ sie abgeschieden sein von der Welt und stumm und selig in sich ruhen als die vollendete Gestalt, der Geist der Erkenmtnis erschaute das Göttliche als das durch den Begriff zu Erfassende und zu Bestimmende, von dem die Gnade und Herrliehkeit des theoretischen Verstehens ausgeht. Nummehr erschien dem theoretischen Bewußtsein das Göttliche als das Unbegreifliche und Unfaßbare, das sich vor dem Begriff verbirgt und ihn niemals zu sich kommen läßt. Durch den Zweifel an aller Erkenntnis hindurch gelangte die Philosophie zur wahrhaftigen Erfassung und Bestimmung des religiösen Gegenstandes, indem sie ihm die Prädikation des Unendlichen und des Unbestimmten gab.

Nummehr verband sich die Idee des absolut Wertvollen nicht mehr allein mit der Idee des Begrenzten und Insichruhenden, sondern im Gegenteil, das Prinzip der Begrenzung, in dem sich das Wertbewußtsein der Hellenen vollendete, ersehien von jetzt an als das Unwertige. Die religiöse Weihe erhielt in der sogenannten negativen Philosophie eines Philo und Plotin der Begriff des Unendlichen und Unbestimmten. Damit war der religiöse Gegenstand ein für allemal den Diskussionen der Logik und der Herrschaft der theoretischen Philosophie entzogen. Es bestand nummehr die Möglichkeit, ihn sogar als das Paradoxe und Widerspruchsvolle zu denken oder als ein Etwas, für das der Satz des Widerspruches jeden Simn verliert. So konnte er als der stille und varschwiegene Ort gedacht werden, in dem die ewigen Mysterien ruhen.

\section{k) Das System Plotins.}

Der vollondete philosophisch-systematische Ausdruck dieser Úbergangs\%eit ist rlie Lchre Plotins. Dies System gehört seiner ganzen Struktur nach lurchans dem 'lypus des Irlealismus an, dessen Charakter ein für allemal diulureh gekemmeichnet ist, daß hier das Subjekt das Objekt bestimmt. Da Her frlablismus von der Macht des Geistes ïherzengt ist, so liegt in seiner ganzen Gestalt anch notwendig der große Erkemntnistrieb und eine sehöne Erkenntnisgewißhoit, wïhrond rie objektivierende, realistisehe Auffassung der Dinge konscruentrowaise zam Skeptizismus getrieben werden müßte. Daß die 
großen Systeme des Naturalismus diese Konsequenz nicht gezogen haben, hängt damit zusammen, daß der Realismus im Grunde ïberhaupt nicht systembildend wirken kann, da ja die mensehliehe Ohmmacht gegenüber der Macht der Materie und der Herrschaft fremder Naturgesetze seine tiefste Uberzeugung ist. Nur dann erseheint der Naturalismus als System, wemn er, inkonsequent und widerspruchsvoll genug, mit der Macht der Materie zugleich die Größe der Erkenntnis feiert.

Das bestimmende Subjekt der Plotinsehen Philosophie ist das göttliche Selbstbewußtsein, das aus der sehweigenden Ureinheit des 气̈: hervorgegangen ist. Jenes Eine liegt jenseits des Wissens im doppelten sime, sofern es eimmal die Stelle bezeichnet, da der Geist noch nicht zum Bewußtsein seiner selbst gelangt ist, und es anderseits auch keine Erkenntnis von diesem Nichtwissenden gibt. Dieser Zustand der göttlichen Unsehuld, da der Geist in sieh selber ruht und noeh nieht aus sieh hervorgegangen ist und von seiner Fülle und Herrlichkeit niehts weiß, dieser Dämmerzustand des Unbewußten, aus dem ein helles Licht hervorbrieht als Emanation und Offenbarung seines Wesens, er wird ron Plotin als der höehste gedacht und empfunden. In dieser Bewertung der noeh nicht offenbarten Kinderunschuld des Geistes steht Plotin im äußersten Gegensatz zum Idealismus der Hegelschen Philosophie. Bei Plotin die Verherrlichung des noeh nicht laut gewordenen seligen Geheimmisses, bei Hegel die Glorifizierung des kund gewordenen göttlichen Seins, des Geistes, der sieh offenbart und in der Offenbarung sein eigenes Wesen zum deutlichen Selbstbewußtsein erhoben hat. Naeh Spinoza erleuchtet die Wahrheit sieh und den Irrtum. Nach Plotin geht alle Erkemntnis ron dem Urgeheimnis des Geistes aus, der seine letzte Tiefe nieht durchdringt. Das Urgeheimmis des Einen, in dem die Reflexion noeh nieht ihrem Gegenstande gegenübersteht, entfaltet sich zu dem göttlichen Subjekt der Erkenntnis, zur reinen Intelligenz, in der das Denken dem Gedaehten als seinem Gegenstande gegenübersteht. Der Gegenstand des göttlichen Denkens ist nieht etwa die simnliche Wirkliehkeit — ihr gegenïber bleibt das Göttliche rollkommen transzendent —, sondern die Ideenwelt als das ïbersinnliche Substrat für das synthetische Bewußsein Gottes. Gegenüber der reinen Kontemplation des Aristotelisehen Selbstbewußtseins ist das göttliehe Selbstbewußtsein, wie es Plotin deutet, tätig und spontan. Seine Aktivität bildet und gestaltet die reine Geisteswelt. Die Ideenwelt hat nur Bestand, sofern sie die Gottheit in der Form des Seins denkt. Die Form seines Denkens verbindet die Mannigfaltigkeit der Ideen zu einer Einheit, sie ist das Identisehe gegenüber ihrer Versehiedenheit. Ruhe und Bewegung sind dann endlich noeh notwendige Kategorien der übersinnlichen Welt, sofem nach dem System der Emanation die rerschiedenen Stufen des Geistes in einander übergehen oder rielleicht noch bezeiehnender überströmen, anderseits aber die versehiedenen Sphären in sich gesättigt und erfüllt ruhen, wie die Marmorsehalen eines römischen Brumnens.

Der Idealismus Plotins hat zum Ausdruek gebraeht, daß das Wesen der Wirklichkeit das schaffende und bildende Wertleben des Geistes sei. Dieses Wertleben bleibt nicht für sich in einer anderen, jenseitigen Welt, sondern ergießt sieh in die Sinnenwelt hinein. Das Sinnliche ist im Grunde genommen ein Nichts: der finstere, leere Raum, den das ausströmende Lieht des Geistes 
immer schwächer und sehwächer durchleuchtet, bis es sich schließlich unter schweren Schatten zu verlieren scheint. Das Prinzip aber, welches die Brüeke schlägt zwischen der reinen ungetrübten Geisteswelt und der Simnenwirklich-

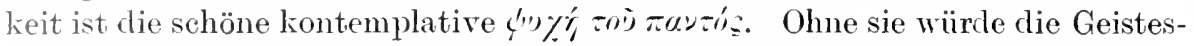
welt für sich rerharren und die Welt der simmlichen Schönheit nicht werden, die dadurch entsteht, daß der Geist die Materie durchleuchtet. Die Welt des göttlichen Selbstbewußtseins ist das Reich der Vernmet, und die Simenwelt ist das Land der Schönheit. Durch die Vermittlung der Seele geht das eine in das andere über. Die reinen Vemmftbilder, die Ideen, welche die Seele im seligen Schauen empfängt, erscheinen in der Sinnenwelt als die schönen Gestalten der Natur, der Kultur und des Lebens. Ohne das Simnliche bliebe die Geisterwelt ruhige Vernünftigkeit. Schönheit entsteht allein, wenn Geist und Materie sich verbindet. Was uns im Lande der Simne als Schönheit erseheint, wird uns im Geisterreiche als Wahrheit entgegentreten. Der ästhetische Wert ist die

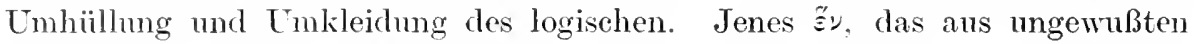
Tiefen sein schimmerndes Licht in das trübe Schattenreich des Nichts aus-

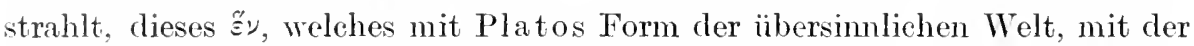
Idee des Guten, verwandt ist. kennzeichnet die Sphäre des religiösen Wertes und ist Gegenstand (ler religiösen Ekstase. Das göttliche Selbstbewußtsein. das reine Subjekt erfüllt die theoretische Sphäre im Reiche des Absoluten. Thr ist die reine Theoria des erkennenden Menschen zugewendet.

Über das Ästhetische und Ethische regiert die Seele. Sie sind keine reinen Wertformen, sondern Simugebilde, die in der Beziehnng zum Sinnlichen wurzeln. In der Idee des Schönen kommt der Wertgehalt des Sinnlichen zum Ausdruck, und die ästhetische Theoria hat diese große Nacht, daß sie hinter allen Verhüllungen und Umschleierungen den Geist erkennt, der sich in der Natur verbirgt. Die kontemplative Weltseele. welche die Ideen empfängt und von ihnen hefuchtet wirl, cutspricht der Natur des Schönen in der Haltung des ruhigen Schanens, das der himmlichen Welt gehört. Aber die Seele der Welt ist nicht nur liontemplativ, sondern auch alitiv. Sofern wie Seele der Welt sich auf ihren göttlichen Lrsprung besinnt, verweilt sie in reiner und heiliger Passivitait; sofern sie aber Borlen gewinnt in der Sinnenwelt, wird sie zum Tun und zum Jeisten getrieben. Die der ir.lischen Wirkliehkeit zugewendete Weltseele ist tïtig. Fie bildet die Natur und anch die Gestalt des eigenen Leibes. Sie "rwirkt das sithliche Leben in Gesellschaft und Staat, doch bleibt die politische Tätigkeit, die sich in start und in sittliehen Leben vollendet, im Verhïltnis zol1 ïsthetischen 'Theoria ein durchaus Intergeorlnetes.

Wie dir iihersinmliehe Welt dureh ganz besondere Formen gebildet und rerkannt wird, so anch dic Sinnenwelt. Sic ist die Wolt der niederen Bewegung, der Ortsuriumlerung in Ramm mul Zeit. Nie ist anch fermer die Welt des Quantitafiven mol Qmalitativen ganz im Sinno des Aristoteles. So gibt es nach

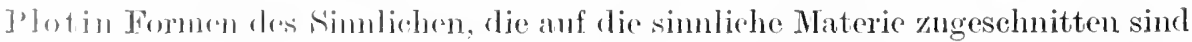
mul zur Erkomntuis der Ninnenwelt hinfïhren, und andere, welche fïr jene Welt

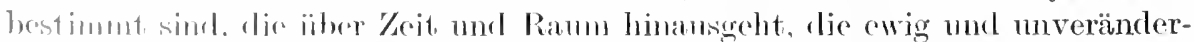
lich ist. So hat dio Frkemmtnis ein grobes Fold. Sie ist keineswegs nur anf die

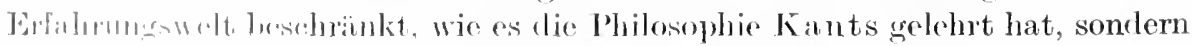
dureh 'Trilnalmor all dem Allemeinen der Weltsecle und der göttlichen In- 
telligenz ssi uns die Erkenntnis der Gesamtwirklichkeit besehieden. Nur dem

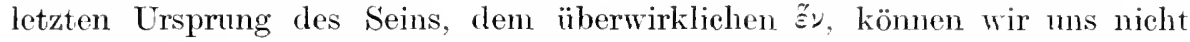
auf dem Wege der Begriffserkemntnis, sondern nur in der Begriffslosigkeit und Bewußtlosigkeit der dunklen Ekstasis nahen.

So hat das Utbergangszeitalter der alexandrinischen Epoche, das zwischen dem analytischen Zeitalter der griechischen Epoche und dem synthetischen Zeitalter der mittelalterlichen Welt in der Mitte steht, die Wertabscheidung und -trennung fortgesetzt, indem es die eigentümliche Struktur des ästhetischen und religiösen Wertes deutlicher heranszuarbeiten vermochte, zugleich aber auch, wie das im System Plotins unverkembar hervortritt, eine Pangordnung des Wertlebens unter der Herrschaft des religiösen Wertes angebahnt. Allerdings bewahren die versehiedenen Wertformen im System Plotin noch eine relative Selbständigkeit, wem sie auch alle rom religiösen Werte überschattet sind. Der theoret ische Wert ist genau so absolnt wie der religiöse, der ästhetische und ethische dagegen auf die Simenwelt beschränkt oder doch gar eng mit dem Schicksal des Endlichen verkniipft. Noch sind nicht alle Wertformen in den Dienst des religiösen Wertes getreten, sie bewahren einen eigentümlichen Sinn; aber wir erkennen, daß sie dem Religiösen sich zuneigen, in ihm sieh vollenden und aufgehoben sind.

\section{1) Die Philosophie des Mittelalters.}

Das synthetiscne Zeitalter der Philosophie des Mittelalters, die darauf ausging, die Herrschaft der Religion zu begründen, nachdem das alexandrinische Zeitalter die Herrlichkeit und Einzigkeit des religiösen Lebens erschant, liegt zwisehen den großen Systemen des Augustin und Thomas ron Aquino ausgebreitet. Das Verhältnis von Philosophie und Religion beginnt nummehr eine Wandlung zu erfahren, die sich in Thomas ron Aquino vollendet hat. Das alexandrinische Zeitalter und die Entwicklung der Philosophie bis zu Plotin hin suchte die Eigentiimlichkeit des religiösen Wertes und des religiösen Lebens zu verstehen, ron dem sie das Heil der Welt erwartete. Dabei wurde das Wissen, das sich in der Philosophie vollendete, im allgemeinen über den Glauben gestellt. jucios: ist mehr als rirts, ein Standpunkt, der auch noch von Augustin rertreten wird. Das soll nun allerdings nicht bedeuten, daß die Philosophie mehr sei als die Religion. sondern lediglich, dab ein Wissen von den religiösen Wahrheiten mehr bedeute als ein bloßes Glauben der religiösen Heilslehren. Die Philosophie vermag ein Wissen von dem übersinnliehen Gegenstand des religiösen Lebens zu geben, und die Philosophie hat nur insofern eine besondere Bedeutung, als sie uns ein Wissen vom Göttliehen gibt. Anfangs vermag die Philosophie mit vollkommener Freiheit das religiöse Leben zu deuten, später aber wird sie durch Kirehenkonzile und -beschtiisse gebunden und darf die religiöse Ưberlieferung der Evangelien nur in einem ganz bestimmten Sime und innerhalb eines festgesetzten Rahmens verstehen. Sofern nun die Philosophie und das Wissen in seiner Auffassung und Deutung des religiösen Lebens und der religiösen Überlieferung zu ganz bestimmten Dogmen und Lehrsätzen gelangt, die ein für allemal geglaubt werden müssen. da sie endgültige Einsichten in das Wesen des Göttlichen darstellen, wird die Religionsphilosophie zur Theologie. Die Theologie ist weder Religion noch Philosophie, 
die ja beicie Vollendungswerte sind und deswegen nur als Schöpfung des Einzelnen verstanden werden können. Dagegen ist die Theologie nur als Produkt des sozialen Zusanmenhanges, speziell als Instrument der Kirche, begreiflich und verständlich. In der Theologie wird die Philosophie nicht sowohl der Religion in ihrer Reinheit und Lauterkeit, sondern vielmehr den praktischen Zwecken der kirchlichen Organisation dienstbar gemacht. Die Theologie stellt also den Punkt da, wo die sozial-ethische und wissenschaftliche Reihe der menschlichen Entwicklung mit der philosophischen und religiösen sich schneidet.

Das große synthetische Zeitalter des Mittelalters wollte die Religion nicht nur zur Herrscherm im Reiche der Werte machen und dadurch eine gemeinsame religiöse Weltansicht begrïnden, sondern es wollte vor allen Dingen auch im Simne dieser Weltansicht die Verhältnisse unter den Menschen umbilden und restaurieren. Deswegen verband sie die Ideen der Philosophie und Religion auf das engste mit dem Begriff der Kirche und des Staates.

\section{m) Augustiu.}

Augustin ist überzeugt von der Göttlichkeit und Macht des Geistes, aber die Materie ist ihm gegenïber nicht zı vollkommener Ohnmacht verdammt, weil sie Werkzeng und Mittel in der Hand des Wertwidrigen, des Teuflisehen und Bösen ist. In dem Begriff des Bösen beginnt besonders seit Augustin ein folgenschweres Problem für die Philosophie zu entstehen. Der Verstoß gegen die Norm erscheint nun nicht mehr als Irrtum oder als eine große Notwendigkeit des Weltlebens, sondern als ein radikal Böses, das anfgchoben und ausgetilgt werden soll. Die Materie, die der Idealismus eines Aristoteles als das Starre und Bewegungslose verstanden hatte, sie bekommt jetzt plötzhich Kraft und Aktivitä, dem sie wirl von einem Prinzip beherrscht, das früher selber der sphäre der reinen Geistigkeit angehört hat und deswegen auch als verborgener Feind das Leben des Geistes versteht, nummehr aber, weil es gegen des Geistes Art verstoßen und eine Schuld auf sich geladen hat, der Sphäre des Sinnlichen zugeordnet ist. Der entfremdete, der versinnlichte Geist ist das Böse, das alles Mensehliche bedroht, weil es so nah dem Simnlichen wie dem Göttlichen steht. Das Böse ist somit ein theoretisch Unbegreifliches, da es weder dem Stoff noch der Jorm zuzuordnen ist, da es weder ein Wertfreies bedentet, noch aus dor Idee der Wertfeindlichkeit verstanden werden kann, sofern hier die Vernumft mit sich selber in Streit und Gegensatz liegt. Das Verhältnis zwisehen dem Göttlichen und dem Bösen beruht also weder auf dem Gegensatz von Moralität und Simnlichkeit, der für alles sittliche Leben entscheidend ist, noch auf dem Gegensatz der verschiedenen Formen des vernïnftigen Lebens, deren IViclerspicl die Entwicklung des großen historisehen Geschehens beherrseht. Ex ist cine V'rkehrung des Wertvollen, die iiber alles Verstehen der Philosophie hinausgeht, dessen Wesen Kant als Umkehrung der moralisehen Triebfedern zu druten gesucht hat.

Augustin hat den Kampf zweicr entgegengesetzten Mächte auf das schuriste gefühlt, von denen die eine ihn hinleiten wollte zur Sphäre der übersimulichen Wolt, die andore ihn aber immer wieder anf das emsthafteste verstrickte in die ganze Sehönheit und Tïßlichkeit der Simmenwelt. Der Geist der 
Wahrheit und der Geist der Lüge, des Lebens und des Todes hatten sich sein mutiges und umbengsames Herz zum Schauplatz ihres Kampfes gewählt. Dabei machte er aber die eigentïmliche Erfahrung, daß gerade dasjenige, was ihm anfangs als das Gefährlichste erschien und sein ganzes Leben und seine Utberzeugung bedrohte, der Geist des Zweifels und der Negation, zum Prinzip der Gewißheit führte. Aus dem großen Erlebnis des Zweifels heraus erschloß sich ihm die Daseinsgewißheit seiner eigenen großen Individualität. Und dieses persönliche zweifelnde und urteilende Ich der psychologischen Erfahrung, dieser Inbegriff seines ureigensten Lebens, wurde für ihn der Ausgangspunkt zur ErschlieBung des Uber-Ich. Er sah ein, daß der Zweifel notwendig zusammengehen müsse mit der Enge und Begrenztheit der menschlichen Natur, daß aber auch das Verstehen dieser Enge und Begrenztheit nicht möglich sei ohne ein Wissen von der Idee des Úberindividuellen und Unbegrenzten, das iiber alle menschliche Natur hinausgeht. Das eben ist das Geheimnis der menschlichen Natur, dab sie einerseits ein Verstehen hat von dem Ähnlichen und Verwandten, wie das in der philosophischen Lehre vom Makrokosmos und Mikrokosmos zum Ausdruck kommt, anderseits aber auch ein Wissen von dem Entgegengesetzten. Würde ich nicht die Macht besitzen, mit meinen Gedanken über die Idee der Begrenztheit hinauszugehen, d. h. würde ich nicht das Unbegrenzte wissen, so würde ich auch die Begrenztheit und Endlichkeit nicht so tief durchschanen und begreifen können. Was ich objektivieren und zum Gegenstand meines Nachdenkens machen kann, das habe ich bis zu einem gewissen Grade schon überwunden. So schließe ich ja auch den Tod in den Kreis meines Nachdenkens ein. Wäre er die absolute Schranke für den menschlichen Geist, so vermöchten wir die Idee der Unsterblichkeit nicht zu denken.

Der Idealismus Augustins geht vom persönlichen Ich aus. Dieses persönliche Ich war ja auch der Ausgangspunkt der sophistischen Uberlegungen. Aber jene fanden in sich nur das bloße Meinen, und so sehr sie das Prinzip des Zweifels handhabten, als dessen Konsequenz sich für sie die absolute Skepsis ergab, so waren sie doch nicht imstande, den Zweifel zu begreifen und zu deuten, indem ihre Reflexion über dies Prinzip nicht hinausging. Augustin kannte nicht nur das leere Meinen, sondern er hatte auch die Macht des Denkens in sich erlebt, die im Zweifel zum Ausdruck kommt und den Zweifel selber wicder überwindet. Vom Prinzip des Idealismus aus hat er die Macht des Denkens verherrlicht, das über den Glauben weit hinausgeht und sich mit der Kraft des IVillens in Bejahung und Vemeinung verbindet.

Aber neben dem Prinzip des Geistes, das sich in der Herrlichkeit der Kirche offenbart als Symbol eines höheren Daseins, sucht seine Verkehrung, die Gewalt des Bösen, mit Herrlichkeit und Pracht das simnliche Leben und die Diesseitigkeit zu schmücken, wie das vor allem in der Gottlosigkeit des römischen Imperiums geschah. Durch machtrolle Gestaltungen des Lebens suchte man das irdische Dasein zu festigen und zu behaupten und die Kluft zwischen Gott und Menschheit in Permanenz zu erhalten. Nach Augustin gibt es nur eine Wertgestaltung des irdischen Lebens, nämlich die religiöse Bildung, welche von dem großen Institut der Kirche, dem Symbol des Gottesstaates, dem Reich Gottes auf Erden, selber gefördert und geleitet wird. Philosophie und Wissenschaft haben hohen Ruhm, soweit sie dem Verstehen der religiösen 
Heilswahrheiten dienen. Auf einen anderen Gegenstand geriehtet, sind sie bedeutmingslos und unter Umständen gefährlieh. Das ästhetische Bewußtsein kommt in diesem System nieht zu Worte, das Sittliehe sprieht eine große, aber religiös gebundene Sprache, und der Staat mit seiner Weltfreudigkeit gilt als gottlos und böse. Denn die große mystische Liebessehnsucht des Angustin ist daranf gerichtet, daß die unselige Welt wieder mit Gott vereinigt werde, daß unsere Begrenztheit, unser Zweifel und unsere Simnlichkeit aufhöre und wir im stummen seligen Schanen mit Gott verbunden sind.

\section{n) Thomas von Aquino.}

Das System des Thomas von Aquino, das am Ende der großen synthetisehen Epoche des Mittelalters steht, vertritt einen Idealismus, der in zwiefacher Weise der Lehre Augustins besonders scharf entgegengesetzt ist, nämlich einmal, sofern er an die Stelle des Dualismus und der Verkehrung des geistigen Wesens in das Böse das Prinzip der teleologisehen Einheit erriehtet, welehe den Gegensatz mildert und das Böse des Weltlebens zum Mittel des Guten wandelt, zweitens aber, indem er die Ansprüche des Augnstinisehen Wissens, das in einer kühnen, willensbetonten Ratio sieh erhebt und in der Ekstasis des Sehanens sich vollendet, daß3 er diesen Forderungen gegenüber eine kühle Grenze setzt. Hatte Augustin jene Gestaltungen des geistigen Lebens, die sieh im Staat und in großen politisch-historischen Verbindungen erfüllen, als feindlich dem religiösen Leben rerworfen und rerurteilt, indem seine Weltverneinung das Reich Gottes crstrebte, der Staat ihm aber als Prinzip der Welt böse und gefährlich schien, so erschaute Thomas von Aquino in der weltlichen Kultur ein Mittel zm Hervorbringmg und Vorbereitung der höheren geistigen Kultur. Diese woltliche Kultur, die vor allem bestrebt ist, feste soziale Organisationen zu begründen und Recht und Gesetz für Tolk und Staat zu sehaffen, sie gibt der heiligen Kirche den notwendigen Sehutz, dessen sie so dringend bedarf. Thr feingegliedertes, unstoffliehes Wesen braucht zu seiner Entfaltung einen vorbereiteten Boden, der sehon die crste grobe, änßere Kultur erhalten hat, lanit ihm num jene zarte Inmenkultur des Herzens eingepflanzt werde, die das sittlich-religiöse Leben hervorbringt, und die ganz allein von der Kirehe ausgeht.

J) Wissensehaft und die Philosophie steht nach der Auffassung Thomas ron Aquinos vollkommen in dem Dienst des religiös-sittliehen Lehens. Jie Thilosophie begründet, ausgehend von der Natur, die Vorstufen der himmliehen Hicrarchic. J)ie Theologie, die götthiche Wisscuschaft, verkïndet die unbengsinnen dianbenssïtze der Kirche und den verborgenen göttliehen Gehalt der Mysterien. Es gilot gewisse Lehren der heiligen Sehrift, die niemals dureh den B)orgiff dentlich gomaleht worlen kömmen, weil sie über alles endliehe Verstehen hinansehenen. Jort liegt das Land der Mysterien. Hier handelt es sieh um das IVumlerbare mol lonergrïnlliche in lor Roligion, um jene sphäre tiefster

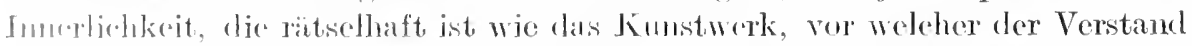
notur.gulig Ilalt machen mul., zu der ilm kein Eingang offen steht. Thr gegen-

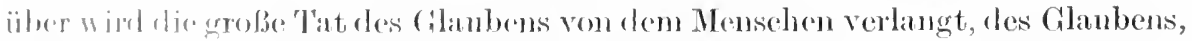

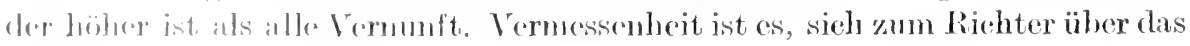

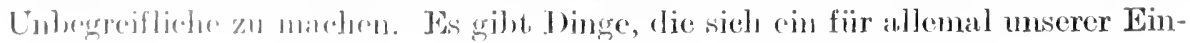


sicht entziehen, zu deren begrifflichen Erkemntnis auch die Weiterentwicklung der Menschheit niemals führen wird und kann. Wohl kann der Verstand und sein großes Medium, die Philosophie, das Dasein Gottes beweisen, aber das Wunder der Trinität entzieht sich ein für allemal der Erkenntnis. Diese Mysterien sind ron höchster Bedentung, denn sie erinnern uns immer wieder daran, daß unser endliches Verstehen erst in einem unendlichen seine Erfülhng findet. Wohl erwächst aus ihmen heraus die Gefahr einer Autorität für die blinde Unwissenheit und die Gefahr einer Schranke für den erkenmenden Geist, aber das Wunderbare muß auch wieder als ein Symbol dafür gelten, daß das Ủbersinnliche seine Verbindung und Beziehung zur simnenwelt hat.

Eigentümlich ist die Stellung, dieThomas von Aquino dem Problem der Wertgegensätzlichkeit gegenüber einnimmt. Während die vorhergehende Philosophie in der seltsamen Formulierung dieses Problems als der Frage zweier verschieden geltender Wahrheiten die Antinomien der Termunft auf das schärfste gefühlt hatte, vertritt Thomas die Auffassung, daß die Wertgegensätzlichkeit überhaupt nicht besteht. Bei Augustin merken wir deutlich. wie die verschiedenen Forderungen, die das ethische Bew $3 t$ sein in der Behauptung der Freiheit und das kirehlich-religiöse in der Behauptung der Bindung und Totwendigkeit stellt, wie sie in seiner großen Persönlichkeit kämpfen und auch in seiner Lehre nie ganz zum Austrag gekommen sind. Nach Thomas besteht ein vollkommener Ausgleich zwischen Theologie und Philosophie. Bei richtiger Besinnung können beide unmöghich miteinander in Konflikt geraten. Die Theologie, welche die religiösen Heilswahrheiten formuliert hat, gibt gewissermaßen das regulative Prinzip für Philosophie und Wissenschaft her, die mit ihren Einsichten und Erkemntnissen notwendig anf eine bestimmte Grenze stoßen. Das Gebiet der Natur ist ihrem Verstehen im allgemeinen zugängig, und die Metaphysik darf kühnlich den Flug in die Sphäre der übersimmlichen Welt wagen. Sie kam die großen Ideen der Religion: Gott, Freiheit und Unsterblichkeit beweisen. bis sie zu jener dunklen Pforte gelangt, da Rätsel und Mysterien begimen. das Wissen notwendig enden muß und nur der Glaube zu Recht besteht.

In dem System des Thomas trimphiert das Prinzip des Cieistes rollkommen über die Simnlichkeit. Die simnenwelt, das Reich der Natur, verhält sich zur übersinnlichen Welt als dem Reich der Gnade so, wie sich das Mittel zum Zweck rerhält. Es ist die dunkle Folie für die helle Herrlichkeit der Geisteswelt. In ihrem ganzen Aufbau und ihrer Ordmung entspricht die Natur der übersinnlichen Welt ron weitem. Der Mensch aber ist der Bürger zweier Welten. Als reine und getremte Form gehört seine Seele dem Gicisterreiche an. als anhaftende Form gehört sie zu den Bewegungskräften der Natur. Eben dieselbe Seele also, welehe die Nacht besitzt. losgelöst ron aller simlichkeit in der Sphäre des Übersinnlichen zu wohnen. ist anch wieder auf das engste mit dem Werden und Vergehen der Natur rerknüpft. Wie die schöne kontemplative Weltseele Plotins, nach oben schauend, der reinen Geisteswelt angehört und, nach unten gerichtet, simliches Dasein formiert und bildet, so ist auch der menschlichen Seele nach Thomas zu gleicher Zeit ein Verhältnis zum Simliehen und Ủbersinnlichen gegeben. Sie ist, wie Kant sagen würde, sowohl intelligibeler wie empirischer Charakter. Die Bewertung der Seele aber hat seit Plato und Plotin 
eine ungeheure Steigerung erfahren. Nach Pla tos Lehre ist die Seele vom Lande der Ideen ein für allemal ausgeschlossen. In dem Seelenlande, in dem Reiche der psychischen Wirklichkeit, hat sie eine Heimstätte, aber die übersinnliche Welt der Ideen ist ihr verschlossen. Nunmehr ist die Schranke zwischen dem sinmlichen und tbersinmlichen vollkommen zerbrochen. In ihrer reinen Form gehört die Seele dem ïbersimnlichen Reiche der Ideen an.

\section{o) Renaissance und Aufklärung.}

Die Weiterentwicklung der Philosophie bis zu den großen Systemen des deutschen Idlealismus zerfällt in zwei deutlich voneinander trennbare Abschnitte. Gemeinsam ist der Philosophie der Renaissance und der Aufklärung der Kampf gegen die Oberherrschaft des Allgemeinen in der Religion. Gemeinsam ist ihnen die Wertung des Besonderen und der analytische Charakter. Sic verzweifeln endgültig an der Möglichkeit, die getrennten Kulturgebiete in einer großen Wertsynthese zu verbinden. Nur hat das Besondere, welches Renaissance und Aufklärung dem Allgemeinen entgegenhalten. einen sehr versehiedenen Charakter. Wenn die Philosophie der Renaissance das Besondere wertet und scin Recht gegenüber dem Allgemeinen verteidigt, so sind es die großen Gattungsindividuen, die sie feiert, nicht aber die Individuen als solche. Die ganze Entwicklıng clieses für die Systembildungen der Zeit so wichtigen Problems hat bis zur Philosophie des deutschen Idlealismus und den Theorien der Romantik schr verschiedene Stufen durchlaufen. Das Besondere als Gattungsindividum, wie es die Renaissance gedacht hat, entbehrt im Grunde genommen eines Wertcharakters. Das Besondere der Individualität empfängt hier weder seine Weihe durch rlie Bindung an einen besonderen Kulturwert, noch wird der Begriff der Individualität zur Idee der Persönlichkeit vertieft. Die Individualität wird also gewissermaßen naturhaft, ohne Wertbetonung verstanden und das, was den Vorrang der einen vor der anderen begründet, ist nicht die Leistung für einen bestimmten Wert oder die Eigentümlichkeit eines besonderen Lebensstiles, sondern vielmehr die großen Dimensionen, die totale Leistungsmöglichkeit und Universalität. Betont wird das mächtige und starke Loben, cincrlei in welcher Richtung es sich betätigt, ob es $n u n$ zu genialer Wertschöpfung sich ersehließst oder in der Pracht riesenhafter Leidensehaften las Leben der Liebe genießt. Die große Lebenskraft wird gefeiert, die alles in sich schliel3t, was das Universm an mannigfaltigen Gaben anfweist und so als kleine Welt der großen Welt gegenübersteht. Jie Stärke des Willens, die Macht des Verstandes, die Gröbe der Leidensehaften, sie entsprachen dem Jebensideal dieser heit.

Die pantheistischen Systeme des Anfangs, div aufflammen zu einer großen Jubelfeier der Welt, vermögen alie Sonderposition cler Indivirlualität noch nieht z.1 Jogründen, so schr sie dio Macht mol Herrlichkeit des menschliehen Geistes

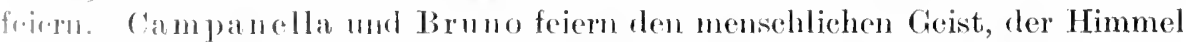
und Hojle verwandt ist mut sich zum Herrn mol Gote der Erde gemacht hat; abme bri innen ruht moch aller Nachdruck anf dem Ganzen der sichtbaren Nalur, iibur dir das Judividum nicht hinausgehen kamm, sondern in die es als

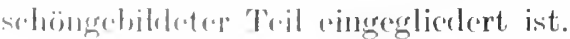


Das nene Lebensgefühl und die neue Mertauffassung der Renaissance hat ihren Ausdruck vor allen Dingen in den großen Systemen des Idealismus und Naturalismus gefunden, wie sie ron Descartes, Spinoza und Leibniz gebildet sind. In all diesen Lehren wird der Individualität ihr besondcres Recht gewahrt, das gilt ebensogut für die endliche Substanz Descartes' und die Monade Leibnizens wie für den endlichen modus Spinozas, der in der Erkenntnisliebe so groß und mächtig wird, daß er sich zum absoluten Verstehen des Göttlichen erhebt. In der idealistischen Lehre Descartes' ist die endliche geistige Substanz, die sich in dem Begriff der cogitatio rollendet, hinsichtlich ihrer Erkenntnisfähigkeit ron Gottes Wesen prinzipiell geschieden, aber in der Kraft des Willens dem Göttlichen verwandt. Nur in dem Willen kann unsere Gottähmlichkeit gefunden werden.

\section{) Das System Descartes".}

In dem Idealismus der kartesianischen Philosophie wird der Begritf des erkennenden Ich zum Prinzip der Philosophie erhoben und die Funktionen der Erkemutnis ron seiner begrifflichen Struktur abgelesen. Er hat, so können wir sagen, den Wertbegriff des endlich erkenmenden Ich zuerst entdeckt, wem er ihn auch noch nicht in seiner Reinheit festzuhalten vermochte. Dem indem er den Begriff der Substanz auf das Ich anwandte, fiel er in die objektirierende Auffassung zurück und suchte das Ich durch eine sekundäre Form des Begriffes, nämlich die Substanz, sich deutlich zu machen, während doch vielmehr umgekehrt der Sinn der Substanz erst durch das Ichprinzip deutlich wird. Auch nach dem System des Descartes, das seiner Grund these nach die Behauptung vertritt, daß das Subjekt das Objekt bestimmt, ist dem Geiste alle Macht im Himmel und auf Erden gegeben. Die Materie kommt lediglich in dem Begriff der ausgedehnten Substanz zu Worte, die, für sich betrachtet, ohne jede Kraft und Bewegungsfähigkeit ist. Gestalt und Ausdehnung bestimmen ihr Wesen das lediglich ron den mathematischen Bestimmungen des Raumes gebildet wird. Solche Substanzen kömnen gewiß keine Wirkung ausüben, und so sind die materiellen Dinge zu rollkommener Ohnmacht verurteilt. Die Bewegungen, die ihnen eigen sind, haben ihren Trsprung nicht in der Natur der ausgedehnten Substanz, sondern bedeuten eine Funktion, die Gott den endich-sinnlichen Dingen rerliehen hat, und die er ihnen immer wieder nehmen kam, um sie in rollkommene Nichtigkeit rersinken zu lassen.

Die menschlichen Seelenindividualitäten dagegen vermögen Großes zu erreichen durch ihren lebendigen Anteil an der geistigen Substanz der Welt, in der die Allgemeinguiltigkeit der Erkemntnis beschlossen ist. Der menschliche Verstand, für sich betrachtet, bleibt ein begrenzter, sofern wir nicht alle Terstellungen, die uns bestïmen, zur Klarheit und Deutlichkeit der rationalen Einsicht läutern und erheben kömmen. Del unendliche Geist der unendlichen göttlichen Substanz vermag allein in vollkommener Irrtumslosigkeit frei und offen das Tirkliche zu schanen. Tns muß der Irrtum notwendig ergreifen, wenn wir das Einsichtslose bejahen. Doch ist uns durch die Kraft des natïrlichen Lichtes die Möglichkeit gegeben, bis zu jenen Prinzipien vorzudringen, auf denen alle Gewißheit ruht. Wir wissen in klarer und deutlicher Vermunft- 
anschanung das zweifelnde, bejahende und verneinende, das denkende und urteilende Ieh, den Archimedespunkt der Gewißheit, und wir sehen anch jenen anderen Pol der Erkenntnis deutlich ein, der unsere Endlichkeit und Unrollkommenheit erfüllt: die Göttliehkeit der unendlichen Substanz.

\section{q) Das System Spinozai}

Das grolße System Spinozas hat seinen Ausgangspunkt in der Lehre Deseartes' genommen, steht aber im schroffen Gegensatz zum kartesianischen Idlealismus. Es bedentet die größte und erhabenste Leistung des Naturalismus oder Realismus, welcher die Auffassung vertritt, daß das Ich oder das Subjekt restlos ron der Natur bestimmt wird und nicht iiber sie hinausdringen kann in eine höhere Sphäre des Vertlebens. Prinzipiell erscheint somit das Ich als vollkommen bestimmt und an die große Ordnung der Natur gebunden, die mit dem Göttlichen gleichgesetzt wird - eine Welt, in der nach dem ursprünglichen Sim dieses Systems alles mit Notwendigkeit geschieht, so daß alle mensehliehe Ziel- und Wertsetzung ihren Sinn verliert. In diesem System des Müssens und der strengen Kausalität ist die Idee der Freiheit begraben, und die religiösen Ideen von Gott und Unsterblichkeit verlieren alle diejenigen Bedentungen, welche die sehnsüchtige Mensehheit früher mit ihnen verbunden hat. Denn unsterblich und ewig ist nur die unverbrüchliche, ewige Ordnung der Natur, die in ihrer strengen Gesetzmäßigkeit uns überall umsehließt. Gott. aber ist niehts anderes wie diese Naturordnung selber, die willenlos und mitleidlos unser Dasein und unser Sehicksal bestimmt.

Dennoch ist dieses große System, das in seiner herben Strenge die Kultur und den Geist bedroht, rom Materialismus sehr weit entfent. Es handelt sich nieht $u$ ein System der Philosophie, das lediglich das Prinzip des Stoffes zur Geltung bringt. Vielmehr stehen im Spinozismus Geist und Materie, psychisehes und physisches Sein in einer notwendigen Korrelation zneinander, und zwar in eincr Wrise, daß beide auseinander nicht begriffen und dureh kein ursächliches Verhältnis aufeinander zurïekgeführt werden kömen. Geist und Materie haben denselben ursprüngliehen Realitätswert. Aber diese beiden Entgegengesetzten folgen doeh sehließlieh nieht aus zwoi versehiedenen letzten Ursaehen, sondern müssen dem monistisehen Charakter des Systems gemäB in einem letzten Grunde rerankert sein. Die eine unendliche Substanz, die Spinoza mit dem Nannon der Gottheit benennt, und die sich restlos in der Natur entfaltet und ansdriickt, ist zwar an sieh genommen rollkommen unbestimmt ihrem Wesen nach, anderseits alser erseheint und enthïllt sie sich in unendlieh vielen Attributen, von denen dem mensehlichen Geist nur dic BewnBtheit als Prinzip les gristigen Letoens und die Rümmliehkeit als Prinzị des körperliehen Geschehens zugängig sind. BewnBtscinsgesetzmäBigkeit mol RammgesetzmäBigkroit durchwalten diese Wirklichkeit. Sie sind Gestaltungen der einen ersten fribtulichen lisilde. Wir dïrfen uns aber das Verhältnis zwischen beiden nicht so vorstellen, als ob etwa die Bewubtscinsgesetzmäbigkeit der Gottheit, die

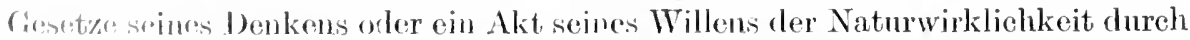

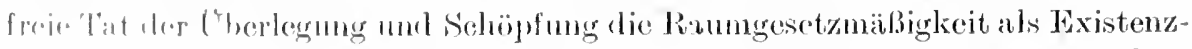
grmul verlinhon häte, sondern ans der willenlosen und einsichtslosen Gotheit 
ging mit gleicher Notwendigkeit das Prinzip des psychischen und physischen Geschehens herror. Die Materie ist ebenso göttlich wie der Geist, und wenn wir das Absohte zu begreifen suchen, so kömen wir es ebensogut im Bilde der Seele wie im Bilde des Körpers erschanen. Es ist gleich wahr und falsch, das Göttliche geistig wie materiell zn denken. Gott kann ebensogut als Raumgesetzmäßigkeit wie als Gesetzmäßigkeit des Denkens gedacht werden.

Es scheint nun aber so zu sein, daß das geistige Prinzip die Gleichordnung und Gleichsetzung mit dem materiellen schlecht verträgt. Das Prinzip des Geistes kann nur dann zu seinem Recht gelangen, wenm das Simmliche ihm gegenüber etwas Sekundäres ist. Wemn das Göttliche ebensowohl in der Materie erschaut wird wie in dem stillen Wertleben der Seele, so scheint das Göttliche selber materialisiert zu werden. Die monistische Vorstellung, die den Dualismns aufheben will, kommt weit mehr der Simnlichkeit als der Geistigkeit zu Hilfe. Da ist es nun die Erkenntnislehre gewesen, die, über alle Bindıng und Gleichordnumg hinausstrebend, auch in diesem naturalistischen System dem geistigen Leben ein gewisses Übergewicht gegeniiber der Naterie gesichert hat.

Gewiß ist das Seelische oder das Psychische im spinozistischen Simne nicht mehr als die Körperlichkeit. Im Rahmen der spinozistischen Metaphysik wird das Psychische ebenso wertfrei gedacht wie das Physische. Beide sind notwendige Produkte gleichgeordneter göttlicher Attribute. Weder bestimmt das Psyehische das Physische noch umgekehrt das Physische das Psychische. Seelisches kann nur durch Seelisches, Materielles nur durch Materielles bestimmt werden.

Aber der menschliche Geist als solcher gliedert sich doch nicht so ohne weiteres in diese psycho-physische Wirklichkeit ein. Seine Úberlegenheit gibt sich schon darin kund, daß er als Wissen ron dem Dinglichen (idea rei) bestimmt wird. Denn dieses Dingliche zerfällt in Körperlichkeit und Geistigkeit, so daß der menschliche Geist augenscheinlich ein Wissen ron der Geistigkeit und der Körperlichkeit besitzt. Er ist idea corporis und gleichzeitig idea ideae. Er ist ein Wissen ron körperlichen Bewegungszuständen und Wissen ron unserem Vorstellungsleben. Damit ist seine Úbermacht gekennzeichnet. Als Wissen ron sich selber bildet er die doppelte Reihe gegenüber der einfachen Reihe der körperlichen Bewegungen. Der menschliche Geist vermag sich über sich selber und über die Sphäre der Körperlichkeit zu erheben.

Indem dann Spinoza die Erhebung des Geistes in die Sphäre des Unendlichen schildert, empfängt er den höchsten Wertcharakter. Wie bei Fichte rerbindet sich auch für Spinoza die Idee des Werthaften, die ja prinzipiell in diesem System keine Stelle hat, mit dem Begriff der Aktivität. In der Gleichsetzung der Aktivität mit Affekt und Leidenschaft offenbart sich der Geist der Renaissance. Es gibt körperliche Affekte, die uns bewegen und bedriicken. die uns Traurigkeit bereiten, und es gibt geistige Affekte, verwandt dem platonischen youns, die unsere Lebenskraft und unser Dasein erhöhen. Der mächtigste Affekt ist die Erkenntnisliebe, die ihre höchste Form findet in dem amor dei intellectualis, in der intellektuellen Liebe zu Gott, welche, da in den Weihestunden des Geistes Gott im Menschen und der Mensch in Gott lebt, gleichbedeutend ist mit der Liebe Gottes zu sich selber. 


\section{r) Das System Leibniz'.}

Das Leibnizische Sistem endlich, das die Renaissance rollendet und aie Anfklärung bestimmt, ist absoluter Idealismus und Spiritualismus, sofern in der Lehre ron den Monaden das in sich ruhende Bewußtsein als geistige Weltwirklichkeit erscheint. Von allen Wertformen trat bei Spinoza nur der Erkemntniswert deutlich hervor, der in der Gotteserkenntnis eine religiösmrstische Weihe erfährt. Anch bei D escart es hatte die Aufwerfung des Willensproblems nur zur Verdentlichung der Erkenntnislehre beigetragen, während die Probleme des sittlichen Lebens in der Affektenlehre zu keiner Klärung gelangen konnten. Die ästhetisehe Vermunft aber fand bei Descartes ihren Ansdruek nur in dem einen schönen Bilde von dem Gotteskünstler, welcher der Seele gleichsam als Siegel die innate Vorstellnng seines Wesens aufdrückt.

In Leibniz' großem metaphysischen System sind die Wertformen deutlicher entwickelt. Die Wirklichkeit als geistiges Leben zu erfassen, wurde ihm erleichtert durch die von ihm zuerst in großem Stile vollzogene Unterscheidung zwischen unbewußten und bewußten Vorstellungen und somit anch zwischen dem unbewnßten und bewnßten Geiste. Der Geist der Natur, der anorganischen und organischen Wirklichkeit, bis zur Stufe der Pflanzen- und Tierform ist der Bezirk des trämmenden Geistes, der schlafenden Monaden, für die es kein helles Erwachen gibt. Der bewußte Geist hingegen manifestiert sich in der Kulturbetätigung. Sein Wesen ist Schaffen und Leisten. Die Natur des Menschen entfaltet sich in dieser Sphäre, die Lebenseinheit jener Monaden, denen begriffliche Klarheit und Dentlichkeit als Ziel der Erkenntnis zuteil wird.

In jeder Monade ruht der ganze Reichtum des Vorstellungslebens nur in mehr oder weniger bewnter und umbewnßter Form. Jener Ranm, den Spinoza die Selbständigkeit eines göttlichen Attributes gegeben hatte - er wird zu einem Produkt der Monaden, erzengt nach der Gesetzmäßigkeit des Geistes. Das Ziel des Menschen ist, wissend $\mathrm{zu}$ sein, sich anfzuklären und die Vorstellungen zu bilden. Insofern hat der theoretische Wert die Leitung und Her'schaft in Haushalt der Monade. Aber wie vermöehte er dies Ziel zu erreichen ohne die sittliche Kraft des Willens. So findet der ethische Wert seine Stelle in dem unwiderstehlichen Drang der Monaden nach Anfklärung. Hier liegt das schwere und strenge Soll, nur nieht lässig zu sein, sondern mit aller Macht des Willens um das Ziel unseres irdischen und göttlichen Daseins zu ringen.

Und anch die asthetisehe und religiöse Wertsetzmng findet sich in der Mctaphysik ron Leibni\%, nur noch in undurehsichtiger Gestalt. So macht sich cin ästhetisches Wertungsmoment geltend, wem Leibniz die Monaden nit (ler mendlichen Fïlle der Vorstellungen ausstattet und sie aus tiefer Verhorgenheit zum gestaltenreichen Dasein erhebt, oder wenn er ihre Begrenztheit nucl Alugeschlossenheit, ihn in sich rulıendes Dascin betont. Ein religiöses Motiv aber scheint in der Vorstelhmg jhror unvergleiehlichen und wnwiederholbaren Eigentïmlichkeit \% liegen, in der Idee, dab jerte Mondule das Weltall anders spiegrelo mol in dem Kusammenhang des Wirklichen nur einmal da ist.

Von roncm gowissen Standpmukt ans kann man sagen, daß die so stark intollektundistisch hrotonte Motaphysik Leibniz' sich in einer ästhetisehen Weltanicht vollenlet. Tis gibt nach Leibniz ane theoretisehe, ethisehe und 
ästhetische Auffassung der Wirklichkeit. Die theoretische bezieht sich in der Hauptsache auf die Natur und verläuft nach dem Satz rom Grunde. Die ethische bezieht sich auf die Kulturmenschheit und wurzelt in dem Prinzip der göttlichen Gnade und Freiheit. Thre Versöhmung liegt in der Idee einer Harmonie zwischen der Natur als dem Reiche der Notwendigkeit und der Kultur als dem Reiche der Freiheit. Schließlich aber erhält die ganze Weltrorstellung noch einen religiösen Überbau, sofern Gott als die Zentralmonade gilt, der die unendliche Mannigfaltigkeit endlicher Monaden in sehmsiichtiger Liebe zustrebt.

\section{s) Der analytische Geist der Aufklärung.}

In der Philosophie der Aufklärung erreicht der Geist der Analysis seine höchste Zuspitzung und Verschärfung. Die Analysis kamm sich eimmal daranf beziehen, daß der eigentümliche Gehait der verschiedenen Wertformen entdeckt wird, das ist das Wesen der positiven Kritik, oder aber die Gültigkeit des Wertlebens selbst wird herabgesetzt und in Zweifel gezogen, das ist der Charakter und die Art der negativen Kritik und Skepsis. Der Geist der Negation war der überwiegende in der Aufklärung, und das hing damit zusammen, dafs das Einzelindiriduum, das Durehsehnittsindividum mit seinem sogenannten gesunden Mensehenverstande zum Richter ïber alle Verhältnisse gemacht wurde. Nicht mit der Göttlichkeit des Absohıten, noeh mit dem Begriff eines erkennenden Ich wude nummehr das Problem der Erkemntnis rerbunden, sondern mit dem psychologischen Einzel-Ich. Aus der Genesis seines Werdens, aus der Art und Weise, wie es zu bestimmten Vorstellungen gelangt, wollte man den Geltungscharakter ron Wissenschaft und Wirklichkeit begreifen. Damals reifte das verhängnisvolle Dogma, daß die Genesis einer Vorstellung für ihren Geltungseharakter entseheidend sei. und der gesunde Menschenverstand war stolz auf dies endgültige Resultat aller Philosophie. Das Problem der Erkenntnis stand im Vordergrund des Interesses, aber nicht das Problem der Erkenntnisbegriindung, sondern die Frage der Erkemntnisentstehung, bzw. wurde die Frage der Erkemntnisentstehung mit dem Problem der Erkenntnisbegründung vollkommen amalgamiert. Auf diesem Wege komnte die Philosophie zu keinen großen Systembildungen gelangen. Der Begriff des Ich wurde ausgehöhlt und ausgeleert. Nichts in der Welt war so arm wie dieses Ich, das alles von auBen empfing. Das Ich erschien als ein unbesehriebenes Blatt, olne Kraft zu bilden und zu formen. Nicht war ihm Erimerung verliehen oder ein gottrerwandter Wille oder eine große Erkemtnisliebe oder der Reichtum einer Welt. Das arme leere Ich wurde von Empfindungen allerlei Art bestïrmt, und diese Sensationen bauen die Seele auf. Wiederum bereitet sich der Typus des Naturalismus vor: nach dem das Ich durch das Nicht-Ieh bestimmt wird und der Geist in Abhängigkeit gedacht wird ron einer fremden Weit. Und zwisehen diesen Sensationen wird ein eigentïmliches System ron Wertunterscheidungen errichtet. Diejenigen, welche zuerst und ursprïnglich in die Seele gelangen, die groben Simnesempfindungen, wie sie Tastsinn und Gesichtssinn rermitteln, und die sinnlichen Bilder von Tisch und Herd, sie sind das zurerlässigste Erkenntnisergebnis. Jene gerade, aus denen der Sophismus das Resultat des Zweifels 
und schließlich der absoluten Skepsis zog, jene, die für P l a to so umproblematisch und deswegen anch ohne jedes philosophische Interesse waren. Die anderen aber, deren abstraktere Natur sie in eine gewisse Ferne von der Sinnenwelt riickte, die Ordnungsprinzipien der Tatsachen und des Geschehens, die Formen ler Wahrheit und schönheit, sie enthüllten sich dem bloß reflektierenden leeren Terstand als blasse Schemen einer unsicheren Induktion, als schwache Kopien primärer sensitiver Impressionen.

Wie nämlich das Ich als Prinzip der Erkenmtnis zn einem hilflosen schatten oder zu einem bloßen Nichts herabgesetzt wurde, so wurden auch die Kulturgüter ausgehöhlt und ausgeleert. Das Primzip der Moral wurde in dem Gedanken des Utilarismus begraben, der Religion wurde aller Reichtum und alle Schönheit genommen. In den dürren Begriffen von Gott, Freiheit und Unsterblichkeit sollte ihr ganzes Wesen enthalten sein. Dabei brachte das philosophische BewuBtsein vor allen das Moralische in eine so enge Beziehung zur Religion, daß es schließlich die Auffassung vertrat, das wahrhaft verstandene religiöse Leben sei das moralische Leben. Der Religion in der Eigentümlichkeit ihrer Erscheinung wurde jeder Geltungscharakter abgesprochen. Das religiöse Leben, so hieß es, ist das primitive Wertleben der Menschheit. Wenn sich die Menschheit besser versteht, wem sie gereift und vollendet ist, damn löst sich die Religion in Moralität und Wissenschaft auf. Als die Wissenschaft schlechthin erschien die Naturwissenschaft, als Moral die Nützlichkeitslehre, die Krunst sollte ihren Zweck nur erfüllen, sofern sie die Wirklichkeit nachahmte. In ihr sollte die simnliche Wirklichkeit mit ihrer ängstlichen Kleinheit noch eimmal da sein. Nachdem dann das theoretische Bewbtsein durch eine zersetzende Kritik den IVertcharakter aller anderen Kulturgebiete in Frage gezogen hatte, ron cinem blinden Haß gegen alle Tradition erfüllt, wandte es die Waffe der Kritik schließlich gegen sich selber und verzweifelte an dem Prinzip, auf dessen vorausgesetzte Geltung es seine ganzen Argumentationen gestützt hatte, um in eine haltlose Skepsis zu versinken. So erleben wir im Zeitalter der Aufklärung (in eigentümliches Bild. Das Zeitalter ist durchaus analytisch gerichtet. Das Zoitalter der Denkfreiheit und Gewissensfreiheit will die Autonomie der Philosophie, der Wissensehaft und Moral gegenüber der Religion, und zwar besonders gegeniber ihrer theologiseh-dogmatischen Fassung proklamieren. Aber das Zcitalter ist nicht imstande, diese Wertgebilde in ihrer Eigenart zu verstehen, und so schrumpfen sie an Ende in nichts zusammen. Insofern ist die Lehre Humes, der die Ideen als Kopien von Tmpressionen bezeichnet hat, durchaus symptomatisch für das analytische Zeitalter der Aufklärmo. Die Ideen, die Wertformen, die Plato als höchste Wirklichkeiten, als Urbilder und Vorbilder rles Scins gedacht hatte, sind Kopien, sehwache Abbilder simnlirher Findrïcke. So komte Fichte mit Recht von aler Idcenfeindlichkeit les \%eitalters der vollendeten sïnlhaftigkeit sprechen.

I) (nnoch hat dieses \%citalter, trotz seiner in allgemeinen ideenfeindlichen Haltung, mzweifelhafte Verdienste um die Horausarbeitung gewisser Wertformen; so ist vor allen] Jingen der simn und Wert des politisch-sozialen Lebens in diencm \%eitalter dentlieher verstanden und dam besonders auch eine geschichtsphilosphische Besinmung durch die Herausarbeitung des Fortsehrittsbegriff armöglicht worden. 
Das Zeitalter der Aufklärung war gar zu sehr ron praktisch-politisehen Interessen oder ron reformatorischen ldeen erfüllt, um Zent und MuBe zu haben, den großen Gegensatz von Idealismus und Naturalismus, welcher der einzig prinzipielle in der Philosophie ist, sofern in ihm die Grundprinzipien der Philosophie, Form und Inhalt in der Weise ausgebaut sind, daß in dem System des Idealismus die Form, im Materialismus und Naturalismus aber der Inhalt das Bestimmende und Entscheidende ist, $u m$ diesen grundlegenden Gegensatz in mommentaler Weise zu gestalten. Berkley, der den Standpunkt des Idealismus vertrat, zerstörte den Begriff der materiellen Substanz und löste die ganze Wirklichkeit in ein Reich geistiger Substanzen anf, die ron Gott als der höchsten geistigen Substanz das Geschenk der Erkenntnis empfangen. Der 'Typus des Naturalismus fand für das, was er sagen wollte, keinen großen und geschlossenen Ausdruck. Der Sensualismus lehrte, daß wir allen Erkenntnisinhalt dureh die Sinne erhalten, daß der Intellekt durch die Impressionen bestimmt wird, und daß die primären Impressionen die zuverlässigsten sind. Der Positivismus behauptete, daß es überhaupt unmöglich sei, irgendetwas zu wissen anßer den Tatsachen der Impressionen und den Tatsachen ihrer Sukzession und Koexistenz. Der Materialismus endlich remeinte, daß dieses Etwas, das Ich, die Seele, das Subjekt, dessen Ohmmacht ja die Philosophie schon hinlänglich erwiesen hatte, aus einem anderen Stoff gebildet sei als die Simnenwelt, und behauptete, daß es sich bei dem Erkenntnisprozeß 1 m ein Zusammenwirken rerschiedener Energieformen handle, in die sich die eine Materie spezialisiert habe. Man fand es geistreich, den Menschen a Is eine Maschine zu bezeichnen, ohne den göttlichen Ingenieur noch femer anzuerkennen, dem man war zu der Úberzengung gelangt, daß die Hypothese der Gottheit überflüissig sei. So war das letzte Wort des großen analytischen Zeitalters, das alle Verhältnisse rationalisieren wollte. der Kultus der Vermunft in der Haterie.

\section{t) Die Systeme des deutschen Idealismus.}

Mit den Systemen des dentschen Idealismms und den Theorien der Romantik beginnt ein neues synthetisches Zeitalter, das letzte, von dem wir cin Wissen haben, ein Zeitalter, das noch das Gegenwartsleben der Philosophie bestimmt. Dies Zeitalter bedentet somit für uns das letzterkennbare große Symbol der endgiiltigen Einheit, die wir mer dem Bilde der irdischen Glückseligkeit und schließlich unter dem Ende aller Dinge verstehen, da der Wertgegensatz ïberhaupt zur Ruhe gebracht ist.

Durch die Schule der Aufklärung gereift, war die Menschheit rorbereitet für die Einsicht, daß es verschiedene Gebiete des geistigen Lebens gibt, die für sich bestehen, ihren eigentümlichen Charakter haben und ihrem besonderen Sinn gemäß nicht miteinander kollidieren, wemn sie auch rermöge der ganzen Härte der Lebensgestaltung und rermöge der Begrenztheit des individuellen Lebens immer wieder in Streit und Hader geraten. Trsprïnglich hatte der Philosoph den prophetischen Dichter als seinen Feind empfunden, und auch der sittlich religiöse Reformator hatte die Kunst und die Schönheitsgestaltung des Lebens bekämpft. Später war ein scheinbar unüberbrückbarer Gegensatz 
zwischen Philosophie und Religion, Glaube und Wissenschaft herrorgetreten, und die Wissenschaft ron den psychisehen Phänomenen ging darauf aus, das Grundprinzip alles sittlichen Lebens, die Idee der Freiheit in ihrem Geltungscharakter anzuzweifeh. Das Imperium und Sacerdotium hatten sieh tödlich bekämptt mit ihren entgegengesetzten Ansprïchen anf weltliche und geistliehe Macht. Gegen die Fordermngen des Rechtes lehnte sich die Reinheit des sittlichen Bewußtseins auf.

\section{1) Kani.}

Dieseı Zerwürfnissen und Gegensätzen des vernumurgen Lebens gegenüber, deren Härte der Mensehen sehweres Schicksal, deren Größe die Großartigkeit der mensehliehen Entwieklung hervorgebracht hat, unternahm es Kant, den einzehnen Kulturgebieten ihre Grenzen zu setzen, den Simn der verschiedenartigen Kulturmächte zu deuten und den Zusammenhang zwischen den Getrennten aufzuweisen. Die Kritik sollte deutlich machen, wie jedes Wertgebiet in seinen eigentünlichen Begründıngsprinzipien ruht, von denen aus allein sein eigentïmliches Wesen erhellt. Denten wir den Sim der Wissenschaft, die anf Erkenntnis der Sinnenwelt abzielt, so muß als Erkenntnisprinzip der Kausalitätssatz eine entseheidende Rolle spielen, aber die Idee der Freiheit kam in den Grenzen dieser Problemstellung niemals rerstanden werden. Die Freiheit ist die einzig zutreffende Antwort anf eine ganz andere Frage, die mit wissensehaftlicher Erkenntnis nichts zu tmn hat, nämlich anf die Frage: wie ist sittliches Leben möglich? Der ästhetisch wertvolle Zustand, in dem Verstand und Einbildungskraft in Harmonic gesetzt sind, kann der Erkenntnis nur hinderlieh sein und muß in bezug auf die sittliche Lebensgestaltung als vollkommen indifferent ausscheiden. Daß ein gänzlich verschiedenartiges Verhalten, eine verschiedene Einstelhung und besondere Prinzipien in jedem einzehen Falle erforderlich sind, um die Gesamtheit des Wirklichen in Natur, Kultur und Leben der Erkemntnis zugänglich zu machen, das gehörte zu dem ganz Nenen der Entdeckung Kants. Die frühere Philosophie kannte nur einenallmähliehen Aufstieg der Frkenntnisfunktionen und erhob etwa in diesem simne das Wissen über den Glauben oder suchte anch wohl, wie im alexandrischen Zeitalter, die verschiedene Zustände des wertanerkemnenden Subjekts als Stufen seiner Erlösmng von der Wirklichkeit zu begreifen. Kant denkt diese verschiedenen Bew utseinsformen und Bewubtseinstagen nicht in einer steilen Hierarehie, sondern als frei für sieh dastehrude Wristelhmgen, die keine Unterordnung vertragen. Der theoretisehe, der roligiöse und der ästhetisehe Menseh sind einzigartige Typen, die in keinem Subordinationsverhätnis stehen. Das endlieh erkemente Bewntsein ist eine cigentiimlicho l'osition der Weltstelhung und kam von lem ästhetischen Subjokt nieht ïberhol, werden. Aber anch das erkemende Subjekt mit seiner theroretisehen Einstellung von Begriff und Anschanung kann niemals die ahichtslose ästhetisehr Betrachtnng und ihren Gegenstand ïberwältigen und

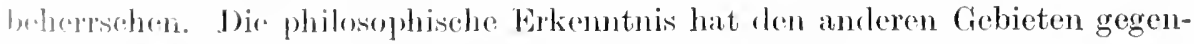
iiber ror allan nur diese Uberlegenheit, dabs sic ihren Sinn zu denten vermag,

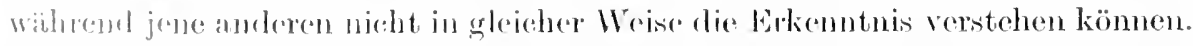

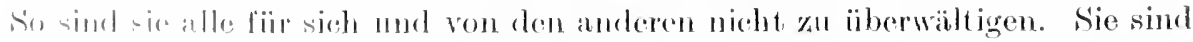

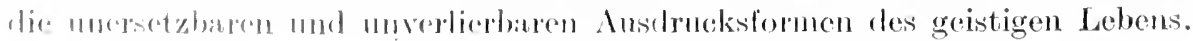


Niemals kamn die Religion ron der Philosophie, die Philosophie von der Wissenschaft oder die Moralität von der Kunst abgelöst werden. Sie sind im Verhältnis. zueinander und auch dem Leben gegenüber autonom. $\mathrm{T}$ m zu versehiedenen Wirklichkeiten Stellung zu nehmen, um verschiedenartige Welten zu verstehen. ist es notwendig, daß dor Mensch von einer Bewnßtseinslage in die andere, von dieser geistigen Stelhungnahme in jene übergeht, oder, wic die Romantiker sich mit einem künstlerischen Bild anszudrücken liebten, es ist notwendig, daß der Mensch sich verschieden stimmen kann. Zugewendet dem Bilde cler Schönheit und dem Gegenstande der Forsehung, darf er nicht denselben Funktionen des Geistes in gleicher Form zugewendet sein, sondern er muß ein anderer sein, sofern er von einemanderen Wert bestimmt ist. Was gewiB nicht anssehließt, da B hinter dieser rerschiedenen Wertstelhung eine einheitliehe Persönliehkeit steht. Bleibt die Persönhichkeit starr in einseitiger Pose, so kann sich das All ihrem Verständnis nicht erschließen; - erst wenn sie sich verschiedenartig bestimmen läßt, vermag sie in das Ganze der Wirkliehkeit Einschau zu halten. Dem Philosophen ist die Möghichkeit gegeben, das theoretisehe Leben und gleiehzeitig auch anderes Leben, wie das ästhetisehe und das sittliche. zu deuten. Die Anerkennung des theoretischen Wertes führt zur notwendigen Besinnung anf die Begründungsprinzipien aller Wissenschaft. Dem sittlichen und ästhetischen Gegenstande gegenüber befindet sieh die Philosophie in einem Zustande höherer Fremdheit, weil sie es mit dem Atheoretischen zu tun hat. Wir können uns eine Philosophie denken, die den Gegenstand des sittlichen Lebens verneint: will sie aber sittliches Leben deutend verstehen, so kann sie das nur unter Voraussetzung der Gültigkeit sittlicher Normen, die sich in der Idee ker Freiheit rollenden. So wird die philosophische Spekulation durch jede nene Wertanerkennung weiter getrieben und die philosophische Erkenntnis immer reicher und fruchtbarer gemacht. Wenn die Dentung des wissenschaftlichen Lebens in der Kritik der reinen Vernunft das metaphysische Verlangen noch nicht befriedigen komnte, sofern die transzendentalen Ideen wohl zahllose Hinweine auf die übersimnliche Welt enthielten, selber aber noch von ihrer höheren Heimat ausgeschlossen blieben, so vermochte die Philosophie der Moral die übersinnliche Welt als die Welt der Freiheit und der autonomen Persönlichkeiten sinnvoll zu erschließen. So entsteht der Philosophie aus dem Problem des sittlichen Lebens der denkbar höehste Gegenstand, und wem man darauf ausgeht, zu erforschen, was wohl die einzelnen Formen im Zusammenhang der geistigen Wirklichkeit bedeuten. so ergibt sich etwa folgendes Resultat: das theoretische BewuBtsein führt zum Verstehen der Totalität der Wirklichkeit, der Natur- und Kulturwelt, des simnlichen und Übersinnlichen; aus der Reflexion über das sittliche Leben entspringt der Philosophie das höchste Prinzip in der Sollensgesetzgebung und der Idee der Freiheit; die Bestimmung des ästhetischen Gegenstandes führt endlich zu der Einsieht, daß im Leben der Vernunft bei aller Selbständigkeit der einzelnen Teile, die keine Unterordnung dulden, doch ein Zusammenhang besteht; die Kritik der Urteilskraft stellt die Verbindung zwischen der theoretischen und praktischen Philosophie her.

Schon Kant hat gezeigt, daß die Probleme der theoretisehen Philosophie zu denen der praktischen hintreiben, und daß die Philosophie der Kunst den 
Abschhß des Systems und die Terbindung der getrennten Teile herstellt. In der Durchforschung und Deutung der drei Gebiete gelangt die Philosophie mit Rücksicht auf das Absolute zu einer immer neuen Bestimmung ihres höchsten Gegenstandes. Im Sinne der theoretischen Philosophie ist Gott der intuitive Verstand, der den Gegensatz von Begriff und Ansehanung überwunden hat, im Sinne der praktisehen Philosophie der heilige Wille, in dem der Gegensatz von Pflicht und Neigung überwunden ist, im Sinne der Ästhetik das ,übersinnliche Substrat der Menschheit", das die Antinomie zwisehen der Begrenztheit des Begreifens und der Unendlichkeit der Anschaunng, sowie zwischen der Ohmmaeht des mensehlichen Willens und einer übermenschlichen Kraft in der Torstellung das Erhabenen zur Ruhe gebracht hat. Die Vexbindungen, die das philosophische Bewutsein vollzieht, indem es die rerschiedenen Kulturgïter zum Gegenstand der Reflexion macht, stiftet keine Tnterordnung, sondern eine Einordnung, indem die Fülle der Kulturbeziehungen in einem großen Simnzusammenhang begriffen wird.

Kant ist es gewesen, der das Ich der Erkemntnis am tiefsten gelebt und verstanden hat. Er hat die Position des Ich ein für allemal zum Ausgangspunkt der Erkenntnislehre erhoben. Er hat die große Altemative eingesehen, daß im Grunde genommen nur zwei Standpunkte in der Philosophie möglich sind, daß nämlich entweder der Gegenstand das Ich möglich macht oder das Ich den Gegenstand. Die subjektivierende Auffassung Kants, die das Ich als das Bestimmende erkemnt, formuliert den durch sie vertretenen Standpumkt näher dahin, daß das Ich den Gegenstand möglich mache, nicht seinem Dasein nach, sondern seiner Erkenntnis nach. Das endliche erkennende Ich, das Prinzi] der theoretisehen Philosophie muß dahin verstanden werden, daß es niemals das Gewordensein des Gegenstandes erklärt, die Ursachen, die dahin geführt haben, daß er so ist, wie er ist, wohl aber seinen Erkemntnischarakter. Dic Lehre vom Ich läßt uns einsehen und verstehen, daß der Gegenstand nichts Fremdes und Jenseitiges ist. Wäre der Gegenstand ein Etwas, das nichts mit Geist und Sim zu tum hätte, so müBte es als vollkommen ausEeschlossen gelten, daß der erkennende Geist irgendein VerhäItnis zu ihm sewinnen kömnte. Ratlos und hilflos stïnde er einer fremden Welt gegenüber, ohne Hoffmmg und Anssicht, jemals in sie einzudringen. Und ist der Gegenstand nicht nur fremd, sondem gar hestimmend für die Struktur des Ich, so bedrängt uns dieses Fremde mit rätselhaften Zeiehen, mit Charakteren, lie wir unmöglich verstehen kömmen, weil sie einer geistesfremclen Welt entstammen. Jam drückt us das Nicht-Ieh gewaltsam cine fremde Signatur auf, gegen die wir ms nicht wehren kömnen, wir sind Sklaven der Dinge, beherrseht von ihrer fremden, uns wesensfeindlichen Gesetzgebung. Niemals ist so din Verstchen denkbar, das Wirkliehe bleibt mbekannt. Oder - der kopernikanische Standpmukt gilt, mol die Gosetzgebung der Dinge erweist in als die Gesctggebung moneres Geistes. Dann int die Natur nicht mehr vine fremrle Welt, somlern etwas, das zu ums gehört, ein Vertrautes und Ver"andtes, das wir denten und rerstehen kömen. D)am hat muser Denken oder muscre Fokenntnisfunktion alles das an dem Gegroustande gebildet, was uns

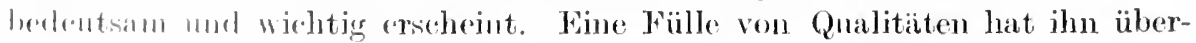
formt, in zahlroiche Jexichungen ist er gesetzt, und all diese Uberformungen 
gehen zurück auf die Funktion der Erkemntnis, und all diese Beziehnngen hat das Denken gestiftet. Wenn überhaupt Erkemtnis möglich ist, und in den weiten Bezirken der Natur ïberall ein rernünftiger sim ruht, wem es wahr ist, daß wir mit Erwartungen an sie herantreten, die ihre Erfüllung finden, daß wir mit ihx rechnen, sie in mseren Dienst stellen und beherrschen kömnen, dann wird es wohl so sein, daß unser Denken der Natur das Gesetz gibt, denn es ist doch wohl ummöglich, daß wir etwas ancleres in der Natur erkennen als dasjenige, was wir selber in sie hineingelegt haben. So ist alles Große in der Natur, was die Antike so sehr bewundert hat, die strenge Ordnung und Gesetzmäßigkeit, die wir ïberall in ihr vorfinden, ein Produkt unseres Geistes. Und jenes Staunen, das bisher der fremden Welt da dranßen galt, wendet sich nummehr endgültig der Welt des inneren Erlebens zu.

Mit dieser neuen Form des Idealismms ist die Wendung zur Innerlichkeit vollzogen, die der Philosophie der Dentschen um die Wende des 19. Jahrhunderts ihr großes Gepräge gibt. Wie reich ist doch das remünftige, das denkende Ich in der Fülle seiner Formen gegenüber der Natur als bloßem Formungsstoff! Wie mächtig ist doeh dieses Ich, das die Welt schafft, so wie wir sie anerkemnen. Alle Gliederung, Ordnung und Schönheit, die wir vorfinden und erleben: im Ich ist sie begründet, denn rom Ich geht alle Simngebung aus. Ohne das Ich keine Welt der Dinge, ohne das Ich keine Gesetzmäßigkeit der Dinge. Die Natur ohne das Ieh ist ein dmmpfes Chaos, die absolute Sinnlosigkeit ungeordneter Elemente. Das Ich der Erkemntnis, das vernünftige Denken überhaupt, hat diese Welt so reich und so sehön gemacht. Die trübe Sinnenwelt ist durch das Ich zum Wohmplatz des Geistes erhoben und geläutert.

Wenn nun das Ich der Welt der Erscheinungen gegenüber so mächtig ist, sofern es die simmliche Natur recht eigentlich schafft und in dieser seiner Schöpfung sich versteht und wiederfindet, so ist ihm doch auch wieder eine absolute Grenze gesetzt. Erfolgreich und bestimmend ist das endlich erkennende Ich, wie es in der Wissenschaft sieh entfaltet, nur gegenüber der Simnenwelt, aber über die Erfahrungswelt reicht seine Funktion nicht hinaus. Denn der Stoff der übersinnlichen Welt, die für Kant eine absolute Gewißheit war, ist dem erkennenden Ich niemals gegeben, und das Bewubtsein hat auch keine Formen zur Bestimmung des Ubersimnlichen. Seine sieghafte Position gegenïber dem Sinnlichen muß der erkennende Geist mit Ohmmacht und Verzicht gegenüber dem Unsimlichen erkaufen. Die Geltung der theoretischen Prinzipien ist begrenzt und anf den Erfahrungsstoff ein fïr allemal zugeschnitten. Das Subjekt der Erkenntnis begrenzt sich mit seinen Formen, es kam nicht über sich hinaus, und die logischen Fordermugen, die von ihm ausgehen, können nur in der Diesseitigkeit ihre Erfüllung finden.

Den Formen der theoretischen Erkenntnis mangelt somit die Absolutheit. Gegenüber dem Unbedingten müssen sie versagen. Ihr ganzer Sim und Bedeutungsgehalt steht und fällt mit der Simnenwelt. Weil sie ihre Inhaltserfüllung in der Simmenwelt finden und in ihrer Leistungsmöglichkeit auf diese beschränkt sind, hat man den Kategorien Kants den Vorwurf der Formalität und Relativität gemacht. Diese Vorwïrfe sind umberechtigt, sofern die logischen Kategorien sowie die Formen von Raum und Zeit der sinn- 
lichen Inhaltsbestimmtheit gegenüber doch ihren logischen Eigensinn haben. Es ist nicht die Hinwendung zu einer besonderen sinnlichen Inhaltlichkeit iiberhampt, welche die Form der Erkenntnis zur Form der Kausalität macht, so daß das Moment der Spezifikation und Besonderung ausschließlich in dem Prinzip des Inhalts läge. Jede Form trägt ihren Simn in sich und ist durch Bestimmungen ausgezeichnet, die sie ron jeder anderen Form unterscheiden. Und wem anch die Kategorien nicht in dem Sinne absolut sind, daß sie als in sich ruhende Werte über die Sinnenwelt hinaus für alle Zeit gelten, so gelten sie doch mit Notwendigkeit, solange endliches Erkenmen gilt und Stoff der Erfahrung dem endlichen Bewußtsein zur Bestimmung gegeben ist.

Aber mit dem Begriff der Kategorie der Erfahrmng ist die philosophusche spekulation noch nicht am Ziele, demn diejenigen Prinzipien, die für die Philosophieselber am wich tigsten sind, entbehrten noch bisher eler philosophischen Besinnnng. Die Ideen sind die wichtigsten Gegenstände der Philosophie. Sie fïhren inmer wieder auf die Frage der übersinnlichen Welt, und wenn wir die ïbersinnliehe Wirklichkeit, diecin notwendiges Postulatunseres Denkens ist, auch niemals im wissensehaftlichen Simme begrifflich verstehen können, so vermögen wir doch auf die allgemeine Frage nach ihrer Bedeutung und nach ihrem Simn Antwort zu geben. Die Frage der Unsterblichkeit und Unzerstörbarkeit der Seele, das Problem des notwendigen Wesens, die Idee der Freiheit und der Begriff der Gottheit, sie sind keinerlei Forderungen des theoretischen BewuBtseins. Die wissensehaftliche Welt ist erklärbar auch ohne sie. Erst wenn wir das sittliche Leben zu deuten suchen, damn sehen wir die Notwendigkeit dieser Idecn ein. In der Kritik der reinen Vernunft erscheinen sie als unerlaubte, nicht zu rechtfertigende Überspannungen des kategorischen Denkens. Thre theoretischen Ansprüche müssen die Ideen fallen lassen, es gibt keine Metaphysik der Natur: das wahrhafte Interesse, das die Vernunft an den Ideen nimmt, ist das Praktische. Nach der philosophisehen Einsicht in den Charakter dor Wissenschaftslehre werlen wir in die Dialektik der Vernunftideen eingeführt. Ihre Richtung auf das Unbedingte seheint unberechtigt zu sein vom Standpunkt der Wissenschaft und der Erfahrungserkemntnis ans, mul doch ist ein für allemal alles philosophische Interesse mit ihnen verknüpft. Sie reichen an das ferne Land muserer Sehusueht heran und umstehen als große, stumme Schatten die unbekannte Schwelle. Sie können nicht laut werden: die theoretische form hat keine Hcimatstelle im Reiche des Ubersinulichen, ihr Simn für das Chersimnliche ist uns verborgen. In theoretischer Hinsicht sind wir Bürger dieser brde und haben keine Verbindung mit der übersinnlichen Welt. Wir sind gebengt unter rlie Gesetzgebung des Müssens, unter die Norm der Kausalität, lic für ms als Erseheinungswesen gilt, und ler wir bedingungslos unter-

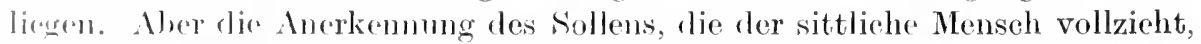
fïhrt zur Gesetzohomg der Freiheit. Jene Ideen, die als bloße Sehemen und Sidaten ror das Antitz der theoretischen Vernunft traten, sie ompfangen unn anf rimmal aimen mnenthohrlichen Kimm als Vormunftorderungen des sitłlichrol Ixhens. Soforn die Thilosopinie das sittliehe Jeben versteht und

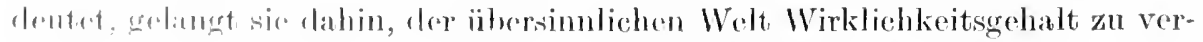

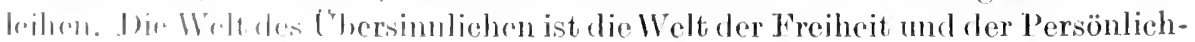


keiten, wo das Gebot der Not und des Müssens getilgt ist und alles in schöner Freiheit das Seine tut.

Kant war ein großer Entclecker auf dem Gebiet der Werte. Er hat zuerst die Autonomie des ästhetischen Wertes zu begründen unternommen, der allerdings durch seine Lehre von dem Erhabenen und den ästhetischen Ideen in ein gewisses Subordinationsverhältnis zur Ethik gerüekt wird. Er hat dam weiter das rechtliche und sittliche Gebiet mit hoher Eindeutigkeit geschieden und die Wissenschaft von der Philosophie deutlich abgegrenzt. Die im engeren Simn theoretische Erkemmtnis der Naturwissenschaft ist nur eine Provinz im Reiche des vemünftigen Denkens. Die Wissenschaft und ihre möglichen Ergebnisse, sowie die Prinzipien, auf denen sie beruht, sind durchaus nicht das interessanteste Objekt der philosophischen Deutung. Die Betrachtung der Geisteswelt in Religion und Geschichte, Kunst, Recht und Sittlichkeit führt die philosophische Spekulation sehr viel weiter. Die Philosophie aber ist es, die mit ihrer deutenden Funktion in allen Gegenständen der Wirklichkeit lebt und durch ihre Methode die getremnten Gebiete zusammenschließt.

Das geringste Verständnisma $B$ hat $K$ ant dem religiösen Wert entgegengebracht. Er hat ihn in ein gar zu nahes Verhältnis zur Ethik gerückt und vermochte auf diese Weise seiner Eigentümlichkeit nicht gerecht zu werden. Seine ethische Spekulation war zu dem Resultat gekommen, daß die Sittlichkeit endlicher Wesen in dem notwendigen Gegensatz von Sein und Sollen, von Pflicht und Neigung wurzle und begründet sei. Die Sittlichkeit erweist sich in der Anerkennung des Sollens, das sinngemäß das Sein bestimmt, in der Betrachtung des Gebotes, vor dem die Neigung verstummen muß. Durch die Bejahung des Sollens und seiner Gesetzgebung gewimnt der Mensch die Reinheit des Willens und das Verhältnis zur ïbersinnlichen Welt. Diese Beziehung zur übersinnlichen Welt führt den notwendigen Konflikt mit der Sinnenwelt herbei. Die Größe des sittlichen Lebens offenbart sich nun sowohl in der Härte und Schwere des Gegensatzes von Pflicht und Neigung, wie sie heroischen Naturen eigen ist, als anch in der Tendenz, jene Gegensätze in Einklang zu bringen. Das Ideal einer solchen harmonischen Vereinigung von Pflicht und Neigung liegt auf dem Wege zur Reinheit des göttlichen Willens, der in seiner Heiligkeit den Gegensatz ron Sein und Sollen iberwunden oder die Seinsgesetzgebung in der Sollensgesetzgebung aufgehoben hat. Die Spannung des Gegensatzes ist dem ästhetischen Ideal des Erhabenen, sein harmonischer Ausgleich dem ästhetischen Ideal der Schönheit verwandt. Ein Wille, der das Sollen nicht bejaht, lebt lediglich der Simnenwelt. Er hat die Unschuld und Gleichgültigkeit des bloßen Trieblebens und ist weder gut noch böse.

Das Böse ist für Kant ein religionsphilosophischer Begriff, wird aber im engsten Zusammenhang mit der Ethik deduziert, wie ja auch die Ideen des Heiligen, der Unsterblichkeit und der Gotheit von der ethischen Problemstellung aus deduziert werden und hier die Reinheit der antonomen Ethik notwendig bedrohen müssen. Kant hat den grumdlegenden Gegensatz des religiösen Lebens nicht deutlich zu machen gewußt, so mußte diese Sphäre in der Abhängigkeit von der Ethik verharren. 


\section{v) Der Geist der Synthese in der Philosophie des dentschen Idealismus.}

Die großen Nachfolger Kants, die Verkünder des deutsehen Idealismus, haben die versehiedenen Möglichkeiten zur Systembildung, die in Kants Philosophie vorlagen, nach entgegengesetzten Seiten zum Austrag gebracht. Sie alle beschäftigt das Problem eines leitenden Wertes, von dem aus der ganze Wertkosmos begriffen werden soll. Gegenüber dem analytisehen Charakter der Renaissance und Aufklärung ist dieses neue Zeitalter vom Geist der Synthese bestimmt. Und der Gedanke einer höchsten Synthesis alles wertvollen geistigen Lebens zentriert sich in dem Begriff des Unbedingten und Absoluten. Die religiöse Vorstellung der Gottheit wird in der Philosophie als das Absolute gedacht. Diesen Begriff des Absolnten kennt die Philosophie Kants nieht. Das Absolute ist dort gleichsam aufgeteilt in ein höchstes theoretisehes, praktisches und ästhetisches Ideal. Der theoretische Begriff des Absoluten als das höchste Ideal der Erkenntnis ist die Idlee eines intuitiven Verstandes. Der ethische Begriff des Absolnten als das höchste Ziel des sittlichen Strebens ist die Idee eines heiligen Willens. Der ästhetisehe Begriff des Absoluten, der vor allem im Eindruck des Erhabenen sich entfaltet, ist die Idee eines übersimnlichen Substrats der Mensehheit. Fichte, Schelling und Hegel haben im Gegensatz zu Kant wieder einen Begriff für die Totalität des Absoluten in ihren philosophisehen Systemen aufgestellt, in dem alles Sein und aller Wert sieh vollendet. Dieser Begriff, der als Einheit aller Wertgegensätze notwendig iiber die Einseitigkeit cines einzelnen Werteharakters hinausgehen muB, hat in den drei großen Systemen des dentsehen Idealismus vermöge der Orientiermng an einem bestimmten Wert drei ganz verschiedene Ausprägungen erfahren. Kant hat den Zugang in das Reich der übersimnlichen Welt von der Dentung des sittlichen Lebens her gefunden. Fiehte versteht das Absolute der Philosophie in seiner ethisehen Dentung als Sollen und Tat. Kant hatte das Gebiet des Asthetischen als clas Zwisehenreich zwisehen dem Theoretisehen und Ethisehen verstanden. Sehelling versteht das Absolute der Philosophie in seiner ästhetisehen Deutung als Identität und absolute Harmonie. Kant hatte in dem erkemenden Subjekt die Form der Form anfgewiesen, die alle Gebiete des Geistes umfängt und durehdringt. Hegel hat in dieser Einheit der philosophisehen Methorle dis Wesentliehe in dor Philosophie erkamt, und er versteht clas Absolute in seincr theoretischen Dentung als die Vollendung des logisehen IVeges, der von Form zu Form, von Problem zu Problem geht und sich in der Irlee rles Absoluten als clem Ziel aller Erkenntnissehmsneht erfüllt. Dabei ist das Absolute dieser drei systeme atueh immer von Bestimmungen des religiösen Wrates erfïllt, die sehlicßlich so selbständig gerlacht werden, daß im innigen '/llsammenhang mit der romantischen Kultur der religiöse Wert in seiner Eigentïmlichkeit von der Philosophie gedentet und zu einer selten großen Darstellung gereriaht wirk.

\section{w) Fichte.}

Jichtes rthischer Irlealismus hat die gewhichtsphilosophiseh so bedent-

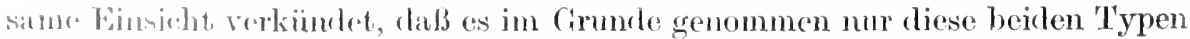
phifusphischer fisstence gibt, den Irlealismus und den Naturalismus, von denen 
der eine nach der berühmten Formuliermug Kants dadurch gekennzeichnet ist, daß die Vorstellung den Gegenstand möglich macht oder das Ich das Nicht-Ich bestimmt, während nach der Auffassung des anderen der Gegenstand in seiner sinnlichen Struktur die Vorstelhung möglich macht oder das Nicht-Ich das Ich bestimmt. Der Idealismus ist das System der Freiheit, denn er setzt voraus die Anerkennung des Sollens und versteht die höchsten Prinzipien der Erkenntnis als Werte und Normen. Dagegen ist der Naturalismus in seiner realistischen Auffassung der Welt das System der Notwendigkeit im Sinne des Müssens. Sein höchster Begriff ist das Seiende, die Substanz, und er versteht die letzten Prinzipien der Wirklichkeit und Erkenntnis als Seinsgesetzmäßigkeiten. Der Idealismus ist dem Materialismus und Naturalismus überlegen, sofern er ihn deuten und die verborgenen Wertvoraussetzungen, die er macht, aufweisen kann. Dagegen kann der Materialismus den Idealismus niemals begreifen.

Die Position Fichtes ist der absolute Idealismus, der dahin bestimmt werden muß, daß hier das Ich oder das Bewußtsein den Gegenstand möglich macht, nicht nur nach seiner Erkenmbarkeit, sondern auch nach seinem Dasein. Mit anderen Worten: das Ich des absoluten Idealismus ist kein erkenntnistheoretisches, sondern ein metaphysisches Ich. Das göttliche Ich hat die Welt der Gegenstände durch freie Tat erzeugt. Diese Freiheit des Bewußtseins, die im Anerkennen und Verwerfen, im Bejahen und Vermeinen zum Ausdruck kommt, ist Existenzbedingung und Erkenntnisbedingung der Gesamtwirklichkeit. Das freie Tm ist reine Tätigkeit, die allem Sein vorausgeht. Am Anfang war die Tat, nicht der Sinn oder die Kraft. Dieses reine grenzenlose Tun, das der Schöpfertätigkeit des Künstlers verwandt ist als Idee einer wahrhaft produktiven Einbildungskraft, erstarrt unter dem erkenntnistheoretischen Gesichtspunkt zu der Vorstellung eines Sollens, einer moralischen Ordnung der Weit. clie umbedingte Anerkenmung fordert. Das absolute göttliche Ich entfaltet sich in zwei entgegengesetzten Tätigkeitsrichtıngen, von denen die eine emanatistisch anf das Unendliche gerichtet ist, ein unaufhaltsam rordringendes Tnn, die andere dagegen das Prinzip der Begrenzung zum Ansdrnck bringt. Diese läßt uns den Gegenstand als absolute und feststehende, jene als beweghiche und relative Grenze erscheinen. Die begrenzende Tätigkeit ist die Offenbarung der theoretischen, die unendliche die Offenbarung der praktischen Vernunft. Beide sind erforderhich, um Erkenntnisgegenstände zu erzeugen und Erkenntnissinn zu verstehen. Die begrenzende Tätigkeit ist Symbol der antiken, die unendliche Symbol der modernen romantischen Kultur. Die unendliche Tätigkeit bestimmt die endliche, $\mathrm{k}$.h. die praktische Vermunft ist der theoretischen übergeordnet, und der Sinn des Gegebenen ist nur aus der praktischen Philosophie zu verstehen. In der unendlichen Tätigkeit liegt jener göttliche Impuls, der immer wieder über das Objekt als das Produkt der beiden Tätigkeiten hinanstreibt. Denken wir das Problem der theoretischen Ternunft zu Ende, so müssen wir doch immer schließlich vor der Tatsache Halt machen, daß wir von einem anderen abhängig sind, das uns bestimmt. Dieses andere vermag die praktische Philosophie noch aus der Natur des Ich zu erklären, so daß unter dem höchsten philosophischen Gesichtspunkt alle Hemmungen und alle Schranken beseitigt und aufgehoben sind. Die Schranke ist da, um immer wieder überwnnden zu werden. An der Größe des Widerstandes erprobt sich die Kraft. Darin ist der 
Sinn der Tielt beschlossen, daß sich das Ich immer wieder neue Objekte zum Gegenstand des praktischen Handelns, als Material der Pflichterfüllung setzt.

Der Idealismus Fichtes verbindet mit der Position des bestimmenden Ich a uf das engste den Gedanken der Spontaneität und des Tuns, und das Besondere nnd Einzigartige dieser Philosophie ist es doch schließlich, daß sie das Tun mit dem Wert gleichgesetzt hat. Alles Tun ist wertvoll, nach welcher Seite es auch gerrendet sein mag, und nur eins ist rom Úbel, nur eins ist schlecht und böse, die Aktionslosigkeit, Trägheit und Faulheit.

Tom Standpunkt dieses ahsoluten Idealismus aus hat die Erkenntnis ein weites Feld. Wir wissen den Grund unseres Begrenztseins, wir entdecken den Simn unseres Lebens im machtrollen Handeln, und wir verstehen rom Sinn des Lebens ans den Simn der Welt. Wir erkemen die Gottähnlichkeit unseres Tuns und könmen unsere Bestimmung erkennen und c ngreifen. Dennoch bleibt für Fichte das göttliche Absolute in der Hauptsache unbestimmt. Wir wissen es als Wert und Sinn, als Sollen und Weltordnumg, als mendliche Tätigkeit und als Ziel unseres Strebens, aber wir wissen es nicht in der Fülle seiner Qualitäten. So sind wohl die Formen unseres Denkens, durch die wir das Gegebene ordnen, in ursprïnglichen Vernmfthandlungen des göttlichen Wesens begründet, aber wir kemnen diese Handlungen und Aktionen nicht in ihrer reinen Göttlichkeit, sondern nur in Spiegel der endlichen Reflexion, indem jene ursprünglichen Aktionen dem endlichen Bewußtsein als Normen und Fordermingen entgegentreten.

\section{x) Schelling.}

Der große Philosoph der Romantik, Joseph Schelling, hat dann in seinem ästhetisch orientierten Idealismus zuerst mit dem Gedanken Ernst gemacht, daß das Göttliche als die Eimheit, Identität und Harmonie der Wertgegensätze zu begreifen ist. Gott ist die Eimheit der Gegensätze, auf denen sich lie verschicrlenen Wertgebiete aufbanen. So besteht etwa für das religiöse Bewrobsein des Menschen der Gegensatz des Unendliehen und Endlichen; in Gott aher ist dieser Gegensatz anfgehoben. Gott ist in Wahrheit die Einheit und I larmonie der Endlichkeit und Unendlichkeit. Das endliche Ich lebt ferner in dem Gegensatz des Seins und Sollens als der Grundbedingung des sittlichen Lehens. Wïrde diese Entgegensetzmng aufgehoben, so könnten wir nicht mehr von eincm Begriff des Sittlichen sprechen, der uns verständlich wäre. In Gottes heiligem Willen ist aber dieser Gegensatz ganz ohne Zweifel mit Notwendigkeit anfechoben, das sein ist in das Sollen anfgenommen und vom absoluten Wert verklärt, so das keine Bediüftigkeit mehr zurïckbleibt. Fïr die menschliche Erkrnntnis bestelet der Gegensatz ron Form und Inhalt. von Begriff und Ansrehammg. In Gott ist diese Antimomic des endliehen Geistes überwunden dureh dir. lelee des intuitiven Vorstandes als Winhejt von Form und Inhalt.

Indem damn Scluelling dic Struktur der cinzelnen Wertformen dureh-

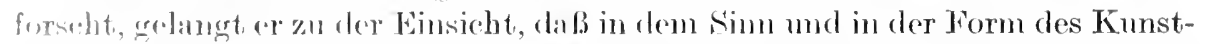
wots das theoret ische mol ethische Moment, aufgehoben ist. Dem Ästhetisehen

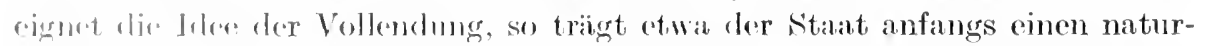

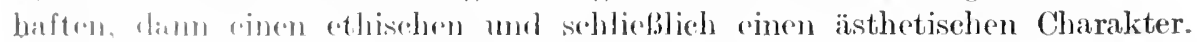
Jas. Was diro Struktur flo asthetischen Wrortes vor allen anderen Wertgebieten 
auszeichnet, ist der Charakter der Universalität und Vollendung. Es gehört zum Sim der theoretischen Erkenntnis und des sittlichen Lebens, einseitig und fragmentarisch zu sein, zum Simn der Kunst gehört die Tollending. Das Kunstwerk ist immer am Ziele. Die Aufgabedes theoretisch-wissensehaftlichen Bewußtseins muß darin gesucht werden, die unerschöpfliche individuelle Wirklichkeit durch Begriffe zu überwinden. Damit stellt sieh die Wissenschaft eine im doppelten Sinne unlösliche Aufgabe, nämlich einmal, sofern der Begriff von vornherein nicht imstande ist, den Wirklichkeitsgehalt anszuschöpfen. dann aber auch, sofern die L'msetzung der Wirklichkeit in Begriffe einen unendlichen Prozeß darstellt. Etwas Ähnliches gilt für das sittliche Leben. Das sittliche Streben führt auf das Unendliche. Das Unendliche ist Ziel und Aufgabe, kann aber im Sinne menschlicher Handlungen nie erreicht werden. Immer wird dem Sein und der Zuständlichkeit ein Sollen entgegenstehen, immer wird das Ich sich nene Anfgaben setzen. Niemals ist der Kreis der Forderungen geschlossen, niemals wird dem sehnsuchtsvollen Streben die absolute Erfüllung zuteil. Niemals sind Pflicht und Neigmng harmoniseh verbunden. Dagegen ist jedes Kunstwerk eine absolute Erfüllung. Die Vollendung gehört zu seinem Sinncharakter. Seinen Crsprung hat es nach Schelling in zwei entgegengesetzten Tätigkeiten, einer bewußten und einer reflektionslosen. Der Gegensatz dieser Tätigkeiten ist im Kunstwerk zum Austrag und zur Harmonie gebracht. Das Kunstwerk erlöst den Künstler von der Disharmonie seines Wesens. Eine bewußtose Unendlichkeit, die niemals rationalisiert werden kamn, strahlt dem Beschauer aus dem Kunstwerk entgegen. In ihm ist rlie Identität, die Versöhmung ron Geist und Simnlichkeit zu finden. In ihm ist das Werthafte nicht teilweise, sondern voll und ganz zugegen. So eint sich in Schellings Anffassung des Absoluten ästhetische und religiöse Wertbestimmung, und von ihr aus gewamm er die Möglichkeit zu einer tiefsinnigen Deutung auch des historischen Geschehens.

Vielleicht hängt es mit dieser Orientierung am ästhetischen und religiösen Werte zusammen, da.ß das Pathos des Irrationalen bei schelling sehr viel stärker ist als bei Fichte. Die Zusammenstimmung alles Wertlebens in Gott kam regulativ gedacht werden: wie aber dic Aufhebung der Gegensätze selber zu denken sei, oder wie sie zustande kommt, das entzieht sich ein für allemal der menschlichen Einsicht. In die Sphäre des Absoluten könmen wir nicht auf dem Wege rerstandesmäBiger Reflexion gelangen. Nach Schelling vollendet sich das Theoretische in einer intellektuellen Anschammg, die den Gegensatz des Begriffs und der Anschaumng überwunden hat, die das Einzelne vom Standpunkt der Totalität aus erkemnt und weiß. weil hier das Besondere zugleich mit dem Allgemeinen gegeben ist. Diese dem ästhetischen Schanen verwandte Funktion des erkemnenden Geistes vermag das Absolute zu verstehen, doch bleibt es ihr ein für allemal versagt. das Göttliche in einem deutlichen Begriffssystem auseinanderzulegen. Nur die Grundauffassung des Göttlichen als Identität, als jene Eimheit, welche die Indifferenz und den Gegensatz überwmden hat, bleibt bestehen, und von hier aus lassen sich Bestimmungen geben, die an sein heiliges Wesen ron ferne rühren. ohne es doch jemals rollkommen durchdringen zu kömen. Gott bleibt das Irrationale, das durch Begriffe nicht erreicht, durch Wertbestimmungen nicht erschöpft werden kamn. 


\section{у) Hegel.}

Im Gegensatz zum ästhetischen Idealismus Schellings erscheint das Logisehe als das leitende Wertprinzip im absoluten Idealismus Hegels. Die Philosophie ist das Organ zum Verständnis der anderen Geistesgebiete und gleichzeitig zur Erkenntnis ihres eigenen Wesens. Die philosophische Methode Kants hat uns das Ethische und Ästhetische verständlich gemacht. Die Philosophie vermag zu zeigen und deutlich zu machen, welchen Stufen des geistigen Lebens, das sich im Absoluten vollendet, die einzelnen Wertformen angehören, und so ihre Rangordnung zu bestimmen. Sie erkennt etwa, daß sich das sittliche Leben in der Idee des Staates vollendet, und daß sich im Leben der Staaten die Kulturwelt beschließt, während Religion, Kunst und die Philosophie selber über die Kultur hinaus in die Sphäre des Absoluten hineinreichen. Indem sie nun aber iber die Offenbarmgsmittel dieser drei nachdenkt, gelangt sie zu der Einsicht, daß ihre Form der Darstellung des Göttlichen im Begriff durch das selbstbewußte Denken die höchste Form der Erkenntnis sei, und betrachtet die Philosophie selher als Synthese der Kunst und Religion. Ästhetisches Schamen, künstlerisehe Intuition, religiöser Glaube, mystische Erfahrung, sittliche Überzeugung, das sind doch im Grunde alles Wissensstufen, die an einem einheitlichen Wertmaßstabe gemessen werden kömnen, und dieser Wertmaßstab ist nichts anderes als das vernünftige Denken. Der Trimmph des menschlichen Geistes muB doch darin gesucht werden, lichtvoll und klar das Absolute zu begreifen, nicht aber in dunklen Träumen oder in mystisehen Verzückungen ihm zu nahen. Nu an der Klarheit kann das Wissen gemessen werden. Jene dunkle Fïlle von Ahmungen, die sich nicht selber durehleuchten, sondern sich selber unverstanden bleiben, bezeichnen ron dem einzig möglichen Gesichtspunkt ler logischen Besimmung ans eine niedere Form des geistigen Lebens. So ist für Hegel der logisch-theoretische Wert zum entseheidenden und herrschenden geworden. Das Logische weiß ron sich selber, es ist die Form der Formen, das Selbstbewnßtsein des Geistes. Es weiß ron sich selber und den anderen Wrertgebieten. Es versteht alle Gebiete des geistigen Lebens als Formen des Wissens, sich selber aber als des Wissens höchste Form. Die Würde des geistigen Jebens kann im Simo der Hegelschen Philosojhie nur bestimmt werden naeh dem ('harakter und der Wiirde des Gegenstandes, auf den es gerichtet ist, und nach der Klarheit des Wissens von diesem Gegenstande. Der höchste Gegenstand der Erkemntnis ist das Absolute, die dentliehe Erkemntnis dieses Ciegenstandes findet sich in der Philosophie und speziell in der Logik. Die Jrogik enthält das rejne Wissen des Göttliehen ron sich selber, und der Charaktry der absoluten Wrerte ist dachreh hestimmt, daB es sich hier immer um ein

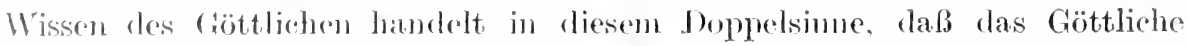

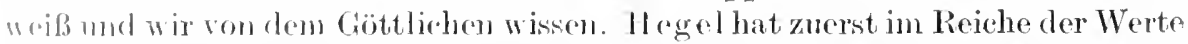

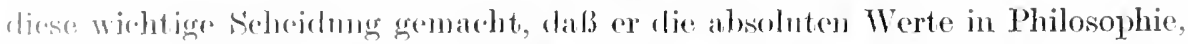
Kimst morl Roligion den objektiven Werten gegenïberstellte. In den absoluten

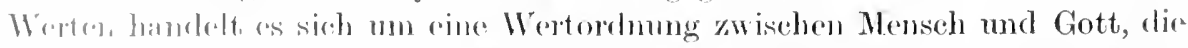

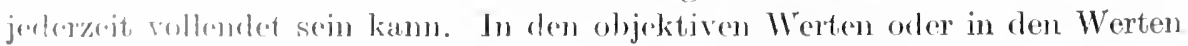

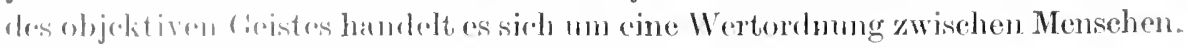


Dadurch wird aber in Hegels Simne der Geltungscharakter nicht tangiert, weil ja zwischen allen Formen des geistigen Lebens ein lebendiger Zusammenhang besteht, ein simmolles Gefüge, das im System zur Darstellung gelangt.

Das Wesen der Vernunft und des Geistes offenbart sich nach Hegel in drei Stufen, in die alle Wertformen und Kategorien sich ordnen lassen: das Prinzip der Thesis, die Unsehuld und Unmittelbarkeit des Geistes, das Prinzip der Antithesis, die Bewegung des Geistes, und die Sinthesis als die Einheit des Geistes. Das Prinzip der Thesis hat seiner Herkunft nach ein gewisses Verhältnis zur theoretischen Vermunt, sofern in ihm eine Bezichung zum Naturbegriff gedacht und die Natur im Sinne Kants vorzugsweise als die Domäne des wissenschaftlichen Geistes aufzufassen ist. Die Antithesis offenbart ror allem das Wesen der sittlichen Vermunf, die Spannung ron Sein und Sollen, die ewige Unruhe und Bewegung des Geistes. In dem Prinzip der Synthesis endlich ist alles rollendet und aufgehoben, in ihr scheint das Prinzip der ästhetischen Vernunft vor allem mächtig zu sein.

Anderseits lassen sich diese drei Prinzipien, die den Charakter aller Formgebungen bestimmen, auch unter den religiösen Gegensatz der rollendeten Cnendlichkeit und der antinomischen Diesseitigkeit bringen. Dam sind es die Bestimmungen der Thesis und Synthesis allein, die auf die Gotheit anwendbar sind. Die Begriffsmomente der Antithesis charakterisieren lediglich irdische Endlichkeit. Auf der Stufe der Thesis erscheint das Göttliche rerhüllt, auf der Stufe der Synthesis ist es kund und offenbar geworden. Schließlich ist dieser große Dreiklang des Geistes auch typisch für das Schicksal der Philosophie und Religion. Die Thesis ist gleichbedeutend mit der unbeweglichen Einheit des Dogmatismus und mit dem göttlichen Prinzip des Anfangs, das in starrer Jenseitigkeit ruht. Die Antithesis entspricht der skeptischen negativen Philosophie, und in religiöser Hinsicht liegt in ihr die Torstellung des göttlichen Logos, der sich an die Welt rerschwendet hat. In der Synthesis endlich hat die Philosophie als absolnter Idealismus ihre Erfüllung gefunden, und die göttliche Vorstellung des Geistes ist erreicht, der das Endliche mit dem Unendlichen versöhnt hat.

In der Philosophie Hegels ist dem Wissen eine große Macht beschieden. Wir haben ein absolutes Wissen rom Absoluten. Wir haben em absolutes Wissen, denn der Geltungscharakter der Denkformen ist durch nichts eingeschränkt. Gott ist die Fülle aller Formen. Indem wir den Sim der Kategorien deutend rerstehen, denken wir dem remünftigen Wesen Gottes nach. Die Kategorien sind keine leeren Formen, die auf einen übersinnlichen Inhalt warten, sondern sie tragen die Fülle des logisehen Inhaltes in sich, den der denkende Geist im ,,bacchantischen Taumel ${ }^{\cdot *}$ dahinträgt. Rationalität und Irrationalität sind bei Hegel auf das engste verbunden. Wir vermögen in der reinen Logik das Wesen Gottes ron Form zu Form immer deutlicher zu erkennen. Aber dieser Erkenntnisprozeß ist kein Weg abstrakt logischer Schlußfolgerungen, sondem wir verstehen das Göttliche nur hingegeben dem Leben und Weben des Geistes, der aus sich heraus in rollkommener Kontinuität den heiligen Strom der Gestalten entläßt.

Der Idealismus begründet die Macht des Wissens. Wenn der letzte Erkenntnisgrund verhültt ist, dann droht aller Erkemntnis Gefahr, dann kaim alle Ein- 
sicht der Menschen trügerisch, alles Wissen gefälscht sein. Nur aus dem höchsten Prinzip heraus läßt sich eine Einsicht in den Weltzusammenhang gewinnen, unel das höchste Prinzip ist auch viel genauer und zuverlässiger zu durchforschen als die Wirklichkeit der Natur und Kultur. In der Logik als der Sphäre des reinen in sich ruhenden Geistes, da schanen wir die Gedanken und Gestalten rer Gottheit in ihrer reinen Schlichtheit und Helle. Hier zeigt der Erkemntnisweg die höchste Deutlichkeit. In dem Reich der simnlichen Wirklichkeit, im Gebiet der Natur und Kultur hat der Geist mit seinen Formen den Charakter der Endlichkeit angenommen. In der Natur ist das Absolute am meisten versteckt und verhüllt. Hier dominiert das Prinzip der Rämmlichkeit, die Gleichgültigkeit des Nebeneinanderseins. Hier ist das Wirkliche Gott entfremdet. In Kultur und Geschichte rollzieht sich die Rückkehr der Welt zu ihrem ewigen Ursprung.

Das Ich und Subjekt des Hegelschen Idealismus ist das absolute göttliche Ich, neben dem der Begriff desendlich erkementen Ichs, wie es, vor allem von Fichte, noch dentlich unterschieden war, vollkommen verschwindet. Wem ich das Absolute denke, so denkt das Absolute in mir, und meine von aller Begrenzung befreite Erkenntnis verweilt im seligen Zwiegespräch mit dem göttlichen Geiste.

\section{z) Die Romantik.}

Die Romantik erscheint als die Vollendmug des neuen synthetischen Zeitalters. Sie suchte alle Gegensätze des Lebens und der Kultur zu verbinden. Sie wollte die lebensfeindliche Theorie mit dem unvernünftigen Leben versöhnen. Sie gelangte zur Torstcllung eiuer Wertsynthese, die ron derjenigen, die das Mittelalter erstrebt hatte, sehr verschieden war, und nicht Im deshalb, weil in dieser neuen Synthese der ästhetische Wert neben dem religiösen so stark zum Ausrlruck kam. Das ästhetisch-religiöse Wertbewußtsein der Romantik dachte den leitenden Wert nicht als ein subordinierendes Prinzip, das alle anderen Formen des Geistes in einem Sklavensystem strenger Abhängigkeit hielt, sondem weit mehr als eine Totalität, welche die Gesamtheit cles Geisteslebens lieberoll mufaßt und umsehlingt. Wie in einer bestimmten Kunst, etwa der Malerej, hänfig der Geist einer anderen Kunst, z. B. der Plastik, zu sp ïren ist. kann der Geist der Kunst anch in der Wissensehatt und der Geist der Wissenschaft in der Kunst weilen. Im Grmule genommen sind die Gebiete des Geistes gar nicht scharf voneinander getrennt, sondern hängen auf das imnigste zulsammen. Es wirl cinmal die Keit kommen, da all die versehiedenen Formen des Goistesleheus in den müterlichen Schob der Poesie zuriickkehren, aus der sie hervorgegangen sind. Das, was un an einer absoluten brkenntmis hindert, ist die cinsejtige und begrenzte Haltung, die wir den Universmm gegenüber einnehmen. Kömnten wir als ganze und mugetcilte Mensehen in der mugeschwichton Füll. der Intnition dem Universum gegeniiberstehen, so wïrde uns der voluserene simn der Welt kumd werden.

1) () rientierumg des religiösen Wertes an der ästhetisehen Form, wie sie wo fiehlojumather versmeht wurle, hat viel dazn beigetragen, dureh alle Vemustalnumen hindureh das religiose leben in seiner Reinheit zu erfassen. śchlojemanchror hat ein für allemal das Gefühl als den psychologisehen Ort 
des religiösen Lebens bestimmt und die religiöse Persönlichkeit mnd die religiöse Ideen von allen ethischen und theoretischen Utberformungen befreit. So ist er ror allem anch den großen religiösen Naturen durch die Orientiermy an dem Begriff des ästhetischen Genies näher gekommen.

Bis zur Romantik hin läßt sich der Sinn der philosophiegesehichtliehen Entwicklung deuten. Die Philosophie der Gegenwart sheint auf dem Wege der Synthese fortschreiten $\mathrm{zu}$ wollen.

\section{Sechstes Kapitel. \\ Die sittlich - statitliche Entwicklung.}

a) Der ethische Grundgegensatz.

Der Gegensatz, in dem das sittliche BewnBtsein lebt, ist dureh den Dualismus von Sein und Sollen gekennzeiehnet. Das Individuum ist niemals das, was es sein soll, es hat unendlich viele Bildungsmöglichkeiten. die ansgereift und gestaltet werden sollen. Sein zuständliehes Sein steht immer im Gegensatz zn gewissen Forderungen, die an das Individum ergehen, und deren Erfülhung ihm zur Pflicht gemaeht ist. Das bedentet also schließlich. dafo die Individualität. wemn wir den Wert des sittlichen Lebens anerkennen, nicht tum und lassen darf, was sie will, sondern durch Anerkemmung des Sollens eine hestimmte Gemütsverfassung, die wir moralische Gesimmmg nennen, in sich kultivieren soll. Wenn mm der Menseh als Persönlichkeit die Fähigkeit besitzt, diesen wünschenswerten mond rorbildlichen Zustand in sich zu realisicren, so bezeichnen wir ihn als frei. Frei ist der Mensch, der dureh das Sollen bestimmt wird. Das ist die Idee der autonomen Moral, wie sie Kant gedacht hat. und gleichzeitig diejenige Auffassung, an der wir am hesten ras sittliche Leben orientieren kömmen. Abgelehnt wirl von diesem Standpunkt einer hochkultivierten Moral jede fremde Bestimmmng. Das Indiridum soll sich selbst Gesetzgeber sein. Es darf sich nie mol nimmer einer fremden Gesetzgebung unterwerfen. Sei es nun, daß dieses Gesetzgebende und Bestimmende cine andere Person sei, oder die Macht unserer Triebe oder die Fremtheit rines anderen Wertes.

Diesem Verhälnis ron Sein und Sollen gegenüber treten eine Reihe anclerer Mögliehkeiten, die als Abweichungen von der Norm mol somit als Tnterstufen des sittlichen Lebens betraehtet werden müssen. Als absolut wertfeindlich, schlecht und böse wäre eine Verfassung des Individumms anzusehen, nach der das Sollen von der Last des Seins vollkommen unterdrückt wirch, eine Dentmng des sittlichen Lebens, welche die Pflicht rollkommen ableiten will ans der Organisation des Einzelindividumms. Was mir als Pflicht entgegentritt, das sind nur potenzierte Neigungen, Wünsche und Begehrungen der simnlichen Individualität. Jene Imperative sind nur eine feine Answahl mol Seligpreisung meiner wilden und trotzenden Simmlichkeit. Es gibt nichts Intelligibeles und deswegen auch keine Brücke und Verbindmg mit dem Übersimnlichen. Das Simnliche ist allein da und nimmt nur manehmal höchst sublime Formen an, die dann als etwas Simenfremdes und der Simnlichkeit Cherlegenes gedentet 
werden. Es gibt eine Bejahmng der platten Sinnlichkeit ohne Ziel und Wert, das ist die spezifisch antimoralische Haltung des Individumns. Zwischen diesen Gegensätzen ron Gut und Böse gibt es nun eine Reihe von Zwischenstufen sowie Stufen der Utberwindung und Auflösung. Böse und wertfeindlich ist die Bejahung der platten Simnlichkeit, die Feier des bloß tierischen Daseins und die bewußte Verlengnung der Mensehenwürde. Wertindifferent ist die Nichtbejahung des Sollens und das ruhige und selbstverständliche Leben im Bann der Instinkte. Das Leben im Unbewußten der Natur ist das Leben der Unschuld diesseits ron Gut und Böse. Ferner kömnen wir uns sittliches Leben in der Form denken, daß das Sinnliche neben dem Übersinnlichen bejaht wird, daß das Sollen anerkannt wird, aber anch sein Entgegengesetztes: die Neigung. Weiter können wir uns vorstellen, daß diese beiden in ein Einvernehmen gesetzt sind, und zwar in der Weise, daß das Simnliche dem Ủbersinnlichen und das Übersinnliche dem Sinnlichen dient. Und wiederum kann das Sinnliche dem Sollen vollkommen nnterworfen sein. Oder sie sind ein für allemal in lebendigen Widerstreit gesetzt in der Weise, daß die Pilicht gegen die Neigung und die Neigung gegen die Pflicht protestiert.

\section{b) Die Ethik Homers.}

Das sittliche Leben der Griechen hat große Wandlungen erfahren. Die Zielsetzungen, an die das sitthiche Bewnßtsein appelliert, haben von Homer bis Pla to in entscheidender Weise ihren Charakter verändert. Charakteristiseh ist im allgemeinen für die griechische Moral der Eudämonismus und der Intellektnalismus. Somit wäre im Simme Kants die griechische Ethik heteronom, weil dasjenige, was den Bestimmungsgrund des Willens ausmacht, nieht das reine sollen, sondern die theoretische Vermunft oder Ejoruurovér ist. Die Ethik Homers feiert die alte dorische Herrenmoral, and besonders wichtig ist die Auffassung der natiirlichen Triebe und Instinkte, denen hier ein großes freies Feld ïberlassen wird. Die Instinkte gelten nicht als böse oder als wertfeindlich. Anch wird keine Unterordnumg der Triebe unter das Sollen verlangt. Das Simliche wird vielmehr im allgemeinen als wertvoll bejaht, und des Helden Natur wird nicht herabgesetzt dureh Furcht und Zorn, durch wilde Leidenschaft und Begehren. Mit (ler P'̉lichtanerkennung gegenüber dem Vaterland, der Familie, dem Fremul geht anf das beste zusammen das Recht der Individualität, seine großen Neigungen, Instinkte mud 'Triebe rïcksichtslos zu entfalten. Das ist ras Herrenrecht der großen Naturen, maßlos und gewalttätig in ihren Leidenschaften zu sein. Wir können somit sagen, daß das sittliche Leben der Griechen, wie es uns in der Anffassung Homers entgegentritt, in glcicher Wrisc hureh Bejahung ter Pílicht und Neigmng ansgezeichnet ist, wobei abor koincowegs das Póliehtmäbige und das Neigungsgemäße in eine schöno Harmonie gebracht sint. Viehmehr stehen beicle ziemlich unvermittelt nebrominander nud wirken mit groBer Selhstrerständlichkeit, so daß man zu dro duffassmug gelangt, dal.s die ganze ethisehe Haltung dieser Mensehen von der athischen lieflexion moeh sehr wenig betroffen ist. Insofern kann man sagen, dafo das Sittliche hier noch nicht als deutlicher Imperativ, als klar

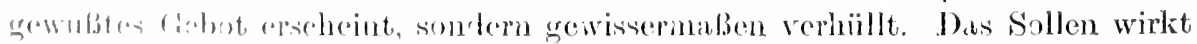

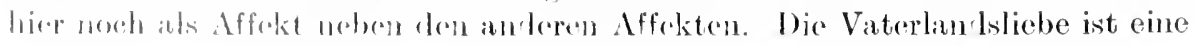


Leidenschaft so gut wie die sinnliche Liebe zum Weibe und zum Nanne. Das Moralische erscheint somit hier auf der Stufe der Unschnld als ein kräftiger mingebrochener Instinkt, so daß das Sollen dem Charakter des Seins angeglichen ist. Diese Angeglichenheit läßt die Helden Homers in allgemeinen als glückliche und harmonische Menschen erscheinen, sofern der Gegensatz ron Pflicht und Neigung in ihnen noch gar nicht zum Ausdruck gelangt ist.

Mit der naiven Sittlichkeit geht die Vermischung der Seinsordnung und Wertordnung zusammen. So hat etwa Heraklit die Úberzengung zum Austrag gebracht, daß alle menschlichen Gesetze in göttlichen Gesetzen verankert seien. Er vertritt die Auffassung, daß die sittliche Ordnung der Welt gleichbedentend sei mit der Naturgesetzmäßigkeit. Was nach den Gesetzen der Natur notwendig geschehen muß, das ist auch gut und wertvoll. Ans dieser Auffassung ergibt sich die Idee einer strengen Einordnung und Eingliedernng des Menschen in den Naturzusammenhang. Jede Auflehnung und Empörung gegen die festgesetzte Ordnung der Natur muß unter diesem Gesichtspunkt als Cnrecht erscheinen. Alles Recht und Unrecht der Welt, Krankheit, Not und Tod, erscheint bei der Verherrlichung der Naturgesetzmäßigkeit als gerecht und gut, weil es nun eimmal so kommen mußte, weil das Walten der Notwendigkeit es hervorgebracht hat.

\section{c) Moral der griechicchen Aufklärung.}

Die große Einheit ron Wert- und Seinsordnung, mit der durch sie geforlerten pflichtmäßigen Lnterordnung des Menschen unter Gesetz, Autorität. Sitte, Satzung und Tradition, wie sie Heraklit verkündet hatte, weicht in der griechischen Aufklärung einem schroffen Dualismus. Nicht alles Geschehen dieser Welt, nicht alle Einrichtungen der Kultur und des sozialen Lebens können als gut und wertvoll betrachtet werden. Wohl ist die Ordnung der Natur an sich gut und wertvoll; aber sie hat eine Verschlechterung erfahren durch das Kleimmenschliche. Das mensehliche Gesetz und die menschlichen Satzungen und Institutionen gründen nicht unbedingt und ummittelbar in dem göttlichen Gesetz. Das menschliche Gesetz und das menschliche Recht steht vielfach als ein unbegründetes dem göttlichen entgegen. Auf das ursprünglich gute und wertvolle Leben haben wir uns zu besinnen, dessen Antlitz noch nicht durch die Einseitigkeiten menschlicher Kulturbetätigung entstellt und entweiht ist. Wir haben uns auf das Ursprüngliche und auf das Zukïnftige zu besinnen, auf das, was war, und auf das, was werden soll. So, wie es ist, darf das Sein nieht bleiben. Es muß zu einem anderen werden. Durch reformatorische Tätigkeit soll das Gegenwärtige so werden, wie es früher war, oder es soll zu einem vollkommen Neuen, noch nie Dagewesenen sich herausbilden. Das Sollen erscheint so im Gewande des Ursprünglichen und des Znkunftsfemen und protestiert gegen das Bestehende. Die Menschheit ist reif geworden für den Gedanken, daß es ein Recht gibt über dem Recht. Das sittliche Bewußtsein kann die bestehende Ordnung der Dinge nicht bejahen und appelliert darüber hinaus an eine höhere Ordnung, die einst gewesen und wiederkommen wird, oder die immer unsichtbar da ist. Es gibt ursprügliche sittliche Werte, die jeder anerkennen muß, der einmal in ermster Weise über Menschliches nachgedacht hat, wie etwa die Idee der Gerechtigkeit. Niemals dürfen wir so ohne weiteres gerecht nennen, 
was der Staat als Gesetz rerkïndet. Das Recht, das er uns rorschreibt, widerstrebt nur zu oft mserem höheren moralischen Bewnisein. Schwere Konflikte können dadurch entstehen, daß die Pflicht gegen den Staat in Widerspruch gerät mit unseren höheren moralischen Pflichten. Damn muß das Individumm schuldig werden, demn das Ungerechte darf es nicht bejahen, und so muß es gegen die bestehende geltende Ordmung streiten. Was gerecht ist, kamn niemals ans fler Struktur eines bestehenden Staatswesens abgeleitet werden, sondern der bestehende Staat muB an dem Begriff der Gerechtigkeit, wie ihn die menschliche Seele weiß, gemessen werden.

So tritt das Sollen mit großer Schärfe als Ankläger gegen das Sein auf, nnd es ist $11 m$ in der Tat interessant zu beobachten, wie sich in der sophistischen Lehre dieses Soll doch wicder in ein Sein verkehrt. Denn was ursprïnglich als das andere dem Sein der psychischen Affekte gegenüberstand als das Normative und Bestimmende. als Inbegriff sittlicher Fordermngen, das ist munmehr selbst zn einem simmlich Seienden individucller Leidenschaft geworden. Dem gegebenen Kulturzustand wird ein gewollter und ersehnter Naturzustand entgegengestellt. Der Kulturzustand ist das Schlechte, der Naturzustand ist das Gute, weil alles Natiurliche und NaturgemäBe gut und wertroll ist. Dieser Naturzustand aber erscheint im verschiedenen Lichte, nämlich entweder als ein Znstand urspringlicher Gleichheit oder als ein soleher usprïnglicher Ungleichheit. Die Menschen waren ursprïnglich gleich an Besitz und Rechten, deswegen sollen sie wieder gleich an Besitz und Rechten werden, so lantet die eine sophistische 'Theorie, in welcher die Demokratie ihr Heil erblickt. Die Iensehen waren ursprünglich moleich an Fähigkeit nnd Anlagen, an der Kraft des Leistens und Schaffens. Der gegenwärtige Zustand der Gesellschaft schützt rlie Schwachen und Elenden. Diesc Entstellung des nrsprünglichen Naturzustandes soll aufgehoben werden, damit der Starke und Mäehtige vermögre seines angeborenen Reehtes der Natur wieler tun und lassen kam, was (r) will. So lantet die andere entgegengesetzte sophistische Theorie.

\section{d) Sokrates.}

In Sokrates küudigt sich zuerst ein höheres sittliches Bewnßsein an. Erfiillt ron dem Glauben an eine reine sittliche Ordnung der Welt, wollte dieser grobe Lehrer und Prophet den Pfad rer 'Tugend weisen. Ws gibt einc doppelte Art der Bestimmmng, nämlich aine Bestimmmng durch die Affekte und eine

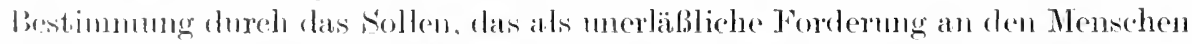
"rgeht, seine Aufgabe und Mission zu erfïllen. Wer clureh die Leidensehaften.

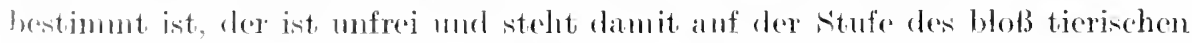

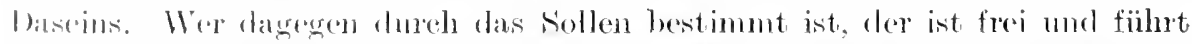

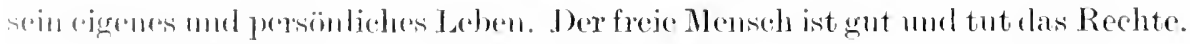

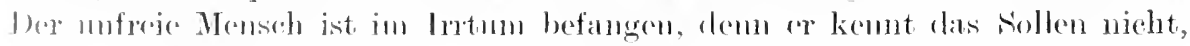
das im mit, Notwendigkeit zu gnten Taten treiben wïrde. Fr sündigt ans Un-

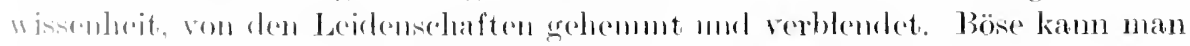

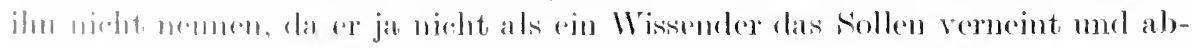

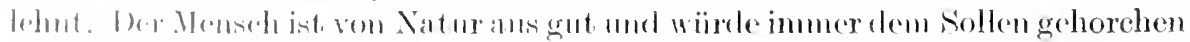

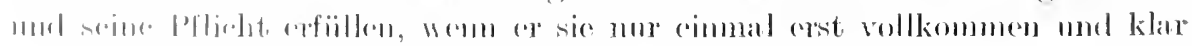


durchschaut hätte. Worin seine Pflicht und Anfgabe besteht, das weib im Grunde jeder einsiehtsrolle Mensch. Lnd wer seine Pflicht und Schuldigkeit. tut, der wird auch ein wahrhaft glückseliges Leben führen, ein Leben, das der Seele niitzlich ist und frommt. Die Leidensehaften machen den Mensehen unglücklich. Sie sollen dureh die rernünftige Einsicht ersetzt werden. Man soll die Leidenschaften nicht töten, aber mit Termmft durehdringen und sie zu läutern suchen.

Diese seine sittliche Lehre hat Sokrates gelebt und in einem weiten schülerkreis die leidenschaftliche Liebe zur Tugend erweekt. Er ist für ms der schönste Gradmesser für die Höhe der sittlichen Kultur in Griechenland, demn die Tugendlehre der griechischen Weisen kann für ms nichts anderes bedeuten als Blïte und Frucht am Tugendstamm dieses Volkes. Was die große Masse dumpf fühlt und ersehnt, was die Aktivität des sittliehen Helden von der Innerlichkeit einer reinen Gesinnung aus in Taten umsetzt, das rerkündet der sittliche Reformator und Prophet. Dentlieh und erkembar erscheinen dem Blick des Geschichtsphilosophen Kunst, Philosophie und Religion in den Werdegange ihrer Entwicklung. Demn die Geschichte der Kunst meint ganz in erster Linie das Kunstwerk, und die Geschichte der Philosophie das System der Erkenntnis, und die Geschichte der Religion die Lehre des religiösen Genies. Sie tragen den Charakter der Vollendung und sind die Angelegenheit weniger. anserwählter Mensehen. Das sittliche Leben aber ist die Angelegenheit aller Jensehen und spricht sehr hänfig eine leise und verschwiegene Stimme, die nicht so weit ersehallt, daß sie in den großen Zusammenhängen des historischen Lebens Aufuahme finden könnte und sollte. Große Taten des sittliehen Heroismus kömnen im Verborgenen gesehehen und die Kultur nur sehr gering bereichem. Der Idee der Universalgeschichte gemäß würden auch sie in den Kreis ihrer Darstellung gehören, weil sie simgemäß die Totalität des Wertlebens umfaßt. Wenn wir die Geschichte des sittlichen BewuBtseins betrachten wollen, so dürfen wir sie niemals in einer Gesehichte der ethischen Lehren besehlossen denken. Die Größe und Nenheit emer ethischen Lehre enthüllt uns zwar ummittelbar die Größe und Bedeutmg einer ethisehen Persönlichlieit, zumal wenn in Griechenland Lehre und Leben so mmittelbar zusammengehen, und ihre Wirksamkeit läßt uns Schlïisse ziehen auf das sittliche Nivean einer Nation, aber das sittliche Leben eines Volkes läßt sich nicht an wenigen einzelnen messen. Das moralische Gesamtbewnßsein wird vor allem sichtbar bei Ereignissen ron hoher sozialer Bedentung, z. B. im Fall eines Krieges, doeh in einer eigentümlichen Steigermu und um ganz gewisser Ziele willen, die der Öffentlichkeit gehören. Von dem lanten Heroismus der politischen Bïhıe ist der stille Heroismus des Duldens wolnl zu unterscheiden, und alle jene Taten stehen für sich. die reine und romehme Gesinnung für kleine Kreise gewirkt hat.

Wir wissen, daß jene Zeit, in der Sokrates zuerst die Idee des Sollens und die erhabene Majestät des Sittengesetzes rerkündet hat. ron einer Größe des Persönlichkeitslebens erfüllt war, wie es die Weltgeschichte nur selten erschaute. So war es möglich, daß seine Lehre in großer reich entfalteter Individnalität lebendige Träger der Ĺberzengmg fand. Es war jene Zeit, in weleher der Heroismus der Nation, der sich in den Perserkriegen erprobt und bewährt hatte, in seiner Totalität erlahmt war und nur noeh in erlesenen 
großen Naturen eine seltene Nachblüte fand. Die großen Instinkte der Synpathie, der leidenschaftlichen Hingabe an Vaterland und tranten Familienkreis, cler Enthusiasmus freundschaftlicher Beziehungen, aus denen alles große sittliche Wertleben herrorgeht, und die in dem Weltbilde der Pythagoräer einen. so schönen philosophischen Ausdruck gefunden hatten, sie waren in ihrer Stärke gebrochen und gelähmt, ihre Selbstverständlichkeit war durch den Rationalismus der Aufklänung erschïttert. Es war die Mission des Sokrates, bewußtes sittliches Leben an die Stelle der schönen und liebenswürdigen sittlichen Instinkte seines Volkes zu setzen. Er war ein Wegweiser zu höchsten Zielen für die Besten seiner Nation, sofern er auf die Selbständigkeit und Bewußtheit ‘es Persönlichkeitslebens abzielte, aber vielleicht eine Gefahr für die große Masse der C'nreifen und Zurückgebliebenen, sofern die lcuchtende Helle seiner Reflexion die natürliche Sozialität bedrohte.

\section{e) Die sokratischen Schüler.}

Die neuc sittliche Erfahrung, die er verkiindet, wraeh sich in den versehiedenen Gestalten seines Schülcrkreises zu einer bunten Mannigfaltigkeit ethischer Maximen, an der zum Teil die Unbestimmtheit seines sittlichen Wertbegriffes sehuld trug. Vielleicht hat sein Lieblingsjünger Phaedon am getreusten im Simne des Meisters gelebt und gelehrt und den Begriff des Sollens im Gegensatz zu jeder simnlichen Wirklichkeit gewahrt. In der megarischen Lehre ist ganz augenscheinlich das unsinnliche Sollen wieder in das Dasein des Wirklichen verstriekt, und diekynisehe und kyrenaische Schule entfremdeten sich der Lehre des Meisters, sofern sie das Prinzip und Kriterium der Moral in etwas suchten, das im Simne des Sokrates nur als sekundäre Folgeerseheinung betrachtet werden konnte. Gewiß haben sie treu gewahrt den Gedanken der Freiheit und dor bewußten Lebensgestaltung. Niemals Sklaveder Leidenschaften zu sein, sondern die Leidenschaften sonverän zu beherrschen, das erschien trotzaller Versehiedenheit der Lehreim einzelnen Aristip p und An tis thenes in gleicher Weise als erstrebenswertes Ziel. Jene Euclämonie aber, die für Sokrates eine notwendige Folge der Tugend war, die erhob Aristipp zum Kriterinm der Moral und maß ilren Wert vor allen Dingen an ihrer Mäehtigkeit, ric am stärksten sieh kmurl tut in der Sinnlichkeit des Geschlechtslebens. Er bejahte das bein der simmlieh erotisehen Triebe als wertroll und bedentsam mol sah den sinn des Sollons nur in Verhinderung des Úbermaßes. Bewußtes Genießen ist wertvoller als rlie instinktive Hingabe an den Gegenstand der Lust, nud cin Ubermaß des Genießens wird auf die Daner die Kraft der Genußfähigkrit schwächen. Die Herabsetzmng mol schwächung der Lust sollte verhindert werlen. So machte er das Sollen zum Diener der Lust. Antisthenes dageren mointe, daß jene Ruhe, die im Sime des Sokrates die Folge der situlielun Tat ist, scther das Kriterium des sittlichen Lebens sei. Nach seiner Uhrowengung kann mur der als tugendhaft gelten, der durch nichts bewegt mul bestimnt wirl, der sich in einem Zustande vollkommener Indifferenz bofindret und \%u der Einsicht gelangt ist, daß alle Wertberielungen des Lebens

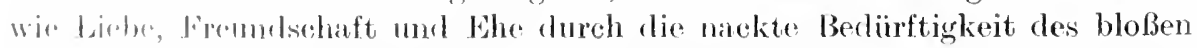

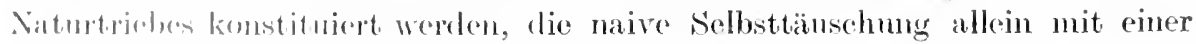


Fiille von Fiktionen umhiillt und verkleidet. Das Soll aber soll dem tugendhaften Menschen jene Unabhängigkeit von allen Lebensverhältnisscn verbürgen. die allein ihn befähigt, ein so ungerührtes und bewegungsloses Dasein zu führen.

\section{i) Platos sittliche Lehre.}

Haben somit jene mehr oder weniger das Werk des Meisters verstiummelt. so hat es Plato um so herrlicher aufgebant. Er hat den in sich ruhenden, absoluten Charakter des sittlichen Wertes betont und ihn weit von aller simnlichen Wirklichkeit entrückt. Das Gute hat seine Heimat in der übersimnlichen Welt und kamn auch durch die löchste Intensität unseres sittlichen Lebens nie erfüllt werden. Das Gute ist das Unerreichbare, das seinen höchsten Ausdruck findet in dem, was wir als Gerechtigkeit preisen und nemnen. Nicht die Ruhe kontemplativer Vernünftigkeit ist der eigentliche Wohnsitz des sittlichen Lebens, sondern vielmehr eine edle und vornehme Willensrichtung, die der niederen Leidenschaft entgegentritt. Der Gegensatz von edler Leidenschaft und niederer Triebbestimmtheit im Verhältnis zur ïbersinnlichen Winklichkeit des Guten konstituiert das sittliche Leben. In der edlen Leidenschaft offenbart sich der reine Wille, der auf die Unerreichbarkeit des Übersinnlichen gerichtet ist. In der niederen Leidenschaft, die mit der hohen erotischen Triebbestimmtheit in Konflikt liegt, kündigt sich der Hang zum bloßen simnlichen Dasein und die Abwendung von allem höheren Wertleben an.

Zur Zeit Platos hat das sittliche Bewußtsein des Griechentums gegenüber dem Zeitalter Homers eine tiefgründige Wandlung erfahren, und der Verkünder dieser Wandlung ist Plato vor allem in der Politeia. Eine leichte und heitere Auffassung des Lebens, ein freudiger Genuß am Dasein, wie sie noch jetzt den Menschen des südlichen Italiens eigentümlich ist, war jenem glïcklichen Zeitalter eigen. Hingeben darf sich der Mensch der simnlichen Lust, und selbstrerständlich darf anch der Held, ohne an Wert zu verlieren, dem drohenden Tode durch Flucht sich entziehen, in wilden Klagen jedem körperlichen und seelischen Schmerz Ausdruck verleihen, sowie mit List und Lüge für seinen persönlichen Vorteil und seine Lebenserhaltung streiten. Nummehr ist das sittliche Bewußtsein geschärft und sehr viel erusthafter und empfindlicher geworden, nachdem es die Größe des Sollens eingesehen und die Vorstelhung des idealen Typus gefaßt hatte. Dieses ernste und geschärfte sittliche Bewußtsein verlangt die Aufopferung bis zum Tode. Flucht vor der drohenden Gefahr bedeutet Aufgabe des Heldentumes und Verschlagenheit und List einen Verstoß gegen die gebietende Norm der Wahrhaftigkeit, wie endlich anch die leichte und bequeme Hingabe an das simnliche Genießen dem Ernst und der Würde des Sittengesetzes widerstreitet.

\section{g) Aristoteles.}

Aristoteles hat das sittliche Leben in einer Form gedentet, die der Mannigfaltigkeit der vorhergehenden Motive Rechumng trägt. Er hat den Sollenscharakter der sittlichen GesetzmäBigkeit vollkommen eingeschen. Das sittliche Sollen ist eine ideale Forderung, die sich an das zuständliche Sein der menschlichen Seele richtet. Aber dieses spezifische sittliche Sollen wird zugleich 
seines metaphrischen Glanzes entkleidet, sofern die sittliche Sphäre, in der sich das nur Menschliche vollendet, an die Sphäre des Göttlichen und Absoluten nieht heranreicht. An Würde des Gegenstandes ist das Theoretische dem Ethischen weitaus überlegen. Das Ethische ist die Sphäre der Aktivität und des Dualismus, das Theoretische hingegen das Gebiet der Passivität und des Ionismus. In der Beschäftigmng mit Philosophie und Wissensehaft gelangen wir zur Ruhe und Einheit, für das sittliche Streben bleibt die Dualität ein für ałlemal bestehen, und die Seele kommt nie zur Ruhe. Das Theoretische ist, nm mit Hegel zu sprechen, die sphäre des absoluten Geistes, das Sittliche die Sphäre des objektiven Geistes. Im Theoretischen nehmen wir teil an rler Seligkeit Gottes. im Ethischen und speziell anch im staatlichen Lebęn vollentet sich menschliches Tun und mensehliche Art. A ris to teles hat den versehiedenen Werteharakter des 'Theoretischen und Moralischen deutlich erkannt und fie besonders enge Beziehung des Sittliehen zum Willen eingesehen. Den antinomischen Charakten des ruheloson Willens hat or verstanden und wie Fiehte das Kriterimm der Sittlichkeit ror allem im Tun mol Handeh erblickt. Aber das sittliche Gut ist fïr ihn keme mendliche Aufgabe, denn mit der Unerreichbarkeit des Zieles scheint der Sinn des Strebens in Frage gestellt, sondern das iroidin ist ein Etwas, was durch Handeln mol Leisten erreicht werden kann. J)as sittlieh Gute ist aber erreicht, wenn dic Inclividualität, in der die Möglichkeit zu sittlich freiem Handeln angelegt ist, zur Persönlichkeit geworden ist, die Fertigkeit und sittliche Virtuosität besitzt. Die sittliche Begabung, die in jerlem Menschen vorausgesetzt worlen muß, soll sich frei und groß entfalten; nur so allein kam von werthaftem Leben die Rede sein. Bleibt das Individum auf dex Stufe der bloBen Potentialität. der Triebe nur der Instinkte stehen, so untriseheidet es sich nicht von der Stufe des Tierischen. Der Simn des menschlichen Lebens muß darin gesucht werden, daß das sittliche Ternunftwesen zmm Ausdruck gelangt, an dessen Festigung und Estarkung Erziehming und kewönung arbeitet. Je tiefor der Menseh in die sphäre des Sittlichen aindringt, um so freier wird er auch, wenn wir unter Freiheit jene schöne Selbständigkeit verstehen, jene ('harakterbildung, die in konstanten Motiven sich kund gilst, aus denen alles Handeln in vorgezeichueter Richtung fließt. jenc. Energie mul Fotschlosisenheit, die sieh selbst bestimmt und unbeirrt den ror-

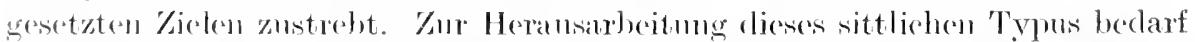

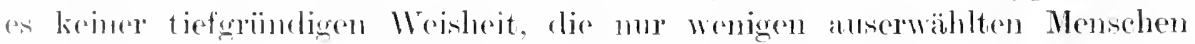
beschieden ist. somderm num oin Minimmm dros Theoretischen, eine gewisse Einsight ist anforderlich. Jie Macht des Theoretischen mol spezicll der Aufklärung

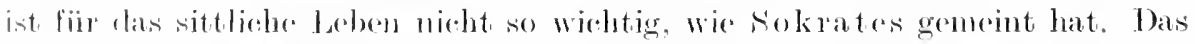

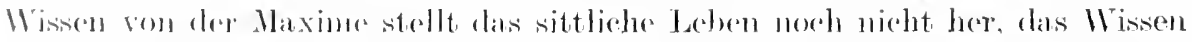

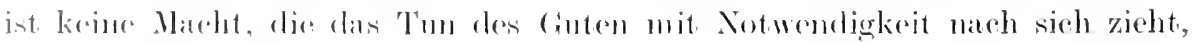

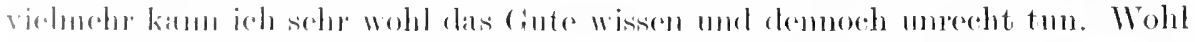

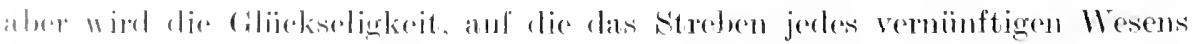

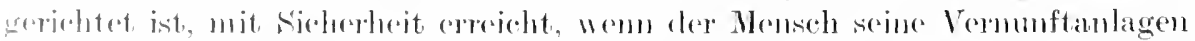

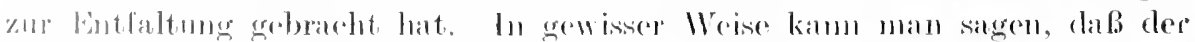

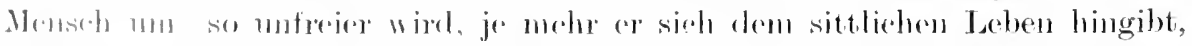

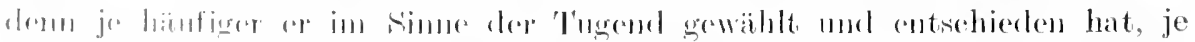

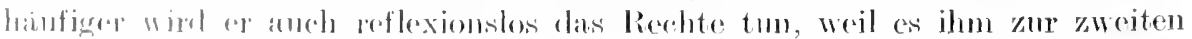


Natur geworden ist, und jeder Wahlentscheidnng und jedes Konfliktes überhoben sein.

Jede Tugend ist ein werthafter Zustand odler ein Gut, das zwischen Gegensätzen liegt. Der Heroismus eines Menschen oder die sittliche Norm der Tapferkeit ist von Tollkühnheit und Feigheit gleich weit entfernt. Tollkühnheit und Feigheit sind beide dem Sollen fern, dem Tollk ühnheit schließt ein blindes, bewußtloses Handeln in sich. Nicht um des Vorbildes und Zweckes willen wird hier gehandelt, sondern unüberlegt, von wildem Verlangen getrieben, das eigene Leben für eine Nichtigkeit aufs Spiel gesetzt. Feigheit aber bedentet gewuBt oder nicht gewußt eine Abkehr von der sittlichen Forderung.

Die Fïlle unserer Triebe und Leidenschaften ist an sich etwas Indifferentes. Unsere Anlagen können die verschiedenartigste Ausgestaltung erfahren, und in jeder unserer Eigenschaften liegt die Gefahr eines Zuviel und Zuwenig. So kommt es vor allem darauf an, daß sie in maßroller Weise nach cler richtigen Mitte gebildet werden. An sich kömnen die Leidenschaften mud Neigungen nicht als ein Wertfeindliches angesehen werden, dessen Bekämpfung oder gar Austilgung erwünscht wäre, sondem die Leidenschaften und Instinkte sind das notwendige Material zur Bildung der sittlichen Persönlichkeit.

\section{h) Die Entwicklung der Staatsidee in Griechenland.}

Wenn wir nummehr die Entwicklung der Staatsidee verfolgen, wie sie in der großen analytischen Epoche des Griechentumes der Entfaltung des sittlichen Bewußtseins zur Seite ging, so bemerken wir in der Theorie immer dia enge Beziehung zwischen dem Staatsgedanken und der moralischen Auffassung und Deutung. Es muß uns aber vor allen Dingen darauf ankommen, festzustellen, welche Form des staatlichen Lebens selber in Griechenland verwirklicht war, um dann weiter zu vertehen, welche Forderungen an den Staat gestellt wurden, und wie weit die Idee des Staates seine Glieder und Teile erfüllte und durchdrang. Das bloße faktische Dasein einer Staatsorganisation will noch wenig für seine Wertwirklichkeit bedenten. Es kommt ror allem anf den Geist an, der die Organisation durchdringt, auf die wertende Stellungnahme der Individuen zu dem sozialen Gebilde.

Der Charakter cines States, wie er die Geschichtsphilosophie interessiert, bestimmt sich nun ror allem nach vier verschiedenartigen Wertgesichtspunkten. Zunächst können wir an den Staat mit der Frage herantreten, ob er im Bewnßtsein seiner Bürger als eine konkrete Totalität orler als eine abstrakte Allgemeinheit gilt. Gilt er als abstrakte Allgemeinheit, so betrachtet man ihn in der Regel, wemn nicht direkt als feindliche Macht, so doch als ein begrenztes und begrenzendes Etwas. Er fällt dam zusammen nit dem Willen des Herrschers oder mit dem abstrakten Mechanismus, der als Zusammenhang ron Regeln das individuelle Leben an seiner starren Einseitigkeit mißt. Gilt er als konkrete Totalität, so schließt und ordnet er die Fülle des Lebens in sich ein und wird geliebt und geachtet. Der Staat der Griechen weist in hohen Maße einen konkreten Charakter anf, wenn wir an die Natur des öffentlichen Lebens in Hellas und an die Dentung denken, die ihm Plato und Aristoteles haben zuteil werden lassen. 
Ein zweiter Gesichtspunkt für die Bestimmung der Struktur eines staatlichen Gebildes ist die Frage nach dem Verhältuis des Allgemeinen zum Besonderen oder auch des Ganzen zu seinen Teilen. Die Unterordmung und Einordnung kamn nämlich mehr oder weniger streng gedacht werden. Der absolute Wille les Herrschers kam sich im schroffen mpersönlichen oder im väterlichen. Despotismus offenbaren. Das Einzelne kam als Glied dem Ganzen mehr oder weniger verpflichtet sein. In der Regel wird in abstrakten Staat mehr der Geist der Strenge, im konkreten mehr der Geist der Liebe walten.

Femer kommt es daranf an, welcher Wertcharakter sich mit dem Staat verbinclet. der ethische etwa oder der religiöse, wenn ihm nämlich überhaupt Wertcharakter zugesprochen wird, und schließlich ist festzustellen, welche Stufe dem Staat in der Rangordnming der Werte zukommt, insbesondere auch, ob es eine sozia le Wertgemeinschaft über dem Staat noch gibt, oder ob eine solche nieht anerkamnt wird.

Dem flïchtigen Betrachter der politischen Geschichte des Altertums wird es in der Regel so scheinen, daß das analytische Zeitalter der Griechen in seimen politisehen Bildungen weit hinter dem Römertum zurücksteht. Man wird zugeben, daß das Griechentum eine Fülle wertvoller Kulturgüter geschaffen. und ihre Sonderung und Gliederung vollzogen hat; aber diese große Geistesleistung mußte es, so pflegt man zu sagen, mit politischer Zerrüttung erkaufen. Ein unseliger Individualismus und Partikularismus befähigte das Griechentum nicht zu großen politischen Bildungen, deshalb mußte es dem Römertum unterliegen.

Fiir eine politisch-historisehe Betrachtung mag diese Auffassung im allgemeinen zutreffend sein. nicht aber für eine geschichtsphilosophische Jeutung der politischen Entwicklung. Staat ist im Sime der Geschichtsphilosophie soziale Wertgememschaft, und auf den imneren lebendigen Zusammonhang seiner Teile und Glieder kommt es ganz in erster Linie an, wem hier ron Werthenrteilung die Rerle ist. Fin großer und mächtiger Staat brancht darum noeh kein wertvoller Staat zu sein. Die Macht ist die bloße Naturseite des Staates. die besonders im Verhältnis zn anderen Staaten als den, fremden Nächten“ Anwendumg findet. Während die Beziehungen zwischen den Bürgern rines States durch Gesetzgebung geregelt und Leben und Eigentum geschützt sind, so daß lier die allgemeinsten Vorbedingungen für werthaftes Gemeinschaftsleben vorliegen, ist das Verhältnis zwisehen verschiedenen Staaten ein gesetzlich mugeregeltes. Nichts Sicheres und Verpfliehtendes besteht hier zur Herstellung einer wertoollen intemationalen Gemeinschaft, außer dem wenigen, rlas Sitte, Gewohnheit und Konvention geschaffen. Alle diese Bindungron aber brechen vollkommen in sich zusammen, wem die Staaten aus dem Friedenstanstand in das Torhältuis des Krieges ïbergehen. Von diesem Augenbick an bestehen für die kriegführenden Staten die Gebote der Moral nicht melır; dom es ist ja crlaubt, den Bürger des fremden States zu töten, oder

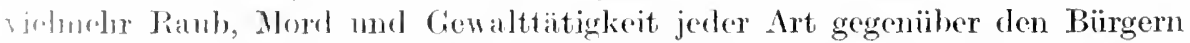
des fremelen Stantes wird len biïgern des anderen Staates zur Pflicht gemacht. Jir. Stalten kehren somit im Kriegsfall zu jenem Naturzustande der Willkür mul rowalt \%nrïrk, den sie durch Gesctzeshestimmmngen für das Verhältnis der regenen biirger untereinander abgesebafft und ïberwunden haben. Und 
die Macht eines Staates bedeutet doch schließlich nichts mehr als die Summe aller Einrichtungen und Veranstaltungen, die der Aufrechterhaltung und Potenzierung des natürlichen Gewaltzustancles dienen, mag es sich $1 \mathrm{~m}$ eine Wehrhaftmachung gegen äußere Feinde ocler um ein mögliehes System der Unterdrückung gegen Erhebungen und Erregungen im Imnem handeln.

So ist es deutlich, daß Macht an sich noch keineswegs ein Wertprädikat bedentet, und im Prinzip sehr wohl die Möglichkeit besteht, daß ein mäehtiger, weil großer, eimheitlicher und straff organisierter Staat an Wert und Bedeutung hinter einem relativ kleinen und an Kampf gegen fremce Gewalten weniger widerstandsfähigen Staate weit zurïcksteht.

Der Staat der Griechen, wie er ron seinen größten Denkem gedacht wurde und teilweise auch in der Wirklichkeit sich entfaltete, bedentet in seinen rerhältnismäßig engen Grenzen, die in der Regel nicht weit über eine Stadtgemeinschaft hinausreichen, ein durchaus konkretes soziales Gebilde, indem die Idee des Staates im wesentlichen mit der Idee einer Nation, d. h. einer ganz bestimmten Volkes- und Stammeseinheit zusammenfällt. Ein solcher enger Stammesrerband als Staatsrerband mußte in mannigfaltiger Weise durch Sippschaft, FreundschaftundVerwand tschaft Beziehungen undVerhäItnisse des Lebens aufweisen, die ein Gefühl engster Zusammengehörigkeit erregten. In der Nähe und dem Reichtum der Lebensbeziehungen, auf einen engen sozialen Kreis verteilt, lag die Möglichkeit für eine sehr starke und schöne Liebe dem heimatlichen Verbande gegenüber. Sämtliche Bürger jeder Klasse und jedes Standes galten als Mitglieder des Staates, und die ganze Summe ron Freundschaft und Liebe, ron sittlicher Leistung und Tat, von ästhetischer und wissenschaftlicher Bildung und Erziehung, von religiöser Hingabe, Demut und Duldung, diese ungeheure Potenz ron Wirkung und Gegenwirkung gehörte dem Staate an und bezog sich in sehr vieler Hinsicht auf ihn in seiner Ganzheit. Ein großer Lebensreichtum war in ihm rereint, und die Lebensbeziehungen wurden zu Trägern mannigfaltigster Wertmomente. Entscheidend und dominierend blieb aber für die Auffassung der Griechen das Sittliche für den Staat. Wohl erkannten sie die Bedentung der Liebeswertgemeinschaft für das Staatswesen und rerkündeten die ästhetische Erziehung als notwendiges Bildungselement des Bürgers, aber nach der Auffassung ihrer größten Denker komnte nur das Sittliche die Krone des Gemeinschaftslebens sein, während das wissenschaftliche Leben seinem letzten Sime nach ïber das soziale Ganze hinausfïhrt. Der Staat vollendet sich in der sittlichen Idee, die das ganze öffentliche Leben durchdringen soll, oder der Staat ist, philosophisch betrachtet, die Bedingung für die Entfaltung der sittlichen Vernunftanlage. Nicht nur die dureh Rechtsbestimmungen geordneten Beziehungen zwischen den Bürgern gehören dem Staate an, sondern alle LebensverhäItnisse, die im Ethischen aufgipfeln. Der Staat umgrenzt nicht nur die juristischen Personen, sondem ror allem die sittlichen Persönlichkeiten.

Wie steht nun nach der griechischen Auffassung das Individuum zum Allgemeinen oder Ganzen des staatlichen Lebens, und welche Rangstufe nimmt der Staat selber in der Skala der Wertgemeinschaften ein? In bezug auf die erste Frage gehen die Auffassungen erheblich auseinander; handelt es sich doch um nichts geringeres als um die Frage, wie die Idee eines werthaften 
Ganzen, das seinem Charakter gemäß Einordnung und Unterordnung verlangt, mit der Individualität der sozialen Eimheiten zu versöhnen sei. Von den beiden größten Staatstheoretikern der Griechen hat Plato ohne Frage mehr die Idee der Wertallgemeinheit und Einheit, Aristoteles mehr den Gedanken der Besonderheit und Mannigfaltigkeit betont. So werden im simne der platonischen Staatsidee alle engeren sozialen Gemeinschaften, wie etwa die Familie, nicht nur aufgehoben in dem Sinne, daß sie sich als Wertteile dem Staate eingliederten, sondem aufgesogen, sofern sie ihres Individuahertes enthoben werden und etwa in ihmen enthaltene besondere Wertmomente ganz ummittelbar mit der Idee des Ganzen verbunden werden.

Im Gegensatz zu Plato läßt Aris to teles der Individualität weit größeren Spielranm. Die Familie bleibt als eigentümliche Wertgemeinsehaft im Staate bestehen und wird nicht von ihm absorbiert. Neben der Familie bildet besonders auch die Freundschaft ein wertvolles soziales Verhältnis, dessen Ausschließlichkeit die Kräfte des Staates nicht verringert, sondern im Gegenteil sie vermehrt und stärkt.

Was dam endlich die Stelhung des Staates in der Rangordnung möglicher sozialer Verhältnisse angeht, so ist die Auffassung des griechisehen Geistes (larin beschlossen, daß sich alles soziale Leben im Staat rollendet, und daß es keine soziale Gemeinschaft gibt, die über die roiks hinausgeht. Der soziale Wertgesichtspunkt ist also in Griechenland umbedingt die nationale Idee, aber allerdings in einer Auffassung, die von der modemen sehr verschieden; demn eimmal bleibt sie in der Hauptsache anf den Bezirk engster Stammeszugehörigkeit beschränkt, und damn ist der nationale Gedanke in Griechenland gewissermaßen noch mbewnbt mol nnerprobt vorhanden, da er das Prinzip der Weltherrschaft noch nicht ïberwmolen hat. Das BewuBtsein muB die Erfahrung des imperiums gemacht haben, um die nationale Idce in ihrer Eigentiimlichkeit anznerkennen. Gilt die Idee des nationalen Staates, dam muB das P'rinzip der Nation nnd der nationalen Ehre anch gegenüber anderen Staaten anerkannt werden. Die griechisehe Nation ist noch nicht dahin gelangt, das Prinzip, das sie selbst vertritt, in einem anderen zu ehren.

Das hängt vielleicht im Grumcle mit einer religiösen Irlee zusammen, die sehon in Inukel der Vorzeit mo entgegentritt, mnd die anch in Griechenland ihre stäte gefmulen hat, nämlich mit dem Gedanken des anserwïhlten Volkes. Das anserwählte Volk ist das gottgelicbte Volk, das Werkzeng seiner Gnade mol seiner Off(nbarmo. Das anserwählte Volk weil. den Willen Gottes und ist in Cimmle genommen das cinzige Volk, weil es als das Volk Gottes absolute Jerlentmug besitzt. So sehr cine solehe Lehre dem nationalen Egoismus dienen kamm, so verkchrt mol cinscitig wäre es doch, sie ans den Ansprüchen des nationalon Egoismus restlos exklïren zo wollen. Es liegt in ihr der religiöse Gankn an cine besondere Mission, der Gedanke einer sozialen Unsterbliehkeit mor anos aigrntümlichen Werteharakters. Die form, welehe diese Idee in He Has annahm, mub darin gesncht werden, daB das griechisehe Volk unter allon Vijlkern das anzige vermunftbegabte und startenbildende Volk sein sollte. 


\section{i) Moralität und Staat im Römertum.}

Auf das analytische Zeitalter der griechischen Kultur folgte im Römertum eine Epoche anhebender Synthesis, die in der Idee des imperium romanum ihre höchste Gestaltung fand. In bezug auf die moralisch-politische Entwicklung blieb aber zunächst eine scharfe Trennung und Absonderung des moralischen Wertlebens ron den politischen Einheitsgedanken. Während in griechischen Kulturbewußtsein die sittliche Idee mit der staatlichen zusammenfiel und in ihr die Vollendung suchte, rerstand das neue Kulturbewußtsein die moralische Welt als die Welt der Immerlichkeit und stellte sie der Außerlichkeit des politischen Lebens entgegen. Das geschah um so mehr, je drückender die Herrschaft des Römertumes empfunden wurde. Damals erfaßte die Menschheit eine große Sehnsucht, die Welt zu verlassen, da den Besten unter ihr das Leben nicht mehr lebenswert erschien. Aber die Tore der übersinnlichen Welt, die sich Platos Seherblick erschlossen, hatten sich den Augen der suchenden Menschheit verhüllt, die im traurigen Zerfall und geistiger Zerrüttung nicht mehr die Kraft hatte, die großen Gedanken der Torzeit nachlebend zu verstehen. Die Menschen sehnten sich aus der Welt hinaus, aber der Glaube an die übersinnliche Welt war gebrochen und leer und dunkel der ïberhimmlische Ort, wo einst die platonischen Ideen als ewige Wahrzeichen des Absoluten und Göttlichen gewohnt hatten. Damals verstummten die Orakel, und das Schicksal übte mit herben und gewaltigen Schlägen an der Schönheit der griechischen Kultur seine Tücke aus. Man verließ das politische Leben und flüchtete in die Einsamkeit geheimer religiöser Genossenschaften oder in der Stoa weltabgewandten emsten Lebenskreis oder in die Schönheitsgärten des Epikur. Aber am liebsten wäre die Seele der Menschheit weit fortgegangen ron der Welt, der Vergangenheit Schönheit entbehrend und in bezug auf die Zukunft ohne jede Hoffunng und Fernsicht.

Die Stoa und Epikur haben in gleicher Weise die Entfernung rom politischen Leben als sittliche Pflicht betont. Die rechtlich-staatliche und die sittlichmoralische Sphäre sind jetzt ein für allemal geschieden. Herr des Lebens und des Todes sollte der Weise sem: frei, innerlich und unerschïtterlich. Die Idee dieser Freiheit war die Erinnerung an jenes Sollen des moralischen Gesetzes. wie es Sokrates zuerst gedacht hatte. Doch remochte man es nicht mehr in alter Stärke dem Sein entgegenzustellen. Tor allem hat Epikur den sinm des sittlichen Sollens rollkommen gewandelt, wenn er aus ihm eine Regel des Geschmackes machte, die Anweisung geben sollte für eine schöne ästhetische Lebensführung. Dagegen hat die Stoa das Sollen als Bejahung der Weltremunft mit grausamer Härte und Starrheit gedacht. Das Sollen hatte die Aufgabe, das Sein der Leidenschaften zu vernichten, in denen doch num einmal unsere größten Lebensgefühle wohnen. Ohne Haß und Liebe, ohne Schmerz, Sehnsucht und Hoffnung sollte der Mensch sein. Das Sollen sollte nicht aufklären wie bei Sokrates, noch bilden und gestalten wie bei Aristoteles, noch befehlen und gebieten wie später bei $\mathrm{K}$ ant, sondern es sollte sein Gegenüber vernichten und zerstören. Das Sollen sollte somit das Leben vernichten und den Menschen in eisiger Kälte und Starrheit zurücklassen. Die Leidenschaften sollten ausgetilgt, die Weltvernunft des Logos als das wahrhaft Gute bejaht werden. 
Dieses Sollen aber verwandelt sieh unversehens wieder in ein Sein, indem es als die strenge Notwendigkeit des Fatums und sehließlich als Naturgesetzmäßig. keit und unersehöpfliehe Naturkraft verstanden wurle. Immerhin bildete die Lehre der Stoa in ihrer stolzen Strenge eine Schutzwehr gegen die Theorien eines blasierten Skeptizismus, dessen mehr oder weniger geistvolle Paradoxien schließlich den Sinn des Handelns vollkommen in Frage stellten.

Die Stoa hat die Sphäre des sittliehen Lebens zuer'st deutlich rom reehtlichpolitisehen Leben gesehieden. Alle Sittliehkeit ruht auf innerer Freiheit, einem Gut, das mir niemand nehmen kann, und das ich auch in Ketten zu bewahren rermag. Nicht im Staat rollendet sich das sittliche Leben. Der Staat ist eine Hemmung und Begrenzung der Individualität, und die staatliche Verpfliehtung kann ihre Schönheit zerstören. Es gibt eine Gemeinschaft des Guten und Edlen. lie über alle Grenzen des Staates hinansführt, ein Weltbürgertum, ein Heimatsrecht in der moralischen Welt, das iiber alle staatlichen Gesetze hinaus von der Idee der Gerechtigkeit bestimmt wird.

Aber schließlich hat die Stoa diese Scheidung zweier Wertgebiete doeh nur vollzogen, um ihr herbes Soll dann wieder rlem römisehen Staatsgedanken zn vermählen. Sie hat viele jener heroischen Naturen gebildet, die im Dienste ler römisehen Republik so Großes vollbrachten. Sie ist auch die Philosophie ler römischen Caesaren geblieben. Selten ist vielleieht eine Moraltheorie so sehr zum Eigentum eines Volkes und, da es sich um ein welteroberndes Volk handelte, so sehr zum Eigentum der Welt geworden wie die Ethik der Stoa. An rlen großen Gestalten der römisehen Republik und an den Handlungen der Cäisaren läßt sich diese Lehre demonstrieren, so daß wir meinen möchten. Zenon habe in seiner Ethik den sittlichen Typus des römisehen Volkes gedentet.

Diese Sittliehkeit des römisehen Volkes erseheint num aber nieht als die freie und sehöne Bliite rles Lebens, als die ruhige Entfaltung der persönlichen Eigenart, sonrlern einmal als das schwere Joeh des militärisehen Gehorsams und dann anch wiecler als die völlige Ungebundenheit des gott- und weltverlassenen Mensehen. Die stoisehe Lehre ließ diese doppelte Auffassung zu, daß der sittliche Menseh entweder ler ganz Gebengte oder der vollkommen Ungebengte sei. Denken wir daran, dab das kalte und unbarmherzige Sollen der stoisehen Vermunt die Austilgung und Verniehtung der Leidenschaften verlangte, in dronen foch sehließlich die Fülle unseres persönliehen Eigenlebens ruht, so setzte es an die Stelle des lebendigen Menschen die starre Allgemeinheit des Gesetzes und listete schwer auf den Mensehen und bedrohte alle Sehnsweht und Liebe und gah ihn als Werkzeug und Mittel den stat mol seinen Forderungen hin. J)iesces starre Sollen komnte za Taten höchster Aufopfermng füluren, wenn es lie Stalatsifle verlangte. Von seiner Allmach besessen, komnte der Vater lio aigenen söhne zum Tode verurteilen und zum Vollstreeker des Gesetzes warlen, weil jene gegen Rom gof revelt latten. Diese Moral machte das Männerwort zu einer heiligen Sache und ließ den gofangenen Feldherrn, der naeh Rom granndt war, am den Frielen zu betreiben, lie Röner zu nenem Kampfe rufen, mun ditun zuribkzukchren, dureh das Wort gebunden, den sieheren Tod vor Alegen. Jjose Moral ließ Gato das Wukle ler Republik nicht überleben. Fr mulst. sidh solluer töten, weil scin Statsideal gefallen war. Dieses herbe und hittere Sollon verpflichtote Brutus, den väterlichen Freund zu töten, weil "re 
mit seinen Herrschergelüsten das freie Rom verriet. Die Lehre der Stoa war eine gute Moral für Helden, Sklaven, Soldaten und Cäsaren, also für Römer. Demn auch des Cäsars einsames Dasein lag in der stoisehen Moral begründet. Ist doch der Weise ein Gott und Herr dieser Erde und der Cäsar der höchste Repräsentant der Staatsvernunft. Was in seinem grausamen und gewalttätigen Tun sich offenbart, was seine zügellose Kraftentfaltung ausriehtet, das ist der Vernunft geheiligtes Werk, denn in ihm ist die Leidensehaft selber zur Vernunft geworden.

\section{k) Die Universalmonarchie.}

In der Entfaltung des staatlichen Lebens verwirklichte sich damals die Idee des einen Weltreiches, das die gesamte Menschheit umfaßte, kurz bevor die neue große Religion das eine göttliehe Reich rerkündete. Wohl hatte es schon vor der Römerherrschaft Weltmonarchien gegeben, aber nie zuvor war die Idee des imperiums so bewußt und vollendet in Erscheinung getreten. Die Idee des imperiums vernichtete den Gedanken des nationalen Staates, wie er in Griechenland aufgedämmert war, und setzte an seine Stelle den internationalen Staat, die Vereinigung der verschiedenartigsten Nationen und Völkermassen. Aber diese Nationen durften sieh nicht in ihrer Eigenart dem Gesamtstaat eingliedern, sondern nußten entweder selber Römer werden oder Roms Beherrsehte sein. So entspringt aus der römischen Nation heraus die ungeheure Idee der politischen Einigung der Welt.

\section{l) Die christliche Ethik.}

Der äußeren politischen Synthese des Römertums suehte das Christentum eine höhere innerliche hinzuzufügen. Aus der großen religiösen Lehre ihres Sehöpfers ergab sich eine Ethik, die sich in dem äußersten Gegensatz zu der Herrenmoral der Stoa und ihrem kalten Sollensbegriff stellte. Dieser neve Wertbegriff war die Idee der Liebe, die wir hier nur auf ihre ethische Bedeutsamkeit hin untersuchen wollen. Diese Liebeslehre war zunächst ein Protest gegen die kalte Sollenslehre und den starren Tugendbegriff der Stoa. In der Idee der Liebe ist das starre Gegenüberstehen von Pflicht und Neigung überwunden. In der Sphäre jener Leidenschaften, welche die Stoiker zerstören wollten, ruhte eine wertvolle Kraft der Seele, die gepflegt und geheiligt werclen soll, weil sie aus den tiefsten Tiefen des mensehlichen Gefühlslebens stammt und das Sollen erwärmt und verklärt, das seinerseits gewiß ebenso notwendig zur Sphäre des Sittlichen gehört. Vielleicht gibt es eine Sittlichkeit ohne Liebe, aber diese Form der Moralität hat nur geringen Wert. In der Regel versehanzt sich hinter ihr ein kleiner und kleinlicher Tugendstolz oder Henchelei und Scheinheiligkeit. Dies aber ist der Liebe eigentïmlicher Sinn, daß Handeln und Leisten nicht notwendig zu ihr gehört, daß sie vielmehr in der Ruhe und im Leisesein der Seele am sehönsten erblüht. Aneh gehört zu ihrem Wesen das Dienen ohne Sklave zu sein, das Dienen und das Dulden. Ma rias stilles Hören gilt mehr als Marthas unruhiges Tun. Das Handeh kam gewiß gut und wertvoll sein, aber es verstriekt uns zu tief in die geräusehvolle Welt. Nur der stille Lauseher remimmt die innere göttliche Stimme. Wein 
die Stoa das männliche Ideal des Stolzes und des Herrseins rerkündete, lehrte das Christentum das weibliche Ideal der Hingabe und der Demut. Aber das sollen erscheint nicht als despotisches Gebot, vor dem die Knechtsseele erzittert, sondern wie des Vaters gütig mahnendes Wort, dem sich die Kinderliebe entgegensehnt. In dem Gedanken der überwindenden Liebe ist das ursprünglich sinnliche Gefühl der erotischen Leiclenschaft auf das schönste geläutert und das Sollen jeder Fremdheit beraubt. Vom Standpunkt des starren Sollens aus ist jeder Fehltritt zu verwerfen, und eine Verzeihung kann es hier nicht geben, demn das Recht verlangt die Strafe für den Schuldigen. Aber die Liebe verzeiht und duldet alles. Auch in der höchsten Form der Gottesliebe vergißt sie ihre irdische Heimat nicht. Unendlich zartes Verstehen verbindet das Höchste mit dem Tiefsten. Auch in der entstellten Gestalt der armen Buhlerin ist noch der Liebe göttliches Sehnen zu spüren. Nicht die Herren und Mächtigen der Erde sind einem wertvollen Ziele nah, sondern die Schwachen und jene, die arm am Geiste sind.

In der Idee dieser Liebe, die alle Menschen vereinigen soll, ist der Gegensatz von Sein und Sollen überwunden, sofern sich die Pflicht ganz unmittelbar mit der Neigung, das Sinnliche mit dem Úbersinnlichen verbindet zu einer einzig schönen Gestalt. Gesollte Liebe und geliebtes Sollen, darin liegt die eigentümliche Paradoxie dieser Lehre. Ich soll das tum, was meine Liebe will. $\mathrm{Tu}$ ich nicht von selber das Geliebte und Wünschenswerte? Wozu bedarf es da eines Sollens? Aber meme Liebe ist noch gar klein und wenig entfaltet. Nur weniges rermag sie zu lieben und zu beglücken. Meine Liebe und meine Sehnsucht soll reicher und größer werden, auf die Fülle des Menschlichen soll sie gerichtet sein. Und schließlich soll sie groß und herrlich äber diese Welt sich hinaussehnen. Und das Sollen soll geliebt sein? Wie kann man das Sollen lieben. Ist nicht Pflicht und Gebot eine schwere Last, der unsere ungeduldige Hoffnung und unsere Wunschbegierde zu entgehen strebt? Aber das Sollen hat ja seinen harten Befehlscharakter vollkommen abgelegt. Es ist zu einer leisen Stimme geworden, die mahnt und ruft und lockt zu nie geschauten Fernen.

Die Idee dieser umfassenden Bruderliebe setzt die Einheit und imnige Verwand tsehaft alles Menschlichen voraus. Ein Verhältnis engster Zusammengehörigkeit begrïndet sie unter den Liebenden. Sie hebt den Gegensatz der Nationen auf und verschmilzt sie zu ein er Gemeinsehaft. Damit zerstört sie allen Krieg und alle Feinclschaft in der Welt und macht den Staat, das Recht und die politische Ordnung überflüssig, demn es gibt nichts mehr zu sehützen und zu verteidigen, keine Hersseher und Bcherrsehte, keine Richter und Gerichtete mehr.

Dic grofe Jiebessynthese des Christentums hat eine ungeheure moralisehe Wirkmng amsgeïbt. Barmherzigkeit und Gïte und Gnade und Aufopferung hatte sie in ihrem Gefolge. Sie wollte alle Sehranken niederreißen und jene alsolute Jinheit herstellen, die gleichbedentend ist mit dem Ende der Welt. Sir berlyohte das Christentum die Idee des imporiums, das auf Maeht und Herrschaft gregriunlet war. J)ic Cäsaren verfolgten das Bokenntnis der Liebe mit lojelcoscinaftichem Hab, bis eine dritte grobe Synthese die Rolle der Vermittlung ähermahon. 


\section{m) Staat und Kirche.}

Das imperium wollte die Beherrsehnng dieser Welt, das Christentum in seiner ursprünglichen Gestalt die Aufhebung dieser Welt und rler in ihr gesetzten politischen Ordnung. Die Kirche deutete die Idee des Christentums als ein Ziel ferner Zukunft, als ein richtunggebendes Menschheitsideal. Sie söhnte so die Irlee des Christentums mit dem Gegebenen aus. Sie umgab den zarten Leib der schönen Liebeslehre mit einer schützenden Organisation und schob sie vor zur Abwehr gegen die staatlichen Angriffe. Sie verkündete die Idee einer höchsten weltlichen Macht als Wächter und Schirmherr des Christentumes und stellte dem imperium das sacerdotium gegenüber. Sie begründete eine Rangordmung im Reiche der Liebe, eine Stufenordnung der Weltüberwindung, eine civitas Dei, der das Kulturleben der Welt sich mehr und mehr eingliederte. An der Spitze dieses Reiches als höchster Würdenträger und Statthalter des Herm steht der von Gott ernannte Papst, der über die Zugehörigkeit zum Gottesreiche zu entscheiden hat, und dessen Entscheidungen keinem Irrtum unterworfen sind, sofern sie ex cathedra verkündet werden. Die Kardinäle umgeben als engste Gemeinschaft den Herrscher der Kirehe. Sie sind die enge Zahl der Anserwähltell, aus deren Mitte Gott den künftigen Nachfolger beruft. Unter dem Papste die große Zahl der Erzbischöfe, Bischöfe und niederen Geistlichkeit, eine ganz neue Organisation, welche die politische durchdrang und den rohen und unkultivierten Völkem der damaligen Zeit immer wieder die Vorstellung einer ïbersinnlichen Welt vor Augen hielt. Durch geistliche Gesetze, Gebote und Heilsmittel aller Art wurde diese geistliche Welt in der politischen Welt selbständig organisiert. Zur Kirche gehörten alle wahrhaft Gläubigen der politischen Welt, aber doch als solche, die der Anweisung, Leitung und Vermittlung bedürfen, und die durch ihr weltliches Leben gehindert sind, schon in diesem sinnlichen Dasein eine bleibende und mmittelbare Gemeinschaft mit dem Göttlichen zu erlangen. Uber die Weltgeistlichkeit hinaus komnte sich dann die Ordensgeistlichkeit einer noch engeren Gemeinschaft mit dem Göttlichen rühmen, da sie dem Leben des Herrn gemäß auf Gut und Besitz verzichteten und der heiligen Armut lebten. Wenn irgendwo, so ist in diesen Orden das Torbild des Herm am trenesten gepflegt. Sie führten ein gemeinsames Leben in Abgezogenheit von der Welt in einer schönen Einsankeit und Verborgenheit, die die Welt nicht kemnt.

Das geistige und weltliche Oberhaupt nahmen in der Organisation des Mittelalters eine Stellung ein, deren gegenseitiges Verhältnis sowohl wie auch die Beziehung zu den von ihnen geleiteten Reichen sehr schwer zu normieren und festzustellen war. Papst und Kaiser, die beiden universalen Gewalten, waren Herren der Welt. Jeder war Herr einer besonderen Welt. Die Welt der religiösen und moralischen Gesinmung war dem Papste untertan; aber alles praktische Tun und Handeln, das anf äußere Zwecke gerichtet war, das diese irdische Welt zum Ziel und Zweck hatte, das unterstand des Kaisers Gewalt. Doch diese Welten berührten sich notwendig: moralische Gesinnung führte zu politischem Tum, und hinter den Werken der Staatskumst verbarg sich ein sittlicher Wille. Wie nun, wenn die Menschen das nicht leisteten, was sie Gott, der Kirche und dem geistlichen Oberhaupte schuldig waren? Wenn sie sich 
nicht schenten, das Heilige zu schänden oder durch falsche Glaubenslehren die treuen Söhne der Kirche irreführten, wenn sie wohl gar die Diener Gottes in ihrem Frevelsimn verfolgten und so das große Werk des göttlichen Christus bedrohten? Sollte die Kirche und ihr päpstliches Oberhaupt das alles geschehen lassen? Erwuchs ihr nicht vielmehr die heilige Pflieht, das anvertraute köstliche Gut zu bewahren und es rein und fleckenlos zu erhalten zum Segen künftiger Generationen, die alle dermaleinst den Weg des Heils betreten sollten? Gewiß war das weltliche Oberhaupt dazu berufen, der Kirche Schutz angedeihen zu lassen; wenn num aber die kaiserliche Macht versagte und gegen den Geist der Firche rerstieß, war dann das Papsttum zum mindesten nicht berechtigt, den weltlichen Herrseher an seine Pflicht zu ermahnen? Wenn er aber alle Ermahnungen kalt und stolz verhöhnte oder wohl gar zum verderblichen Schlag die Hand erhob, mußte das Papsttum damn nicht auf Mittel und Wege sinnen, um sein Recht und das ihm anvertraute Gut zu schützen?

Und wie sollte der Kaiser sein Verhältnis zu diesem anderen Weltreich auffassen? Solange die Kirche ohne jeden weltlichen Besitz an Grund und Eigentum war, so lange sie lediglich ein Leben in Geiste lebte, den Gläubigen die heilige Tradition verkïndete, die Seelen für ein besseres Jenseits vorbereitete, die Verfolgten sehirmte, die Leidtragenden tröstete und allen Handlungen der Menschen eine fromme Weihe gab, so lange konnte der Kaiser mit der Kirche in Frieclen leben. Von dem Augenblick aber an, wo das Oberhaupt der Kirche und die Bischöfe nud Äbte weltlichen Besitz emwarben oder mit solchem belehnt wurden, mußte die weltliche Macht mit der geistlichen in Konflikt geraten.

Das Mittelalter bedeutet in seiner politischen Entwicklung die Geschichte dieses Kampfes. Das Ende des Mittelalters fällt zusammen mit dem Untersang der beiden universalen Mächte. Am Anfang war die päpstliche Gewalt der kaiserlichen untergeordnet, aber immer größer und selbständiger wurde ihre Bedeutung. War der ursprünglichen Idee des imperiums gemäß der Bischof ron Rom verpflichtet, den ron den deutschen Fürsten gewählten König in Rom zu krönen, so konnte der späteren Idee des sacerdotiums gemäß der Papst sich unter Umständen recht- und pflichtmäßig weigern, den Akt der Kaiserkrönung zu vollzichen. Die Wahl von Gegenkaisern und Gegenpäpsten gab jedesmal der anderen Macht Gelegenheit zum Einsehreiten und zur Verstärkung ihrer Herrseherstellung.

Es unterliegt wohl keinem Zweifel, daß Papsttum und Kaisertum ursprünglich in sinne einer großen Kulturaufgabe gehandelt haben, und raß lie groben Kaiser und Päpste würdige Reprüsentanten eines erhabenen Gedankens gewesen sind. Damals gal, es in der Tat eine höchste entscheidende Instan\% fiir alle geistlichen und weltlichen J)inge, und die kultivierte Mensehleeit orkannte cin gemeinsames Obcrhaupt an. Fricle anf Erolen hätte ausgrhen können von diesen Mächten, aber das Selncksal führte sie zum Streit. Dirser Kanıpf war um so heftiger und zorstörender, je größer die Menschen "aren, die sich frindlich und halierfüllt gegenülerstanden. Von Gregor VII. his Jimnifaz VHJ. mel von Heinich IV. bis Friedrieh II. ist eine Fülle herrlicher Kraft varbrancht und zerstört worden.

l)in Kajor wurlen der Idee des imperimms untreu, als sie nicht mehr in

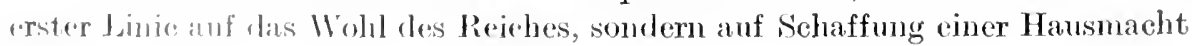


bedacht waren. Dahin trieb sie die Macht der partikularen Gewalten, die in einem ganz losen Verhältnis zum Reiche standen, und deren Lehngut, das sie ursprünglich rom Reich erhalten, sich mit dev Zeit allmählich in Privateigentum verwandelt hatte. Und ebenso wurden die Päpste der Idee des sacerdotiums untreu, als sie, wie im Zeitalter der Renaissanee, lediglich auf die Verstärkung ihres Familienbesitzes hinarbeiteten. Päpste wie Julius II. wirken durehaus als italienicche Fürsten und stehen der Idee der geistlichen Weltherrschaft, wie sie ursprïnglich semeint war, so fern wie nur möglich.

\section{n) Dic nationalen fiewalten.}

we Idee der miversalen Gewalten muBte aber anch im Ansehen des Tolkes an Macht und Einfluß verlieren, wenn die Menschheit Papst und Kaiser in danerndem Konflikt, die Kirche dureh ein Schisma, das Kaisertum durch den Kampf zweier Prätendenten bedroht sah. So traten allmählich mit voller Bewnßtheit und vollendeter Kraft die nationalen Gewalten an die Stelle der universalen Mächte. Statt im Kampfe gegen die partikularen Interessen und den nationalen Gedanken zusammenzuwirken, hatten sich imperinm und sacerdotium anf das grimmigste befehdet. So konnten die nationalen Mächte emporkommen und, als sie Kraft genug besaßen. ihre Lnbotmäßigkeit erweisen. Die Fürsten lehnten sich gegen die kaiserliche Gewalt und die Nationalkirchen gegen das Papsttum auf. Ton der Renaissance anfangend, erhebt sich die nationale Icee immer bewuBter und bestimmter. Das Papsttum verliert seine Macht, es gerät in Abhängigkeit von den verschieclenen Nationen, besonders ron Frankreich. Die Idee des imperiums schwinclet dahin wie ein Traum. Innerhalb der großen nationalen Staaten ringt aber das Königtum mit den großen Baronen um die entscheidence Machtstellung, cin Kampf. cer in England mit dem Siege c'es Ac'els. in Frankreich mit d'em Siege des Königtums geendet hat.

\section{o) Die Renaissance.}

Mit der Renansance keginnt c'as große analytirche Zeitalter. das vielfaeh zu eirer Zersetzung des moralischen und politischen Lebens getürt hat und jene große einheitliche Substanz auflöste, die in c.er Struktur ces Mittelalters uns entgegentritt. Wenn wir an den Gegensatz ron Sein und Sollen, ron Pflieht und Neigung denken, jene Antinomie, die alles sittliche Leben konstituiert, und die das Christentum zu einer vorläufigen Einheit gebracht hat, so muß man sagen, daß die Reniassance die Verherrlichnng des Seins becentet, da sie den großen Kultus der Leidenschaften treibt. Jene Kräfte der mensehlichen Seele also, die die Stoa zerstören wollte, sie sind es. die nach der Auffassung der nenen Zeit in erster Linie alles große sittliche Leben bilc'en. da sie Grund und Crsache aller Macht und aller Größe sind. Größe, Macht und Stärke des Lebens, das sind clie Eigenschaften, die die Renaissance im Begriff der virtu zusammenschließt. Man hat ron cer Entcleckung der Persönlichkeit oder ron der Entcleckung der Individualität in diesem Zeitalter gesprcehen. Auch das Mittelalter kemnt gewiß eine Fülle mächtiger Pєrönlichkeiten, aber jene waren in der Regel hirgefflen $c^{\prime} \in \mathrm{n}$ grolen Icleen, die sie vertraten, und hatten keine Zeit, sieh auf 
ihr persönliches Leben zu besinnen. Sie waren noeh nicht zu dem Selbstgenuß ihres Wesens gelangt. Es war ein ganz nenes und eigentümliches Lebensgefühl, das diese Zeit durchwaltete, die den Mensehen anf sich selbst zu stellen suchte und ihn so mancher Bande der Autorität enthob. Das Mittelalter hatte ein Śrstem gemeinsamer Überzeugungen errichtet, die das Lebensgefühl der Menschen in ziemlich gleichförmiger Weise gestaltet hatten. Nachdem die sozialen Bindungen loser geworden wareu, trat jetzt das Eigenleben gar mächtig hervor. Einer anderen Welt waren die mittelalterlichen Menschen hingegeben und gerade in ihren schönsten Individualitäten der Diesseitigkeit abgewendet. Das nene sittliche Bewußtsein bejahte die Sinnenwelt, und obwohl die moderne naturwissensehaftliche Erkenntnis den Menschen aus seiner zentralen Stellung im Weltall an die Peripherie des Somnensystems gedrängt hatte, so feierte die Philosophie dieser Zeit den Mensehen doch nicht weniger als den mächtigen Herm der Erde. Gewertet wird am persönlichen Leben wohl alles dieses, was künstlerisch reizvoll erseheinen muß; die große schön abgerundete Geste, die ungeheure Vitalität, das Großartige im Tun und Empfinden, das Maßlose und Cngeheuerliche im guten und bösen Simne und vor allen Dingen die Vielseitigkeit der Empfindungen und Fertigkeiten. Der eigentïmliche Lebenstypus, den eine Zeit gebildet, wird immer mehr oder weniger auch als das Ideal dieser Zeit angesehen werden müssen. Allem Kleinen und Kleinlichen war diese Zeit ahgewendet. Sie war dem Reiehtum des Lebens zugeneigt und ließ nichts Schönes und Bedlentsames mangetastet an sich vorübergehen. Es war eine Zeit der höchsten Bildung, ungeheurer Leistungen und Gestaltungen. Damals, als die Individualität dem System der mittelalterlichen Weltansehaumng entwachsen war, da bildete sie mit großer Schönheit ihre eigene Welt, die von so reichem Naturgefühl und Kunstrerstehen durehdrungen war. Der allseitig gehildete Menseh. der homo universale, der alle Kiäfte der Welt in sich trug und in immer neuen Fertigkeiten sein Wesen offenbarte, er hatte sich damals in einigen großen Erscheinungen vollendet.

Alles Große in der Welt ist durch Leidenschaften geschehen; denn die Leidenschaften erhöhen unsere Kraft und machen uns fähig und tüchtig, das ÄuBerste zu wagen. Wie wäre Heldentum ohne Leidenschaft zu denken! Wo überall in der Welt sich ein großer Wille regt, da ist anch die Leidensehaft zu Hause. Wie könnte der Küustler das Sehöne sehaffen, wenn er nieht die wililen und süßen Erregungen und Verwirrungen der Leidensehaften gespürt! Die Denker dieser Zeiten ron Bruno bis Spinoza habendas moralische Problem nur als Problem der Leidensehaften betrachtet. Hatte Doseartes in ihnen Störungen der Secle erbliekt, die die Klarheit und Unbefangenheit unseres Urteils schädigen, so vermag Spinoza deutlich zu unterseheiden zwischen jenen passiven körperliehen Leidensehaften, die msere Kraft verringern und schwichen, mol den tätigen geistigen Leidensehaften, deren höchste Entfaltung lic rotteserkenntnis ist.

Wonn somit die gesteigerte Jeidensehaft unter Umständen zur wertvollsten Lefistung zull führen vermag, so kann doch aus ihren 'Tiefen heraus auch das furchthare Chars der Grausamkeit und des Verbrechens hervorgehen, das alle

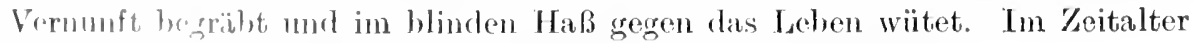
ler Ronassance standen Genie mul Verbreehen nahe heieinander. 


\section{p) Der Individualismus der Aufklärung.}

Wenn sich das differenzierte Leben der nenen Zeit mit ihrem Persönlichkeitsgefühl und Ichbewußtsein in cler Renaissance nur gewissermaßen vorbildlich in einigen großen Gattungsindividuen äußerte, bezieht sich der Individualismus der Aufklärung anf das Individuum schlechthin. Gehen wir wieder daron aus, daß das Wesen der sittlichen Individualität. wie es eine bestimmte Zeit lebt und versteht, aus dem Gegensatz von Pflicht und Neigumg begriffen werden muß, so sehen wir, daß die Aufklärung mit ihrem rationalistischen Geist sich dem Pathos der Leidenschaften entfremdet hat, mag anch die Betonung des Irrationalen als Unterströmung erhalten bleiben und in einzelnen großen Naturen wie Rousseau mächtig zum Durchbruch gelangen.

Das Lebensideal dieser Zeit ist nun nicht mehr das mächtige, schöne und miversale Individuum, eine Lebensform, die nur selten und vereinzelt in Erscheinung treten kann, sondern vielmehr der anfgeklärte Mensch. Die Vollkommenheit des sittlichen Lebens wird in die Aufklärung gesetzt und damit eine theoretische Norm zum Richtpunkt des sittlichen Handelns gemacht. In dem Lebenstypus des aufgeklärten Menschen drängen sich eine Fülle versehiedenartiger Bestimmungen zusammen. Der aufgeklärte Mensch ist der freie Mensch im Sinne des rorurteilslosen Mensehen, dessen Blicke durch Autorität und Tradition nicht getrübt sind, sondern der die Dinge ansieht, wie sie wirklich sind. Er ist der tolerante Mensch, sofern er das Glaubensbekenntnis und die Ủberzeugung anderer Menschen zu respektieren weiß und von jedem Fanatismus weit entfernt ist. Er ist der verstehende Mensch, der jede fremde Meinung zu ehren weiß. Er ist der kritische Mensch, der das dogmatiseh Geltende mit scharfen Waffen des Geistes bedroht. Er ist der duldsame Mensch, der jeden nach seiner Fasson selig werden läßt. Er ist der skeptische Mensch, für den es nichts Feststehendes und Absolutes gibt. Es ist der überzeugunglose Mensch, der an sich und der Welt verzweifelt. Er ist ein Individuum, das sieh in maßlosem Dünkel überhebt, alle Dinge der Welt von seinem begrenzten Standpunkt aus ïbersehen und beurteilen zu kömnen.

Der Individualismus der Renaissance und der Aufklärung stand vielfach in einem scharfen Gegensatz zum sozialen Ganzen. Der Staat wird in der Regel als abstrakte Allgemeinheit vorgestellt, die dem Individuum mehr oder weniger ernst und feindlich gegenübertritt. Oder auch der Staat wird als eine Institution betrachtet, die nun eimmal wohl oder übel in dieser schlechten Welt notwendig ist. Der Begriff des Staates entfernt sich weit von dem Begriff des Volkes und der Nation. Er ist nicht mehr der Begriff einer konkreten sozialen. Gemeinschaft, die alles Leben in sich schließt, sondem der Begriff einer starren äußerlichen Organisation an dieser Lebensfülle. Für Spinoza fällt der Begriff des Staates zusammen mit dem Mechanismus aller jener Gesetze, die Leben und Eigentum der Bürger schützen sollen. Hobbes identifiziert den Staat mit dem Willen des Herrschers, der schrankenlos gilt, und Rousseau mit dem allgemeinen Willen des Volkes, der sich kundgibt in der freien Abstimmung sämtlicher Bürger. Wohl suchte der Protestantismus dem Staat und dem Königtum einen gewissen religiösen Glanz zu verleihen, während der Katholismus den Eigenwert des staatlichen Lebens nach wie vor gering schätzte; im allgemeinen 
läßt sich aber sagen, daß in jener großen analytischen Epoche alles wertvolle Leben in Religion, Kunst, Wissenschaft und Moralität als etwas betrachtet wurde, das anßerhalb der Sphäre des Staates lag und seinem Einfluß entzogen werden sollte. Der Staat wurde somit nicht als der befreundete, fruchtbare Boden für die Entfaltung der Lebensgüter betrachtet, noch gar als ihre Vollendung, sondem rielmehr als etwas, das diese Entfaltung feindlich bedrohte. Der Staat galt als eine Institution, die mit den Forderungen der Gerechtigkeit nnd Billigkeit nicht recht in Einklang stand, er galt vielfaeh als ein ummoralisehes Wesen, gegen das sich das gesunde sittliche Gefühl empörte und auflehnte. Das Indiridum stellte sich in Gegensatz zum Staat, bedrohte seine Existenz und forderte seine radikale Ungestaltung. Das soziale Gewissen war damals sehr verschärft, und als schweres Unrecht wurde empfunden, was die Jahrhunderte hindureh nicht beanstandet war. Es sollte nummehr dem Mensehen überlassen sein, das religiöse Bekenntnis frei zu wählen und auszuüben. Jeder Glaubenszwang sollte aufhören. Es sollte jedem gestattet sein, frei und umgehindert seine Gedanken und Meinungen auszusprechen, und ohne staatlichen Zwang sollten die Lehrer der Wissensehaft mingehindert ihre Auffassungen über alle Dinge rertreten können. Endlich sollte auch den niederen Volksschichten ein menschenwürdiges Dasein geschaffen werden. Thre abhängige und unterdriickte Lage sollte gehessert werden. Es gab nach der Anffassung der Zeit unveräußerliche Nenschenrechte, deren Durchführung und Anwendung allein das menschliche Leben lebenswert macht. Mit drohender Haltung und Gebärde fordcrte man ihre Herstellung dureh den Staat.

\section{y) Die framzösische Revolution.}

So war das letzte Wort der Auflkärung die Revolution, die rollkommene Absage an die bestehende soziale Ordnung, die absolute Trenmung des sittlichen BewuBtscins von der Idee des Staates, wie sie damals wirklich war. Wem man ron der furehtbaren Ausschreitung absicht, welche die Lösung aller sozialen Bande damals in Frankreieh notwendig im Gefolge hatte, so kamn man dem Genius der französischen Nation, der, erfüllt von dem Gedanken einer höheren Ordnung dor Dinge, über das Morsche und Überlebte der Vergangenheit damals zu Gerichte sab, seine Bewmderung nicht versagen. Hat doch in einzolnen groBen Individuen, unberihnt durch die Versuchungen der augenblieklichen Lage, mbeirrt rlurch die Sehrecknisse der Anarchie, der moralisehe Gedanke hohe 'Triumphe gefeiert. Die Idee des moralisehen Richteramtes über die sïnden der Vergangenheit war einzelnen großen Individuen der Zeit zu einer hriligen Pflicht geworden. Die Üherlegenheit des sittlichen BewuBtseins gegeniiber allers statlichen mo rechtlichen Institutionen, dor groBe Ernst und dio Harto des Sollens - alles das trat damals in den klaren BewnBtseinskreis der Mlenschhoit, mel ein Haueh rom Größo durehzitterte die Wrelt.

\section{r) Kants Reorganisation des sittlichen Bewubtseins.}

IV therend so in der Anfklämug und sehlieBlich in der Revolution das analy-

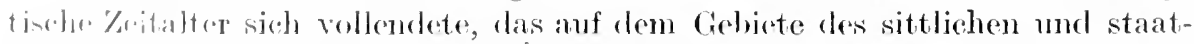

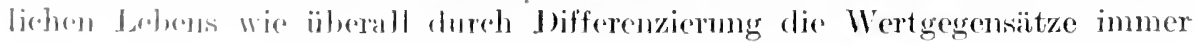


schärfer und mächtiger entfaltete und Grenzen und Unterschiede setzte, die das absolute Postulat einer endgültigen Versöhnmng der Gegensätze immer nehr als mendliche Aufgabe erseheinen ließen, hat der deutsche Idealismus und seine schöne Schwester, die Romantik, ein neues stnthetisehes Zeitalter als Symbol des letzten Zieles angebahnt. So hat vor allem $\mathbf{K}$ a n $t$ die Reorganisation des sittlichen Bewußtseins rollzogen. inden er gleichzeitig als Tollender der Aufklärung überall die Grenzen zog, die durch die verschiedene Struktur der einzelnen Wertgebiete gefordert waren. Für den verstehenden Menschen ist die Wertfeindlichkeit munnehr in die immeren Zentren der Wertgebiete hineingelegt, nachdem die verschiedene und eigentiunliche Gestalt der Wertformen ein für allemal eingesehen ist.

Kant hat als Grundbedingnng des sittlichen Lebens clie Spannnng von Sein und Sollen ein für allemal erkannt. Die psychische Realität der Neigungen und Wünsche, der Begierden und Affekte ist weder ein absolnt gefügiges Material der sittlichen Forderung gegenüber, das sich gem und freiwillig unterwirft oder wohl gar nach sittlicher Gestaltung sehnt, noch dürfen die Leidenschaften als ein Böses und Wertfeindliches gedacht werden, das die sittliche Betätigung hemmt und deswegen ausgerottet und rertilgt werden muß, sondern sie sind unbedingt erforderlich, um das Spannungsverhältnis zu erzeugen, auf dem die Sphäre des sittlichen Lebens ruht. Wie es keine Erkenntnis geben kamn ohne das Verhältnis ron Form und Inhalt und kein Kunstwerk olne Gestalt und Liebe, so fordert die sittliche Norm der Pflicht als ihren Gegenpol die Leidenschaft. Das leidenschaftslose und wunschlose Wesen gibt dem Appell des Sollens keinen Widerhall.

Tritt nun das sittliche Leben in den Kampf und Streit von Sein und Sollen. von Pflicht und Neigung, so ist das sittliche Gut die Resultante dieser beiden Mächte. Die sittlich wertrolle Tat erscheint als etwas Erkämpftes und Abgermgenes, nicht als freiwillige Gabe, sondem als Opfer und Sieg. Wem ein sittlich wertvolles Gut erreicht worden ist, so muß das Sollen die entscheidende Dominante gewesen sein. Was Leidensehaften und Sympathien mitgewirkt haben, ist wertroll nur, sofem in ihnen ein Widerstand überwunden nnd zerbrochen ist. Sofern die Leidensehaft Bestimmungsgrund des Willens war, beraubt sie die Tat an sittlichem Wert. Das Mitschwingen einer persönlichen Srmpathie macht den rein moralischen Charakter der Handlung verdächtig. Wenn wir, durch Bitten und Wünsche bestürmt, den Gegenstand unserer Neigung erfreuen und beglücken, wenn wir, rom weichen Gefühl des Mitleids erregt, fast blind und instinktiv die Gabe der Wohltat spenden, dam ist der hohen Forderung der Pflicht noch kein Genüge geschehen. Die Idee der Pflicht ist viel zn ernst und groß, als daß sie ihre Erfüllung finden kömnte nnr durelı das weiche lieberolle Herz, das zu schwaeh ist, um Widerstand zu leisten, das nichts rersagen kann. Der Wert der sittlichen Handlung aber kam in zwei verschiedenen Richtungen sich steigem, und dieser rerschiedenen Richtung entspreehend entspringt ein besonderer Typus der ethisch werthaften Persönlichkeit, ron denen der eine mehr dem ästhetischen Ideal des Erhabenen, der andere mehr dem des Schönen entspricht. Der erste Typus der Persönlichkeit trittdortin Erscheinung, wo der Gegensatz und Widerstand gar mächtig ist, wo sich die ungeheure Macht der Leidenschaften und Triebe immer wieder den reinen Bestimmungsgründen 
des Willens entgegenwirft. Dieser Typus, den wir den heroischen nennen könnten. erstarkt in der immer wieder neuen Brechung und Niederwerfung der sinmlichen Begehrmngen und offenbart in diesem dämonischen Ringen die sieghafte Herrlichkeit der übersinnlichen Welt. Dieser Typus kommt nie zur Ruhe. sondern ist in einer immer wieder gesteigerten inneren Bewegung begriffen. Je größer und schwieriger aber der Kampf war und die sittliche Aufgabe, die ihm Nahrming gab. um so größer und herrlieher war auch der Sieg.

Dem heroischen Typus gegenüber stellt sich der andere dar als die Überwindung des Gegensa tzes von Pflicht und Neigung, die im Ideal aufgegeben ist, aber niemals rollkommen erreicht werden kam. In der Idee dieser Harmonisierung ist ausgedrückt. daß dieLeidenschaften mit der Zeit aufhören, so heftig gegen (las Sollen zu opponieren, ohne deswegen in bloße Materialstellung herabzusinken. Und auch das Sollen kamn seinen Charakter leise verändern, sofern es mum nicht mehr als unerbittliche Pflieht, als herber Wunschversager auftritt, sondern als ein liebgewordenes Ideal, dem meine Seele und mein Wille gehört. Auch dam wird zwar nicht die ganze Fïlle der Affekte dem Sollen zugewandt sein, aber es wird doeh eine gewisse Leidenschaft, die dem Sollen gehört, die Brïeke schlagen zur Vereinheitlichıng und Harmonisierung meiner Persönlichkeit.

Was den Persönlichkeitsbegriff Kants besonders charakterisiert, das ist seine Innerlichkeit und seine abstrakte Allgemeinheit. Der Idee eines ethischen Sollens, einer moralischen Wertallgemeinheit ordnet sich die Individualität unter, und gut und wertvoll ist nur das an ihr, was unter das Wertallgemeine suborlinierbar ist. Das absolut Wertvolle ist die Pflicht als Gebot der übersinnlichen Welt; das aber, was zu ihr gehört und mein Wesen adelt und meinem ('harakter Würde gibt, ist das pflichtmäßige Tun, das mich zum Bürger einer höheren Welt macht und mich als freies Wesen teilnehmen läßt an der moralischen Weltordnung. Und nicht sowohl anf das Handeln, auf die Durchsetzung les sollens gegenïber der simnlichen Wirklichkeit kommt es an, denn der sittliche Erfolg steht nur zum geringsten Teile in meiner Macht, sondern die Reinheit rler Gesimmmg ist allein entscheidend, die in der unbedingten und rücksichtslosen Bejahung des Sollens zur Sprache kommt. Wie das Sollen selber als ein kategorischer Imperativ, als eine schlechthin gültige Forderung sich an das Individuum richtet, so soll auch das Individuum ausnahmslos und unberlingt dem Sollen hingegeben sein.

\section{s) Die schöne Secele.}

Dieser Persönlichkeitshegriff Kants hat von Schiller und Fichte noch vine weitere Ausgestaltung erfahren. Wem allerdings sehiller in dem Begriff dor ..schönen Seele" die Idee einer freiwilligen Vereinigung von Pflicht und Virgung verkündete. indem ar gegen die Härte und Unliebenswürdigkeit des kintischen Sollens protestierte und den willigen Sohn der moralisehen Ordnung dron sklaven des Sithengesetzes entgegenstellte, so sprach er damit doch nur rimen Goxtanken aus, dor anch in Kants Moraltheorie enthalten war, nur nicht

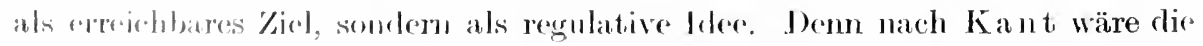

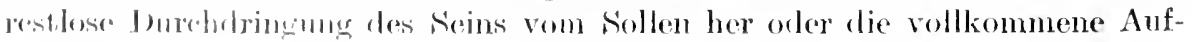


hebung des Affektiven in der Idee der Pflicht gleichbedeutend mit dem Ende der spezifisch menschlichen Sittlichkeit und gleichzeitig auch mit dem Ende aller historischen Kultur. Mit Erreichung dieses Zieles wäre die Menschheit von der Sinnenwelt erlöst.

\section{t) Fichte.}

Fichte hat den Begriff der sittlichen Persönlichkeit von seiner Metaphysik des Tuns aus gebildet und bestimmt. Das sittlich Wertrolle liegt nach ihm vor allem in der Aktionskraft, in der Energie und Unverzagtheit eines unbengsamen Willens. Nur das Handeln und Leisten bestimmt den moralischen Wert des Menschen. Der träge und willensschwache Mensch erniedrigt sich zur bloßen Materie. Nur kein dumpfes Brüten und Träumen, nur kein ruhiges Himnehmen des dargebotenen Schicksalsloses, sondern mutige Selbstgestaltung und Selbstbesinnung. Der Mensch, der ziellos dahinlebt, hat an der moralischen Welt keinen Anteil. Es kommt vor allem darauf an, in mutiger Tathandlung seine Bestimmung zu ergreifen und sich so als lebendiges Glied der moralischen Welt zu wissen und zu fühlen.

Aus dem sittlichen Reich der Gesinnung, mit dem Kant die Sphäre des Sittlichen verknüpft, führte Fichte diese große und schöne Lebensform auf den Schauplatz der Handlung und des Kampfes hinaus. Die Anerkennung des hohen Pflichtgebotes im rerschwiegenen Herzen genügt noch nicht zur sittlichen Vollendung. Jene, die reinen Herzens sind und das Gute aufrichtig wollen, sind schön und selig als Gestalten des Friedens. Wenn aber die Stunde der Not und des Kampfes schlägt für die Menschheit oder für eine Nation, dann gilt es nicht nur zu wollen, dam kommt es darauf an, in einer Stunde ernster Weihe sich den großen Entschluß zur Tat abzuringen.

Die Anerkennung des Sollens sei unbedingt, und die Befolgung der sittlichen Normen duldet keine Ausnahme. Nichts in der Welt gibt dir das Recht, der Pflicht der Wahrhaftigkeit untreu zu werden. Mag sein, daß die Schönheit und Liebenswürdigkeit des Lebens durch rücksichtslose und unbedingte Aufrichtigkeit und Offenheit zerstört werden kann; aber die Grundfesten der sittlichen Ordnung sind mit diesem hohen Gebot unlöslich verbunden.

In Zeiten der Puhe und des Friedens mag es uns seltsam erscheinen, daß jede Handlung, die wir ausüben, sittlich bedeutungsvoll sein soll. In schönen Friedenszeiten gibt es viele Gebärden und Bewegungen, die der Lust und der Schönheit dienen und dienen diurfen. Wenn aber die Zeit der schweren und ermsten Not an eine Nation herantritt, dam kommt es darauf an, daß jede Bewegung und Handlung in den Dienst der allgemeinen Sache gestellt wird. Dann soll jeder an seiner Stelle alles tun und leisten, um das Schicksal des Vaterlandes zum Guten zu wenden. Damn wird jede kleine Handreichung, jedes gutgemeinte sinngemäße Wort seine Weihe erhalten durch die allgemeine Idee, die nunmehr auch dem sonst Unbedeutenden höchsten Bedeutungsgehalt verleiht.

Es sind das jene Zeiten, da alle Gegensätze innerhalb der schicksalsbedrohten Nation notwendig verstummen. Die beiden feindlichen Staaten kehren in den Naturzustand zurück. All die internationalen Abmachungen und Höflichkeiten kommen in Fortfall. Die Binden und Hüllen fallen ab. 
und aus der feindlichen Nation starrt uns ein absehenlich entstelltes Antlitz entgegen. Was wir in Friedenszeiten anerkamnt und gewertet haben, das ist nunmehr der Mörder, der mein Leben bedroht, und ich greife zur IVaffe, um das wilke Tier zn erlegen.

Wemn somit zwisehen den Nationen die absolute Kluft feindlieher Naturmächte klafft und ihre Beziehungen jeglichen Werteharakters entkleidet sind, so ist in der Nation die Einheit und der Friede eingekehrt. Sie hat alles überwunden und tritt als Wertindividualität großen Stiles uns entgegen. Wenn sich dunkle Schatten zwischen die Nationen legen, so glïht die einzelne Nation, die von der Idee des Allgemeinen ergriffen ist, um so schöner und herrlicher auf. Wenn die Existenz des ganzen Staates bedroht ist, dann muß der Hader der Parteien und Konfessionen notwendig verstmmmen. Dann gibt es keine Liberalen und Konservative, keine Katholiken und Protestanten mehr. Damm gibt es nur Angehörige der einen deutsehen Nation und des einen französisehen Staates. Damn erfährt das Leben eine eigentïmliche Steigerıng, die sich besonders darin kundgibt, daß auch fliejenigen, denen in ihrem Alltagsdasein die mmittelbare Beziehung zur Idee gefehlt hat, nummehr von ihr erfüllt und ergriffen sind und ladurch in einem höheren Lichte glänzen, von einer seltsam nenen Sehönheit umflntet sind. In dem Künstler, dem Gelehrten tund in dem religiösen Mensehen haben die Ideen dauerndes Leben gefunden. Jene werden durch den Krieg nicht erhöht und müssen die sehwere Enttäuschung erleben, daß die Mensehheit noeh weit entfernt ist von dem ersehnten Ziel der vollendeten Kultur. Die anderen aber sind von einem ungewohnten und ungekannten Großen ergriffen, und dies Ergriffensein macht sie so sehön. Der Jüngling, der bisher dem frohen Genießen und der Frende an seiner Körperliehkeit gelebt, er fühlt in seinem Herzen zum erstenmal mit Allgewalt die Idee der grol3en Sache. Was er zuvor als kindisehes Spiel getrieben, das wird ihm jetzt z!m großen ernsthaften Lebenszweck. Sein natürlicher Egoismus wird dureh den großen Stil der Aufopferung geadelt, und Heldenfencr rötet seine Wangen.

Der schlichte Bürgersmann und Baner gelangt selten zu Wort und Ausdruck. Aus der Prosa seines Alltagslebens glüht ihm keine Flamme entgegen, und die Sorge um des Lebens Not füllt in ren Zeiten des Friedens das Ganze seines Daseins aus. Wenn aber die Sehicksalsstunde für eine große Nation gesehlagen hat, dam wirl auch er so mïehtig ergriffen, daß er Worte finclet wie nie zuvor und auch die Macht empfängt, sie in Taten umzusetzen.

Wenn eine Nation schwer bedroht ist und in stolzer Eimmütigkeit sich zum Kampfe erhebt, dam müssen wir als Angehörige der Nation sie von ganzem Herzen licben. Dem ihre Not, ist unsere Not, und ihre Taten sind unsere Taten. l) große Stil ihrer Haltung verleiht anch uns Wiirle und Ansehen, und der Finhoitsgerlanke wind so mäehtig, daß die Idee les platonisehen Staates ver"irklicht scheint. In jerlem Kinde lieben wir unser Kind, in jeder Mutter ehren wir Inscres Mnutter.

Fichte foicrt in der Porsönlichkeit des Helden gegenïber Kants Moralfrinzi]) rine höhere Moralitit, die den kategorischen Imperativ hinter sieh

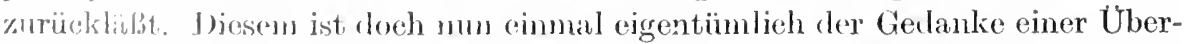

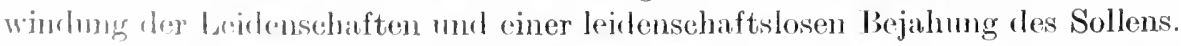
In fer höheren Moralitit ist die Leidensehaft Bremstoff und Fener für die Idee. 
Der heroische Mensch tritt mit seiner ganzen Leidenschaft für die Idee ein, er bringt sein Persönliches ihr zum Opfer dar und lebt in ihr sein unsterbliches Leben.

Wie hat doch Fichte die Tat geadelt und damit dem Leben einen großen Reichtum offenbart! Wir wissen, daß die Tat am Anfang war, und der große Dichter vermochte des unendlichen Strebens Ziel und Erfüllung zı preisen. Rastlosigkeit ist diesem Trieb nach Wechsel eigen, der zu immer nenen Betätigungsformen unseres Daseins ruft. So drängt er in die Weite, von einem Lebenskreis zum andern. Das Fernste will er sich zum Nächsten machen. Alles will er genießend verstehen, und immer wieder lockt und verführt ihn der Reiz des Fremden und Unbekannten.

Und von diesem großen Zug in die Ferne befreit uns die erlösende Tat, die wir an uns selber vollziehen, indem wir unsere Bestimmung ergreifen. Wir müssen wissen, wozu wir da sind, wo wir hingehören und in weleher form unser eigentümlicher Lebenssinn zu suchen ist. Habe ich meine Bestimmung ergriffen, bin ich an den Posten getreten, der mir vermöge meiner eigentümlichen Fähigkeiten gehören soll, dam nehme ich teil an der ewigen moralischen Ordnung der Welt, und wenn die Natur zerbricht und zerstört wird, mein unbesiegbares Ich kann sich kalt und stolz darüber erheben.

Wie nun nach Fichte dem Einzehnen ein eigentümlicher Sin zukommt, so auch besonders dem Leben der Nationen. Und einen ganz unersetzlichen, unverlierbaren Wert besitzt nach ihm die deutsche Nation. Sie hat das Erbe der Griechen und Römer angetreten und rein und umvermischt sich erhalteı durch die Jahrtausende. Sie ist ein unverlierbares Glied im Kreise der Nationen. Deutschlands Untergang ist gleichbedeutend mit dem Untergang der Gesamtkultur.

Die großen Tage der Befreiungskriege haben es wohl gezeigt, daß es der deutschen Nation an Heroismus und Opfermut nicht fehlte. Das, was Kant und Fichte verlangten und als Norm und Regel groß und sichtbar herausstellten, das hat in unserer Nation sein verborgenes Leben gelebt. In den Zeiten der Not und des Schicksals hat es dam immer wieder Gestalt gewomnen und sich als ruhiger Ernst, als hingebende Treue, als eisemer Gehorsam, als selbstrerständliche Pflichterfüllung offenbart.

\section{u) Die Sittlichkeitsidee der Romantik.}

Die Romantik hat, so sehr sie den Begriff der Persönlichkeit vertiefte, indem sie der Natur des künstlerischen und religiösen Menschen nachging, das Problem des sittlichen Lebens nur wenig gefördert, aber sie hat in mancher großen und schönen Erscheinung das hohe Leben gelebt, das die Denker des deutschen Idealismus als Vorbild aufgestellt hatten. Sie kounte die Härte der Gegensätze nicht dulden und drängte ïberall nach Synthese und Versöhnung. Deshalb ließ sie den schroffen Gegensatz von Pflicht und Neigung, wie ihn Kant aufgestellt hatte, nicht bestehen und suchte ihn durch die Idee der Harmonie und Liebe zu überwinden. Sie suchte die Konkretheit des Lebens zu erfassen. und erfreute sich an der buntschillernden Mannigfaltigkeit der Welt und an dem. Reichtum der Gestalten und Formen. Deswegen konnte ihr die moralische 
Persönlichkeit Kants in ihrer Einseitiglieit und Abstraktheit nicht genügen, und sie ging dem sittlichen Wert der verschiedenen Lebensziele nach: Ein rersehiedener Rhythmus ist in den Mensehen zu finden, und von diesem Rhythmus ans muB ein jeder verstanden und gewïdigt werden. Nienand darf sich gregen die Melodie seines Wesens versündigen, alle Handlungen müssen mit Ruhe und Selbstverständlichkeit aus dieser inneren Lebenseinheit fließen. so kann eben dieselbe Handlung für den einen Menschen Recht und für den anderen Unrecht sein, weil sie mit dem Lebensziel der einen Persönlichkeit vereinbar, mit dem der anderen aber unvereinbar ist und ihre Natur verwirren und stören muß.

Gegenüber Fichte verlegen die Romantiker das sittliche Leben mehr in die irrationalen Tiefen der Gefühlswelt und führen es von der großen liehtvollen Bühne äußerer Handlungen und Begebenheiten in die weiehen Sehatten der Mystik hinein. Aber auch sie betonen die sittliche Tat und sehen den sinn des sittlichen Lebens darin, durch Schaffen und Bilden die Welt des Geistes zu vollenden, die von Gott nur begonnen, aber nicht zu Ende geführt ist.

\section{v) Die Entwicklung des Staatsgedankens durch den deutsehen Idealismus.}

Für die Entwicklung des Staatsgedankens hat damn endlich das neue synthetische Zeitalter entscheidende Bedeutung gewommen. Für die Renaissance und Aufklärung war die abstrakte Auffassung der Staatsidee und ihre Ablösung von der Idee der Nation charakteristisch. Der soziale Zusammenhang wurde in einer Gemeinschaft gesucht, die über die Enge des Staates hinausführte. Wohl hatte sich der nationale Staat den miversalen Gewalten gegenüber siegreich durchgesetzt, aber er stand da in der ganzen Spröde und Härte eines bloßen Machtfaktors. Noch war sein Antlitz nicht geistig verklärt, noch war (er nicht zum Lielbstbewubtsein seiner Kulturmission herangereift. Die schwere Form der Despotie lastete auf der sozialen Gemeinschaft, die sieh als Mittel und bloßes Werkzeng für die Ziele und Wünsche eines Einzehen betraehten mußte und dadurch in ihrem moralischen Bewußtsein schwerc Kränkung und Einluße erlitt. Noch fühlte sich der Fürst als außerhall) der sozialen Gemeinschaft stehend und verlangte ein einseitiges Verhälnis der Lnterordnung. Die Pflicht des Gehorsams aber komnte sich nur auf äußere Leistungen beziehen. In ihren sehönsten und wichtigsten Angelegenheiten blieben Volk und Herrseher getrennt. Und so suchte sich dem die Mensehheit einen sozialen Zusammenhang auBerhalh, des Staates, in cinsamer Inselforne dic blihende Utopie, oder hekimnte sich zum Welthürgertum, das immer lort zu Hause ist, wo wertvolles Kulturlelecen sich bililet.

Mit drum Lnde des 18. Jahrhunderts setzt clann jene Bewegung ein, die Irn Gedanken des wertwollen Kulturlebens mit der Idee des Staates versöhnt und ihn zuniuchst als das uncnthehliehe Sulsstrat aller Kulturbetätigung dexlit. Wohl mag dio: Wissenschaft international scin und for Künstler überall

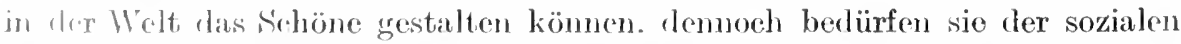
Orelumm, dis ihnen limhe"zum Sichaffen gibt. Auch hat jede Nation gemäß ihrer cigntionlinhen Individualität cine besondere Mission zu erfüllen, und die 
Organisation des Staates ist der äußere Ausdruek für diesen nationalen Willen. So sehien Fich te die deutsehe Nation für das Kulturleben der Welt unentbehrlieh zu sein. Alle Kraft muB darauf geriehtet sein, die nationale Eigenart aufrecht zu erhalten und dauernd zu bewahren.

Bei Kant und dem jungen Fich te findet sich in der Hauptsache noeh das Staatsideal der Aufklärung. Der Staat wird als Reehtsinstitut gewertet, hat aber mit den höehsten Gütem der Nation, mit Wissensehaft, Kunst und Religion nichts zu tun. Allmählieh wird dem Staat immer mehr gegeben, und er gewinnt zusehends an Leben, Fülle und Schönheit. So bildet Fich te in den Grundzügen die Idee des modernen Kulturstaates, wie wir sie ein für allemal rerstehen müssen. Das ist der Staat des gleichen Reehts für alle, der wohl den einzelnen Bürgern verschiedene Rechte gibt, aber kein Ausnahmerecht duldet. Alles künstlerische Sehaffen und Wirken gliedert sich dem Staat ein. Ohne künstlerisches und industrielles Leben kann von keinem Staatsganzen die Rede sein. Dagegen besteht zwischen dem Staat und den anderen Wertideen ein gewisser Gegensatz. So strebt die Wissenschaft naeh der reinen Theorie und sueht in ihr die Vollendung, während das Interesse des Staates darauf gerichtet ist, der Wissenschaft die Richtung auf das praktische Leben zu geben, mag es sieh nun um technisehe Ausnïtzung wissensehaftlicher Gedanken oder auch um die erzieherische Verwertung großer historischer Begebenheiten handeln. Ein anderer Gegensatz liegt zwisehen Moralität und Staat. Der Staat ist die Sphäre der Legalität, da kommt es ror allem auf das Tun an, denn die Gedanken als solehe sind unstrafbar. Dagegen kommt für die Moralität gerade in erster Linie die Gesimnung in Betraeht. Und sehließlich besteht auch zwischen Religion und Staat eine gewisse Antinomie, sofern die Religion ein Reich ersehnt und bejaht, das nicht von dieser Welt ist.

So trat der Staat in der Ansehauung der großen Denker dem Volk und dem Leben wieder nah und näher. Und der Staat sehmiegte sich wieder dem Leben des Volkes an, und die Nation gewann ihn lieb und war stolz, zu ihm zu gehören. Die höehste Fülle der Wertbestimmungen hat ihm Sehelling geschenkt, der ihn gar nicht schön und konkret genug auffassen und deuten kann. Tom staatlichen Leben kann nach Sch elling keine Rede sein, wemn seine Aufgabe sich auf den Schutz der notwendigsten Lebensbedingungen beschränkt. Ein solcher Notstaat entspricht nicht der Vernunftidee der sozialen Gemeinschaft. Auch ist der Idee des Staates noch nicht Genüge gesehehen, wem er im Stande der Unschuld verbleibt und besinnungslos und reflexionslos seinen Zielen nachgeht. Dem idealen Staate muß selbst die herbe Spannung fernliegen, die sieh in der Härte des Solkens ankïndigt. Am besten ist der ideale Staat von dem Begriff der Schönheit her zu begreifen. Es kommt in erster Linie darauf an, daß die verschiedenen Kulturbetätigungen sich nicht kreuzen und hemmen, sondern einmütig zusammenarbeiten. Eine Harmonie muß das Ganze durehdringen, die das Allgemeine mit dem Besonderen und die Theorie mit der Praxis versöhnt. Wenn aueh der theoretisehe Gehalt der Wissensehaft die interessenlose Betrachtung verlangt, so muß die theoretische Erkenntnis doch für den Staat nutzbar gemacht werden. In der Gesetzgebung eines Volkes, in seinen Wohlfahrtseinrichtungen und Regierungsformen muß die Wissensehaft zu lebendigem Ausdruek kommen. Die Sittlichkeit lebt in dem Heroismus der Nation, und die 
Formen des öffentliehen Lebens, der Gesellsehaft und des $V_{c}$ : hrs soll der Zanber der Sehönheit als ein leiser Rhythmus durchdringen.

Hat so Sehelling die Gesamtheit der Kulturbetätigungen mit der Ideo des Staates verbunden. so ging die Erkemtnis Hegels im Einklang mit Aristoteles dahin, da 3 sieh das sittliche Leben in ihm vollende, während das Gebiet der Kunst. der Religion und der Philosophie über alles Cemeinsehaftsleben weit hinausgehen, da sie auf die Einsamkeit Gottes bezogen sind. Der Staat ist die Tollendung des objektiven Geistes als der Sphäre der Kultur, im sittliehen Leben rollendet sich die Idee des Staates. Die Sphäre des Rechtes ist das Gebiet der Formalität und der Abstraktheit, das seinen letzten Ausdruek findet in clem Begriff der Person. Das Gebiet der Moralität ist die Sphäre einer tiefen Innerlichkeit, aber aneh gleichzeitig ciner vollkommenen Isoliertheit, die dem Gemeinschaftsleben als einer fremden Beziehmig gegenübersteht. Erst in der Idee des States ist dieser Gegensatz überwmden. In ihm ist das Besondere mit dem Allgemeinen versöhnt. Der Staat ist notwendig eine Begrenztheit, weil er die Vollendung des mensehlichen Gemeinsehaft slebens bedeutet und nicht in die Sphäre des Absoluten hineinragt. Aber er ist die konkret gewordene sittliche Vernunft, und alle sittliche Kulturbetätigung findet in ihm ihre Vollendung.

fo sehen wir in der Entwicklung des sittliehen Lebens und in der Idee des Staates Kräfte naeh Ansgleieh ringen, deren Gespaltenheit gerade die ungchenre Bewegung des historischen Lebens hervorruft. Und dieselbe Erscheinumg ist uns auch auf dem Gebiete der Religion, der Kunst und der Philosophio entgegengetreten. Vielleicht ist unser Zeitalter dem vorläufigen Endziel der Geschichte nah, wo die genaue Erkenntnis der einzelnen Wertgebiete des kulturellen Lebens mol das Bewbtsein ihrer eigentïmlichen und un̈̈berschreitbaren Geltungssphäre die Irlee der irdisehen Glibkseligkeit uns nahe bringt. Lnsere moderne Kultur hat es eingesehen, daß die Fordernngen der Religion mit den Begriffen dex Wissenschaft niemals zu widerlegen sind. Wir dürfen aber nicht glauben, dals mit der Beseitignng dieser Hemmungen die große Bew ergung des welthistorischen Gescheheus ihr Ende erreicht hat. Vielmehr ist der Ciegensatz nummehr erst von der Peripherie in das Zentrum verschoben, und lic größten Geistestaten gesehehen dort, wo Verwandtes mit Verwandtem lingt und kümpft.

Wir wissen ein Zicl, aber das Ziel hat eine grane Ferne und bedentet die Uborwindung und Inthelonng von alledem, was wir als mensehlich groß und reatvoll ampfinlen. I)iesem Ziele sehnen wir ms entgegen, obwohl es die Aufhebung vom alledenn bedentet, was ms menschlieh verständlich erseheint.

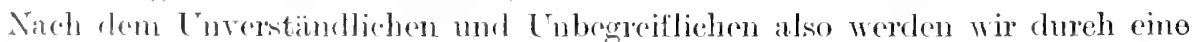
hunkle Notwemligkeit fortgatrichen, unl so sehr wir das simnvolle der Gegen-

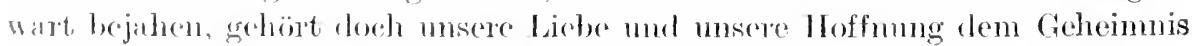

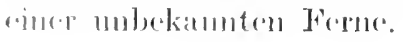


THE LIBRARY

UNIVERSITY OF CALIFORNIA

Santa Barbara

THIS BOOK IS DUE ON THE LAST DATE STAMPED BELOW. 


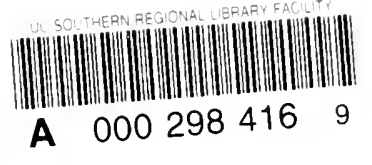


